\title{
$L A-13478$
}

Approved for public release;

distribution is unlimited.

\section{Volcanism Studies: Final Report for the Yucca Mountain Project}

\section{Los Alamos}

NATIONAL L A B ORA TOR Y

Los Alamos National Laboratory is operated by the University of California for the United States Department of Energy under contract W-7405-ENG-36. 
This work was supported by the Yucca Mountain Site Characterization Project Office as part of the Civilian Radioactive Waste Management Program of the U.S. Department of Energy.

An Affirmative Action/Equal Opportunity Employer

This report was prepared as an account of work sponsored by an agency of the United States Government. Neither The Regents of the University of California, the United States

Government nor any agency thereof, nor any of their employees, makes any warranty, express or implied, or assumes any legal liability or responsibility for the accuracy, completeness, or usefulness of any information, apparatus, product, or process disclosed, or represents that its use would not infringe privately owned rights. Reference herein to any specific commercial product, process, or service by trade name, trademark, manufacturer, or otherwise, does not necessarily constitute or imply its endorsement, recommendation, or favoring by The Regents of the University of California, the United States Government, or any agency thereof. The views and opinions of authors expressed herein do not necessarily state or reflect those of The Regents of the University of California, the United States Government, or any agency thereof. Los Alamos National Laboratory strongly supports academic freedom and a researcher's right to publish; as an institution, however, the Laboratory does not endorse the viewpoint of a publication or guarantee its technical correctness. 


\section{Volcanism Studies: Final Report for the Yucca Mountain Project}

\section{Editors:}

Frank V. Perry

Bruce M. Crowe

Greg A. Valentine

Lynn M. Bowker* 
This report has been reproduced directly from the best available copy.

It is available to DOE and DOE contractors from the Office of Scientific and Technical Information,

P.O. Box 62,

Oak Ridge, TN 37831.

Prices are available from

(423) 576-8401.

http://www.doe.gov/bridge

It is available to the public from the

National Technical Information Service,

U.S. Department of Commerce,

5285 Port Royal Rd.,

Springfield, VA 22161.

(800) 553-6847 


\section{Los Alamos \\ NATIONAL LABORATORY \\ Los Alamos, New Mexico 87545}




\section{Abstract}

This report synthesizes the results of volcanism studies conducted by scientists at the Los Alamos National Laboratory and collaborating institutions on behalf of the Department of Energy's Yucca Mountain Project. An assessment of the risk of future volcanic activity is one of many site characterization studies that must be completed to evaluate the Yucca Mountain site for potential long-term storage of high-level radioactive waste. The presence of several basaltic volcanic centers in the Yucca Mountain region of Pliocene and Quaternary age indicates that there is a finite risk of a future volcanic event occurring during the 10,000-year isolation period of a potential repository. Chapter 1 introduces the volcanism issue for the Yucca Mountain site and provides the reader with an overview of the organization, content, and significant conclusions of this report. The risk of future basaltic volcanism is the primary topic of concern including both events that intersect a potential repository and events that occur near or within the waste isolation system of a repository. Future volcanic events cannot be predicted with certainty but instead are estimated using formal methods of probabilistic volcanic hazard assessment (PVHA). Chapter 2 describes the volcanic history of the Yucca Mountain region (YMR) and emphasizes the Pliocene and Quaternary volcanic record, the interval of primary concern for volcanic risk assessment. The distribution, eruptive history, and geochronology of Plio-Quaternary basalt centers are described by individual center emphasizing the younger postcaldera basalt $(<5 \mathrm{Ma})$. The Lathrop Wells volcanic center is described in detail because it is the youngest basalt center in the YMR. The age of the Lathrop Wells center is now confidently determined to be about 75 thousand years old. Chapter 3 describes the tectonic setting of the YMR and presents and assesses the significance of multiple alternative tectonic models. The Crater Flat volcanic zone is defined and described as one of many alternative models of the structural controls of the distribution of Plio-Quaternary basalt centers in the YMR. Geophysical data are described for the YMR and are used as an aid to understand the distribution of basaltic volcanic centers. Chapter 4 discusses the petrologic and geochemical features of basaltic volcanism in the YMR, the southern Great Basin and the Basin and Range province. Geochemical and isotopic data are presented for post-Miocene basalts of the Yucca Mountain region. Alternative petrogenetic models are assessed for the formation of the Lathrop Wells volcanic center. Based on geochemical data, basaltic ash in fault trenches near Yucca Mountain is shown to have originated from the Lathrop Wells center. Chapter 5 synthesizes eruptive and subsurface effects of basaltic volcanism on a potential repository and summarizes current concepts of the segregation, ascent, and eruption of basalt magma. Chapter 6 synthesizes current knowledge of the probability of disruption of a potential repository at Yucca Mountain. In 1996, an Expert Elicitation panel was convened by DOE that independently conducted PVHA for the Yucca Mountain site. Chapter 6 does not attempt to revise this PVHA; instead, it further examines the sensitivity of variables in PVHA. The approaches and results of PVHA by the expert judgment panel are evaluated and incorporated throughout this chapter. The disruption ratio (E2) is completely re-evaluated using simulation modeling that describes volcanic events based on the geometry of basaltic feeder dikes. New estimates of probability bounds are developed. These comparisons show that it is physically implausible for the probability of magmatic disruption of the Yucca Mountain site to be $>$ than about $7 \times 10-8$ events $\mathrm{yr}^{-1}$. Simple probability estimates are used to assess possible implications of not drilling aeromagnetic anomalies in the Amargosa Valley. The sensitivity of the disruption probability to the location of northeast boundaries of volcanic zones near the Yucca Mountain site is assessed. A new section on modeling of radiological releases associated with surface and subsurface magmatic activity has been added to chapter 6 . The modeling results are consistent with past total system performance assessments that show volcanic and magmatic events are not significant components of repository performance. 


\section{Volcanism Studies: \\ Final Report for the Yucca Mountain Project}

\section{Contents}

Chapter One

Overview

Page

Bruce M. Crowe, Frank V. Perry, and Greg A. Valentine

I. Introduction

$1-1$

II. Chapter Summaries

$1-2$

III. References

$1-4$

IV. Acknowledgments

$1-5$

Chapter Two

Geology and Geochronology of Basaltic Volcanism in the Yucca Mountain Region

Frank V. Perry, Bruce M. Crowe, Stephen G. Wells,

Les D. McFadden, John W. Geissman, Jane Poths,

Mike T. Murrell, Matthew T. Heizler, Lynn M. Bowker,

Kean P. Finnegan, and Greg A. Valentine

I. Summary 2-1

II. Introduction 2-6

III. Basaltic Volcanism: Yucca Mountain Region 2-9

IV. The Lathrop Wells Center 2-40

V. References 2-113

Chapter Three Tectonic Setting of the Yucca Mountain Region: Relationship to Episodes of Cenozoic Basaltic Volcanism

Bruce Crowe, Chris Fridrich, George Thompson,

Ken Smith, Glen Biasi, Peter Wallman, and Lynn Bowker

I. Summary 3-1

II. Introduction 3-2

III. Southern Great Basin 3-6

IV. Tectonic and Volcanic Setting: Yucca Mountain Region 3-14

V. Tectonic Setting: Time-Space Patterns of the Distribution
of Basaltic Volcanism

VI. Geophysical Studies: Yucca Mountain Region $3-50$

VII. References 3-65

Chapter Four Petrologic and Geochemical Constraints on Basaltic

Volcanism in the Great Basin

Frank V. Perry and Lynn M. Bowker

I. Summary 4-1

II. Introduction 4-1

III. Time-Space Trends in Location, Composition, and Volume of Basaltic Volcanism 4-3

IV. The Role of Mantle in Basaltic Volcanism 4-5

V. Evolution of Basaltic Volcanic Fields 4-7

VI. Geochemical Studies of the Lathrop Wells Volcanic Center 4-13

VII. References 4-31 
Physical Processes of Magmatism and Effects on the Potential Repository: Synthesis of Technical Work through Fiscal Year 1995

Greg A. Valentine, Giday Woldegabriel, Nina D. Rosenberg, Karen E. Carter Krogh, Bruce M. Crowe, Phil Stauffer, Larry H. Auer, Carl W. Gable, Fraser Goff, Rick Warren, and Frank V. Perry

I. Summary

II. Introduction

$5-2$

III. Eruptive Effects

$5-3$

IV. Subsurface Effects

V. Magma System Dynamics: Segregation, Transport, and Local Storage of Basaltic Magma

$5-91$

VI. References

Probabilistic Modeling of Volcanism Data: Final Volcanic Hazard Studies for the Yucca Mountain Site Bruce M. Crowe, Peter Wallmann, and Lynn M. Bowker

I. Summary 6-1

II. Introduction

6-2

III. Probability Model

6-7

IV. Strategy for Assessing the Volcanism Issue

6-11

V. Assumptions and Physical Models

6-14

VI. Volcanic Events at Volcanic Centers in the Yucca Mountain Region

6-21

VII. Revised Probability Modeling

6-43

VIII. Probabilistic Volcanic Risk Assessment

6-91

IX. Final Conclusions of Volcanism Studies by Los Alamos National Laboratory

6-95

$\mathrm{X}$. Acknowledgments

6-96

XI. References

6-96 


\title{
Figures
}

\author{
Chapter Two: Geology and Geochronology of Basaltic Volcanism in the \\ Yucca Mountain Region
}

Page

Figure 2.1 Digital satellite image showing the location of the Yucca

Figure 2.2 Mountain site and Quaternary volcanic centers in the YMR

$2-6$

Figure 2.3 Time-transgressive, mid-Cenozoic volcanism of the Basin and Range province

Figure 2.4

Distribution of the BSE

$2-8$

Figure 2.5

Postcaldera Basalt of the YMR

2-9

2-15

$2-17$

Figure 2.6 Generalized geologic map of the Little Black Peak volcanic center of the basalt of Sleeping Butte compiled on an uncorrected aerial photograph

Figure 2.7 Generalized geologic map of the Hidden Cone volcanic center of the basalt of Sleeping Butte

$2-35$

$2-39$

Figure 2.A

U-Th disequilibrium isochron for Little Black Peak

$2-42$

Figure 2.9

Geologic setting of the Lathrop Wells volcanic center Generalized map of the outlines of the Lathrop Wells volcanic center showing the informal names of the lava units

$2-46$

Figure 2.10

Geologic map of the distribution of volcanic subunits of chronostratigraphic unit I of the Lathrop Wells volcanic center

$2-47$

Figure 2.11 Spidergram of elemental compositions normalized to an average composition for all analyzed samples of the volcanic units of the Lathrop Wells center

$2-48$

Figure 2.12 Geologic map of the distribution of volcanic subunits of chronostratigraphic unit II of the Lathrop Wells volcanic center

Figure 2.13 Spidergram of elemental compositions normalized to an average composition for all analyzed samples of the volcanic units of the Lathrop Wells center

Figure 2.14 Digitized image of aerial photograph of the Lathrop Wells volcanic center showing the outcrop distribution of the Lathrop lava flow

Figure 2.15

Geologic map of the distribution of volcanic subunits of chronostratigraphic unit III of the Lathrop Wells center

Figure 2.16 Spidergram of elemental compositions normalized to an average composition for all analyzed samples of the volcanic units of the Lathrop Wells center

Figure 2.17 Spidergram of elemental compositions normalized to an average composition of all analyzed samples of the volcanic units of the Lathrop Wells center

Figure 2.18

Geologic map of the distribution of volcanic subunits of chronostratigraphic unit IV of the Lathrop Wells volcanic center

Figure 2.19 Historic photograph of the south flank of the Lathrop Wells volcanic center

Figure 2.20 data of Turrin et al.

Figure 2.21 Probability and box plots of the conventional whole-rock, K-Ar data of Turrin et al. with outliers removed

Figure 2.22

Plot of percentage radiogenic argon versus age by the conventional K-Ar age determinations of Turrin et al.

Figure 2.23 Probability and box plots of the ${ }^{39} \mathrm{Ar} /{ }^{40} \mathrm{Ar}$ data of Turrin et al.

Figure 2.24 Probability and box plots of the ${ }^{39} \mathrm{Ar} /{ }^{40} \mathrm{Ar}$ data set of Turrin et al. with outliers removed 
Figure 2.25 Plot of percentage radiogenic argon versus age for the ${ }^{40} \mathrm{Ar} /{ }^{39} \mathrm{Ar}$ age determinations of Turrin et al. 2-83

Figure 2.B Comparison of ${ }^{40} \mathrm{Ar}{ }^{39} \mathrm{Ar}$ whole-rock plateau ages of Q1 flow samples from NMBM and Turrin et al. $2-84$

Figure 2.26 U-Th isochron plot for the Q13 lava, sample LW-89-3-21-2BMC 2-87

Figure 2.27 U-Th isochron for the Ql1d lava, sample LW-2-21-91-1BMC 2-88

Figure 2.C U-Th disequilibrium isochron plots for Qs3 and Q13 2-89

Figure 2.28 Cosmogenic ${ }^{3} \mathrm{He}$ ages of chronostratigraphic unit I plotted with minimum estimated thickness of scoria-fall deposits of chronostratigraphic unit II $\quad$ 2-93

Figure 2.29 Locations of the 23 paleomagnetic sampling sites at the Lathrop Wells volcanic center

Figure 2.30 Representative modified orthogonal demagnetization diagrams showing the endpoint of the magnetization vector projected onto the horizontal plane

Figure 2.31 Examples of site-level dispersion of paleomagnetic data from lava flows at the Lathrop Wells volcanic center 2-102

Figure 2.32 Summary of paleomagnetic data from the Lathrop Wells volcanic center

Figure 2.33 Geologic map of the Lathrop Wells volcanic center showing the distribution of all chronostratigraphic units of the center

\section{Chapter Three: Tectonic Setting of the Yucca Mountain Region:}

Relationship to Episodes of Late Cenozoic Basaltic Volcanism Page

Figure 3.1 Physiographic subdivisions of North America 3-6

Figure 3.2 Distribution of late Cenozoic faults in the western United States 3-7

Figure 3.3 Subdivisions of the Basin and Range province 3-9

Figure 3.4 Seismicity map of the western United States 3-13

Figure 3.5 Proposed caldera complexes and the distribution of Quaternary

Figure 3.6

basaltic volcanic rocks of the Crater Flat area

Distribution of post-Miocene silicic and basaltic

(black) volcanic rocks of the southern Great Basin $\quad 3-20$

$\begin{array}{lll}\text { Figure 3.7 Kawich-Greenwater rift zone } & 3-22\end{array}$

Figure 3.8 ADRZ superimposed on the Bouguer gravity map 3-24

Figure 3.9 Major structural features of the Crater Flat basin from the Fridrich tectonic model $\quad 3-27$

Figure 3.10 Distribution of the BSE 3-32

Figure 3.11 Geographic subdivisions of the PCB episode of the YMR 3-34

Figure 3.12 Alternative map of the distribution of the PCB in the YMR 3-35

Figure 3.13 Histogram of ages for the PCB of the YMR 3-36

Figure 3.14 Location of the volcanic vents and the distribution centroids by basalt episodes for the PCB 3-37

Figure 3.15 Plot of the location of basaltic volcanic centers of the
PCB in the YMR

Figure 3.16 Earthquakes in the southern Nevada Test Site from the June 29, 1992 Little Skull Mountain earthquake, through September 1995 3-54

\section{Chapter Four: Petrologic and Geochemical Constraints on Basaltic Volcanism in the} Great Basin

Page

Figure 4.1 Map of the western United States showing the distribution of basalt erupted during the past $16-5$ and 5-0 Ma

Figure 4.2 Estimated volume versus eruption duration for late Cenozoic Basaltic volcanic fields in the southwestern United States 
Figure 4.3 $\mathrm{MgO}$ versus saturation index for basalts of the Basin and Range province, after Fitton et al.

Figure 4.4 Quaternary and Pliocene basalt centers of the Yucca Mountain Region

Figure 4.5 Age versus Mg number for post-Miocene basalts of the Yucca Mountain Region

Figure 4.6 La versus Th for post-Miocene basalts of the Yucca Mountain Region

Figure 4.7 Nd and $\mathrm{Sr}$ isotopic composition of post-Miocene basalts of the Yucca Mountain Region

Figure 4.9 Normalized multi-element diagram of incompatible elements comparing compositions of lava flows Q11a, Q12 and

Q13 from Lathrop Wells normalized to lava flow Q11d

Figure 4.10

Results of a multi-element tephra-silt mixing model to test whether the composition of Qs4 tephra has been modified by silt addition

Figure 4.11

Histogram of Mg numbers of samples from the Lathrop Wells volcanic center

4-20

Figure 4.12 Mg number versus Th/La for eruptive units at Lathrop Wells $\quad$ 4-21

Figure 4.13 Normalized multi-element diagram showing the results of modeling of fractionatal crystallization and mixing with Miocene tuff wall rock

Figure 4.14 Lathrop Wells eruptive unit Q13 and upper crustal lithologies normalized to eruptive unit Q11d. Note log scale

Figure 4.15 $\mathrm{Rb}$ versus $\mathrm{Sr}$ for representative eruptive units at the Lathrop Wells volcanic center and results of 2500 Monte Carlo simulations

Figure 4.16 $\mathrm{Nd}$ versus $\mathrm{Sm}$ (determined by isotope dilution) for eruptive units at Lathrop Wells

Figure 4.17 Normalized multi-element diagram comparing the composition of Trench ash samples and representative compositions of

Figure 4.18 Quaternary basalt centers to a mean Lathrop Wells composition ${ }^{40} \mathrm{Ar} /{ }^{39} \mathrm{Ar}$ release spectra from HD1070-5, a sample of the Solitario Canyon Fault basaltic ash

SEM image of a representative sampling of $\sim 660$ grains from Sample HD1070, an ash from the Solitario Canyon fault trench

Figure 4.19

Figure 4.20 SEM element map showing the relative concentration of $\mathrm{K}$ in approximately 15 grains from the Solitario Canyon fault ash, sample HD1070

Figure 5.1 Simplified geologic map of the northern part of the Lucero

Figure 5.2 Geologic map of Alkali Buttes, showing distribution of volcanic facies, bed orientations, and station locations

Figure 5.3

Four stratigraphic columns from Alkali Buttes

Figure 5.4 Geologic map of Volcano Hill, showing distribut
facies, bed orientations, and station locations Maximum sizes of juvenile and xenolith clasts and

Figure 5.5 Matal volume fraction of xenoliths

Figure 5.6 Entrainment rate plots for measured section S1 at southern Alkali Butte
$5-15$ 
Figure 5.7 Entrainment rate plots for measured section N6 at northern Alkali Butte 5-18

Figure 5.8 Entrainment rate plots for Volcano Hill 5-20

Figure 5.9 Entrainment rate plots for measured section S7 at southern Alkali

Butte

Figure 5.10 Entrainment rate plots for measured section N4 at northern Alkali Butte $\quad 5-22$

Figure 5.11 Outline of San Francisco Volcanic Field, north central Arizona 5-23

Figure 5.12 Geologic map of eastern SFVF, showing distribution of basaltic vents exposed at the surface

Figure 5.13 Simple geologic map of Merriam and East Merriam cones

Figure 5.14 Simple geologic map of Dry Lake volcano, showing station locations

Figure 5.15 Simplified geologic map of the Paiute Ridge area, emphasizing basaltic rocks

Figure 5.16 Cross sections through Paiute Ridge area showing present-day topography and geology, with inferred topography at the time of basaltic activity

Figure 5.17 Lower hemisphere stereogram of structures at Paiute Ridge

$5-35$

Figure 5.18 Possible stress gradients for conditions during intrusive activity in the Paiute Ridge area

$5-39$

$5-45$

Figure 5.20 X-ray diffraction patterns of representative bulk samples from the Ammonia Tanks Tuff at the southeastern part of the Slanted Buttes

Figure 5.21 X-ray diffraction patterns of representative bulk samples from the Tiva Canyon Tuff at the southeastern part of the Slanted Buttes

Figure 5.22 X-ray diffraction patterns of representative bulk samples from a pumice fall in the northern part of Slanted Buttes

Figure 5.23 Variation diagrams of major elements versus $\mathrm{SiO}_{2}$

$5-51$

$5-52$

Figure 5.24 Conventional chondrite-normalized rare earth element plots of the Ammonia Tanks Tuff, a dike within the same tuff, and the Tiva Canyon Tuff

Figure 5.25 Distribution of volcanic rocks of the Pliocene Mt. Taylor and the Pleistocene Zuni-Bandera volcanic fields

Figure 5.26 Panoramic view of the basaltic plug and the silicic ash flow tuff of East Grants Ridge taken from the main highway looking northwest

Figure 5.27 (a) X-ray diffraction patterns of representative silicic tuffs and lavas and volcaniclastic sediments collected at different distances from the plug

(b) X-ray diffraction patterns of representative silicic tuffs and lavas and volcaniclastic sediments collected at different distances from the plug

Figure 5.28 Variation diagrams of major elements versus $\mathrm{SiO}_{2}$

Figure 5.29 Variation diagrams of major elements compositions of volcanic glass from microprobe analyses versus $\mathrm{SiO}_{2}$

Figure 5.30 Plots of elemental concentrations of B, Cl, F, Li, $\mathrm{P}_{2} \mathrm{O}_{5}$, and $\mathrm{S}$ versus distance from the basaltic plug. Legends of symbols are given in boxes

Figure 5.31 Variation diagrams of trace element compositions in parts per million versus $\mathrm{SiO}_{2}$

Figure 5.32 Chondrite-normalized rare earth element plots of silicic tuffs and basaltic lavas 
Figure 5.33 Domain, boundary and initial conditions for finite amplitude numerical simulations reported in this study $\quad 5-80$

Figure 5.34 Rate of change of temperature at a point vs. time 5-80

Figure 5.35 $\mathrm{Nu}$ vs. Ra for air from low Ra FEHM simulations $\quad$ 5-81

Figure 5.36 $\mathrm{Nu}$ vs. Ra for air and water from FEHM simulations 5-82

Figure 5.37 Time to steady-state vs. Nu for air from FEHM simulations for systems with several different thermal gradients and different heights $\quad 5-82$

Figure 5.38 Domain and boundary conditions $\quad 5-85$

Figure 5.39 Particle and temperature fields for $180 \mathrm{~m}$ dike at various times $\quad 5-87$

Figure 5.40 Particle and temperature fields for $360 \mathrm{~m}$ dike at various times $\quad 5-87$

Figure 5.41 Particle and temperature fields for $560 \mathrm{~m}$ dike at various times $\quad 5-88$

Figure 5.42 Particle and temperature fields for $680 \mathrm{~m}$ dike at various times $\quad 5-88$

Figure 5.43 Particle and temperature fields for a sill at the water table at various times

Figure 5.44 Particle and temperature fields for a permeable and an impermeable sill at $360 \mathrm{~m}$ at various times

Figure 5.45 Particle and temperature fields for a permeable and an impermeable sill at $520 \mathrm{~m}$ at various times $\quad 5-90$

Figure 5.46 Particle fields for a $560 \mathrm{~m}$ dike at various times for different porosity values

Figure 5.47 Particle fields for a $560 \mathrm{~m}$ dike at various times for different permeability values

\section{Chapter Six: Probabilistic Modeling of Volcanism Data: Final Volcanic Hazard Studies for the Yucca Mountain Site}

Figure 6.1 Distribution areas defined by Pliocene and Quaternary volcanic events in the YMR, including aeromagnetic anomalies of Crater Flat and the Amargosa Valley assumed to be buried volcanic centers

Figure 6.2 Alternative probability distributions used for the event-count simulations, Quaternary basalt of Crater Flat

Figure 6.3 Probability distributions used for the event-count simulations, basalt of Sleeping Butte

Figure 6.4 Probability distributions used for the event-count simulations, Lathrop Wells volcanic center

Figure 6.5 Probability distributions used for the event-count simulations, basalt of Thirsty Mesa

Figure 6.6 Probability distributions for the event-count simulations, aeromagentic anomalies of Crater Flat and Amargosa Valley

Figure 6.7 Probability distributions used for the event-count simulations, 3.7 Ma basalt of Crater Flat

6-36

6-39

Figure 6.8 Probability distributions used for the event-counts simulations, basalt of Buckboard Mesa

$6-42$

Figure 6.9 Simulated Disruption Probabilities for the High Temperature Repository

$6-50$

Figure 6.10 Simulated Disruption Probabilities for the Low Temperature Repository

6-50

6-51

Figure 6.11 Simulated Disruption Probabilities for the Repository System

Figure 6.12 Plot of magma volume versus the event age for the Pliocene and Quaternary volcanic centers of the YMR

6-59

Figure 6.13 Plot of the duration between volcanic events versus the age of volcanic events for the Pliocene and Quaternary volcanic events of the YMR 
Figure 6.14 Probability distributions used in event-count simulations, Quaternary Crater Flat volcanic zone

Figure 6.15 Probability distributions used in event-count simulations, Pliocene-Quaternary Crater Flat volcanic zone

Figure 6.16 Probability distributions used in event-count simulations, Pliocene-Quaternary YMR

Figure 6.17 Probability distributions used in event-count simulations, Quaternary pull-apart basin

6-74

Figure 6.18 Probability distributions used for event-count simulations, Pliocene and Quaternary pull-apart basin

6-76

Figure 6.19 Probability distributions used in event-count simulations, Walker Lane structural zone

6-78

Figure 6.20 Probability distributions used in event-count simulations, Northeast-trending structural zone

6-80

Figure 6.21 Disruption ratio versus dike length for high temperature

$6-87$ repository

Figure 6.22 Disruptive ratio versus dike length for low temperature

6-87 repository

Figure 6.23 Disruptive ratio versus dike length for repository system

$6-88$

Figure 6.24 High Temperature repository - change in E2 6-89

Figure 6.25 Low Temperature repository - change in E2 6-90

Figure 6.26 Repository system - change in E2 6-90

Figure $6.27 \quad 100,000$ year RIP simulation 6-94

Figure 6.28 Aggregate frequency of the probability of magmatic disruption of the Yucca Mountain site

6-95 


\section{Tables}

Chapter Two: Geology and Geochronology of Basaltic Volcanism in the

Yucca Mountain Region

Table $2.1 \quad{ }^{40} \mathrm{Ar}{ }^{39} \mathrm{Ar}$ Ages of Basaltic Volcanic Centers in the YMR ${ }^{1} \quad 2-11$

Table 2.A Additional ${ }^{40} \mathrm{Ar} /{ }^{39} \mathrm{Ar}$ (Plateau) Ages of Basaltic Volcanism in the YMR (not including Lathrop Wells) ${ }^{1}$

Table 2.B Summary of ${ }^{40} \mathrm{Ar} /{ }^{39} \mathrm{Ar}$ ages (excluding Lathrop Wells) from Tables 2.1 and 2.A, sorted by age 2-13

Table 2.2 K-Ar and ${ }^{40} \mathrm{Ar}{ }^{39} \mathrm{Ar}$ Age Determinations for the Quaternary Basalt of Crater Flat 2-30

Table 2.3 Descriptive Statistics for Conventional K-Ar and ${ }^{40} \mathrm{Ar} /{ }^{39} \mathrm{Ar}$ Data Sets of Turrin et al. (1991b) 2-78

Table 2.C Summary of whole-rock ${ }^{40} \mathrm{Ar}{ }^{39} \mathrm{Ar}$ results from Lathrop Wells using different reduction methods 2-85

Table 2.D Summary of xenolith sanadine plateau ages from NMBM 2-86

Table 2.4 Summary of cosmogenic ${ }^{3} \mathrm{He}$ data and ages from Lathrop Wells $2-91$

Chapter Three: Tectonic Setting of the Yucca Mountain Region: Relationship to Episodes of Late Cenozoic Basaltic Volcanism

Table 3.1 Location, Age, Elevation and Volume of Basaltic Volcanic Centers of the PCB (data from Crowe et al., 1995) 3-39

Table 3.2 Alternative Structural/Spatial Models of the YPB of the YMR 3-43

Chapter Four: Petrologic and Geochemical Constraints on Basaltic Volcanism in the Great Basin

Table 4.1 Isotopic compositions of basalts from the YMR 4-11

Table 4.2 INAA of tephra and silt from Lathrop Wells 4-18

Table 4.3 INAA of basaltic ash from fault trenches near Yucca Mountain 4-30

Chapter Five: Physical Processes of Magmatism and Effects on the Potential Repository: Synthesis of Technical Work Through Fiscal Year 1995

Table 5.1 Volume fractions of sedimentary xenoliths from South Merriam and Dry Lake volcanoes, Strombolian facies

Table 5.2 Representative major element oxide composition of Paiute Ridge alkali basalt ${ }^{*}$, determined by x-ray fluorescence analysis 5-31

Table 5.3 Quantitative X-ray diffraction data for Paiute Ridge samples 5-49

Table 5.4 INAA and halogen data from Paiute Ridge, NTS, Nevada $\quad 5-50$

Table 5.5 Halogen data from Grants Ridge $\quad 5-71$

Table 5.6 Physical Properties of Air and Water at 293K and 373K 5-77

Chapter Six: Probabilistic Modeling of Volcanism Data: Final Volcanic Hazard Studies for the Yucca Mountain Site

Table 6.1 Eruption characteristics of Pliocene and Quaternary volcanic centers in the YMR

Table 6.2 Distribution and Event Percentages of Pliocene and Quaternary Volcanic Events in the YMR by Spatial and Structural Models 
Table 6.3 Topographic Setting of Pliocene and Quaternary Volcanic Events in the YMR

Table 6.4 Univariate Statistics and Percentiles from Simulation Modeling of Event Counts Using Alternative Probability Distributions for the Quaternary Basalt of Crater Flat

Table 6.5 Univariate Statistics and Percentiles from Simulation Modeling of Event Counts Using Alternative Probability Distributions for the Basalt of Sleeping Butte

Table 6.6 Univariate Statistics and Percentiles from Simulation Modeling of Event Counts Using Alternative Probability Distributions for the Lathrop Wells Volcanic Center

Table 6.7 Univariate Statistics and Percentiles from Simulation Modeling of Event Counts Using Alternative Probability Distributions for the Basalt of Thirsty Mesa

Table 6.8 Univariate Statistics and Percentiles from Simulation Modeling of Event Counts Using Alternative Probability Distributions for the Aeromagnetic Anomalies of Crater Flat and Amargosa Valley

Table 6.9 Univariate Statistics and Percentiles from Simulation Modeling of Event Counts Using Alternative Probability Distributions for the 3.7 Ma Basalt of Crater Flat

Table 6.10 Univariate Statistics and Percentiles from Simulation Modeling of Event Counts Using Alternative Probability Distributions for the Basalt of Buckboard Mesa

Table 6.11 Mean Estimates of the Probability of Magmatic Disruption of the Potential Repository and Repository System Based on the FracMan Simulations

Table 6.12 Age, volume, cumulative volume and repose intervals for Pliocene and Quaternary volcanic events of the YMR

Table 6.13 Event Counts Applied to Volcanic Zones: Assignments of the Volcanism Expert Judgment Panel

Table 6.14 Univariate Statistics and Percentiles From Event Count Simulation Modeling for the Quaternary Crater Flat Volcanic Zone: E1 and E2 Given E1

Table 6.15 Univariate Statistics and Percentiles From Event Count Simulation Modeling for the Pliocene and Quaternary Crater Flat Volcanic Zone: E1 and E2 Given E1

Table 6.16 Univariate Statistics and Percentiles From Event Count Simulation Modeling for the YMR: E1 and E2 Given E1

Table 6.17 Univariate Statistics and Percentiles From Event Count Simulation Modeling for the Quaternary Pull-Apart Basin: E1 and E2 Given E1

Table 6.18 Univariate Statistics and Percentiles From Event Count Simulation Modeling for the Pliocene and Quaternary Pull-Apart Basin: E1 and E2 Given E1

Table 6.19 Univariate Statistics and Percentiles From Event Count Simulation Modeling for the Walker Lane Structural Zone: E1 and E2 Given E1

Table 6.20 Univariate Statistics and Percentiles From Event Count Simulation Modeling for the Northeast-trending Structural Zone: E1 and E2 Given E1

$6-79$

$\begin{array}{lll}\text { Table 6.21 } & \text { Minimum Probability Bounds for Regional Volcanic Zones } & 6-82 \\ \text { Table 6.22 } & \text { Maximum Probability Bounds for PVHA for the YMR } & 6-82\end{array}$

Table 6.23 Variation in the Disruption Ratio with Increasing Dike Length (complex dikes, uniform distribution)

$6-86$ 


\section{Appendices}

Chapter One: Overview

Page

Appendix 1.1 Chapter 1: Introduction to the Volcanism Issue

(from the 1995 volcanism status report)

$1-6$

Chapter Two: Geology and Geochronology of Basaltic Volcanism in the Yucca Mountain Region

Appendix 2.1 $\quad{ }^{40} \mathrm{Ar} /{ }^{39} \mathrm{Ar}$ Analytical results from Lehigh University

Appendix 2.2

${ }^{40} \mathrm{Ar} /{ }^{39} \mathrm{Ar}$ analytical results from New Mexico Bureau of Mines

$2-124$

Appendix 2.3

U-Th Disequilibrium Analytical Results

$2-141$

Appendix 2.4

Paleomagnetic data for the Lathrop Wells Volcanic Center

$2-142$

Appendix 2-M1

Map: Geology of Pliocene Basalt of Crater Flat

$2-148$

Appendix 2-M2

Map: Geology of Little Cones

$2-149$

Appendix 2-M3

Map: Geology of Makani Cone

$2-150$

Appendix 2-M4 Map: Geology of the Sleeping Butte Cones: Little Black

Peak and Hidden Cone

2-151

Appendix 2-M5

Map: Geology of Lathrop Wells Volcanic Center

$2-152$

Chapter Four: Petrologic and Geochemical Constraints on Basaltic Volcanism in the Great Basin

Appendix 4.1 Major and trace-element data for basalts of the YMR determined by XRF

4-36

Appendix 4.2

Instrumental neutron activation trace-element analyses of basalts from the YMR

$4-44$

Chapter Five: Physical Processes of Magmatism and Effects on the Potential Repository: Synthesis of Technical Work Through Fiscal Year 1995

Appendix 5.1

Appendix 5.2

Appendix 5.3

Appendix 5.4
Xenolith abundance data for Lucero Volcanic Field

Major and trace element data for Paiute Ridge samples

Major and trace element data for Grants Ridge samples

Electron microprobe data from Grants Ridge
$5-120$

$5-125$

$5-128$

$5-130$ 


\title{
CHAPTER ONE
}

\section{Overview}

\author{
Bruce M. Crowe \\ Frank V. Perry \\ Greg A. Valentine \\ Earth and Environmental Sciences Division, Los Alamos National Laboratory
}

\author{
A thousand probabilities does not make a single fact. \\ -Italian Proverb
}

\section{Introduction}

This report presents the results and synthesis of concluding volcanism studies conducted by scientists at the Los Alamos National Laboratory and collaborating institutions on behalf of the Department of Energy's Yucca Mountain Project. It follows the format and content of the report by Crowe et al. (1995) titled "Status of Volcanism Studies for the Yucca Mountain Site Characterization Project" (volcanism status report) and adds information obtained since that report was completed in March 1995. The interested reader is referred to the volcanism status report for a complete perspective on Los Alamos volcanism studies conducted between 1988 and 1995. Chapter 1 of the volcanism status report, which describes the major technical issues and strategies involved in volcanic hazard assessment at Yucca Mountain, as well as the major conclusions of that report, is included as Appendix 1 of this chapter.

This report has been revised, based on the following significant new information:

1. results of a probabilistic volcanic hazard assessment (PVHA) conducted by an expert judgment panel convened by the DOE;

2. new geochronology data for Pliocene and Quaternary volcanic centers in the Yucca Mountain region (YMR);

3. results of simulation modeling of the disruption of a repository and repository system using the FracMan computer code;

4. results of performance assessment simulations of radiological releases associated with magmatic disruption of a repository and repository system using the Repository Integration Program (RIP);

5. continuing acquisition of geophysical data for the YMR;

6. results of field and tectonic studies on the origin of the Crater Flat basin;

7. results of modeling of geochemical data for Pliocene and Quaternary volcanic centers of the YMR;

8. results of the correlation and age of basaltic ashes in fault trenches near Yucca Mountain; 
9. results of eruptive effects studies at analog volcanoes yielding data critical to performance assessment calculations of the quantity of debris that can be entrained and erupted onto the surface during basaltic eruptions (Strombolian, Hawaiian, and hydrovolcanic);

10. studies of the factors controlling geometry of shallow basaltic intrusions, based on data collected at analog sites, which provides information for subsurface (indirect) effects;

11. results of studies of chemical and mineralogical alteration of silicic tuffs intruded by basalts at analog sites (subsurface effects);

12. results of initial theoretical and numerical modeling studies aimed at predicting subsurface effects of basaltic intrusions; and

13. revisions of the eruptive history of the Lathrop Wells volcanic center.

The chapters were written by different authors, and the report is structured so that each chapter may be individually referenced. The degree of revision is different for each chapter, and to maintain continuity, the organization of the original volcanism status report (Crowe et al., 1995) has been retained.

\section{Chapter Summaries}

This section provides a brief overview of how this report compares with the volcanism status report (Crowe et al. 1995).

Chapter 1. This chapter has been completely revised. The original chapter is included as an appendix to Chapter 1 of this report to provide documentation of the background and scope of volcanism studies conducted by the Los Alamos National Laboratory.

Chapter 2. The original content of chapter 2 of the volcanism status report (Crowe et al., 1995) has been kept largely intact, except for correction of errors and the revision of tables to reflect the most current data. We have made significant additions to the chapter, largely in the area of geochronology; additions are highlighted in boxes labeled "FY96 \& FY97 revisions" and are in a different font.

Because the post-5-Ma record of basaltic volcanism in the YMR is judged to be the period most relevant to probabilistic volcanism studies, PVHAs conducted by the authors and by the expert judgment panel focused only on this period. Our recommendation to the DOE is that the pre-5-Ma record of basaltic volcanism is of minor importance for site suitability and licensingapplication decisions. Consequently, we have added very little material to the sections on the pre5-Ma record of basaltic volcanism in the YMR.

New geologic maps on digitized topographic bases have been included for the basalts of southeastern Crater Flat, Sleeping Butte, Makani Cone, Little Cones, and Lathrop Wells.

Additional information on the occurrence and distribution of aeromagnetic anomalies in the Amargosa Valley has been added to this chapter. New geochronology data for the basalt of Buckboard Mesa have resulted in a minor revision of the age of this center. Minor revisions have also been added to the geology and chronology sections of the Quaternary basalt of Crater Flat. 
The results of new geologic mapping of the Hidden Cone center have been included in chapter 2, and we now agree with other researchers that a northern lava lobe was erupted from the center. New geochronology and geochemical data have been obtained and provide somewhat contradictory evidence on the eruptive history of the center.

We have extensively revised discussion of geochronology and geochemical data for the Lathrop Wells volcanic center, but have retained most of the descriptions of the field data. At the end of field studies, trenching of the crater of the main cinder cone provided stratigraphic evidence that the cone is more erosionally modified than previously thought. This finding reconciles some of the perceived discrepancies in field relationships and aids in the interpretation of ${ }^{3} \mathrm{He}$ cosmogenic exposure ages measured on volcanic bombs from the cone rim. New ${ }^{40} \mathrm{Ar} /{ }^{39} \mathrm{Ar}$ data, combined with data on thermoluminescence ages for the scoria-fall sheet, and data on cosmogenic ${ }^{3} \mathrm{He}$ ages for surface exposure of volcanic deposits, agree with and provide compelling support for an age of about $75 \mathrm{Kyr}$ for all eruptive units of the center. Our revised geochemical models of the Qs4 scoria units indicate that the inferred unique chemistry of the deposits results from infiltration of loess and pedogenic alteration. The distribution and sedimentological features of the deposits remain enigmatic, but we now believe the unit did not result from Holocene eruptive activity at the center. Collectively, our new information on the Lathrop Wells center provides greatly increased support for a conventional, monogenetic eruptive history but some perplexing aspects of field and geomorphic data remain and appear contradictory with that interpretation.

Chapter 3. There are minor changes in the introduction and in the section on regional background. Some new references were added, and minor editorial changes were made. The section on tectonic models has been modified considerably, and interpretative sections of individual volcanic-tectonic models have been refined. A major addition is an expanded section on the origin of the Crater Flat basin. The regional seismic reflection/refraction line across Crater Flat and Yucca Mountain has greatly improved our understanding of the subsurface structure of the basin and basin edge. These data show conclusively that the shallow detachment and caldera models are not valid interpretations of the tectonic setting of the YMR. In contrast, the geophysical data are consistent with a pull-apart half-graben origin of the Crater Flat basin involving combined extension and strike-slip faulting. The section on time-space patterns of post9-Ma basaltic volcanism in the YMR has been revised, incorporating new information on the sequences of volcanic events. These data are consistent with a southwest drift of sites of basaltic volcanism through time and allow recognition of small-scale $(<10 \mathrm{~km})$ fractal processes in event distributions (clustered, near- synchronous volcanic centers) and larger scale $(>15 \mathrm{~km})$ Brownian processes in the formation of successive, age-distinct new volcanic centers. The larger-scale processes are the volcanic events that are important to PVHA. The sequence and location of sites of formation of new volcanic centers oscillate between mostly NW- and SE-directions. The location of Pliocene and Quaternary volcanic centers provide limited constraints on the location of future volcanic events except for a tendency for event sites to oscillate between the Sleeping Butte/Thirsty Mesa cluster and the Crater Flat cluster. These patterns are consistent with the inference that the next volcanic event may occur near the former cluster.

Chapter 4. Much of this chapter has been extensively revised. We present new data and discussion concerning the isotopic and geochemical composition of post-Miocene basalts in the YMR and their implications for the evolution of volcanism in the YMR. Geochemical modeling is presented for soil-bound tephras at Lathrop Wells, which show that the composition of the Qs4 tephra deposit is probably due to pedogenic alteration of tephra from the main cinder cone. Alternative petrogenetic models are presented to account for the systematic compositional variations observed in lava flows at Lathrop Wells. Lastly, geochemical evidence is presented 
that correlates ashes found in fault trenches near Yucca Mountain to the Lathrop Wells volcanic center, consistent with an age of the trench ashes of $\sim 75 \pm 10 \mathrm{ka}$.

Chapter 5. This chapter is substantially revised. The original version focused on theoretical aspects of magma system dynamics. The new version includes detailed reports on studies of eruptive effects and subsurface effects carried out at analog sites throughout the southwestern US. These include detailed lithic abundance studies that constrain eruptive effects (quantity of potential repository debris that can be erupted onto the surface given formation of a new volcano that penetrates the potential repository) for Strombolian (including limited data on violent Strombolian eruptions), Hawaiian, and hydrovolcanic eruptions. Also reported are data and interpretations of alteration of silicic-tuff host rocks induced by intrusion of basaltic dikes and sills. These studies, which pertain to subsurface (indirect or secondary) effects, were conducted at sites where the host rocks were both vitric and zeolitic tuffs, as is the case at the Yucca Mountain site. Also reported are studies of factors influencing shallow intrusion geometry. Preliminary modeling and theoretical studies of subsurface effects are also presented.

Chapter 6. Chapter 6 of the volcanism status report, which described the history of volcanism studies for the YMR, has not been included in this report. We have replaced chapter 7 of the former report with chapter 6 in this report. The introductory sections of this new chapter 6 are similar to the original chapter 7, but they have been shortened and partially rewritten to reflect the decision by the DOE to terminate volcanism studies. The remainder of chapter 6 is completely rewritten. The new sections do not revise estimates of PVHA; instead, they describe further examinations of the sensitivity of variables in PVHA. The approaches and results of PVHA by the expert judgment panel are evaluated and incorporated throughout this chapter. The disruption ratio (E2) is completely re-evaluated using simulation modeling that describes volcanic events based on the geometry of basaltic feeder dikes. Disruption of a repository or repository system can occur either by direct intersection by a volcanic event (conduit plug) or by intersection by feeder dikes. This approach solves a previous problem of assessing the likelihood of disruption of a repository for volcanic zones that do not include the areas of interest. The sensitivity of event rates are assessed by treating them as probability distributions both for individual volcanic centers and individual spatial and structural zones. Contrasting assumptions are used to describe the probability distributions, and these assumptions incorporate and contrast the results from the expert judgment panel and an assessment of undetected events. New estimates of probability bounds are developed. These comparisons show that it is physically implausible for the probability of magmatic disruption of the Yucca Mountain site to be greater than about $7 \times 10^{-8}$ events per year. Simple probability constraints are used to assess possible implications of not drilling aeromagnetic anomalies in the Amargosa Valley. The PVHA results are insensitive to drilling data for the anomalies if they are assumed to be buried centers and not young (Late Quaternary) intrusions. However, the aeromagnetic anomaly south of Little Cones should be drilled to adequately characterize the Pliocene and Quaternary volcanic record of Crater Flat. The sensitivity of the disruption probability to the location of northeast boundaries of volcanic zones near the Yucca Mountain site is assessed. A new section on modeling of radiological releases associated with surface and subsurface magmatic activity has been added to chapter 6 . The modeling results are consistent with past total system performance assessments that show volcanic and magmatic events are not significant components of repository performance.

\section{References}

Crowe, B., F. Perry, J. Geissman, L. McFadden, S. Wells, M. Murrell, J. Poths, G.A. Valentine, L. Bowker, and K. Finnegan, "Status of Volcanism Studies for the Yucca Mountain Site Characterization Project," Los Alamos National Laboratory report LA-12908-MS, 1-363 (1995). 


\section{Acknowledgments}

This report is the culmination of a decade of volcanism studies with the current volcanism team (the authors of the six chapters in this report). We are grateful to have worked with such a superb team of individuals. Don DePaolo served as our scientific advisor for the geochronology studies. We are indebted to the professional and long-term support of volcanism studies that has been provided by Susan Klein, Lynn Bowker, Dianne Hyer, Jania Ruhala, and Kate Fitzgerald (editorial assistance), Andrew Burningham, Mike Clevenger, Cleoves Martinez, Andy Gallegos, Jim Young, Dan Stone (Technical and Data Assurance), Alice Thompson, Sandy Martinez, Beth Gray (Records Management), and Lynn Bowker, Kean Finnegan and Craig Scherschel (field and sample support). We could not have completed our work without their help. 
Appendix 1.1 Chapter 1 of Crowe et al. (1995) - volcanism status report

\section{CHAPTER 1: INTRODUCTION TO THE VOLCANISM ISSUE}

\section{Summary}

An assessment of the risk of future volcanic activity is one of many site characterization studies that must be completed to evaluate the Yucca Mountain site for potential long-term storage of high-level radioactive waste. There are two topics for volcanism that require study. The first is the risk of silicic volcanism. This risk is judged to be negligible primarily because of the absence of silicic volcanism in the region for the last 8.5 million years (Ma). The second topic is the risk of basaltic volcanism. The presence of multiple basaltic volcanic centers in the Yucca Mountain region (YMR) of Pliocene and Quaternary age indicates that there is a finite risk of a future volcanic event occurring during the 10,000-yr isolation period of a potential repository. The risk is that magma feeding a surface eruption could ascend directly through a repository or erupt/intrude near a repository and modify the waste isolation system.

Four scenarios have been identified with respect to the risk of future basaltic volcanic events. The first scenario, which is the most important event from the perspective of disqualification of the potential repository site, is penetration of a repository by ascending magma that erupts at the surface. Such an event could possibly lead to eruptive (direct) release of radionuclides to the accessible environment. The second scenario includes volcanic eruptions through the controlled area, or the YMR. The third scenario includes intrusion of magma near a repository without accompanying eruptions. The fourth scenario includes intrusion of magma into the controlled area, or the YMR, also without accompanying eruptions. The latter three scenario classes may not lead to immediate releases of radionuclides; their effects are primarily on the waste isolation system. The latter two scenarios, the intrusion scenarios without eruptions, may be unlikely in the YMR. All basaltic eruptions are accompanied by the formation of minor to significant intrusions (dikes, conduit plugs, sills). However, intrusion of magma into the shallow crust $(<1 \mathrm{~km})$ without an associated eruption appears unlikely. All known occurrences of shallow basalt intrusions in the YMR were associated with eruptions. Each scenario component of volcanic risk is studied from the perspective of suitability of the Yucca Mountain site as well as the contribution of future volcanic processes to radiological releases from the waste isolation system (system performance). The emphasis of this report is on assessment of the likelihood of occurrence of the first two scenarios: the probability of basaltic eruptions through or near a potential repository. The timing and location of future volcanic events in the YMR cannot be predicted with certainty because of the small number of Pliocene and Quaternary volcanic events. A probabilistic assessment of the risk of future volcanic events can be modeled as a conditional probability comprising the recurrence rate of volcanic events, the probability of disruption, and the probability of volcanic-driven, radiological releases exceeding regulatory requirements. This volcanism status report summarizes work through April 1994 on probabilistic assessment of magmatic disruption of a potential repository at the Yucca Mountain site.

The major conclusions of the report include:

1. the recurrence probability of silicic volcanism is so low that it is not a significant issue for the potential Yucca Mountain site;

2. the most current estimate of the probability of future volcanic events directly penetrating the repository and erupting at the surface are low (slightly greater than $10^{-8}$ events per yr or about 1 chance in 10,000 during the 10,000 -yr period of required waste isolation); 
Appendix 1.1 Chapter 1 of Crowe et al. (1995) - volcanism status report

3. the low estimate of the probability of repository disruption continues to support the previous judgments that the Yucca Mountain site is not disqualified solely on the basis of volcanic risk;

4. the uncertainty of the estimates of the probability of magmatic disruption is constrained through development of cumulative probability distributions using multiple eruptive, chronological and structural models, and comparison with analog basaltic volcanic fields; and

5. the uncertainty of probability estimates is sufficiently great that no classes of volcanic scenarios can be excluded from consideration with respect to their contribution to the cumulative releases from the waste isolation system.

\section{Introduction}

An evaluation of the risk of future volcanic activity with respect to geologic isolation of high-level radioactive waste is an important part of studies for the Yucca Mountain Site Characterization Project (YMP). The issues generated by questions about future volcanic activity are among a number of issues requiring resolution, either positively or negatively, for assessing the suitability of the Yucca Mountain site (Department of Energy [DOE] 1988). Volcanism studies have been ongoing for over a decade (Crowe and Carr 1980; Crowe et al. 1992, 1993). Future volcanism is a natural geologic process that could pose a risk to the integrity of a repository's waste isolation system (risk is used as a general term to describe attempts to quantify an identified hazard; volcanic risk assessment refers to attempts to quantify the occurrence probability and consequences of a future volcanic or intrusive event). Volcanic risk assessment must be performed for the 10,000-yr period required for isolation of high-level radioactive waste. Penetration of a repository by ascending magma followed by surface eruption of waste contaminated volcanic rocks could, under some conditions, lead to direct releases of radionuclides to the accessible environment. Also, intrusion of magma through or near an underground repository could alter the integrity of the waste isolation system even if no magma erupts at the surface. If the risk of volcanism from future eruptions of magma through or near a repository is judged to exceed the regulatory requirements for licensing of such a repository, the Yucca Mountain site cannot be found acceptable. If the risk of magmatic intrusion accompanied or not by eruptions exceeds regulatory requirements, the Yucca Mountain site cannot be found acceptable as a repository. Alternatively, if the risk of volcanism or intrusion is judged to be acceptable, the Yucca Mountain site still may not be suitable for a repository. The site must also meet regulatory requirements that limit the allowable releases of radionuclides over the next $10,000 \mathrm{yr}$. The DOE is charged with the responsibility of assessing the significance of issues that could potentially disqualify the Yucca Mountain site.

There are two aspects to an assessment of the risk of future volcanism. The first is the risk of future silicic volcanic activity. The rocks that were uplifted by faulting in the Miocene to form Yucca Mountain were deposited as outflow facies of large volume, explosive eruptions of silicic magma. These eruptions produced hot pyroclastic flows (ignimbrites) and formed multiple, coalesced caldera complexes. The age of this silicic activity ranges from about 15 to $11 \mathrm{Ma}$. Silicic volcanism in a related but spatially separated caldera complex occurred about $8.5 \mathrm{Ma}$ (in the Black Mountain caldera complex). There are no Pliocene or younger silicic centers within a $50-\mathrm{km}$ radius of the Yucca Mountain site. The nearest young silicic center is the Mount Jackson rhyolite dome (2.9 Ma). It is located $105 \mathrm{~km}$ to the northwest of Yucca Mountain. Quaternary 
Appendix 1.1 Chapter 1 of Crowe et al. (1995) - volcanism status report

centers of silicic volcanic activity occur at the eastern and western margins of the Great Basin, more than $100 \mathrm{~km}$ from Yucca Mountain. The absence of post-Miocene silicic volcanism in the YMR provides the major basis for the interpretation that the likelihood of recurrence of a large volume, explosive silicic eruption is very low, perhaps extremely low. Accordingly, it is judged not to be a significant issue for isolation of high-level radioactive waste isolation at the potential Yucca Mountain site (Crowe et al. 1983a; National Research Council 1992).

A second more critical issue for studies of the Yucca Mountain site is an evaluation of the risk of future basaltic volcanism. There are five small-volume Quaternary basalt centers within a $25-\mathrm{km}$ radius centered at the exploratory block of the Yucca Mountain site. The closest Quaternary volcanic center is the 1.0-Ma Black Cone center. It is $9 \mathrm{~km}$ from the southwestern edge of the exploratory block. The youngest volcanic center in the region, the Lathrop Wells center, is $20 \mathrm{~km}$ south of the exploratory block. Other basalt sites of Pliocene or Quaternary age include two centers of the basalt of Sleeping Butte (0.32 Ma) and that of Buckboard Mesa (2.9 $\mathrm{Ma})$. These centers are located, respectively, $47 \mathrm{~km}$ northwest and $35 \mathrm{~km}$ northeast of the potential site. A north-trending alignment of eroded basalt centers (five or six centers), which are about 3.7 Ma, is present in the southeast part of Crater Flat. A 4.8-Ma basalt mesa is located south of Black Mountain. It is $35 \mathrm{~km}$ northwest of Yucca Mountain. A 3.8-Ma basalt center is buried beneath alluvial deposits several kilometers south of the town of Amargosa Valley and $25 \mathrm{~km}$ southeast of the central part of Yucca Mountain.

Stated simply, the risk represented by the Quaternary record of volcanism is the possible recurrence of basaltic eruptive activity during the 10,000-yr performance period of a potential repository at Yucca Mountain. The nature of the future risk of volcanism can be summarized in the context of four questions:

1. Could a future pulse of basaltic magma penetrate through or near the repository, erupt, and release waste radionuclides to the accessible environment (eruption scenario)?

2. Could intrusion of magma into or around the repository perturb the waste isolation system and cause increased or accelerated release of waste radionuclides (subsurface scenario)?

3. Is the risk of eruption, subsurface magmatic effects, or combined eruption and subsurface effects sufficient to disqualify the Yucca Mountain site from consideration for underground storage of high-level radioactive waste?

4. Is the contribution of accelerated radiological releases from possible future magmatic processes (eruptive and subsurface) significant for the integrated performance of a repository system over a 10,000 -yr period?

Several types of data are required to answer these questions. The recurrence rate or the frequency of occurrence of basaltic eruptions and subsurface intrusions needs to be established for the YMR. Possible future sites of eruptions or intrusions need to be identified or bounded. An evaluation of subsurface intrusion effects requires estimating the likelihood of intrusions and their effect on both the repository and the waste isolation system encompassing the repository. A subset of the first question, the eruption scenario, is that an identified event could directly affect the suitability of the potential Yucca Mountain site. The volcanic event of concern is disruption of a repository by ascending magma followed by eruption of waste-contaminated magma at the surface. This scenario could lead to immediate release of radionuclides along pathways that may bypass the multiple natural barriers of the waste isolation system. 
Appendix 1.1 Chapter 1 of Crowe et al. (1995) - volcanism status report

Acquisition of the data needed to answer these questions has been the focus of volcanism studies for the last decade. The emphasis of current volcanism studies includes completion of field and geochronology studies, assessment of geochemical models of basalt centers, studies of the evolutionary patterns of basaltic volcanic fields, and a recent emphasis on studies of the effects of basaltic eruptions and intrusions on the repository and the waste isolation system (Valentine et al. 1992, 1993a). However, two principal areas of progress have been in gathering the data needed for site characterization studies (Crowe 1990; Perry and Crowe, 1992; Crowe et al. 1993) and estimating the occurrence probability of magmatic disruption of a potential repository (Crowe 1986; Crowe et al. 1992, 1993). There has been sufficient progress in these studies to bound the range of possible events (minimum and maximum values) and estimate the cumulative probability distribution for the case of intersection of the repository by ascending magma and eruption at the surface (intrusion-eruption scenario). This subset of volcanic scenarios has been examined in a series of papers and reviews both external and internal to the YMP. The conclusions reached in the papers and reviews have been that current data indicate the probability of magmatic disruption of a repository with accompanying eruption is too low to disqualify the potential Yucca Mountain site (Crowe et al. 1983a; Link et al. 1983; Crowe 1986; DOE 1986, 1988; Younker et al. 1992; National Research Council 1992; Wallmann et al. 1993; Crowe et al. 1993). The DOE will make the formal assessment of the potential disqualification of the Yucca Mountain site with respect to the issue of future volcanism.

The Nuclear Regulatory Commission (NRC) has evaluated the conclusions concerning the volcanism studies for the YMP. They have neither refuted nor accepted conclusions about the significance of volcanism for the potential Yucca Mountain site. The NRC has provided questions and comments about the methods used for probability calculations, the uncertainty of the probability calculations, and the completeness of information used in risk assessment. The state of Nevada has argued in both oral and written form that volcanism is an unresolved issue with respect to the safety of the Yucca Mountain site. Their arguments were derived from qualitative judgments of the risk of volcanism and from uncertainty in evaluations of volcanic risk. The potential risk of future volcanism with respect to underground storage of radioactive waste at the Yucca Mountain site is an issue of considerable interest and some difference of opinion.

The view that future volcanic events are not a significant issue for the disqualification of the potential Yucca Mountain site requires clarification. There can be apprehension from the simple perception of a finite probability of a future volcanic event. An erupting volcano invokes images of explosions accompanied by ejection of towering columns of ash, and devastation of the surrounding areas, destruction of forests and wildlife, lost lives, and ruined property. This imagery is reinforced by media dramatizations of volcanic eruptions, filled with photography of the eruptions and zones of destruction. The series of well publicized major eruptions in the last 12 years (Mount St. Helens 1980; El Chichon 1982; Mount Pinatubo 1991-1992) have made the public more aware of the potential effects of explosive volcanic eruptions.

However, the public is generally unfamiliar with the wide range in the eruptive energy, particle fragmentation, and eruptive volume, and of the mechanisms of dispersal of volcanic materials in different types of volcanic eruptions. Additionally, critics of the Yucca Mountain site often exaggerate publicly sensitive issues, such as, the risks of volcanic eruptions and earthquakes. The Pliocene and Quaternary volcanic centers (basaltic volcanoes) in the YMR comprise relatively small scoria and spatter cones with associated low-volume, blocky aa lava flows. The nature of the deposits of the basalt centers requires that they were formed from mildly explosive, hawaiian and strombolian eruptions and more explosive, but less common, hydrovolcanic eruptions of basaltic magma. The depth of the water table at the potential Yucca Mountain site $(0.6 \mathrm{~km})$ should limit but not preclude the occurrence of hydrovolcanic eruptions 
Appendix 1.1 Chapter 1 of Crowe et al. (1995) - volcanism status report

(Crowe et al. 1986). The expected type of volcanic eruption with magma penetrating a potential repository at Yucca Mountain should have a limited capability to carry radioactive waste from depth and disperse the material long distances at the surface of the earth. There is a finite risk to storage of high-level radioactive waste from future basaltic volcanic events, but the risks are limited by the established geologic record of mildly explosive, small volume eruptions of basaltic magma at locations well removed from the Yucca Mountain site. Future basaltic volcanic events would have to intersect or erupt near a potential repository under most conditions to release radionuclides directly into the accessible environment.

An important, perhaps critical, aspect of geologic predictions concerned with future volcanic events is the uncertainty associated with the predictions. A common misconception is that comprehensive studies will lead to highly precise predictions of the time and location of future volcanic eruptions. That is impossible for two reasons. First, predictions of future events are based on the assumption that the record of volcanism provides a suitable indicator of the rates and style of future volcanic activity, or simply that the history of eruptive activity can be used to predict the most likely patterns of future volcanic activity. However, rates and processes of volcanic activity can change, and moreover, the record of past volcanic processes may be incomplete or hard to decipher, particularly with increasing age of the deposits. Second, there is a limited record of volcanic events in the YMR, providing only a small number of past events to forecast future volcanic events.

These uncertainties markedly constrain both the formulation and accuracy of volcanic predictions. We have a limited ability to predict the location in space and time of future volcanic activity. In fact, such predictions are probably not possible for the types of volcanoes and the small number of past volcanic events in the YMR. Currently, volcanic eruptions have been predicted only for special conditions at historically active volcanoes (UNESCO 1971; Bolt et al. 1975; Tazieff and Sabroux 1983; Swanson et al. 1985), in which a relatively large number of recent events or a consistent pattern of past events provides the basis for predictions.

The problem of prediction of eruptions is much more difficult for spatially isolated, smallvolume basalt centers, because there is insufficient data to statistically define or test distribution models for the timing of future volcanic events. We can bound models of how often volcanoes might occur but cannot predict the specific time of a future eruption. Equally, we can define the general area where volcanic events might occur but cannot define specific sites of future volcanic events. We currently lack, and are unlikely to develop during the next few decades, predictive models of the triggering mechanisms of generation, ascent, or eruption of magma for areas of intermittent volcanic activity like the southern Great Basin.

Further, the recently evolving ideas of chaos and nonlinear dynamics arising in complex natural systems provide a new perspective of how unpredictable complex processes may be through time (Briggs and Peat, 1989; Stewart 1989; Devaney 1990; Peitgen et al. 1992). The processes controlling the intermittent generation, ascent, and eruption of magma at the surface exhibit many properties of chaotic systems (Shaw 1987; Dubois and Cheminee 1991; Sornette et al. 1991; Turcotte 1992) and may be particularly applicable to the relatively new field of spatiotemporal chaotic dynamics (Moon 1992). Studies applying these ideas suggest currently that accurate predictions of future volcanic events over an extended period may, like weather forecasts, be impossible. The record of scientists at predicting the future across a range of disciplines is marginal at best (Casti 1990). These difficulties appear, on first examination, disconcerting. But the questions posed for the volcanism studies at Yucca Mountain are not how well we can predict the future. The challenge for volcanism studies for the potential Yucca Mountain site is assessing risk. There is a subtle but important distinction between prediction of 
Appendix 1.1 Chapter 1 of Crowe et al. (1995) - volcanism status report

events and assessing the risk of future volcanic events. The prediction of future volcanic eruptions requires identifying when and where an eruption might occur and forecasting its type, or nature. The usefulness of the predictions is determined by their accuracy in time and space. In contrast, risk assessment requires estimating the likelihood and effects of future volcanism. Exact predictions of when (timing), where (location), and how large (magnitude) are not required. Instead, the risk of future volcanic events is estimated through probabilistic assessment of the likelihood and effects of the events. The important questions for forecasting volcanic risk for a 10,000-yr period become what methods can be used for assessment, what are the differences in the estimated risk using alternative methods of risk identification, and what is the uncertainty associated with the risk assessment? Ultimately, the volcanism issue will be resolved by assessing the estimation of risk, coupled with realistic estimations of the uncertainty of the risk assessment.

The statement that current data support the judgment that the Yucca Mountain site will not be disqualified because of the risk of a future volcanic eruption through the potential repository must be examined within the perspective of the uncertainty of that conclusion (DOE, 1986 1988). First, this judgment does not constitute a decision about the suitability of the potential site. The suitability of the site will be based on an assessment of the performance of the waste isolation system site. Second, the DOE will, in future program documents, make the formal decision on the qualification of the Yucca Mountain site with respect to volcanism. Third, no consensus on the issue of volcanic risk will ever exist. A judgment must be made about what constitutes a sufficient level of agreement to make a decision. Disagreement among reputable scientists is common, perhaps expected, when dealing with uncertain data and events. However, the significance of different views must be examined from a risk perspective, not on judgments of the individual merits of different data interpretations. Fourth, an indeterminate aspect of assessing volcanic risk is judging the amount and confidence needed in the information used to resolve the issue. What level of information is required for completeness? There will always be benefits from further studies, further testing of assumptions and conclusions, and further development of alternative models. These potential benefits must be weighed against the cost, the time requirements, and reasonableness of continuing studies. Part of the process of balancing these alternatives is assessing what level of uncertainty is acceptable for judging issues that could disqualify a site. These decisions will be made by the DOE in future program documents.

Finally, there is a paradox that envelops volcanism studies. There were only a few volcanic centers (seven or eight centers) formed in the YMR during the last $2 \mathrm{Ma}$ (Crowe 1990). This small number of past events means the risk of future eruptions is low, but the uncertainty of calculating that risk is large. If there had been more volcanic events in the Yucca Mountain area, there would be a more robust data set to define the risk of future eruptions, but the risk of a future eruption would be higher. This tradeoff must, of course, be viewed positively. Again, the challenge is to define risk, bound the risk by realistic assessments of uncertainty, and compare the results with both the qualification and licensing requirements. While this is a difficult task, data summarized in this report provide a reasonable degree of confidence that the risk of future volcanism can be adequately assessed for geologic disposal of high-level radioactive waste.

The purpose of this volcanism status report is to bring a sense of scientific perspective to the many questions raised in this Introduction. Additionally, this report should provide a better understanding of the uncertainty associated with volcanic risk assessment. Society has entered an era of increased concern over the interactions between man and the environment, and we must somehow learn to make objective decisions balancing risk with potential benefits (Lewis 1990). This report provides a summary current to the date of publication of the results of a long history of volcanism studies (1978 to early 1994). It provides more complete arguments, with accompanying supporting data, that the Yucca Mountain site is not disqualified with respect to 
Appendix 1.1 Chapter 1 of Crowe et al. (1995) - volcanism status report

the risk of a future volcanic eruption through the potential repository site. The conclusion continues to be supported by site characterization studies and will continue to be assessed in future studies pending formal decisions on site suitability by the DOE.

The unique perspectives of this volcanism status report are several. First, we present the most current and comprehensive information concerning the geologic record of the YMR. Second, we assess topics related to volcanism such as the tectonic setting of past volcanic events, the petrology of the basaltic lavas, and the current scientific understanding of processes of magma dynamics. Third, we present our best estimates of the probability of magmatic disruption of a potential repository at Yucca Mountain, the controlled area surrounding a repository, and the YMR. These estimates are presented both as mean, or most likely values, and as cumulative probability distributions obtained through risk simulation. These probability estimations are used primarily to aid the DOE in assessing the possible disqualification of the Yucca Mountain site, and the data presented in the report may eventually become an important component of future studies concerned with evaluation of the performance of the waste isolation system.

The approach used to assess the risk of volcanism follows a threefold process (Crowe et al. 1992). We first identify the sequence of volcanic events and coupled effects that could affect a buried repository. Second, data are obtained to predict the controlling rates of volcanic activity and the spatial relations of this activity with respect to the location of a repository site. Third, those events are combined into a logical framework to estimate the risk of future volcanism. The framework of these volcanism studies involves a probabilistic assessment of risk, where risk is a combination of the probability of a volcanic event and the consequences of that event for an underground repository (Crowe et al. 1982; Crowe 1986; Crowe et al. 1992). This probabilistic approach provides a progressive, or iterative, method of evaluating the volcanism problem. Initial probability calculations are made using assumptions supported by the most current data for the Yucca Mountain site. These calculations are tested continuously and refined as more data are gathered.

The initial stages of probability calculations were made from 1980 to 1982 . We have tested these conclusions with respect to site disqualification nearly continuously for more than a decade. It is time, therefore, to present the calculations formally and to solicit evaluations of the validity of the arguments. By making decisions now concerning the presented assessments of the risk of future volcanism, we can assess the validity of these decisions, the assumptions required for the decisions, and the quality of data supporting the decisions.

The risk of volcanism can be divided into four categories or scenarios from the perspective of the geometry of magma intersection and the mechanism of potential dispersal of waste radionuclides. These are

1. Direct intersection of a potential repository by ascending magma accompanied by eruptions (upper two parts of Fig. 1.1);

2. Direct intersection of the controlled area or the YMR by ascending magma accompanied by eruptions;

3. Intrusion of magma near the repository (below, into, or above) without eruptions (bottom part of Fig. 1.1); and

4. Intrusion of magma away from the repository in the controlled area or the YMR without eruptions. 
Appendix 1.1 Chapter 1 of Crowe et al. (1995) - volcanism status report

These categories are established from the perspective of the mechanisms of dispersal of radioactive waste (Fig. 1.1). For the first two categories, the radioactive waste is dispersed by eruptive processes. There may be enlargement of the zone of magma/waste contact by secondary processes (thermal convection, groundwater effects) but the driving force for dispersing the waste is magmatic, and the dispersal is nearly instantaneous (compared with a 10,000-yr isolation time). The driving force for the dispersal of waste for categories three and four is secondary or coupled processes. Not only the effects of volcanism on a repository must be forecast, but also how those effects might change the ability of a repository system to isolate waste.

The categories are useful for identifying the effects on a repository of different volcanic events, but they cannot be completely separated as physical processes. Basaltic volcanic eruptions are invariably accompanied by intrusions at depth. The intrusions mark the shallow pathways of magma ascent to the

surface and may range from simple vertical dikes to complex, sill-like bodies (Crowe et al. 1983b; Valentine et al. 1992; 1993a). Intrusion of basalt magma into the shallow crust (>1 km) may be unlikely without associated eruptions. All known field sites of shallow basalt intrusions in the YMR were also sites of eruptions (Crowe et al. 1983a; 1986; Crowe 1990; see also Chapters 2 and 7). Generally, the closer to the surface a basalt magma ascends in the crust, the more likely it is to erupt simply because of decreasing lithostatic overburden.

This report provides a summary of volcanism work through April 1994 and is divided into nine chapters. Chapter 1 is this introduction. Chapter 2 describes the geologic setting and history of volcanism in the YMR. Chapter 3 describes the tectonic setting of the YMR and the relationship of sites of basaltic volcanism to that setting. Chapter 4 provides a brief overview of the geochemistry of basalt magmatism and magmatic models of the evolution of basalt centers in the YMR. Chapter 5 presents an overview of magma dynamics. The evolutionary pathways of volcanism are traced from generation of magma in the mantle, through ascent and interim storage in the mantle or crust. Pertinent parts of the problem are surveyed and mathematical and physical descriptions of magma processes are emphasized. Chapter 6 is a summary, in chronological order, of the papers and conclusions developed in volcanism studies providing a complete bibliography of volcanism studies and documenting important conclusions developed from past work. Volcanism studies are summarized for work sponsored by the DOE, the NRC and their contractors, the state of Nevada, and other participants in the repository program. Many review questions and comments about volcanism studies neglect material already covered at length in published volcanism studies. We have attempted to make this work more assessable by summarizing the results of the past decade of volcanism studies. Chapter 7 of this report describes the current results of an assessment of volcanic risk for the Yucca Mountain site. The status of data is summarized current to the writing of this report. Chapter 8 examines remaining site characterization issues. The pros and cons of different interpretations of volcanism data are examined, and the impact of these different models is evaluated for the probabilistic risk assessment. Chapter 9 summarizes conclusions of this volcanism status report. 
Appendix 1.1 Chapter 1 of Crowe et al. (1995) - volcanism status report

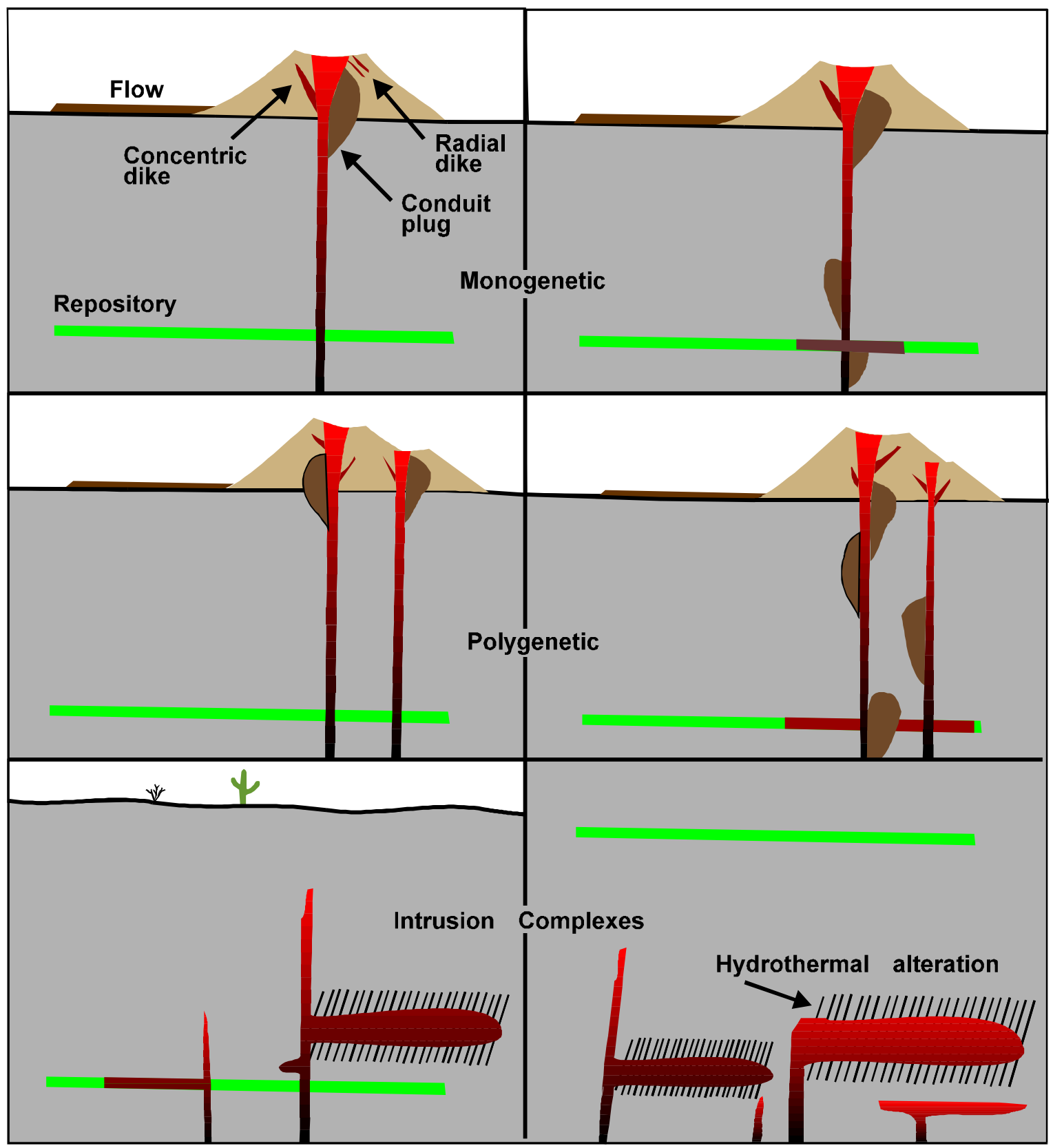

Fig. 1.1. Schematic diagrams of eruption and intrusion scenarios for potential magmatic activity in the Yucca Mountain region.

Each chapter of this report is written purposefully to stand alone. Sufficient background discussion and reference material are presented in each chapter so it can be read separately. To facilitate access to background material, we provide a reference list at the end of each section. This organization leads to some repetition of information, but it allows the reader to focus on selected topics of interest without having to read the entire report. The most important chapters for understanding the volcanism issue are Chapters 1, 2 and 7. Chapters 3, 4, 5, and 6 provide extended background information on specific topics. 
Appendix 1.1 Chapter 1 of Crowe et al. (1995) - volcanism status report

The following conclusions concerning the risk of volcanism for the Yucca Mountain site of the potential repository are presented early in order to guide the reader to relevant chapters for further information. A major goal is to encourage discussion about the completeness or validity of the conclusions in order to resolve some volcanism issues by illuminating any differences of opinion that may exist and identifying any gaps in the logic of the arguments used. We are still in the site characterization phase of studies and have continuing opportunities to collect focused data to resolve different views that affect probabilistic volcanic risk assessment. We recognize also that no attempt to synthesize data and complex arguments will be fully acceptable to all readers. By presenting the volcanism work and conclusions in a single report, we hope to facilitate identification of any parts of the work that may be unacceptable, as well as identify topics that may benefit from further study or modification.

Stated briefly, the major conclusions and perspectives of this volcanism status report are

1. The absence of post-Miocene silicic volcanism in the YMP makes the recurrence probability so low that the risk of silicic volcanism is insignificant for the potential Yucca Mountain site. No additional information is needed to resolve this issue other than an evaluation of the results of drilling of exploratory holes at aeromagnetic anomaly sites identified as potential buried volcanic centers or intrusions to determine if the anomaly sites are produced by Pliocene or Quaternary silicic volcanic rocks.

2. The occurrence probability of future volcanic event's directly intersecting the repository and dispersing radioactive waste through surface eruptions is low-mean and median values are slightly greater than $10^{-8}$ events per $y r$. This conclusion supports the judgments that the potential Yucca Mountain site is not disqualified solely because of the risk of a future volcanic eruption through the site. The logic, supporting data, and risk simulation modeling for this conclusion are presented in Chapter 7.

3. The judgment of a low probability of magmatic disruption of the potential Yucca Mountain site is not final. It will be tested constantly and reformed, if required, through the full process of site characterization. Alternative models will continue to be developed and tested to decide if they invalidate any conclusions or any steps leading to the conclusions. Lists and discussion of alternative models for the recurrence rate and structural controls of sites of basaltic volcanism are described in Chapters 3 and 7.

4. The uncertainty of estimates of the probability of magmatic disruption of the repository, the controlled area, and the YMR can be constrained by considering both (1) multiple alternative chronology models and (2) multiple eruptive and structural models of basaltic volcanism. Bounds on the distribution of these data can be established through comparison with analogous basaltic volcanic fields. The uncertainty of this information is conveyed by presenting the data as cumulative probability distributions. The data and background information explaining the derivation of cumulative probability distributions are presented in Chapter 7.

5. The uncertainty of the estimations of the probability of magmatic disruption is sufficiently large that no major classes of volcanic scenarios can currently be eliminated from consideration for their contribution to the cumulative releases of the waste isolation system during 10,000 yr. All volcanic events will be considered in studies of the performance of the waste isolation system of the potential Yucca Mountain site. 
Appendix 1.1 Chapter 1 of Crowe et al. (1995) - volcanism status report

6. The conclusions presented for parts of the volcanism issue do not imply prejudgment of the information. The basic premise of scientific research is continuous testing of models. The best approach to establishing the validity of a conclusion is through repeated attempts to disprove either the conclusion or its assumptions. By stating early judgments concerning the volcanism issue, we can extend the process of attempting to disprove. Additionally, if the site should be disqualified because of the risk of volcanism, then it is prudent to do so immediately.

7. The conclusions of this report are presented primarily to solicit formal interactions and comments from interested parties. It is important to determine now, if there are disagreements with the methodology and the logic of the approaches used, if there are

flaws in the assumptions, or if the conclusions are incorrect or supported inadequately. The logic, the methodology, and the results of probabilistic risk assessment of volcanism are an important part of performance assessment studies that will provide the basis for judging the suitability of the site should it be submitted for a license application. The basis for estimation of the probability of magmatic disruption of the repository, the controlled area, and the region needs to be examined. Are the assumptions and conclusions of the estimations valid? Are supporting data sufficient to draw conclusions? Have data been ignored? Are alternative models omitted from the analyses? It is critical to start a questioning period immediately.

8. A secondary goal of this report is to subject the volcanism studies and conclusions to the scrutiny of the scientific community by publishing it in the open literature.

9. Important topics of continuing work in volcanism studies are drilling of aeromagnetic anomalies; completion of field, geochronology, and geochemistry studies; and assessment and analog comparisons of the magmatic evolution Crater Flat volcanic zone. Revised probability calculations will incorporate the results of this work. Probability calculations will be completed for the probability of polygenetic activity at existing volcanic centers and for the formation of polygenetic volcanic clusters. These topics are discussed in Chapters 2, 4, 7, and 8.

10. A major emphasis of future volcanism studies will be on assessing eruptive and subsurface effects of volcanic activity. This work is not described in this volcanism status report. It is discussed in Study Plan 8.3.1.8.1.2 (Valentine et al. 1993b).

\section{References}

Bolt, B. A., W. L. Horn, G. A. Macdonald, and R. F. Scott, Geological Hazards (SpringerVerlag, New York, 1975), 328 p.

Briggs, J., and F. D. Peat, Turbulent Mirror (Harper and Row, New York, 1989), 222 p.

Casti, J. L., Searching for Certainty (William Morrow and Comp., New York, 1990), 496 p.

Crowe, B. M., "Volcanic Hazard Assessment for Disposal of High-Level Radioactive Waste," in Active Tectonics: Impact on Society (National Academy Press, Washington, DC., 1986), Chap. 16, p. 247-260. 
Appendix 1.1 Chapter 1 of Crowe et al. (1995) - volcanism status report

Crowe, B. M., "Basaltic Volcanic Episodes of the Yucca Mountain Region ," in Proceedings High-Level Radioactive Waste Management Conference, Las Vegas, Nevada, (American Nuclear Society, La Grange Park Illinois, 1990), Vol. 1, pp. 65-73.

Crowe, B. M., and W. J. Carr, "Preliminary Assessment of the Risk of Volcanism at a Proposed Nuclear Waste Repository in the Southern Great Basin," U.S. Geological Survey Open-File Report 80-375, 15 p. (1980).

Crowe, B. M., M. E. Johnson, and R. J. Beckman, "Calculation of the Probability of Volcanic Disruption of a High-Level Radioactive Waste Repository Within Southern Nevada, U.S.A.," Radioactive Waste Management 3, 167-190 (1982).

Crowe, B. M., D. T. Vaniman, and W. J. Carr, "Status of Volcanic Hazard Studies for the Nevada Nuclear Waste Storage Investigations," Los Alamos National Laboratory Report LA-9325-MS 47 p (1983a).

Crowe, B. M., S. Self, D. Vaniman, R. Amos, and F. Perry, “Aspects of Potential Magmatic Disruption Of A High-Level Radioactive Waste Repository In Southern Nevada.," Journal Geology 91, 259-276 (1983b).

Crowe, B. M., R. Picard, G. Valentine, and F. V. Perry, "Recurrence Models of Volcanic Events: Applications to Volcanic Risk Assessment," in Proceedings High-Level Radioactive Waste Management Conference, Las Vegas, Nevada, (American Nuclear Society, La Grange Park Illinois, 1992) 2, pp. 2344-2355.

Crowe, B.M., F.V. Perry, G.A. Valentine, P.C. Wallmann and R. Kossik, "Simulation Modeling of the Probability of Magmatic Disruption of the Potential Repository Yucca Mountain Site," in Proceedings Site Characterization and Model Validation Focus'93 Symposium Volume (American Nuclear Society, La Grange Park, Illinois, 1993), pp. 182-191.

DOE (U.S. Department of Energy), "Environmental Assessment: Yucca Mountain Site, Nevada Research and Development Area, Nevada," Office of Civilian Radioactive Waste Management report DOE/RW-0073, (1986).

DOE (U.S. Department of Energy), "Site Characterization Plan, Yucca Mountain Site, Nevada Research and Development Area, Nevada," Office of Civilian Radioactive Waste Management report DOE/RW-0199, (1988).

Dubois, J., and J. L. Cheminee, "Fractal Analysis of Eruptive Activity of Some Basaltic Volcanoes," Journal Volcanology Geothermal Research 45, 197-208 (1991).

Devaney, R. L., "Chaotic Explosions in Simple Dynamical Systems," in The Ubiquity of Chaos, S. Krasner, Ed., (American Association Advance Science, Washington, DC. 1990), Chapter 1.

Lewis, H. W., Technological Risk (W. W. Norton and Company, Inc., New York, 1990), 353 p.

Link, R., S. E. Logan, H. S. Ng, F. A. Rockenbach, and K. J. Hong, Parametric Studies of Radiological Consequences of Basaltic Volcanism," Sandia National Laboratories Report SAND 81-2375, 219 p., (1983).

Moon, F. C., Chaotic and Fractal Dynamics (John Wiley \& Sons, Inc., New York, 1992), 508 p. 
Appendix 1.1 Chapter 1 of Crowe et al. (1995) - volcanism status report

National Research Council, "Ground Water at Yucca Mountain, How High Can It Rise?," Final Report of the Panel on Coupled Hydrologic/Tectonic/Hydrothermal Systems at Yucca Mountain (National Academy Press, Washington, DC., 1992), 231 p.

Peitgen, H.-O., H. Jurgens, and D. Saupe, Chaos and Fractals: New Frontiers of Science (Springer-Verlag, New York, 1992), 984 p.

Perry, F. V., and B. M. Crowe, "Geochemical Evidence for Waning Magmatism and Polycyclic Volcanism at Crater Flat, Nevada," in Proceedings High Level Radioactive Waste Management Conference, Las Vegas, Nevada, (American Nuclear Society, La Grange Park, Illinois, 1992),Vol. 2, pp. 2356-2365.

Shaw, H. R., “Uniqueness of Volcanic Systems," U.S. Geological Survey Professional Paper 1350, pp. 1357-1394 (1987).

Sornette, A., J. Dubois, J. L. Cheminee, and D. Sornette, “Are Sequences of Volcanic Eruptions Deterministically Chaotic?” Journal Geophysical Research 96, 11931-11945 (1991).

Stewart, I., Does God Play Dice (Blackwell, Cambridge, Massachusetts, 1989), 348 p.

Swanson, D. A., T. J. Casadevall, D. Dzurisin, R. T. Holcomb, C. G. Newhall, S. D. Malone, and C. S. Weaver, "Forecasts and Predictions of Eruptive Activity at Mount St. Helens, 1975-1984," Journal Geodynamics 3, 397-423 (1985).

Tazieff, H. and J. C. Sabroux, Forecasting Volcanic Events (Elsevier, Amsterdam, 1983), 635 p.

Turcotte, D.L., Fractals and Chaos in Geology and Geophysics (Cambridge, University Press, New York, 1992), 221 p.

United Nations Educational, Scientific, and Cultural Organization, The Surveillance and Prediction of Volcanic Activity, (UNESCO, Paris, 1971), 166 p.

Valentine, G.A., B.M. Crowe, And F.V. Perry, "Physical Processes and Effects of Magmatism in the Yucca Mountain Region," in Proceedings High Level Radioactive Waste Management Conference Las Vegas, Nevada, (American Nuclear Society, La Grange, Illinois, 1992) Vol. 3, pp. 234-2355.

Valentine, G.A., K.M. Growes, C.W. Gable, F.V. Perry And B.M. Crowe, "Effects of Magmatic Processes on the Potential Yucca Mountain Repository: Field and Computational Studies," in Proceedings Focus'93 Symposium Volume, (American Nuclear Society, La Grange, Illinois, 1993a) pp. 167-173.

Valentine, G.A., B. M. Crowe, and F.V. Perry, "Study Plan 8.3.1.8.1.2 Physical Processes of Magmatism and Effects on the Potential Repository," YMP-LANL-SP-8.3.1.8.1.2, Los Alamos National Laboratory (1993b).

Wallmann P.C., I. Miller, and R. Kossik, “Assessment of Volcanic and Tectonic Hazards to High Level Radioactive Waste Repositories," in Proceedings High Level Radioactive Waste

Management, Las Vegas, Nevada, (American Nuclear Society, La Grange, Illinois, 1993), Vol. 4, pp. 188-195. 
Appendix 1.1 Chapter 1 of Crowe et al. (1995) - volcanism status report

Younker, J. L., W. B. Andrews, G. A. Fasano, C. C. Herrington, S. R. Mattson, R. C. Murray, L. B. Ballou, M. A. Revelli, L. E. Shephard, W. W. Dudley, D. T. Hoxie, R. J. Herbst, E. A. Patera, B. R. Judd, J. A. Docka, and L. D. Rickertsen, "Report of the early site suitability evaluation of the potential repository site at Yucca Mountain, Nevada," Science Applications International Corporation Report SAIC-91/8000 (1992). 


\title{
CHAPTER TWO
}

\section{Geology and Geochronology of Basaltic Volcanism in the Yucca Mountain Region}

\author{
Frank V. Perry \\ Bruce M. Crowe \\ Earth and Environmental Sciences Division, Los Alamos National Laboratory \\ Stephen G. Wells \\ Quaternary Sciences Center, Desert Research Institute, Reno \\ Les D. McFadden \\ John W. Geissman \\ Department of Earth and Planetary Sciences, University of New Mexico \\ Jane Poths \\ Mike T. Murrell \\ Chemical Science and Technology Division, Los Alamos National Laboratory \\ Matthew T. Heizler \\ New Mexico Bureau of Mines and Mineral Resources, Socorro \\ Lynn M. Bowker \\ College of Law, University of Wyoming \\ Kean P. Finnegan \\ Greg A. Valentine \\ Earth and Environmental Sciences Division, Los Alamos National Laboratory
}

\section{Summary}

\section{FY96 \& FY97 revisions}

This chapter includes most of the original text, figures, and tables of chapter 2 of Crowe et al. (1995). Descriptions of geochronology results in the original text were corrected if they did not accurately represent the original data sources, although in many cases the original data has been superseded by newer data. This chapter includes significant new data (particularly geochronology data) and interpretations from late FY95, FY96, and FY97 not included in chapter 2 of Crowe et al. (1995). New text, highlighted in boxes and displayed in a different font, is interspersed throughout the original text. Some of the original tables in Chapter 2 of Crowe et al. (1995) have been updated or deleted to reflect the latest geochronology data. Figures 2.A, 2.B, and 2.C and Tables 2.A - 2.D have been added to present new geochronology data. Appendices $2.1-2.4$ present complete ${ }^{40} \mathrm{Ar} /{ }^{39} \mathrm{Ar}$ analytical results for post-Miocene basalts of the Yucca Mountain region (YMR) and paleomagnetic data for Lathrop Wells.

The main new data presented are age determinations of post-Miocene centers in the Yucca Mountain region. New ${ }^{40} \mathrm{Ar} /{ }^{39} \mathrm{Ar}$ ages are presented for the basalts of Buckboard Mesa, Crater Flat, Sleeping Butte, and Lathrop Wells. New U-Th disequilibrium ages and thermoluminescence (TL) ages are presented for basalt of Lathrop Wells. Revised ${ }^{3} \mathrm{He}$ ages (Table 2.4) are presented for the basalt of Lathrop Wells, based on new production rate data from Cerling and Craig (1994). These new data supersede 
corresponding data presented in any previous Los Alamos reports (e.g., Crowe et al. [1995] and Los Alamos Milestone 4049). A major new conclusion of the geochronology studies is that the age of the Lathrop Wells center can be confidently interpreted to be $\sim 75 \pm 10 \mathrm{ka}$, with the possible exception of the youngest stratigraphic unit, which U-Th data indicate may be as young as $\sim 50 \mathrm{ka}$.

Trenching results at Sleeping Butte and Lathrop Wells completed in late FY95 provide new information on the eruptive history of these volcanic centers and potentially resolve some of the stratigraphic complexity at Lathrop Wells. Trenching of the crater of the main scoria cone at Lathrop Wells indicates that the cone is more erosionally modified than previously thought. This result, combined with geochemical modeling indicating that the Qs4 tephras are probably pedogenically altered tephra that may have been derived from the main cone, leads us to conclude that the Qs4 tephras probably are a reworked deposit and not a primary Holocene volcanic deposit. Greater erosional modification of the main cone also suggests that perceived erosional differences between the main cone and the Qs2 scoria fall-sheet may not be significant.

Based on new field study and geochronology results, five alternative models are presented for the evolution of the Lathrop Wells volcanic center. Weighting each of these models for relative probability, we conclude that there is a $70 \%$ probability that Lathrop Wells is a complex monogenetic center and a $30 \%$ probability that it is polygenetic.

Yucca Mountain is a linear mountain range, which is composed of Miocene ignimbrite erupted from the Timber Mountain-Oasis Valley (TM-OV) caldera complex, the major silicic complex of the southwest Nevada volcanic field. Miocene silicic volcanism in the field was succeeded by late Miocene/Quaternary basaltic volcanic activity. This basaltic activity is divided into two episodes: basalt of the Silicic episode (BSE) that occurred during the waning stage of silicic volcanism and Postcaldera basalt (9 million years [Ma] to Quaternary). These two major episodes of basaltic volcanism have been studied as part of the Yucca Mountain Site Characterization Project (YMP). The levels of detail of the studies vary with the age of the volcanic activity. The most detailed studies are of the Pliocene and Quaternary (4.8 to 0.1 Ma) basaltic volcanic centers because they provide the most representative record of the nature of the most recent volcanic activity in the Yucca Mountain region (YMR) and the most important data for assessing the risk of future volcanism.

The BSE occurs in three major geographic groups: (1) basalt exposed in the moat zone of the Timber Mountain caldera, (2) basalt near and flanking the Black Mountain caldera, and (3) basalt of the YMR. The Postcaldera episode includes the Older postcaldera basalt (OPB) that occurs north and northeast of Yucca Mountain and the Younger postcaldera basalt (YPB) that crops out west, southwest, and south of Yucca Mountain (except the basalt of Buckboard Mesa). The OPB consists of the $8 \mathrm{Ma}$ basalt of Rocket Wash, the basalt of Pahute Mesa ( 9 Ma), the basalt of Paiute Ridge (8.0-8.7 Ma), the basalt of Scarp Canyon (8.7 Ma), the basalt of Frenchman Flat (8.6 Ma), and the basalt of Nye Canyon (6.5-7.0 Ma). Each basalt unit is a relatively smallvolume basalt center $\left(<1 \mathrm{~km}^{3}\right)$ formed by clusters of scoria cones with associated lava flows. The centers formed at or along basin-range faults and at the intersection of basin-range faults and ringfracture zones of caldera complexes, except for the basalt of Nye Canyon. The latter basalt unit forms a northeast-cluster of centers that does not follow local structure. Two centers of the basalt 
of Nye Canyon formed partly from hydrovolcanic eruptions. The basalt of Paiute Ridge consists of dissected scoria cones and flows underlain by a complex of sills, dikes, and lopolithic intrusions.

The YPB consists of seven clusters of Pliocene and Quaternary volcanism; six of the clusters occur in a narrow northwest-trending zone called the Crater Flat volcanic zone (CFVZ). The oldest and largest volume basaltic volcanic center of the YPB is the basalt of Thirsty Mesa, a newly recognized Pliocene volcanic center. It consists of three coalesced, small scoria cones surmounting a lava mesa. The age of the unit is $4.8 \mathrm{Ma}$. A negative aeromagnetic anomaly was drilled by a private company and has been shown to be a buried basalt center of 3.9 Ma. The 3.7-Ma basalt of southeast Crater Flat comprises six north-trending dissected scoria cones and associated moderatevolume lava flows. It is the largest volume Plio/Quaternary basalt in the Crater Flat alluvial basin. The unit formed largely from Hawaiian fissure eruptions accompanied by outpouring of sheet-like lobes of $a a$ lava flows. The basalt of Buckboard Mesa (2.9 Ma) crops out in the moat zone of the Timber Mountain caldera, northeast of Yucca Mountain. Nearly $1 \mathrm{~km}^{3}$ of lava vented from a small scoria cone and an associated northwest-trending fissure located southeast of the scoria cone. The Quaternary basalt of Crater Flat consists of an arcuate alignment of basalt centers extending along the axis of Crater Flat. Individual centers of the alignment include, from southwest to northeast, the Little Cones, the Red Cone, the Black Cone, and the Makani Cone centers. Greater than $90 \%$ of the volume of the four centers is contained in the scoria cone and lava units of the Red Cone and Black Cone centers. The Little Cones center consists of two closely spaced, small scoria cones. Lava flows were extruded from and breached the south wall of the southwest center. The Little Cones yield K-Ar age determinations of 1.1 to $0.76 \mathrm{Ma}$. These ages are consistent with the degree of dissection, the degree of horizon development in soils, and with the magnetic polarity of the center. The Red Cone and Black Cone centers are analogous volcanic landforms with similar eruptive histories. Each consists of a main scoria cone surmounted by a crater filled with agglutinated spatter, large lava blocks, and scoria. The main scoria cones of both centers are flanked to the south by eroded scoria mounds that vented $a$ a lava flows. Potassium-argon ages of between 0.84 and $1.55 \mathrm{Ma}$ were reported for Red Cone; radiometric ages for Black Cone range between 0.8 and 1.1 Ma. Soil and geomorphic data are consistent with these ages. The Makani center is a deeply dissected remnant of a scoria cone and lava flow. Potassium-argon age determinations for this center range from 1 to $1.66 \mathrm{Ma}$. A continuing area of controversy for the Quaternary basalt of Crater Flat is the eruptive models of individual centers, and the age differences between each center. Exploratory data analyses of $\mathrm{K}-\mathrm{Ar}$ and ${ }^{40} \mathrm{Ar} /{ }^{39} \mathrm{Ar}$ age determinations using standard statistical methods (with outliers removed) indicated that the mean age of all centers is $1.0 \pm 0.1 \mathrm{Ma}$. Paleomagnetic data are consistent with the findings that the centers are all close in age and formed from a single pulse of magma, but they do not provide conclusive proof of this. Field, geomorphic, soil, and petrologic data suggest some of the centers could be polygenetic and might differ slightly in age. The difference in ages of the centers must be less than the detection limits of $\mathrm{K}-\mathrm{Ar}$ and ${ }^{40} \mathrm{Ar} /{ }^{39} \mathrm{Ar}$ chronology methods (0.1 Ma).

The Sleeping Butte centers are located $45 \mathrm{~km}$ northwest of Yucca Mountain. They consist of two centers: the southwest Little Black Peak center and the northeast Hidden Cone center. Each consists of a small-volume main scoria cone flanked by blocky $a a$ lava flows that vented from radial dikes at the base of the cone. The Little Black Peak center appears from field, geomorphic, petrologic, and paleomagnetic data to be a simple monogenetic center with a K-Ar age of about 320 to 380 thousand years (ka). The Hidden Cone center is more complex and may have formed from at least two temporally distinct eruptions. The age of the major volume of the Hidden Cone center is also about 320 to $380 \mathrm{Ma}$. The scoria-fall eruptions that mantled the main cone of the center may be as young as late Pleistocene. 
The Lathrop Wells volcanic center is the youngest and most carefully studied basaltic volcanic center of the YMR. The center is located at the south end of Yucca Mountain, near the intersection of northwest- and northeast-trending fault systems; most of the vents are aligned along northwest-trending fissure systems. The basalt center formed from multiple time-distinct eruptions that comprise four chronostratigraphic units. The oldest chronostratigraphic unit (I) consists of four groups of lava flows and local pyroclastic deposits marking the vents for the lava flows. These volcanic deposits occur along multiple, northwest-trending fissures located south, beneath, north, and northeast of the main cone. The scoria and spatter deposits of chronostratigraphic unit I were modified extensively by erosion prior to formation of chronostratigraphic unit II.

Chronostratigraphic unit II consists of two sets of lava and pyroclastic deposits. The largest volume lava of the center was erupted from a northwest-trending fissure that is coparallel to a northwest-trending normal fault, which displaces the Timber Mountain tuff but not the basaltic deposits. Small-volume lobes of lava were erupted from a west/northwest-trending fissure that extends from the north end of the northwest-trending fissure system. A short, northwest-trending fissure marked by scoria mounds formed at the northeast base of the main scoria cone. Widespread scoria-fall and pyroclastic-surge deposits were erupted from vents that are inferred to be concealed beneath the modern main cone. The eruptive events of chronostratigraphic unit III formed most of the main scoria cone and small-volume lobes of a blocky a $a$ lava flow that erupted from a vent northeast of the main cone. Chronostratigraphic unit IV includes small-volume eruptions from a cluster of inferred small satellite vents south of the main cone that have been removed by commercial quarrying. The eruptive events of this chronostratigraphic unit have been established through the identification of local tephra beds that have distinctive major- and trace-element chemistry.

The delineation of individual chronostratigraphic units has been established on the basis of detailed field, stratigraphic, geomorphic, and soils studies. The individual chronostratigraphic units can be discriminated uniquely by their major- and trace-element geochemical compositions. The chemistry of the units is inconsistent with a simple monogenetic eruption model and instead requires formation from multiple magma batches consistent with a polygenetic classification of the volcanic center (multiple, time-distinct volcanic eruptions).

The difficult problem of establishing the age of the multiple volcanic events at the Lathrop Wells volcanic center has been approached by applying multiple geochronology and age-correlated methods (K-Ar, U-Th disequilibrium, cosmogenic helium, thermoluminescence (TL), geomorphic, soils, paleomagnetic, and petrologic studies). Recent results show some convergence in the range of ages obtained using the different methods, but the data remain consistent with multiple eruptive and chronology models. Conventional whole-rock K-Ar ages of lava units of the Lathrop Wells volcanic center give a mean age of $137 \pm 52(1 s) \mathrm{ka}$. The age is obtained by averaging age determinations from chronostratigraphic units of probable different ages. Moreover, the age determinations show a positive correlation between percentage radiogenic argon and the measured age of the sample. Published ${ }^{40} \mathrm{Ar} /{ }^{39} \mathrm{Ar}$ age determinations of the same rock samples as the conventional K-Ar data set also show a positive correlation between percentage radiogenic argon and age. The mean age of all measured ${ }^{40} \mathrm{Ar} /{ }^{39} \mathrm{Ar}$ age determinations is $162 \pm 62(1 \mathrm{~s}) \mathrm{ka}$ and is again obtained by averaging age determinations from separate chronostratigraphic units. At best, the $\mathrm{K}-\mathrm{Ar}$ and ${ }^{40} \mathrm{Ar} /{ }^{39} \mathrm{Ar}$ ages provide maximum estimates of the ages of the two oldest chronostratigraphic units (I and II). The data sets cannot be used to establish the range in age of the volcanic center or to discriminate the ages of individual chronostratigraphic units. Uraniumthorium disequilibrium age determinations have been obtained for lavas of chronostratigraphic units I and III. Mass spectrometric analyses of separated phases yielded isochrons with ages of 135 
$+20-15$ and $125+45-30(1 \sigma) \mathrm{ka}$, in apparent agreement with the K-Ar and ${ }^{40} \mathrm{Ar} /{ }^{39} \mathrm{Ar}$ age determinations. Problems with the results of U-Th disequilibrium measurements include 1) a small degree of U-Th fractionation in measured phases, and 2) a similarity in measured ages of volcanic units that are inferred to be of probable different ages.

The ages of the chronostratigraphic units at Lathrop Wells center have also been estimated by measuring the accumulation of cosmogenic ${ }^{3} \mathrm{He}$ in 25 surface samples. The preferred ${ }^{3} \mathrm{He}$ ages of chronostratigraphic unit I range from about 80 to $90 \mathrm{ka}$, but represent minimum ages because the sampled deposits were covered by scoria-fall deposits of chronostratigraphic unit II. The ${ }^{3} \mathrm{He}$ ages of chronostratigraphic unit II range from 80 to $100 \mathrm{ka}$. Deposits of chronostratigraphic unit III show the greatest range in ${ }^{3} \mathrm{He}$ ages (30-65 ka) because many of the samples were collected from the main scoria cone, a nonresistant geomorphic feature. The age of the unit may be $>65 \mathrm{ka}$ if the ages are interpreted as minimum ages. This interpretation does not explain, however, the wide variations $(40 \%)$ in replicate ages for samples collected from the geomorphically unmodified main cone. A sample collected from the interior of a lava flow yielded an age of about 6 ka consistent with a zero age. TL age determinations give reproducible and consistent ages of 4 to $8 \mathrm{ka}$ for tephra units of chronostratigraphic unit IV that are interbedded with soils showing horizon development. TL ages of about $30 \mathrm{ka}$ for baked sediments beneath lava of chronostratigraphic unit II are inconsistent with the age determinations of all other chronology methods.

Geomorphic studies of the degree of dissection of deposits of the Lathrop Wells volcanic center are consistent with an age of no older than $20 \mathrm{ka}$ for the youngest events (chronostratigraphic units III and IV) at the center. This is consistent with the TL ages of the youngest tephra units but is somewhat younger than the measured ${ }^{3} \mathrm{He}$ ages of the main cone. The systematic differences in degree of erosion of volcanic landforms of chronostratigraphic units I, II, and III require a time difference between each unit. Paleomagnetic data have been obtained to augment studies by Champion (1991) and Turrin et al. (1991b) and now have been measured for all chronostratigraphic units at the volcanic center. The between-site dispersion of directions of the primary magnetization of units differs considerably for some sites because of a combination of difficulty in sampling intact material and lightning strikes. Paleomagnetic data obtained are not dissimilar from those reported by Turrin et al. (1991b). However, the data do not support the contention that individual eruptive features have unique paleomagnetic signatures that can be confidently separated from other eruptive features. Eruptive features of the center have recorded directions of the latest Quaternary geomagnetic field that are well within the expected one-sigma range of paleosecular field variation about the spin-axis direction and have limited application to stratigraphic studies. There is no indication of a single volcanic event occurring during a period of unusual geomagnetic activity.

The field relations of the volcanic units are well constrained. The chronology of the units remains uncertain, and the existing data must be used cautiously to test the field relations. Three alternative models are presented for the eruptive history of the Lathrop Wells center. These include, respectively, a four-event eruption model (>130, 80-90, 65, and 4-8 ka), a three-event eruption model (120-140, 65 and 4-8 ka), and a two-event eruption model (120-140, 4-8 ka). 


\section{Introduction}

Yucca Mountain is a linear range located in southern Nevada, near the south end of the Great Basin physiographic province. The range extends from Highway 95 northward to Yucca Wash (Figure 2.1). Yucca Mountain is broken into individual blocks separated by linear valleys. These physiographic features were produced by sets of north and northeast-trending faults that have displaced fault-bounded blocks down to the west accompanied by gentle $\left(6-7^{\circ}\right)$ east-directed tilting (Scott and Bonk, 1984). The linear valleys mark generally the surface traces of the block-bounding faults.

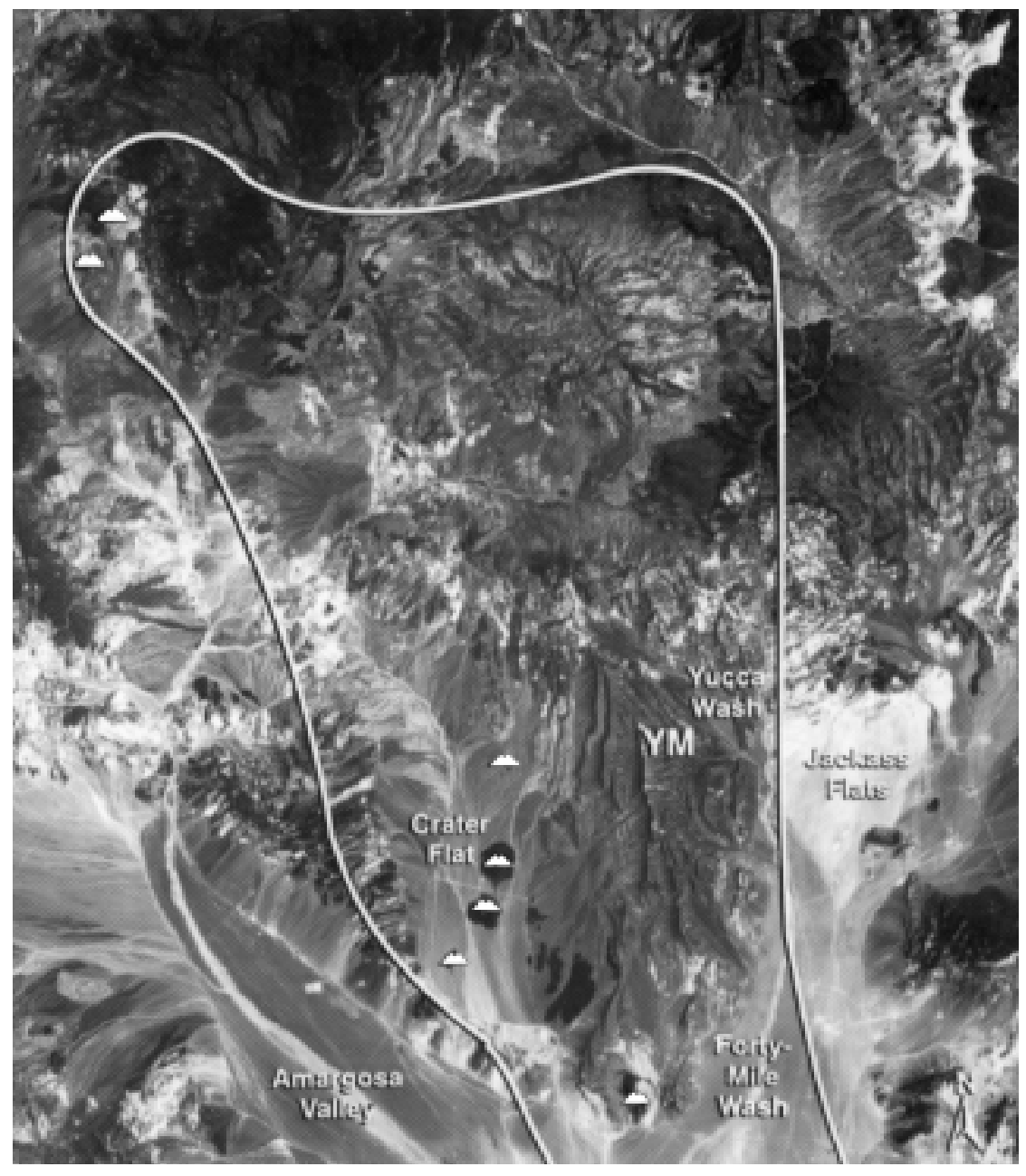

Figure 2.1. Digital satellite image showing the location of the Yucca Mountain site and Quaternary volcanic centers in the YMR. The YMR is defined as the area of the irregular polygon that encloses the Yucca Mountain site and the Pliocene and Quaternary basaltic volcanic centers in the region. Yucca Mountain is a linear range located on the southwest edge of the Nevada Test Site, about 160 $\mathrm{km}$ northwest of Las Vegas, Nevada. The mountain extends from Highway 95 on the south to Yucca Wash on the north, a distance of about $25 \mathrm{~km}$. The mountain is bounded on the east by Jackass Flat (the western boundary of Jackass Flat is defined by Fortymile Wash), on the west by Crater Flat, and on the south by the Amargosa Valley. An approximately 6- $\mathrm{km}^{2}$ area in the center part of Yucca Mountain has been identified as the exploratory block (DOE, 1988). It is surrounded by the controlled area, about $86 \mathrm{~km}^{2}$. There are seven Quaternary basaltic volcanic centers in the Yucca Mountain area $(<1.6 \mathrm{Ma})$. These centers are noted by the special symbol on Figure 2.1. 
Early exploration studies of the YMR consisted primarily of drilling of continuously cored boreholes for geologic studies and large diameter boreholes for hydrologic investigations (Department of Energy [DOE], 1986, 1988). The drilling was supplemented by surface mapping and geophysical studies. These combined studies lead to the identification of a central part of the range as the most structurally intact segment. A 6- $\mathrm{km}^{2}$ area was designated as the exploratory block (Figure 2.1), and an area surrounding the exploratory block $\left(86 \mathrm{~km}^{2}\right)$ was designated as the controlled area.

The volcanic rocks that formed Yucca Mountain were emplaced during eruptive cycles of the TM-OV caldera complex (Christiansen et al., 1977; Byers et al., 1976; Broxton et al., 1989; Byers et al., 1989). The Yucca Mountain site itself, including the surface rocks and the rocks extending to the depth of the potential repository horizon, comprise volcanic units of the Paintbrush Tuff, which is a major outflow ignimbrite of the Claim Canyon caldera segment of the TM-OV caldera complex (Lipman et al., 1966a).

The voluminous record of silicic volcanism in the YMR is part of an extensive, timetransgressive pulse of mid-Cenozoic volcanism that occurred throughout much of the southwestern United States. The Yucca Mountain range is in the south-central part of a major Cenozoic volcanic field that covered an area exceeding $11,000 \mathrm{~km}^{2}$. The field has been named the Southwestern Nevada Volcanic Field (SNVF) (Christiansen et al., 1977; Byers et al., 1989) (Figure 2.2).

The time-space distribution of volcanic activity in the Basin and Range province has been described by many authors (Armstrong et al., 1969; McKee, 1971; Lipman et al., 1971; Lipman et al., 1972; Christiansen and Lipman, 1972; Snyder et al., 1976; Stewart et al., 1977; Stewart and Carlson, 1978; Christiansen and McKee, 1978; Cross and Pilger, 1978; Smith and Luedke, 1984; Luedke and Smith, 1984; Axen et al., 1993). During the Mesozoic era, magmatism in the cordillera was distributed in linear belts parallel to the continental margin (Armstrong and Ward, 1991). In the southwestern United States, these belts became locally inactive or disrupted about $80 \mathrm{Ma}$ and formed the Laramide magmatic gap (Armstrong, 1974). Renewed silicic magmatism following the Laramide hiatus initiated about $50 \mathrm{Ma}$ in the northeastern part of the Great Basin. Sites of eruptive activity migrated south and southwest progressively in time and space across an area of Nevada and adjoining parts of Utah (Stewart et al., 1977; Armstrong and Ward, 1991). The loci of eruptive centers during this voluminous silicic volcanism were distributed along arcuate east/westtrending volcanic fronts (Stewart et al., 1977). The leading edge of the migrating front during successive increments of time marked the area of the most intensive volcanic eruptions. There was a dramatic waning of volcanic activity in the lee, or backside, of the front (Stewart et al., 1977) and virtually no volcanic activity ahead of the front. The period of most voluminous silicic volcanic activity in the YMR occurred between 15 to $11 \mathrm{Ma}$. The YMR marks the southern limit of the spread of time-transgressive volcanic activity.

Two significant changes in the regional volcanic and tectonic patterns occurred about 13 to 10 $\mathrm{Ma}$ at the approximate latitude of the YMR. First, the progressive southern migration of volcanism halted. Silicic eruptive activity continued in diminished volumes and migrated predominantly to the southwest and southeast, following less systematic spatial patterns than the preceding silicic volcanic activity. Post-Miocene volcanic activity approached present positions along the east and west margins of the Great Basin (Christiansen and McKee, 1978; Smith and Luedke, 1984). These changed patterns in the migration of volcanism left a conspicuous amagmatic gap extending from the southern edge of the Nevada Test Site south to the latitude of Las Vegas (Figure 2.3). This gap coincides with a major increase in the regional gravity field that forms the southern boundary of the 
gravity low of the Great Basin (Eaton, 1978). This latitude $\left(35^{\circ} \mathrm{N}\right)$ also coincides with the approximate position at 10-20 million years ago of the boundary between the incoherent subducted slab or "slab gap" south of the Mendocino fracture zone and the persisting subducted slab to the north (Severinghaus and Atwater, 1990).

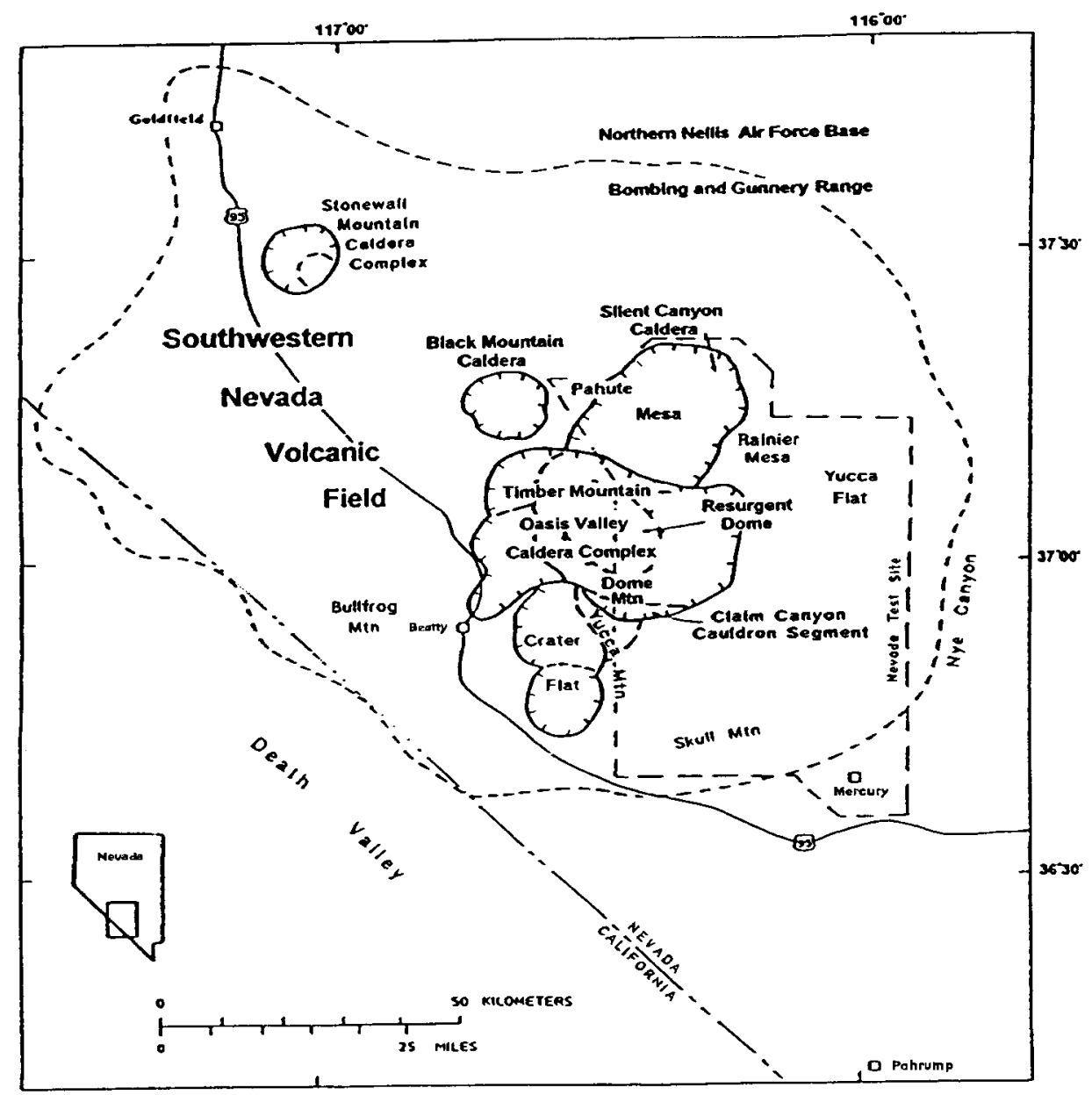

Figure 2.2. The Southwest Nevada Volcanic Field (from Byers et al., 1989). Yucca Mountain is upheld by a thick sequence of ignimbrites derived from multiple caldera-forming, eruptive cycles of the Claim Canyon and TM-OV caldera complexes. The existence of caldera complexes at Crater Flat, which borders Yucca Mountain to the west, is regarded as controversial by some workers.

Second, at about 10 million years ago, a transition in the composition of volcanic activity occurred. This change is consistent with a time-transgressive switch across the southwestern United States from predominantly silicic volcanism to bimodal basalt-rhyolite volcanism (fundamentally basaltic volcanic activity) (Christiansen and Lipman, 1972). The exact timing of this transition in the YMR cannot be defined precisely. It may be marked by a transition from near homogeneous quartz latite and rhyolite ignimbrite (>13 Ma) to eruptions of compositionally zoned ash-flow units $(<12 \mathrm{Ma})$ that range from high-silica rhyolite at their base $\left(\mathrm{SiO}_{2}>75 \%\right)$ to quartz latitic caprocks $\left(\mathrm{SiO}_{2}<70 \%\right)$. This transition in the Nevada Test Site region is probably marked by the eruption of the Paintbrush Tuff (Christiansen and Lipman, 1972; Christiansen et al., 1977). Alternatively, the transition may be recorded by the widespread appearance of moderately voluminous basaltic volcanism (Crowe, 1990). The age of this basaltic volcanic activity is 
bracketed between the eruption of the Timber Mountain Tuff (11.2 Ma) and the peralkaline ashflow sheets of the Black Mountain caldera complex (8.5 Ma) (Crowe, 1990).

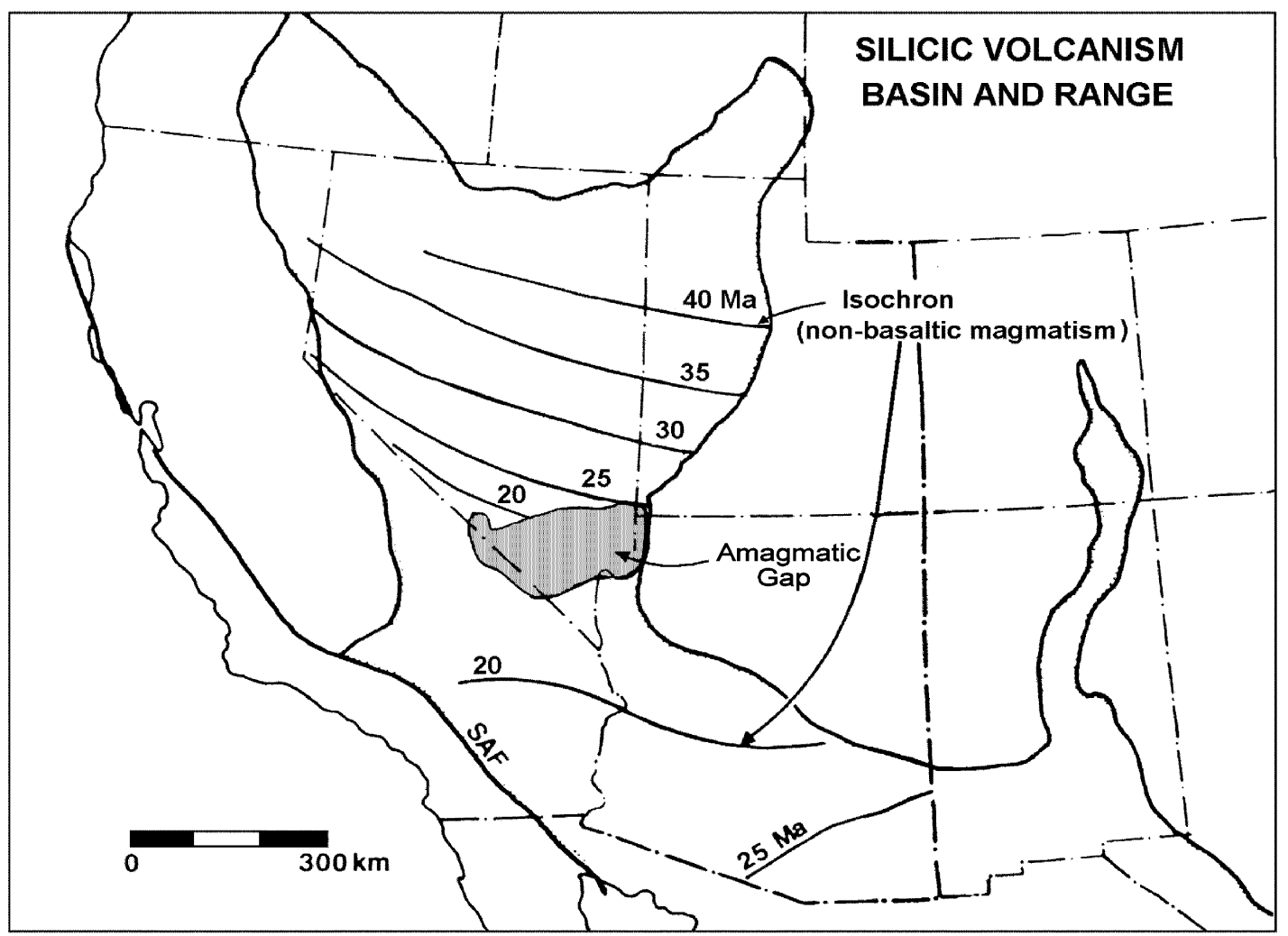

Figure 2.3. Time-transgressive, mid-Cenozoic volcanism of the Basin and Range province (modified from Farmer et al., 1989). Numbered contour lines locate the position of arcuate, migrating fronts of silicic volcanism during increments of Cenozoic time. Yucca Mountain is located at the southern limit of the southern migration mid-Cenozoic silicic volcanism. The YMR borders the north edge of a zone in southern Nevada distinguished by its absence of Mesozoic and Cenozoic volcanism and plutonism. This zone, referred to as the amagmatic gap, includes much of the central Basin and Range subprovince of Wernicke (1992) and Jones et al. (1992).

\section{Basaltic Volcanism: Yucca Mountain Region}

\section{FY96 \& FY97 revisions}

We have restricted the scope of revisions of Chapter 2 of the volcanism synthesis report (Crowe et al., 1995). The following restrictions have been used: 1) only very limited revisions have been made for volcanic rocks older than $5 \mathrm{Ma}$ because this older record of basaltic volcanism is not used in probabilistic volcanic hazard assessment (PVHA) (Crowe et al., 1995; Geomatrix, 1996), 2) for rocks younger than $5 \mathrm{Ma}$, revisions have been made only to those sections that have changed significantly as a result of newly acquired data, and 3) existing text, except for minor corrections, has been retained to provide a record of volcanism investigations, which is particularly important where studies have focused on assessment of alternative volcanism models. 
Field and geochronology data for the basaltic volcanic rocks of the YMR define two episodes (Crowe, 1990). The first episode of bimodal basalt-rhyolite volcanism is called the basalt of the Silicic episode (BSE) and this episode postdates but is close in age to most of the silicic eruptions of the TM-OV complex. For this report, we describe only the basaltic units present in and around the Timber Mountain highland and the YMR. Other basaltic units, associated primarily with the Black Mountain-Stonewall Mountain calderas, are not described.

The second basaltic episode includes spatially scattered, small-volume centers marked by scoria cones and lava flows of alkali basalt. These rocks range in age from $8 \mathrm{Ma}$ to Quaternary. They are divided into two cycles (Crowe, 1990), the Older postcaldera basalt (OPB) and the Younger postcaldera basalt (YPB). The field relations and geochronology of the basalt cycles of the YMR are described in the following sections.

The level of detail of studies of basaltic units of the YMR varies with the age of the volcanic units. Pre-Pliocene basalt units of the region $(>6.5 \mathrm{Ma}$ ) were studied primarily in reconnaissance. The outcrop relations of the units, as depicted on published quadrangle maps of the U.S.

Geological Survey, were checked in the field, and samples were collected of the basalt units. They were examined petrographically and analyzed geochemically (Crowe et al., 1986). The stratigraphic relations of the pre-6.5 Ma basaltic volcanic units were evaluated in the field, and geochronology data (whole-rock K-Ar age determinations) were obtained, where required, to discriminate the ages of the rocks.

By contrast, the basaltic units of the YPB have been the focus of much more detailed studies. All units of this cycle have been mapped or remapped at scales of 1:12,000 to 1:4000, with the exception of the basalt of Thirsty Mesa and the basalt of Buckboard Mesa. The eruptive sequences of individual centers were assessed largely by detailed mapping using new geochronology data (Crowe, 1990; Crowe et al., 1992) aided by petrographic and geochemical analyses of the rocks. Geochronology results from conventional K-Ar age determinations have been supplemented with results from application of age-calibrated geochronology methods to cross check the ages of the youngest Quaternary volcanic centers. The increased level of detail of geologic and geochronologic data as the age of basalt centers decreases is a purposeful attempt to focus the work on assessment of the Pliocene and Quaternary volcanic history of the YMR. It is this part of the geologic record that provides the most important basis for forecasting the risk of future volcanic activity.

Much of the geochronology data for the basalt of the YMR is unpublished or collected before implementation of a fully qualified Quality Assurance program. While these data are of high scientific quality, they do not meet the recent Los Alamos YMP quality assurance requirements. Because of this problem, we present only minor discussion of the nonqualified geochronology data, adding references to publications, if available. In contrast, the fully qualified data are presented in Table 2.1 and are discussed in the text. Again, this treatment of the nonqualified data is not a negative reflection on the scientific quality of the data. If necessary, some of these data will be evaluated with respect to current QA requirements. If the data cannot meet the new QA requirements, it will be used to guide the acquisition of new needed information should the Yucca Mountain site be considered formally as a potential repository site for high-level radioactive waste. 
Table 2.1. ${ }^{40} \mathrm{Ar} /{ }^{39} \mathrm{Ar}$ Ages of Basaltic Volcanic Centers in the YMR ${ }^{1}$

\begin{tabular}{|c|c|c|c|c|c|c|c|c|c|c|c|}
\hline Sample & Laboratory & Geologic Unit & $=\overline{\text { Description }}$ & ${ }^{40} \mathrm{Ar} /{ }^{39} \mathrm{Ar}^{2}$ & ${ }^{37} \mathrm{Ar} /{ }^{39} \mathrm{Ar}{ }^{2}$ & ${ }^{36} \mathrm{Ar} /{ }^{39} \mathrm{Ar}^{2}$ & $\begin{array}{c}{ }^{39} \mathrm{Ar} \\
\left(10^{-13} \mathrm{~mol}\right)\end{array}$ & $\begin{array}{l}{ }^{40} \mathrm{Ar} * \\
\% \text { rad. }\end{array}$ & $\begin{array}{l}\text { Age } \\
\text { (Ma) }\end{array}$ & $(2 \sigma)$ & $\begin{array}{c}\text { Weighted Age } \\
\text { (Ma) }\end{array}$ \\
\hline NE-10-1-91-1-BMC & Lehigh & Thirsty Mesa & $\begin{array}{l}\text { Basal lava flow, } \\
\text { west side }\end{array}$ & $\begin{array}{c}19.58 \\
23.1\end{array}$ & $\begin{array}{l}1.05 \\
1.06\end{array}$ & $\begin{array}{l}0.04 \\
0.05\end{array}$ & $\begin{array}{l}7.47 \\
5.69\end{array}$ & $\begin{array}{l}40.5 \\
33.9\end{array}$ & $\begin{array}{l}4.68 \\
4.68\end{array}$ & $\begin{array}{l}0.04 \\
0.05\end{array}$ & $4.68 \pm .03$ \\
\hline NE-10-1-91-2-BMC & Lehigh & Thirsty Mesa & $\begin{array}{l}\text { Dike, summit scoria } \\
\text { cone }\end{array}$ & $\begin{array}{c}19.29 \\
23.1\end{array}$ & $\begin{array}{l}0.92 \\
0.93\end{array}$ & $\begin{array}{l}0.04 \\
0.05\end{array}$ & $\begin{array}{l}5.22 \\
5.73\end{array}$ & $\begin{array}{l}41.9 \\
35.7\end{array}$ & $\begin{array}{l}4.79 \\
4.96\end{array}$ & $\begin{array}{l}0.05 \\
0.05\end{array}$ & $4.88 \pm .04$ \\
\hline Well 25-1-BMC & Lehigh & Amargosa Valley & Cuttings, drill hole & $\begin{array}{l}23.22 \\
24.92\end{array}$ & $\begin{array}{l}1.48 \\
1.47\end{array}$ & $\begin{array}{l}0.06 \\
0.06\end{array}$ & $\begin{array}{l}4.11 \\
3.34\end{array}$ & $\begin{array}{l}27.8 \\
25.9\end{array}$ & $\begin{array}{l}3.88 \\
3.81\end{array}$ & $\begin{array}{l}0.07 \\
0.08\end{array}$ & $3.85 \pm .05$ \\
\hline CF10FVP & Lehigh & SE Crater Flat & Dike, southern vent & $\begin{array}{c}40.04 \\
29.4\end{array}$ & $\begin{array}{l}2.16 \\
2.18\end{array}$ & $\begin{array}{l}0.12 \\
0.08\end{array}$ & $\begin{array}{l}3.14 \\
4.07\end{array}$ & $\begin{array}{l}14.9 \\
21.1\end{array}$ & $\begin{array}{l}3.58 \\
3.71\end{array}$ & $\begin{array}{l}0.09 \\
0.08\end{array}$ & $3.65 \pm .06$ \\
\hline CF12FVP & Lehigh & SE Crater Flat & $\begin{array}{l}\text { Lava lake, central } \\
\text { vent }\end{array}$ & $\begin{array}{l}30.23 \\
28.71\end{array}$ & $\begin{array}{c}2.3 \\
2.31\end{array}$ & $\begin{array}{l}0.08 \\
0.08\end{array}$ & $\begin{array}{l}3.49 \\
3.99\end{array}$ & $\begin{array}{l}20.9 \\
21.3\end{array}$ & $\begin{array}{l}3.71 \\
3.67\end{array}$ & $\begin{array}{l}0.07 \\
0.06\end{array}$ & $3.69 \pm .05$ \\
\hline CF14FVP & Lehigh & SE Crater Flat & $\begin{array}{l}\text { Lava flow, north } \\
\text { exposure }\end{array}$ & $\begin{array}{l}19.85 \\
17.74\end{array}$ & $\begin{array}{l}2.29 \\
2.32\end{array}$ & $\begin{array}{l}0.05 \\
0.04\end{array}$ & $\begin{array}{l}4.58 \\
9.15\end{array}$ & $\begin{array}{c}32.2 \\
35\end{array}$ & $\begin{array}{c}3.8 \\
3.73\end{array}$ & $\begin{array}{l}0.06 \\
0.04\end{array}$ & $3.75 \pm .04$ \\
\hline BC1FVP & Lehigh & Quat. Crater Flat & $\begin{array}{l}\text { Black Cone, } \\
\text { summit lava lake }\end{array}$ & $\begin{array}{c}89 \\
74.21\end{array}$ & $\begin{array}{l}1.98 \\
1.94\end{array}$ & $\begin{array}{c}0.3 \\
0.25\end{array}$ & $\begin{array}{c}3.8 \\
2.89\end{array}$ & $\begin{array}{l}1.9 \\
2.4\end{array}$ & $\begin{array}{l}1.03 \\
1.07\end{array}$ & $\begin{array}{l}0.21 \\
0.18\end{array}$ & $1.05 \pm .14$ \\
\hline BC3AFVP & Lehigh & Quat. Crater Flat & $\begin{array}{l}\text { Black Cone, } \\
\text { replicate of } \\
\text { BC1FVP }\end{array}$ & $\begin{array}{l}82.31 \\
77.27\end{array}$ & $\begin{array}{c}1.89 \\
2\end{array}$ & $\begin{array}{l}0.27 \\
0.26\end{array}$ & $\begin{array}{l}4.55 \\
2.48\end{array}$ & $\begin{array}{l}2 \\
2\end{array}$ & $\begin{array}{l}1.01 \\
0.91\end{array}$ & $\begin{array}{l}0.21 \\
0.21\end{array}$ & $0.96 \pm 0.15$ \\
\hline BC6FVP & Lehigh & Quat. Crater Flat & $\begin{array}{l}\text { Black Cone, } \\
\text { southern lava flow }\end{array}$ & $\begin{array}{c}27.29 \\
29.1\end{array}$ & $\begin{array}{l}2.05 \\
2.07\end{array}$ & $\begin{array}{l}0.09 \\
0.09\end{array}$ & $\begin{array}{l}3.75 \\
3.45\end{array}$ & $\begin{array}{l}5.9 \\
5.1\end{array}$ & $\begin{array}{l}0.96 \\
0.92\end{array}$ & $\begin{array}{l}0.07 \\
0.07\end{array}$ & $0.94 \pm .05$ \\
\hline BC12FVP & Lehigh & Quat. Crater Flat & $\begin{array}{l}\text { Black Cone, } \\
\text { northern lava flow }\end{array}$ & $\begin{array}{l}33.37 \\
38.14\end{array}$ & $\begin{array}{l}1.62 \\
1.75\end{array}$ & $\begin{array}{l}0.11 \\
0.12\end{array}$ & $\begin{array}{l}4.31 \\
3.94\end{array}$ & $\begin{array}{l}5.4 \\
4.2\end{array}$ & $\begin{array}{l}1.08 \\
0.99\end{array}$ & $\begin{array}{l}0.09 \\
0.12\end{array}$ & $1.05 \pm .08$ \\
\hline CF15FVP & Lehigh & Quat. Crater Flat & $\begin{array}{l}\text { Little Cones, } \\
\text { southern dike }\end{array}$ & $\begin{array}{l}58.88 \\
56.65\end{array}$ & $\begin{array}{l}1.64 \\
1.65\end{array}$ & $\begin{array}{l}0.19 \\
0.19\end{array}$ & $\begin{array}{l}3.65 \\
4.82\end{array}$ & $\begin{array}{l}3.1 \\
2.7\end{array}$ & $\begin{array}{l}1.11 \\
0.93\end{array}$ & $\begin{array}{l}0.14 \\
0.15\end{array}$ & $1.02 \pm 0.10$ \\
\hline LW20FVP & Lehigh & Lathrop Wells & $\begin{array}{l}\text { Q11d, Old Quarry } \\
\text { Flow }\end{array}$ & $\begin{array}{l}29.63 \\
29.62 \\
23.75\end{array}$ & $\begin{array}{l}1.62 \\
1.65 \\
1.63\end{array}$ & $\begin{array}{c}0.1 \\
0.1 \\
0.08\end{array}$ & $\begin{array}{c}5.9 \\
5.98 \\
5.13\end{array}$ & $\begin{array}{l}1.6 \\
1.8 \\
0.7\end{array}$ & $\begin{array}{l}0.28 \\
0.31 \\
0.09\end{array}$ & $\begin{array}{l}0.06 \\
0.08 \\
0.06\end{array}$ & $* * *$ \\
\hline
\end{tabular}

${ }^{1}$ Samples were irradiated at the Ford Reactor, University of Michigan, using ANU K-Ar standard GA1550 biotite as a flux monitor and Fish Canyon biotite as a cross check. J-factor = $0.00033 \pm 1$.

${ }^{2}$ Not corrected for interfering reactions. K correction $\left({ }^{40} \mathrm{Ar} /{ }^{39} \mathrm{Ar}\right)=0.0467 ;$ Ca correction $\left({ }^{36} \mathrm{Ar} /{ }^{37} \mathrm{Ar}\right)=0.0002279 ; \mathrm{Ca} \operatorname{correction}\left({ }^{39} \mathrm{Ar} /{ }^{37} \mathrm{Ar}\right)=0.0007$.

*** Replicate ages are too variable to calculate a meaningful weighted age. 
FY96 \& FY97 revisions

Fifteen new whole-rock ${ }^{40} \mathrm{Ar}{ }^{39} \mathrm{Ar}$ ages were completed in late FY95 and FY96 for younger, post-Miocene basalts of the YMR. These ages were obtained under the Los Alamos Quality Assurance program at either the New Mexico Bureau of Mines (NMBM) or Lehigh University. A summary of this data (excluding the basalt of Lathrop Wells) are presented in Table 2.A, with complete analytical data in Appendices 2.1 and 2.2. A summary of all ${ }^{40} \mathrm{Ar} /{ }^{39} \mathrm{Ar}$ ages obtained during the volcanism studies, sorted by age, is presented in Table 2.B. New ages were obtained for the basalts of Buckboard Mesa, the Pliocene and Quaternary centers in Crater Flat, and Sleeping Butte. These ages are discussed individually in the discussion of younger postcaldera basalt.

Table 2.A. Additional ${ }^{40} \mathrm{Ar} /{ }^{39} \mathrm{Ar}$ (Plateau) Ages of Basaltic Volcanism in the YMR (not including Lathrop Wells) ${ }^{1}$

\begin{tabular}{|llllcr||}
\hline Sample & Laboratory & Geologic Unit & Description & Age (Ma) & $( \pm 2 \sigma)$ \\
\hline CF6-17-94-1BMC & NMBM & SE Crater Flat & eastern exposure & 3.75 & 0.04 \\
BB1FVP & Lehigh & Buckboard Mesa & dike, Scrugham Peak & 3.08 & 0.04 \\
BB4FVP & Lehigh & Buckboard Mesa & main flow & 3.15 & 0.08 \\
MC7-18-94-1A-BMC & Lehigh & Makani Cone & west flow & 1.17 & 0.07 \\
MC7-18-94-3B-BMC & Lehigh & Makani Cone & northeast flow & 1.16 & 0.10 \\
RC7-18-94-4BMC & Lehigh & Black Cone & southeast flow & 1.10 & 0.05 \\
LW149FVP & NMBM & Red Cone & southwest flow & 0.92 & 0.06 \\
RC1FVP & NMBM & Red Cone & east flow & 1.08 & 0.04 \\
RC4FVP & NMBM & Red Cone & dike in south scoria complex & 1.05 & 0.14 \\
LW147FVP & NMBM & Little Cones & bomb, SW Little Cone & 0.83 & 0.16 \\
LW146FVP & NMBM & Little Cones & bomb, NE Little Cone & 0.77 & 0.02 \\
HC17FVP & NMBM & Hidden Cone & east flow & 0.32 & 0.03 \\
SB5-24-95-1BMC & NMBM & Hidden Cone & north flow & 0.56 & 0.10 \\
SB90-8-20-1BMC & NMBM & Little Black Peak & southwest flow & 0.39 & 0.03 \\
SB90-8-20-1BMC & NMBM & Little Black Peak & southwest flow & 0.36 & 0.04 \\
\hline \hline
\end{tabular}

${ }^{1}$ Complete analytical data are in Appendices 2.1 and 2.2.

${ }^{2}$ New Mexico Bureau of Mines

\section{A. Basalt of the Silicic Episode}

The BSE crops out throughout the YMR and the basaltic rocks of this episode are identified by a suite of characteristics; however, none of the features are individually unique. The first is the close association, in space and time, with the eruptive activity of the calderas of the TM-OV complex. The BSE postdates closely the eruption of the Timber Mountain Tuff (11.2 Ma). Many of the basalt units of this episode underlie stratigraphically the Thirsty Canyon Tuff (8.5 Ma). Second, the largest-volume centers of the BSE are located in the ring-fracture zone of the Timber Mountain caldera complex and record a waning phase of the caldera-related volcanic activity (Figure 2.4). Third, all centers of the BSE were large volume eruptive units ( $>3 \mathrm{~km}^{3}$ dense rock equivalent $[\mathrm{DRE}]$ ). Their present surface outcrops form major topographic features (eroded shield 
volcanoes or lava mesas where basalt lavas cap modern topographic ridges). Third, the BSE exhibit a wide range in geochemical composition (basalt to basaltic andesite or latite). They exhibit a much larger range of compositional variation than the Postcaldera basalt (Crowe et al., 1986; Crowe, 1990).

Table 2.B. Summary of ${ }^{40} \mathrm{Ar} /{ }^{39} \mathrm{Ar}$ ages (excluding Lathrop Wells) from Tables 2.1 and 2.A, sorted by age

\begin{tabular}{|lcclll||}
\hline \hline Geologic Unit & Age $(\mathbf{M a})$ & $\mathbf{( \pm 2 \sigma )}$ Description & Laboratory & Sample \\
\hline Thirsty Mesa & 4.88 & 0.04 & Dike, summit scoria cone & Lehigh & NE-10-1-91-2-BMC \\
Thirsty Mesa & 4.68 & 0.03 & Basal lava flow, west side & Lehigh & NE-10-1-91-1-BMC \\
Amargosa Valley & 3.85 & 0.05 & Cuttings, drill hole & Lehigh & Well 25-1-BMC \\
SE Crater Flat & 3.75 & 0.04 & Eastern exposure & NMBM & CF6-17-94-1BMC \\
SE Crater Flat & 3.75 & 0.04 & Lava flow, north exposure & Lehigh & CF14FVP \\
SE Crater Flat & 3.69 & 0.05 & Lava lake, central vent & Lehigh & CF12FVP \\
SE Crater Flat & 3.65 & 0.06 & Dike, southern vent & Lehigh & CF10FVP \\
& & & & & \\
Buckboard Mesa & 3.15 & 0.08 & Main flow & Lehigh & BB4FVP \\
Buckboard Mesa & 3.08 & 0.04 & Dike, Scrugham Peak & Lehigh & BB1FVP \\
& & & & & \\
Makani Cone & 1.17 & 0.06 & West flow & Lehigh & MC7-18-94-1A-BMC \\
Makani Cone & 1.16 & 0.10 & Northeast flow & Lehigh & MC7-18-94-3B-BMC \\
Black Cone & 1.10 & 0.05 & Southeast flow & Lehigh & RC7-18-94-4BMC \\
Red Cone & 1.08 & 0.04 & East flow & NMBM & RC1FVP \\
Red Cone & 1.05 & 0.14 & Dike, south scoria complex & NMBM & RC4FVP \\
Black Cone & 1.05 & 0.14 & Summit lava lake & Lehigh & BC1FVP \\
Black Cone & 1.05 & 0.08 & Northern lava flow & Lehigh & BC12FVP \\
Little Cones & 1.02 & 0.10 & Dike, SW Little Cone & Lehigh & CF15FVP \\
Black Cone & 0.96 & 0.15 & Replicate of BC1FVP & Lehigh & BC3AFVP \\
Black Cone & 0.94 & 0.05 & Southern lava flow & Lehigh & BC6FVP \\
Red Cone & 0.92 & 0.06 & Southwest flow & NMBM & LW149FVP \\
Little Cones & 0.83 & 0.16 & Bomb, SW Little Cone & NMBM & LW147FVP \\
Little Cones & 0.77 & 0.02 & Bomb, NE Little Cone & NMBM & LW146FVP \\
Hidden Cone & 0.56 & 0.10 & North flow & & \\
Little Black Peak & 0.39 & 0.03 & Southwest flow & NMBM & SB5-24-95-1BMC \\
Little Black Peak & 0.36 & 0.04 & Southwest flow & NMBM & SB90-8-20-1BMC \\
Hidden Cone & 0.32 & 0.03 & East flow & SB90-8-20-1BMC \\
\hline
\end{tabular}

The BSE is divided into three major groups based on their geographic distribution. These are (1) basalt exposed in the moat zone of the Timber Mountain caldera, (2) basalt near and flanking the Black Mountain caldera, and (3) basalt of the Yucca Mountain area (Figure 2.4).

1. Mafic Lavas of Dome Mountain. The most important occurrence of basaltic rocks by volume is in the southeastern edge of the Timber Mountain caldera (Figure 2.4). Here, mafic lavas are interbedded with two major successions of rhyolite lava. They overlie the rhyolite of Fortymile Wash and underlie the rhyolite of Shoshone Mountain (10.3 $\pm 0.3 \mathrm{Ma}$ ) (Minor et al., 1993). The basalt and rhyolite define a bimodal association marking the waning postresurgence stage of the Timber Mountain caldera (Christiansen et al., 1977). The largest volume of basaltic magma is the 
mafic lavas of Dome Mountain. These lavas have been described by Luft (1964) and Marsh and Resmini (1992). They form an assemblage of basalt and basaltic andesite with a local thickness of $>300 \mathrm{~m}$. The volcanic rocks are locally interbedded with volcaniclastic breccia and conglomerate in the ring-fracture zone of the Timber Mountain caldera and these sedimentary units are moat breccias deposited in the collapsed interior of the Timber Mountain caldera. The outcrops of the mafic lavas of Dome Mountain form a slightly arcuate shield volcano centered at Dome Mountain proper (Figure 2.4). The area of surface exposure of the mafic lavas of Dome Mountain is about $50 \mathrm{~km}^{2}$ and their minimum volume is about $10 \mathrm{~km}^{3}$ (DRE). The feeder vents for the mafic lavas of Dome Mountain, as noted by Luft (1964), are not exposed. However, a source near Dome Mountain is required by the near-symmetrical centering and increased thickness of the lava shield and individual lava flows at Dome Mountain. The likely structural control for the eruption of the mafic lavas of Dome Mountain is the ring-fracture system of the Timber Mountain caldera.

The mafic lavas of Dome Mountain can be divided into two informal units, based on their petrographic features. Porphyritic basalt (phenocrysts of olivine-clinopyroxene) crops out in east Cat Canyon. The lavas are overlain locally by the Thirsty Canyon Tuff and have been dated at $10.8 \pm 0.5 \mathrm{Ma}$ (Kistler, 1968). These basalts were mapped as separate units from the mafic lava of Dome Mountain (Carr and Quinlivan, 1966; Byers et al., 1966). However, basalt lavas interbedded in the upper part of the mafic lavas of Dome Mountain in Fortymile Canyon are identical petrographically and chemically and are probably equivalents of the Cat Canyon lavas. Pilotaxitic to trachytic textured basaltic andesite forms the major volume of the shield lavas of Dome Mountain. Luft (1964) describes trachyandesite to latite lavas in the upper part of the section at Dome Mountain that are similar to the basaltic andesite but with somewhat higher contents of $\mathrm{SiO}_{2}$ (56-60 weight percentage [wt\%]).

In the northern and western part of the outcrop area of the mafic lavas of Dome Mountain, the unit is onlapped with a slight angular discordance by thin basalt flows informally called the basalt of Beatty Wash. These lavas were mapped separately from the mafic lavas of Dome Mountain (Christiansen and Lipman, 1965) and extend from Dome Mountain west along Beatty Wash (Figure 2.4).

2. Basaltic Rocks of the Black Mountain Caldera. Basaltic volcanic rocks crop out on all but the eastern flanks of the Black Mountain caldera (Figure 2.4). These basalt units overlap in age with the peralkaline volcanic units of the caldera. They underlie, are interbedded with, and overlie ash-flow units of the Thirsty Canyon Tuff (Minor et al., 1993). Many of the outcrops of basalt are located in the Nellis Bombing and Gunnery Range. Because of restricted access, the basalts have been sampled only at scattered localities around Black Mountain (Crowe et al., 1986). A sequence of eroded basalt vents and lava flows are exposed south of Black Mountain (Minor et al., 1993). These lavas underlie the Thirsty Canyon Tuff. Basalt lava exposed north of Black Mountain (Minor et al., 1993) underlie and locally overlie the Thirsty Canyon Tuff.

3. Basaltic Volcanic Rocks, Yucca Mountain Area. Basaltic volcanic rocks of the BSE comprise three geologic units in the eastern Yucca Mountain area and two additional units at and southwest of Yucca Mountain. Two of the eastern units were shown on published geologic maps (Ekren and Sargent, 1965; Sargent and Stewart, 1971; Sargent et al., 1970). These are the basaltic andesite of Skull Mountain and the basalt of Kiwi Mesa (Figure 2.4). A third unit, the basalt of Jackass Flats, has been separated in more recent geologic reports (Crowe et al., 1986; Frizzel and Shulters, 1990). 


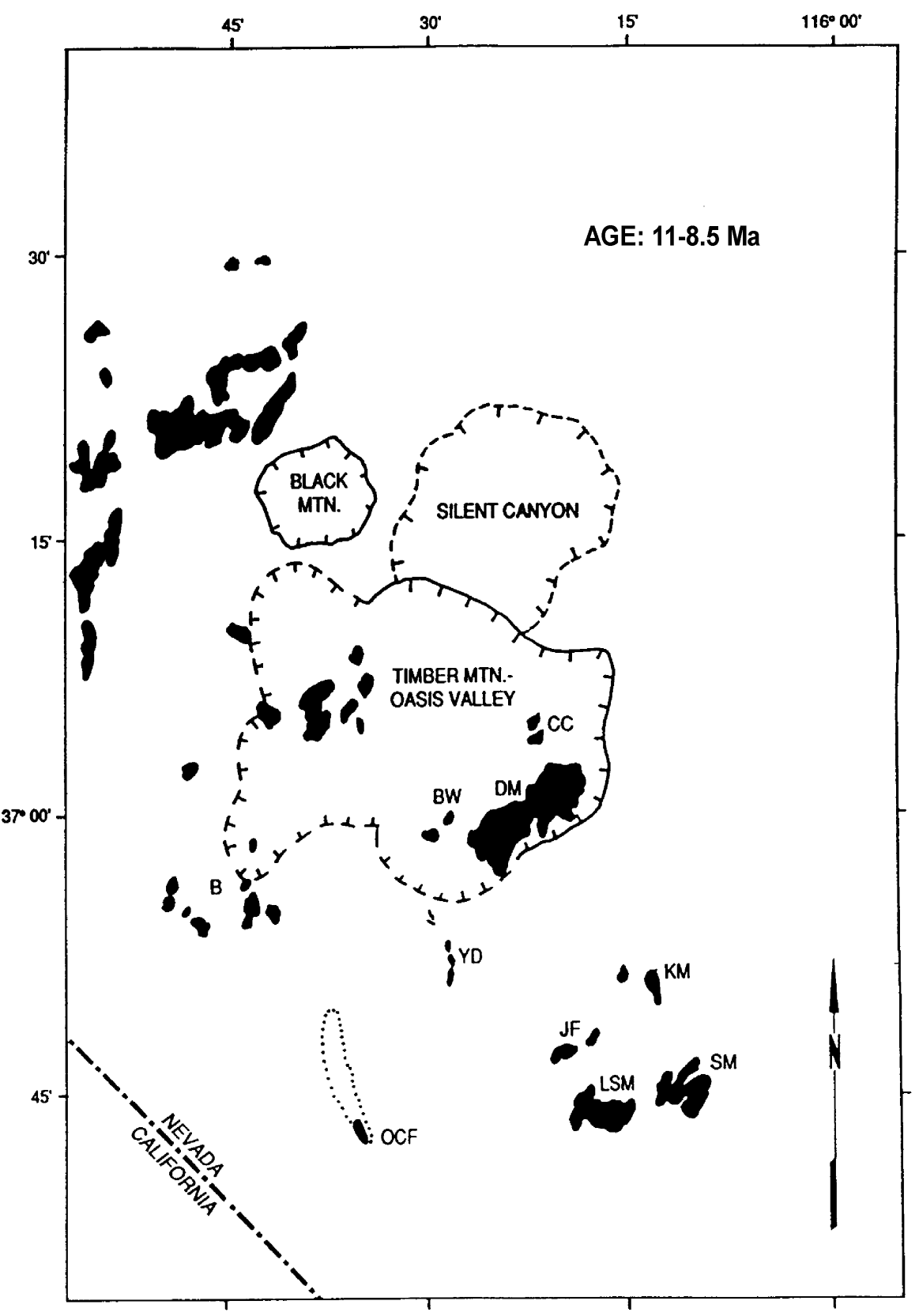

Figure 2.4. Distribution of the BSE. CC: basalt of Cat Canyon, DM: basalt of Dome Mountain, BW: basalt of Beatty Wash, B: basalt of the Beatty area, SM: basaltic andesite of Skull Mountain, LSM: Little Skull Mountain, KM: mafic rocks of Kiwi Mesa, JF: basalt of Jackass Flat, YD: dike of Yucca Mountain, OCF: older basalt of Crater Flat (modified from Crowe, 1990). The basalt of Kiwi Mesa crops out as a small lava mesa on the east side of Jackass Flats. The lavas overlie the Timber Mountain Tuff and are locally overlain by the rhyolite of Shoshone Mountain. The basaltic andesite of Kiwi Mesa is chemically and petrographically identical to the mafic lavas of Dome Mountain (Crowe et al., 1986).

The southern and southeastern perimeters of Jackass Flat are bounded by Skull and Little Skull Mountains. These small ranges are capped by a sequence of mesa-forming lava flows and flow breccia that locally exceed $60 \mathrm{~m}$ in thickness. This unit is the basaltic andesite of Skull Mountain. The lavas are distinguished in the field by the presence of abundant phenocrysts of 
bipyrimidal quartz (Crowe et al., 1986). Moreover, they are the only known lavas in the region that are subalkaline in composition (Crowe et al., 1983a, 1986). This quartz-bearing basaltic andesite of Skull Mountain overlies the lavas of the Wahmonie-Salyer center and the Paintbrush and Timber Mountain tuffs. It has a whole-rock K-Ar age of 10.2 \pm 0.5 Ma.

Several small outcrops of dissected lava are flanked by alluvium in the central part of Jackass Flats (Fig 2.4) (Frizzel and Shulters, 1990). These lavas have been dated by the K-Ar method at $11.0 \pm 0.4$ and $11.2 \pm 0.4 \mathrm{Ma}$. Correlative lavas (petrographically and geochemically) are interbedded with the upper part of the sequence of basaltic andesite of Skull Mountain at Little Skull Mountain but not at Skull Mountain (Crowe et al., 1986). Samples of the lavas at Little Skull Mountain have been dated at $8.4 \pm 0.4 \mathrm{Ma}$, which is inconsistent with the age of the inferred correlative lavas of Jackass Flats.

The Solitario Canyon fault forms the western edge of the Yucca Mountain site (Scott and Bonk, 1984). The north trace of the fault near its intersection with Drill Hole wash is intruded by a basaltic dike. The dike is exposed locally along the northwestern edge of the block (Figure 2.4) and in trench 10. Exposures of the dike in trench 10 show that the dike both intrudes the fault plane and has been offset by subsequent episodes of movement on the Solitario Canyon fault. North of trench 10 , the strike of the dike swings to the northwest. It crops out discontinuously, forming en echelon dikes in the Tiva Canyon member of the Paintbrush Tuff. This change in strike coincides with an abrupt change in the trend of the topography of ridges and valleys, from north/south- to northwesttrending, and occurs at the northern end of the exploratory block of Yucca Mountain. Scott et al. (1984) suggest that the northwest-trending valleys are underlain by right-slip faults that are inferred to be part of the Walker Lane structural system. Alternatively, Carr (1984, 1988, 1990), Carr and Parrish (1985), and Carr et al. (1986) suggest that the dikes follow the outer-ring fracture zone of a buried caldera. The dike has been dated at 10.0 $\pm 0.4 \mathrm{Ma}$ (Carr and Parrish, 1985).

The older basalt of Crater Flat (Crowe et al., 1986) crops out along the south slope of an arcuate ridge forming the southern boundary of Crater Flat (Figure 2.4). The outcrops consist of the remnants of oxidized vent-scoria intruded by dikes and small plugs. These units are probable eroded roots of at least one, and more likely several, scoria cones. Directly east of the scoria deposits, there is a sequence of thin lava flows and flow breccia that are petrographically similar to and probably derived from the plugs or cones. These lavas are overlain by slide blocks of Paleozoic carbonate. They have been dated by the whole-rock K-Ar method at $10.5 \pm 0.1 \mathrm{Ma}$. The lavas dip to the northeast and are inferred to underlie the southern and southwestern parts of Crater Flat. This is suggested by several lines of evidence (Crowe et al., 1986). First, the lavas have a reversed magnetic polarity. They coincide with, and are the probable source of, an arcuate negative magnetic anomaly that borders the southwest part of Crater Flat (Kane and Bracken, 1983). Second, petrographically and chemically similar lavas were cored at about $360 \mathrm{~m}$ beneath the surface in Drill Hole USW VH-2 located between Red Cone and Black Cone in the central part of Crater Flat (Carr et al., 1984; Crowe et al., 1986). These lavas were dated at about $11 \mathrm{Ma}$ (Carr et al., 1984). The lavas in the drill hole have a reversed magnetic polarity, similar to the older basalt of Crater Flat. They are the inferred source of a large circular negative aeromagnetic anomaly located in west-central Crater Flat (Kane and Bracken, 1983). This aeromagnetic anomaly extends south to the described anomaly of southwest Crater Flat. The combined field, geochronology, geochemical, and aeromagnetic data suggest that the western and southwestern parts of Crater Flat are floored by an extensive basalt unit of 10.5 to $11 \mathrm{Ma}$. 


\section{B. Postcaldera Basalt of the Yucca Mountain Region}

The second recognized episode of basaltic volcanism in the YMR is the Postcaldera basalt. These basalt centers occur at sites either well removed from eruptive centers of the TM-OV complex or are younger than and cannot be related in time to the silicic magmatic activity. The basalts consist of small-volume $\left(<1 \mathrm{~km}^{3}\right)$ centers marked by clusters of scoria cones and lava flows (except for the basalt of Thirsty Mesa that has a volume of $>3 \mathrm{~km}^{3}$ ). They are divided into two groups, the Older postcaldera basalt and the Younger postcaldera basalt. This division is based on differences in their ages and geographic distribution (Figure 2.5).

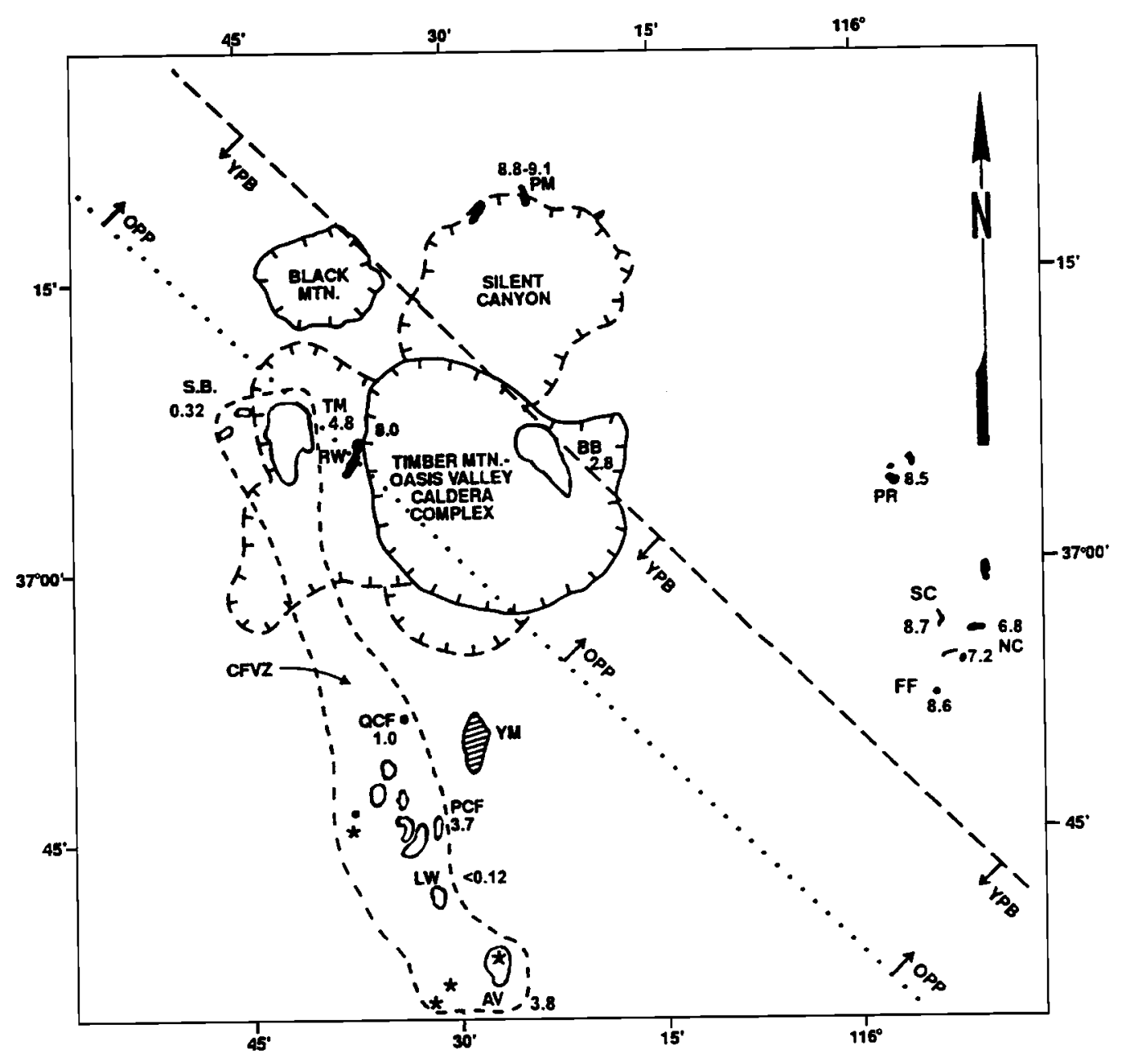

Figure 2.5. Postcaldera Basalt of the YMR. Solid areas are the Older postcaldera basalt, including: RW: basalt of Rocket Wash, PM: basalt of Pahute Mesa, PR: basalt of Pauite Ridge, SC: basalt of Scarp Canyon, NC: basalt of Nye Canyon, FF: buried basalt of Frenchman Flat. Stippled areas are the Younger postcaldera basalt, including: TM: basalt of Thirsty Mesa, AV: basalt of Amargosa Valley, PCF: Pliocene basalt of southeast Crater Flat, BB: basalt of Buckboard Mesa, QCF: Quaternary basalt of Crater Flat, SB: basalt of Sleeping Butte, LW: basalt of Lathrop Wells. Asterisks mark aeromagnetic anomalies identified as potential buried basalt centers or intrusions (Kane and Bracken, 1983, Crowe et al., 1986). Dashed line encloses the area of the Crater Flat Volcanic Zone. Numbers associated with the symbols for the volcanic units of the OPB and YPB are the age of the volcanic centers in million of years. Modified from Crowe and Perry (1989). 
1. Older Postcaldera Basalt. The OPB occurs at five localities, all north and east of Yucca Mountain (Figure 2.5). The OPB was erupted along either north/northwest-trending basin-range faults or at the intersection of basin-range faults with the ring-fracture zone of older calderas. Field evidence shows that some of the basalt units were erupted contemporaneously with movement on the extensional faults (Crowe et al., 1983b, 1986). The OPB ranges in age from 9 to $6.3 \mathrm{Ma}$ (Figure 2.5).

a. Basalt of Rocket Wash. A platy series of thin, basalt lava flows, informally named the basalt of Rocket Wash, overlies the Thirsty Canyon Tuff in the northwestern edge of the Timber Mountain caldera (Figure 2.5). This basalt, which was mapped by Lipman et al. (1966b), O'Connor et at. (1966), and Minor et al. (1993), erupted along a north-trending normal fault that marks the approximate edge of the ring-fracture zone of the Timber Mountain caldera. The vent for the basalt lavas was located at the northern edge of the mapped outcrops based on two features. First, the outcrops of the flow thicken consistently northward. Second, deposits of eroded cone scoria are present at the northern end of the exposed outcrops where they have been preserved beneath lava flows. The basalt of Rocket Wash overlies the Thirsty Canyon Tuff and the approximate volume of lavas (DRE) is about $0.2 \mathrm{~km}^{3}$. The basalt yielded a K-Ar age of $8.0 \pm 0.2$ Ma.

b. Basalt of Pahute Mesa. Three spatially separate but related basalt units of the OPB crop out in the northern part of the ring-fracture zone of the Silent Canyon caldera. These basalts, which are informally named the basalt of Pahute Mesa, are localized at the intersection of north/northeast-trending basin-range faults within the ring-fracture zone of the Silent Canyon caldera (Figure 2.5). They are divided into three units, each separate geographically. These are a western basalt, a central basalt, and an eastern basalt.

The western basalt is distinctly porphyritic with large resorbed megacrysts of black clinopyroxene and plagioclase and overlies the Thirsty Canyon Tuff. Exposed outcrops are primarily dissected cone scoria with numerous intrusive dikes. A feeder dike associated with the scoria deposits can be traced to the southwest and parallels the trend of basin-range faults. The minimum volume of the basalt center is about $0.7 \mathrm{~km}^{3}$ (DRE). A sample collected from the feeder dike was dated at $9.1 \pm 0.7 \mathrm{Ma}$.

The central basalt center consists of at least three separate but subparallel dike systems associated with probable surface scoria cones. The existence of the scoria cones is inferred from the presence of eroded scoria deposits containing aerodynamically shaped bombs. The scoria deposits overlie the Thirsty Canyon Tuff, and feeder dikes of the center intrude the Timber Mountain Tuff and rhyolite of Quartet Dome. The lava of the middle basalt center is conspicuously less porphyritic than the western basalt; megacrysts of black clinopyroxene and plagioclase are rare. The central basalt yielded a K-Ar age of $8.8 \pm 0.1$ and $10.4 \pm 0.4 \mathrm{Ma}$. The older age is inconsistent with the stratigraphic relations of the central basalt center (overlying the Thirsty Canyon Tuff) and is probably in error.

The eastern basalt occurs only as three small remnant outcrops of lava and dikes. Two of the lavas crop out in alluvium, the third intrudes the Trail Ridge member of the Thirsty Canyon Tuff. The outcrop patterns of each site are elongate parallel to north/northeast-trending basin-range faults and are located on the ring-fracture zone of the Silent Canyon caldera (Orkild et al., 1972). The eastern basalt is identical petrographically to the western basalt and has not been dated. 
c. Basalt of Paiute Ridge. The Halfpint Range, which forms the eastern margin of Yucca Flat, exposes a complex sequence of sills, dikes, and lopolithic intrusions of basaltic composition (Byers and Barnes, 1967). Dissected scoria cones and lava flows are associated with the intrusive bodies indicating that surface eruptions accompanied the formation of the intrusions (Crowe et al., 1983b; Valentine et al., 1992). The sills and lopolithic bodies occur in the interior of a northwesttrending graben. Subsurface magma intruded generally upward and locally eastward from dikes that are coplanar with northwest-trending basin-range faults. Eastward intruded magma formed sills by lifting and locally intruding the overlying sequence of tuff. At several localities, primarily in the axis of the graben, the sills sagged to form lopolithic intrusions (Byers and Barnes, 1967; Crowe et al., 1983b; Valentine et al., 1992). Some of the sills differentiated in situ to form pods of syenite (Byers and Barnes, 1967).

The northwest-trending dikes locally expand or flare upward forming vertically jointed, cylindrical bodies with associated near-vertical radial dikes. These are probably roots of eroded scoria cones (Crowe et al., 1983b; Valentine et al., 1992). In the eastern and central area of the graben, irregular feeder dikes can be traced upward into surface deposits of scoria cones and lava. This complex of intrusive and extrusive basalt, which is informally called the basalt of Paiute Ridge, exposes the geometry of shallow intrusive rocks and feeder dikes and provides an ideal locality to study the effects of shallow basalt intrusions (Valentine et al., 1992).

The surface lava from the basalt of Paiute Ridge has been dated by the whole-rock K-Ar method at $8.5 \pm 0.3 \mathrm{Ma}$ (Crowe et al., 1983b). The geologic relations of the surface basalt outcrops and dikes and sill complexes record a complex history of basin-range faulting in the Half Pint range. Dikes of basalt intrude into and are coplanar with several northwest-trending faults. The faults and the main graben system must, therefore, predate the basalt (>8.5 Ma). Sills of basalt are offset and downfaulted outcrops of cone scoria are present in the center of the graben. Both relationships require continuing offset on the faults after eruption and intrusion of the Miocene basalt. A possible correlative basalt with the basalt of Paiute Ridge has been reported in the subsurface of southern Yucca Flat (Drill hole UE1-H; $784 \mathrm{ft}$ below the surface) and has been dated at $8.1 \pm 0.3 \mathrm{Ma}$.

Recent paleomagnetic investigations by Ratcliff et al. (1994) have demonstrated that emplacement of the basalt of Paiute Ridge occurred during a geomagnetic polarity transition, probably from reverse to normal polarity. All the sills, dikes, lopolithic intrusions, and lava flows give transitional paleomagnetic data and, together, define a relatively smooth "path" for the field reversal. These data are of considerable interest for the emplacement dynamics of mafic magmas in such a setting. Given our current understanding of the duration of geomagnetic polarity reversals, it is probable that the entire complex of mafic intrusions at Paiute Ridge was emplaced in less than a few hundred to a few thousand years.

A separate but petrologically related basalt, the basalt of Scarp Canyon, crops out southeast of the basalt of Paiute Ridge and west of Nye Canyon. It consists of a 3- to 4-km-long, north/south-trending basalt dike that intrudes nonwelded ash-flow, ash-fall, and reworked tuff that predates the Paintbrush Tuff. The dike locally branches into vertical radial dikes of irregular strike, then widens where it crosses a northwest-trending normal fault (Henrichs and McKay, 1965). The widened dike portion has funnel-shaped outer contacts marked by scoriaceous breccia mixed with country rock and forms a plug mass that is probably the eroded roots of a former surface center. The basalt of Scarp Canyon yielded a whole-rock K-Ar date of $8.7 \pm 0.3 \mathrm{Ma}$. 
d. Basalt of Nye Canyon. The last major unit of the OPB is the basalt of Nye Canyon (Figure 2.5). This unit consists of at least four centers; one is buried beneath alluvial deposits of northeast Frenchman Flat (Carr, 1974). There are three surface centers of basalt that define a northeast-trending alignment of basalt centers. The basalt of Nye Canyon is the oldest basalt unit in the YMR that shows a northeast-structural trend. That direction is the predominant one of dike orientation and alignment of clusters of centers in post-Pliocene basalt in the region (Crowe et al., 1983b; Crowe and Perry, 1989; Crowe, 1990).

The northeastern center of the basalt of Nye Canyon consists of a moderately dissected scoria cone surrounded on the south and southwest by a thin lava flow, mostly buried beneath alluvial deposits. The northeastern center has been dated at $6.3 \pm 0.2 \mathrm{Ma}$. The middle and southern basalt centers are eroded tuff rings (Crowe et al., 1986) formed by mixed strombolian and hydrovolcanic activity. The interiors of both tuff rings are partly to completely filled by scoria deposits and lava and record episodes of mixed strombolian and hawaiian eruptive activity that followed the hydrovolcanic eruptions. The middle basalt center is the most primitive basalt geochemically in the region (Crowe et al., 1986; Farmer et al., 1989). It contains abundant nodules of gabbro, and less commonly, wherlite. A plug from the middle center has been dated at 6.8 $\pm 0.2 \mathrm{Ma}$. The southern center is formed at the eastern edge of a large ring dike. The dike extends nearly continuously in a $320^{\circ}$ arc extending westward from the southern center (Henrichs and McKay, 1965). The ring dike has an approximate diameter of $1 \mathrm{~km}$. It locally widens to form cylindrical plugs that probably mark the eroded roots of former scoria cones. The south center has been dated at 7.2 $\pm 0.2 \mathrm{Ma}$.

A fourth basalt center was intersected in a drill hole in alluvium beneath Frenchman Flat (Carr, 1984). It has been dated at 8.6 Ma. This basalt may be correlative with the basalt of Nye Canyon. Alternatively, its K-Ar age suggests it may be correlative with the basalt of Scarp Canyon (Figure 2.5).

\section{FY96 \& FY97 revisions}

Additional unpublished ${ }^{40} \mathrm{Ar} /{ }^{39} \mathrm{Ar}$ whole-rock ages have been obtained for the basalts of Nye and Scarp Canyons through site characterization studies for the DOE low-level radioactive waste disposal site in Frenchman Flat. The ages are generally consistent with previously obtained age determinations and support several minor changes in the volcanism status report. First, the new age determinations are superior analytically to the older conventional K-Ar whole-rock age determinations and provide preferred ages for the basalts. Second, the age of the basaltic volcanic rocks penetrated in the subsurface in Frenchman Flat $(8.6 \mathrm{Ma})$ are consistent with their correlation with the basalt of Scarp Canyon, not the basalt of Nye Canyon. Third, the results of the new age determinations for the basalt of Nye Canyon are consistent with an age of about 7.2 Ma for each of the centers. The new age determinations will be published through DOE-funded studies of the low-level radioactive waste disposal site in Frenchman Flat. Dennis Gustafson of Bechtel Nevada (702-295-0684) can be contacted for further information on the chronology data for these rocks.

2. Younger Postcaldera Basalt. A brief but regionally significant hiatus in volcanic activity of about 2.5 Ma followed eruption of the basalt of Nye Canyon. No volcanic rocks of the YMR, including both surface and subsurface rocks, have yielded age determinations in the range from 7.2 
Ma (basalt of Nye Canyon) to 4.7 Ma (basalt of Thirsty Mesa). The second cycle of the postcaldera basalt, the YPB includes all volcanic rocks younger than the basalt of Nye Canyon. In order of decreasing age, these basalts include the basalt of Thirsty Mesa, the basalt of Amargosa Valley, the basalt of southeast Crater Flat, the basaltic andesite of Buckboard Mesa, the Quaternary basalt of Crater Flat, the basalt of Sleeping Butte, and the Lathrop Wells basalt center (Crowe, 1990). These basalt centers, except the basaltic andesite of Buckboard Mesa, all occur in a narrow northwest-trending zone located west and south of the Yucca Mountain site (Figure 2.5), and this zone has been named the Crater Flat Volcanic Zone (Crowe and Perry, 1989). The basalt centers of the YPB, with two exceptions, consist of clusters of probably coeval, small-volume centers aligned along predominantly northeastern (one northern) structural trends. The exceptions are the basaltic andesite of Buckboard Mesa and the Lathrop Wells center. The basaltic andesite of Buckboard Mesa consists of a main scoria cone located on a northwest-trending fissure. The Lathrop Wells cone consists of only one center.

a. Basalt of Thirsty Mesa. The basalt of Thirsty Mesa comprises a thick accumulation of fluidal lava and local feeder vents marked by dissected scoria cones surmounting the lava mesa (Figure 2.5). These lavas, viewed from the west, appear to form a shield volcano, but the volcanic landform is actually more complex than a simple shield. The lavas were erupted onto a pre-existing plateau formed by ignimbrite of the Thirsty Canyon Tuff. The flows form a convex upward-mesa surface above the plateau.

The topographic summit of the mesa is formed by eroded deposits of scoria marking subdued mounds that probably represent the main sites of extrusion of the lavas. This interpretation is supported by the gradual increase in thickness and the symmetrical distribution of the lava flows about the scoria mounds. The mounds trend north/south, probably reflecting the predominant structural control of the center. The basalt of Thirsty Mesa covers an area of about $22 \mathrm{~km}^{2}$ with a maximum thickness of about $200 \mathrm{~m}$. The approximate volume of the center was estimated at $3 \mathrm{~km}^{3}$ (DRE)(Crowe et al., 1992). However. recent field work revealed that we may have overestimated the lava thickness and the volume of the center may be less than $3 \mathrm{~km}^{3}$. The lavas are sparsely porphyritic olivine-basalt with phenocrysts and microphenocrysts of olivine.

The lava mesa shows moderate geomorphic degradation. Lava flow margins are eroded. The lava flow surfaces have well-developed surface pavements containing soil with horizon development. There is no evidence of preserved primary flow-top topography. The scoria vents have been dissected significantly but still maintain a rounded mound-form and uphold the highstanding topography of the mesa. Minor et al. (1993) reported an ${ }^{40} \mathrm{Ar} /{ }^{39} \mathrm{Ar}$ age of $4.6 \mathrm{Ma}$ for the basalt of Thirsty Mesa. We have obtained ${ }^{40} \mathrm{Ar} /{ }^{39} \mathrm{Ar}$ ages for a sample collected from the west base of the lavas of Thirsty Mesa and a dike sample collected from one of the summit scoria cones. The ages are, respectively, $4.68 \pm 0.03$ and $4.88 \pm 0.04(2 \sigma)$ Ma (Table 2.1). These ages are in good agreement with the age reported by Minor et al. (1993), and geomorphic data (Crowe et al., 1992). The basalt of Thirsty Mesa has a reversed magnetic polarity. Adequate geochronology data have been obtained to document the age of the basalt of Thirsty Mesa.

\section{FY96 \& FY97 revisions}

There are several minor data additions for the basalt of Thirsty Mesa since completion of the volcanism status report. First, Fleck et al. (1996) reported a weighted mean ${ }^{40} \mathrm{Ar} /{ }^{39} \mathrm{Ar}$ age of $4.68 \pm 0.03 \mathrm{Ma}$ for the basalt of Thirsty Mesa. This age is consistent 
with previously obtained chronology data (Crowe et al., 1995). We use an age of 4.7 Ma for the basalt of Thirsty Mesa that is the mean of our data set and the data set of Fleck et al. (1996). Second, Fleck et al. (1996) reported a volume for the basalt unit of $3.4 \mathrm{~km}^{3}$ that is consistent with our volume determination when corrected to magma densities $\left(3.0 \mathrm{~km}^{3}\right)$. The consistency in volume estimations suggests that we may not have overestimated volume as we suggested in the volcanism status report (Crowe et al., 1995).

The lava mesa, prior to 1992, was thought to underlie the Thirsty Canyon Tuff, and, therefore, to be of Miocene age. The revised field relations and the new age determinations show that it is a newly identified Pliocene volcanic unit of the YMR as first noted by Fleck et al. (1991). Accordingly, the basalt of Thirsty Mesa is significant for several reasons. First, the mesa is located in and provides additional evidence for the existence of the CFVZ of Crowe and Perry (1989). Second, the basalt of Thirsty Mesa is the largest-volume volcanic unit of the YPB. The volume of basalt $\left(\leq 3 \mathrm{~km}^{3}\right)$ equals the volume of some of the basaltic units of the BSE. Third, the basalt of Thirsty Mesa is an evolved alkali basalt, but is distinguished chemically from the basalt of Crater Flat by significantly higher potassium content (Vaniman and Crowe, 1981; Vaniman et al., 1982).

b. Basalt of Amargosa Valley. A negative aeromagnetic anomaly was identified in the Amargosa Valley, several kilometers south of the town of Amargosa Valley (Kane and Bracken, 1983; Crowe et al., 1986) (Figure 2.5). The anomaly was drilled in 1991 by a private company (Harris et al., 1992). Samples of cuttings of the basalt were obtained and submitted for K-Ar age determinations. An age of 3.85 \pm 0.05 Ma was obtained for the cuttings under YMP controls (Table 2.1). Turrin $\left(1992\right.$, p. 231) reported an ${ }^{40} \mathrm{Ar} /{ }^{39} \mathrm{Ar}$ age of a basalt sample from the exploratory drill hole of $4.4 \pm 0.07 \mathrm{Ma}$. This age is significantly older than the age of $3.85 \mathrm{Ma}$, and additional age determinations may be required to investigate the discrepancy in ages.

\section{FY96 \& FY97 revisions}

We regard the difference in apparent ages of the basalt samples as insignificant. We favor our age of $3.85 \mathrm{Ma}$ for the age of the buried basalt because this age is close to the age of the basalt of southeast Crater Flat. The simplest interpretation is that the buried basalt is part of an existing volcanic episode. The difference in measured ages is not significant for PVHA.

The boundaries of this newly drilled basalt unit are prominently delineated on aeromagnetic maps (Kane and Bracken, 1983; Langenheim et al., 1991, 1993). The main mass of the basalt is located $3 \mathrm{~km}$ south of the town of Amargosa Valley. The near-circular outline of the northern part of the anomaly suggests it may be the main conduit or vents for the center. A lobate aeromagnetic mass extends to the south of the main mass and may outline a lava flow derived from the center. The aeromagnetic anomaly is inferred to represent a former surface basalt center buried by alluvium deposits in a zone of higher sedimentation along the trace of the Fortymile Wash (Figure 2.1; Figure 2.5). The area of coverage of the aeromagnetic anomaly is about $20 \mathrm{~km}^{2}$. If the basalt is a buried center and has dimensions typical of local lava flows and scoria cones, its volume is estimated to be about 0.2 to $0.4 \mathrm{~km}^{3}$ (DRE). An estimate of $0.3 \mathrm{~km}^{3}$ was obtained for the basalt based on modeling of the gravity and aeromagnetic data (Langenheim, 1995). Two other 
aeromagnetic anomalies are present in the south-central part of the Amargosa Valley and may represent buried basalt centers (Langenheim et al., 1993).

FY96 \& FY97 revisions

New aeromagnetic studies (Langenheim, 1995) show that there are a total of 6 anomaly sites that could be buried basalt centers in the Amargosa Valley. These sites are described and assessed with respect to PVHA in separate reports (Geomatrix, 1996 and Chapter 6); both reports used the aeromagnetic data of Langenheim (1995).

c. Basalt of Southeast Crater Flat. The basalt of southeast Crater Flat has been described by Crowe and Carr (1980), Vaniman and Crowe (1981), Vaniman et al. (1982), Crowe (1990), and Perry and Crowe (1992). Geologic maps of the centers were presented in Vaniman and Crowe (1981). The basalt unit consists of an alignment of north-trending dissected scoria cones and associated moderate-volume lava flows (Figure 2.5). The scoria cones extend south in an en echelon pattern from the east-central part of Crater Flat. The former presence of individual centers is indicated primarily by the presence of eroded deposits of oxidized cone scoria. The scoria contains aerodynamically shaped bombs and spatter. The large size of the bombs $(>0.5 \mathrm{~m})$ and local agglutination of the spatter requires near-vent deposition. However, scoria outcrops are deeply eroded, discontinuous, and retain no primary constructional topography.

\section{FY96 \& FY97 revisions}

We have completed a revised geologic map of the basalt of southeast Crater Flat compiled on 1:12,000-scale orthophotographic quadrangles and transferred to a 20foot-contour-interval topographic base (Appendix 2-M1).

The geometry of vent zones can be reconstructed by detailed mapping of three surface features. First, the northern and eastern parts of one cone (here named the Radial center) are preserved beneath a cover of thin $a a$ flows probably derived from the center. The south side of this cone is upheld by an increased degree of induration of the scoria in proximity to a north/southtrending swarm of lenticular dikes. This combination of features provides sufficient preservation of the radial dips of scoria deposits to reconstruct the location of the former near-circular cone. Second, a series of elongate lava masses are exposed in the center parts of vents of the basalt of southeast Crater Flat. These masses are not lava flows. They are preserved remnants of lava ponded in the elongate vent of individual centers. This interpretation is suggested by the gentle inward dips of the lava $\left(10^{\circ}-20^{\circ}\right)$ around the circumference of the exposures and the presence of scoria deposits beneath and buttressed against the lava ponds. These elliptical lava ponds have long axes trending north/south suggesting that the lava ponds filled elongate vents (fissures), and not the craters of symmetrical scoria cones. The direction of the elongation of the lava ponds is coparallel to the trend (north/south) of linear feeder dikes. Third, lenticular dikes enlarge locally to form irregular plugs with vertical cooling joints and these plugs are associated with areas of increased thicknesses of indurated deposits of scoria. The dips of the scoria deposits, recognized by the presence of aerodynamically shaped bombs, are relatively steep $\left(15^{\circ}-25^{\circ}\right)$ and require deposition at or near eruptive vents. 
Lavas of the basalt of southeast Crater Flat are the most aerially extensive of the YPB. They form sheet-like flows that flank, to the south and east, the described vent zones. In no case, however, can the lavas be traced directly to their individual feeder sources. Cross sections of the flows show that they are relatively thin $(3-5 \mathrm{~m}) a a$ flows with basal breccia of clinker and blocky vesicular upper surfaces. The flows are offset more than a meter (west-side down) along north/south-trending faults that may be related to exposed faults in the northwestern part of Yucca Mountain (Crowe and Carr, 1980; Smith et al., 1990). The lava flows are covered to the east by alluvium, and the section is probably displaced downward several tens of meters by faults concealed beneath alluvium. This displacement is suggested by several features. First, the eroded outcrop edge of the flows trends north/south and parallels local basin-range faults, suggesting that the present flow margin is fault-controlled. Second, petrologically similar lava flows are exposed in easternmost Crater Flat where they are faulted against the bedrock tuff of Yucca Mountain or overlie an erosional surface developed on the poorly consolidated deposits of the Paintbrush and Timber Mountain Tuffs. Third, aeromagnetic data show the lava flows are continuous beneath the alluvium (Kane and Bracken, 1983). Vents distinguished in the field can be identified in the aeromagnetic data by north/south elongation and local near-circular patterns of magnetic contours. These patterns are not observed in the eastern outcrop areas of the basalt of southeast Crater Flat where the rocks are concealed beneath alluvium or are faulted against Miocene tuff. This fact suggests that there are probably no major eruptive centers concealed beneath the alluvial deposits.

The basalt of southeast Crater Flat was dated initially at $3.84 \pm 0.13$ and $3.64 \pm 0.13 \mathrm{Ma}$ (Vaniman et al., 1982). Sinnock and Easterling (1983) obtained ages of $4.27 \pm 0.46,3.73 \pm 0.06$, and 3.89 $\pm 0.17 \mathrm{Ma}$ for replicate sets of whole-rock, K-Ar age determinations obtained from splits of the same sample collected at one site in the basalt of southeast Crater Flat. The samples were analyzed at three separate chronology laboratories (values reported as unweighted averages with $1 \sigma$ standard deviations). A second sample site was collected from outcrops of the basalt of southeast Crater Flat and analyzed at the same three laboratories. This site yielded average ages of $4.22 \pm 0.08,3.69 \pm 0.09$, and 4.00 $\pm 0.13 \mathrm{Ma}$, respectively (Sinnock and Easterling, 1983). The differences in age determined from the three laboratories are systematic (i.e., laboratory "B" generally reported the youngest date from any sample site) and are probably related to differences in sample preparation methods and instrumentation among the three laboratories. Unpublished KAr ages of about $3.91 \pm 0.20$ and $3.75 \pm 0.12$ Ma have been obtained by the U.S. Geological Survey for samples collected from a dike exposed in cone scoria and a lava, respectively. New ${ }^{40} \mathrm{Ar} /{ }^{39} \mathrm{Ar}$ ages of $3.65 \pm 0.06,3.69 \pm 0.06$, and $3.75 \pm 0.04(2 \sigma)$ Ma have been obtained for the basalt of southeast Crater Flat (Table 2.1). The consistency of age determinations for this unit at multiple analytical laboratories suggests the chronology of this unit is well established by the existing radiometric ages. All measured samples of the basalt of southeast Crater Flat have a reversed magnetic polarity (Vaniman and Crowe, 1981; Vaniman et al., 1982). The similarity in age of the basalt of Amargosa Valley and the basalt of Crater Flat suggests that the units were probably erupted about the same time but as spatially separate units.

\section{FY96 \& FY97 revisions}

Fleck et al. (1996) report a weighted mean K-Ar age of $3.73 \pm 0.02 \mathrm{Ma}$ for the basalt of southeast Crater Flat. A new ${ }^{40} \mathrm{Ar} /{ }^{39} \mathrm{Ar}$ age determination from NMBM indicates an age of $3.75 \pm 0.04$ for the eastern-most exposure in Crater Flat (Table 2.A). 
d. Basalt of Buckboard Mesa. The basalt of Buckboard Mesa is the second largest basalt by volume of the postcaldera basalt units of the region $\left(1 \mathrm{~km}^{3}\right.$ [DRE]). It comprises aphyric to sparsely porphyritic lavas erupted in the northeastern part of the ring-fracture zone of the Timber Mountain caldera (Figure 2.5). The lavas were erupted mainly from a scoria cone in the northwestern part of the outcrop area (Scrugham Peak). Additional lava flows vented from a fissure that extends southeast for about $5 \mathrm{~km}$ from the base of Scrugham Peak. This fissure is marked both by a subdued linear ridge in the present-day topography and by the presence of scoria and agglutinated spatter exposed in craters excavated during high-explosive experiments (Lutton, 1968, Figure 1). The basalt erupted into and filled topographic valleys between the eastern and western branches of Fortymile canyon (Lutton, 1968). Subsequent erosion lead to inverted topography and the flows now form a mesa top. The majority of outcrops of the basalt of Buckboard Mesa around the margins of the mesa and within the explosion craters expose a single major lava flow with only local multiple flow lobes (Lutton, 1968). Lutton (1968) described cores from boreholes near Scrugham Peak in which two flows could be distinguished. A second lava flow can also be discriminated in outcrops northwest of Scrugham Peak by local changes in topography and the presence of phenocrysts of kaersutite in the upper lava flow.

The major volume of the basalt of Buckboard Mesa is an aphyric to sparsely porphyritic olivine-bearing trachyandesite (mean $\mathrm{SiO}_{2}$ content of 53.5 wt\% (Lutton, 1968; Crowe et al., 1986) with abundant plagioclase microphenocrysts and microlites and minor clinopyroxene. Whole-rock K-Ar ages of $2.82 \pm 0.04$ and $2.79 \pm 0.10$ Ma were obtained for cores from the basalt of Buckboard Mesa recovered from Drill holes WDH-11 and WDH-12. Unpublished whole-rock KAr ages of $2.93 \pm 0.03 \mathrm{Ma}$ for the kaersutite-bearing flow and 3.07 $\pm 0.29 \mathrm{Ma}$ for the main flow unit have been obtained by the U.S. Geological Survey; these ages are consistent with the positive magnetic polarity of the lavas. Additional samples of the basalt of Buckboard Mesa have been submitted for ${ }^{40} \mathrm{Ar} /{ }^{39} \mathrm{Ar}$ age determinations and these data should be available in calendar year 1995.

\section{FY96 \& FY97 revisions}

Fleck et al. (1996) report a weighted mean K-Ar age of $2.87 \pm 0.06 \mathrm{Ma}$ for the basalt of Buckboard Mesa. Two new ${ }^{40} \mathrm{Ar} /{ }^{39} \mathrm{Ar}$ age determinations from Lehigh University indicate an age of $\sim 3.1 \mathrm{Ma}$ (Table 2.A). We do not consider these ages to be significantly different for PVHA, for which an age of 3.0 Ma was used (see Chapter 6)

e. Quaternary Basalt of Crater Flat. A series of four Quaternary basalt centers form a northeast-trending, slightly arcuate cluster of basalt centers extending along the axis of Crater Flat. From southwest to northeast, these centers consist of, respectively, Little Cones, Red Cone, Black Cone, and the Makani Cone (the latter cone is named informally in this report). 1:5000-scale topographic base maps were not available through the YMP to compile geologic maps for the Makani and Little Cones. Aerial photographs with mapping of these centers have been entered into the volcanism QA record.

(1) The Little Cones. The Little Cones consist of two separate cones of small dimensions. The southwestern cone is breached on the southern side, probably from extrusion of a lava flow that is buried beneath alluvial deposits. Two, possibly three, small mounds of eroded-cone scoria are present about $0.5 \mathrm{~km}$ south of the southwest cone and are marked by erosional rubble of cone 
scoria containing aerodynamically shaped bombs; a small feeder dike is exposed in the cone rubble. Most of the samples of basalt of Little Cones that have been collected for chemistry and K-Ar age determinations have been obtained from this feeder dike. Trenching of the scoria deposits show that they are deposits of vent facies and represent eroded remnants of satellite cones. Two small lava flows partly covered by alluvium flank the northwestern and southwestern edges of the southeastern satellite cone.

The northeastern cone is a symmetrical scoria cone and is slightly smaller than the southwestern cone. There is no evidence of extrusion of lava from this cone, based either on examination of surface exposures or the aeromagnetic data of Kane and Bracken (1983).

Both of the Little Cones centers are eroded significantly, and rills are conspicuously developed on the cone slopes. The cone-slope angles are less than the angle of repose and cone-slope aprons are developed at the base of the cones. Wells et al. (1990) described preliminary soils and geomorphic data for both centers. They note that the degree of soil development and geomorphic degradation of the Little Cones is comparable to stage-II soils in the Cima volcanic field. A K-Ar age of about $1.1 \pm 0.3 \mathrm{Ma}$ was obtained for the feeder dike south of the Little Cones (Crowe et al., 1982; Vaniman et al., 1982). An unpublished K-Ar age of a sample collected at the same site was dated by the U.S. Geological Survey at $0.76 \pm 0.20 \mathrm{Ma}$. A recently obtained ${ }^{40} \mathrm{Ar} /{ }^{39} \mathrm{Ar}$ age of the Little Cones feeder dike is $1.02 \pm 0.10 \mathrm{Ma}$ (Table 2.1). Additional samples of the Little Cones center, including volcanic bombs from the cones, have been submitted for ${ }^{40} \mathrm{Ar} /{ }^{39} \mathrm{Ar}$ age determinations. Both the Little Cone centers have reversed magnetic polarity consistent with the negative aeromagnetic anomaly associated with the centers (Kane and Bracken, 1983). The reversed magnetic polarity and the current K-Ar ages indicate the Little Cones center was probably formed in the Matayama reversed magnetic epoch.

\section{FY96 \& FY97 revisions}

We have completed a revised geologic map of the Little Cones compiled on a $1: 12,000$ - scale orthophotographic quadrangle and transferred to a 20-foot-contourinterval topographic base (Appendix 2-M2).

Fleck et al. (1996) report a single K-Ar age from Little Cones of $1.042 \pm 0.045 \mathrm{Ma}$. To compare the ages of the two scoria cones that comprise Little Cones, ${ }^{40} \mathrm{Ar} /{ }^{39} \mathrm{Ar}$ ages were determined at NMBM from volcanic bomb samples collected from each of the cone summits. These samples yielded reasonably reproducible ages of $0.77 \pm 0.04 \mathrm{Ma}$ and $0.83 \pm 0.16 \mathrm{Ma}$ (Table 2.A). In addition, two ${ }^{40} \mathrm{Ar} /{ }^{39} \mathrm{Ar}$ measurements of sanidine within a tuff xenolith from SW Little Cone yielded ages of $902 \pm 34$ and $905 \pm 92 \mathrm{ka}$ (Table 2.D, page 2-86). It is thus not clear whether the age of the Little Cones is $\sim 1 \mathrm{Ma}$ or $\sim 0.75 \mathrm{Ma}$.

(2) Red Cone and Black Cone Centers. The Red and Black cone centers are analogous volcanic landforms with similar eruptive histories. Each consists of a main scoria cone surmounted by a summit crater filled with agglutinated spatter, large lava blocks, and scoria (Vaniman and Crowe, 1981; Smith et al., 1990; Feuerbach et al., 1990; Ho et al., 1991). The main cones are flanked by scattered scoria mounds, which are erosional remnants of satellite vents. Some, or 
perhaps all, of the lavas of both centers were erupted from the satellite vents (Vaniman and Crowe, 1981; Vaniman et al., 1982; Smith et al., 1990; Ho et al., 1991).

The Red Cone is significantly modified by erosion. The basal diameter of the cone is $440 \mathrm{~m}$ and the height is $55 \mathrm{~m}$ (measurements made using the morphometric parameters of scoria cones and colluvial aprons of Wells et al. [1990]). The cone slopes have extensive development of rills, integrated channel networks, and deep radial gullies filled with reworked scoria interbedded with soil. Erosional processes have produced a cone-slope apron extending as much as $400 \mathrm{~m}$ from the base of the cone slope (Wells et al., 1990). Two small dikes, which are probable offshoots from the main conduit, are exposed in the western wall of the cone (Vaniman and Crowe, 1981). The vent or summit crater of the cone is filled by an accumulation of inward-dipping scoria and agglutinated spatter; aerodynamically shaped bombs in the crater-fill sequence exceed $2 \mathrm{~m}$ in length (Vaniman and Crowe, 1981). A series of satellite cones or scoria mounds is exposed south of the main cone (Vaniman and Crowe, 1981; Ho et al., 1991). These are clustered along northeast and northwest trends. Locally, the mounds were the source vents of $a a$ lava flows that flank the south part of the main cone and surround the scoria mounds (Smith et al., 1990). These lavas extend for as much as $1 \mathrm{~km}$ from the vents. The outcrop edges of the lavas have abrupt flow fronts with steep flow foliations, indicating the present edges are close to the original flow margins; however, there has been sufficient removal of flow-top clinker and flow-margin breccia to expose the massive interior lobes of some of the $a a$ flows.

The Black Cone center is $75 \mathrm{~m}$ high. The summit of Black Cone is upheld by a crater-fill sequence consisting of large blocks of strongly agglutinated spatter and small lava masses. This agglutinated sequence is much more resistant to erosion than the surrounding nonagglutinated scoria deposits and may explain partly the better geomorphic preservation of the Black Cone center, which has generally steeper cone slopes, a higher cone-height to cone-width ratio, and smaller apron development than Red Cone (Wells et al., 1990, Figure 2).

There is limited evidence of preservation of original primary flow topography of the lava flows of both the Red Cone and Black Cone centers. The lava surfaces have been smoothed from a combination of erosion, deposition of loess, and pedogenic processes. The flow surfaces immediately north of the Black Cone center, however, retain local irregularities in the flow-top surface that are probably remnants of primary flow topography. Smith et al. (1990) noted that the northern flow abutted against topography created by the southern flows and the main cone. This abutment prevented the northern flow from flowing south of the main cone.

An initial K-Ar age determination of $1.5 \pm 0.1$ Ma was obtained for a lava flow directly east of the main cone of the Red Cone center (Crowe et al., 1982; Vaniman et al., 1982). Sinnock and Easterling (1983) obtained ages of, respectively, $1.53 \pm 0.31,1.12 \pm 0.27$, and $1.55 \pm 0.15 \mathrm{Ma}$ for splits of a sample collected from the same lava flow. Smith et al. (1990) reported ages of $0.98 \pm$ $0.10,1.01 \pm 0.06$, and $0.95 \pm 0.08 \mathrm{Ma}$ for samples from the Red Cone center. Unpublished ages by the U.S. Geological Survey for two samples of the same lava site located east of the main cone are $0.84 \pm 0.15$ and $1.07 \pm 0.34 \mathrm{Ma}$. There is a slightly larger spread in K-Ar ages of the Red Cone center than other centers. Additional samples have been submitted for ${ }^{40} \mathrm{Ar} /{ }^{39} \mathrm{Ar}$ age determinations from the Red Cone center to provide final documentation of the chronology of this center. 
FY96 \& FY97 revisions

Fleck et al. (1996) report a weighted mean K-Ar age of $0.977 \pm 0.027 \mathrm{Ma}$ for the basalt of Red Cone. ${ }^{40} \mathrm{Ar} /{ }^{39} \mathrm{Ar}$ ages determined at NMBM yielded ages of $0.92 \pm 0.06,1.05 \pm$ 0.14 , and $1.08 \pm 0.04 \mathrm{Ma}$ (Table 2.A). These determinations indicate that the age of Red Cone is $\sim 1 \mathrm{Ma}$.

Potassium-argon ages of $1.09 \pm 0.3$ and $1.07 \pm 0.4$ Ma were obtained for the Black Cone center (Crowe et al., 1982; Vaniman et al., 1982). Unpublished K-Ar ages by the U.S. Geological Survey are $0.80 \pm 0.06$ for lava at the southern edge of the Black Cone center and $0.83 \pm 0.09 \mathrm{Ma}$ for a spatter sample from the crater-fill at the summit of the cone. New ${ }^{40} \mathrm{Ar} /{ }^{39} \mathrm{Ar}$ ages of the Black Cone center are $1.05 \pm 0.14,0.96 \pm 0.15,0.94 \pm 0.05(2 \sigma)$ Ma (Table 2.1).

\section{FY96 \& FY97 revisions}

A single new ${ }^{40} \mathrm{Ar} /{ }^{39} \mathrm{Ar}$ age was determined at Lehigh for a basalt from the southeast side of the Black Cone center. This sample yielded an age of $1.10 \pm 0.05 \mathrm{Ma}$ (Table 2.A), which is consistent with previous age determinations from Black Cone. Fleck et al. (1996) report a weighted mean K-Ar age of $0.986 \pm 0.047 \mathrm{Ma}$ for Black Cone.

(3) Makani Cone. The northernmost basalt center of the Quaternary basalt of Crater Flat is herein named the Makani Cone. It is the most deeply incised of the four Quaternary basalt centers. The Makani Cone consists of two small eroded remnants of $a a$ lava flows on the western and southeastern sides of the center. We originally were puzzled by the apparent degree of dissection of the Makani center (Vaniman and Crowe, 1981; Crowe et al., 1992) and speculated that it may be attributed to several causes. The center is located on a higher and steeper topographical part of the Crater Flat basin than the other centers, which may have resulted in higher erosion rates. Alternatively, the center may be slightly older than the other Quaternary basalt centers of Crater Flat, but new age determinations show that this is not the case. A third alternative is the Makani cone may have originally been a small center. The major volume of eruptions of the Quaternary basalt of Crater Flat is contained in the Red Cone and Black Cone centers. The volume of the Little Cones center represents, for example, only about $5 \%$ of the volume of the Black Cone and Red Cone centers. The Makani Cone may have been only a small center like the Little Cones center, and a small original size may account for its poor geomorphic preservation. New geologic mapping has shown that the major part of the center is formed by a scoria-spatter cone that has been eroded to a near horizontal surface. Lava flows that flank the center probably vented from radial dikes similar to many of the other Plio-Quaternary basalt centers in the YMR (Little Cones, basalt of Sleeping Butte, and the Lathrop Wells center). The major erupted volume of the Makani cone center formed a small scoria cone, and the ratio of pyroclastic deposits to lava is low. We infer that the degree of dissection of the center is a combination of three factors: accelerated erosion rates at higher and steeper parts of the Crater Flat basin, a relatively small erupted volume of the center, and a center formed mostly of relatively nonresistant cone scoria-spatter. Our original estimates of the volume of lava and pyroclastic components of the center (Crowe et al., 1983b) are incorrect and will be revised. 
Potassium-argon ages of $1.14 \pm 0.3$ and $1.07 \pm 0.04$ were obtained for the Makani center (Crowe et al., 1982; Vaniman et al., 1982). Unpublished ages of $1.66 \pm 0.5$ and $1.04 \pm 0.03 \mathrm{Ma}$ have been obtained for the Makani center by the U.S. Geological Survey. The older age was obtained for a sample of a basalt dike that is moderately altered. The age may be anomalously old. Additional ${ }^{40} \mathrm{Ar} /{ }^{39} \mathrm{Ar}$ age determinations will be obtained for the center to attempt to resolve the chronology data.

\section{FY96 \& FY97 revisions}

We have completed a revised geologic map of Makani Cone compiled on a 1:12,000scale orthophotographic quadrangle and transferred to a 20-foot-contour-interval topographic base (Appendix 2-M3).

Fleck et al. (1996) report a weighted mean K-Ar age of $1.076 \pm 0.026$ Ma for "Northernmost" cone (Makani Cone). Two new ${ }^{40} \mathrm{Ar} /{ }^{39} \mathrm{Ar}$ ages determined at Lehigh University indicate an age of $\sim 1.2 \mathrm{Ma}$ (Table 2.A). These ages and the age reported in Fleck et al. (1996) are slightly older than ages reported from any of the other Quaternary Crater Flat basalt centers and indicate that Makani Cone may be slightly older than the other Quaternary centers in Crater Flat.

(4) Eruptive Models for the Quaternary Basalt of Crater Flat. One area of continuing controversy is assessing eruptive models for individual centers of the Quaternary basalt of Crater Flat. This a problem for three reasons: (1) it has been difficult to evaluate whether each center formed in a single eruption (monogenetic) or multiple time-separate eruptions (polygenetic), analogous to the Lathrop Wells center (Crowe et al., 1988; Wells et al., 1990; Crowe and Perry, 1991; Crowe et al., 1990; Perry and Crowe, 1992), (2) it is difficult to apply detailed methods of field, geomorphic, and soils studies because of the degree of dissection of the centers, and (3), with the uncertainty of the chronology methods it is difficult to discriminate the ages of eruptive activity between volcanic centers. Twenty-one $\mathrm{K}-\mathrm{Ar}$ and ${ }^{40} \mathrm{Ar} /{ }^{39} \mathrm{Ar}$ age determinations have been obtained for the Quaternary basalt of Crater Flat (Table 2.2), and the mean age of the centers is $1.11 \pm 0.25$ Ma. Exploratory statistical analyses of the K-Ar ages using the stem and leaf, box, and probability plots show that the data distribution is nonnormal, and four samples are identified as outliers. If these samples are removed, the mean age of the centers is $1.00 \pm 0.11 \mathrm{Ma}(1 \sigma)$, and the data show a near normal distribution with no outliers. The statistically refined data set can be interpreted to indicate the centers are coeval. However, based on analog studies of the Lathrop Wells center (Crowe et al., 1992), the time between polygenetic events may be less than the $90 \%$ confidence interval of the mean ages. Thus, the precision of the chronology methods may be insufficient to test the polygenetic model. We prefer to reserve judgment on the ages and eruptive models of the basalt centers until additional ${ }^{40} \mathrm{Ar} /{ }^{39} \mathrm{Ar}$ age determinations have been obtained and geochemical studies completed. 
Table 2.2. K-Ar and ${ }^{40} \mathrm{Ar} /{ }^{39} \mathrm{Ar}$ Age Determinations for the Quaternary Basalt of Crater Flat.

\begin{tabular}{|c|c|c|c|c|}
\hline Volcanic Center & Age & Error $(1 \sigma)$ & Method & Source \\
\hline \multicolumn{5}{|l|}{ Little Cones } \\
\hline & 1.1 & 0.3 & Whole-rock. K-Ar & USGS (Carr) \\
\hline & 0.76 & 0.2 & Whole-rock. K-Ar & USGS (Carr) \\
\hline & 1.02 & $0.1(2 \sigma)$ & ${ }^{40} \mathrm{Ar} /{ }^{39} \mathrm{Ar}$ & This Report \\
\hline \multicolumn{5}{|l|}{ Red Cone } \\
\hline & $1.5 * * *$ & 0.1 & Whole-rock. K-Ar & USGS (Carr) \\
\hline & $1.53 * * *$ & 0.31 & Whole-rock. K-Ar & USGS (Carr) \\
\hline & 1.12 & 0.27 & Whole-rock. K-Ar & Sinnock \\
\hline & $1.55 * * *$ & 0.15 & Whole-rock. K-Ar & Sinnock \\
\hline & 0.98 & 0.1 & Mineral Separate K-Ar & State of Nevada (Smith) \\
\hline & 1.01 & 0.06 & Mineral Separate K-Ar & State of Nevada (Smith) \\
\hline & 0.95 & 0.08 & Mineral Separate K-Ar & State of Nevada (Smith) \\
\hline \multicolumn{5}{|l|}{ Black Cone } \\
\hline & 1.09 & 0.3 & Whole-rock. K-Ar & USGS (Carr) \\
\hline & 1.07 & 0.4 & Whole-rock. K-Ar & USGS (Carr) \\
\hline & 0.8 & 0.06 & Whole-rock. K-Ar & USGS (Turrin) \\
\hline & 0.83 & 0.09 & Whole-rock. K-Ar & USGS (Turrin) \\
\hline & 1.05 & $0.14(2 \sigma)$ & ${ }^{40} \mathrm{Ar} /{ }^{39} \mathrm{Ar}$ & This report \\
\hline & 0.96 & $0.15(2 \sigma)$ & ${ }^{40} \mathrm{Ar} /{ }^{39} \mathrm{Ar}$ & This report \\
\hline & 0.94 & $0.05(2 \sigma)$ & ${ }^{40} \mathrm{Ar} /{ }^{39} \mathrm{Ar}$ & This report \\
\hline \multicolumn{5}{|l|}{ Makani Cone } \\
\hline & 1.14 & 0.3 & Whole-rock. K-Ar & USGS (Carr) \\
\hline & 1.07 & 0.04 & Whole-rock. K-Ar & USGS (Carr) \\
\hline & $1.66 * * *$ & 0.5 & Whole-rock. K-Ar & USGS (Turrin) \\
\hline & 1.04 & 0.3 & Whole-rock. K-Ar & USGS (Turrin) \\
\hline Mean (all data) & 1.11 & 0.25 & $n=21$ & \\
\hline Mean (outliers removed) & 1 & 0.11 & $n=17$ & \\
\hline
\end{tabular}


Champion (1991) suggested all Quaternary basalt centers of Crater Flat record a single reversed-polarity remanent magnetization on the basis of field and paleomagnetic analyses of samples collected from 20 sites. These paleomagnetic data were interpreted by Champion (1991) to permit the inference that the Quaternary basalt centers of Crater Flat formed contemporaneously (single magma pulse) with each center being of monogenetic origin (formed in one brief eruptive cycle). Although this interpretation is consistent with the paleomagnetic data, it requires several critical underlying assumptions. First, Champion (1991, p. 63) argued that modern (Holocene) secular variation occurs at a rate of about $4^{\circ}$ to $5^{\circ}$ per century. He did not assess the temporal variability of the geomagnetic field during the period of eruption of the Quaternary basalt of Crater Flat. Second, the paleomagnetic data for the Quaternary centers of Crater Flat were assumed to adequately represent all volcanic events at these centers. The sample sites for collection of paleomagnetic material were not identified (Champion, 1991), so this assumption cannot be evaluated. Third, and related to the second argument, is the reliability of the overall paleomagnetic data. Champion (1991) presented only site-mean directions of remanent magnetization for the Quaternary basalt of Crater Flat. Both lava and scoria were sampled for the paleomagnetic studies (Champion, 1991, p. 63). The latter material may be a less reliable recorder of the ancient geomagnetic field. Without presentation of data, and in particular the demagnetization results, it is impossible to assess the variability of the field magnetization directions. The dispersion of sample directions at a site level is particularly important if the secular variation is less than the assumed 4 to $5^{\circ}$ per century. Fourth, the four basalt centers extend in a northeast-trending arc for a distance of about $12 \mathrm{~km}$, a distance longer than expected for basalt feeder dikes (except bladed dikes), which makes it unlikely that the centers were fed by a single-feeder dike system (Crowe et al., 1983b). More information is required to determine if the centers were fed from multiple dike systems and if the geochemistry of the centers is consistent with single or multiple pulses of magma. Finally, the paleomagnetic data must be considered in light of the evidence of geochemical diversity in the lavas (Vaniman et al., 1982; Perry and Crowe, 1992). The assumptions associated with the paleomagnetic study must be more carefully evaluated before accepting the conclusion that each center is monogenetic and, specifically, that all centers were formed from a single magmatic event.

The recognition of time-separate events at basalt centers must be based on establishing unequivocal time gaps between eruptive events, such as the presence of soil-bounded unconformities (Crowe et al., 1992). The variable K-Ar age determinations provide permissive but not conclusive evidence of polygenetic events. Additionally, the precision of the K-Ar methods may be insufficient to test the polygenetic model.

f. Sleeping Butte Centers. The Sleeping Butte volcanic centers are located about $20 \mathrm{~km}$ north of Beatty, straddling the boundary of Nellis Air Force Range (Figure 2.5). They are $47 \mathrm{~km}$ northwest of the potential Yucca Mountain site. The Sleeping Butte centers consist of two spatially separate small-volume $\left(<0.1 \mathrm{~km}^{3}\right)$ basaltic centers. The basalt centers comprise a main scoria cone flanked by small satellite scoria cone(s). Each center erupted multiple lobes of blocky a $a$ lava flows that extruded from the base of their main scoria cone. The southwestern center, the Little Black Peak Cone, erupted through fanglomerate deposits. The northeast center, the Hidden Cone, erupted through and draped the north/northeast-facing slope of Sleeping Butte. This prominent topographic mount is upheld by resistant outcrops of moderately welded ignimbrite of Miocene age located about $1 \mathrm{~km}$ inward of the range front of the Pahute Mesa-Black Mountain highland. The two centers are aligned in a north/northeast direction, the preferential direction of alignment of post-Pliocene volcanic centers in the YMR (Crowe et al., 1983; Crowe and Perry, 1989). The separation of the centers is $2.6 \mathrm{~km}$, measured from crater center to crater center. These centers have been mapped at a scale of 1:5000 (Crowe and Perry, 1991). 
(1) The Little Black Peak Center. The oldest volcanic unit of the Little Black Peak volcanic center includes two mound-shaped accumulations of basalt scoria and volcanic bombs (Qs3, Figure 2.6) located at the southern margin of the main cone. These mounds are similar to the scoria mounds described at the Red Cone, Black Cone (Smith et al., 1990; Crowe, 1990), and the Lathrop Wells centers (Crowe et al., 1992). There are no distinct vents or craters at the crest of the mounds. However, the abundance of large bombs ( $>1 \mathrm{~m}$ in diameter) suggests the mounds were vents for basaltic eruptions. Lenticular dikes are exposed locally in the mounds. The dikes fed short, lobate lava flows exposed west of the eastern scoria mound (Crowe and Perry, 1991).

The main scoria cone (Qs1, Figure 2.6) of the Little Black Peak center has a basal diameter of $500 \mathrm{~m}$ and a height of $70 \mathrm{~m}$. The cone is symmetrical with a summit crater elongated slightly in a north/south direction. The upper slopes of the eastern side of the cone collapsed, forming an eastfacing landslide scarp extending from the eastern edge of the crater halfway down the eastern cone flank. Exposures of scoria deposits in the scarp show that the main cone is composed predominantly of scoria-fall deposits with minor agglutinated spatter. Zones of oxidized scoria in the cone deposits were produced by oxidization of the deposits from volcanic gases emitted from the conduit or feeder dikes. The zone of oxidization is elongate in a north-northwest direction, probably reflecting the strike of the underlying feeder dike for the volcanic center. The outer slopes of the scoria cone are moderately dissected with development of radial rills. The base of the cone is encompassed by a well-developed cone-slope apron (Qs1, Figure 2.6).

A $a$ lava flows were extruded from two sites on the flanks of the scoria cone. The larger, western flow vented from the northwestern base of the main scoria cone. This vent site is marked by a concave indentation in the profile of the cone slope, although the vent is largely covered by deposits of the cone-slope apron. The vent location is also suggested by the thickening of the flow near the vent, and an asymmetrical extension of the zone of red oxidization of cone scoria also extends radially from the summit crater to the flank vent. The latter evidence suggests the lava flow was fed by a radial dike extending from the main conduit (Crowe and Perry, 1991). Original primary flow topography of the $a a$ flow has been infilled by eolian material, producing a largely smooth pavement surface. Remnants of the primary flow topography occur only as local areas of stepped topography in the flow top, and margins of the lava flow are eroded.

A second lava flow was extruded from the east side of the cone, and is concealed partly by the landslide deposits, so the actual vent site could not be confirmed. Cross-sectional exposures of the flow show that it exhibits a morphology. This flow shows the same degree of geomorphic modification as the western flow.

Minor et al. (1993) reported a K-Ar age of about 350 ka for the Little Black Peak volcanic center.

(2) Hidden Cone Center. The Hidden cone center consists of a main scoria cone formed on the north-facing slope of Sleeping Butte (Figure 2.7). The center was constructed in two stages: (1) a main scoria cone formed from central vent eruptions of the mildly explosive strombolian type, accompanied by extrusion of multiple lava flows at the northeastern flank of the cone, and (2) a thin sequence of scoria-fall deposits was erupted during mildly explosive strombolian eruptions. These deposits mantled the eroded slopes of the previously formed main scoria cone.

The first, or oldest, event at the Hidden Cone center was the formation of most of the volume of the main scoria cone (Figure 2.7). Scoria was deposited from strombolian eruptions and built an 
asymmetrical cone that draped the north-facing slope of Sleeping Butte. Because of the steeply sloped topography underlying the cone, it is highest on the northern side (downslope) and lowest on the southern side (upslope). The basal diameter of the cone is $0.62 \mathrm{~km}$, and it is $110 \mathrm{~m}$ high measured from the northern cone base and $25 \mathrm{~m}$ high measured from the southern cone base. The scoria cone has an elliptical summit crater, elongate to the north. Oxidization of the cone scoria is centered on the crater but skewed slightly to the west, which suggests the eruptions that formed the center were fed by magma that moved upward along a west-dipping dike. Because of the subsequent mantling of the cone slopes by younger scoria deposits, the older scoria deposits (Qs4, Figure 2.7) are exposed only in the summit crater and the eastern side of the cone (Crowe and Perry, 1991). A cone-slope apron containing soils with well-developed soil horizons is exposed mostly at the northern and western base of the main scoria cone (Crowe and Perry, 1991).

Lava vented from two radial dike sets and from a satellite cone at the northeastern flank of the main scoria cone. The major feeder vent for the flows is the northern radial dike that passes upward into a thin lava flow. The lava breached the surface above the dike about $10 \mathrm{~m}$ upslope from the cone base and extended eastward and laterally down the cone slope for $1.3 \mathrm{~km}$. Other lavas were fed from a second set of radial dikes and a satellite cone located east of the northeastern base of the main scoria cone (Crowe and Perry, 1991). All lava flows of the center show an $a a$ flow morphology.

The lava flow units of Hidden Cone show similar degrees of erosional degradation to the lava units of the Little Black Peak center. Most of the original a $a$ flow topography has been smoothed and the flow tops are pavement surfaces. Margins of the lava flow are erosional, not flow margins.

The youngest unit of the Hidden Cone center (Qs1, Figure 2.7) comprises scoria-fall deposits that mantle the older cone except for the perimeter of the northern and eastern base of the cone. The existence and inferred young age of this eruptive event are suggested by the following:

1. The outer slopes of the main cone are smooth, showing only minor degradation denoted by the formation of rills and other evidence of mass wasting on the cone slopes.

2. There is a marked contrast in the degree of degradation of the cone slopes of the Little Black Peak cone compared to the Hidden Cone despite their geographic proximity.

3. There are no apron deposits associated with the Qs1 deposits, suggesting there was an insufficient time subsequent to the youngest eruption for significant cone-slope erosion.

4. There is an erosional unconformity between the Qs4 and the Qs1 deposits exposed in the northeastern section of the main cone. 


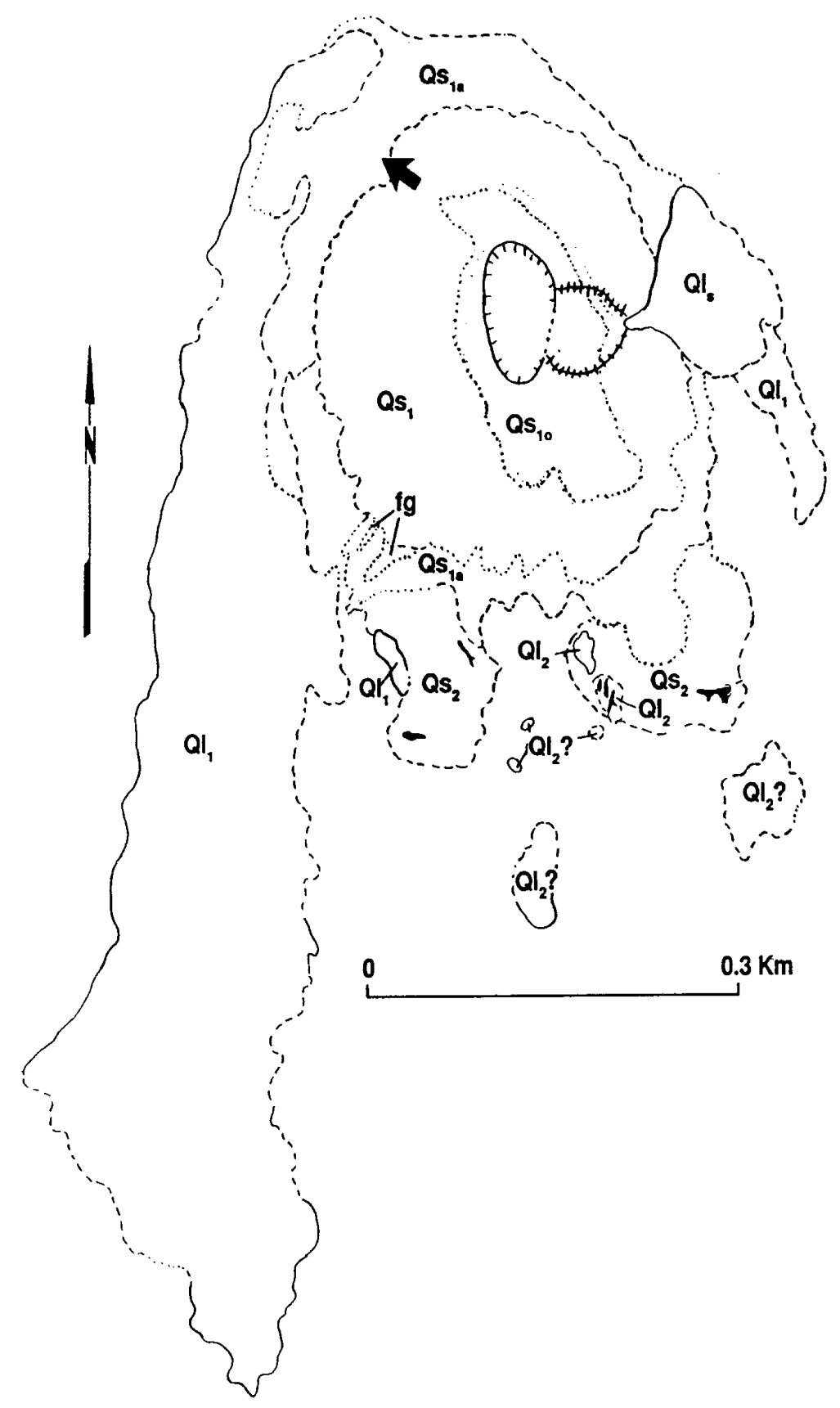

Figure 2.6. Generalized geologic map of the Little Black Peak volcanic center of the basalt of Sleeping Butte compiled on an uncorrected aerial photograph. Lines mark contacts between geologic units and are dashed where they have been approximately located and dotted where inferred or concealed. The area outlined by dots at the summit of the main cone is the vent area and underlying feeder dikes. These features are inferred from the distribution of zones of oxidization of the cone scoria. The large arrow marks the vent for the western lava lobe. Wide, dark lines are feeder dikes in cone scoria. The line with inward facing dashes marks the crater rim of the summit cone. The line with cross-dashes is the slump scarp of the eastern crater wall. Fg: Plio-Pleistocene fanglomerate deposits, Qs3: scoria deposits of the south scoria mounds, Q12: older lava associated with the south scoria mounds; queried where identification is uncertain, Qs1: scoria deposits of the main cone; Qs1a: cone-slope apron deposits of the main cone, Qls: slide deposits, Q11: lava flows derived from the main cone. Figure is modified from Crowe and Perry (1991). 


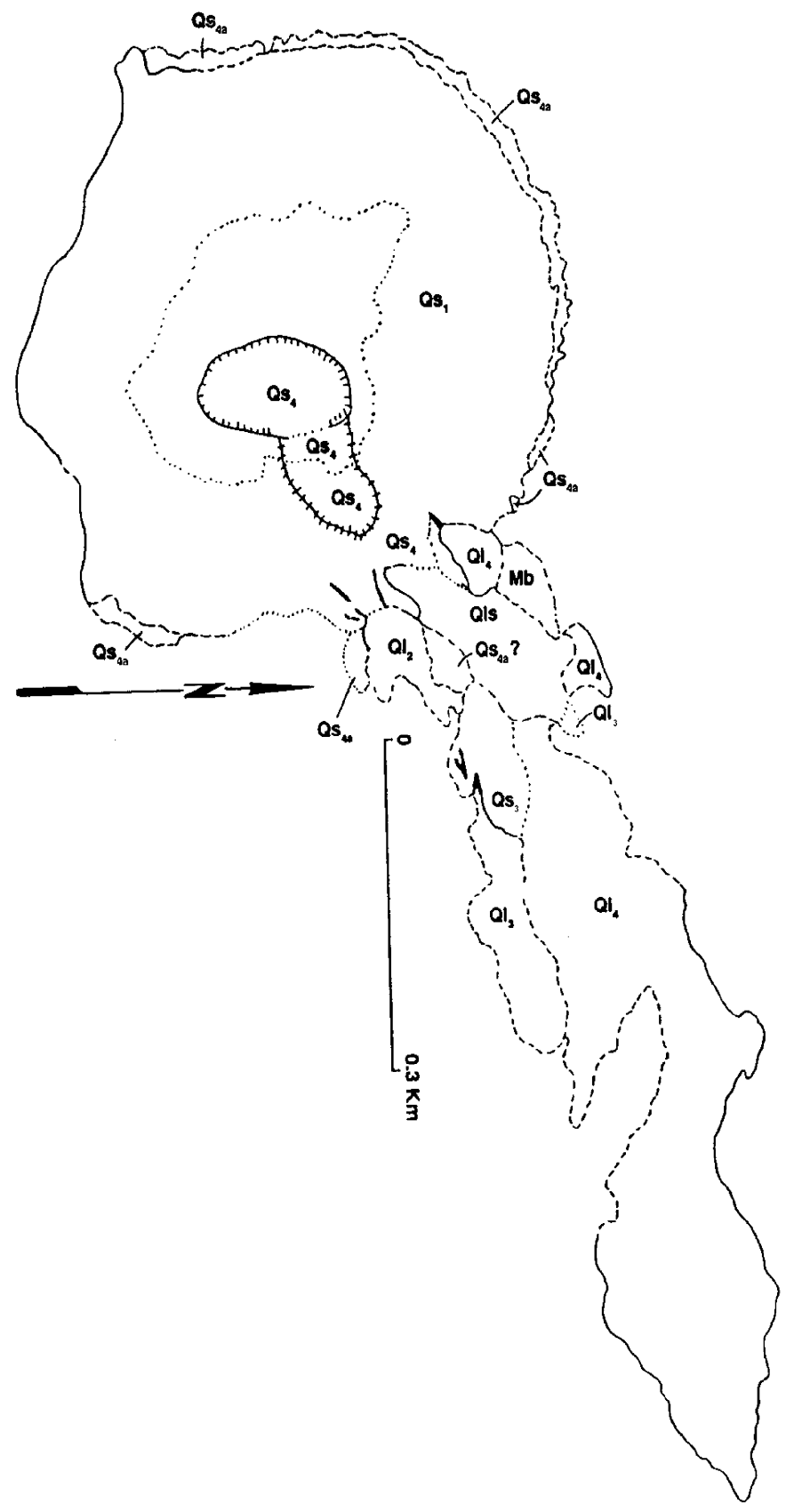

Figure 2.7. Generalized geologic map of the Hidden Cone volcanic center of the basalt of Sleeping Butte. Map is compiled on uncorrected aerial photographs. Lines mark contacts between geologic units and are dashed where they have been approximately located and dotted where inferred or concealed. The area outlined by dots at the summit of the main cone is the vent area and underlying feeder dikes. These features are inferred from the distribution of zones of oxidization of the cone scoria. The line with inward facing dashes is the summit crater; the line with cross-dashes outlines the slump scarp of the eastern crater wall. Wide dark lines are feeder dikes. Bm: Miocene basalt, Q14: lava flow associated with the radial feeder dike, Qs4: older scoria deposits of the main cone, Qs1a: cone-slope apron deposits of the main cone, Qls: lava flow associated with the Qs3 scoria mound, Qs3: flank scoria mound, Q12: lava flow associated with the radial feeder dikes, Qs1: late Pleistocene or Holocene scoria-fall deposits. Figure is modified from Crowe and Perry (1991). 
5. There is significant horizon development in the soil on the Qs4 deposits and limited horizon development in the soil on the Qs1 deposits.

6. Fine-grained scoria-fall deposits are preserved on the modern alluvial surface about $0.5 \mathrm{~km}$ northeast of the main scoria cone.

Champion (1992, pp. 254-255) and Minor et al. (1993) noted the presence of a possible second lava flow associated with the Hidden Cone center, located northwest of the north cone base. Champion (1992) reported a K-Ar age of about $380 \mathrm{ka}$ for the flow, consistent with the age of the lava flows of the Hidden Cone center. This western lava flow was identified in preliminary mapping in 1981 as being part of the Hidden Cone center. However, detailed field examination showed that the western lava flow could not be traced to the Hidden Cone. Instead, it appears to be associated with deeply dissected scoria deposits that mark one of a series of basalt centers stratigraphically beneath the Thirsty Canyon Tuff. Additionally, the western lavas are overlain by a thick soil with dramatically greater horizon development than the Hidden Cone lava flows. The new K-Ar age determination provides evidence that the western flow could be associated with the Hidden Cone center. Additional field work will be conducted to verify the stratigraphic position of the western lava flow.

\section{FY96 \& FY97 revisions}

We have completed a revised geologic map of the Sleeping Butte basalt centers compiled on a 1:29,800 air photo (EG\&G aerial photograph 6615-002-BMC) and transferred it to a 20-foot-contour-interval topographic base (Appendix 2-M4).

Field geologic studies, including trenching and collection of samples for geochemistry studies at the basalt of Sleeping Butte, were completed in FY95 (Crowe and Perry, 1995). Geologic mapping of the northern lava lobe of the Hidden Cone center was completed to assess whether the lava is associated with the center. The lava was mapped as part of the center in geologic mapping completed during the early $1980 \mathrm{~s}$ (see data appendix for the volcanism status report). Subsequently the flow was remapped and judged not to be derived from the center (Crowe and Perry, 1991). The new geologic mapping shows conclusively that the northern lava flow is from the Hidden Cone center (see also Fleck et al., 1996). The controversy in the source of the lava flow resulted from two somewhat confusing geologic relationships:

1. The flow near the base of the scoria cone is mantled by strongly oxidized scoria-fall deposits and rafted parts of the cone walls.

2. The lava flow wrapped around and buttressed against topography northwest of the Hidden Cone center. This topography is upheld by eroded scoria deposits with exposed feeder dikes that were source vents for the eruption of Miocene basalt that underlies and interfingers with ash-flow deposits of the Thirsty Canyon Tuff.

Geochemical analyses of the northern flow indicate that it is geochemically distinct from the eastern flow. The La/Th ratio of the northern flow is higher than that of the eastern flow, indicating that it may be derived from a separate magma batch or be related to the eastern flow by a magmatic process that fractionates Th from La (see Chapter 4). 
A remaining controversy concerning the Hidden Cone volcanic center is the possibility of multiple, time-separate eruptive events (polycyclic or polygenetic eruptions; see Crowe and Perry, 1991; and Crowe et al., 1995). Trenching was completed in coneslope apron deposits on the northern flank of Hidden Cone to test eruptive models of the center. We excavated and described three shallow trenches (less than $1.5 \mathrm{~m}$ depth) using a $4 \times 4$ truck-mounted backhoe. Additionally, several sections in cone-tephra on the slopes of the scoria cone were excavated by shovel. Deposits exposed in the trenches demonstrated that there is significant development of horizons in soils preserved on the cone-slope apron of the Hidden Cone. The degree of horizon development is sufficient to be consistent with an age of at least several hundred thousand years. The dilemma at the center is how to explain the marked difference in degree of horizon development in soils on deposits of the cone-slope apron with the extremely weak horizon development (weak vesicular Av horizon) on the cone slopes. We have developed two alternative eruptive models for Hidden Cone. Because of limited and conflicting data, we do not strongly favor either model, and the choice of model does not affect PVHA, unless it could be shown that the last eruption at Hidden Cone was very recent (see Chapter 6).

Model 1: Monogenetic Center. Model 1 assumes the Hidden Cone center is a simple monogenetic center formed during a single and brief eruptive event (months or years). Most volcanologists accept the interpretation that small volume basalt centers are monogenetic. The apparently conflicting geomorphology of center are judged to not be important. The cone slopes of the center are unstable and are undergoing erosion, thus promoting continuous removal and destabilization of deposits that allow the development of soils. For model 1, the poor development of horizons in soils are inferred to be a result of slope instability and are not indicative of differences in the ages of deposits of the center. The major inconsistency with this model however, is the smooth profiles of the cone and the steep cone slopes (near the angle of repose of the scoria deposits) and the contrast in slope angle and soil development on the northern cone apron versus the steep upper cone slopes.

Model 2: Polygenetic Center. Model 2 assumes the Hidden Cone center formed in multiple, time-separate volcanic events and there is a significance age difference between the deposits forming the upper cone slopes of the center and the cone-slope apron deposits. These age differences allowed horizon development in soils on the cone-slope apron and different degrees of geomorphic preservation of the deposits (unrilled cone slopes with weak horizon development in soils contrasted with significant erosional dissection and significant horizon development in soils formed on the coneslope apron at the base of the scoria cone). Recently obtained geochronology data provide further support for model 2 . Two reproducible ${ }^{3} \mathrm{He}$ cosmogenic surface exposure ages of $\sim 15-20$ ka were obtained (Poths, unpublished data) for samples collected from 1) a location southwest of the present cone crater on the low-angle saddle surface between the cone crater and the underlying topography of the Sleeping Butte topographic feature, and 2) a location on the smooth, high-angle southern cone flank. These young ages would require removal by erosion of several tens of meters of scoria deposits that would have shielded the sampled deposits from the cosmic-ray influx if the scoria deposits are $>300 \mathrm{ka}$. This amount of erosion is inconsistent with the observed geomorphic characteristics of the scoria cone. Inconsistencies with model 2 are the absence of soils or erosional unconformities in the walls of the summit crater and the absence of an identifiable vent or crater that can be related to a separate and 
younger eruption (late Pleistocene?) that would have mantled the cone slopes and cone-slope apron deposits with scoria-fall deposits.

A significant observation made at the Hidden Cone center during field studies conducted in FY95 is the geomorphic implications of the somewhat unusual setting of the Hidden Cone center. The scoria cone of the center was constructed on and drapes a topographic high upheld by Miocene tuff. The geomorphic models developed for cone erosion at the Cima volcanic field apply to cones that were constructed on alluvial surfaces. Thus, the base of the scoria cones in Cima volcanic field are sites of accumulation of reworked scoria transported down the cone slopes. In contrast, the eastern and western base of the scoria cone of the Hidden Cone center formed on the steep slopes of the underlying topography. Reworked scoria transported down the cone slope does not accumulate but instead continues to be transported downslope from the base of the cone by processes of slope erosion. Thus, the base of the cone in this somewhat unusual setting is not a site of depositional accumulation and a cone-slope apron would not be expected to form. By inference, the steep cone slopes (angle of repose) of Hidden Cone could be maintained because of the steep topographic slopes below the base of the cone. The only site at which cone-slope apron deposits might be expected to form is at the northern base of the cone where a depositional platform is upheld by topography created by the northern lava flow. Here, the cone-slope apron deposits are present and were studied through the trenching studies. Thus, these observations allow the development of a conceptual model that may explain the apparently conflicting soil and geomorphic features of the Hidden Cone.

Whole-rock, K-Ar age determinations have been obtained for both centers of the basalt of Sleeping Butte. They are 0.29 $\pm 0.11,0.32 \pm 0.15$, and 0.24 $\pm 0.22 \mathrm{Ma}$ (Crowe et al., 1982). The analytical uncertainty of individual analyses generally exceeds 100 ka (Crowe and Perry, 1991). Turrin (1992, p. 231) reported ${ }^{40} \mathrm{Ar} /{ }^{39} \mathrm{Ar}$ ages of about $380 \mathrm{ka}$ for lavas of both Sleeping Butte centers. Minor et al. (1993) reported an age of about $350 \mathrm{ka}$ for the Hidden Cone center. The degree of erosional dissection of the lavas we found is consistent with these age determinations. Also, the degree of horizon development of soil on the lavas and cone-apron deposits and the degree of dissection and development of a cone-slope are consistent with a minimum age of greater than several hundred thousand years (Crowe and Perry, 1991). A U-Th disequilibrium age measurement is being processed for the western lava lobe of the Little Black cone. Cosmogenic surface exposure ages using the ${ }^{3} \mathrm{He}$ method will be obtained for surface scoria deposits of the youngest event of the Hidden cone. We will also obtain ${ }^{40} \mathrm{Ar} /{ }^{39} \mathrm{Ar}$ age determinations of multiple eruptive units of both Little Black Peak and Hidden Cone by the end of 1995.

Preliminary paleomagnetic data from a limited number of sites in the lava and scoria deposits of both basalt centers were interpreted as a single or closely grouped direction of remanent magnetization (Champion, 1991). Champion (1991) inferred from these data that both centers formed in a single eruptive event and, therefore, are monogenetic volcanic centers. Such an interpretation is consistent with the geology and stratigraphy of the Little Black Peak center (Crowe and Perry, 1991). Unfortunately, the monogenetic classification of the Hidden Cone center may not be verifiable using paleomagnetic data, because there are no deposits of agglutinated spatter associated with the youngest eruption of the Hidden Cone center, which would provide reliable indicators of the field direction at the time of formation of this deposit. Additional 
geochronology work is planned to evaluate the different models of the eruptive history of the Hidden Cone center (Crowe and Perry, 1991).

FY96 \& FY97 revisions

Several new ages of the Sleeping Butte centers became available in FY96. Fleck et al. (1996) report weighted mean K-Ar ages of $0.323 \pm 0.027 \mathrm{Ma}$ and $0.373 \pm 0.042 \mathrm{Ma}$ for Little Black Peak and Hidden Cone, respectively. Duplicate ${ }^{40} \mathrm{Ar} /{ }^{39} \mathrm{Ar}$ measurements of the main flow at Little Black Peak from NMBM yielded reproducible ages of $0.39 \pm 0.03$ and $0.36 \pm 0.04 \mathrm{Ma}$ (Table 2.A), slightly older than the K-Ar ages reported by Fleck et al. (1996). A U-Th disequilibrium age of $445+\infty-156(2 \sigma)$ ka was measured at Los Alamos for the same Little Black Peak sample measured for ${ }^{40} \mathrm{Ar} /{ }^{39} \mathrm{Ar}$ at NMBM (Figure 2.A).

Sleeping Butte

SB-90-8-20-1BMC

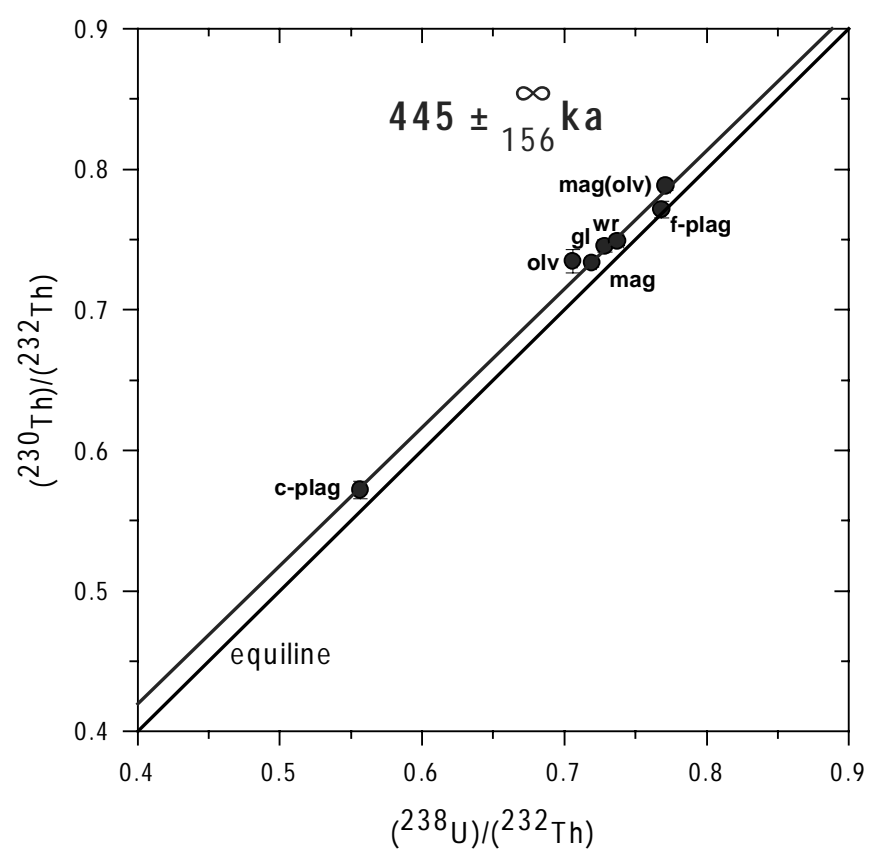

Figure 2. A U-Th disequilibrium isochron for Little Black Peak

${ }^{40} \mathrm{Ar} /{ }^{39} \mathrm{Ar}$ measurements of the eastern and northern flow at Hidden Cone from NMBM yielded ages of $0.32 \pm 0.03$ and $0.56 \pm 0.10 \mathrm{Ma}$ (Table 2.A). Additional measurements would have to be obtained to verify whether the northern flow is in fact significantly older than the eastern flow as indicated by the ${ }^{40} \mathrm{Ar} /{ }^{39} \mathrm{Ar}$ data, but we note that Fleck et al. (1996) report that the two flows have distinct remanent magnetization directions, consistent with an age difference between the two flows. We also note that ${ }^{3} \mathrm{He}$ cosmogenic surface exposure ages obtained from Hidden Cone indicate that the scoria cone surface may be much younger than the lava flows (discussed above). In summary, the age of Hidden Cone cannot be completely resolved with existing data. 


\section{The Lathrop Wells Center}

\section{A. Introduction}

\section{FY96 \& FY97 revisions}

After several years of study, we now have obtained sufficient data to bring the Lathrop Wells studies to closure. Several new conclusions have brought us to this point. First, and most important, new ${ }^{40} \mathrm{Ar} /{ }^{39} \mathrm{Ar}$ data for both basaltic lava samples and partially fused sanidine in tuff xenoliths provide convincing and reproducible evidence that the Lathrop Wells center formed about 75 thousand years ago. These data provide a foundation for integrating all other chronology data. Second, cosmogenic ${ }^{3} \mathrm{He}$ and ${ }^{36} \mathrm{Cl}$ ages, new TL ages for silt beneath the scoria-fall deposits, and most of the geomorphic and pedogenic features of the center provide a generally consistent set of data that further support the interpretation of a single eruptive event at $\sim 70-90 \mathrm{ka}$. Third, we conclude that the isochron ages from the $U$-Th disequilibrium measurements in some cases do not record the crystallization age of the basalt flows. Fourth, paleomagnetic data support an interpretation of a monogenetic eruptive history of the center but do not preclude a more complex eruptive history. Fifth, the stratigraphy of primary and reworked deposits in the summit crater of the main scoria cone provide evidence for a greater degree of erosional modification of the cone than originally estimated, consistent with an age of the cone of $~ 75 \mathrm{ka}$. Sixth, new geochemical studies indicate that tephras of the Qs4 deposits are pedogenically altered and do not have a composition requiring a new volcanic event. However, like many geologic data sets, interpretation of the origin of the Qs4 deposits are ambiguous, and some fabric and depositional features of the rocks remain enigmatic. This uncertainty is exacerbated by the complete removal of the Qs4 deposits by quarrying. Resolution of the origin of the Qs4 deposits is not particularly significant for probabilistic volcanic hazard assessment (PVHA). Finally, an age difference between eruptive events of no more than about $15 \mathrm{ka}$ at the center (mean ${ }^{40} \mathrm{Ar} /{ }^{39} \mathrm{Ar}$ ages and the youngest $\mathrm{U}$-Th disequilibrium age from the flows) allows resolution of many of the somewhat puzzling geomorphic features of the volcanic center. Discriminating ages at this level with geomorphic data is almost certainly difficult or impossible. But the refined age of the center does remove much of the original controversy that developed when the lavas were considered to be possibly as old as about 120 or $130 \mathrm{ka}$, resulting in a total age span of the center that might possibly be discriminated through application of geomorphic criteria. Some of the field and geomorphic data for the Lathrop Wells center remain problematic. The center-wide erosional unconformities and degradational differences between the Q1 and the Q2/Q3 deposits are difficult to explain without an age difference between the respective deposits. We continue to suspect that there is an age difference between the Q1 and the Q2/Q3 deposits, but this age difference must be less than about 10 ka according to geochronology results and is unresolvable using current geochronology methods. Again, this possible age difference is not significant in PVHA. Thus, we conclude that it is reasonable to assign an age of $75 \mathrm{ka}$ to the Lathrop Wells center and bring this aspect of volcanism studies to closure.

The issue of the age and eruptive history of the Lathrop Wells center (polygenetic versus monogenetic) has been given much attention in volcanism studies. While we have never preferred the polygenetic model from the perspective of volcanic 
processes, the potential significance of this model with respect to a potentially young age of the center cannot be ignored. Our responsibility has been to investigate multiple alternative models so that no model that might significantly affect PVHA is overlooked.

The geology and chronology of the Lathrop Wells volcanic center was described by Crowe and Carr (1980), Vaniman and Crowe (1981), Crowe et al. (1983), Crowe (1986), Wells et al. (1990, 1991, 1992), Turrin et al. (1991b, 1992), Crowe et al. (1992), and Zreda et al.(1993). The volcanic deposits of the center overlie volcanic bedrock of the Paintbrush and Timber Mountain Tuffs, and alluvial deposits. These deposits are overlain locally by younger alluvium and are mantled on the north and south sides by sand, silt, and loess of Holocene age. Active sand dunes are present on the surface of lava flows exposed in the east part of the center. The Lathrop Wells center is located near the intersection of several northwest-trending faults that extend from the west parts of Yucca Mountain and the northeast-trending Stagecoach Road fault (Figure 2.8). The center consists of a large main scoria cone and three or four sets of fissures marked by paired or individual accumulations of spatter, bombs, and scoria. Multiple-eruptive events repeatedly reoccupied two sets of the fissure systems. The majority of vents and fissures for the center are aligned along northwest trends, parallel to the northwest-trending faults. Small-volume, blocky $a a$ lava flows vented from numerous sites along some of the fissures.

The largest scoria cone of the Lathrop Wells center, the main cone, is elongate northwest. This elongation probably was controlled in part by prevailing winds during the pyroclastic eruptions that formed the cone. Additionally, the feeder dike for the center appears to be oriented north-northwest, as indicated by two lines of evidence. First, there is a summit zone of red scoria centered about the crater and extending to the southeast and northwest. This cone feature was formed from oxidization of the scoria deposits by rising volcanic gases emitted from an inferred underlying northwest-trending dike. Second, multiple sets of northwest-trending, locally paired spatter cones and scoria mounds that demarcate eruptive fissures are present along the east base of the main cone, southeast of the main cone, and at the northeast edge of the volcanic center. An alignment of west/northwest-trending spatter cones and scoria mounds marking another fissure zone is located north-northeast of the main cone.

In the early stages of this research, the Lathrop Wells center was assumed to be a simple monogenetic volcano with an age, based on whole-rock K-Ar age determinations, of about $300 \mathrm{ka}$ (Vaniman and Crowe, 1981; Vaniman et al., 1982; Crowe, 1986). However, two lines of evidence resulted in reevaluation of the chronology and eruptive history of the volcanic center. First, additional whole-rock, K-Ar age determinations were obtained (Sinnock and Easterling, 1983) These ages ranged from about 20 to $>700 \mathrm{ka}$, an unacceptably large range to have even the remotest confidence in the results of K-Ar age determinations. Second, the degree of horizon development in soils and geomorphic features of the main cone were recognized to be inconsistent with an inferred age of $300 \mathrm{ka}$. They were judged to be more consistent with an age of late Pleistocene or Holocene (Wells et al., 1988). This was a critical observation because we did not want to disregard potential evidence of recent eruptive events at the center that could result in underestimation of the risk of future volcanism for the potential Yucca Mountain site (Crowe et al., 1992). Accordingly, a new phase of field and geochronology studies was initiated in 1987. 


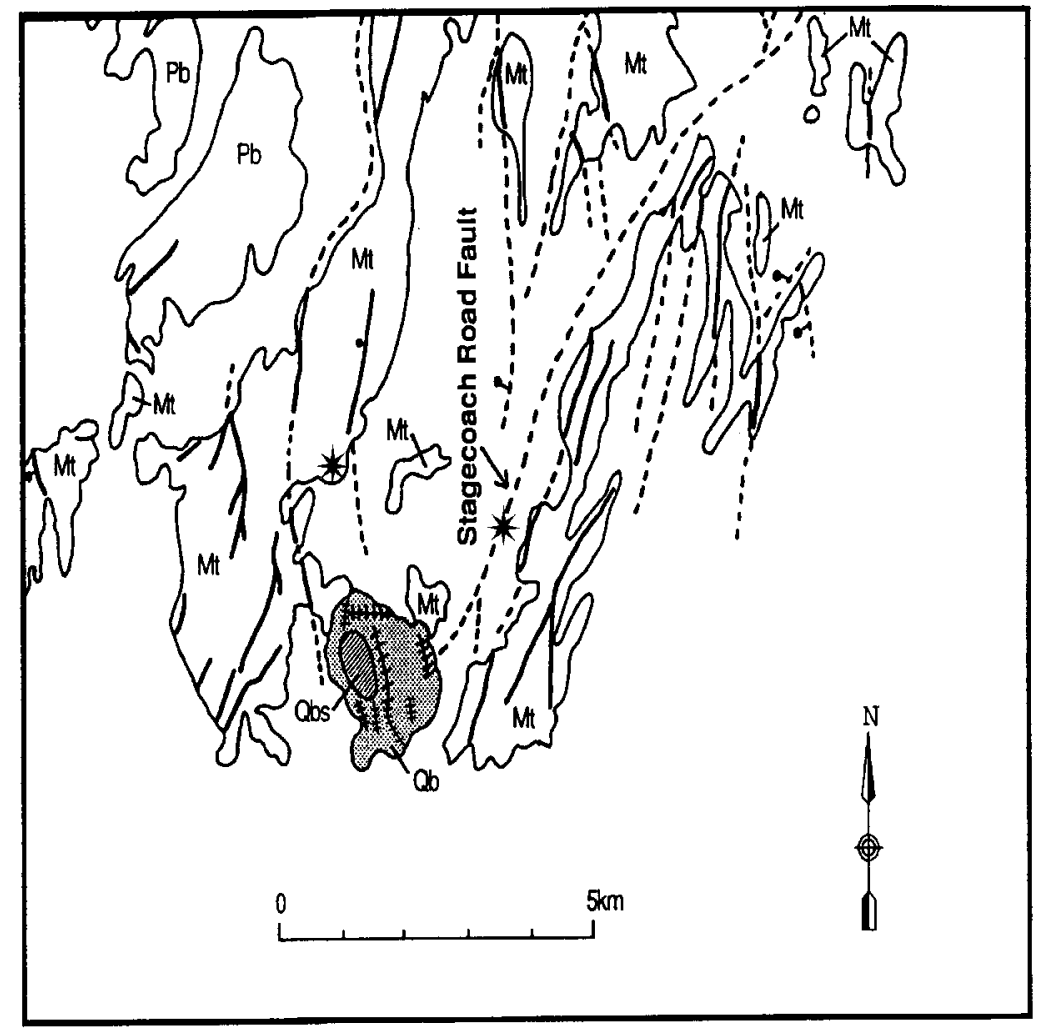

Figure 2.8. Geologic setting of the Lathrop Wells volcanic center. The center is located at the south end of Yucca Mountain. Volcanic deposits of the center overlie Miocene tuff and alluvial deposits and are locally overlain by alluvium and eolian deposits. Mt: Miocene tuff undivided, Pb: Pliocene basalt of Crater Flat, Qb: Quaternary lava and pyroclastic deposits of the Lathrop Wells center, Qbs: Main scoria cone of the center. Cross-hatched lines are eruptive fissures and denote structural trends of eruptive vents. The star symbols mark sites where distal ash deposits from the Lathrop Wells volcanic center have been identified. Modified from Crowe et al. (1992).

The Lathrop Wells volcanic center was remapped at a scale of 1:4000, and the volcanic rocks were divided into five lithostratigraphic units (Crowe et al., 1988). More than 60 soil and tephra pits, and trenches were constructed to expose stratigraphic contacts, to assess the degree of soil development, and to facilitate collection of samples for geochronology and geochemistry studies. Five large trenches were constructed using heavy construction equipment; four were constructed on the north flanks of the center and one on the south flank. The northern trenches exposed the contacts between lava units and pyroclastic deposits, and the internal geometry and stratigraphy of scoria mounds. The south trench exposed possible late Pleistocene or Holocene tephra and soils (Wells et al., 1990; Crowe et al., 1992). Additional geochronology studies were attempted using multiple independent isotopic methods to further constrain the age of the center (Crowe et al., 1992). Tephra-fall units were identified in surficial deposits mantling topography $3 \mathrm{~km}$ north of the Lathrop Wells center.

The wealth of new stratigraphic, geochemical, and geochronologic information provided us with increased confidence that the Lathrop Wells center was formed during four distinct eruptive episodes. Two episodes of lava extrusion occurred along flank fissures that are secondary to the site of the main cone. This eruptive activity was accompanied by deposition of scoria-fall sheets from a probable vent or vents now concealed beneath the main cone. A third eruptive episode 
formed the major volume of the main cone and lobes of blocky a a lava extruded from a satellite vent northeast of the main cone. The youngest eruptions of the main cone did not produce widely distributed scoria-fall deposits. The delineation of the three oldest eruptive episodes is based primarily on the recognition of erosional unconformities in the scoria-fall and vent-scoria deposits. The fourth eruptive episode is marked only by small-volume and local fall-and-pyroclastic-surge deposits present on the south part of the center, locally separated from underlying volcanic deposits by nonconformities marked by soils with horizon development. The vents for the youngest deposits have not been identified and are inferred to have been destroyed by commercial quarrying. Recognition of these deposits has been aided, however, by their unique geochemistry, which can be discriminated from all other deposits of the center.

The complex evolution of the Lathrop Wells volcanic center requires that it is not a simple monogenetic volcano and instead must be classified as a polygenetic volcano (Crowe et al., 1988, 1989; Wells et al., 1990). Primary evidence of polygenetic events at the center is provided from field, stratigraphic, geomorphic, and soils data. Geochemical data for the volcanic center are inconsistent with a monogenetic eruptive model and are consistent with the polygenetic eruption model (see Chapter 4). Current geochronology data, while generally supporting the polygenetic model, do not definitively prove or refute the concept of multiple eruptive events. The geochronology data are inconsistent with a monogenetic model, but the model cannot be excluded solely on the basis of geochronology data. Disproving the monogenetic model requires consideration of both the geochronology and the field, stratigraphic, geomorphic, soil, and geochemistry data. Some workers regard the latter data as controversial (Whitney and Shroba, 1991; Turrin et al., 1991b, 1992). Because of this controversy, we consider both monogenetic and polygenetic models in probabilistic volcanic risk assessment (see Chapter 6).

From oldest to youngest, the eruptive intervals of the Lathrop Wells volcanic center consist of

1. Chronostratigraphic unit I: Chronostratigraphic unit I consists of four groups of lava flows and local pyroclastic deposits that crop out along multiple, northwest-trending fissures located south, beneath, north, and northeast of the main cone. The scoria and spatter deposits mark eruptive vents of chronostratigraphic unit I and were modified extensively by erosion prior to emplacement of chronostratigraphic unit II. The age of the lava and scoria deposits of chronostratigraphic unit I are constrained to be $>85$ or $95 \mathrm{ka}$ (minimum, cosmogenic helium and chlorine surface exposure ages), and possibly about $135+20-15 \mathrm{ka}$ (U-Th disequilibrium age). The eruptions of chronostratigraphic unit I are inferred to be the source of a carbonatecemented, basal fall deposit interbedded with alluvial deposits several kilometers northwest, north, and northeast of the main cone.

\section{FY96 \& FY97 revisions}

We no longer use the term "chronostratigraphic unit" for the eruptive units of the Lathrop Wells center because there is not a demonstrated age difference between deposits. Instead, we designate the four possible eruptive episodes at Lathrop Wells Q1-Q4 (oldest to youngest) with subunit designations remaining the same. We still regard the scoria and lava units of eruptive unit Q1 to be more extensively modified by erosion than the other eruptive units. The U-Th disequilibrium age of Q1 probably does not reflect the crystallization age of the lavas because the olivine phenocrysts do not exhibit reliable $\mathrm{U}$-Th systematics (see section $\mathrm{F}$ below). 
Examination of carbonate-cemented basal scoria-fall deposits in trenches has raised an alternative interpretation of the tephra deposits $\sim 2 \mathrm{~km}$ north of the main cone. The observed carbonate induration in the lower tephra unit may be due to the effect of pedogenic alteration associated with lateral movement of water from upslope infiltration along a permeability contrast (interflow). Whatever the origin of the lower tephra, the upper tephra has been positively correlated geochemically with the Q2/Q3 fall-sheet deposits.

2. Chronostratigraphic unit II: Chronostratigraphic unit II consists of the largest-volume lava of the Lathrop Wells center, local spatter and scoria deposits that form a short, northwesttrending fissure at the northeast base of the main cone, and widespread scoria-fall and pyroclasticsurge deposits erupted from vents inferred to be concealed mostly beneath the present main cone. The lava sequence erupted from a northwest-trending fissure that parallels a northwest-trending normal fault that predates the basaltic center. The ages of deposits of chronostratigraphic unit II are presently constrained to be between about 80-90 ka (cosmogenic helium surface exposure ages) and $107 \pm 33 \mathrm{ka}\left({ }^{40} \mathrm{Ar} /{ }^{39} \mathrm{Ar}\right.$ step-heating isochron). Existing chronology data cannot discriminate the ages of chronostratigraphic unit I from chronostratigraphic unit II. The chronostratigraphic units (I and II) are distinguished by their spatially separate eruptive vents, stratigraphic position, contrasts in their degree of geomorphic preservation and development of pedogenic carbonate, and different geochemical compositions. The scoria-fall deposits of chronostratigraphic unit II are correlated tentatively with fall and surge deposits interbedded with alluvium that overlie ash deposits of chronostratigraphic unit I several kilometers north and northeast of the main cone and are exposed in fault trenches on the west and east sides of Yucca Mountain.

3. Chronostratigraphic unit III: The eruptive events of chronostratigraphic unit III formed most of the main scoria cones of the Lathrop Wells volcanic center and small-volume lobes of blocky $a a$ lava flows from a vent located northeast of the main cone. The scoria deposits were emplaced by intermixed strombolian and weak hydrovolcanic eruptions and did not form an extensive scoria-fall sheet. The age of this event is $>40 \mathrm{ka}$, and possibly $>65 \mathrm{ka}$ on the basis of cosmogenic ${ }^{3} \mathrm{He}$ and ${ }^{36} \mathrm{Cl}$ ages of bombs from the main cone and cosmogenic ${ }^{3} \mathrm{He}$ ages of the lava flow. Present geochronology data indicate the main cone and lava flow are younger than the deposits of chronostratigraphic units I and II but do not conclusively rule out the possibility that the main cone could be as old as chronostratigraphic unit II. However, the marked contrast between the degree of geomorphic modification of the main cone and fall deposits of chronostratigraphic unit II indicate that chronostratigraphic unit III is significantly younger than chronostratigraphic unit II.

FY96 \& FY97 revisions

Two interpretations have changed since the volcanism status report. First, we have returned to an earlier interpretation that the most likely event to have produced a scoria-fall sheet is the formation of the main cone. This requires that the geochemical differences between the main cone and the fall-sheet are produced by continuous magmatic processes that as of now are not fully understood (see Chapter 4). Further, 
equating stratigraphically the fall-sheet and the main cone previously required ignoring the perceived dissection differences between the upper surfaces of the respective deposits (i.e., the perception that the fall-sheet surface is more eroded than the main cone surface). The perceived difference in erosion must be reconsidered now in light of new evidence, discussed below, that the main cone is more erosionally modified than previously thought. Thus, there may be no difference in the degree of erosion of the main cone and the scoria-fall sheet. Second, the lava flow ages of $\sim 75$ ka are now considered to be compatible with a similar age of the main cone, an interpretation that is also largely compatible with the cosmogenic ${ }^{3} \mathrm{He}$ and ${ }^{36} \mathrm{Cl}$ age determinations.

4. Chronostratigraphic unit IV: Small-volume eruptions formed probable small satellite vents south of the main cone that have been removed by commercial quarrying of the scoria deposits. The eruptive events of chronostratigraphic unit IV have been established from recognition of local thin beds of scoria that overlie scoria and lava flow deposits of the older chronostratigraphic units. The identification of scoria deposits of chronostratigraphic unit IV is aided by their distinctive major- and trace-element geochemistry. The age of chronostratigraphic unit IV may be bracketed by TL age determinations of silt from soil beneath ( 8 and $4 \mathrm{ka}$ ) and above (4 ka) the units.

\section{FY96 \& FY97 revisions}

The origin and significance of the Q4 scoria deposits and the possibility that they might represent Holocene eruptive events has been one of the more controversial aspects of volcanism studies (Wells et al., 1990; Whitney and Shroba, 1991; Wells et al., 1991; Turrin et al., 1991b, 1992; Wells et al., 1992). We conclude that the Q4 deposits represent an incompletely understand deposit (either volcanic or non-volcanic) that postdates the age of the main cinder cone by at least $10 \mathrm{ka}$, as evidenced by the presence of soils separating the two units and the results of TL dates on these soils. If the age of the main scoria cone is $\sim 75 \mathrm{ka}$, then the age of the Q4 deposits is probably in the range of $60-65 \mathrm{ka}$.

There is now convincing evidence that the geochemistry of Q4 does not require a unique volcanic event but originated from pedogenic alteration of scoria from Q3 (see Chapter 4). Revisions to our interpretation of the origins of Q4 are discussed fully in Section $\mathrm{E}$ below.

The subdivisions of chronostratigraphic units for the Lathrop Wells volcanic center are described below, from oldest to youngest. The subdivisions used in this report are modified from Crowe et al. (1988), and Crowe et al. (1992). They are based on the most recent geologic mapping, interpretation of stratigraphic relations observed from field studies and geologic contacts exposed in trenches, and geochemical and geochronology data for all units. The unit identifications used in this report replace all previous stratigraphic subdivisions of the Lathrop Wells volcanic center. We have informally named each of the major lava sequences at the center (Figure 2.9). These names are used in combination with the unit designations to facilitate descriptions of the eruptive events. 


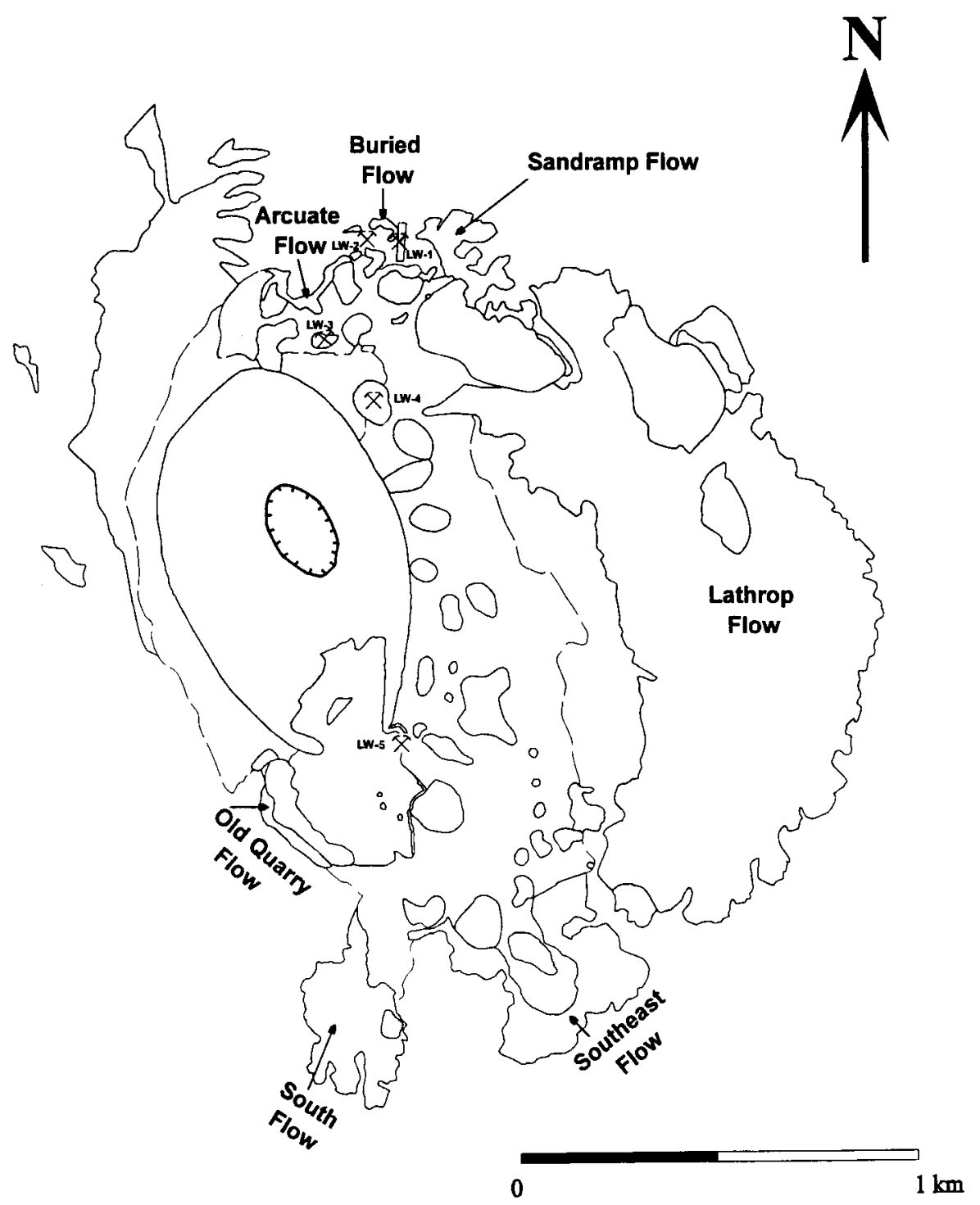

Figure 2.9. Generalized map of the outlines of the Lathrop Wells volcanic center showing the informal names of the lava units. LW-1 through LW-5 are, respectively, the location of major trench excavations at the volcanic center.

\section{B. Chronostratigraphic Unit I}

The oldest identified chronostratigraphic unit at the Lathrop Wells center comprises four sets of lava flow units associated with a series of overlapping, northwest-trending fissure systems that extend beneath and flank the main cone, and a second set of west/northwest-trending fissures northeast of the main cone (Figure 2.10). Spatially associated with the lavas are eroded moundshaped accumulations of scoria, spatter, and bombs. These pyroclastic deposits mark the vents for weakly explosive (hawaiian) pyroclastic eruptions and the eruptive sites of the lava flows. Chemically, the lavas and related pyroclastic deposits of chronostratigraphic unit I are characterized by depletions in rubidium, thorium, and the heavy rare-earth elements and by enrichments in strontium, phosphorous, the middle rare-earth elements and titanium relative to the other chronostratigraphic units (Figure 2.11). 


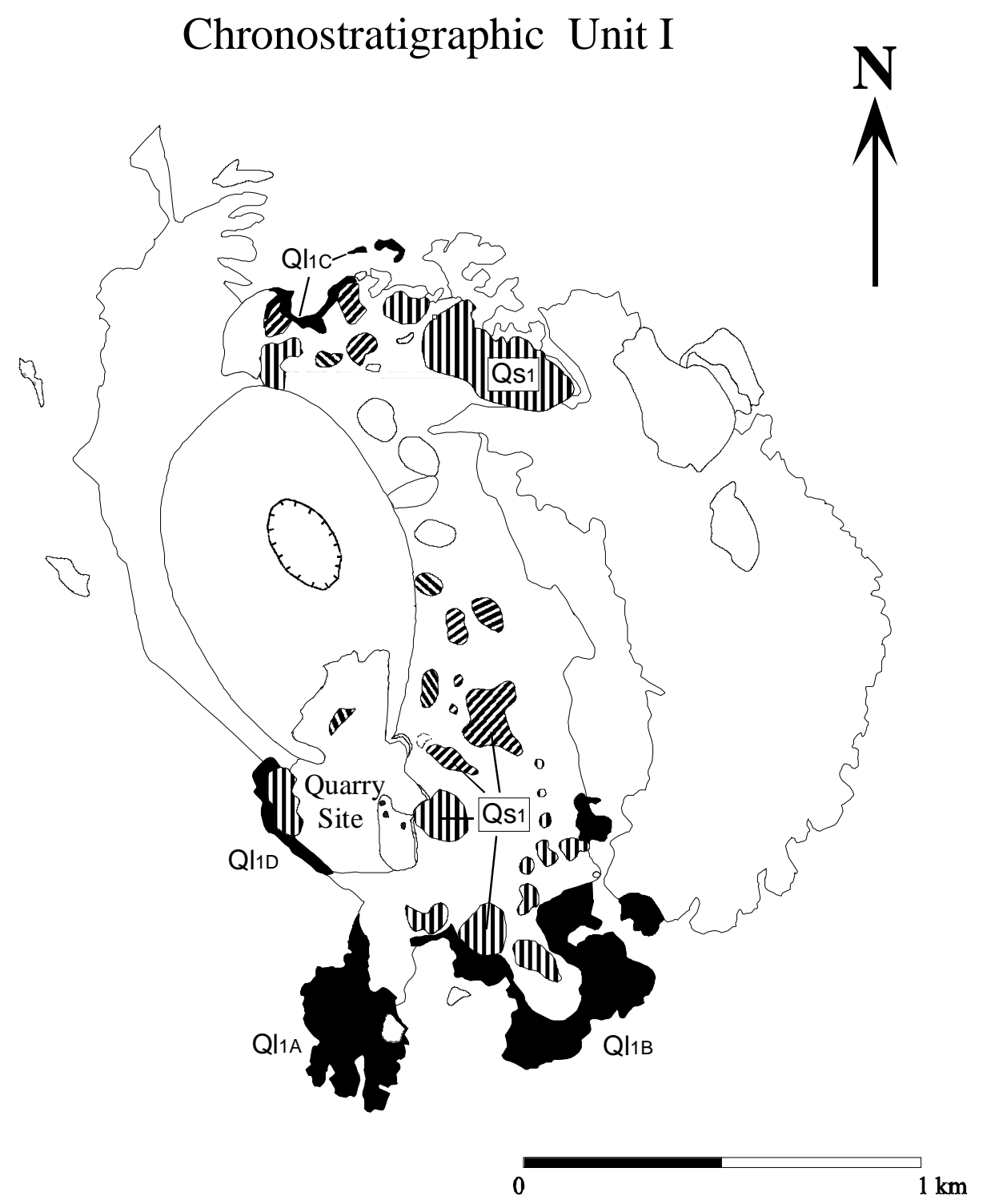

Figure 2.10. Geologic map of the distribution of volcanic subunits of chronostratigraphic unit I of the Lathrop Wells volcanic center. The black areas of the figure represent the lava flow subunits; the cross-hatched areas outline recognizable vents (scoria and spatter mounds) for the lava subunits and fissure systems.

1. The Qs1/Q11 Unit. The Qs1/Q11 unit is subdivided into four subunits on the basis of the spatial distribution of their source vents and lava flows (subunit designations are indicated on Figure 2.10; lava names on Figure 2.9).

a. Subunit Qs1d/Q11d: The Old Quarry Flow. Subunit Qs1d/Q11d, informally named the Old Quarry flow because of its proximity to the original site of commercial quarrying of the scoria deposits, consists of northwest-trending, degraded mounds of scoria, local sites of agglutinated spatter, and minor, small-volume lavas. The scoria mounds, which are presumed to be the vents for the scoria deposits, have no recognizable vents or craters. They consist of conical mounds of scoria with eroded upper surfaces. However, the local thickness of scoria deposits, the coarse size of bombs (locally $>1 \mathrm{~m}$ in long dimension), and the presence of lenticular zones of 


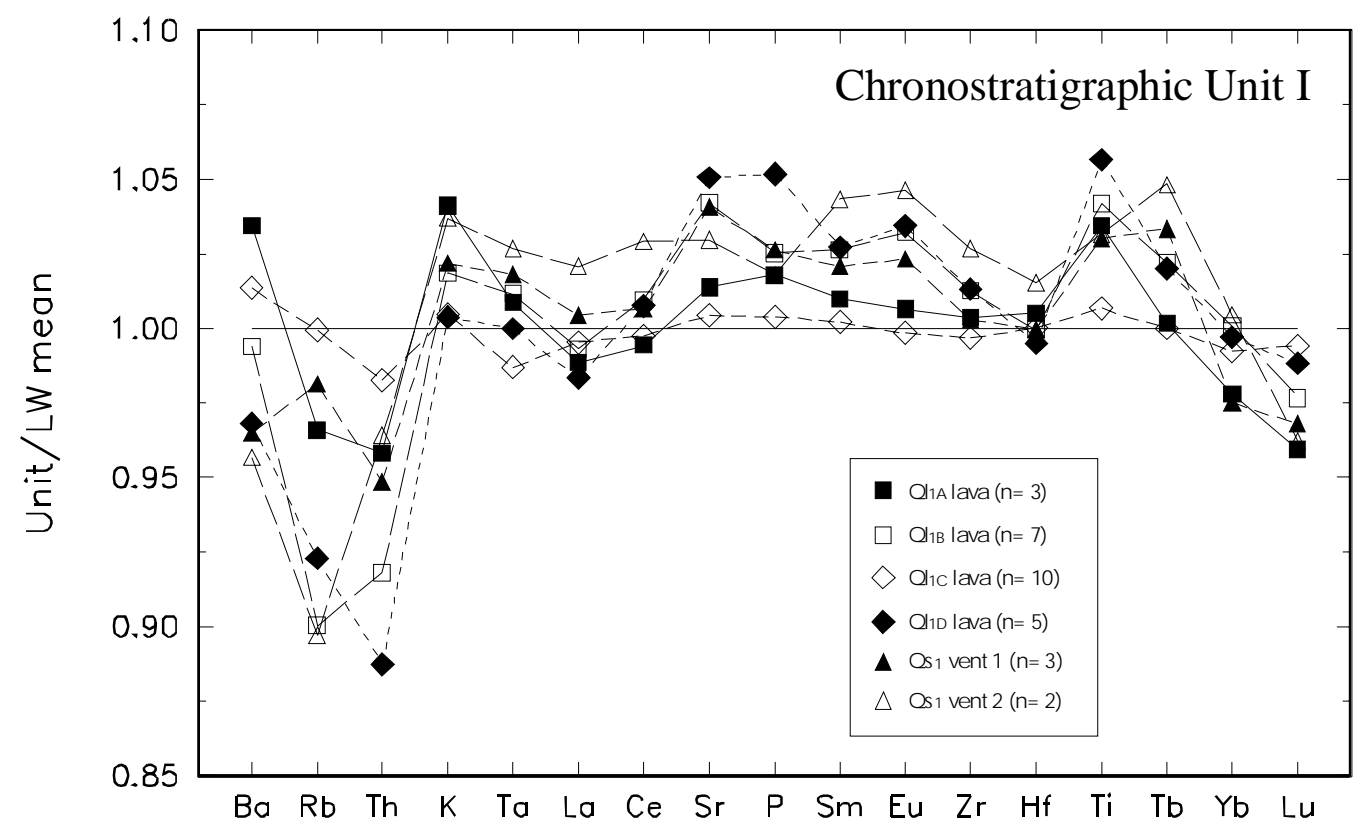

Figure 2.11. Spidergram of elemental compositions normalized to an average composition for all analyzed samples of the volcanic units of the Lathrop Wells center $(n=99)$. Samples are designated by lava and vent deposits. Each pattern is plotted as the average of multiple analyses of specific eruptive subunits.

agglutinated spatter require that the deposits were erupted at the approximate site of the mounds. There has been sufficient erosional modification of the mounds to remove or obscure the primary constructional features of the vent or vents. Derivation of the scoria mounds from lava-rafting and destruction of the main cone can be eliminated by: (1) field and trench exposures that show the lava flows overlie the scoria deposits; (2) exposure of dikes in the scoria deposits; (3) the size of spatter and bombs in the scoria-mound deposits exceeds the size of spatter and bombs in the main cone; and (4) the chemistry of the scoria-mounds matches the chemistry of the associated lavas and is distinct from the scoria deposits of the main cone.

\section{FY96 \& FY97 revisions}

The alternative view of Qs1 outcrops, that they were produced by rafting of the walls of the main cone on Q11 lavas, was preferred by some members of the volcanism expert judgment panel (Geomatrix, 1996). We disagree with a rafting interpretation of the deposits for the reasons presented above and, additionally, because the morphology of the lavas of the Lathrop Wells center is consistent with formation from low effusion rates that typically do not raft cone scoria. Moreover, road cuts and trenching exposures show that the scoria deposits have radial dips. In contrast, rafted deposits should have mostly unidirectional dips consistent with the portion of the wall of main cone that was rafted. We find it unlikely that a rafted cone segment would show the radial dips of the observed outcrops. Finally, while we disagree with a rafting interpretation of these outcrops, we think it is important to record the rafting model as an alternative interpretation of the described outcrops. Neither interpretation (rafting versus satellite vent) is significant with respect to monogenetic versus polygenetic interpretations or PHVA. 
Blocky $a a$ lava flows flank the scoria mounds on the north (now covered by quarry debris), west, and south sides. The lavas overlie or can be traced to the scoria mounds and were extruded from multiple sites, mostly at the base of and on the lower slopes of the scoria mounds. The flows are blocky $a a$ lavas and were unusually viscous for magma of basaltic composition. They form small lobate flows that extend no further than several tens of meters from their vents (Figure 2.10). The blocky $a a$ flows were disrupted by flowing down the slopes of their associated scoria mounds. This downslope movement $\left(15^{\circ}\right.$ to $20^{\circ}$ slopes) oversteepened the flows causing slumping and local breakup of the lava lobes. Outcrops of the flows expose steep zones of contorted flow foliation, blocky flow-top rubble, and internal zones of massive lava that mark the cores of the $a a$-flow interiors.

The Old Quarry flow subunit can be distinguished in outcrop by the presence of small microphenocrysts of plagioclase. It is the only unit with visible (hand lens identification) microphenocrysts of plagioclase. A scoria mound of the subunit, identified on the basis of geochemical composition and the presence of plagioclase microphenocrysts, could be traced originally beneath the main cone of the Lathrop Wells center. The exposures of this mound have now been removed by the commercial quarrying activity.

A sample of the Q11d Old Quarry flow has been dated by the U-Th disequilibrium method at $135+20-15(1 \sigma) \mathrm{ka}$. A cosmogenic helium age (surface exposure age) of $80 \pm 14(2 \sigma) \mathrm{ka}$ has been obtained for a bomb collected from the surface of a scoria mound. This is inferred to be a minimum exposure age for two reasons. First, the sampled outcrops of the Old Quarry flow subunit are adjacent to the main cone. They were covered by scoria-fall deposits from multiple eruptive phases of the main cone and vents located beneath the main cone. Second, the modern surfaces of the Qs1 subunit are erosional; an unknown thickness of scoria has been removed from the sample site. Replicate ${ }^{40} \mathrm{Ar} /{ }^{39} \mathrm{Ar}$ ages of the Old Quarry flow are highly variable, and provide limited information on the age of the Qs1d/Q11d unit (Table 2.1).

b. The Northern Lava Subunit. The Qs1c/Q11c subunits comprise eroded scoria mounds exposed beneath and extending north of the main cone, scoria deposits that mark a west/northwesttrending fissure, and local lava units derived from the scoria mounds. The subunits are deeply eroded, draped by scoria-fall deposits from chronostratigraphic unit II, and locally covered by alluvium, and sand and silt of eolian origin. The distribution of the subunits, where obscured by overlying deposits, has been established through excavation of numerous small pits and two large trenches (Figure 2.9).

A north/northeast-trending cluster of scoria mounds is exposed directly north of the main cone (Figure 2.10). These deposits have subdued topography and diffuse boundaries between the mounds. The mounds have been eroded significantly and no longer have distinct topographic expression (primary constructional topography). Three lines of field evidence indicate considerable erosion of the scoria mounds. First, short segments of vertically dipping dikes are exposed at several locations in the scoria mounds. The dikes project 1 to $1.5 \mathrm{~m}$ above the scoria surface. The dikes must have been emplaced originally in scoria deposits. The projection of the dikes above the modern surface requires the removal of more than a meter of unconsolidated scoria above and flanking the dikes. Second, the crests of the mounds are marked by an anomalous concentration of large bombs. Trenching of several of the scoria mounds revealed that the abundance of large bombs is notably less in the interior of the mounds than on the crests. The accumulation of bombs on the crests of the mounds is inferred to be an effect of erosion. The coarser bomb debris was not removed during degradation of the mounds and became concentrated as a lag deposit during 
progressive stripping of the finer-grained scoria. Third, exposure windows through the overlying scoria-fall deposits show that the Qs1c surfaces have well developed cut-and-fill structures forming an integrated network of rills. At the north flank of the cone, these rilled surfaces can be traced beneath the geomorphically unmodified slopes of the main cone (Figure 2.10).

\section{FY96 \& FY97 revisions}

An alternative interpretation of the above described rocks expressed by some members of the expert judgment panel (Geomatrix, 1996) is that they are rafted remnants of cone scoria and rest directly on mostly concealed aa lava flows. Thus, the subdued, non-primary topography of the scoria mounds by this interpretation did not result from erosion but is simply an expected irregular form of rafted segments of cone-wall scoria deposits. Further, the eroded dike in cone scoria was inferred to be a channel-edge segment of an aa lava flow channel. While acknowledging that this is an alternative interpretation, we argue that multiple lines of evidence are inconsistent with a rafted origin of the deposits. First, trenching of one of the scoria mounds shows that it has radial dips consistent with a vent, not rafted scoria. Second, measurement of the field magnetization direction of scoria deposits exposed in the trench walls using a specialized sampling method (see paleomagnetic studies in section $\mathrm{F}$ below) shows that the deposits have a coherent field magnetization direction, which is unlikely if the deposits are rafted segments of the main cone. Further, studies of the field magnetization directions of scoria deposits of the main cone show incoherent field magnetization directions consistent with emplacement temperatures below the Curie isotherm, evidence again that is inconsistent with the scoria deposits being rafted from the main cone. Third, trench exposures at the north outcrop area of the Ql1 lava flows show that they overlie, not underlie the scoria deposits. Finally, there are excellent exposures of outcrops of cone scoria at the southern edge of the scoria deposits. These outcrops can be traced continuously toward and beneath the main cone, a very unlikely geometry if lava flows are inferred to have rafted the scoria deposits from the main cone.

An arcuate band of lava (Q11c), informally named the arcuate flow, crops out north of and flanks the scoria mounds of Qs1c (Figures 2.9, 2.10). This lava unit was probably derived from the flanking scoria mounds, but the exact relations have been obscured by erosion. The lava is similar in morphology to the flanking lava flows of the other Q11d unit described previously; and they were erupted from the base and flank scoria mounds of the Qslc scoria mound. The Q11c lava can be traced beneath and underlies lava of the topographically higher-standing Q12 unit. Moreover, there are local contrasts in the degree of development of carbonate coating on lava clasts in the Q11c lava compared with the younger Q12 lava (trenches LW-1 and LW-2). These differences may reflect different ages of the lava units, although we have not systematically examined the accumulation of carbonate in the lavas to discriminate uniquely the causes of the variations of secondary carbonate.

A second site of the Qs1c unit is present northeast of the previously described lava and scoria (Figure 2.10). Here the scoria deposits are completely buried by pyroclastic-surge deposits of chronostratigraphic unit II and eolian sand and silt. Identification of the scoria deposits is based entirely on exposure of the units in trenches (Figure 2.9) and the coincidence of the distribution of the scoria deposits with a sand draped, topographic mound. A lava unit of this northeast flow crops 
out discontinuously beneath a thick cover of eolian sand and silt and flanks the north side of the concealed Qs1c scoria deposits (Figure 2.9). This lava was informally named the buried flow (Crowe et al., 1988; 1992) (see Figure 2.9, this paper). A T-shaped trench was constructed across the east edge of the buried flow. The base of the buried lava is locally greater than $10 \mathrm{~m}$ below the modern alluvial surface. The lava consists of a massive lobe ( $2 \mathrm{~m}$ thick) of a single flow of blocky $a a$ lava that overlies lava clinker and thin scoria-fall deposits. The lava lobe is overlain by $5 \mathrm{~m}$ of autoclastic flow rubble. The flow rubble is overlain by $2 \mathrm{~m}$ of reworked flow rubble, in turn overlapped unconformably by eolian sands. At the south end of the trench, the buried lava underlies pyroclastic-surge deposits (Qs2fs), lava of the Q12 subunit, and scoria of the Qs1c subunit (Figure 2.10). Field relations here provide constraints on the interval between eruptive events of chronostratigraphic unit I and II. The flow interior of the upper part of the buried lava flow contains irregular coatings of calcite on fracture surfaces. Overlying the flow is a colluvial wedge consisting of calcite-coated scoria clasts derived from colluvial deposits formed at the north base of the scoria mound of Qs1c. Both the buried flow and the colluvial deposits are overlain by the pyroclastic surge deposits of Qs2fs, which have only minor coating of pedogenic carbonate on the bottom of tephra clasts. These stratigraphic relations require a time break between chronostratigraphic units I and II of sufficient duration to allow formation of extensive secondary pedogenic carbonate in fractures of the buried lava and Qs1c scoria deposits before deposition and cover by the pyroclastic surge deposits.

A discontinuous, west/northwest-trending fissure is marked by elongate mounds of subunit Qs1c (Figure 2.10). These lavas are draped by scoria-fall deposits and are partly overlapped to the east by lava flows of chronostratigraphic unit II. The mounds have been exposed by trenching at two locations and are identical in morphology and origin to the previously described scoria mounds of the Qs1d subunit. Scattered pods of lava, partly concealed by scoria-fall deposits, are present within the scoria mounds (Figure 2.10) and probably are small flows (tens $\mathrm{of}^{3}$ ) fed from radial dikes at the flanks of the mounds of either chronostratigraphic units I or II.

No chronology data have been obtained for the Qs1c/Q11c unit. A sample of the interior of the buried lava flow was collected for dating by the U-Th disequilibrium method and is still being processed. A sample of a Q11c lava was dated by the cosmogenic ${ }^{3} \mathrm{He}$ method and is also being processed.

c. Subunits Qs1a/Ql1a and Qs1b/Ql1b: The South and Southeast Flows. Subunits Qs1a/Q11a and Qs1b/Q11b are informally named the south and southeast flows because of their locations in the south part of the Lathrop Wells volcanic center (Figure 2.10). They consist of two separate lava flows (south and southeast flows), scattered outliers of lava, and eroded scoria mounds. The south flow and vent complex were erupted from multiple sites near the southwest base of scoria mounds exposed in the central part of the outcrop area of subunits Q11a and Q11b (Figure 2.10). The flow consists of three, possibly four, lobes that partly coalesced on their distal ends but can be traced to separate sites at the inferred source vents. Scattered small outcrops of lava are present on the scoria deposits. These are partly covered by both scoria-fall deposits from chronostratigraphic unit II and eolian sands. Some of these lava outcrops can be traced laterally to their vents where they are delineated by vertical dikes. They are inferred to represent erosional remnants of small lava lobes extruded from radial dikes that extended outward from the scoria mounds. These dikes breached the surface at the flanks of some scoria mounds and erupted small volumes of lava (tens of $\mathrm{m}^{3}$ ). The scoria mounds of subunit Qs1a are identical to previously described deposits. They consist of erosionally beveled deposits of vent scoria with surficial concentrations of coarse aerodynamically shaped bombs. The scoria mounds form discontinuous 
alignments of vents that mark fissures coparallel to and west of the Q11d fissure. En echelon fissure systems of the Qs1a unit extend close to and probably project beneath the main cone (Figure 2.10).

Six samples of the south flow (Q11a) were dated by the cosmogenic ${ }^{3} \mathrm{He}$ method and give calculated ages that range from 83 to $97 \pm \sim 15 \mathrm{ka}$ (Table 2.4). Zreda et al. (1993) obtained a cosmogenic ${ }^{36} \mathrm{Cl}$ age of $81 \pm 7.3 \mathrm{ka}$ for the Q11a lava, closely agreeing with the cosmogenic ${ }^{3} \mathrm{He}$ ages. Interpretation of the ages is complicated by the presence of extensive scoria-fall deposits that originally mantled the south lava flow. Scoria-fall deposits more than $1 \mathrm{~m}$ thick (exposed by trenching) overlie bedrock surfaces of Paintbrush Tuff directly east of the south lava flow. These deposits locally overlie and must have draped the lava units of chronostratigraphic unit I; cosmogenic ages of the lava surfaces therefore must be minimum ages.

Turrin et al. (in press) reported a weighted mean of $157 \pm 98 \mathrm{ka}$ for the Q11a lava (mean of the data set is $214 \pm 86 \mathrm{ka}$ ) from conventional whole-rock, K-Ar age determinations. Subsequently, Turrin et al. (1991b) obtained a weighted mean of $138 \pm 54 \mathrm{ka}$, and a mean of $170 \pm 114 \mathrm{ka}$ for ${ }^{40} \mathrm{Ar} /{ }^{39} \mathrm{Ar}$ ages of the Q11a lava. These inferred mean ages are somewhat older than the cosmogenic ages, but analytical uncertainty of the ages overlap. The wide range in replicate $\mathrm{K}-\mathrm{Ar}$ and ${ }^{40} \mathrm{Ar} /{ }^{39} \mathrm{Ar}$ ages is too large to discriminate the age of the Q11a subunit.

The southeast flow (Q11b) erupted from multiple vents marked by eroded scoria mounds (Qs1b) distributed along coparallel, northwest-trending fissures with minor conjugate northeasttrending vents. These scoria mounds mark discontinuous fissures that extend from the south part of the center to the west/northwest-trending fissure of subunit Qs1c and flank the east side of the site of the main cone. The lava flows of the southeast flow are inferred to have vented from the southeast ends of the en echelon fissures (Figure 2.10). The lavas of the southeast flow are blocky $a a$ lava flows similar in morphology to the south flow. However, individual lobes of the southeast flow cannot be distinguished because of thick eolian sand cover. One lobe of the southeast flow is overlain by topographically higher-standing lavas of chronostratigraphic unit II.

Eruptive vents of the southeast flow are eroded scoria mounds with local small lava lobes and exposed feeder dikes. They are identical in morphology and occurrence to the vents of the south flow with one exception. A small cluster of northeast-trending mounds is capped by an asymmetrical accumulation of coarse agglutinated spatter. The morphology and shape of the spatter mounds indicate that they formed from weakly explosive spatter eruptions. The magma columns that vented to form the spatter mounds probably dipped to the southwest so that spatter erupted and accumulated preferentially to the northeast side of the vents (northeast-directed, weaklava fountains).

A sample of flow-top clinker from the southeast flow was dated by the cosmogenic ${ }^{3} \mathrm{He}$ method at $98 \pm 17 \mathrm{ka}$ (Table 2.4), within the range of cosmogenic ages obtained for the south flow. This age is also interpreted as a minimum age because the sample site must have been covered by scoria-fall deposits of chronostratigraphic unit II. A sample of aerodynamically shaped spatter was collected from the surface of a southeast spatter mound (Qs1b). It yielded a cosmogenic ${ }^{3} \mathrm{He}$ age of $64 \pm 13 \mathrm{ka}$ (Table 2.4). This age is slightly younger than all other cosmogenic ${ }^{3} \mathrm{He}$ ages obtained for deposits of chronostratigraphic unit I (Table 2.4). However, the spatter mound, located on the immediate flanks of the main cone, was draped by thick scoria-fall deposits of chronostratigraphic unit II. Again, the measured ${ }^{3} \mathrm{He}$ age must be a minimum exposure age. 
Turrin et al. (1991b) reported an age of $116 \pm 13$ (weighted mean) and $214 \pm 86$ (mean) for the samples collected from deposits of the Qs1b fissure for conventional whole-rock, K-Ar age determinations. These mean ages were obtained by combining the Qs1b ages with age determinations from the south flow (the Q11a lavas of chronostratigraphic unit I). The large analytical uncertainty and poor reproducibility of replicate ages indicates that the age determinations are not useful for constraining the age of the Qs1a or the Qs1b subunits. The ${ }^{40} \mathrm{Ar} /{ }^{39} \mathrm{Ar}$ age determinations for samples that are inferred from the sample locations and descriptions of Turrin et al. (1991b) to be collected from the Qs1b fissure are $149 \pm 45$ (weighted mean) or $129 \pm 77$ (mean) ka (Turrin et al., 1991b). The large analytical uncertainty and poor reproducibility of these ages suggest they provide limited constraints on the age of the Qs1b subunit.

d. Scoria-Fall Deposits of chronostratigraphic unit I. An episode of cone-building pyroclastic eruptions that produced regionally dispersed scoria-fall deposits is correlated with chronostratigraphic unit I. However, because of the extensive erosion of chronostratigraphic unit I, these deposits are only partly preserved in the mappable volcanic units of the center. The recognition of this eruptive event is based on multiple lines of inferential stratigraphic and pedogenic relationships. First, carbonate cemented scoria-fall deposits have been recognized at scattered localities several kilometers north and northwest of the Lathrop Wells center. These deposits consist entirely of scoria with well-developed bubble-wall textures and no hydrovolcanic ash. Second, the basal scoria-fall deposits underlie scoria-fall and pyroclastic-surge deposits with local interbeds of alluvium between the two ashes. The upper ash is markedly less affected by pedogenic alteration than the underlying ash. Third, the upper ash is correlated with chronostratigraphic unit II on the basis of the presence of pyroclastic-surge deposits in the upper ash. The correlative pyroclastic-surge deposits at the Lathrop Wells center are interbedded with lava flows and proximal scoria-fall deposits of chronostratigraphic unit II (see discussion below). Fourth, the degree of carbonate cementation of the basal scoria-fall deposit is consistent with the degree of erosional dissection and pedogenic alteration of deposits of chronostratigraphic unit I.

Several potential inconsistencies with the correlation of the basal distal scoria-deposit to the deposits of chronostratigraphic unit I exist. Accumulations of widely dispersed scoria deposits associated with the subunits of chronostratigraphic unit I have not been identified at the Lathrop Wells center. Scoria deposits of the subunit are composed mostly of coarse spatter and agglutinate probably formed in weak hawaiian eruptions that typically do not produce widely dispersed scoriafall deposits. These inconsistencies have several possible explanations. First, scoria deposits of chronostratigraphic unit I may have been deposited around the Lathrop Wells center but then were removed by erosion. If the time between eruptions of chronostratigraphic units I and II was of sufficient duration (several tens of thousands of years), there may have been time to erode scoriafall deposits of chronostratigraphic unit I prior to deposition of the scoria-fall deposits of chronostratigraphic unit II. This is consistent with the erosion of vent scoria of chronostratigraphic unit I and the field relations of the distal scoria-fall deposits that are correlated tentatively with chronostratigraphic unit I. The deposits are present only where preserved in topographic lows marked by sites of accumulation of alluvium. Second, scoria deposits of subunits of chronostratigraphic unit I (Qs1d, Qs1c, and Qs1a) can be traced beneath the main cone. Thick accumulations of scoria associated with chronostratigraphic unit I may have been present at and beneath the present site of the main cone. These deposits have been modified by erosion, by hydrovolcanic eruptions of chronostratigraphic unit II, and are concealed by deposits of chronostratigraphic unit III. These interpretations are supported in part, by the identification of bombs in deposits of chronostratigraphic unit III that are chemically identical to scoria of 
chronostratigraphic unit I (see following discussions). Finally, hawaiian eruptions accompanied by high-eruption fountains can sometimes produce voluminous scoria-fall deposits (Cas and Wright, 1987). We are in the process of obtaining geochemical data for the distal ashes that can be used to further test unit correlations.

\section{Chronostratigraphic Unit II}

1. Unit Qs2/Q12. Chronostratigraphic unit II was formed by the most voluminous pyroclastic and lava eruptions of the Lathrop Wells volcanic center. The lavas vented predominantly from a northwest-trending fissure located on the east-northeast edge of the volcanic center that coincides with the projected trace of a fault offsetting the underlying Timber Mountain Tuff (Figure 2.12). The scoria eruptions occurred from a small, northwest-trending cluster of scoria mounds that crop out at the east base of the main cone and, inferentially, from vents beneath the main cone (Figure 2.12). The lava and scoria subunits of chronostratigraphic unit II can be distinguished from the lava and scoria subunits of chronostratigraphic unit I by the lesser degree of erosional modification of the former. The scoria mounds of chronostratigraphic unit II are higher standing topographically than those of chronostratigraphic unit I, they have more complete conical forms, and the boundaries between individual scoria mounds can be readily identified by their topographic expression. The lava and scoria of chronostratigraphic unit II can be distinguished chemically from deposits of chronostratigraphic unit I by higher thorium concentrations and lower concentrations of strontium, phosphorus, the middle rare-earth elements, and titanium (Figure 2.13).

a. Subunit $Q \mathbf{s} 2 \boldsymbol{b}$. A northwest-trending fissure system consisting of four paired and individual spatter mounds forms subunit Qs2b (Figure 2.12). The fissure is coparallel with and partly overlaps the northwest-trending fissure system of the Qs1b subunit. Spatter mounds of subunit Qs $2 b$ are exposed for a distance of $0.5 \mathrm{~km}$ at the east base of the main cone (Figure 2.12). The Qs $2 b$ deposits are overlain by the scoria-fall deposits of the main cone and therefore predate the eruptions of the main scoria cone (chronostratigraphic unit III). The spatter and scoria mounds of Qs2b show minor to moderate erosional modification. The summits of the conical mounds are marked by an increased concentration (erosional lag) of large volcanic bombs. Trench exposures in a large trench cut at the northwest scoria mound of the fissure show that there is a direct correlation between the dip of spatter and scoria deposits forming the mounds and the mound topography. That is, the present topography of the scoria mounds represents partially the primary volcanic topography. This is the main basis for contrasting, in the field, the scoria units of chronostratigraphic units II and I. There are two small outcrops of lava associated with the Qs $2 b$ subunit and these are exposed beneath scoria-fall deposits and eolian sand just north of the northwest scoria mound (Figure 2.12). The lava outcrops are correlated with the Qs2b vents on the basis of similarities in major and trace element chemistry. No age determinations have been obtained for subunit Qs2b. 


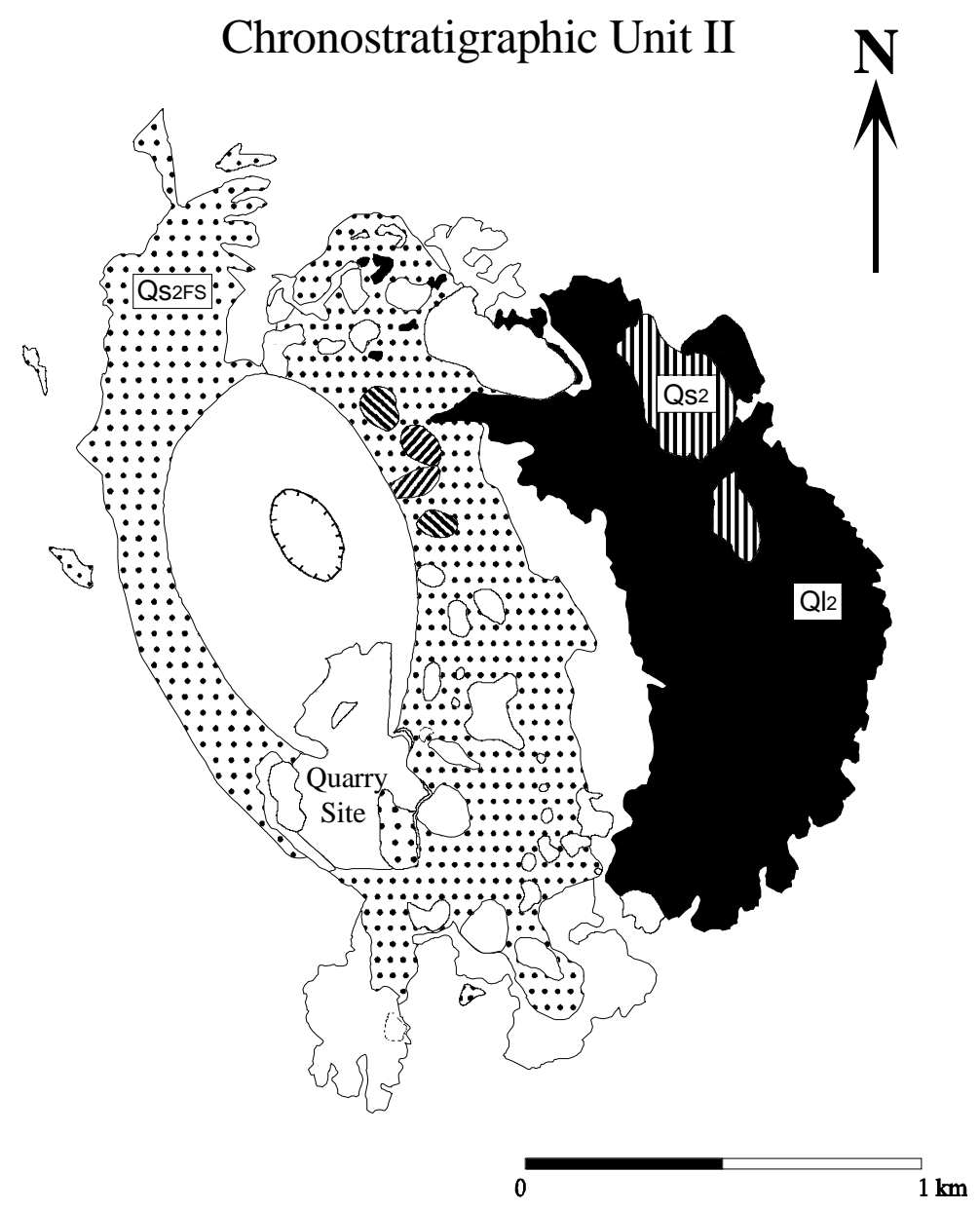

Figure 2.12. Geologic map of the distribution of volcanic subunits of chronostratigraphic unit II of the Lathrop Wells volcanic center. The black areas represent lava flows; the cross-hatched areas denote scoria and spatter mounds; the dotted area outlines the distribution of outcrop areas of the scoria-fall sheet (with interbedded pyroclastic-surge deposits).

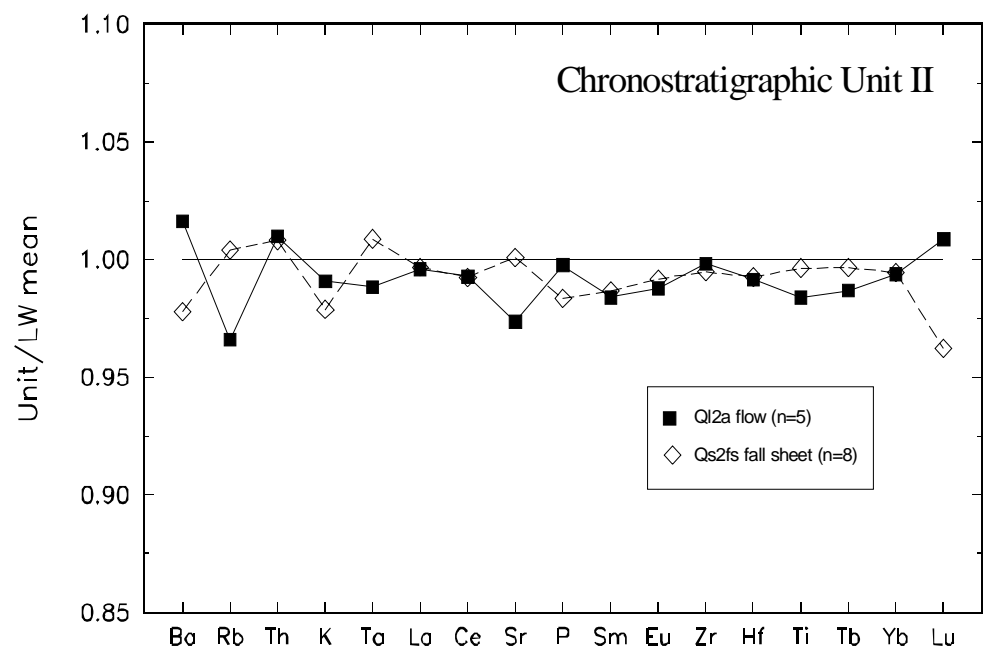

Figure 2.13 Spidergram of elemental compositions normalized to an average composition for all analyzed samples of the volcanic units of the Lathrop Wells center $(n=99)$. Samples of chronostratigraphic unit II are designated by lava and vent deposits. Each pattern is plotted as the average of multiple analyses of specific eruptive subunits. 
FY96 \& FY97 revisions

One member of the volcanism expert judgment panel argued that the Qs2b fissure system was not formed by spatter/scoria vents and, instead, consists of rafted scoria formed during partial collapse of the east wall of the main scoria cone. The arguments in support of a rafted origin of the deposits are the proximity of the deposits to the main cone, the slightly arcuate form of the Qs2b deposits, and the slight topographic asymmetry of the eastern side of the summit crater. The rafted interpretation of the deposits requires that the main cone was reformed by subsequent eruptions after collapse of the crater wall, a not uncommon sequence of eruptive events based on historic observations of scoria-cone forming basaltic volcanic eruptions. While the rafting origin of the Qs2b deposits is an intriguing alternative interpretation of the eruptive history of the volcanic center, multiple lines of evidence are inconsistent with this interpretation. First, and most important, the required eruptive event that was inferred to have rafted the scoria deposits is eruption of the Q12a lava. However, detailed mapping of this lava unit shows that it cannot be traced to the main cone and, instead, erupted from a northwest fissure system near the northeast edge of the volcanic center. In fact, no lava flow in the center can be traced to the main cone; therefore, there is no lava unit capable of rafting the Qs2b deposits. Second, trenching of the northern scoria mound of the Qs2b deposits reveals radial dips that are inconsistent with a rafted origin of the deposits. Finally, paleomagnetic studies show that the scoria mounds have a coherent direction of field magnetization consistent with emplacement of the scoria clasts at high temperatures with the magnetization representing a post-emplacement thermally acquired remanence. It is extremely unlikely that the deposits could have been rafted or acquired the magnetization after a rafting event. Further, paleomagnetic studies of scoria clasts in quarry exposures of the main cone show mechanical disruption at moderate temperatures after acquisition of magnetization. Thus, the studied parts of the cone are consistent with deposits formed from dispersed eruptions with cooling of clasts prior to deposition. These types of deposits could not been rafted to form the Qs2b scoria mounds.

b. Subunit Qs2a/Ql2a. Three sites of small-volume blocky aa lavas crop out, forming a northwest-trending fissure alignment that parallels a previously formed west-northwest fissure of subunit Qs1c. These lavas mark a fissure system that did not vent notable quantities of scoria. The lavas are identical in morphology to the Q11 subunits. They consist of oversteepened and broken lobes of lava where they extruded down the slopes of underlying scoria deposits of Qs 1c. All of the lavas are small volume. They appear to have vented directly from a fissure without any significant pyroclastic eruptions.

The major lava and scoria subunit of chronostratigraphic unit II, Qs2a/Q12a, includes a series of scoria mounds and related lavas erupted along a northwest trending fissure at the northeast edge of the volcanic center (Figure 2.12). The fissure is coparallel to the trace of a west-down, northwest-trending fault that offsets the underlying Timber Mountain Tuff. The fault does not offset the lavas of the subunit. However, the preexisting topography associated with the fault controlled partly the distribution of the lava flows of subunit Q12a (Figure 2.12).

The main eruptive sites for the subunit are marked by one large and one smaller scoria mound that define the trace of the northwest-trending fissure. The fissure may extend further to the 
southeast, but it is covered both by its own lava flows, and eolian sand. The Q12a lavas, informally named the Lathrop flow, form a near-continuous sheet of coalesced lobate blocky $a a$ lava flows extending for a maximum length of $2.1 \mathrm{~km}$ and a maximum width of $0.9 \mathrm{~km}$ (Figure 2.12). The Qs2a lavas ponded against topography upheld by the Qs1c scoria mounds on the northwest and, therefore, postdate these deposits. West of the source fissure zone, the lavas of subunit Q12a flowed into and coalesced within a fault-controlled topographic low. This topographic low probably coincided with a buried stream channel that followed the trace of the northwest-trending fault. The trace of the stream was diverted subsequently by emplacement of the Q12a lavas and now follows the eastern margin of the lava flows.

East of the northwest-trending fissure, the Qs2a lavas consist of multiple flow lobes extruded from the fissure zone eastward down the dip slope formed on a shallow-dipping hogback upheld by the underlying Timber Mountain Tuff. Two lines of evidence indicate the eastern Q12a lavas were extruded from multiple sites along the strike of the northwest-trending fissure. First, detailed field and aerial photographic examination of flow fronts and flow morphology shows that the flows form distinct flow lobes and are not a single continuous flow; a minimum of twenty individual flow lobes have been identified. There are probably more flow lobes on the southern exposure edge of the subunit but there they are obscured by a thick cover of eolian sand. Second, the flow directions of the lavas are marked by the trace of narrow ( 2 to $5 \mathrm{~m}$ width; 1 to $3 \mathrm{~m}$ depth) linear depressions on the flow surfaces. The features marked poorly developed $a a$ channels that deflated below their adjoining $a a$ flow surfaces by continued lateral flowage at the ends of the flow when lava extrusion ceased. The channels extend east and southeast of the main northwest-trending fissure indicating the lavas were extruded along the fissure length and the southeast projection of the fissure (Figure 2.14).

Age determinations using the cosmogenic ${ }^{3} \mathrm{He}$ method were obtained for three samples collected at multiple sites on a Q12a lava at the northeast exposure edge of the subunit. These ages range from 85 to $99 \pm \sim 18 \mathrm{ka}$ (Table 2.4). These ages are tightly clustered, suggesting an uncomplicated surface exposure history. A second sample site located on the west/northwesttrending fissure yielded the oldest cosmogenic ${ }^{3} \mathrm{He}$ age of $107 \pm 19 \mathrm{ka}$ (Table 2.4). There is some uncertainty in the assignment of the former sample to subunit Q12a. This will be tested by obtaining geochemical data for the sample site. The lavas of subunit Q12a are located northeast of the main cone, outside the primary dispersal axis of scoria-fall deposits of chronostratigraphic unit II, which reach maximum thickness northwest and southeast of the main cone. Moreover, streamcut exposures of the base of the Q12a lava flow show that the units overlies pyroclastic surge deposits that are correlated with more extensive pyroclastic surge deposits to the west. These pyroclastic surge deposits occur in the upper third of the scoria-fall deposits and indicate the lava flows were extruded during the latter stages of formation of the scoria-fall deposits. This stratigraphic position and the location of the Q12a lava unit indicates that only a limited thickness of scoria was deposited on unit Q12a. The tight clustering of cosmogenic ${ }^{3} \mathrm{He}$ ages suggests the ages may approach the crystallization age of the subunit. The cosmogenic ${ }^{3} \mathrm{He}$ ages are slightly younger than but are not analytically distinguishable from the ages obtained for the Q11a, Q11b and Q11c lavas; the emplacement age of the latter lavas is almost certainly older because they were covered by the scoria-fall deposits of chronostratigraphic unit II.

Conventional K-Ar whole-rock ages of the same Q12a lavas are $188 \pm 22 \mathrm{ka}$ (weighted mean) and $139 \pm 68 \mathrm{ka}$ (arithmetic mean) for three replicate samples (Turrin et al. in press). The ${ }^{40} \mathrm{Ar} /{ }^{39} \mathrm{Ar}$ age determinations of splits of the same samples yielded a weighted mean of $217 \pm 64 \mathrm{ka}$ and a mean of $153 \pm 110 \mathrm{ka}$ (Turrin et al., 1991b). An age of $239 \pm 189$ ka was obtained by the 
conventional K-Ar method (mean of all whole-rock age determinations of the Q12a subunit reported in Turrin et al. [in press]). They also reported a weighted mean of the K-Ar age determinations of $137 \pm 37 \mathrm{ka}$, but this number was obtained by discarding the results of one sample set of the Q12a lava. Turrin et al. (1991b) reported an age of $183 \pm 21 \mathrm{ka}$ for the Qs2a lavas based on ${ }^{40} \mathrm{Ar} /{ }^{39} \mathrm{Ar}$ age determinations, but this age was reported as a weighted mean that included samples from both the Q11c and Q12a subunits. Moreover, four samples were discarded from the data set without defined rejection criteria. The mean age of the ${ }^{40} \mathrm{Ar} /{ }^{39} \mathrm{Ar}$ age determinations is $277 \pm 234 \mathrm{ka}$ for the combined data sets using the published values of Turrin et al. (1991b, Table 1). The mean age of the sample set becomes $182 \pm 97 \mathrm{ka}$ if four samples are removed from the data set. These samples are identified as outliers using standard statistical tests of the data distribution and can be rejected on that basis. Turrin et al. (1992) reported an isochron age of $107 \pm 33 \mathrm{ka}$ from ${ }^{40} \mathrm{Ar} /{ }^{39} \mathrm{Ar}$ stepheating spectra for a sample of the Q12a lava (see also discussion in Zreda et al., 1993). This age is in close agreement with the cosmogenic ${ }^{3} \mathrm{He}$ surface exposure ages. All of these $\mathrm{K}-\mathrm{Ar}$ and ${ }^{40} \mathrm{Ar} /{ }^{39} \mathrm{Ar}$ age determinations are in agreement with the cosmogenic ${ }^{3} \mathrm{He}$ ages on the basis of the following assumptions: (1) the calibration accuracy of the ${ }^{3} \mathrm{He}$ exposure ages is $\pm 30 \%$, and (2) the best representation of the $\mathrm{K}-\mathrm{Ar}$ and ${ }^{40} \mathrm{Ar} /{ }^{39} \mathrm{Ar}$ ages is the mean, not the weighted mean, of replicate age determinations (see discussions in Section $\mathrm{F}$ of this chapter).

TL age determinations on sediments exposed beneath the Q12a lava yielded ages of $28.0 \pm 3.0$ and $31.0 \pm 3.0 \mathrm{ka}$. These ages are discordant with ages obtained by other chronology methods and may not reflect the emplacement age of the lava. We have been unable to explain this discordance. To further constrain the emplacement age of this unit, we are obtaining ${ }^{40} \mathrm{Ar} /{ }^{39} \mathrm{Ar}$ dating of sanidine from tuff xenoliths enclosed within the Q12a lava.

c. Subunit Qs2fs: The Scoria-fall sheet of chronostratigraphic unit II. A subunit of chronostratigraphic subunit II is formed by widespread interbedded scoria-fall and pyroclasticsurge deposits (Qs2fs) of chronostratigraphic unit II. This unit is distributed elliptically around the main cone and was probably erupted from concealed vents beneath the cone. The deposits are correlated with chronostratigraphic unit II on the basis of multiple lines of evidence. First, the pyroclastic-surge deposits are interbedded with the scoria-fall sheet. These pyroclastic-surge deposits overlie lavas of Q12b in trench LW-2 and underlie lavas of Q12a in stream-cut exposures at the north outcrop area of the Lathrop lava. These interfingering stratigraphic relations require that the fall sheet is equivalent stratigraphically to the Q12 lava sequence. Second, exposed deposits of the widespread scoria-fall sheet are reworked. Locally, the upper parts of the fall sequence have been removed by erosion even where the scoria deposits covered low-angle topography. The large continuous mantle of scoria-fall deposits northwest of the main cone that drapes a ridge upheld by exposures of the Topopah Springs tuff has well developed rills. The degree of reworking and geomorphic modification of the scoria-fall deposits contrasts markedly with the unrilled, $29^{\circ}$ slopes of the outer surface of the main cone. Thus, the deposits that form the outer cone slopes of the main cone (chronostratigraphic unit III) must be younger than and cannot be correlated with the rilled, reworked scoria-fall sheet. Finally, the scoria-fall sheet can be distinguished chemically from scoria deposits of the main cone (chronostratigraphic unit III) by lower thorium and higher titanium concentrations (Figures 2.13 and 2.16).

\section{FY96 \& FY97 revisions}

An alternative explanation of the correlation of the scoria-fall sheet is that it is correlative to eruptive units Q2 and Q3 (i.e., Q2 and Q3 are contemporaneous). The 
primary evidence for this interpretation includes: 1) the most likely eruptive event to produce the scoria-fall sheet is the eruptions that formed the main cone; the Qs3 eruptive unit, 2) no depositional or erosional breaks have been recognized in the scoria-fall sheet in shallow trenches constructed around all parts of the main cone except the eastern side-the absence of a break in the deposits is not consistent with the stratigraphic divisions and inferred time breaks between the Q2 and Q3 eruptive units, 3) the interfingering stratigraphic relations between the QI2 lavas and the scoriafall sheet require correlation of the units, and 4) the above relations lead, by inference, to correlation between the Q2 and Q3 units. This alternative interpretation is now made more reasonable because of the recognition through trenching of the crater of the main cone that the cone is more erosionally modified than previously thought; thus, the perceived difference in erosional modification of the scoria-fall sheet versus the main cone may not be significant. Geochemical differences between the Q2 and Q3 units are still not understood. There may have been gradational geochemical variations in the magma composition associated with the fall-sheet and cone-forming eruptions, which are now reflected as geochemical differences between the fall sheet and the cone This would suggest that the two units are related and time equivalents. However, we have not been able to identify gradational geochemical changes in either the scoriafall sheet or the main cone.

The scoria-fall deposits (Qs2fs) mantle the underlying basaltic and alluvial units and locally rest on bedrock of Miocene tuff. The fall deposits are thickest on the northwest and southeast sides of the cone, probably reflecting prevailing winds during the eruptions. We have systematically examined the scoria-fall deposits in trenches constructed around the cone except on the east side, where the mantle of sand covering the deposits is too thick to penetrate with our backhoe equipment. Three distinctive layers are present in the scoria-fall deposits. Each layer consists of multiple-fall units with reversely graded bases and fine-grained tops. The subdivisions in the fall sheet are identified on the basis of multiple fine-grained ash layers between layers and the local presence of pyroclastic-surge deposits, which form the middle layer of the scoria-fall deposits. Size data for maximum clast size and layer thickness have been measured in the fall layers and are currently being processed. We will use the clast size data to constrain models of the location of the vents for the deposits and to reconstruct column dynamics for studies of effects of volcanism (Valentine et al., 1992, 1993).

\section{FY96 \& FY97 revisions}

Studies of eruption dynamics for volcanism studies are important only if the results can be applied to suitability or regulatory issues for the Yucca Mountain site. Regulatory requirements for licensing of an underground repository for disposal of high-level radioactive waste are currently based on cumulative release standards where the identified site of sensitivity is the accessible environment. These regulations do not require assessment of dispersal patterns of radioactive waste within the accessible environment. We have chosen, for this reason, not to process clast-size data for the scoria-fall sheet in an attempt to constrain eruption-column dynamics. This conclusion could change however, if the regulatory standard for high-level radioactive waste is changed to a dose- or risk-based standard. 
Locally the Qs2fs fall sheet rests on scoria-fall deposits of chronostratigraphic unit I. The upper part of these underlying scoria-fall deposits are weathered and there is a marked increase in the degree of pedogenic alteration of the scoria-fall deposits of chronostratigraphic unit I versus the overlying scoria deposits; the alternation contrast can be traced along a planar contact suggesting the fall-sheet deposits of chronostratigraphic unit II buried a weathered surface formed on the underlying deposits. Locally, there are stringers of carbonate cemented silt at the contact but no development of soil.

Hydrovolcanic eruptions occurred during the middle eruptive stage of chronostratigraphic unit II. The distribution of pyroclastic-surge deposits from the hydrovolcanic eruptions has been determined through systematic examination of the scoria-fall sheet in trenches. The deposits crop out extensively northwest and west of the main scoria cone (Figure 2.12). Deposits of the pyroclastic surge are present in the subsurface beneath eolian sands and silt north of the main cone; they locally exceed $2 \mathrm{~m}$ in thickness where ponded in topographic lows. The contact between pyroclastic-surge deposits and Q11c lavas was exposed in trenches LW-1 and LW-2. In trench LW-1, vesicular clinker marking the upper surface of the lava shows coatings of pedogenic carbonate along fractures at the edges and bottoms of lava blocks. The overlying pyroclastic-surge deposits contain very limited or no amounts of carbonate coating. This requires a time break between emplacement of the Q11c lava flow and subsequent deposition of the pyroclastic-surge deposits, consistent with stratigraphic relations described above.

The pyroclastic-surge unit was probably derived from a vent located beneath the main cone. This conclusion is based on two observations. First, the pyroclastic-surge deposits are present in outcrops on the north and northwest circumference of the main cone. The proximity of the deposits to the cone suggest they were derived from the vicinity of the main cone. Second, the pyroclasticsurge deposits are interbedded with the scoria-fall deposits that encompass the main cone. The thickest accumulations of the pyroclastic-surge deposits occur directly north and northwest of the main cone. This locally reflects channeling of the pyroclastic surges in preeruption topographic lows. Additionally, the phreatomagmatic eruptions that produced the deposits may have been erupted preferentially to the north and northwest by the blast dynamics. The volumes of the surge deposits are sufficiently large that the eruptions should have formed a tuff ring or wide, flat-floored crater. The absence of such a volcanic landform is enigmatic. The preferred explanation for the absence of a tuff ring is that it is buried beneath deposits of subsequent strombolian eruptions of chronostratigraphic unit III. Continued commercial quarrying of the main cone may resolve this question.

Probable correlative scoria and ash deposits are present $\sim 2 \mathrm{~km}$ north and northwest of the Lathrop Wells center and in a trench exposure cut across the Stagecoach fault, $5 \mathrm{~km}$ northeast of the Lathrop Wells center (Figure 2.9). At both localities, an upper ash with recognizable crossbedded deposits characteristic of deposition by pyroclastic-surge processes overlies an alluvial deposit that in turn is underlain by fall deposits correlated with chronostratigraphic unit I. The distal ash deposits thus closely match the stratigraphic relations of the lower part of the volcanic stratigraphy of the Lathrop Wells volcanic center. 


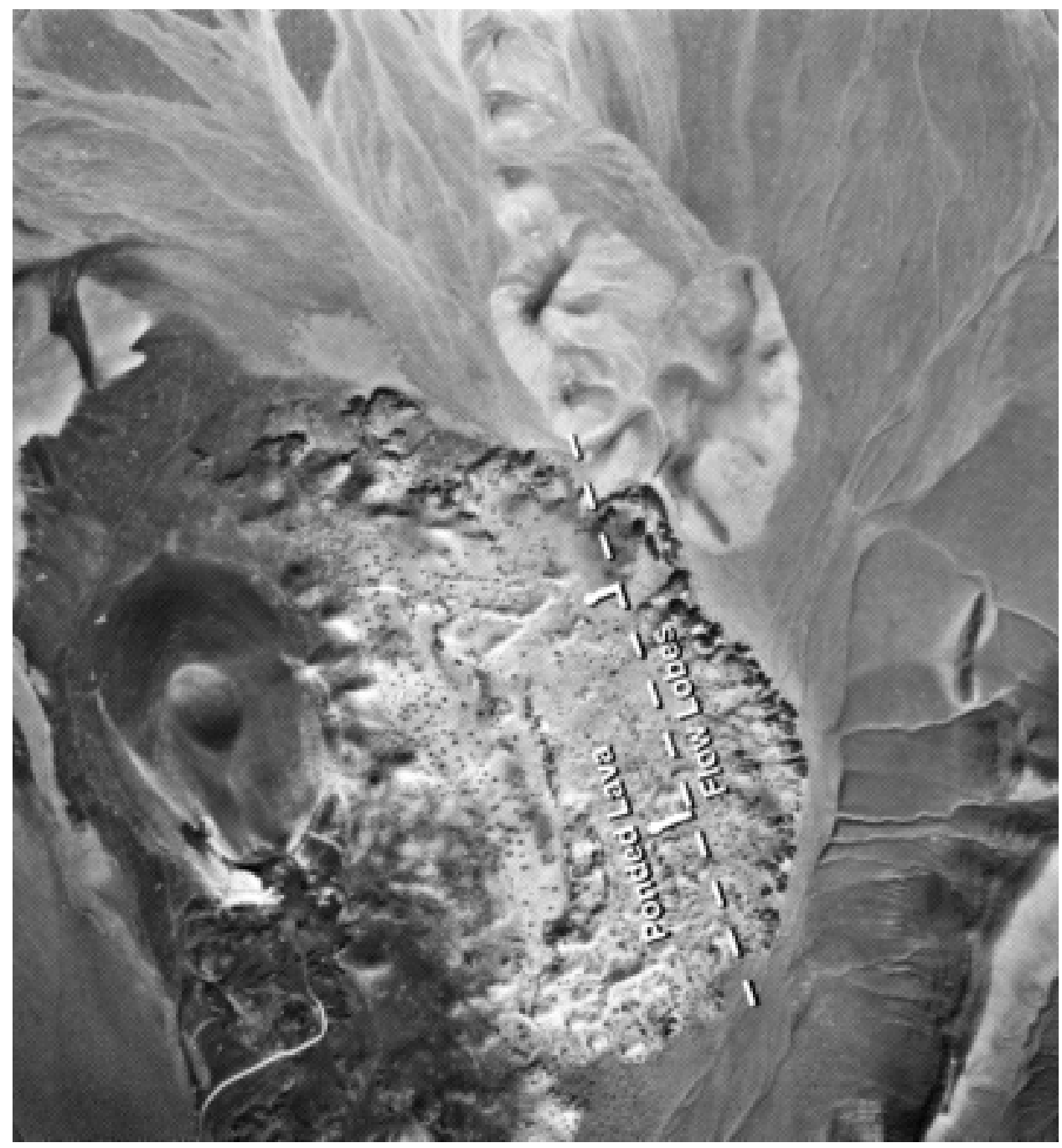

Figure 2.14. Digitized image of aerial photograph of the Lathrop Wells volcanic center showing the outcrop distribution of the Lathrop lava flow. The flow was emplaced in two settings. West of the northwest-trending fissure, the lavas ponded in a topographic low formed parallel to the trace of the now buried northwest-trending (down to the west) fault (ponded flows). East of the fissure, the lavas were extruded down a gentle, east-tilted hogback formed on the upthrown side of the fault. The lavas formed lobate flows with small aspect ratios (lava lobes). Aa flow channels extend along the central part of individual lava lobes channels and can be traced toward their source: the trace of the northwest-trending fissure.

\section{Chronostratigraphic Unit III}

1. Unit Qs3/Q13. Chronostratigraphic unit III of the Lathrop Wells center comprises two subunits, Qs3, the scoria deposits of the main cone and Q13, multiple lobes of small volume blocky $a a$ lavas erupted along the trace of the west/northwest-trending fissure of chronostratigraphic unit II (Figure 2.15). The scoria and lava units of chronostratigraphic unit III are distinguished from units I and II by thorium enrichment and titanium depletion of the former units (Figure 2.16). 


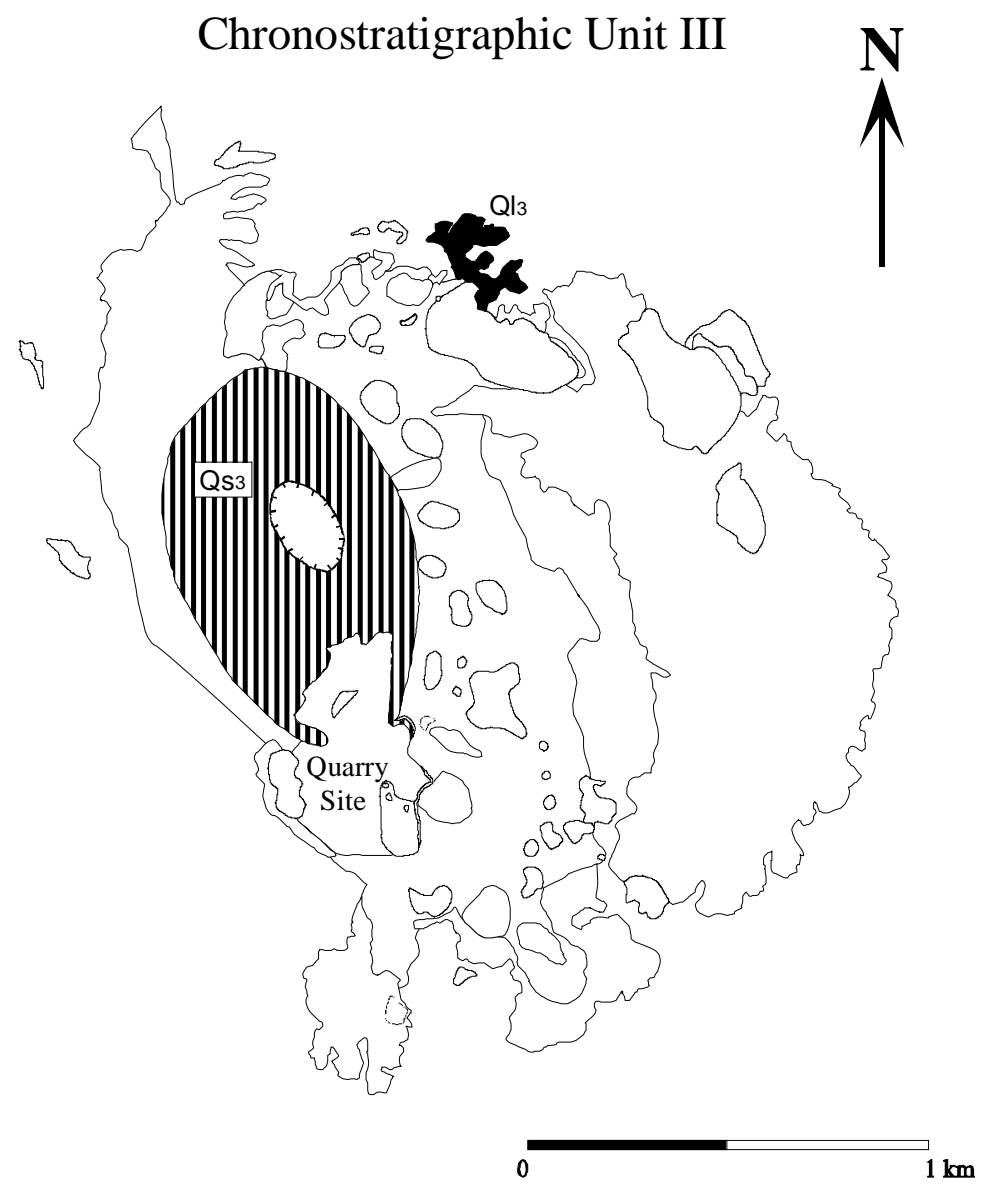

Figure 2.15. Geologic map of the distribution of volcanic subunits of chronostratigraphic unit III of the Lathrop Wells center. The solid black area represents the lava flow subunit; the black, horizontallyhatched area represents the main scoria cone. The scoria-fall deposits for unit III are not widely distributed and they are infiltrated by eolian sand. They cannot be mapped as a separate geologic unit.

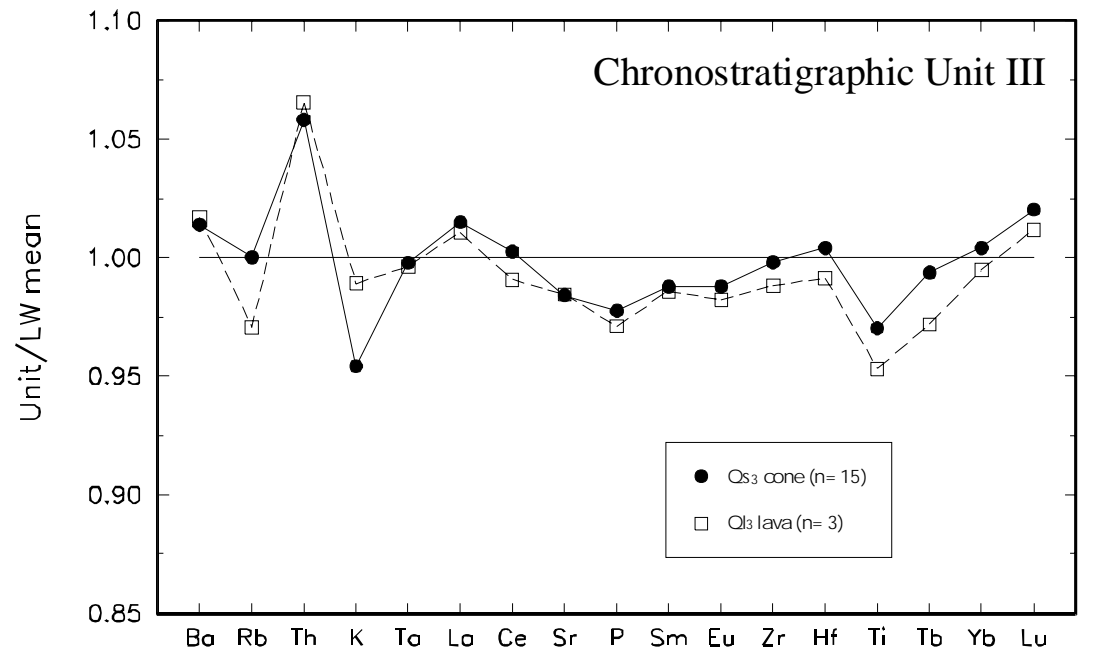

Figure 2.16. Spidergram of elemental compositions normalized to an average composition for all analyzed samples of the volcanic units of the Lathrop Wells center $(n=99)$. Samples of chronostratigraphic unit III are designated by lava and vent deposits. Each pattern is plotted as the average of multiple analyses of specific eruptive subunits. 
a. Subunit Qs3: The Main Cone. The scoria deposits of the main cone comprise subunit Qs3 (Figure 2.16). These deposits were emplaced from mildly explosive strombolian eruptions with intervals of more energetic explosions of hydrovolcanic origin. The resulting landform is a composite scoria cone with dimensions slightly larger than typical scoria cones (Wood, 1980; Crowe et al., 1983a). The main scoria cone is elongate northwest/southeast, has a maximum diameter of $1 \mathrm{~km}$ (northwest/southeast), a minimum diameter of $0.5 \mathrm{~km}$ (southwest/northeast), and a height of about $100 \mathrm{~m}$. The cone is surmounted by a crater, elongate to the northwest, with a maximum diameter of $250 \mathrm{~m}$ and depth of $<20 \mathrm{~m}$. The cone has been excavated extensively on the southeast side. Cliff exposures reveal the internal structure and sequence of eruptive events that formed the volcanic landform. Interior parts of the cone consist of massive-to-fine-bedded scoriafall deposits exhibiting radial dips of $15^{\circ}$ to $>22^{\circ}$. The interior exposures of these deposits are strongly oxidized along a northwest-trending zone; outer deposits of the cone away from the zone are formed of black tephra. The oxidization, as noted above, was probably produced by alteration of the scoria from gases emitted from an underlying feeder dike. The northwest trend of the oxidized scoria deposits is coparallel to the elongation of the cone, and also aligns with the en echelon fissures of the southern fissure systems of chronostratigraphic unit I. This northwesttrending zone controlled the eruptive sites of part of the oldest eruptive events and was reoccupied by subsequent eruptive events during formation of chronostratigraphic units II and III.

Middle cliff exposures in the main cone expose radially dipping scoria deposits, interbedded with lenticular zones of slope-reworked scoria deposits. The latter beds formed from avalanching or slumping of scoria down the cone slopes during cone growth. These types of deposits and the processes associated with their formation were described for the growth of Mount Etna volcano by McGetchin et al. (1975). The upper parts of the cliff exposures on the southeast and southwest sides of the main cone expose distinctive plane-parallel to low-angle cross-bedded scoria. These beds are composed of mixtures of red and black scoria and were emplaced by pyroclastic surge processes associated with weak hydrovolcanic eruptions. The inference of hydrovolcanic eruptive events is based on the presence in the Qs3 deposits of fragmental clasts with angular faces broken across vesicular structure, the presence of sideromelane and hydrovolcanic shards in groundmass ash (Crowe et al., 1986; Wohletz, 1986), local lenses of slightly palagonitized fine-grained ash in the deposits, and an abundance of cauliflower-shaped bombs (see Fisher and Schminike, 1984). The red and black scoria deposits, which have a distinctive purple appearance in outcrop, are composed of varying proportions of scoria reworked from preexisting parts of scoria cone. These deposits have been observed only on the southern sides of the main cone. The upper surface of the main cone is capped by thin soils with weak horizon development (Wells et al., 1990).

\section{FY96 \& FY97 revisions}

The inference of hydrovolcanic eruptions associated with the Qs3 eruptive units is also supported by trenching at the west rim crest and west crater interior that exposed relatively fine-grained scoria deposits that anticlinally drape the rim crest, which is a common feature of hydrovolcanic deposits and rarely observed in the rim crests of cones formed by predominantly strombolian eruptive activity. Additionally, the somewhat large crater compared to the cone size is consistent with mild hydrovolcanic activity. We note that two members of the volcanism expert judgment panel (Geomatrix, 1996) do not interpret any of the deposits of the Lathrop Wells center to have been formed by hydrovolcanic activity. The different interpretations are probably not significant for PVHA for the Yucca Mountain site because the probability of the 
occurrence of hydrovolcanic activity in the YMR based on assignments by the volcanism expert judgment panel (Geomatrix, 1996) is less than $10^{-8}$ per year or 1 in 10,000 in 10,000 years and, thus, probably does not require consideration in the total systems performance assessment.

The interior of the crater walls of the main cone is composed predominately of relatively finegrained, highly vesiculated scoria with a paucity of large bombs. There is no agglutination of the scoria-fall deposits exposed through the complete section of deposits in the quarry cliffs at the south end of the cone. The cone must have been constructed from strombolian bursts that efficiently fragmented the melt. A slightly greater content of moderate-sized bombs are exposed in the summit crater compared to the interior parts of the cone.

Accidental lithic fragments of the underlying Miocene tuff are present in the scoria deposits. They range in size from $<1 \mathrm{~mm}$ to $>0.3 \mathrm{~m}$. The fragments were partly to moderately fused during contact with basalt melt; some of the fragments are banded with intermixed layers of basalt and fused tuff. The lithic fragments are conspicuous in outcrop because of their marked contrast in color with the red and black scoria. While visually striking, their abundance by volume is $<0.1 \%$ (Crowe et al., 1983a).

\section{FY96 \& FY97 revisions}

Field studies in FY96 in conjunction with researchers from the tectonics program of the YMP allowed constraints to be placed on the stratigraphic position of the lithic fragments observed in the scoria deposits of Qs3. Lithic fragments were identified that were derived from the Timber Mountain, Paintbrush, and Crater Flat Tuffs as well as a distinctive sequence of fluvial and lake deposits exposed locally beneath the Bullfrog Member of the Crater Flat Tuff.

The pyroclastic eruptions of chronostratigraphic unit III did not form a widely distributed scoria-fall sheet. There are exposures of the eroded deposits of Qs1c at the north base of the main cone. These deposits are not erosional windows through a fall sheet of chronostratigraphic unit III, but instead are areas of the older deposits that were not covered by the younger eruptions. This is indicated by two lines of evidence. First, the outer slopes of the main cone are unmodified (Wells et al., 1990). They have not been affected by down-slope wasting. Second, trenches constructed at the north base of the main cone show that there are no cone-slope apron deposits at the base of the cone. We have been unable to find identifiable scoria-fall deposits beyond the flanks of the main cone primarily because of development of a limited fall sheet associated with subunit Qs3. However, the base of the cone is covered by thick ramps of eolian sand and silt, which probably conceal scoria-fall deposits of Qs3. The surficial exposures of the scoria-fall sheet of chronostratigraphic unit II are distinguished from cone-slope deposits of chronostratigraphic unit III by two criteria. First, the scoria-fall deposits of chronostratigraphic unit II are extensively reworked, rilled, and locally channeled. The cone slopes are unmodified except for minor slope slumping (Wells et al., 1990). The prominent geomorphic differences between the deposits require a time break between the eruptions of chronostratigraphic units II and III (Figure 2.15). Second, the scoria deposits of chronostratigraphic units II and III have slightly different geochemical compositions (Figures 2.13 and 2.16). 
Multiple cosmogenic ${ }^{3} \mathrm{He}$ ages have been obtained for the scoria deposits of chronostratigraphic unit III. Cone scoria scraped from the outer cone-slope surface several tens of meters below the west summit of the main cone yielded ages of $\sim 40 \pm 10 \mathrm{ka}$ (Table 2.4). Multiple bombs collected from the cone summit yielded ages ranging from $64 \pm 15$ to $30 \pm 9$ ka (Table 2.4). The bombs were collected from a flat part of the rim crest of the main cone to minimize the effects of erosion through mass wasting down the cone slopes. A large bomb collected about 10-20 m below the crest yielded an age of $47 \pm 7 \mathrm{ka}$ (Table 2.4). This bomb projected $20 \mathrm{~cm}$ above the modern cone surface. The variability in exposure ages for the multi-sample cosmogenic ${ }^{3} \mathrm{He}$ ages indicates the samples do not share a uniform exposure history.

The traditional interpretation of the cosmogenic ages is that the best approximation of the age of the cone is $>64 \pm 15 \mathrm{ka}$. This is the maximum measured exposure age (Poths and Crowe, 1992). Zreda et al. (1993) reported cosmogenic ${ }^{36} \mathrm{Cl}$ ages of $83 \pm 9.2$ and $68 \pm 5.7 \mathrm{ka}$ for bombs from the summit of the main cone. The two ages are indistinguishable analytically and give a mean age of $76 \pm 10 \mathrm{ka}$. The mean age is slightly older than the cosmogenic ${ }^{3} \mathrm{He}$ ages of summit bombs. However, Zreda et al. (1993) noted that the bomb sample giving the oldest cosmogenic ${ }^{36} \mathrm{Cl}$ age is altered, and the alteration component could not be separated from the rest of the rock. If this sample is suspect and should be discarded because of alteration, the remaining sample $(68 \pm 5.7$ $\mathrm{ka})$ is in reasonable agreement with the oldest cosmogenic ${ }^{3} \mathrm{He}$ age.

An alternative explanation for the spread of cosmogenic surface ages for chronostratigraphic unit III is that some of the dated bombs debris may be derived from the underlying deposits of either chronostratigraphic unit I or II. They therefore could have had cosmogenic exposure history prior to their incorporation in deposits of chronostratigraphic unit III and thus give anomalously old ages. This alternative explanation is rejected for two reasons. First, only the upper surface of older cones would have been exposed to the cosmogenic influx, and the underlying and larger volume of the deposits should have been shielded. Second, the geochemistry of summit bombs used for the cosmogenic ${ }^{3} \mathrm{He}$ age determinations matches the geochemistry of chronostratigraphic unit III.

There is a remaining unresolved inconsistency with the results of the cosmogenic ${ }^{3} \mathrm{He}$ ages. The oldest ages obtained for bombs from the summit are about $40 \%$ older than ${ }^{3} \mathrm{He}$ ages obtained for scoria and bombs on the cone slopes. The younger ages of the latter samples would require a minimum $0.5 \mathrm{~m}$ of erosional removal of scoria to shield the deposit and produce the resulting age differences. The pristine, unrilled cone slopes and absence of a cone-slope apron at the base of the cone are inconsistent with this interpretation.

The cosmogenic ${ }^{3} \mathrm{He}$ ages are slightly younger than the exposure ages obtained for the subunits of chronostratigraphic units I and II. The cosmogenic ${ }^{36} \mathrm{Cl}$ ages from the cone summit are younger if the altered sample is discarded. If that sample is included, the cone summit and lava ages of chronostratigraphic unit I overlap analytically (Zreda, 1993). However, the cosmogenic ${ }^{36} \mathrm{Cl}$ samples were collected from the south lava flow at a locality that must have been covered by at least a meter of scoria-fall deposits. Thus, the coincidence in ages of the ${ }^{36} \mathrm{Cl}$ ages of the cone summit (chronostratigraphic unit III) and the southern lava flow is attributable to the lava flow's being shielded by the now eroded scoria-fall deposits of chronostratigraphic unit II.

Turrin and Champion (1991) show sample sites for conventional K-Ar age determinations for the main cone (samples TSV-283 and TSV-129) but do not report results. Champion (1991) and Turrin et al. (1991b) have argued that the main cone and associated subunits of 
chronostratigraphic unit II are no more than 100 years younger than the lava flow units. This conclusion is based largely on paleomagnetic studies where the authors cite a $4.7^{\circ}$ difference in the two grand mean magnetization directions for the main cone and associated subunits and the lavas of chronostratigraphic unit III. Regardless of the interpretation of the paleomagnetic data, the reported differences in the grand mean magnetization directions, if valid, are consistent with the contrasting degrees of erosional modification of the respective chronostratigraphic units. (Note: The cited paleomagnetic correlations may be obscured by the inclusion of data from scoria and lava deposits of Qs1a and Q11a with the volcanic units of the main cone. We assign, in this report, Qs1a/Q11a to the oldest chronostratigraphic unit based on field, geomorphic, and petrologic criteria.)

There are several concerns with the quality of the paleomagnetic data and the stratigraphic and chronological interpretations based on the paleomagnetic data of Champion (1991) and Turrin et al. (1991b). First, samples for paleomagnetic studies of chronostratigraphic unit II were collected from both weakly agglutinated and nonagglutinated scoria deposits (Turrin et al., 1991b). At best, some of the samples may be marginally suitable for reliable high-precision determinations of field directions (Holcomb et al., 1986). In addition, the sample sites should have markedly different measurement precision although there is no way of evaluating this because the data are not presented in sufficient detail. Discrimination of the chronostratigraphic units can be demonstrated only through presentation and analysis of both demagnetization data and statistical parameters for individual sites. Second, the cone summit is formed primarily of nonagglutinated spatter. There is only a small population of slightly agglutinated bombs that possibly could record satisfactorily the field magnetization directions. Third, the cone summit is the highest topographic point in the area. Samples collected from the summit for paleomagnetic studies should be highly susceptible to modification from exposure to lightning strikes. We encountered difficulties in obtaining high-precision magnetization directions for samples collected from the topographically low-standing lava flows because of high-intensity lightning effects (Crowe et al., 1992). Fourth, the summit eruptions of the main scoria cone were formed partly by hydrovolcanic eruptions. This interpretation is based on the local presence of fine-bedded, partly palagonitized ash and cauliflower bombs (Crowe et al., 1986, Wohletz, 1986) in the summit deposits. These deposits, unless carefully screened to eliminate sampling of redeposited hydrovolcanic clasts, are unsuitable for paleomagnetic studies. This has been verified by the identification of bombs in the summit deposits that have been reworked from scoria deposits of chronostratigraphic unit I. Finally, it is difficult, if not impossible, to use paleomagnetic data to provide absolute differences in the ages of volcanic deposits. The measured field magnetic directions of the center are close to the mean Quaternary dipole field (spin axis) (Turrin et al., 1991b, 1992; Crowe et al., 1992; Wells et al., 1992). Even if the main cone and chronostratigraphic unit III prove to be distinct, the different directions can be used only to establish a minimum age difference between the rocks (Turrin et al., 1992; Wells et al., 1992).

\section{FY96 \& FY97 revisions}

In late FY95 trenching was completed within the summit crater of the main cone. The purpose of the trenching was to further evaluate the eruptive and erosional history of the cone, assuming that eruptive or erosional deposits formed within the crater would have a high likelihood of preservation because of the internally drained, closed crater form. A series of trenches were constructed within the crater that extended from the western rim to the crater floor. Trenching revealed that the uppermost primary tephra 
unit is a $\sim 1$ meter thick, black, primary scoria-fall deposit that overlies red oxidized scoria deposits with no evidence of any temporal break between the units. Significantly, the black scoria unit does not extend to the crater rim but is truncated within the present inner crater wall by an erosional surface $\sim 4$ meters vertically below the present rim. Truncation of the upper black tephra unit below the present cone rim can be seen on color aerial photographs as a contact between red and black tephra on both the inner and outer crater slopes and is particularly prominent on infrared photos. The contact between the black and the underlying red scoria deposit has a dip of $33^{\circ}$. The contact intersects the present inner crater surface, which has a dip of $\sim 20 \pm 2^{\circ}$ at the point of intersection, at 17 meters surface distance below the midpoint of the present rim. Using these angles and distances as constraints, trigonometric calculations indicate that the red-black contact would project $\sim 4.5$ meters above the present rim surface, assuming that the contact maintained a constant $33^{\circ}$ dip to the rim midpoint. An additional 1 meter of black tephra probably existed above the contact based on trench exposures inside the crater, bringing the minimum thickness of tephra removed by erosion from the cone rim to $\sim 5.5$ meters. This assessment does not take into account that the present inner-crater-surface slope decreases as the rim is approached. If the geometry of the present rim is accounted for, the true amount of scoria removed by erosion would be greater than 5.5 meters. Analysis of digital elevation data from the cone indicates that up to 9 meters of rim material may have been removed.

Trenching also revealed a colluvial wedge of sand-supported reworked tephra exposed in the lower $2 / 3$ of the crater interior. In the center of the crater, the colluvial unit is at least 1.3 meters thick (constrained by limit of trenching depth), but is overlain by a 0.5 meter-thick clast-supported tephra unit infilled with sand. The upper tephra unit has a sharp basal contact and fabric and scoria characteristics similar to the Qs4b deposit south of the main cone. Overall, while differing in detail, the crater-fill sequence is similar to the sequence of soil-bounded tephra units described south of the main cone (Wells et al., 1990). It is notable that the upper tephra unit present within the crater fill is thicker and composed of larger scoria clasts than the Qs4b unit south of the cone.

The described section of colluvial and scoria deposits and the constraints on crater geometry obtained from trenching studies indicate that the cone is more modified by erosion than previously thought; the elevation of the original rim may have been 5-9 m above the present rim. Cosmogenic ${ }^{3} \mathrm{He}$ surface exposure ages obtained from the samples of volcanic bombs in the cone deposits yield exposure ages ranging from 64 to $30 \mathrm{ka}$ (Table 2.4) and appear consistent with the erosional history of the cone. The spread in ages is probably a result of shielding of the dated samples by overlying scoria deposits for variable intervals prior to erosional exposure. A minimum age of $\sim 64 \pm 15 \mathrm{ka}$ is consistent with reproducible ${ }^{40} \mathrm{Ar} /{ }^{39} \mathrm{Ar}$ ages of $\sim 75 \mathrm{ka}$ and cosmogenic ${ }^{3} \mathrm{He}$ ages of $\sim 90$ ka determined from lava flows, and provides evidence that both the cone and flows erupted at $\sim 75 \mathrm{ka}$. Alternatively, if QI3 and the main cone are contemporaneous (as suggested by chemical correlation), the oldest ${ }^{3} \mathrm{He}$ age from the cone is within error of a new U-Th isochron age of $\sim 50 \pm 15$ ka for QI3, which could suggest that both the cone and QI3 are measurably younger than the Q1 and Q2 eruptive units.

b. Subunit Ql3. All lava subunits were assumed in previously published field studies of the Lathrop Wells volcanic center to predate eruptions of the main cone (chronostratigraphic unit III). Newly obtained geochemical data provide evidence that one set of lavas is chemically identical to 
the scoria deposits of the main cone (thorium enrichment and titanium depletion) and could be assigned to chronostratigraphic unit III. These lavas comprise a group of topographically highstanding lavas (Q13) that crop out about $0.5 \mathrm{~km}$ northeast of the north base of the main cone (Figure 2.15). They are herein informally named the Sand Ramp lava flow because they were emplaced over a low-angle sand-ramp surface.

The Q13 lava consist of three distinct lobes of blocky $a a$ lava flows. They were erupted from the center part of the west/northwest-trending fissure of chronostratigraphic unit II. The Q13 lava was erupted over low-angle sand-ramp surfaces. Several lines of geomorphic evidence are consistent with the assignment of the Q13 lavas to chronostratigraphic unit III. First, the lavas are not draped by scoria-fall deposits of chronostratigraphic unit II, and they have a relatively thin covering of eolian sand. Second, they have steep, unmodified flow fronts ranging in height from 3 to $4 \mathrm{~m}$ with only minimum areas of exposure of massive $a a$ flow interiors. In contrast, the $a a$ flow interiors are commonly exposed in all other lava units from erosion of the blocky a a flow rubble. Third, the lava has the best preserved surface morphology of any lava flow in the center using comparative assessment of the morphology of lava units from aerial photographs.

Replicate cosmogenic ${ }^{3} \mathrm{He}$ surface exposure ages were obtained for a surface sample from the Q13 subunit. Two measurements of the sample give ages of $72 \pm 12$ and $59 \pm 15$ ka (Table 2.4). The surface exposure ages, which are from samples of unmodified lava flow surfaces, overlap with the oldest cosmogenic ${ }^{3} \mathrm{He}$ ages of bombs from the summit of the cone. This provides an independent collaboration that formation age of the main cone could be recorded by the oldest cosmogenic ages of the main cone. One potential inconsistency remains, however, in establishing the age of the Q13 lava flow. A cosmogenic ${ }^{3} \mathrm{He}$ age of $107 \pm 19 \mathrm{ka}$ was obtained for a surface lava sample collected near the source of the Q13 lava. We tentatively correlate this sample with the Q12b lava subunit but cannot distinguish definitively the sample site from the Q13 lava unit. We are obtaining geochemical data for this sample to assign it more definitively to either chronostratigraphic unit II or III.

\section{FY96 \& FY97 revisions}

Sample LW152FVP was collected from the same site as the sample collected for ${ }^{3} \mathrm{He}$ dating that has an age of $107 \mathrm{ka}$. Based on a Th concentration of $6.76 \mathrm{ppm}$ measured from this sample, the sample with a ${ }^{3} \mathrm{He}$ age of $107 \mathrm{ka}$ can be confidently assigned to the Q12 flow. Q12 samples have Th concentrations ranging from 6.84 to $7.15 \mathrm{ppm}$, while Q13 samples have Th concentrations ranging from 7.26 to 7.40 ppm (Perry and Straub, 1996). The first sample collected from QI3 gave replicate ages of 72 and 59 ka (Table 2.4). This sample was collected early in the ${ }^{3} \mathrm{He}$ exposure age study at Lathrop Wells. Late in the study, a second sample was collected from an aa spine near the toe of the Q13 flow, with the objective of maximizing the probability of obtaining a "true" surface exposure age. This sample yielded an age of $92 \pm 17 \mathrm{ka}$ (Table 2.4), which is within the range of both the Q1 and Q2 eruptive units. Our interpretation of these ages is that the earliest collected sample does not represent an original flow surface (basalt had likely been spalled off from above the sample). The second sample, collected to maximize the probability that it most closely represented the original flow surface, is interpreted to represent the best ${ }^{3} \mathrm{He}$ exposure age of the QI3 flow. 
A U-Th disequilibrium isochron age of the Q13 lava is $125+45-30(1 \sigma) \mathrm{ka}$, a reproducible age verified by replicate analyses of mineral and phase separates collected from the same sample of the Q13 lava. Analytically this appears to be a valid isochron age, but the age is determined from phases with only small degrees of fractionation of uranium and thorium.

\section{FY96 \& FY97 revisions}

A new U-Th disequilibrium isochron age of $49.5+16.9-14.6(2 \sigma)$ ka for the Q13 lava flow supersedes the previous age of $125 \mathrm{ka}$ because of more efficient mineral separations. This result is discussed more fully in section $\mathrm{F}$ below.

The ${ }^{40} \mathrm{Ar} /{ }^{39} \mathrm{Ar}$ age determinations for the Q13 lavas range from 66 to $311 \mathrm{ka}$ with a mean age of $153 \pm 110 \mathrm{ka}$ (Turrin et al., 1991b). These ages are too variable to constrain precisely either the age or the stratigraphic assignment of the lava.

\section{E. Chronostratigraphic Unit IV}

1. Unit Qs4. The deposits of chronostratigraphic unit IV are small-volume tephra deposits that crop out only south of the main cone (Figure 2.17). This is in an area of commercial quarrying activity and many critical outcrops have been modified or removed; the south side of the cone continues to be an area of active commercial quarrying of cinder. The Qs4 unit consists of local fall and flow-emplaced basaltic tephra, inferred to be derived from small satellite cones (now quarried with only remnants present) south of the main cone. The tephra units of chronostratigraphic unit IV overlie deposits of chronostratigraphic units I, II and III, and are separated from tephra of chronostratigraphic unit III by soil deposits with horizon development. They thus must be separated by a time break from deposits of chronostratigraphic unit III. The tephra units of chronostratigraphic unit IV are chemically diverse and have chemical characteristics that are distinct from other chronostratigraphic units (Figure 2.18).

a. Qs4c. Subunit Qs4c consists of a locally prominent black tephra-fall deposit about $0.5 \mathrm{~m}$ thick with thin interbedded, pyroclastic-surge units. It is exposed only in quarry cuts southeast of the main cone. This deposit cannot be traced directly to local vent conduits but does overlie deposits of chronostratigraphic unit II. We therefore identify the black tephra fall as a subunit of chronostratigraphic unit IV on the basis of its stratigraphic position and distinctive chemical composition. This subunit has the highest magnesium number $([\mathrm{Mg} / \mathrm{Mg}+\mathrm{Fe} 2+] \times 100)$ of any volcanic unit at the Lathrop Wells center (58 versus $54 \pm 1$ for all other units) indicating a less evolved magma. Lesser fractionation may account for the lower incompatible trace-element concentrations of this subunit relative to all other eruptive units at the Lathrop Wells center. 

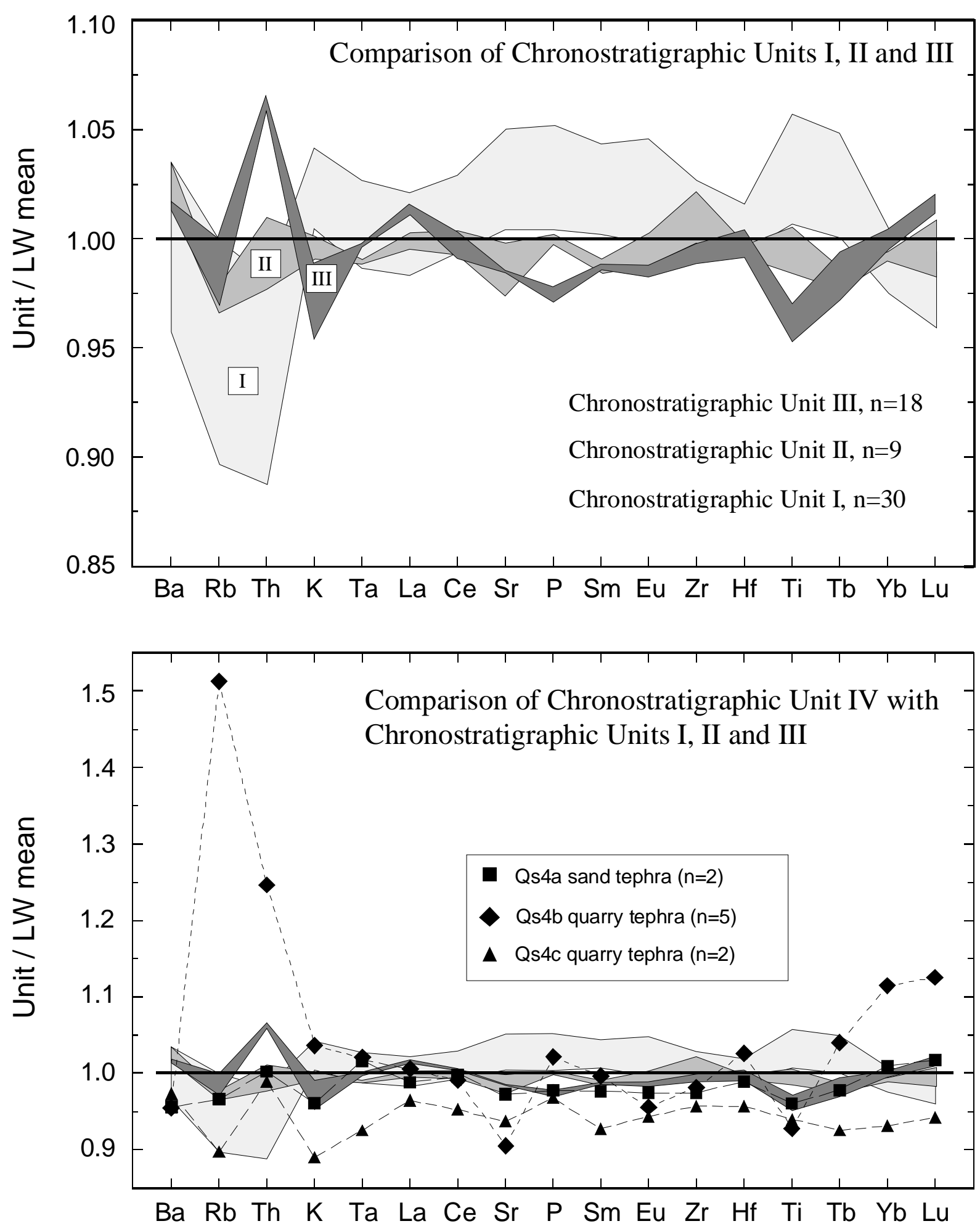

Figure 2.17. Spidergram of elemental compositions normalized to an average composition of all analyzed samples of the volcanic units of the Lathrop Wells center $(n=99)$. Samples of

chronostratigraphic unit IV are designated by subunit. Each pattern is plotted as the average of multiple analyses of specific eruptive subunits. 


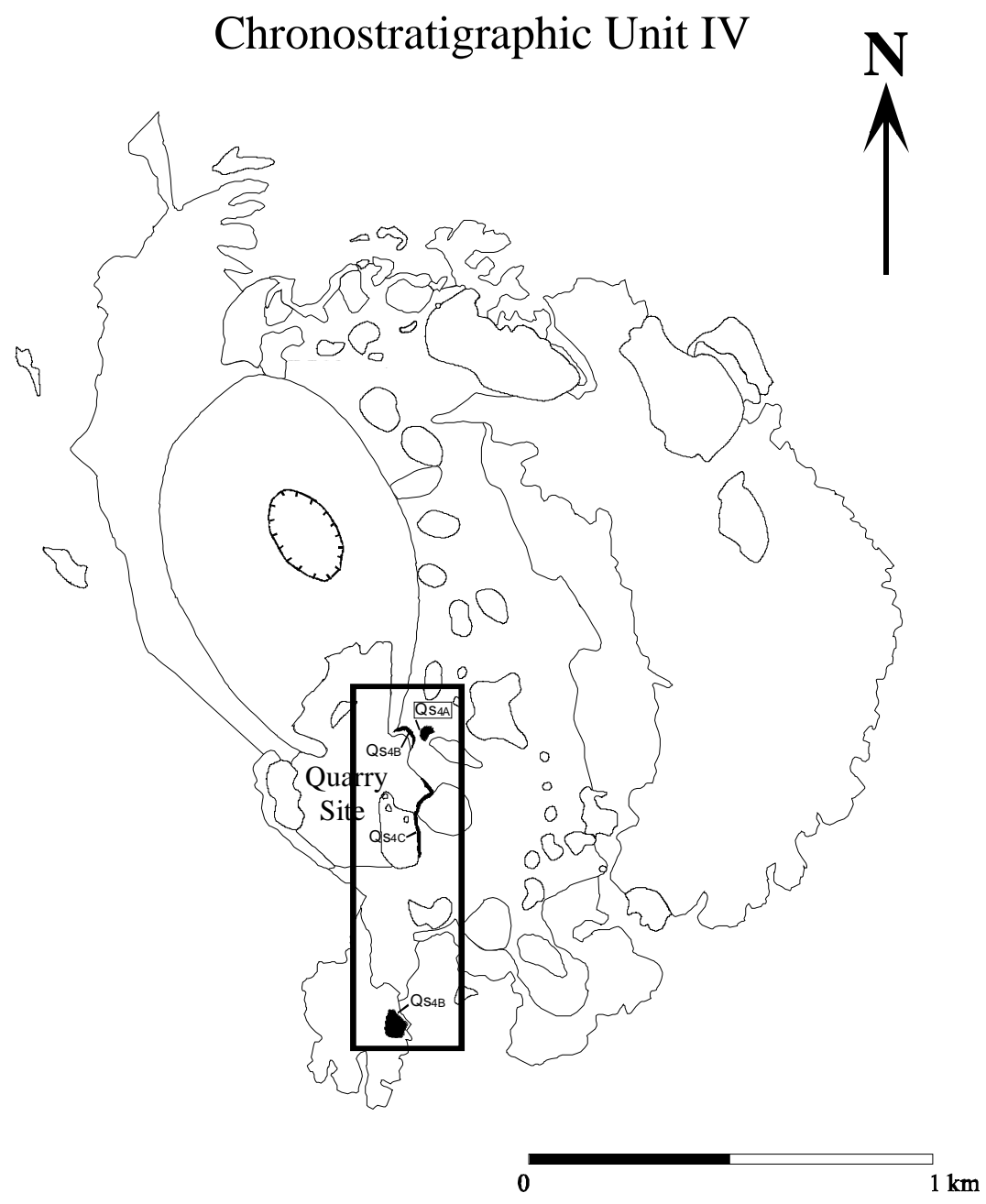

Figure 2.18. Geologic map of the distribution of volcanic subunits of chronostratigraphic unit IV of the Lathrop Wells volcanic center. The deposits consist only of thin beds of tephra that are interbedded with soil containing horizon development. These deposits occur only on the south side of the volcanic center, mostly in the area outlined by the vertical rectangle.

\section{FY96 \& FY97 revisions}

We now believe that the Qs4c deposits are not a primary volcanic unit but are simply a subunit of the scoria-fall deposits of Qs2/3, based primarily on equivalent La/Th ratios.

b. Subunit Qs4b. Scoria-fall and pyroclastic-surge (?) deposits probably associated with or erupted from the Qs4 vents were described originally at only one outcrop (Crowe et al., 1988, 1992; Wells et al., 1990), a small cliff exposed by quarrying activity, several tens of meters south of the base of the main cone. Here, thin tephra beds, inferred to be primary flow deposits of hydrovolcanic origin, are separated by multiple soils with weak horizon development. These tephra units were correlated initially with a distinctive sequence of plane-parallel bedded, scoria-fall and hydrovolcanic deposits identified in the south quarry wall of the main cone (Crowe et al., 1992). 
However, petrologic studies have shown that the tephra units in the quarry (Qs4b) are chemically distinctive from the scoria units $(\mathrm{Qs} 3)$ of the main cone.

The presence of the soil deposits beneath and between the Qs4b tephra units at the base of the cone requires their separation as a distinct chronostratigraphic unit. While this separation is used herein, there is controversy concerning the origin of the tephra deposits (Whitney and Shroba, 1991; Turrin et al., 1992). The basis of the controversy is whether the tephra beds are primary (deposited directly from fallout from eruption columns) (Wells et al., 1991) or have been reworked from tephra deposits on the flanks of the main cone (Qs3) by surficial processes. If the deposits are of primary volcanic origin, they record a complex history of intermittent volcanic activity with periods of inactivity that must exceed several thousands of years to permit the development of horizons in the interbedded soils. Alternatively, if the deposits are reworked, they record episodes of surficial erosion and deposition and do not require multiple eruptive events.

Evidence cited in support of a reworked origin of the deposits include the presence of eolian sand or silt in the tephra deposits (Whitney and Shroba, 1991) and granulometric data for the tephra beds that are inferred to be inconsistent with a primary origin of the deposits (Turrin et al., 1992). The authors of both papers suggest the deposits were formed from slope erosion of the main scoria cone of the Lathrop Wells center. The evidence supporting a primary origin of the beds includes the planar tops and bottom contacts over an outcrop distance of several tens of meters, draping or uniformity of the thickness of the deposits over basal contact irregularities, unsupported fabric of the deposits, and reverse grading reflecting eruption column dynamics (Wells et al., 1991, p. 662).

Several points provide strongly contradictory evidence for a reworked origin of the deposits. First, there is an absence of cross-bedding and bedding lenticularity. The tephra deposits show uniformity of bedding thickness and no bedding lamination except poorly developed, reverse grading. These deposits contrast markedly with a sequence of reworked deposits that overlie the section above the tephra beds (Wells et al., 1990). These reworked deposits are lenticular, and locally cross-bedded within discrete erosional channels. They contain supported clasts of basaltic debris with rotated long dimensions. Second, proponents of the interpretation that the tephra beds are reworked suggested they are "... younger cone-apron deposits formed during subsequent erosion of the cinder cone" (Turrin et al., 1992, p. 556). A key and generally undisputed observation of the characteristics of the main cone of the Lathrop Wells center is the absence of cone-slope erosion and formation of a cone-slope apron (Wells et al., 1990). A further complication is that the tephra deposits are located several tens of meters from the base of the main cone. The only way the tephra beds could represent cone-slope deposits would be if the south part of the cone (which has been removed by quarrying) was, in contrast to the rest of the cone, significantly eroded. To investigate this unlikely possibility, historic photographs of the south cone exposure have been obtained. These photographs were taken in the 1930s prior to any modification of the cone by quarrying (Figure 2.19). There is no evidence in the photograph of extensive cone-slope erosion of the south cone wall that would be required to form cone-slope apron deposits tens of meters from the base of the cone. Third, the presence of eolian silt and sand in the tephra beds is not inconsistent with a primary origin of the deposits. This material was introduced as a wind-blown constituent during soil pedogenesis. It is precisely the presence and formation of soil horizons in this material that requires time intervals between the tephra-fall units. Granulometric analyses cannot easily be used to discriminate reworked from primary tephra. Granulometric analyses of undisputed scoria-fall deposits with soil at the Lathrop Wells center and other Quaternary basalt centers in the southwest United States overlap with the grain-size 
distribution curves of Turrin et al. (1992). Finally, the distinctive geochemistry of the Qs4b tephra rules out derivation by reworking from either the main cone or any other eruptive unit identified at the Lathrop Wells volcanic center (Figure 2.18). The tephra is distinguished by higher concentrations of thorium, rubidium, and the heavy rare-earth elements, indicating that it represents a primary volcanic event from a magma of different chemical composition than preceding eruptive units. Thus, multiple lines of evidence indicate it is physically impossible for the tephra deposits to be reworked, cone-slope deposits.

\section{FY96 \& FY97 revisions}

The arguments summarized above continue to be consistent with a primary origin of the Qs4b deposits with three exceptions: 1) based on new geochemical modeling, the composition of the Qs4b scoria is due to pedogenic alteration of a (likely) Qs3 parent composition (see Chapter 4), and thus cannot be used as additional evidence for a primary origin; 2) careful re-examination of field notes, field photographs of the deposits, and discussion with researchers specializing in pedogenic processes has revealed that some fragmental clasts of the Qs4b deposits are partially coated with thin layers of pedogenic calcite-silica. Furthermore, these coatings were broken during clast fragmentation, and the coatings of the clasts in the deposits are not confined to the bottom surfaces of the clasts, as would be expected if the coatings had developed after clast deposition. These relations require that the clasts were exposed to a period of pedogenic alteration prior to incorporation in the Qs4b deposits and fragmentation of the clasts; and 3) no vent has been identified that could be the source of the Qs4b deposits.

Thus, we are faced with somewhat conflicting evidence for the origin of the Qs4b deposits. The depositional and textural data described above continue to be consistent with a primary-volcanic rather than secondary-erosional origin of the deposits. Moreover, several somewhat puzzling features of these deposits remain unexplained. First, extensive trenching described in the volcanism status report has been completed for all but the sand-mantled east side of the main cone. Moreover, the outer cone walls have been increasingly exposed through quarrying activity. The perplexing relationship is that deposits like the Qs4 deposits have been observed only at the south cone base. At every other site, there are no cone-slope apron deposits, and trenched sand-ramp deposits at the base of the cone have only minor components of basaltic scoria. In all cases scoria clasts in the sand ramp deposits are supported in a sand matrix and do not form distinct beds like the Qs4 deposits. These relations are inconsistent with a secondary or erosional origin of the Qs4 deposits, as slope erosion should produce cone-slope apron deposits that are distributed nearly uniformly around the base of the cone slope. This observation is also somewhat inconsistent with a volcanic origin of the deposits as eruptive processes generally disperse scoria approximately radially. A second perplexing relationship relative to a non-volcanic origin of the Qs4 deposits is the planar geometry of the base of the deposits, their sheet-like geometry (thickness $<<$ length) and location several tens of meters from the south base of the cone.

Three speculative interpretations of the origin of the deposits are that they formed during 1) a local but significant collapse of the south-cone wall where the deposits were formed by higher energy avalanche or debris-flow mechanisms; 2) hydrovolcanic explosions and associated mass-flow processes that affected only the south cone wall; 
or 3) phreatic explosions that disrupted and redeposited Qs3 tephra without the involvement of any juvenile magma. Any of these events would have had to occur several thousands of years after formation of the main cone, given the presence of soil horizons between the Qs3 and Qs4b deposits (Wells et al. 1990). A phreatic explosion would not necessarily require a new magmatic event and is consistent with most of the geologic observations, including the primary fabric of the deposits, the presence of broken, partially coated and rotated clasts, and the planer nature of the deposits. It would not be surprising that a small and shallow phreatic crater would not be preserved in the geologic record after several tens of thousands of years.

The first two interpretations involving disruption of the south cone wall are not very appealing given the apparent smooth profile of the south cone wall on the historic photograph (Figure 2.19). The third possibility of a phreatic explosion several thousands of years after the main volcanic activity at the center had ceased must remain speculative, but would seem to satisfy all of the geologic observations related to the Qs4 deposit. A phreatic explosion could not have originated within the present crater, given the preservation of crater-filling deposits revealed by trenching. Because of the removal of the Qs4 deposits by the quarrying activity at the Lathrop Wells volcanic center and the closure of volcanism studies, it is highly unlikely that the origin of the deposits will be resolved in future studies.

A surficial cover of local lenses of reworked tephra overlie the surface of the Q11a lava flow at multiple localities 0.5 to $1.0 \mathrm{~km}$ south of the Qs4b quarry. Samples of the tephra were collected and analyzed for their major and trace-element composition. These data show that the tephra can be correlated geochemically and texturally with the Qs4b tephra and thus indicate the Qs4b unit represents a relatively widely dispersed tephra fall event.

\section{FY96 \& FY97 revisions}

As mentioned earlier and described in detail in Chapter 4, geochemical analysis and modeling of silt addition to tephra indicates that the unique Qs4b composition is due to the presence of $\sim 10 \%$ eolian silt within tephra vesicles. The parent tephra probably had a composition similar to Qs3. Geochemical evidence alone, therefore, cannot be used to argue that the Qs4b tephra represents a widely dispersed volcanic event.

c. Subunit Qs4a. Recent trenching a few tens of meters east of the original Qs4b quarry exposure revealed a $0.5 \mathrm{~m}$ thick section of fine-grained, slightly reworked tephra overlying sand and silt deposits that, in turn, overlie the Qs4b tephra units. This tephra is somewhat similar to the scoria of the main cone (Qs3) in concentrations of most incompatible elements (Figure 2.17), but has slightly lower concentration of barium, thorium, and lanthanum, lower lanthanum/cesium ratio, a slightly higher magnesium number (55.2 versus 53.6), and higher cobalt (32.4 versus 30.0 ). Thus, for the same reasons presented for the Qs $4 b$ tephra, this tephra could not be derived from scoria reworked from the main cone. We interpret this tephra to represent the deposits of a primary volcanic event. 


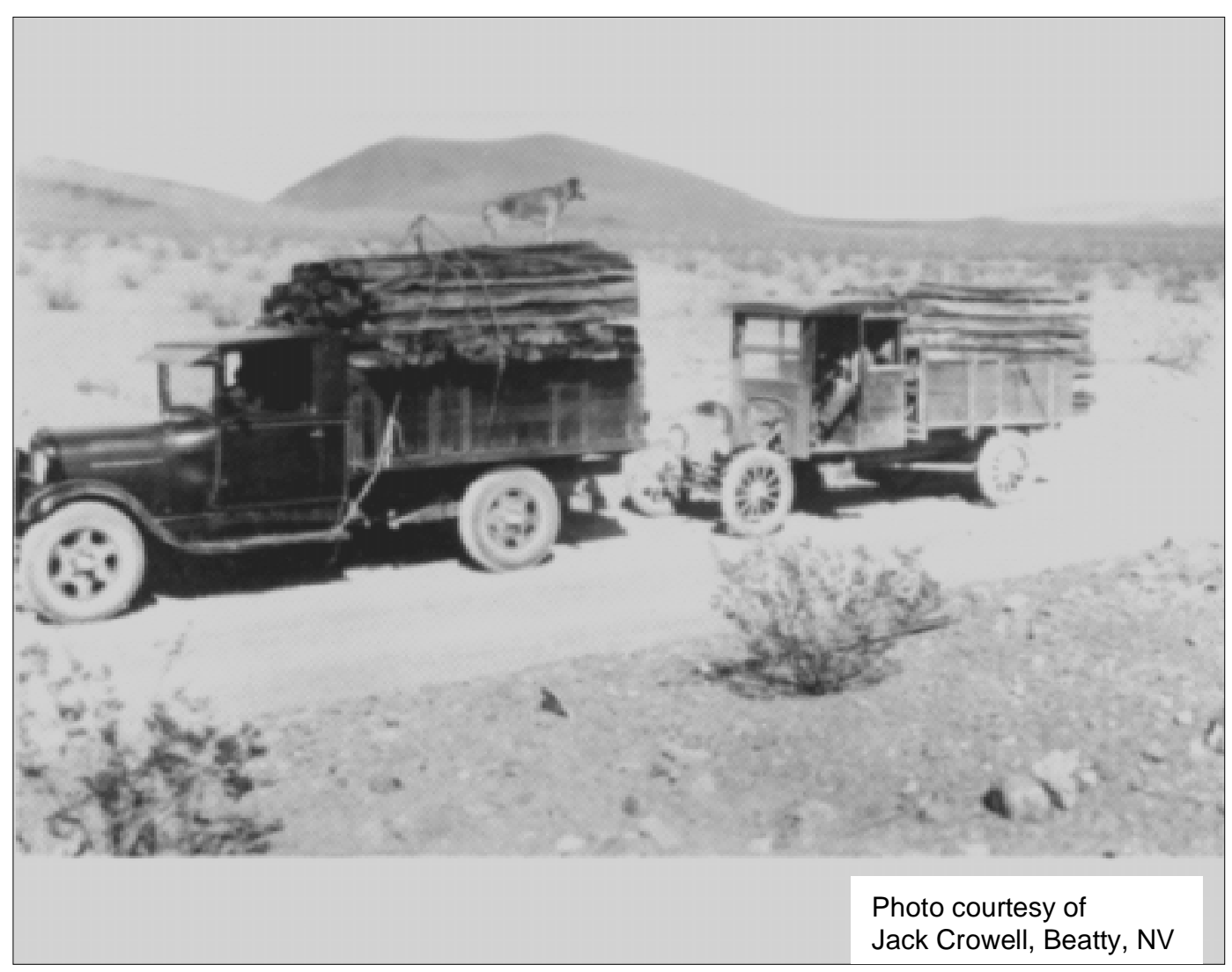

Figure 2.19. Historic photograph of the south flank of the Lathrop Wells volcanic center. The photograph was taken before initiation of quarrying activity at the center. The south flanks of the center are unmodified by erosion indicating that tephra deposits south of the cone could not be derived from erosion of the cone slopes. The date of the photograph is estimated to be about, 1930 based on identification of the approximate date of manufacture of the automobiles.

\section{FY96 \& FY97 revisions}

We have no new data to report for subunit Qs4a. Based on revised interpretations of subunits Qs4b and Qs4c, however (discussed above), we are less confident that this unit represents a primary volcanic event.

Local sections of thin primary and reworked basaltic scoria were recently noted in field and trenching studies immediately south of the Old Quarry lava flow. A thin deposit of subunits Qs4b or Qs4a has been identified tentatively at this site about $1.0 \mathrm{~km}$ south of the main cone. Here unconsolidated, fine-grained tephra about $3 \mathrm{~cm}$ thick overlies a thick, prominent Av soil zone that caps scoria-fall deposits of chronostratigraphic unit II. Trace element analyses of this tephra will be obtained to test for correlations of these upper tephra units.

\section{FY96 \& FY97 revisions}

Based on relatively low Th concentration, we now interpret this tephra to be reworked from the adjacent Qs1 deposits. 
Two soil units beneath the tephra beds of chronostratigraphic unit IV in the quarry deposits have been dated by the TL method at $\sim 8$ and $4 \mathrm{ka}$, and the ages are in correct stratigraphic sequence (Wells et al., 1992). If these age determinations correctly record the chronology of primary volcanic activity, two small volume eruptions have occurred at the Lathrop Wells center since $\sim 4 \mathrm{ka}$, indicating an unusually long and complicated eruptive history, which is somewhat unexpected based on historic and geologic studies of small-volume basalt centers (Wood, 1980; Wood and Kienle, 1990).

No direct radiometric age determinations have been obtained for chronostratigraphic unit IV.

\section{FY96 \& FY97 revisions}

The interpretation of late Holocene eruptions at Lathrop Wells rests on the assumption that the main scoria cone is itself relatively young, on the order of $20 \mathrm{ka}$ (Wells et al., 1990). The TL age determinations and presence of soils between Qs3 and Qs4 indicate only that an age difference of $\sim 10-15$ ka exists between the two units. If, as we now believe, the cone has an age of $75 \mathrm{ka}$, the Qs4 deposits were probably emplaced at 60-65 ka.

F. Application of Multiple Geochronology Methods: The Chronology of the Lathrop Wells Center

\section{FY96 \& FY97 revisions}

A major goal of volcanism geochronology studies since their inception was to constrain the age of the Lathrop Wells volcanic center by achieving convergence of multiple geochronologic techniques. This goal has been illusive and difficult to attain, but new measurements completed in FY96 lead us to believe that we have largely achieved the original goal. The major accomplishment towards attaining this goal was the completion of multiple whole-rock and tuff xenolith sanidine ${ }^{40} \mathrm{Ar} /{ }^{39} \mathrm{Ar}$ ages at the New Mexico Bureau of Mines. These ages are surprisingly reproducible and are generally concordant with existing ${ }^{3} \mathrm{He}$ and ${ }^{36} \mathrm{Cl}$ cosmogenic exposure ages and with new TL ages. Together these techniques indicate that the Lathrop Wells center formed between about 65 and $85 \mathrm{ka}$. The only defensible evidence contrary to this conclusion is a U/Th disequilibrium isochron of $50 \pm 15 \mathrm{ka}$ from the stratigraphically youngest flow, which leaves open the possibility that some eruptive activity took place 10-20 ka after the majority of the center had formed. The new geochronology data are discussed by technique in the following sections.

The Lathrop Wells volcanic center has been the subject of comprehensive geochronology studies. More field and geochronology data have been gathered at the Lathrop Wells center than all of the Pliocene and Quaternary volcanic centers of the YMR; it may be one of the most carefully studied small-volume Quaternary basaltic volcanic centers in the world. Establishing the chronology of the center has proven to be problematic using both conventional and developmental geochronology methods. The age of the center $(<150 \mathrm{ka})$ is near the lower analytical limit for the conventional K-Ar methods, particularly for low-potassium, basaltic volcanic rocks. The ages of 
most of the volcanic units of the center are too old to date using the ${ }^{14} \mathrm{C}$ method, even if sources of datable carbon were present. We are applying developmental chronology methods that have limited histories of testing and development for young volcanic rocks (U-Th disequilibrium, cosmogenic $\left.{ }^{3} \mathrm{He}, \mathrm{TL}\right)$. Finally, we are attempting to resolve stratigraphic relations and the chronology of volcanic events at a level that is near the limit of the discrimination abilities of current geochronology methods and field geologic studies.

Not surprisingly, given the unprecedented level of detail of studies of the Lathrop Wells center, there have been and continue to be controversies concerning the interpretations of the data. The origins of the controversies are differences in interpretation of the age and eruptive history of the center (Turrin et al., 1991b, 1992; Wells et al., 1992) and differences in opinions of what constitutes a conclusive data set (Crowe et al., 1992). We have chosen, in recognition of these controversies, to apply a variety of largely independent geochronology methods. It is important to establish the age of the Lathrop Wells volcanic center with an acceptable degree of confidence in order to apply this information to volcanic risk assessment for the potential Yucca Mountain site. Increased confidence in the results of chronology studies will be obtained if there is convergence in the age determinations using independent chronology methods.

In the following parts of Chapter 2, we assess by individual methods the results of geochronology studies for the Lathrop Wells center. We attempt to evaluate the underlying assumptions, resulting data, and the strengths and the weakness of each method recognizing that there may never be a complete consensus concerning the results and interpretations of the geochronology data.

1. K-Ar Age Determinations. A large number of conventional K-Ar age determinations of whole-rock samples of basalt from the Lathrop Wells volcanic center have been obtained from multiple analytical laboratories (Sinnock and Easterling, 1983; Turrin and Champion, 1991; Turrin et al., 1991b). These age determinations show a wide range in measured ages (negative ages to $>700 \mathrm{ka}$ ), generally large analytical errors for individual measurements, and poor reproducibility between analytical laboratories (Crowe et al., 1992). The most comprehensive summaries of the results of the whole-rock K-Ar age determinations are by Turrin and Champion (1991) and Turrin et al. (in press). They obtained replicate K-Ar ages of whole-rock, samples collected at separate sites in the Q11, Qs3, and Q13 units. The measured ages of their samples range from 34 to $>650 \mathrm{ka}$. Turrin and Champion (1991) reported a weighted mean of $116 \pm 13 \mathrm{ka}$ for their Q15 unit (a combination of Q11a, Qs1b, and Qs3 units) and $133 \pm 10 \mathrm{ka}$ for their Q13 unit (a combination of Q12 subunits).

There are three concerns with these reported ages. First, the combination of units does not correspond to the stratigraphic subdivisions established from the field and trenching studies. Second, the analytical errors of the K-Ar ages are too large because of low radiogenic yield for the results to be used to discriminate the ages of different volcanic units. Third, the weighted mean is not an acceptable method for calculating the age of the units because the data show a nonGaussian distribution (Crowe et al., 1992; Wells et al., 1992), and there is evidence of systematic bias in the age determinations toward older ages.

We have attempted to evaluate the conventional K-Ar age determinations of Turrin and Champion (1991). Their measured ages are grouped by the defined volcanic stratigraphic units used in this report. The age determinations were not obtained under an approved Quality Assurance program and cannot be used for the YMP. However, the age determinations are of high 
quality analytically and can be used as an aid to interpreting the age of the volcanic center. Additional K-Ar or ${ }^{40} \mathrm{Ar} /{ }^{39} \mathrm{Ar}$ age determinations are being obtained under a fully qualified Quality Assurance program and will be used to verify the nonqualified $\mathrm{K}-\mathrm{Ar}$ data.

Sixteen whole-rock, K-Ar age determinations were reported for chronostratigraphic units I, II, and III (3 age determinations for subunit Q13, 9 age determinations for subunit Q12a, and 4 age determinations for subunit Q11a) (Turrin et al. in press). Descriptive statistics for the age determinations are listed in Table 2.3. The ages range from a minimum of $37 \pm 29 \mathrm{ka}$ to a maximum of $571 \pm 360 \mathrm{ka}$.

Table 2.3. Descriptive Statistics for Conventional K-Ar and ${ }^{40} \mathrm{Ar} /{ }^{39} \mathrm{Ar}$ Data Sets of Turrin et al. (1991b).

\begin{tabular}{|c|c|c|c|c|}
\hline Statistics & $\begin{array}{c}\text { Ages in } \\
\text { ka. }\end{array}$ & $\begin{array}{c}\text { Conventional K-Ar } \\
\text { (outliers removed) }\end{array}$ & ${ }^{40} \mathrm{Ar} /{ }^{39} \mathrm{Ar}$ & $\begin{array}{c}{ }^{40} \mathrm{Ar} /{ }^{39} \mathrm{Ar} \text { (outliers } \\
\text { removed) }\end{array}$ \\
\hline $\mathrm{N}$ & 16 & 12 & 32 & 25 \\
\hline Min & 37 & 37 & -20 & 42 \\
\hline Max & 571 & 211 & 947 & 311 \\
\hline Range & 534 & 174 & 967 & 269 \\
\hline Mean & 214 & 134 & 231 & 161 \\
\hline Median & 154 & 147 & 170 & 147 \\
\hline Variance & 22,719 & 2,717 & 40,082 & 4,545 \\
\hline Standard Deviation & 150 & 52 & 200 & 67 \\
\hline Standard Error & 38 & 15 & 35 & 13 \\
\hline Skewness & 1.13 & -0.49 & 2.1 & 0.5 \\
\hline
\end{tabular}

The mean of the data set is $214 \pm 151 \mathrm{ka}(1 \mathrm{~s})$. The sample variance is large (22719) and there are several indicators of a nonnormal data distribution. These include that the mean $(214 \mathrm{ka})$ is greater than the median (154 ka) and the data are positively skewed (1.13). The nonnormal distribution of the data is shown in Figure 2.20, a probability plot of the data set. The plot shows a nonlinear data distribution, with significant deviation in the upper tail (older ages). The data set was evaluated using the box, and stem and leaf diagrams. These plots show the presence of outlier data points in the data set. The outliers are samples collected from a flow lobe of subunit Q12a. This flow is notable in the field by the presence of abundant fragments of tuff probably derived from the underlying Timber Mountain Tuff. These samples were judged to have a high possibility of being contaminated and were removed from the data set. The revised data were rerun through successive iterations using the statistical routines. All outlier points identified in successive runs were removed from the data set. Twelve K-Ar determinations remain after this screening. Descriptive statistics for the edited sample set are listed in the second column of Table 2.3. The minimum age of the edited sample subset is $37 \pm 29 \mathrm{ka}$ (unchanged from the original data set), and the revised maximum age is $211 \pm 340 \mathrm{ka}$. The sample mean of the screened data set is $134 \pm 52$ $\mathrm{ka}$ and its probability plot is near-linear (Figure 2.21). The variance of the sample set is reduced by almost an order of magnitude from the original data set and the mean is close to but still slightly smaller than the median. The data set with outliers removed shows negative skewness $(-0.49)$. 


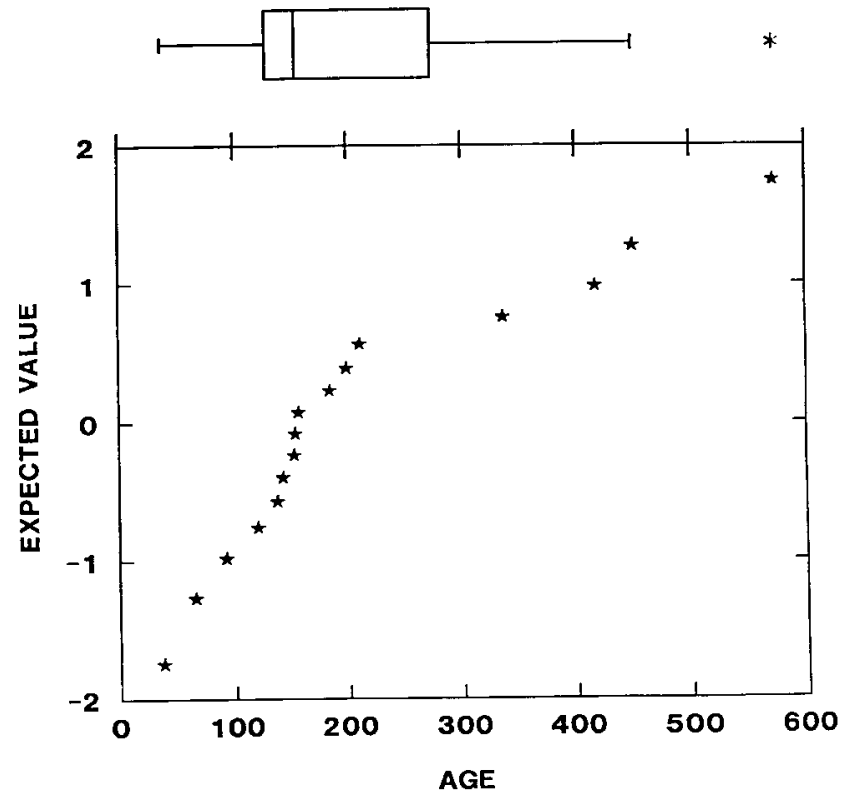

Figure 2.20. Probability and box plots of the conventional whole-rock, K-Ar data of Turrin et al. (1991a). The data are nonlinear on the probability plot indicating a nonGaussian distribution. This is verified by box diagram, which shows nonsymmetrical hinges and the presence of outliers. The median of the box diagram is marked by the center vertical line. The median splits the data in half, and the hinges split the remaining halves in half. The whiskers, or end lines of the box diagram, bound the range of data, which falls within 1.5 Hspreads, where Hspread is the interquartile range. Values outside the whiskers are plotted with asterisks and are considered outliers. The scale of the box diagram is the same as the $\mathrm{x}$-axis of the probability plot. Plots and statistical routines are from SYSTAT version 5.0.

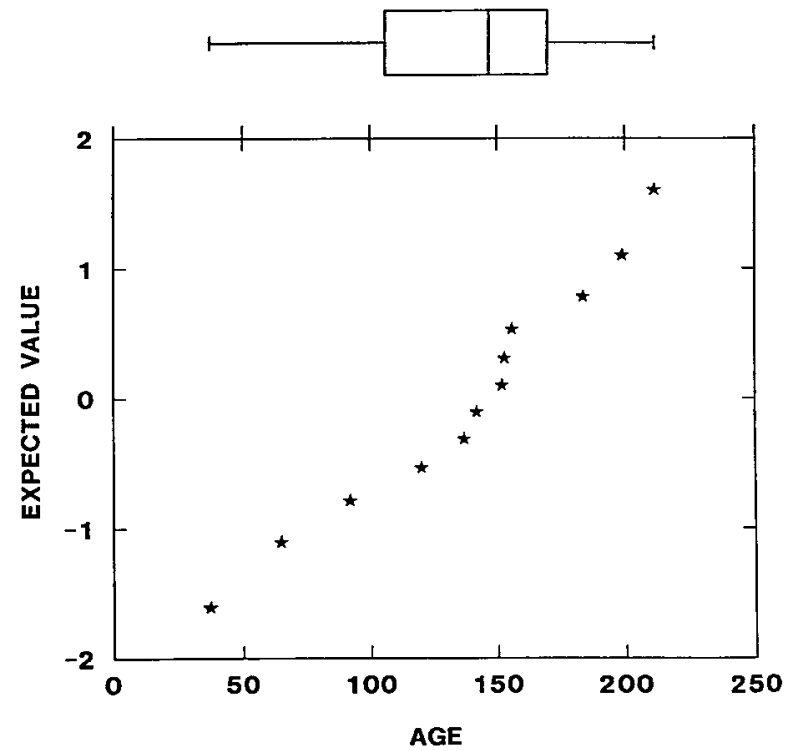

Figure 2.21. Probability and box plots of the conventional whole-rock, K-Ar data of Turrin et al. (1991a) with outliers removed. The data show improved linearity on the probability plot and near symmetrical hinges on the box diagram. The features of the box diagram are the same as for Figure 2.20. The scale of the box diagram is the same as that of the x-axis of the probability plot. 
The sample mean of $134 \pm 52 \mathrm{ka}(1 s)$ can be regarded as an approximation of the age of lava units of the Lathrop Wells volcanic center with two cautions. First, the data set, even with outliers removed, shows a positive correlation between percentage radiogenic argon and measured age of the sample (Figure 2.22). This positive correlation suggests the whole-rock age determinations are probably biased toward older ages. The real age of the dated lavas may be somewhat younger than the mean of $137 \mathrm{ka}$. Second, the mean age of the conventional K-Ar data set is valid only if the dated volcanic units are from the same volcanic unit or all the volcanic units have the same age. This is contradicted by field, stratigraphic, geomorphic, soil, and chemical data that show the dated lavas are from three distinct chronostratigraphic units with probable different ages. We conclude that the conventional K-Ar data set provides only a gross estimation of the age of the Lathrop Wells volcanic center and cannot be used to discriminate the identity or ages of individual units.

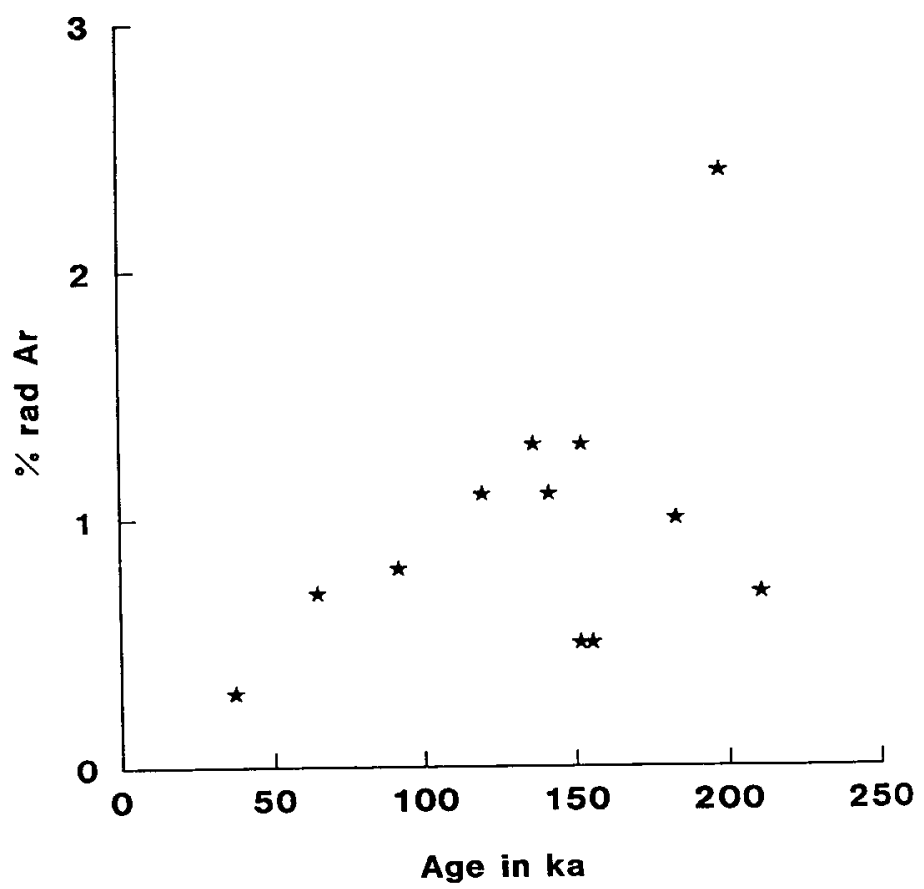

Figure 2.22. Plot of percentage radiogenic argon versus age by the conventional K-Ar age determinations of Turrin et al. (1991a). The data show a positive correlation between age and percentage radiogenic argon, suggesting the age determinations are contaminated and biased toward older ages. The plot uses the same data set as Figure 2.20, so the effect of outliers is removed.

2. ${ }^{40} \mathrm{Ar} /{ }^{39} \mathrm{Ar}$ Age Determinations. Turrin et al. (1991b) report weighted means of $183 \pm 21$ $\mathrm{ka}$ for a combination of units Q13 and Q12a, $138 \pm 54 \mathrm{ka}$ for unit Q11a, and $149 \pm 45 \mathrm{ka}$ for unit Qs1b for samples from the Lathrop Wells center that were analyzed using a whole-rock ${ }^{40} \mathrm{Ar} /{ }^{39} \mathrm{Ar}$ method, fundamentally the same method as the K-Ar method. These age determinations were not obtained under approved YMP quality assurance requirements. However, they again are judged to be good data analytically and useful potentially for constraining the age of the Lathrop Wells center. However, the same interpretative concerns exist for these samples as the conventional K-Ar age determinations. Specifically, the chronology data are combined for units that do not correspond to the chronostratigraphic units. Additionally, the data distribution is nonGaussian and there is evidence of contamination (correlation between percentage radiogenic argon and age - Figure 2.25) of some of the samples. However, in this case, Turrin et al. (1991b) note that some of the samples are contaminated and exclude these age determinations from their data interpretations. 
The ${ }^{40} \mathrm{Ar} /{ }^{39} \mathrm{Ar}$ ages of samples from chronostratigraphic units I, III, and III range from $-20 \pm$ 263 to $947 \pm 24 \mathrm{ka}$. The mean age is $232 \pm 200 \mathrm{ka}$ (Turrin et al., 1991b). Descriptive statistics for this sample set are listed in Table 2.3. The mean (232 ka) is greater than the median (170 ka). The data are strongly skewed positively (2.1), and there is large variance. The probability plot (Figure 2.23) shows the data are nonnormal with an upper tail skewed toward older ages. The box, and stem and leaf diagrams identify, through successive iterations, four samples as outliers. These are the same four samples that were inferred to be contaminated by Turrin et al. (1991b). The samples were removed from the data set and the data set rerun through the statistical routines until all identified outliers were removed. Descriptive statistics for the revised data set are listed in Table 2.3. The revised data show improved linearity on the probability plot (Figure 2.24). However, the mean still exceeds the median and the data remain positively skewed (0.5). This strongly suggests that the variance in the data set cannot be entirely analytical. The best estimate of the age of the older three chronostratigraphic units combining all data is $162 \pm 67(1 s)$ or $162 \pm 134(2 s) \mathrm{ka}$. However, the revised data set of the ${ }^{40} \mathrm{Ar} /{ }^{39} \mathrm{Ar}$ age determinations, similar to the conventional $\mathrm{K}-\mathrm{Ar}$ age determinations, shows a positive correlation between percentage radiogenic argon and age (Figure 2.25). The ${ }^{40} \mathrm{Ar} /{ }^{39} \mathrm{Ar}$ data must, like the conventional K-Ar data set, provide only an estimated maximum age estimate for the older chronostratigraphic units.

Turrin (1992, pp. 226-235) reported preliminary results of step-heating data for selected samples of the Lathrop Wells centers. These results show increased abundance of radiogenic argon, and are less subject to bias toward older ages from the presence of excess argon or contamination. The preliminary results show promise for constraining more precisely the ages of the Lathrop Wells center. The revised ages of subunit Q12a from the Lathrop Wells center are 104, 123, and $122 \mathrm{ka}$ (Turrin et al., 1992). Insufficient information was presented to list the analytical errors associated with these measurements. However, Turrin et al. (1992) presented an isochron age of $107 \pm 33 \mathrm{ka}$ for unit Q12a. These ages are younger than the conventional K-Ar and data of Turrin and Champion (1991) and Turrin et al. (1991b) and support the interpretation that the latter age determinations are somewhat old because of excess argon. They overlap analytically with ages reported for the lavas of Q12a obtained by the cosmogenic ${ }^{3} \mathrm{He}$ method.

3. Summary. Conventional K-Ar and ${ }^{40} \mathrm{Ar} /{ }^{39} \mathrm{Ar}$ age determinations can be examined only for samples collected from combinations of chronostratigraphic units I, II, and III. The methods yield mean ages of about $137 \pm 52 \mathrm{ka}(1 \mathrm{~s})$ and $162 \pm 67 \mathrm{ka}(1 \mathrm{~s})$, respectively. Both methods are insufficiently precise to discriminate the ages of individual volcanic units. The presence of data outliers, the positively skewed data distribution, and the positive correlation between percentage radiogenic argon and age all suggest the age determinations are biased slightly toward older ages. The presence of excess argon in olivine phases (Poths and Crowe, 1992) indicates that excess argon could be present in other phases, notably glass, which is a common groundmass constituent. An alternative source of the excess argon may be from incorporation of lithic fragments of Miocene tuff. These fragments show evidence megascopically of partial melting, and the excess argon introduced into the lava during partial melting may have had insufficient time to degas efficiently before solidification of the lavas. Concerns about the range of data and particularly the correlation between radiogenic argon and age suggest that the radiometric age determinations must be interpreted cautiously. At best they may be maximum ages. Although the age bias may not be large, it is complicated by combining radiometric ages from different chronostratigraphic units. 


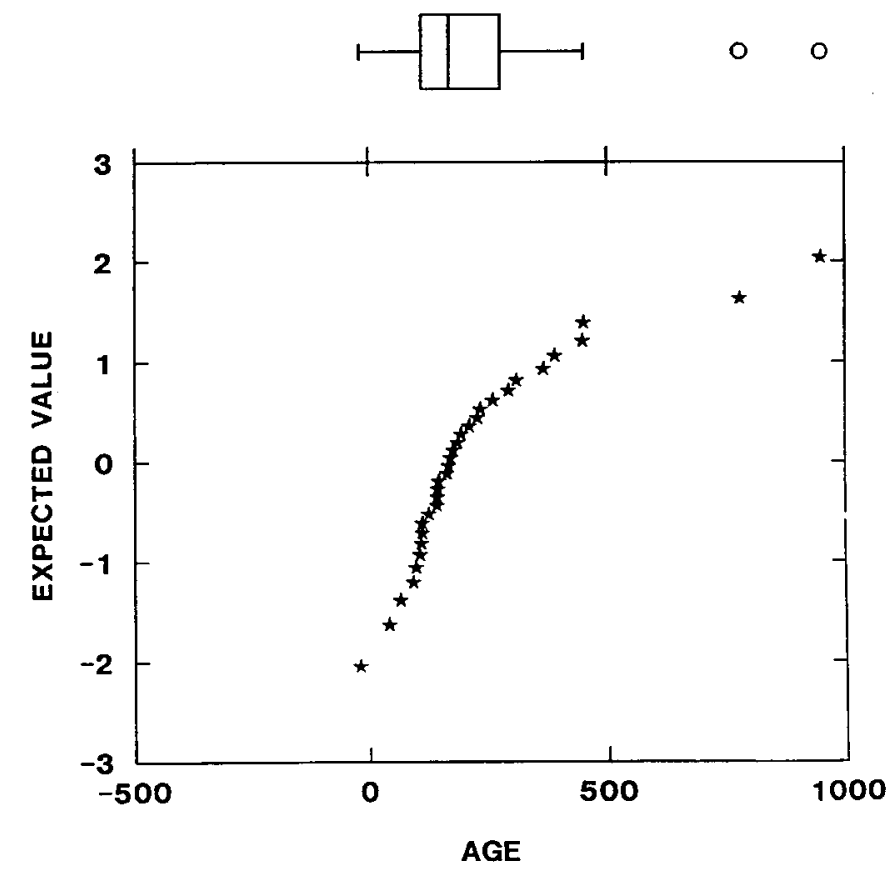

Figure 2.23. Probability and box plots of the ${ }^{39} \mathrm{Ar} /{ }^{40} \mathrm{Ar}$ data of Turrin et al. (1991b). The data show a nonlinear distribution on the probability plot indicating a nonGaussian distribution. The box diagram shows nonsymmetrical hinges and the presence of outliers and far outside outliers. The markings of the box diagram are the same as Figure 2.20. The scale of the box diagram is the same as that of the $\mathrm{x}$-axis of the probability plot.

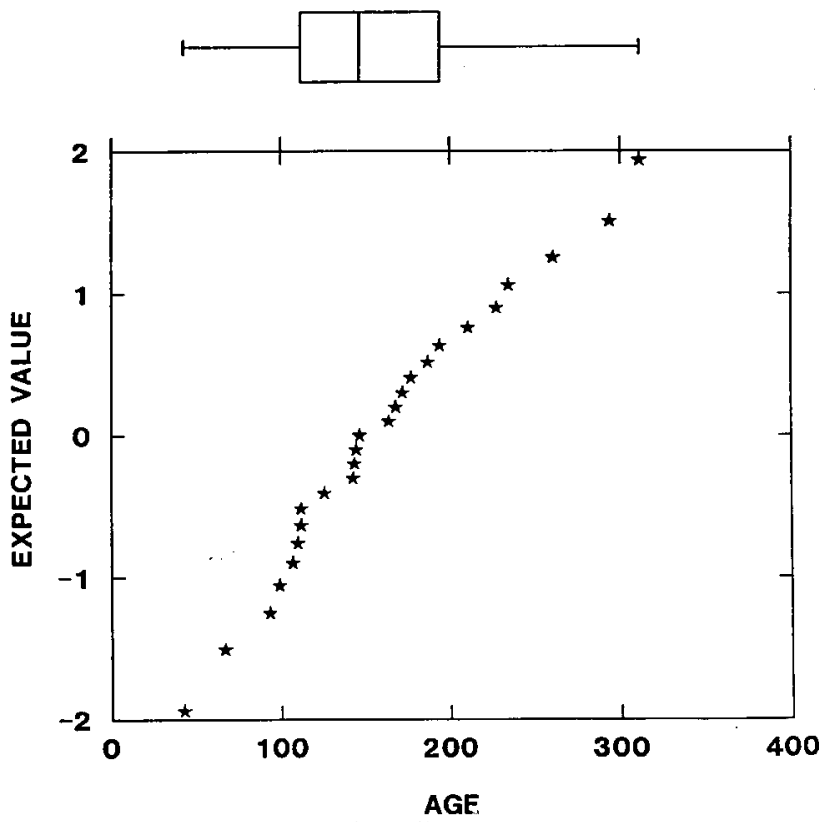

Figure 2.24. Probability and box plots of the ${ }^{39} \mathrm{Ar} /{ }^{40} \mathrm{Ar}$ data set of Turrin et al. (1991b) with outliers removed. The data show an improved distribution on both the probability and box plots but are still skewed toward older ages. The features of the box diagram are the same as Figure 2.20. The scale of the box diagram is the same as that of the $\mathrm{x}$-axis of the probability plot. 


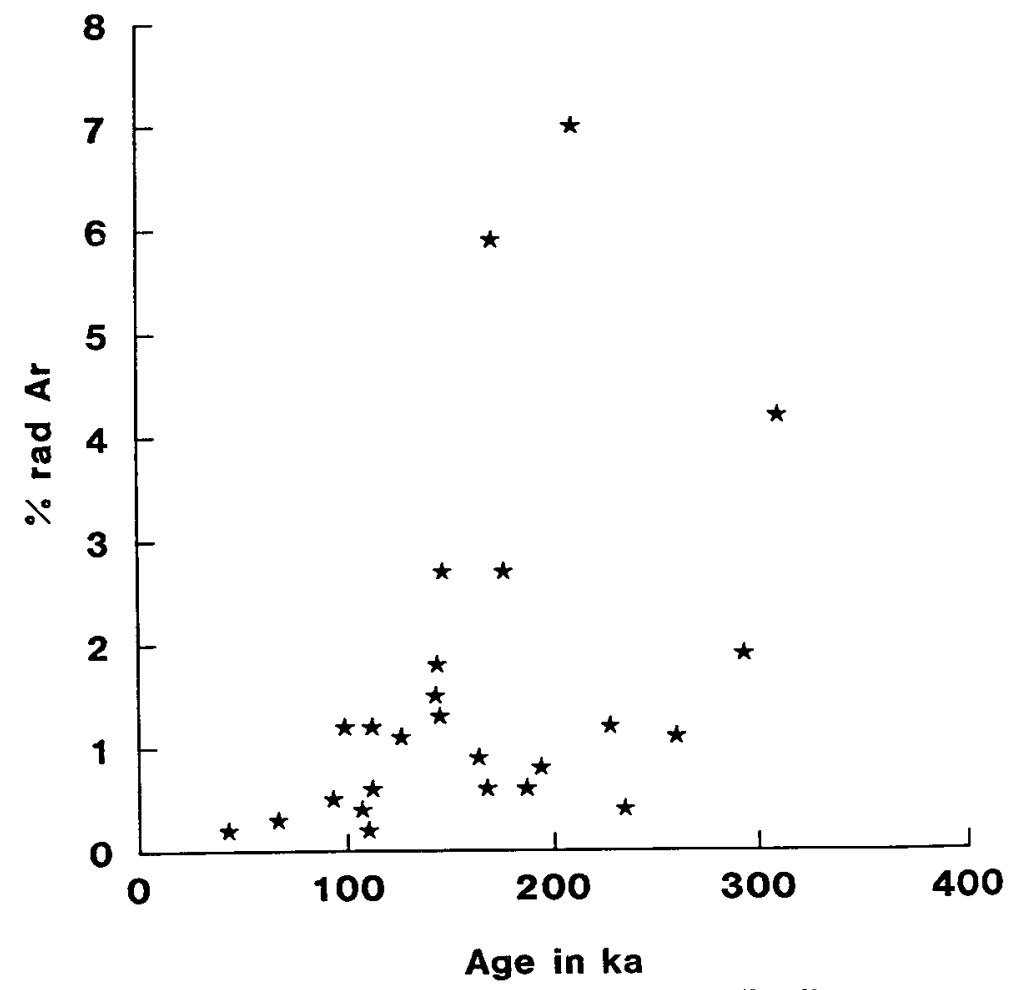

Figure 2.25. Plot of percentage radiogenic argon versus age for the ${ }^{40} \mathrm{Ar} /{ }^{39} \mathrm{Ar}$ age determinations of Turrin et al. (1991b). These data, like the conventional K-Ar age determinations, show a positive correlation between percentage radiogenic argon and age, suggesting the age determinations are biased toward older ages.

FY96 \& FY97 revisions

During FY95 and FY96, new ${ }^{40} \mathrm{Ar} /{ }^{39} \mathrm{Ar}$ measurements were completed at NMBM for eruptive units at Lathrop Wells. Because of their reproducibility and small analytical error, these measurements, in our opinion, supersede all previous $\mathrm{K}-\mathrm{Ar}$ and ${ }^{40} \mathrm{Ar} /{ }^{39} \mathrm{Ar}$ measurements for Lathrop Wells discussed in Crowe et al. (1995). The samples analyzed included modified whole rock (phenocrysts removed) and partially melted sanidine from Miocene tuff xenoliths in eruptive unit Q2. It should be emphasized that the basalt whole-rock and xenolith sanidine represent completely independent systems for estimating the age of the Lathrop Wells center. Concordance in age determinations using these two systems would suggest with a high degree of confidence that an accurate age has been determined.

Five samples, from lava flows Q11b, Ql1c, Q11d, QI2 and Q13, were selected for ${ }^{40} \mathrm{Ar} /{ }^{39} \mathrm{Ar}$ analysis. Six replicate splits of four samples and four replicates of the remaining sample were analyzed using ${ }^{40} \mathrm{Ar} /{ }^{39} \mathrm{Ar}$ incremental step heating. These results, including all of the individual split plateau and isochron ages as well as the weighted means of the replicate age determinations for each sample, are summarized in Table 2.C. Individual replicate plateau ages and weighted means for each sample are summarized and compared with previous replicate ${ }^{40} \mathrm{Ar}{ }^{39} \mathrm{Ar}$ whole-rock determinations from Turrin et al. (1991b) in Figure 2.A. Complete analytical data for all of the replicate splits are presented in Appendix 2.2. 
Plateau and isochron ages calculated from the ${ }^{40} \mathrm{Ar} /{ }^{39} \mathrm{Ar}$ data give concordant results for four of the five samples, with ages ranging from $\sim 65$ to $85 \mathrm{ka}$ (Table 2.C, Figure 2.B). The fifth sample, from QI3, yields a geologically unreasonable age of $200-300 \mathrm{ka}$ for reasons that are not clear. Based on the whole-rock ages of flows Q11b, Ql1c, Ql1d and QI2, no age difference can be demonstrated between flows, and we conclude that all of the flows erupted at $\sim 75 \pm 10 \mathrm{ka}$. The ${ }^{40} \mathrm{Ar} /{ }^{39} \mathrm{Ar}$ ages are in accord with multiple ${ }^{3} \mathrm{He}$ cosmogenic exposure ages of flows ranging from $\sim 80-100 \mathrm{ka}$, with no systematic age differences between flows (Table 2.4).

Thermally reset sanidine within Miocene tuff xenoliths of Q12 and the Qs2fs scoria fall sheet yield ${ }^{40} \mathrm{Ar} /{ }^{39} \mathrm{Ar}$ plateau ages ranging from 69-106 ka with an outlier at $309 \mathrm{ka}$ (Table 2.D). Complete analytical data are presented in Appendix 2.2. These ages are considered maximum ages because of the possibility of excess argon and degassing of older crystal cores that were not completely thermally reset. Ages at the younger end of the age spectrum are, thus, considered to more accurately reflect the true age of the thermal event (i.e., inclusion within lava). The best sanidine measurement (LW140FVPa1, Lab\# 818-01) yielded 5 heating steps with ages ranging from 74 to 81 $\mathrm{ka}$ and \% radiogenic argon ranging from $21-53 \%$ (Appendix 2.2). The plateau age of this sample (78.8 \pm 3.6$)$ is in close accord with whole-rock ${ }^{40} \mathrm{Ar} /{ }^{39} \mathrm{Ar}$ ages from Lathrop Wells, indicating that an age of $\sim 75 \mathrm{ka}$ is a reliable estimate of the age of the Lathrop Wells center.

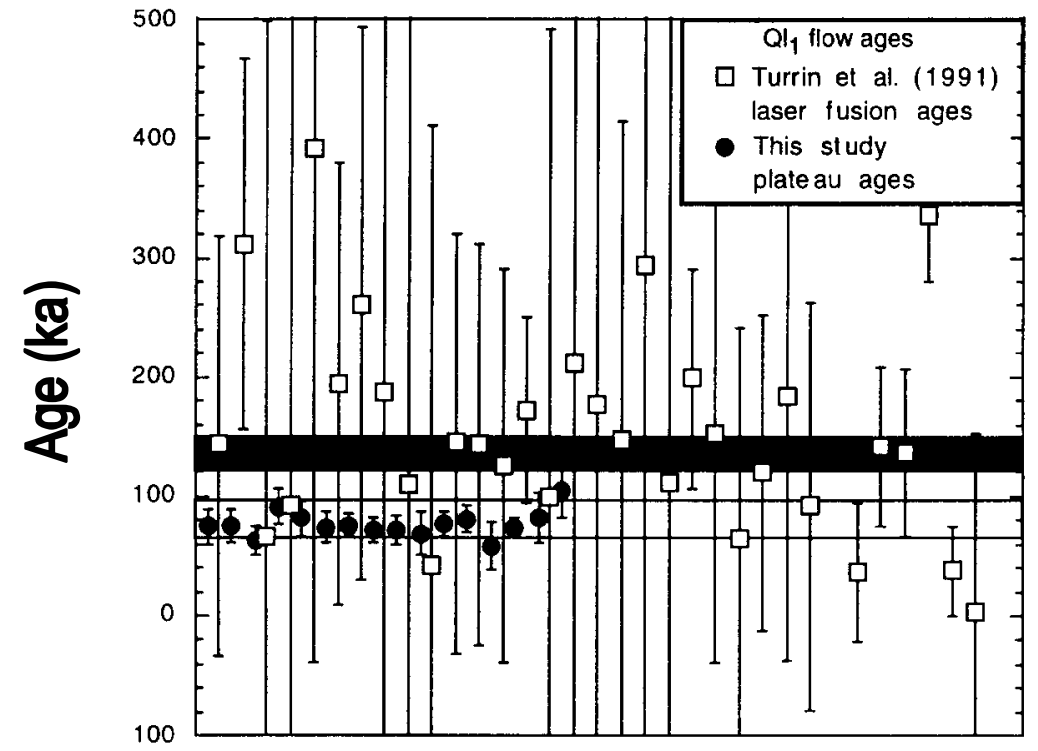

Figure 2.B. Comparison of ${ }^{40} \mathrm{Ar} /{ }^{39} \mathrm{Ar}$ whole-rock plateau ages of $\mathrm{Q} 1$ flow samples (Ql1b, Ql1c, Q11d flows) from NMBM (solid circles) and Turrin et al. (1991b, open squares). Error bars are 20. Despite the lack of reproducibility among individual determinations and the large analytical uncertainties, Turrin et al. (1991b) concluded that the age of the Lathrop Wells center is approximately $140 \pm 10 \mathrm{ka}$. Data from NMBM indicate the age of the center is $\sim 75 \pm 10$ ka based on reproducible determinations with relatively small analytical errors. 
Table 2.C. Summary of whole-rock ${ }^{40} \mathrm{Ar} /{ }^{39} \mathrm{Ar}$ results from Lathrop Wells using different reduction methods

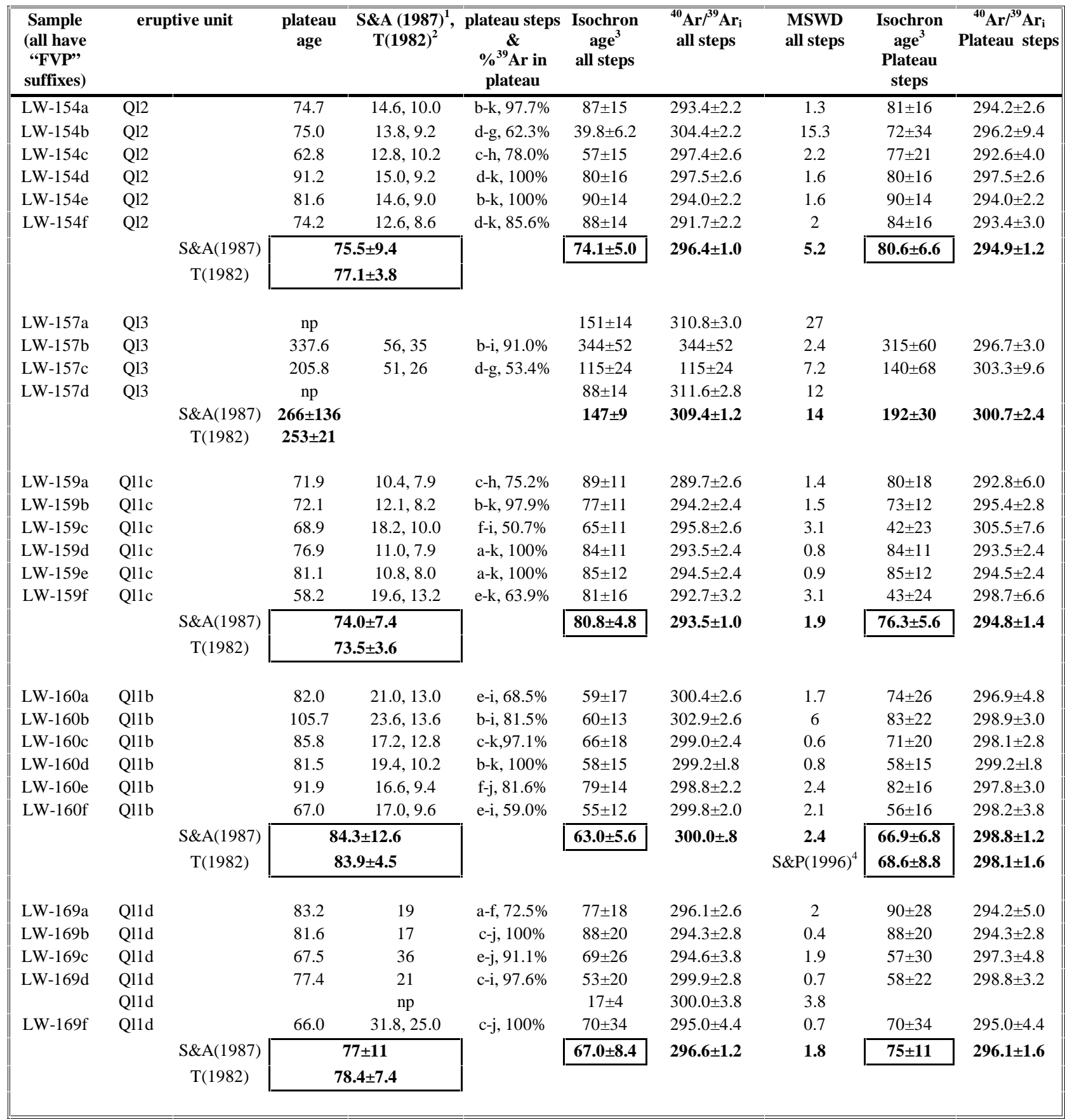

1 S\&A(1987) - Error calculation using the method of Samson and Alexander (1987)

$2 \mathrm{~T}$ (1982) - Error calculation using the method of Taylor (1982)

3 Isochron intercepts determined using the regression method of York(1969)

4 S\&P(1996) - Isochron age given using only the plateau steps from the LW-160 replicates (LW-160a,c,e,f) which meet the criteria of Singer and Pringle (1996)

Bold type indicates either weighted mean plateau ages of combined replicate runs or isochron ages determined by regression of all steps of all sample runs or regression of just the plateau steps of all replicate runs 5 -The decimal for the plateau age and error for individual runs is not significant, but is provided to prevent rounding errors for those wishing to reproduce the weighted mean calculations

All ages are in ka, and all errors are $2 \sigma$ 
Table 2.D. Summary of xenolith sanidine plateau ages from NMBM

\begin{tabular}{|c|c|c|c|c|c|c|}
\hline $\begin{array}{l}\text { Sample } \\
\text { (all have } \\
\text { "FVP" } \\
\text { suffixes) } \\
\end{array}$ & Location & $\begin{array}{c}\text { HF acid } \\
\text { Treatment }\end{array}$ & $\begin{array}{l}\text { Plateau steps \& } \\
\%{ }^{39} \mathrm{Ar} \text { in plateau }\end{array}$ & $\begin{array}{c}\text { Plateau age } \\
\text { (ka) }\end{array}$ & ${ }^{40} \mathrm{Ar} /{ }^{36} \mathrm{Ar} \mathbf{r}_{\mathrm{i}}$ & MSWD \\
\hline LW140a1 & Lathrop Wells, Qs2fs & yes & G-K, $37.8 \%$ & $78.8 \pm 3.6$ & $294.5 \pm 6.6$ & 4.1 \\
\hline LW140a2 & Lathrop Wells, Qs2fs & no & A-J, $46.1 \%$ & $75.4 \pm 8.4$ & $288 \pm 12$ & 0.5 \\
\hline LW143a1 & Lathrop Wells, Q12 & yes & F-J, $35.5 \%$ & $83.7 \pm 5.9$ & $312 \pm 14$ & 3.2 \\
\hline LW143a2 & Lathrop Wells, Q12 & no & $\mathrm{H}-\mathrm{N}, 30.9 \%$ & $101.1 \pm 7.2$ & $303 \pm 11$ & 1.7 \\
\hline LW143a3 & Lathrop Wells, Q12 & yes & A-I, $24.3 \%$ & $79 \pm 12$ & $302.5 \pm 6.0$ & 1.8 \\
\hline LW143a4 & Lathrop Wells, Q12 & yes & A-K, $38.2 \%$ & $309 \pm 11$ & $307 \pm 15$ & 1.7 \\
\hline LW143o1 & Lathrop Wells, Q12 & yes & A-J, $62.5 \%$ & $72 \pm 10$ & $298.3 \pm 2.6$ & 1.7 \\
\hline LW143o2 & Lathrop Wells, Q12 & no & A-N, $53.4 \%$ & $69 \pm 17$ & $297.0 \pm 1.6$ & 0.8 \\
\hline LW143p & Lathrop Wells, Q12 & yes & A-H, $43.8 \%$ & $105.7 \pm 6.5$ & $294.8 \pm 2.6$ & 1.4 \\
\hline LW143u & Lathrop Wells, Q12 & no & $\mathrm{H}-\mathrm{N}, 32.4 \%$ & $89.2 \pm 6.5$ & $295.7 \pm 2.6$ & 0.6 \\
\hline LW145a1 & Little Cone, SW & yes & A-G, $15.0 \%$ & $902 \pm 34$ & $297.0 \pm 8.0$ & 1.9 \\
\hline LW145a2 & Little Cone, SW & no & A-F, $20.4 \%$ & $905 \pm 92$ & $292.5 \pm 3.6$ & 1.6 \\
\hline
\end{tabular}

${ }^{1}$ Plateau ages and errors calculated with Samson and Alexander (1987) method All errors are $2 \sigma$

4. U-Th Disequilibrium Age Determinations. Mass spectrometric techniques were used to obtain ${ }^{238} \mathrm{U}^{230} \mathrm{Th}$ disequilibrium isochron ages for lavas from chronostratigraphic units I and III. Under appropriate conditions, this method can provide the crystallization age of the lava. A fundamental assumption of application of the U-Th disequilibrium method is a short residence time for the crystallized mineral assemblages both in storage and in ascent relative to the eruption age of the rocks. The small grain size and the absence of phenocrysts (only microphenocrysts) suggest this assumption has been met. Application of the U-Th disequilibrium method also requires measurable fractionation between the phases that can be separated from the rock. We have been unable, despite considerable laboratory effort, to obtain phases with sufficient U-Th separation to produce high precision isochrons. The observed small degree of U-Th fractionation in measured phases appears to be a characteristic of the minerals themselves, not a reflection of poor physical separation of phases.

Two attempts were made to obtain an isochron age for the Q13 lava. The first measurement, made using solid source mass spectrometry, was $140 \pm 40(1 \sigma)$ ka (Crowe et al., 1992). Additional attempts were made to obtain more refined separation of mineral phases using the same sample of the Q13 lava. A second mass spectrometric measurement gave an isochron age of $125+45-30(1 \sigma)$ ka (Figure 2.26). A larger spread in U/Th ratios was obtained for the Ql1d lava (Figure 2.27). The isochron age of this sample is $135+20-15(1 \sigma) \mathrm{ka}$. The microphenocrystic olivine and plagioclase separates for the Q11d isochron plot off the isochron in the direction of uranium enrichment (Figure 2.27). Interactions between uranium-rich fluids and magma are commonly discussed in the literature and may provide an explanation for the points of Figure 2.27 that plot off the isochron. However, examples similar to the plot of the Q11d data have not been reported previously in the literature. The fine-grained phases of the sample appear to have been unaffected by the uranium enrichment and therefore may postdate the interaction with uranium-rich fluids. Electron 
microprobe data for the microphenocrysts and fine-grained phases of the sample may provide more information about the relationship among the analyzed phases used for the isochron of Figure 2.27.

Two lines of evidence support the reliability of the U-Th disequilibrium isochron ages: (1) the ages are internally consistent and reproducible for both replicate and separate samples of lava units, and (2) the ages are generally consistent with the results of the K-Ar ages of the lava units (Turrin et al., 1991b;, 1992). The weaknesses or inconsistencies of the isochron ages are twofold: (1) there is limited U/Th fractionation of analyzed phases in both sample sets and some evidence of complexity in the distribution of uranium in the analyzed phases of the Q11d sample; and (2) field, stratigraphic, geomorphic, and chemical data suggest that the two lava units are from distinct volcanic events of probably different ages. This is perhaps best illustrated by the field relations of the lavas of chronostratigraphic units I and III. A Q11c lava crops out about $0.4 \mathrm{~km}$ directly east of the analyzed Q13 lava. The flow bottom is $10 \mathrm{~m}$ below the modern surface, and the flow top is covered by several meters of colluvial and eolian debris. The top of the Q13 lava is 3 to $4 \mathrm{~m}$ above the modern surface. We conclude that there should be a measurable difference, using the U-Th disequilibrium method, in the ages of the analyzed lavas. Two explanations are possible for the similarity in measured ages. First, differences in the ages of the two lavas may be less than the analytical precision of the U-Th isochron ages ( 25 to $40 \mathrm{ka}$ ). Second, the U-Th isochron ages may be affected by other processes and may not record the eruption age of the volcanic events.

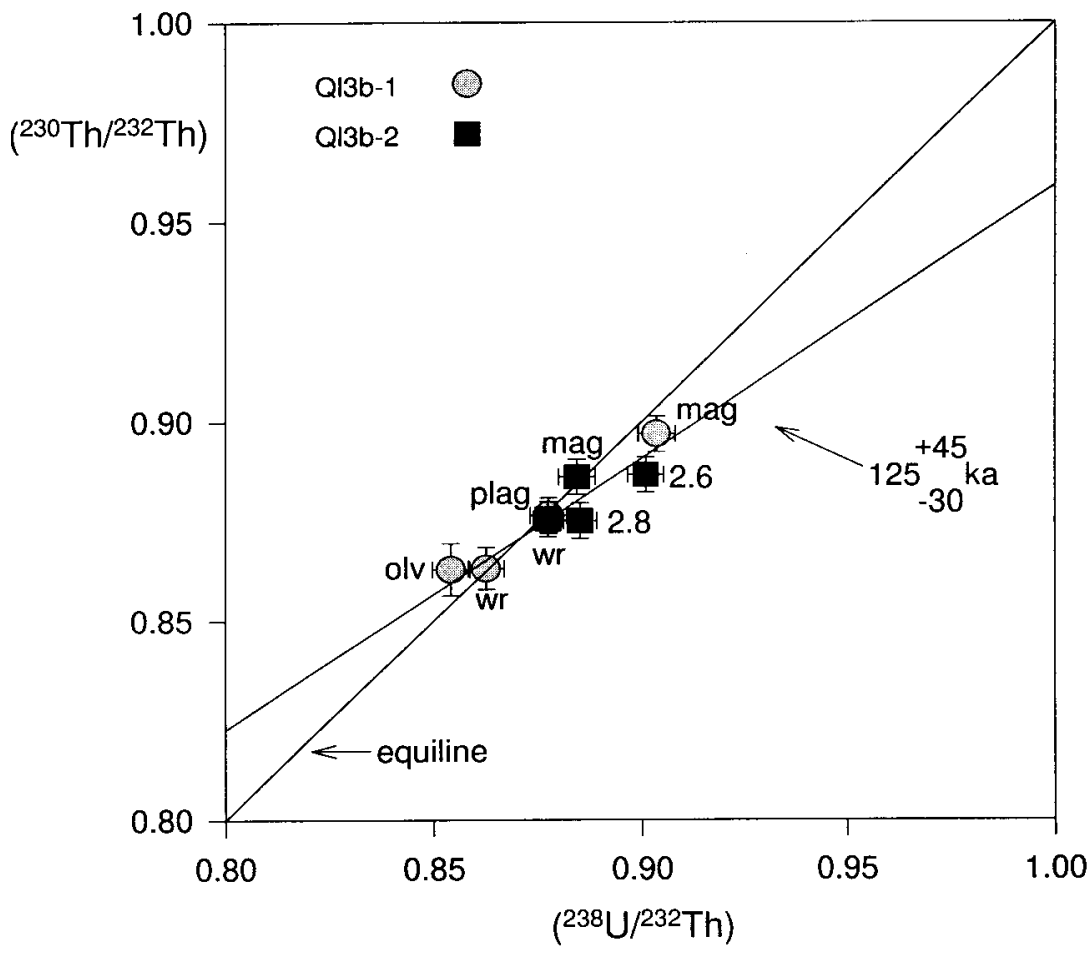

Figure 2.26. U-Th isochron plot for the Q13 lava, sample LW-89-3-21-2BMC. 


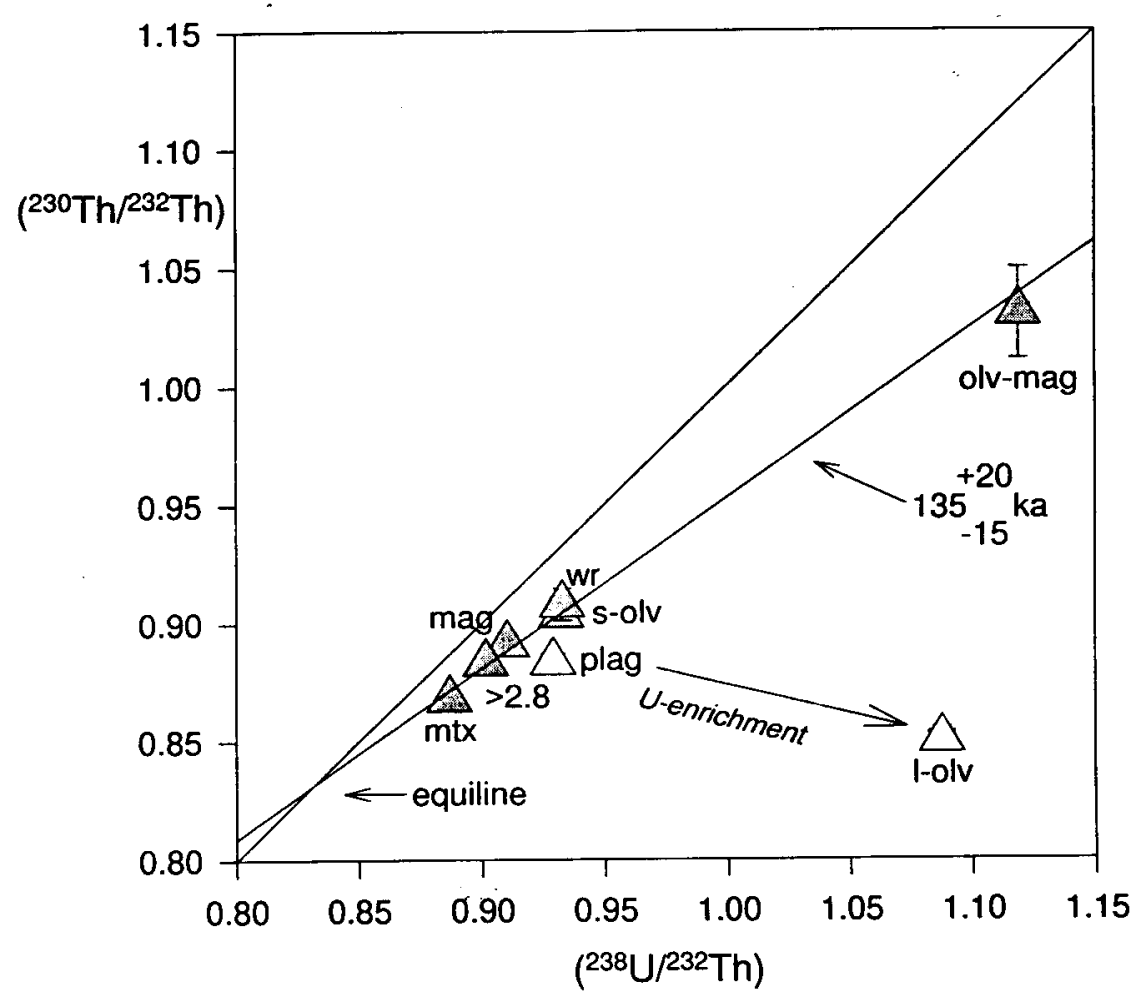

Figure 2.27. U-Th isochron for the Q11d lava, sample LW-2-21-91-1BMC.

FY96 \& FY97 revisions

Two new U-Th disequilibrium isochron ages were completed in Late FY95: 1) a bomb sample from the main cinder cone (Qs3), and 2) a re-measurement of the Q13 lava flow, using more efficiently separated mineral phases that included groundmass clinopyroxene (Figure 2.C). Analytical data for these measurements and a previous measurement of Q11d are presented in Appendix 2.3.

The U-Th age obtained from Qs3 of $324 \mathrm{ka}$ is geologically unreasonable and is strongly controlled by the U-Th isotopic composition of olivine and magnetite contained within olivine. A possible explanation of the apparently old age is that some proportion of the olivine phenocrysts are older xenocrysts. Calculation of an isochron age using only groundmass phases would yield a much younger age that may be closer to the crystallization age of Qs3 but would have a large error. The U-Th age for Q11d of 135 ka reported earlier in Crowe et al. (1995) is older than the new ${ }^{40} \mathrm{Ar} /{ }^{39} \mathrm{Ar}$ age of $\sim 75 \mathrm{ka}$ (Table 2.D). Possibly, like the Qs3 isochron, the older age is due to a component of xenocrystic olivine.

The U-Th age for Q13 of $\sim 50 \pm 15 \mathrm{ka}$ is younger than the $\sim 75 \mathrm{ka}$ age of the other lava flows based on ${ }^{40} \mathrm{Ar} /{ }^{39} \mathrm{Ar}$ data. The U-Th age is strongly controlled by the isotopic composition of groundmass clinopyroxene, a mineral phase that should reliably record the crystallization age of the lava. Based on U-Th data, therefore, an argument can be made that the Q13 flow is measurably younger than the other lava flows by 10-20 ka. 
The only other age constraint on the Q13 flow is ${ }^{3} \mathrm{He}$ cosmogenic exposure ages of $59 \pm 15,72 \pm 12$, and $92 \pm 17 \mathrm{ka}$ (Table 2.4). We interpret the oldest (and most recently obtained) of the ${ }^{3} \mathrm{He}$ ages as most accurate, because it was sampled after experience was gained in identifying lava surfaces most likely to be original lava surfaces. We note that the $\sim 50 \mathrm{ka}$ isochron for QI3 is the only U-Th isochron from Lathrop Wells not dependent on the composition of olivine phenocrysts or magnetite inclusions within olivine. It is therefore probably the most reliable U-Th isochron from Lathrop Wells.
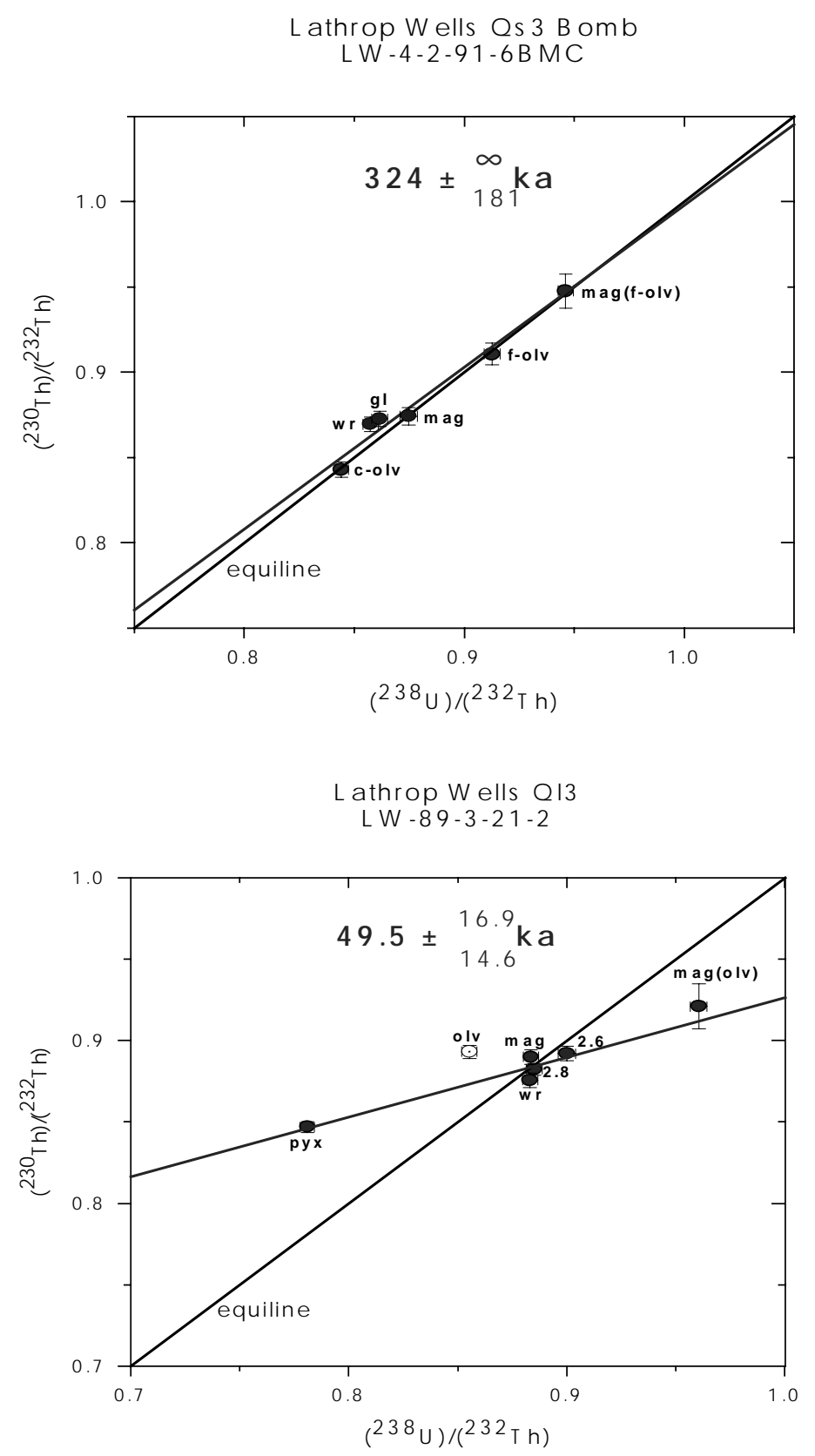

Figure 2.C. U-Th disequilibrium isochron plots for Qs3 (top) and QI3 (bottom). 
5. Cosmogenic Helium Surface Exposure Ages. We have estimated the ages of chronostratigraphic units at the Lathrop Wells volcanic center by measuring the accumulation of cosmogenic ${ }^{3} \mathrm{He}$ in samples collected from surface outcrops of subunits (Crowe et al., 1992, Poths and Crowe, 1992). Multiple samples were collected from surface exposures on the Q11, Q12, and Q13 lavas. Collections of volcanic bombs were made from the summit and the flanks of the main scoria cone (Qs3), and a scoria mound of the and Qs1 subunit. The results of these measurements are reported in Table 2.4.

Lava samples were collected from primary lava flow surfaces with unrestricted exposure to the cosmic ray influx. Several tens of square meters of outcrop were inspected at each site in an attempt to identify unmodified surfaces. A variety of criteria were employed. Generally, we attempted to avoid areas of active sand accumulation. Samples were collected from $a a$ spines that projected above the height of active sand deposition/movement to avoid samples with histories of surface cover. Primary surfaces could be identified by the presence of vesicular flow tops and irregular clinker surfaces. In some cases we were able to collect specimens with preservation of fragile surface flow textures. Areas of fractured rock were avoided where samples could spall, rotate, or change surface geometry. The degrees of rock varnish coatings were examined on the flow surfaces. Freshly exposed surfaces or surfaces with complex exposure history from processes of rock fracturing, spallation, or mechanical weathering could be identified by the contrasts in surface coatings of rock varnish. Generally, replicate samples yielded consistent ages for samples collected in small areas. Additionally, samples collected from related but spatially separate flows gave consistent results (Q11a and Q11b flows). The consistency in the ${ }^{3} \mathrm{He}$ ages suggests that careful collection of surface samples from lava flows can give reproducible results and the exposure history of lava samples to cosmic ray flux at these sites is not complicated. Marked differences in sample ages were noted for only one lava site and the main cone.

Samples collected from scoria cones, not unexpectedly, show more age variability than the lava samples, directly reflecting the erosional instability of the scoria surfaces. The most variable cosmogenic ${ }^{3} \mathrm{He}$ age measurements were obtained for the suite of samples collected from the main cone, the most geomorphically unstable feature in the center. The same effect was noted by Zreda et al. (1993) for ${ }^{36} \mathrm{Cl}$ ages of flow and scoria surfaces although they analyzed only a small number of replicate samples. Generally, ${ }^{3} \mathrm{He}$ ages collected from scoria deposits should be interpreted as minimum ages, and the best approximation of the emplacement age should be provided by the oldest helium exposure ages.

We collected one set of samples to test the assumptions of the cosmogenic ${ }^{3} \mathrm{He}$ surface exposure method for obtaining age determinations and to test independently the assumption of no unidentified inherited ${ }^{3} \mathrm{He}$ component. A sample was collected in the interior of the buried flow (Q11c) exposed in trench LW-1. The flow was shielded from the surface by at least $5 \mathrm{~m}$ of debris. If all of the methods for obtaining surface exposure ages are correct and the sample was always shielded form cosmic rays, it should give a zero age. The measured age of the sample is $6 \pm 5(2 \sigma)$ ka for a lava from chronostratigraphic unit I that should be $\sim 100 \mathrm{ka}$ and provides verification that the method assumptions for the cosmogenic ${ }^{3} \mathrm{He}$ method are reasonable. The non-zero age of the sample may result from penetration of the muon component of the cosmic ray flux to considerable depth. 
Table 2.4. Summary of cosmogenic ${ }^{3} \mathrm{He}$ data and ages from Lathrop Wells

\begin{tabular}{|c|c|c|c|c|c|c|c|c|}
\hline Sample & Unit & $\begin{array}{c}\text { Sample } \\
\text { type }\end{array}$ & $\begin{array}{c}\text { cosmogenic } \\
{ }^{3} \mathrm{He} \\
\left(\times 10^{6} \text { atoms }\right)^{\mathrm{a}}\end{array}$ & $\begin{array}{c}2 \sigma \\
\left(\times 10^{6}\right. \\
\text { atoms })\end{array}$ & $\begin{array}{c}\text { percent } \\
\text { cosmo- } \\
\text { genic }{ }^{3} \mathrm{He}\end{array}$ & $\begin{array}{l}\text { Production rate } \\
(\text { atoms/gram/yr) }\end{array}$ & $\begin{array}{l}{ }^{3} \mathrm{He} \\
\text { Age } \\
(\mathbf{k a})^{\mathrm{c}}\end{array}$ & $\begin{array}{c}2 \sigma \\
\text { (ka) }\end{array}$ \\
\hline LW86FVP mostmag/1 ${ }^{\mathrm{d}}$ & Qs3 & bomb & 11.73 & 3.56 & 94 & 230 & 51 & 15 \\
\hline LW86FVP mostmag/2 & Qs3 & bomb & 10.29 & 3.33 & 89 & 230 & 45 & 14 \\
\hline LW86FVP medmag & Qs3 & bomb & 14.83 & 3.37 & 92 & 230 & 64 & 15 \\
\hline LW86FVP leastmag & Qs3 & bomb & 14.29 & 2.88 & 96 & 230 & 62 & 13 \\
\hline LW87FVP & Qs3 & bomb & 8.79 & 2.42 & 91 & 230 & 38 & 11 \\
\hline LW88FVP/1 & Qs3 & bomb & 7.70 & 2.75 & 86 & 230 & 33 & 12 \\
\hline LW88FVP/2 & Qs3 & bomb & 6.90 & 2.10 & 90 & 230 & 30 & 9 \\
\hline LW4-2-91-6 BMC & Qs3 & bomb & 10.70 & 1.61 & 90 & 227 & 47 & 7 \\
\hline LW4-2-91-8BMC/1 & Qs3 & bomb & 7.81 & 2.43 & 81 & 229 & 34 & 11 \\
\hline LW4-2-91-8BMC/2 & Qs3 & bomb & 8.05 & 1.97 & 89 & 229 & 35 & 9 \\
\hline QCS1-2BMC & Qs3 & scoria & 9.75 & 2.06 & 92 & 228 & 43 & 9 \\
\hline QCS1-1BMC & Qs3 & scoria & 8.67 & 2.28 & 90 & 228 & 38 & 10 \\
\hline LW83FVP/1 & Q13 & flow & 14.97 & 2.59 & 94 & 209 & 72 & 12 \\
\hline LW83FVP/2 & Q13 & flow & 12.33 & 3.08 & 89 & 209 & 59 & 15 \\
\hline QH4-2FVP & Q13 & flow & 19.16 & 3.63 & 95 & 209 & 92 & 17 \\
\hline LW4-2-91-1BMC & Q12 & flow & 17.77 & 3.68 & 89 & 208 & 85 & 18 \\
\hline LW4-2-91-3BMC/1 & $\mathrm{Q} 12$ & flow & 20.54 & 4.27 & 97 & 208 & 99 & 21 \\
\hline LW4-2-91-3BMC/2 & Q12 & flow & 18.85 & 2.71 & 96 & 208 & 90 & 13 \\
\hline Q3H-1FVP & Q12 & flow & 18.61 & 2.21 & 97 & 208 & 89 & 11 \\
\hline $\mathrm{Q} 4 \mathrm{H}-1 \mathrm{FVP}$ & Q12 & flow & 22.56 & 3.95 & 97 & 210 & 107 & 19 \\
\hline LW89FVP/1 & Q11a & flow & 18.23 & 2.71 & 91 & 203 & 90 & 13 \\
\hline LW89FVP/2 & Q11a & flow & 16.90 & 3.68 & 89 & 203 & 83 & 18 \\
\hline Q5H-1BMC/1 & Q11a & flow & 16.76 & 2.67 & 92 & 203 & 83 & 13 \\
\hline Q5H-1BMC/2 & Q11a & flow & 18.39 & 2.35 & 93 & 203 & 91 & 12 \\
\hline Q5H-2BMC & Q11a & flow & 19.76 & 3.02 & 91 & 203 & 97 & 15 \\
\hline Q5H-3BMC & Q11a & flow & 17.80 & 2.20 & 89 & 203 & 88 & 11 \\
\hline Q5H-4BMC & Q11a & flow & 17.63 & 3.11 & 94 & 203 & 87 & 15 \\
\hline Q5H-5BMC & Q11a & flow & 18.52 & 2.35 & 92 & 203 & 91 & 12 \\
\hline Q5BH-1FVP & Q11b & flow & 19.95 & 3.51 & 95 & 205 & 98 & 17 \\
\hline Q7H2-FVP & Q11c & flow & 18.99 & 3.72 & 93 & 211 & 90 & 18 \\
\hline Q6H-2BMC & Q11d & flow & 16.59 & 2.86 & 96 & 209 & 80 & 14 \\
\hline Q1H-1BMC & Qs1 & bomb & 13.42 & 2.69 & 85 & 208 & 64 & 13 \\
\hline
\end{tabular}

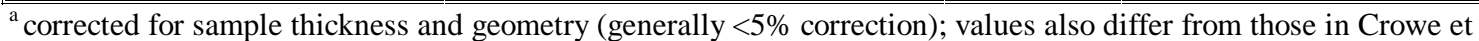
al. (1995) due to a $5 \%$ correction for ${ }^{3} \mathrm{He}$ mass bias during measurement.

${ }^{\mathrm{b}}$ production rates based on data from Cerling and Craig (1994); these production rates result in ages several percent older than any previously reported from the Los Alamos studies.

${ }^{\mathrm{c}}$ boxed values are considered lower age limits due to uncertainties regarding sample alteration (Qs3 and Qs1 samples) and preservation of original volcanic surfaces (all samples).

$\mathrm{d}$ "/1" and "/2" indicate replicate analyses; "mostmag", "medmag", and "leastmag" refer to most, medium, and least magnetic olivine separates. 
There are two concerns with age determinations obtained by the cosmogenic ${ }^{3} \mathrm{He}$ method. The first is the possible varied surface exposure history of the dated material. Minimum ages will be obtained if there has been erosional removal of deposits originally covering the sampled surface. For example, field studies have shown that the deposits of chronostratigraphic unit I were covered by as much as $2.5 \mathrm{~m}$ of scoria-fall deposits. Resulting cosmogenic ${ }^{3} \mathrm{He}$ ages of these surfaces must be minimum ages. We attempt to minimize this effect by measuring samples from multiply correlated surfaces, and emphasize the oldest ages obtained from a suite of age determinations. If the ${ }^{3} \mathrm{He}$ ages are strongly biased toward younger ages, we should obtain a spread of ages for samples collected from multiple sample sites. The surfaces can be no younger than the oldest age determination. Second, the calibration of the ${ }^{3} \mathrm{He}$ surface production rates are still subject to debate and vary significantly with altitude and latitude. Most of the cited helium ages in the western United States are calibrated to one locality (Cerling, 1990). The calibration of the ${ }^{3} \mathrm{He}$ production rate is undergoing refinements. Several workers have recently published calibrations in the 10-20 ka age range that are in good agreement (Cerling and Craig, 1994; Laughlin et al., 1994). However, some caution is reasonable given that calibrations of production rates for rock units with ages $>20 \mathrm{ka}$ are lacking in the geologic literature. We cannot rule out the possibility that calibrations may be off as much as $30 \%$ (Poths and Crowe, 1992) for rocks with ages of $100 \mathrm{ka}$.

The oldest age obtained by the cosmogenic ${ }^{3} \mathrm{He}$ method provides a preferred estimate of the ${ }^{3} \mathrm{He}$ age of the chronostratigraphic units of the Lathrop Wells center. Mean values of replicate measurements are not valid estimates of the age of units. However, comparison of mean values and standard deviations can aid in interpreting the data. The mean value of replicate measurements is $87 \pm 9 \mathrm{ka}$ (chronostratigraphic unit I), $94 \pm 9 \mathrm{ka}$ (chronostratigraphic unit II), and $50 \pm 17 \mathrm{ka}$ (chronostratigraphic unit III). The most variable measurements, as expected are for the scoria units of chronostratigraphic unit III. One obvious observation from Table 2.4 is an older mean age of chronostratigraphic unit II compared to chronostratigraphic unit I. However, this difference can be explained readily from the field relations of the volcanic units. First, large-volume scoria-fall deposits were erupted during the evolution of chronostratigraphic unit II. Scoria-fall deposits more than $2 \mathrm{~m}$ thick covered and shielded outcrops of chronostratigraphic unit I near the main scoria cone. Second, the Lathrop flow overlies the pyroclastic-surge deposits of chronostratigraphic unit II. It therefore was emplaced after eruption of the largest volume of the scoria-fall deposits. Third, the Lathrop flow, where the majority of samples were collected for cosmogenic ${ }^{3} \mathrm{He}$ age determinations, is located east of the northwest-trending elliptical dispersal axis of the scoria-fall deposits. These field relations strongly suggest that the similarity in cosmogenic ${ }^{3} \mathrm{He}$ ages of chronostratigraphic units I and II were produced by shielding of the surfaces of chronostratigraphic unit I by scoria-fall deposits of chronostratigraphic unit II. This is further demonstrated by Figure 2.28, a plot of the south part of the Lathrop Wells center showing the minimum thickness of the Qs2fs deposits and the cosmogenic ${ }^{3} \mathrm{He}$ ages of lava surfaces from chronostratigraphic unit I. The measured thickness of the scoria-fall deposits is a minimum thickness, as noted above, because the upper surface of the unit is an erosional surface. Thickness measurements show that the lava flows of chronostratigraphic unit I must have been covered by more than $2 \mathrm{~m}$ of scoria-fall deposits. Moreover, the thickness of the fall deposits near the cone flanks probably exceeded $3 \mathrm{~m}$. The measured cosmogenic ${ }^{3} \mathrm{He}$ ages for deposits of chronostratigraphic unit I decrease systematically with decreased distance from the area of the main cone, the inferred source of the voluminous scoria-fall deposits (Figure 2.28). This provides confirmation that the measured cosmogenic ages $\left({ }^{3} \mathrm{He}\right.$ and $\left.{ }^{36} \mathrm{Cl}\right)$ (Zreda et al., 1993) of chronostratigraphic unit I are minimum ages. 


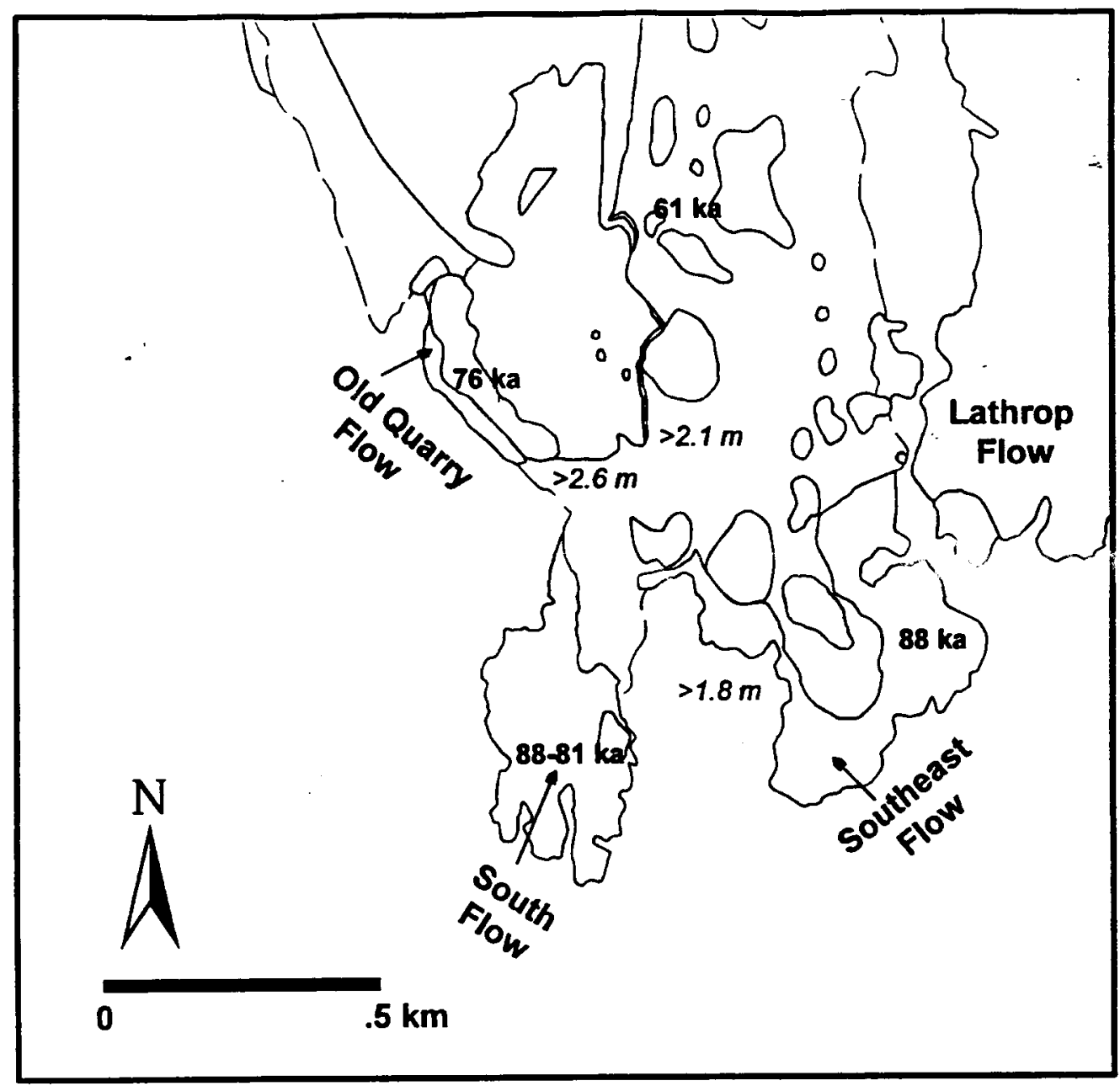

Figure 2.28. Cosmogenic ${ }^{3} \mathrm{He}$ ages of chronostratigraphic unit I plotted with minimum estimated thickness of scoria-fall deposits of chronostratigraphic unit II. The thicknesses of scoria-fall deposits were measured in trenches cut with a $4 \times 4$, truck-mounted backhoe. The sites listed are localities where the base of the fall deposits could be located, and most of the section of fall-deposits are exposed. The top of the fall-deposits is moderately to deeply eroded. All thickness is therefore a minimum. Reconstruction of the preserved thickness shows that all sites where cosmogenic ${ }^{3} \mathrm{He}$ ages were measured were covered by at least $2 \mathrm{~m}$ of scoria-fall deposits. The effect of this cover is shown by the distribution of the surface exposure ages. They decrease in age with decreasing distance from the main cone.

Corrections of the cosmogenic ${ }^{3} \mathrm{He}$ ages could possibly be estimated by calculating the cosmogenic ray shielding produced by the variable thicknesses of scoria for the individual sample localities. While this is possible in principle, the assumptions required for the estimations do not give reasonable constraints on the ages of deposits of chronostratigraphic unit I. Age corrections can be estimated according to the formula:

$$
E a=S e+(P c \text { depth/Pc surface } x T b)
$$

where $E a$ is the measured cosmogenic ${ }^{3} \mathrm{He}$ age, $P c$ depth is the ${ }^{3} \mathrm{He}$ cosmogenic production rate at depth $\mathrm{x}$, where $\mathrm{x}$ is given in $\mathrm{cm}$ below the surface, Pc surface is the ${ }^{3} \mathrm{He}$ cosmogenic 
production rate at the surface, and $T b$ is the time buried at depth $x$. The ratio of $P c$ depth/Pc surface can be readily calculated assuming a bulk density of scoria deposits of $1.6 \mathrm{~g} / \mathrm{cm}^{3}$ and an attenuation length of $179 \mathrm{~g} / \mathrm{cm}^{2}$. The $S e$ can be only approximated since it is a sum of two components: (1) the interval following the eruption of chronostratigraphic unit I and preceding eruption of chronostratigraphic unit II, and (2) the interval after erosional exposure of the dated lava surface. The best estimate of the first component is about $45 \mathrm{ka}$, but this presumes an estimate of the age of chronostratigraphic unit I, the information we are attempting to obtain by the corrected calculation. The $T b$ cannot be estimated because it is dependent on rates of erosion that must be climate-dependent and, therefore, varied considerably during the last $100 \mathrm{ka}$. Assuming a 2 $m$ initial depth of burial and substituting this minimum depth in the equation shows that dated surfaces cannot be buried very long and still give the measured ages of Figure 2.28. The scoria must have been stripped rapidly in comparison to the age of the surface. One perplexing observation, however, is the uniformity of measured ages for replicate samples collected from the south lava flow surface. These samples were collected from $a a$ flow spines that projected variable distances ( 0.1 to $0.5 \mathrm{~m}$ ) above the general flow surface. The observed uniformity of measured ages for the samples requires that the scoria was stripped both uniformly and rapidly. All assumptions concerning the measured cosmogenic ${ }^{3} \mathrm{He}$ ages of chronostratigraphic unit I, however require them to be minimum ages.

A secondary finding from studies of the noble gas components of the lavas of the Lathrop Wells center is the presence of excess ${ }^{40} \mathrm{Ar}$ released by crushing olivine (Poths and Crowe, 1992). Crushing of olivine grains released an argon component with ${ }^{40} \mathrm{Ar} /{ }^{36} \mathrm{Ar}$ ratios of $371 \pm 8$ and $328 \pm$ 7 for the olivine in the Q13 and the Q12a lavas. These ratios are substantially above the atmospheric ratio of 295 and indicate the presence of ${ }^{40} \mathrm{Ar}$ in excess of that produced by decay of ${ }^{40} \mathrm{~K}$. Age determinations based on the ${ }^{40} \mathrm{Ar} /{ }^{39} \mathrm{Ar}$ system require careful evaluation for the potential effects of excess argon.

6. Thermoluminescence Age Determinations. Eight analyses of four different samples have been obtained using the TL method. These results are judged to be analytically reliable and reproducible but must be viewed as preliminary. The TL method has not been used previously in attempts to date soil units for a volcanic center. Analytical methods used for this method are described in Crowe et al. (1992).

Three samples were collected from a buried soil separating the upper tephra deposits of the main cone in the south quarry wall and tephra of chronostratigraphic unit IV. These samples yielded TL ages of $8.0 \pm 1.0,8.0 \pm 2.0$, and $8.5 \pm 1.0 \mathrm{ka}$. Soil units within and above the scoriafall deposits of chronostratigraphic unit IV (Wells et al., 1990) yielded ages of $4.0 \pm 0.5,4.0 \pm 0.5$, and $4.5 \pm 0.5 \mathrm{ka}$. Important features of these TL ages are that the replicate analyses are reproducible and that the data are in correct stratigraphic sequence. They provide the only numerical age constraints on the youngest eruptions of the center. The TL ages of soil units overlying the tephra deposits constrain the age of pedogenic processes that post-date volcanic activity.

A second set of TL samples was collected from reworked, volcaniclastic deposits. These deposits were exposed several tens of centimeters from the basal contact of an overlying $a a$ flow lobe of Q12. These samples yielded ages of $28.0 \pm 3.0$ and $31.0 \pm 3.0 \mathrm{ka}$. Thus, reproducible TL ages of the Q12 lava unit are significantly younger than the results of other chronology methods. We currently have no reasonable explanation for the age discrepancy. 
FY96 \& FY97 revisions

Based on arguments presented below, it is our conclusion that all TL data obtained and reported to date (pre-1997, including original text of this chapter) from the Los Alamos volcanism studies are superseded by new TL data obtained in collaboration with the USGS. The only exception are the TL dates from the quarry section containing the Qs4 deposits. These analysis were not reproduced before the outcrops were destroy by quarrying operations, but the existing TL dates are consistent with analyses of soil profiles present between the Qs3 and Qs4 deposits and indicate that a period of 1015 ka elapsed between deposition of the two units, with the Qs3 deposits being emplaced at about $75 \mathrm{ka}$.

In FY94 we began a collaborative study with the USGS to date eruptive unit Q2 at Lathrop Wells using the TL method (Paces et al., 1995). Silt from three sites was collected for TL dating: 1) beneath the QI2 lava flow (site 1) that had been previously dated by TL at Ohio State to test for reproducibility, and 2) beneath the Qs2fs fall sheet at the south (site 2) and north (site 3) edges of the Lathrop Wells center. Based on stratigraphic correlation, dating silt from these three sites should yield the same age, as all three sites are stratigraphically equivalent. TL ages were calculated using both TL normalization and infra-red stimulated luminescence (IRSL) normalization (Paces et al., 1995). In every case, TL normalization gave younger ages than IRSL normalizations. TL normalization results were, however, equivalent to earlier ages obtained at Ohio State from site 1 (USGS age $=25 \pm 5 \mathrm{ka}$, Ohio State age $=\sim 30 \pm 3 \mathrm{ka}$ ). IRSL normalizations are preferred for calculating TL ages in the Yucca Mountain region because of the mineralogical complexity and presence of devitrified tuff in the samples (Paces et al., 1995). ISRL normalized total bleach TL ages obtained for the three sites at Lathrop Wells (including a duplicate determination at site 2) are $48 \pm 17(2 \sigma)$ ka (site 1), $52 \pm 23,92 \pm 17$ (site 2), and $55 \pm 14$ (site 3 ). These ages are reasonably consistent, given the relatively large errors, with the ${ }^{40} \mathrm{Ar} /{ }^{39} \mathrm{Ar}$ ages from eruptive unit Q2 of $\sim 75 \pm 10 \mathrm{ka}$. For the reasons discussed above, we conclude that the TL age of $48 \pm 17$ ka determined by the USGS for the Q12 flow site supersedes the age of $\sim 30 \mathrm{ka}$ determined earlier at Ohio State using TL normalization, and is more consistent with the ${ }^{40} \mathrm{Ar} /{ }^{39} \mathrm{Ar}$ ages.

7. Geomorphic Studies. Geomorphic features of the Lathrop Wells volcanic center were described previously by Wells et al. (1990). They equated the geomorphic and pedogenic features of the Lathrop Wells center with a 15 to $20 \mathrm{ka}$ cone in the Cima volcanic field. The close comparison of the centers suggested, by inference, that the youngest eruption of the Lathrop Wells center is no older than $20 \mathrm{ka}$. These constraints are based on the assumption that the rates of operation of erosion and soil formation are approximately similar between the Cima and Crater Flat volcanic fields. New cosmogenic ${ }^{3} \mathrm{He}$ and TL ages for the Black Tank center in the Cima volcanic field provide increased support for the geomorphic correlation (Crowe et al., 1992). These data support an age between 9 and 14 ka for the main cone sequences at the Black Tank center. Trenching has demonstrated that the base of the main scoria cone at Lathrop Wells is flanked by an eolian sand-ramp deposit which displays little evidence of mass wasting or colluviation from the cone slopes, supporting the inference that the cone slope is virtually unmodified by erosional processes (Wells et al., 1990). 
Preliminary mapping has been completed of the surficial geology of the Lathrop Wells volcanic center and immediately surrounding areas. The purpose of the mapping is to show the geologic context of the volcanic center with respect to surficial deposits and landforms that surround, underlie, and overlie the volcanic units of the center. Three major types of surficial deposits and features have been mapped: those associated with (1) volcanic landform development (constructional volcanic features) and the modification of the landforms, (2) eolian erosion and deposition, and (3) fluvial and colluvial processes. Initial observations from the geologic mapping include the following:

1. Garland development (eruption-induced mass movement deposits) is primarily limited to the northern and western flanks of the main scoria cone. Weakly developed rills occur near the cone summit on the southwestern and eastern flanks of the main cone.

\section{FY96 \& FY97 revisions}

We now believe, based on the evidence of erosional modification of the cone summit and cone slopes, that the garland development is from slope-induced mass movement and not eruption-induced mass movement

2. Large-scale eolian landforms including transverse dunes, coppice dunes, and eolian wind streaks occur primarily on the Q12a lava flow; older lava flows are mantled by scoria-fall deposits and eolian sand mantles.

3. The scoria-fall deposits of Qs2fs have been extensively modified by erosional and depositional processes. These deposits are locally interbedded with alluvial units.

4. The volcanic units at the Lathrop Wells center appear to have the following landscape/stratigraphic relations with alluvial fan and stream deposits:

a. all volcanic units are inset below and possibly are older than alluvial fan units.

b. the main scoria-fall sheet is interbedded with and underlies alluvial fan deposits.

c. younger alluvial units are inset into or overlie the youngest volcanic units.

The significance of the field and geomorphic observations can be related to the models of landscape evolution which have been developed for desert basins of the western U.S. Timetransgressive changes from Pleistocene-dominant climatic regimes to those of the Holocene yield significant changes in the vegetation and consequently the response of alluvial systems. Specifically, this transition is marked by destabilization of hill slopes with vegetation reduction, movement of sediment from hill slopes into streams, and the deposition of alluvial fan units. It is hypothesized that an alluvial unit designated as Qf1 may be late Pleistocene/early Holocene alluvial fan deposits which have been recognized so widely in this region. If so, the scoria-fall sheet and associated pyroclastic-surge deposits (Qs2fs), which are stratigraphically beneath unit Qf1, should correspond to the late Pleistocene ( $<30 \mathrm{ka}$ ) and not to the late-middle Pleistocene ( $>70 \mathrm{ka}$ but $<140$ $\mathrm{ka})$.

The systematic differences in degree of erosion of volcanic landforms between chronostratigraphic units I, II, and III suggest a time difference between the units. The most compelling argument for this time difference is provided by exposures located directly north of the main cone. Here the degraded surface formed on the Qs1c scoria deposits can be traced beneath the 
virtually unmodified cone slope of Qs3. Similarly, there is a marked contrast between the degree of erosional modification of the Qs2fs surfaces compared to the main cone slopes (Qs3). These relations appear difficult to explain without a time gap between the respective units.

Two tephra units have been recognized in outcrops located about 2-3 km north and northwest of the Lathrop Wells center. Several features of the tephra demonstrate a significant difference in age between the two deposits. There are marked differences in the amount of calcium carbonate cementation and the relations of the units to the local landscape and stratigraphy. The older, cemented scoria shows clast displacement by calcium carbonate plasma and locally is within a channel bottom that lies below an alluvial fan unit with moderately well-developed soil. The younger tephra unit is uncemented, lies stratigraphically above the cemented scoria, is concordant with the slopes of the present landscape, and is overlain by alluvial fan deposits with a weakly developed soil profile.

8. Soil Studies. Study of soils on volcanic landforms associated with the Lathrop Wells center shows that weakly developed calcic soils have formed in scoria deposits that flank the north and south side of the main cone and on the cone slope (Wells et al., 1990). The surface of the lava flows is almost completely mantled by eolian deposits or by pyroclastic deposits. These deposits have only incipient soil development in the upper several decimeters. The primary pedogenic features exhibited by the soils include weakly developed "vesicular A" horizons and weakly developed B horizons in which fine sands, silt, clay, calcium carbonate, and trace amounts of soluble salts have accumulated. The presence of substantial amounts of quartz and other pedogenic materials (calcium carbonate and sulfates or chloride salts) that are rare or absent in the basaltic tephra unequivocally demonstrates the eolian origin of most of these pedogenic materials.

The most strongly developed soils have been observed on the erosional surface cut into scoria mound deposits of Qs1c located northeast of the main cone. These soils have the thickest, most well-developed vesicular A horizons in soil observed to date, ranging from 5 to $8 \mathrm{~cm}$ thick and possessing strong, coarse, platy structure with subordinate subangular blocky to prismatic structure. The subjacent Bwk horizons are approximately 8 to $17 \mathrm{~cm}$ thick with subangular to blocky structure. These horizons do not, however, exhibit color hues or chromas substantially redder than those of the least-altered loamy sandy parent materials or the most recently accumulated materials above the vesicular A horizon. Pedogenesis in the lowest $1 \mathrm{~m}$ of the profile exposed in pits is characterized by the accumulation of moderately thick to thin, largely discontinuous coatings of carbonate, gypsum, and soluble salts. A small amount of pedogenic silica may also have accumulated. The content of these materials diminishes progressively with depth with the most incipient coatings being observed at depths of 1.3 to $1.5 \mathrm{~m}$ in the parent scoria materials. A soil observed on the steeper part of the cone slope has a similarly thick, calcareous B horizon, but lacks the well-developed vesicular A horizon.

Soil observed in the sequence of buried scoria units exposed in the quarry on the south side of the center (Wells et al., 1990) is more weakly developed. It exhibits 2 to $4 \mathrm{~cm}$ thick vesicular horizons and very incipient, calcareous cambic B horizons. The scoria parent materials have carbonates, salts, and perhaps silica accumulated primarily on the bottoms of scoria fragments.

In contrast, soil formed in sand ramps that flank the cone is very weakly developed. Pedogenesis is indicated primarily by slight increases in disseminated carbonate with depth and accumulation of very thin, discontinuous coatings of carbonates and perhaps salts on the bottoms of many of the larger coarse fragments. Scoria fragments in such deposits commonly exhibit 
thicker and nearly continuous coatings of carbonate. However, the nonsystematic spatial location of the coatings on the fragments as a function of depth shows that only a minor volume of material has been derived from higher positions on the cone slope by gravitational forces. Soil on the cone slope, as noted previously, has Bk horizons with carbonate-coated fragments, which provide a source for most of the fragments with thick carbonate coatings observed in the sand ramp deposits and distal cone-slope sediments and soils.

The medium- and fine-grained sandy deposits of eolian origin are inferred to bury previously formed vesicular horizons of soils in the scoria deposits. These deposits range from $2 \mathrm{~cm}$ to over $1.3 \mathrm{~m}$ thick in the sand ramps. They are present below the weakly developed scoria pavement and have little or no soil development. These soil/stratigraphic relations suggest an increase in eolian activity during the late Holocene, resulting in the deposition of locally thick accumulations of sand. Subsequent to deposition of the sand, geomorphic conditions were presumably sufficiently different to enable the development of cumulic soils. These soils incorporated much finer-grained desert loess and formed accretionary cambic B and vesicular A horizons.

Soils formed in scoria deposits or in aprons that flank flows at the Cima volcanic field have also been examined (Wells et al., 1985; Renault, 1989; Royek, 1991). These soils are generally similar to soil on the flow surfaces. However, the soils formed in scoria deposits associated with the youngest scoria cones in the Cima volcanic field possess relatively weak development of Avk horizons. Their B horizons are not as red or thick as those typically observed in the phase 1 soils on associated lavas. This indicates that much of the eolian material entrapped on surfaces associated with scoria is readily translocated through the highly permeable, open framework scoria to depths of more than a meter by infiltrating soil water. In the lower part of the soil profiles, the initially fragile, glass-coated irregularities and edges of scoria fragments are altered by infiltrating water, as shown by the presence of reddish-brown coatings on the tops of the fragments, the destruction of vesicle edges and spines, and the chemical alteration of glass. Pedogenic accumulation of calcium carbonate, salts, and perhaps some amorphous silica primarily on the bottoms of the fragments is a major attribute of these soils. Soil development in cone aprons resembles that observed on flows. Similarly, soil development on scoria-cone aprons of older cones resembles observed phase 2 soils, demonstrating the primary role of cumulic pedogenesis on this volcanic landform.

Crowe et al. (1992) compared the development of soils on volcanic units of the Lathrop Wells volcanic center with studied centers of the Cima volcanic field (Dohrenwend et al., 1986; Wells et al., 1990). They did not propose that pedogenic processes at the Lathrop Wells center are identical to those at the Cima volcanic field. However, they did note that there are no indications that the rates or processes of soil formation are substantially different. If eolian influx had been higher at the Lathrop Wells center, thick deposits of desert loess would have mantled stable Pleistocene and Holocene landforms and soils throughout the area. This has not been observed. Equally, eolian activity in the YMR cannot be substantially lower than the Cima volcanic field because of the presence, in the former, of active sand dunes on flows and the nearby dune field (Big Dune) in the Amargosa Valley. Abundant sources of eolian materials, including desert loess, are provided by the adjacent basins, many of which contain large playas. Accordingly, we conclude that the weakly developed soils of the Lathrop Wells center closely resemble the Holocene soils in the Silver Lake area and the Cima volcanic field. We infer that the soils must have formed over a similar time span, the soil on the volcanic units of the Lathrop Wells center having formed over a period spanning the late Pleistocene and Holocene. 
Soil development on chronostratigraphic unit III appeared initially to be inconsistent with K$\mathrm{Ar}$ and U-Th age determinations for the lava flows of greater than $100 \mathrm{ka}$ (Wells et al., 1990). Instead, the degree of soil development is more consistent with the cosmogenic ${ }^{3} \mathrm{He}$ age determinations that indicate the lava flow sequences could be $<100 \mathrm{ka}$. However, several factors may have affected the degree of soil development on the deposits of chronostratigraphic unit I. First, studies of volcanic surfaces in the Cima volcanic field show that soil development may be retarded on rubbly $a a$ flows compared with pahoehoe flows. The fragmental nature of the $a a$ flow surfaces and resulting high porosity enable repeated deep flushing of eolian materials to depths of several meters. This may prohibit development of an increasingly less permeable surface mantle in which well developed cumulic soils (and stone pavements) can form. Second, there are local indicators of greater soil development or pedogenesis on some of the lavas of chronostratigraphic unit I. Trench exposures show locally the development of laminated calcite zones in buried soil and carbonate-coated fractures and joint surfaces in greater thickness and continuity than expected given the weak development of surface soils. Third, intermittent surface cover by active dunes has occurred on many of the lava and scoria surfaces of the Lathrop Wells volcanic center. Deposition of a sand mantle has profoundly influenced soil development. Where the sand deposits are deep, the development of soils has been terminated. Where sand deposits are thinner, there has been an accelerated rate of development of cumulic horizons. Fourth, the scoria mounds of chronostratigraphic unit I are not stable landforms where parent materials conducive to soil formation are preserved. The evidence of erosional modification of the scoria mounds (exposed feeder dikes, nonprimary [volcanic] surface forms; lag accumulations of bombs) indicates that the summits and slopes of the mounds are not stable surfaces. Finally, there has been insufficient trenching of chronostratigraphic unit I to provide thorough documentation of the maximum development of soils. It is premature and outside the scope of completed soil studies to conclude that soil development is inconsistent with geochronology data suggestive of ages of $>100$ ka for some volcanic units. The major emphasis of work to date has been on the geomorphology and development of soils on the youngest units of the volcanic center (Wells et al., 1990, 1991).

The differences in the degree of soil development between chronostratigraphic units I and II and chronostratigraphic unit III are consistent with a time gap between the units. However, it is difficult and unwarranted to speculate on the extent of the time differences between the units. The unmodified geomorphic form and weak degree of horizon development in soil on the Qs3 deposits (Wells et al., 1990) are consistent with an age of <50 ka. This unit has been sufficiently well studied to conclude that the limited development of horizons in soils and unmodified geomorphic form is inconsistent with an age of the cone of $>100 \mathrm{ka}$ (compare with Turrin et al., 1991b).

9. Paleomagnetic Studies. Considerable paleomagnetic data have been obtained for the Lathrop Wells volcanic center to test inferred age differences of different eruptive events (Figure 2.29, Appendix 2.4). Turrin et al. (1991b) report that the paleomagnetic data from the volcanic rocks fall into two statistically distinguishable populations. They correlated the populations with their revised definitions of units Qs5 and Q13. Champion (1991) and Turrin et al. (1991b) interpreted the angular difference between the means of the two field magnetic populations to indicate an age difference between the two events of only about 100 years. We note however, that the geologic unit Qs5 defined by Turrin et al. (1991b) includes subunits of chronostratigraphic units I, II, and III as defined in this report. Specifically, our subunit Qs3 (one of the younger subunits) was included in the paleomagnetic data used to define a magnetization characteristic of their map unit Qs5. Additionally, not all volcanic subunits of the Lathrop Wells center were sampled in their paleomagnetic studies (Wells et al., 1992). The conclusions regarding the paleomagnetic data of Turrin et al. (1991b) are premature, at best, because of inconsistent 
stratigraphic assignment of volcanic units and the incompletely reported paleomagnetic data set. We have attempted to augment the paleomagnetic data set for the Lathrop Wells volcanic center of Champion (1991) and Turrin et al. (1991b) for two reasons. First, as noted above, not all units were sampled for paleomagnetic studies. Unsampled and unstudied units from their studies include Q11d, Qs1d, Q11c, Qs1c, and the Qs1b/Q11b lava flows. This omission includes the major lava subunits of the oldest volcanic units. Second, previously conducted paleomagnetic studies of the Lathrop Wells center were not completed under an approved Quality Assurance program.

Although the data may be of good quality analytically, they cannot be used directly for licensing in the YMP. We have sampled and analyzed new paleomagnetic sites and have attempted to qualify, by comparison, much of the previously obtained paleomagnetic data.

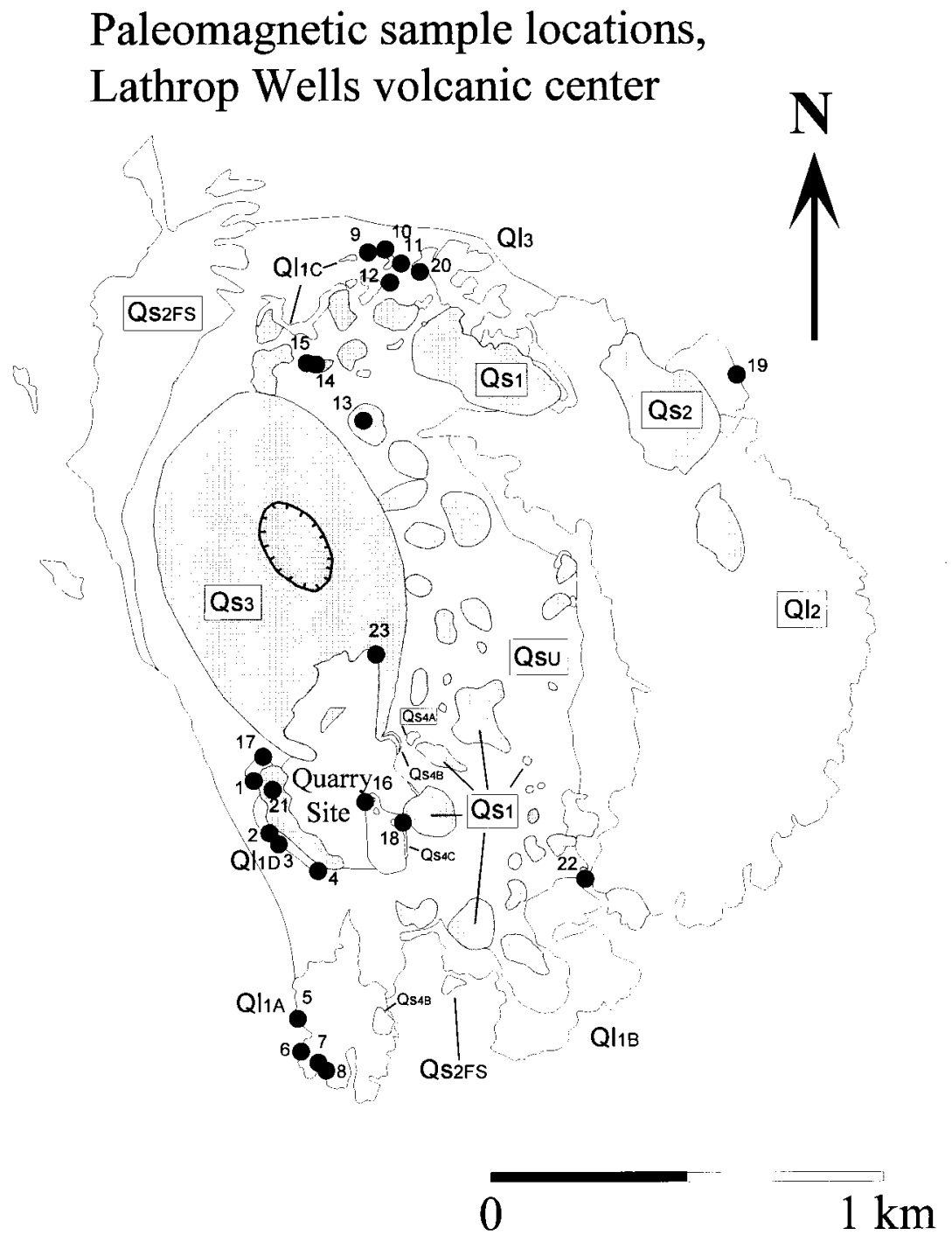

Figure 2.29. Locations of the 23 paleomagnetic sampling sites at the Lathrop Wells volcanic center (Appendix 2.4).

Ten paleomagnetic sites were sampled for paleomagnetic studies at the Lathrop Wells center in 1991. Each sampling site consisted of eight to twelve independently oriented samples, collected as cylinders using a portable drilling apparatus. Individual sample sites were collected over an area 
of several cubic meters. Four sites were located in the Q11d lavas, four in the Q11a lavas, and two in the Q11c lava on the north flank of the main cone (Figure 2.29). At least one specimen per site has been subjected to progressive alternating field demagnetization, the technique most commonly used to assess the direction and relative intensity of all components of magnetization in magnetitebearing rocks. In most cases a well-defined, univectoral decay of the magnetization to the origin of the demagnetization diagram is identified (Figure 2.30). This magnetization is interpreted to be the primary thermoremanent magnetization acquired in the initial cooling of each lava flow. The directions of primary magnetizations have been calculated after visual inspection of demagnetization diagrams three-dimensional least-squares fit. The observed between-site dispersion of the directions of the primary magnetization differs considerably (Figure 2.31).
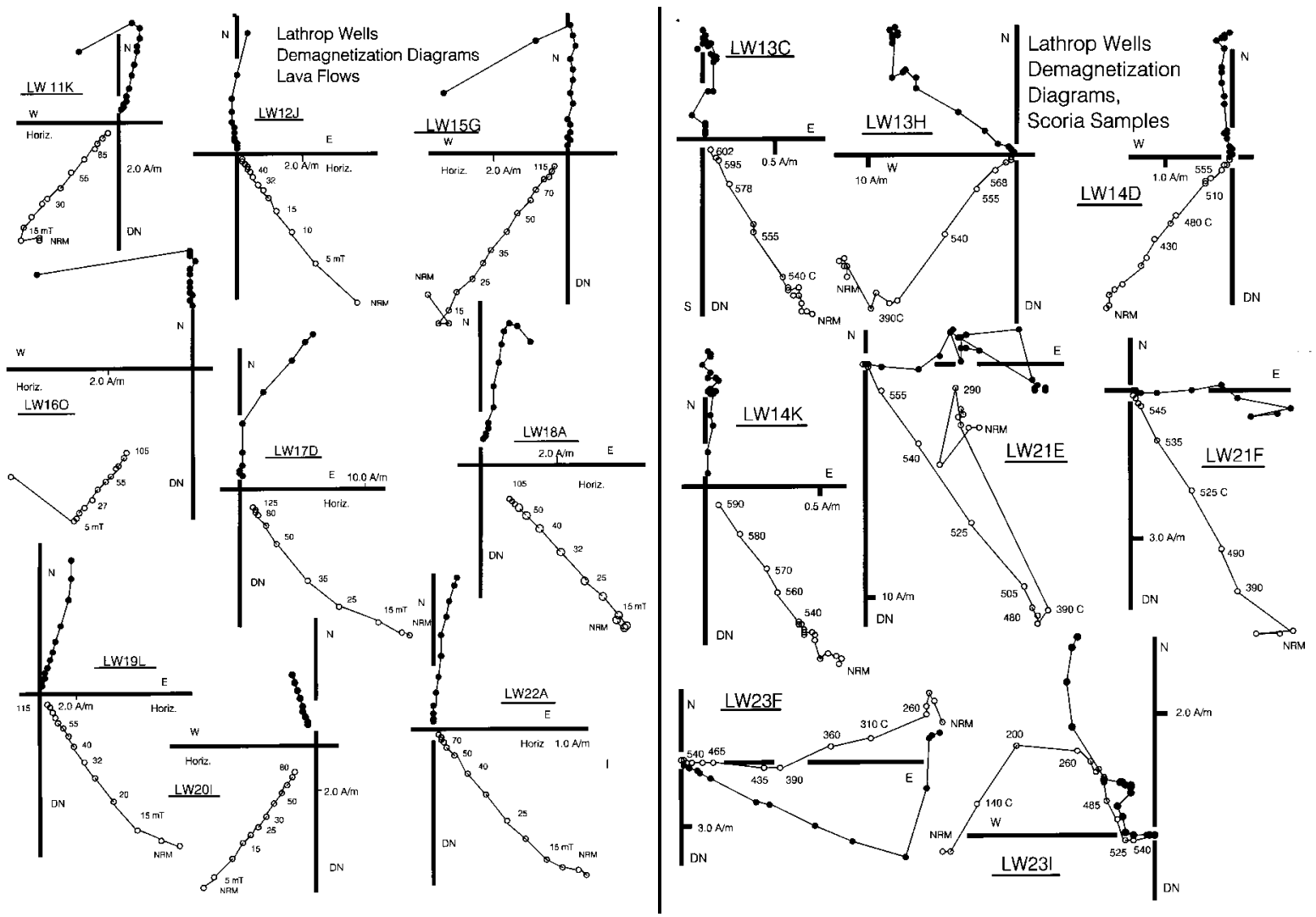

Figure 2.30. Representative modified orthogonal demagnetization diagrams showing the endpoint of the magnetization vector projected onto the horizontal (EW, NS) plane (filled circles) and the true vertical (horizontal, U/D) plane (open circles) for samples from lava flows (Figure 2.30a) and scoria mounds (Figure 2.30b) from the Lathrop Wells volcanic center. Each projection shows the complete demagnetization sequence, using either alternating magnetic field (peak fields given beside vertical projections, in MilliTesla) or thermal (temperatures beside vertical projections) demagnetization. For most of the examples shown, the direction of the magnetization vector trending toward the origin of the diagram and isolated over a broad range of peak fields or laboratory unblocking temperatures is determined with a high degree of confidence.

The differences in direction are interpreted to reflect one of two problems associated with sampling surface exposures of young basaltic lavas. The first is the difficulty in sampling intact material. Samples in one or a series of adjacent and rotated blocks may give directions of magnetization that are internally consistent yet discrepant in comparison to those from samples 
collected from the same part of the site (Figure 2.31). The second problem is lightning strikes. Here, an artificial, generally randomly dispersed magnetization is superimposed on a primary, wellgrouped magnetization. In some cases this artificial magnetization can be fully removed in alternating field demagnetization; in others it cannot be removed and results at best in a site-mean direction defined with poor precision.

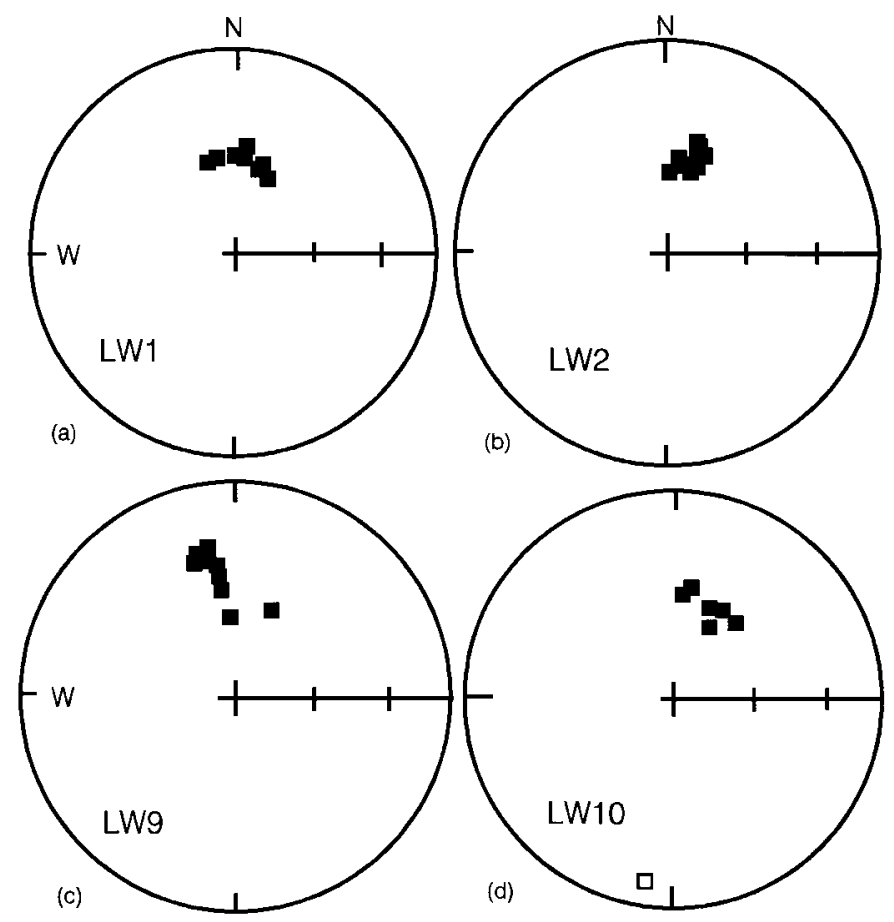

Figure 2.31. Examples of site-level dispersion of paleomagnetic data from lava flows at the Lathrop Wells volcanic center. Equal area projections of sample magnetization directions determined from progressive demagnetization for the following sites: LW1 and LW2 from the Q11d lava; LW9 and LW10 from the Q11c lava. For all projections, lower hemisphere projections are indicated in solid symbols and upper hemisphere projections in open symbols.

Several sites give well-grouped, interpretable paleomagnetic data. Two sites in Q11d give site mean directions of magnetization (Declination $=2.7$, Inclination $=53.5, \mathrm{n}=8$ samples, site LW1; Declination $=13.8$, Inclination $=53.3, \mathrm{n}=9$ samples site LW2) (Figure 2.31). These directions are statistically indistinguishable, at a $95 \%$ level of confidence, from the directions reported by Turrin et al. (1991b) for their unit Q13. Two other sites in Q11d give dispersed paleomagnetic data. Finding intact material in the Q11a subunit has proven more difficult. Three sites in the Q11a subunit yield well-grouped site-mean directions of magnetization $($ Declination $=18.5$, Inclination $=$ 53.6, $\mathrm{n}=8$ samples, LW5; Declination $=346.3$, Inclination $=53.8, \mathrm{n}=10$ samples, site LW7; and Declination $=358.3$, Inclination $=45.3, n=6$ samples site LW8) (Figure 2.29). Again, these directions are similar to the two group mean directions reported by Turrin et al. (1991b) for their unit Q13. Two sites sampled in subunit Q11c (LW9, LW10) yielded magnetizations that vary in dispersion (Figure 2.31). Because of the poor surface exposures of this flow, it is unlikely that a well-grouped direction of magnetization will be obtained for these deposits.

New and probably final sets of samples for paleomagnetic study were collected in the fall of 1992. Sample sites (LW11 to LW23) were chosen in an attempt to provide optimum determinations of field magnetization directions for the volcanic subunits. The buried lava flow of 
subunit Q11c was excavated to expose the massive interior of the blocky $a a$ flow at two localities, and the two sites give well-grouped magnetizations (Declination $=11.2$, Inclination $=46.9, n=11$ samples, site LW11; and Declination $=6.8$, Inclination $=54.6, \mathrm{n}=9$ samples, site LW12). Scoria mounds dissected by backhoe, of subunits Qs1c and Qs2a (sites LW13, LW14), were studied by collecting oriented scoria clasts from intact sequences of vent scoria buried originally beneath several meters of vent scoria. The clasts were sampled using a relatively unorthodox technique that is explained herein in sufficient detail to preclude confusion. Selected clasts were fixed with glass cover slips using auto-seal cement. The cement dried in less than an hour providing a firm, flat surface for orientation that was permanently fixed to the sample. A strike and dip orientation was made on the cover slip using both magnetic and, when possible, solar, compass and clinometer. The scoria clast was then easily removed from the dissected unconsolidated scoria deposits. Clasts were prepared into specimens for paleomagnetic measurement by drilling cylinders perpendicular to the oriented cover slip face. The sampling technique proved effective, and the only difficulty encountered was with labeling of final specimens because of the high vesicularity of the scoria clasts. All specimens were demagnetized using progressive thermal methods because of their potentially complex thermal history over the temperature range of magnetization blocking and because of the possibility that much of the geologically significant remanence was carried in hematite. The results from the two backhoe-dissected scoria mounds were most acceptable (Declination $=2.8$, Inclination $=57.7, \mathrm{n}=12$ independent clasts, site LW13; and Declination $=$ 2.0, Inclination $=46.7, n=11$ independent clasts, site LW14) and consistent with the sampled lava flows. We interpret the paleomagnetic data to indicate that these deposits remained at elevated temperatures (i.e., at least $500^{\circ} \mathrm{C}$ ) throughout the time of formation (aerial ejection and accumulation). Further, the magnetization in the clasts represents a post-emplacement thermally acquired remanence. Demagnetization behavior and overall intensities of magnetization of these clasts give no indication that the mounds were affected by lightning strikes.

We also used this technique to collect scoria clasts from a newly constructed roadcut in subunit Qs1d (site LW21) and from a quarry exposure of the main cone (site LW23). Scoria clasts from site LW21 yield a magnetization direction that is well-grouped at the site level (Declination = 93.8, Inclination $=43.9, \mathrm{n}=10$ independent clasts) but unusual with respect to the late Quaternary time-averaged geomagnetic field for the Lathrop Wells locality and, of course, all of the other paleomagnetic data obtained from the volcanic center. The results could be interpreted in several ways. One possibility is that the site records a short-lived, high-amplitude excursion of the geomagnetic field. A second is that the magnetization characteristic of the site/deposit is an artifact of post-emplacement mechanical disruption of at least the sampled part of the deposit. At present, we find the first interpretation unrealistic or difficult to assess. None of the other features of the Lathrop Wells volcanic center yield magnetization indicative of high-amplitude field excursions. Moreover, we have limited faith in the paleomagnetic results because of the nature of the sampled deposits. The second alternative is preferred but remains untested. Individual scoria clasts from site LW23 generally give well-defined magnetization in progressive demagnetization (Figure 2.30). The directions isolated from the clasts are highly dispersed at the site level, and no interpretable magnetization could be obtained from the sampled site in the main cone. Unlike the small and relatively oxidized scoria mounds at sites LW13 and LW14, it appears that scoria clasts comprising at least part of the main cone have been mechanically disrupted at moderate temperatures after the majority of the magnetization in the clasts was thermally blocked. This is consistent with the morphology and inferred eruptive mechanisms of the respective deposits. Sites LW13 and LW14 were collected from small scoria mounds probably formed by weak, poorly dispersed hawaiian spatter eruptions. The well-grouped magnetizations are consistent with limited cooling of the samples before deposition. In contrast, the eruptions of the main cone (Qs3) 
produced highly fragmented and dispersed scoria that must have cooled before deposition. This is consistent with an absence of a well-grouped, interpretable magnetization from the main cone sample sites.

Outcrops of strongly agglutinated scoria were drilled, and oriented cores were collected from two vent zones (sites LW16 and LW18) in unit Qs1 located southwest of the main cone. These features yield exceptionally well-grouped magnetizations that are statistically indistinguishable (at $>95 \%$ confidence) from results reported by Turin et al.(1991b) for their unit Q13 (Declination $=3.6$, Inclination $=52.2, \mathrm{n}=10$ samples, site LW18). For purposes of comparison, one site was established in the Q12a lava (site LW19) on the southeast margin of the volcanic center. This site gave a well-defined site-mean direction (Declination $=6.3$, Inclination $=52.5, \mathrm{n}=10$ samples) consistent with the findings of Turin et al. (1991b) for this eruptive unit. One additional site was established in subunit Q11d (site LW17), which gave a site-mean magnetization (Declination = 355.0, Inclination $=52.0, \mathrm{n}=10$ samples) that is statistically indistinguishable from the results from site LW1, the site we place most faith in defining the magnetization characteristic of the volcanic feature. We occupied a site in Q13 along the northeast margin of the volcanic center (site LW20) that yielded a site-mean direction of magnetization (Declination $=352.9$, Inclination $=$ $53.6, \mathrm{n}=10$ samples) slightly west of the majority of the Lathrop Wells results but of similar inclination. Finally, site LW 22 was in the Qs1scoria and yielded an exceptionally well-defined site-mean direction (Declination $=2.8$, Inclination $=53.6, \mathrm{n}=10$ samples) that is indistinguishable from the two unit mean directions reported by Turin et al. (1991b).

Paleomagnetic investigations at the Lathrop Wells volcanic center were designed to extend and not duplicate completely the voluminous work by Champion (1991). Rather, the investigations principally involved gathering paleomagnetic data for newly identified eruptive units as well as testing the suitability of different types of basaltic volcanic rocks (pyroclastic deposits versus lava) for recording high-quality paleomagnetic information. The paleomagnetic data obtained from the two phases of sampling at the Lathrop Wells volcanic center are not dissimilar from those reported by Turin et al. (1991b). Except for the results from site LW21, which are difficult to interpret at present, the data obtained in this study do not reveal any evidence for relatively high-amplitude field phenomena recorded by the Lathrop Wells volcanic deposits. In addition, the data do not support the contention that individual eruptive features have unique paleomagnetic signatures that can be confidently separated from other eruptive features. This conclusion must be placed into perspective. It is difficult to compare thoroughly the results of the present study with previous efforts (Champion, 1991; Turin et al., 1991b). An insufficient amount of information has been published in their studies to document the manner in which mean magnetizations and, thus, associated statistics were established for their unit Q15 (which includes deposits from both chronostratigraphic units I and III). An even more fundamental concern is the lack of adequate discussion or documentation of raw demagnetization data and the compilation of results (for example, acceptance criteria and ratios), including pertinent statistical parameters, at the site level.

Champion (1991) and Turin et al. (1991b) argue that deposits of their unit Q15 yield a magnetization direction that differs by $4.7^{\circ}$ from what we interpret to be a grand mean magnetization direction(obtained from several site means) primarily from our chronostratigraphic unit II. This difference, if real, provides support for the subdivisions between chronostratigraphic units I and III and between units II and III. Acceptance of their interpretation requires two sets of information. First, their information needs to be separated and evaluated independently for each of the four chronostratigraphic units. Second, acceptance of their interpretation requires more information on the integrity of the demagnetization data for individual samples as well as the 
statistical parameters associated with site- and overall unit-mean determinations. In principle, the quality of the determination of a "grand" mean for a particular eruptive unit (for example, multiple lobes of a single lava flow or aligned sets of scoria mounds where several site means have been obtained), must consider the dispersion of results at the site level. Methods for evaluating this problem have been discussed by Cox (1970). A "grand" mean may be associated with a high concentration of site means (and thus a very small value of alpha 95), but each of the site means may in fact be very poorly determined. Other concerns include: (1) the ability of nonagglutinated scoria deposits that include a hydrovolcanic component to record and preserve the primary magnetic signature with high fidelity, (2) much of the information for the Q15 unit of Turrin et al. (1991b) was obtained from non-agglutinated volcanic bombs from the summit of the main cone that is especially susceptible to lightning strikes, and (3) essentially all of the paleomagnetic data for the Lathrop Wells center fall near the time-averaged (spin axis), late Quaternary field direction (Declination $=0.0$, Inclination $=+57$ ) (Figure 2.32). We elaborate below on the third point.

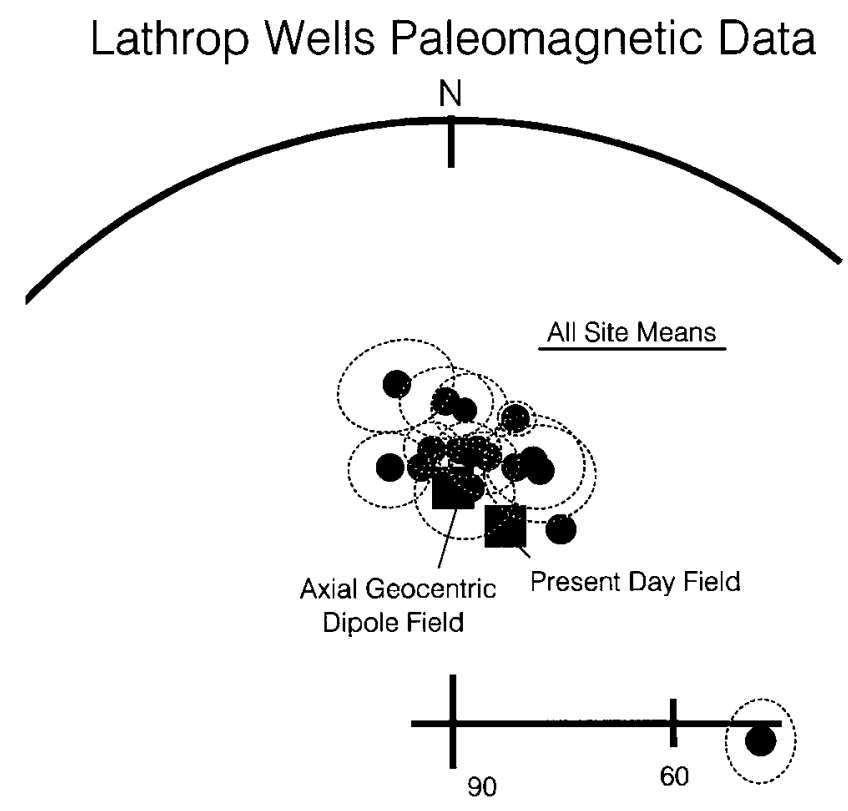

\begin{abstract}
Figure 2.32. Summary of paleomagnetic data from the Lathrop Wells volcanic center. Equal area projection of in situ mean paleomagnetic directions for the total number of accepted and/or interpretable paleomagnetic sites. Large squares are the Quaternary time-averaged (spin axis) axial geocentric dipole field and the present-day (1985) field. Projected cones of 95\% confidence are shown for each site mean. There is a $95 \%$ level of confidence that the true mean direction for the site, determined from an infinite number of independent samples, lies within the cone of $95 \%$ confidence.
\end{abstract}

The secular variation record of the paleomagnetic field has been studied and modeled by numerous investigators over the past two decades using the highest quality paleomagnetic data available (for example, sequences of lava flows from relatively undisturbed areas). The paleosecular variation is described in terms of the scatter or dispersion about the spin axis of Virtual Geomagnetic Poles (VGPs) obtained from the raw paleomagnetic data. Most models for the scatter of the results are based on several possible contributors to paleosecular variation. One is simple dipole wobble. The result of virtually all the models proposed is that the VGP scatter (angular standard deviation) is quite large. For example, using Model G (McFadden et al., 1991), the VGP scatter at the latitude of the Lathrop Wells center is about $15^{\circ} \pm 1^{\circ}$. The angular standard 
deviation of field directions, randomly sampled over a period of time of constant polarity (groups of $10^{4} \mathrm{yr}$ or more) would be slightly less than the VGP scatter, but nonetheless greater than $10^{\circ}$. Essentially all the eruptive features of the Lathrop Wells center have recorded directions of the latest Quaternary geomagnetic field that are well within the expected two-sigma range of paleosecular field variation about the spin-axis direction (Figure 2.32). These data provide at best only a very limited opportunity to identify time-distinctive eruptive events. There is no indication of a single volcanic event occurring during a period of unusual geomagnetic activity.

\section{FY96 \& FY97 revisions}

10. Summary of Geochronology Studies. The acquisition of new geochronology data between late FY95 and FY97 clarifies much of the eruptive history of the Lathrop Wells volcanic center. Based on whole-rock ${ }^{40} \mathrm{Ar} /{ }^{39} \mathrm{Ar}$ measurements, we conclude that all of the lava flows were emplaced during a short time period at about $75 \pm 10 \mathrm{ka}$. This conclusion is independently corroborated by ${ }^{40} \mathrm{Ar} /{ }^{39} \mathrm{Ar}$ measurements of tuff xenoliths within the Q2 eruptive unit, the most precise of which indicate an age of 75-85 ka. Cosmogenic ${ }^{3} \mathrm{He}$ measurements also indicate that all the flows were emplaced at about the same time, at about $90 \mathrm{ka}$. Paleomagnetic data are also consistent with all the flows being emplaced at about the same time. The slightly older ages derived from the cosmogenic ${ }^{3} \mathrm{He}$ measurements probably reflect uncertainty in determining the production rate over the past $80 \mathrm{ka}$. TL ages from the USGS (given that the age estimates have fairly low precision) indicate that eruptive unit Q2 was emplaced between about 50 and $90 \mathrm{ka}$, in accord with the ${ }^{40} \mathrm{Ar} /{ }^{39} \mathrm{Ar}$ and ${ }^{3} \mathrm{He}$ results. U-Th disequilibrium ages are somewhat problematic due to the unreliable $U$-Th systematics of olivine phenocrysts, but the most defensible age determination indicates that the stratigraphically youngest flow $(\mathrm{Q} \mid 3)$ has an age of about $50 \mathrm{ka}$. This age, if correct, provides the only geochronology evidence of a significant time difference between eruptive units at Lathrop Wells. The only ages obtained from the main scoria cone are from cosmogenic ${ }^{3} \mathrm{He}$ measurements (minimum age of $\sim 65 \mathrm{ka}$ ), which are consistent with some erosion of the cone, and the cone having the same age as the lava flows.

G. Alternative Models of the Eruptive History of the Lathrop Wells Volcanic Center

\section{FY96 \& FY97 revisions}

Several areas of new data emerged in late FY95 and FY96 that have led us to reevaluate some of the conclusions of Crowe et al. (1995) pertaining to models of the eruptive history of the Lathrop Wells volcanic center. These data, discussed previously but reiterated here, are:

New ${ }^{40} \mathrm{Ar} /{ }^{39} \mathrm{Ar}$ data indicate that eruptive units Q1 and Q2 have an age of $\sim 75 \pm 10 \mathrm{ka}$ and that there is no discernible age difference between the two. This conclusion is consistent with existing ${ }^{3} \mathrm{He}$ cosmogenic exposure ages from units Q1 and Q2. 
Trenching of the crater of the main scoria cone (Qs3) indicates that it is more modified than previously thought. This finding supports the conclusion that the oldest ${ }^{3} \mathrm{He}$ age obtained from the cone $(64 \pm 15)$ is a minimum age.

If the main cone has been significantly eroded (5-9 $\mathrm{m}$ of rim erosion), there may be no inconsistency between the degree of erosion of the main cone and the Qs2fs fall sheet.

The age of eruptive unit Q3, consisting of the Q13 lava flow and the main cinder cone (Qs3), is still problematic. A defensible U-Th isochron age of $50 \pm 15$ ka from QI3 indicates that Q13 is measurably younger than eruptive units Q1 and Q2. The best ${ }^{3} \mathrm{He}$ age estimate from QI3 is $92 \pm 17 \mathrm{ka}$, the same age as the Q1 and Q2 flows. The oldest ${ }^{3} \mathrm{He}$ age of Qs3 (64 ka) can be interpreted to be within error of the U-Th age from QI3 of $50 \mathrm{ka}$ (in which case both Qs3 and QI3 are measurably younger than Q1 and Q2) or it is a minimum age consistent with the ${ }^{40} \mathrm{Ar} /{ }^{39} \mathrm{Ar}$ and He ages of Q1 and Q2 (i.e., there is no age difference between the main cone and the lava flows).

The chemical composition of Qs4b, previously used as an argument to support a primary volcanic origin, was found through geochemical modeling to be a result of pedogenic alteration, probably from a Qs3 parent tephra. The origin of the Qs4b deposit remains enigmatic. From a fabric and depositional viewpoint, it appears to be primary tephra, although partial carbonate coatings on rotated clasts indicate a previous depositional history. The deposit may represent (1) material reworked by surface processes, (2) products of a hydrovolcanic eruption, or (3) products of a phreatic explosion that redeposited Qs3 tephra. An any case, no source, either representing erosion of the cone slope, or a hydrovolcanic or phreatic vent, has been identified for the Qs4 deposit.

We have reached an important stage in field, stratigraphic, geochronologic, and geochemical studies of the Lathrop Wells volcanic center. Nearly all planned field, stratigraphic, and trenching studies have been completed. The field and stratigraphic studies appear well integrated, and many diverse observations have converged into a coherent understanding of the eruptive history of the volcanic center. A particularly gratifying aspect of the work is the strong agreement obtained between the established stratigraphic units and geochemical data. Four major eruptive intervals have been identified and described as chronostratigraphic units (time-distinctive eruptive intervals) and each unit has a distinctive geochemical composition. What remains elusive, however, is the establishment of a consistent chronologic framework for the chronostratigraphic units. There are two philosophies or approaches that can be applied generally to the integration of field and geochronology data. One approach emphasizes the observable field relations over the results of chronology methods. When apparent conflicts develop between data sets, the field relations are given precedence over the results of chronology measurements. The second approach takes the opposite perspective. Proponents of this approach tend to emphasize the results of one chronology method over another, sometimes but not always with good justification. We prefer the first approach and place a higher level of confidence on the fundamental field relationships of stratigraphic units over discordant chronology data.

The following field observations and interpretations appear firm for the Lathrop Wells volcanic center. They provide the fundamental foundation for the development of three evolutionary models of the eruptive history of the Lathrop Wells volcanic center. 
1. The vent deposits of chronostratigraphic unit I are deeply dissected and generally have poorly preserved primary constructional volcanic landforms. The erosional surface developed on these deposits can be traced beneath the unmodified slopes of the main cone. Deeply dissected scoria vents of chronostratigraphic unit I underlie and are juxtaposed with topographically higher standing scoria vents and lavas of chronostratigraphic unit II. The deposits of chronostratigraphic unit I must be significantly older than chronostratigraphic unit III and may be somewhat older than deposits of chronostratigraphic unit II.

\section{FY96 \& FY97 revisions}

We consider this interpretation to be still valid for the Lathrop Wells center. There is a significant apparent difference between the degree of dissection of the Q1 eruptive unit and all other eruptive events of the Lathrop Wells center. If this is indeed an erosional unconformity, it requires a time difference between Q1 and the other eruptive units. However, the results of the new ${ }^{40} \mathrm{Ar} /{ }^{39} \mathrm{Ar}$ studies indicate that the time difference cannot be large $(<10 \mathrm{ka})$. At present we have no explanation for this apparent discrepancy between field observations and geochronologic data.

2. The scoria-fall deposits of chronostratigraphic unit II can be uniquely correlated with the lava events of the unit by the interfingering stratigraphic relations of their associated pyroclastic-surge deposits.

3. The degree of erosional dissection of the scoria-fall sheet of chronostratigraphic unit II contrasts markedly with the unmodified slopes of the main cone (formed by the eruptions of chronostratigraphic unit III). The outer slopes of the main cone are as steep as $29^{\circ}$. The topographic slopes of the scoria-fall sheet are subhorizontal to $<15^{\circ}$. It appears physically impossible for the units to be of similar age and have the observed different degrees of erosional dissection. This provides strong evidence that deposits of chronostratigraphic unit II must be older than deposits of chronostratigraphic unit III.

\section{FY96 \& FY97 revisions}

The new U-Th disequilibrium isochron of 50 ka for Q13 supports the conclusion that the main cone is younger than deposits of eruptive unit Q2, if the main cone and Q13 are contemporaneous. This conclusion is consistent with geochemical differences between the cone and the scoria fall sheet, which are difficult to explain if the cone and fall sheet were emplaced during the same eruption.

4. Scoria deposits of chronostratigraphic unit IV are separated from scoria deposits of chronostratigraphic unit III by multiple occurrences of soil with horizon development. The fundamental debate concerning the deposits of chronostratigraphic unit IV is whether they are primary or secondary (reworked) in origin. The field characteristics and unique chemical composition of the deposits of chronostratigraphic unit IV in comparison to deposits of all other chronostratigraphic units requires that they were formed by a unique volcanic event-they cannot be reworked from a preexisting deposit. 
FY96 \& FY97 revisions

As discussed previously, the origin of the Qs4 deposits remains enigmatic. New geochemical modeling (see Chapter 4) shows that the geochemical composition of Qs4 is due to pedogenic alteration, probably of a Qs3 parent tephra associated with formation of the main cone, and thus by itself cannot be used to infer a new volcanic event.

5. The removal of the inferred eruptive vents for chronostratigraphic unit IV by commercial quarrying activity may make it impossible to achieve a scientific consensus on the recognition of this unit.

\section{FY96 \& FY97 revisions}

We continue to believe that the origin of the Qs4 deposits will never be completely resolved. Along with their origin, their source also remains unknown (conversely, if their source were known, so probably would be their origin). A south cone-wall source, either by erosional or explosive processes, is inconsistent with the relatively undisturbed profile of the south cone, and a cone crater source is inconsistent with the stratigraphic sequence within the crater. The only other source constraint is that the Qs4 deposits are recognized only to the south of the cone, and possibly within the cone crater. If the Qs4 deposits are the result of a phreatic or hydrovolcanic eruption, the vent area remains unidentified.

6. Multiple lines of stratigraphic, geomorphic, soil, geochemical, and geochronology data suggest The Lathrop Wells volcanic center formed during multiple, time-distinct eruptive events and is not a simple monogenetic volcanic center. Figure 2.33 is a geologic map of the Lathrop Wells volcanic center showing the combined distribution of rock units for the four chronostratigraphic units. The chronology data for the Lathrop Wells center are not definitive with respect to the ages of the four chronostratigraphic units. We have been unable to obtain definitive chronology data using the applied range of geochronology methods. New step heating ${ }^{40} \mathrm{Ar} /{ }^{39} \mathrm{Ar}$ data are being obtained for suites of fragments of partly fused tuff collected from lava and scoria units of the Lathrop Wells center. Preliminary data from these studies will be available in early calendar year 1995 . We will make further revisions to the chronology models of the center using these new results, but anticipate that the data may not be definitive. The chronology data are used to develop three alternative models for the evolution of the Lathrop Wells volcanic center. The first model (Model A) is a four-fold division of the volcanic deposits of the Lathrop Wells volcanic center emphasizing constraints from the field and stratigraphic data. We attempt to assign approximate or best estimates of ages to the four chronostratigraphic units using primarily insights from field data supplemented by the chronology data. We emphasize the field data for Model A where there are inconsistencies in the geochronology data. Models B and C assign increased importance to the results of chronology data for the four chronostratigraphic units. These models may be preferred by workers choosing to emphasize the results of individual geochronology methods over field and stratigraphic relations. 


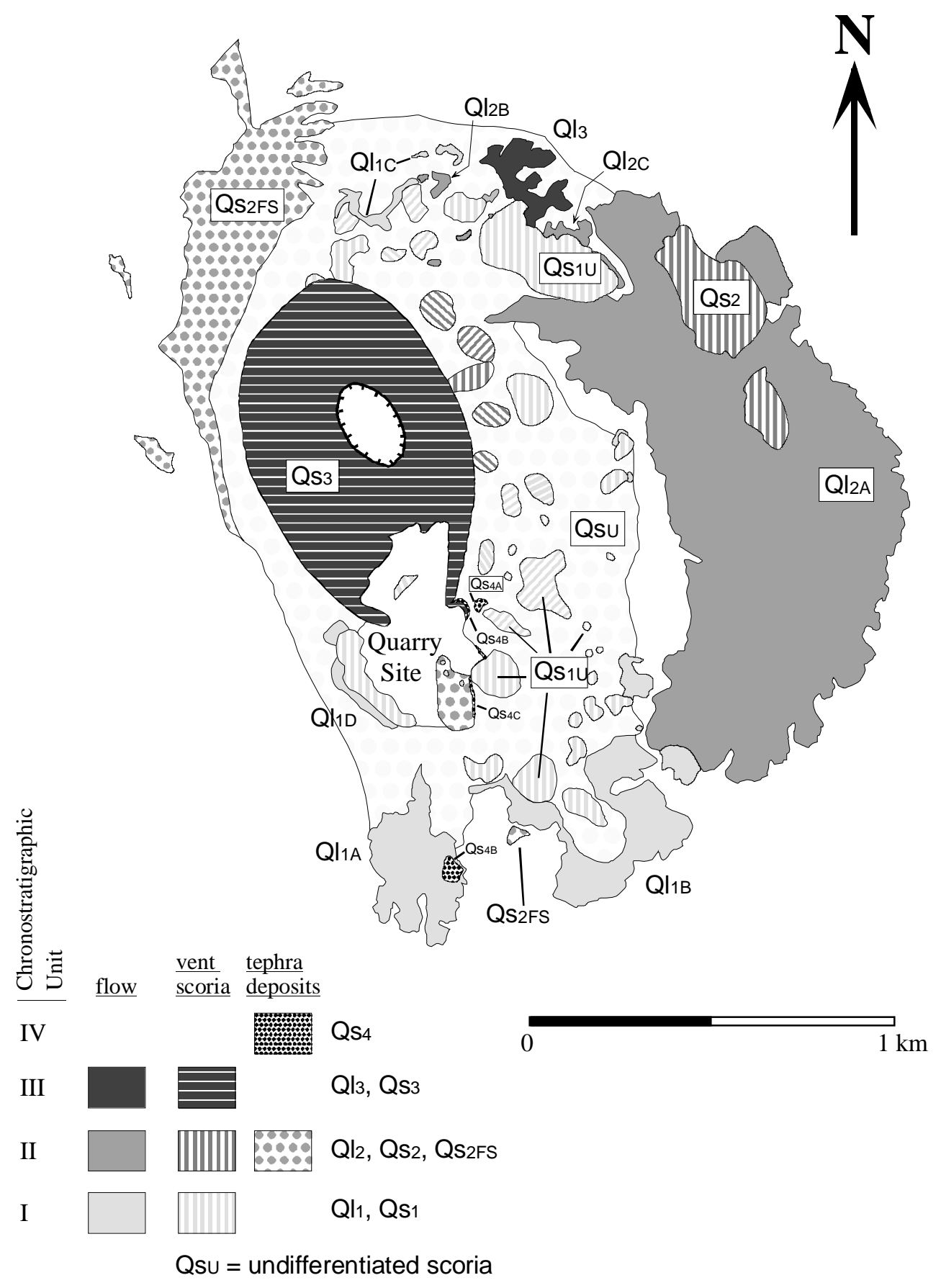

Figure 2.33. Geologic map of the Lathrop Wells volcanic center showing the distribution of all chronostratigraphic units of the center.

1. Model A. Model A is a four-event polygenetic model. The age of the lava and scoria sequences of chronostratigraphic unit I are presumed to be at least 120 to $130 \mathrm{ka}$ based on (in decreasing order of acceptability) the U-Th disequilibrium age of the Old Quarry flow lava, the minimum cosmogenic ${ }^{3} \mathrm{He}$ ages of multiple units, and the mean ages of multiple $\mathrm{K}-\mathrm{Ar}$ and ${ }^{40} \mathrm{Ar} /{ }^{39} \mathrm{Ar}$ age determinations. The discordance in erosion between chronostratigraphic units I and II is 
assumed to have significance in age assignments. The age of chronostratigraphic unit II is assumed to be between 85 and $95 \mathrm{ka}$ (oldest cosmogenic ${ }^{3} \mathrm{He}$ age determinations). The age of chronostratigraphic unit III is inferred to be best estimated at about 55 to $65 \mathrm{ka}$ on the basis of the oldest cosmogenic ages $\left({ }^{3} \mathrm{He},{ }^{36} \mathrm{Cl}\right)$ of the main cone and the Q13 lava flow (Sandramp lava). The erosional unconformity between the scoria-fall deposits of chronostratigraphic unit I and the coneslope deposits of the main cone is assumed to be significant. The age of eruptive events of chronostratigraphic unit IV is less than $\sim 4$ and $8 \mathrm{ka}$ on the basis of TL ages of soil beneath tephrafall units. The two tephra units observed in distal sections and fault trenches are correlated with chronostratigraphic unit II.

2. Model B. Model B is a three-event polygenetic model. It is identical to Model A, except that chronostratigraphic unit II is not inferred to be distinctively younger than chronostratigraphic unit I. This model assumes that the difference in erosion and burial of the different units is not significant and represents differences in the erosional resistance of vent scoria versus lava flows. The U-Th disequilibrium age of the Old Quarry lava and the mean $\mathrm{K}-\mathrm{Ar}$ and ${ }^{40} \mathrm{Ar} /{ }^{39} \mathrm{Ar}$ ages of other lavas are assumed to be the best estimate of the age of chronostratigraphic units I and II. All cosmogenic ${ }^{3} \mathrm{He}$ and ${ }^{36} \mathrm{Cl}$ ages for the units are assumed to be minimum ages because of shielding of primary surfaces by scoria-fall deposits of chronostratigraphic unit II and local cover by eolian sand. The ages of chronostratigraphic unit III and IV are assumed to be the same as in Model A. The tephra units observed in distal sections are correlated with the oldest chronostratigraphic units (>120 to $130 \mathrm{ka}$ ) and chronostratigraphic unit III (55 to $65 \mathrm{ka}$ ).

3. Model C. Model C is a two-event polygenetic model. The age of the three oldest volcanic units at the Lathrop Wells center is assumed to be about 125 to $140 \mathrm{ka}$ on the basis of the results of the U-Th disequilibrium ages and the mean $\mathrm{K}-\mathrm{Ar}$ and ${ }^{40} \mathrm{Ar} /{ }^{39} \mathrm{Ar}$ ages. The results of all other age determinations are assumed to be invalid. The results would, in this model, represent a combination of poorly developed and/or calibrated methods and shielding of samples used for cosmogenic age determinations from scoria-fall and eolian deposits. The age of eruptive events of chronostratigraphic unit IV is less than $\sim 4$ and $8 \mathrm{ka}$. The multiple ash horizons observed in distal outcrops and trenches are assumed to be stratigraphic complications of erosional reworking of surficial ash.

\section{FY96 \& FY97 revisions}

We have completed a revised geologic map of the Lathrop Wells volcanic center compiled on 1:12,000 scale orthophotographic quadrangles and transferred onto a 20foot-contour-interval topographic base (Appendix 2-M5). Based on field and stratigraphic data, this map emphasizes the separation of lava flows and scoria deposits of the center into three eruptive units. This geologic interpretation of the Lathrop Wells center is not dependent on a specific geochronologic model. Whether the center formed in one week or over a period of several tens of thousands of years, field evidence indicates that the volcanic history began with emplacement of lava flows and scoria deposits of eruptive unit Q1, which erupted from several separate fissures. Following emplacement of Q1, Q2 was emplaced, consisting mainly of a large lava flow that flowed to the east of the pre-existing Q1 topography. Finally, the main scoria cone and small lava lobe of Q3 were emplaced. We continue to show the location of the Qs4 tephra deposit on this map, although we reach no final conclusion as to whether this deposit has a primary volcanic or reworked non-volcanic origin. 
Based on the existing stratigraphic and geochronologic information and the completion of volcanism studies, we recognize five modified models of alternative interpretations of the Lathrop Wells volcanic center. Evidence exists for and against each of these models and no model can be clearly rejected. We apply a weighting factor that is an assigned percentage that sums to $100 \%$ of our judgment of the likelihood of the validity of each model recognizing that, like most complex issues, there are no black and white answers and there are pros and cons to each of the models. Moreover, we emphasize that it is important to retain multiple alternative models for consideration in suitability and licensing assessments of the significance of the volcanism issue for the Yucca Mountain site.

Model A: The Lathrop Wells volcanic center is a complex monogenetic volcanic center. The Q1, Q2 and Q3 deposits all formed in a single eruptive event within a few months or years of each other. This is the traditional interpretation of small-volume basalt centers based on historical observation and somewhat limited studies of prehistoric centers. The age of the center is $\sim 75 \mathrm{ka}$ and is considered to be well established on the basis of the ${ }^{40} \mathrm{Ar} /{ }^{39} \mathrm{Ar}$ age determinations for samples of the lava units and xenolith sanidines in the scoria and lava deposits. This age is corroborated by cosmogenic ${ }^{3} \mathrm{He}$, ${ }^{36} \mathrm{Cl}$, and TL age determinations and paleomagnetic data for the center. Evidence that may not be compatible with this model are the different degrees of erosional modification of the Q1 versus Q2 and Q3 eruptive units, systematic geochemical differences between the eruptive units of a type never previously documented for a monogenetic center, the U-Th disequilibrium age of $\sim 50 \mathrm{ka}$ for Ql3, and the somewhat younger ${ }^{3} \mathrm{He}$ cosmogenic exposure ages from Q3 compared to Q1/Q2. The Q4 unit is inferred to be a deposit resulting from scoria redeposition, either from surficial processes or, perhaps more likely, a phreatic explosion that occurred several thousands of years after the main activity of the center had ceased. Weighting: $70 \%$.

Model B: The Lathrop Wells volcanic center is a polygenetic center formed during two relatively closely spaced eruptions associated with the formation of the Q1 (first event) and the Q2/Q3 (second event) volcanic events. The more pronounced erosional modification of the Q1 deposits is due to a brief interval $(<10 \mathrm{ka})$ separating the volcanic events that possibly occurred during a wetter climate when erosional rates were higher. Geochemical differences between the Q1 and Q2/Q3 are a result of their formation from separate magma batches. The perceived erosional differences between the Q2 and Q3 units are inferred not to be significant nor are the geochemical differences between the units. The Q4 unit is inferred to be a non-volcanic deposit. The age of the center is $\sim 75 \mathrm{ka}$ and uses the same assumptions as Model A for the different geochronology methods. Weighting: $10 \%$.

Model C: The Lathrop Wells volcanic center is a polygenetic center formed during two events associated with formation of Q1/Q2 (first event) and Q3 (second event). The Q1 and Q2 units formed at $\sim 75 \mathrm{ka}$, as indicated by the ${ }^{40} \mathrm{Ar} /{ }^{39} \mathrm{Ar}$ and ${ }^{3} \mathrm{He}$ data. The Q3 unit formed at $\sim 50-60 \mathrm{ka}$, as indicated by the U-Th isochron on Q13 and the ${ }^{3} \mathrm{He}$ data from Qs3. Because Q3 is 10-20 ka younger than Q2, this model accounts for the perceived erosional and geochemical differences between the Qs2 fall-sheet and the main cinder cone (Qs3). Differences in the erosional modification of Q1 and Q2 are not significant. Weighting: $10 \%$. 
Model D: The Lathrop Wells volcanic center is a polygenetic volcanic center formed during three eruptive events. The first event, the Q1 event, is assumed to be similar to the Q1 event of Model B. The second event-the Q2 event-and the Q1 event are assumed to be $\sim 75 \mathrm{ka}$, with a small and unresolvable age difference between the events. The third event is the Q3 events which consists of the formation of the main cone and eruption of the QI3 lava northeast of the main cone. This event is separated from the Q2 event on the basis of chemical differences between the units, and the UTh isochron age of $\sim 50 \mathrm{ka}$ for Q13. The Q4 unit is inferred not to be a primary volcanic deposit. Weighting: $5 \%$.

Model E: The Lathrop Wells volcanic center is a polygenetic volcanic center formed during four eruptive events. The first three events are identical to model D. The fourth eruptive event is recorded by the Q4 deposits south of the main cone and is presumed to have occurred 10-15 ka after the Q3 eruptive event. The Q4 deposits were formed during weak hydrovolcanic explosions from an area south of the main cone in an area that has now been extensively quarried. Weighting: $5 \%$.

\section{REFERENCES}

Armstrong, R. L., "Magmatism, Orogenic Timing, and Orogenic Diachronism in the Cordillera from Mexico to Canada," Nature 247, 348-351 (1974).

Armstrong, R. L., E. B. Ekren, E. H. Mckee, and D. C. Noble, "Spacetime Relations of Cenozoic Silicic Volcanism in the Great Basin of the Western United States," America Journal of Science 267, 478-490 (1969).

Armstrong R. L., and P. Ward, "Evolving Geographic Patterns of Cenozoic Magmatism in the North American Cordillera: the Temporal and Spatial Association of Magmatism and Metamorphic Core Complex," Journal Geophysical Research 96, 13, 201-13, 224 (1991).

Axen, G. J., W. J. Taylor, and J. M. Bartley, "Space-Time Patterns and Tectonic Controls of Tertiary Extension and Magmatism in the Great Basin of the Western United States," Geological Society America 105, 56-76 (1993).

Broxton, D. E., R. G. Warren, F. M. Byers, Jr., and R. B. Scott, "Chemical and Mineralogic Trends Within the Timber Mountain Oasis Valley Caldera Complex, Nevada: Evidence for Multiple Cycles of Chemical Evolution in a Long-Lived Silicic Magma System," Journal Geophysical Research 94, 59615985 (1989).

Byers, F. M., Jr., C. L. Rogers, W. J. Carr, and S. J. Luft, "Geologic Map of the Buckboard Mesa Quadrangle, Nye County, Nevada,” U.S. Geological Survey Map GQ-552 (1966).

Byers, F. M., Jr., and H. Barnes, "Geologic Map of the Paiute Ridge Quadrangle, Nye and Lincoln Counties, Nevada,” U.S. Geological Survey Quadrangle Map GQ-577 (1967).

Byers, F. M., Jr., W. J. Carr, P. P. Orkild, W. D. Quinlivan, and K. A. Sargent, "Volcanic Suites and Related Cauldrons of Timber Mountain-Oasis Valley Caldera Complex, Southern Nevada," U.S. Geological Survey Professional Paper 919, 70 pp. (1976).

Byers, F. M., Jr., W. J. Carr, and P. P. Orkild, "Volcanic Centers of Southwestern Nevada: Evolution of Understanding,” 1960-1988, Journal Geophysical Research 94, 5908-5924 (1989). 
Carr, W. J., "Regional Structural Setting of Yucca Mountain, Southwestern Nevada, and Late Cenozoic Rates of Tectonic Activity in Part of the Southwestern Great Basin, Nevada and California," U.S. Geological Survey Open-File Report 84-854, 109 pp. (1984).

Carr, W.J. "Summary of the Tectonic and Structural Evidence for Stress Orientation at the Nevada Test Site," U.S. Geological Survey Open-file report 74-176 (1974).

Carr, W. J., "Volcanic-Tectonic Setting of Yucca Mountain and Crater Flat, Southwestern Nevada," in U.S. Geological Survey 1790: U.S. Geologic and Hydrologic Investigations of a Potential Nuclear Waste Disposal Site at Yucca Mountain, Southern Nevada, M. D. Carr and J. C. Yount, Eds., (Department of Interior, U.S. Geological Survey, Reston, Virginia, 1988), pp. 35-49.

Carr, W. J., and L. D. Parrish, "Geology of Drill Hole USW VH-2, and Structure of Crater Flat, Southwestern Nevada,” U.S. Geological Survey Open-File Report 85-475, 41 pp. (1985).

Carr, W. J., and W. D. Quinlivan, "Geologic Map of the Timber Mountain Quadrangle, Nye County, Nevada,” U.S. Geological Survey Map GQ-503 (1966).

Carr, W. J., F. M. Byers, Jr., and P. P. Orkild, "Stratigraphic and Volcano-Tectonic Relations of Crater Flat Tuff, and Some Older Volcanic Units, Nye County, Nevada," U.S. Geological Survey Professional Paper 1323, 28 pp. (1986).

Carr, W. J., "Styles of Extension in the Nevada Test Site Region, Southern Walker Lane Belt; an Integration of Volcano-Tectonic and Detachment Fault Models," in Geological Society America Memoir 176: Basin and Range Extensional Tectonics Near the Latitude of Las Vegas, Nevada, B. P. Wernicke, Ed., (Geological Society America, Boulder, Colorado, 1990), pp. 283-303.

Cas, R.A.F, and J.V. Wright, Volcanic Successions, Modern and Ancient, (Unwin Hyman, London, 1987), $528 \mathrm{pp}$.

Cerling, T., "Dating Geomorphologic Surfaces Using Cosmogenic ${ }^{3} \mathrm{He}$," Quaternary Research 33, 148156 (1990).

Cerling, T. E., and H. Craig, "Cosmogenic ${ }^{3} \mathrm{He}$ Production Rates from $39^{\circ} \mathrm{N}$ to $46^{\circ} \mathrm{N}$ Latitude, Western USA and France," Geochemica Cosmochemica Acta 58, 249-255 (1994).

Champion, D. E., "Volcanic Episodes Near Yucca Mountain as Determined by Paleomagnetic Studies at Lathrop Wells, Crater Flat, and Sleeping Butte, Nevada," in Proceedings High Level Radioactive Waste Management Conference, Las Vegas, Nevada, (America Nuclear Society, La Grange Park, Illinois) 61-67 (1991).

Champion, D. E., Oral Presentation to the United States Nuclear Waste Technical Review Board, Panel On Structural Geology and Geoengineering, Meeting on Volcanism, Las Vegas, Nevada (September 14, 1992).

Christiansen, R. L., and P. W. Lipman, "Geologic Map of Topopah Spring NW Quadrangle, Nye County, Nevada,” U.S. Geological Survey Quadrangle Map GQ-444 (1965).

Christiansen, R. L., and P. W. Lipman, "Cenozoic Volcanism and Plate Tectonic Evolution of the Western United States, II, Late Cenozoic," Philosophical Transactions Royal Society London Series A, 271, 249-284 (1972). 
Christiansen, R. L., P. W. Lipman, W. J. Carr, F. M. Byers, Jr., P. P. Orkild, and K. A. Sargent, "The Timber Mountain-Oasis Caldera Complex of Southern Nevada," Geological Society America 88, 943-959 (1977).

Christiansen, T. L., and E. H. McKee, "Late Cenozoic Volcanic and Tectonic Evolution of the Great Basin and Columbia Intermontane Regions," in Cenozoic Tectonics and Regional Geophysics of the Western Cordillera, R. B. Smith and G. P. Eaton, Eds., Geological Society America Memoir 152, 283-311 (1978).

Cox, A., "Latitude Dependence of Angular Dispersion of the Geomagnetic Field", Geophysical Journal Royal Astron. Society, 20, 253-292 (1970).

Cross, T. A., and R. H. Pilger, "Constraints On Absolute Motion and Plate interaction inferred from Cenozoic Igneous Activity in the Western United States," America Journal of Science 278, 865-902 (1978).

Crowe, B. M., "Volcanic Hazard Assessment for Disposal of High-Level Radioactive Waste," in Active Tectonics: Impact On Society (National Academy Press, Washington, DC., 1986), Chap. 16, 247-260

Crowe, B. M., "Basaltic Volcanic Episodes of the Yucca Mountain region," Proceedings High-Level Radioactive Waste Management Conference, Las Vegas, Nevada(American Nuclear Society, La Grange Park Illinois, 1990), pp. 65-73.

Crowe, B. M., and W. J. Carr, "Preliminary Assessment of the Risk of Volcanism at a Proposed Nuclear Waste Repository in the Southern Great Basin," U. S. Geological Survey Open-File Report 80-375, 15 pp. (1980).

Crowe, B.M. and F.V. Perry, "Completion of Field, Geochemistry and Geochronology Studies at the Sleeping Butte and Buckboard Mesa Basalt Centers," Los Alamos Letter Report, Milestone 3169, 4 pp. (1995)

Crowe, B. M., M. E. Johnson, and R. J. Beckman, "Calculation of the Probability of Volcanic Disruption of a High-Level Radioactive Waste Repository Within Southern Nevada, USA," Radioactive Waste Management 3, 167-190 (1982).

Crowe B. M., D. T. Vaniman, and W. J. Carr, "Status of Volcanic Hazard Studies for the Nevada Nuclear Waste Storage Investigations," Los Alamos National Laboratory report LA-9325-MS 47 p. (1983a).

Crowe, B. M., S. Self, D. Vaniman, R. Amos, and F. Perry, "Aspects of Potential Magmatic Disruption of a High-Level Radioactive Waste Repository in Southern Nevada," Journal of Geology 91, 259-276 (1983b).

Crowe, B. M., K. H. Wohletz, D. T. Vaniman, E. Gladney, and N. Bower, "Status of Volcanic Hazard Studies for the Nevada Nuclear Waste Storage Investigations," Los Alamos National Laboratory Report LA-9325-MS, Vol. II, 101 p. (1986).

Crowe, B., C. Harrington, L. McFadden, F. Perry, S. Wells, B. Turrin, and D. Champion, "Preliminary Geologic Map of the Lathrop Wells Volcanic Center," Los Alamos National Laboratory Report LA-UR88-4155 (1988).

Crowe, B. M., and F. V. Perry, "Volcanic Probability Calculations for the Yucca Mountain Site: Estimation of Volcanic Rates," Proceedings Nuclear Waste Isolation in the Unsaturated Zone, Focus '89, Symposium, America Nuclear Society, 326-334 (1989). 
Crowe, B. M., and F. V. Perry, "Preliminary Geologic Map of the Sleeping Butte Volcanic Centers," Los Alamos National Laboratory Report LA-12101-MS, 11 pp. (1991).

Crowe, B., R. Morley, S. Wells, J. Geissman, E. McDonald, L. McFadden, F. Perry, M. Murrell, J. Poths, and S. Forman, "The Lathrop Wells Volcanic Center: Status of Field and Geochronology Studies," Proceedings High-Level Radioactive Waste Management Conference, Las Vegas, Nevada (American Nuclear Society, La Grange Park, Illinois, 1992), pp. 1997-2013.

Crowe, B., F. Perry, J. Geissman, L. McFadden, S. Wells, M. Murrell, J. Poths, G.A. Valentine, L. Bowker, and K. Finnegan, "Status of Volcanism Studies for the Yucca Mountain Site Characterization Project," Los Alamos National Laboratory report LA-12908-MS, 1-363 (1995).

DOE (U.S. Department of Energy), "Environmental Assessment: Yucca Mountain Site, Nevada Research and Development Area, Nevada," Office of Civilian Radioactive Waste Management Report DOE/RW0073, (1986).

DOE (U.S. Department of Energy), "Site Characterization Plan, Yucca Mountain Site, Nevada Research and Development Area, Nevada," Office of Civilian Radioactive Waste Management Report DOE/RW0199, (1988).

Dohrenwend, J. C., S. G. Wells, and B. D. Turrin, "Degradation of Quaternary Cinder Cones in the Cima Volcanic Field, Mojave Desert, California," Geological Society America 97, 421-427 (1986).

Eaton, G. P., R. R. Wahl, H. J. Prostka, D. R. Mabey, and M. D. Kleinkopf, "Regional Gravity and Tectonic Patterns: their Relation to Late Cenozoic Epirogeny and Lateral Spreading in the Western Cordillera," in Cenozoic Tectonics and Regional Geophysics of the Western Cordillera, R. B. Smith, R. B., and G. P. Eaton, Eds., Geological Society America Memoir 152, 51-91 (1978).

Ekren, E. B., and K. A. Sargent, "Geologic Map of the Skull Mountain Quadrangle, Nye County, Nevada,” U.S. Geological Survey Quadrangle Map GQ-387 (1965).

Farmer, G. L., F. V. Perry, S. Semken, B. Crowe, D. Curtis, and D. J. DePaolo, "Isotopic Evidence On the Structure and Origin of Subcontinental Lithospheric Mantle in Southern Nevada," Journal Geophysical Research 94, 7885-7898 (1989).

Faulds, J. E., J. W. Bell, D. L. Feuerbach, and A. R. Ramelli, "Geologic Map of the Crater Flat Area, Nevada," Nevada Bureau of Mines and Geology Map 101 (1994).

Feuerbach, D. L., E. I. Smith, and M. Shafiqullah, "Structural Control of Pleistocene Volcanism in Crater Flat, Nevada," Geological Society America Abstracts with Programs 22, p. A134 (1990).

Fisher, R. V., and H. U. Schminike, Pyroclastic Rocks, (Springer-Verlag, Berlin, 1984) 472 p.

Fleck, R.J., M.A. Lanphere, B.D. Turrin, and D.A. Sawyer, "Chronology of late Miocene to Quaternary volcanism and tectonism in the southwest Nevada volcanic field," Geological Society of America Abstracts with Programs, 23, 25 (1991).

Fleck, R.J., B.D. Turrin, D.A. Sawyer, R.G. Warren, D.E. Champion, M.R. Hudson, and S.A. Minor, "Age and Character of Basaltic Rocks of the Yucca Mountain Region, Southern Nevada," Journal of Geophysical Research 101, 8205-8227 (1996).

Frizzel, V. A., and J. Shulters, “Geologic Map of the Nevada Test Site," U.S. Geological Survey, Misc. Invest. Series, Map I-2046 (1990). 
Geomatrix Consultants, Inc., "Probabilistic Volcanic Hazard Analysis for Yucca Mountain, Nevada." Civilian Radioactive Waste Management System, Management and Operating Contractor (TRW), Report BA0000000-01717-2200-00082 (1996).

Harris, A. G., J. E. Repetski, J. L. Clayton, J. A. Grow, M. D. Carr, and T. A. Davis, "Results from, 1991 Wildcat Wells Near Yucca Mountain, Nevada," Geological Society America Abstracts with Programs 24, 17 (1992).

Henrichs, E. N., and E. J. Mckay, Geologic Map of the Plutonium Valley Quadrangle, Nye and Lincoln Counties Nevada: U.S. Geological Survey Geologic Quadrangle Map GQ-384, Scale 1:24,000 (1965).

Ho, C. H., E. I. Smith, D. L. Feuerbach, T. R. Nauman, "Eruptive Probability Calculation for the Yucca Mountain Site, USA: Statistical Estimation of Recurrence Rates," Bulletin Volcanology 54, 50-56 (1991).

Holcomb, R., D. E. Champion, and M. L. McWilliams, "Dating Recent Hawaiian Lava Flows Using Paleomagnetic Spectral Variation," Geological Society America 97, 829-839 (1986).

Jones, J.H., B.P. Wernicke, G.L. Farmer, J.D. Walker, D.S. Colman, L.W. Mckenna, and F.V. Perry, "Variations Across and Along a Major Continental Rift: An Interdisciplinary Study of the Basin and Range Province, Western USA," Tectonophysics 213, 57-96 (1992).

Kane, M. F., and R. E. Bracken, "Aeromagnetic Map of Yucca Mountain and Surrounding Regions, Southwest Nevada," U.S. Geological Survey, Open-File Report 83-616, 19 pp. (1983).

Kistler, R. W., "Potassium-Argon Ages of Volcanic Rocks in Nye and Esmeralda Counties, Nevada, Studies of Geology and Hydrology, Nevada Test Site," Geological Society America Memoir 110, 252-262 (1968).

Langenheim, V. E., S. F. Carle, D. A. Ponce, and J. D. Philips, "Revision of An Aeromagnetic Survey of the Lathrop Wells Area, Nevada," U.S. Geological Survey, Open-File Report 91-46, 17 pp. (1991).

Langenheim, V.E., K.S. Kirchoff-Stein, and H.W. Oliver, "Geophysical Investigations of Buried Volcanic Centers Near Yucca Mountain, Southwest Nevada", in Proceedings High Level Radioactive Waste Management Conference, Las Vegas, Nevada, (American Nuclear Society, La Grange Park, Illinois, 1993), pp. 1840-1846.

Langenheim, V.E., "Magnetic and Gravity Studies of Buried Volcanic Centers in the Amargosa Desert and Crater Flat, Southwest Nevada," U.S. Geological Survey Open-File report, (1995).

Laughlin, A. W., J. Poths, H. A. Healey, S. Reneau, and G. WoldeGabriel, "Dating of Quaternary Basalts Using the Cosmogenic ${ }^{3} \mathrm{He}$ and ${ }^{14} \mathrm{C}$ Methods With Implications for Excess ${ }^{40} \mathrm{Ar}$," Geology 22, 135-138 (1994).

Lipman, P. W., R. L. Christiansen, and J. T. O'Connor, “A Compositionally Zoned Ash-Flow Sheet in Southern Nevada,” U.S. Geological Survey Professional Paper 524, 47 pp. (1966a).

Lipman, P. W., W. D. Quinlivan, W. J. Carr, and R. E. Anderson, "Geologic Map of the Thirsty Canyon Se Quadrangle, Nye County, Nevada,” U.S. Geological Survey Quadrangle Map, GQ-489 (1966b).

Lipman, P. W., H. J. Prostka, and R. L. Christiansen, "Evolving Subduction Zones in the Western United States, As Interpreted from Igneous Rocks," Science 174, 821-825 (1971). 
Lipman, P. W., H. J. Prostka, and R. L. Christiansen, in "Cenozoic Volcanism and Plate Tectonic Evolution of the Western United States, I: Early and Middle Cenozoic," Philosophical Transaction Royal Society London, Series A 271, 217-248 (1972).

Luedke, R. G., and R. L. Smith, "Map Showing Distribution, Composition, and Age of Late Cenozoic Volcanic Centers in the Western Conterminous United States," U.S. Geological Survey, Misc. Inv. Series, Maps I-1523 (1984).

Luft, S. J., "Mafic Lavas of Dome Mountain, Timber Mountain Caldera, Southern Nevada," U.S. Geological Survey Professional Paper 501d, 14-21 (1964).

Lutton, R. J., "Internal Structure of the Buckboard Mesa Basalt," Bulletin Volcanology 579-593 (1968).

Marsh, B. D, and R. G. Resmini, "Longevity of Magma in the Near Surface: A Study Using Crystal Sizes in Lavas," in Proceedings High Level Radioactive Waste Management Conference, Las Vegas, Nevada, (American Nuclear Society, La Grange Park, Illinois, 1992) pp. 2025-2032.

McFadden, P.L., R.T. Merril, M.W. Mcelhinny, and S. Lee "Reversals of the Earth's Magnetic Field and Temporal Variations of the Dynamo Families," Journal Geophysical Research 96, 3923-3933 (1991).

McGetchin T.R., M. Settle, and B.A. Chouet, " Cinder Cone Growth Modeled after Northeast Crater, Mount Etna, Sicily,” Journal Geophysical Research 79, 3257-3272 (1975).

McKee, E. H., "Tertiary Igneous Chronology of the Great Basin of Western United States Implications for Tectonic Models," Geological Society America Bulletin 82, 3497-3502 (1971).

Minor, S.A., D.A. Sawyer, R.R. Wahl, V.A. Frizzell, Jr., S.P. Schilling, R.G. Warren, P.P. Orkild, J.A. Coe, M.R. Hudson, R.J. Fleck, M.A. Lanphere, W.C. Swadley, and J.C. Cole, "Preliminary Geologic Map of the Pahute Mesa 30' X 60' Quadrangle, Nevada," U.S. Geological Survey, Open-File Report 93-229, (1993).

O'Connor, J. T., R. E. Anderson, and P. W. Lipman, "Geologic Map of the Thirsty Canyon Quadrangle, Nye County, Nevada,” U.S. Geological Survey Quadrangle Map, GQ-524 (1966).

Orkild, P. P., K. A. Sargent, and R. P. Snyder, "Geologic Map of Pahute Mesa, Nevada Test Site, and Vicinity, Nye County, Nevada,” Map I-567, U.S. Geological Survey, Washington, D.C., (1972).

Paces, J.B., S.A. Mahan, K.R. Ludwig, L.M. Kwak, L.A. Neymark, K.R. Simmons, L.D. Nealey, B.D. Marshall, and A. Walker, "Progress Report on Dating Quaternary Surficial Deposits," U.S. Geological Survey - Yucca Mountain Project Branch, 1995 Milestone report 3GCH510M (1995).

Perry, F. V., and B. M. Crowe, "Geochemical Evidence for Waning Magmatism and Polycyclic Volcanism at Crater Flat, Nevada," in Proceedings High Level Radioactive Waste Management: Conference Las Vegas, Nevada, (American Nuclear Society, La Grange Park, Illinois, 1992), pp. 23562365 .

Perry F.V. and K.T. Straub, "Geochemistry of the Lathrop Wells Volcanic Center," Los Alamos National Laboratory report LA-13113-MS (1996).

Ratcliff, C. D., Geissman, J. W., Perry, F. V., Crowe, B. M., and P. K. Zeitler, "Paleomagnetic Record of a Geomagnetic Field Reversal from Late Miocene Mafic Intrusions, Southern Nevada, Science 266, 412416 (1994). 
Poths, J., and B. M. Crowe, "Surface Exposure Ages and Noble Gas Components of Volcanic Units at Lathrop Wells Volcanic Center, Nevada," American Geophysical Union 73, 610 (1992).

Renault, C. E., "Hillslope Processes On Late Quaternary Cinder Cones of the Cima Volcanic Field, Eastern Mojave Desert, California," M.S. Thesis, University of New Mexico, Albuquerque, New Mexico, 121 pp. (1989).

Royek, T. M., "Soil Stratigraphic and Soil Geomorphic Studies in Eolian Deposits Mantling Late Pleistocene Basalt Flows, Cima Volcanic Field, Mojave Desert," California, M.S. Thesis, University of New Mexico Albuquerque, New Mexico, 109 pp. (1991).

Samson, SJ. D. and E. C. Alexander, "Calibration of the Interlaboratory ${ }^{40} \mathrm{Ar} /{ }^{39} \mathrm{Ar}$ Dating Standard, MMhb-1," Chemical Geology 66, 27-34 (1987).

Sargent, K. A., and J. H. Stewart, "Geologic Map of the Specter Range NW Quadrangle, Nye County, Nevada,” U.S. Geological Survey Geologic Quadrangle Map GQ-884, Scale 1:24,000 (1971).

Sargent, K. A., E. J. McKay, and B. C. Burchfiel, “Geologic Map of the Striped Hills,” Quadrangle Map GQ-882, Scale 1:24,000 (1970).

Scott, R. B., and J. Bonk, “Preliminary Geologic Map of Yucca Mountain, Nye County, Nevada,” U.S. Geological Survey Open-File Report 84-494, Scale 1:12,000 (1984).

Scott, R. B., G. D. Bath, V. J. Flanigan, D. B. Hoover, J. G. Rosenbaum, and R. W. Spengler, "Geological and Geophysical Evidence of Structures in Northwest-Trending Washes, Yucca Mountain, Southern Nevada, and their Possible Significance to a Nuclear Waste Repository in the Unsaturated Zone," U.S. Geological Survey Open-File Report 84-567, 23 pp. (1984).

Severinghaus, J., and T. Atwater, "Cenozoic Geometry and Thermal State of the Subducting Slabs Beneath Western North America," in Basin and Range Extensional Tectonics Near the Latitude of Las Vegas, Nevada, B. P. Wernicke, Ed., Geological Society America 176, 1-22 (1990).

Singer, B. S. and M. S. Pringle, "Age and Duration of the Matuyama-Brunhes Geomagnetic Polarity Reversal from ${ }^{40} \mathrm{Ar}-{ }^{39} \mathrm{Ar}$ Incremental Heating Analysis of Lavas," Earth and Planetary Science Letters 139, 47-61 (1996).

Sinnock, S., and R. G. Easterling, "Empirically Determined Uncertainty in Potassium-Argon Ages for Plio-Pleistocene Basalts from Crater Flat, Nye County, Nevada," Sandia National Laboratories, Albuquerque, New Mexico, Sand82-2441, 17 p. (1983).

Smith, E. I., D. L. Feuerbach, T. R. Nauman, and J. E. Faulds, "The Area of Most Recent Volcanism Near Yucca Mountain, Nevada: Implications for Volcanic Risk Assessment," in Proceedings, High-Level Radioactive Waste Management Conference, Las Vegas, Nevada, (American Nuclear Society, La Grange Park, Illinois, 1990) pp. 81-90.

Smith, R. L., and R. G. Luedke, "Potentially Active Volcanic Lineaments and Loci in Western Conterminous United States," in Explosive Volcanism: Inception, Evolution and Hazards, Geophysics Study Committee, National Research Council, (National Academy Press, Washington, D.C., 1984) p. 4766.

Snyder, W. S., W. R. Dickenson, and M. L. Silberman, "Tectonic Implications of Space-Time Patterns of Cenozoic Magmatism in the Western United States," Earth Planetary Science Letters 32, 91-106 (1976). 
Stewart, J. H., W. J. Moore, and I. Zietz, "East-West Patterns of Cenozoic Igneous Rocks, Aeromagnetic Anomalies, and Mineral Deposits, Nevada and Utah," Geological Society America 88, 67-77 (1977).

Stewart, J. H., and J. E. Carlson, "Generalized Maps Showing Distribution, Lithology, and Age of Cenozoic Igneous Rocks in the Western United States," Geological Society America 152, 263-264 (1978).

Taylor, J. R., An Introduction to Error Analysis: The Study of Uncertainties in Physical Measurements (University Science Books, Mill Valley, California, 1982), 270 pp.

Turrin, B. D., and D. E. Champion, ${ }^{* 40} \mathrm{Ar} /{ }^{39} \mathrm{Ar}$ Laser Fusion and K-Ar Ages from Lathrop Wells Nevada, and Cima, California: The Age of the Latest Volcanic Activity in the Yucca Mountain Area," in Proceedings High Level Radioactive Waste Management Conference, Las Vegas Nevada, (American Nuclear Society, La Grange Park, Illinois, 1991a) pp. 68-75.

Turrin, B. D., D. Champion, and R. J. Fleck, “" ${ }^{40} \mathrm{Ar}{ }^{39} \mathrm{Ar}$ Age of the Lathrop Wells Volcanic Center, Yucca Mountain, Nevada," Science 253, 654-657 (1991b).

Turrin, B. D. Oral Presentation to the United States Nuclear Waste Technical Review Board, Panel on Structural Geology and Geoengineering, Meeting on Volcanism, Las Vegas, Nevada (September 15, 1992, pp. 222-273).

Turrin, B. D., D. E. Champion, and R. J. Fleck, "Measuring the Age of the Lathrop Wells Volcanic Center at Yucca Mountain," Science 257, 556-558 (1992).

Turrin, B. D., D. E. Champion, R. J. Fleck, G. H. Curtis, and R. E. Drake, "K-Ar Ages and Paleomagnetic Directions from the Lathrop Wells Volcanic Center, Southwestern Nevada: Evidence for Polycyclic Volcanism" (in Press).

Valentine, G.A., B.M. Crowe, And F.V. Perry, "Physical Processes and Effects of Magmatism in the Yucca Mountain Region," in Proceedings High Level Radioactive Waste Management Conference Las Vegas, Nevada (American Nuclear Society, La Grange, Illinois, 1992), 3, pp. 2344-2355.

Valentine, G.A., K.R. Groves, C.W. Gable, F.V. Perry, and B.M. Crowe, "Effects of Magmatic Processes on the Potential Yucca Mountain Repository: Field and Computational Studies," in Proceedings: Site Characterization and Model Validation Focus '93 (American Nuclear Society La Grange Park, Illinois, 1993), pp. 167-173.

Vaniman, D. T., and B. M. Crowe, "Geology and Petrology of the Basalts of Crater Flat: Applications to Volcanic Risk Assessment for the Nevada Nuclear Waste Storage Investigations," Los Alamos National Laboratory Report LA-8845-MS, 67 pp. (1981).

Vaniman, D. T., B. M. Crowe, and E. S. Gladney, "Petrology and Geochemistry of Hawaiite Lavas from Crater Flat, Nevada," Contributions Mineralogy Petrology 80, 341-357 (1982).

Wells, S. G., J. C. Dohrenwend, L. D. McFadden, B. D. Turrin, and K. D. Mahrer, "Late Cenozoic Landscape Evolution on Flow Surfaces of the Cima Volcanic Field, Mojave Desert, California," Geological Society America 96, 1518-1529 (1985).

Wells, S. G., L. D. McFadden, C. E. Renault, B. D. Turrin, and B. M. Crowe, “A Geomorphic Assessment of Quaternary Volcanism in the Yucca Mountain Area, Nevada Test Site, Southern Nevada," Geological Society America Abstracts With Programs 20, 242 (1988). 
Wells, S. G., L. D. McFadden, C. E. Renault, and B. M. Crowe, "Geomorphic Assessment of Late Quaternary Volcanism in the Yucca Mountain Area, Southern Nevada: Implications for the Proposed High-Level Radioactive Waste Repository," Geology 18, 549-553 (1990).

Wells, S. G., L. D. McFadden, C. E. Renault, and B. M. Crowe, "Reply On Geomorphic Assessment of Late Quaternary Volcanism in the Yucca Mountain Area, Southern Nevada: Implications for the Proposed High-Level Radioactive Waste Repository," Geology, 19, 661-662 (1991).

Wells, S. G., B. M. Crowe, and L. D. McFadden, "Measuring the Age of the Lathrop Wells Volcanic Center at Yucca Mountain," Science 257, 555-556 (1992).

Wernicke, B., "Cenozoic Extensional Tectonics of the US Cordillera," in The Cordilleran Orogeny: Conterminous US, B.C. Burchfiel, M.L. Zoback, and P.W. Lipman, Eds. (Geological Society of America, Boulder, Colorado, 1992), pp. 553-582.

Wohletz, K. H., "Explosive Magma-Water Interactions: Thermodynamics Explosion Mechanisms, and Field Studies," Bulletin Volcanology 48, 245-264 (1986).

Whitney, J. W., and R.R. Shroba, "Reply On Geomorphic Assessment of Late Quaternary Volcanism in the Yucca Mountain Area, Southern Nevada: Implications for the Proposed High-Level Radioactive Waste Repository" Geology, 19, 661, (1991).

Wood, C. A., "Morphometric Analysis of Cinder Cone Degradation" Journal Volcanology Geothermal Research 8, 137-160 (1980).

Wood, C. A., and J. Kienle, Volcanoes of North America, (Cambridge University Press, Cambridge, 1990) $354 \mathrm{pp}$.

York, D., "Least Squares Fitting of a Straight line with Correlated Errors," Earth and Planetary Science Letters 5, 320-324 (1969).

Zreda, M. G., F. M. Phillips, P. W. Kubik, P. Sharma, and D. Elmore "Cosmogenic ${ }^{36} \mathrm{Cl}$ Dates for a Young Basaltic Eruption Complex, Lathrop Wells, Nevada," Geology 21, (1993). 
Appendix 2.1. $\quad{ }^{40} \mathrm{Ar} /{ }^{39} \mathrm{Ar}$ Analytical results from Lehigh University

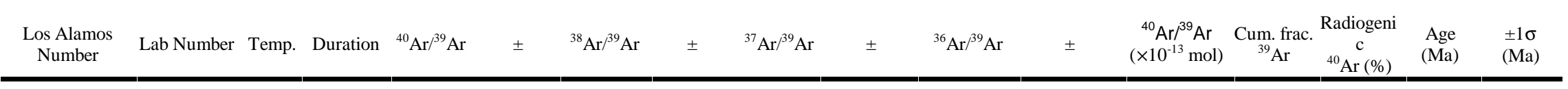

Total-Fusion Analyses:

\begin{tabular}{|c|c|c|c|c|c|c|c|c|c|c|c|c|c|c|c|c|}
\hline $\begin{array}{l}\text { MC7-18-94-1A } \\
\text { BMC }\end{array}$ & LU552-1 & 1350 & 10 & 305.55 & 1.0642 & 0.27489 & 0.001311 & 2.0118 & 0.0082027 & 1.0225 & 0.0044592 & 0.054812 & 0 & 1.14 & 1.929 & 0.92971 \\
\hline $\begin{array}{l}\text { RC7-18-94-4 } \\
\text { BMC }\end{array}$ & LU553-1 & 1350 & 10 & 224.11 & 0.65921 & 0.20175 & 0.001015 & 1.735 & 0.0091534 & 0.74827 & 0.0033683 & 0.072839 & 0 & 1.37 & 1.74 & 0.67059 \\
\hline $\begin{array}{l}\text { MC7-18-94-3B } \\
\text { BMC }\end{array}$ & LU554-1 & 1350 & 10 & 362.8 & 1.1747 & 0.26784 & 0.001155 & 1.4889 & 0.0056446 & 1.2138 & 0.0055718 & 0.039697 & 0 & 1.15 & 2.353 & 1.1317 \\
\hline BB1FVP & LU555-1 & 1350 & 10 & 106.8 & 0.18098 & 0.10312 & 0.000525 & 1.2323 & 0.0034806 & 0.34339 & 0.0012758 & 0.062035 & 0 & 5 & 3.036 & 0.23591 \\
\hline $\begin{array}{l}\text { CF6-17-94-1 } \\
\text { BMC }\end{array}$ & LU556-1 & 1300 & 10 & 164.21 & 0.46194 & 0.12453 & 0.000892 & 2.2432 & 0.0078439 & 0.53281 & 0.0022316 & 0.031923 & 0 & 4.09 & 3.88 & 0.45227 \\
\hline B4FVP & LU557-1 & 1350 & 10 & 319.79 & 1.0654 & 0.23826 & 0.001535 & 1.1115 & 0.0060636 & 1.0667 & 0.0047989 & 0.049063 & 0 & 1.45 & 2.601 & 0.99248 \\
\hline
\end{tabular}

Step-Heating Analyses:

\begin{tabular}{|c|c|c|c|c|c|c|c|c|c|c|c|c|c|c|c|c|}
\hline \multirow{2}{*}{$\begin{array}{l}\text { MC7-18-94-1A } \\
\text { BMC }\end{array}$} & LU552-2 & 500 & 10 & 184.2 & 0.26771 & 0.26579 & 0.000553 & 0.53834 & 0.0022903 & 0.62105 & 0.001983 & 0.0395 & 0.122 & 0.38 & 0.38 & 0.35226 \\
\hline & LU552-3 & 1350 & 10 & 18.263 & 0.024091 & 0.09271 & 0.000139 & 2.4627 & 0.0051172 & 0.055088 & 0.00019327 & 0.28528 & 1 & 11.57 & 1.168 & 0.03465 \\
\hline \multirow{2}{*}{$\begin{array}{l}\text { RC7-18-94-4 } \\
\text { BMC }\end{array}$} & LU553-2 & 500 & 10 & 148.81 & 0.24846 & 0.21668 & 0.000734 & 0.3225 & 0.0018772 & 0.49783 & 0.0017224 & 0.10856 & 0.194 & 1.14 & 0.941 & 0.31301 \\
\hline & LU553-3 & 1350 & 10 & 14.07 & 0.018386 & 0.05893 & 0.000134 & 2.3241 & 0.0047884 & 0.041352 & 0.00014675 & 0.45215 & 1 & 14.03 & 1.101 & 0.02692 \\
\hline \multirow{2}{*}{$\begin{array}{l}\text { MC7-18-94-3B } \\
\text { BMC }\end{array}$} & LU554-2 & 500 & 10 & 1535.6 & 5.8727 & 1.0708 & 0.005819 & 0.47036 & 0.0069634 & 5.1948 & 0.024859 & 0.005845 & 0.117 & 0.03 & 0.281 & 5.2824 \\
\hline & LU554-3 & 1350 & 10 & 20.381 & 0.033606 & 0.04825 & 0.000284 & 2.0213 & 0.0052565 & 0.062385 & 0.0002737 & 0.044066 & 1 & 9.59 & 1.16 & 0.04969 \\
\hline BB1FVP & LU555-2 & 500 & 10 & 656.51 & 3.8764 & 0.44401 & 0.003208 & 0.63024 & 0.006761 & 2.217 & 0.014578 & 0.014855 & 0.039805 & 0.21 & 0.789 & 3.2638 \\
\hline
\end{tabular}




\begin{tabular}{|c|c|c|c|c|c|c|c|c|c|c|c|c|c|c|c|c|}
\hline $\begin{array}{l}\text { Los Alamos } \\
\text { Number }\end{array}$ & Lab Number & Temp. & Duration & ${ }^{40} \mathrm{Ar} /{ }^{39} \mathrm{Ar}$ & \pm & ${ }^{38} \mathrm{Ar} /{ }^{39} \mathrm{Ar}$ & \pm & ${ }^{37} \mathrm{Ar} /{ }^{39} \mathrm{Ar}$ & \pm & ${ }^{36} \mathrm{Ar} /{ }^{39} \mathrm{Ar}$ & \pm & $\begin{array}{l}{ }^{40} \mathrm{Ar} r^{39} \mathrm{Ar} \\
\left(\times 10^{-13} \mathrm{~mol}\right)\end{array}$ & $\begin{array}{l}\text { Cum. frac. } \\
{ }^{39} \mathrm{Ar}\end{array}$ & $\begin{array}{c}\text { Radiogeni } \\
\mathrm{c} \\
{ }^{40} \mathrm{Ar}(\%)\end{array}$ & $\begin{array}{l}\text { Age } \\
(\mathrm{Ma})\end{array}$ & $\begin{array}{l} \pm 1 \sigma \\
(\mathrm{Ma})\end{array}$ \\
\hline & LU555-3 & 700 & 10 & 27.09 & 0.028161 & 0.03019 & 0.00011 & 1.0998 & 0.002073 & 0.072932 & 0.00025795 & 0.076986 & 0.2461 & 20.5 & 3.149 & 0.04947 \\
\hline & LU555-4 & 850 & 10 & 8.9194 & 0.010608 & 0.01672 & $6.80 \mathrm{E}-05$ & 0.90702 & 0.0018869 & 0.011731 & $6.86 \mathrm{E}-05$ & 0.14433 & 0.63286 & 60.86 & 3.093 & 0.0226 \\
\hline & LU555-5 & 1000 & 10 & 12.153 & 0.014367 & 0.04257 & 0.000163 & 0.99148 & 0.0020541 & 0.023026 & 0.00011972 & 0.093889 & 0.88445 & 43.72 & 3.038 & 0.02819 \\
\hline & LU555-6 & 1150 & 10 & 28.402 & 0.040574 & 0.1889 & 0.000408 & 3.8514 & 0.008208 & 0.078516 & 0.00035347 & 0.037719 & 0.98552 & 18.82 & 3.076 & 0.06574 \\
\hline & LU555-7 & 1350 & 10 & 27.858 & 0.10539 & 0.18814 & 0.001575 & 5.8562 & 0.024042 & 0.076212 & 0.00094705 & 0.0054007 & 1 & 16.85 & 3.239 & 0.16937 \\
\hline \multirow{10}{*}{$\begin{array}{l}\text { CF6-17-94-1 } \\
\text { BMC }\end{array}$} & LU556-2 & 500 & 10 & 1701.5 & 9.8621 & 1.1133 & 0.007599 & 0.44626 & 0.0064001 & 5.7375 & 0.038109 & 0.0066833 & 0.18172 & 0.36 & 3.425 & 8.409 \\
\hline & LU556-3 & 650 & 10 & 129.84 & 0.7305 & 0.09825 & 0.001063 & 1.7858 & 0.013016 & 0.41482 & 0.0029036 & 0.0044926 & 0.30387 & 5.32 & 4.143 & 0.63325 \\
\hline & LU556-4 & 750 & 10 & 31.024 & 0.10612 & 0.03022 & 0.000714 & 1.2654 & 0.0087322 & 0.073704 & 0.0013938 & 0.0034571 & 0.39787 & 22.02 & 5.236 & 0.24074 \\
\hline & LU556-5 & 850 & 10 & 20.994 & 0.066047 & 0.02099 & 0.000728 & 1.0677 & 0.0042443 & 0.027507 & 0.0008236 & 0.0059961 & 0.56091 & 46.75 & 7.26 & 0.14789 \\
\hline & LU556-6 & 900 & 10 & 28.295 & 0.12133 & 0.03172 & 0.001382 & 1.3425 & 0.0090914 & 0.063668 & 0.0020404 & 0.0023207 & 0.62401 & 20.89 & 5.372 & 0.34661 \\
\hline & LU556-7 & 950 & 10 & 13.273 & 0.096236 & 0.02429 & 0.001884 & 0.66273 & 0.019205 & -0.061967 & -0.000429 & 0.0022455 & 0.68506 & 99.75 & 17.709 & 0.13802 \\
\hline & LU556-8 & 1025 & 10 & 16.281 & 0.091796 & 0.02876 & 0.001461 & 1.0528 & 0.0097678 & 0.026634 & 0.0012802 & 0.0041598 & 0.79817 & 31.75 & 4.758 & 0.22037 \\
\hline & LU556-9 & 1075 & 10 & 17.166 & 0.08941 & 0.03766 & 0.001516 & 1.8643 & 0.0097192 & -0.015161 & $-6.19 \mathrm{E}-05$ & 0.0035133 & 0.8937 & 72.83 & 12.218 & 0.08913 \\
\hline & LU556-10 & 1150 & 10 & 19.615 & 0.14353 & 0.04569 & 0.001367 & 7.3071 & 0.054007 & 0.030938 & 0.0017602 & 0.0034445 & 0.98735 & 32.79 & 6.197 & 0.30497 \\
\hline & LU556-11 & 1350 & 10 & 41.739 & 1.0005 & 0.04466 & 0.010709 & 25.034 & 0.56909 & 0.10441 & 0.011466 & 0.00046474 & 1 & 7.1 & 7.243 & 1.981 \\
\hline \multirow[t]{3}{*}{ BB4FVP } & LU557-2 & 500 & 10 & 880.34 & 5.638 & 0.61123 & 0.005133 & 0.25329 & 0.0048278 & 2.9723 & 0.020501 & 0.0093432 & 0.05605 & 0.23 & 1.131 & 4.6425 \\
\hline & LU557-3 & 1350 & 10 & 24.998 & 0.052231 & 0.05199 & 0.000253 & 1.3121 & 0.0040845 & 0.065491 & 0.00030287 & 0.077094 & 0.51854 & 22.28 & 3.207 & 0.06118 \\
\hline & LU557-4 & 1350 & 10 & 25.75 & 0.031077 & 0.05271 & 0.000175 & 1.3124 & 0.0030556 & 0.068801 & 0.00031249 & 0.080258 & 1 & 20.81 & 3.08 & 0.05765 \\
\hline
\end{tabular}


Appendix 2.2. ${ }^{40} \mathrm{Ar} /{ }^{39} \mathrm{Ar}$ analytical results from New Mexico Bureau of Mines

\begin{tabular}{|c|c|c|c|c|c|c|c|c|c|c|}
\hline ID & $\begin{array}{l}\text { Temp } \\
\left({ }^{\circ} \mathrm{C}\right)\end{array}$ & ${ }^{40} \mathrm{Ar} /{ }^{39} \mathrm{Ar}$ & ${ }^{37} \mathrm{Ar} /{ }^{39} \mathrm{Ar}$ & $\begin{array}{c}{ }^{36} \mathrm{Ar} /{ }^{39} \mathrm{Ar} \\
\left(\mathrm{x} 10^{-3}\right)\end{array}$ & $\begin{array}{c}{ }^{39} \mathrm{Ar}_{\mathrm{K}} \\
\left(\mathrm{x} 10^{-15} \mathrm{~mol}\right)\end{array}$ & $\mathrm{K} / \mathrm{Ca}$ & $\begin{array}{l}{ }^{40} \mathrm{Ar}^{*} \\
(\%)\end{array}$ & $\begin{array}{l}{ }^{39} \mathrm{Ar} \\
(\%)\end{array}$ & $\begin{array}{l}\text { Age } \\
\text { (Ma) }\end{array}$ & $\begin{array}{l} \pm 2 \sigma \\
(\mathrm{Ma})\end{array}$ \\
\hline
\end{tabular}

\begin{tabular}{|c|c|c|c|c|c|c|c|c|c|c|}
\hline \multicolumn{11}{|c|}{ LW154FVPa whole rock, J=0.0000453, NM-39, Lab\#=5613-01 } \\
\hline A & 500 & 309.3 & 0.9465 & 1063 & 0.41 & 0.54 & -1.5 & 2.3 & -0.38 & 0.41 \\
\hline B & 600 & 73.20 & 1.717 & 246.8 & 1.29 & 0.30 & 0.5 & 9.3 & 0.032 & 0.077 \\
\hline $\mathrm{C}$ & 700 & 37.41 & 1.880 & 124.2 & 1.76 & 0.27 & 2.2 & 18.9 & 0.069 & 0.039 \\
\hline $\mathrm{D}$ & 775 & 22.34 & 1.216 & 73.20 & 2.86 & 0.42 & 3.5 & 34.5 & 0.065 & 0.024 \\
\hline $\mathrm{E}$ & 825 & 15.45 & 0.9549 & 48.50 & 2.63 & 0.53 & 7.5 & 48.9 & 0.095 & 0.021 \\
\hline $\mathrm{F}$ & 900 & 13.01 & 0.9364 & 41.40 & 3.12 & 0.54 & 6.3 & 65.9 & 0.067 & 0.019 \\
\hline $\mathrm{G}$ & 1000 & 15.93 & 1.028 & 50.20 & 1.52 & 0.50 & 7.1 & 74.2 & 0.093 & 0.030 \\
\hline $\mathrm{H}$ & 1100 & 26.79 & 1.291 & 88.40 & 1.40 & 0.40 & 2.8 & 81.8 & 0.060 & 0.036 \\
\hline I & 1200 & 59.12 & 2.520 & 198.8 & 1.04 & 0.20 & 0.9 & 87.5 & 0.046 & 0.072 \\
\hline $\mathrm{J}$ & 1300 & 75.58 & 8.370 & 252.6 & 0.64 & 0.061 & 2.1 & 91.0 & 0.13 & 0.10 \\
\hline $\mathrm{K}$ & 1650 & 67.47 & 7.692 & 227.4 & 1.65 & 0.066 & 1.2 & 100.0 & 0.068 & 0.069 \\
\hline \multicolumn{3}{|c|}{ total gas age } & $\mathrm{n}=11$ & & 18.31 & 0.39 & & & 0.061 & 0.048 \\
\hline
\end{tabular}

\section{LW154FVPb whole rock, J=0.0000456, NM-39, Lab\#=5614-01}

\begin{tabular}{ccccccccccc}
$\mathrm{A}$ & 500 & 328.7 & 0.9409 & 1123 & 0.30 & 0.54 & -1.0 & 1.6 & -0.27 & 0.48 \\
$\mathrm{~B}$ & 600 & 76.38 & 1.681 & 257.0 & 1.08 & 0.30 & 0.7 & 7.5 & 0.044 & 0.086 \\
$\mathrm{C}$ & 700 & 39.38 & 1.944 & 133.2 & 1.62 & 0.26 & 0.3 & 16.2 & 0.011 & 0.046 \\
$\mathrm{D}$ & 775 & 21.93 & 1.285 & 71.90 & 2.58 & 0.40 & 3.5 & 30.2 & 0.063 & 0.024 \\
$\mathrm{E}$ & 825 & 14.62 & 0.9744 & 46.40 & 2.80 & 0.52 & 6.6 & 45.3 & 0.079 & 0.018 \\
$\mathrm{~F}$ & 900 & 12.23 & 0.9269 & 38.70 & 3.28 & 0.55 & 6.9 & 63.1 & 0.070 & 0.015 \\
$\mathrm{G}$ & 1000 & 18.49 & 1.090 & 59.10 & 2.85 & 0.47 & 5.9 & 78.5 & 0.089 & 0.021 \\
$\mathrm{H}$ & 1100 & 41.72 & 1.355 & 132.6 & 0.54 & 0.38 & 6.3 & 81.5 & 0.215 & 0.083 \\
$\mathrm{I}$ & 1200 & 53.25 & 2.469 & 172.1 & 1.04 & 0.21 & 4.8 & 87.1 & 0.210 & 0.061 \\
$\mathrm{~J}$ & 1300 & 77.80 & 8.766 & 251.3 & 0.51 & 0.058 & 5.4 & 89.9 & 0.35 & 0.11 \\
$\mathrm{~K}$ & 1650 & 66.69 & 7.579 & 210.7 & 1.88 & 0.067 & 7.5 & 100.0 & 0.411 & 0.059 \\
& \multicolumn{1}{c}{ total gas age } & $\mathrm{n}=11$ & & 18.49 & 0.39 & & & 0.115 & 0.044
\end{tabular}

LW154FVPc whole rock, J=0.0000455, NM-39, Lab\#=5615-01

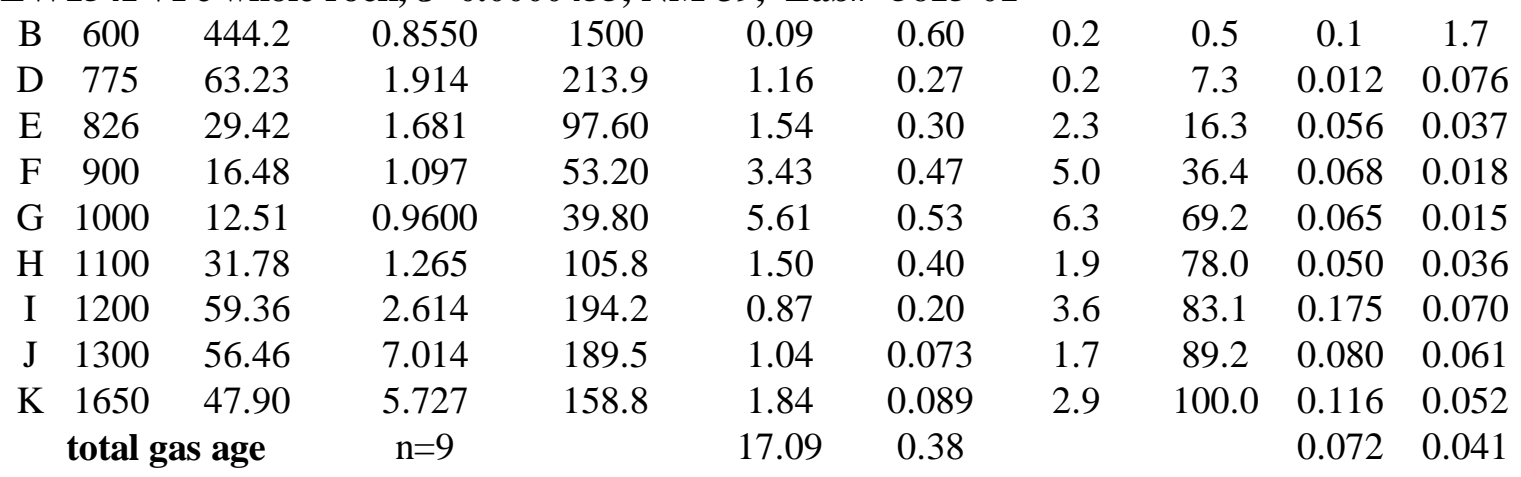

\section{LW154FVPd whole rock, J=0.0000455, NM-39, Lab\#=5616-01}

$\begin{array}{lllllllllll}\mathrm{D} & 775 & 50.77 & 1.877 & 167.4 & 2.03 & 0.27 & 2.8 & 11.6 & 0.117 & 0.045 \\ \mathrm{E} & 825 & 26.01 & 1.420 & 85.40 & 1.66 & 0.36 & 3.3 & 21.1 & 0.070 & 0.033 \\ \mathrm{~F} & 900 & 15.87 & 1.053 & 49.60 & 2.93 & 0.48 & 8.0 & 37.9 & 0.104 & 0.019\end{array}$




\begin{tabular}{|c|c|c|c|c|c|c|c|c|c|c|}
\hline ID & $\begin{array}{l}\text { Temp } \\
\left({ }^{\circ} \mathrm{C}\right)\end{array}$ & ${ }^{40} \mathrm{Ar} /{ }^{39} \mathrm{Ar}$ & ${ }^{37} \mathrm{Ar} /{ }^{39} \mathrm{Ar}$ & $\begin{array}{c}{ }^{36} \mathrm{Ar} /{ }^{39} \mathrm{Ar} \\
\left(\times 10^{-3}\right)\end{array}$ & $\begin{array}{c}{ }^{39} \mathrm{Ar}_{\mathrm{K}} \\
\left(\times 10^{-15} \mathrm{~mol}\right)\end{array}$ & $\mathrm{K} / \mathrm{Ca}$ & $\begin{array}{l}{ }^{40} \mathrm{Ar}^{*} \\
(\%)\end{array}$ & $\begin{array}{l}{ }^{39} \mathrm{Ar} \\
(\%)\end{array}$ & $\begin{array}{l}\text { Age } \\
\text { (Ma) }\end{array}$ & $\begin{array}{l} \pm 2 \sigma \\
(\mathrm{Ma})\end{array}$ \\
\hline G & 1000 & 11.69 & 0.9214 & 36.20 & 4.92 & 0.55 & 8.9 & 66.1 & 0.086 & 0.014 \\
\hline $\mathrm{H}$ & 1100 & 24.14 & 1.168 & 79.20 & 1.89 & 0.44 & 3.3 & 76.9 & 0.066 & 0.029 \\
\hline I & 1200 & 39.68 & 1.820 & 129.7 & 1.26 & 0.28 & 3.7 & 84.1 & 0.120 & 0.046 \\
\hline $\mathrm{J}$ & 1300 & 59.60 & 7.068 & 198.9 & 1.03 & 0.072 & 2.3 & 90.0 & 0.111 & 0.062 \\
\hline K & 1650 & 54.03 & 6.664 & 179.5 & 1.75 & 0.077 & 2.7 & 100.0 & 0.122 & 0.054 \\
\hline & \multicolumn{2}{|c|}{ total gas age } & $\mathrm{n}=8$ & & 17.48 & 0.38 & & & 0.096 & 0.031 \\
\hline
\end{tabular}

\section{LW154FVPe whole rock, J=0.0000460, NM-39, Lab\#=5616-02}

\begin{tabular}{|c|c|c|c|c|c|c|c|c|c|c|}
\hline A & 500 & 551.9 & 1.011 & 1880 & 0.12 & 0.50 & -0.6 & 0.7 & -0.3 & 1.4 \\
\hline B & 600 & 114.1 & 1.513 & 387.6 & 0.77 & 0.34 & -0.3 & 5.2 & -0.03 & 0.13 \\
\hline $\mathrm{C}$ & 700 & 51.43 & 1.977 & 172.1 & 0.93 & 0.26 & 1.3 & 10.6 & 0.058 & 0.069 \\
\hline $\mathrm{D}$ & 775 & 26.36 & 1.475 & 85.70 & 2.14 & 0.35 & 4.3 & 23.1 & 0.095 & 0.030 \\
\hline $\mathrm{E}$ & 825 & 17.19 & 1.051 & 54.50 & 2.42 & 0.49 & 6.6 & 37.2 & 0.094 & 0.023 \\
\hline $\mathrm{F}$ & 900 & 13.73 & 0.9353 & 44.00 & 3.03 & 0.55 & 5.7 & 54.8 & 0.065 & 0.016 \\
\hline $\mathrm{G}$ & 1000 & 14.16 & 0.9964 & 44.20 & 2.64 & 0.51 & 8.2 & 70.2 & 0.096 & 0.017 \\
\hline $\mathrm{H}$ & 1100 & 25.98 & 1.253 & 85.00 & 1.31 & 0.41 & 3.6 & 77.8 & 0.077 & 0.036 \\
\hline I & 1200 & 56.23 & 2.331 & 188.0 & 1.03 & 0.22 & 1.5 & 83.8 & 0.069 & 0.065 \\
\hline $\mathrm{J}$ & 1300 & 59.73 & 7.135 & 199.3 & 1.08 & 0.072 & 2.3 & 90.1 & 0.114 & 0.065 \\
\hline K & 1650 & 59.43 & 6.993 & 201.2 & 1.70 & 0.073 & 0.8 & 100.0 & 0.042 & 0.060 \\
\hline \multicolumn{3}{|c|}{ total gas age } & $\mathrm{n}=11$ & & 17.15 & 0.38 & & & 0.072 & 0.049 \\
\hline
\end{tabular}

\section{LW154FVPf whole rock, $\mathrm{J}=\mathbf{0 . 0 0 0 0 4 5 8 , ~ N M - 3 9 , ~ L a b \# = 5 6 1 6 - 0 3 ~}$}

$\begin{array}{ccccccccccc}\mathrm{A} & 500 & 408.8 & 0.9947 & 1395 & 0.27 & 0.51 & -0.8 & 1.4 & -0.27 & 0.66 \\ \mathrm{~B} & 600 & 70.39 & 1.452 & 238.3 & 1.21 & 0.35 & 0.1 & 7.8 & 0.006 & 0.074 \\ \mathrm{C} & 700 & 32.69 & 1.578 & 111.0 & 1.61 & 0.32 & -0.1 & 16.3 & -0.002 & 0.037 \\ \mathrm{D} & 775 & 19.69 & 1.160 & 63.40 & 2.72 & 0.44 & 5.2 & 30.8 & 0.084 & 0.023 \\ \mathrm{E} & 825 & 14.30 & 0.9181 & 45.20 & 2.46 & 0.56 & 6.9 & 43.8 & 0.082 & 0.018 \\ \mathrm{~F} & 900 & 11.82 & 0.8962 & 37.40 & 3.16 & 0.57 & 6.9 & 60.5 & 0.068 & 0.015 \\ \mathrm{G} & 1000 & 15.47 & 0.9740 & 49.10 & 2.08 & 0.52 & 6.5 & 71.6 & 0.083 & 0.021 \\ \mathrm{H} & 1100 & 24.88 & 1.173 & 82.20 & 1.29 & 0.43 & 2.7 & 78.4 & 0.055 & 0.035 \\ \mathrm{I} & 11200 & 49.04 & 2.066 & 163.3 & 1.29 & 0.25 & 1.9 & 85.2 & 0.076 & 0.057 \\ \mathrm{~J} & 1300 & 56.79 & 6.950 & 193.2 & 1.10 & 0.073 & 0.4 & 91.1 & 0.017 & 0.065 \\ \mathrm{~K} & 1650 & 58.15 & 7.135 & 196.4 & 1.68 & 0.072 & 1.1 & 100.0 & 0.053 & 0.063 \\ & \text { total gas age } & \mathrm{n}=11 & & 18.87 & 0.40 & & & 0.054 & 0.044\end{array}$

\section{LW157FVPa whole rock, J=0.0000746, NM-28, Lab\#=3127-01}

$\begin{array}{ccccccccccc}\text { A } & 500 & 276.6 & 0.4624 & 919.0 & 0.81 & 1.1 & 1.8 & 6.9 & 0.69 & 0.52 \\ \text { B } & 600 & 83.08 & 0.8987 & 265.7 & 1.39 & 0.57 & 5.5 & 18.6 & 0.62 & 0.17 \\ \text { C } & 700 & 39.28 & 1.376 & 115.5 & 1.97 & 0.37 & 13.3 & 35.3 & 0.704 & 0.074 \\ \text { D } & 775 & 17.12 & 1.365 & 47.90 & 1.97 & 0.37 & 17.8 & 52.0 & 0.410 & 0.042 \\ \text { E } & 825 & 9.226 & 1.191 & 26.70 & 1.70 & 0.43 & 15.1 & 66.5 & 0.188 & 0.030 \\ \text { F } & 900 & 7.837 & 1.184 & 22.80 & 1.75 & 0.43 & 14.9 & 81.3 & 0.157 & 0.027 \\ \text { G } & 1000 & 12.72 & 1.639 & 37.90 & 0.82 & 0.31 & 12.6 & 88.3 & 0.217 & 0.057 \\ \text { H } & 1100 & 18.35 & 3.006 & 61.90 & 0.39 & 0.17 & 1.5 & 91.6 & 0.036 & 0.121 \\ \text { I } & 1200 & 26.69 & 10.58 & 90.60 & 0.75 & 0.048 & 2.7 & 97.9 & 0.096 & 0.080\end{array}$




\begin{tabular}{|c|c|c|c|c|c|c|c|c|c|c|}
\hline ID & $\begin{array}{l}\text { Temp } \\
\left({ }^{\circ} \mathrm{C}\right)\end{array}$ & ${ }^{40} \mathrm{Ar} /{ }^{39} \mathrm{Ar}$ & ${ }^{37} \mathrm{Ar}{ }^{39} \mathrm{Ar}$ & $\begin{array}{c}{ }^{36} \mathrm{Ar} r^{39} \mathrm{Ar} \\
\left(\mathrm{x} 10^{-3}\right)\end{array}$ & $\begin{array}{c}{ }^{39} \mathrm{Ar}_{\mathrm{K}} \\
\left(\mathrm{x} 10^{-15} \mathrm{~mol}\right)\end{array}$ & $\mathrm{K} / \mathrm{Ca}$ & $\begin{array}{l}{ }^{40} \mathrm{Ar}^{*} \\
(\%)\end{array}$ & $\begin{array}{l}{ }^{39} \mathrm{Ar} \\
(\%)\end{array}$ & $\begin{array}{l}\text { Age } \\
\text { (Ma) }\end{array}$ & $\begin{array}{l} \pm 2 \sigma \\
\text { (Ma) }\end{array}$ \\
\hline $\mathrm{J}$ & $\begin{array}{l}1650 \\
\text { total \& }\end{array}$ & $\begin{array}{r}29.68 \\
\text { as age }\end{array}$ & $\begin{array}{l}7.246 \\
n=10\end{array}$ & 98.90 & $\begin{array}{c}0.25 \\
11.79\end{array}$ & $\begin{array}{c}0.070 \\
0.42\end{array}$ & 3.3 & 100.0 & $\begin{array}{l}0.13 \\
0.38\end{array}$ & $\begin{array}{c}0.18 \\
0.10\end{array}$ \\
\hline
\end{tabular}

\section{LW157FVPb whole rock, J=0.0000753, NM-28, Lab\#=3128-01}

\begin{tabular}{|c|c|c|c|c|c|c|c|c|c|c|}
\hline A & 500 & 581.7 & 0.4962 & 1994 & 0.97 & 1.0 & -1.3 & 6.8 & -1.0 & 1.1 \\
\hline B & 600 & 230.4 & 0.8907 & 778.2 & 1.67 & 0.57 & 0.2 & 18.4 & 0.06 & 0.41 \\
\hline $\mathrm{C}$ & 700 & 146.8 & 1.429 & 484.9 & 2.40 & 0.36 & 2.4 & 35.1 & 0.49 & 0.25 \\
\hline D & 775 & 89.35 & 1.367 & 289.3 & 2.30 & 0.37 & 4.4 & 51.1 & 0.54 & 0.16 \\
\hline $\mathrm{E}$ & 825 & 49.40 & 1.132 & 160.1 & 2.03 & 0.45 & 4.4 & 65.3 & 0.293 & 0.092 \\
\hline $\mathrm{F}$ & 900 & 28.88 & 1.153 & 89.60 & 1.89 & 0.44 & 8.5 & 78.5 & 0.335 & 0.059 \\
\hline $\mathrm{G}$ & 1000 & 30.13 & 1.600 & 93.90 & 1.11 & 0.32 & 8.2 & 86.2 & 0.337 & 0.079 \\
\hline $\mathrm{H}$ & 1100 & 31.68 & 2.899 & 100.3 & 0.49 & 0.18 & 7.1 & 89.6 & 0.31 & 0.10 \\
\hline I & 1200 & 49.93 & 8.448 & 162.7 & 1.18 & 0.060 & 5.0 & 97.8 & 0.34 & 0.10 \\
\hline $\mathrm{J}$ & 1650 & 41.67 & 7.606 & 137.9 & 0.32 & 0.067 & 3.6 & 100.0 & 0.20 & 0.16 \\
\hline & \multicolumn{2}{|c|}{ total gas age } & $\mathrm{n}=10$ & & 14.35 & 0.42 & & & 0.26 & 0.23 \\
\hline
\end{tabular}

\section{LW157FVPc whole rock, $J=0.0000752$, NM-28, Lab\#=3129-01}

\begin{tabular}{|c|c|c|c|c|c|c|c|c|c|c|}
\hline A & 500 & 224.5 & 0.5131 & 746.2 & 0.83 & 0.99 & 1.8 & 7.1 & 0.54 & 0.44 \\
\hline B & 600 & 88.74 & 0.9327 & 286.5 & 1.32 & 0.55 & 4.7 & 18.4 & 0.56 & 0.17 \\
\hline $\mathrm{C}$ & 700 & 56.32 & 1.435 & 177.8 & 1.93 & 0.36 & 6.8 & 34.8 & 0.52 & 0.10 \\
\hline $\mathrm{D}$ & 775 & 32.25 & 1.341 & 103.0 & 1.95 & 0.38 & 5.9 & 51.5 & 0.257 & 0.067 \\
\hline $\mathrm{E}$ & 825 & 18.65 & 1.151 & 57.40 & 1.70 & 0.44 & 9.4 & 66.0 & 0.239 & 0.047 \\
\hline $\mathrm{F}$ & 900 & 14.31 & 1.167 & 44.36 & 1.70 & 0.44 & 8.9 & 80.6 & 0.172 & 0.043 \\
\hline $\mathrm{G}$ & 1000 & 23.62 & 1.569 & 76.20 & 0.90 & 0.33 & 5.1 & 88.3 & 0.164 & 0.068 \\
\hline $\mathrm{H}$ & 1100 & 26.22 & 3.011 & 80.10 & 0.36 & 0.17 & 10.6 & 91.3 & 0.38 & 0.14 \\
\hline I & 1200 & 24.03 & 9.977 & 83.16 & 0.83 & 0.051 & 0.8 & 98.4 & 0.027 & 0.078 \\
\hline $\mathrm{J}$ & 1650 & 31.36 & 7.198 & 97.50 & 0.19 & 0.071 & 9.8 & 100.0 & 0.42 & 0.23 \\
\hline & \multicolumn{2}{|c|}{ total gas age } & $\mathrm{n}=10$ & & 11.71 & 0.42 & & & 0.32 & 0.11 \\
\hline
\end{tabular}

\section{LW157FVPd whole rock, J=0.0000743, NM-28, Lab\#=3130-01}

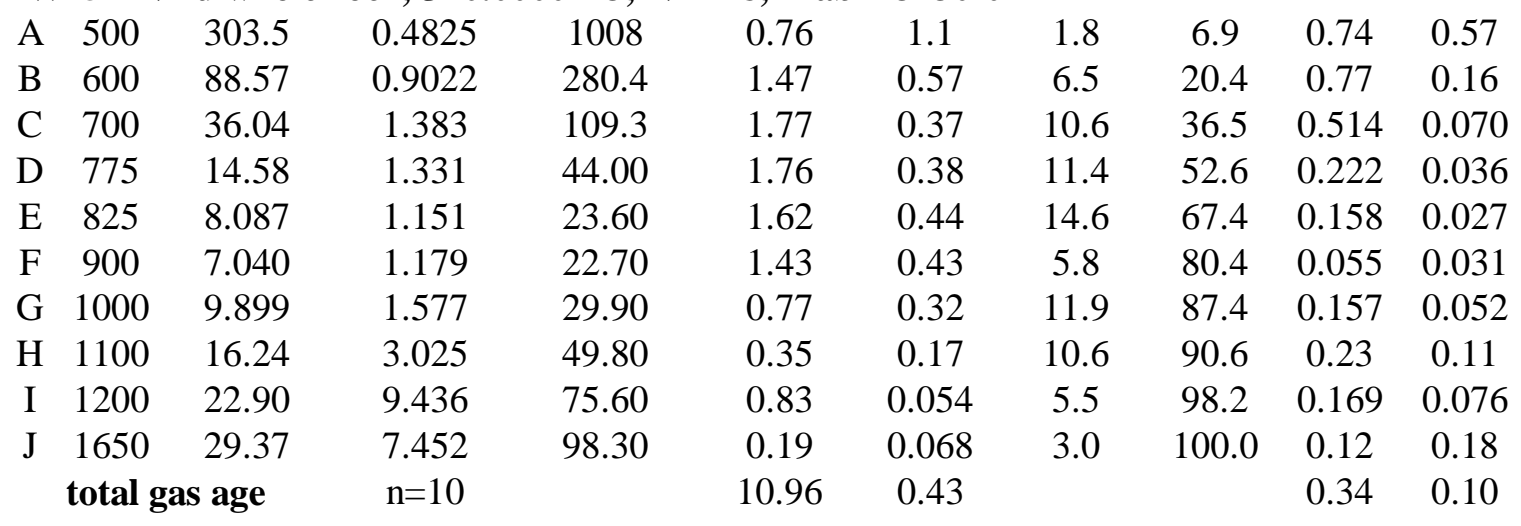

LW159FVPa whole rock, $J=0.0000453$, NM-39, Lab\#=5618-01
A 500
282.2
0.8504
973.9
0.27
0.60
$-2.0$
$\begin{array}{lll}1.8 & -0.46 & 0.42\end{array}$
$\begin{array}{lllll}\text { B } & 600 & 70.08 & 1.561 & 239.1\end{array}$
$\begin{array}{lll}0.95 & 0.33 & -0.7\end{array}$
$\begin{array}{lll}8.1 & -0.039 & 0.086\end{array}$ 


\begin{tabular}{|c|c|c|c|c|c|c|c|c|c|c|}
\hline ID & $\begin{array}{l}\text { Temp } \\
\left({ }^{\circ} \mathrm{C}\right)\end{array}$ & ${ }^{40} \mathrm{Ar} r^{39} \mathrm{Ar}$ & ${ }^{37} \mathrm{Ar} /{ }^{39} \mathrm{Ar}$ & $\begin{array}{c}{ }^{36} \mathrm{Ar} /{ }^{39} \mathrm{Ar} \\
\left(\mathrm{x} 10^{-3}\right)\end{array}$ & $\begin{array}{c}{ }^{39} \mathrm{Ar}_{\mathrm{K}} \\
\left(\mathrm{x} 10^{-15} \mathrm{~mol}\right)\end{array}$ & $\mathrm{K} / \mathrm{Ca}$ & $\begin{array}{l}{ }^{40} \mathrm{Ar}^{*} \\
(\%)\end{array}$ & $\begin{array}{l}{ }^{39} \mathrm{Ar} \\
(\%)\end{array}$ & $\begin{array}{l}\text { Age } \\
(\mathrm{Ma})\end{array}$ & $\begin{array}{l} \pm 2 \sigma \\
(\mathrm{Ma})\end{array}$ \\
\hline $\mathrm{C}$ & 700 & 33.87 & 1.883 & 112.5 & 1.19 & 0.27 & 2.2 & 16.1 & 0.060 & 0.049 \\
\hline D & 775 & 15.92 & 1.309 & 51.20 & 2.13 & 0.39 & 5.4 & 30.3 & 0.071 & 0.021 \\
\hline $\mathrm{E}$ & 825 & 10.13 & 0.9907 & 31.20 & 2.15 & 0.52 & 9.6 & 44.7 & 0.079 & 0.018 \\
\hline $\mathrm{F}$ & 900 & 8.195 & 0.9339 & 25.10 & 2.68 & 0.55 & 10.0 & 62.6 & 0.067 & 0.015 \\
\hline $\mathrm{G}$ & 1000 & 11.15 & 1.096 & 34.70 & 2.56 & 0.47 & 8.5 & 79.7 & 0.077 & 0.014 \\
\hline $\mathrm{H}$ & 1100 & 22.40 & 1.452 & 75.30 & 0.54 & 0.35 & 1.1 & 83.3 & 0.021 & 0.055 \\
\hline I & 1200 & 35.97 & 2.470 & 123.6 & 0.74 & 0.21 & -1.1 & 88.2 & -0.032 & 0.059 \\
\hline $\mathrm{J}$ & 1300 & 59.81 & 9.735 & 206.5 & 0.20 & 0.052 & -0.8 & 89.6 & -0.04 & 0.17 \\
\hline $\mathrm{K}$ & 1650 & 42.21 & 7.839 & 142.7 & 1.56 & 0.065 & 1.5 & 100.0 & 0.050 & 0.047 \\
\hline & \multicolumn{2}{|c|}{ total gas age } & $\mathrm{n}=11$ & & 14.98 & 0.39 & & & 0.044 & 0.040 \\
\hline
\end{tabular}

\section{LW159FVPb whole rock, J=0.0000456, NM-39, Lab\#=5618-02}

\begin{tabular}{ccccccccccc}
$\mathrm{A}$ & 500 & 247.6 & 0.9487 & 847.9 & 0.32 & 0.54 & -1.2 & 2.1 & -0.24 & 0.31 \\
$\mathrm{~B}$ & 600 & 61.95 & 1.631 & 206.8 & 1.09 & 0.31 & 1.5 & 9.4 & 0.078 & 0.066 \\
$\mathrm{C}$ & 700 & 29.51 & 1.806 & 97.20 & 1.50 & 0.28 & 3.0 & 19.3 & 0.073 & 0.044 \\
$\mathrm{D}$ & 775 & 14.05 & 1.217 & 44.80 & 2.28 & 0.42 & 6.2 & 34.4 & 0.071 & 0.022 \\
$\mathrm{E}$ & 825 & 9.348 & 0.9577 & 27.90 & 2.18 & 0.53 & 12.2 & 48.9 & 0.094 & 0.018 \\
$\mathrm{~F}$ & 900 & 7.931 & 0.9393 & 24.20 & 2.75 & 0.54 & 10.4 & 67.1 & 0.068 & 0.013 \\
$\mathrm{G}$ & 1000 & 15.08 & 1.013 & 48.99 & 1.01 & 0.50 & 4.3 & 73.8 & 0.054 & 0.033 \\
$\mathrm{H}$ & 1100 & 17.08 & 1.317 & 56.02 & 1.21 & 0.39 & 3.5 & 81.8 & 0.050 & 0.027 \\
$\mathrm{I}$ & 1200 & 32.70 & 2.333 & 107.6 & 0.82 & 0.22 & 3.3 & 87.3 & 0.088 & 0.048 \\
$\mathrm{~J}$ & 1300 & 52.73 & 8.542 & 177.7 & 0.23 & 0.060 & 1.6 & 88.8 & 0.07 & 0.15 \\
$\mathrm{~K}$ & 1650 & 41.98 & 7.548 & 141.0 & 1.68 & 0.068 & 2.1 & 100.0 & 0.073 & 0.047 \\
& \multicolumn{1}{l}{ total gas age } & $\mathrm{n}=11$ & & 15.07 & 0.39 & & & 0.066 & 0.039
\end{tabular}

\section{LW159FVPc whole rock, J=0.0000455, NM-39, Lab\#=5618-03}

\begin{tabular}{ccccccccccc}
$\mathrm{A}$ & 500 & 229.9 & 0.9612 & 780.1 & 0.33 & 0.53 & -0.2 & 2.4 & -0.05 & 0.31 \\
$\mathrm{~B}$ & 600 & 66.72 & 1.626 & 224.4 & 1.09 & 0.31 & 0.7 & 10.5 & 0.041 & 0.076 \\
$\mathrm{C}$ & 700 & 34.36 & 1.888 & 115.8 & 0.73 & 0.27 & 0.8 & 15.9 & 0.022 & 0.062 \\
$\mathrm{D}$ & 775 & 17.75 & 1.403 & 56.97 & 1.58 & 0.36 & 5.6 & 27.6 & 0.082 & 0.025 \\
$\mathrm{E}$ & 825 & 12.40 & 1.084 & 41.20 & 0.92 & 0.47 & 2.2 & 34.4 & 0.022 & 0.033 \\
$\mathrm{~F}$ & 900 & 8.799 & 0.9407 & 27.33 & 2.86 & 0.54 & 8.8 & 55.7 & 0.063 & 0.014 \\
$\mathrm{G}$ & 1000 & 9.209 & 0.9657 & 28.67 & 1.82 & 0.53 & 8.5 & 69.2 & 0.065 & 0.019 \\
$\mathrm{H}$ & 1100 & 15.63 & 1.258 & 49.70 & 1.39 & 0.41 & 6.5 & 79.5 & 0.084 & 0.026 \\
$\mathrm{I}$ & 1200 & 32.30 & 2.312 & 104.7 & 0.76 & 0.22 & 4.7 & 85.1 & 0.124 & 0.051 \\
$\mathrm{~J}$ & 1300 & 47.60 & 7.282 & 154.0 & 0.29 & 0.070 & 5.5 & 87.3 & 0.22 & 0.11 \\
$\mathrm{~K}$ & 1650 & 40.44 & 7.068 & 136.7 & 1.71 & 0.072 & 1.4 & 100.0 & 0.046 & 0.045 \\
& \multicolumn{1}{c}{ total gas age } & $\mathrm{n}=11$ & & 13.48 & 0.38 & & & 0.063 & 0.042
\end{tabular}

\section{LW159FVPd whole rock, J=0.0000452, NM-39, Lab\#=5619-01}

$\begin{array}{ccccccccccc}\text { A } & 500 & 273.6 & 1.084 & 926.6 & 0.34 & 0.47 & 0.0 & 2.1 & -0.01 & 0.36 \\ \text { B } & 600 & 68.98 & 1.673 & 233.4 & 1.20 & 0.30 & 0.2 & 9.4 & 0.010 & 0.070 \\ \text { C } & 700 & 33.09 & 1.836 & 110.0 & 1.40 & 0.28 & 2.1 & 18.0 & 0.057 & 0.043 \\ \text { D } & 775 & 16.01 & 1.260 & 51.30 & 2.30 & 0.40 & 5.9 & 32.1 & 0.077 & 0.020 \\ \text { E } & 825 & 10.27 & 0.9754 & 31.40 & 2.20 & 0.52 & 10.3 & 45.7 & 0.086 & 0.019\end{array}$




\begin{tabular}{|c|c|c|c|c|c|c|c|c|c|c|}
\hline $\mathrm{ID}$ & $\begin{array}{l}\text { Temp } \\
\left({ }^{\circ} \mathrm{C}\right)\end{array}$ & ${ }^{40} \mathrm{Ar} /{ }^{39} \mathrm{Ar}$ & ${ }^{37} \mathrm{Ar} r{ }^{39} \mathrm{Ar}$ & $\begin{array}{c}{ }^{36} \mathrm{Ar} r^{39} \mathrm{Ar} \\
\left(\times 10^{-3}\right)\end{array}$ & $\begin{array}{c}{ }^{39} \mathrm{Ar}_{\mathrm{K}} \\
\left(\times 10^{-15} \mathrm{~mol}\right)\end{array}$ & $\mathrm{K} / \mathrm{Ca}$ & $\begin{array}{l}{ }^{40} \mathrm{Ar} * \\
(\%)\end{array}$ & $\begin{array}{l}{ }^{39} \mathrm{Ar} \\
(\%)\end{array}$ & $\begin{array}{l}\text { Age } \\
(\mathrm{Ma})\end{array}$ & $\begin{array}{l} \pm 2 \sigma \\
(\mathrm{Ma})\end{array}$ \\
\hline $\mathrm{F}$ & 900 & 8.317 & 0.9334 & 25.20 & 2.91 & 0.55 & 10.9 & 63.5 & 0.074 & 0.013 \\
\hline G & 1000 & 11.61 & 1.061 & 36.19 & 2.27 & 0.48 & 8.4 & 77.5 & 0.079 & 0.017 \\
\hline $\mathrm{H}$ & 1100 & 21.88 & 1.382 & 69.90 & 0.56 & 0.37 & 5.9 & 80.9 & 0.106 & 0.046 \\
\hline I & 1200 & 30.42 & 2.270 & 99.20 & 0.87 & 0.22 & 4.2 & 86.3 & 0.104 & 0.055 \\
\hline $\mathrm{J}$ & 1300 & 41.87 & 6.751 & 142.2 & 0.41 & 0.076 & 0.8 & 88.8 & 0.029 & 0.084 \\
\hline K & 1650 & 40.67 & 7.064 & 136.7 & 1.82 & 0.072 & 2.0 & 100.0 & 0.067 & 0.042 \\
\hline & \multicolumn{2}{|r|}{ as age } & $\mathrm{n}=11$ & & 16.27 & 0.38 & & & 0.070 & 0.038 \\
\hline
\end{tabular}

LW159FVPe whole rock, J=0.000046, NM-39, Lab\#=5619-02

\begin{tabular}{|c|c|c|c|c|c|c|c|c|c|c|}
\hline A & 500 & 362.0 & 1.096 & 1228 & 0.27 & 0.47 & -0.2 & 1.8 & -0.06 & 0.48 \\
\hline B & 600 & 70.27 & 1.670 & 233.6 & 1.10 & 0.31 & 1.9 & 9.0 & 0.110 & 0.070 \\
\hline $\mathrm{C}$ & 700 & 37.38 & 1.836 & 124.8 & 1.20 & 0.28 & 1.7 & 16.9 & 0.052 & 0.046 \\
\hline $\mathrm{D}$ & 775 & 17.09 & 1.299 & 54.90 & 2.09 & 0.39 & 5.5 & 30.6 & 0.077 & 0.020 \\
\hline $\mathrm{E}$ & 825 & 10.51 & 0.9752 & 32.30 & 2.24 & 0.52 & 9.6 & 45.3 & 0.084 & 0.015 \\
\hline $\mathrm{F}$ & 900 & 8.511 & 0.9232 & 25.20 & 2.49 & 0.55 & 12.9 & 61.7 & 0.091 & 0.015 \\
\hline G & 1000 & 10.08 & 0.9778 & 31.30 & 1.26 & 0.52 & 8.8 & 69.9 & 0.074 & 0.021 \\
\hline $\mathrm{H}$ & 1100 & 17.34 & 1.258 & 56.40 & 1.19 & 0.41 & 4.3 & 77.7 & 0.062 & 0.032 \\
\hline I & 1200 & 30.14 & 2.280 & 99.30 & 0.88 & 0.22 & 3.1 & 83.5 & 0.078 & 0.053 \\
\hline $\mathrm{J}$ & 1300 & 36.66 & 5.755 & 124.4 & 0.53 & 0.089 & 0.8 & 87.0 & 0.025 & 0.079 \\
\hline $\mathrm{K}$ & 1650 & 37.39 & 6.322 & 124.3 & 1.99 & 0.081 & 3.0 & 100.0 & 0.092 & 0.045 \\
\hline \multicolumn{3}{|c|}{ total gas age } & $\mathrm{n}=11$ & & 15.24 & 0.37 & & & 0.077 & 0.041 \\
\hline
\end{tabular}

\section{LW159FVPf whole rock, $J=0.000046$, NM-39, Lab\#=5619-03}

\begin{tabular}{ccccccccccc}
$\mathrm{A}$ & 500 & 305.8 & 0.8444 & 1046 & 0.53 & 0.60 & -1.1 & 3.2 & -0.28 & 0.45 \\
$\mathrm{~B}$ & 600 & 80.51 & 1.548 & 276.5 & 0.96 & 0.33 & -1.4 & 9.2 & -0.09 & 0.10 \\
$\mathrm{C}$ & 700 & 33.99 & 1.843 & 111.6 & 2.01 & 0.28 & 3.3 & 21.6 & 0.093 & 0.042 \\
$\mathrm{D}$ & 775 & 16.84 & 1.292 & 52.80 & 2.36 & 0.40 & 7.8 & 36.1 & 0.110 & 0.030 \\
$\mathrm{E}$ & 825 & 12.34 & 1.038 & 40.33 & 1.99 & 0.49 & 3.9 & 48.5 & 0.040 & 0.025 \\
$\mathrm{~F}$ & 900 & 13.20 & 1.033 & 41.70 & 1.94 & 0.49 & 7.0 & 60.4 & 0.076 & 0.024 \\
$\mathrm{G}$ & 1000 & 18.47 & 1.156 & 60.75 & 1.49 & 0.44 & 3.1 & 69.6 & 0.048 & 0.039 \\
$\mathrm{H}$ & 1100 & 31.11 & 1.754 & 102.1 & 0.99 & 0.29 & 3.3 & 75.8 & 0.087 & 0.049 \\
$\mathrm{I}$ & 1200 & 24.89 & 3.362 & 82.10 & 1.22 & 0.15 & 3.4 & 83.3 & 0.071 & 0.050 \\
$\mathrm{~J}$ & 1300 & 20.53 & 3.946 & 68.62 & 2.11 & 0.13 & 2.6 & 96.3 & 0.044 & 0.033 \\
$\mathrm{~K}$ & 1650 & 58.99 & 5.203 & 197.2 & 0.60 & 0.098 & 1.9 & 100.0 & 0.09 & 0.12 \\
& \multicolumn{1}{c}{ total gas age } & $\mathrm{n}=11$ & & 16.19 & 0.34 & & & 0.051 & 0.056
\end{tabular}

LW160FVPa whole rock, $J=0.0000454$, NM-39, Lab\#=5598-01

$\begin{array}{ccccccccccc}\text { B } & 600 & 733.5 & 3.483 & 2456 & 0.22 & 0.15 & 1.1 & 1.1 & 0.7 & 2.7 \\ \text { C } & 700 & 86.46 & 2.639 & 284.8 & 1.33 & 0.19 & 2.8 & 7.6 & 0.20 & 0.13 \\ \text { D } & 775 & 51.11 & 1.531 & 164.8 & 1.17 & 0.33 & 4.9 & 13.3 & 0.205 & 0.071 \\ \text { E } & 825 & 23.07 & 0.7841 & 73.99 & 2.10 & 0.65 & 5.4 & 23.5 & 0.102 & 0.033 \\ \text { F } & 900 & 15.48 & 0.6880 & 48.70 & 3.20 & 0.74 & 7.3 & 39.1 & 0.093 & 0.021 \\ \text { G } & 1000 & 17.26 & 0.7679 & 56.00 & 4.73 & 0.66 & 4.3 & 62.1 & 0.061 & 0.021 \\ \text { H } & 11100 & 36.38 & 1.026 & 119.8 & 2.51 & 0.50 & 2.9 & 74.3 & 0.086 & 0.046 \\ \text { I } & 1200 & 78.54 & 1.565 & 261.9 & 1.53 & 0.33 & 1.6 & 81.8 & 0.101 & 0.097\end{array}$




\begin{tabular}{|c|c|c|c|c|c|c|c|c|c|c|}
\hline ID & $\begin{array}{l}\text { Temp } \\
\left({ }^{\circ} \mathrm{C}\right)\end{array}$ & ${ }^{40} \mathrm{Ar} /{ }^{39} \mathrm{Ar}$ & ${ }^{37} \mathrm{Ar}{ }^{39} \mathrm{Ar}$ & $\begin{array}{c}{ }^{36} \mathrm{Ar} r^{39} \mathrm{Ar} \\
\left(\times 10^{-3}\right)\end{array}$ & $\begin{array}{c}{ }^{39} \mathrm{Ar}_{\mathrm{K}} \\
\left(\times 10^{-15} \mathrm{~mol}\right)\end{array}$ & $\mathrm{K} / \mathrm{Ca}$ & $\begin{array}{l}{ }^{40} \mathrm{Ar}^{*} \\
(\%)\end{array}$ & $\begin{array}{l}{ }^{39} \mathrm{Ar} \\
(\%)\end{array}$ & $\begin{array}{l}\text { Age } \\
(\mathrm{Ma})\end{array}$ & $\begin{array}{l} \pm 2 \sigma \\
(\mathrm{Ma})\end{array}$ \\
\hline $\mathrm{J}$ & 1300 & 99.66 & 5.924 & 330.5 & 3.02 & 0.086 & 2.4 & 96.4 & 0.20 & 0.11 \\
\hline $\mathrm{K}$ & 1650 & 126.3 & 4.207 & 420.6 & 0.73 & 0.12 & 1.9 & 100.0 & 0.19 & 0.18 \\
\hline & \multicolumn{2}{|c|}{ total gas age } & $\mathrm{n}=10$ & & 20.54 & 0.47 & & & 0.125 & 0.087 \\
\hline
\end{tabular}

\section{LW160FVPb whole rock, J=0.0000457, NM-39, Lab\#=5599-01}

\begin{tabular}{|c|c|c|c|c|c|c|c|c|c|c|}
\hline B & 600 & 299.4 & 3.314 & 1000 & 0.70 & 0.15 & 1.4 & 3.2 & 0.34 & 0.39 \\
\hline $\mathrm{C}$ & 700 & 67.87 & 2.230 & 222.6 & 1.42 & 0.23 & 3.3 & 9.8 & 0.185 & 0.085 \\
\hline $\mathrm{D}$ & 775 & 31.96 & 0.9736 & 103.8 & 2.47 & 0.52 & 4.2 & 21.1 & 0.111 & 0.038 \\
\hline $\mathrm{E}$ & 825 & 19.96 & 0.6972 & 63.90 & 2.45 & 0.73 & 5.5 & 32.4 & 0.091 & 0.027 \\
\hline $\mathrm{F}$ & 900 & 16.83 & 0.7150 & 52.10 & 3.41 & 0.71 & 8.7 & 48.0 & 0.121 & 0.024 \\
\hline G & 1000 & 24.62 & 0.8348 & 80.30 & 4.28 & 0.61 & 3.8 & 67.6 & 0.077 & 0.029 \\
\hline $\mathrm{H}$ & 1100 & 45.53 & 1.093 & 148.4 & 1.42 & 0.47 & 3.8 & 74.1 & 0.143 & 0.067 \\
\hline I & 1200 & 86.51 & 1.678 & 286.5 & 1.60 & 0.30 & 2.2 & 81.5 & 0.16 & 0.10 \\
\hline $\mathrm{J}$ & 1300 & 104.1 & 5.976 & 344.4 & 2.79 & 0.085 & 2.6 & 94.3 & 0.23 & 0.12 \\
\hline K & 1650 & 92.20 & 3.522 & 290.6 & 1.24 & 0.14 & 7.1 & 100.0 & 0.54 & 0.11 \\
\hline \multicolumn{3}{|c|}{ total gas age } & $\mathrm{n}=10$ & & 21.78 & 0.47 & & & 0.161 & 0.068 \\
\hline
\end{tabular}

\section{LW160FVPc whole rock, J=0.0000456, NM-39, Lab\#=5600-01}

\begin{tabular}{|c|c|c|c|c|c|c|c|c|c|c|}
\hline $\mathrm{B}$ & 600 & 254.8 & 3.359 & 842.6 & 0.57 & 0.15 & 2.4 & 2.9 & 0.50 & 0.33 \\
\hline $\mathrm{C}$ & 700 & 52.68 & 2.385 & 175.4 & 1.09 & 0.21 & 1.9 & 8.3 & 0.084 & 0.082 \\
\hline $\mathrm{D}$ & 775 & 24.88 & 1.041 & 80.10 & 2.18 & 0.49 & 5.1 & 19.2 & 0.105 & 0.035 \\
\hline $\mathrm{E}$ & 825 & 13.53 & 0.7208 & 43.00 & 2.38 & 0.71 & 6.2 & 31.1 & 0.070 & 0.023 \\
\hline $\mathrm{F}$ & 900 & 12.07 & 0.7088 & 37.50 & 3.10 & 0.72 & 8.4 & 46.5 & 0.083 & 0.026 \\
\hline $\mathrm{G}$ & 1000 & 19.83 & 0.8372 & 63.60 & 4.01 & 0.61 & 5.4 & 66.6 & 0.089 & 0.029 \\
\hline $\mathrm{H}$ & 1100 & 39.58 & 1.140 & 130.4 & 1.58 & 0.45 & 2.8 & 74.4 & 0.091 & 0.055 \\
\hline I & 1200 & 76.88 & 1.681 & 254.5 & 1.20 & 0.30 & 2.3 & 80.4 & 0.146 & 0.098 \\
\hline $\mathrm{J}$ & 1300 & 95.41 & 5.840 & 318.0 & 2.88 & 0.087 & 1.9 & 94.8 & 0.15 & 0.11 \\
\hline K & 1650 & 104.4 & 4.865 & 350.1 & 1.04 & 0.10 & 1.2 & 100.0 & 0.11 & 0.13 \\
\hline \multicolumn{3}{|c|}{ total gas age } & $\mathrm{n}=10$ & & 20.03 & 0.46 & & & 0.113 & 0.063 \\
\hline
\end{tabular}

\section{LW160FVPd whole rock, J=0.0000453, NM-39, Lab\#=5601-01}

\begin{tabular}{ccccccccccc}
$\mathrm{B}$ & 600 & 231.2 & 3.272 & 771.8 & 0.65 & 0.16 & 1.5 & 3.4 & 0.28 & 0.22 \\
$\mathrm{C}$ & 700 & 58.93 & 2.233 & 193.7 & 1.29 & 0.23 & 3.1 & 10.1 & 0.151 & 0.064 \\
$\mathrm{D}$ & 775 & 25.38 & 0.9390 & 81.63 & 2.36 & 0.54 & 5.1 & 22.3 & 0.106 & 0.030 \\
$\mathrm{E}$ & 825 & 16.74 & 0.6988 & 54.00 & 2.41 & 0.73 & 4.9 & 34.8 & 0.067 & 0.023 \\
$\mathrm{~F}$ & 900 & 13.60 & 0.7197 & 43.20 & 3.22 & 0.71 & 6.3 & 51.5 & 0.071 & 0.017 \\
$\mathrm{G}$ & 1000 & 22.89 & 0.8672 & 74.60 & 3.71 & 0.59 & 3.9 & 70.8 & 0.072 & 0.022 \\
$\mathrm{H}$ & 1100 & 41.76 & 1.130 & 136.0 & 0.88 & 0.45 & 3.9 & 75.3 & 0.134 & 0.061 \\
$\mathrm{I}$ & 1200 & 76.33 & 1.722 & 253.7 & 1.52 & 0.30 & 1.9 & 83.2 & 0.120 & 0.067 \\
$\mathrm{~J}$ & 1300 & 106.3 & 6.383 & 355.9 & 2.00 & 0.080 & 1.5 & 93.6 & 0.130 & 0.085 \\
$\mathrm{~K}$ & 1650 & 109.1 & 5.173 & 363.3 & 1.23 & 0.099 & 1.9 & 100.0 & 0.17 & 0.11 \\
& \multicolumn{1}{c}{ total gas age } & $\mathrm{n}=10$ & & 19.28 & 0.47 & & & 0.107 & 0.049
\end{tabular}




\begin{tabular}{|c|c|c|c|c|c|c|c|c|c|c|}
\hline ID & $\begin{array}{l}\text { Temp } \\
\left({ }^{\circ} \mathrm{C}\right)\end{array}$ & ${ }^{40} \mathrm{Ar} /{ }^{39} \mathrm{Ar}$ & ${ }^{37} \mathrm{Ar} /{ }^{39} \mathrm{Ar}$ & $\begin{array}{c}{ }^{36} \mathrm{Ar} /{ }^{39} \mathrm{Ar} \\
\left(\mathrm{x} 10^{-3}\right)\end{array}$ & $\begin{array}{c}{ }^{39} \mathrm{Ar}_{\mathrm{K}} \\
\left(\mathrm{x} 10^{-15} \mathrm{~mol}\right)\end{array}$ & $\mathrm{K} / \mathrm{Ca}$ & $\begin{array}{l}{ }^{40} \mathrm{Ar}^{*} \\
(\%)\end{array}$ & $\begin{array}{l}{ }^{39} \mathrm{Ar} \\
(\%)\end{array}$ & $\begin{array}{l}\text { Age } \\
(\mathrm{Ma})\end{array}$ & $\begin{array}{l} \pm 2 \sigma \\
\text { (Ma) }\end{array}$ \\
\hline
\end{tabular}

LW160FVPe whole rock, J=0.0000456, NM-39, Lab\#=5602-01

\begin{tabular}{ccccccccccc}
$\mathrm{D}$ & 775 & 136.5 & 3.311 & 459.1 & 0.58 & 0.15 & 0.8 & 3.1 & 0.09 & 0.16 \\
$\mathrm{E}$ & 825 & 36.09 & 1.957 & 116.3 & 1.20 & 0.26 & 5.1 & 9.6 & 0.152 & 0.045 \\
$\mathrm{~F}$ & 900 & 16.55 & 0.8751 & 52.00 & 2.20 & 0.58 & 7.5 & 21.4 & 0.102 & 0.022 \\
$\mathrm{G}$ & 1000 & 12.71 & 0.7314 & 39.70 & 6.73 & 0.70 & 7.9 & 57.6 & 0.083 & 0.012 \\
$\mathrm{H}$ & 1100 & 25.05 & 0.9425 & 80.00 & 2.34 & 0.54 & 5.9 & 70.2 & 0.121 & 0.027 \\
$\mathrm{I}$ & 11200 & 51.93 & 1.580 & 172.3 & 1.77 & 0.32 & 2.1 & 79.8 & 0.091 & 0.052 \\
$\mathrm{~J}$ & 1300 & 74.41 & 5.575 & 248.4 & 2.12 & 0.092 & 1.9 & 91.2 & 0.117 & 0.064 \\
$\mathrm{~K}$ & 1650 & 65.27 & 3.911 & 214.3 & 1.64 & 0.13 & 3.4 & 100.0 & 0.183 & 0.061 \\
& \multicolumn{1}{c}{ total gas age } & $\mathrm{n}=8$ & & 18.56 & 0.46 & & & 0.108 & 0.036
\end{tabular}

LW160FVPf whole rock, J=0.0000457, NM-39, Lab\#=5603-01

\begin{tabular}{|c|c|c|c|c|c|c|c|c|c|c|}
\hline B & 600 & 130.5 & 3.273 & 433.6 & 0.74 & 0.16 & 2.0 & 3.6 & 0.21 & 0.15 \\
\hline $\mathrm{C}$ & 700 & 36.37 & 2.144 & 120.2 & 1.46 & 0.24 & 2.8 & 10.6 & 0.083 & 0.047 \\
\hline $\mathrm{D}$ & 775 & 17.93 & 0.9178 & 56.50 & 2.43 & 0.56 & 7.0 & 22.3 & 0.104 & 0.022 \\
\hline $\mathrm{E}$ & 825 & 11.68 & 0.7040 & 37.30 & 2.60 & 0.72 & 6.0 & 34.9 & 0.057 & 0.019 \\
\hline $\mathrm{F}$ & 900 & 11.28 & 0.7238 & 35.20 & 3.39 & 0.70 & 8.1 & 51.2 & 0.075 & 0.014 \\
\hline G & 1000 & 19.17 & 0.8822 & 62.80 & 3.93 & 0.58 & 3.4 & 70.2 & 0.053 & 0.019 \\
\hline $\mathrm{H}$ & 1100 & 37.08 & 1.134 & 121.5 & 0.99 & 0.45 & 3.3 & 75.0 & 0.102 & 0.055 \\
\hline I & 1200 & 75.76 & 1.646 & 251.4 & 1.33 & 0.31 & 2.1 & 81.4 & 0.131 & 0.076 \\
\hline $\mathrm{J}$ & 1300 & 86.57 & 6.139 & 288.1 & 2.16 & 0.083 & 2.2 & 91.8 & 0.156 & 0.073 \\
\hline K & 1650 & 82.01 & 4.917 & 271.3 & 1.70 & 0.10 & 2.7 & 100.0 & 0.182 & 0.078 \\
\hline \multicolumn{3}{|c|}{ total gas age } & $\mathrm{n}=10$ & & 20.72 & 0.46 & & & 0.100 & 0.041 \\
\hline
\end{tabular}

LW169FVPa whole rock, J=0.0000655, NM-48, Lab\#=6462-01

\begin{tabular}{|c|c|c|c|c|c|c|c|c|c|c|}
\hline A & 500 & 613.5 & 2.835 & 2053 & 1.22 & 0.18 & 1.2 & 2.6 & 0.9 & 1.3 \\
\hline B & 600 & 72.29 & 2.628 & 242.5 & 1.88 & 0.19 & 1.1 & 6.7 & 0.09 & 0.16 \\
\hline $\mathrm{C}$ & 700 & 26.79 & 1.397 & 89.70 & 5.58 & 0.37 & 1.4 & 18.8 & 0.045 & 0.053 \\
\hline D & 775 & 14.74 & 0.6871 & 47.10 & 7.83 & 0.74 & 5.7 & 35.8 & 0.099 & 0.030 \\
\hline$E$ & 825 & 10.17 & 0.6673 & 32.10 & 7.70 & 0.76 & 6.8 & 52.4 & 0.082 & 0.021 \\
\hline $\mathrm{F}$ & 900 & 12.36 & 0.9029 & 39.70 & 9.27 & 0.57 & 5.6 & 72.5 & 0.082 & 0.026 \\
\hline $\mathrm{G}$ & 1000 & 27.70 & 1.146 & 94.50 & 2.63 & 0.45 & -0.5 & 78.2 & -0.018 & 0.068 \\
\hline $\mathrm{H}$ & 1100 & 50.82 & 1.398 & 170.7 & 3.76 & 0.36 & 0.9 & 86.4 & 0.05 & 0.10 \\
\hline I & 1200 & 66.34 & 5.202 & 221.4 & 5.04 & 0.098 & 1.9 & 97.3 & 0.15 & 0.12 \\
\hline $\mathbf{J}$ & 1300 & 119.1 & 8.788 & 398.9 & 1.26 & 0.058 & 1.5 & 100.0 & 0.22 & 0.27 \\
\hline & \multicolumn{2}{|c|}{ total gas age } & $\mathrm{n}=10$ & & 46.17 & 0.49 & & & 0.105 & 0.094 \\
\hline
\end{tabular}

LW169FVPb whole rock, J=0.0000660, NM-48, Lab\#=6463-01

$\begin{array}{ccccccccccc}\mathrm{C} & 700 & 452.0 & 2.359 & 1524 & 0.31 & 0.22 & 0.4 & 0.7 & 0.2 & 1.4 \\ \mathrm{D} & 775 & 63.73 & 2.506 & 216.7 & 3.97 & 0.20 & -0.2 & 9.2 & -0.02 & 0.13 \\ \mathrm{E} & 825 & 16.10 & 0.8847 & 52.40 & 10.95 & 0.58 & 4.1 & 32.9 & 0.078 & 0.031 \\ \mathrm{~F} & 900 & 9.522 & 0.7104 & 29.90 & 14.93 & 0.72 & 7.6 & 65.1 & 0.087 & 0.017 \\ \mathrm{G} & 1000 & 19.55 & 1.055 & 64.40 & 6.26 & 0.48 & 2.9 & 78.6 & 0.068 & 0.043 \\ \mathrm{H} & 1100 & 46.08 & 1.335 & 154.0 & 3.57 & 0.38 & 1.4 & 86.3 & 0.08 & 0.10 \\ \mathrm{I} & 1200 & 58.01 & 5.270 & 195.1 & 5.13 & 0.097 & 1.2 & 97.4 & 0.09 & 0.10\end{array}$




\begin{tabular}{|c|c|c|c|c|c|c|c|c|c|c|}
\hline $\mathrm{ID}$ & $\begin{array}{l}\text { Temp } \\
\left({ }^{\circ} \mathrm{C}\right)\end{array}$ & ${ }^{40} \mathrm{Ar} /{ }^{39} \mathrm{Ar}$ & ${ }^{37} \mathrm{Ar}{ }^{39} \mathrm{Ar}$ & $\begin{array}{c}{ }^{36} \mathrm{Ar} /^{39} \mathrm{Ar} \\
\left(\times 10^{-3}\right)\end{array}$ & $\begin{array}{c}{ }^{39} \mathrm{Ar}_{\mathrm{K}} \\
\left(\times 10^{-15} \mathrm{~mol}\right)\end{array}$ & $\mathrm{K} / \mathrm{Ca}$ & $\begin{array}{l}{ }^{40} \mathrm{Ar}^{*} \\
(\%)\end{array}$ & $\begin{array}{l}{ }^{39} \mathrm{Ar} \\
(\%)\end{array}$ & $\begin{array}{l}\text { Age } \\
\text { (Ma) }\end{array}$ & $\begin{array}{l} \pm 2 \sigma \\
(\mathrm{Ma})\end{array}$ \\
\hline $\mathrm{J}$ & $\begin{array}{l}1300 \\
\text { total } g\end{array}$ & $\begin{array}{l}114.6 \\
\text { as age }\end{array}$ & $\begin{array}{c}8.774 \\
n=8\end{array}$ & 387.3 & $\begin{array}{c}1.22 \\
46.34\end{array}$ & $\begin{array}{c}0.058 \\
0.49\end{array}$ & 0.7 & 100.0 & $\begin{array}{c}0.09 \\
0.074\end{array}$ & $\begin{array}{c}0.25 \\
0.065\end{array}$ \\
\hline
\end{tabular}

LW169FVPc whole rock, J=0.0000655, NM-48, Lab\#=6464-01

\begin{tabular}{|c|c|c|c|c|c|c|c|c|c|c|}
\hline $\mathrm{C}$ & 700 & 437.3 & 2.605 & 1477 & 0.10 & 0.20 & 0.3 & 0.8 & 0.1 & 2.4 \\
\hline D & 775 & 62.10 & 2.526 & 213.7 & 1.04 & 0.20 & -1.4 & 8.9 & -0.10 & 0.15 \\
\hline $\mathrm{E}$ & 825 & 16.63 & 0.9186 & 55.10 & 2.83 & 0.56 & 2.4 & 31.2 & 0.047 & 0.054 \\
\hline $\mathrm{F}$ & 900 & 9.728 & 0.7130 & 31.10 & 3.56 & 0.72 & 5.7 & 59.3 & 0.066 & 0.034 \\
\hline $\mathrm{G}$ & 1000 & 17.07 & 1.023 & 55.90 & 2.07 & 0.50 & 3.5 & 75.6 & 0.072 & 0.053 \\
\hline $\mathrm{H}$ & 1100 & 45.13 & 1.343 & 150.3 & 1.16 & 0.38 & 1.8 & 84.8 & 0.10 & 0.13 \\
\hline I & 1200 & 59.98 & 5.039 & 198.4 & 1.53 & 0.10 & 2.9 & 96.8 & 0.20 & 0.14 \\
\hline $\mathbf{J}$ & 1300 & 119.8 & 8.390 & 411.7 & 0.41 & 0.061 & -1.0 & 100.0 & -0.15 & 0.35 \\
\hline & \multicolumn{2}{|c|}{ total gas age } & $n=8$ & & 12.69 & 0.47 & & & 0.06 & 0.10 \\
\hline
\end{tabular}

\section{LW169FVPd whole rock, J=0.0000654, NM-48, Lab\#=6465-01}

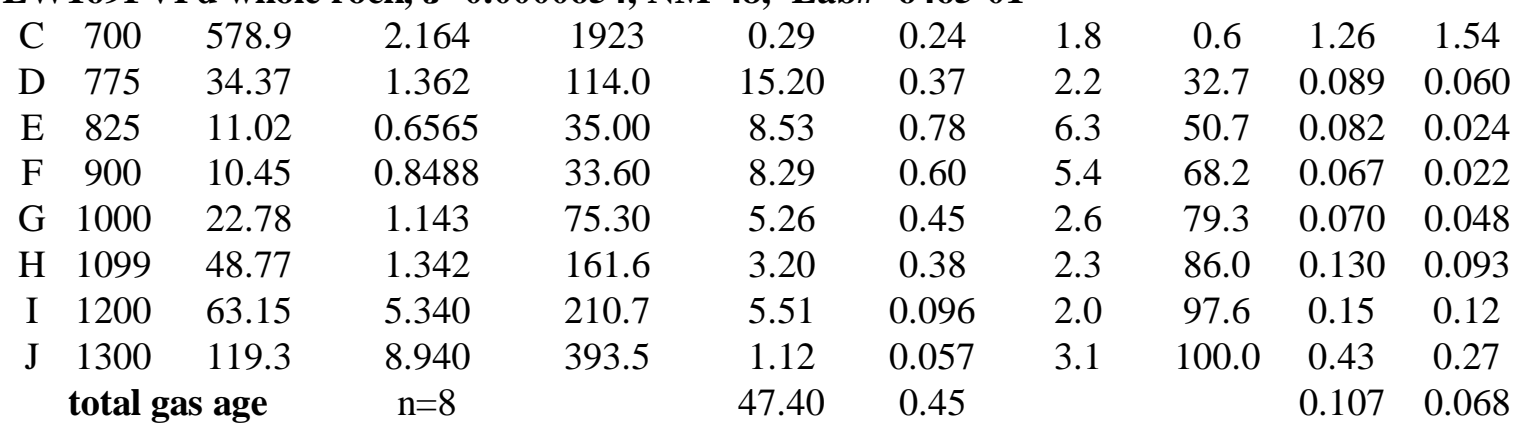

\section{LW169FVPe whole rock, J=0.0000660, NM-48, Lab\#=6466-01}

\begin{tabular}{|c|c|c|c|c|c|c|c|c|c|}
\hline $\mathrm{C}$ & 450.1 & 2.706 & 1511 & 0.13 & 0.19 & 0.8 & 0.7 & 0.4 & 2.6 \\
\hline $\mathrm{D}$ & 59.84 & 2.448 & 203.6 & 1.61 & 0.21 & -0.3 & 9.6 & -0.02 & 0.13 \\
\hline $\mathrm{E}$ & 13.80 & 0.7958 & 44.90 & 6.70 & 0.64 & 4.1 & 46.6 & 0.068 & 0.027 \\
\hline $\mathrm{F}$ & 10.42 & 0.7844 & 35.70 & 3.48 & 0.65 & -0.9 & 65.8 & -0.011 & 0.033 \\
\hline $\mathrm{G}$ & 20.96 & 1.110 & 68.60 & 2.20 & 0.46 & 3.6 & 77.9 & 0.090 & 0.061 \\
\hline $\mathrm{H}$ & 47.02 & 1.297 & 153.7 & 1.29 & 0.39 & 3.6 & 85.0 & 0.20 & 0.12 \\
\hline I & 60.47 & 4.951 & 203.8 & 2.15 & 0.10 & 1.0 & 96.9 & 0.07 & 0.13 \\
\hline $\mathrm{J}$ & 112.4 & 8.568 & 373.1 & 0.57 & 0.060 & 2.4 & 100.0 & 0.33 & 0.34 \\
\hline & total gas age & $n=8$ & & 18.14 & 0.48 & & & 0.069 & 0.089 \\
\hline
\end{tabular}

\section{LW169FVPf whole rock, J=0.0000654, NM-48, Lab\#=6467-01}

$\begin{array}{ccccccccccc}\text { C } & 700 & 495.5 & 2.636 & 1639 & 0.09 & 0.19 & 2.3 & 0.7 & 1.3 & 3.4 \\ \mathrm{D} & 775 & 67.56 & 2.536 & 228.6 & 0.97 & 0.20 & 0.3 & 9.1 & 0.02 & 0.18 \\ \mathrm{E} & 825 & 15.29 & 0.7950 & 50.00 & 4.29 & 0.64 & 3.6 & 45.8 & 0.065 & 0.039 \\ \mathrm{~F} & 900 & 12.52 & 0.7920 & 40.40 & 2.40 & 0.64 & 5.0 & 66.3 & 0.074 & 0.040 \\ \mathrm{G} & 1000 & 21.50 & 1.121 & 71.03 & 1.43 & 0.46 & 2.7 & 78.6 & 0.068 & 0.074 \\ \mathrm{H} & 1100 & 48.87 & 1.293 & 165.3 & 0.81 & 0.39 & 0.2 & 85.5 & 0.01 & 0.14 \\ \mathrm{I} & 1200 & 64.08 & 4.948 & 217.7 & 1.31 & 0.10 & 0.2 & 96.7 & 0.01 & 0.15 \\ \mathrm{~J} & 1300 & 111.1 & 8.497 & 367.3 & 0.38 & 0.060 & 2.9 & 100.0 & 0.38 & 0.43\end{array}$




\begin{tabular}{|c|c|c|c|c|c|c|c|c|c|c|}
\hline $\mathrm{ID}$ & $\begin{array}{l}\text { Temp } \\
\left({ }^{\circ} \mathrm{C}\right)\end{array}$ & ${ }^{40} \mathrm{Ar} /{ }^{39} \mathrm{Ar}$ & ${ }^{37} \mathrm{Ar} /{ }^{39} \mathrm{Ar}$ & $\begin{array}{c}{ }^{36} \mathrm{Ar} /{ }^{39} \mathrm{Ar} \\
\left(\times 10^{-3}\right)\end{array}$ & $\begin{array}{c}{ }^{39} \mathrm{Ar}_{\mathrm{K}} \\
\left(\times 10^{-15} \mathrm{~mol}\right)\end{array}$ & $\mathrm{K} / \mathrm{Ca}$ & $\begin{array}{l}{ }^{40} \mathrm{Ar}^{*} \\
(\%)\end{array}$ & $\begin{array}{l}{ }^{39} \mathrm{Ar} \\
(\%)\end{array}$ & $\begin{array}{l}\text { Age } \\
\text { (Ma) }\end{array}$ & $\begin{array}{l} \pm 2 \sigma \\
\text { (Ma) }\end{array}$ \\
\hline & total g & age & $\mathrm{n}=8$ & & 11.67 & 0.48 & & & 0.07 & 0.11 \\
\hline
\end{tabular}

\section{RC1FVP whole rock, J=0.0000696, NM-22, Lab\#=2305-01}

\begin{tabular}{|c|c|c|c|c|c|c|c|c|c|c|}
\hline $\mathrm{AA}$ & 500 & 303.1 & 0.4529 & 1013 & 0.77 & 1.1 & 1.3 & 5.5 & 0.48 & 0.61 \\
\hline A & 600 & 40.05 & 0.9836 & 104.3 & 1.17 & 0.52 & 23.1 & 13.8 & 1.16 & 0.10 \\
\hline B & 700 & 22.71 & 1.455 & 47.60 & 1.67 & 0.35 & 38.5 & 25.7 & 1.099 & 0.048 \\
\hline $\mathrm{C}$ & 775 & 17.46 & 1.370 & 29.60 & 1.30 & 0.37 & 50.3 & 34.9 & 1.104 & 0.054 \\
\hline $\mathrm{D}$ & 825 & 15.85 & 1.253 & 25.89 & 1.10 & 0.41 & 52.2 & 42.8 & 1.040 & 0.058 \\
\hline E & 900 & 15.94 & 1.377 & 27.40 & 1.21 & 0.37 & 49.8 & 51.4 & 0.997 & 0.063 \\
\hline $\mathrm{F}$ & 1000 & 21.51 & 1.568 & 44.20 & 1.07 & 0.33 & 39.7 & 59.0 & 1.072 & 0.079 \\
\hline G & 1100 & 27.56 & 1.797 & 63.70 & 1.36 & 0.28 & 32.1 & 68.7 & 1.112 & 0.073 \\
\hline $\mathrm{H}$ & 1200 & 38.93 & 3.477 & 102.7 & 1.36 & 0.15 & 22.6 & 78.4 & 1.108 & 0.091 \\
\hline I & 1300 & 30.60 & 4.110 & 72.40 & 1.67 & 0.12 & 31.0 & 90.2 & 1.196 & 0.067 \\
\hline $\mathrm{J}$ & 1650 & 34.51 & 2.696 & 59.40 & 1.37 & 0.19 & 49.7 & 100.0 & 2.157 & 0.067 \\
\hline \multicolumn{3}{|c|}{ total gas age } & $\mathrm{n}=11$ & & 14.06 & 0.34 & & & 1.17 & 0.10 \\
\hline
\end{tabular}

RC4FVP whole rock, J=0.0000677, NM-22, Lab\#=2317-01

\begin{tabular}{|c|c|c|c|c|c|c|c|c|c|c|}
\hline $\mathrm{AA}$ & 500 & 7112 & 0.6441 & 24444 & 0.23 & 0.79 & -1.6 & 1.8 & -14 & 27 \\
\hline A & 600 & 1605 & 1.034 & 5458 & 0.35 & 0.49 & -0.5 & 4.6 & -1.0 & 4.2 \\
\hline B & 700 & 602.7 & 1.799 & 2035 & 0.81 & 0.28 & 0.2 & 11.1 & 0.2 & 1.2 \\
\hline $\mathrm{C}$ & 775 & 303.2 & 1.758 & 994.9 & 1.03 & 0.29 & 3.1 & 19.3 & 1.14 & 0.57 \\
\hline D & 825 & 196.8 & 1.397 & 637.5 & 0.78 & 0.37 & 4.3 & 25.6 & 1.04 & 0.40 \\
\hline $\mathrm{E}$ & 900 & 108.7 & 1.134 & 339.3 & 1.79 & 0.45 & 7.8 & 39.9 & 1.04 & 0.19 \\
\hline $\mathrm{F}$ & 1000 & 84.15 & 1.208 & 252.7 & 1.82 & 0.42 & 11.3 & 54.4 & 1.17 & 0.15 \\
\hline G & 1100 & 153.5 & 1.784 & 491.3 & 1.18 & 0.29 & 5.5 & 63.8 & 1.03 & 0.29 \\
\hline $\mathrm{H}$ & 1200 & 299.5 & 2.171 & 997.2 & 1.36 & 0.23 & 1.7 & 74.6 & 0.61 & 0.53 \\
\hline I & 1300 & 218.6 & 3.893 & 713.6 & 2.10 & 0.13 & 3.7 & 91.4 & 0.98 & 0.37 \\
\hline $\mathrm{J}$ & 1650 & 188.1 & 3.984 & 617.3 & 1.08 & 0.13 & 3.2 & 100.0 & 0.74 & 0.36 \\
\hline \multicolumn{3}{|c|}{ total gas age } & $\mathrm{n}=11$ & & 12.53 & 0.30 & & & 0.61 & 0.98 \\
\hline
\end{tabular}

LW149FVP whole rock, $J=0.0000692$, NM-22, Lab\#=2314-01

$\begin{array}{ccccccccccc}\mathrm{AA} & 500 & 270.2 & 0.1748 & 913.6 & 1.15 & 2.9 & 0.1 & 6.6 & 0.02 & 0.54 \\ \mathrm{~A} & 600 & 124.4 & 0.2987 & 400.6 & 0.60 & 1.7 & 4.8 & 10.1 & 0.75 & 0.29 \\ \mathrm{~B} & 700 & 85.18 & 0.7370 & 271.1 & 2.43 & 0.69 & 6.0 & 24.0 & 0.63 & 0.15 \\ \mathrm{C} & 775 & 58.34 & 1.291 & 174.4 & 1.38 & 0.40 & 11.8 & 32.0 & 0.86 & 0.11 \\ \mathrm{D} & 825 & 43.24 & 1.342 & 120.7 & 0.81 & 0.38 & 17.7 & 36.7 & 0.96 & 0.12 \\ \mathrm{E} & 900 & 37.41 & 1.273 & 100.4 & 1.95 & 0.40 & 20.9 & 47.9 & 0.977 & 0.075 \\ \mathrm{~F} & 1000 & 37.49 & 1.509 & 102.0 & 2.09 & 0.34 & 19.9 & 60.0 & 0.930 & 0.067 \\ \mathrm{G} & 1100 & 49.39 & 2.071 & 145.3 & 1.11 & 0.25 & 13.3 & 66.3 & 0.82 & 0.12 \\ \mathrm{H} & 1200 & 65.41 & 1.936 & 197.1 & 2.27 & 0.26 & 11.2 & 79.4 & 0.91 & 0.12 \\ \mathrm{I} & 1300 & 58.73 & 4.151 & 174.8 & 2.97 & 0.12 & 12.6 & 96.5 & 0.924 & 0.098 \\ \mathrm{~J} & 1650 & 58.37 & 6.582 & 177.9 & 0.61 & 0.078 & 10.8 & 100.0 & 0.79 & 0.16 \\ & \text { total gas age } & \mathrm{n}=11 & & 17.38 & 0.56 & & & 0.810 & 0.141\end{array}$




\begin{tabular}{|c|c|c|c|c|c|c|c|c|c|c|}
\hline ID & $\begin{array}{l}\text { Temp } \\
\left({ }^{\circ} \mathrm{C}\right)\end{array}$ & ${ }^{40} \mathrm{Ar} /{ }^{39} \mathrm{Ar}$ & ${ }^{37} \mathrm{Ar} /{ }^{39} \mathrm{Ar}$ & $\begin{array}{c}{ }^{36} \mathrm{Ar} /{ }^{39} \mathrm{Ar} \\
\left(\mathrm{x} 10^{-3}\right)\end{array}$ & $\begin{array}{c}{ }^{39} \mathrm{Ar}_{\mathrm{K}} \\
\left(\mathrm{x} 10^{-15} \mathrm{~mol}\right)\end{array}$ & $\mathrm{K} / \mathrm{Ca}$ & $\begin{array}{l}{ }^{40} \mathrm{Ar} * \\
(\%)\end{array}$ & $\begin{array}{l}{ }^{39} \mathrm{Ar} \\
(\%)\end{array}$ & $\begin{array}{l}\text { Age } \\
(\mathrm{Ma})\end{array}$ & $\begin{array}{l} \pm 2 \sigma \\
(\mathrm{Ma})\end{array}$ \\
\hline
\end{tabular}

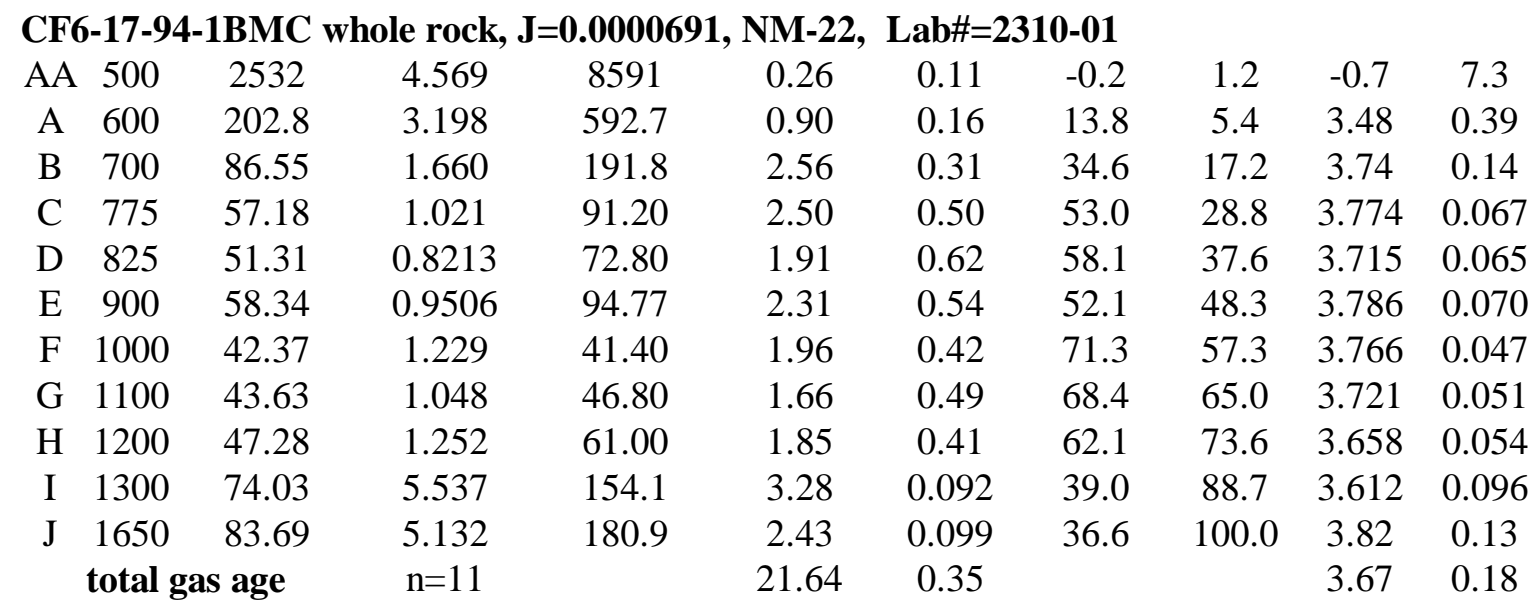

LW146FVP whole rock, J=0.0000691, NM-22, Lab\#=2311-01

$\begin{array}{ccccccccccc}\mathrm{AA} & 500 & 276.3 & 1.925 & 927.1 & 0.85 & 0.27 & 0.9 & 3.6 & 0.30 & 0.55 \\ \mathrm{~A} & 600 & 23.95 & 0.7393 & 59.70 & 3.56 & 0.69 & 26.5 & 18.8 & 0.792 & 0.040 \\ \mathrm{~B} & 700 & 15.95 & 0.5077 & 33.28 & 4.92 & 1.0 & 38.4 & 39.8 & 0.764 & 0.022 \\ \mathrm{C} & 775 & 16.55 & 0.5110 & 34.30 & 2.93 & 1.00 & 38.9 & 52.3 & 0.803 & 0.032 \\ \mathrm{D} & 825 & 18.35 & 0.7520 & 41.30 & 1.65 & 0.68 & 33.6 & 59.4 & 0.769 & 0.048 \\ \mathrm{E} & 900 & 21.68 & 1.040 & 53.50 & 1.30 & 0.49 & 27.4 & 64.9 & 0.741 & 0.058 \\ \mathrm{~F} & 1000 & 26.81 & 1.427 & 71.00 & 1.16 & 0.36 & 22.0 & 69.8 & 0.736 & 0.070 \\ \mathrm{G} & 1100 & 30.29 & 1.552 & 83.10 & 0.70 & 0.33 & 19.2 & 72.8 & 0.726 & 0.092 \\ \mathrm{H} & 1200 & 34.16 & 3.259 & 96.30 & 5.36 & 0.16 & 17.4 & 95.7 & 0.742 & 0.053 \\ \mathrm{I} & 1300 & 61.89 & 7.551 & 191.2 & 0.51 & 0.068 & 9.6 & 97.9 & 0.74 & 0.18 \\ \mathrm{~J} & 1650 & 44.15 & 2.206 & 124.7 & 0.49 & 0.23 & 16.8 & 100.0 & 0.93 & 0.14 \\ & \text { total gas age } & \mathrm{n}=11 & & 23.45 & 0.59 & & & 0.751 & 0.067\end{array}$

LW147FVP whole rock, $J=0.0000693$, NM-22, Lab\#=2308-01

\begin{tabular}{|c|c|c|c|c|c|c|c|c|c|c|}
\hline $\mathrm{AA}$ & 500 & 11111 & 3.207 & 37660 & 0.13 & 0.16 & -0.2 & 0.8 & -2 & 60 \\
\hline A & 600 & 668.2 & 1.307 & 2248 & 0.69 & 0.39 & 0.6 & 4.7 & 0.5 & 1.2 \\
\hline B & 700 & 395.9 & 0.7396 & 1313 & 1.41 & 0.69 & 2.0 & 12.7 & 1.00 & 0.73 \\
\hline $\mathrm{C}$ & 775 & 612.5 & 0.5805 & 2049 & 1.09 & 0.88 & 1.1 & 18.9 & 0.9 & 1.2 \\
\hline $\mathrm{D}$ & 825 & 352.9 & 0.6647 & 1163 & 0.74 & 0.77 & 2.6 & 23.1 & 1.17 & 0.73 \\
\hline $\mathrm{E}$ & 900 & 353.9 & 0.7565 & 1164 & 0.95 & 0.67 & 2.8 & 28.5 & 1.25 & 0.69 \\
\hline $\mathrm{F}$ & 1000 & 228.2 & 0.7273 & 747.1 & 1.02 & 0.70 & 3.3 & 34.3 & 0.94 & 0.43 \\
\hline G & 1100 & 66.53 & 0.7782 & 204.4 & 1.24 & 0.66 & 9.2 & 41.4 & 0.77 & 0.15 \\
\hline $\mathrm{H}$ & 1200 & 363.2 & 1.790 & 1205 & 8.96 & 0.29 & 2.0 & 92.3 & 0.91 & 0.68 \\
\hline I & 1300 & 388.9 & 7.466 & 1361 & 0.04 & 0.068 & -3.2 & 92.5 & -1.6 & 5.6 \\
\hline $\mathrm{J}$ & 1650 & 95.64 & 1.393 & 214.8 & 1.32 & 0.37 & 33.7 & 100.0 & 4.03 & 0.15 \\
\hline \multicolumn{3}{|c|}{ total gas age } & $\mathrm{n}=11$ & & 17.61 & 0.45 & & & 1.1 & 1.1 \\
\hline
\end{tabular}

HD1070-5 glass, J=0.0000748, NM-28, Lab\#=3123-02
A 500
1472
$0.0000 \quad 4837$
0.01
$-\quad 2.9$
$0.73-2.1$
0.1
$6 \quad 36$
B $600 \quad 1648$
$0.7008 \quad 5458$
0.33
0.73
2.1
3.6
$4.7 \quad 4.1$ 


\begin{tabular}{|c|c|c|c|c|c|c|c|c|c|c|}
\hline $\mathrm{ID}$ & $\begin{array}{l}\text { Temp } \\
\left({ }^{\circ} \mathrm{C}\right)\end{array}$ & ${ }^{40} \mathrm{Ar} /{ }^{39} \mathrm{Ar}$ & ${ }^{37} \mathrm{Ar} /{ }^{39} \mathrm{Ar}$ & $\begin{array}{c}{ }^{36} \mathrm{Ar}{ }^{39} \mathrm{Ar} \\
\left(\mathrm{x} 10^{-3}\right)\end{array}$ & $\begin{array}{c}{ }^{39} \mathrm{Ar}_{\mathrm{K}} \\
\left(\mathrm{x} 10^{-15} \mathrm{~mol}\right)\end{array}$ & $\mathrm{K} / \mathrm{Ca}$ & $\begin{array}{l}{ }^{40} \mathrm{Ar}^{*} \\
(\%)\end{array}$ & $\begin{array}{l}{ }^{39} \mathrm{Ar} \\
(\%)\end{array}$ & $\begin{array}{l}\text { Age } \\
(\mathrm{Ma})\end{array}$ & $\begin{array}{l} \pm 2 \sigma \\
(\mathrm{Ma})\end{array}$ \\
\hline $\mathrm{C}$ & 700 & 347.9 & 0.8736 & 1097 & 0.26 & 0.58 & 6.9 & 6.3 & 3.2 & 1.2 \\
\hline $\mathrm{D}$ & 775 & 159.0 & 1.364 & 490.0 & 1.50 & 0.37 & 8.9 & 22.1 & 1.92 & 0.23 \\
\hline $\mathrm{E}$ & 825 & 91.12 & 1.828 & 283.5 & 1.36 & 0.28 & 8.2 & 36.4 & 1.01 & 0.15 \\
\hline $\mathrm{F}$ & 900 & 85.53 & 2.312 & 269.9 & 1.03 & 0.22 & 6.9 & 47.2 & 0.80 & 0.15 \\
\hline $\mathrm{G}$ & 1000 & 213.1 & 2.333 & 701.9 & 1.51 & 0.22 & 2.7 & 63.1 & 0.79 & 0.31 \\
\hline $\mathrm{H}$ & 1100 & 320.2 & 2.383 & 1057 & 2.06 & 0.21 & 2.5 & 84.8 & 1.07 & 0.45 \\
\hline I & 1200 & 167.9 & 3.131 & 553.2 & 1.31 & 0.16 & 2.8 & 98.6 & 0.63 & 0.25 \\
\hline $\mathrm{J}$ & 1300 & 80.63 & 4.646 & 225.8 & 0.10 & 0.11 & 17.7 & 99.6 & 1.93 & 0.52 \\
\hline K & 1650 & 122.1 & 6.719 & 357.4 & 0.04 & 0.076 & 13.9 & 100.0 & 2.3 & 1.4 \\
\hline \multicolumn{3}{|c|}{ total gas age } & $\mathrm{n}=11$ & & 9.50 & 0.27 & & & 1.26 & 0.49 \\
\hline
\end{tabular}

HC17FVP whole rock, J=0.0000659, NM-48, Lab\#=6468-01

\begin{tabular}{|c|c|c|c|c|c|c|c|c|c|c|}
\hline $\mathrm{C}$ & 700 & 549.3 & 1.323 & 1870 & 0.40 & 0.39 & -0.6 & 1.0 & -0.4 & 1.4 \\
\hline D & 775 & 58.01 & 1.871 & 186.9 & 10.78 & 0.27 & 5.0 & 27.9 & 0.347 & 0.097 \\
\hline $\mathrm{E}$ & 825 & 15.27 & 1.088 & 41.40 & 7.62 & 0.47 & 20.3 & 46.9 & 0.370 & 0.026 \\
\hline $\mathrm{F}$ & 900 & 11.01 & 1.008 & 28.40 & 8.96 & 0.51 & 24.1 & 69.2 & 0.315 & 0.023 \\
\hline $\mathrm{G}$ & 1000 & 15.48 & 1.111 & 43.50 & 6.33 & 0.46 & 17.3 & 85.0 & 0.319 & 0.029 \\
\hline $\mathrm{H}$ & 1100 & 37.96 & 1.582 & 120.1 & 2.77 & 0.32 & 6.7 & 91.9 & 0.304 & 0.074 \\
\hline I & 1200 & 78.82 & 11.02 & 255.1 & 1.15 & 0.046 & 5.4 & 94.8 & 0.51 & 0.21 \\
\hline $\mathbf{J}$ & 1300 & 74.54 & 12.49 & 241.7 & 1.73 & 0.041 & 5.4 & 99.1 & 0.48 & 0.15 \\
\hline $\mathrm{K}$ & 1650 & 89.99 & 9.440 & 288.3 & 0.37 & 0.054 & 6.1 & 100.0 & 0.66 & 0.40 \\
\hline & \multicolumn{2}{|c|}{ total gas age } & $\mathrm{n}=9$ & & 40.10 & 0.38 & & & 0.343 & 0.076 \\
\hline
\end{tabular}

SB5-24-95-1BMC whole rock, J=0.0000658, NM-48, Lab\#=6470-01

\begin{tabular}{|c|c|c|c|c|c|c|c|c|c|c|}
\hline B & 600 & 3272 & 0.6551 & 11226 & 0.17 & 0.78 & -1.4 & 0.4 & -5 & 17 \\
\hline $\mathrm{C}$ & 700 & 1672 & 0.7659 & 5671 & 0.67 & 0.67 & -0.2 & 2.0 & -0.5 & 4.3 \\
\hline D & 775 & 387.7 & 1.416 & 1289 & 12.53 & 0.36 & 1.8 & 32.1 & 0.83 & 0.69 \\
\hline $\mathrm{E}$ & 825 & 152.2 & 0.8893 & 493.5 & 7.58 & 0.57 & 4.2 & 50.3 & 0.76 & 0.25 \\
\hline $\mathrm{F}$ & 900 & 81.70 & 1.015 & 259.6 & 7.51 & 0.50 & 6.2 & 68.3 & 0.60 & 0.14 \\
\hline G & 1000 & 69.24 & 1.608 & 216.3 & 4.98 & 0.32 & 7.8 & 80.2 & 0.64 & 0.12 \\
\hline $\mathrm{H}$ & 1100 & 90.58 & 2.213 & 294.8 & 2.26 & 0.23 & 4.0 & 85.7 & 0.43 & 0.17 \\
\hline I & 1200 & 96.04 & 5.562 & 314.3 & 3.62 & 0.092 & 3.7 & 94.4 & 0.42 & 0.18 \\
\hline $\mathrm{J}$ & 1300 & 121.0 & 9.300 & 401.7 & 2.27 & 0.055 & 2.5 & 99.8 & 0.36 & 0.24 \\
\hline K & 1650 & 408.1 & 14.10 & 1336 & 0.08 & 0.036 & 3.5 & 100.0 & 1.7 & 3.6 \\
\hline & \multicolumn{2}{|c|}{ total gas age } & $\mathrm{n}=10$ & & 41.67 & 0.38 & & & 0.63 & 0.47 \\
\hline
\end{tabular}

\begin{tabular}{ccccccccccc}
\multicolumn{2}{l}{ SB90-8-20-1BMC } & whole rock, J=0.0000694, & NM-22, & Lab\#=2306-01 & & & \\
AA & 500 & 735.4 & 0.9601 & 2555 & 0.52 & 0.53 & -2.6 & 2.9 & -2.4 & 1.7 \\
A & 600 & 224.0 & 1.633 & 771.0 & 1.00 & 0.31 & -1.7 & 8.6 & -0.47 & 0.45 \\
B & 700 & 74.53 & 1.430 & 246.0 & 2.54 & 0.36 & 2.6 & 23.1 & 0.24 & 0.14 \\
C & 775 & 32.97 & 1.047 & 102.7 & 2.73 & 0.49 & 8.1 & 38.6 & 0.335 & 0.065 \\
D & 825 & 20.93 & 0.9712 & 60.90 & 2.00 & 0.53 & 14.3 & 50.0 & 0.374 & 0.050 \\
E & 900 & 16.16 & 1.189 & 44.70 & 2.22 & 0.43 & 18.6 & 62.6 & 0.377 & 0.042 \\
F & 1000 & 22.99 & 1.396 & 68.70 & 1.59 & 0.37 & 12.0 & 71.7 & 0.346 & 0.062
\end{tabular}




\begin{tabular}{|c|c|c|c|c|c|c|c|c|c|c|}
\hline ID & $\begin{array}{l}\text { Temp } \\
\left({ }^{\circ} \mathrm{C}\right)\end{array}$ & ${ }^{40} \mathrm{Ar} /{ }^{39} \mathrm{Ar}$ & ${ }^{37} \mathrm{Ar} /{ }^{39} \mathrm{Ar}$ & $\begin{array}{c}{ }^{36} \mathrm{Ar} /^{39} \mathrm{Ar} \\
\left(\times 10^{-3}\right)\end{array}$ & $\begin{array}{c}{ }^{39} \mathrm{Ar}_{\mathrm{K}} \\
\left(\mathrm{x} 10^{-15} \mathrm{~mol}\right)\end{array}$ & $\mathrm{K} / \mathrm{Ca}$ & $\begin{array}{l}{ }^{40} \mathrm{Ar}^{*} \\
(\%)\end{array}$ & $\begin{array}{l}{ }^{39} \mathrm{Ar} \\
(\%)\end{array}$ & $\begin{array}{l}\text { Age } \\
\text { (Ma) }\end{array}$ & $\begin{array}{l} \pm 2 \sigma \\
(\mathrm{Ma})\end{array}$ \\
\hline $\mathrm{G}$ & 1100 & 26.19 & 1.301 & 75.80 & 0.94 & 0.39 & 14.8 & 77.0 & 0.486 & 0.080 \\
\hline $\mathrm{H}$ & 1200 & 25.16 & 4.104 & 73.30 & 1.95 & 0.12 & 15.0 & 88.1 & 0.475 & 0.057 \\
\hline I & 1300 & 30.96 & 6.535 & 89.60 & 0.71 & 0.078 & 16.0 & 92.1 & 0.62 & 0.11 \\
\hline $\mathrm{J}$ & 1650 & 41.39 & 2.269 & 115.8 & 1.38 & 0.22 & 17.7 & 100.0 & 0.92 & 0.10 \\
\hline \multicolumn{3}{|r|}{ s age } & $\mathrm{n}=11$ & & 17.57 & 0.36 & & & 0.29 & 0.15 \\
\hline
\end{tabular}

\section{SB90-8-20-1BMC whole rock, J=0.0000452, NM-39, Lab\#=5604-01}

\begin{tabular}{|c|c|c|c|c|c|c|c|c|c|c|}
\hline A & 500 & 2086 & 1.073 & 7088 & 0.26 & 0.48 & -0.4 & 1.7 & -0.7 & 4.1 \\
\hline B & 600 & 509.3 & 1.932 & 1728 & 0.61 & 0.26 & -0.2 & 5.8 & -0.08 & 0.59 \\
\hline $\mathrm{C}$ & 700 & 183.0 & 2.042 & 605.9 & 0.98 & 0.25 & 2.2 & 12.3 & 0.34 & 0.19 \\
\hline $\mathrm{D}$ & 775 & 86.79 & 1.538 & 276.9 & 1.64 & 0.33 & 5.8 & 23.2 & 0.413 & 0.086 \\
\hline $\mathrm{E}$ & 825 & 51.20 & 1.226 & 156.2 & 1.88 & 0.42 & 10.0 & 35.8 & 0.417 & 0.055 \\
\hline $\mathrm{F}$ & 900 & 41.23 & 1.168 & 124.4 & 1.41 & 0.44 & 11.0 & 45.2 & 0.369 & 0.053 \\
\hline $\mathrm{G}$ & 1000 & 42.50 & 1.363 & 130.3 & 1.25 & 0.37 & 9.6 & 53.5 & 0.331 & 0.059 \\
\hline $\mathrm{H}$ & 1100 & 61.05 & 1.857 & 190.7 & 1.13 & 0.27 & 7.9 & 61.0 & 0.393 & 0.079 \\
\hline I & 1200 & 55.03 & 2.873 & 171.3 & 3.40 & 0.18 & 8.4 & 83.7 & 0.377 & 0.045 \\
\hline $\mathrm{J}$ & 1300 & 45.79 & 4.559 & 138.9 & 1.97 & 0.11 & 11.1 & 96.8 & 0.415 & 0.048 \\
\hline $\mathrm{K}$ & 1650 & 117.6 & 7.428 & 383.0 & 0.48 & 0.069 & 4.2 & 100.0 & 0.41 & 0.19 \\
\hline & \multicolumn{2}{|c|}{ total gas age } & $\mathrm{n}=11$ & & 15.00 & 0.27 & & & 0.35 & 0.16 \\
\hline
\end{tabular}

LW140FVPa1 sanidine, J=0.0000798, NM-10, Lab\#=818-01

\begin{tabular}{|c|c|c|c|c|c|c|c|c|c|c|}
\hline A & 500 & 264.3 & 0.0109 & 902.7 & 0.68 & 46.8 & -0.9 & 0.3 & -0.36 & 0.58 \\
\hline B & 600 & 797.8 & 0.0238 & 2656 & 0.13 & 21.4 & 1.6 & 0.4 & 1.8 & 3.2 \\
\hline $\mathrm{C}$ & 700 & 56.46 & 0.0205 & 188.5 & 0.43 & 24.9 & 1.3 & 0.6 & 0.10 & 0.18 \\
\hline D & 800 & 14.53 & 0.0215 & 46.90 & 1.64 & 23.7 & 4.6 & 1.4 & 0.095 & 0.042 \\
\hline E & 900 & 3.467 & 0.0180 & 9.170 & 5.28 & 28.3 & 21.2 & 3.9 & 0.106 & 0.013 \\
\hline $\mathrm{F}$ & 975 & 1.409 & 0.0163 & 2.180 & 4.42 & 31.3 & 52.5 & 6.0 & 0.107 & 0.008 \\
\hline G & 1050 & 1.244 & 0.0156 & 2.230 & 11.09 & 32.7 & 45.1 & 11.2 & 0.081 & 0.004 \\
\hline $\mathrm{H}$ & 1100 & 1.019 & 0.0154 & 1.540 & 6.66 & 33.2 & 53.1 & 14.4 & 0.078 & 0.006 \\
\hline I & 1150 & 1.275 & 0.0150 & 2.360 & 17.97 & 34.0 & 43.5 & 22.9 & 0.080 & 0.003 \\
\hline $\mathrm{J}$ & 1180 & 1.523 & 0.0150 & 3.340 & 21.79 & 34.0 & 33.6 & 33.3 & 0.074 & 0.003 \\
\hline K & 1220 & 2.597 & 0.0147 & 6.830 & 21.98 & 34.7 & 21.3 & 43.7 & 0.080 & 0.004 \\
\hline $\mathrm{L}$ & 1300 & 6.045 & 0.0147 & 18.20 & 30.11 & 34.7 & 10.8 & 58.0 & 0.094 & 0.010 \\
\hline M & 1400 & 6.714 & 0.0145 & 18.90 & 65.09 & 35.2 & 16.3 & 88.9 & 0.157 & 0.009 \\
\hline $\mathrm{N}$ & 1500 & 9.605 & 0.0138 & 26.60 & 19.89 & 37.0 & 17.8 & 98.4 & 0.246 & 0.015 \\
\hline $\mathrm{O}$ & 1650 & 44.97 & 0.0166 & 146.7 & 3.47 & 30.7 & 3.5 & 100.0 & 0.23 & 0.12 \\
\hline & \multicolumn{2}{|c|}{ total gas age } & $\mathrm{n}=15$ & & 210.63 & 34.4 & & & 0.124 & 0.014 \\
\hline
\end{tabular}

LW140FVPa2 sanidine, J=0.0000704, NM-22, Lab\#=3207-01

$\begin{array}{ccccccccccc}\text { A } & 700 & 94.94 & 1.556 & 326.4 & 0.12 & 0.33 & -1.5 & 0.4 & -0.18 & 0.51 \\ \text { B } & 800 & 4.397 & 0.0000 & 14.40 & 0.30 & - & 3.0 & 1.5 & 0.02 & 0.11 \\ \text { C } & 900 & 1.972 & 0.1309 & 4.740 & 0.67 & 3.9 & 28.2 & 3.9 & 0.071 & 0.043 \\ \text { D } & 950 & 1.526 & 0.2620 & 2.430 & 0.82 & 1.9 & 52.6 & 6.8 & 0.102 & 0.041 \\ \text { E } & 1000 & 1.666 & 0.1833 & 3.850 & 1.12 & 2.8 & 31.0 & 10.8 & 0.066 & 0.027 \\ \text { F } & 1050 & 1.167 & 0.1048 & 1.860 & 1.40 & 4.9 & 51.3 & 15.7 & 0.076 & 0.019\end{array}$




\begin{tabular}{|c|c|c|c|c|c|c|c|c|c|c|}
\hline $\mathrm{ID}$ & $\begin{array}{l}\text { Temp } \\
\left({ }^{\circ} \mathrm{C}\right)\end{array}$ & ${ }^{40} \mathrm{Ar} /{ }^{39} \mathrm{Ar}$ & ${ }^{37} \mathrm{Ar} /{ }^{39} \mathrm{Ar}$ & $\begin{array}{c}{ }^{36} \mathrm{Ar} /{ }^{39} \mathrm{Ar} \\
\left(\mathrm{x} 10^{-3}\right)\end{array}$ & $\begin{array}{c}{ }^{39} \mathrm{Ar}_{\mathrm{K}} \\
\left(\mathrm{x} 10^{-15} \mathrm{~mol}\right)\end{array}$ & $\mathrm{K} / \mathrm{Ca}$ & $\begin{array}{l}{ }^{40} \mathrm{Ar}^{*} \\
(\%)\end{array}$ & $\begin{array}{l}{ }^{39} \mathrm{Ar} \\
(\%)\end{array}$ & $\begin{array}{l}\text { Age } \\
\text { (Ma) }\end{array}$ & $\begin{array}{l} \pm 2 \sigma \\
(\mathrm{Ma})\end{array}$ \\
\hline $\mathrm{G}$ & 1100 & 1.166 & 0.0231 & 1.890 & 1.85 & 22.1 & 50.0 & 22.3 & 0.074 & 0.016 \\
\hline $\mathrm{H}$ & 1130 & 1.304 & 0.0677 & 2.260 & 1.66 & 7.5 & 47.4 & 28.2 & 0.078 & 0.020 \\
\hline I & 1180 & 1.493 & 0.0758 & 2.870 & 2.42 & 6.7 & 42.0 & 36.7 & 0.080 & 0.013 \\
\hline $\mathrm{J}$ & 1220 & 2.062 & 0.0468 & 5.010 & 2.64 & 10.9 & 27.2 & 46.1 & 0.071 & 0.014 \\
\hline $\mathrm{K}$ & 1260 & 5.165 & 0.0599 & 14.70 & 3.27 & 8.5 & 15.6 & 57.7 & 0.102 & 0.015 \\
\hline $\mathrm{L}$ & 1300 & 6.991 & 0.0582 & 19.60 & 3.59 & 8.8 & 17.1 & 70.5 & 0.151 & 0.018 \\
\hline M & 1400 & 5.608 & 0.0613 & 10.80 & 3.39 & 8.3 & 42.5 & 82.5 & 0.303 & 0.013 \\
\hline $\mathrm{N}$ & 1650 & 7.912 & 0.3053 & 15.20 & 3.88 & 1.7 & 43.1 & 96.3 & 0.433 & 0.018 \\
\hline $\mathrm{O}$ & 1750 & 32.20 & 1.702 & 100.7 & 1.06 & 0.30 & 7.9 & 100.0 & 0.32 & 0.10 \\
\hline \multicolumn{3}{|c|}{ total gas age } & $\mathrm{n}=15$ & & 28.19 & 7.4 & & & 0.173 & 0.024 \\
\hline
\end{tabular}

\section{LW143FVPa1 sanidine, J=0.0000802, NM-10, Lab\#=821-01}

$\begin{array}{ccccccccccc}\mathrm{A} & 750 & 108.7 & 0.2812 & 360.8 & 2.18 & 1.8 & 1.9 & 0.9 & 0.29 & 0.17 \\ \mathrm{~B} & 850 & 51.96 & 0.0652 & 170.2 & 3.89 & 7.8 & 3.2 & 2.6 & 0.240 & 0.085 \\ \mathrm{C} & 950 & 17.28 & 0.0331 & 55.40 & 9.78 & 15.4 & 5.1 & 6.9 & 0.128 & 0.026 \\ \mathrm{D} & 1025 & 7.817 & 0.0176 & 23.80 & 14.33 & 29.0 & 9.6 & 13.1 & 0.108 & 0.012 \\ \mathrm{E} & 1075 & 4.405 & 0.0121 & 12.50 & 16.44 & 42.3 & 15.5 & 20.2 & 0.099 & 0.008 \\ \mathrm{~F} & 1120 & 3.096 & 0.0109 & 8.290 & 20.55 & 46.8 & 20.1 & 29.1 & 0.090 & 0.005 \\ \mathrm{G} & 1140 & 2.616 & 0.0096 & 6.900 & 15.67 & 53.4 & 21.1 & 35.9 & 0.080 & 0.006 \\ \mathrm{H} & 1160 & 2.757 & 0.0096 & 7.450 & 14.36 & 53.3 & 19.3 & 42.1 & 0.077 & 0.006 \\ \mathrm{I} & 1180 & 3.092 & 0.0089 & 8.440 & 14.17 & 57.5 & 18.5 & 48.3 & 0.083 & 0.007 \\ \mathrm{~J} & 1220 & 3.977 & 0.0095 & 11.32 & 17.25 & 53.8 & 15.3 & 55.7 & 0.088 & 0.007 \\ \mathrm{~K} & 1260 & 5.697 & 0.0095 & 16.90 & 20.36 & 53.9 & 11.9 & 64.6 & 0.098 & 0.009 \\ \mathrm{~L} & 1320 & 8.914 & 0.0098 & 26.30 & 28.72 & 52.3 & 12.5 & 77.0 & 0.161 & 0.012 \\ \mathrm{M} & 1450 & 8.364 & 0.0081 & 21.40 & 39.45 & 62.8 & 24.1 & 94.1 & 0.292 & 0.010 \\ \mathrm{~N} & 1650 & 14.37 & 0.0096 & 38.90 & 10.37 & 53.3 & 19.9 & 98.6 & 0.414 & 0.024 \\ \mathrm{O} & 1650 & 19.11 & 0.0098 & 52.30 & 3.19 & 52.3 & 19.0 & 100.0 & 0.525 & 0.031 \\ & \text { total gas age } & \mathrm{n}=15 & & 230.70 & 49.4 & & & 0.160 & 0.013\end{array}$

\section{LW143FVPa2 sanidine, J=0.0000703, NM-22, Lab\#=2234-01}

$\begin{array}{ccccccccccc}\text { A } & 700 & 1235 & 1.073 & 4182 & 0.44 & 0.48 & -0.1 & 0.4 & -0.1 & 2.1 \\ \text { B } & 800 & 293.6 & 0.8352 & 991.8 & 0.67 & 0.61 & 0.2 & 1.1 & 0.07 & 0.45 \\ \text { C } & 900 & 80.62 & 0.0785 & 267.3 & 1.67 & 6.5 & 2.0 & 2.8 & 0.21 & 0.11 \\ \text { D } & 950 & 40.87 & 0.0469 & 134.1 & 1.79 & 10.9 & 3.0 & 4.6 & 0.156 & 0.069 \\ \text { E } & 1000 & 22.95 & 0.0278 & 74.10 & 2.24 & 18.4 & 4.5 & 6.9 & 0.130 & 0.038 \\ \text { F } & 1050 & 14.15 & 0.0182 & 43.70 & 3.27 & 28.1 & 8.6 & 10.2 & 0.155 & 0.024 \\ \text { G } & 1100 & 8.047 & 0.0137 & 23.40 & 4.33 & 37.2 & 13.8 & 14.5 & 0.141 & 0.015 \\ \text { H } & 1120 & 5.721 & 0.0123 & 16.20 & 3.78 & 41.5 & 15.7 & 18.3 & 0.114 & 0.013 \\ \text { I } & 1140 & 4.459 & 0.0112 & 12.40 & 3.67 & 45.6 & 17.3 & 22.0 & 0.098 & 0.014 \\ \text { J } & 1160 & 4.136 & 0.0103 & 11.00 & 3.62 & 49.5 & 20.7 & 25.7 & 0.109 & 0.011 \\ \text { K } & 1180 & 4.132 & 0.0102 & 11.20 & 3.70 & 50.0 & 19.2 & 29.4 & 0.101 & 0.012 \\ \text { L } & 1210 & 4.031 & 0.0097 & 11.10 & 4.19 & 52.5 & 18.3 & 33.7 & 0.093 & 0.010 \\ \text { M } & 1240 & 4.596 & 0.0096 & 12.90 & 5.03 & 53.3 & 16.5 & 38.7 & 0.096 & 0.009 \\ \text { N } & 1280 & 7.118 & 0.0095 & 21.20 & 6.68 & 53.6 & 11.5 & 45.5 & 0.104 & 0.013\end{array}$




\begin{tabular}{|c|c|c|c|c|c|c|c|c|c|c|}
\hline ID & $\begin{array}{l}\text { Temp } \\
\left({ }^{\circ} \mathrm{C}\right)\end{array}$ & ${ }^{40} \mathrm{Ar} /{ }^{39} \mathrm{Ar}$ & ${ }^{37} \mathrm{Ar} /{ }^{39} \mathrm{Ar}$ & $\begin{array}{c}{ }^{36} \mathrm{Ar} /{ }^{39} \mathrm{Ar} \\
\left(\mathrm{x} 10^{-3}\right)\end{array}$ & $\begin{array}{c}{ }^{39} \mathrm{Ar}_{\mathrm{K}} \\
\left(\mathrm{x} 10^{-15} \mathrm{~mol}\right)\end{array}$ & $\mathrm{K} / \mathrm{Ca}$ & $\begin{array}{l}{ }^{40} \mathrm{Ar}^{*} \\
(\%)\end{array}$ & $\begin{array}{l}{ }^{39} \mathrm{Ar} \\
(\%)\end{array}$ & $\begin{array}{l}\text { Age } \\
\text { (Ma) }\end{array}$ & $\begin{array}{l} \pm 2 \sigma \\
(\mathrm{Ma})\end{array}$ \\
\hline $\mathrm{O}$ & 1350 & 14.52 & 0.0088 & 41.70 & 16.88 & 58.3 & 14.9 & 62.5 & 0.275 & 0.016 \\
\hline $\mathrm{P}$ & 1400 & 12.18 & 0.0077 & 33.25 & 18.67 & 66.3 & 19.1 & 81.3 & 0.295 & 0.013 \\
\hline Q & 1650 & 22.20 & 0.0079 & 62.30 & 12.91 & 64.3 & 16.9 & 94.3 & 0.477 & 0.023 \\
\hline $\mathrm{R}$ & 1800 & 55.80 & 0.0079 & 174.6 & 5.66 & 64.3 & 7.5 & 100.0 & 0.529 & 0.062 \\
\hline \multicolumn{3}{|c|}{ total gas age } & $\mathrm{n}=18$ & & 99.21 & 53.2 & & & 0.247 & 0.033 \\
\hline
\end{tabular}

\section{LW143FVPa3 sanidine, J=0.0000445, NM-39, Lab\#=5610-01}

\begin{tabular}{|c|c|c|c|c|c|c|c|c|c|c|}
\hline A & 700 & 468.3 & 0.0884 & 1580 & 0.19 & 5.8 & 0.3 & 0.3 & 0.1 & 1.6 \\
\hline B & 800 & 78.41 & 0.0499 & 255.3 & 0.41 & 10.2 & 3.7 & 0.8 & 0.24 & 0.19 \\
\hline $\mathrm{C}$ & 900 & 23.79 & 0.0209 & 75.60 & 0.97 & 24.4 & 6.0 & 2.2 & 0.115 & 0.059 \\
\hline $\mathrm{D}$ & 950 & 11.51 & 0.0150 & 34.90 & 1.20 & 34.0 & 10.3 & 3.9 & 0.095 & 0.039 \\
\hline $\mathrm{E}$ & 1000 & 6.778 & 0.0128 & 20.70 & 1.62 & 39.9 & 9.4 & 6.1 & 0.051 & 0.027 \\
\hline $\mathrm{F}$ & 1050 & 4.418 & 0.0098 & 10.90 & 2.39 & 52.2 & 26.5 & 9.5 & 0.094 & 0.018 \\
\hline $\mathrm{G}$ & 1100 & 2.965 & 0.0096 & 6.970 & 3.04 & 53.2 & 29.7 & 13.7 & 0.071 & 0.014 \\
\hline $\mathrm{H}$ & 1130 & 3.251 & 0.0085 & 8.100 & 3.00 & 59.9 & 25.6 & 17.9 & 0.067 & 0.015 \\
\hline I & 1180 & 6.104 & 0.0081 & 16.85 & 4.59 & 62.9 & 18.0 & 24.3 & 0.088 & 0.011 \\
\hline $\mathrm{J}$ & 1220 & 4.038 & 0.0081 & 9.690 & 4.89 & 62.8 & 28.5 & 31.1 & 0.093 & 0.008 \\
\hline $\mathrm{K}$ & 1260 & 4.242 & 0.0080 & 10.30 & 5.94 & 64.2 & 27.6 & 39.4 & 0.094 & 0.009 \\
\hline $\mathrm{L}$ & 1300 & 6.663 & 0.0081 & 17.20 & 7.17 & 63.4 & 23.2 & 49.5 & 0.124 & 0.009 \\
\hline $\mathrm{M}$ & 1400 & 11.71 & 0.0074 & 26.30 & 20.66 & 68.9 & 33.4 & 78.3 & 0.314 & 0.010 \\
\hline $\mathrm{N}$ & 1650 & 16.62 & 0.0074 & 38.90 & 10.09 & 68.9 & 30.7 & 92.4 & 0.410 & 0.016 \\
\hline $\mathrm{O}$ & 1750 & 29.29 & 0.0105 & 83.30 & 5.44 & 48.6 & 15.8 & 100.0 & 0.373 & 0.042 \\
\hline \multicolumn{3}{|c|}{ total gas age } & $\mathrm{n}=15$ & & 71.60 & 61.6 & & & 0.224 & 0.042 \\
\hline
\end{tabular}

\section{LW143FVPa4 sanidine, $\mathrm{J}=\mathbf{0 . 0 0 0 0 4 5 3}$, NM-39, Lab\#=5612-01}

$\begin{array}{ccccccccccc}\mathrm{A} & 700 & 173.4 & 0.0364 & 559.5 & 0.11 & 14.0 & 4.6 & 0.2 & 0.65 & 0.82 \\ \mathrm{~B} & 800 & 22.12 & 0.0266 & 64.60 & 0.25 & 19.2 & 13.6 & 0.7 & 0.25 & 0.17 \\ \mathrm{C} & 900 & 7.902 & 0.0194 & 14.60 & 0.60 & 26.3 & 45.2 & 2.0 & 0.292 & 0.063 \\ \mathrm{D} & 950 & 6.481 & 0.0112 & 10.30 & 0.81 & 45.6 & 52.8 & 3.7 & 0.280 & 0.048 \\ \mathrm{E} & 1000 & 4.050 & 0.0108 & 1.810 & 1.04 & 47.2 & 86.2 & 5.8 & 0.285 & 0.034 \\ \mathrm{~F} & 1050 & 4.530 & 0.0108 & 1.980 & 1.45 & 47.2 & 86.6 & 8.8 & 0.320 & 0.026 \\ \mathrm{G} & 1100 & 4.850 & 0.0107 & 4.360 & 1.94 & 47.9 & 72.9 & 12.9 & 0.289 & 0.021 \\ \mathrm{H} & 1130 & 4.776 & 0.0079 & 3.890 & 1.96 & 64.5 & 75.4 & 16.9 & 0.294 & 0.020 \\ \mathrm{I} & 1180 & 5.126 & 0.0086 & 4.670 & 3.28 & 59.6 & 72.6 & 23.7 & 0.304 & 0.012 \\ \mathrm{~J} & 1220 & 5.946 & 0.0083 & 6.890 & 3.23 & 61.5 & 65.4 & 30.4 & 0.317 & 0.012 \\ \mathrm{~K} & 1260 & 6.240 & 0.0087 & 7.790 & 3.78 & 58.8 & 62.7 & 38.2 & 0.320 & 0.011 \\ \mathrm{~L} & 1300 & 9.285 & 0.0083 & 16.30 & 4.67 & 61.8 & 47.8 & 47.9 & 0.362 & 0.012 \\ \mathrm{M} & 1400 & 20.08 & 0.0080 & 27.60 & 14.14 & 63.9 & 59.3 & 77.2 & 0.973 & 0.013 \\ \mathrm{~N} & 1650 & 29.94 & 0.0078 & 69.30 & 7.28 & 65.4 & 31.6 & 92.3 & 0.772 & 0.026 \\ \mathrm{O} & 1750 & 37.69 & 0.0109 & 101.8 & 3.71 & 46.8 & 20.1 & 100.0 & 0.620 & 0.051 \\ & \text { total gas age } & \mathrm{n}=15 & & 48.26 & 59.2 & & & 0.602 & 0.023\end{array}$

LW143FVPo1 sanidine, J=0.00008, NM-10, Lab\#=828-01

$\begin{array}{lcccccccccc}\text { A } & 750 & 196.1 & 0.0904 & 657.6 & 2.04 & 5.6 & 0.9 & 1.4 & 0.25 & 0.34 \\ \text { B } & 850 & 15.28 & 0.0384 & 49.40 & 3.96 & 13.3 & 4.3 & 4.2 & 0.095 & 0.030\end{array}$




\begin{tabular}{|c|c|c|c|c|c|c|c|c|c|c|}
\hline ID & $\begin{array}{l}\text { Temp } \\
\left({ }^{\circ} \mathrm{C}\right)\end{array}$ & ${ }^{40} \mathrm{Ar} /{ }^{39} \mathrm{Ar}$ & ${ }^{37} \mathrm{Ar} /{ }^{39} \mathrm{Ar}$ & $\begin{array}{c}{ }^{36} \mathrm{Ar} /{ }^{39} \mathrm{Ar} \\
\left(\mathrm{x} 10^{-3}\right)\end{array}$ & $\begin{array}{c}{ }^{39} \mathrm{Ar}_{\mathrm{K}} \\
\left(\times 10^{-15} \mathrm{~mol}\right)\end{array}$ & $\mathrm{K} / \mathrm{Ca}$ & $\begin{array}{l}{ }^{40} \mathrm{Ar}^{*} \\
(\%)\end{array}$ & $\begin{array}{l}{ }^{39} \mathrm{Ar} \\
(\%)\end{array}$ & $\begin{array}{l}\text { Age } \\
\text { (Ma) }\end{array}$ & $\begin{array}{l} \pm 2 \sigma \\
(\mathrm{Ma})\end{array}$ \\
\hline $\mathrm{C}$ & 950 & 8.545 & 0.0207 & 26.90 & 8.15 & 24.6 & 6.7 & 9.8 & 0.082 & 0.016 \\
\hline $\mathrm{D}$ & 1025 & 6.317 & 0.0151 & 19.60 & 11.57 & 33.8 & 8.0 & 17.9 & 0.073 & 0.012 \\
\hline $\mathrm{E}$ & 1060 & 6.892 & 0.0135 & 21.50 & 11.88 & 37.8 & 7.4 & 26.1 & 0.074 & 0.013 \\
\hline $\mathrm{F}$ & 1100 & 7.972 & 0.0128 & 25.60 & 10.52 & 39.9 & 4.9 & 33.5 & 0.056 & 0.015 \\
\hline $\mathrm{G}$ & 1120 & 9.752 & 0.0124 & 31.70 & 9.59 & 41.1 & 3.8 & 40.1 & 0.054 & 0.017 \\
\hline $\mathrm{H}$ & 1160 & 11.83 & 0.0118 & 38.20 & 12.60 & 43.2 & 4.4 & 48.9 & 0.076 & 0.020 \\
\hline I & 1180 & 16.68 & 0.0113 & 54.30 & 10.31 & 45.2 & 3.6 & 56.0 & 0.087 & 0.027 \\
\hline $\mathbf{J}$ & 1200 & 21.72 & 0.0115 & 71.10 & 9.30 & 44.4 & 3.2 & 62.5 & 0.101 & 0.034 \\
\hline $\mathrm{K}$ & 1240 & 32.08 & 0.0112 & 103.7 & 13.15 & 45.6 & 4.4 & 71.6 & 0.204 & 0.047 \\
\hline $\mathrm{L}$ & 1300 & 45.70 & 0.0110 & 146.0 & 18.97 & 46.4 & 5.6 & 84.8 & 0.368 & 0.067 \\
\hline M & 1450 & 51.68 & 0.0105 & 162.9 & 13.70 & 48.6 & 6.8 & 94.3 & 0.508 & 0.074 \\
\hline $\mathrm{N}$ & 1650 & 89.49 & 0.0115 & 284.8 & 8.14 & 44.4 & 5.9 & 100.0 & 0.77 & 0.13 \\
\hline \multicolumn{3}{|c|}{ total gas age } & $\mathrm{n}=14$ & & 143.88 & 40.6 & & & 0.209 & 0.044 \\
\hline
\end{tabular}

\section{LW143FVPo2 sanidine, J=0.0000705, NM-22, Lab\#=2235-01}

\begin{tabular}{|c|c|c|c|c|c|c|c|c|c|c|}
\hline A & 700 & 1974 & 0.4609 & 6662 & 0.66 & 1.1 & 0.3 & 0.9 & 0.7 & 2.8 \\
\hline B & 800 & 430.2 & 0.4189 & 1443 & 0.91 & 1.2 & 0.9 & 2.1 & 0.47 & 0.54 \\
\hline $\mathrm{C}$ & 900 & 131.1 & 0.1208 & 438.3 & 2.01 & 4.2 & 1.2 & 4.7 & 0.19 & 0.17 \\
\hline D & 950 & 49.56 & 0.0593 & 164.1 & 2.03 & 8.6 & 2.1 & 7.4 & 0.132 & 0.074 \\
\hline $\mathrm{E}$ & 1000 & 31.31 & 0.0370 & 104.3 & 2.32 & 13.8 & 1.5 & 10.5 & 0.061 & 0.049 \\
\hline F & 1050 & 24.65 & 0.0258 & 81.10 & 3.06 & 19.8 & 2.7 & 14.5 & 0.083 & 0.037 \\
\hline G & 1100 & 21.71 & 0.0191 & 71.40 & 3.84 & 26.7 & 2.8 & 19.6 & 0.076 & 0.030 \\
\hline $\mathrm{H}$ & 1120 & 19.59 & 0.0173 & 64.40 & 3.11 & 29.5 & 2.7 & 23.7 & 0.066 & 0.034 \\
\hline I & 1140 & 20.54 & 0.0162 & 67.70 & 2.78 & 31.5 & 2.5 & 27.3 & 0.065 & 0.030 \\
\hline $\mathrm{J}$ & 1160 & 21.69 & 0.0151 & 71.33 & 2.87 & 33.8 & 2.7 & 31.1 & 0.075 & 0.033 \\
\hline K & 1180 & 49.54 & 0.0141 & 166.1 & 2.94 & 36.2 & 0.8 & 35.0 & 0.053 & 0.068 \\
\hline $\mathrm{L}$ & 1210 & 27.65 & 0.0152 & 92.60 & 3.24 & 33.6 & 1.0 & 39.3 & 0.035 & 0.037 \\
\hline M & 1240 & 36.74 & 0.0144 & 122.6 & 4.18 & 35.4 & 1.3 & 44.8 & 0.063 & 0.046 \\
\hline $\mathrm{N}$ & 1280 & 56.72 & 0.0150 & 189.7 & 6.51 & 34.0 & 1.1 & 53.4 & 0.081 & 0.069 \\
\hline $\mathrm{O}$ & 1350 & 92.42 & 0.0153 & 302.0 & 14.81 & 33.3 & 3.4 & 72.9 & 0.40 & 0.12 \\
\hline $\mathrm{P}$ & 1400 & 90.91 & 0.0132 & 298.1 & 7.23 & 38.7 & 3.1 & 82.5 & 0.35 & 0.11 \\
\hline Q & 1650 & 103.3 & 0.0136 & 334.3 & 10.66 & 37.5 & 4.3 & 96.5 & 0.57 & 0.11 \\
\hline $\mathrm{R}$ & 1800 & 163.1 & 0.0136 & 532.0 & 2.63 & 37.5 & 3.6 & 100.0 & 0.75 & 0.20 \\
\hline & \multicolumn{2}{|c|}{ total gas age } & $\mathrm{n}=18$ & & 75.81 & 31.1 & & & 0.27 & 0.11 \\
\hline
\end{tabular}

LW143FVPp sanidine, J=0.0000795, NM-10, Lab\#=829-01

$\begin{array}{ccccccccccc}\text { A } & 750 & 104.1 & 0.1082 & 347.6 & 2.00 & 4.7 & 1.3 & 1.6 & 0.19 & 0.18 \\ \text { B } & 850 & 26.97 & 0.0823 & 89.70 & 2.91 & 6.2 & 1.7 & 3.9 & 0.064 & 0.051 \\ \text { C } & 950 & 14.36 & 0.0509 & 46.10 & 5.84 & 10.0 & 4.9 & 8.6 & 0.101 & 0.030 \\ \text { D } & 1025 & 6.449 & 0.0302 & 19.30 & 8.43 & 16.9 & 11.3 & 15.3 & 0.104 & 0.011 \\ \text { E } & 1075 & 4.552 & 0.0216 & 12.90 & 9.51 & 23.6 & 15.5 & 22.9 & 0.101 & 0.010 \\ \text { F } & 11120 & 3.954 & 0.0179 & 10.90 & 10.12 & 28.5 & 18.1 & 31.0 & 0.103 & 0.007 \\ \text { G } & 11140 & 4.086 & 0.0163 & 11.10 & 8.49 & 31.3 & 19.0 & 37.8 & 0.111 & 0.009 \\ \text { H } & 1160 & 4.105 & 0.0140 & 11.20 & 7.60 & 36.4 & 19.0 & 43.8 & 0.112 & 0.009 \\ \text { I } & 11180 & 4.064 & 0.0128 & 10.70 & 7.53 & 39.9 & 21.6 & 49.9 & 0.126 & 0.008\end{array}$




\begin{tabular}{|c|c|c|c|c|c|c|c|c|c|c|}
\hline ID & $\begin{array}{l}\text { Temp } \\
\left({ }^{\circ} \mathrm{C}\right)\end{array}$ & ${ }^{40} \mathrm{Ar} /{ }^{39} \mathrm{Ar}$ & ${ }^{37} \mathrm{Ar} /{ }^{39} \mathrm{Ar}$ & $\begin{array}{c}{ }^{36} \mathrm{Ar} /{ }^{39} \mathrm{Ar} \\
\left(\mathrm{x} 10^{-3}\right)\end{array}$ & $\begin{array}{c}{ }^{39} \mathrm{Ar}_{\mathrm{K}} \\
\left(\times 10^{-15} \mathrm{~mol}\right)\end{array}$ & $\mathrm{K} / \mathrm{Ca}$ & $\begin{array}{l}{ }^{40} \mathrm{Ar}^{*} \\
(\%)\end{array}$ & $\begin{array}{l}{ }^{39} \mathrm{Ar} \\
(\%)\end{array}$ & $\begin{array}{l}\text { Age } \\
(\mathrm{Ma})\end{array}$ & $\begin{array}{l} \pm 2 \sigma \\
(\mathrm{Ma})\end{array}$ \\
\hline $\mathrm{J}$ & 1220 & 4.941 & 0.0119 & 12.20 & 10.36 & 42.7 & 26.8 & 58.1 & 0.190 & 0.009 \\
\hline $\mathrm{K}$ & 1260 & 6.984 & 0.0111 & 16.50 & 9.49 & 46.0 & 30.0 & 65.7 & 0.300 & 0.011 \\
\hline $\mathrm{L}$ & 1320 & 12.11 & 0.0099 & 20.50 & 15.85 & 51.7 & 49.8 & 78.4 & 0.864 & 0.013 \\
\hline M & 1450 & 13.92 & 0.0087 & 18.40 & 20.19 & 59.0 & 60.8 & 94.5 & 1.213 & 0.012 \\
\hline $\mathrm{N}$ & 1650 & 32.10 & 0.0142 & 65.30 & 3.55 & 35.9 & 39.8 & 97.3 & 1.833 & 0.042 \\
\hline $\mathrm{O}$ & 1650 & 116.8 & 0.0145 & 352.0 & 3.37 & 35.2 & 10.9 & 100.0 & 1.82 & 0.18 \\
\hline \multicolumn{3}{|r|}{ s age } & $\mathrm{n}=15$ & & 125.25 & 37.7 & & & 0.498 & 0.021 \\
\hline
\end{tabular}

\section{LW143FVPu sanidine, J=0.0000702, NM-22, Lab\#=2236-01}

$\begin{array}{ccccccccccc}\mathrm{A} & 700 & 1430 & 0.2077 & 4780 & 0.33 & 2.5 & 1.2 & 0.4 & 2.18 & 3.10 \\ \mathrm{~B} & 800 & 329.6 & 0.1209 & 1093 & 0.58 & 4.2 & 2.0 & 1.0 & 0.83 & 0.43 \\ \mathrm{C} & 900 & 68.76 & 0.0681 & 224.9 & 1.54 & 7.5 & 3.3 & 2.7 & 0.287 & 0.082 \\ \mathrm{D} & 950 & 34.62 & 0.0404 & 113.4 & 1.67 & 12.6 & 3.1 & 4.5 & 0.137 & 0.045 \\ \mathrm{E} & 1000 & 23.85 & 0.0250 & 77.60 & 2.18 & 20.4 & 3.7 & 6.8 & 0.111 & 0.031 \\ \mathrm{~F} & 1050 & 14.15 & 0.0158 & 44.70 & 3.10 & 32.3 & 6.5 & 10.2 & 0.117 & 0.019 \\ \mathrm{G} & 1100 & 11.43 & 0.0127 & 35.90 & 4.04 & 40.2 & 7.1 & 14.6 & 0.102 & 0.015 \\ \mathrm{H} & 1120 & 8.753 & 0.0121 & 27.10 & 3.61 & 42.2 & 8.1 & 18.5 & 0.090 & 0.012 \\ \mathrm{I} & 1140 & 8.210 & 0.0121 & 25.30 & 3.47 & 42.2 & 8.7 & 22.3 & 0.090 & 0.011 \\ \mathrm{~J} & 1160 & 7.151 & 0.0123 & 21.84 & 3.42 & 41.5 & 9.4 & 26.0 & 0.086 & 0.010 \\ \mathrm{~K} & 1180 & 8.448 & 0.0123 & 26.16 & 3.49 & 41.5 & 8.2 & 29.8 & 0.088 & 0.012 \\ \mathrm{~L} & 1210 & 21.69 & 0.0124 & 70.80 & 4.32 & 41.1 & 3.4 & 34.5 & 0.093 & 0.025 \\ \mathrm{M} & 1240 & 35.13 & 0.0117 & 116.8 & 5.43 & 43.6 & 1.6 & 40.4 & 0.073 & 0.040 \\ \mathrm{~N} & 1280 & 15.29 & 0.0113 & 49.00 & 6.12 & 45.0 & 5.2 & 47.0 & 0.100 & 0.018 \\ \mathrm{O} & 1350 & 28.08 & 0.0107 & 87.90 & 15.01 & 47.7 & 7.5 & 63.3 & 0.265 & 0.029 \\ \mathrm{P} & 1400 & 25.69 & 0.0090 & 77.28 & 16.36 & 57.0 & 11.0 & 81.1 & 0.359 & 0.026 \\ \mathrm{Q} & 1650 & 32.84 & 0.0085 & 99.00 & 12.30 & 59.8 & 10.8 & 94.5 & 0.451 & 0.034 \\ \mathrm{R} & 1800 & 72.29 & 0.0084 & 230.9 & 5.08 & 60.7 & 5.6 & 100.0 & 0.510 & 0.079 \\ & \text { total gas age } & \mathrm{n}=18 & & 92.04 & 46.8 & & & 0.255 & 0.042\end{array}$

LW145FVPa1 sanidine, J=0.0000798, NM-10, Lab\#=827-01

$\begin{array}{ccccccccccc}\text { A } & 700 & 370.5 & 0.0392 & 1222 & 0.14 & 13.0 & 2.5 & 0.5 & 1.3 & 1.6 \\ \text { B } & 800 & 12.93 & 0.0284 & 19.30 & 0.28 & 18.0 & 55.8 & 1.6 & 1.04 & 0.15 \\ \text { C } & 875 & 4.553 & 0.0280 & -5.7600 & 0.43 & 18.2 & 137 & 3.2 & 0.897 & 0.072 \\ \text { D } & 930 & 5.249 & 0.0252 & -2.8900 & 0.56 & 20.2 & 116 & 5.3 & 0.875 & 0.067 \\ \text { E } & 980 & 9.041 & 0.0355 & 9.170 & 0.72 & 14.4 & 69.8 & 8.0 & 0.908 & 0.042 \\ \text { F } & 1030 & 8.559 & 0.0333 & 7.480 & 0.87 & 15.3 & 73.9 & 11.2 & 0.911 & 0.037 \\ \text { G } & 11070 & 8.888 & 0.0308 & 8.420 & 1.00 & 16.6 & 71.8 & 15.0 & 0.918 & 0.029 \\ \text { H } & 1100 & 10.30 & 0.0298 & 8.890 & 1.05 & 17.1 & 74.3 & 18.9 & 1.100 & 0.027 \\ \text { I } & 1120 & 10.17 & 0.0265 & 2.470 & 1.09 & 19.3 & 92.6 & 23.0 & 1.356 & 0.034 \\ \text { J } & 1140 & 190.8 & 0.0292 & 600.9 & 1.10 & 17.5 & 6.9 & 27.0 & 1.90 & 0.38 \\ \text { K } & 1170 & 22.12 & 0.0291 & 23.53 & 0.91 & 17.5 & 68.5 & 30.5 & 2.179 & 0.047 \\ \text { L } & 11200 & 24.68 & 0.0273 & 22.00 & 1.47 & 18.7 & 73.6 & 36.0 & 2.613 & 0.040 \\ \text { M } & 1260 & 42.49 & 0.0287 & 26.50 & 3.55 & 17.8 & 81.5 & 49.2 & 4.981 & 0.031 \\ \text { N } & 1340 & 38.46 & 0.0274 & 24.50 & 4.63 & 18.6 & 81.1 & 66.5 & 4.487 & 0.032 \\ \text { O } & 1450 & 40.71 & 0.0263 & 37.52 & 1.33 & 19.4 & 72.7 & 71.5 & 4.256 & 0.056\end{array}$




\begin{tabular}{|c|c|c|c|c|c|c|c|c|c|c|}
\hline $\mathrm{ID}$ & $\begin{array}{l}\text { Temp } \\
\left({ }^{\circ} \mathrm{C}\right)\end{array}$ & ${ }^{40} \mathrm{Ar} /{ }^{39} \mathrm{Ar}$ & ${ }^{37} \mathrm{Ar} /{ }^{39} \mathrm{Ar}$ & $\begin{array}{l}{ }^{36} \mathrm{Ar} r^{39} \mathrm{Ar} \\
\left(\times 10^{-3}\right)\end{array}$ & $\begin{array}{c}{ }^{39} \mathrm{Ar}_{\mathrm{K}} \\
\left(\times 10^{-15} \mathrm{~mol}\right)\end{array}$ & $\mathrm{K} / \mathrm{Ca}$ & $\begin{array}{l}{ }^{40} \mathrm{Ar}^{*} \\
(\%)\end{array}$ & $\begin{array}{l}{ }^{39} \mathrm{Ar} \\
(\%)\end{array}$ & $\begin{array}{l}\text { Age } \\
\text { (Ma) }\end{array}$ & $\begin{array}{l} \pm 2 \sigma \\
\text { (Ma) }\end{array}$ \\
\hline $\mathrm{P}$ & 1650 & 48.59 & 0.0300 & 49.60 & 5.76 & 17.0 & 69.8 & 93.0 & 4.876 & 0.042 \\
\hline Q & 1650 & 156.9 & 0.0410 & 412.4 & 1.87 & 12.4 & 22.3 & 100.0 & 5.03 & 0.22 \\
\hline \multicolumn{3}{|c|}{ total gas age } & $\mathrm{n}=17$ & & 26.77 & 17.3 & & & 3.583 & 0.074 \\
\hline
\end{tabular}

\section{LW145FVPa2 sanidine, J=0.0000697, NM-22, Lab\#=2246-01}

$\begin{array}{ccccccccccc}\mathrm{A} & 700 & 273.6 & 0.2307 & 907.7 & 0.51 & 2.2 & 2.0 & 2.6 & 0.68 & 0.38 \\ \mathrm{~B} & 800 & 165.0 & 0.2567 & 537.4 & 0.43 & 2.0 & 3.8 & 4.7 & 0.78 & 0.25 \\ \mathrm{C} & 900 & 105.3 & 0.0533 & 329.5 & 0.67 & 9.6 & 7.5 & 8.1 & 1.00 & 0.14 \\ \mathrm{D} & 950 & 93.89 & 0.0419 & 296.9 & 0.56 & 12.2 & 6.5 & 11.0 & 0.77 & 0.13 \\ \mathrm{E} & 1000 & 76.67 & 0.0363 & 234.3 & 0.77 & 14.1 & 9.7 & 14.9 & 0.930 & 0.097 \\ \mathrm{~F} & 1050 & 70.19 & 0.0334 & 212.1 & 1.09 & 15.3 & 10.7 & 20.4 & 0.942 & 0.096 \\ \mathrm{G} & 1100 & 58.60 & 0.0318 & 170.9 & 1.10 & 16.0 & 13.8 & 26.0 & 1.015 & 0.069 \\ \mathrm{H} & 1120 & 50.42 & 0.0313 & 140.0 & 0.80 & 16.3 & 17.9 & 30.1 & 1.134 & 0.069 \\ \mathrm{I} & 1140 & 47.09 & 0.0289 & 127.5 & 0.66 & 17.7 & 19.9 & 33.5 & 1.179 & 0.070 \\ \mathrm{~J} & 1160 & 41.66 & 0.0285 & 108.1 & 0.71 & 17.9 & 23.3 & 37.1 & 1.220 & 0.061 \\ \mathrm{~K} & 1180 & 43.15 & 0.0274 & 112.6 & 0.60 & 18.6 & 22.8 & 40.2 & 1.239 & 0.065 \\ \mathrm{~L} & 1210 & 41.40 & 0.0281 & 105.2 & 0.71 & 18.2 & 24.8 & 43.8 & 1.293 & 0.061 \\ \mathrm{M} & 1240 & 50.80 & 0.0299 & 129.8 & 1.14 & 17.1 & 24.5 & 49.6 & 1.563 & 0.060 \\ \mathrm{~N} & 1280 & 66.45 & 0.0318 & 138.9 & 1.84 & 16.0 & 38.2 & 59.0 & 3.190 & 0.059 \\ \mathrm{O} & 1350 & 64.37 & 0.0306 & 113.4 & 3.76 & 16.7 & 47.9 & 78.0 & 3.874 & 0.051 \\ \mathrm{P} & 1400 & 110.0 & 0.0270 & 259.7 & 0.64 & 18.9 & 30.2 & 81.3 & 4.17 & 0.12 \\ \mathrm{Q} & 1650 & 82.80 & 0.0312 & 156.8 & 3.19 & 16.4 & 44.0 & 97.5 & 4.576 & 0.065 \\ \mathrm{R} & 1800 & 574.3 & 0.0156 & 1793 & 0.49 & 32.7 & 7.8 & 100.0 & 5.60 & 0.87 \\ & \text { total gas age } & \mathrm{n}=18 & & 19.67 & 16.0 & & & 2.60 & 0.10\end{array}$

Isotopic ratios corrected for blank, radioactive decay, and mass discrimination, not corrected for interfering reactions.

Individual analyses show analytical error only; mean age errors also include error in $\mathrm{J}$ and irradiation parameters.

Correction factors:

$$
\begin{aligned}
& \left({ }^{39} \mathrm{Ar} r^{37} \mathrm{Ar}\right)_{\mathrm{Ca}}=0.00070 \pm 0.00005 \\
& \left({ }^{36} \mathrm{Ar} r^{37} \mathrm{Ar}\right)_{\mathrm{Ca}}=0.00026 \pm 0.00002 \\
& \left({ }^{38} \mathrm{Ar} r^{39} \mathrm{Ar}\right)_{\mathrm{K}}=0.0119 \\
& \left({ }^{40} \mathrm{Ar} r^{39} \mathrm{Ar}\right)_{\mathrm{K}}=0.0250 \pm 0.0050
\end{aligned}
$$


Appendix 2.3. U-Th Disequilibrium Analytical Results.

\begin{tabular}{|c|c|c|c|c|c|c|c|c|c|c|}
\hline Sample $^{1}$ & $\begin{array}{c}\text { Th } \\
(\mathrm{ppm})\end{array}$ & $\begin{array}{c}\mathrm{U} \\
(\mathrm{ppm}) \\
\end{array}$ & $\begin{array}{l}\mathrm{Th} / \mathrm{U} \\
\text { (wt.) }\end{array}$ & $\begin{array}{c}(+/-) \\
(\%)\end{array}$ & $\begin{array}{l}\left({ }^{238} \mathrm{U}\right) / \\
\left({ }^{232} \mathrm{Th}\right)\end{array}$ & $\begin{array}{c}(+/-) \\
(\%)\end{array}$ & $\begin{array}{l}\left({ }^{230} \mathrm{Th}\right) / \\
\left({ }^{232} \mathrm{Th}\right)\end{array}$ & $\begin{array}{c}(+/-) \\
(\%)\end{array}$ & $\begin{array}{l}\left({ }^{230} \mathrm{Th}\right) / \\
\left({ }^{238} \mathrm{Th}\right)\end{array}$ & $\begin{array}{c}(+/-) \\
(\%)\end{array}$ \\
\hline Q11d plag & 3.9026 & 1.1952 & 3.2653 & 0.4545 & 0.9291 & 0.4545 & 0.8876 & 0.4717 & 0.9554 & 0.6551 \\
\hline Q11d wr & 6.0981 & 1.8734 & 3.2552 & 0.4387 & 0.9325 & 0.4387 & 0.9036 & 0.5057 & 0.9690 & 0.6695 \\
\hline Q11d olv & 0.2645 & 0.0948 & 2.7889 & 0.4295 & 1.0878 & 0.4295 & 0.8503 & 0.6440 & 0.7817 & 0.7741 \\
\hline Q11d mag & 2.4354 & 0.7313 & 3.3301 & 0.4545 & 0.9105 & 0.4545 & 0.8910 & 0.5814 & 0.9786 & 0.7380 \\
\hline Q11d f-olv & 0.5797 & 0.1782 & 3.2523 & 0.4295 & 0.9238 & 0.4295 & 0.9080 & 0.7467 & 0.9829 & 0.8615 \\
\hline Ql1d $\rho>2.8$ & 3.6159 & 1.0747 & 3.3645 & 0.4341 & 0.9017 & 0.4341 & 0.8833 & 0.4518 & 0.9796 & 0.6265 \\
\hline Q11d glass & 6.8557 & 2.0044 & 3.4204 & 0.4171 & 0.8870 & 0.4171 & 0.8679 & 0.4565 & 0.9786 & 0.6184 \\
\hline Ql1d o-mag & 0.2335 & 0.0861 & 2.7106 & 0.3600 & 1.1192 & 0.3600 & 1.0306 & 1.8682 & 0.9208 & 1.9025 \\
\hline Q13 o-mag & 0.1890 & 0.0598 & 3.1581 & 0.3808 & 0.9606 & 0.3808 & 0.9209 & 1.4985 & 0.9587 & 0.3808 \\
\hline Q13 2.8 & 8.2377 & 2.4057 & 3.4243 & 0.5333 & 0.8851 & 0.5333 & 0.8823 & 0.3967 & 0.9968 & 0.7310 \\
\hline Q13 pyx & 2.3001 & 0.5922 & 3.8837 & 0.4152 & 0.7811 & 0.4152 & 0.8470 & 0.4014 & 1.0844 & 0.4152 \\
\hline Q13 wr & 7.5233 & 2.2005 & 3.4188 & 1.2679 & 0.8831 & 1.2679 & 0.8756 & 0.5025 & 0.9916 & 1.3629 \\
\hline Q13 olv & 0.0861 & 0.0243 & 3.5466 & 0.3464 & 0.8554 & 0.3464 & 0.8931 & 0.3700 & 1.0441 & 0.5069 \\
\hline Ql3 2.6 & 5.3700 & 1.5970 & 3.3626 & 0.4545 & 0.9000 & 0.4545 & 0.8920 & 0.5045 & 0.9911 & 0.5737 \\
\hline Q13 mag & 3.2390 & 0.9350 & 3.4642 & 0.3808 & 0.8836 & 0.3808 & 0.8900 & 0.5056 & 1.0073 & 0.5039 \\
\hline LBP f-plag & 0.5770 & 0.1461 & 3.9494 & 0.3682 & 0.7682 & 0.3682 & 0.7715 & 0.7518 & 1.0043 & 0.3682 \\
\hline LBP c-plag & 0.3180 & 0.0583 & 5.4515 & 0.3464 & 0.5567 & 0.3464 & 0.5719 & 1.1016 & 1.0273 & 0.3464 \\
\hline LBP o-mag & 1.0870 & 0.2765 & 3.9318 & 0.4455 & 0.7713 & 0.4455 & 0.7881 & 0.4060 & 1.0218 & 0.4455 \\
\hline LBP gl & 6.6840 & 1.6050 & 4.1644 & 0.3731 & 0.7285 & 0.3731 & 0.7454 & 0.6037 & 1.0232 & 0.3731 \\
\hline LBP wr & 8.6730 & 2.1080 & 4.1143 & 0.4387 & 0.7374 & 0.4387 & 0.7486 & 0.4007 & 1.0152 & 0.4387 \\
\hline LBP olv & 0.3990 & 0.0928 & 4.2996 & 0.3975 & 0.7060 & 0.3975 & 0.7345 & 1.1028 & 1.0404 & 0.3975 \\
\hline LBP mag & 8.2930 & 1.9669 & 4.2162 & 0.4069 & 0.7195 & 0.4069 & 0.7332 & 0.3955 & 1.0190 & 0.4069 \\
\hline Qs3 wr & 7.6226 & 2.1544 & 3.5382 & 0.3982 & 0.8574 & 0.3982 & 0.8694 & 0.4946 & 1.0140 & 0.3982 \\
\hline Qs3 c olv & 0.2018 & 0.0562 & 3.5937 & 0.3826 & 0.8442 & 0.3826 & 0.8428 & 0.5339 & 0.9984 & 0.3826 \\
\hline Qs3 f olv & 0.3091 & 0.0930 & 3.3238 & 0.4119 & 0.9127 & 0.4119 & 0.9106 & 0.7028 & 0.9977 & 0.4119 \\
\hline Qs3 gl & 7.6001 & 2.1588 & 3.5204 & 0.3929 & 0.8617 & 0.3929 & 0.8726 & 0.5042 & 1.0126 & 0.3929 \\
\hline Qs3 mag & 8.7082 & 2.5111 & 3.4679 & 0.4387 & 0.8748 & 0.4387 & 0.8741 & 0.5949 & 0.9992 & 0.4387 \\
\hline Qs3 f-omag & 0.5977 & 0.1864 & 3.2064 & 0.3640 & 0.9461 & 0.3640 & 0.9476 & 1.0553 & 1.0015 & 0.3640 \\
\hline
\end{tabular}


Appendix 2.4. Paleomagnetic data for the Lathrop Wells Volcanic Center.

\begin{tabular}{|c|c|c|c|c|c|c|c|c|c|c|c|c|c|c|}
\hline $\begin{array}{l}\text { Site } \\
\text { [Sample] }\end{array}$ & $\begin{array}{l}\text { Rock Type, } \\
\text { ID }\end{array}$ & $\begin{array}{l}\text { NRM } \\
\text { Intensity }\end{array}$ & $\mathbf{n} / \mathbf{N} / \mathbf{N o}$ & Decl. & Incl. & $\alpha 95$ & $\mathbf{k}$ & $\alpha 951-3$ & $\alpha 951-2$ & k1-3 & k1-2 & $\begin{array}{c}\text { Azimuth VGP } \\
\text { Lat }\end{array}$ & $\begin{array}{l}\text { VGP } \\
\text { Long }\end{array}$ & Comments \\
\hline LW1 & Flow, Q11d & & $9 / 9 / 09$ & 2.7 & 53.5 & 5.4 & 93.2 & 2.3 & 6 & -201.9 & -31.1 & 81.3 & & \\
\hline LW2 & Flow, Q11d & & 9/9/09 & 13.8 & 53.3 & 3.5 & 210.9 & 2.2 & 3.6 & -216.4 & -82.9 & 145.4 & & \\
\hline LW3 & Flow, Q11d, c & It of place & & & & & & & & & & & & \\
\hline LW4 & Flow, Q11d, c & at of place & & & & & & & & & & & & \\
\hline LW5 & Flow, Q11a & & 8/8/11 & 18.5 & 53.6 & 7.1 & 62.3 & 4.4 & 7 & -63.2 & -26.1 & 132.8 & & \\
\hline LW6 & Flow, Q11a, o & it of place & & & & & & & & & & & & \\
\hline LW7 & Flow, Q11a & & $\begin{array}{r}10 / 10 / \\
12\end{array}$ & 346.3 & 53.8 & 5.3 & 83.8 & 3.6 & 5.4 & -75.9 & -34.9 & 179.3 & & \\
\hline LW8 & Flow, Q11a & & 6/6/08 & 358.3 & 45.3 & 5.5 & 147.9 & 3.6 & 4.9 & -127.9 & -69 & 106 & & \\
\hline LW9 & Buried Flow, & Q11c & $\begin{array}{r}10 / 10 / \\
10\end{array}$ & 350.8 & 42.1 & 7.5 & 42.9 & 2.8 & 8.7 & -131.5 & -14.1 & 30.5 & & \\
\hline LW10 & Buried Flow, & Q11c & 7/7/10 & 17.1 & 52.2 & 6.6 & 85.2 & 2.6 & 7.1 & -211.4 & -29 & 66.2 & & \\
\hline LW11 & Flow Q11c, tr & nch & $\begin{array}{r}11 / 11 / \\
16\end{array}$ & 11.2 & 46.9 & 2.4 & 359.2 & 1.6 & 2.6 & -370.5 & -136.4 & 94.4 & & \\
\hline LW12 & Flow Q11c, tr & nch & $9 / 9 / 13$ & 6.8 & 54.6 & 5.1 & 102.3 & 2.1 & 5.8 & -247.5 & -33.5 & 126.9 & & \\
\hline LW13 & Scoria Moun & Qs $2 u$ & & $\begin{array}{l}\text { Spec. } \\
\text { Decl. }\end{array}$ & $\begin{array}{l}\text { Spec. } \\
\text { Incl }\end{array}$ & MAD & Circle & Circle & MAD & & & & & \\
\hline A & & & & 29.1 & 45.6 & 3.8 & & & & & & & & \\
\hline B & & & & 22.4 & 55.4 & 3.7 & & & & & & & & \\
\hline $\mathrm{C}$ & & & & 6.4 & 61.1 & 1.9 & & & & & & & & \\
\hline $\mathrm{D}$ & & & & 323.2 & 64.5 & 7.1 & & & & & & & & \\
\hline $\mathrm{E}$ & & & & 7 & 54.9 & 6.4 & & & & & & & & \\
\hline $\mathrm{F}$ & & & & 6.3 & 55.3 & 3.3 & & & & & & & & \\
\hline $\mathrm{G}$ & & & & 24.3 & 49.9 & 2.8 & & & & & & & & \\
\hline $\mathrm{H}$ & & & & 303.7 & 51.2 & 2.2 & & & & & & & & \\
\hline I & & & & 352.3 & 56 & 5.3 & & & & & & & & \\
\hline $\mathrm{J}$ & & & & 6.2 & 49.2 & 4.8 & & & & & & & & \\
\hline K & & & & & & & & & & & & & & \\
\hline $\mathrm{L}$ & & & & 353.1 & 57.4 & 1.3 & & & & & & & & \\
\hline
\end{tabular}


Appendix 2.4. (continued)

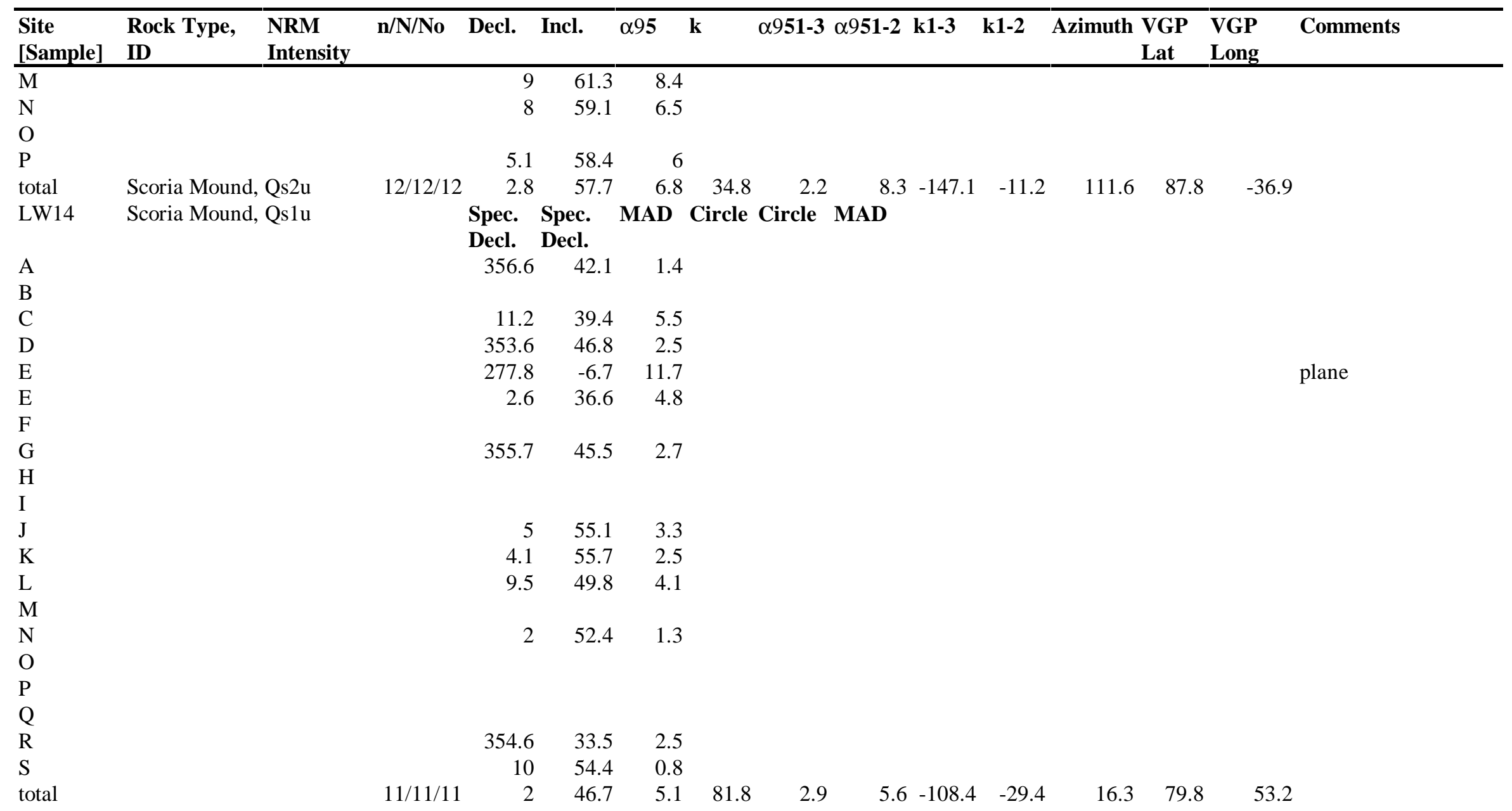


Appendix 2.4. (continued)

\begin{tabular}{|c|c|c|c|c|c|c|c|c|c|c|c|c|c|c|c|}
\hline $\begin{array}{l}\text { Site } \\
\text { [Sample] }\end{array}$ & $\begin{array}{l}\text { Rock Type, } \\
\text { ID }\end{array}$ & $\begin{array}{l}\text { NRM } \\
\text { Intensity }\end{array}$ & n/N/No & Decl. & Incl. & $\alpha 95$ & $\mathbf{k}$ & $\alpha 951-3$ & $\alpha 951-2$ & k1-3 & k1-2 & Azimuth & $\begin{array}{l}\text { VGP } \\
\text { Lat }\end{array}$ & $\begin{array}{l}\text { VGP } \\
\text { Long }\end{array}$ & Comments \\
\hline LW15 & Dike, Qs1u & & $10 / 10 / 10$ & 2.2 & 52.2 & 3.1 & 364.9 & 2.3 & 2.8 & -254.3 & -184.6 & 20.7 & & & \\
\hline LW16 & Plug, Q11u & & $10 / 10 / 10$ & 3.6 & 52.2 & 1.2 & 935 & 0.9 & 1.3 & -675.8 & -400.4 & 33.3 & & & \\
\hline LW17 & Flow, Q11d & & $10 / 10 / 10$ & 355 & 52 & 3.8 & 128.6 & 2 & 4.4 & -197.7 & -43.7 & 61.3 & & & \\
\hline LW18 & Plug, Q11u & & $10 / 10 / 10$ & 6.8 & 53.7 & 4.1 & 142.1 & 2.6 & 5.8 & -239 & -48.5 & 117.4 & & & \\
\hline LW19 & Flow, Q12 & & $10 / 10 / 10$ & 6.3 & 52.5 & 2.9 & 307.7 & 1.7 & 3.1 & -372.8 & -114.4 & 65.8 & & & \\
\hline LW20 & Flow, Q13 & & $10 / 10 / 10$ & 352.9 & 53.6 & 5.2 & 215.5 & 2 & 5 & -474.9 & -79.8 & 103.8 & & & \\
\hline LW21 & Q11d, Rubble & & & $\begin{array}{l}\text { Spec. } \\
\text { Decl }\end{array}$ & $\begin{array}{l}\text { Spec. } \\
\text { Incl. }\end{array}$ & MAD & \multicolumn{3}{|c|}{ Circle Circle MAD } & & & & & & \\
\hline A & & & & 343.6 & 39.5 & 4.2 & & & & & & & & & \\
\hline B & & & & 74 & 34.9 & 3.8 & 326.6 & 20.7 & 14.9 & & & & & & \\
\hline $\mathrm{C}$ & & & & 95.5 & 61.5 & 4.6 & & & & & & & & & \\
\hline $\mathrm{D}$ & & & & 87.5 & 57.9 & 2.3 & & & & & & & & & \\
\hline $\mathrm{E}$ & & & & 75 & 54.8 & 4.1 & & & & & & & & & \\
\hline $\mathrm{F}$ & & & & 95.2 & 59.2 & 3.1 & & & & & & & & & \\
\hline $\mathrm{G}$ & & & & 101.2 & 59.4 & 5.6 & & & & & & & & & \\
\hline $\mathrm{H}$ & & & & 204 & 30 & 4.4 & & & & & & & & & \\
\hline \multicolumn{16}{|l|}{ I } \\
\hline $\mathrm{J}$ & & & & 112 & 25.4 & 4.8 & & & & & & & & & \\
\hline \multicolumn{16}{|l|}{$\mathrm{K}$} \\
\hline $\mathrm{L}$ & & & & 121 & 27.7 & 7.5 & 220.7 & 19.3 & 7.4 & & & & & & \\
\hline M & & & & 77.1 & 35.2 & 8.5 & & & & & & & & & \\
\hline \multicolumn{16}{|l|}{$\mathrm{N}$} \\
\hline $\mathrm{O}$ & & & & 103 & 60 & 10.2 & & & & & & & & & \\
\hline $\mathrm{P}$ & & & & 92.9 & 60.1 & 8.2 & & & & & & & & & \\
\hline total & & & $10 / 10 / 14$ & 93.9 & 48.9 & 11.4 & 18.9 & 8.3 & 11.3 & -16.2 & -9.1 & 143 & 15 & -53 & $\begin{array}{l}3 \text { Combined } 1 \\
95.0,52.6,8\end{array}$ \\
\hline
\end{tabular}


Appendix 2.4. (continued)

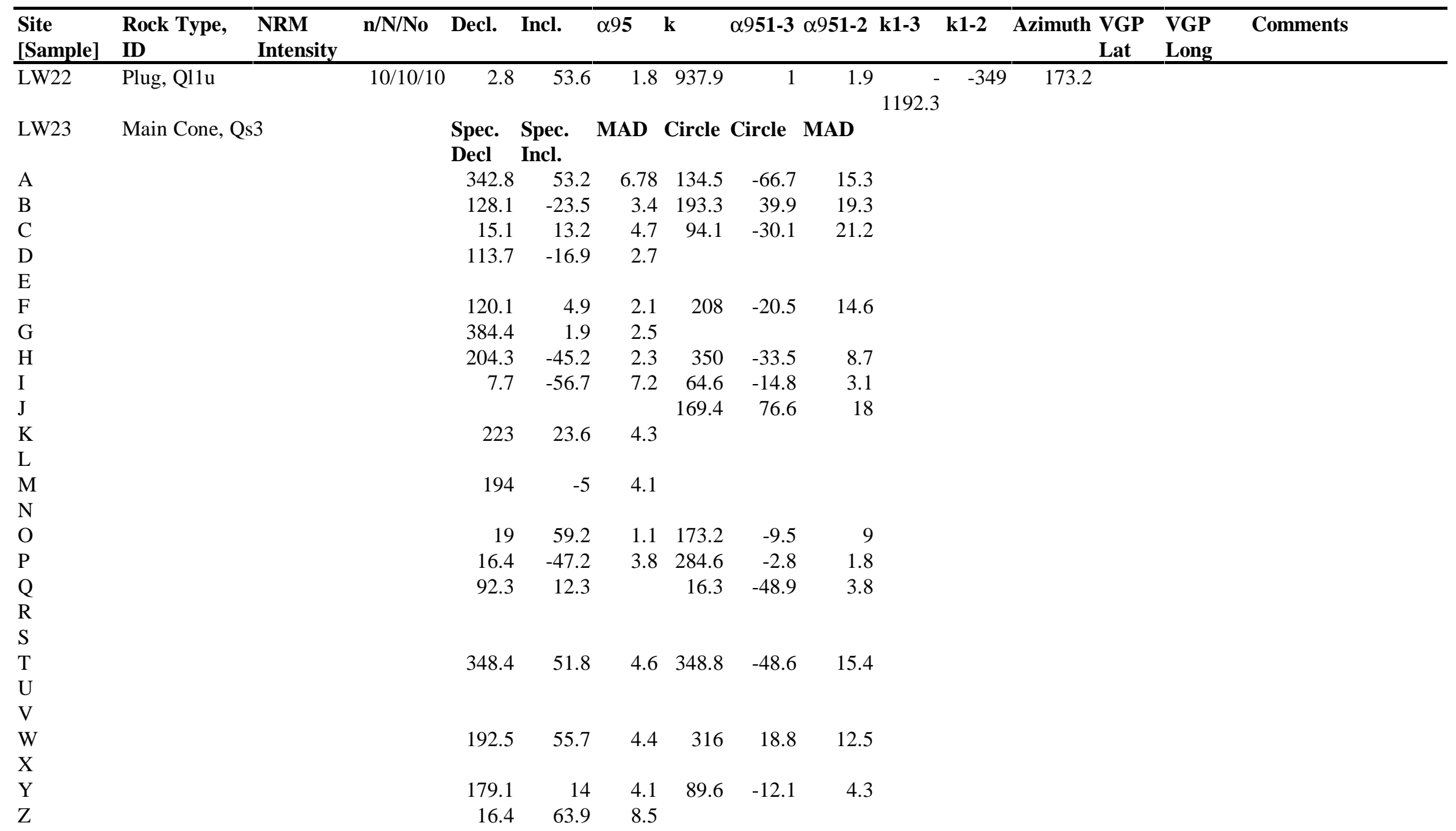


Appendix 2.4. (continued)

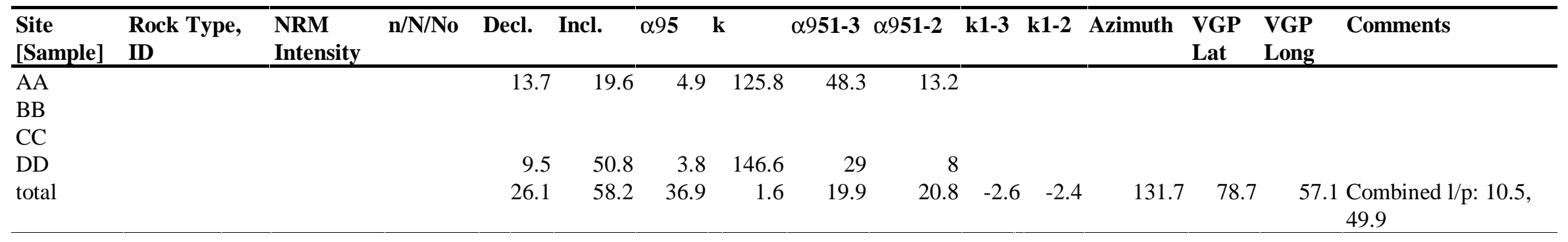

Sample \#
\begin{tabular}{|l|l|l|l|}
\hline LW1 & LW 6-3-91-1-JWG & LW13 & LW 11-10-92-13-JWG \\
\hline LW2 & LW 6-3-91-2-JWG & LW14 & LW 11-10-92-14-JWG \\
\hline LW3 & LW 6-3-91-3-JWG & LW15 & LW 11-10-92-15-JWG \\
\hline LW4 & LW 6-3-91-4-JWG & LW16 & LW 11-23-92-16-JWG \\
\hline LW5 & LW 6-3-91-5-JWG & LW17 & LW 11-23-92-17-JWG \\
\hline LW6 & LW 6-3-91-6-JWG & LW18 & LW 11-23-92-18-JWG \\
\hline LW7 & LW 6-3-91-7-JWG & LW19 & LW 11-23-92-19-JWG \\
\hline LW8 & LW 6-3-91-8-JWG & LW20 & LW 11-23-92-20-JWG \\
\hline LW9 & LW 6-3-91-9-JWG & LW21 & LW 11-23-92-21-JWG \\
\hline LW10 & LW 6-3-91-10-JWG & LW22 & LW 11-23-92-22-JWG \\
\hline LW11 & LW 11-10-92-11-JWG & LW23 & LW 11-23-92-23-JWG \\
\hline LW12 & LW 11-10-92-12-JWG & & \\
\hline
\end{tabular}


FY96 \& FY97 revisions

\section{Appendix 2-M1 through 2-M5: Captions for geologic maps on topographic bases}

We have completed, in collaboration with the TRW GIS group, compilation of five geologic maps of post-Miocene volcanic centers on digital topographic bases. Equivalent maps for Black and Red Cones in Crater Flat can be found in Faulds et al. (1994). The five maps consist of

Appendix 2-M1 Geology of Pliocene Basalt of Crater Flat. The revised geologic map of the basalt of southeast Crater Flat was compiled from geologic mapping on 1:12,000scale uncorrected air photos onto 1:12,000-scale orthophotographic quadrangles and then transferred to a 20-foot-contour-interval topographic base.

Appendix 2-M2 Geology of Little Cones. The geologic map of Little Cones was compiled from geologic mapping on 1:12,000-scale uncorrected air photos onto a 1:12,000-scale orthophotographic quadrangle and then transferred to a 20 -footcontour-interval topographic base. There is a slight mismatch between the geologic and topographic data of Little Cones because the topographic data was generated from digital data of a different scale than that of which the geologic map was compiled.

Appendix 2-M3 Geology of Makani Cone. The geologic map of Makani Cone was compiled from geologic mapping on 1:12,000-scale uncorrected air photos onto a $\sim 1: 12,000$-scale orthophotographic quadrangle and then transferred to a 20 -footcontour-interval topographic base.

Appendix 2-M4 Geology of the Sleeping Butte Cones: Little Black Peak and Hidden Cone. The geologic map of the Sleeping Butte basalt centers was compiled from geologic mapping on a 1:30,000 uncorrected air photo ( $E G \& G$ aerial photograph 6615-002-BMC) and then transferred to a 20-foot-contour-interval topographic base.

The geology of the Little Black Peak center is unchanged from the description in Crowe and Perry (1991). The Hidden Cone center now includes a north flow that was mapped originally as part of the center but not included in the report by Crowe and Perry (1991). We now agree with Fleck et al. (1996) that the flow is derived from Hidden Cone. The line denoting the north Qsf deposits of Hidden Cone is dotted because the contact edge is very approximate. The dashed line of the north lava flow is a lineament on aerial photographs and probably marks the flow edge of an aa flow lobe. The flow lobe overlies an earlier flow-lobe segment exposed to the south and in turn is overlain by rafted cone-scoria and scoria-fall deposits. The arrows mark flank breakout sites that were the sources of the flank, blocky aa lava flows.

Appendix 2-M5 Geology of Lathrop Wells Volcanic Center. The revised geologic map of the Lathrop Wells volcanic center was compiled from geologic mapping on $1: 4,000$, $1: 7,370$, and 1:12,000 uncorrected air photos compiled on 1:12,000-scale orthophotographic quadrangles and then transferred onto a 20 -foot-contour-interval topographic base. 


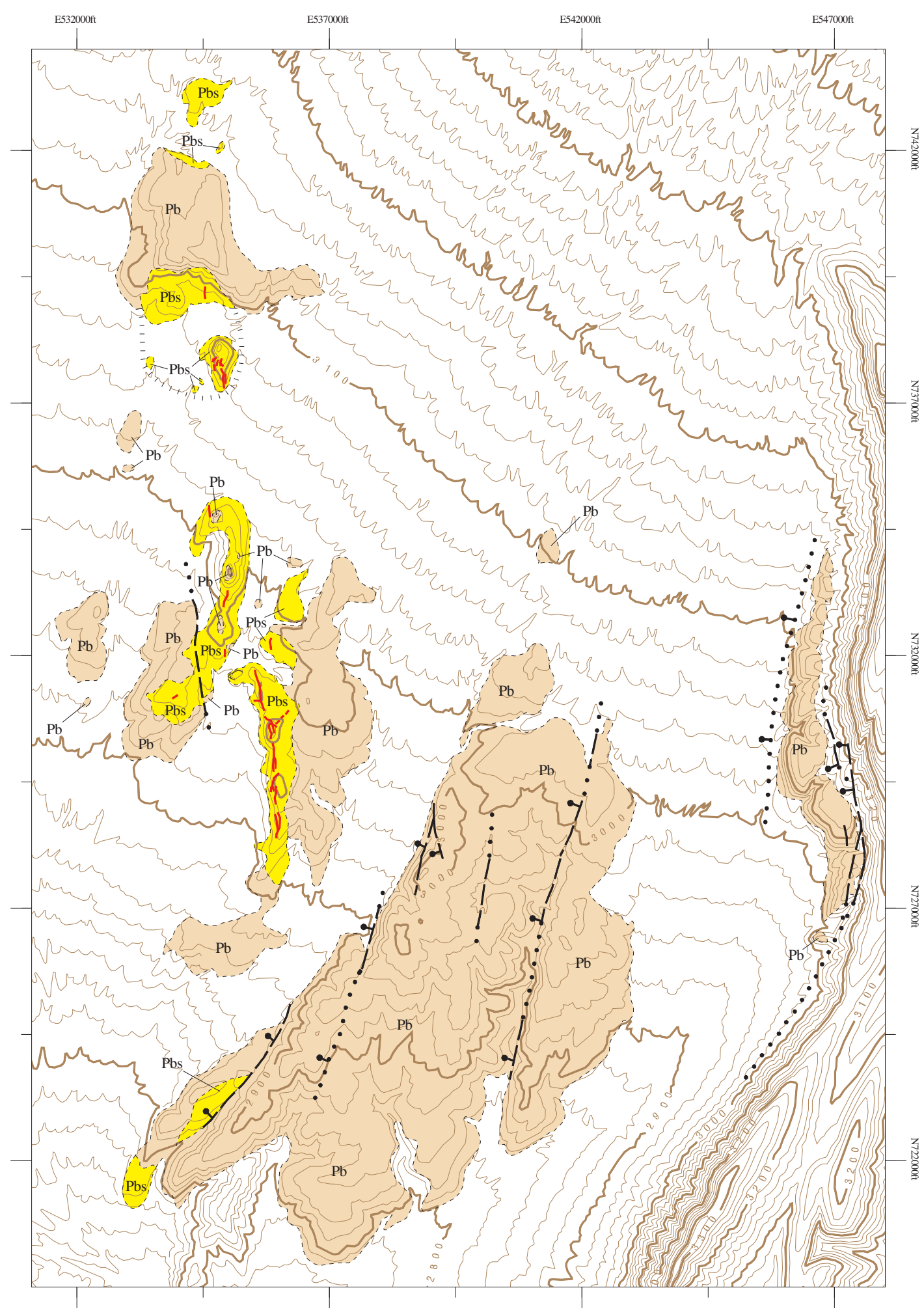

$\mathrm{Pb}$ Alkali Basalt Lava Flow

Pbs Basaltic Scoria

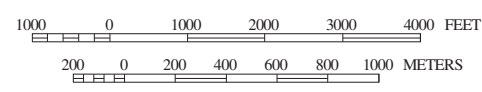

Yucca Mountain Site

$\simeq$ Basaltic Dike Intrusion

工 Fault, Ball on Downthrow Side

' ', , , Inferred Margin of Eroded Scoria Cone

$\checkmark$ Contour Index Interval 100 feet

GEOLOGY OF PLIOCENE BASALT IN CRATER FLAT 


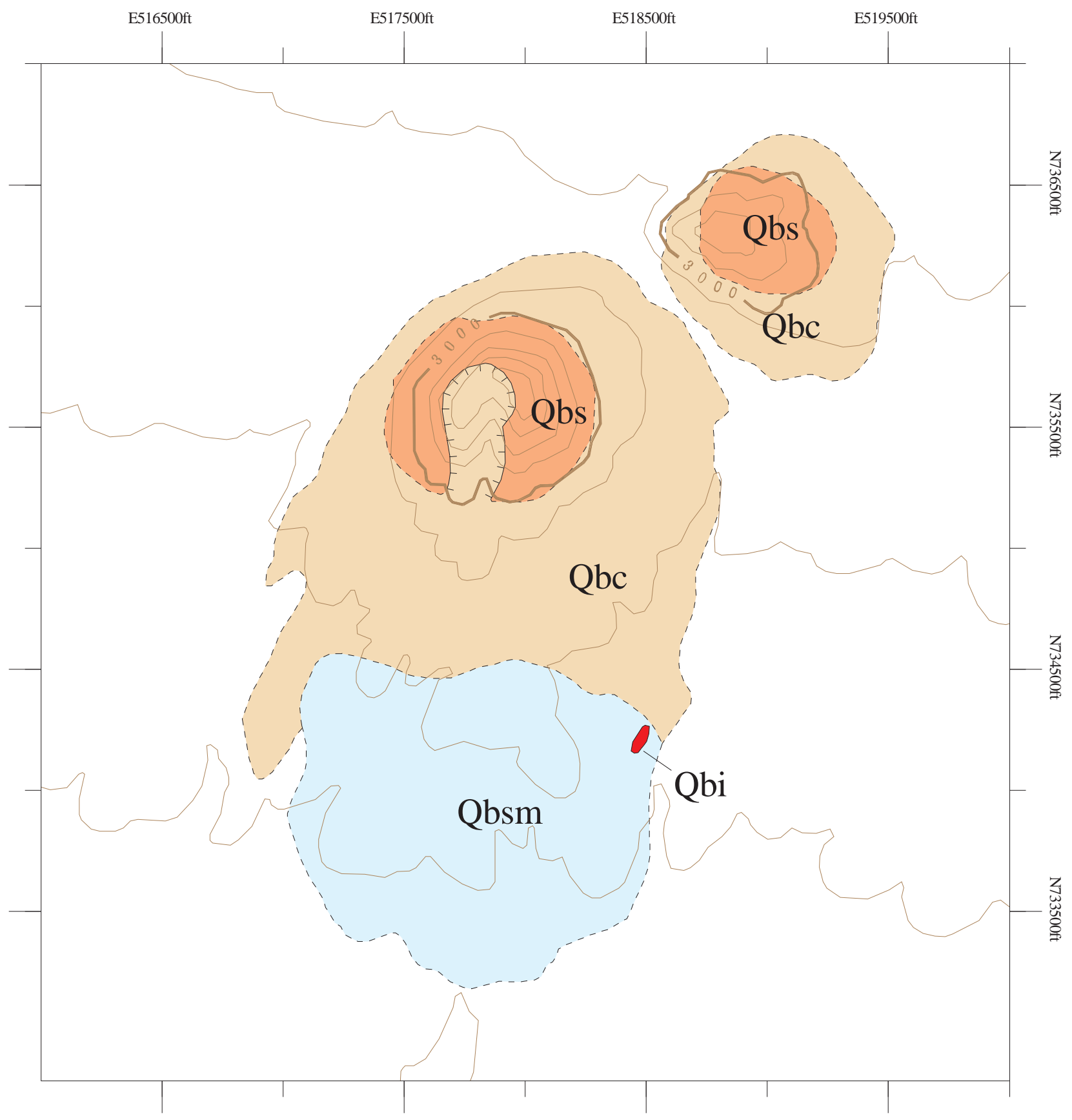

Qbs Scoria of Basaltic Scoria Cones

Qbsm Scoria of Basaltic Scoria Mounds

Qbc Colluvial Basalt and Scoria Surrounding Scoria Cones

Qbi Basaltic Dike Intrusion

$\checkmark$ Contour Index Interval 100 feet

Contour Interval 20 feet

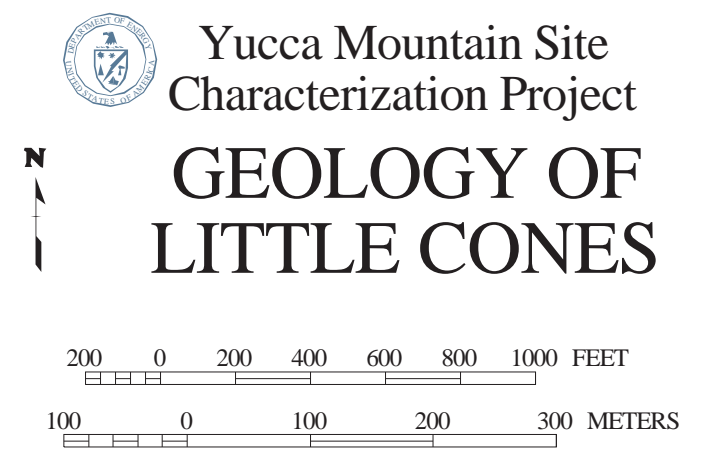




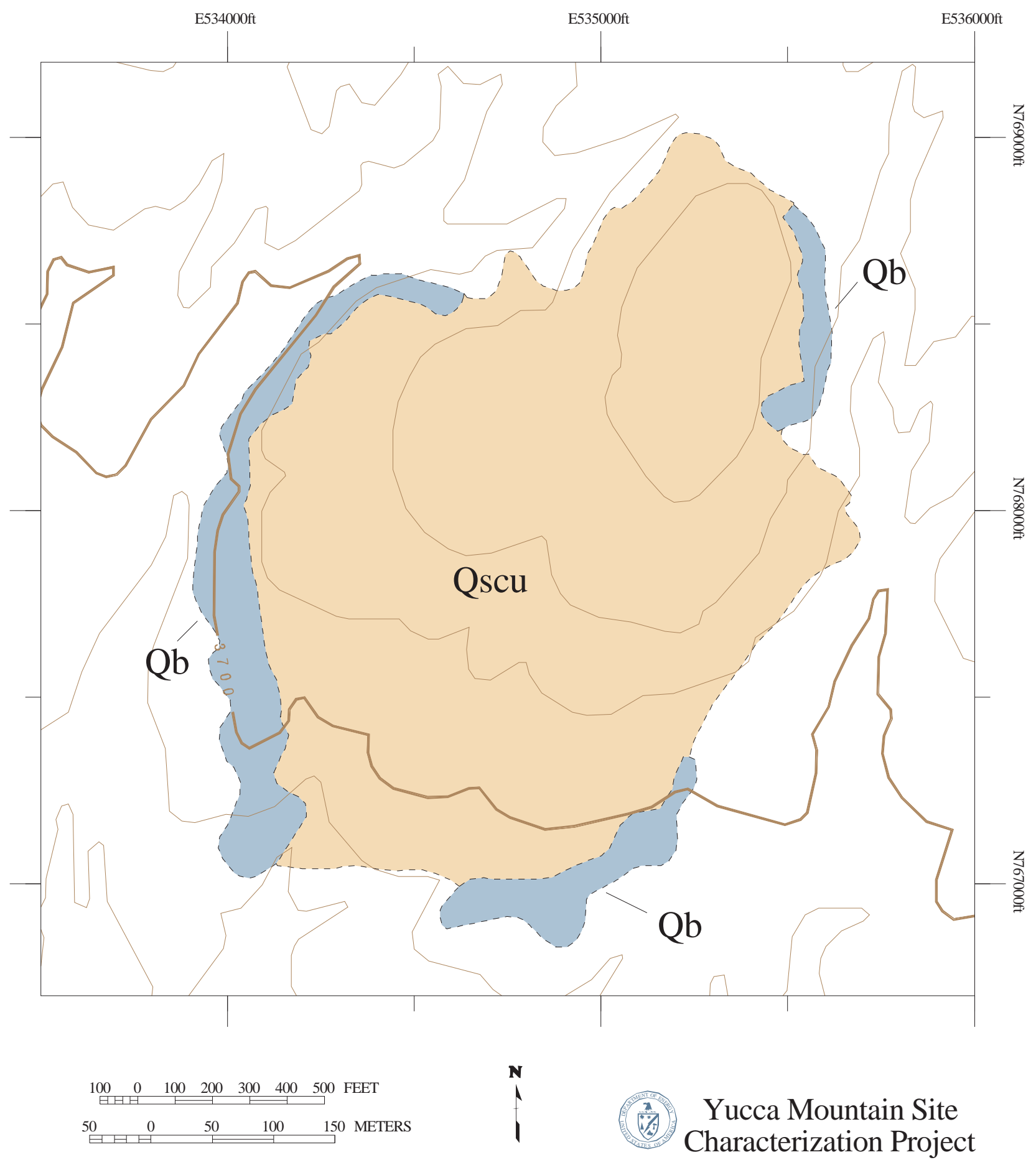

Qb Alkali Basalt Flow

Qscu Basaltic Scoria and Colluvium, Undifferentiated

$\checkmark$ Contour Index Interval 100 feet

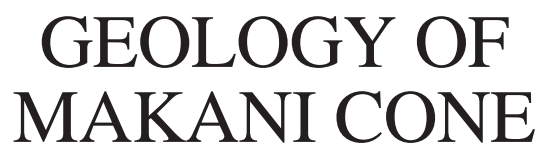

Contour Interval 20 feet 


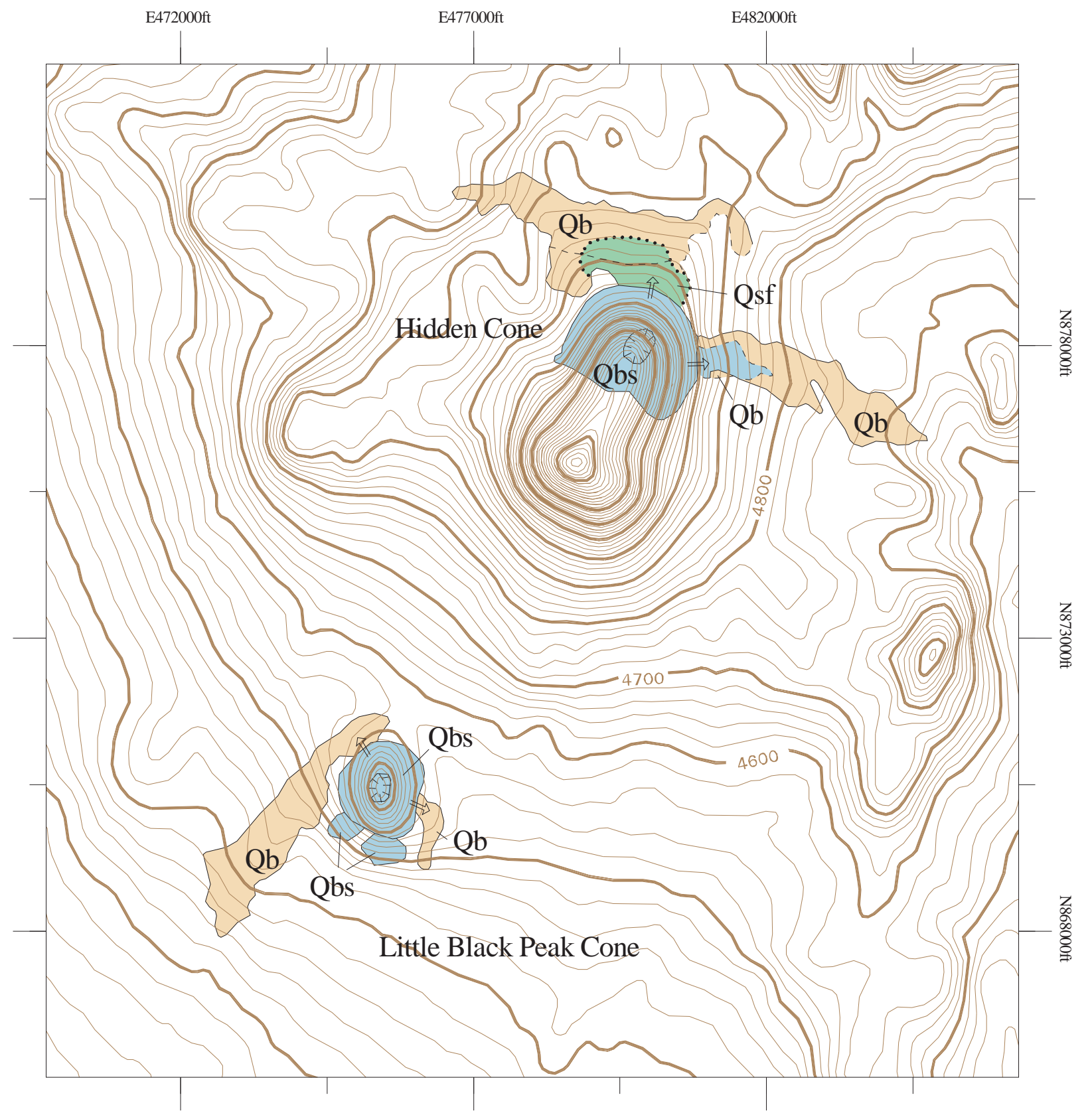

\section{Qsf Scoria-Fall Sheet \\ Qb Alkali Basalt Flow \\ Qbs Basaltic Vent Scoria \\ $\Longrightarrow$ Basalt Flow Sources \\ Contour Index Interval 100 feet \\ Contour Interval 20 feet \\ i}
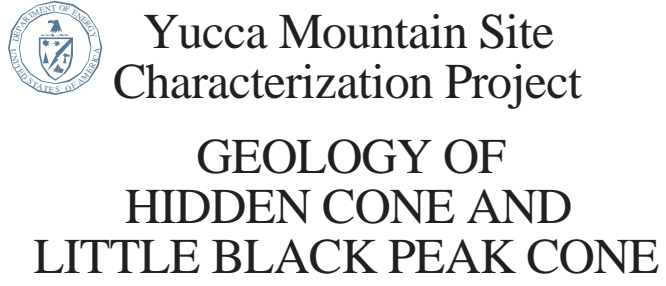

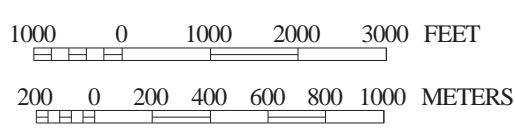

YMP- 97- 210.0 


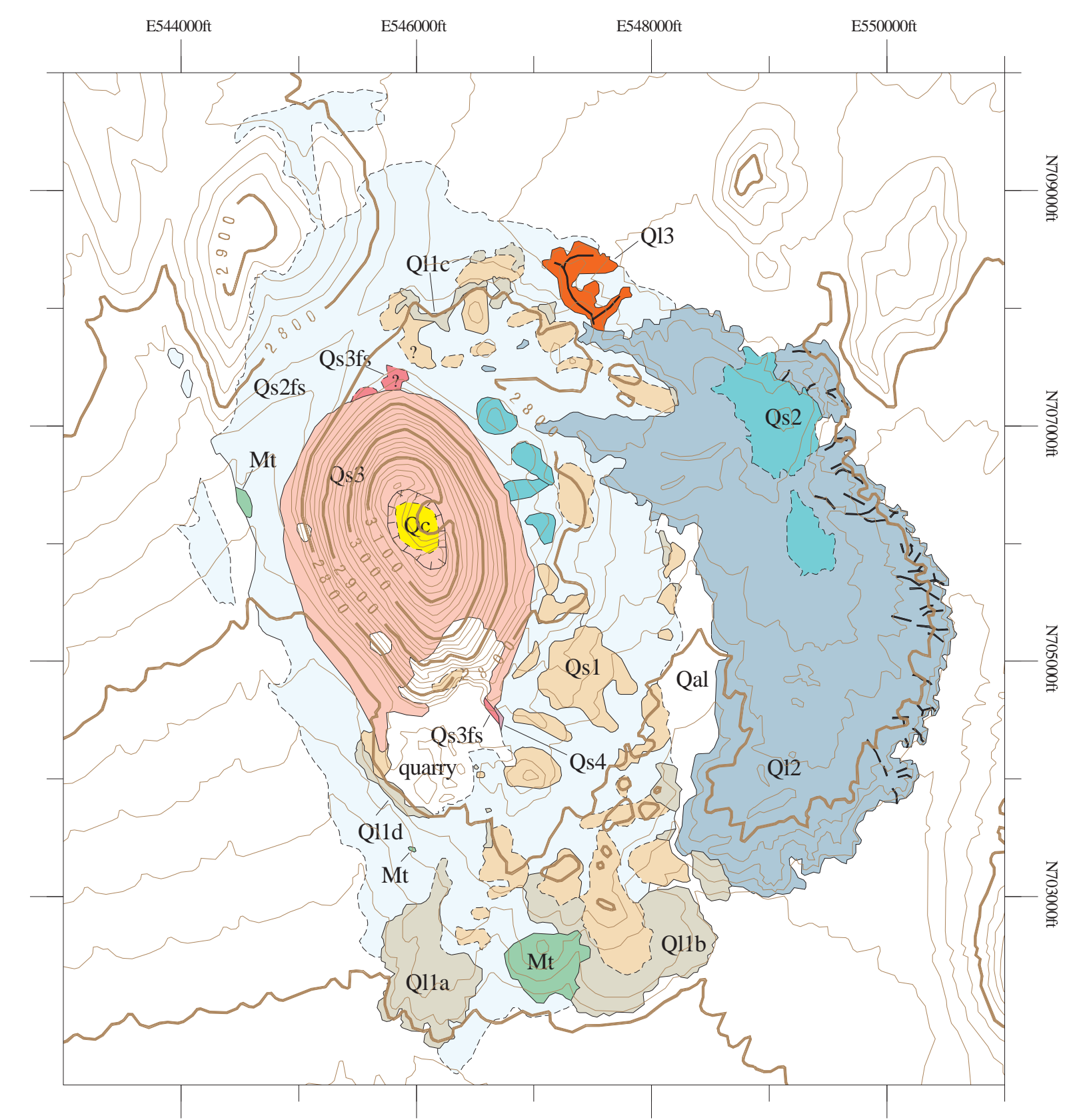

\begin{tabular}{|c|c|c|c|}
\hline Qc & \multirow{2}{*}{\multicolumn{3}{|c|}{$\begin{array}{l}\text { Sand-Supported Colluvial Teph } \\
\text { in Crater of Main Cinder Cone } \\
\text { Reworked or Primary Tephra }\end{array}$}} \\
\hline Qs4 & & & \\
\hline Q13 & Qs3 & Qs3fs & \\
\hline Q12 & Qs2 & Qs2fs & \\
\hline Q11 & Qs1 & \multicolumn{2}{|c|}{ Lava Flow and $\mathrm{V}$} \\
\hline Mt & \multicolumn{3}{|c|}{ Miocene Tuff } \\
\hline & $\mathrm{AA} \mathrm{Fl}$ & annel & \\
\hline
\end{tabular}

Yucca Mountain Site GEOLOGY OF
LATHROP WELLS
VOLCANIC CENTER

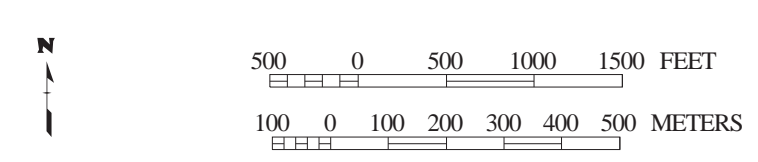
Contour Interval 20 feet 


\title{
CHAPTER THREE
}

\section{Tectonic Setting of the Yucca Mountain Region: Relationship to Episodes of Late Cenozoic Basaltic Volcanism}

\author{
Bruce M. Crowe \\ Earth and Environmental Sciences Division, Los Alamos National Laboratory \\ Chris Fridrich \\ U.S. Geological Survey, Denver \\ George Thompson \\ Professor Emeritus, Department of Geophysics, Stanford University \\ Ken Smith \\ Glen Biasi \\ Seismological Laboratory, University of Nevada, Reno \\ Peter Wallmann ${ }^{1}$ \\ Golder Associates, Inc., Seattle \\ Lynn M. Bowker \\ College of Law, University of Wyoming
}

\section{Summary}

Yucca Mountain is located in the southern part of the Great Basin physiographic province, which is a complex region of Cenozoic mantle upwelling, extensional faulting, and timetransgressive silicic and basaltic volcanic activity. The mountain developed as a physiographic feature through a combination of eruption and deposition of large-volume ignimbrite from the Timber Mountain-Claim Canyon caldera complexes and subsequent uplift and offset by extensional faulting. Yucca Mountain is located at the southern edge of a pulse of timetransgressive silicic volcanism and at the northern edge of an amagmatic gap that coincides with an area of preservation of cold lithospheric mantle. The mountain overlaps a $90 \mathrm{mGal}$ gradient in the regional Bouguer gravity field. Four sets of tectonic models have been developed for the Yucca Mountain region including regional detachment models, caldera models, rift models, and models incorporating and related to systems of the Walker Lane structural zone. Basaltic volcanism in the Yucca Mountain region (YMR) includes the basalt of the silicic episode (BSE; 9-12 Ma) that is temporally and spatially associated with Miocene caldera complexes and the postcaldera basalt episode (PCB) that is divided into the older postcaldera basalt cycle (OPB; 9-7.2 Ma) and the younger postcaldera basalt cycle (YPB; 4.7 to $0.07 \mathrm{Ma}$ ). The latter cycle is important for volcanic hazard assessment for the Yucca Mountain site. Volcanic centers of the YPB occur mostly in a northwest-trending zone called the Crater Flat volcanic zone (CFVZ). The age and spatial patterns of the PCB show southwest migration of sites of volcanic activity through time. Analyses of timespace patterns that include the sequencing of volcanic events show that volcanic processes have been consistent for the last $9 \mathrm{Ma}$ and operated on two scales: 1) processes involving small-scale clustering $(<10 \mathrm{~km})$ of contemporaneous volcanic centers and 2$)$ processes involving the formation

\footnotetext{
${ }^{1}$ Deceased
} 
of spatially and temporally discrete volcanic centers with separation distances of $>15 \mathrm{~km}$. The distribution and sequencing of basaltic volcanic events in the YMR during the last $9 \mathrm{Ma}$ are consistent with W-SW spatial drift through time coupled with oscillations perpendicular to the drift direction. Alternative spatial, structural, and temporal models developed for basaltic episodes of the YMR include the preferential occurrence of basalt centers along specific structures (areas of extension, ring-fracture zones of calderas, and intersections of strike-slip faults), the Death ValleyPancake Range, rift models involving combined strike-slip and extensional tectonic processes, and identification of high risk volcanic chains. Instrumentally recorded seismicity in the region is distributed across an east/west zone and displays strike-slip and dip-slip offsets consistent with a northwest-trending orientation of the least principal stress axis. Yucca Mountain is located in an earthquake-free zone (historic record), a reflection of either low stress accumulation or prehistoric seismic release, and there may be a negative correlation between seismicity and the distribution of Quaternary basalt centers. Gravity models of the YMR show a gravity high associated with Bare Mountain and a gravity low centered in the Crater Flat basin and extending partly beneath Yucca Mountain to the east. Pliocene and Quaternary basalt centers in Crater Flat tend to be associated spatially with the gravity low of Crater Flat but cannot be correlated with specific structural features. Drape aeromagnetic and local ground magnetic data reveal the presence of multiple anomalies, some of which correlate with the surface and inferred subsurface distribution of Cenozoic basaltic volcanic rocks. Exploratory drilling has confirmed these inferences at three sites. Geoelectric and magnetotelluric data show a conductive anisotropy aligned parallel to the structures of the Walker Lane structural system. Seismic refraction data confirm the general model of Yucca Mountain being located above and on the eastern edge of a thick accumulation $(3.5 \mathrm{~km})$ of sediments and volcanic rocks that fill the Crater Flat basin. High-resolution seismic reflection data show that the basin formed during multiple episodes of extensional and probable strike-slip deformation. The seismic reflection data are inconsistent with the presence of an active, westdipping detachment system at the Cenozoic/pre-Cenozoic contact and are also inconsistent with caldera models of the Crater Flat basin. Teleseismic data reveal the possible presence of a lowvelocity anomaly below Crater Flat and the Amargosa Valley that may record the presence of magma near the crust-mantle boundary. Other interpretations of the data are possible and the presence of an inferred magma body is inconsistent with integrated geologic, seismic, heat flow, and magnetic data. The Yucca Mountain site is located in a heat-flow low, and there is no apparent correlation between sites of Quaternary basaltic volcanism and areas of elevated heat flow.

\section{Introduction}

The primary goal of this chapter is to integrate the record of Cenozoic basaltic volcanism of the Yucca Mountain region (YMR) with the regional tectonic setting of Yucca Mountain using current data available through the Yucca Mountain Site Characterization Project (YMP). The area under exploration for potential underground disposal of high-level radioactive waste is an approximately $5 \mathrm{~km}^{2}$ area in the interior of Yucca Mountain (DOE, 1988), a linear mountain range located on the southwestern edge of the Nevada Test Site (NTS). This exploratory area, hereafter referred to as the Yucca Mountain site, is located on the southern edge of the southwest Nevada volcanic field (SNVF), and is flanked on the west by the Crater Flat basin, on the east by Jackass Flats, and on the south by the Amargosa Valley (Crowe et al., 1995; their Fig. 2-1).

The task of integrating volcanism and tectonism studies is somewhat difficult for three reasons. First, there is a limited geologic record of Pliocene and Quaternary volcanic events in the YMR. Only 5, possibly 6, volcanic centers of Quaternary age are located within a 25-km radius of the Yucca Mountain site (Crowe et al., 1995; see Chapter 2). The small number of events does not 
permit hypothesis testing using standard statistical tests of significance and, therefore, multiple alternative models of tectonism and volcanism must be considered. Second, the geologic and tectonic setting of Yucca Mountain is complex. Yucca Mountain is upheld by a thick accumulation of Cenozoic volcanic rocks that overlie largely concealed Paleozoic rocks. The volcanic rocks were deposited during multiple cycles of large volume silicic volcanic eruptions that were preceded by, were partly contemporaneous with, and are post-dated by episodic tectonic events associated with the formation of the Crater Flat basin. During the early phase of basin evolution prior to about 13 Ma, the Yucca Mountain site was part of the Crater Flat basin. The basin geometry has evolved through time, and the northern part of Yucca Mountain is now a faulted volcanic highland that flanks the Crater Flat basin whereas the southern part of the mountain merges with the basin and is still an area of active extension. The Paleozoic rocks that underlie Yucca Mountain were faulted and folded during multiple episodes of pre-Cenozoic deformation. These rocks are exposed to the east and west of Yucca Mountain but not within the mountain itself. Their structural configuration beneath Yucca Mountain and the Crater Flat basin is only partly known, primarily from geophysical studies and limited drill hole exploration. Third, there is not a direct relationship between tectonic features and sites of Quaternary basaltic volcanism. Quaternary volcanic centers of the YMR occur generally in or at the edges of alluvial basins with one center (Hidden Cone) located just inside a range edge. Some of the Pliocene and Quaternary volcanic centers occur on or near faults or tectonic features (basalt of Buckboard Mesa, Lathrop Wells center) whereas other centers appear not to follow or be directly related to surface structures (1.0 Ma Quaternary basalt centers of Crater Flat). Quaternary faults in the YMR can only indirectly be correlated with sites of Quaternary volcanism, and the shallow stress field may control the locations and alignment of individual volcanic centers.

Yucca Mountain developed as an identifiable physiographic feature during the mid-Miocene. Multiple large-volume, silicic pyroclastic eruptions resulted in the formation of coalesced calderas of the Timber Mountain caldera complex, which is the largest caldera complex of the SNVF (Byers et al, 1976; Christiansen et al, 1977; Crowe et al., 1995; see Chapter 2; Sawyer et al., 1994). The volcanic rocks that form the surface rocks of Yucca Mountain were deposited during closely spaced explosive eruptions of silicic magma from about 15 to 11.5 Ma (Sawyer et al., 1994) and formed plateau highlands encompassing the Timber Mountain complex. During the latter stages of the silicic eruptions, the ignimbrite plateau at the location of what is now Yucca Mountain was extended and broken by normal faulting associated with Basin and Range tectonism. The volcanic rocks were offset along closely spaced north and north/northeast-trending, mostly west-dipping faults and the faulting was accompanied by eastward tilting of the volcanic units (Scott and Bonk, 1984; Scott, 1990). These tectonic events defined the outlines of what is now the physiographic form of Yucca Mountain.

Before emplacement of the Paintbrush Group, which is one of the large-volume, calderaforming eruptions (Sawyer et al., 1994), there may have been earlier episodes of deformation in the Yucca Mountain area involving extensional, strike-slip, and possibly detachment faulting. The eruption of over $10,000 \mathrm{~km}^{3}$ of mid-Miocene volcanic rocks formed a thick volcanic cover that blankets the older volcanic rocks of the YMR, making it difficult to reconstruct the detailed history of early Cenozoic tectonic events.

Large-volume basaltic volcanism accompanied episodic phases of Miocene tectonic activity. Miocene basaltic volcanism shows strong spatial associations with preexisting structural features (basin-range faults and ring-fracture zones of caldera complexes). Many sites of basaltic volcanism formed contemporaneously with phases of extensional faulting (for example, the older basalt of 
Crater Flat, the basaltic volcanic rocks of Dome Mountain; Crowe et al., 1995). In contrast, Pliocene and Quaternary basaltic activity in the YMR is of small volume, postdates the major phases of extensional faulting, and is more difficult to relate to local structural features.

A second purpose of this chapter is to provide a summary of the current understanding of the geologic and tectonic features of the region, progressing in scale from the southern Great Basin region to the Yucca Mountain area. Such a progression places the geologic setting of Yucca Mountain into a regional tectonic perspective and is aided by regional geophysical data that provide important insights into possible interrelationships between regional, local, and subsurface structures. The geophysical data can also be combined with petrologic studies of basaltic volcanism (Crowe et al., 1995; Chapter 4, this report) to provide constraints on the fundamental causes and processes of basaltic volcanism. This composite view gives a perspective for evaluating not only the structural controls of volcanic activity but also the operation of magmatic processes that produced the past record of volcanism and may control future volcanic events.

Any attempt at describing the relationship between tectonism and basaltic volcanism must be recognized as an evolving perspective linked to the present state of understanding of the geological processes affecting the YMR. Concepts concerning, for example, the origin and tectonic development of the Basin and Range province have changed dramatically during the last few decades. During the 50s and 60s, the province was recognized as a site of structural extension. The mountains and valleys were viewed as rigid horsts and grabens, structurally bounded by steeply dipping, planar faults. Important advances during the latter part of the 60s and early 70s strongly reshaped thinking about the origin of the Basin and Range province. The unifying concepts of plate tectonics were developed, and these concepts presented a largely new perspective for evaluating the driving mechanisms for development of a major extensional province in a continental setting. The Basin and Range province, based on plate tectonic concepts, attracted comparison to oceanic and continental rift zones behind active arc systems. The widespread application of radiometric dating methods to the volcanic and plutonic rocks of the province revealed complex time-space patterns in the sequences of igneous rocks. The plutonic and volcanic rocks formed during Cenozoic magmatic activity in the Basin and Range province are now recognized to be part of widespread and continuing magmatic events that occurred along the western length of the North American continent since at least the Eocene. Plate-tectonic processes of subduction of oceanic crust associated inland by overlapping belts of continental magmatism intermixed with extensional deformation provide a conceptual framework for explaining many, but not all, of the complex timespace associations of tectonism and volcanism in the Basin and Range province of the southwestern United States.

During the 70s and 80s, perplexing sites of low-angle faulting with large sections of rock displaced or missing were recognized throughout the province. The timing of movement along many of these low-angle fault systems is now sufficiently well established to relate the tectonic events to Cenozoic extension. The identification of low-angle faults of Cenozoic age was paralleled by recognition of exposures of complexes of metamorphic and igneous rocks throughout the Basin and Range province. The depth of formation of these rocks and their mid-Cenozoic uplift ages necessitated the removal of many kilometers of crust, presumably associated with the Cenozoic extension. The Basin and Range province is now recognized as a region of time-transgressive extension accompanied by spatially varying mantle upwelling, volcanism, and lateral flow of the mantle and crust. 
There undoubtedly will be continued progress in the reconstruction of geologic events that will lead to further understanding of the processes of tectonism and volcanism in this complex, continental, arc-rift setting. Future advances in thinking will produce new ideas, force rethinking, or even invalidate currently accepted concepts. Discussion of the tectonic setting of Yucca Mountain and the patterns of basaltic volcanism must be viewed only as a time-slice of the present state of knowledge of the region.

Three perspectives are emphasized in the process of identifying and assessing tectonic models for the occurrence of Pliocene and Quaternary basaltic volcanism in the YMR. First, it is important to evaluate and incorporate a comprehensive set of all reasonable tectonic-volcanic models for basaltic volcanism. Because of the small number of basaltic centers, multiple tectonic models are permissive and can be neither proved nor disproved. Instead, the priority is to assess complete ranges of alternative models; it is of lesser importance to make judgments about which set or sets of tectonic models are most or even more correct. This chapter attempts to identify a range of tectonic models for application in probabilistic volcanic hazard assessment (PVHA) (Crowe et al., 1995; Geomatrix, 1996). Second, a key perspective in an evaluation of different tectonic models is an identification of the effects of the alternative models on assessing probabilistic models of the hazards of future volcanism for the Yucca Mountain site. Third, while the task of developing tectonic models for volcanism is difficult, it must be placed into the perspective of the goals of isolation of high-level radioactive waste. A required 10,000-yr. isolation period of high-level radioactive waste is long relative to societal perspectives, but it is a relatively short period compared to the millions of years required to initiate, evolve, and change the fundamental tectonic processes that have shaped and will continue to shape the Yucca Mountain area.

Finally, a third purpose of this chapter is to update information obtained since completion of the volcanism status report (Crowe et al., 1995). The primary areas of new information included in this report are the following:

1) Refinements in the pull-apart models of the Crater Flat basin (Fridrich, in preparation).

2) Incorporation of the interpretative results of regional seismic reflection lines across Crater Flat and Yucca Mountain (Brocher et al., 1996, in press).

3) Incorporation of preliminary results of data obtained from the upgraded regional seismic net (Smith et al., 1995).

4) Additional analyses of the spatial patterns of basaltic volcanism in the YMR (Golder Associates, 1995).

5) Incorporation of the results and tectonic models that are part of studies by the Center for Nuclear Waste Regulatory Analyses (CNWRA), a contractor for the Nuclear Regulatory Commission (NRC; see Ferrill et al., 1995a,b).

6) Incorporation of results of geophysical studies described in a summary report by the US Geological Survey (Oliver et al., 1995).

7) Incorporation and description of alternative tectonic models developed by the volcanism expert judgment panel (Geomatrix, 1996). 
8) Incorporation of limited new information obtained from ground magnetic surveys across the Solitario Canyon fault and southern Crater Flat. The planned volcanism work for the fall of 1995 and calendar year 1996 included additional ground-magnetic studies and evaluation of aeromagnetic data for an assessment of the detection of basaltic intrusions. These studies were not implemented in the volcanism work scope and therefore there is only limited discussion of new magnetic studies related to the issue of basalt intrusions.

\section{Southern Great Basin}

The Yucca Mountain site is located in the southern part of the Great Basin, a subpart of the Basin and Range physiographic province of the southwestern United States. The term "Basin and Range province" as used herein refers to the broad area of the western United States dominated by fault-bounded mountain ranges separated by alluvial valleys (Fig. 3.1; see also Stewart, 1978). The province was subdivided originally on physiographic criteria (Fig. 3.1; see Fenneman, 1931) but many geological and geophysical properties of the province extend beyond the strict physiographic boundaries. Eaton (1982) argued that the Basin and Range province can be defined as a tectonophysical region that includes parts of ten western states and more than $10 \%$ of the land area of the contiguous United States. A much larger area of the Basin and Range province can be demarcated simply from the distribution of late Cenozoic faults (Fig. 3.2) and this area is close to the size of the Basin and Range province as defined by the thermophysical criteria of Eaton (1982).

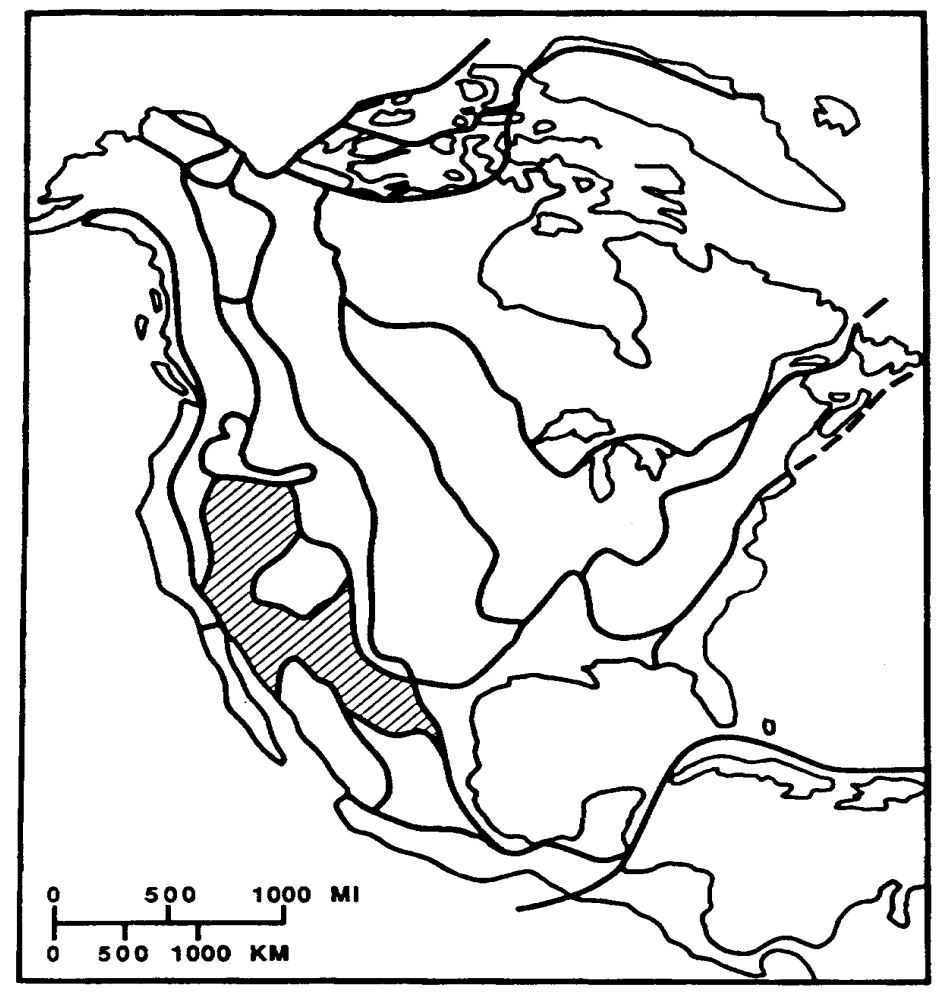

Figure 3.1. Physiographic subdivisions of North America (modified from Bally et al., 1989). The Basin and Range province (cross-hatched area), defined on geomorphic criteria, occupies a broad area of the west and southwest United States and adjoining areas of northern Mexico. 


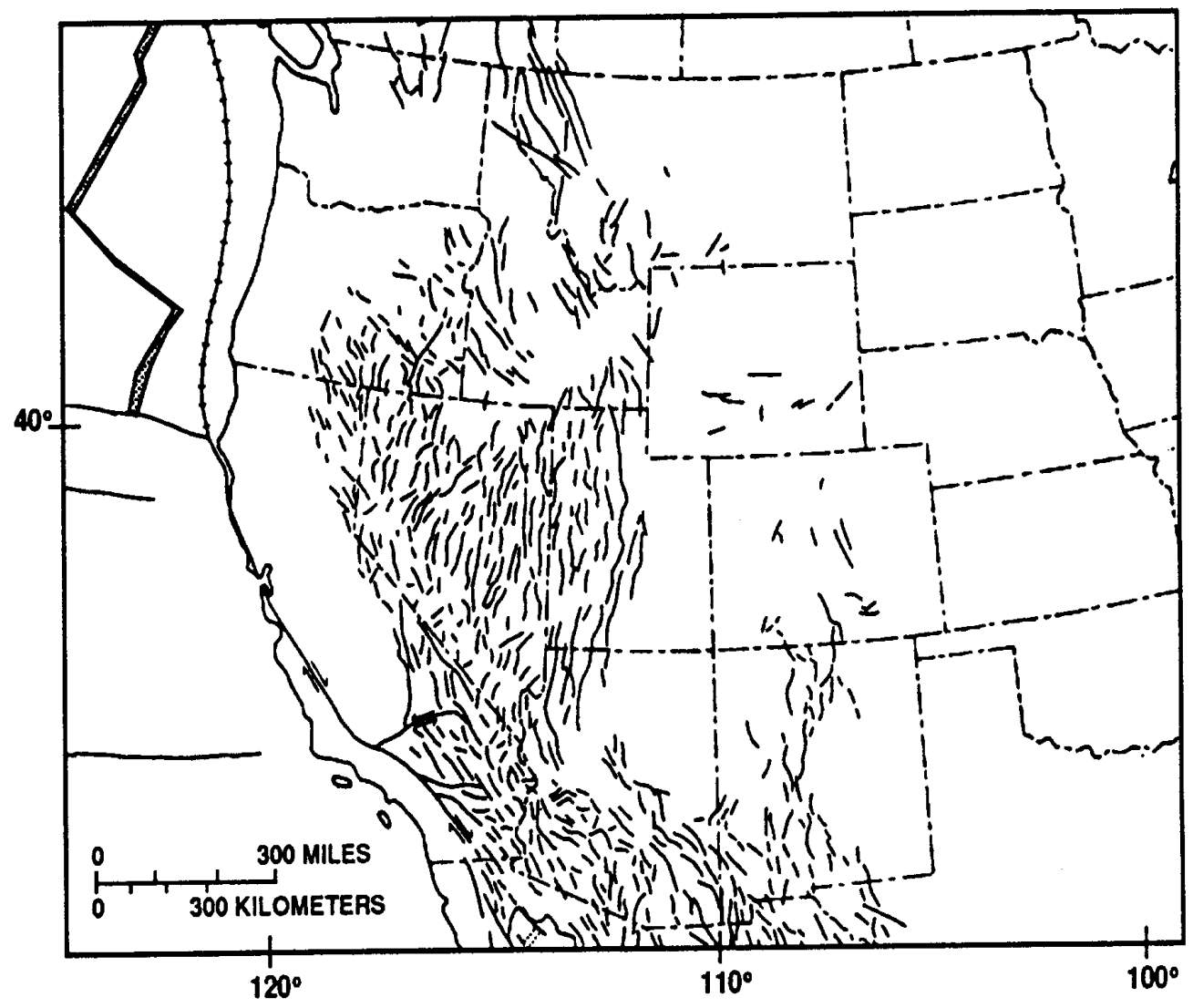

Figure 3.2. Distribution of late Cenozoic faults in the western United States (modified from Stewart, 1978). The area outlined by faults in this figure denotes the broader Basin and Range province as defined by the thermophysical criteria of Eaton (1982).

There is an important distinction between the Great Basin part of the Basin and Range province and the southern Basin and Range (Fig. 3.3) with the former area recognized generally as being affected by more recent operation of active extensional processes. Accordingly, most areas of the Great Basin are higher standing topographically with increased seismicity and higher heat flow in comparison with the southern Basin and Range province (Eaton, 1982; Jones et al., 1992). The boundary between these subprovinces coincides generally but not exactly with the eastward projection, between the latitudes of $36^{\circ}$ and $37^{\circ} \mathrm{N}$, of the Garlock fault, extending from California across Nevada and continuing to the Colorado Plateau in Arizona (Fig. 3.3) (see also Suppe et al.1975; Eaton, 1982). This boundary forms the northern edge of an area with no Cenozoic or Mesozoic magmatism or plutonism (Farmer et al., 1989) and marks the approximate location of a gradient in the Bouguer gravity field of almost $100 \mathrm{mGal}$ (increasing to the south; Eaton et al., 1978; Hildenbrand et al., 1988; Saltus and Thompson, 1995). The boundary or gravity step is a recognizable feature on the Bouguer gravity anomaly map of North America (Hanna et al., 1989). It is less prominent but recognizable on the map of historical seismicity of North America (Hildenbrand et al., 1988, their Fig. 2.3; Engdahl and Rinehart, 1988).

Wernicke (1992) and Jones et al. (1992) divide the Basin and Range into three tectonic provinces, the northern Basin and Range, the southern Basin and Range, and the central Basin and 
Range. Their central Basin and Range province encompasses most of the area surrounding the YMR. The YMR lies in the Walker Lane structural belt, which is a complex zone of northwesttrending right-slip and subordinate northeast-trending left-slip faults that bounds the southwestern parts of the Great Basin (Fig 3.3).

There are many published reviews of the geology and geophysical characteristics of the Basin and Range province, and the following sections provide only a brief overview of the voluminous literature with an emphasis on aspects of the geologic and geophysical characteristics of the Great Basin that provide an important framework for tectonic models of the YMR. Noteworthy papers that describe important properties of the Basin and Range province with emphasis on the central Basin and Range subprovince include Nolan (1943), Shawe (1965), Hamilton and Myers (1966), Armstrong et al. (1969), Atwater (1970), Anderson (1971), Scholz et al. (1971), Stewart (1971), Lipman et al. (1972), Christiansen and Lipman (1972), Noble (1972), Kistler and Peterman, (1973), Best and Brimhall (1974), Thompson (1974), Smith and Sbar (1974), Wright et al. (1974), Snyder et al. (1976), Wright (1976), Proffett (1977), Stewart et al. (1977), Best and Hamblin (1978), Christiansen and McKee (1978), Eaton et al. (1978), Lachenbruch and Sass (1978), Smith (1978), Stewart (1978), Zoback and Thompson (1978), Eaton (1979), Eaton (1980), Lipman (1980), Stewart (1980), Guth (1981), Wernicke (1981), Zoback et al. (1981), Armstrong (1982), Eaton (1982), Hill (1982), Glazner and Supplee (1982), Vaniman et al. (1982), Wernicke and Burchfiel (1982), Coney and Harms (1984), Farmer and DePaolo (1983; 1984), Smith and Luedke (1984), Hudson and Geissman (1987), Hamilton (1988), Snoke and Miller (1988), Wernicke et al. (1988), Farmer et al.,(1989), Gans et al. (1989), Oldow et al. (1989), Carr (1990), Hodges and Walker (1990), McKenna and Hodges (1990), Scott (1990), Severinghaus and Atwater (1990), Armstong and Ward (1991), Walker and Colman (1991), Jones et al. (1992), Stirewalt et al. (1992; Wernicke (1992), and Axen et al. (1993). Parsons (1995) provides a recent overview of many of the features of the Basin and Range province.

The most striking feature of the Great Basin, relative to adjacent regions of the western United States, is the contrasting topography. The region has been broken by complex, spatially and temporally heterogeneous extensional faulting into broad basins separated by narrow, highstanding ranges (Stewart and Carlson, 1974; Eaton, 1982; Hildenbrand et al., 1988; Wernicke et al., 1988; Jones et al., 1992). This extension occurred primarily in the Cenozoic, but the detailed timing and spatial variability of the faulting remains controversial. Many workers restrict the development of the so-called classical Basin and Range tectonism to episodes of extensional faulting that are younger than $17 \mathrm{Ma}$ (post-middle Miocene; see Stewart, 1978; Christiansen and McKee, 1978). There is evidence of early Cenozoic faulting that preceded and was synchronous with subduction and arc magmatism (Axen et al., 1993). However, this faulting may not be related directly to the later faulting that shaped much of the modern topography (Coney, 1978; Mayer, 1986; Okaya and Thompson, 1986; Best and Christiansen, 1991). Other workers have emphasized the time-transgressive nature and spatial complexity of extensional faulting. The onset of the extensional deformation is emphasized rather than the age of continued faulting. In many areas of the Basin and Range province, extensional faulting may have begun in the Oligocene (Proffett, 1977; Crowe, 1978; Crowe et al., 1979; Rehrig, 1986; Snoke and Miller, 1988; Gans et al., 1989; Axen et al., 1993). 


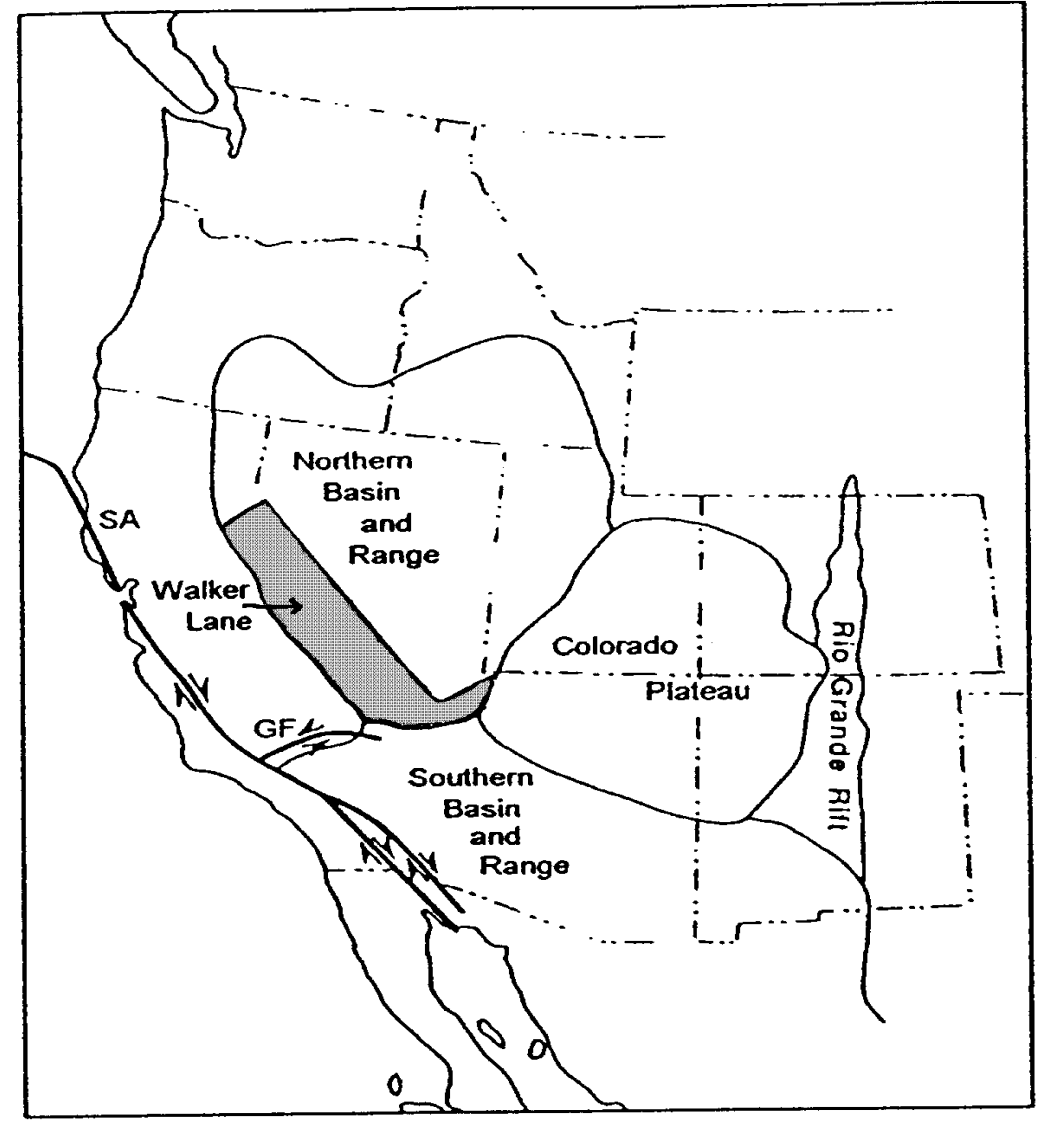

Figure 3.3. Subdivisions of the Basin and Range province. The province is divided into the northern Basin and Range (Great Basin), and the southern Basin and Range (Sonoran Desert). The YMR is located near the southern end of the Great Basin north of a transition zone between the provinces that coincides with the approximate eastward extension of the Garlock fault. This transition zone has been called the central Basin and Range (Wernicke, 1992; Jones et al., 1992). The cross-hatched area of the southwestern Great Basin outlines the boundary of the Walker Lane structural zone. SA: San Andreas fault; GF: Garlock fault; WL: Walker Lane structural zone.

Many workers have noted the association between magmatism, low-angle extensional faulting and the development of metamorphic core complexes (Crittendon et al., 1980; Gans et al., 1989; Parsons and Thompson, 1993) although some workers dispute whether magmatism and faulting are always closely related (Christiansen and McKee, 1978; Best and Christiansen, 1991). Armstrong and Ward (1991) completed a detailed analysis of the time-space patterns of magmatism and development of core complexes. They argue that there is a close link between magmatism and core complex formation and that magmatism may directly or indirectly lower the strength of the crust and permit formation of the core complexes. They also note that rates of magmatism, extension, and core complex formation have declined since the Miocene.

Many authors link the time-transgressive magmatism of the Basin and Range province with tectonism suggesting the tectonic activity, by inference, was time-transgressive. The timetransgressive nature of Basin and Range tectonism may be reflected in the modern distribution of faulting and volcanic activity. The most active areas of volcanism and tectonism in the Great Basin are along its active western and eastern margins. The present eastern margin of the Great Basin, for example, appears to be expanding outward into largely unextended terrain of the Colorado 
Plateau (Suppe et al., 1975; Best and Hamblin, 1978; Tanaka et al., 1986). The Yucca Mountain site, from this perspective, is located in an interior area of the Great Basin where tectonic and volcanic processes have waned since the late Miocene.

Coney (1978) divided tectonic and magmatic activity in the Basin and Range province into a period of vast ignimbrite eruptions (ignimbrite flare-up of the late Eocene to early Miocene) followed by a period of widespread basalt eruptions, block faulting, and collapse of the Basin and Range province (post-20 Ma). He suggested that the first period was controlled by subduction of the Farallon plate and the latter period by cessation of subduction and growth of the San Andreas transform system.

Severinghaus and Atwater (1990) provided a refined plate tectonic perspective for the controls of basin-range faulting and volcanism. They examined the geometry and thermal state of subducting slabs beneath North America through time by reconstructing the magnetic patterns of the preserved ocean floor. Severinghaus and Atwater (1990) suggested subducting slabs became aseismic through time and cease to affect continental tectonism strongly. The period required for reduction of the tectonic activity associated with subduction is dependent not only on the age of termination of subduction but also on the age of the subducted oceanic crust. The latter factor became important in the Miocene as segments of the oceanic rise approached the Americas plate (Severinghaus and Atwater, 1990) resulting in subduction of young, buoyant oceanic crust.

The tectonic evolution of western North America can be constrained partly by the timing of formation and expansion of an aseismic slab gap associated with the termination of subduction. A slab gap developed as early as $35 \mathrm{Ma}$ in southeastern Arizona and southwestern New Mexico and extended generally northwest in time across the Basin and Range province, paralleling the development of the San Andreas transform system (Severinghaus and Atwater, 1990; their Figs. 814). While the associations between plate locations and continental tectonic events have spatial uncertainty, they provide a conceptual framework from the perspective of plate tectonic interactions to explain the time-transgressive magmatic and tectonic patterns of the southern Basin and Range province. Three important constraints for the YMR can be identified through the plate tectonic reconstruction of Severinghaus and Atwater (1990). First, subduction continued in the Great Basin after development of an aseismic gap in the southern Basin and Range. This is consistent with higher rates of modern tectonism and a somewhat younger age of initiation of extension in the Great Basin compared to the southern Basin and Range. Second, a slab-free zone inland of the Mendocino and Pioneer fracture zones formed beneath the Yucca Mountain area at about the time of cessation of silicic volcanism and during a major and possibly peak phase of extensional faulting (11 Ma). Third, the timing of the termination of the southern spread of volcanism, the development of the amagmatic gap, and the east/west-trending boundary between the Great Basin and southern Basin and Range provinces coincides with the location and the timing of development of slab incoherence beneath the southern Great Basin and onland effects of the Mendocino-Murray transform zones (Severinghaus and Atwater, 1990). Additionally, the development and southward spread of the plume head of the Yellowstone hotspot starting about 17 Ma is inferred to have had profound effects on the northern Basin and Range province (Parsons et al., 1994; Saltus and Thompson, 1995).

Late Cenozoic basin-range faults in the eastern Great Basin trend predominantly north and northeast. The consistencies of fault trends are interrupted on the southwestern side of the Great Basin. Here, there may be multiple sets of normal faults with variable strikes and the range trends are more diverse, which is typical of the Walker Lane structural zone. Evidence of the Walker 
Lane structural features in the southwestern Great Basin include northwest alignment of silicic volcanic centers (Carr, 1974, 1990; Carr et al., 1984), northwest alignment of large-volume Miocene basalt centers (Crowe, 1990), zones of oroclinal bending of mountain ranges (Shawe, 1965; Guth, 1981; Scott, 1990), segmented and largely inactive zones of northwest-trending probable right-slip faults (Guth, 1981; Scott et al., 1984; Carr, 1974, 1990), and northeasttrending left-slip faults (Carr, 1984). Blakely (1988) noted that magnetic anomalies in the Walker Lane structural zone of Nevada have arcuate, northwest trends, but the width of the zone of aeromagnetic anomalies is wider than the boundaries of the Walker Lane. He suggests that the magnetic anomalies may be shaped by an underlying tectonic fabric that predates the modern topography-perhaps related to the Precambrian breakup of North America.

Blackwell (1978) and Lachenbruch and Sass (1978) described high values of observed heat flow in the Great Basin and noted that the data are consistent with the occurrence of Quaternary volcanic rocks and thermal springs in the region. Lachenbruch and Sass (1978) suggested that much of the anomalous heat is transferred from the asthenosphere by convection accommodated by pervasive flow of the crust or intrusion of magma. They developed thermomechanical models of these processes and demonstrated a relationship between heat flow, asthenosphere flux, lithosphere thickness, extension rate, and the rate of production of basalt magma in the mantle. Extension, based on their heat-flow models, was facilitated through brittle fracturing and penetration of the crust by basalt dikes or by warming and thinning of the crust through underplating by basalt. The YMR is located in a region of lower heat flow called the Eureka Low. Suppe et al.,(1975), Eaton et al.,(1978), and Eaton (1982) noted the high average elevation of the Great Basin (>1.4 km) and the general coincidence of this area of high topography with areas of high heat flow. Eaton (1982) concluded that the high topography of the region is best explained by isostatically driven vertical expansion of the lithosphere as a result of heating from below.

An additional major feature of the Great Basin is its position in a regional gravity low (Eaton et al., 1978; Eaton, 1980, 1982; Hildenbrand et al., 1988; Hanna et al., 1989). Eaton et al.,(1978) described the collection of associated features that provide constraints on the gravity field and tectonic setting of the Great Basin. These features are the low Bouguer gravity field with a bilateral distribution of long-wavelength anomalies, the thin crust, the high heat flow, the past record of widespread magmatic activity, the concentration of Quaternary volcanic rocks at the east and west margins, and widespread extensional faults.

Jones et al. (1992) examined the geological, geochemical, and geophysical data for the central part of the Basin and Range province. They note that there is significant heterogeneity in the record of the response of the mantle and crust to Cenozoic extension. Jones et al. (1992) suggest that the limited topographic differences between strongly extended and largely unextended regions of the central Basin and Range require lateral flow of crustal material into the extended areas. They summarized geochemical data supporting movement of crustal material. Specifically, these interpretations are based on isotopic data for basaltic rocks that show preservation of ancient lithospheric mantle beneath the central Basin and Range (Vaniman et al., 1982; Farmer et al., 1989; Jones et al., 1992) whereas to the north and west, asthenospheric mantle lies beneath the crust. The most buoyant and, by inference, warmest mantle lies under the Sierra Nevada range and not under the strongly thinned crustal sections of Death Valley and Lake Mead (Jones et al., 1992). Thus, there is not a simple relationship between degree of extension of the crust, crustal thickness, and preservation of lithospheric mantle. 
Hildenbrand and Kucks (1988) and Hildenbrand et al. (1988) compiled aeromagnetic data for the state of Nevada and the southern Great Basin. Blakely (1988) used a two-step process to calculate apparent magnetization contrasts for these data. He first analyzed the distribution of the Curie temperature isotherm and assessed the tectonic implications of regional features from an analysis of the aeromagnetic data. One of the most prominent features of the region is the presence of a magnetic "quiet zone," which is a zone on the aeromagnetic map of Nevada located east and northeast of the YMR (Carr, 1984; his fig. 16) showing a lack of magnetization contrasts. This feature has commonly been interpreted as the product of a relatively shallow depth to the Curie temperature isotherm (Zeitz et al., 1970; Christiansen and McKee, 1978). However, Blakely (1988) showed that the absence of short-wavelength anomalies in the quiet zone cannot be explained by a shallow Curie temperature isotherm. He argued that deep magnetic sources influence the long-wavelength anomalies but not the short-wavelength attributes. Blakely (1988) examined alternative causes and suggested that the quiet zone may be caused by intense hydrothermal alteration that could have diminished the magnetic properties of the magnetic rocks (see Eaton et al., 1978).

Blakely (1988) described the northern Nevada rift, which is a north/northwest-trending zone of aeromagnetic anomalies that is best developed in north central Nevada. This rift zone is inferred to be underlain by mafic extrusive and intrusive rocks that formed in response to mid-Miocene extension perpendicular to the then-active subduction zone at the coast (Zoback and Thompson, 1978). The rift zone extends from the Oregon border to southern Nevada (Zoback et al., 1994), and its development is coeval with the first emergence of the Yellowstone mantle plume and eruption of the Columbia River basalt. The rift ends in central Nevada, but gravity data indicate it could extend further south (Blakely, 1988). The gravity anomalies that extend to the south of the rift are probably produced by upper crustal sources (Simpson et al., 1986) and may coincide with thick low-density fill of caldera complexes (Carr, 1990). Carr (1984; his Fig. 18) suggests that the northern Nevada rift may connect with the Death Valley-Pancake range volcanic zone (see following section).

Blakely (1988) applied a Fourier domain technique to the Nevada aeromagnetic data, noting carefully the assumptions and cautions required in applying this method. He used these data to estimate basal depths of magnetic sources. Two regional features persist in his analyses that correlate with recognized heat-flow anomalies. These are the Battle Mountain high and the Eureka low. The Battle Mountain high is an area of shallow depth to the Curie temperature isotherm and coincides with an area of exceptionally high heat flow (Lachenbrach and Sass, 1978). The Eureka low has an unusually deep basal depth to the Curie temperature isotherm (> $25 \mathrm{~km}$; see Blakely, 1988). This correlation is not expected if the Eureka low is caused by a near-surface hydrologic phenomena (contrast with Sass et al., 1987). It must be associated with deep-seated features. Especially notable, again, is the coincidence of this area with the amagmatic gap and an area of probable preservation of Proterozoic lithosphere (Farmer et al., 1989; Jones et al., 1992).

Patterns of historic seismicity broadly outline the borders of the Great Basin with diffuse but significant seismicity in the interior parts (Smith and Sbar, 1974; Smith, 1978; Engdahl and Rinehart, 1988; Hildenbrand et al., 1988) (Fig. 3.4). Distinctive zones of seismicity extend along the western margin of the province (eastern edge of the Sierra Nevada range, Owens Valley-Long Valley region). A secondary belt of seismicity extends from this zone into central Nevada. The southern seismic belt (Smith, 1978) defines the eastern margin of the Great Basin. A somewhat diffuse zone of east/west seismicity extends across the southern Great Basin through the YMR (Smith and Sbar, 1974). The record of seismicity in the latter area has been complicated, however, 
by underground explosions from testing of nuclear weapons at the NTS. A somewhat diffuse but distinctive zone of seismicity extends around the borders of the Colorado plateau (Smith, 1978; Engdahl and Rinehart, 1988). There is an approximate, although imperfect, correlation between zones of seismicity in the Great Basin and sites of Quaternary faulting (Hill, 1982; Carr et al., 1988). However, diffuse seismicity commonly does not coincide with surface faults, and seismic slip at depth may be discordant with fault patterns (Arabasz and Julander, 1986; Gomberg, 1991a,b). Focal depths tend to be shallow and rarely exceed $20 \mathrm{~km}$ (Smith, 1978; Eaton, 1982).

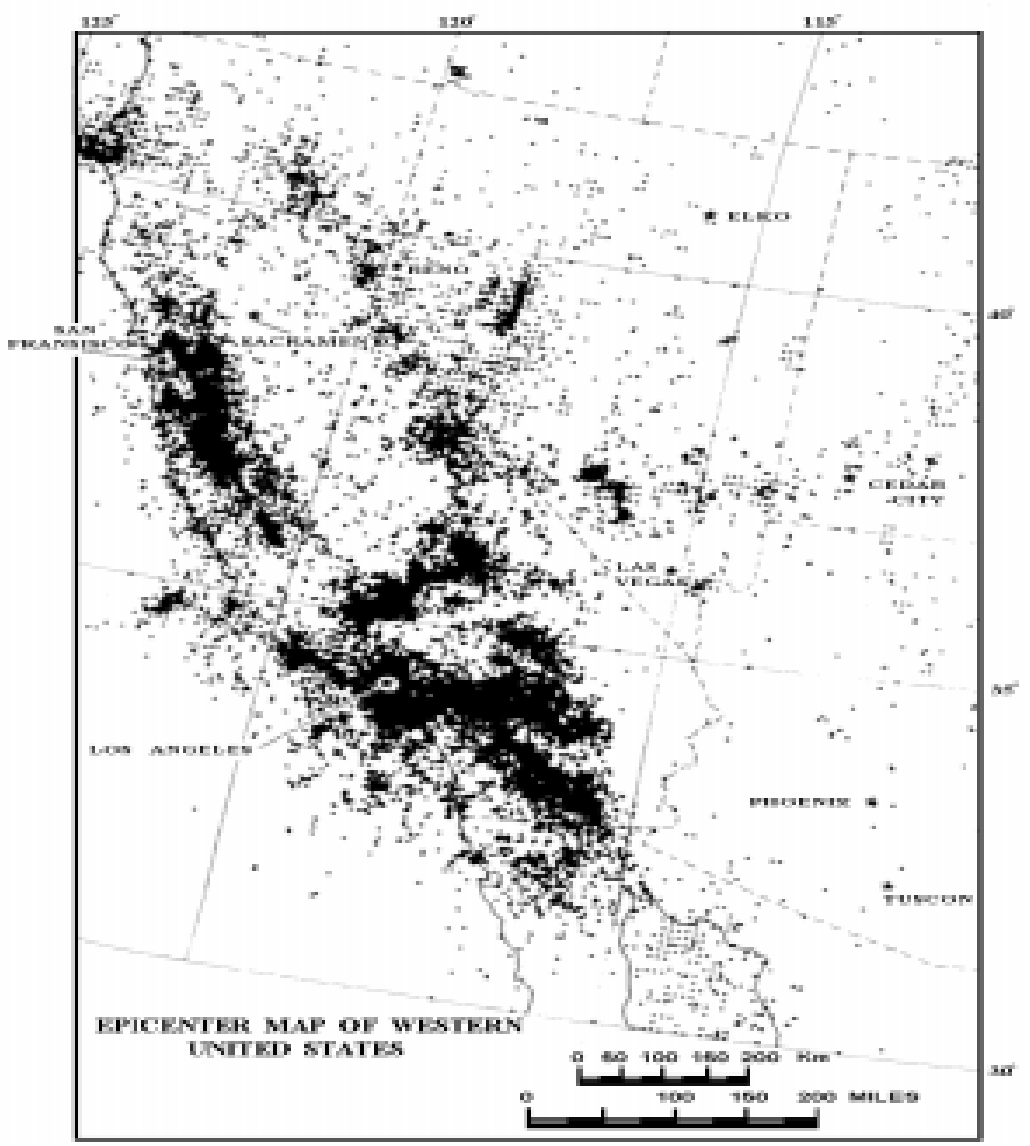

Figure 3.4. Seismicity map of the western United States (from Smith, 1978).

The Great Basin is characterized, from seismic studies, by a relatively thin crust ( $<30$ to 35 km) (Mooney and Braile, 1989; Benz et al., 1990; Jones et al., 1992). Mooney and Braile (1989) noted slightly lower crustal seismic velocities of the Basin and Range province $\left(6.2 \mathrm{~km} \cdot \mathrm{sec}^{-1}\right)$, and the local presence of a high-velocity basal crustal layer $\left(7.3\right.$ to $\left.7.5 \mathrm{~km} \cdot \mathrm{sec}^{-1}\right)$, which is a feature that may be consistent with intrusion of mantle melts into the lower crust (Lachenbrach and Sass, 1978; Okaya and Thompson, 1986). An important characteristic of this region is the anomalous lowvelocity, low-density upper mantle with P-wave velocities of 7.6 and $7.9 \mathrm{~km} \cdot \mathrm{sec}^{-1}$ (Priestley et al., 1982; Benz et al., 1990; Holbrook, 1990). Jones et al. (1992) emphasized that there is not a close correlation between buoyancy of the crustal column and degree of crustal extension. They suggest that the style of lithospheric extension must vary both along and across the strike of the Great Basin. Humphreys and Dueker (1994a, 1994b) examined the upper mantle structure of the western United States through examination of teleseismic $P$ wave travel time residuals. They argue that 
while the patterns of variation are somewhat heterogeneous, the Great Basin is underlain by a buoyant upper mantle with decreased solidus temperature and decreased density.

\section{Tectonic and Volcanic Setting: Yucca Mountain Region}

In this section, we examine the tectonic and volcanic setting of the YMR focusing on the structure of Yucca Mountain and the adjacent Crater Flat basin, which is the occurrence area of most of the Pliocene and Quaternary basaltic volcanic centers in the YMR. The most recent descriptions of the tectonic setting of the area are emphasized because these discussions include data acquired through the site characterization studies for the Yucca Mountain site. The tectonic setting of Yucca Mountain is described for four sets of tectonic models including: 1) detachment models, 2) caldera models, 3) rift models, and 4) Walker Lane models.

Yucca Mountain, as noted in Chapter 2 of the volcanism status report (Crowe et al., 1995), forms part of the southern flank of the Timber Mountain caldera complex (Byers et al., 1976, 1989; Christiansen et al., 1977), a Miocene volcanic feature, that is still expressed physiographically. Many of the constructional features formed during volcanic eruptions (caldera depression, resurgent dome) are still preserved topographically. The caldera depression is outlined by an annular valley surrounding the central resurgent dome of the caldera.

Ekren et al. (1968) documented two sets of basin-range faults in the Nevada Test Site and Nellis Air Force Range. They noted that older basin-range faults trend northwest and northeast. These faults locally predate the Belted Range Group and may have formed as early as about $26 \mathrm{Ma}$ (Ekren et al., 1968). A second set of north-trending faults is constrained by stratigraphic relations to be younger than about $18 \mathrm{Ma}$. These faults had well developed, probable fault-controlled topography before the eruption of the Thirsty Canyon Tuff (Ekren et al., 1968). Extensional faulting in the Yucca Mountain vicinity is largely contemporaneous with volcanic activity at about 11-13 Ma (Scott, 1990; Carr, 1990; Fridrich in preparation). There are suggestions of a poorly documented phase of tectonism, possibly basin and range tectonism, that predates the Paintbrush Group (Snyder and Carr, 1984; Wright, 1989; Carr, 1990; Fridrich, in preparation). Evidence is persuasive that an episode of range-bounding faulting postdates eruption of the Paintbrush Group (12.8 to $12.7 \mathrm{Ma}$ ) and partly predates but locally involves the Timber Mountain Group (11.7 to 11.4 Ma) (see Snyder and Carr, 1984; Scott, 1990; Carr, 1990; Fridrich, in preparation).

Considerable work for the site characterization studies has been conducted to assess the risk of future seismic activity for the Yucca Mountain site. A key finding from these studies is the identification of multiple faults with Quaternary displacement (Simonds and Whitney, 1993). Many of these faults have now been re-mapped at larger scales building on the work of Scott and Bonk (1984; for example Dickerson and Spengler, 1994), and paleoseismic studies have been conducted using information from logged trenches and natural exposures (for example, Menges et al., 1994). Some key issues concerning seismic risk for both the preclosure and postclosure periods of a potential repository are the effect of seismicity and tectonic deformation on unsaturated and saturated ground water flow and the rocks of a repository system, and the relationship between tectonism and volcanism (for example, Stirewalt et al., 1992; Ferrill et al., 1995b). 


\section{A. Detachment Models}

Scott and Bonk (1984; Scott, 1990) provided a comprehensive description of the shallow structure of Yucca Mountain based on detailed geologic mapping at a scale of 1:12,000. They argued that Yucca Mountain has been modified by structures that are typically associated with extended terranes of the Basin and Range province and also contains areas of oroclinal bending, which is a common feature of strike-slip deformation in the Walker Lane structural system. Scott (1990) described the mountain as a series of east-tilted, fault-controlled ridges or blocks that bifurcate southward. The northern end of the range is marked by northwest-trending topography that may be associated with largely concealed northwest-trending strike-slip faults (Scott et al., 1984; O'Neill et al, 1992). The interior part of Yucca Mountain and the areas associated with the exploratory block consist mostly of north-trending, gently east-tilted fault blocks bounded by westdipping, high-angle normal faults. The southern part of the mountain shows an increase in the number of faults, an increase in the offset along the faults, a decrease or shallowing of the west dip of the faults, and an increase in the amount of eastward to southeastward stratal tilting of the volcanic section (Scott, 1990). Paleomagnetic data from the Tiva Canyon member of the Paintbrush Group indicate a stepped, southward increase in the degree of clockwise rotation across Yucca Mountain (Scott, 1990; Rosenbaum et al., 1991; O'Neill et al., 1992), and this change coincides approximately with a slight disruption of the range trend and the occurrence of northeasttrending, left-slip faults (Fridrich, in preparation).

Scott (1990) summarized three types of evidence suggesting that the major normal faults of Yucca Mountain could be listric faults (flattening downward). First, he cited a $12^{\circ}$ downward decrease in the dip of a fault cutting the western slope of Busted Butte. Second, he noted, from drilling data, a downward decrease in dip of about $21^{\circ} \mathrm{km}^{-1}$ for the Ghost Dance fault. The third line of evidence is a progressive eastward increase in stratal tilts toward the major normal faults that cut the mountain. Scott (1990) inferred the presence of a low-angle normal fault as an accommodation structure beneath Yucca Mountain. Such an interpretation requires the faults of Yucca Mountain to form a low-angle stack of normal faults above a basal detachment fault. The east-bounding breakaway zone for a detachment system could be the Paintbrush Canyon fault (Fox and Carr, 1989) or a structural zone bounding the east side of Yucca Mountain (Brocher et al., 1993). An alternative explanation, however, is that the observed flattening of faults is a nearsurface phenomenon and the faults are high-angle structures $\left(\geq 50^{\circ}\right)$ that extend downward to the seismogenic base of the crust at 10- to 15-km depth (Brocher et al., in press).

Hamilton (1988) described detachment faulting in the Death Valley region of California and Nevada. He suggested that detachment faults exposed in Bare Mountain, the Bullfrog Hills, and the Funeral Mountains to the west and southwest of Yucca Mountain may be domiform exposures of a single west/northwest-dipping fault surface that was eroded as the upper plate of the Grapevine Mountains slid westward. Key points of the Hamilton model (1988) are twofold. First, the detachment faults may be major, initially west-dipping faults that were raised and rotated as they were unroofed progressively by tectonic denudation. Second, the detachment systems decrease in age to the southwest. The youngest activity on these systems is in the Death Valley region. Hamilton (1988) agrees with the model of Scott (1990) that the middle Miocene faulting of Yucca Mountain represents a headwall complex that allowed slip on the Bare Mountain detachment fault to reach the surface. However, Hamilton (1988) argues that the Quaternary displacement of these faults only applies to the final "gasps" of detachment slip. Thus, most of the detachment deformation predated the episodes of extensional faulting that displaced the ignimbrite sheets of Yucca Mountain. 
Another perspective for the regional models of detachment systems is provided by Carr and Monsen (1988). They accept the continuous detachment model of Hamilton (1988) but argue that the faults of Yucca Mountain have a different movement history than the extensional terrain of Bare Mountain and the Bullfrog Hills. Fox and Carr (1989) endorse the detachment models but argue that the listric nature of normal faults at Yucca Mountain can be neither confirmed nor refuted with current data.

Ferrill et al. (1995a) argue that there are two end-member models for detachment fault systems and their association with faults of Bare Mountain and Yucca Mountain. The first assumes the faults of Yucca Mountain are related to a detachment system at the Bullfrog Hills, and the faults of Yucca Mountain, while related originally to the detachment system, were cut off by the rise of Bare Mountain. The second model assumes that faults of the Yucca Mountain block formed to accommodate deformation in the hanging wall in response to movement on the Bare Mountain fault.

A major difficulty with almost all of the detachment models was noted by Brocher et al. (1996; in press) from their interpretations of studies of seismic reflection lines collected across Crater Flat and Yucca Mountain. They argued that the inferred upper contact of the Tertiary and Paleozoic section of rocks can be traced discontinuously in the reflection data and is offset by relatively steep faults, which is an observation that is inconsistent with the contact representing an active, lowangle detachment surface (Brocher et al., in press). None of these observations, however, preclude low-angle shear deformation at greater depth in the brittle-ductile transition zone of the middle crust (McCarthy and Thompson, 1988).

There is general agreement that even if detachment processes have affected the fault systems at Yucca Mountain, the systems are now either inactive or have very limited effects on modern fault systems. The detachment models may affect interpretations of the timing of past faulting events and potentially assessments of seismic risk for Yucca Mountain. However, more important to the purposes of this report, the distribution of basaltic volcanism in the Yucca Mountain region does not appear to be related in any systematic manner to known or inferred detachment faults. Moreover the low-angle geometry of detachment systems make them unlikely pathways for ascent of basalt magma at depth because magma probably follows or is most influenced by near-vertical structures (see Crowe et al., 1995, Chapter 5). We conclude that tectonic models involving detachments systems may be important for seismic studies but probably do not play a significant role in the location and structural setting of sites of Pliocene and Quaternary basaltic volcanism in the YMR.

\section{B. Caldera Models}

A second set of largely different tectonic models for the Yucca Mountain setting, corresponding to caldera models, has been proposed by W. J. Carr and associated co-authors (Carr, 1984; Snyder and Carr, 1984; Carr and Parrish, 1985; Carr et al., 1986; Carr, 1988). These models were proposed mostly before the development of concepts of detachment systems for the YMR. The caldera models infer that Yucca Mountain is bordered to the west and partly underlain by a caldera complex, the Crater Flat-Prospector Pass caldera. The collapse of two inferred nested calderas associated with this caldera complex was assumed to be the primary cause for the formation of the Crater Flat depression which was partly filled by ignimbrites of the Paintbrush and Timber Mountain Groups and alluvial sediments (Fig. 3.5). Carr et al. (1986) and W. Carr (1988) suggested that the caldera is divided into two parts. The northern part of the caldera, the 
Prospector Pass caldera segment, is believed to be the source of the Tram Tuff of the Crater Flat Group. The larger Crater Flat caldera is believed to be the source of the Bullfrog and Prow Pass Tuffs of the Crater Flat Group. Evidence for the caldera complex includes:

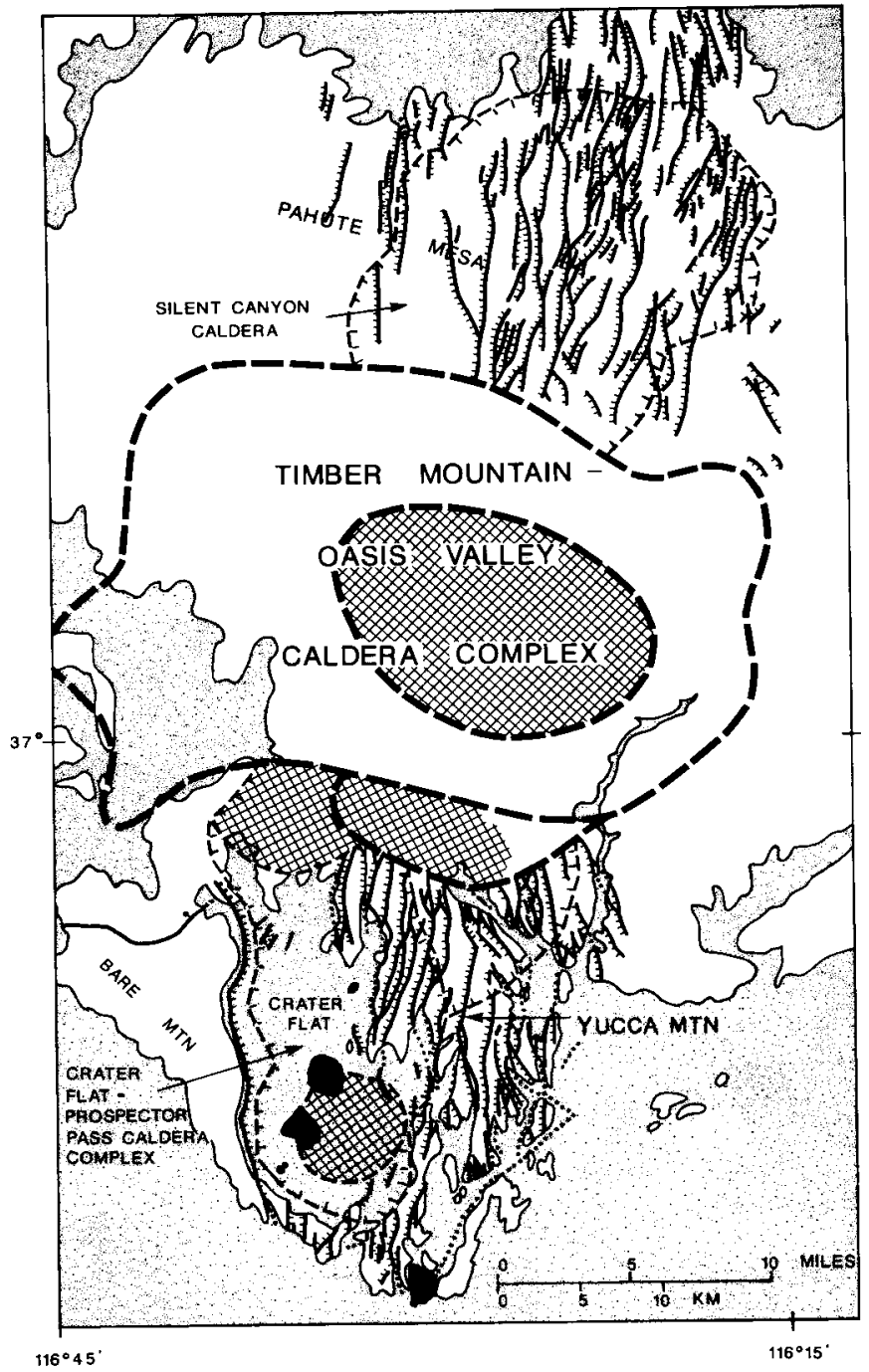

Figure 3.5. Proposed caldera complexes and the distribution of Quaternary basaltic volcanic rocks of the Crater Flat area (modified from Carr, 1990). Snyder and Carr (1984), Carr and Parrish (1985), Carr et al. (1986), and Carr $(1982,1984,1988,1990)$ propose that the southern part of Crater Flat is underlain by the Crater Flat caldera and the northern half of the Crater Flat basin is a segment of the larger Prospector Pass caldera. The Pliocene and Quaternary volcanic rocks of Crater Flat occur in the moat zone and across the resurgent dome of the proposed Crater Flat caldera. One center (Makani cone) is located in the Prospector Pass caldera segment. The cross-hatched areas are the inferred resurgent domes of the caldera complexes (after Carr, 1990) and the black areas are Quaternary basalt centers. 
1. the semicircular shape of the southern part of Crater Flat;

2. the large compound gravity low of Crater Flat (nearly $50 \mathrm{mGal}$ ), which is inferred to be produced by low density fill in a compound caldera depression;

3. the distribution and thickness of the individual members of the Crater Flat Group;

4. the presence of local Miocene dike systems in Bare and Yucca Mountains that may represent ring dikes of the caldera complex;

5. the presence of a thick local wedge of monolithologic breccia, resembling collapse breccia, in the upper part of the Bullfrog Tuff near the southern edge of Crater Flat; and

6. the truncation in Crater Flat of a persistent east/west aeromagnetic anomaly.

Carr and Monsen (1988), Hamilton (1988), Scott (1990), and Fridrich and Price (1992) summarized arguments against an origin of the Crater Flat depression as a caldera complex. The primary arguments are several. First, the facies variations of the Crater Flat Group do not appear consistent with a caldera source in Crater Flat. Second, the stratigraphic sequence noted in VH-1 and $\mathrm{VH}-2$, particularly the absence of a intracaldera deposits between the Prow and Bullfrog Tuffs of the Crater Flat Group, are inconsistent with the presence of a caldera in southern Crater Flat associated with the eruption of the Crater Flat Group. Third, the gravity data indicate the Crater Flat basin extends in the subsurface southward beyond the southern physiographic margin of the Crater Flat and, thus, is not uniquely associated with the proposed caldera boundaries. Oliver and Ponce (1995) noted that the seismic refraction profile across the Amargosa Valley south of the town of Amargosa shows a structural depression with dimensions and trends that are similar to the Crater Flat depression. The subdued aeromagnetic signature of the basin continuation shows that it cannot be associated spatially with volcanic rocks and cannot be a caldera depression. Fourth, intrusive dikes inferred to follow the ring-fracture zone and mark the margin of the calderas may simply follow local basin-range structure. Finally, interpretations from seismic reflection profiling (Brocher et al., 1996), while not completely definitive, are generally inconsistent with the caldera model of Crater Flat. The Crater Flat basin is a non-circular depression and it is deeper on the west than the east side. The eastern side of the basin is bounded by a series of moderate-to high-angle planar faults rather than arcuate bounding faults typical of ring-fracture zones of a caldera complex. Additionally, there is no indication in the reflection data of a resurgent dome or structures typically associated with a resurgent dome in the subsurface of Crater Flat east of Red Cone and Black Cone (compare with Carr, 1990).

\section{Rift Models}

The rift models are divided into three sets including: 1) the Death Valley-Pancake Range volcanic zone, 2) Rift-caldera models, and 3) Rift/strike-slip models.

1. Death Valley-Pancake Range Volcanic Zone. Crowe and Carr (1980) and Crowe et al. (1980) defined the Death Valley-Pancake Range volcanic belt (DV-PR), which is a northnortheast-trending zone extending across the central part of the Great Basin from Death Valley on the south to the Pancake Range on the north and including the Yucca Mountain site (Fig. 3.6). They noted that the belt is demarcated by scattered sites of Pliocene and Quaternary basaltic 
volcanism and is similar to a north-trending "prong" of fundamental basaltic volcanism denoted by the boundaries of zone II of Best and Hamblin (1978; page 332). Crowe et al. (1983a) attempted to further define the DV-PR noting that it developed as a recognizable zone of diffuse but persistent basaltic volcanism following spatial migration and cessation of silicic volcanism in the southern Great Basin at about 8-9 Ma. They described two types of volcanic fields in the belt including large volume, long-lived basaltic volcanic fields (Type I field) with high densities of scoria cones (Lunar Crater and Death Valley volcanic fields), and relatively short-lived, small volume basalt fields (Type II fields) with low densities of scoria cones (Crater Flat volcanic field). Vaniman et al. (1982) described the petrology and geochemistry of the basalt cycles of Crater Flat and briefly discussed systematic spatial changes (increasing from north to south) in the isotopic ratios of ${ }^{87} \mathrm{Sr} /{ }^{86} \mathrm{Sr}$ of Pliocene and Quaternary basalt in the DV-PR (Vaniman et., 1982; their Fig. 1).

Carr (1984) attempted to integrate the DV-PR into the structural and tectonic framework of the southern Great Basin. He summarized evidence of multiple features that appear to be somewhat unique for the DV-PR including (Carr, 1984, p. 32-39; his Fig.18):

1. Aligned basalt centers and exposed dikes of less than $4.0 \mathrm{Ma}$ age trend generally N. $20^{\circ}-30^{\circ} \mathrm{E}$ and parallel the trend of the DV-PR.

2. The DV-PR parallels and is locally east of a tilt reversal of linear ranges in the central and southern part of the Great Basin. Additionally, the DV-PR parallels and is adjacent to a series of topographically high-standing mountain ranges.

3. There is a slight increase in concentration of Quaternary faulting in the DV-PR compared to immediately adjacent regions of the Great Basin.

4. The DV-PR may be a paleoseismic zone. This interpretation is complicated by nuclear explosions at the Nevada Test Site and aftershocks triggered by the explosions as well as limited historical record from seismic nets that record lower magnitude earthquakes.

5. While the DV-PR is not well expressed as a geophysical feature, Carr (1984) argues that a north-south axis of symmetry in the Bouguer gravity field parallels the belt, and it is also paralleled by prominent magnetic "quiet zone" (see earlier section). Carr (1984) argues that the DV-PR could be a zone of slightly higher heat flow and may be associated with an east to west increase in upper mantle velocities.

6. The northern end of the DV-PR may be aligned with the Cortez Rift or the OregonNevada lineament (see Carr, 1984; his Fig. 18). Note: The Cortez Rift of Carr (1984) is the same as the northern Nevada rift (see pages 11-12 of this paper). 


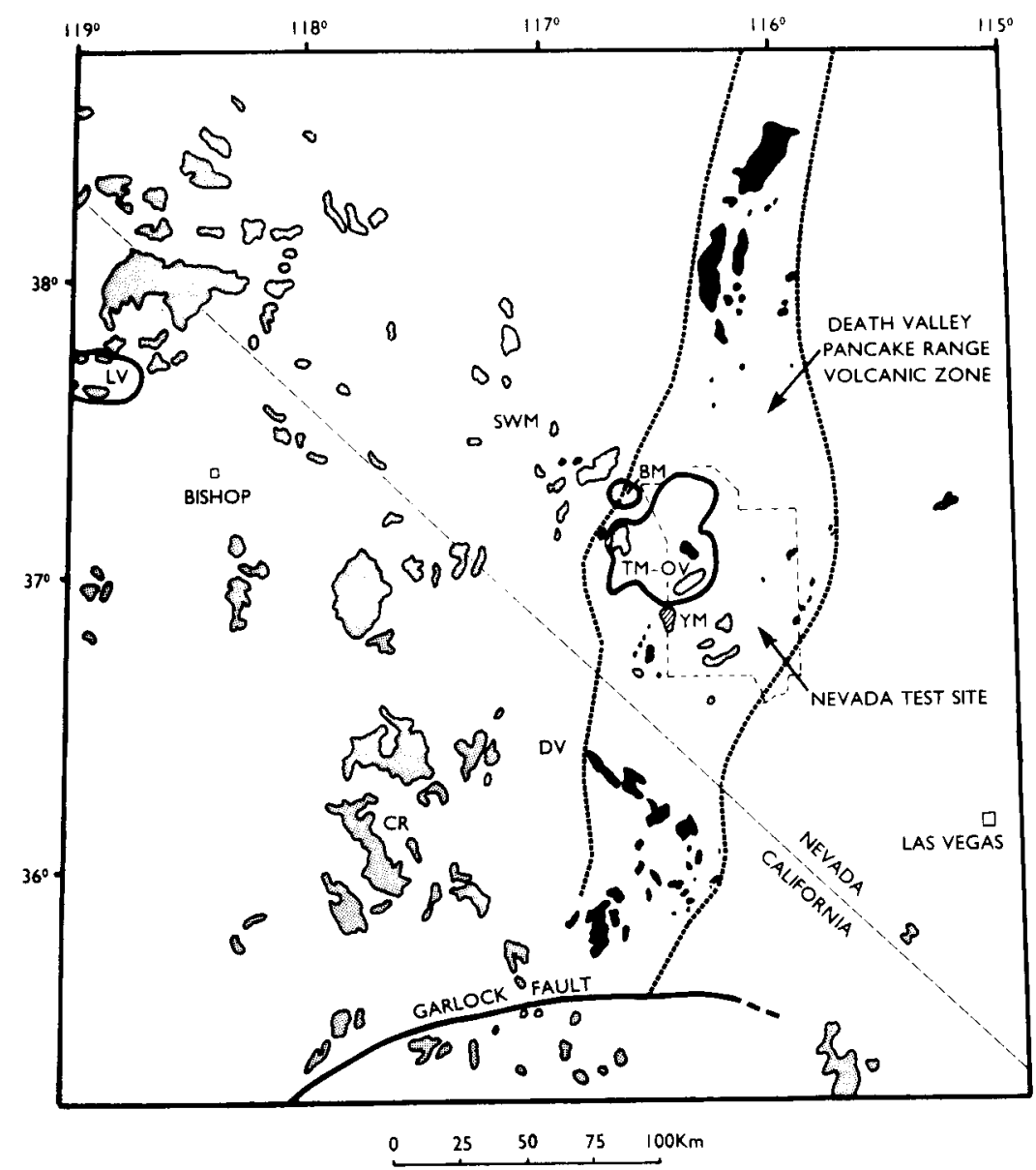

Figure 3.6. Distribution of post-Miocene silicic (stippled) and basaltic (black) volcanic rocks of the southern Great Basin. Basaltic rocks are inferred to be part of the Death Valley/Pancake Range volcanic zone (Crowe et al., 1983a; Crowe, 1986). An alternative interpretation is that the zone may consist of three unrelated, complex volcanic fields: (1) the Lunar Crater-Reveille range volcanic fields, (2) basaltic and silicic volcanic rocks of the Timber Mountain-Oasis Valley/Black Mountain-Stonewall Mountain volcanic fields, and (3) basaltic and silicic volcanic rocks of southern Death Valley. TM-OV: Timber Mountain caldera complex; BM: Black Mountain caldera; SWM: Stonewall Mountain caldera (caldera boundaries not shown on the figure); LV: Long Valley caldera complex; CR: volcanic rocks of the Coso volcanic field; DV: Death Valley; YM: Yucca Mountain.

Carr (1984) concluded his discussion of the DV-PR by arguing that the zone may simply be a linear region of slightly higher tectonic flux that has allowed an increased concentration of Quaternary faulting, seismicity, and basaltic volcanism. Such an interpretation is consistent with the DV-PR being a relatively subtle feature in which ascending basaltic magma is slightly more likely to reach the surface than areas flanking the zone.

Smith et al. (1990) defined an "Area of Most Recent Volcanism" (AMRV) and included this area in the DV-PR (in Smith et al., 1990; their Fig. 2). They emphasized that the direction of elongation of their high-risk volcanic chains in Crater Flat is parallel to the DV-PR.

Some studies have downplayed or questioned the existence of the DV-PR. Smith and Luedke (1984) did not include the DV-PR in their summation of potentially active volcanic lineaments and loci in the western United States. Crowe (1993) noted that there are gaps in the distribution of Pliocene and Quaternary basaltic volcanic centers in the DV-PR between the YMR and the 
southern Reveille Range and between the central Amargosa Valley and Death Valley. He suggested the alternative interpretation that the DV-PR zone may consist of three unrelated, volcanic fields: the Lunar Crater-Reveille volcanic field, the SNVF, and the late Cenozoic volcanic rocks of southern Death Valley (see Fig. 3.6). A critical distinction for the DV-PR may be in the use of the terms "belt" or "zone" for this feature. Crowe et al. (1986) and Crowe (1986) describe the DV-PR as a zone that is defined only on the basis of a slightly greater abundance of Pliocene and Quaternary basaltic centers than adjacent areas on either side of the zone. This usage is similar to the definition of the basaltic volcanic zone II of Best and Hamblin (1978). In contrast, Carr (1984) argues that the DV-PR is a belt that is marked by topographic, seismic, and geophysical features in addition to an increased abundance of sites of Pliocene and Quaternary basaltic volcanism. He suggests that the DV-PR is a structural feature. The interpretation and origin of the DV-PR was identified as a topic for resolution through geophysical studies by the US Geological Survey (Crowe et al., 1986). However, follow-up studies were not conducted.

Whatever the inferred origin of DV-PR, there is agreement that it marks a zone of slightly increased concentration of Pliocene and Quaternary basaltic volcanism in the southern Great Basin. The DV-PR has been proposed and described by a number of authors, and there is agreement that the boundaries of the DV-PR enclose the Yucca Mountain site.

Two other sets of rift models-the rift-caldera models and the rift/strike-slip models-are related partly to the DV-PR but are applied to only the southern part of the zone. They are considered as separate categories of rift models in the following discussions.

2. Rift-Caldera Models. W. J. Carr extended his concepts of the tectonic setting of the YMR and defined the Kawich-Greenwater rift (Carr, 1990), which is a north-northeast trending rift that coincides spatially with the southern part of the DV-PR belt. He suggested that the YMR is split by a north-trending volcano-tectonic rift, the Kawich-Greenwater rift, that encompasses several coalesced caldera complexes and represents a pull-apart or a right-stepped zone of rifting in the larger Walker Lane structural system (Fig. 3.7). Carr (1990) attempted to integrate this rift with the proposed detachment models for the fault systems of Yucca Mountain. Rather than classic detachment faulting, he argued that Yucca Mountain is located on the approximate area of a breakaway zone that allowed development of detachment-style faulting to the west as an accommodation to "slumping" of the Yucca Mountain highland into the Crater Flat depression.

The major characteristics of the Kawich-Greenwater rift (all from Carr, 1990) include inferred features that could be important to the Yucca Mountain site.

1. The rift is identified structurally on the north and south by aligned caldera complexes and by closely spaced sets of north-to-northeast-trending faults that offset the ignimbrite sheets. These fault systems may be distinguished by their close surface spacing and the geometry and distribution of offset of the Timber Mountain Group. Part of the fault system is exposed in a northeast zone extending across Pahute Mesa with the inferred southern continuation of this fault zone extending through Yucca Mountain (Carr, 1990, his Fig. 6). 


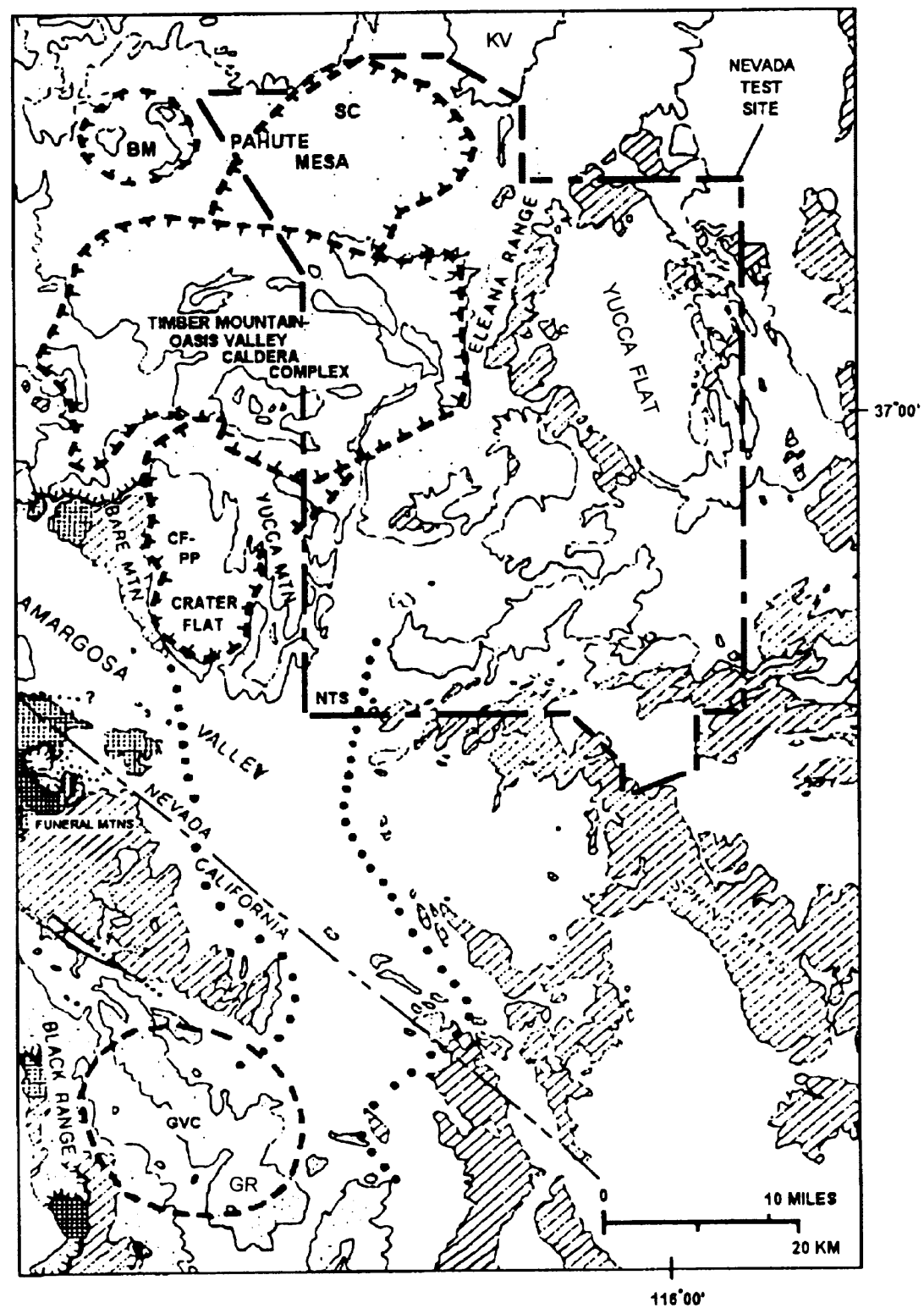

Figure 3.7. Kawich-Greenwater rift zone (after Carr, 1990). The zone is marked by an alignment of coalesced caldera complexes of the Timber Mountain caldera complex. It extends south across the Amargosa Valley into the Death Valley area of California and coincides with the southern part of the DV-PR. Notched lines outline caldera-complexes of the TM-OV (BM: Black Mountain caldera; SC: Silent Canyon caldera; CF-PP: the proposed Crater Flat/Prospector pass caldera that is not generally regarded as a caldera complex; GVC: Greenwater Valley caldera (shown as a dashed not notched line because it is a speculative caldera). The heavy dashed line outlines the boundaries of the Nevada Test Site (NTS) and the dotted lines outline the boundaries of the Kawich-Greenwater rift zone. KV: Kawich Valley; GR: Greenwater Range.

2. The west side of the rift is structurally more abrupt than the east, and the rift forms an asymmetrical graben structure.

3. The axis of the rift, particularly on the south side, may be marked by a diffuse gravity low in the regional Bouguer gravity map. 
4. Volcanic activity occurred along the length of the rift, primarily during the Miocene, and included large-volume eruptions associated with caldera centers in the YMR. The southern part of the rift was active about the same time as the northern rift, but silicic eruptions continued in the southern part until about $5 \mathrm{Ma}$ (Death Valley area). The Kawich-Greenwater rift lies near and parallel to a regional volcanotectonic feature, the DV-PR.

5. Carr (1990) argued that the presence of Pliocene and Quaternary basalt in the Crater Flat area indicates the ". . p process of rifting may be continuing but at a very much reduced rate and probably under a different stress regime than in the Miocene" (Carr, 1990, p. 290). The basalts are inferred to have followed ring-fracture zones of calderas at depth and diverted to northeast-striking tension fractures as they neared the surface.

The Kawich-Greenwater rift model of Carr (1990) represents an important modification of his caldera model and an attempt to reconcile the mapped patterns of the closely spaced normal faults of Yucca Mountain. The primary importance of the proposed rift (Carr, 1990) to volcanism studies is its location and structural orientation. The rift, or structural trough, trends north/northeast from the Greenwater Range, on the eastern flank of southern Death Valley, through the Yucca Mountain area to Kawich Valley (Carr, 1990) (Fig. 3.7). This proposed rift zone obliquely spans part of the Walker Lane structural zone in the southern Great Basin and encompasses the Yucca Mountain site. So defined, it could provide a controlling structure for the location of the past and possibly future occurrences of basaltic volcanism in the YMR. The Kawich-Greenwater model retains the interpretation that Yucca Mountain is at least partly underlain by a buried caldera and the Yucca Mountain site is included in a larger rift zone that is also part of the DV-PR.

3. Rift/Strike-Slip Models. Multiple models have been proposed that attribute the Crater Flat basin to different combinations of extension and strike-slip deformation that may or may not be associated with detachment faulting. This section briefly reviews and attempts to contrast the different models. The models share many common features but are separated in categories corresponding to the worker who proposed the different models.

a. Amargosa Desert Rift Zone. An alternative rift model of the tectonic setting of Yucca Mountain involves episodes of older strike-slip faulting directly or indirectly associated with extensional deformation. Wright (1989) argues that detachment systems typical of the Death Valley area are not regional features and suggests instead that they are unconnected systems that were bounded originally by strike-slip faults. The timing and style of development of low-angle detachment faults by this model are dependent on the history of faulting of individual basins. Wright (1989) infers that the Crater Flat basin may be the north part of a zone of pull-apart basins called the Amargosa Desert Rift Zone (ADRZ). This structure encompasses a series of structural blocks bounded by segments of strike-slip faults connected by en echelon, obliquely oriented normal faults (Fig. 3.8). The primary evidence in support of this rift is threefold. First, a series of gravity lows is inferred to define pull-apart basins extending to the south and southeast of Crater Flat (Wright, 1989). Second, pull-apart basins associated with extensional and strike-slip faulting have been documented in other adjoining areas of the Basin and Range (Death Valley, Emigrant Valley). Third, northwest-trending faults of the Pahrump Valley area may be still active strands of basin bounding, strike-slip faults. 


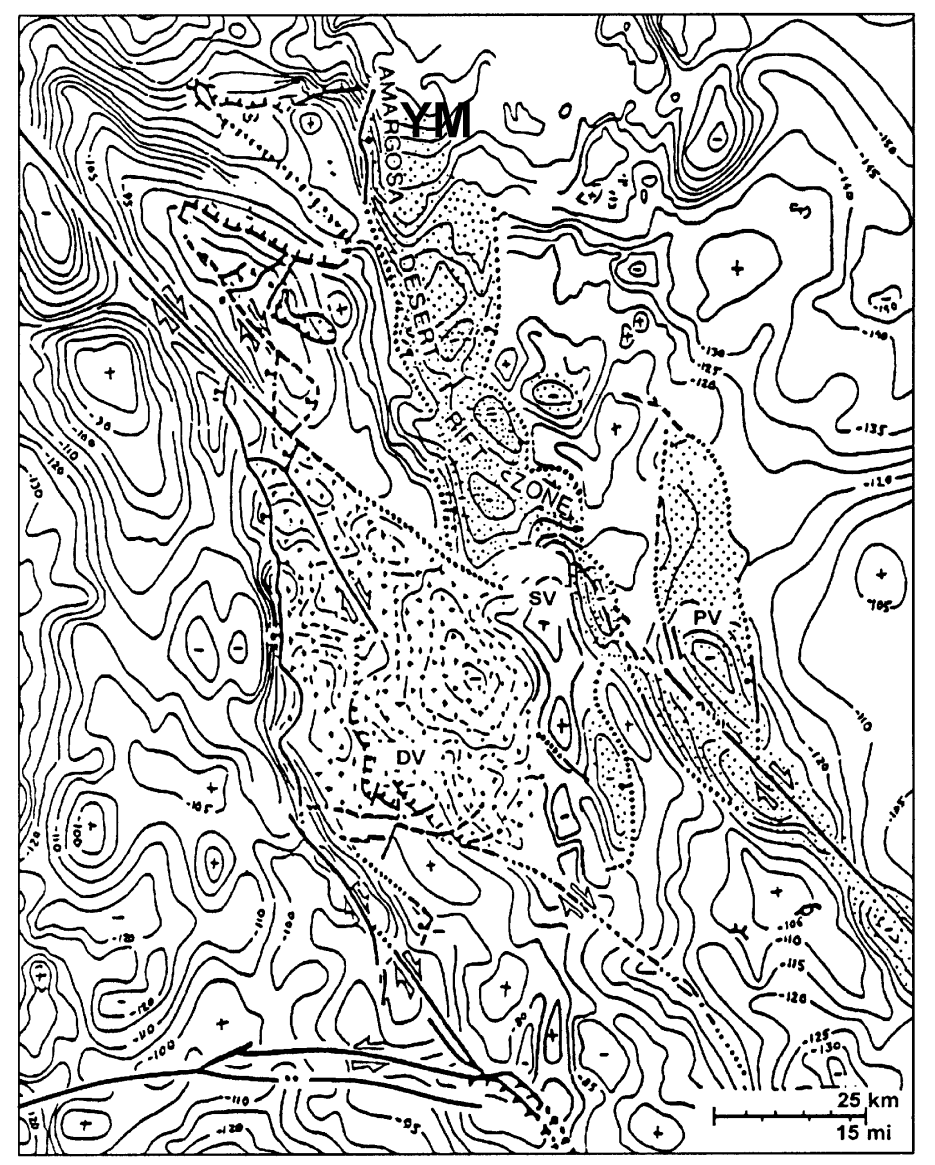

Figure 3.8. ADRZ superimposed on the Bouguer gravity map (modified from Wright, 1989). The rift zone extends from Crater Flat on the north, south-southwest across the Amargosa Valley, and bifurcates into the Stewart Valley (SV) and Pahrump Valley (PV) basins, and the central Death Valley plutonic-volcanic field (DV). The YM is the location of the exploratory block of Yucca Mountain.

Pull-apart activity based on the Wright model (1987) may have begun in the YMR as early as 14 to $16 \mathrm{Ma}$ and was replaced in time by predominantly normal faulting. The Crater Flat basin, with associated sites of volcanic activity, could represent a northern segment of the ADRZ. A strike-slip component of the late Miocene $(<12.4 \mathrm{Ma})$ development of the Crater Flat basin is suggested by the rotation of the Tiva Canyon member, as inferred from paleomagnetic data (Rosebaum et al., 1991).

The Wright (1989) model shares some common features with the Kawich-Greenwater rift model of Carr (1990). A key difference is that the Wright model attributes basin formation primarily to tectonic processes with volcanic activity secondary to tectonic activity. The Carr model relates the primary development of the northern part of the Kawich-Greenwater rift zone to volcanic processes with tectonic activity only a secondary process. The models overlap and are in agreement generally for the southern part of the Kawich-Greenwater rift zone and the northern part of the ADRZ. Both models emphasize development of tectonic rifts or pull-apart zones south of Crater Flat and possibly extending to Death Valley (Wright, 1989; Carr, 1990). Wright (1989) suggests that the ADRZ may not connect with the southern Death Valley volcanic field but instead with pull-apart basins formed in the Pahrump-Stewart Valleys. Carr (1990) extends the Kawich- 
Greenwater rift into the volcanic and pull-apart basins of southern Death Valley. The most marked differences in the rift models are for the origin of the Crater Flat basin. Carr (1990) maintains that the creation of the Crater Flat depression is from caldera collapse associated with cycles of ashflow eruption. He notes, however, that the caldera collapse may have been contemporaneous with or modified by rifting and graben formation.

The absence of distinctive magnetic anomalies in or beneath the alluvial fill of the Amargosa Valley suggests strongly that the proposed pull-apart basins of this valley were not accompanied by eruption of voluminous volcanic rocks (Kane and Bracken, 1983; Wright, 1989; Langenheim, 1995). Wright suggests the timing of development of the basins of the Amargosa Valley is prePaintbrush (>13 Ma). His arguments are based on the geologic relations of the Crater FlatProspector Pass caldera and a K-Ar age of 13.2 Ma for an ash found in sedimentary fill near Ash Meadows.

The ADRZ model of Wright (1989) was one of the first tectonic models to recognize the potential importance of strike-slip faulting in the development of the Crater Flat basin through comparison to analogous relationships in the pull-apart setting of southern Death Valley. Wright (1989) also recognized the importance of linear gradients in the Bouguer gravity field that may mark the locations of inferred basin-bounding, strike-slip faults.

b. Amargosa Valley Isotopic Province. A related but not specific tectonic or volcanic model of the distribution of the Pliocene and Quaternary basalt centers of the southern Great Basin was defined by Gene Yogodzinski (University of Nevada, Las Vegas) at a workshop in conjunction with probabilistic volcanic hazard analyses for the Yucca Mountain site (Geomatrix, 1996). He argued that the isotopic composition of $\mathrm{Sr}$ and $\mathrm{Nd}$ for basaltic volcanic rocks can be used to outline a definable spatial province named the Amargosa Valley Isotopic Province (AVIP). The boundaries of this province coincide almost identically with a composite of the Kawich-Greenwater rift of Carr (1990) and the ADRZ of Wright (1989). The AVIP represents a zone of basaltic volcanic activity where the magma source was an unusually thick and temporally persistent section of Proterozoic lithospheric mantle (Geomatrix, 1996; see elicitation by R. Carlson). This spatial/geochemical "tectonic" model was used by many panel members of the volcanism expert judgment panel (Geomatrix, 1996) and, for this reason, is identified as a separate model in this report.

c. Concealed Strike-Slip Model. A slightly different origin for the Crater Flat basin was suggested by Schweickert (1989) who proposed the presence of a buried right-slip fault that transects the southern Amargosa Valley and Crater Flat basin. He suggested a cumulative offset of about $26 \mathrm{~km}$ along a concealed fault zone on the basis of offset of a distinctive overturned foldthrust system of Mesozoic age. The lack of surface expression of the fault led Schweickert (1989) to suggest that activity on the fault predates the Paintbrush Group. He argues, however, that the clockwise rotation of the Tiva Canyon member may indicate continued shear strain along the fault. Schweickert (1989) notes further that the strong northwest-trending alignment of the Quaternary volcanic centers may mark the surface projection of the trace of the concealed strike-slip fault. This model is largely compatible with the Wright model (1987). However, the strike-slip model of Schweickert (1989) requires only a single strike-slip fault whereas the rift model of Wright (1989) requires that the basins of the rifts formed by movement on a combination of en echelon northwesttrending faults. The latter interpretation is more consistent with the gravity data of southern Crater Flat and the Amargosa Valley, which shows distinct zones of northwest-trending gravity lows outlining en echelon basins (Wright, 1989). 
d. Pull-Apart Basin Models. Fox and Carr (1989) emphasized extension over strike-slip faulting in basin formation and presented a modification of the rift/strike-slip models. They suggested that the resumption of basaltic magmatism in Crater Flat about 3.7 Ma marked a renewed episode of extensional tectonism in the Yucca Mountain area. The eruption sites of the basalts were inferred to coincide with an axis of extension and crustal pull-apart between eastdipping faults of Bare Mountain and west-dipping faults of Yucca Mountain. O’Neill et al. (1992) described evidence of strike-slip faulting and oroclinal bending of Yucca Mountain. They suggested, on the basis of fault geometry, fault offsets, and paleomagnetic data, that formation of strike-slip, pull-apart basins on scales of meters to kilometers may be an ongoing process. Both the Fox and Carr (1989) and the O'Neill et al. (1992) models require extension and pull-apart formation to be an active process, albeit at rates much reduced from earlier Miocene extension.

A modified pull-apart model that focuses on the structural resemblance of the Crater Flat basin to a sphenochasm has been developed by Fridrich and Price (1992), Fridrich et al. (1994), and Fridrich (in preparation). The latter paper (Fridrich, in preparation) provides the most recent summary of studies of the basin and it is used as the primary reference in the following summary of the important points concerning the origin of the Crater Flat basin.

In the sphenochasm model (Fridrich, in preparation), arguments are presented that the Crater Flat alluvial basin and the flanking ridge (Yucca Mountain) are structurally linked and together constitute the Crater Flat structural basin, the northernmost subbasin of a large graben that extends from the Timber Mountain caldera complex to the Furnace Creek fault. This larger-scale central Amargosa graben is the same feature that Wright (1989) named the Amargosa Desert Rift Zone.

The Crater Flat basin resembles a sphenochasm because the magnitudes of extension and verticalaxis rotation within the basin are both a minimum in the northeastern corner of the basin, at the north end of Yucca Mountain, and both increase strongly to the south and west from there. The basin, thus opened in an oblique manner, indicates a transtensional structural setting.

A key feature of the Crater Flat basin is that it is bounded by discrete structural domain boundaries, and there are abrupt fundamental changes in the style, timing, and magnitude of extension and other deformation across the basin (Fig. 3.9). The basin is bounded on the west side by the east-dipping Bare Mountain range-front fault. The eastern boundary of the basin is less well defined; it is, apparently, a large buried west-dipping structure named the Gravity fault by Winograd and Thordarson (1975) or buried structures beneath Yucca Mountain. The basin terminates northward in the outermost moat of the Timber Mountain caldera complex, and on the northeast side is bounded by the Yucca Wash right-slip fault. The southern boundary of Crater Flat basin is concealed under alluvium; Fridrich (in preparation) has interpreted this boundary as being demarcated by a minor gravity high that separates the deep gravity low of Crater Flat basin from lows corresponding to the other subbasins of the Central Amargosa graben (ADRZ of Wright, 1989; Fig. 3.8). The eastern boundary of the Crater Flat basin is less well defined and has migrated to the west-southwest through time (Fridrich, in preparation; Brocher et al., 1996; in press). The present eastern boundary of the Crater Flat basin and its implications on PVHA for the Yucca Mountain site is discussed in Chapter 6 of this report. 

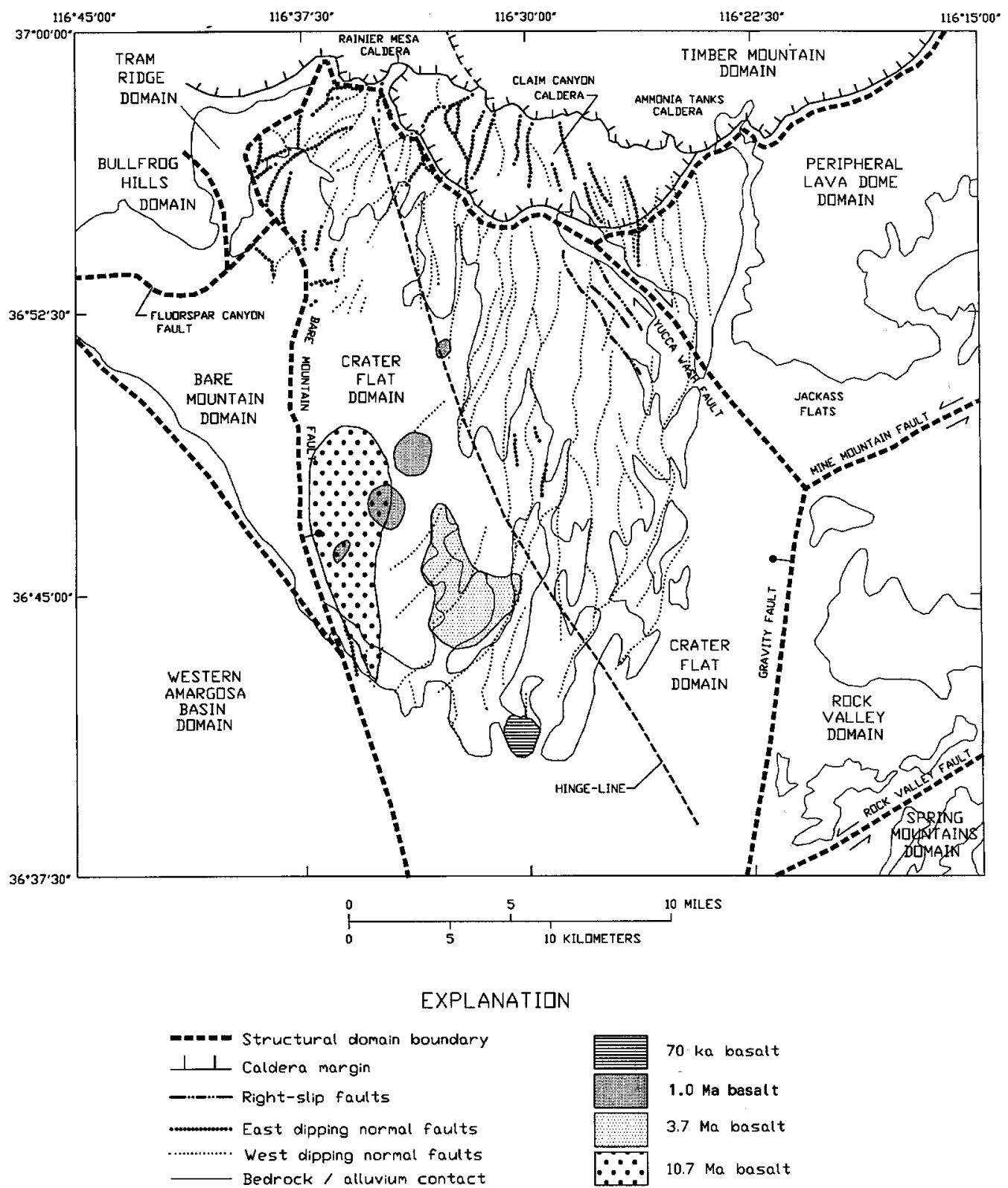

Figure 3.9. Major structural features of the Crater Flat basin from the Fridrich (in preparation) tectonic model. Shaded areas show the surface distribution of basaltic volcanism in the Crater Flat basin, and the major tectonic features of the basin and surrounding area are labeled on the figure.

All of the previously proposed models for the tectonics of the Crater Flat basin have been developed from attempts to explain the structural features of this area in terms of an invoked single master structure, such as a buried caldera or a concealed detachment fault or strike-slip fault. In contrast, the sphenochasm model proposes that this basin is a hybrid feature that can be explained from surface geologic and geophysical evidence. Structurally, the Crater Flat basin reflects three major influences: (1) east-west- to northwest-southeast directed extension, (2) northwest-directed dextral deformation, and (3) doming around the caldera complex, which also acted as a pivot point for oblique extension. This mixture of influences is consistent with the setting of this basin on the flank of a large caldera complex 
that was active during its formation, and within the Walker Lane belt near the boundary between this province, which is characterized by strike-slip deformation and extension, and the northern Basin-andRange province, which is characterized by more purely extensional deformation.

The sphenochasm model stresses the progressive structural evolution of the Crater Flat basin from its formation in a large extensional pulse between 12.7 and 11.7 Ma. Deformation in this peak phase followed a simple sphenochasm-like pattern of oblique extensional opening of the basin. In contrast, deformation from 11.7 to $10.5 \mathrm{Ma}$ involved a larger ratio of strike-slip deformation to extension, and was concentrated in the southwestern part of the basin. It is this second phase of deformation that is most responsible for creating the physiographic distinction between Crater Flat and Yucca Mountain within the structural basin. Since 11.7 Ma, extension in Crater Flat basin has declined in a roughly exponential pattern to the present, and deformation has become progressively more concentrated in the southern part of the basin (Fridrich, in preparation).

The most important implication of the sphenochasm model with respect to volcanic patterns is the relationship between the structural features of the basin and the locations of basaltic vents. Basaltic volcanism began in the basin during the 11.7 to 10.5 Ma period when the rate of strike-slip deformation was at its peak. In all four episodes of volcanism, vents have been strongly concentrated in the southern part of the basin where transtensional deformation has been greatest at the time of volcanism. The only basaltic vent area outside of the southwestern part of the basin is a small cluster of 10.5 Ma dikes (Carr, 1984) located on northern Yucca Mountain. Most dikes in this zone are located within the zone of minor northwest-trending right-slip faults near Yucca Wash, which is the northeastern domain boundary of the basin. Basaltic volcanism in Crater Flat may, thus, have been preferentially localized along transtensional features in this basin throughout its history.

\section{Walker Lane Models}

A fourth set of tectonic/volcanic models relates the distribution of sites of Pliocene and Quaternary basaltic centers to control by largely concealed structural features of the Walker Lane structural system (see previous section). Carr (1984, p. 30) summarized the occurrence of largely northeast-trending structures in the southern part of the Walker Lane structural system and argued that many of these features are associated with important volcanic centers. He suggested that the Spotted Range-Mine Mountain zone is one of the more important structures of these systems because it is presently active, and structural features of the zone may affect the southern part of Yucca Mountain. Crowe and Perry (1989) defined the Crater Flat volcanic zone (CFVZ), an elongate north-northwest trending zone that includes the distribution of all Pliocene and Quaternary volcanic centers of the YMR except the basalt of Buckboard Mesa. Crowe (1990) argued that the northwest-orientation of the zone may be consistent with structural control by tectonic features of the Walker Lane structural zone. Crowe et al. (1995) further described the CFVZ and added the Pliocene basalt of Thirsty Mesa to the zone as well as several additional aeromagnetic anomalies of the Amargosa Valley (Langenheim, 1995). They noted that the latitude and longitude coordinates of the Pliocene and Quaternary basalt centers of the CFVZ produce a highly correlated linear regression fit, including multiple regression models where magma volume is added as a third variable.

There are a variety of permissive explanations of the CFVZ, which is a direct result of the observation that the zone does not follow a continuous surface structure. The feature may follow and reflect a preferential pathway for the ascent of basalt magma (Crowe et al., 1995, Chapter 5). This model assumes that the mantle beneath most of the Basin and Range province is of low 
density and may contain a small component of partial melt and is, therefore, capable of generating basaltic magmas (for example Humphreys and Dueker, 1994b; Crowe et al., 1995; Chapters 4 and 5). Ascent of basalt magma in the crust and surface eruption in a waning tectonic setting such as the YMR may be facilitated by magma intersecting preferential pathways; for example, structural features of the Walker Lane system. Thus, zones of the Walker Lane structural system, in this model, represent permissive regions of fractured rock along which magma has an increased probability of ascending to the surface. The existence of fractured rock with orientations parallel to the Walker Lane structural system have been noted from analyses of magnetotelluric data for the southern Great Basin (Klein, 1995). The widely scattered distribution of the postcaldera basalt in the YMR suggests the Walker Lane does not form a discrete structure but rather a range of widely distributed features that have been partly to completely overprinted by Miocene volcanism and plutonism.

The most important implication of the Walker Lane structural model is that northwesttrending structures of the zone are preferential pathways for ascending basalt magma. The features are not genetically related to basaltic magmatism but instead are inferred to be more deeply penetrating crustal structures that permit the ascent of basaltic magma to the upper crust. Thus the occurrences of sites of Pliocene and Quaternary basaltic volcanism are distributed randomly wherever ascending basalt magma followed the structures. The northwest alignment of basalt centers in the CFVZ (Crowe et al., 1995, Chapter 3) may reflect the overall importance and geographical controls of the Walker Lane structural system.

There are several possible inconsistencies with the Walker Lane structural model. First, the alignment of basalt centers in Crater Flat does not coincide directly with surface faults or subsurface locations of faults from gravity and seismic reflection data. Second, the Walker Lane structures do not appear to form a continuous zone or structural feature in the YMR. Third, the Sleeping Butte and Thirsty Mesa basalt centers are separated from the basalt centers of Crater Flat by a distance of $>20 \mathrm{~km}$. They may represent a separate volcanic field that is unrelated to the Crater Flat basalt sites. Fourth, the north end of Yucca Mountain is cross-cut by linear northwesttrending washes that may be controlled by northwest-trending right-slip faults of the Walker Lane structural system (Scott et al., 1984; Fridrich, in preparation; see Fig. 3.9 of this report). These faults potentially could represent preferred pathways for the ascent of basalt magma, yet they have not been sites of active volcanism since formation of the $10.5 \mathrm{Ma}$ basalt of Solitario Canyon. No known Pliocene or Quaternary basaltic centers are associated with these faults. One possible explanation for the absence of basaltic volcanism along these structures is the proximity of the faults to the southern caldera margin of the Timber Mountain complex. The faults are probably intruded at depth by extensive plutonic rocks associated with the caldera-forming eruptions so that the faults are no longer preferred pathways for basaltic magmatism.

\section{E. Summary}

This section has summarized multiple alternative tectonic and structural models for the setting of the YMR and the inferred relationships of sites of post-Miocene basaltic volcanism with respect to each model. A number of alternative structural and tectonic models of the YMR have been

proposed by a range of highly credible scientists. This section does not include every model that has been proposed but it does attempt to consolidate proposed models into a consistent framework (see Geomatrix, 1996 for other tectonic models). Not surprisingly, given the limited record of basaltic volcanism, there is not a consensus concerning the tectonic setting of sites of basaltic volcanism or conceptual models used to explain the basaltic centers. However, some 
generalizations are possible. Two of the models, detachment faulting and caldera models, appear difficult to support given the recent results of seismic reflection studies of the Crater Flat basin and the Yucca Mountain highland (Brocher et al., 1996). Moreover the models, even if correct, are difficult to relate to and may not be important in affecting the patterns of Pliocene and Quaternary volcanism in the YMR. The caldera model is potentially important because its leads to the inference, supported by gravity data (Snyder and Carr, 1984) that the eastern edge of the structure is beneath the Yucca Mountain site, which is an interpretation shared by other rift models (for example, Fridrich, in preparation). The remaining models share a commonality of features: they all, either partly or completely, infer that the Crater Flat basin developed as an extensional rift or pullapart; different models assign different degrees of importance to strike-slip versus extension faulting. The models also differ in scale. Some are regional tectonic models whereas others are specific to the Crater Flat basin and the local setting of the Yucca Mountain site. Third, an area of agreement of most structural and tectonic models is that the shallow stress field played an important role in the small-scale location and direction of alignment of Pliocene and Quaternary volcanic features. Stress measurements in drill holes are consistent with a least horizontal stress direction of $\mathrm{N} 60^{\circ} \mathrm{W}$ (Stock and Healy, 1988); many of the cone alignments and the alignment of fissure systems within basalt centers are perpendicular to this direction consistent with the local stress field playing an important role in the location of basalt centers.

Perhaps the most compelling observation concerning the tectonic setting of Pliocene and Quaternary basaltic volcanism in the YMR is that there are no consistent generalizations that can be made to explain the setting of all basalt sites. Basalt magma probably ascends on pathways that follow the path of least resistance (favorably oriented fractured rock), and the selection of one pathway versus another pathway may, like many complex systems, be largely a random and unpredictable process.

\section{Tectonic Setting: Time-Space Patterns of the Distribution of Basaltic Volcanism}

This section examines the distribution of basaltic volcanic rocks in the region by defined basaltic episodes (Crowe, 1990; see also Crowe et al., 1995; Chapter 2) and emphasizes conclusions that can be derived primarily from the temporal and spatial patterns of Miocene and younger basaltic volcanism in the YMR.

\section{A. Silicic Episode}

The basalt of the silicic episode (BSE) was studied in the early 1980s, and most of the interpretations of the rock units are from summary information presented in Crowe et al. (1983a, 1986). The distribution and stratigraphic relations of surface outcrops of the BSE are well established from geologic quadrangle maps produced by the U.S. Geological Survey in the 1960s and early 1970s (Eckel, 1968; see also Crowe et al., 1995; Chapter 2). More recent studies of the BSE have not been conducted for the YMP because the rock units have only limited application to PVHA (Crowe et al., 1995; Geomatrix, 1996). The PVHA studies that incorporate the Miocene BSE yield estimates of magmatic disruption of a repository that approach background estimates and are nearly an order of magnitude smaller than mean estimates of magmatic disruption of the Yucca Mountain site (Geomatrix, 1996; Chapter 6 of this report). The most complete information on the distribution, age, and composition of basalt sites of the BSE are for those units that are present inside the boundaries of the Nevada Test Site (NTS) (Crowe et al., 1995; Chapter 2). Basaltic volcanic rocks outside the NTS, such as scattered outcrops near and west of Beatty and 
flanking the Black Mountain caldera complex, have less complete information. It is possible that all sites of Miocene volcanism, particularly subsurface sites of volcanism, have not been identified in areas of limited geological information.

Two major distribution patterns are exhibited by the BSE: (1) spatial associations with caldera complexes, and (2) distribution parallel to the Walker Lane structural zone (Fig. 3.10). Many of the basalt units of the BSE occur in or on the flanks of the Timber Mountain caldera complex. The basalt of Dome Mountain was erupted in the moat zone of the Timber Mountain caldera and basaltic volcanic rocks crop out along the western caldera, segments of the Timber Mountain caldera complex (Fig. 3.10; see also Crowe et al., 1995; Chapter 2). Basaltic volcanic rocks are present on both the north and south flanks of the Black Mountain caldera. These rocks underlie and overlie the Thirsty Canyon Tuff. An extensive sequence of basaltic volcanic rocks is present in the subsurface along the western, southern, and southeastern margins of Crater Flat (Kane and Bracken, 1983; Crowe et al., 1986). These basaltic rocks were penetrated in VH-2 (Carr and Parrish, 1985). The basalt lavas may have erupted along the ring-fracture zone of the proposed Crater Flat-Prospector Pass caldera (Carr, 1990). Alternatively, a more likely interpretation, given the results of seismic reflection exploration of Crater Flat, is that these basaltic rocks formed at the western edge of a strike-slip bounded, pull-apart basin. North/southtrending basalt dikes dated at 10.5 Ma (Scott, 1990; Carr, 1990) are exposed along the Solitario Canyon fault at the northwest edge of the Yucca Mountain site (Fig 3.10). The dikes are inferred by Carr (1984) to follow the eastern edge of the Crater Flat-Prospector Pass caldera. Alternatively, as noted by Scott (1990), the dikes may follow basin-range faults. A large positively polarized aeromagnetic anomaly in the center of Crater Flat (Kane and Bracken, 1983) remains unexplained despite exploratory drilling (Carr, 1982) and extensive geophysical studies (see following sections). One possible interpretation raised from interpretations of seismic reflection profiling across Crater Flat (Brocher et al., 1996) is that the anomaly is produced by basaltic intrusions (sills), which may be identified by strong reflections at depths of about $4000 \mathrm{~m}$ near the Tertiary-Paleozoic contact directly below exploratory drill hole VH-1 in central Crater Flat (see Brocher et al., 1996; their Fig. 16). If this interpretation is correct, the relatively large volume of basaltic volcanic rocks required to form the mass represented by seismic reflectors would be more consistent with the rocks being of Miocene age. The volume of known Miocene basaltic volcanic rocks in Crater Flat is $>2 \mathrm{~km}^{3}$ whereas the volume of surface Pliocene and Quaternary basaltic volcanic rocks is $<1 \mathrm{~km}^{3}$.

The basaltic volcanic rocks of Little Skull and Skull Mountains (10 Ma) (Crowe et al., 1983a) exhibit no obvious relationships to caldera complexes. They occur on the southern and southwestern flanks of the $15 \mathrm{Ma}$ Wamonie-Salyer volcanic center. However, the age difference between the volcanic groups (10 Ma versus $14 \mathrm{Ma}$ ) suggests that they are unrelated. Scattered volcanic rocks thought to correlate with the BSE have been reported in drill holes in the Amargosa Valley (Brocher et al., 1993; Langenheim, 1995; Oliver et al., 1995). The relatively subdued aeromagnetic signature of the Amargosa Valley suggests these basaltic rocks are small in volume. 


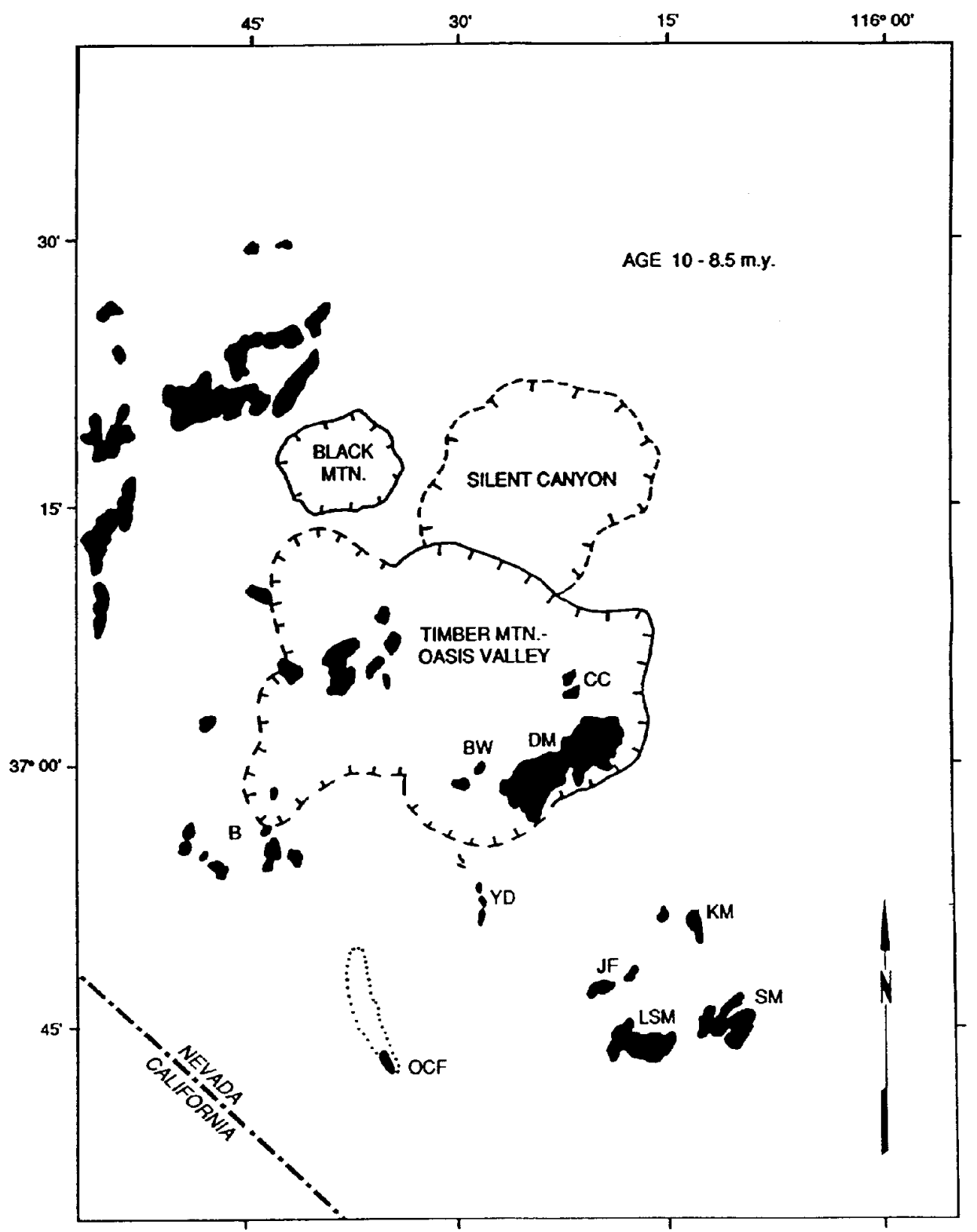

Figure 3.10. Distribution of the BSE. CC: basalt of Cat Canyon, DM: basalt of Dome Mountain, BW: basalt of Beatty Wash, B: basalt of the Beatty area, SM: basaltic andesite of Skull Mountain, LSM: Little Skull Mountain, KM: mafic rocks of Kiwi Mesa, JF: basalt of Jackass Flat, YD: dike of Yucca Mountain, OCF: older basalt of Crater Flat, scattered subsurface occurrences of basaltic volcanic rocks in the Amargosa are not shown (modified from Crowe, 1990).

The BSE is inferred to represent the final phase of a major pulse of silicic volcanism associated with the Timber Mountain caldera complex. The close association in space and time between silicic and basaltic magmatism strongly suggests that the magmatic events are related. Incursion of basaltic magma into the interior parts of the Timber Mountain caldera complex suggests that the underlying silicic magma was sufficiently solidified to allow propagation of basalt magma through the chamber. A waning phase of basaltic volcanism has been recognized as the 
terminal stage of volcanism at many silicic centers in the southwest United States (for example, Bailey et al., 1976; Crowe et al., 1979).

\section{B. Postcaldera Basalt}

The distribution of the Postcaldera basalt (PCB) is more restricted spatially compared to the distribution of the BSE. The PCB occurs at spatially scattered localities including the CFVZ and a diffuse northwest-trending zone east of Frenchman and Yucca Flats; most of the basalt centers are unrelated to the Miocene caldera complexes (Fig. 3.11). Basalt units of the PCB are markedly smaller in volume than the BSE. The volume decrease and lack of temporal or spatial association with the caldera complexes are consistent with the PCB representing a phase of basaltic volcanic activity that is unrelated to Miocene volcanism of the SNVF (Crowe, 1990). The PCB are divided into two cycles: Older Postcaldera basalt (OPB) and Younger Postcaldera basalt (YPB; Crowe, 1990). Volcanic rocks of the OPB occur northwest (basalt of Rocket Wash), north (basalt of Pahute Mesa) and northeast (all other centers of the OPB; see Fig. 3.11) of anomalies of Crater Flat). The basalts of Sleeping Butte and Thirsty Mesa are northwest of Yucca Mountain and the basalt of Buckboard Mesa is north-northeast of Yucca Mountain (Fig. 3.11).

Boundaries between the two basalt cycles of the PCB (Fig. 3.11) can be drawn differently using alternative approaches. The most direct and simple approach is to draw a boundary by visual inspection to delineate the distribution areas of the two cycles. This boundary (Fig. 3.11) is a curving line that trends approximately west/northwest and separates geographically the PBC. A second approach assumes structural features associated with the Walker Lane structural system have controlled the distribution of the basaltic volcanic centers. Based on this assumption, northwest-trending boundaries between the basalt cycles can be drawn (Fig. 3.12) that separate the basalt units into two northwest-trending zones that overlap in the area of the Timber Mountain caldera (Fig. 3.12). These spatially separate zones are consistent with a southwest migration or more correctly, a southwestward stepping, through time of the areas of basaltic activity (late Miocene to Quaternary; Crowe and Perry, 1989; Crowe, 1990). Note that the northwest-trending boundaries are not drawn solely from the distribution of basaltic volcanic rocks. Instead the orientation of the lines is defined from inferred northwest-trending structural features of the Walker Lane structural zone and the distribution of Cenozoic volcanic rocks in the SNVF (Carr, 1984; Crowe, 1990). The location of the lines is, however, partly constrained from the distribution of the volcanic centers of the PCB.

A third approach is to assume the basaltic volcanic rocks correspond to spatial clusters regardless of the age of the volcanic units, an approach used by Connor and Hill (1995). They divided basalt centers of the YPB into the Buckboard Mesa, Sleeping Butte, Crater Flat and the Amargosa Valley clusters (see Connor and Hill, 1995; their Fig. 2).

Another approach, which is independent of underlying assumptions, is to use statistical tests to examine different models of the time-space distribution of basaltic volcanic centers of the PCB. If there are no temporal or spatial differences in the cycles, the statistical descriptors of the PCB should be nondiscriminatory. If there has been time or spatial migration, the distributions should be distinctive. 


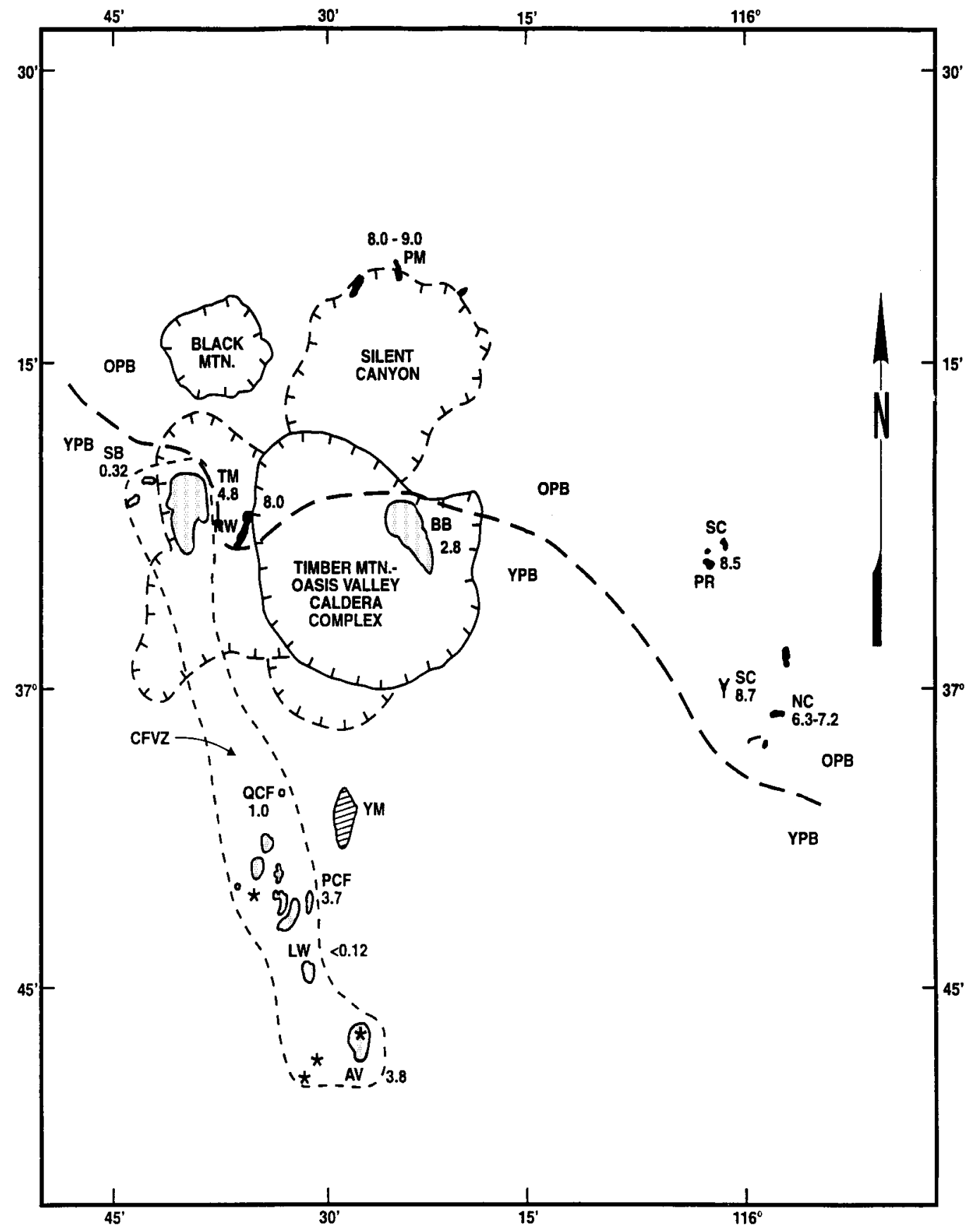

Figure 3.11. Geographic subdivisions of the PCB episode of the YMR. Black areas are the volcanic units of the OPB and YPB including: RW: basalt of Rocket Wash, PM: basalt of Pahute Mesa, PR: basalt of Paiute Ridge, SC: basalt of Scarp Canyon, NC: basalt of Nye Canyon, TM: basalt of Thirsty Mesa, AV: basalt of Amargosa Valley, PCF: Pliocene basalt of southeast Crater Flat, BB: basalt of Buckboard Mesa, QCF: Quaternary basalt of Crater Flat, SB: basalt of Sleeping Butte, LW: basalt of Lathrop Wells. Asterisks mark aeromagnetic anomalies identified as potential buried basalt centers or intrusions (Kane and Bracken, 1983; Crowe et al., 1986). Dashed line encloses the area of the CFVZ. Numbers associated with the symbols for the OPB and YPB are the ages of the volcanic centers in Ma. The thick dashed line is a line drawn visually that separates the OPB and the YPB. 


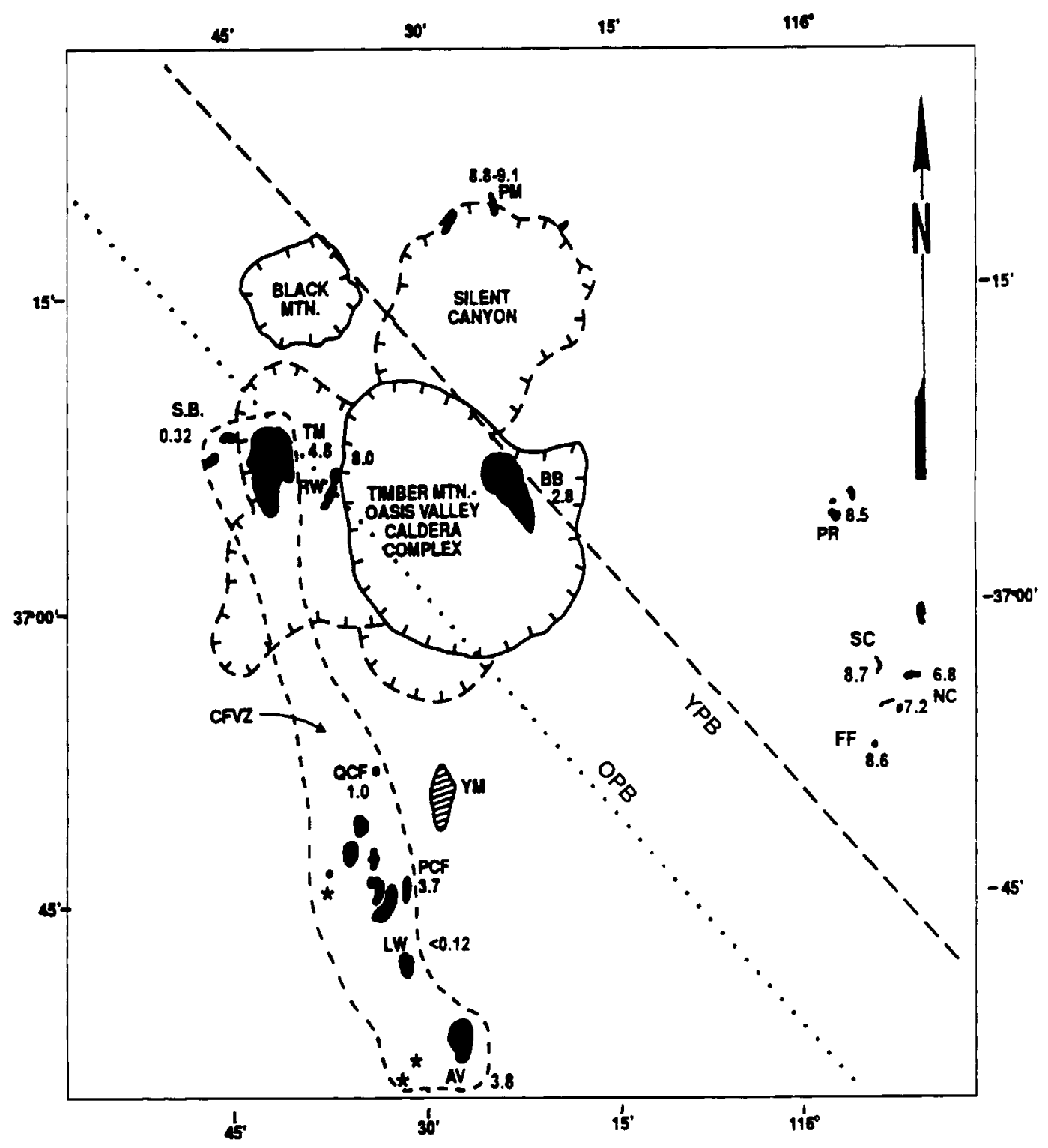

Figure 3.12. Alternative map of the distribution of the PCB in the YMR. Symbols and numbers are the same as in Figure 3.11. The northwest-trending lines subdivide the OPB and the YBP into southwest and northeast fields with the boundaries following the orientation of structural features of the Walker Lane structural system. Modified from Crowe and Perry (1989).

Figure 3.13 is a histogram of the ages of the volcanic events of the PCB using chronology data from Crowe et al. (1995; Chapter 2). The number of assigned ages for each unit is equated to the number of volcanic events for each cycle, where an event is a discrete volcanic center. This approach uniformly weights all volcanic centers and is more representative than examining a histogram of the distribution of individual K-Ar age determinations, which is partly controlled by completeness of the K-Ar data set. The histogram shows the distribution of estimated ages for the PCB is bimodal with peaks in event ages at about 8-9 and 3-4 Ma. A two-sample t-test rejects the null hypothesis that the means are similar for the basalt cycles with a $p$-value of $<0.0005$. Thus, the basalt episodes can be separated statistically solely on the basis of their ages. 


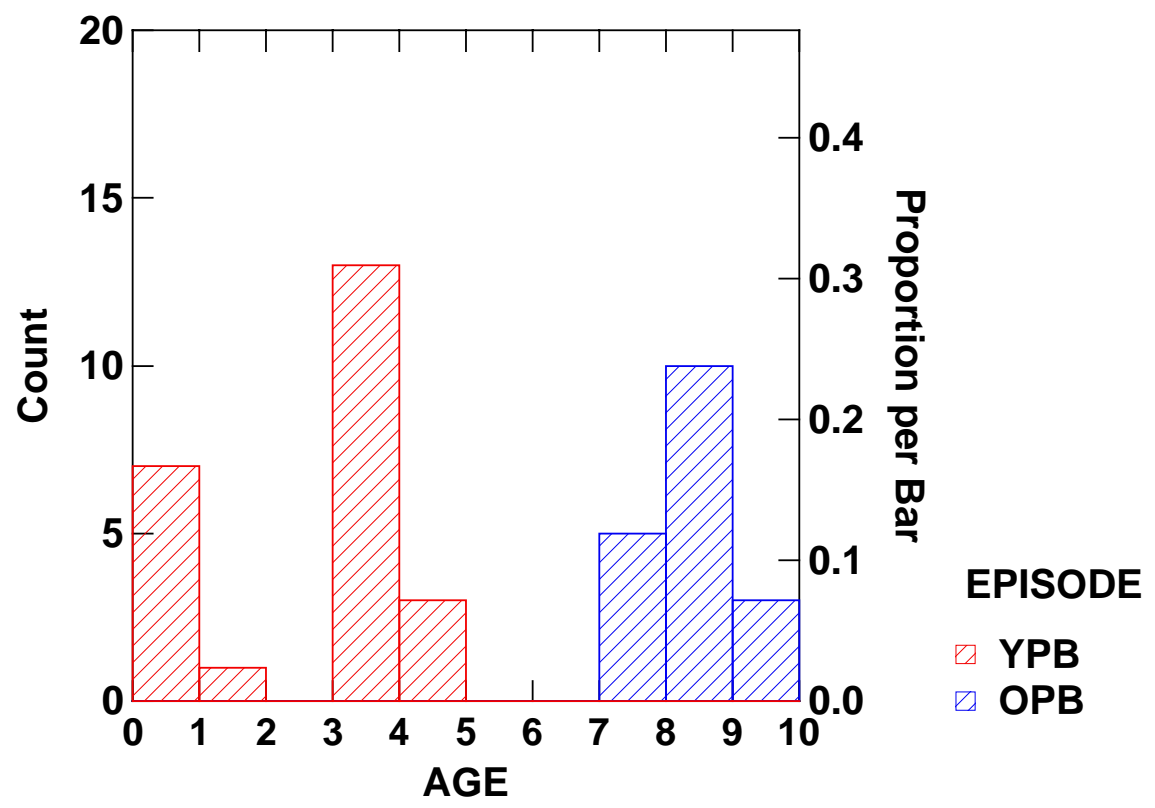

Figure 3.13. Histogram of ages for the PCB of the YMR. The number of ages assigned to the PCB is equated to the number of volcanic centers, not individual K-Ar age determinations. The histogram shows a bimodal distribution with peaks at 3-4 and 8-9 Ma. A two-sample t-test rejects the null hypothesis that the means are similar for the basalt cycles with a $p$-value of $<0.0005$.

Figure 3.14 is a plot of the locations (Mercator-projected) by latitude and longitude of the volcanic centers of the PCB, separated by basalt cycles. The centroid of each distribution is calculated at the $95 \%$ confidence limit using a Gaussian ellipsoid approximation for the distributions. The plot confirms observations from Figs. 3.11 and 3.12 that the distribution centroids of the OPB and the YPB are spatially distinct. A west/northwest-trending ellipse, calculated for the centroid of the OPB is located near the northeast edge of the Timber Mountain caldera and the northwest edge of Yucca Flat (Fig. 3.14). A spatially separate centroid at the 95\% confidence limit is obtained for the basalt units of the YPB (Figure 3.14) and is centered in Crater Flat. The location of the centroids of the basalt distributions is based on the variance in the $X$ and Y coordinates of the vents, assuming a Gaussian spatial distribution. This distribution assumption may not be correct but the uncertainty introduced by the assumption is small and would not lead to rejection of the conclusion that the volcanic centers for the basalt cycles of the PCB have distinctively different ages and spatial distributions.

An assessment of the spatial-temporal patterns of basaltic volcanism of the PCB was also completed by Golder Associates (1995) through a study funded by the YMP volcanism task and using the data shown on Table 3.1 for the location, age and volume of basalt centers of the PCB (data from Crowe et al., 1995 updated by additional information on the location of aeromagnetic anomalies in the Amargosa Valley (see Langenheim, 1995; Geomatrix, 1996). Golder Associates (1995) noted that a weakness of a Poissonian model (for example Crowe et al., 1982), a nonhomogeneous temporal model (for example Ho, 1992) or a nonhomogeneous cluster model (for example Connor and Hill, 1995) for spatial analyses is that these models do not account for the sequence of volcanic events. Accordingly, they evaluated whether it is possible to apply other types of models for testing the spatial and temporal patterns of volcanic events in the YMR. Golder Associates (1995) argued that the PCB data set is best examined using a Lévy flight analysis; they used this approach for the data in Table 3.1. While these interpretations are limited somewhat by 
the sparse and uncertain data, two separate volcanic processes operating at two difference scales in the YMR could be identified (Golder Associates, 1995).

The first step in application of the Lévy flight model to the data set of past volcanic events was a consideration of spatial flights or the distances between successive volcanic events. Different approaches to the data set were used including lumping of all events of the PCB, as well as splitting of the events into the OPB and YPB. No significant differences between data sets were noted for the different basalt episodes (Golder Associates, 1995), an important point that seems to contradict evidence of differences between the OPB and YBP based on temporal and spatial constraints. However, the Lévy flight analysis demonstrates that the scaling and operation of the spatial processes for the two basalt episodes are similar. This observation is not inconsistent with the two groups having different spatial and temporal distributions.

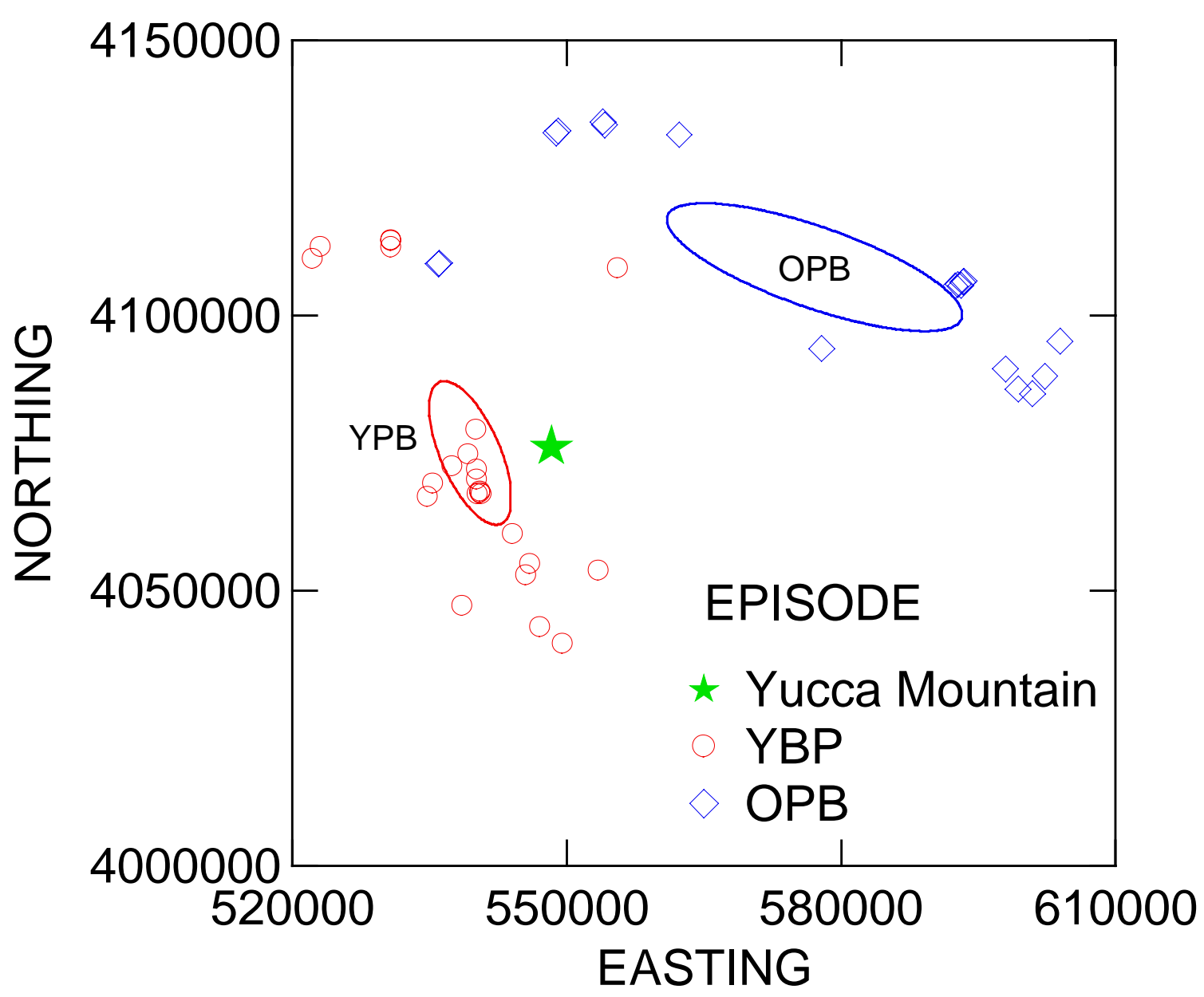

Figure 3.14. Location of the volcanic vents (Mercator-projected) and the distribution centroids by basalt episodes for the PCB. The centroids were drawn as the $95 \%$ confidence interval using the bivariate ellipse module of SYSTAT. The northeast centroid is for the OPB and the southwest centroid is for the YPB, which is centered in the Crater Flat basin. The diamonds mark the vents of the OPB; the cirlcles mark the vents of the YPB; the star symbol marks the approximated center of the Yucca Mountain site. 
Golder Associates (1995) noted that the data were somewhat difficult to model using different fitting functions (power-law, exponential, and normal distributions) and the Kolmogorov-Smirnov statistic as a measure of the significance of data fits. They attributed this problem to an inability to model the spatial patterns with a single process and were able to obtain an alternative and substantially better fit using a power-law model for events with flight lengths of less than $20 \mathrm{~km}$ and exponential or normal fits for the remaining data (see Golder Associates, 1995; Fig. 3-1). Based on this analysis, they suggested that smaller scale flight lengths follow a fractal process whereas longer flight-lengths are Brownian. The scale separation between the two processes is similar (15 to $25 \mathrm{~km}$ ) to the scale reported by Conner and Hill (1995) between self-contained clusters and area-wide linked clusters. Conceptually the smaller scale or short-flight process should correspond to volcanic clusters as defined by Crowe and Perry (1989) and also by Conner and Hill $(1993 ; 1995)$, although the latter workers used a statistical rather than a physical or process approach in defining their clusters. Crowe and Perry (1989) noted that basaltic volcanic centers of the PCB tend to form as clusters consisting of multiple small volume scoria cones and associated lava flows where the individual centers within clusters tend to be aligned spatially and are of similar age within the constraints of the geochronology data (Crowe and Perry, 1989; p. 327). They identified 6 clustered basalt centers in the PCB and 3 basalt centers that do not form clusters. Based on these concepts, the clustered centers of the PCB probably control or form the small-scale data set that follows a fractal process in the data analyses by Golder Associates (1995). The second or larger scale process corresponds to the formation of a new or discrete volcanic center where the center is not correlated in time or space with the preceding volcanic event (see Crowe et al., 1995, Chapter 7). The distinction between the process scales can best be illustrated by example. The basalt of Buckboard Mesa, an approximately 3.0 Ma basalt center, corresponds to a discrete volcanic center. That is, it is spatially, temporally and compositionally separate from the preceding basaltic volcanic event, the basalt of Thirsty Mesa, and the succeeding basaltic volcanic event, the 1.0 Ma Quaternary basalt of Crater Flat. The latter basaltic event is a discrete volcanic center but it is composed of 4 clustered centers. The individual centers of the 1.0 Ma Quaternary basalt of Crater Flat correspond to the smaller scale (small flight length) or clustered volcanic events whereas the jump from the basalt of Buckboard Mesa to the 1.0 Ma Quaternary basalt of Crater Flat corresponds to the larger scale, Brownian process.

There are insufficient data to identify the crossover point between the two scale processes; it could be somewhere between 10 or $15 \mathrm{~km}$ or as great as $25 \mathrm{~km}$ (Golder Associates, 1995). However, the scale change can probably be identified through examination of the geologic record of clustered events. Cluster lengths of the 6 clustered centers of the PCB identified by Crowe and Perry (1989) range from $2.6 \mathrm{~km}$ (basalt of Sleeping Butte) to $12.6 \mathrm{~km}$ (1.0 Ma Quaternary basalt). The longest cluster length provides a reasonable estimate of the maximum cluster length and is an indicator of the approximate scale of the crossover length between fractal and Brownian spatial processes. This length is consistent with the analyses by both Golder Associates (1995) and Connor and Hill (1995). Confirmation of this inference is provided by an alternative Lévy flight analysis by Golder Associates (1995). They plotted the data set for the PCB by "lumping" closely spaced events, which is analogous to removing the clustered events and analyzing the distribution of the spatial patterns of new or discrete volcanic events. The "lumped" data set gives an acceptable fit to a normal distribution and they suggest the data are well described by a Brownianwalk model. 
Table 3.1. Location, Age, Elevation and Volume of Basaltic Volcanic Centers of the PCB (data from Crowe et al., 1995)

\begin{tabular}{|c|c|c|c|c|c|c|c|}
\hline VOLCANIC EVENTS & $\begin{array}{l}\text { North } \\
\text { Latitude }\end{array}$ & $\begin{array}{c}\text { West } \\
\text { Longitude }\end{array}$ & $\begin{array}{c}\text { UTM } \\
\text { Easting }\end{array}$ & $\begin{array}{c}\text { UTM } \\
\text { Northing }\end{array}$ & $\begin{array}{l}\text { Elevation } \\
\text { (ft) }\end{array}$ & $\begin{array}{l}\text { Age } \\
(\mathrm{Ma})\end{array}$ & $\begin{array}{c}\text { Volume } \\
\left(\mathrm{km}^{3}\right)\end{array}$ \\
\hline \multicolumn{8}{|c|}{ Younger Postcaldera basalt } \\
\hline Thirsty Mesa -1 & 37.2 & 116.7 & 530792 & 4113698 & NA & 4.7 & $\overline{3}$ \\
\hline Thirsty Mesa -2 & 37.2 & 116.7 & 530792 & 4113513 & NA & 4.7 & \\
\hline Thirsty Mesa -3 & 37.2 & 116.7 & 530781 & 4112402 & NA & 4.7 & \\
\hline Amargosa Valley & 36.6 & 116.4 & 553449 & 4053595 & NA & 3.9 & 0.3 \\
\hline Amargosa Valley & 36.5 & 116.4 & 549546 & 4040382 & NA & * & 0.1 \\
\hline Amargosa Valley & 36.5 & 116.5 & 547094 & 4043353 & NA & * & 0.1 \\
\hline Amargosa Valley & 36.6 & 116.6 & 538546 & 4047304 & NA & * & 0.1 \\
\hline Amargosa Valley & 36.6 & 116.5 & 545550 & 4052751 & NA & * & 0.1 \\
\hline Amargosa Valley & 36.6 & 116.5 & 546012 & 4054851 & NA & * & 0.1 \\
\hline Crater Flat 3.7 basalts -1 & 36.8 & 116.6 & 540156 & 4070137 & NA & 3.8 & \\
\hline Crater Flat 3.7 basalts -2 & 36.8 & 116.6 & 540148 & 4072023 & NA & 3.8 & \\
\hline Crater Flat 3.7 basalts -3 & 36.8 & 116.5 & 540523 & 4068032 & NA & 3.8 & \\
\hline Crater Flat 3.7 basalts -4 & 36.8 & 116.5 & 540524 & 4067810 & NA & 3.8 & \\
\hline Crater Flat 3.7 basalts --5 & 36.8 & 116.5 & 540258 & 4067587 & NA & 3.8 & \\
\hline Crater Flat 3.7 basalts -- 6 & 36.8 & 116.5 & 540704 & 4067589 & NA & 3.8 & \\
\hline Crater Flat Anomaly & 36.8 & 116.6 & 534815 & 4067008 & NA & ** & 0.1 \\
\hline Buckboard Mesa & 37.1 & 116.4 & 555610 & 4108608 & 5400 & 3.0 & 0.92 \\
\hline Makani Cone & 36.9 & 116.6 & 540114 & 4079234 & 3771 & 1.1 & 0.006 \\
\hline Black Cone & 36.8 & 116.6 & 539243 & 4074792 & 3687 & 1.0 & 0.105 \\
\hline Red Cone & 36.8 & 116.6 & 537469 & 4072566 & 3410 & 1.0 & 0.105 \\
\hline Little Cone & 36.8 & 116.6 & 535349 & 4069488 & 3041 & 0.8 & 0.002 \\
\hline Hidden Cone & 37.2 & 116.7 & 523086 & 4112450 & 5520 & 0.4 & 0.03 \\
\hline Little Black Peak Cone & 37.1 & 116.8 & 522204 & 4110229 & 4826 & 0.4 & 0.03 \\
\hline Lathrop Wells Cone & 36.7 & 116.5 & 544106 & 4060332 & 3233 & 0.1 & 0.14 \\
\hline \multicolumn{8}{|l|}{ Older Postcaldera Basalt } \\
\hline $\begin{array}{l}\text { Rocket Wash --1 } \\
\text { Rocket Wash --2 }\end{array}$ & $\begin{array}{l}37.1 \\
37.1\end{array}$ & $\begin{array}{l}116.6 \\
116.6\end{array}$ & $\begin{array}{l}535969 \\
536085\end{array}$ & $\begin{array}{l}4109333 \\
4109482\end{array}$ & $\begin{array}{l}\text { NA } \\
\text { NA }\end{array}$ & $\begin{array}{l}8.0 \\
8.0\end{array}$ & \\
\hline Paiute -1 & 37.1 & 116.0 & 592460 & 4105289 & NA & 8.6 & \\
\hline Paiute -2 & 37.1 & 116.0 & 593100 & 4105459 & NA & 8.6 & \\
\hline Paiute -3 & 37.1 & 116.0 & 592795 & 4105579 & NA & 8.6 & \\
\hline Paiute -4 & 37.1 & 116.0 & 593309 & 4106019 & NA & 8.6 & \\
\hline Paiute -5 & 37.1 & 115.9 & 593435 & 4106239 & NA & 8.6 & \\
\hline Pahute-1 & 37.4 & 116.4 & 553964 & 4135143 & NA & 9.1 & \\
\hline Pahute-2 & 37.4 & 116.4 & 554142 & 4134602 & NA & 9.1 & \\
\hline Pahute-3 & 37.3 & 116.3 & 562283 & 4132819 & NA & 9.1 & \\
\hline Pahute-4 & 37.3 & 116.4 & 549058 & 4133489 & NA & 8.8 & \\
\hline Pahute-5 & 37.3 & 116.4 & 548839 & 4133161 & NA & 8.9 & \\
\hline Nye $-1^{\star \star \star}$ & 37.0 & 115.8 & 603934 & 4095263 & NA & 7.3 & \\
\hline Nye-2 & 36.9 & 115.9 & 602272 & 4088948 & NA & 7.4 & \\
\hline Nye-3 & 36.9 & 115.9 & 599333 & 4086580 & NA & 7.3 & \\
\hline Scarp-1 & 37.0 & 115.9 & 600911 & 4085735 & NA & 8.6 & \\
\hline Scarp-2 & 37.0 & 115.9 & 597970 & 4090258 & NA & 8.6 & \\
\hline Yucca-1 & 37.0 & 116.1 & 577860 & 4093930 & NA & 8.1 & \\
\hline
\end{tabular}

Age and volume estimates are from Crowe et al., 1995

* undrilled aeromagnetic anomaly of Amargosa Valley; age estimated to be the same as drilled aeromagnetic anomaly (3.8 Ma)

** undrilled aeromagnetic anomaly of Crater Flat; no information available for estimating age

${ }^{* * *}$ table and data plots were completed before release of new K-Ar ages for the basalt of Nye Canyon 
A similar analysis was conducted for the timing of basaltic volcanic events using the same data groups as in the spatial analyses (Golder Associates, 1995). This analyses shows that the time between events is not related to the event age; short and medium intervals (up to $0.5 \mathrm{Ma}$ ) can be fit as a power law, but not the longer intervals, which are better fit with an exponential distribution. This also suggests that the shorter temporal subdivisions may correspond to clusters of cones (clustered events which have limited age differences) and the longer times between events are equivalent to the formation of a new or discrete volcanic center. Lumped events, using an approach similar to that used in the spatial analyses, are poorly fit by a power law but give an acceptable fit to an exponential distribution and indicate that a Poisson process provides a reasonable characterization of the temporal patterns of formation of discrete volcanic centers.

The analyses by Golder Associates (1995) strongly suggests that volcanic processes operate at two scales in the YMR including smaller scale processes (clustered events) characterized by a fractal geometry $(10-25 \mathrm{~km})$ and larger scale processes that exhibit random spatial and temporal patterns. They conclude that future volcanism at the Yucca Mountain site is unlikely to be part of a clustered event because there are no post-10 Ma events at the site. Instead, event probabilities should be estimated for Poisson and Brownian walk models with the hazard dominated by the spatial movements of volcanic centers. These movements are not stationary and show a nearconstant westward drift over the last 3 to $4 \mathrm{Ma}$. That movement is sufficiently slow to not be significant in the next 10,000 years but over longer periods (>105 yr.) could decrease the likelihood of volcanic events at Yucca Mountain (Golder Associates, 1995; p. 58). Additionally, they recognized a consistent oscillation perpendicular to the drift direction (north-northwest or south-southeast) and suggested modeling strategies that could be used to incorporate this oscillation.

Fig. 3.15 which is modified from Fig. 3-3 of the Golder report (Golder Associates, 1995), is a plot of the coordinates of the locations of volcanic centers of the PCB and illustrates the observations concerning event drift and oscillations. Each star represents a volcanic center of the PCB and the lines connecting the points are drawn in order of the sequence of events using geochronology data from Table 3.1. Volcanic events have jumped in predominantly NW and SE directions while oscillating across eastern and western parts of the YMR. The only reversals in those patterns are marked by jumps to and from the basalt of Paiute Ridge and Buckboard Mesa where jump directions are NE-SW. A southwest/west drift is superimposed on the oscillations (Golder Associates, 1995) and is consistent with southwestward stepping of volcanic events through time (Crowe and Perry, 1989).

\section{Older Postcaldera Basalt (OPB)}

Basalt centers of the OPB show close spatial and temporal associations with sites of extensional faulting. The vents for the basalt of Rocket Wash are located on a north/south-trending basin-range fault that follows the approximate location of the ring-fracture zone of the Timber Mountain caldera (Lipman et al., 1966; O'Connor et al., 1966). The three spatially separate eruptive centers of the basalt of Silent Canyon all occur on the Silent Canyon ring-fracture zone where it is intersected by northeast-trending basin-range faults (Orkild et al., 1969). Erosion has cut into these centers exposing feeder dikes. These dikes all trend northeast, paralleling the basinrange faults. These field relations are consistent with the shallow rise of magma along or subparallel to the basin and range faults (Orkild et al., 1969). 
The basalt of Paiute Ridge occurs as a complex of basalt dikes, sills, and discordant intrusions with local preservation of surface lava flows and scoria cones (Byers and Barnes, 1967; Crowe et al., 1983a; Valentine et al., 1992). Multiple sets of dikes locally fed intrusions that follow northwest-trending basin-range faults. At several localities, the dikes are offset by the northwesttrending faults. These relations require that the basaltic magmatism closely accompanied extensional faulting (Crowe et al., 1983a).

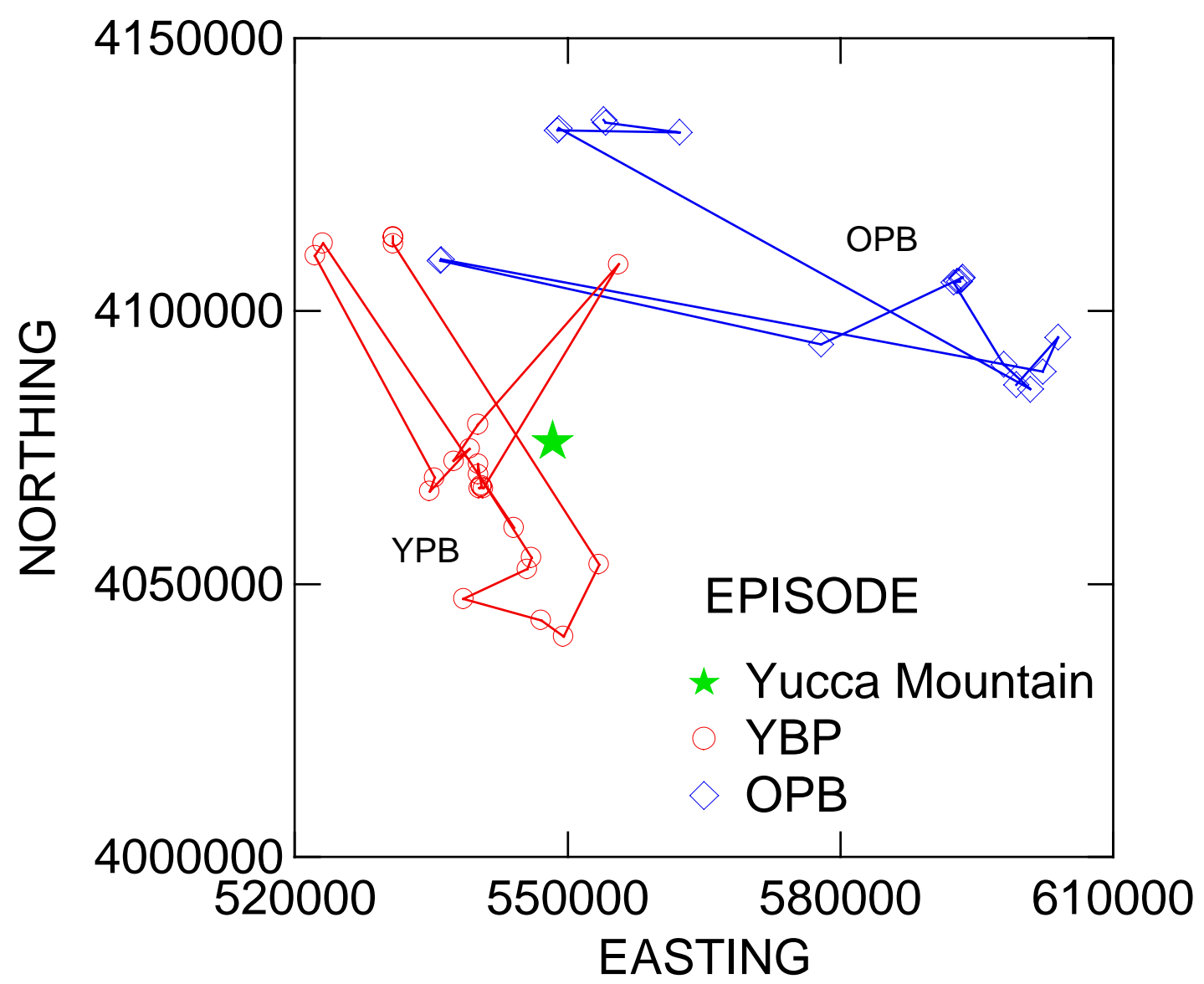

Figure 3.15. Plot of the location (Mercator-projected) of basaltic volcanic centers of the PCB in the YMR. The asterisks are the location of centers from Table 3.1. The lines connect successive locations of volcanic events and trace the sequence of volcanic events. The star symbol is the location of the center of the exploratory block of Yucca Mountain.

The basalt of Scarp Canyon consists of multiple sets of north/south-trending basalt dikes (3-4 $\mathrm{km}$ exposed lengths) that locally follow northwest-trending extensional faults (Henrichs and McKay, 1965). The dikes expand into probable conduit plugs near the intersection of northwestand north-trending faults.

The basalt of Nye Canyon, the youngest basalt cluster of the OPB, does not appear to follow existing bedrock structure. It comprises an aligned set of three northeast-trending basalt centers. These centers are parallel to the maximum compressive stress direction, which is the most likely direction of dike propagation in the modern stress field (Crowe et al., 1983a, Zoback, 1989). This 
represents the first occurrence of a change in the structural-parallel patterns of the basalt centers of the OPB, which is a change that has persisted for the YPB. Thus, the basalt of Nye Canyon is significant for two reasons. First, it is the oldest basalt cluster that exhibits a northeast trend of age-correlated, aligned basalt centers. Second, it is the only basalt unit of the OPB that crosscuts and appears to have formed independently of the prevailing shallow bedrock structure.

\section{Younger Postcaldera Basalt}

Crowe and Perry (1989) described the patterns of distribution of volcanic centers of the PCB. They noted several spatial trends. First, basalt centers of the OPB and the YPB tend to form in northwest-trending zones parallel to the trends of structures associated with the Walker Lane system. The northwest-trending alignment of centers is best expressed by the distribution of basalt centers for the YPB. All centers of this cycle, except the basalt of Buckboard Mesa, occur in a narrow northwest-trending zone that was named the CFVZ (Fig. 3.11). Second, the time-space distribution of the PCB is consistent with a southwest-directed stepping of sites of basaltic volcanic activity through time. Third, basaltic activity of the PCB tends to occur as clusters of volcanic centers where the centers form distinct aligned clusters and appear to be of similar ages. Finally, Crowe and Perry (1989) and Crowe et al., 1995 noted that there were no systematic time-space patterns to the distribution of volcanic events within the CFVZ.

\section{E. Development of Alternative Models of the Distribution of Basalt Centers in the YPB.}

There has been an increased effort in recent years to develop more quantitative methods for assessing patterns of alignment of volcanic vents or centers in volcanic fields (for example, Hasenaka and Carmichael, 1985; Lutz, 1986; Wadge and Cross, 1988). Connor (1990) and Connor et al. (1992) have summarized applications using a range of bivariate methods to assess patterns in the distribution of vents in volcanic fields with high vent densities. The advantages of these methods are twofold. First, they provide quantitative and testable methods for identifying spatial patterns. Second, the methods can often distinguish random alignments from those produced by underlying structural or mechanistic controls (Wadge and Cross, 1988; Connor et al., 1992). Connor (1990) used cluster analysis to search for natural groupings in the spatial distribution of over 1000 scoria cones in the TransMexican volcanic belt. He demonstrated that there is significant structure in cone distribution and used multiple methods for assessing vent alignments to reveal vent orientations within clusters.

A major difficulty with applying existing methods of evaluating distribution patterns of volcanic centers in the YMR is the limited number of centers. Additionally, and partly because of

the limited number of volcanic centers, there are both more abundant and a greater diversity of data available for each volcanic center in the YMR (the data include location, age, volume, composition of the centers). Thus, evaluation of spatial patterns of volcanic centers can be extended to multivariate space, where the limited data become, unfortunately, even more restrictive. We are faced with the situation where, as noted previously, multiple alternative models of the spatial patterns of volcanic events are possible, and it is difficult to prove or disprove alternative models. The approach used for volcanism studies is to develop as many alternative models as possible and to assess the impact of individual models on PVHA. We use the perspective, as stated in the introductory sections, that it is of greater value to the YMP to examine the impact of alternative models on PVHA than it is to assess the strengths and weaknesses of individual models. The geographic, structural, and spatial setting, emphasizing alternative interpretations of Pliocene and Quaternary basaltic volcanic centers in the YMR, are summarized in Table 3.2. 
Table 3.2. Alternative Structural/Spatial Models of the YPB of the YMR.

\begin{tabular}{|c|c|c|}
\hline $\begin{array}{l}\text { Volcanic } \\
\text { Center }\end{array}$ & Location & Alternative Structural/Spatial Models \\
\hline $\begin{array}{l}\text { Basalt of } \\
\text { Thirsty Mesa }\end{array}$ & $\begin{array}{l}\text { Lava mesa on the } \\
\text { south flank of Black } \\
\text { Mountain caldera } \\
\text { complex }\end{array}$ & $\begin{array}{l}\text { Trace of concealed strike-slip fault (Schweickert, 1989); CVFZ } \\
\text { (Crowe and Perry, 1989; Sleeping Butte cluster (Connor and } \\
\text { Hill, 1995) }\end{array}$ \\
\hline $\begin{array}{l}\text { Basalt of } \\
\text { Amargosa } \\
\text { Valley }\end{array}$ & $\begin{array}{l}\text { Buried basalt } \\
\text { centers in center of } \\
\text { the Amargosa } \\
\text { Valley }\end{array}$ & $\begin{array}{l}\text { DV-PR (Carr, 1984); bounding faults of the of the ADRZ of } \\
\text { Wright (1989); closely spaced normal faults of the Kawich- } \\
\text { Greenwater Rift of Carr (1990); CFVZ (Crowe and Perry, } \\
\text { 1989); Amargosa Valley cluster (Connor and Hill (1995); } \\
\text { Amargosa Valley segment of the Crater Flat half graben } \\
\text { (Fridrich, in preparation) }\end{array}$ \\
\hline $\begin{array}{l}3.7 \text { Ma Basalt } \\
\text { of Southeast } \\
\text { Crater Flat }\end{array}$ & $\begin{array}{l}\text { Eastern half of the } \\
\text { Crater Flat basin }\end{array}$ & $\begin{array}{l}\text { DV-PR (Carr, 1984); ADRZ of Wright (1989); trace of } \\
\text { concealed strike-slip fault (Schweickert, 1989); CFVZ (Crowe } \\
\text { and Perry, 1989); basin projection of bedrock faults of Yucca } \\
\text { Mountain (Smith et al., 1990); moat basalt of caldera model of } \\
\text { Carr (1990); extensional axis of Crater Flat basin (Fridrich, in } \\
\text { preparation); adjacent to major buried basin-edge fault } \\
\text { (Brocher et al., 1996) }\end{array}$ \\
\hline $\begin{array}{l}\text { Basalt of } \\
\text { Buckboard } \\
\text { Mesa }\end{array}$ & $\begin{array}{l}\text { Moat zone of the } \\
\text { Timber Mountain } \\
\text { caldera }\end{array}$ & $\begin{array}{l}\text { Ring-fracture zone of Timber Mountain caldera (Crowe and } \\
\text { Carr, 1980); DV-PR (Carr, 1984); intersection of ring-fracture } \\
\text { zone and N-NE trending normal fault N-NE fault (Smith et al., } \\
\text { 1990; Nauman et al., 1991); Kawich-Greenwater Rift of Carr } \\
\text { (1990); Buckboard Mesa cluster of Connor and Hill (1995) }\end{array}$ \\
\hline $\begin{array}{l}1.0 \text { Ma Basalt } \\
\text { of Crater Flat }\end{array}$ & $\begin{array}{l}\text { Center of Crater Flat } \\
\text { basin }\end{array}$ & $\begin{array}{l}\text { Small rift within Crater Flat basin (Crowe and Carr (1980); DV- } \\
\text { PR (Carr, 1984); ADRZ of Wright (1989); trace of concealed } \\
\text { strike-slip fault (Schweickert, 1989); moat basalt of caldera } \\
\text { model of Carr (1990); basin projection of bedrock faults of } \\
\text { Yucca Mountain (Smith et al., 1990); Crater Flat cluster } \\
\text { (Connor and Hill, 1995); axis of Crater Flat basin/half graben } \\
\text { (Fridrich, in preparation) }\end{array}$ \\
\hline $\begin{array}{l}\text { Basalt of } \\
\text { Sleeping } \\
\text { Butte }\end{array}$ & $\begin{array}{l}\text { Range edge south } \\
\text { of Black Mountain } \\
\text { caldera highland }\end{array}$ & $\begin{array}{l}\text { DV-PR (Carr, 1984); trace of concealed strike-slip fault } \\
\text { (Schweickert, 1989); CFVZ (Crowe and Perry (1989); AMRV } \\
\text { (Smith et al., 1990); localized on N-S trending bedrock fault } \\
\text { (Minor et al., 1993); ;Sleeping Butte cluster (Connor and Hill, } \\
\text { 1995). }\end{array}$ \\
\hline $\begin{array}{l}\text { Basalt of } \\
\text { Lathrop Wells }\end{array}$ & $\begin{array}{l}\text { South end of Yucca } \\
\text { Mountain adjacent } \\
\text { to the Amargosa } \\
\text { Valley }\end{array}$ & $\begin{array}{l}\text { Intersection of basin-range and NE-trending faults (Crowe and } \\
\text { Carr, 1980); DV-PR (Carr, 1984); ADRZ of Wright (1989); trace } \\
\text { of concealed strike-slip fault (Schweickert, 1989); north-north- } \\
\text { east trending bedrock faults (Solitario Canyon fault) of Yucca } \\
\text { Mountain (Smith et al., 1990; Trapp and Justus, 1992); } \\
\text { intersection of Windy Wash and Stagecoach faults (Crowe et } \\
\text { al., 1995); Lathrop Wells cluster (Connor and Hill, 1995); active } \\
\text { area of extension in the southeast side of the Crater Flat half } \\
\text { graben (Fridrich, in preparation) }\end{array}$ \\
\hline
\end{tabular}


This section briefly summarizes, in order of sequence of model development, the alternative models used to identify the structural setting of basaltic volcanic centers of the YPB. The section repeats information from some previous sections so that discussion of tectonic models can be coupled directly with comments on the strengths and weakness of each model as well as the significance with respect to PVHA for the Yucca Mountain site.

Crowe and Carr (1980) suggested basaltic volcanic centers occur mostly along: 1) small northeast-trending rift zones or areas of relatively recent extension, 2) ring-fracture zones of caldera complexes, and 3) intersection zones between northwest-trending right-slip faults and northeast trending left slip faults. They also presented the first description of a "medial basalt belt" that was named the DV-PR (Death Valley-Pancake Range volcanic zone) in subsequent publications and provided subjective observations on the zones of the southern Great Basin with respect to the "risk" of future basaltic volcanism. Based on their descriptions, the most likely sites of future volcanism would be the Crater Flat basin, a presumed site of extension, and the southern end of Yucca Mountain, an area located at the $g$ of northwest and northeast structures.

The exploratory block at Yucca Mountain would be a site of lower likelihood of basaltic volcanism based on these zones because it is located outside of the areas of most active extension. Information was not available at that time on the distribution and number of faults showing Quaternary displacement in the YMR including faults that bound and possibly cut the exploratory block of Yucca Mountain.

Crowe et al. (1982) used structural controls in their attempts to identify bounds in PVHA for the Yucca Mountain site. They identified the spatial patterns of sets of volcanic events to define areas for estimating volcanic recurrence rates and assumed that the distribution of events reflected structural controls of sites of basaltic volcanism. Their distribution areas or zones were developed for different time periods including all Quaternary basalt sites $(<1.6 \mathrm{Ma})$, and the last 2.8 million years. They also extended their area of interest to include the sites of basaltic volcanism in the Lunar Crater volcanic field. The volcanic zones used in their assessment incorporated regional structural controls of the distribution of volcanic events but not local or small-scale structural controls. The spatial distribution models they used included the DV-PR as well as what was subsequently defined as the AMRV (Smith et al., 1990) or the YMR (Crowe et al., 1995).

Carr (1984, 1988, 1990), Carr et al. (1984, 1986), and Carr and Parrish (1985) presented a range of arguments in support of a caldera origin of the Crater Flat basin and suggested that sites of Pliocene and Quaternary basaltic volcanism in the Crater Flat basin were associated with and probably controlled by the ring-fracture zones of the calderas. More important, the exploratory block of Yucca Mountain was inferred from gravity data (Snyder and Carr, 1984) to be underlain at least in part by the eastern ring-fracture zone of a buried caldera, and the Miocene dikes north of the intersection of the Drill Hole wash and Solitario Canyon were inferred to follow the caldera edge. However, the distribution of Pliocene and Quaternary basaltic centers in the Crater Flat basin does not coincide with the location of the ring-fracture zone of the inferred calderas. Carr suggested in a following paper that the basalt probably followed the ring-fracture zone but diverted at shallow levels to follow northeast-striking tension fractures (Carr, 1990; p. 290). The possible existence of a caldera edge beneath Yucca Mountain raises the possibility, based on an observed common structural relationships between ring-fracture zones and sites of basaltic volcanism, that a potential feeder structure for the ascent of basalt magma may be present directly beneath the Yucca Mountain site. Crowe and Carr (1980; p. 12) rated caldera ring-zones as the highest "risk" sites in the southern Great Basin for the recurrence of basaltic volcanism. 
The caldera model for Crater Flat has not been supported by more recent data obtained during site characterization studies, particularly the results of seismic reflection studies (Brocher et al., 1996). Moreover, despite a nearly 4 million years record of Pliocene and Quaternary basaltic volcanic events in the Crater Flat basin, there are no recognized sites of young basaltic volcanism along the inferred ring-fracture zone beneath Yucca Mountain. However, it is possible that small basaltic intrusion(s) could be present in the subsurface along the structure. Their detectability using exploratory aeromagnetic data would be limited if the intrusions were located below the Topopah Springs Tuff of the Paintbrush Group because this ash-flow unit dominates the shallow magnetic field (Oliver et al., 1995).

Schweickert (1989) argued that the basalt centers of the CFVZ may mark the location of a concealed right-slip fault beneath Crater Flat. However, a major strike-slip fault was not noted on the seismic reflection line across Crater Flat although the orientation of the seismic line would make detection of a northwest-trending fault difficult. If a major concealed fault were present, it would not directly intersect Yucca Mountain.

Smith et al. (1990) proposed an area of most recent volcanism (ARMV) that included all sites of post-6 Ma volcanism in the YMR and enclosed the Yucca Mountain site. They attempted to identify high risk zones in the AMRV on the basis of the observation that the alignment of $1.0 \mathrm{Ma}$ centers of the Quaternary basalt of Crater Flat parallels the orientation of faults that disrupt Yucca Mountain. Analog basalt sites in the Fortification Hill volcanic field of Nevada and adjoining areas of Arizona and the Reveille Range were used to establish dimensions of chains associated with clusters of volcanic centers. Accordingly, Smith et al. (1990) argued that high risk zones or rectangles can be placed around Quaternary volcanic centers and future volcanic activity will occur preferentially within the zones. They suggested that the exploratory block of Yucca Mountain is located in a high-risk chain that extends to the north-northeast and south-southwest of the Lathrop Wells center (Smith et al., 1990; his Fig. 7). This latter observation leads to the argument that the probability of disruption of the Yucca Mountain site may be underestimated by structural models that do not include the Yucca Mountain site in high risk zones. The potential weaknesses of these arguments are several. The chain lengths used are longer than the longest observed cluster length of basalt centers of the PCB. If the longest cluster length is used for the chain dimension $(12.6 \mathrm{~km})$, the exploratory block would not be located in the high risk zone. The orientation of the high risk chains is somewhat sensitive to the inclusion of the exploratory block in the chain. The chain orientation drawn for the Lathrop Wells (Smith et al., 1990; his Fig. 7) is rotated to a more northerly strike to intersect the exploratory block in comparison to other chains. If the same orientation of the other chains is used for the Lathrop Wells high risk zone, the exploratory block would not be located in the zone. However, in support of the Smith et al. (1990) model, they orient the chains relative to the location of the basalt of Buckboard Mesa, which does require a more northerly strike of the Lathrop Wells chain.

The most important weakness of the model of Smith et al. (1990) is the observation noted previously that the sequence of volcanic events does not necessarily follow a predictable pattern (Crowe et al., 1995; Golder Associates, 1995). Subsequent basalt centers jump to new locations in patterns more closely resembling Brownian motion and as a result, the location of previous events may not be a good predictor of sites of future volcanic events.

Connor and Hill $(1993 ; 1995)$ used cluster analysis to show that the volcanic centers cluster and applied nonparametric methods incorporating temporal and spatial variations to estimate the probability of disruption of an $8-\mathrm{km}^{2}$ potential repository site at Yucca Mountain. The advantages 
of the approaches by Connor and Hill (1995) are several. The method can account for migration in sites of volcanic activity and should be sensitive to regional structural controls. The approach does not require definitions of volcanic zones that must be developed for homogeneous Poisson models, and the models can be modified to incorporate geologic controls, and uncertainty in the location and chronology of events. They argue that the most significant result of their analyses is the observation that the exploratory block of Yucca Mountain is located on a steep probability gradient on contour maps of the probability of repository disruption. The modeling approach developed by Connor and Hill (1995) is not specific to any structural or tectonic feature, but the cluster analyses should be sensitive to regional structural trends. For example, all of their models show closely spaced contours or clusters around Crater Flat, which is a probable pull-apart half graben. The weaknesses of the nonhomogeneous cluster models are several. The results are strongly dependent on the choice of $h$, the smoothing constant (Connor and Hill, 1995; see their Fig. 6). The weightedcentroid cluster analysis of Connor and Hill (1995; their Fig. 2) shows conclusively that there are two scales of clusters including smaller clusters with distances of less than 8 to $10 \mathrm{~km}$ and largerscale clusters with distances of $>25 \mathrm{~km}$. These correspond to the process scales described by Golder Associates (1995) with the smaller-scale processes (fractal) representing clustering about a center and the larger-scale processes representing jumps to the formation of a new or discrete volcanic center (Brownian process). The structural-spatial models should be concerned with the larger-scale processes that potentially could lead to magmatic disruption of the Yucca Mountain site. The inclusion of the smaller-scale clusters in the nonhomogeneous models of Connor and Hill (1995) may bias the data with small-scale spatial processes that are not relevant to volcanic hazards. The most serious weakness of the Connor-Hill model is the fundamental assumption underlying their model. Application of their cluster model assumes that the location of an initial volcanic event constrains the location of a succeeding volcanic event. Assessment of the Yucca Mountain data for the PCB shows that the location of the next new volcanic center is not constrained by the location of a preceding event (Crowe et al., 1995; Golder Associates, 1995). Spatial location only provides information on the potential location of centers within small-scale clusters.

1. Structural and Tectonic Models used in the Volcanism Expert Judgment Panel: This final part of section V identifies the tectonic and structural models applied to the YMR by individual members of the volcanism expert judgment panel. The assignments of the panel members are described below in alphabetical order (all information from Geomatrix, 1996).

a. Richard W. Carlson: Richard Carlson examined volcanism within an area of 50-km radius of Yucca Mountain. He argued that the area is representative of the Basin and Range province where extension has occurred in response to a subduction system overriding oceanic spreading centers. Miocene silicic volcanism is attributed to subduction but post-Miocene basaltic volcanism is not subduction related and is more likely a response to conductive heating of the lithosphere. Carlson argues that the extreme isotopic composition of $\mathrm{Sr}$ and $\mathrm{Nd}$ requires derivation from unusually thick and non-extended Proterozoic lithospheric mantle beneath Yucca Mountain. His region of interest for PVHA is the AVIP, and he examined subdivisions of the AVIP using data from teleseismic tomography and caldera locations and concluded that evidence of clustering of centers is weak and the distribution of volcanic centers appears to be random. Spatial-Structural Zones: AVIP.

b. Bruce Crowe: Bruce Crowe argued that late Miocene and younger basaltic volcanism in the YMR are unrelated to the large volume silicic volcanism of the SWNFV and used the meltsource models of Richard Carlson to explain Pliocene and Quaternary basaltic volcanism. He noted 
that the upper mantle contains or is capable of generating partial melts, that there have been timespace variations in sites of volcanism in the YMR, and the region is located at the northern end of the amagmatic gap. His region of interest is the southern Great Basin, and he used a combination of spatial and structural models to define zones within the region. These spatial zones include: 1) the CFVZ, 2) a distribution area similar to the AMRV of Smith et al. (1990) but expanded to include the aeromagnetic anomalies of the Amargosa Valley (YMR) and 3) an area corresponding to the distribution basalt centers of the PCB (see Fig. 3.11). Structural models included the Quaternary and Pliocene Quaternary pull-apart zone after Fridrich (in preparation), a Walker Lane structural zone, and a northeast-trending structural zone that is a composite of the models of Wright (1989), Carr (1990), and Smith et al. (1990). Spatial-Structural Zones: CFVZ, YMR, Crater Flat pull-apart, Walker Lane structural system, Northeast rift zone.

c. Wendell Duffield: Wendell Duffield argued that the Great Basin is an area of high heat flow and extension that produced conditions favorable for volcanism along northwest-trending structure/fracture systems of the Walker Lane structural zone. These zones in the Yucca Mountain region are inferred to provide structures that focus the location of volcanic centers. He suggests that volcanism may be a random process, but Quaternary volcanic fields are the most likely sites for future events in the next 10,000 years. Duffield's region of interest is a circle with a radius equal to the maximum length of a dike (30-40 km). He developed a primary zone of interest for PVHA using the spatial distribution of events and added secondary modifications for structural features. These zones were all established for a circular region centered at Yucca Mountain. Subzones within this circular zone are: 1) a Crater Flat-Lathrop Wells area that coincides with part of the Crater Flat pull-apart model, 2) flanking zones adjacent to the Crater Flat-Lathrop Wells subzone and parallel to the Walker Lane structural system (this zone is largely coincident with the Plio-Quaternary CFVZ) and 3) a small subzone that extends around the occurrence area of the basalts of Thirsty Mesa and Sleeping Butte. Spatial-Structural Zones:40-km radius circle centered at Yucca Mountain, Crater Flat basin, CFVZ, Sleeping Butte-Thirsty Mesa zone.

d. Richard Fisher: Richard Fisher identified two regions: one within a 100-km radius of Yucca Mountain; the other an area drawn from volcanism distribution maps that included the Lunar Crater volcanic field and parts of Death Valley. Fisher argued that sites of volcanism in these areas are no longer driven by subduction processes but instead developed in response to regional extension. He emphasized that the volcanic events in the area of Crater Flat and the Amargosa Valley define a Crater Flat field (CFF), and this field differs from the CFVZ by not including the basalts of Sleeping Butte and Thirsty Mesa. Fisher noted that the CFF follows the trend of the Walker Lane structural system, but this system has limited importance because it is not an extensional structure. Spatial-Structural Zones: Crater Flat basin and part of the Amargosa Valley.

e. William Hackett: William Hackett identified a region within a 100-km radius of Yucca Mountain where regional extension is expressed through normal faulting, diking, and strike-slip offset. He outlined the AVIP as an area of distinctive $\mathrm{Sr}$ and $\mathrm{Nd}$ isotopic compositions of basalt, probably reflecting a common mantle source characterized by preservation of old lithospheric mantle. Hackett chose regions of interest that correspond to the northern AVIP (excluding Death Valley but otherwise similar to the Greenwater-Kawich zone), the ADRZ, and a zone that encompasses the distribution area of basalt centers younger than $10 \mathrm{Ma}-$ each zone is linked to a time interval and is not necessarily defined only on the basis of structural/tectonic setting. He emphasized that volcanoes in the region cluster as proposed by Connor and Hill (1995) and that future volcanism will occur near the locations of existing volcanoes. Spatial-Structural Zones: 
northern AVIP, Greenwater-Kawich zone, ADRZ, distribution area of the post-10 Ma basalt centers, nonhomogeneous cluster models of Connor-Hill.

f. Mel Kuntz: Mel Kuntz identified a region enclosed by a circle centered at Yucca Mountain and with a radius of $100 \mathrm{~km}$. He argues that the structural setting is characterized by regional extension but included in that extension zone is the Walker Lane structural system that acts as an accommodation zone or diffuse boundary between areas of extension and the north-south translational movement of the Sierra Nevada mountain range. He noted that there was a transition in the nature of volcanism through time from caldera-related eruptions associated with rapid extension to small volume, widely dispersed basaltic volcanism that is associated with waning extension. Kuntz argues that the geothermal gradient in the region results in the upper asthenosphere being close to incipient melting and that generation of basaltic magma may occur from plume development, decompression melting, or from volatiles/fluids lowering the melting point of mantle source rocks; these events may or may not be related to regional tectonic events. The AVIP is used to define a region of interest and is judged to be the surface expression of a unique mantle region that has been isolated from the convecting mantle. Magma generation and ascent to the surface is inferred to be a complex mechanism controlled by many processes that are poorly understood. He notes that surface eruptions in the YMR may be facilitated either by a north-south structure or, alternatively, may reflect the orientation of the melting anomaly represented by the AVIP. At shallow depths, near-surface structures are judged to affect the orientation of feeder dikes and the location of basalt centers. Kuntz notes that there may be a sharp boundary between Crater Flat and Yucca Mountain, but the boundary may not be structural and is not well defined. Another factor in localizing volcanism in Crater Flat may be the integrated density contrast over the crustal and mantle column involved in magma ascent and eruption. $\mathrm{He}$ identifies a subregion of the AVIP, extending from Buckboard Mesa on the north to the Amargosa Valley aeromagnetic anomalies on the south, and uses four alternative models including:

1. Zone A that is equivalent to the AMRV (uniform occurrence).

2. Zone $\mathrm{A}$ is subdivided into 5 subzones (B through $\mathrm{F}$ ) each with different likelihood of future eruptions.

3. Zone B is drawn around the Sleeping Butte-Thirsty Mesa area near the west edge of the ring-fracture zone of the Timber Mountain caldera.

4. Zone $\mathrm{F}$ is the interior of the Timber Mountain caldera.

5. Zones E and D are range highlands that have not experienced Pliocene or Quaternary volcanism ( $\mathrm{E}$ is around Yucca Mountain, $\mathrm{F}$ is around the Bare Mountain block and areas west of Beatty), Zone $\mathrm{C}$ includes the Crater Flat basin and parts of the Amargosa Valley.

The nature of the boundaries between the zones are inferred to be variable with the most important being the Crater Flat basin edge, a boundary Kuntz argues, that cannot be fixed and must be assessed in PVHA using a smoothing function. Spatial-Structural Zones: northern AVIP, Crater Flat-Amargosa Valley pull-apart area, Timber Mountain caldera. 
g. Alexander McBirney: Alexander McBirney argues that the time-space distribution of volcanism is controlled by a combination of conditions in the mantle and overlying lithosphere. $\mathrm{He}$ infers that the AVIP is probably the surface expression of a melting anomaly, but that resulting volcanism has an uneven spatial distribution in the AVIP-the primary controls are the orientation of faults relative to the regional stresses. The distribution of basaltic volcanic centers is, therefore, mostly a reflection of conditions within each structural block, and he uses a relative ranking system for the frequency of eruptions in different structural blocks. These structural blocks are based on geologic structure, presence or absence of young volcanic centers, the ages of centers (if present) and the composition of the basaltic volcanic rocks. The southern part of the AVIP is not used in his analysis for PVHA. The Crater Flat basin is judged to be a pull-apart basin with an eastern boundary that is somewhat difficult to define. However, he argues that the elevated and depressed blocks must be treated independently. Alluvial valleys are recognized as regions of maximum extension and the orientations of dike systems are inferred to be consistent with the stress field coupled with right-slip movement on boundary faults and possibly buried faults of the Walker Lane system. The Lathrop Wells center is included in the Crater Flat domain but is inferred to differ somewhat from the cones of Crater Flat. The Lathrop Wells center is located at the intersection of several faults. Sites of volcanism are rated in decreasing order of potential for future eruption including:

1. Pull-apart basins.

2. Intersections of strike-slip faults.

3. Ring fracture zones of calderas.

4. Interiors of fault-bounded blocks.

5. Transcurrent fault systems.

Spatial-Structural Zones: pull-apart basins, intersections of strike-slip faults, caldera ringfracture zones.

h. Michael Sheridan: Michael Sheridan argues that new basaltic volcanic fields have appeared randomly over much of the Basin and Range province in the past $15 \mathrm{Ma}$ in response to plate tectonic interactions involving the western margin of the North American continent. The most likely location of future volcanic events is inside the boundaries of known volcanic fields. Events outside of a field represent the initiation of a new field and are much less likely than an event within a field. Magma-generation models provide very limited information on spatial or temporal patterns of volcanism but volcanic fields may reflect the distribution of melt source zones or be leaky pathways to the surface. Near-surface faults play limited roles in locating volcanic fields but may have some influence on the locations of vents and cones. Sheridan uses the concept of volcanic fields to identify a region of interest for the PVHA and argues that the volcanic fields have lengths of 15 to $50 \mathrm{~km}$ and mean duration of activity of 5 million years. A new volcanic event is unlikely to be at the exact location of a previous event but has a high probability of occurring in the boundaries of a volcanic field. Sheridan evaluates volcanic fields within a 200-km radius of Yucca Mountain as well as volcanic fields, events, and cones within a 40-km radius area of Yucca Mountain, the latter corresponding generally to the northern part of the AVIP. He uses a volcanic field approach and a volcanic zone approach to define spatial models. The hazard with respect to Yucca Mountain is largely from the Crater Flat field, and typical dimensions are assigned to the 
field for hazard assessment. Sheridan argues that other volcanic sites in the YMR are separated from and are not part of the Crater Flat field. Spatial-Structural Zones: volcanic fields, AVIP, Crater Flat field.

i. George Thompson: George Thompson defines a region within a circle of 50-km radius and centered at Yucca Mountain and notes that the mountain is located at the boundary between the Basin and Range province and the Walker Lane structural system. The setting of Yucca Mountain is consistent with Basin and Range extension with volcanic centers following the maximum compressional stress direction and the Lathrop Wells center being at the southern end of a zone of active Quaternary faults. Thompson argues that dike emplacement and normal faulting are mechanisms for accommodating regional extension, and sites of volcanism or magma supply are exclusionary to sites of faulting. Analogous areas in the Basin and Range province show a close temporal relationship between normal faulting and dike emplacement. Inherently, extensional features tend to be concentrated in basins because normal faults that formed the basins dip inward and converge beneath the basins. The orientation of dikes in the YMR is roughly parallel with the trends of active fault systems, and it is unlikely that future volcanism will occur in structural blocks with no evidence of late Cenozoic faulting. Accordingly, the Lathrop Wells site is the most likely site for future volcanism. The region of interest used by George Thompson is the AVIP, a region of a common magma source, and a second region of interest is used that is similar to the areas of development of volcanic fields (as described by Michael Sheridan). Spatial zones are identified in the AVIP with different recurrence rates assigned that take into consideration the age and style of tectonism. Three local zones are defined. The first is a Local Domain zone that includes an area south of the Timber Mountain caldera complex, the eastern side of the Bare Mountain uplifted block, and the uplifted Yucca Mountain block. Within this domain, there is a volcanic subdomain that includes the Quaternary centers of Crater Flat and the Lathrop Wells center, as well as the aeromagnetic anomalies of the Amargosa Valley and a Quaternary faulting domain that includes Quaternary faults in the YMR. The two subzones represent two different mechanisms for responding to regional extension with the overlap area being in the vicinity of the area of the 3.7 Ma basalt centers where faulting has replaced dike emplacement. The zones of the volcanic and faulting domains have changed through time. Spatial-Structural Zones: AVIP, the Crater Flat extensional basin.

j. George Walker: George Walker argues that the presence of basaltic volcanic centers in the YMR requires the presence of a melting anomaly in the underlying mantle characteristic of melting anomalies of the Basin and Range province. Volcanic centers in Crater Flat appear structurally controlled, but it is difficult to determine whether orientations of centers reflects structure or the shape of the melting anomaly. Walker infers that the DV-PR zone reflects the possible trend of a melting anomaly. The region of interest identified by Walker is the DV-PR, and the CFVZ within the belt is especially significant to PVHA whereas the DV-PR provides a background zone. Spatial-Structural Zones: DV-PR, CFVZ.

\section{Geophysical Studies: Yucca Mountain Region}

A wide range of geophysical data has been obtained for the YMR (Oliver et al., 1992; 1995). In this section, we discuss aspects of the geophysical data and the constraints these data place on models of the distribution of basaltic volcanism in the YMR. 


\section{A. Seismic Studies}

Seismic studies have constituted a major part of the site characterization studies since the earliest stages of investigations. A 47-station vertical-component seismic network was installed within a 160-km radius of Yucca Mountain in 1979 (Rogers et al., 1987). A six-station supplemental mini-net was deployed on Yucca Mountain in 1981. This net lowered the detection threshold and improved the accuracy of the location of earthquakes near the Yucca Mountain site (Rogers et al., 1987). Horizontal component instruments were deployed at selected stations in 1984. This network, called the southern Great Basin seismograph network (SGBSN) (Rogers et al., 1981, 1983, 1987; Mermonte and Rogers, 1987; Gomberg, 1991a, 1991b; Harmsen and Bufe, 1992), was designed to locate and study properties of earthquakes for a region containing tectonic features of possible significance to seismic risk assessment for the YMR. Tectonic features of regional interest (not all of which are significant for seismic risk assessment for Yucca Mountain) were reviewed by Carr (1984). They include the Death Valley-Furnace Creek fault zone and extension along the Fish Lake Valley fault zone, the east/west seismic zone (Smith and Sbar, 1974; Smith, 1978), the Nevada-California seismic zone, and the Nevada Test Site Paleoseismic belt that now would be called the Kawich-Greenwater rift (Carr, 1990). The process of upgrading the SGBSN to a digital three-component network is being completed by the University of Nevada, Reno Seismological Laboratory (UNRSL). The upgrade was undertaken to provide both higher quality earthquake locations with the routine recording of horizontal S-waves at all stations and the capability of adapting modern waveform modeling techniques to study seismic source parameters to further refine models of the crustal structure in and around Yucca Mountain (Smith et al, 1995).

Rogers et al. (1987) summarized earthquake hypocenters and selected focal mechanisms and other inferred seismicity characteristics through 1987. Conclusions from this report are as follows.

1. Earthquakes are distributed in an east/west zone generally coincident with the east/west seismic zone.

2. Earthquakes display strike/slip and normal/slip over a depth range from near-surface to $10-15 \mathrm{~km}$ consistent with seismic patterns of much of the Great Basin. There is an apparent preference for right/slip on north-trending faults. Left/slip is also observed on north-northeast striking faults.

3. Earthquakes are consistent with a northwest-trending orientation of the least principal stress axis, which is rotated clockwise relative to surrounding regions (Carr, 1974; Zoback, 1989).

4. Earthquake clusters are difficult commonly to associate with specific faults although epicenter alignments and earthquake nodal planes are frequently subparallel to fault trends (Hildenbrand et al., 1988, Fig. 2.3).

5. A seismicity minimum may be observed between depths of 3.5 to $4.0 \mathrm{~km}$.

6. Earthquake energy release per unit area is lower in the immediate Yucca Mountain area compared to regional levels. This may be attributed to low stress from tectonic uncoupling or significant prehistoric seismic energy release. Alternatively, it could be an area of low seismicity with high stresses and locked faults. Rogers et al. (1987) 
summarized several lines of evidence supporting seismic uncoupling but noted that other interpretations are possible.

Gomberg (1991a) reviewed the seismicity patterns and the detection and location threshold of the SGBSN. She derived a spatially varying model of the detection/location capabilities of the network based on empirical relations and statistics. She used several validation tests for the model and showed that the threshold map accurately predicts the observed distribution of epicenters for all magnitude bins. This approach permits use of most of the earthquake catalog and allows evaluation of the completeness level of each subroutine. Gomberg (1991a) used the threshold model to develop a series of magnitude independent masks that were overlaid on patterns of seismicity and Quaternary faults. She identified several areas as active because they exhibit the greatest number of events at all magnitudes. These are the north end of the Furnace Creek fault, the Pahranagat Shear Zone, and the northern and southeastern parts of the Nevada Test Site. Gomberg noted that there is an absence of seismicity at Yucca Mountain. She discussed the same causes of low seismicity as Rogers et al. (1987) but noted that seismic models predict a minimum in shear strain at Yucca Mountain. Additionally, she drew attention to relatively low levels of seismicity west of the Death Valley-Furnace Creek faults despite an abundance of young fault scarps indicative of recent tectonic activity.

In a companion paper, Gomberg (1991b) evaluated seismicity and shear strain in the southern Great Basin focusing on identifying information that can be obtained from the distribution of earthquakes in an area with long intervals between large earthquakes. She developed strain-field models assuming that the long-term behavior of faults perturbs an otherwise uniform strain field. An important conclusion developed from the models is that a complex distribution of seismicity with off-fault locations is expected. These traits match the seismicity recorded by the SGBSN (Rogers et al., 1987; Gomberg, 1991a). Gomberg (1991b) developed a boundary element representation of faults with historic or Holocene displacement that she used as input to the shear strain field. Modeled faults in the Yucca Mountain area were the Bare Mountain fault, the Rock Valley fault system, and the Yucca Flat fault. She assumed a maximum extension direction of $\mathrm{N}$ $52^{\circ} \mathrm{W}$ and an orientation of the regional displacement vector of $\mathrm{N} 34^{\circ} \mathrm{W}$. The model relates the highest shear strain areas, south and east of Yucca Mountain, to regions of observed high seismicity. The model showed a lack of shear strain in the northern part of the Nevada Test Site. The high seismicity of this area may be induced by underground explosions from testing of nuclear weapons (Gomberg, 1991b, pp. 16, 392). The low seismicity in the Yucca Mountain area is coincident with a region of modeled lowest shear strain. Parsons and Thompson (1991) suggested this feature could result from non-seismic stress release associated with active magmatism (see models of Shaw, 1980). Gomberg (1991b) suggests that because of the low strain rate in the Yucca Mountain area it is not an area of significant seismic hazard. The simple shear model also showed a rotational component of the regional deformation field, possibly compatible with paleomagnetic studies (Hudson and Geissman, 1991; Rosenbaum et al., 1991). Additional iterations of the shear model were used with slip distributions assigned to fault systems (Gomberg, 1991b). Results were not dissimilar to the simple shear model.

Harmsen and Bufe (1992) summarized seismic data obtained for the seismic net through 1989. They noted the development of a concentration of earthquakes in the Reveille Range. They also discussed the difficulties of obtaining accurate data for earthquake hypocenters and the ambiguity this creates for focal mechanism solutions. 
The largest and most significant earthquake recorded in the SGBSN since the network was established in 1979 has been the June 29 1992, M 5.6, Little Skull Mountain (LSM) earthquake (Lum and Honda, 1992; Harmsen, 1993; Walter, 1993; Meremonte et al, 1995; Smith et al., 1997a). The earthquake caused some damage at the Yucca Mountain Field Operations Center and was widely felt throughout the region. This earthquake appears to have been triggered by the M 7.1 Landers, California, event that occurred approximately 20 hours earlier. LSM foreshock activity initiated soon after the Landers earthquake and continued until the M 5.6 main shock (Anderson et al., 1994). This prompted several studies of the triggering mechanism involved. Anderson et al. (1994) proposed that dynamic stresses resulting from surface waves generated during the Landers earthquake initiated the LSM sequence, and Bodin and Gomberg (1994) have proposed a model in which strain was propagated through the fault systems throughout the region resulting in failure of the fault at LSM. The LSM earthquake initiated at a depth of $11.7 \mathrm{~km}$ and there was no evidence of surface rupture. The earthquake occurred on a northeast-striking fault plane dipping steeply to the southeast (Harmsen, 1993; Meremonte et al., 1995), and the event involved nearly pure normal-slip with a small left-slip component. The mainshock rupture and nearly the entire aftershock sequence was confined to between 6 and $12 \mathrm{~km}$ depth (Smith et al, 1997a). The sequence was recorded on a number of portable digital seismographs deployed in the epicentral area by the USGS (Meremonte et al., 1993) and the UNRSL (Sheehan et al., 1994). These threecomponent waveform data have formed the basis for ground-motion modeling exercises that have been carried out for the YMP (Schneider, written communication, 1995). Since the LSM earthquake, there has been a notable increase in earthquake activity in the Rock Valley fault zone adjacent to LSM (Smith et al., 1997b, Shields et al., 1995). Only two M 3+ earthquakes are included in the SGBSN earthquake catalog from 1979 until the LSM earthquake in the southern NTS region adjacent to the Rock Valley fault zone. Since the LSM event, three M 3.5+ earthquakes and an unusual sequence of very shallow earthquakes in mid-1993 (Smith et. al, 1997b) have taken place in the Rock Valley fault zone (Fig. 3.16). This increase of seismicity in the Rock Valley fault zone may have resulted from stresses induced by the LSM earthquake (Smith et al., 1997b).

Smith et al. (1997c) modeled the P-wave velocity structure through Yucca Mountain along a reversed refraction profile from Rainier Mesa, on the northern NTS, to Ryan, California, near the Death Valley National Monument. This profile took advantage of the NPE (Non-Proliferation Experiment), which was a 3200-lb. conventional explosion. They observed early P-wave arrivals through eastern Crater Flat that were modeled as a high-velocity upper crustal material. Mooney and Shapper (1995) had observed high P-wave velocities at shallow depths in Crater Flat but only along their east-west shot line. Observations of early arrivals on the NPE line may have been because of size of the NPE shot. Smith et al (1997c) suggested that this high velocity material may represent a cooled block or zone of Cenozoic basaltic magma within the upper crust in eastern Crater Flat.

There is no evidence of a positive correlation between recorded seismicity and the distribution of Quaternary basaltic centers in the Yucca Mountain area. In fact, there may be evidence of a negative correlation of seismicity with sites of Quaternary volcanism in Crater Flat (see elicitation section by George Thompson in the report by Geomatrix, 1996). Increased seismicity has occurred in the Pahranagat Shear Zone (Rogers et al., 1987) near an area of basaltic volcanism (Ekren et al., 1977). However, these lavas are of Miocene age and the correlation is not significant for PVHA for the Yucca Mountain site. Two cautions must accompany any discussion of historic seismicity and the spatial distribution of basaltic volcanism. First, the period of recording of earthquake locations is very short relative to the recurrence rate of basaltic volcanic events. The latter is on the order of 
several hundred thousands of years (Crowe et al., 1992). Second, patterns of historic seismicity may not be good predictors or indicators of future sites of Quaternary basaltic volcanism. Basalt magma probably ascends rapidly through the crust. While the ascent may be facilitated or guided by fractured rock, these pathways need not necessarily be correlated with areas of historic seismicity.

To summarize, seismicity studies of the YMR offer limited potential for evaluating patterns of future basaltic volcanic activity. This is an unsurprising result, given the long recurrence time of basaltic volcanic events. One interpretation of the aseismic zone noted for the Yucca Mountain area is non-seismic stress release associated with Quaternary basaltic volcanism (Parsons and Thompson, 1991). Alternatively, the shear models of Gomberg (1991b) suggest that the low seismicity may simply represent an area of low shear strain accumulation. Both models are compatible with the seismic record of the region.

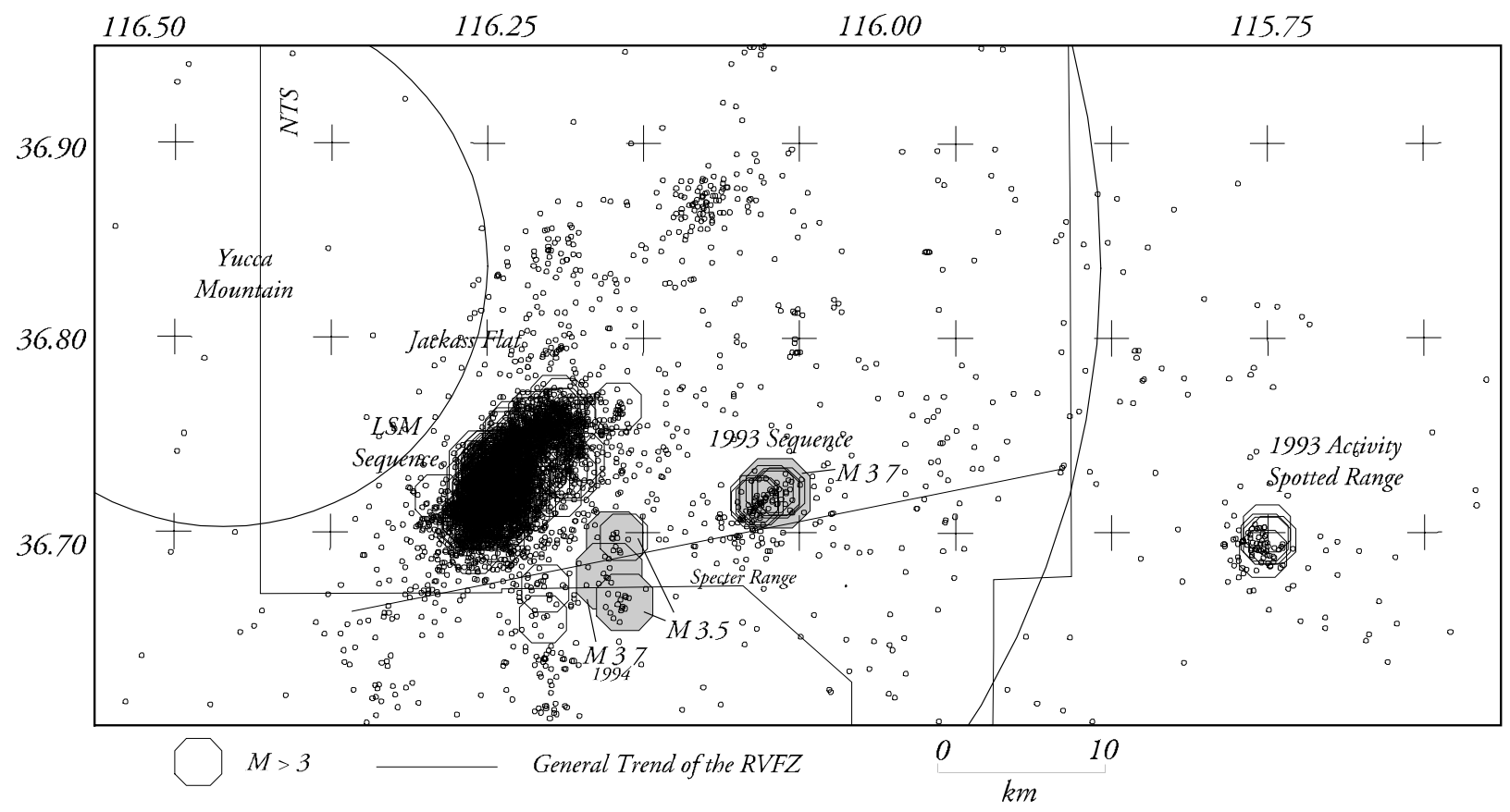

Figure 3.16. Earthquakes in the southern Nevada Test Site from the June 291992 Little Skull Mountain earthquake, through September 1995. The location of the 1993 sequence and the series of M 3.5+ earthquakes in the Rock Valley fault zone locate southeast of the large cluster of activity that makes up the Little Skull Mountain aftershock zone. The M 3.5 event just north of the 1994 M 3.7 earthquake took place in 1992 at a depth of $10 \mathrm{~km}$; the hypocentral depths for other M 3.5+ earthquakes are less than $5 \mathrm{~km}$. Also shown is a cluster of activity that occurred in 1993 in the Spotted Range east of the Nevada Test Site.

\section{B. Gravity Investigations}

Gravity investigations in the NTS and YMR were initiated as early as 1978, and over 33,000 gravity measurements have been made with all measurements adjusted to a common gravity datum and recompiled (Oliver et al., 1992). Complete Bouguer gravity maps have been published of the Nevada Test Site (Healey et al., 1987), Death Valley (Healey et al., 1980a), Goldfield (Healey et al., 1980b), Caliente (Healey et al., 1981), and Las Vegas (Kane et al., 1979) sheets. A residual gravity map of Yucca Mountain and vicinity was produced by Snyder and Carr (1982), and free- 
air, Bouguer, and isostatic residual gravity maps were compiled for the YMR (Hilldenbrand et al., 1988). A 1:100,000-scale isostatic gravity map of the Nevada Test Site that covers an area northeast of Yucca Mountain was published in 1990 (Oliver and Fox, 1993). An important aspect of gravity studies is that the gravity field is particularly sensitive to the large density contrast between basement rocks and Cenozoic deposits, and the method is useful in identifying the depth and geometry of the Cenozoic/pre-Cenozoic contact. However, this large density contrast may mask smaller density contrasts in basement rocks (Oliver and Ponce, 1995).

Snyder and Carr $(1982,1984)$ summarized the volcano-tectonic setting of the YMR based largely on gravity data. They summarized interpretations of more than 2500 gravity measurements on an approximately 2-km, irregular grid. In their original work, Snyder and Carr (1982) analyzed the complete Bouguer gravity anomalies using a reference crustal density of $2.67 \mathrm{~g} \cdot \mathrm{cm}^{-3}$. They reduced the data a second time at a density of $2.0 \mathrm{~g} \cdot \mathrm{cm}^{-3}$ to compensate for gravity stations within lower-density volcanic terrain. They applied an isostatic correction assuming Airy-type isotasy to remove effects of density variations deeper than $5 \mathrm{~km}$. Density control for their interpretations was provided by density measurements of core samples and surface samples. These density data were augmented by gamma-gamma and borehole gravity measurements in several drill holes (Snyder and Carr, 1984). Further, they used a two-dimensional model from an east/west cross section and a three-dimensional multiple-polygon gravity model.

The most distinctive feature of the regional gravity field is a gravity high associated with Bare Mountain that is connected with a larger gravity high over the Funeral Mountains. This high may delineate the elevated Paleozoic basement rocks of the Funeral Mountain-Bullfrog Hills-Bare Mountain detachment complex (Hamilton, 1988; Carr and Monsen, 1988; Oliver and Fox, 1993). It is interrupted only by a gravity saddle across the area of the Amargosa River, which is a probable result of thick accumulation of clastic sediments of the Amargosa Valley (Snyder and Carr, 1984). A second gravity high, the Calico Hills gravity anomaly, coincides with the area of the Calico Hills and probably extends to the southwest beneath Busted Butte. Snyder and Carr (1984) interpret this gravity high as the product of a shallower depth to Paleozoic rocks, possibly augmented by a fault zone of pre-Paintbrush age near Busted Butte.

An additional major feature is a large gravity low with amplitude of about $35 \mathrm{mGal}$, whose extent is defined by the 8-mGal residual gravity contour (Snyder and Carr, 1984, their Fig. 4c) centered in Crater Flat but also extending east partly under Yucca Mountain and south into the Amargosa Valley. Snyder and Carr (1984) interpret this low as a combination of sector grabens and caldera collapse associated with the eruption of the Crater Flat Group. A permissive alternative explanation of these data is that the gravity low is the result of a thick accumulation of tuff and alluvial fill deposits in a series of pull-apart basins marking Crater Flat and extending to the south. Neither model can be discriminated solely on the basis of the gravity data. The base of the caldera or alluvial section in Crater Flat is estimated to be about $4 \pm 2 \mathrm{~km}$ from gravity modeling or between 2 and $4 \mathrm{~km}$ based on seismic refraction (Snyder and Carr, 1984, pp. 10, 204).

A narrow band of gravity highs separates the negative gravity anomalies of Crater Flat and the Claim Canyon and Timber Mountain caldera segments to the north (Snyder and Carr, 1984). These highs are bounded to the north by a large gravity low associated with the Timber Mountain and Silent Canyon calderas (Snyder and Carr, 1984). 
Ponce and Oliver (1995) reviewed gravity investigations conducted in the southern Great Basin including both compilations of regional gravity data as well as studies associated with the Yucca Mountain site and the site vicinity. They noted three major gravity anomalies that are significant for the Yucca Mountain site including:

1. A northwest decrease of about $20 \mathrm{Mgal}$ in the Bouguer gravity field across Yucca Mountain.

2. The steep gravity gradient of about $30 \mathrm{Mgal}$ at the western edge of Crater Flat.

3. A large gravity anomaly centered over the Silent Canyon and Timber Mountain calderas located north of the Yucca Mountain site.

The gravity decrease across Yucca Mountain, as noted previously, was attributed to the presence of a caldera complex west of and beneath Yucca Mountain (Snyder and Carr, 1984). Ponce and Oliver (1995) noted that the caldera model is limited somewhat by an absence of density data for the Cenozoic deposits below a depth of about $2 \mathrm{~km}$. They referenced the alternative caldera and detachment models for Yucca Mountain and the Crater Flat basin and argued that ambiguities in interpretations of the gravity data do not allow differentiation between the caldera or detachment models. The gravity data show clearly a structural basin filled with low-density rocks (tuff and alluvium) but do not discriminate the origin of the basin.

The Fortymile Wash area has also been a site of continuing gravity studies, primarily to determine whether the east side of Yucca Mountain is fault-controlled. Ponce and Oliver (1995) note that the largest gravity anomaly in the vicinity of Fortymile Wash is along the Paintbrush fault near Fran Ridge and suggest that the Wash itself does not overlie a fault unless movement has juxtaposed rock types of similar density.

The combination of the depth of the structural basin and the small volume of Pliocene and Quaternary basaltic rock makes gravity models of limited use in delineating the local structural controls of sites of basaltic volcanism. However, the Pliocene and Quaternary basalt centers in Crater Flat are associated spatially with the prominent gravity low of the basin, suggesting that the basaltic rocks may have followed or been influenced by structures associated with this basin, a topic that is discussed in more detail in a following section on seismic reflection/refraction studies. Oliver and Ponce (1995) suggest that the coincidence of the Pliocene and Quaternary basalt field with the Crater Flat basin requires a genetic relationship between faulting and basaltic volcanism. They draw an analogy between faulting and volcanism in the southern Death Valley region and suggest that a similar relationship may be possible for the basalt centers of Crater Flat.

\section{Magnetic Investigations}

A wide variety of aeromagnetic and ground magnetic data have been obtained for the YMR. These data have been summarized in recent reports by the U.S. Geological Survey (Oliver et al., 1992, 1995). Draped aeromagnetic profiles were flown with spacing of 0.4 and $0.8 \mathrm{~km}$ for a large area surrounding Yucca Mountain extending from Pahute Mesa, south to southern Death Valley, west to beyond Bare Mountain, and east into Frenchman and Yucca Flat (Oliver et al., 1992, their Fig. 2.2-1). This area covers most of the terrain of interest for tectonic and volcanic studies in the YMR. Compiled maps of these areas were presented by Hildenbrand et al. (1988). Bath (1968) and 
Bath and Jahren $(1984,1985)$ presented data showing that the remanent magnetization of Cenozoic volcanic rocks was responsible for most of the aeromagnetic anomalies of the YMR.

Oliver et al. (1995) noted that regional aeromagnetic data show broad magnetic highs adjacent to the Yucca Mountain site, the Spring Mountains, the Mormon Mountains, and the GreenwaterFuneral Mountains of eastern Death Valley. They also recognized a northeast-trending zone in eastern Nevada characterized by an absence of short-wavelength anomalies (see earlier section). More detailed analyses of aeromagnetic data in the YMR show that the magnetic high near the Yucca Mountain site can be resolved into a series of spatially separated highs over the Wahmonie area, the Calico Hills, the northern part of Yucca Mountain, and central Crater Flat (Oliver et al., 1995; p. 69).

Kane and Bracken (1983) described aeromagnetic anomalies in the Yucca Mountain area and surrounding region and also noted the strong correlation between Cenozoic volcanic rocks and aeromagnetic anomalies. The surface basaltic volcanic rocks of the Crater Flat basin have marked magnetic contrasts with surrounding rocks, particularly the magnetically quiet alluvial fill of the basin. These rocks can be correlated with a high degree of confidence with positive or negative anomalies on the aeromagnetic map of Kane and Bracken (1983). Langenheim et al. (1991; 1993) and Langenheim (1995) summarized aeromagnetic studies conducted in direct support of volcanism studies for the YMP including more detailed studies, with acquisition of ground magnetic and gravity data, of anomaly sites identified by Kane and Bracken (1983) and suspected to represent buried volcanic centers.

Crowe et al. (1986) described aeromagnetic anomalies in Crater Flat and the Amargosa Valley that may represent buried volcanic centers or intrusive rocks. Exploratory drilling at two sites has penetrated buried basalt lavas, which correlate with recognized surface anomalies (Carr and Parrish, 1985; Crowe et al., 1986; Langenheim, 1995); a third basalt site was penetrated in an exploratory hole by a private company (Harris et al., 1992; Oliver et al., 1995; Langenheim, 1995). Langenheim et al. (1991; 1993) and Langenheim (1995) summarized geophysical data for this anomaly site, which is about $25 \mathrm{~km}$ south-southeast of the Yucca Mountain site. They constructed alternative two-dimensional magnetic models to fit the anomaly and suggested that the maximum depth to the top of a magnetic body was less than $150 \mathrm{~m}$ below the alluvial surface. They also argued that the anomaly is most likely a basalt center buried in alluvium. These conclusions were verified through subsequent exploratory drilling by a private company (Harris et al., 1992).

Magnetic anomalies near the potential repository site have been described by Bath and Jahren (1984). These investigations were conducted primarily to evaluate buried geologic units or structures beneath the potential site area. A tabular mass of sedimentary rock was noted beneath thick deposits of the volcanic units, and major faults of the site were outlined from their displacement of the magnetized volcanic rock. The Topopah Springs Tuff of the Paintbrush Group was identified as the primary source of anomalies from faulted sequences of volcanic rock. An east/west pattern of anomalies was identified that is part of the regional magnetic high near the Yucca Mountain high described by Oliver et al. (1995). However, Bath and Jahren (1984) noted that the amplitudes of these anomalies were reduced significantly when effects of the deeply buried magnetic argillite unit were removed.

More detailed drape aeromagnetic studies were conducted for parts of the Yucca Mountain site (Bath and Jahren, 1985). These studies detected a prominent magnetic anomaly of $290 \mathrm{nT}$ located 
about $1 \mathrm{~km}$ northwest of USW H-3. Ground magnetic traverses were run to delineate the identified anomaly, and three possible contributing sources were assessed (Bath and Jahren, 1985). First, elevated topography across the Solitario Canyon declivity gives a terrain effect. Second, ground anomalies south of the drape air anomaly indicate either an increase in magnetization or the presence of a small intrusive body. Third, there is an increase in magnetic influence from offset of the Topopah Spring Member along the Solitario Canyon fault. One possible interpretation of this anomaly is that it may be related to a 10-Ma basalt dike that intrudes the Solitario Canyon fault (Crowe et al., 1983a; Scott, 1990; Carr, 1990). In fact, Bath and Jahren (1985, p. 15) suggested that the anomaly could represent a small intrusive body of basalt composition (dike or sill) emplaced off the main trace of the fault. Ground magnetic data were collected along multiple profiles across the Solitario Canyon fault adjacent to the northwest edge of the exploratory block; three of the profiles crossed the fault along or adjacent to surface and trench outcrops of the basalt dike (Ponce and Langenheim, 1995). The locations of the three ground magnetic profiles (SCF1, SCF2 and SCF3) and preliminary interpretations of the data are summarized in Ponce and Langenheim (1995) who noted a magnetic low with an amplitude of about $100 \mathrm{nT}$ that coincides approximately with the location of a basalt dike near a trench cut along a ridge crest at the intersection of Solitario Canyon and Drillhole Wash. They suggested from modeling of the magnetic data that the anomaly can be matched to the amplitude of the observed low, assuming the presence of a vertical dike of reversed polarity and $1.6 \mathrm{~m}$ thickness. A second magnetic low of similar amplitude was noted west of the described trench and could be attributed to a second dike or the affect of surface rubble (Ponce and Langenheim, 1995). Ground magnetic traverses located south of the trench show a magnetic high of about $150 \mathrm{nT}$ that could be associated with a basalt dike of normal polarity or possibly effects of west-down displacement on the Solitario Canyon fault. The interpretation of the anomaly is complicated by the short length of the magnetic profile and possible effects of magnetic sources above the sensor in the confines of the Solitario Canyon (Ponce and Langenheim, 1995). Surface outcrops and trench exposures of the basalt dike of Solitario Canyon were sampled for paleomagnetic studies. These studies confirmed that the polarity of the basalt is reversed. The ground magnetic profiles across the basalt dike provide a representation of the magnitude of magnetic signal (100 to $200 \mathrm{nT}$ ) from a basalt dike in Miocene tuff and can be used with other regional aeromagnetic data to assess the detectability of basalt dikes in magnetic country rock. A significant finding of the data obtained from the ground magnetic profiles is that the magnetic anomaly associated with exposures of the basalt dike is a magnetic low. In contrast, the anomaly described by Bath and Jahren (1984) is a magnetic high.

High quality drape aeromagnetic data have been obtained for much of the YMR and have been supplemented locally by ground magnetic data. This information allows a relatively high degree of confidence in the judgment that all significant sites of Pliocene and Quaternary volcanic activity have been identified in areas of alluvial fill and nonmagnetic Paleozoic rocks in the YMR. Several of the aeromagnetic anomalies first identified by Kane and Bracken (1983) have been assessed through exploratory drilling, and buried basalt has been identified as the source of the anomalies at two sites (VH-2 in Crater Flat; the Amargosa Valley anomaly). For example, data from drill hole VH-2 show that basalt lava buried in alluvium at depths of over $300 \mathrm{~m}$ was recognized readily from drape aeromagnetic data (Carr and Parish, 1985; Crowe et al., 1986).

The remaining aeromagnetic sites identified by Kane and Bracken (1983) and the more detailed studies summarized in Langenheim (1995) may or may not be assessed through exploratory drilling. The implications on PVHA of not drilling the aeromagnetic anomalies has been described in Chapter 6. Two anomaly sites remain somewhat problematic. First, the small aeromagnetic anomaly in southern Crater Flat is a positive anomaly whereas all other basaltic sites in the basin 
have reversed polarity. The buried anomaly could record a brief normal event or it could be produced by buried basaltic rocks that are different in age from the surface centers. The latter interpretation means that there is some uncertainty in the inferred age of this anomaly. Ground magnetic data supplemented by gravity data obtained earlier were collected across this anomaly, which is identified as anomaly 26 on the aeromagnetic data of Kane and Bracken (1983). The amplitude of the anomaly from ground magnetic profiles is almost $1000 \mathrm{nT}$, and the predicted depth to the top of the body is about $200 \mathrm{~m}$ (Langenheim, 1995). Additional ground magnetic data have been collected at the Little Cones directly north of the aeromagnetic anomaly site, by the Center for Nuclear Waste Regulatory Analysis, and suggest the presence of a more extensive buried lava flow. However, this information was not released at the time of completion of this report and could not be included in the report. A second large positive aeromagnetic anomaly in central Crater Flat, as noted earlier, remains unexplained despite the drilling of a 2500-foot exploratory drill hole, $\mathrm{VH}-1$, directly above the anomaly site.

\section{Geoelectric Surveys}

Geoelectric surveys were conducted at the Yucca Mountain site in the early stages of site characterization studies. The locations of these surveys are presented by Oliver et al. (1992). Over 130 Schlumberger soundings have been obtained in an area labeled F on Figure 2.3-1 in Oliver et al. (1992) that covers the southern part of Crater Flat and parts of the Amargosa Valley.

Klein (1995) summarized regional magnetotelluric investigations (MT) by the US Geological Survey that cover all or parts of the YMR. These surveys extend from Death Valley east across the Amargosa Desert, Bare Mountain, Crater Flat, Yucca Mountain and Jackass Flats, and include MT measurements made in 1986 that were centered on Yucca Mountain (Klein, 1995; his Fig. 4.1). The MT data from Furgerson (1982) show conductive anisotropy aligned in west to northwest directions and secondarily conductive zones aligned in northeast directions. These data are consistent with faults or fractures associated with the Walker Lane structural system that are either significantly altered or contain anomalous concentrations of conductive fluids (Klein, 1995). The one-dimensional interpretations of MT data show significant discontinuities in structure including a deep low-resistivity zone at depths between 10 and $30 \mathrm{~km}$ associated with the Amargosa Valley and Jackass Flats that could be related to wet crust or the brittle to ductile crustal transition (Klein, 1995). Two-dimensional MT modeling was completed for soundings across the southern part of Yucca Mountain and shows shallow low-resistivity zone probably associated with westward thickening alluvial and volcanic units (Klein, 1995). This upper crust is electrically homogeneous, and resolution and correlation to specific rock units is limited. Low resistivities in the upper crust could have a variety of interpretations; one that is allowable is the presence of a small degree of partial melt (Klein, 1995; p. 113).

\section{E. Seismic Investigations}

Seismic investigations have included both seismic refraction and seismic reflection surveys (Oliver et al., 1992). The most useful application from these investigations have been summarized in recent papers by Mooney and Schapper (1995) and Brocher et al. (1996).

1. Seismic Refraction. Five seismic refraction profiles were obtained in the vicinity of the Yucca Mountain site including two refraction profiles collected in 1983 along N-S and E-W orientations across Crater Flat (Ackerman and others, 1988) and three profiles acquired in 1985: one across Yucca Mountain, the second along Fortymile Wash, and the third in an E-W direction 
across the Amargosa Valley directly south of Yucca Mountain (Mooney and Schapper, 1995). The results of the seismic profiles were described by Mooney and Schapper (1995). They attempted to integrate the seismic data with intersecting seismic profiles, gravity data, and information from five drill holes. The data show that Yucca Mountain is an uplifted, east-tilted volcanic plateau that is located above and at the east edge of a west-thickening sequence of basin-fill deposits of the Crater Flat basin. In most cases the velocity contrast between the Cenozoic volcanic deposits and basin fill with the pre-Cenozoic strata is large so that seismic data provide a reliable representation of the geometry of this contact. The Crater Flat depression is an asymmetric, westward-deepening structure with a maximum thickness of about $3.5 \mathrm{~km}$ of Cenozoic fill (Mooney and Schapper, 1995). However, at shallow depths velocities of pre-Cenozoic rocks can decrease and become difficult to separate from the Cenozoic rocks. For example, the Paleozoic rocks at the pre-Cenozoic contact in drill hole UE-25p\#1 are fractured and brecciated with no appreciable velocity contrast at the contact (Mooney and Schapper, 1995). In this case gravity data (Snyder and Carr, 1984) provide a more accurate approximation of the pre-Cenozoic contact. South of Yucca Mountain the seismic data allow interpretation of a higher-standing pre-Cenozoic surface in close agreement with the gravity model of Snyder and Carr (1984). Seismic layers within the Cenozoic volcanic section do not conform to formation boundaries except for the top and bottom of the Crater Flat Group. A buried basaltic center was probably intersected at the south end of the Fortymile Wash profile, and the location of the center coincides with an aeromagnetic anomaly (Mooney and Schapper, 1995). Mooney and Schapper (1995) discuss evidence of detachment faults in the seismic reflection profiles and conclude that a single detachment surface has not been active during the Cenozoic in the YMR, but further resolution would require additional high-quality seismic reflection data.

2. Seismic Reflection. Seismic reflection studies have been used primarily to examine shallow structure in the Yucca Mountain area. Recently acquired test lines that provide data on the deeper structure (up to 15 seconds) have been run in the Amargosa Valley (Oliver et al., 1992). Brocher et al. $(1990,1993)$ described the results of a $27-\mathrm{km}$ seismic reflection profile across the Amargosa Valley. The line crossed three Cenozoic alluvial basins. Interpretations of the line were concerned primarily with extensional structures. A laterally continuous, near-flat-lying reflector at 100 to $200 \mathrm{~m}$ was interpreted as a basalt flow, a flow that probably is part of the BSE. Brocher et al. (1993) reported a large-amplitude reflection or midcrustal bright spot on the seismic reflection profile. While the reflection could be interpreted as a midcrustal magma body, Brocher et al. (1993) argue that the Amargosa Valley and a similar anomaly in Death Valley are caused by focusing of energy reflected from the midcrust by low-velocity basin fill lying above the bright spot (see also Hamilton, 1988).

Brocher et al. (1996, in press) described the preliminary interpretations of regional seismic reflection lines collected across Yucca Mountain (37 km of seismic lines). The objectives of this study were to evaluate the Cenozoic/pre-Cenozoic contact, identify and evaluate faults in the subsurface, and gather subsurface data related to alternative tectonic models of the Yucca Mountain setting. Two seismic lines were acquired. The first ran from the Amargosa Desert on the southwest, across Steve's pass and Crater Flat to Yucca Mountain, intersecting drill hole VH-1 and terminating near well UE25 UZ-16 (26 km length). The second line extended from drill hole USW H-6 on the east side of Solitario Wash to the east through drill hole UE25p\#1 and into Jackass Flat. The top of the Paleozoic section (Cenozoic/pre-Cenozoic contact) can be traced discontinuously in the seismic reflection data and is offset by moderate-to steep dipping faults. Brocher et al. (1996, in press) note that the offset of this surface by high-angle faults indicates it does not represent an active detachment fault as proposed by many proponents of the detachment models. The upper volcanic section in southwest Crater Flat is above an angular unconformity that 
deepens westward. The unconformity lies above deposits of the Tiva Canyon member of the Paintbrush Group in drill hole USW-VH-1 (Brocher et al., 1996), an observation that is consistent with field relations between the Timber Mountain and Paintbrush Groups (Scott, 1990; Fridrich, in preparation). The seismic reflection data of Brocher et al. (1996) verify interpretations from gravity and seismic refraction data (Ponce and Oliver, 1995; Mooney and Schapper, 1995) that Crater Flat is an asymmetrical basin and is deeper on the west and shallower to the east. The higher resolution reflection data suggest, with support from magnetic studies, that the east side of the basin is offset along a series of west-down, west-dipping normal faults. Further, tracing of inferred volcanic units of the Paintbrush Group shows that the east edge of the Crater Flat basin extended originally under Yucca Mountain, consistent with gravity data (Snyder and Carr, 1984; Fridrich, in preparation) but the modern basin-edge has migrated westward.

Two observations from the seismic reflection data are important for volcanism studies in the YMR. First, the Pliocene and Quaternary basalt centers of Crater Flat are above the deepest parts of the Crater Flat basin and are near areas of east-dipping normal faults (Brocher at al., 1996; Brocher et al., in press). The basalt centers tend to occur mostly along or near structural features of the western part of the basin. Second, reflective lower crust is imaged only on the southwest end of the seismic lines where the depth to reflective lower crust is about $15 \mathrm{~km}$, and the Moho is between 27 and $30 \mathrm{~km}$ (Brocher et al., 1996). However, the reflection studies do not provide an image of the lower crust in the vicinity of Yucca Mountain. Brocher et al. (1996) did note, however, that there is no evidence of bright-spot reflectors as observed in the Amargosa Valley seismic reflection survey (Brocher et al., 1993).

\section{F. Teleseismic Studies}

Teleseismic tomography has been used to explore the three-dimensional seismic properties of the YMR (Iyer, 1988; Montfort and Evans, 1982). The recent reports by Evans and Smith (1992, 1995) have the most application to evaluations of volcanism studies for the Yucca Mountain site. While the results of teleseismic tomography can be ambiguous, the method has been the most successful of geophysical techniques used for delineating large volume magma bodies (> several tens of $\mathrm{km}^{3}$ ) in the crust or mantle (Iyer, 1988).

Evans and Smith (1992) described the results of analyzing analog teleseismic data from 1979 to 1980 and digital data collected in 1982. They noted two large velocity anomalies. The first is centered beneath the Silent Canyon caldera and the northern part of the Timber Mountain caldera. The body is present near the depth of the Moho downward to about $200 \mathrm{~km}$. This high-velocity body has been noted in many previous studies (Spence, 1974; Montfort and Evans, 1982; Taylor, 1983). It has been interpreted as the crystallized roots of silicic calderas and the depleted "paleomagma pathway" through the lower crust and mantle below the coalesced calderas. The second anomaly is a velocity low inferred to be in the lower crust and upper mantle. It is centered south and southeast of Yucca Mountain and Crater Flat (Evans and Smith, 1992, Fig. 3.3). Evans and Smith (1992) suggest that this velocity low trends east/west to northeast/southwest. They argue it may extend to an area of Pliocene and Quaternary basaltic volcanism near St. George, Utah (Dueker and Humphreys, 1990). Humphreys and Dueker (1994a) note that the seismic velocity of the upper mantle of the western U.S. is considerably slower than the upper mantle beneath the North American craton. In a companion paper, Humphreys and Dueker (1994b) infer from $P$ wave imaging that the lower velocity upper mantle beneath the continental interior of the western U.S. trends northeast, discordant to tectonic structure but consistent with the distribution of young 
volcanic activity. They suggest that the mantle trends are a consequence of partial melt variations enhanced by compositional variations.

A third significant observation from the teleseismic tomography data is the presence of lowvelocity material in the crust beneath and east of the Solitario Canyon area (Evans and Smith, 1992). They argue that this feature is most likely related to the eastern edge of an inferred caldera or volcano-tectonic depression in Crater Flat based on the caldera model of Carr $(1988,1990)$. A more likely interpretation given new information is that the feature noted by Evans and Smith (1992) is simply the buried edge or basin-margin of the pre-Paintbrush Crater Flat basin (Brocher et al., 1996; Fridrich, in preparation).

Evans and Smith (1995) provided a more recent summary of their teleseismic studies of the Yucca Mountain region. In this paper, similar to their previous study, they identified two large velocity anomalies. The first is the previously noted high-velocity body beneath the Silent Canyon caldera and the northern part of the NTS; they describe the anomaly as circular in plan view and about 3\% above the mean mantle velocities (Evans and Smith, 1995; p. 182). Their second anomaly is also the previously described low-velocity anomaly south of Crater Flat, and they argue that it is an elongate anomaly (E-W to NE-SW) that is about $3 \%$ slower than the surrounding mantle. They suggest that the low-velocity anomaly flanks the southern part of the NTS and joins the Crater Flat basin from the south. Evans and Smith (1995) also note a poorly resolved, highvelocity body beneath the Funeral Mountains but on the edge of their teleseismic study and suggest the anomaly could be related to detachment processes in Death Valley. On a local scale, Evans and Smith (1995) identify high velocity perturbations associated with Paleozoic rocks at Bare Mountain and a low associated with the Crater Flat basin. They argue that their data show that the east edge of the Crater Flat basin is between Solitario Canyon and Fortymile Wash. Evans and Smith (1995) used an iterative procedure to remove the effects of the low density basin fill of Crater Flat and find that a low-velocity anomaly remains in the middle and lower crust beneath Crater Flat. They argue that this low-velocity anomaly is, therefore, not an artifact of their inversions nor can it be produced by the basin fill of Crater Flat. Evans and Smith (1995) suggest that their teleseismic data are more consistent with the Crater Flat basin being a caldera complex, an interpretation that is somewhat different than most other workers (see earlier sections). They further argue, drawing on the work of Carr $(1984,1988,1990)$, that the Spotted Range-Mine Mountain section of the Walker Lane structural system may provide structurally controlled pathways for basaltic magma.

Evans and Smith (1992) note that the large low-velocity anomaly may be partial melt that represents the source of the basaltic magma that formed the volcanic centers in Crater Flat. They suggest further, that the location of the Crater Flat field is controlled by the intersection of the Walker Lane structural zone and the Spotted Range-Mine Mountain subzone and, again because of the correlation with the data of Dueker and Humphreys (1990), that the low-velocity anomaly forms a track subparallel to the hot-spot vector of the North America plate with a concentration of volcanic activity at both ends of the anomaly. This track corresponds to the St. George Volcanic Trend (SGVT) of Humphreys and Dueker (1994a,b). In their later paper, Evans and Smith (1995) provide several alternative interpretations of the source of their low velocity anomaly including a weak hot-spot trace, a deep Proterozoic plate structure, a mantle convection roll, or an effect of fragmentation of old subducted plates. 
The low-velocity teleseismic anomaly, if produced by magma, is very large-on a scale approaching the size of continental or oceanic hotspots. If it exists, it would represent a large heat source possibly capable of generating significant future volumes of presumably basaltic magma. The east/west to north/northeast trend of the proposed anomaly is parallel to volcanic features of the southwest United States that have been interpreted to track motion of the North American plate (Smith and Luedke, 1984; Spence and Gross, 1990; Humphreys and Dueker, 1994a,b). The presence of sites of Quaternary basaltic activity at the ends of the anomaly are analogous to the patterns of magmatism in the Great Basin, which are concentrated at the east and west margins (Best and Brimhall, 1974). The tectonic setting of Crater Flat near the intersection of possible buried northwest-trending right-slip faults and the zone of northeast-trending left-slip faults may be conducive to the transmittal of magma through the upper crust.

However, when examined in detail, the proposed low-velocity anomaly has inconsistencies with the geologic and geophysical record of the region. Multiple lines of evidence are inconsistent with a long-lived magma body. The center of the anomaly is south of the YMR region where there is no Pliocene or Quaternary basaltic volcanism. The anomaly area coincides with the area of the amagmatic gap of the southern Great Basin, which is an anomalous area that exhibited no Cenozoic volcanism during intense episodes of extension (Guth, 1981; Wernicke et al., 1988). Much of the anomaly is located beneath the Las Vegas shear zone, a structure proposed by Evans and Smith (1992) to have influenced the shallow rise of basaltic magma. However, no record of basaltic magma is present anywhere along the length of this zone. The proposed anomaly overlaps in location with the major step in the regional gravity field, the trend of which partly parallels the low velocity anomaly. Further, this area was probably positioned above a zone of incoherent slab or a slab gap during the period of extension and silicic volcanism to the north (Severinghaus and Atwater, 1990).

Continuing, the shape of the anomaly and its extension to the east and northeast do not appear obvious from the data of Evans and Smith (1992, their Fig. 3.3). The low velocity zone appears better defined in adjoining areas of Death Valley and southern and southeast Nevada then in adjoining areas of east Nevada and western Utah. The volume of surface volcanism associated with the low-velocity anomaly is extremely small. In fact, the total volume of Pliocene and Quaternary basalt magma erupted in Crater Flat is about $1 \mathrm{~km}^{3}$ (Crowe et al., 1995). This is about equal to the volume of the basalt of Buckboard Mesa, which is a 3.0 Ma center formed near the interior of the high-velocity anomaly inferred to be the cooled residuum from magma production and ascent associated with caldera eruptions. These volumes of magma are trivial to virtually insignificant compared to the volcanic record of other hotspot traces. Detailed time-volume and petrologic studies of the basalt cycles of Crater Flat suggest a history of waning volcanism that appears inconsistent with a large body of partial melt in the lower crust and upper mantle (Perry and Crowe, 1992; Crowe et al., 1995; see Chapter 4).

The continuing and systematic upgrading of the SGBSN to a digital three-component network (for example, Smith et al., 1995) has allowed acquisition of higher resolution teleseismic data for the YMR. To date, data acquisition and processing is too preliminary to provide a comprehensive assessment of the data and interpretations of Evans and Smith (1992) and Evans et al. (1995). However, several preliminary observations can be provided. First, the magnitude of the teleseismic low velocity zone for the YMR may be partly an artifact of the domain depth used by Evans and Smith (1992). Evaluations of the same data set show that the low-velocity anomaly changes from a $3.6 \%$ velocity low compared to surrounding mantle-crust to a $2.8 \%$ difference with, respectively, a $41 \mathrm{~km}$ versus a $60 \mathrm{~km}$ depth domain. Second, some of the teleseismic delays may be attributed to 
regionally extensive and relatively shallow structure. Third, data reduction methods used by Evans and Smith (1992) may artificially increase amplitudes of teleseismic anomalies, and the anomaly may not be as significant as they suggest (for example, Biasi and Humphreys, 1992).

There is no recognized surface expression of the low-velocity zone either in the topography or structure of rocks of southern Nevada. If there is truly a large mass of partially molten rock in southern Nevada comparable to a hotspot trace, it could have only formed recently and not modified the shallow crust. Yet, there is no modern recognized tectonic or magmatic process inferred to be affecting the southern Great Basin that would logically lead to formation of such a body. It would have to be formed by a secondary upwelling of mantle material long post-dating the time of most intense volcanic and tectonic activity. Isotopic data for the southern Great Basin show it to be an area of preserved lithospheric mantle with no evidence of a significant asthenospheric component except for Miocene basaltic rocks east of Frenchman flat (Farmer et al., 1989; Jones et al., 1992).

Seismic refraction and reflection lines in the Amargosa Valley overlap the northern part of the teleseismic low-velocity anomaly. No evidence from these seismic profiles (Brocher et al., 1993) imaged the inferred magma body of Evans and Smith (1992). Finally, perhaps the most compelling argument against the magmatic model of Evans and Smith (1992) is the unusually great depth to the basal horizon of magnetic sources calculated by Blakely (1988). This regional anomaly contrasts markedly with the Battle Mountain high, an area of high heat flow, young volcanism, recent faulting, and shallow basal depth of magnetic sources.

The evidence in support of magmatic origin of the teleseismic anomalies of Evans and Smith $(1992 ; 1995)$ are not sufficiently compelling to require priority attention in volcanism studies. A magmatic origin of the $P$-wave low-velocity zones is not unique-other interpretations are possible. The presence of low-velocity teleseismic $P$ wave travel time residuals in the upper mantle is not unique to the Yucca Mountain setting-these types of anomalies are common throughout the Basin and Range province. The more important issue is whether the teleseismic anomalies represent a relatively recent (Quaternary) phenomenon and if their existence reflects the operation of magmatic processes that are not recorded in the geologic and volcanic record of the YMR. The presence of multiple zones of northeast-trending imaged mantle structure suggests that the anomalies developed from regional processes (Humphreys and Dueker, 1994a,b). The chronology of volcanic activity in well studied northeast-trending structural zones (Snake River Plains, Jemez Volcanic Zone) shows that these zones have been active during a significant part of the Cenozoic; there is no evidence to suggest the zones have developed exclusively in the late Cenozoic. To the contrary, the most compelling segment of the volcanic record that may be consistent with the formation and expression of a major zone of partial melt in the mantle is the Miocene pulse of silicic volcanic activity that formed the SNVF. There appears to be no reason to suspect that the mantle anomalies in the YMR, if they exist, have developed exclusively in Late Cenozoic time.

\section{G. Thermal Studies}

Thermal studies of the YMR have been conducted for the YMP and for the NTS for several decades (Sass et al., 1995). The Yucca Mountain site, as noted in a previous section, is located on the southwest edge of the Eureka Low, a large heat-flow minimum that has been attributed to hydrologic effects (Sass et al., 1987, 1995). Blakely (1988), however argues, based on analyses of aeromagnetic data, that the Eureka Low is correlated with an area of unusually deep Curie 
temperature, and this would not be expected if the thermal low is exclusively a result of nearsurface hydrologic phenomena.

Sass et al. (1995) note that attempts to measure and characterize the background heat flow in the YMR have been complicated by evidence from temperature profiles of effects of ground water flow. They argue that the low heat flow observed at and near Yucca Mountain results from capture of heat by water flow at depth in the Paleozoic carbonate aquifer. They note, however, that the low and variable heat flow is not suggestive of active tectonic processes but instead is a result of the complexity of the structural and tectonic setting of the Yucca Mountain site. Sass et al. (1995) note two areas of unusual heat flow that have not been adequately studied. These are at drill hole UE$25 a \# 3$ in the Calico Hills area directly north of central Jackass Flats, where observed heat flow values are about 50\% higher than typical regional values, and in Crater Flat near areas of Quaternary basaltic volcanism. At the latter site, Sass et al. (1995) noted that temperature logs in drill holes $\mathrm{VH}-1$ and $\mathrm{VH}-2$ are too distorted by water flow to allow interpretations but argue that the Quaternary volcanism is too small in volume and likely thermal energy to be source of significant modification of heat flow.

\section{References}

Ackerman, H.D., W.D. Mooney, D.B. Snyder, and V.D. Sutton, "Preliminary Interpretation of Seismic Refraction and Gravity Studies West of Yucca Mountain, Nevada and California," in US Geological Survey Bulletin 1790: Short Contributions to the Geology and Hydrology of a Potential Nuclear Waste Site at Yucca Mountain, Southern Nevada, M.D. Carr and J.C. Yount, Eds. (Department of Interior, US Geological Survey, Reston, Virginia, 1988) pp. 23-33.

Anderson, J.G., J.N. Brune, J.N. Louie, Y. Zeng, M.K. Savage, G. Yu, Q. Chen, D. dePolo, "Seismicity Triggered By The Landers, California, Earthquake, 28 June, 1992," Bulletin of the Seismological Society of America 84, 863-891 (1994).

Anderson, R.E., "Thin Skin Distension in Tertiary Rocks of Southeastern Nevada," Geological Society of America 82, 43-58, (1971).

Arabasz, W.J., and D.R. Julander, "Geometry of Seismically Active Faults and Crustal Deformation Within the Basin and Range-Colorado Plateau Transition in Utah," Geological Society of America Special Paper 208: Extensional Tectonics of the Southwestern United States: A Perspective on Processes and Kinematics, L. Mayer Ed. (Geological Society of America, Boulder, Colorado, 1986), pp. 43-74.

Armstrong, R.L. "Cordilleran Metamorphic Core Complex-From Arizona to Southern California," Annual Review of Earth Planetary Sciences 10, 129-154 (1982).

Armstrong, R.L. and P. Ward, "Evolving Geographic Patterns of Cenozoic Magmatism in the North American Cordillera; The Temporal and Spatial Association of Magmatism and Metamorphic Core Complexes," Journal of Geophysical Research 96, 13,201-13,224 (1991).

Armstrong, R.L., E.B. Ekren, E.H. McKee, and D.C. Noble, "Space-Time Relations of Cenozoic Silicic Volcanism in the Great Basin of the Western United States," American Journal of Science 267, 478-90 (1969).

Atwater, T., "Implications of Plate Tectonics for the Cenozoic Tectonic Evolution of Western North America," Geological Society of America 81, 3513-3536 (1970). 
Axen, G.J., W.J. Taylor, and J.M. Bartley, "Space-Time Patterns and Tectonic Controls of Tertiary Extension and Magmatism in the Great Basin of the Western United States," Geological Society of America 105, 56-76 (1993).

Bailey, R.A., G.B. Dalrymple, and M.A. Lanphere, "Volcanism, Structure, and Geochronology of Long Valley Caldera, Mono County, California," Journal of Geophysical Research 81, 725-744 (1976).

Bath, G.D., and C.E. Jahren, "Interpretations of Magnetic Anomalies at a Potential Repository Site Located in the Yucca Mountain Area, Nevada Test Site," US Geological Survey Open-File report 84-120, pp. 1-40 (1984).

Bath, G.D., "Aeromagnetic Anomalies Related to Remanent Magnetism in Volcanic Rock, Nevada Test Site," in Geological Society of America Memoir 110: Nevada Test Site, E.B. Eckel, Ed. (Geological Society of America Boulder, Colorado, 1968), pp. 135-146.

Bath, G.D., and C.E. Jahren, "Investigation of an Aeomagnetic Anomaly On West Side of Yucca Mountain, Nye County, Nevada," US Geological Survey Open-File report 85-459, pp. 1-24 (1985).

Benz, H.M., R.B. Smith, and W.D. Mooney, "Crustal Structure of the Northwestern Basin and Range Province from the 1986 Program for Array Seismic Experiment," Journal of Geophysical Research 95, 21823-21842 (1990).

Best, M.G., and W.H. Brimhall, "Late Cenozoic Alkalic Basaltic Magmas in the Western Colorado Plateaus and the Basin and Range Transition Zone, USA, and their Bearing on Mantle Dynamics," Geological Society of America 85, 1677-1690 (1974).

Best, M.G., and E.H. Christiansen, "Limited Extension During Peak Tertiary Volcanism Great Basin of Nevada and Utah," Journal of Geophysical Research 96, 13,509-13,528 (1991).

Best, M.G., and W.K. Hamblin, "Origin of the Northern Basin and Range Province: Implications from the Geology of its Eastern Boundary," in Geological Society of America Memoir 152: Cenozoic Tectonics and Regional Geophysics of the Western Cordillera, R.B. Smith, and G.P. Eaton, Eds. (Geological Society of America, Boulder, Colorado, 1978), pp. 313-340.

Biasi, G.P., and E. Humphreys, "P-Wave Image of the Upper Mantle Structure of Central California and Southern Nevada," Geophysical Research Letters 19, 1161-1164 (1992).

Blackwell, D.D., "Heat Flow and Energy Loss in the Western United States," in Geological Society of America Memoir 152: Cenozoic Tectonics and Regional Geophysics of the Western Cordillera, R.B. Smith, and G.P. Eaton, Eds. (Geological Society of America, Boulder, Colorado, 1978), pp. 175-208.

Blakely, R.J., "Curie Temperature Isotherm Analysis and Tectonic Implications of Aeromagnetic Data from Nevada," Journal of Geophysical Research 93, 11,817-11832 (1988).

Bodin, P., and J. Gomberg, "Triggered Seismicity and Deformation Between the Landers, California, and Little Skull Mountain, Nevada, Earthquake," Bulletin of the Seismological Society of America 84, 835843, (1994).

Brocher, T.M., P.E. Hart, and S.F. Carle, "Feasibility Study of the Seismic Reflection Method in Amargosa Desert, Nye County, Nevada," US Geological Survey Open-File report 89-133, pp. 1-150 (1990). 
Brocher, T.M., M.D. Carr, K.F. Fox Jr., and P.E. Hart, "Seismic Reflection Profiling Across Tertiary Extensional Structures in the Eastern Amargosa Desert, Southern Nevada, Basin and Range Province," Geological Society of America 105, 30-46 (1993).

Brocher, T.M., P.E. Hart, W.C. Hunter, and V.E. Langenheim, "Hybrid-Source Seismic Reflection Profiling Across Yucca Mountain, Nevada: Regional Lines 2 and 3," US Geological Survey Open File report 96-28 pp. 1-110 (1996)

Brocher, T.M., W.C. Hunter, and V.E. Langenheim "Structural Framework of Yucca Mountain, Nevada Based on Crustal-Scale Seismic Reflection Profiles and Potential Field Data," Geological Society of America (in press).

Byers, F.M., Jr., and H. Barnes, "Geologic Map of the Paiute Ridge Quadrangle, Nye and Lincoln Counties, Nevada,” US Geological Survey Quadrangle Map GQ-577 (1967).

Byers, F.M., Jr., W.J. Carr, P.P. Orkild, W.D. Quinlivan, and K.A. Sargent, "Volcanic Suites and Related Cauldrons of Timber Mountain-Oasis Valley Caldera Complex, Southern Nevada," US Geological Survey Professional Paper 919, 70 pp. (1976).

Byers, F.M., Jr., W.J. Carr and P.P. Orkild, "Volcanic Centers of Southwestern Nevada: Evolution of Understanding, 1960-1988," Journal of Geophysical Research 94(B5), 5908-5924 (1989).

Carr, W.J., "Summary of Tectonic and Structural Evidence for Stress Orientation at the Nevada Test Site," US Geological Survey Open-File report 74-176, pp. 1-83 (1974).

Carr, W.J., "Volcano-Tectonic History of Crater Flat, Southwestern Nevada, as Suggested by New Evidence from Drill Hole Usw-Vh-1 and Vicinity," US Geological Survey Open-File report 82-457, pp. $1-58$ (1982).

Carr, W.J., "Regional Structural Setting of Yucca Mountain, Southwestern Nevada, and Late Cenozoic Rates of Tectonic Activity in Part of the Southwestern Great Basin, Nevada and California," US Geological Survey Open-File report 84-854, pp. 1-109 (1984).

Carr, W.J., "Volcanic-Tectonic Setting of Yucca Mountain and Crater Flat, Southwestern Nevada," in US Geological Survey Bulletin 1790: US Geologic and Hydrologic Investigations of a Potential Nuclear Waste Disposal Site at Yucca Mountain, Southern Nevada, M.D. Carr and J.C. Yount, Eds., 35-49 (Department of Interior, US Geological Survey, Reston, Virginia, 1988), pp. 35-49.

Carr, W.J., "Styles of Extension in the Nevada Test Site Region, Southern Walker Lane Belt; An Integration of Volcano-Tectonic and Detachment Fault Models," in Geological Society of America Memoir 176: Basin and Range Extensional Tectonics Near the Latitude of Las Vegas, Nevada, B.P. Wernicke, Ed. (Geological Society of America, Boulder, Colorado, 1990), pp. 283-303.

Carr, W.J., and L.D. Parrish, "Geology of Drill Hole USW VH-2, and Structure of Crater Flat, Southwestern Nevada," US Geological Survey Open-File report 85-475, pp. 1-41 (1985).

Carr, W.J., F.M. Byers Jr., and P.P. Orkild, "Stratigraphic and Volcano-Tectonic Relations of Crater Flat Tuff and Some Older Volcanic Units Nye County, Nevada," US Geological Survey Open-File report 84-114, pp. 1-42 (1984).

Carr, W.J., F.M. Byers, Jr., and P.P. Orkild, "Stratigraphic and Volcano-Tectonic Relations of Crater Flat Tuff, and Some Older Volcanic Units, Nye County, Nevada," US Geological Survey Professional Paper 1323, 28 pp. (1986). 
Carr, M.D., and S.A. Monsen, "A Field Trip Guide to the Geology of Bare Mountain," in This Extended Land Geological Society of America Cordilleran Section Meeting, Field Trip Guidebook:, 1988,

D.L. Weide, and M.L. Faber, Eds. (University of Nevada at Las Vegas Geoscience Department Special Publication 2, 1988), pp. 50-57.

Christiansen, R.L., and P.W. Lipman, "Cenozoic Volcanism and Plate Tectonic Evolution of the Western United States, II, Late Cenozoic," Philosophical Transactions of the Royal Society London Series A 271, 249-284 (1972).

Christiansen, R.L., P.W. Lipman, W.J. Carr, F.M. Byers, Jr., P.P. Orkild, and K.A. Sargent, "The Timber Mountain-Oasis Caldera Complex of Southern Nevada," Geological Society of America 88, 943-959 (1977).

Christiansen, T.L., and E.H. McKee, "Late Cenozoic Volcanic and Tectonic Evolution of the Great Basin and Columbia Intermontane Regions," in Geological Society of America Memoir 152: Cenozoic Tectonics and Regional Geophysics of the Western Cordillera, R.B. Smith, and G.P. Eaton, Eds. (Geological Society of America, Boulder, Colorado, 1978), pp. 283-311.

Coney, P.J., "Mesozoic-Cenozoic Cordilleran Plate Tectonics," in Geological Society of America Memoir 152: Cenozoic Tectonics and Regional Geophysics of the Western Cordillera: Cenozoic Tectonics and Regional Geophysics of The Western Cordillera, R.B. Smith, and G.P. Eaton, Eds. (Geological Society of America, Boulder, Colorado, 1978), pp. 33-49.

Coney, P.J., and Harms, T.A., "Cordilleran Metamorphic Core Complexes: Cenozoic Extensional Relics of Mesozoic Compression," Geology 12, 550-554 (1984).

Connor, C.B., "Cinder Cone Clustering in the Transmexican Volcanic Belt: Implications for Structural and Petrologic Models," Journal of Geophysical Research 95, 19,395-19,405 (1990).

Connor, C.B., C.D. Condit, L.S. Crumpler, and J.C. Aubele, "Evidence of Regional Structural Controls on Vent Distribution: Springerville Volcanic Field, Arizona," Journal of Geophysical Research 97, 12,34912,359 (1992).

Connor, C.B., and B.E. Hill, "Estimating the Probability of Volcanic Disruption of the Candidate Yucca Mountain Repository Using Spatially and Temporally Non Homogeneous Poisson Models," in

Proceedings Site Characterization and Model Validation Focus'93 Symposium Volume (American Nuclear Society, La Grange Park, Illinois, 1993).

Connor, C.B., and B.E. Hill, "Three Nonhomogeneous Poisson Models for the Probability of Basaltic Volcanism: Application to the Yucca Mountain Region, Nevada," Journal of Geophysical Research 100, 10,107-10,125 (1995).

Crittendon, M.D., Jr., P.J. Coney, and G.H. Davis, Eds., Geological Society of America Memoir 153: Cordilleran Metamorphic Core Complexes (Geological Society of America, Boulder, Colorado, 1980), 490 pp.

Crowe, B.M., "Cenozoic Volcanic Geology and Probable Age of Inception of Basin-Range Faulting in the Southeasternmost Chocolate Mountains, California," Geological Society of America 89, 251-264 (1978).

Crowe, B.M., "Volcanic Hazard Assessment for Disposal of High-level Radioactive Waste," in Recent Tectonics: Impact on Society (National Academy Press, Washington, D.C., 1986), Chap. 16, pp. 247-260. 
Crowe, B.M., "Basaltic Volcanic Episodes of the Yucca Mountain Region," in High Level Radioactive Waste Management: Proceedings of the First Annual International Topical Meeting, April 8-12, 1990 (American Nuclear Society, La Grange Park, Illinois, 1990), pp. 65-73.

Crowe, B.M., "Study Plan for Probability of Magmatic Disruption of the Repository," Los Alamos National Laboratory YMP-LANL-SP 8. 3. 1. 8. 1. 1, R2 48 pp. (1993).

Crowe, B.M., and W.J. Carr, "Preliminary Assessment of the Risk of Volcanism at a Proposed Nuclear Waste Repository in the Southern Great Basin," US Geological Survey Open-File report 80-375 (1980).

Crowe, B.M. and F.V. Perry, "Volcanic Probability Calculations for the Yucca Mountain Site: Estimation of Volcanic Rates," in Proceedings Nuclear Waste Isolation in the Unsaturated Zone Focus '89, Symposium Volume (American Nuclear Society, La Grange Park, Illinois, 1989), pp. 326-334.

Crowe, B.M., J.C. Crowell, and D. Krummenacher, "Regional Stratigraphy and K-Ar ages of Cenozoic Volcanic Rocks, Southeastern California,” American Journal Science 279, 186-216 (1979).

Crowe, B.M., D. Vaniman, W.J. Carr, and R.J. Fleck, "Geology and Tectonic Setting of a Neogene Volcanic Belt Within the South Central Great Basin, Nevada and California," Geological Society of America, Abstracts with Programs 93, 409 (1980).

Crowe, B.M., M.E. Johnson, and R.J. Beckman, "Calculation of the Probability of Volcanic Disruption of a High-Level Radioactive Waste Repository Within Southern Nevada, USA," Radioactive Waste Management 3, 167-190 (1982).

Crowe, B.M., D.T. Vaniman, and W.J. Carr, "Status of Volcanic Hazard Studies for the Nevada Nuclear Waste Storage Investigations," Los Alamos National Laboratory report LA-9325-MS (1983a).

Crowe, B.M., K.H. Wohletz, D.T. Vaniman, E. Gladney, and N. Bower, "Status of Volcanic Hazard Studies for the Nevada Nuclear Waste Storage Investigations," Los Alamos National Laboratory report LA-9325-MS, Vol. II (1986).

Crowe, B.M., R. Picard, G. Valentine, and F.V. Perry, "Recurrence Models of Volcanic Events: applications to Volcanic Risk assessment," in High Level Radioactive Waste Management: Proceedings of the Third International Conference, Las Vegas, Nevada, April 12-16, 1992 (American Nuclear Society, La Grange Park, Illinois, 1992), pp. 2344-2355.

Crowe, B., F. Perry, J. Geissman, L. McFadden, S. Wells, M. Murrell, J. Poths, G.A. Valentine, L. Bowker, and K. Finnegan, "Status of Volcanism Studies for the Yucca Mountain Site Characterization Project," Los Alamos National Laboratory report LA-12908-MS, 1-363 (1995).

Dickerson, R.P., and R.W. Spengler, "Structural Character of the Northern Segment of the Paintbrush Canyon Fault," in High Level Radioactive Waste Management: Proceedings of the Fifth Annual International Conference, Las Vegas, Nevada, May 22-26, 1994 (American Nuclear Society, La Grange Park, Illinois, 1994), pp. 2367-2372.

DOE (US Department of Energy), "Site Characterization Plan, Yucca Mountain Site, Nevada Research and Development Area, Nevada," Office of Civilian Radioactive Waste Management report DOE/RW0199, (1988).

Dueker, K. and E. Humphreys, "Upper-Mantle Velocity Structure of the Great Basin," Geophysical Research Letter 17, 1327-1330 (1990). 
Eaton, G.P., "A Plate-Tectonic Model for Late Cenozoic Crustal Spreading in the Western United States," in Rio Grande Rift: Tectonics And Land Magmatism, R.E. Riecker, Ed. (American Geophysical Union, Washington D.C, 1979), pp. 7-32.

Eaton, G.P., "Geophysical and Geological Characteristics of the Crust of the Basin and Range Province," in Continental Tectonics, Studies in Geophysics (National Academy of Sciences, Washington, D.C., 1980), pp. 96-113.

Eaton, G.P., "The Basin and Range Province; Origin and Tectonic Significance," Annual Reviews Earth Planetary Science 10, 409-440 (1982).

Eaton, G.P., R.R. Wahl, H.J. Prostka, D.R. Mabey, and M.D. Kleinkopf, "Regional Gravity and Tectonic Patterns: their Relation to Late Cenozoic Epirogeny and Lateral Spreading in the Western Cordillera," in Geological Society of America Memoir 152: Cenozoic Tectonics And Regional Geophysics Of The Western Cordillera, R.B. Smith, and G.P. Eaton, Eds. (Geological Society of America Boulder, Colorado, 1978), pp. 51-91.

Eckel, E.B., "Development of Geologic Knowledge at Nevada Test Site," in Geological Society of America Memoir 110: Nevada Test Site, E.B. Eckel, Ed. (Geological Society of America Boulder, Colorado, 1968), pp. 5-10.

Ekren, E.B., C.L. Rogers, R.E. Anderson, and P.P. Orkild, "Age of Basin and Range Normal Faults in Nevada Test Site and Nellis Air Force Range, Nevada," in Geological Society of America Memoir 110: Nevada Test Site, E.B. Eckel, Ed. (Geological Society of America, Boulder, Colorado, 1968), pp. 247-250.

Ekren, E.B., P.P. Orkild, K.A. Sargent, and G.L. Dixon, "Geologic Map of Tertiary Rocks, Lincoln County, Nevada,” US Geological Survey Quadrangle Map I-1041 (1977).

Engdahl, E.R., and W.A. Rinehart, "Seismicity Map of North America," Geological Society of America Continent-Scale Map-004 (1988).

Evans, J.R., and M. Smith III, "Teleseismic Tomography of the Yucca Mountain Region: Volcanism and Tectonism," in High Level Radioactive Waste Management: Proceedings of the Third International Conference, Las Vegas, Nevada, April 12-16, 1992 (American Nuclear Society, La Grange Park, Illinois, 1992), pp. 2371-2380.

Evans, J.R., and M. Smith, "Teleseismic Investigations," in Major Results of Geophysical Investigations at Yucca Mountain and Vicinity, Southern Nevada, H.W. Oliver, D.A. Ponce, and W.C. Hunter, Eds. US Geological Survey Open-File report 95-74, pp. 171-198. (1995).

Farmer, G.L., and D.J. DePaolo, "Origin of Mesozoic and Tertiary Granite in the Western United States and Implications for Pre-Mesozoic Crustal Structure: 1. Nd and Sr Isotopic Studies in the Geosyncline of the Northern Great Basin,” Journal of Geophysical Research 88, 3379-3401 (1983).

Farmer, G.L., and D.J. DePaolo, "Origin of Mesozoic and Tertiary Granite in the Western United States and Implications for Pre-Mesozoic Crustal Structure: 2. Nd and Sr Isotopic Studies of Unmineralized and $\mathrm{Cu}$ - and Mo-Mineralized Granite in the Precambrian Craton," Journal of Geophysical Research 89,

10141-10160 (1984).

Farmer, G.L., F.V. Perry, S. Semken, B. Crowe, D. Curtis, and D.J. DePaolo, "Isotopic Evidence on the Structure and Origin of Subcontinental Lithospheric Mantle in Southern Nevada," Journal of Geophysical Research 94, 7885-7898 (1989). 
Fenneman, N.M., Physiography of Western United States (Mcgraw-Hill Book Co. Inc., New York, 1931), $534 \mathrm{pp}$.

Ferrill, D.A., J.A. Stamatakos, S.M. Jones, B. Rahe, H.L. McKague, R.H. Martin, and A.P. Morris, "Quaternary Slip History of the Bare Mountain Fault (Nevada) from the Morphology and Distribution of Alluvial Fan Deposits," Geology 24, 559-562, (1995a).

Ferrill, D.A., G.L. Stirewalt, D.B. Henderson, J.A. Stamatakos, A.P. Morris, B.P. Wernicke, and K.H. Spivey, "Faulting in the Yucca Mountain Region: Critical Review and Analyses of Tectonic Data From the Central Basin and Range," Center for Nuclear Waste Regulatory Analyses report CNWRA 95-017 pp. 1-89 (1995b).

Fox, K.F., Jr., and M.D. Carr, "Neotectonics and Volcanism at Yucca Mountain and Vicinity, Nevada," in Radioactive Waste Management 13, 37-50 (1989).

Fridrich, C., and J. Price, “Tectonic Framework of Crater Flat Basin, Adjacent to Yucca Mountain Nevada: A Preliminary report," Abstract Geological Society of America 23, A189 (1992).

Fridrich, C.J., B.M. Crowe, M.R. Hudson, V.E. Langenheim, and G.A. Thompson, "Structural Control of Basaltic Volcanism in a Region of Oblique Extension, Southwest Nevada Volcanic Field," EOS Transactions, American Geophysical Union, 1994 Fall Meeting 75 (44), 603 (1994).

Fridrich, C.J. "Tectonic Evolution of the Crater Flat Basin, Yucca Mountain Region, Nevada," (in preparation).

Furgerson, R.B,. "Remote-reference Magnetotelluric Survey, Nevada Test Site and Vicinity, Nevada and California, with an Introduction by D.B. Hoover," US Geological Survey Open-File report 82-465 pp. 1-156 (1982).

Gans, P.B., G. Mahood, and E. Schermer, "Synextensional Magmatism in the Basin and Range Province: A Case Study of the Eastern Great Basin," Geological Society of America Special Paper 233 (Geological Society of America, Boulder, Colorado, 1989).

Geomatrix Consultants, Inc., "Probabilistic Volcanic Hazard Analysis for Yucca Mountain, Nevada." Civilian Radioactive Waste Management System, Management and Operating Contractor (TRW), Report BA0000000-01717-2200-00082 (1996).

Golder Associates, "Effect of Structural Controls on Basaltic Volcanism and Eruptive Effects at Yucca Mountain, Nevada," Golder Associates, Redmond, Washington (1995).

Glazner, A.F., and J.A. Supplee, "Migration of Tertiary Volcanism in the Southwestern United States and Subduction of the Mendocino Fracture Zone," Earth and Planetary Sciences Letters 60, 429-436 (1982).

Gomberg, J., "Seismicity and Shear Strain in the Southern Great Basin of Nevada and California," Journal of Geophysical Research 96, 16,383-16,399 (1991a).

Gomberg, J., "Seismicity and Detection/Location Threshold in the Southern Great Basin Seismic Network," Journal of Geophysical Research 96, 16401-16414 (1991b).

Guth, P.L., "Tertiary Extension North of the Las Vegas Valley Shear Zone Sheep and Desert Ranges, Clark County, Nevada," Geological Society of America 92, 763-771 (1981). 
Hamilton, W., "Detachment Faulting in the Death Valley Region, California and Nevada" in US Geological Survey Bulletin 1790: Short Contributions to the Geology and Hydrology of a Potential Nuclear Waste Site at Yucca Mountain, Southern Nevada, M.D. Carr and J.C. Yount, Eds. (Department of Interior, US Geological Survey, Reston, Virginia, 1988), pp. 23-33.

Hamilton, W., and W.B. Myers, "Cenozoic Tectonics of the Western United States," Reviews of Geophysics 4, 509-549 (1966).

Hanna, W.F., R.E. Sweeney, T.G. Hildenbrand, J.G. Tanner, R.K. Mc Connell, and R.H. Godson, "The Gravity Anomaly Map of North America," in The Geology of North America: An Overview, W. Bally and A.R. Palmer, Eds. (Geological Society of America, Boulder, Colorado, 1989).

Harmsen, S.C., "The Little Skull Mountain, Nevada, Earthquake of June 29, 1992: Aftershock Focal Mechanisms and Tectonic Stress Field Implications," Bulletin of the Seismological Society of America 84, 1484-1505, (1993).

Harmsen, S.C. and C.G. Bufe, "Seismicity and Focal Mechanism for the Southern Great Basin of Nevada and California:, 1987 Through 1989,” US Geological Survey Open-File report 91-572, pp. 1-208 (1992).

Harris, A.G., J.E. Repetske, J.L. Clayton, J.A. Grow, M.D. Carr, and T.A. Davis, "Results from 1991 Wildcat Wells near Yucca Mountain, Nevada," Geological Society of America Abstracts with Programs 24, 17 (1992).

Hasenaka T., and I.S.E. Carmichael, "The Cinder Cones and Michoacan-Guanajuato, central Mexico: Their Age, Volume and Distribution, and Magma Discharge Rate," Journal of Volcanology and Geothermal Research 25, 105-124, (1985).

Healey, D.L., and C.H. Miller, "Gravity Survey of the Amargosa Desert Area of Nevada and California," US Geological Survey Technical Letter NTS-99, 32 pp. (1965).

Healey, D.L., R.R. Wahl, and H.W. Oliver, "Death Valley Sheet of Complete Bouguer Gravity Map of Nevada," Nevada Bureau of Mines and Geology Map 68 (1980a).

Healey, D.L., R.R. Wahl, and H.W. Oliver, "Bouguer Gravity Map of Nevada, Death Valley Sheet," Nevada Bureau of Mines and Geology Map 69 (1980b).

Healey, D.L., D.B. Snyder, R.R. Wahl, and F.E. Currey, "Bouguer Gravity Map of Nevada; Caliente Sheet," Nevada Bureau of Mines Map M70 (1981).

Healey, D.L., R.H. Harris, D.A. Ponce, and H.W. Oliver, "Complete Bouguer Gravity Map of the Nevada Test Site and Vicinity, Nevada,” US Geological Survey Open-File report 87-506 (1987).

Henrichs, E.N., and E.J. McKay, "Geologic Map of the Plutonium Valley Quadrangle, Nye and Lincoln Counties Nevada," US Geological Survey Geologic Quadrangle Map GQ-384, Scale 1:24,000 (1965).

Hildenbrand, T.G., A.M. Rogers, H.W. Oliver, S.C. Harmsen, J.K. Nakata, D.S. Aitken, R.N. Harris, and M.D. Carr, "Regional Geologic and Geophysical Maps of the Southern Great Basin," in US Geological Survey Bulletin 1790: Geologic and Hydrologic Investigations of a Potential Nuclear Waste Disposal Site at Yucca Mountain, Southern Nevada M.D. Carr, and J.C. Yount, Eds. (Department of Interior, US Geological Survey, Reston, Virginia, 1988), pp. 3-21.

Hildenbrand, T.G., and R.P. Kucks, "Total Intensity Magnetic Anomaly Map of Nevada," Nevada Bureau of Mines and Geology Map 93a (1988). 
Hill, D.P., "Contemporary Block Tectonics; California and Nevada," Journal of Geophysical Research 87, 5433-5450 (1982).

Ho, C.H., "Risk Assessment for the Yucca Mountain High-Level Nuclear Repository Site: Estimation of Volcanic Disruption," Mathematical Geology 24, 347-364 (1992).

Hodges, K.V., and J.D. Walker, "Petrologic Constraints on the Unroofing History of the Funeral Mountain Metamorphic Core Complex, California," Journal of Geophysical Research 95, 8437-8445

(1990).

Holbrook, W.S., "The Crustal Structure of the Northwestern Basin and Range Province, Nevada, from Wide-angle Seismic Data,” Journal of Geophysical Research 95, 21,843-21,869 (1990).

Hudson, M.R., and J.W. Geissman, "Paleomagnetic and Structural Evidence for the Middle Tertiary Counterclockwise Block Rotation in the Dixie Valley Region, West-Central Nevada," Journal of Geology 15, 638-642 (1987).

Hudson, M.R., and J.W. Geissman, "Paleomagnetic Evidence for the Age and Extent of Middle Tertiary Counterclockwise Rotation Dixie Valley Region, West Central Nevada," Journal of Geophysical Research 96, 3979-4006 (1991).

Humphreys, E.D., and K.G. Dueker, "Western US Upper Mantle Structure," Journal of Geophysical Research 99, 9615-9634 (1994a).

Humphreys, E.D., and K.G. Dueker, "Physical State of the Western US Upper Mantle," Journal of Geophysical Research 99, 9635-9650 (1994b).

Iyer, H.M., "Seismological Detection and Delineation of Magma Chambers Beneath Intraplate Volcanic Centers in Western U.S.A." in Modeling of Volcanic Processes, C.Y. King and R. Scarpa, Eds.

(R. Vieweg und Sohn, Wiesbaden, 1988), pp. 1-56.

Jones, J.H., B.P. Wernicke, G.L. Farmer, J.D. Walker, D.S. Colman, L.W. Mckenna, and F.V. Perry, "Variations Across and Along a Major Continental Rift: An Interdisciplinary Study of the Basin and Range Province, Western USA," Tectonophysics 213, 57-96 (1992).

Kane, M.F., D.L. Healey, D.L. Peterson, H.E. Kaufmann, and D. Reidy, "Bouguer Gravity Map of Nevada, Las Vegas Sheet," Nevada Bureau of Mines and Geology Map 61, scale 1:250,000 (1979).

Kane, M.F., and Bracken, R.E., "Aeromagnetic Map of Yucca Mountain and Surrounding Regions, Southwest Nevada," US Geological Survey Open-File report 83-616 (1983).

Kistler, R.W., and Z.E. Peterman, "Variations in $\mathrm{Sr}, \mathrm{Rb}, \mathrm{K}, \mathrm{Na}$, and initial ${ }^{87} \mathrm{Sr} /{ }^{86} \mathrm{Sr}$ in Mesozoic Granitic Rocks and intruded Wall Rocks in Central California," Geological Society of America 84, 3489-3512 (1973).

Klein, D.P., "Regionial Magnetotelluric Investigations," in Major Results of Geophysical Investigations at Yucca Mountain and Vicinity, Southern Nevada, H.W. Oliver, D.A. Ponce, and W.C. Hunter, Eds. U.S. Geological Survey Open-File report 95-74 (1995) pp. 89-124.

Lachenbruch, A.H., and J.H. Sass, "Models of an Extending Lithosphere and Heat Flow in the Basin and Range Province," in Geological Society of America Memoir 152: Cenozoic Tectonics and Regional Geophysics of the Western Cordillera, R.B. Smith, and G.P. Eaton, Eds. (Geological Society of America, Boulder, Colorado, 1978), pp. 209-250. 
Langenheim, V.E., S.F. Carle, D.A. Ponce, and J.D. Philips, "Revision of an Aeromagnetic Survey of the Lathrop Wells Area, Nevada," U.S. Geological Survey, Open-File report 91-46, pp. 1-17 (1991).

Langenheim, V.E., K.S. Kirchoff-Stein, and H.W. Oliver, "Geophysical Investigations of Buried Volcanic Centers Near Yucca Mountain, Southwest Nevada," in High Level Waste Management: Proceedings of the Fourth Annual International Conference, Las Vegas, Nevada, April 26-30, 1993 (American Nuclear Society, La Grange Park, Illinois, 1993), pp. 1840-1846.

Langenheim, V.E., "Magnetic and Gravity Studies of Buried Volcanic Centers in the Amargosa Desert and Crater Flat, Southwest Nevada," U.S. Geological Survey Open-File report, (1995).

Lipman, P.W., "Cenozoic Volcanism in the Western United States: Implications for Continental Tectonics," in Continental Tectonics (National Academy of Sciences, Washington, D.C., 1980), pp. 161-174.

Lipman, P.W., W.D. Quinlivan, W.J. Carr, and R.E. Anderson, "Geologic Map of the Thirsty Canyon SE Quadrangle, Nye County, Nevada,” US Geological Survey Quadrangle Map, GQ-489 (1966).

Lipman, P.W., H.J. Prostka, and R.L. Christiansen, "Cenozoic Volcanism and Plate Tectonic Evolution of the Western United States, I, Early and Middle Cenozoic," Philosophical Transactions of the Royal Society of London Series A 271, 217-248 (1972).

Lum, P.K., and K.K. Honda, "Processed Seismic Motion Records from Little Skull Mountain, Nevada, Earthquake of June 29, 1992, Recorded at Stations in Southern Nevada," Report \# JAB-10733-TM6 UC703; National Technical Information Service, (1992).

Lutz, T.M., "An Analysis of Orientations of Large-Scale Crustal Structures: A Statistical approach Based on Area Distributions of Pointlike Features," Journal of Geophysical Research 91, 421-434 (1986).

Mayer, L., "Topographic Constraints on Models of Lithospheric Stretching of the Basin and Range Province, Western United States," in Geological Society of America Special Paper 208: Extensional Tectonics of the Southwestern United States: A Perspective on Processes and Kinematics, L. Mayer Ed. (Geological Society of America, Boulder, Colorado, 1986), pp. 1-14.

McCarthy, J. and G. A. Thompson, "Seismsic Imaging of Extended Crust with Emphasis on the Western United States," Geological Society of America 100, 1361-1374 (1988)

McKenna, L.W., and K.V. Hodges, "Constraints on the Kinematics and Timing of Late Miocene-Recent Extension Between the Panamint and Black Mountains, Southeastern California," in Geological Society of America Memoir 176: Basin and Range Extensional Tectonics Near the Latitude of Las Vegas, Nevada, B.P. Wernicke, Ed. (Geological Society of America, Boulder, Colorado, 1990), pp. 363-376.

Menges, C.M., F.H. Swan, J.A. Oswald, J.R. Wesling, J.A. Coe, J.W. Whitney, and A.P. Thomas, "Preliminary Results of Paleoseismic Investigations of Quaternary Faults on Eastern Yucca Mountain, Nye County, Nevada," in High Level Radioactive Waste Management: Proceedings of the Fifth International Conference, Las Vegas, Nevada, May 22-26, 1994 (American Nuclear Society La Grange Park, Illinois, 1994), pp. 2373-2390.

Mermonte, M.W., and A.M. Rogers, "Historical Catalog of Southern Great Basin Valleys, West-Central Nevada," M.S. thesis, University of Nevada, Reno (1987). 
Meremonte, M.E., E. Cranswick, J. Gomberg, D. Worley, D. Carver, J. Brooks, R. Banfill, D. Overturf, and T. Bice, "Report on the seismological field investigations of the 29 June, 1992 Little Skull Mountain earthquake", US Geological Survey, Open-File Report 93-555, (1993).

Meremonte, M.E., J. Gomberg, and E. Cranswick, "Constraints on the 29 June, 1992 Little Skull Mountain sequence provided by robust hypocentral estimates," Bulletin of the Seismological Society of America 85, 1039-1049, (1995).

Minor, S.A., D.A. Sawyer, R.R Wahl, V.A. Frizzel, S.P. Schilling, R.G. Warren, P.P. Orkild, F.A. Coe, M.R. Hudson, R.J. Fleck, M.A. Lanphere, W.C. Swadley, and J.C. Cole, "Preliminary Geologic Map of the Pahute Mesa 30' x 60' Quadrangle, Nevada," US Geological Survey Open-File report 93-299 (1993).

Montfort, M.E., and J.R. Evans, "Teleseismic Studies of the Earth's Crust and Upper Mantle in Southern Nevada," EOS Transactions American Geophysical Union 63, 1099 (1982).

Mooney, W.D., and L.W. Braile, "The Seismic Structure of the Continental Crust and Upper Mantle of North America," in The Geology of North America Overview, W. Bally, and A.R. Palmer, Eds. (Geological Society of America, Boulder, Colorado, 1989), pp. 39-52.

Mooney, W.D., and S. Schapper, "Seismic Refraction Investigations," Major Results of Geophysical Investigations at Yucca Mountain and Vicinity, Southern Nevada, in H.W. Oliver, D.A. Ponce, and W.C. Hunter, Eds. U.S. Geological Survey Open-File report 95-74 (1995) pp. 125-154.

Nauman, T.R., D.L. Feuerbach, and E.I. Smith, "Structural Control of Pliocene Volcanism in the Vicinity of the Nevada Test Site, Nevada," Geological Society of America, Abstract with Programs 23, 518 (1991).

Noble, D.C., "Some Observations On the Cenozoic Volcano-Tectonic Evolution of the Great Basin, Western United States," Earth and Planetary Science Letters 17, 142-150 (1972).

Nolan, T.B., "The Basin and Range Province in Utah, Nevada, and California," U.S. Geological Survey Professional Paper, 197-D, 141-193 (1943).

O'Connor, J.T., R.E. Anderson, and P.W. Lipman, “Geologic Map of the Thirsty Canyon Quadrangle, Nye County, Nevada,” US Geological Survey Quadrangle Map, GQ-524 (1966).

O’Neill, J.M., Whitney, J.W., and M.R. Hudson, "Photogeologic and Kinematic Analysis of Lineaments at Yucca Mountain, Nevada: Implication for Strike-Slip Faulting and Oroclinal Bending," US Geological Survey Open-File report 91-623, pp. 1-24 (1992).

Okaya, D.A., and G.A. Thompson, "Involvement of Deep Crust in Extension of Basin and Range Province," in Geological Society of America Special Paper 208: Extensional Tectonics of the Southwestern United States: A Perspective on Processes and Kinematics, L. Mayer Ed. (Geological Society of America, Boulder, Colorado, 1986), pp. 15-22.

Oldow, J.S., A.W. Bally, H.G. Avé Lallemant, and W.P. Leeman, "Phaneraozoic Evolution of the North American Cordillera United States and Canada," A.W. Bally, and A.R. Palmer, Eds., in The Geology of North America: an Overview, W. Bally, and A.R. Palmer, Eds. (Geological Society of America, Boulder, Colorado, 1989), pp. 139-232.

Oliver, H.W., E.L. Hardin, and P.H. Nelson, "Status of Data, Major Results, and Plans for Geophysical activities, Yucca Mountain Project," Prepared for DOE by the USGS and SAIC, (1992). 
Oliver, H.W., and K.F. Fox, "Structure of Crater Flat and Yucca Mountain, Southeastern Nevada, as Inferred from Gravity Data," in High Level Waste Management: Proceedings of the Fourth Annual International Conference, Las Vegas, Nevada, April 26-30, 1993 (American Nuclear Society, La Grange Park, Illinois, 1993), pp. 1812-1817.

Oliver, H.W., and D.A. Ponce, "Introduction and Geologic Setting," in Major Results of Geophysical Investigations at Yucca Mountain and Vicinity, Southern Nevada, H.W. Oliver, D.A. Ponce, and W.C. Hunter, Eds., US Geological Survey Open File-report 95-74 (1995), pp. 9-36.

Oliver, H.W., D.A. Ponce, and H.R. Blank, "Magnetic Investigations," in Major Results of Geophysical Investigations at Yucca Mountain and Vicinity, Southern Nevada, H.W. Oliver, D.A. Ponce, and W.C. Hunter, Eds., US Geological Survey Open File-report 95-74 (1995), pp. 67-89.

Orkild, P.P., K.A. Sargent, and R.P. Snyder, "Geologic Map of Pahute Mesa, Nevada Test Site and Vicinity, Nye County, Nevada,” US Geological Survey Miscellaneous Investigations Map I-567 (1969).

Parsons, T., "The Basin and Range Province," in Continental Rifts: Evolution, Structure, Tectonics, K.H. Olsen, Ed. Developments in Tectonics 25, Elsevier, Amsterdam, pp. 277-324 (1995).

Parsons, T., and G.A. Thompson, "The Role of Magma Overpressure in Suppressing Earthquakes and Topography: Worldwide Examples," Science 253, 1399-1402 (1991).

Parsons, T., and G.A. Thompson, "Does Magmatism Influence Low-Angle Normal Faulting?" Geology 21, 247-250 (1993).

Parsons, T.., G.A. Thompson, and N.H. Sleep, "Mantle Plume Influence on the Neogene Uplift and Extension of the U.S. Western Cordillera," Geology 22, 83-86 (1994).

Perry, F.V., and B.M. Crowe, "Geochemical Evidence for Waning Magmatism and Polygenetic Volcanism at Crater Flat, Nevada," in High-Level Radioactive Waste Management: Proceedings of the Third International Conference, Las Vegas, Nevada, April 12-16, 1992 (American Nuclear Society, La Grange Park Illinois, 1992), pp. 2344-2355.

Ponce, D.A. and V.E. Langenheim, "Gravity and Magnetic Investigations of the Ghost Dance and Solitario Canyon Faults, Yucca Mountain, Nevada," US Geological Survey Open File report 95-521, pp. $1-26$ (1995).

Ponce, D.A. and H.W. Oliver, "Gravity Investigations," in Major Results of Geophysical Investigations at Yucca Mountain and Vicinity, Southern Nevada, H.W. Oliver, D.A. Ponce, and W.C. Hunter, Eds., US Geological Survey Open File-report 95-74 (1995) pp. 37-66.

Priestley, K.F., A.S. Ryall, and G.S. Fezie, "Crust and Upper Mantle Structure in the Northwest Basin and Range Province," Seismology Society American 72, 911-923 (1982).

Proffett, J.M., Jr., "Cenozoic Geology of the Yerington District, Nevada and Implications for the Nature and Origin of Basin and Range Faulting," Geological Society of America 88, 247-266 (1977).

Rehrig, W.A., "Processes of Regional Tertiary Extension in the Western Cordillera: Insights From the Metamorphic Core Complexes," in Geological Society of America Special Paper 208: Extensional Tectonics of the Southwestern United States: A Perspective on Processes and Kinematics, L. Mayer Ed. (Geological Society of America, Boulder, Colorado, 1986), pp. 97-122. 
Rogers, A.M., S.C. Harmsen, and W.J. Carr, "Southern Great Basin Seismological Data Report for, 1981 and Preliminary Data analysis," US Geological Survey Open-File report 81-1086, pp. 1-148 (1981).

Rogers, A.M., S.C. Harmsen, W.J. Carr, and W.J. Spence, "Southern Great Basin Seismological Data Report for 1981, and Preliminary Data Analysis," US Geological Survey Open-File report 83-669, pp. 1-240 (1983).

Rogers, A.M., S.C. Harmsen, and M.E. Meremonte, "Evaluation of the Seismicity of the Southern Great Basin and its Relationship to the Tectonic Framework of the Region," US Geological Survey Open-File report 87-408, pp. 1-196 (1987).

Rosenbaum, J.G., M.R. Hudson, and R.B. Scott, "Paleomagnetic Constraints On the Geometry and Timing of Deformation at Yucca Mountain, Nevada," Journal of Geophysical Research 96, 1963-1980 (1991).

Saltus, R.W. and G.H. Thompson, "Why is it Downhill from Tonopah to Las Vegas? A Case for Mantle Plume Support of the High Northern Basin and Range," Tectonics 14, 1235-1244 (1995).

Sass, J.H., A.H. Lachenbrunch, W.W. Dudley, Jr., S.S. Priest, and R.J. Munroe, "Temperature, Thermal Conductivity, and Heat Flow Near Yucca Mountain, Nevada, Some Tectonic and Hydrologic Implications," US Geological Survey Open-File report 87-649, pp. 1-118 (1987).

Sass, J.H., W.W.J. Dudley, and A.H. Lachenbruch, "Regional Thermal Setting," in Major Results of Geophysical Investigations at Yucca Mountain and Vicinity, Southern Nevada, H.W. Oliver, D.A. Ponce, and W.C. Hunter, Eds., U.S. Geological Survey Open-File report 95-74 (1995) pp. 199-218.

Sawyer, D.A., R.J. Fleck, M.A. Lanphere, R.G. Warren, and D.E. Broxton, "Episodic Volcanism in the Miocene Southwest Nevada Volcanic Field-Stratigraphic Revisions, ${ }^{40} \mathrm{Ar} /{ }^{39} \mathrm{Ar}$ Geochronologic Framework, and Implications for Magmatic Evolution," Geological Society of America 106, 1304-1318 (1994).

Scholz, C.H., M. Barazangi, and M.L. Sbar, "Late Cenozoic Evolution of the Great Basin, Western United States, as an Ensialic Interarc Basin," Geological Society of America 82, 2979-2990, (1971).

Schweickert, R.A., "Evidence for a Concealed Dextral Strike-Slip Fault Beneath Crater Flat, Nevada," Abstract Geological Society of America 20, A115 (1989).

Scott, R.B., "Tectonic Setting of Yucca Mountain, Southwest Nevada," in Geological Society of America Memoir 176: Basin and Range Extensional Tectonics Near the Latitude of Las Vegas, Nevada, B.P. Wernicke, Ed. (Geological Society of America, Boulder, Colorado, 1990), pp. 251-282.

Scott, R.B., and J. Bonk, "Preliminary Geologic Map of Yucca Mountain Nye County, Nevada, With Geologic Sections," US Geological Survey Open-File report 84-494, (1984).

Scott, R.B., G.D. Bath, V.J. Flanigan, D.B. Hoover, J.G. Rosenbaum, and R.W. Spengler, "Geological and Geophysical Evidence of Structures in Northwest-Trending Washes, Yucca Mountain, Southern Nevada, and their Possible Significance to a Nuclear Waste Repository in the Unsaturated Zone," US Geological Survey Open-File report 84-567, pp. 1-23 (1984).

Severinghaus, J., and T. Atwater, "Cenozoic Geometry and Thermal State of the Subducting Slabs Beneath Western North America," in Geological Society of America Memoir 176: Basin and Range Extensional Tectonics Near the Latitude of Las Vegas, Nevada, B.P. Wernicke, Ed. (Geological Society of America, Boulder, Colorado, 1990), pp. 1-22. 
Shaw, H.R., "The Fracture Mechanisms of Magma Transport From the Mantle to the Surface," in Physics of Magmatic Processes, R.B. Hargraves, Ed. (Princeton University Press, Princeton, New Jersey, 1980), pp. 201-264.

Shawe, D.R., "Strike-Slip Control of Basin-Range Structure Indicated by Historical Faults in Western Nevada," Geological Society of America 76, 1360-1378 (1965).

Sheehan, A.F., S.L.Gillett, K.D. Smith, and M.K. Savage, "Data Report on the Seismological Field Investigations of the 29 June, 1992 Little Skull Mountain Earthquake," Special Report to the United States Geological Survey: Yucca Mountain Project; DTN\#: 940283117412.002 (1994).

Shields, G., K.D. Smith, and J.N. Brune, "Source Parameters of a Sequence of Very Shallow Earthquakes in the Rock Valley Fault Zone, Southern Nevada Test Site, EOS (abstract) 76, F426, (1995).

Simonds, F.W., and J.W. Whitney, "Quaternary Fault Distribution at the Potential High-Level Nuclear Waste Repository at Yucca Mountain, Nevada," Geological Society of America Abstracts with Programs 25, A140-A141 (1993).

Simpson, R.W., R.C. Jachens, R.J. Blakely, and R.W. Saltus, "A New Isostatic Residual Gravity Map of the Conterminous United States with a Discussion of the Significance of Isostatic Residual Anamolies," Journal of Geophysical Research 91, 8348-8372 (1986).

Smith, K.D., D. von Seggern, G. Biasi, C.L. Middlebrooks, and J.N. Brune," Performance of the Southern Great Basin Digital Seismic Network," Proceedings Methods of Seismic Hazard Evaluation Focus '95, American Nuclear Society, 64-71 (1995).

Smith, K.D, J.N. Brune, R. Anooshehpoor, M.K. Savage, A.F. Sheehan, "The 1992 Little Skull Mountain Earthquake Sequence, Southern Nevada Test Site,” Tectonics Program, Yucca Mountain Project, in press, Geological Society of America (1997a).

Smith, K.D. J.N. Brune, and G. Shields, "A Sequence of Very Shallow Earthquakes in the Rock Valley Fault Zone Southern Nevada Test Site," Tectonics Program Yucca Mountain Project, in press, Geological Society of America (1997b).

Smith K.D., L. Li, J.N. Brune, R. Anooshehpoor and M.K. Savage, "Preliminary Results from the NPERyan Reversed Refraction Profile," Tectonics Program Yucca Mountain Project, in press, Geological Society of America (1997c).

Smith, R.B., "Seismicity, Crustal Structure and Intraplate Tectonics of the Interior of the Western Cordillera," in Geological Society of America Memoir 152: Cenozoic Tectonics and Regional Geophysics of the Western Cordillera, R.B. Smith, and G.P. Eaton, Eds. (Geological Society of America, Boulder, Colorado, 1978), pp. 111-144.

Smith, R.B., and M.L. Sbar, "Contemporary Tectonics and Seismicity of the Western United States With Emphasis on the Intermountain Seismic Belt," Geological Society of America 85, 1205-1218 (1974).

Smith, R.L., and R.G. Luedke, "Potentially Active Volcanic Lineaments and Loci in Western Conterminous United States," in Explosive Volcanism: Inception, Evolution And Hazards (National Academy Press, Washington, D.C., 1984), pp. 47-66. 
Smith, E.I., D.L. Feuerbach, T.R. Naumann, and J.E. Faulds, "The Area of Most Recent Volcanism Near Yucca Mountain, Nevada: Implications for Volcanic Risk Assessment," in High Level Radioactive Waste Management: Proceedings of the First Annual International Topical Meeting, April 8-12, 1990

(American Nuclear Society, La Grange Park, Illinois, 1990), pp. 81-90.

Snoke, A.W., and D.M. Miller, "Metamorphic and Tectonic History of the Northeastern Great Basin," in Metamorphic and Crustal Evolution of the Western United States, G.W. Ernst, Ed. (Prentice-Hall, Englewood Cliffs, New Jersey, 1988), pp. 606-648.

Snyder, W.S., W.R. Dickenson, and M.L. Silberman, "Tectonic Implications of Space-Time Patterns of Cenozoic Magmatism in the Western United States," Earth and Planetary Science Letters 32, 91-106 (1976).

Snyder, D.B., and W.J. Carr, "Preliminary Results of Gravity Investigations at Yucca Mountain and Vicinity, Southern Nye County, Nevada," US Geological Survey Open-File report 87-701, pp. 1-35 (1982).

Snyder, D.B., and W.J. Carr, "Interpretation of Gravity Data in a Complex Volcano-Tectonic Setting, Southwestern Nevada," Journal of Geophysical Research 89, 10,193-10,206 (1984).

Spence, W.J., "P-Wave Residual Differences and Inferences on an Upper Mantle Source for the Silent Canyon Volcanic Center, Southern Great Basin, Nevada," Journal of Geophysical Research 38, 505-524 (1974).

Spence, W., and R.S. Gross, "A Tomographic Glimpse of the Upper Mantle Source of Magmas of the Jemez Lineament, New Mexico,” Journal of Geophysical Research 95, 10,829-10,849 (1990).

Spengler, R.W., and K.F. Fox, Jr., "Stratigraphic and Structural Framework of Yucca Mountain, Nevada," in Radioactive Waste Management 13, 21-36 (1989).

Stewart, J.H., "Basin and Range Structure: A System of Horsts and Grabens Produced by Deep-Seated Extension," Geological Society of America 82, 1019-1044 (1971).

Stewart, J.H., "Basin-Range Structure in Western North America," in Geological Society of America Memoir 152: Cenozoic Tectonics and Regional Geophysics of the Western Cordillera, R.B. Smith, and G.P. Eaton, Eds. (Geological Society of America, Boulder, Colorado, 1978), pp. 1-31.

Stewart, J.H., "Regional Tilt Patterns of Late Cenozoic Basin-Range Fault Blocks, Western United States," Geological Society of America 91, 460-464 (1980).

Stewart, J.H., and J.E. Carlson, "Preliminary Geologic Map of Nevada," US Geological Survey Misc. Field Studies Map MF-609 (1974).

Stewart, J.H., W.J. Moore, and I. Zietz, "East-West Patterns of Cenozoic Igneous Rocks, Aeromagnetic Anomalies, and Mineral Deposits, Nevada and Utah," Geological Society of America 88, 67-77 (1977).

Stock, J.M., and J.H. Healy, "Stress Field at Yucca Mountain, Nevada" in US Geological Survey Bulletin 1790: Short Contributions to the Geology and Hydrology of a Potential Nuclear Waste Site at Yucca Mountain, Southern Nevada, M.D. Carr and J.C. Yount, Eds. (Department of Interior, US Geological Survey, Reston, Virginia, 1988), pp. 87-93. 
Stirewalt, G.L., S.R. Young, and K.D. Mahrer, "A Review of Pertinent Literature on Volcanic-Magmatic and Tectonic History of the Basin and Range," Center for Nuclear Waste Regulatory Analysis report CNWRA 92-025 pp. 1-168 (1992).

Suppe, J., C. Powell, and R. Berry, "Regional Topography, Seismicity, Quaternary Volcanism and the Present-Day Tectonics of the Western United States," American Journal of Science 274-A, 397-436 (1975).

Tanaka, K.L., E.M. Shoemaker, G.E. Ulrich, and E.W. Wolfe, "Migration of Volcanism in the San Francisco Volcanic Field, Arizona," Geological Society of America 97, 129-141 (1986).

Taylor, S.R., "Three-Dimensional Crust and Upper Mantle Structure at the Nevada Test Site," Journal of Geophysical Research 88, 2220-2232 (1983).

Thompson, G.A., and D.B. Burke, "Regional Geophysics of the Basin and Range Province," Annual Review of Earth Planetary Sciences 2, 213-238 (1974).

Trapp, J.S., and P.S. Justus, "Disposal of High-Level Radioactive Wastes in Geologic Repositories," High Level Radioactive Waste Management: Proceedings of the Third International Conference, Las Vegas, Nevada, April 12-16, 1992 (American Nuclear Society, La Grange Park, Illinois, 1992), pp. 2039-2046.

Valentine, G.A., B.M. Crowe, and F.V. Perry, "Physical Processes and Effects of Magmatism in the Yucca Mountain Region," in High Level Radioactive Waste Management: Proceedings of the Third International Conference, April 12-16, 1992 Las Vegas, Nevada, (American Nuclear Society, La Grange Park, Illinois, 1992), pp. 2344-2355.

Vaniman, D.T., B.M. Crowe, and E.S. Gladney, "Petrology and Geochemistry of Hawaiite Lavas From Crater Flat, Nevada," Contributions to Mineralogy and Petrology 80, 341-357 (1982).

Wadge, G., and A. Cross, "Quantitative Methods for Detecting Aligned Points: an Application to the Volcanic Vents of the Michoacan-Guanajuato Volcanic Field, Mexico," Journal of Geology 16, 815-818 (1988).

Walker, J.D., and D.S. Coleman, "Geochemical Constraints On Mode of Extension in the Death Valley Region," Geology 19, 971-974 (1991).

Walter, W., "Source Parameters of the June 29, 1992 Little Skull Mountain Earthquake from Complete Regional Waveforms at a Single Station”, Geophysical Research Letters 20, 403-406, (1993).

Wernicke, B., "Low-angle Faults in the Basin and Range Province," Nature 291, 645-648 (1981).

Wernicke, B., "Cenozoic Extensional Tectonics of the US Cordillera," in The Cordilleran Orogeny: Conterminous US, B.C. Burchfiel, M.L. Zoback, and P.W. Lipman, Eds. (Geological Society of America, Boulder, Colorado, 1992), pp. 553-582.

Wernicke, B., and B.C. Burchfiel, "Modes of Extensional Tectonics," Journal of Structural Geology 4, 105-115 (1982).

Wernicke, B., G.J. Axen, and J.K. Snow, "Basin and Range Extensional Tectonics at the Latitude of Las Vegas, Nevada," Geological Society of America 100, 1738-1757 (1988). 
Winograd, I.J., and W. Thordarson, "Hydrogeologic and Hydrochemical Framework, South-central Great Basin, Nevada-California, with Special Reference to the Nevada Test Site," US Geological Survey Professional Paper 712-C, 125 pp. (1975).

Wright, L.A., "Late Cenozoic Fault Patterns and Stress Fields in the Great Basin and Westward Displacement of the Sierra Nevada Block," Journal of Geology 4, 489-494 (1976).

Wright, L.A., "Overview of the Role of Strike-Slip and Normal Faulting in the Neogene History of the Region Northeast of Death Valley, California-Nevada," Nevada Bureau of Mines and Geology Open-File 89-1, pp. 1-11, (1989).

Wright, L.A., J.K. Otton, and B.W. Troxel, "Turtleback Surfaces of Death Valley Viewed as Phenomena of Extension," Journal Geology 2, 53-54 (1974).

Zeitz, I., G.E. Andreasen, and J.C. Cain, "Magnetic Anomalies from Satellite Magnetometer," Journal of Geophysical Research 75, 4007-4015 (1970).

Zoback, M.L., "State of Stress and Modern Deformation of the Northern Basin and Range Province," Journal of Geophysical Research 4, 71056-7128 (1989).

Zoback, M.L., and G.A. Thompson, "Basin and Range Rifting in Northern Nevada: Clues From a MidMiocene Rift and its Subsequent Offsets," Geology 6, 111-116 (1978).

Zoback, M.L., R.E. Anderson, and G.A. Thompson, "Cainozoic Evolution of the State of Stress and Style of Tectonism of the Basin and Range Province of the Western United States," Philosophical Transactions of the Royal Society London Series 300, 407-434 (1981).

Zoback, M.L., E.H. McKee, R.J. Blakely, and G.A. Thompson, "The Northern Nevada Rift: Regional Tectonomagmatiac Relations and Middle Miocene Stress Direction," Geological Society of America 106, 371-382 (1994). 


\title{
CHAPTER FOUR
}

\section{Petrologic and Geochemical Constraints on Basaltic Volcanism in the Great Basin}

\author{
Frank V. Perry \\ Earth and Environmental Sciences Division, Los Alamos National Laboratory \\ Lynn M. Bowker \\ College of Law, University of Wyoming
}

\section{Summary}

Basaltic volcanism has been the predominant form of volcanism in the Great Basin over the last 5-10 million years (Ma). Great Basin basalts are primarily alkalic in composition indicating small degrees of partial melting of relatively deep mantle sources. The compositions of basalt have become more undersaturated with time, both in the Basin and Range province as a whole and within individual volcanic fields, suggesting that the intensity of melting in the mantle has declined with time on a regional scale. The volume of basalt flux into the crust has also declined in a broad sense throughout the middle and late Cenozoic, assuming that the enormous volumes of ash-flow tuff erupted in the mid-Cenozoic were fueled by a comparable or greater volume of basaltic magma. The transition from the eruption of evolved magmas to basalt in the late Cenozoic can be attributed to changes in plate tectonic processes and crustal properties with time. Isotopic and trace-element studies of basalt document the role of both asthenospheric mantle and lithospheric mantle in the generation of basaltic magma in the western United States. The regional distribution of these sources correlates with tectonic setting and history and may control the volume and compositional distribution of basalt relative to major physiographic boundaries.

The generation and eruption mechanisms of Pliocene and Quaternary basalt within the Yucca Mountain region follow many of the same patterns believed to occur in many other Cenozoic basalt fields of the western United States. Eruptive volumes decrease and the depths of magma chambers possibly increase with time, suggesting an overall decrease in basalt flux from the mantle with time. Decrease in mantle melt percentage is reflected in increases in several incompatible element concentrations through time. Geochemical variations at the youngest volcano in the region, Lathrop Wells, are unusual compared to variations reported from other small-volume basalt centers. Models of fractional crystallization, magma mixing, or crustal assimilation cannot account for the data at Lathrop Wells. Remaining hypothesis that have not been fully tested are that the geochemical variations at Lathrop Wells are due to systematic changes in mantle melting conditions through time, mantle wall-rock reaction with a single melt batch, or in situ fractional crystallization involving subliquidus phases such as apatite.

The geochemical composition of basaltic ash found in numerous fault trenches near Yucca Mountain indicates that the ash originated from Lathrop Wells and not from any other Quaternary volcanoes in the region. The age of the ash is therefore $\sim 75 \mathrm{ka}$. Direct dating of the Solitario Canyon Fault ash yields an erroneously old age of $\sim 900 \mathrm{ka}$, probably due to a small amount of sample contamination by rhyolitic glass of Miocene age.

\section{Introduction}

The Great Basin (encompassing most of the northern Basin and Range province; see Chapter 3 ) is a region that was affected during middle and late Cenozoic time by extensional tectonism 
and magmatism. As a result, it is characterized by thinned lithosphere, high heat flow, active faulting, high seismicity, abundant thermal springs, and the widespread distribution of Tertiary volcanic rocks (for example, Eaton, 1982; see Chapter 3). Small-volume basaltic volcanism has been the characteristic form of volcanism in the Great Basin since 5-10 Ma.

Basaltic magma is generated in the upper part of the earth's mantle by partial melting of mantle peridotite. Differences in the pressure and composition of the source region, and in the proportion of source rock melted, create a continuous spectrum of basaltic compositions that erupt at the surface. In a simple way, basalt can be divided into two compositional categories, alkalic and tholeiitic (e.g., Morse, 1980). Alkalic basalts have high total alkalis $\left(\mathrm{Na}_{2} \mathrm{O}+\mathrm{K}_{2} \mathrm{O}\right)$ and are generated at relatively great depth by small degrees of partial melting. Tholeiitic basalts have lower total alkalis and are generated at shallower depths $(35-45 \mathrm{~km})$ by relatively larger degrees of partial melting (Jaques and Green, 1980). Experimental data (Takahashi, 1980; Takahashi and Kushiro, 1983) indicate that alkalic basalts compositionally similar to those of the Basin and Range province equilibrated at pressures of 14-20 kilobars $(\mathrm{kb})$, equivalent to a depth of 45-65 $\mathrm{km}$. Nearly all of the basalts erupted within the Great Basin since the late Miocene are alkalic (Leeman and Rogers, 1970; Best and Brimhall, 1974; Farmer et al., 1989; Fitton et al., 1991).

Intermediate to silicic calc-alkaline Cenozoic volcanism began in the northern Great Basin during the late Eocene and gradually swept south, ending in southern Nevada by the late Miocene (see Chapter 3). This southward sweep is thought to be related to declining plate convergence rates and steepening of the dip of the subducted slab, resulting in activation of the asthenospheric mantle wedge and generation of basaltic magma to fuel crustal magmatic systems (Cross and Pilger, 1978; Lipman, 1980; Best and Christiansen, 1991). Eruption of calc-alkaline ash-flow tuffs reached a peak in the Great Basin between 30-20 Ma (the "ignimbrite flare-up") when $>50,000 \mathrm{~km}^{3}$ of tuff was erupted (Best and Christiansen, 1991). Isotopic studies of zoned ignimbrite systems suggest that an equal or greater volume of basaltic magma emplaced at depth was required to generate these ash-flow tuffs (Johnson, 1991). Large-magnitude extension also migrated southward during the Cenozoic (see Chapter 3), although less systematically than silicic volcanism. The timing of extension and volcanism may not be well correlated in any particular area; extension locally may predate, be contemporaneous with, or postdate silicic volcanism (Axen et al., 1993).

The initiation of true basaltic volcanism in the Great Basin began in the early to middle Miocene ( $<17 \mathrm{Ma})$ and generally postdates major silicic volcanism and some of the major phases of extension in any particular region. For example, silicic volcanism of the Timber Mountain caldera complex and peak extension rates in the southern Great Basin occurred simultaneously at 15-10 Ma (Wernicke et al., 1988; Scott, 1990; Carr, 1990). The commencement of basaltic volcanism occurred during the latter part of this period, and small-volume basaltic volcanism has continued into the Quaternary period (see Chapter 2). Citing several similar examples, Glazner and Ussler (1989) argued that the transition to eruption of basalt in the western United States was not due to increased rates of extension, since basaltic volcanism in any region usually begins after extension rates have declined. They proposed instead that the transition was due to increases in mean crustal density resulting from extensional thinning of low-density upper crust and intrusion of mafic magma into the lower crust. Denser crust would enhance buoyant ascent and eruption of basaltic magma (see Chapter 5). This mechanism would, however, be limited to areas that had undergone high-magnitude extension or focused mafic intrusion.

The "ignimbrite flare-up" was fueled by a large flux of basaltic magma into the crust (Johnson, 1991; Best and Christiansen, 1991), probably as a result of reactivation of the mantle wedge above a steepening subducted slab following the slowing of subduction rates after the 
Laramide Orogeny (Coney and Reynolds, 1977; Cross and Pilger, 1978; Lipman, 1980). Basaltic intrusion, convection in the underlying mantle wedge, and thick crust inherited from the Laramide created an unusually hot crust by the end of the Oligocene epoch. Thermally weakened crust may have been a prerequisite for large-magnitude "ductile" extension in the Basin and Range province in the late Oligocene to early Miocene (Morgan et al., 1986). The extensional collapse of over-thickened and thermally weakened crust followed the slowing of subduction and easing of compressional forces at the continental margin (Coney, 1987). Coupled with decreased basalt flux into the crust beginning in the late Oligocene (from breakdown of the mantle wedge), conductive cooling of the thinned crust would follow.

Overall cooling of the Cordilleran crust in late Cenozoic time is consistent with changes in extensional style and the transition to the eruption of basalt. Two overlapping phases of extensional deformation are recognized during the Cenozoic: (1) an early, mid-Tertiary phase characterized by high strain rates, a shallow brittle-ductile transition, shallow fault penetration, and eruption of voluminous intermediate to silicic volcanic rocks, and (2) a late, MiocenePleistocene phase ("Basin and Range event") characterized by lower strain rates, deeply penetrating faults, the establishment of modern basin and range topography, and bimodal eruptions of basalt and high-silica rhyolite (Christiansen and Lipman, 1972; Zoback et al., 1981; Eaton, 1982; Morgan et al., 1986; Coney, 1987; Keller et al., 1990; Armstrong and Ward, 1991). The high strain rates characteristic of Oligocene extension probably in part required a hot and thermally weakened crust, while lower strain rates associated with deep, high-angle faulting are consistent with a cooler, more brittle, and mechanically stronger crust (Morgan et al., 1986). Cooling of the crust may have favored the eruption of basalt because (1) cooling of the crust increases crustal density on a regional scale (enhancing buoyant ascent of basaltic magma), (2) contamination or mixing with more silicic crustal magmas would be inhibited, and (3) basaltic magmas intruded into brittle crust would have access to deeper crustal fractures that would favor rapid ascent without differentiation (Perry et al., 1993).

\section{Time-Space Trends in the Location, Composition, and Volume of Basaltic Volcanism}

Basaltic volcanism in the Great Basin and adjoining regions has exhibited systematic trends in location, composition, and eruption volume through time. These trends can be related to both tectonic processes in the crust and melt generation processes in the underlying mantle. Figure 4.1 summarizes the distribution of basaltic rocks in the western United States (excluding the Columbia Plateau) during two time periods: (1) 16-5 Ma, from near the inception of basaltic volcanism to the end of the Miocene, and (2) 5-0 Ma, from the end of the Miocene to the present. Basaltic volcanism was concentrated increasingly along major physiographic margins with time, in particular along the margins of the Great Basin and the Colorado Plateau. Post-Miocene eruption of basalt within the Great Basin interior has been sparse, with the notable exception of a band of post-Miocene basalt that extends from Death Valley to Lunar Crater in central Nevada, including the basalts of Crater Flat (Crowe et al., 1983). The migration of basaltic volcanism to the margins of the Great Basin correlates with increased extension and seismicity in these areas, indicating that the stress regime exerts a broad control on the location of basaltic eruptions. (Christiansen and McKee, 1978). 


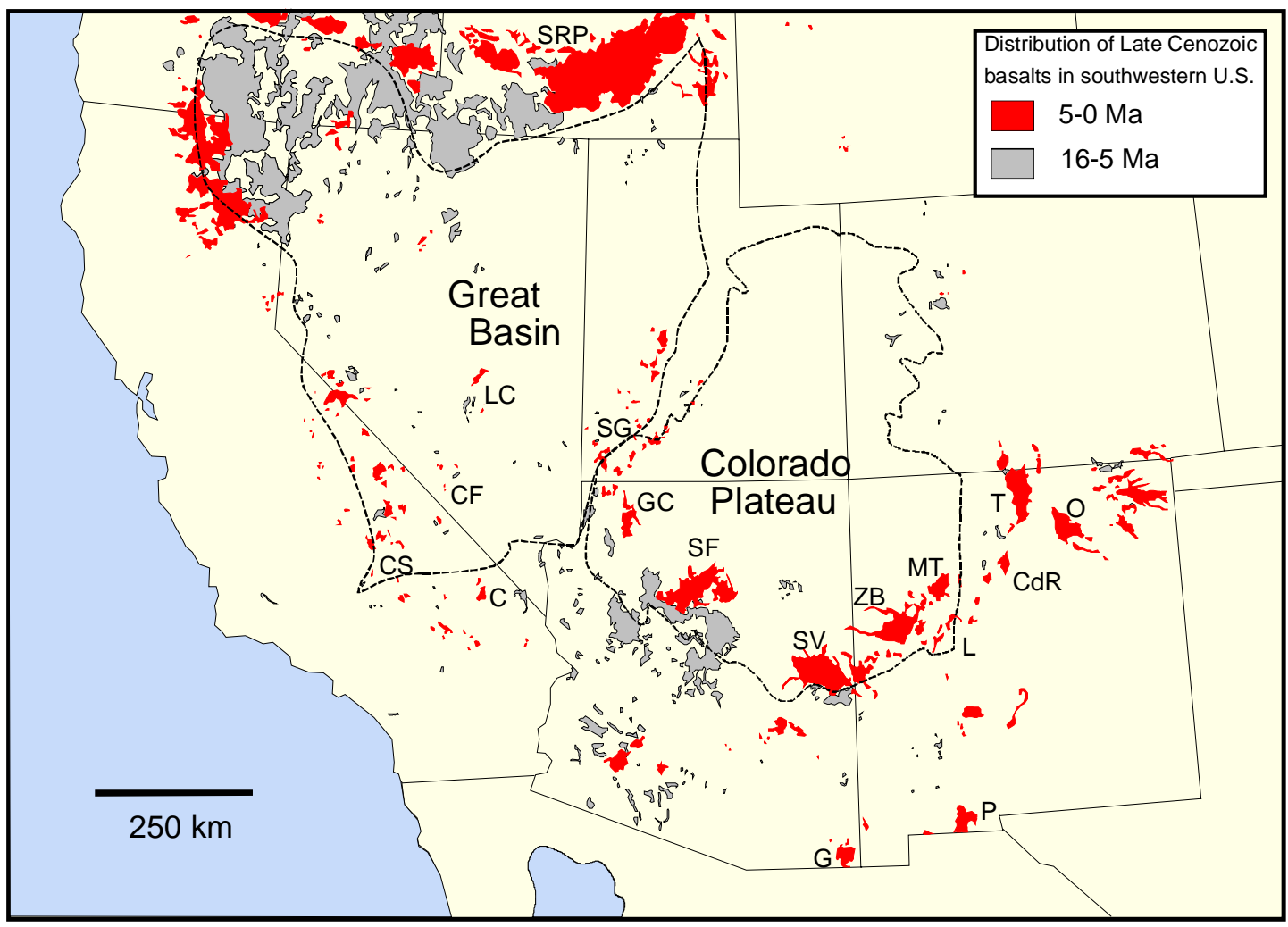

Figure 4.1. Map of the western United States showing the distribution of basalt erupted during the past 16-5 and 5-0 Ma (after Fitton et al., 1991). Labeled volcanic fields are: BP: Big Pine, C: Cima, CdR: Cerros del Rio, CF: Crater Flat; CS: Coso; G: Geronimo; GC: Grand Canyon; L: Lucero; LC: Lunar Crater; MT: Mount Taylor; O: Ocate; P: Potrillo; SF: San Francisco; SG: St. George; SRP: Snake River Plain; SV: Springerville; T: Taos; ZB: Zuni-Bandera.

In the southwestern United States, basaltic volcanic fields of late Miocene and younger age that erupted the largest volumes and had the highest eruption rates are mostly associated with the Colorado Plateau margin (Taos, Cerros del Rio, San Francisco, Springerville, Zuni-Bandera, Mount Taylor; Figure 4.2). Many of these basalt fields erupted tholeiitic basalt in addition to alkalic basalt, indicating higher degrees of partial melting at shallower mantle depths compared to the Great Basin/Basin and Range interior. Basalt fields of this age in the interior of the Basin and Range have volumes that seldom exceed a few tens of cubic kilometers, while several fields along the Colorado Plateau boundary have volumes of 100-300 km³ (San Francisco, Springerville, Zuni-Bandera, Taos). Long-term eruption rates for several volcanic fields on the Colorado Plateau margin exceed $50 \mathrm{~km}^{3} / \mathrm{Ma}$, while rates within the Basin and Range are generally $<20$ $\mathrm{km}^{3} / \mathrm{Ma}$ (Figure 4.2). The volume and eruption rates of basalt fields of the Colorado Plateau margin suggest higher production rates of basaltic magma in the mantle beneath these areas, compared with mantle beneath the Basin and Range interior.

The composition of basalt erupted within the Great Basin/Basin and Range has also changed systematically through time (Fitton et al., 1991). Basalt erupted since $5 \mathrm{Ma}$ are as a group more silica-undersaturated (more nepheline normative) than basalt erupted before $5 \mathrm{Ma}$ and also have a higher average $\mathrm{MgO}$ content, indicating less fractionation en route to the surface (Figure 4.3). These data suggest that the younger group of basalt represents smaller degrees of partial melting at greater depths in the mantle (e.g., Jaques and Green, 1980). Similar changes in composition through time are seen in a number of individual volcanic fields within the Basin and Range, as discussed in a later section of this chapter. The more primitive nature of the younger basalt 
indicates rapid ascent from the mantle with minimal crustal residence time, possibly because of higher volatile concentrations resulting from smaller degrees of partial melting (Fitton et al., 1991). A trend to smaller degrees of partial melting through time in the Basin and Range is consistent with a decrease in volume erupted through time for a number of individual fields in the Basin and Range. The more volatile-enriched nature of these basalts, however, may result in more frequent eruptions (cf. Smith and Luedke, 1984) since these magmas are more likely to ascend rapidly through the crust without achieving buoyancy stagnation (Spera, 1984).

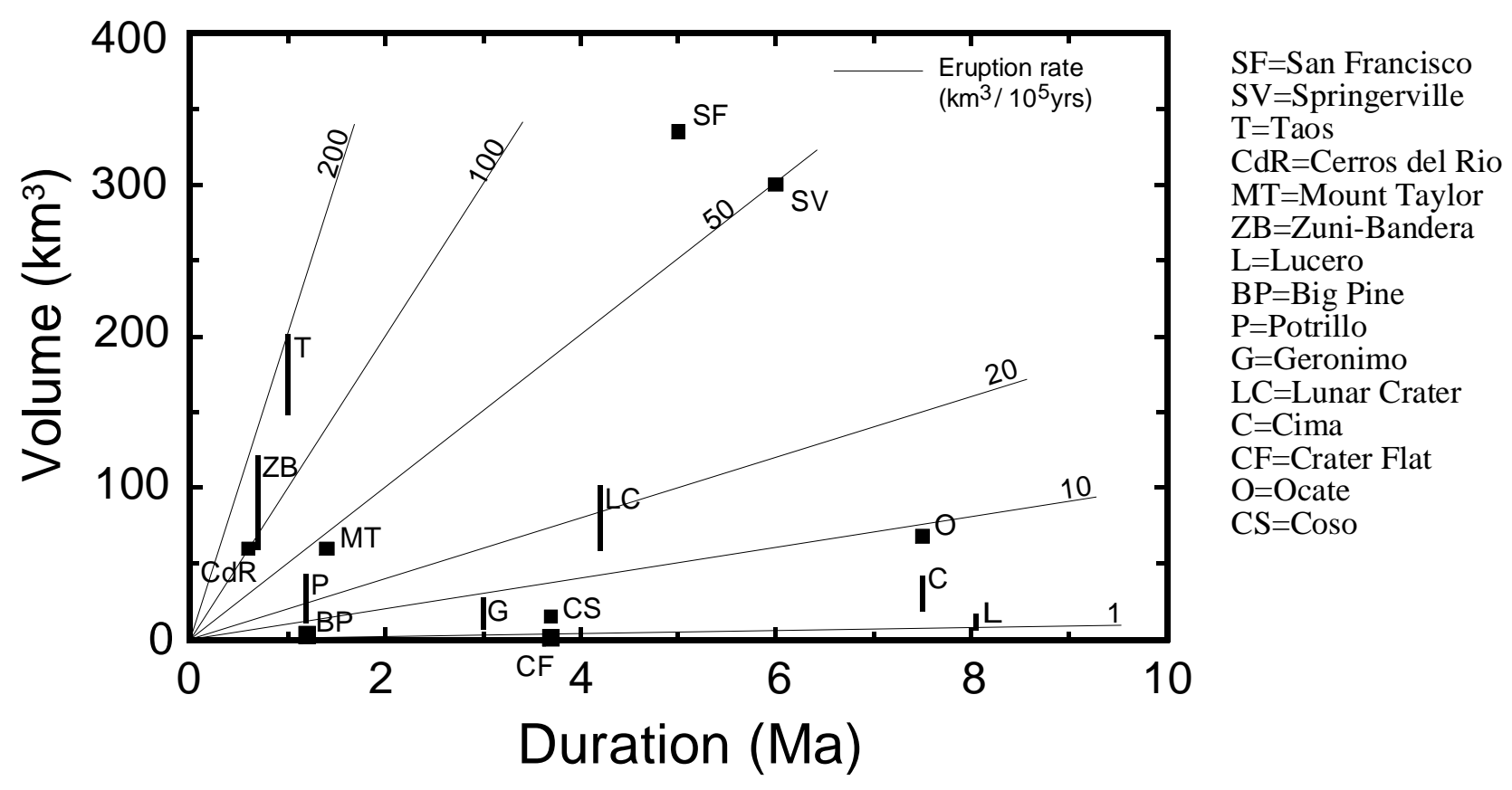

Figure 4.2. Estimated volume versus eruption duration for late Cenozoic basaltic volcanic fields in the southwestern United States.

\section{The Role of the Mantle in Basaltic Volcanism}

Numerous isotopic and trace-element studies of basalt have demonstrated that basalt in the western United States is derived from either asthenospheric mantle (equivalent to oceanic mantle) or ancient lithospheric mantle that has been isolated from asthenospheric convection for periods of greater than a billion years (Menzies et al., 1983; Hart, 1985; Perry et al., 1987, 1988; Farmer et al., 1989; Lum et al., 1989; Menzies, 1989; Cooper and Hart, 1990; Kempton et al., 1991; Fitton et al., 1991; Daley and DePaolo, 1992). Perry et al. (1987, 1988) proposed that the source of basalt in the western United States depends on the timing and intensity of lithospheric extension relative to the timing of basalt eruption. In regions that have undergone little or only recent lithospheric extension, basalts are derived from lithospheric mantle because asthenospheric upwelling has been limited and has not replaced the preexisting lithospheric mantle. In regions of more pronounced or prolonged extension, asthenospheric mantle eventually replaces lithospheric mantle and becomes the source for basalt. Isotopic evidence indicates that asthenospheric sources are present beneath the southern Basin and Range of New Mexico, Arizona, and southeastern California, as well as the central Great Basin of Nevada. These areas generally underwent the earliest and most intense extension within the Basin and Range province. Lithospheric mantle is still preserved beneath the stable regions of the Colorado Plateau, Rocky Mountains, and Great Plains. Mixed asthenosphere/lithosphere sources are present beneath most of the Colorado 
Plateau/Basin and Range transition zone, suggesting that these transitional areas are undergoing active conversion of lithospheric sources to asthenospheric sources (Perry et al., 1987).

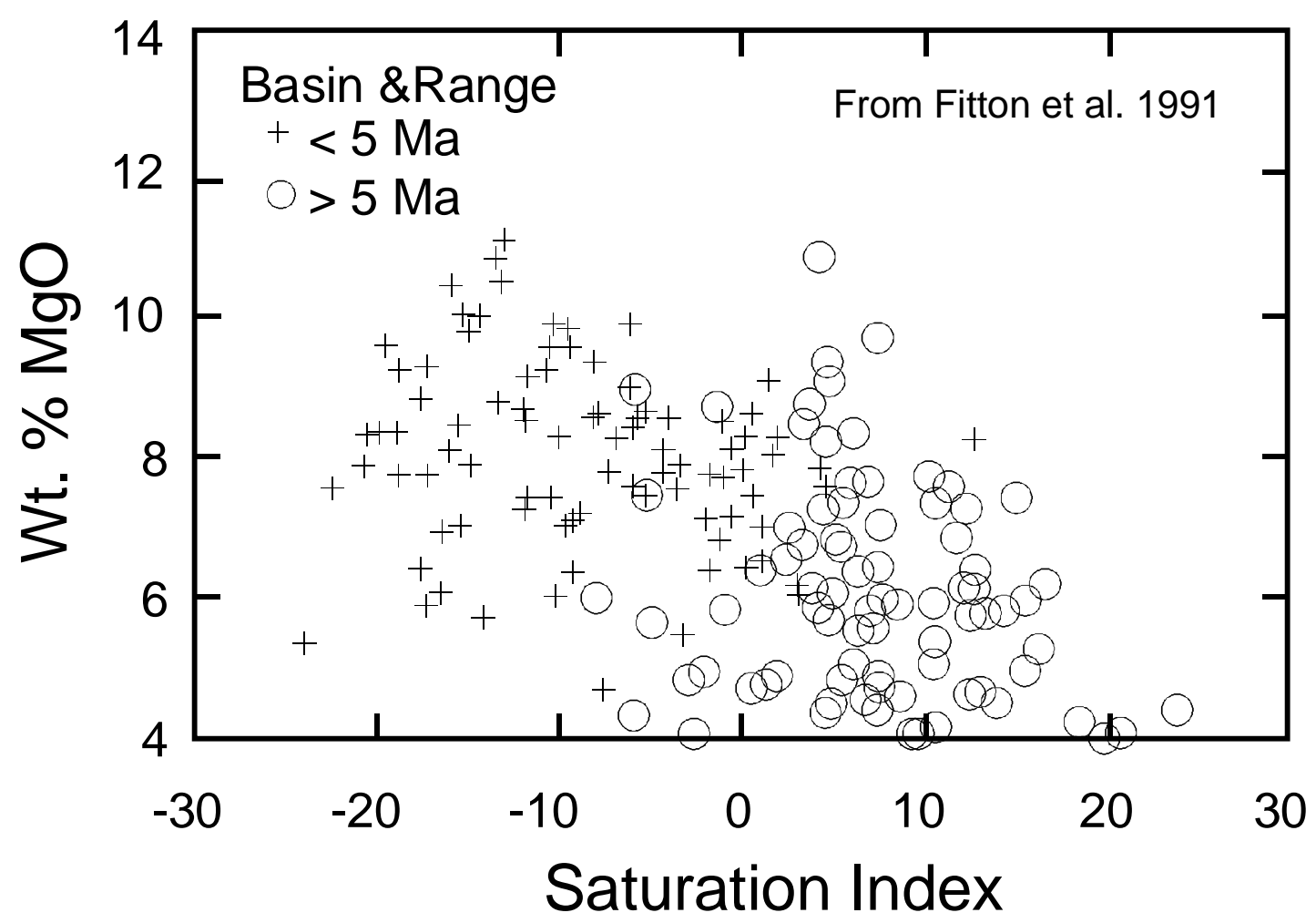

Figure 4.3. $\mathrm{MgO}$ versus saturation index for basalts of the Basin and Range province, after Fitton et al. (1991). Basalts with saturation index $<0$ are nepheline normative; basalts with saturation index $>0$ are hypersthene normative.

Farmer et al. (1989) presented isotopic and trace-element data which suggest that basalts of the southern Great Basin have been derived from lithospheric mantle over the last $10 \mathrm{Ma}$, despite erupting in a region that has undergone active extension for the past 15-10 Ma. This region coincides with the amagmatic gap of Eaton (1982) and was the last portion of the Basin and Range province to begin extending (15-10 Ma). The relative lack of magmatism in this region may have left the lithosphere "cold" and difficult to extend (Wernicke et al., 1987). Both the thermal state and the late initiation of extension of this lithosphere may have combined to preserve lithospheric mantle beneath this region (Farmer et al., 1989).

The presence of lithospheric mantle beneath the southern Great Basin is not wholly compatible with the generation of basaltic magma beneath this region, since lithospheric mantle is generally considered too cold to partially melt. Daley (1992) proposed that if lithospheric mantle beneath the southern Great Basin is hydrous, it can generate basaltic magma at small rates of lithospheric extension, since a small amount of water in the mantle will substantially depress the peridotite solidus. A hydrous mantle source for the basalts of Crater Flat is consistent with their low rubidium contents relative to other incompatible trace elements, which suggests that phlogopite may have played a role in the partial melting process (Vaniman et al., 1982). Daley (1992) calculates that for a 100-km-thick lithosphere and no extension, 1-2 $\mathrm{km}^{3}$ of basalt could be erupted per $100 \mathrm{~km}^{2}$ of surface, assuming that $10 \%$ of the mantle lithosphere is hydrous, $90 \%$ of the melt generated separates from the residue, and $10 \%$ of that melt is erupted. 
Melting of hydrous lithospheric mantle may also have played a role in the concentration and volume of basaltic volcanism along the Colorado Plateau margin. Best and Brimhall (1974) and Tanaka et al. (1986) suggest that volcanism within the Colorado Plateau transition zone may be caused by viscous heating as asthenospheric flow encountered the thicker lithospheric "edge" beneath the Colorado Plateau. Secondary convection in the asthenosphere, caused by lateral temperature variations (juxtaposition of hot asthenosphere and colder Colorado Plateau mantle lithosphere) may have locally enhanced asthenospheric flow, facilitating heat transport into the adjacent lithosphere (Perry et al., 1987). The combination of hydrous lithospheric mantle and enhanced heat transport from the asthenosphere may have favored the generation and eruption of voluminous alkalic and, in some cases, tholeiitic basalt. In the Great Basin/Basin and Range interior, hydrous lithospheric mantle may have been substantially removed by lithospheric extension and asthenospheric upwelling by the end of the Miocene. The absence of easily fusible lithospheric mantle, and of lateral mantle discontinuities found at physiographic margins, may combine to restrict melting to relatively small amounts at greater depths within the dry and relatively less fusible asthenosphere.

Low upper-mantle seismic velocities beneath much of the Basin and Range province suggest that the upper mantle contains a small percentage of partial melt. Ascent of this melt through the crust to produce basaltic volcanism may depend partly on where local stress regimes are conducive to magma ascent (Smith and Luedke, 1984). Against the general background of small melt fractions in the Basin and Range mantle, three northeast-trending zones of enhanced partial melting have been proposed based on identification of low-velocity mantle anomalies (Spence and Gross, 1990; Dueker and Humphreys, 1990; Humphreys et al., 1992). The northernmost and southernmost of these zones correspond to zones of pronounced magmatism: the Snake River Plain - Yellowstone zone and the Jemez zone of the southeastern Colorado Plateau margin (Figure 4.1). The middle zone extends from central Utah to southern Nevada and corresponds with surface volcanism at the St. George area of Utah (Dueker and Humphreys, 1990) and the Crater Flat area of southern Nevada (Evans and Smith, 1992). The volume of basaltic volcanism associated with the St. George zone is far less than the zones to the north and south. At Crater Flat, in particular, $4 \mathrm{Ma}$ of basaltic volcanism has produced only about $1 \mathrm{~km}^{3}$ of basalt. If the lowvelocity anomaly beneath Crater Flat does represent an unusual degree of partial melting relative to the rest of the Basin and Range, this suggests that the local stress regime does not strongly favor magma ascent and eruption.

\section{Evolution of Basaltic Volcanic Fields}

Many long-lived (>2-3 Ma) basaltic volcanic fields in the southwestern United States display a characteristic evolution in terms of eruption volume and basalt composition that can be related to changes in the intensity and depth of partial melting in the mantle. Perhaps the best documented example of systematic volume and compositional relationships through time is the Springerville volcanic field on the southern Colorado Plateau margin of Arizona (Condit et al., 1989). At Springerville, the earliest and most voluminous basalt is tholeiitic (large degree of partial melting), which erupted between 6.5 and $1.75 \mathrm{Ma}$ (Condit et al., 1989; Cooper et al., 1990). After $2 \mathrm{Ma}$, volcanism shifted to less voluminous eruptions of alkalic basalt, representing smaller degrees of partial melting at greater depth in the mantle. A similar relationship is seen in the Zuni-Bandera volcanic field on the Colorado Plateau margin of western New Mexico (Laughlin et al., 1993). Tholeiite was erupted exclusively in the earliest two episodes (700-600 thousand years (ka) and 200-100 ka), while the youngest episode ( $<100 \mathrm{ka})$ erupted both tholeiitic and alkalic basalts. The relationships at Springerville and Zuni-Bandera are consistent with gradual waning of the intensity of mantle melting through time and the eventual extinction of the volcanic field. 
Less voluminous basalt fields in the Basin and Range interior show similar patterns of evolution, although the intensity of mantle melting associated with these volcanic fields was apparently never great enough to produce tholeiitic basalt. Examples are the Cima volcanic field of southeastern California and the Lunar Crater volcanic field of central Nevada (Crowe et al., 1986; Wilshire et al., 1991; Foland and Bergman, 1992). In these volcanic fields, Pliocene eruptions of alkali basalt form relatively voluminous, sheet-like flows, while Quaternary eruptions were less voluminous and compositionally more undersaturated, again indicating a progression to less intense and deeper mantle melting.

\section{A. Evolution of Basaltic Volcanism in the Yucca Mountain Region}

Post-Miocene ( $<5 \mathrm{Ma}$ ) basalts of the Yucca Mountain region occur mainly along a loose north-northwest alignment to the southwest and northwest of Yucca Mountain (Figure 4.4). The exception is Buckboard Mesa, which lies in the moat zone of the Timber Mountain caldera. Pliocene basalt centers have eruptive volumes of $\sim 1 \mathrm{~km}^{3}$ or greater, which is an order of magnitude larger than any of the Quaternary basalt centers. There is, thus, a general decrease in eruptive volume through time for post-Miocene basalts in the Yucca Mountain region.

Geochemical data were obtained for these basalts with the ultimate goal of constraining the nature of magmatic processes beneath the Yucca Mountain region in order to assess whether rates of certain magmatic processes are expected to increase or decrease in the future.

Major-element, trace-element, and $\mathrm{Nd}$ and $\mathrm{Sr}$ isotopic data for the post-Miocene basalts (except Lathrop Wells) are presented in Appendix 4.1, 4.2 and Table 4.1. Equivalent data for Lathrop Wells is presented in Perry and Straub (1996). Basalts of the Yucca Mountain region are generally evolved, alkali olivine basalts. Magnesium $(\mathrm{Mg})$ numbers $\left[\left(\mathrm{Mg} /\left(\mathrm{Mg}+\mathrm{Fe}^{2+}\right)\right) \times 100\right]$, which are a measure of the degree of evolution of basaltic magmas from primary magmas generated in the mantle, range from 61-49 (Figure 4.5). Primary magmas have Mg numbers of approximately 70 , which decrease as olivine and pyroxene are removed from the magma by fractional crystallization. Most basalts of the Yucca Mountain region have Mg numbers $<55$ and, thus, have undergone significant fractionation en route to the surface. On average, Pliocene basalts have slightly higher Mg numbers than Quaternary basalts (Figure 4.5). If any significance can be attached to this, one possibility is that higher extension rates in the Pliocene favored more rapid transit to the surface with less opportunity for fractional crystallization.

Post-Miocene basalts of the Yucca Mountain region vary widely in concentrations of incompatible trace elements, which probably reflect differences in the composition of the mantle and in the conditions of mantle melt generation beneath the Yucca Mountain region. Concentrations of $\mathrm{La}$ and $\mathrm{Th}$ and $\mathrm{La} / \mathrm{Th}$ ratios, for instance, vary considerably; in some cases, even within individual volcanic centers (Figure 4.6). An important observation concerning the genesis of basalts in the Yucca Mountain region is that basalts younger than about 3 Ma have higher concentrations of many incompatible trace elements (e.g., Sr, Th, U, La, Ce) than older basalts (Vaniman et al., 1982; Farmer et al., 1989; Fleck et al., 1996). For melting of mantle source rocks, elements such as $\mathrm{La}$ and $\mathrm{Th}$ are diagnostic of relative degrees of partial melting (e.g., high percentage of partial melt $=$ low concentration of La and Th). These criteria can only be used as a broad guideline because source heterogeneity also has to be taken into account. However, the three Pliocene basalt centers (Thirsty Mesa, SE Crater Flat, Buckboard Mesa) have generally lower La and Th concentrations than Quaternary centers (Figure 4.6), implying larger degrees of partial melting of the mantle source, which is an interpretation that is consistent with their higher eruption volumes. Fleck et al. (1996) observed that the increase in incompatible elements through time is also valid when the time frame is extended to include basalts of Late 
Miocene age $(<11 \mathrm{Ma})$ and concluded that a general decrease through time in the amount of partial melting of the mantle source is the most reasonable explanation.

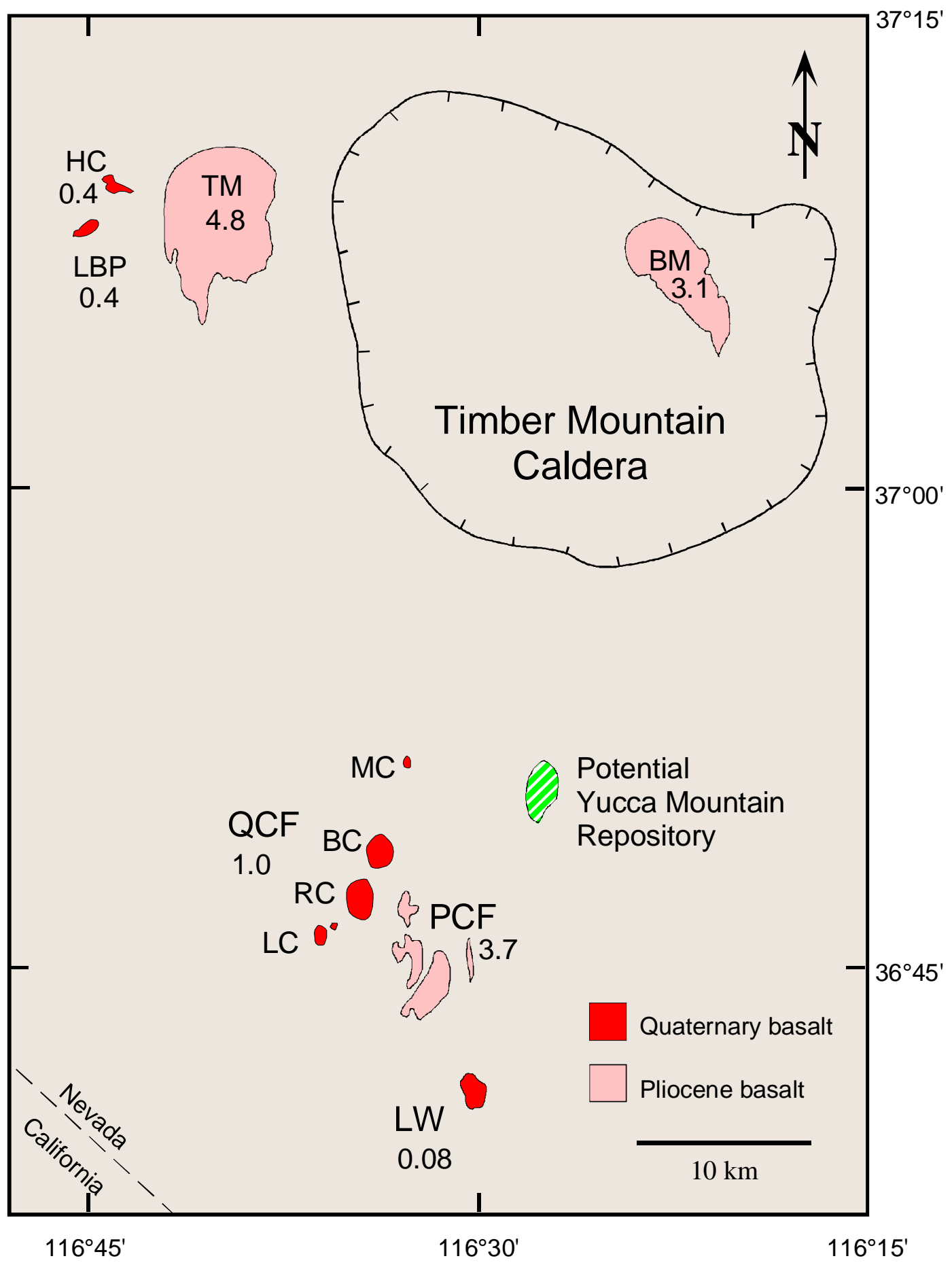

Figure 4.4. Quaternary and Pliocene basalt centers of the Yucca Mountain Region. LW: Lathrop Wells; HC: Hidden Cone; LBP: Little Black Peak; QCF: Quaternary Crater Flat (Makani, Black, Red, and Little Cones); BM: Buckboard Mesa; PCF: Pliocene (SE) Crater Flat; TM: Thirsty Mesa. Numbers below each center designation are approximate ages in millions of years. 


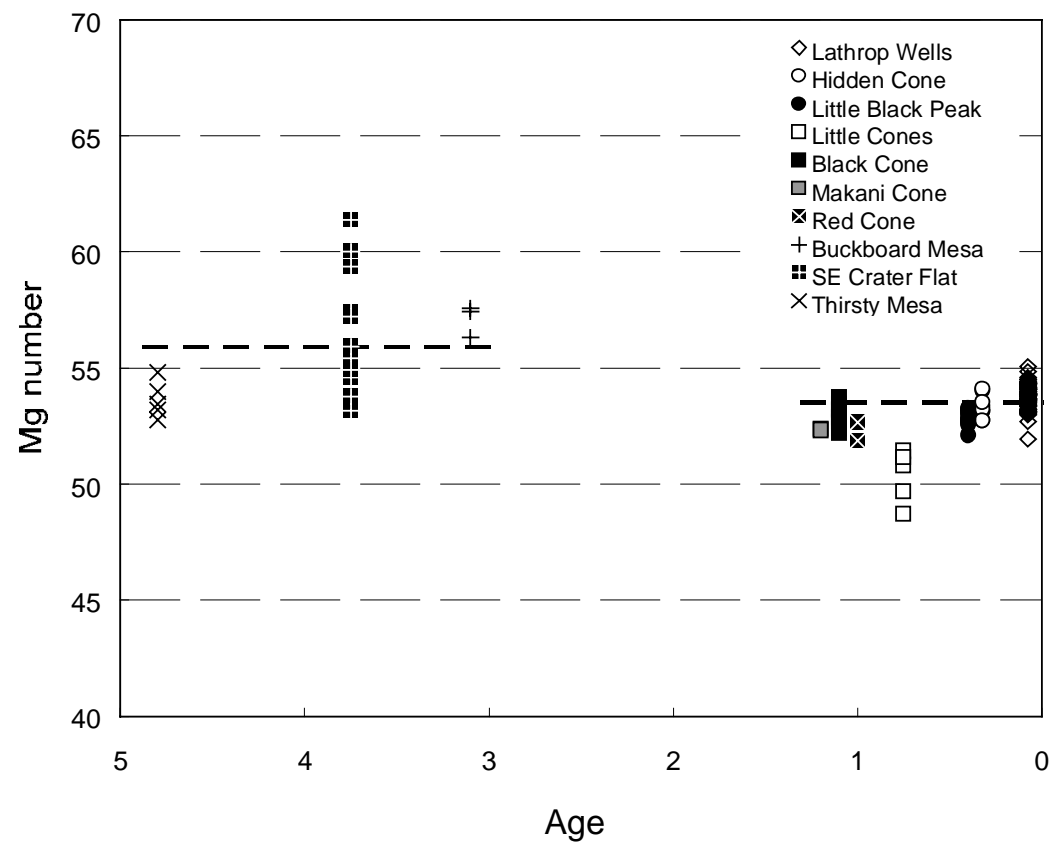

Figure 4.5. Age versus Mg number for post-Miocene basalts of the Yucca Mountain region. Ages of Quaternary centers are offset slightly for clarity. Heavy dashed lines are mean Mg numbers for Pliocene and Quaternary basalts.

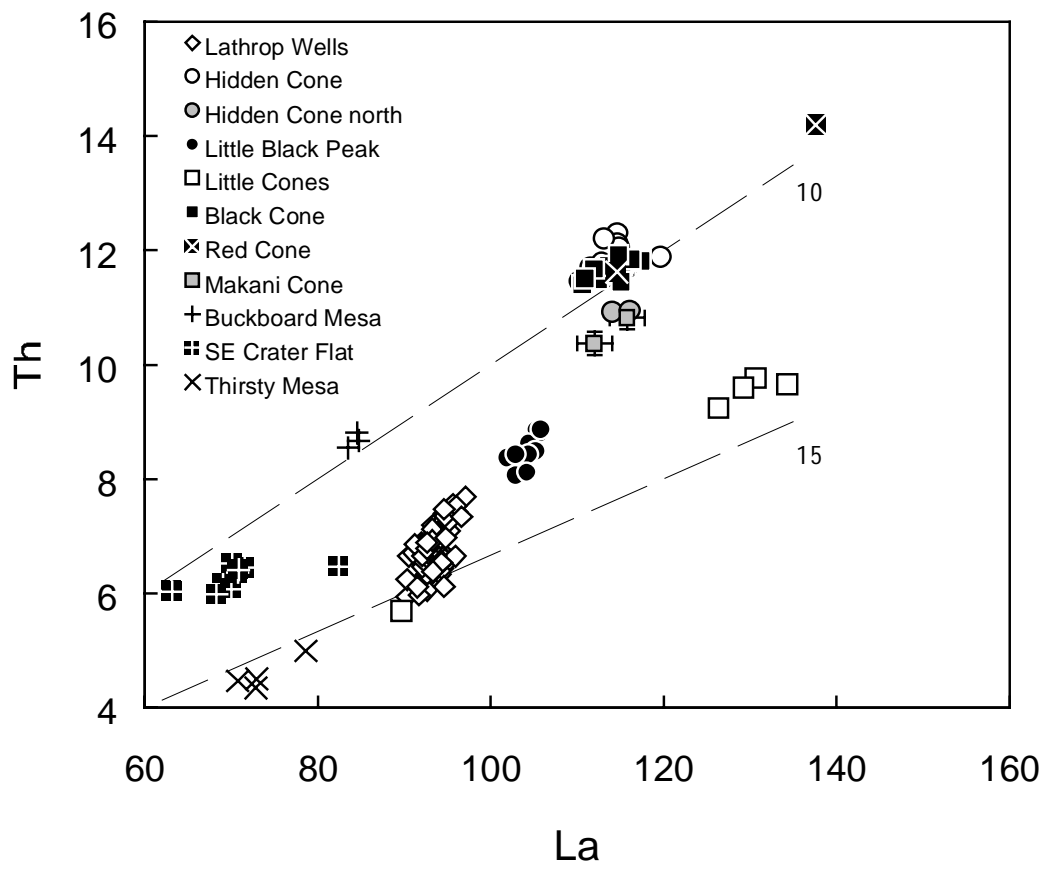

Figure 4.6. La versus Th for post-Miocene basalts of the Yucca Mountain region. Dashed lines represent constant values of 10 and 15 for La/Th. Representative error bars for Makani Cone are $\pm 2 \sigma$. 
Table 4.1. Isotopic compositions of basalts from the YMR.

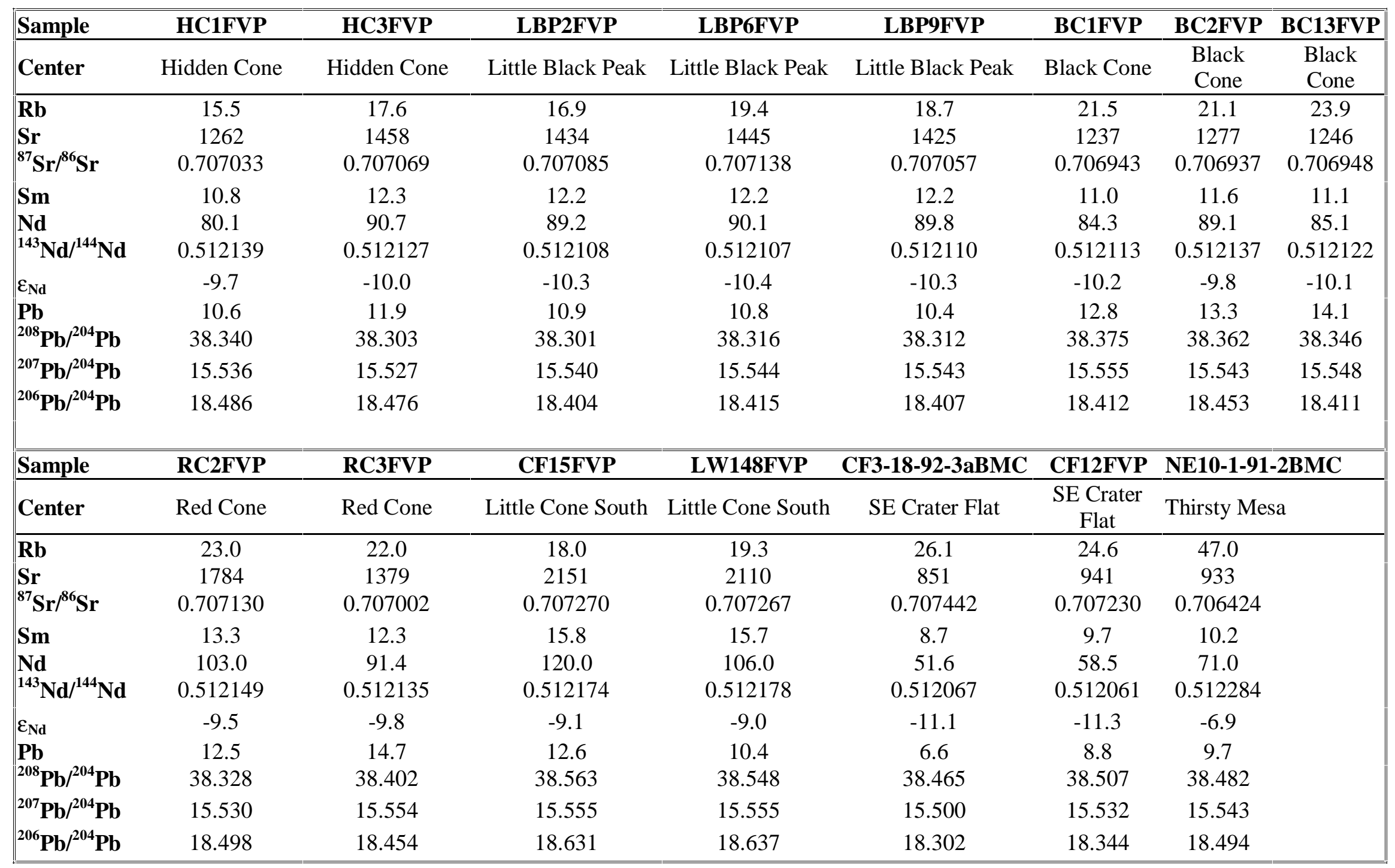


Because $\mathrm{La} / \mathrm{Th}$ ratios do not change significantly during fractional crystallization, different $\mathrm{La} / \mathrm{Th}$ ratios can be used to infer the involvement of different magma batches in volcanism (Figure 4.6). Clearly, differences in La/Th between basalts of Buckboard Mesa and Thirsty Mesa, for instance, are due to derivation from different magma batches since these centers are 20 $\mathrm{km}$ apart and differ in age by almost $2 \mathrm{Ma}$. This type of analysis can be extended to individual volcanic centers and clusters of centers to constrain the number of magma batches (each presumably representing a separate intrusive event) that were involved in the formation of centers or clusters. In the case of the four Quaternary centers of Crater Flat, La/Th data suggest the involvement of at least five magma batches: one each for Black Cone and Makani Cone, two for Little Cones, and two for Red Cone (one of which may have also fed Black Cone; Bradshaw and Smith, 1994). In the case of the two Sleeping Butte centers, Hidden Cone and Little Black Peak, the $\mathrm{La} / \mathrm{Th}$ data indicate that each center was formed from a unique magma batch. Differences in $\mathrm{La} / \mathrm{Th}$ ratios for basalts of the 3.7 Ma cycle in SE Crater Flat suggest the involvement of two or three magma batches. Lathrop Wells has the largest range of La/Th of any basalt center, indicating that eruptive units may be derived from several separate magma batches (see discussion below).

Neodymium, strontium, and lead isotopic data have been obtained for most of the postMiocene volcanic centers of the Yucca Mountain region (Table 4.1). Except for the basalt of Thirsty Mesa, all of the basalt cluster at $\varepsilon_{\mathrm{Nd}}$ values of -9 to -11 and ${ }^{87} \mathrm{Sr} /{ }^{86} \mathrm{Sr}$ values of 0.7069 to 0.7075 (Figure 4.7). These isotopic values are unusual for alkali basalts of the western United States and are interpreted as reflecting the isotopic composition of a lithospheric mantle source (Farmer et al., 1989). The distinctly different $\mathrm{Sr}$ and $\mathrm{Nd}$ isotopic composition of Thirsty Mesa is interesting because the nearby Sleeping Butte Centers have compositions typical of the other Yucca Mountain region basalts. Crustal contamination is unlikely to be the cause of this difference. One possibility for the difference is that the voluminous Thirsty Mesa basalts represent a larger degree of partial melting than other Yucca Mountain region basalts, and the melting process involved a higher proportion of an isotopically "depleted" matrix within a heterogeneous lithospheric source.

\section{B. Crater Flat Volcanism}

Basaltic volcanism at Crater Flat occurred in three episodes at approximately 3.7, 1, and <0.1 Ma. All of the basalt erupted at Crater Flat are alkalic (Vaniman et al., 1982), indicating relatively small degrees of partial melting in the mantle throughout the lifetime of the field. The volume of alkali basalt erupted through time has decreased, from $\sim 1 \mathrm{~km}^{3}$ in the oldest cycle to $\sim 0.1 \mathrm{~km}^{3}$ at the youngest center (Lathrop Wells). The relatively long lifetime of the Crater Flat field combined with the small volume of erupted material results in one of the lowest eruptive rates of any basaltic volcanic field in the southwestern United States (Figure 4.2).

Although declining volumes through time indicate a waning magmatic system, the normative compositions of basalt from different episodes (Vaniman et al., 1982) do not clearly indicate a shift to more undersaturated compositions (and hence, smaller degrees of partial melting) through time. Differences in normative composition appear to be related more to fractionation history (e.g., amphibole removal) than differences in degree of partial melting (Vaniman et al., 1982).

Another factor bearing on the evolution of the Crater Flat field is changes in the fractionation depth of magmas through time, which is probably related to changes in magma chamber depth (Perry and Crowe, 1992). Lavas of the oldest episode contain plagioclase, olivine, and clinopyroxene phenocrysts, while lavas of the younger episodes contain only olivine. Experimental studies of alkali basalt (Knutson and Green, 1975; Mahood and Baker, 1986) 
indicate that clinopyroxene will crystallize early in the crystallization sequence relative to plagioclase at pressures exceeding $8 \mathrm{~kb}$. The lack of plagioclase phenocrysts in lavas of the younger episodes indicates fractionation at high pressure within the lower crust or upper mantle. The high strontium (which partitions into plagioclase) of the younger episodes also indicates that plagioclase was not an important fractionating phase in the younger episodes. Scandium (which partitions into clinopyroxene) is lower in the youngest episodes relative to the oldest episode, indicating fractionation of clinopyroxene at high pressure. In contrast, lava of the oldest episode contains plagioclase phenocrysts, relatively low strontium, and relatively high scandium (Vaniman et al., 1982), indicating fractionation at low pressure where plagioclase and olivine dominate fractionation. These relationships indicate that magma chambers were relatively shallow (middle to upper crust) at 3.7 Ma but were deep (lower crust or upper mantle) during the younger two episodes (Perry and Crowe, 1992). This interpretation implies a decreased generation rate for basaltic magma in the Quaternary. Fleck et al. (1996) noted that the higher abundances of plagioclase phenocrysts in older basalts extend to basalts of late Miocene age and likewise concluded that younger basalts equilibrated at higher pressure, consistent with a reduced magma flux into the crust.

The evolution of volcanism through time near Yucca Mountain has parallels to alkalic volcanism in Hawaii. Frey et al. (1990) suggest that the depth at which magma chambers were established at Mauna Kea is controlled by magma flux into the crust, with older, higher-level chambers being sustained by higher magma flux, and younger, lower crustal chambers being established after magma flux declines. Younger lavas at Mauna Kea are more differentiated (cf. Figure 4.5), suggesting that lavas derived from lower crustal chambers ascend only after magma density is lowered by fractionation of olivine + clinopyroxene. The changes in phenocryst assemblage, trace-element content, and degree of evolution of lavas erupted during the waning of Mauna Kea volcanism almost exactly mirror the changes seen at Crater Flat, suggesting that the evolution to deeper magma chambers at Crater Flat may also reflect a waning magma flux. However, the Mauna Kea model must be applied cautiously to Crater Flat because (1) the eruption rates at Mauna Kea were orders of magnitude higher, raising questions about whether vastly different magma fluxes can lead to similar ascent dynamics, and (2) Mauna Kea is a single volcano with an integrated plumbing system, whereas eruptive activity at Crater Flat is spread over several distinct eruptive centers with separate plumbing systems.

\section{Geochemical Studies of the Lathrop Wells Volcanic Center}

Lathrop Wells is the youngest volcanic center in the CFVZ and, as such, has received the most detailed study of any volcanic center in the Yucca Mountain region. A controversial aspect of the volcanic center is whether it is monogenetic, erupted during a single eruptive episode, or polygenetic, formed by multiple eruptive episodes spanning a period of several tens of thousands of years (Wells et al., 1990; Turrin et al., 1991; Wells et al., 1992; Turrin et al., 1992). A monogenetic volcano is formed by the ascent and eruption of a single batch of magma, generally within a period of months to years (Wood, 1980). A small-volume polygenetic volcano, if formed over a period of thousands to tens of thousands of years, would probably involve the eruption of multiple magma batches since small-volume magmas have limited lifetimes within the lithosphere. Geochemical data can generally distinguish whether lavas erupted from a volcanic center are derived from single or multiple magma batches. To test the possibility that multiple magmas were involved in the formation of the Lathrop Wells center, extensive sampling of eruptive units identified by geologic field studies was begun in 1987. To date, over 120 samples have been collected and analyzed for major-, trace-element, and isotopic geochemistry to constrain the petrologic evolution of the eruptive center. Complete tables of these data have been published elsewhere (Perry and Straub, 1996) and will not be reproduced in this report. 


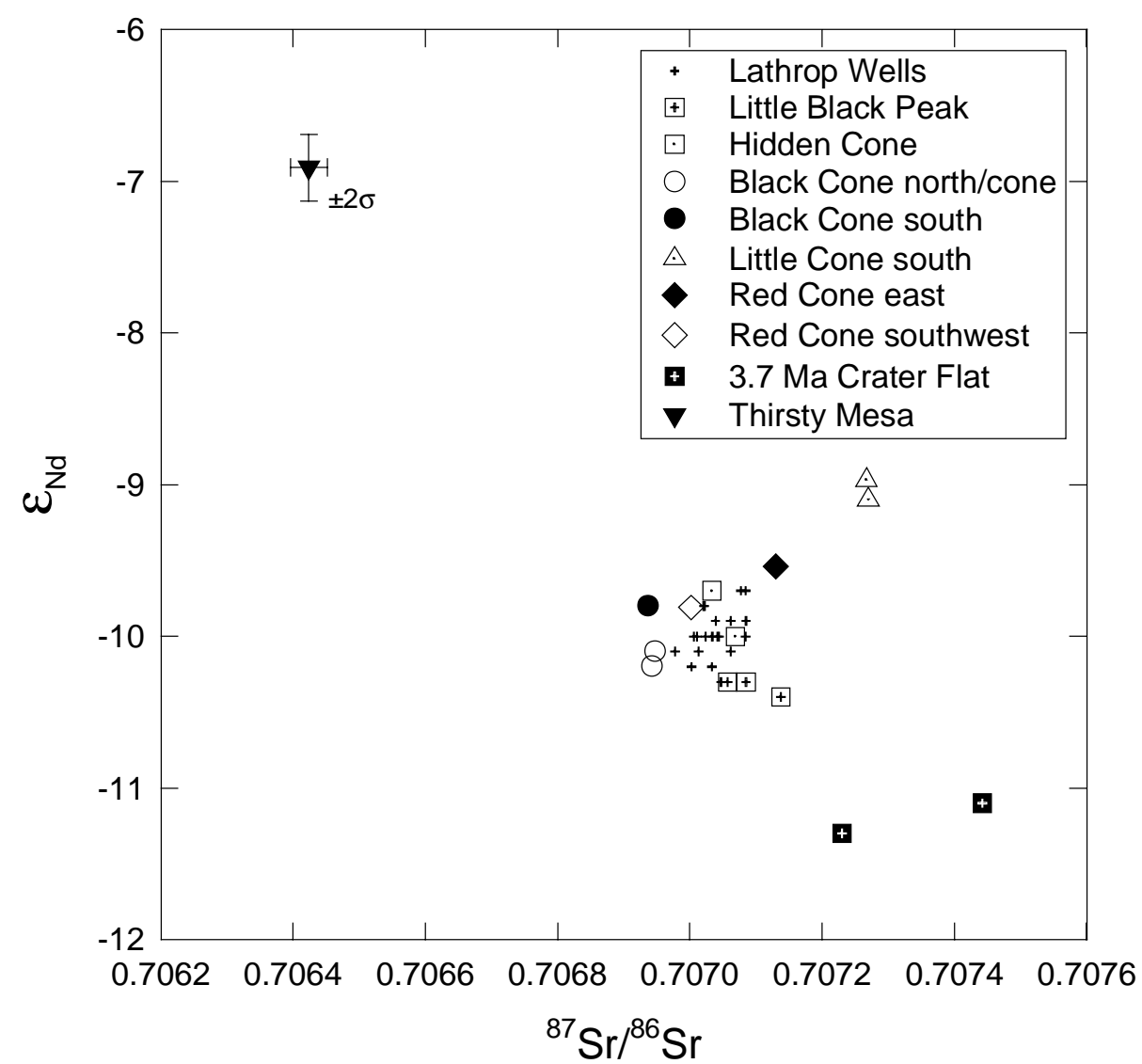

Figure 4.7. Nd and Sr isotopic composition of post-Miocene basalts of the Yucca Mountain region.

As discussed in Chapter 2, geologic mapping of the Lathrop Wells center indicates that the center formed by the emplacement of three eruptive units designated Q1 to Q3 from oldest to youngest. (Figure 4.8). The trace-element compositions of the three eruptive units define a continuum with a distinct pattern of depletion and enrichment of incompatible elements relative to the oldest lava flow of the first eruptive unit (Figure 4.9). The relative depletion and enrichment of incompatible elements requires a petrogenetic process that can fractionate elements of similar incompatibility during magmatic processes.

\section{A. Composition of Tephras within Soils}

Before using the measured compositions of volcanic material to deduce petrogenetic processes, it is necessary to determine whether the compositions have been modified in any way since eruption by alteration or other secondary processes. Lava samples from Lathrop Wells are generally dense, fresh rock with no evidence of alteration under petrographic examination. Thus, we consider the composition of lava samples at Lathrop Wells to represent magmatic compositions. Tephra samples are more prone to compositional alteration due to high porosities and high surface area to volume ratios. The large majority of tephra samples analyzed from Lathrop Wells consist of unaltered glass and mineral crystals and are free of secondary material. In addition, the composition of these tephras usually are compositionally equivalent to associated lava flows, suggesting that they represent magmatic compositions. 


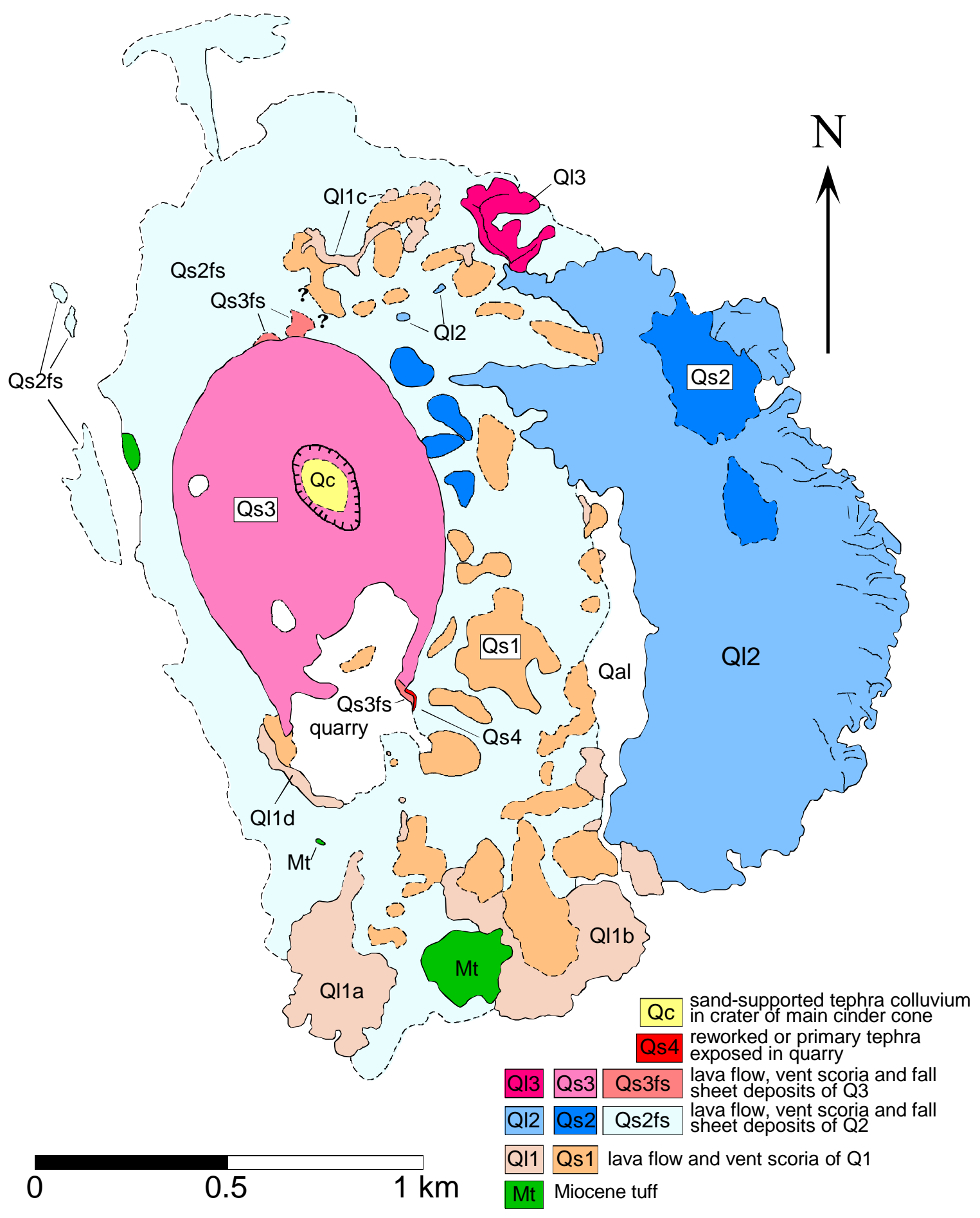

Figure 4. 8. Geologic map of the Lathrop Wells volcanic center.

A sequence of buried tephra deposits separated by soils at the south end of the Lathrop Wells scoria cone has previously been interpreted as supporting a polygenetic eruptive history at Lathrop Wells (Wells et al., 1990; Crowe et al., 1995). Geochemical analysis of one of these tephra units (designated Qs4b) indicated a unique composition which we interpreted as signifying derivation from a separate magma batch. This is an interpretation that would further support the validity of the polygenetic model at Lathrop Wells (Crowe et al., 1995; Perry and Straub, 1996). 


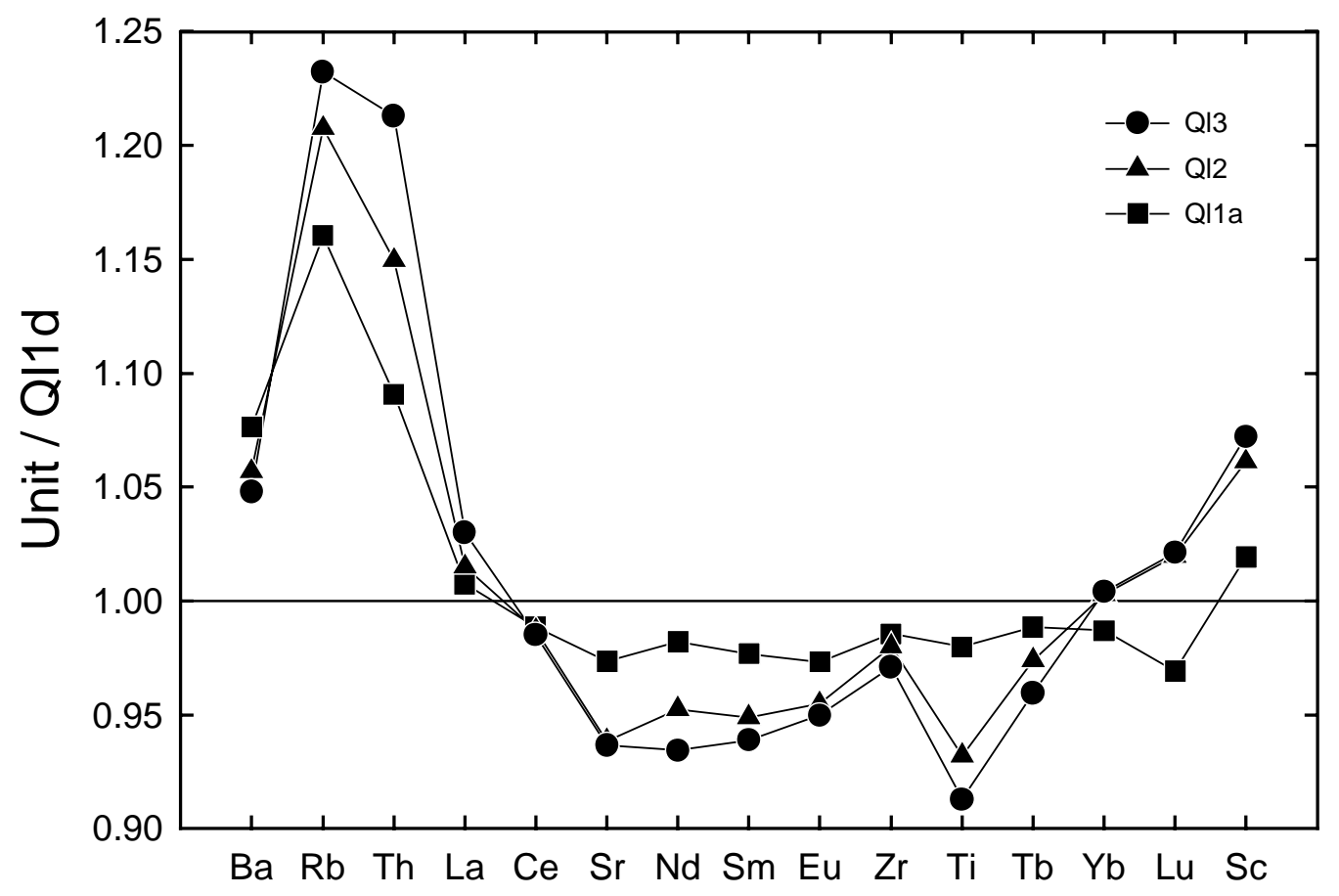

Figure 4.9. Normalized multi-element diagram of incompatible elements (except Sc) comparing compositions of lava flows Q11a, Q12 and Q13 from Lathrop Wells normalized to lava flow Q11d.

The Qs4b tephra lies completely within a buried soil horizon, and we were concerned that its composition may have been affected by pedogenic processes. To test this hypothesis, we collected two samples of the Qs2 scoria fall-sheet exposed by trenching $1 \mathrm{~km}$ north of the Lathrop Wells cone. The first sample (LW162FVP) was collected near the top of the deposit within a well-developed soil horizon; the second sample (LW163FVP) was collected below the soil horizon at a level that did not appear to be affected by pedogenic processes. Both samples were sieved, hand-picked to avoid carbonate coatings and cleaned by ultrasound to remove loose dust. The samples were analyzed by XRF and INAA for major and trace-element compositions (Table 4.2). In addition, two size fractions of silt $(45-125 \mu$ and $<45 \mu)$ from the soil enclosing LW163FVP were sieved and analyzed (Table 4.2). These analytical results show that LW163FVP, collected within the soil, has higher concentrations of $\mathrm{Rb}, \mathrm{Th}, \mathrm{SiO}_{2}$ and $\mathrm{K}_{2} \mathrm{O}$, and lower concentrations of $\mathrm{Sr}$, the light and middle rare-earth elements, $\mathrm{TiO}_{2}, \mathrm{Fe}_{2} \mathrm{O}_{3}$ and $\mathrm{MgO}$ compared to LW162FVP. The pattern of element enrichment and depletion is very similar to that of Qs4b when compared to other eruptive units at Lathrop Wells (Figure 4.10, top).

Examination of the silt compositions (Table 4.2) suggests that mixing of silt and tephra could produce the compositions observed in LW163FVP and the analyzed Qs4b tephra. Petrographic examination and point-counting of Qs4b tephra revealed $~ 7 \%$ silt, which fills $\sim 25 \%$ of the tephra vesicle volume. To test whether addition of silt produced the unique Qs4b composition, we constructed a 15-element mixing model using several alternative parental tephra compositions and the two analyzed silt samples as mixing endmembers. The amount of mixing between tephra and silt was varied to maximize the model fit as measured by minimization of the sum of the squared residuals for all the elements considered. The best model fit was obtained by mixing tephra from the main scoria cone (Qs3) and the smallest size fraction of silt in roughly a 9:1 proportion (Figure 4.10). 

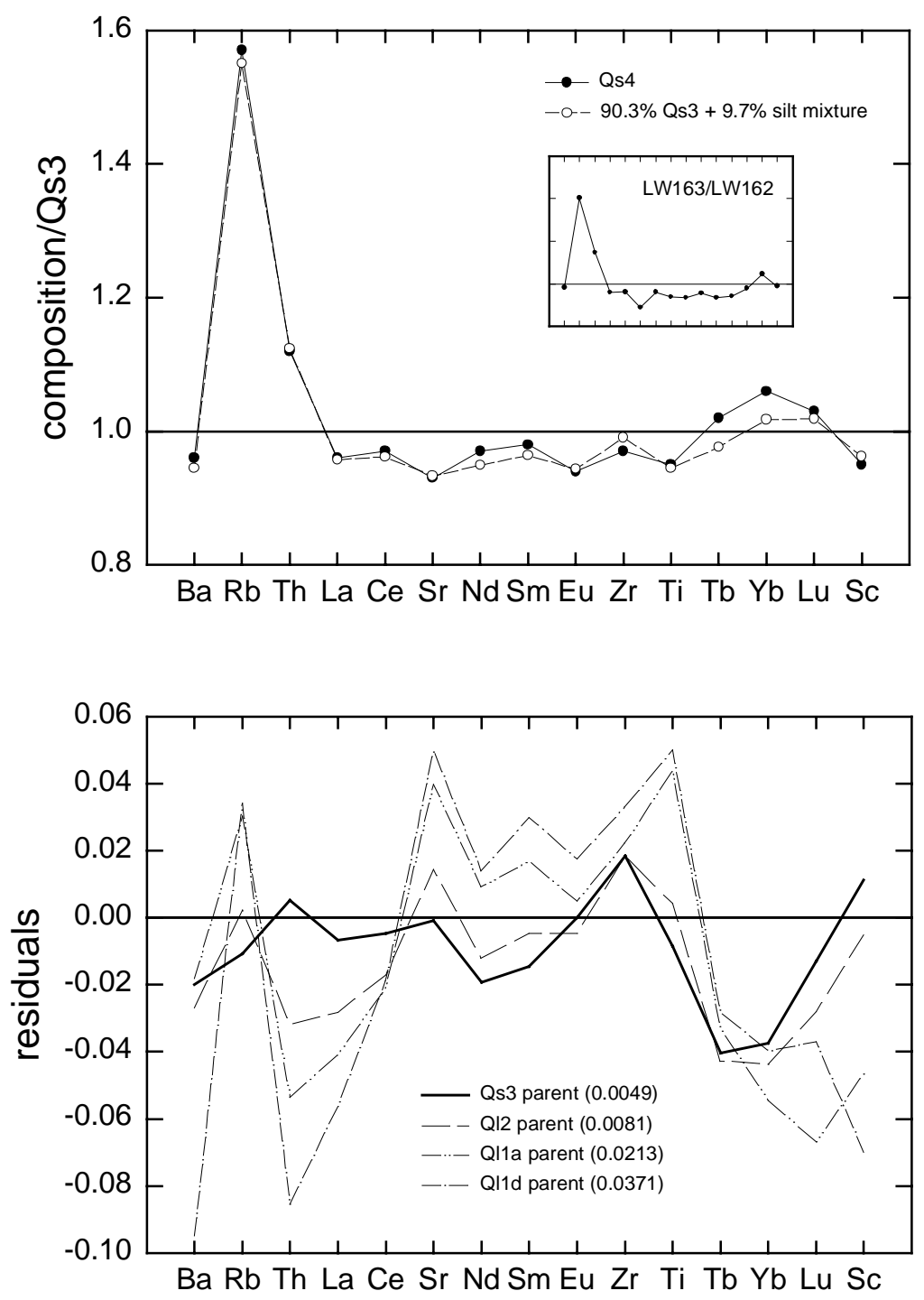

Figure 4.10. Results of a multi-element tephra-silt mixing model to test whether the composition of Qs4 tephra has been modified by silt addition. Upper frame compares the measured composition of Qs4 to a model mixture of Qs3 tephra and silt ( 9:1 mixture). The amount of silt in the mixture was determined by minimizing the sum of the squared residuals for all elements. Upper frame inset is soilbound fall-sheet tephra normalized to fall-sheet tephra not in soil. Lower frame compares the residuals (not squared) for several potential parental compositions. Values in parentheses are the sum of the residuals squared for different parental compositions considered. Mixing between Qs3 tephra and silt produced the best fit (bold line) to the measured Qs4 composition. Residuals are based on Qs4normalized compositions to minimize the effect of orders-of-magnitude differences in absolute elemental abundances on the model results. Using this normalization, residual values for each element correspond to the proportional misfit between the Qs4 composition and the model composition (e.g., $0.02=2 \%$ misfit $)$.

We hypothesize that silt was introduced into the tephra vesicles along fractures via capillary action during soil wetting events. We do not observe silt in tephras not associated with soil formation. Given the modeling results and petrographic observations, it is a reasonable conclusion that the composition of Qs4b is a result of silt addition and does not represent a unique magma composition. 
Table 4.2. INAA of tephra and silt from Lathrop Wells

\begin{tabular}{|c|c|c|c|c|}
\hline Sample & LW162FVP & LW163FVP & $\begin{array}{c}\text { LW163FVP-S1 } \\
(45-125 \mu)\end{array}$ & $\begin{array}{c}\text { LW163FVP-S2 } \\
(<45 \mu)\end{array}$ \\
\hline Type & tephra & $\begin{array}{c}\text { soil-bound } \\
\text { tephra }\end{array}$ & silt & silt \\
\hline $\mathrm{SiO}_{2}$ & 48.29 & 48.58 & 57.69 & 57.60 \\
\hline $\mathrm{TiO}_{2}$ & 1.966 & 1.840 & 0.798 & 0.799 \\
\hline $\mathrm{Al}_{2} \mathrm{O}_{3}$ & 16.81 & 16.69 & 14.95 & 15.23 \\
\hline $\mathrm{Fe}_{2} \mathrm{O}_{3} \mathbf{T}$ & 11.76 & 11.14 & 5.44 & 5.52 \\
\hline MnO & 0.165 & 0.165 & 0.115 & 0.116 \\
\hline MgO & 5.73 & 5.63 & 3.41 & 3.71 \\
\hline $\mathrm{CaO}$ & 8.11 & 8.15 & 4.88 & 4.22 \\
\hline $\mathrm{Na}_{2} \mathrm{O}$ & 3.06 & 3.01 & 1.82 & 1.69 \\
\hline $\mathbf{K}_{2} \mathbf{O}$ & 1.85 & 1.97 & 3.54 & 3.62 \\
\hline $\mathbf{P}_{2} \mathbf{O}_{5}$ & 1.137 & 1.124 & 0.301 & 0.322 \\
\hline Total & 98.88 & 98.31 & 92.93 & 92.83 \\
\hline \multicolumn{5}{|l|}{ (XRF) } \\
\hline $\mathbf{V}$ & 175.3 & 170.5 & 129.1 & 162.4 \\
\hline $\mathrm{Cr}$ & 97.1 & 101.9 & 51.1 & 49.0 \\
\hline $\mathbf{N i}$ & 114.0 & 115.8 & 69.9 & 70.9 \\
\hline Zn & 140.8 & 128.7 & 117.7 & 129.5 \\
\hline $\mathbf{R b}$ & 22.2 & 31.2 & 135.9 & 137.5 \\
\hline $\mathbf{S r}$ & 1546.3 & 1374.9 & 434.7 & 419.5 \\
\hline $\mathbf{Y}$ & 30.1 & 25.0 & 27.2 & 31.0 \\
\hline $\mathbf{Z r}$ & 360.0 & 343.7 & 376.4 & 332.8 \\
\hline $\mathbf{N b}$ & 22.1 & 30.7 & 22.3 & 25.4 \\
\hline Ba & 1394.3 & 1368.9 & 607.2 & 599.5 \\
\hline \multicolumn{5}{|l|}{ (INAA) } \\
\hline Sc & 18.66 & 18.46 & 11.76 & 12.2 \\
\hline Co & 30.6 & 29.3 & 12.45 & 12.99 \\
\hline $\mathbf{R b}$ & 24 & 34 & 136 & 141.5 \\
\hline $\mathbf{S r}$ & 1500 & 1370 & 426 & 414 \\
\hline Ba & 1420 & 1380 & 648 & 621 \\
\hline La & 91.9 & 88.2 & 58.1 & 52.9 \\
\hline Ce & 184.3 & 177.2 & 118.6 & 110.3 \\
\hline Sm & 12.77 & 11.98 & 7.69 & 7.41 \\
\hline $\mathbf{E u}$ & 3.25 & 3.04 & 1.309 & 1.295 \\
\hline $\mathbf{T b}$ & 1.18 & 1.11 & 0.842 & 0.844 \\
\hline $\mathbf{Y b}$ & 2.34 & 2.29 & 2.84 & 2.8 \\
\hline Lu & 0.326 & 0.341 & 0.421 & 0.42 \\
\hline Hf & 7.19 & 7.08 & 9.52 & 8.58 \\
\hline Ta & 1.4 & 1.38 & 1.44 & 1.4 \\
\hline Th & 6.54 & 7.49 & 16.45 & 16.71 \\
\hline
\end{tabular}




\section{B. Tests of Alternative Petrogenetic Models}

The extent of geochemical variation at small-volume monogenetic basaltic centers is generally not well documented due to the small number of samples ( 1 or 2$)$ typically collected and analyzed from such centers. In the few cases where sufficient samples have been analyzed, geochemical data often indicate a relatively simple magma evolution involving fractional crystallization, small amounts of crustal assimilation, or simple mixing between separate magma batches of different composition (e.g., Luhr and Carmichael, 1985; McBirney et al., 1987; Camp et al., 1987; Bradshaw and Smith, 1994). The geochemical variations observed among lava flows and tephra deposits at Lathrop Wells are intriguing, because they are not obviously produced by any of the aforementioned processes. In the following sections, we test alternative petrogenetic models to determine which can best account for the geochemical variations observed at Lathrop Wells. For all the models, we assume that the composition of lava flow Q11d represents the composition of the parental magma, because it has the highest $\mathrm{MgO}$ content and lowest concentrations of the highly incompatible elements $\mathrm{Rb}$ and Th. Lava flows Q11d and Q13 exhibit the maximum contrast in composition at Lathrop Wells (Figure 4.9). The goal of the petrogenetic modeling is to understand the physical processes that produced the geochemical variations, which is a key to understanding the processes and evolution of magmatism beneath the Yucca Mountain region.

1. Fractional Crystallization. An observation of fundamental importance in interpreting the geochemical variations observed at the Lathrop Wells volcanic center is that $\mathrm{Mg}$ numbers $\left[\left(\mathrm{Mg} /\left(\mathrm{Mg}+\mathrm{Fe}^{2+}\right)\right) \times 100\right]$ of the basalts (119 samples) cluster tightly around a value of about 54 (Figure 4.11). Mg numbers are a sensitive indicator of the degree of evolution of a magma undergoing fractional crystallization, particularly of a basaltic magma where ferromagnesium minerals (olivine and clinopyroxene) are important components of the fractionating mineral assemblage. A primary basaltic magma formed in equilibrium with normal mantle peridotite will have a Mg number of approximately 68-72. During subsequent fractional crystallization of olivine and clinopyroxene, this value will decrease. Assuming an initial Mg number of 70 and purely olivine fractionation, about $20 \%$ removal of olivine is required for a magma to evolve to a $\mathrm{Mg}$ number of 54. For a 1/1 mixture of olivine and clinopyroxene in the fractionating assemblage, about $35 \%$ removal of crystals is required. This assumes perfect fractional crystallization and $\mathrm{Fe} / \mathrm{Mg}$ partition values of 0.32 and 0.25 for olivine and clinopyroxene, respectively (Furman et al., 1991). During the evolution of a magma, trace-element concentrations in the magma will change as a function of the partitioning of a particular element between the melt and crystallizing phases and, if assimilation of crustal material or recharge by new magma occurs, the concentration of trace elements in any new material added to the evolving magma. Any model that attempts to account for the trace-element variations between eruptive units at Lathrop Wells (Figure 4.9) must also satisfy the observation that $\mathrm{Mg}$ numbers of eruptive units are almost invariably the same.

Except for lavas of the first eruptive unit (which contain plagioclase and olivine phenocrysts), olivine is the only phenocryst present in Lathrop Wells eruptive units. Lower scandium contents in Lathrop Wells eruptive units compared to older eruptive centers in the CFVZ (Vaniman et al., 1982) suggest that clinopyroxene or amphibole may have crystallized from Lathrop Wells magmas and been removed during high-pressure crystallization, as is relatively common for alkali basalt magmas (e.g., Mahood and Baker, 1986). High strontium contents (>1400 ppm) relative to "normal" alkali basalts (600-800 ppm) and the lack of plagioclase phenocrysts indicate that plagioclase did not crystallize to any significant degree and that strontium has behaved as an incompatible element during the evolution of Lathrop Wells 
magmas. For these reasons, we consider olivine, clinopyroxene and amphibole as the most likely fractionating phases when modeling the evolution of the Lathrop Wells magmas.

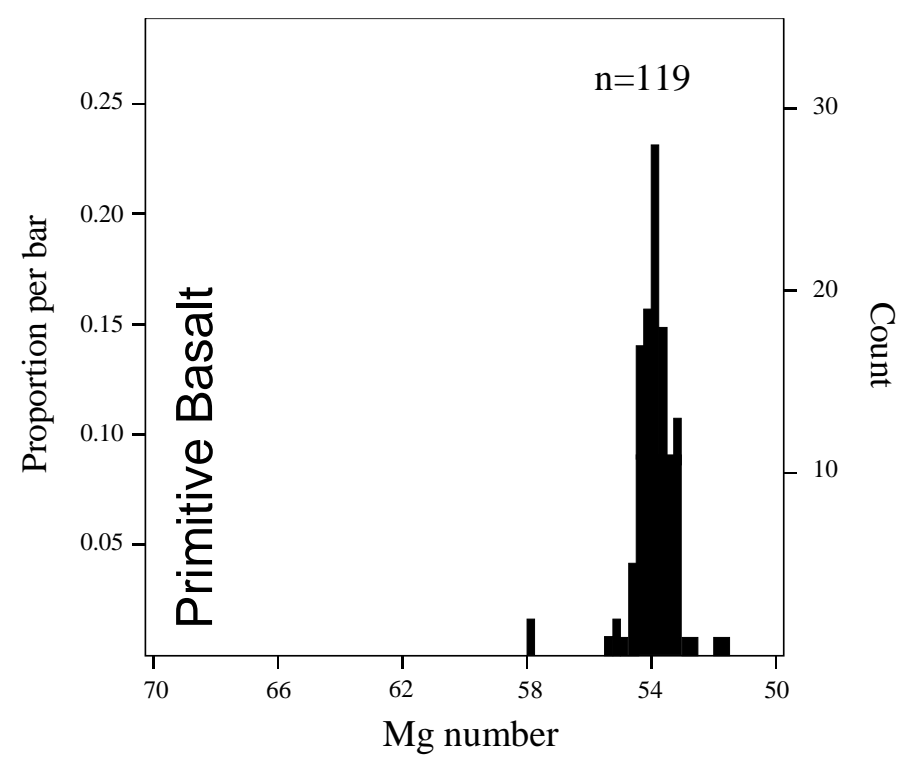

Figure 4.11. Histogram of $\mathrm{Mg}$ numbers of samples from the Lathrop Wells volcanic center.

Assuming the identity of fractionating phases is known, elements that are incompatible during fractionation can be used to test whether variations of incompatible elements are the result of simple fractional crystallization. The ratio of two highly incompatible elements (e.g., Th/La) should not vary during fractional crystallization because La and Th behave similarly during fractionation of ferromagnesian minerals. A plot of $\mathrm{Th} / \mathrm{La}$ versus $\mathrm{Mg}$ number should, therefore, define a nearly horizontal line for a group of basalts undergoing fractional crystallization. Data from Lathrop Wells define just the opposite relationship, which is a systematic increase in $\mathrm{Th} / \mathrm{La}$ from oldest to youngest eruptive units at a constant value of Mg number (Figure 4.12). These data rule out simple fractional crystallization as the mechanism for producing the geochemical variations at Lathrop Wells. Assimilation of high Th/La crustal wall rock combined with fractional crystallization (in the general case where crystallization is the dominant process) can also be ruled out using these data because it will also produce a large decrease in $\mathrm{Mg}$ number for any increase in $\mathrm{Th} / \mathrm{La}$.

Fractional crystallization can also be ruled out by modeling fractional crystallization and examining the results on a normalized multi-element diagram (Figure 4.13). Any combination of olivine, plagioclase, clinopyroxene, and amphibole fractionation cannot produce the decoupling of the concentration of enriched incompatible elements, such as $\mathrm{Rb}$ and $\mathrm{Th}$, and depleted incompatible elements such as $\mathrm{Nd}$ and $\mathrm{Sm}$. The severe constraint imposed by a lack of variation in $\mathrm{Mg}$ number among the eruptive units also limits the amount of fractional crystallization "available" to produce fractionation of incompatible elements. Any assimilation/fractional crystallization process dominated by fractional crystallization likewise cannot account for the relative depletion of elements such as $\mathrm{Nd}, \mathrm{Sm}$, and $\mathrm{Eu}$, regardless of the composition of the assimilate, because the incompatibility of these elements in crystallizing minerals will still result in a net increase in their concentration in the residual magma. 


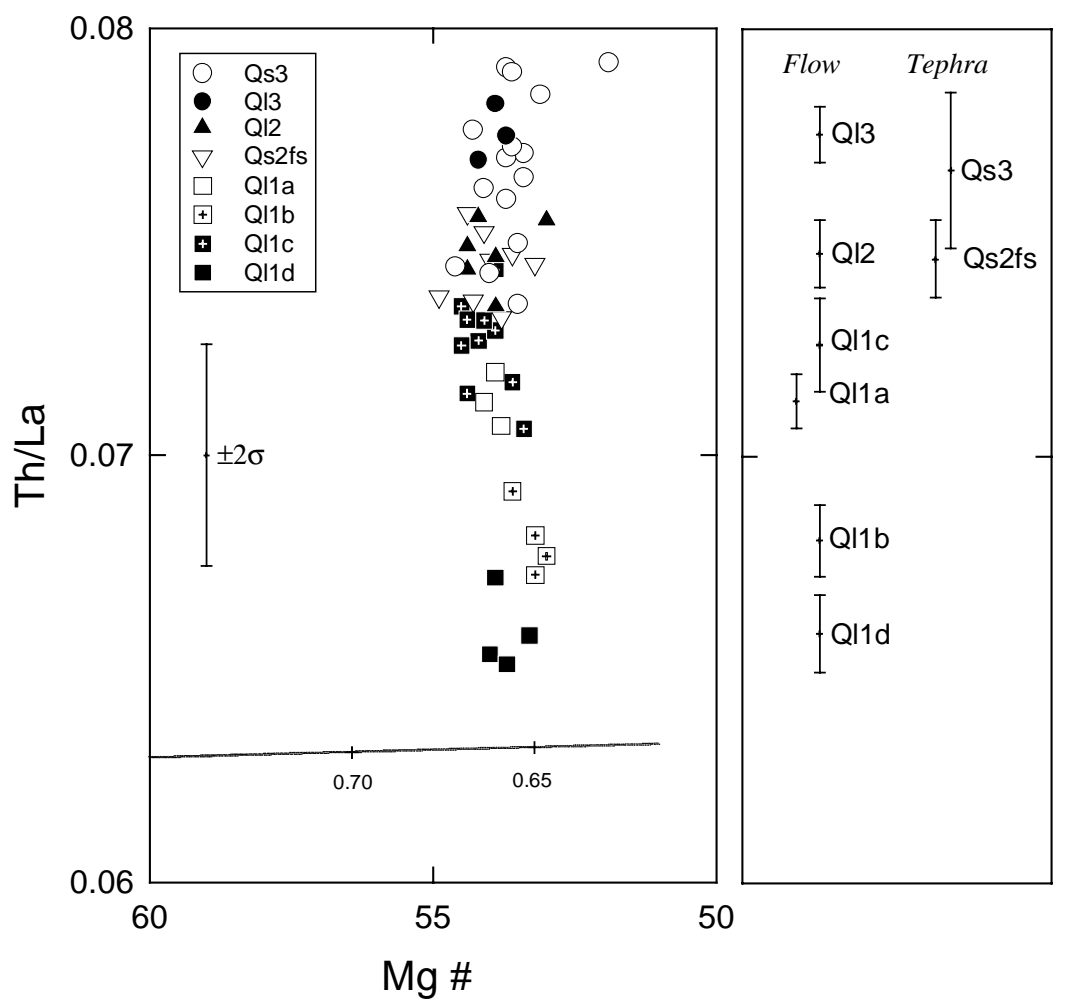

Figure 4.12. $\mathrm{Mg}$ number versus $\mathrm{Th} / \mathrm{La}$ for eruptive units at Lathrop Wells. Right frame indicates mean and standard deviation for each eruptive unit. Line near base of left frame indicates the model change in $\mathrm{Mg \#}$ and $\mathrm{Th} / \mathrm{La}$ for a model parental magma $(\mathrm{Mg \# =70)}$ crystallizing a 1:1 assemblage of olivine and clinopyroxene. Numbers below tick marks on line indicate the amount of residual liquid remaining.

2. Crustal Contamination/Magma Mixing. Previous researchers have ruled out the involvement of crustal contamination in the genesis of basalts within the Yucca Mountain region, citing their low $\mathrm{Rb} / \mathrm{Sr}$ and regional uniformity of $\mathrm{Sr}$ and $\mathrm{Nd}$ isotopic compositions (e.g., Hedge and Noble, 1971; Vaniman et al., 1982; Farmer et al., 1989; Fleck et al., 1996). We have revisited this question in detail because we note that mixing of upper crustal lithologies with a parental Lathrop Wells magma can in general account for the trace-element variations at Lathrop Wells. Compared to eruptive unit Q11d, the eruptive unit with the highest $\mathrm{MgO}$ content (consistent with a parental role), stratigraphically younger eruptive units at Lathrop Wells have systematically higher $\mathrm{Th}, \mathrm{Rb}$, and heavy rare-earth element (REE) contents and systematically lower contents of the middle REE, Sr and Ti (Figure 4.9). Crustal lithologies have higher and lower concentrations of these same elements, respectively, compared to Lathrop Wells magmas, opening the possibility that a single parental magma at Lathrop Wells may have progressively mixed with crustal lithologies to produce the range of compositions seen at Lathrop Wells (Figure 4.14). 


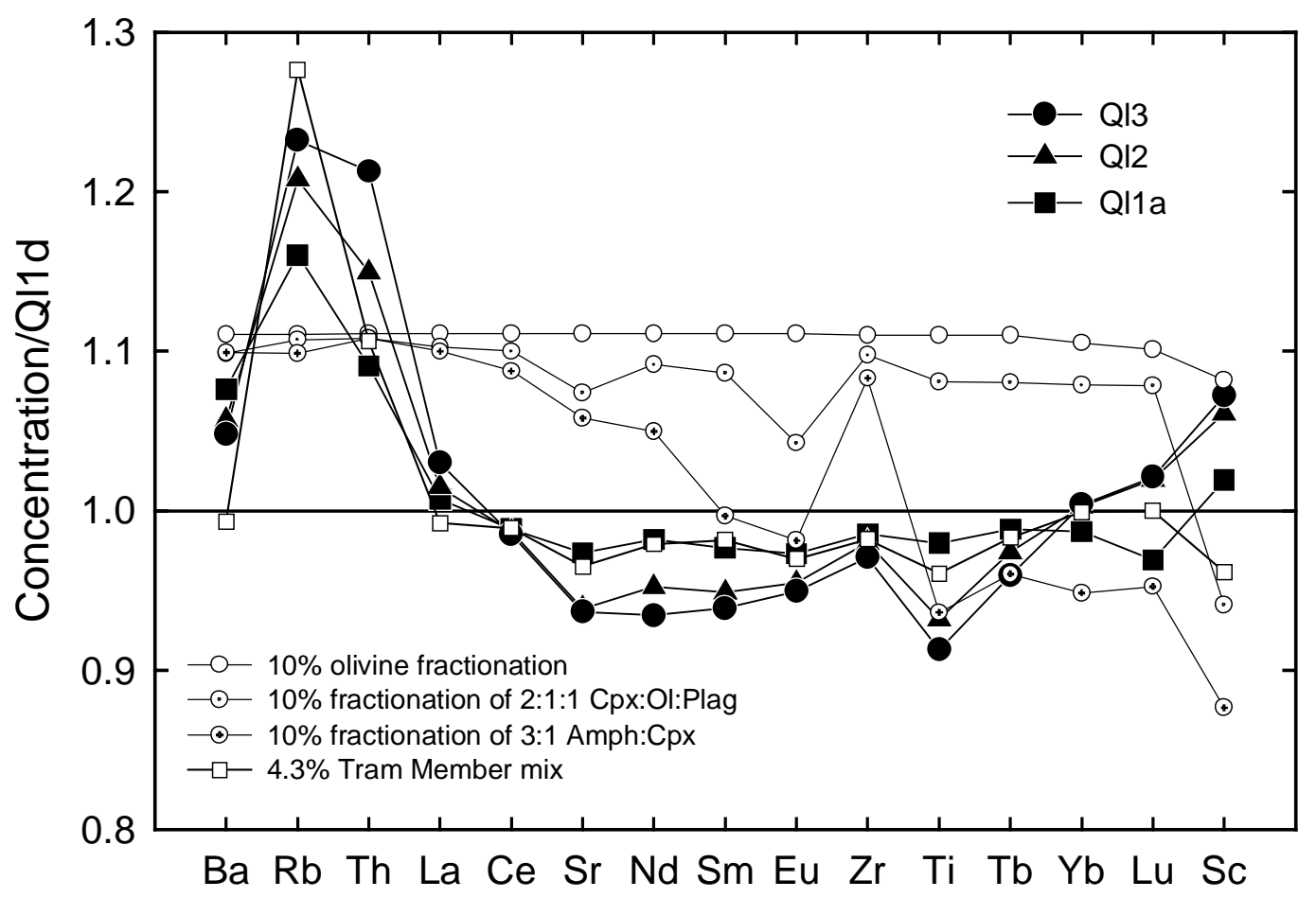

Figure 4.13. Normalized multi-element diagram showing the results of modeling of fractionatal crystallization and mixing with Miocene tuff wall rock.

a. Assimilation-fractional crystallization (AFC) versus simple mixing. Assimilation of crustal wall rock by ascending magmas is generally thought to be accompanied by crystallization of the magma, which supplies the necessary heat to melt the wall rock (referred to as AFC). Because of thermodynamic considerations, it is generally assumed that the mass of assimilated wall rock cannot exceed the mass crystallized in the magma (i.e., mass assimilated/mass crystallized, $r,<1)$. AFC at $r<1$ is precluded as a mechanism to produce the compositional variations at Lathrop Wells as discussed above. Using a simultaneous multi-element AFC model, we tested whether models involving $r>1$ could account for the observed geochemical variations. Using a range of upper crustal lithologies as contaminants, $r$ was varied to obtain a best fit to the composition of Q13 based on a simple routine that minimizes the sum of the squared residuals. Values of $r>5$ best fit the data, depending on the specific crustal endmember used. At these values, the AFC results are indistinguishable from the results of simple mixing models $(r=\infty)$, both in terms of the amount of wall rock mixed into the magma and the model compositions produced. We, therefore, used only simple mixing models to test in detail whether the compositional variations at Lathrop Wells were produced by crustal contamination.

b. Mixing Models. Lower and upper crustal basement lithologies as well as the thick section of Miocene tuff in the Yucca Mountain region were considered as potential endmembers for mixing with a hypothetical Lathrop Wells parental magma (Q11d). Proposed lower crustal compositions for this region (Hanchar et al., 1994) are too low in $\mathrm{Rb}$, Th and $\mathrm{K}$ relative to other elements to account for the range of Lathrop Wells compositions by bulk mixing (Figure 4.14), and partial melts of such lithologies would have concentrations of elements such as Nd and Sm that are too high. Upper crustal granitic lithologies and the Miocene tuff beneath Lathrop Wells have similar compositions (Figure 4.14), and either lithology produces a qualitatively good fit to the Q13 composition when mixed with Q11d. A small percentage of tuff xenoliths are found in 
eruptive units at Lathrop Wells, and contamination of magmas by tuff to produce the range of compositions observed must be considered. Because the composition of tuffs beneath Lathrop Wells is very similar to potential upper crustal compositions, we will only consider the tuff compositions as potential mixing endmembers.

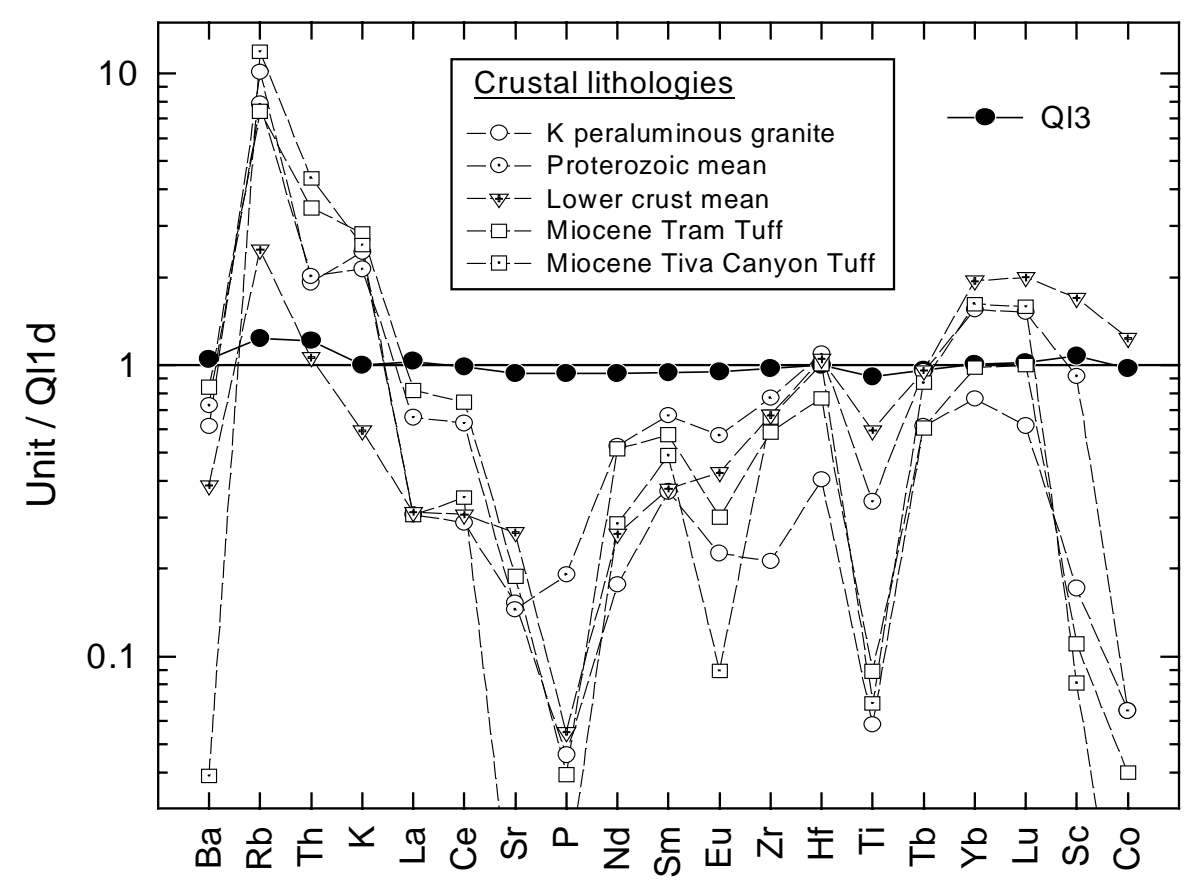

Figure 4.14. Lathrop Wells eruptive unit Q13 and upper crustal lithologies normalized to eruptive unit Q11d. Note log scale. Tuff compositions are from Broxton et al. (1989) and represent the probable range of tuff compositions found beneath the Lathrop Wells volcanic center. Proterozoic mean represents the calculated mean of exposed upper Proterozoic crust in the eastern Mojave (Miller and Wooden, 1994), which lies in the same crustal province as southwestern Nevada. Cretaceous peraluminous granite (Miller and Wooden, 1994) may represent a significant partial melt of Proterozoic crust in this region. Lower crustal mean is a weighted mean of lower crustal xenolith compositions from the eastern Mojave (Hanchar et al., 1994).

A section of Miocene tuff approximately 500-600 meters thick lies directly beneath the Lathrop Wells center. From top to bottom, this section is composed of the Tiva Canyon and Topopah Spring Tuffs of the Paintbrush Group, and the Prow Pass, Bullfrog, and Tram Tuffs of the Crater Flat Group. The Tiva Canyon and Tram Tuffs bound most of the compositional variation within the tuff section. These two tuff units were used as mixing endmembers to test whether mixing a parental magma with the composition of eruptive unit Q11d and tuff could produce the composition of eruptive unit Q13. The amount of mixing was varied to produce the best fit to the Q13 data, based on minimization of squared residuals. The best fit to the Q13 data was obtained by mixing 4\% of the Tram Tuff with Q11d (Figure 4.13). However, while providing a qualitatively good fit to the data, many elements are problematical in detail. To test the mixing model more rigorously, we ran Monte Carlo simulations of mixing using selected elements to better account for the full compositional variability of these elements in the tuff beneath the Lathrop Wells volcanic center. A wealth of compositional data is available for the tuff units represented beneath Lathrop Wells, allowing statistical treatment of potential mixing endmembers. Peterman and Spengler (1994) analyzed tuff samples from an 340-meter-thick outcrop section (Tram through Topopah Spring) at Raven Canyon, approximately $2 \mathrm{~km}$ west of Lathrop Wells. The Raven Canyon section was sampled at $\sim 5$ meter intervals (67 samples), 
providing the best available representation of the compositional variability of tuff beneath Lathrop Wells. Monte Carlo simulations of basalt-tuff mixing for $\mathrm{Rb}$ and $\mathrm{Sr}$ allow assessment of all possible mixing results given the statistical distribution of $\mathrm{Rb}$ and $\mathrm{Sr}$ in the tuff units. The simulations indicate that mixing with tuff cannot account for the $\mathrm{Rb}$ and $\mathrm{Sr}$ compositions of eruptive units Q12 and Q13, which form a strongly curvilinear array that does not match the mixing results (Figure 4.15). This conclusion also applies to mixing with upper crustal wall rock, which has $\mathrm{Rb}$ and $\mathrm{Sr}$ concentrations encompassed by the $\mathrm{Rb}$ and $\mathrm{Sr}$ concentrations in the tuff units. Mixing with a partial melt of wall rock will produce a poorer fit to the data because $\mathrm{Rb} / \mathrm{Sr}$ of the melt will be higher than that of bulk wall rock. The curvilinear nature of the $\mathrm{Rb} / \mathrm{Sr}$ data also indicates that the range of compositions at Lathrop Wells were not produced by mixing between two basalt magmas of different composition. Such mixing will produce a linear array between the endmember compositions (Figure 4.15).

3. Mantle Melting Processes. Variations in incompatible element ratios at constant $\mathrm{Mg}$ number at Lathrop Wells have been interpreted as signifying the involvement of several distinct magma batches during the formation of the center (Crowe et al., 1995; Perry and Straub, 1996). An important observation is that the variation of any particular element is almost always systematic, either increasing or decreasing in concentration through the eruptive sequence (Figures 4.9, 4.12, 4.15, 4.16). This is strong evidence that the variations are not simply due to random geochemical variations in the mantle source. It instead indicates that, if the variations are due to mantle processes, they are processes that varied systematically, such as changes in degree of partial melting, depth of melting, or source mineralogy. Depletion of certain elements through time suggests incremental melting and removal of melts from a common source (Figure 4.16). Complete removal of melt, however, would lead to drastic stripping of incompatible elements from the source. Nd and Sm are only depleted by about 8\% in Q13 compared to Q11d, suggesting that the melt separation process is not efficient and that a large proportion of melt remains in the source between melt removal episodes (dynamic melting model of Langmuir et al., 1977). Other factors that could significantly affect the composition of melt produced during dynamic melting are changes in source mineralogy and changes in phase proportions entering the melt as melting proceeds.

4. Conclusions. Geochemical variations at Lathrop Wells are unusual compared to variations reported from other small-volume basalt centers. Models of (1) fractional crystallization using likely liquidus phases, (2) magma mixing, or (3) crustal assimilation, which successfully account for the geochemical variations observed at other small-volume centers, cannot account for the data at Lathrop Wells. Alternative hypothesis that have not been fully tested to account for the geochemical variations at Lathrop Wells include systematic changes in mantle melting conditions through time, mantle wall-rock reaction with a single melt batch, or in situ fractional crystallization involving subliquidus phases such as apatite.

\section{Correlation of Ashes in Fault Trenches to Quaternary Eruptive Centers}

Basaltic ash occurs as a dilute component in fissure fillings and stratabound alluvial horizons exposed by trenching of several faults near Yucca Mountain. Correlating these ashes (or ash) to the correct eruptive source can constrain the age of the ash and, therefore, provide information about the slip history of a fault. Determining the origin of the ash can also provide information about coupled tectonic-volcanic processes. 


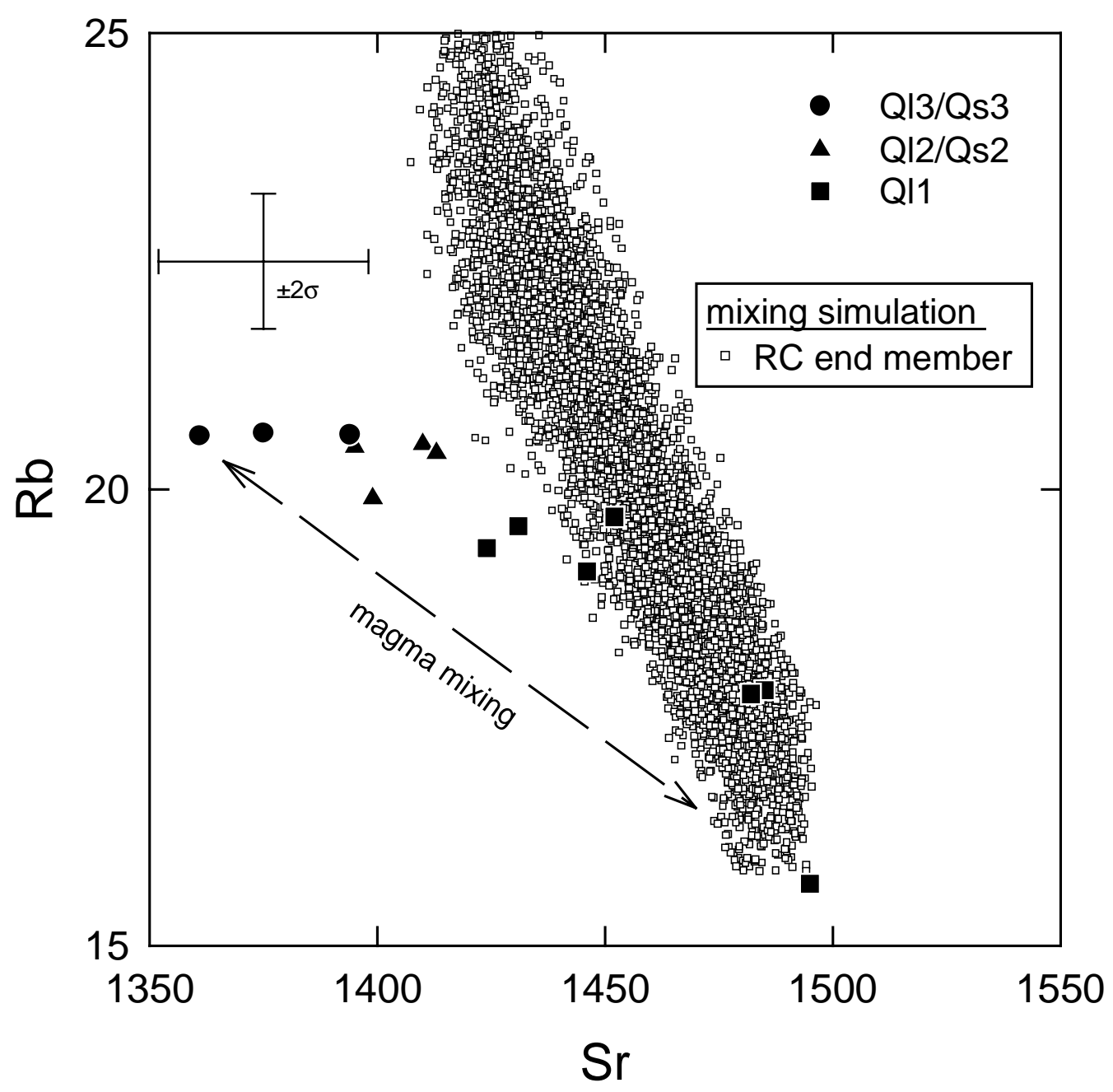

Figure 4.15. $\mathrm{Rb}$ versus $\mathrm{Sr}$ (determined by isotope dilution) for representative eruptive units at the Lathrop Wells volcanic center and results of 2500 Monte Carlo simulations for mixing of Miocene tuff with a magma having the composition of Q11d. Each individual point represents one sampling iteration of the Monte Carlo simulation. Percentage of tuff in the mixture ranges from $0-5 \%$. Rb in the tuff section at Raven Canyon (RC) is normally distributed and has a mean, standard deviation and range of $161.8,18.9,116-211$. Sr is bimodally distributed with ranges of 16-66 and 91-252, with the low range in the upper half of the section. The simulations account for the uncertainty of $\mathrm{Sr}$ and $\mathrm{Rb}$ in $\mathrm{Ql} 1 \mathrm{~d}$ and the overall correlation between $\mathrm{Sr}$ and $\mathrm{Rb}$ in the tuff $(\mathrm{r}=-0.4)$.

1. Geochemical results. Basaltic ash was sampled by scientists from the USGS from 5 trenches near Yucca Mountain: the Solitario Canyon Fault (Trench 8), the Windy Wash Fault (Trench CF3) and the Fatigue Wash Fault (Trench CF1), west of Yucca Mountain, the Stagecoach Road Fault (Trench T1) from south of Yucca Mountain, and the Paintbrush Canyon Fault (Alice Ridge Trench A1). Non-ash components of the samples were removed at the USGS using magnetic techniques and hand-picking. These techniques yielded a sample composed of $99 \%$ or more pure basaltic ash, with the remaining $1 \%$ or less of the sample being composed mainly of Miocene rhyolitic glass (discussed further below), potassium feldspar, and magnetite. Because of the high concentrations of incompatible elements in basalts near Yucca Mountain, interpretation of the ash composition is not significantly affected by $1 \%$ contamination from foreign components. The purified ashes were submitted to Los Alamos for INAA trace-element analysis and interpretation of the trace-element results (Table 4.3). 


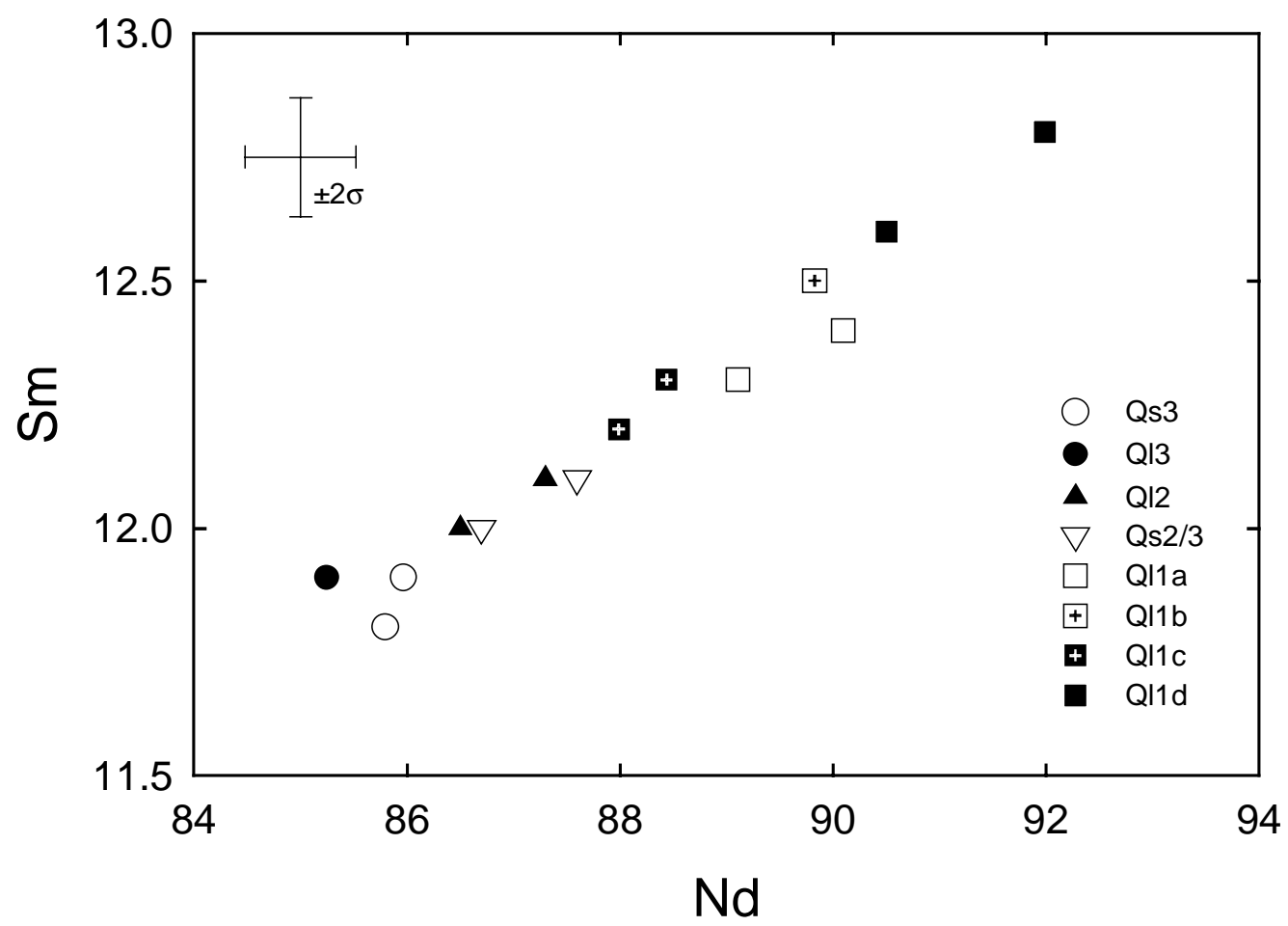

Figure 4.16. Nd versus $\mathrm{Sm}$ (determined by isotope dilution) for eruptive units at Lathrop Wells.

Interpretation of the source or sources of the basaltic ash is based on comparison of the concentrations of 14 trace elements from the ash samples with representative compositions of basalt from the seven Quaternary volcanic centers within $50 \mathrm{~km}$ of Yucca Mountain (Figure 4.17). When normalized to a mean Lathrop Wells composition, all of the ashes from trenches west and south of Yucca Mountain have a similar flat pattern that is near the Lathrop Wells mean composition. The geochemical pattern is distinct from all other Quaternary basalt centers, particularly in the concentration of Th and the light rare-earth elements La and Ce (Figure 4.17). In detail, this geochemical pattern is most similar to the scoria fall-sheet Qs2/3, which is the most voluminous pyroclastic unit at Lathrop Wells and the most likely to have been regionally dispersed. Because of the overall similarity of the geochemical pattern for all ash samples west and south of Yucca Mountain and their geochemical similarity, we interpret this as a single ash that originated from Lathrop Wells. Based on ${ }^{40} \mathrm{Ar} /{ }^{39} \mathrm{Ar}$ results from Lathrop Wells (see Chapter 2 ), the age of this ash is $\sim 75 \pm 10 \mathrm{ka}$.

The ash sample collected at Alice Ridge Trench A1 is distinct from the other ash samples with higher concentrations of $\mathrm{Rb}$, Th and the heavier rare-earth elements $\mathrm{Tb}, \mathrm{Yb}$, and Lu (Figure 4.17). In Th content it is similar in composition to Little Black Peak at Sleeping Butte, but it does not match Little Black Peak in concentrations of $\mathrm{La}, \mathrm{Ce}, \mathrm{Tb}, \mathrm{Yb}$, and Lu. Because of these differences, we cannot confidently match the composition of the Alice Ridge ash with any Quaternary center in the Yucca Mountain region. It is possible that the composition of the analyzed ash has been affected by a small component of adhering eolian silt, which could account for higher $\mathrm{Rb}, \mathrm{Th}$, and heavy rare-earth contents.

2. ${ }^{40} \mathrm{Ar} /{ }^{39} \mathrm{Ar}$ results. An attempt was made to directly date the ash sample from Solitario Canyon fault Trench 8 using the ${ }^{40} \mathrm{Ar} /{ }^{39} \mathrm{Ar}$ method at the New Mexico Bureau of Mines. This sample yielded a plateau age of $0.86 \pm 0.16 \mathrm{Ma}$ (Figure 4.18). This result opens the possibility that 
the basaltic ashes in the Crater Flat trenches may have originated from one of the Quaternary basalt centers in Crater Flat, all of which have ages near $1 \mathrm{Ma}$. We do not think this interpretation is geologically reasonable for two reasons. First, the geochemical composition of the ashes is inconsistent with an origin from any of the 1 Ma Crater Flat centers (Figure 4.17). Second, age constraints of fault stratigraphy established by the USGS indicate that the basaltic ashes have an age of <100 ka (Paces et al., 1995).

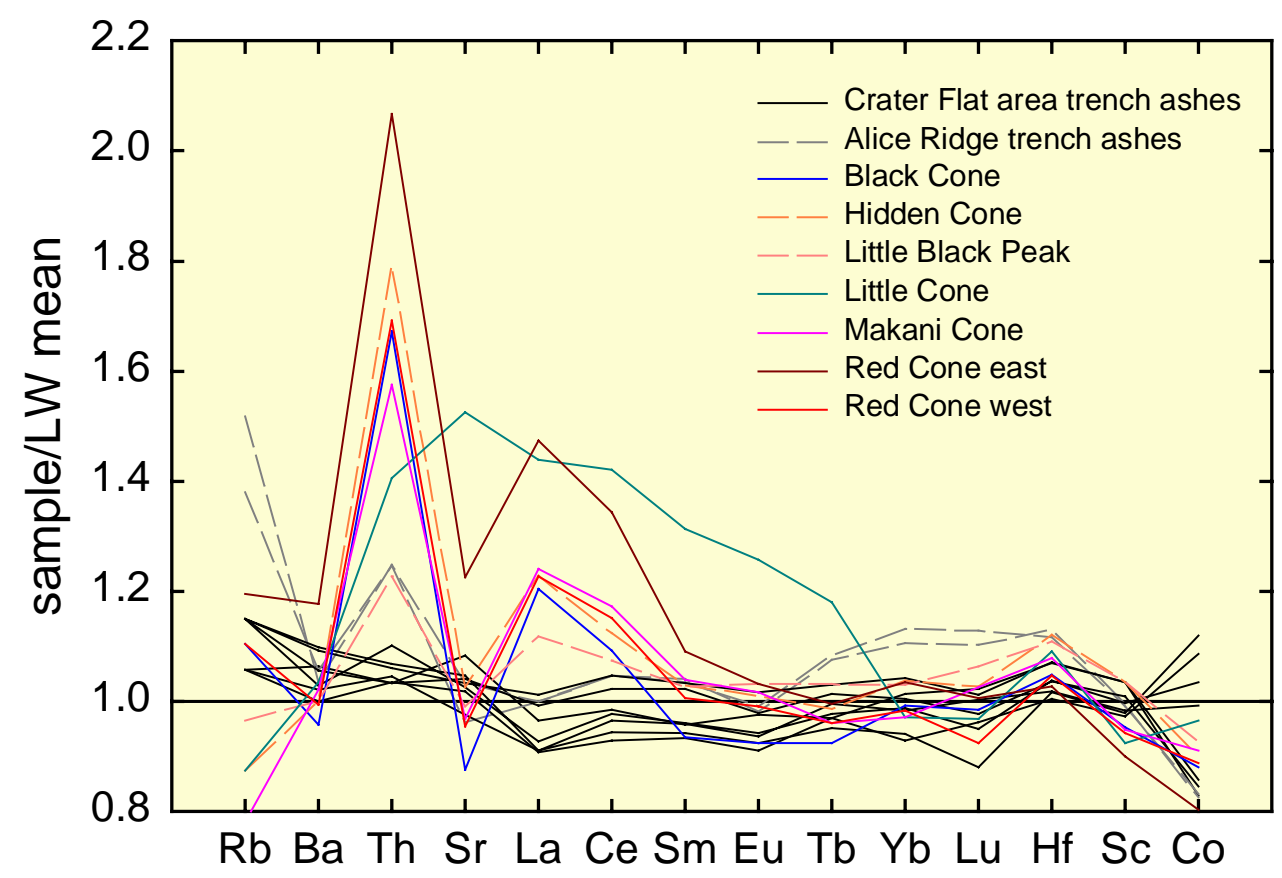

Figure 4.17. Normalized multi-element diagram comparing the composition of trench ash samples and representative compositions of Quaternary basalt centers to a mean Lathrop Wells composition.

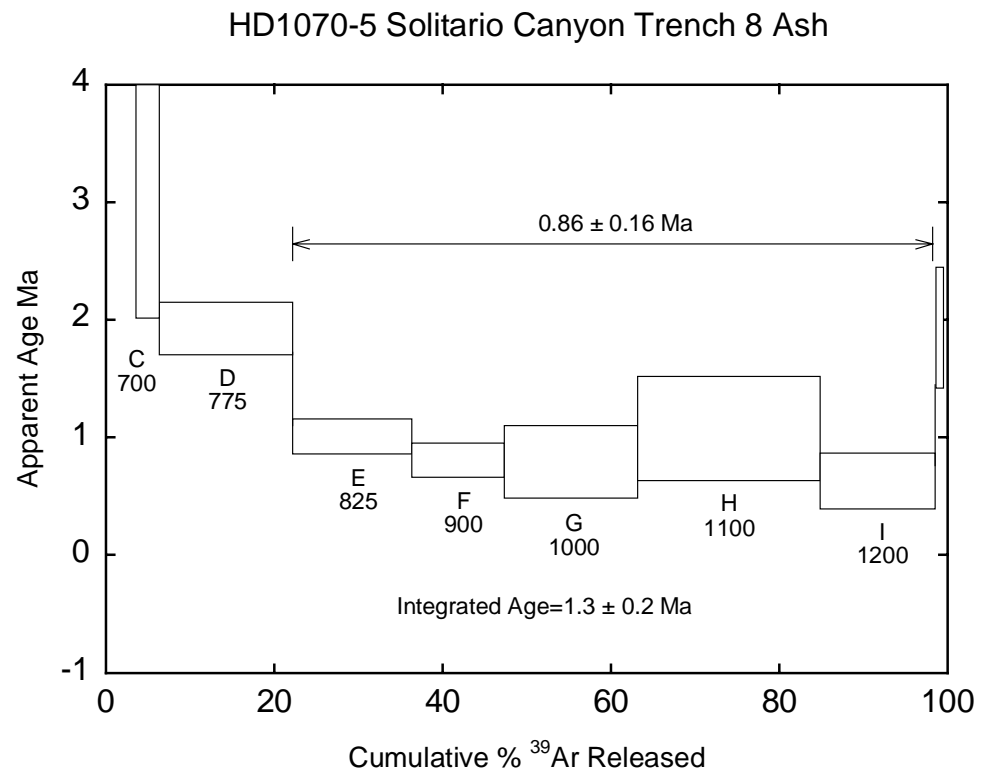

Figure 4.18. ${ }^{40} \mathrm{Ar} /{ }^{39} \mathrm{Ar}$ release spectra from HD1070-5, a sample of the Solitario Canyon Fault basaltic ash. The plateau age of the sample is $0.86 \pm 0.16 \mathrm{Ma}$. Temperature is indicated for each step. 
One possibility for the anomalously old age determined for the Solitario Canyon ash is that the sample is contaminated by a small amount of high- $\mathrm{K}$ rhyolitic glass derived from nearby Miocene tuff bedrock. This high-K glass would have a higher proportion of radiogenic ${ }^{40} \mathrm{Ar}$ than the basaltic ash, and the mixture would give ${ }^{40} \mathrm{Ar} /{ }^{39} \mathrm{Ar}$ ages older than the true age of the basaltic ash. To test this possibility, we made a grain mount of the sample dated by ${ }^{40} \mathrm{Ar} /{ }^{39} \mathrm{Ar}$ and examined it using scanning electron microscopy (SEM) to determine if high-K material was present. We examined an area containing approximately 660 basaltic ash grains, six of which were determined to be non-basaltic. Three are high-K grains containing subequal amounts of clear rhyolitic glass and feldspar with lesser opaque minerals; one is a potassic feldspar crystal, one is a magnetite crystal, and one is a quartz crystal (Figure 4.19). All of the grains were then examined using an optical microscope to verify their identity. The rhyolite glass is optically cloudy, and it would be impossible by visual hand-picking to separate it from the rest of the sample. Figure 4.20 is a detailed SEM element map of the area in Figure 4.19 labeled "rhyolite 1" that shows the relative concentration of potassium in approximately 15 ash grains. The bright grain is a high- $\mathrm{K}$ rhyolite glass; the remaining grains are basaltic ash. From this analysis, we conclude that $\sim 0.5 \%$ of the measured sample consists of Miocene high-K contaminant and this is the likely cause of the erroneous age determination

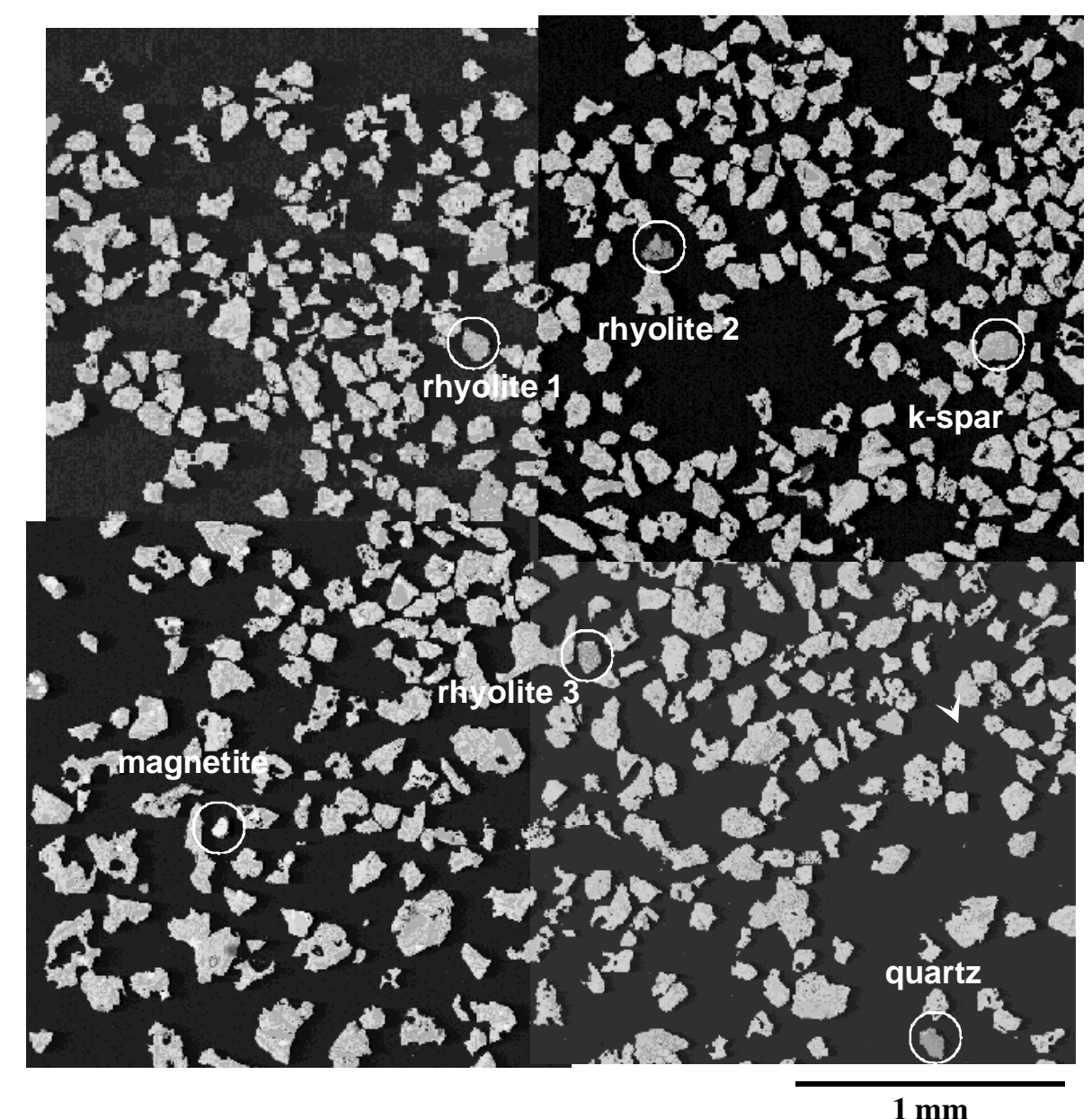

Figure 4.19. SEM image of a representative sampling of $\sim 660$ grains from sample HD1070, an ash from the Solitario Canyon fault trench. The sample was purified using magnetic techniques and handpicking under a binocular microscope to remove the non-basaltic component. Circled grains are nonbasaltic components that were not removed by this method and include rhyolite glass, potassic feldspar, magnetite, and quartz. 


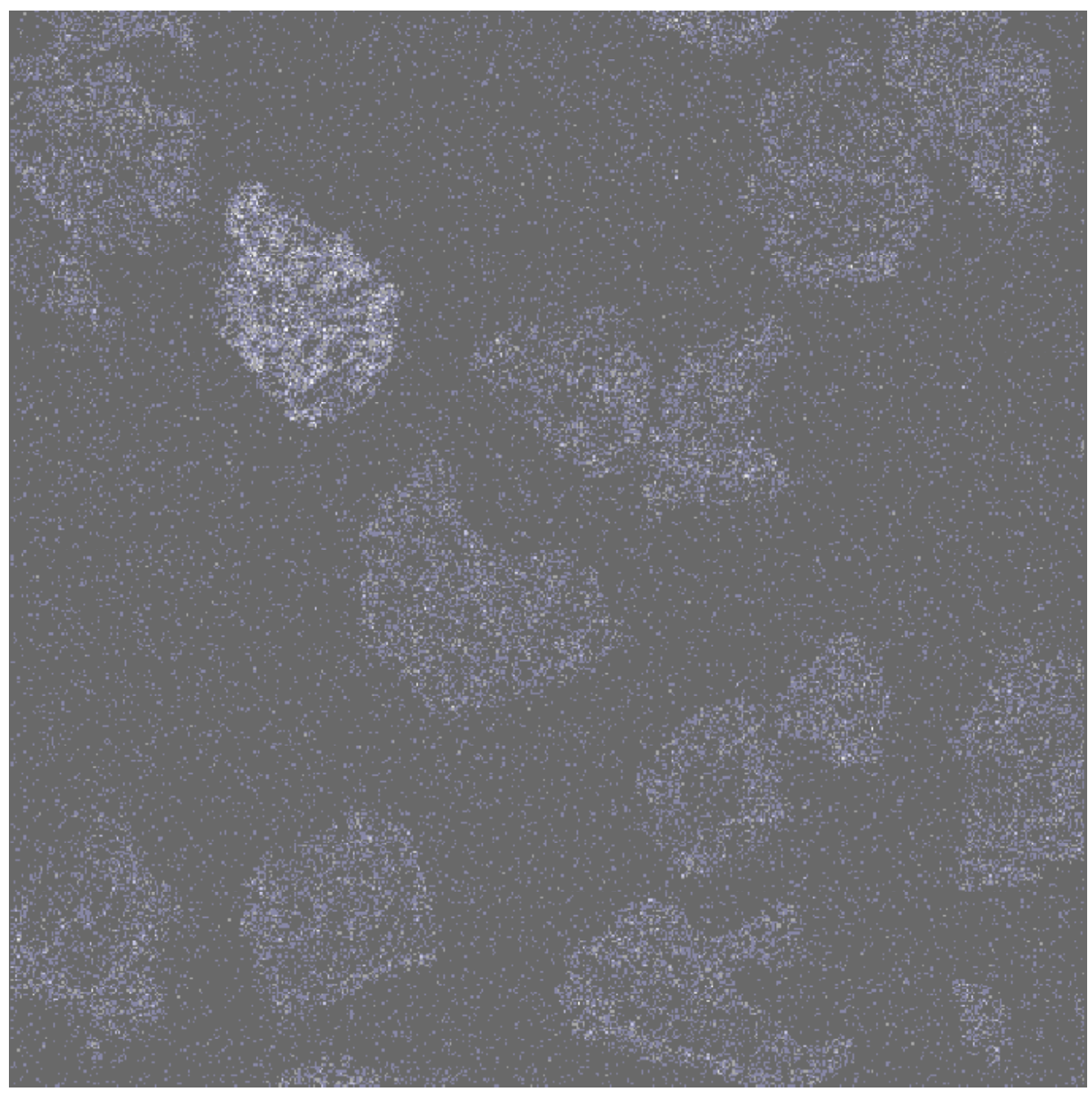

$100 \mu$

Figure 4.20. SEM element map showing the relative concentration of $\mathrm{K}$ in approximately 15 grains from the Solitario Canyon fault ash, sample HD1070. In this image, brighter grains have higher concentrations of $\mathrm{K}$. The bright grain in this image is a fragment of rhyolite with subequal amounts of glass and feldspar crystals. 
Table 4.3. INAA of basaltic ash from fault trenches near Yucca Mountain

\begin{tabular}{|c|c|c|c|c|c|c|c|c|c|}
\hline Sample & $\begin{array}{l}\text { HD1070- } \\
\text { FVP4-P1 }\end{array}$ & HD1628-P1 & HD1628-P2 & HD1727-P1 & HD1727-P2 & HD1728-P1 & HD1728-P2 & HD1826-P1 & HD1826-P2 \\
\hline Locality & $\begin{array}{c}\text { Solitario } \\
\text { Canyon Fault } \\
\text { Trench } 8\end{array}$ & $\begin{array}{c}\text { Paintbrush } \\
\text { Canyon } \\
\text { Fault, Alice } \\
\text { Ridge Trench } \\
\text { A1 }\end{array}$ & $\begin{array}{l}\text { Paintbrush } \\
\text { Canyon Fault, } \\
\text { Alice Ridge } \\
\text { Trench A1 }\end{array}$ & $\begin{array}{l}\text { Windy Wash } \\
\text { Fault Trench } \\
\text { CF3 }\end{array}$ & $\begin{array}{c}\text { Windy Wash } \\
\text { Fault Trench } \\
\text { CF3 }\end{array}$ & $\begin{array}{c}\text { Fatigue Wash } \\
\text { Fault Trench } \\
\text { CF1 }\end{array}$ & $\begin{array}{l}\text { Fatigue Wash } \\
\text { Fault Trench } \\
\text { CF1 }\end{array}$ & $\begin{array}{c}\text { Stage Coach } \\
\text { Road } \\
\text { Fault Trench T1 }\end{array}$ & $\begin{array}{c}\text { Stage Coach } \\
\text { Road } \\
\text { Fault Trench T1 }\end{array}$ \\
\hline $\mathbf{R b}$ & 23 & 30 & 33 & 25 & 25 & 25 & 25 & 23 & 23 \\
\hline $\mathbf{B a}$ & 1510 & 1500 & 1470 & 1560 & 1460 & 1500 & 1550 & 1450 & 1420 \\
\hline Th & 7.09 & 8.56 & 8.57 & 7.33 & 7.56 & 7.1 & 7.28 & 7.18 & 7.11 \\
\hline $\mathbf{S r}$ & 1520 & 1350 & 1450 & 1470 & 1440 & 1460 & 1450 & 1370 & 1430 \\
\hline $\mathbf{L a}$ & 90.1 & 93.3 & 93.3 & 85.1 & 86.6 & 92.6 & 94.5 & 85.1 & 84.7 \\
\hline $\mathrm{Ce}$ & 178.8 & 190.1 & 190.3 & 175.5 & 177.6 & 185.8 & 190.2 & 171.5 & 168.8 \\
\hline Sm & 11.73 & 12.73 & 12.67 & 11.74 & 11.76 & 12.51 & 12.65 & 11.54 & 11.43 \\
\hline $\mathbf{E u}$ & 3.07 & 3.09 & 3.12 & 2.95 & 2.97 & 3.08 & 3.2 & 2.91 & 2.87 \\
\hline $\mathbf{T b}$ & 1.1 & 1.22 & 1.23 & 1.13 & 1.11 & 1.15 & 1.17 & 1.08 & 1.1 \\
\hline $\mathbf{Y b}$ & 2.4 & 2.62 & 2.68 & 2.33 & 2.34 & 2.38 & 2.47 & 2.23 & 2.2 \\
\hline $\mathbf{L u}$ & 0.352 & 0.379 & 0.388 & 0.345 & 0.327 & 0.336 & 0.348 & 0.303 & 0.331 \\
\hline Hf & 7.72 & 8.16 & 8.06 & 7.35 & 7.49 & 7.48 & 7.73 & 7.34 & 7.25 \\
\hline Sc & 20 & 19.24 & 19.16 & 19 & 19.28 & 19.52 & 20 & 18.93 & 18.81 \\
\hline Co & 25.4 & 25.3 & 25.5 & 30.4 & 31.7 & 25.9 & 26.3 & 34.3 & 33.3 \\
\hline
\end{tabular}




\section{References}

Armstrong, R.L., and P. Ward, "Evolving Geographic Patterns of Cenozoic Magmatism in the North American Cordillera: the Temporal and Spatial Association of Magmatism and Metamorphic Core Complexes," Journal Geophysical Research 96, 13,201-13,224 (1991).

Axen, G.J., W.J. Taylor, and J.M. Bartley, "Space-Time Patterns and Tectonic Controls of Tertiary Extension and Magmatism in the Great Basin of the Western United States," Geological Society America Bulletin 105, 56-76 (1993).

Best, M.G., and W.H. Brimhall, "Late Cenozoic Alkali Basaltic Magmas in the Western Colorado Plateaus and the Basin and Range Transition Zone, U.S.A., and their Bearing on Mantle Dynamics," Geological Society America Bulletin 85, 1677-1690 (1974).

Best, M.G., and E.H. Christiansen, "Limited Extension During Peak Tertiary Volcanism, Great Basin of Nevada and Utah,” Journal Geophysical Research 96, 13,509-13,528 (1991).

Bradshaw T.K. and E.I. Smith, "Polygenetic Quaternary Volcanism at Crater Flat, Nevada," Journal of Volcanology and Geothermal Research 63, 165-182 (1994).

Broxton, D.E., R.G. Warren, R.M. Byers, and R.B. Scott, "Chemical and Mineralogic Trends within the Timber Mountain-Oasis Valley Caldera Complex, Nevada: Evidence for Multiple Cycles of Chemical Evolution in a Long-Lived Silicic Magma System," Journal of Geophysical Research 94, 5961-5985 (1989).

Camp, V.E., P.R. Hooper, M.J. Roobol, and D.L. White, "The Madinah Eruption, Saudi Arabia: Magma Mixing and Simultaneous Extrusion of Three Basaltic Chemical Types," Bulletin of Volcanology 49, 489508 (1987).

Carr, W.J., "Styles of Extension in the Nevada Test Site Region, Southern Walker Lane Belt; an Integration of Volcano-Tectonic and Detachment Fault Models," in Geological Society America Memoir 176: Basin and Range Extensional Tectonics Near the Latitude of Las Vegas, Nevada, B.P. Wernicke, Ed. (Geological Society of America, Boulder, Colorado, 1990), pp. 283-303.

Christiansen, R.L., and P.W. Lipman, "Cenozoic Volcanism and Plate Tectonic Evolution of the Western United States, II, Late Cenozoic," Philosophical Transactions Royal Society London, Series A., 271, 249284 (1972).

Christiansen, T.L., and E.H. McKee, "Late Cenozoic Volcanic and Tectonic Evolution of the Great Basin and Columbia Intermontane Regions," in Geological Society America Memoir 152: Cenozoic Tectonics and Regional Geophysics of the Western Cordillera, R.B. Smith and G.P. Eaton, Eds. (Geological Society of America, Boulder, Colorado, 1978), pp. 283-311.

Condit, C.D., L.S. Crumpler, J.C. Aubele, and W.E. Elston, "Patterns of Volcanism Along the Southern Margin of the Colorado Plateau: the Springerville Field," Journal Geophysical Research 94, 7975-7986 (1989).

Coney, P.J., "The Regional Tectonic Setting and Possible Causes of Cenozoic Extension in the North American Cordillera," in Continental Extensional Tectonics, M.P. Coward, J.F. Dewey, and P.L. Hanock, Eds. (Geological Society Special Publication 28, 1987), pp. 177-186.

Coney, P.J, and S.J. Reynolds, “Cordilleran Benioff Zones,” Nature 270, 403-406 (1977).

Cooper, J.L., J.L. Aronson, C.D. Condit, and W.K. Hart, "New K-Ar Ages of Lavas from the Colorado Plateau-Basin and Range Transition Zone, East-Central Arizona," Isochron/West 55, 28-31 (1990). 
Cooper, J.L., and W.K. Hart, "Mantle Sources in the Arizona Transition Zone and Global Mantle Heterogeneity," Geology 18, 1146-1149 (1990).

Cross, T.A., and R.H. Pilger, "Constraints on Absolute Motion and Plate Interaction Inferred from Cenozoic Igneous Activity in the Western United States," American Journal Science 278, 865-902 (1978).

Crowe, B., F. Perry, J. Geissman, L. McFadded, S. Wells, M. Murrell, J. Poths, G. Valentine, L. Bowker, and K. Finnegan, "Status of Volcanism Studies for the Yucca Mountain Project," Los Alamos National Laboratory report LA-12908-MS (1995).

Crowe B.M., D.T. Vaniman, and W.J. Carr, "Status of Volcanic Hazard Studies for the Nevada Nuclear Waste Storage Investigations," Los Alamos National Laboratory report LA-9325-MS (1983).

Crowe, B.M., K.H. Wohletz, D.T. Vaniman, E. Gladney, and N. Bower, "Status of Volcanic Hazard Studies for the Nevada Nuclear Waste Storage Investigations," Los Alamos National Laboratory report LA-9325-MS, Vol. II (1986).

Daley, E.E., "Temporal and Spatial Variations in Compositions of Young Mafic Volcanic Rocks of the Southwestern Basin and Range: Isotopic Constraints on the Relationship Between Thinning in the Lithosphere and Extensional Deformation of the Upper Crust," Ph.D. Dissertation, University of California, Berkeley, 205 pp. (1992).

Daley, E.E., and D.J. DePaolo, "Isotopic Evidence for Lithospheric Thinning During Extension: Southeastern Great Basin," Geology 20, 104-108 (1992).

Dueker, K. and E. Humphreys, "Upper-Mantle Velocity Structure of the Great Basin," Geophysical Research Letters 17, 1327-1330 (1990).

Eaton, G.P., "The Basin and Range Province: Origin and Tectonic Significance," Annual Reviews Earth Planetary Science 10, 409-440 (1982).

Evans, J.R., and Smith, M., "Teleseismic Tomography of the Yucca Mountain Region: Volcanism and Tectonism," Proceedings High-Level Radioactive Waste Management Conference, Las Vegas, Nevada (American Nuclear Society, La Grange Park, Illinois, 1992), pp. 2371-2380.

Farmer, G.L., F.V. Perry, S. Semken, B. Crowe, D. Curtis, and D.J. DePaolo, "Isotopic Evidence on the Structure and Origin of Subcontinental Lithospheric Mantle in Southern Nevada," Journal Geophysical Research 94, 7885-7898 (1989).

Fitton, J.G., D. James, and W.P. Leeman, "Basic Magmatism Associated With Late Cenozoic Extension in the Western United States: Compositional Variations in Space and Time," Journal Geophysical Research 96, 13693-13711 (1991).

Fleck, R.J., B.D. Turrin, D.A. Sawyer, R.G. Warren, D.E. Champion, M.R. Hudson, and S.A. Minor, "Age and Character of Basaltic Rocks of the Yucca Mountain Region, Southern Nevada," Journal of Geophysical Research 101, 8205-8227 (1996).

Foland, K.A., and S.C. Bergman, "Temporal and Spatial Distribution of Basaltic Volcanism in the Pancake and Reveille Ranges North of Yucca Mountain," Proceedings High-Level Radioactive Waste Management Conference, Las Vegas, Nevada (American Nuclear Society, La Grange Park, Illinois, 1992), pp. 23662371.

Frey, F.A., W.S. Wise, M.O. Garcia, H. West, S.T. Kwon, and A. Kennedy, "Evolution of Mauna Kea, Hawaii: Petrologic and Geochemical Constraints on Postshield Volcanism," Journal Geophysical Research 95, 1271-1300 (1990). 
Furman, T., F.A. Frey, and K. Park, "Chemical Constraints on the Petrogenesis of Mildly Alkaline Lavas from Vestmannaeyjar, Iceland: the Eldfell (1973) and Surtsey (1963-1967) Eruptions," Contributions Mineralogy Petrology 109, 19-37 (1991).

Glazner, A.F., and W. Ussler III, "Crustal Extension, Crustal Density, and the Evolution of Cenozoic Magmatism in the Basin and Range of the Western United States," Journal Geophysical Research 94, 7952-7960 (1989).

Hanchar, J.M., C.F. Miller, J.L. Wooden, V.C. Bennett, and J.M.G. Staude, "Evidence from Xenoliths for a Dynamic Lower Crust, Easter Mojave Desert California,” Journal of Petrology 35, 1377-1415 (1994).

Hart, W.K., "Chemical and Isotopic Evidence for Mixing Between Depleted and Enriched Mantle, Northwestern U.S.A.," Geochemica Cosmochemica Acta 49, 131-144 (1985).

Hedge, C.E., and D.C. Noble, "Upper Cenozoic Basalts with High ${ }^{87} \mathrm{Sr} /{ }^{86} \mathrm{Sr}$ and $\mathrm{Sr} / \mathrm{Rb}$ Ratios, Southern Great Basin, Western United States," Geological Society of America Bulletin 82, 3503-3510 (1971).

Humphreys, E.D., Dueker, K.G., and G. Biasi, "Western U.S. Tectonic and Volcanic Activity: the Role of the Mantle," Geological Society America Abstracts with Programs 24, (5) 34 (1992).

Jaques, A.L., and D.H. Green, "Anhydrous Melting of Peridotite at 0-15 Kb Pressure and the Genesis of Tholeiitic Basalts," Contributions Mineralogy Petrology 73, 287-310 (1980).

Johnson, C.M., "Large-Scale Crust Formation and Lithosphere Modification Beneath Middle to Late Cenozoic Calderas and Volcanic Fields, Western North America," Journal Geophysical Research 96, 13,485-13,507 (1991).

Keller, G.R., P. Morgan, and W.R. Seager, "Crustal Structure, Gravity Anomalies and Heat Flow in the Southern Rio Grande Rift and their Relationship to Extensional Tectonics," Tectonophysics 174, 21-37 (1990).

Kempton, P.D., J.G. Fitton, C.J. Hawksworth, and D.S. Ormerod, "Isotopic and Trace Element Constraints on the Composition and Evolution of the Lithosphere Beneath the Southwestern United States," Journal Geophysical Research 96, 13,713-13,735 (1991).

Knutson, J., and T.H. Green, "Experimental Duplication of A High-Pressure Megacryst/Cumulate Assemblage in A Near-Saturated Hawaiite," Contributions Mineralogy Petrology 52, 121-132 (1975).

Langmuir C.H., J.F. Bender, A.E. Bence, G.N. Hanson, and S.R. Taylor, "Petrogenesis of Basalts from the Famous Area: Mid-Atlantic Ridge," Earth and Planetary Science Letters 36, 133-156 (1977).

Laughlin, A.W., F. Perry, P. Damon, M. Shafiqullah, G. WoldeGabriel, W. Mcintosh, C. Harrington, S.G. Wells, and P. Drake, "Geochronology of the Mount Taylor, Cebollita Mesa and Zuni-Bandera Volcanic Fields," Cibola County, New Mexico, New Mexico Geology 15, 81-92 (1993).

Leeman, W.P., and J.W. Rogers, "Late Cenozoic Alkali-Basalts of the Basin-Range Province, USA," Contributions Mineralogy Petrology 25, 1-24 (1970).

Lipman, P.W., "Cenozoic Volcanism in the Western United States: Implications for Continental Tectonics," in Continental Tectonics (National Academy of Science, Washington, D.C., 1980), pp. 161174.

Lum, C.L., W.P. Leeman, K.A. Foland, J.A. Kargel, and J.G. Fitton, "Isotopic Variations in Continental Basaltic Lavas as Indicators of Mantle Heterogeneity: Examples from the Western U.S. Cordillera," Journal Geophysical Research 94, 7871-7884 (1989). 
Luhr, J.F., and I.S.E. Carmichael, "Jorullo Volcano, Michoacán, Mexico (1759-1774): The Earliest Stages of Fractionation in Calc-Alkaline Magmas," Contributions to Mineralogy and Petrology 90, 141-161 (1985).

Mahood, G.A., and D.R. Baker, "Experimental Constraints on Depths of Fractionation of Mildly Alkalic Basalts and Associated Felsic Rocks: Pantelleria, Strait of Sicily," Contributions Mineralogy Petrology 93, 251-264 (1986).

McBirney, A.R., H.P. Taylor, and R.L. Armstrong, "Paricutin Re-Examined: a Classic Example of Crustal Assimilation in Calc-Alkalic Magma," Contributions Mineralogy Petrology 95, 4-20 (1987).

Menzies, M.A., W.P. Leeman, and C.J. Hawksworth, "Isotope Geochemistry of Cenozoic Volcanic Rocks Reveals Mantle Heterogeneity Below Western USA," Nature 303, 205-209 (1983).

Menzies, M.A., "Cratonic Circumcratonic and Oceanic Mantle Domains Beneath the Western United States," Journal Geophysical Research 94, 7899-7915 (1989).

Miller, C.F., and J.L. Wooden, "Anatexis, Hybridization and the Modification of Ancient Crust: Mesozoic Plutonism in the Old Woman Mountains Area, California," Lithos 32, 111-133 (1994).

Morgan, P., W.R. Seager, and M. Golombek, "Cenozoic Thermal, Mechanical and Tectonic Evolution of the Rio Grande Rift,” Journal Geophysical Research 91, 6263-6276 (1986).

Morse, S.A., "Basalts and Phase Diagrams,” Springer-Verlag, New York, 493 pp., (1980).

Paces, J.B., S.A. Mahan, K.R. Ludwig, L.M. Kwak, L.A. Neymark, K.R. Simmons, L.D. Nealey, B.D. Marshall, and A. Walker, "Progress Report on Dating Quaternary Surficial Deposits," U.S. Geological Survey - Yucca Mountain Project Branch 1995 Milestone report 3GCH510M (1995).

Perry, F.V., and B.M. Crowe, "Geochemical Evidence for Waning Magmatism and Polycyclic Volcanism at Crater Flat, Nevada," Proceedings High-Level Radioactive Waste Management Conference, Las Vegas, Nevada (American Nuclear Society, La Grange Park, Illinois, 1992), pp. 2356-2365.

Perry, F.V., and K.T. Straub, “Geochemistry of the Lathrop Wells Volcanic Center," Los Alamos National Laboratory report LA-13113-MS (1996).

Perry, F., W.S. Baldridge, and D.J. DePaolo, "Role of Asthenosphere and Lithosphere in the Genesis of Late Cenozoic Basaltic Rocks from the Rio Grande Rift and Adjacent Regions of the Southwestern United States," Journal Geophysical Research 92, 9193-9213 (1987).

Perry, F., W.S. Baldridge, and D.J. DePaolo, "Chemical and Isotopic Evidence for Lithospheric Thinning Beneath the Rio Grande Rift,” Nature 332, $432-434$ (1988).

Perry, F.V., D.J. DePaolo, and W.S. Baldridge, "Neodymium Isotopic Evidence for Decreasing Crustal Contributions to Cenozoic Ignimbrites of the Western United States: Implications for the Thermal Evolution of the Cordilleran Crust," Geological Society America Bulletin 105, 872-882 (1993).

Peterman, Z.E., and R.W. Spengler," Geochemistry of Outcrop Samples from the Raven Canyon and Paintbrush Canyon Reference Sections, Yucca Mountain Nevada," U.S. Geological Survey Open-File report 94-550 (1994).

Scott, R.B., "Tectonic Setting of Yucca Mountain, Southwest Nevada," Geological Society America Memoir 176: Basin and Range Extension near the Latitude of Las Vegas, Nevada, B.P. Wernicke, Ed. (Geological Society of America, Boulder, Colorado, 1990), pp. 251-282. 
Smith, R.L., and R.G. Luedke, "Potentially Active Volcanic Lineaments and Loci in Western Conterminous United States," in Explosive Volcanism: Inception, Evolution, and Hazards (National Academy Press, Washington, D.C., 1984), pp. 47-66.

Spence, W., and R.S. Gross, "A Tomographic Glimpse of the Upper Mantle Source of Magmas of the Jemez Lineament, New Mexico,” Journal Geophysical Research 95, 10,829-10,849 (1990).

Spera, F.J., "Carbon Dioxide in Petrogenesis III: Role of Volatiles in the Ascent of Alkaline Magma With Special Reference of Xenolith-Bearing Lavas," Contributions Mineralogy Petrology 88, 217-232 (1984).

Stolper, E., and D. Walker, "Melt Density and the Average Composition of Basalt," Contributions Mineralogy Petrology 74, 7-12 (1980).

Takahashi, E., "Melting Relations of an Alkali-Olivine Basalt to $30 \mathrm{Kbar}$, and their Bearing on the Origin of Alkali Basalt Magmas,” Carnegie Institution Washington Year Book 79, 271-276, 1980.

Takahashi, E., and I. Kushiro, "Melting of Dry Peridotite at High Pressures and Basalt Magma Genesis," American Mineralogist 68, 859-879 (1983).

Tanaka, K.L., E.M. Shoemaker, G.E. Ulrich, and E.W. Wolfe, "Migration of Volcanism in the San Francisco Volcanic Field," Geological Society America Bulletin 97, 129-141 (1986).

Turrin, B.D., D. Champion, and R.J. Fleck, ${ }^{\text {“40 }} \mathrm{Ar} /{ }^{39} \mathrm{Ar}$ Age of the Lathrop Wells Volcanic Center, Yucca Mountain, Nevada," Science 253, 654-657 (1991).

Turrin, B.D., D.E. Champion, and R.J. Fleck, "Measuring the Age of the Lathrop Wells Volcanic Center at Yucca Mountain," Science 257, 555-558 (1992).

Vaniman, D.T., B.M. Crowe, and E.S. Gladney, "Petrology and Geochemistry of Hawaiite Lavas from Crater Flat, Nevada," Contributions Mineralogy Petrology 80, 341-357 (1982).

Wells, S.G., L.D. McFadden, C.E. Renault, and B.M. Crowe, "Geomorphic Assessment of Late Quaternary Volcanism in the Yucca Mountain Area, Southern Nevada: Implications for the Proposed High-Level Waste Repository," Geology 18, 549-553 (1990).

Wells, S.G., B.M. Crowe, and L.D. McFadden, "Measuring the Age of the Lathrop Wells Volcanic Center at Yucca Mountain," Science 257, 555-558 (1992).

Wernicke, B.P., R.L. Christiansen, P.C. England, and L.J. Sonder, "Tectonomagmatic Evolution of Cenozoic Extension in the North American Cordillera," in Continental Extensional Tectonics, M.P. Coward, J.F. Dewey, and P.L. Hancock, Eds. (Geological Society Special Publication 28, 1987), pp. 203-221.

Wernicke, B., G.J. Axen, J.K. Snow, "Basin and Range Extensional Tectonics at the Latitude of Las Vegas, Nevada," Geological Society America Bulletin 100, 1738-1757 (1988).

Wilshire, H.G., A.V. McGuire, J.S. Noller, and B.D. Turrin, "Petrology of Lower Crustal and Upper Mantle Xenoliths from the Cima Volcanic Field, California," Journal Petrology 32, 169-200 (1991).

Wood, C.A., "Morphometric Analysis of Cinder Cone Degradation," Journal Volcanology Geothermal Research 8, 137-160 (1980).

Zoback, M.L., R.E. Anderson, and G.A. Thompson, "Cainozoic Evolution of the State of Stress and Style of Tectonism of the Basin and Range Province of the Western United States," Philosophical Transactions Royal Society London 300, 407-434 (1981). 
Appendix 4.1. Major and trace-element data for basalts of the YMR determined by XRF

\begin{tabular}{|c|c|c|c|c|c|c|c|c|c|}
\hline$\overline{\text { Sample }}$ & HC1FVP & HC2FVP & HC3FVP & HC4FVP & HC5FVP & HC6FVP & HC7FVP & HC13FVP & HC15FVP \\
\hline Center & Hidden Cone & Hidden Cone & Hidden Cone & Hidden Cone & Hidden Cone & Hidden Cone & Hidden Cone & Hidden Cone & Hidden Cone \\
\hline $\mathrm{SiO}_{2}$ & 48.78 & 48.49 & 47.49 & 48.70 & 47.86 & 48.14 & 48.58 & 48.26 & 48.37 \\
\hline $\mathrm{TiO}_{2}$ & 1.792 & 1.737 & 1.806 & 1.696 & 1.795 & 1.821 & 1.822 & 1.718 & 1.671 \\
\hline $\mathrm{Al}_{2} \mathrm{O}_{3}$ & 16.87 & 16.87 & 16.72 & 16.65 & 16.70 & 16.98 & 16.85 & 16.82 & 17.03 \\
\hline $\mathrm{Fe}_{2} \mathrm{O}_{3} \mathrm{~T}$ & 11.68 & 11.56 & 11.77 & 11.49 & 11.52 & 11.85 & 11.75 & 11.21 & 10.94 \\
\hline MnO & 0.180 & 0.171 & 0.174 & 0.172 & 0.181 & 0.174 & 0.174 & 0.172 & 0.181 \\
\hline MgO & 5.73 & 5.62 & 5.64 & 5.80 & 5.61 & 5.79 & 5.62 & 5.68 & 5.41 \\
\hline $\mathrm{CaO}$ & 9.19 & 9.01 & 9.62 & 9.08 & 9.61 & 9.33 & 9.23 & 9.16 & 9.12 \\
\hline $\mathrm{Na}_{2} \mathrm{O}$ & 3.44 & 3.40 & 3.26 & 3.32 & 3.37 & 3.33 & 3.38 & 3.25 & 3.01 \\
\hline $\mathbf{K}_{2} \mathbf{O}$ & 1.64 & 1.66 & 1.64 & 1.61 & 1.64 & 1.62 & 1.65 & 1.64 & 1.66 \\
\hline $\mathbf{P}_{2} \mathbf{O}_{5}$ & 1.102 & 1.108 & 1.092 & 1.071 & 1.115 & 1.100 & 1.113 & 1.086 & 1.082 \\
\hline Total & 100.40 & 99.62 & 99.20 & 99.59 & 99.40 & 100.13 & 100.18 & 98.98 & 98.46 \\
\hline Mg\# & 53.34 & 53.12 & 52.73 & 54.02 & 53.13 & 53.22 & 52.72 & 54.11 & 53.53 \\
\hline V ppm & 185.6 & 187.2 & 191.3 & 171.9 & 174.8 & 180.1 & 174.4 & 193.3 & 176.4 \\
\hline Cr ppm & 90.2 & 71.9 & 71.5 & 117.9 & 79.5 & 83.8 & 75.8 & 82.2 & 78.9 \\
\hline Ni ppm & 24.8 & 27.1 & 22.6 & 43.5 & 17.1 & 20.5 & 26.5 & 37.1 & 57.4 \\
\hline Zn ppm & 135.5 & 159.4 & 157.4 & 148.4 & 144.7 & 146.1 & 166.0 & 155.6 & 146.7 \\
\hline Rb ppm & 16.1 & 19.2 & 16.5 & 22.5 & 15.4 & 14.9 & 18.7 & 19.1 & 25.9 \\
\hline Sr ppm & 1479.8 & 1417.7 & 1480.5 & 1364.9 & 1468.0 & 1488.3 & 1483.7 & 1422.8 & 1365.4 \\
\hline Y ppm & 36.7 & 33.7 & 26.2 & 34.7 & 34.5 & 27.8 & 22.6 & 35.7 & 20.7 \\
\hline Zr ppm & 425.7 & 413.1 & 397.5 & 380.3 & 414.6 & 406.6 & 411.2 & 411.8 & 375.9 \\
\hline Nb ppm & 32.4 & 30.2 & 32.0 & 32.3 & 37.2 & 37.3 & 28.4 & 29.2 & 36.7 \\
\hline Ba ppm & 1313.1 & 1445.7 & 1456.4 & 1401.0 & 1357.8 & 1424.1 & 1449.1 & 1482.9 & 1502.0 \\
\hline
\end{tabular}


Appendix 4.1. continued

\begin{tabular}{|c|c|c|c|c|c|c|c|}
\hline Sample & SB7-20-95-1BMC & SB7-20-95-2BMC & LBP1FVP & LBP2FVP & LBP3FVP & LBP4FVP & LBP5FVP \\
\hline Center & Hidden Cone N & Hidden Cone N & Little Black Peak & Little Black Peak & Little Black Peak & Little Black Peak & Little Black Peak \\
\hline $\mathrm{SiO}_{2}$ & 48.96 & 47.97 & 48.37 & 48.15 & 48.21 & 48.23 & 48.05 \\
\hline $\mathrm{TiO}_{2}$ & 48.96 & 47.97 & 1.847 & 1.882 & 1.869 & 1.907 & 1.892 \\
\hline $\mathbf{A l}_{2} \mathbf{O}_{3}$ & 17.28 & 16.73 & 16.80 & 16.77 & 16.57 & 16.67 & 16.43 \\
\hline $\mathrm{Fe}_{2} \mathrm{O}_{3} \mathrm{~T}$ & 11.36 & 11.11 & 11.88 & 11.77 & 11.78 & 11.76 & 11.76 \\
\hline MnO & 0.173 & 0.166 & 0.176 & 0.174 & 0.173 & 0.172 & 0.175 \\
\hline MgO & 5.51 & 5.41 & 5.66 & 5.63 & 5.65 & 5.71 & 5.68 \\
\hline $\mathrm{CaO}$ & 8.90 & 9.56 & 9.17 & 9.37 & 9.45 & 9.12 & 9.34 \\
\hline $\mathrm{Na}_{2} \mathrm{O}$ & 3.44 & 3.26 & 3.27 & 3.36 & 3.32 & 3.41 & 3.32 \\
\hline $\mathbf{K}_{2} \mathbf{O}$ & 1.66 & 1.62 & 1.62 & 1.65 & 1.66 & 1.72 & 1.65 \\
\hline $\mathbf{P}_{2} \mathbf{O}_{5}$ & 1.121 & 1.099 & 1.101 & 1.122 & 1.099 & 1.141 & 1.149 \\
\hline Total & 100.13 & 98.61 & 99.90 & 99.87 & 99.78 & 99.83 & 99.44 \\
\hline Mg\# & 53.17 & 53.04 & 52.62 & 52.69 & 52.76 & 53.07 & 52.94 \\
\hline V ppm & 165.4 & 164.9 & 183.8 & 188.0 & 178.5 & 179.1 & 189.2 \\
\hline Cr ppm & 72.7 & 62.4 & 84.0 & 75.5 & 75.9 & 76.6 & 65.8 \\
\hline Ni ppm & 61.2 & 33.4 & 28.3 & 18.4 & 23.6 & 23.0 & 20.0 \\
\hline Zn ppm & 127.3 & 117.6 & 169.2 & 148.7 & 158.0 & 145.7 & 148.5 \\
\hline Rb ppm & 17.9 & 21.4 & 19.2 & 15.4 & 18.8 & 15.9 & 15.1 \\
\hline Sr ppm & 1421.3 & 1381.8 & 1426.4 & 1462.9 & 1442.9 & 1452.7 & 1462.9 \\
\hline Y ppm & 31.1 & 35.7 & 30.2 & 29.5 & 21.6 & 24.6 & 28.8 \\
\hline Zr ppm & 412.0 & 398.2 & 387.3 & 393.1 & 401.3 & 401.8 & 399.5 \\
\hline Nb ppm & 26.2 & 31.6 & 31.1 & 28.8 & 30.6 & 31.4 & 32.7 \\
\hline Ba ppm & 1480.3 & 1412.7 & 1491.1 & 1369.5 & 1420.8 & 1356.9 & 1338.1 \\
\hline
\end{tabular}


Appendix 4.1. continued

\begin{tabular}{|c|c|c|c|c|c|c|c|}
\hline Sample & LBP6FVP & LBP7FVP & LBP8FVP & LBP9FVP & LBP10FVP & LBP11FVP & LC7-13-94-1BMC \\
\hline Center & Little Black Peak & Little Black Peak & Little Black Peak & Little Black Peak & Little Black Peak & Little Black Peak & Little Cone NE \\
\hline $\mathrm{SiO}_{2}$ & 47.78 & 48.26 & 47.87 & 48.40 & 48.14 & 47.50 & 46.86 \\
\hline $\mathrm{TiO}_{2}$ & 1.885 & 1.901 & 1.896 & 1.875 & 1.873 & 1.815 & 2.461 \\
\hline $\mathrm{Al}_{2} \mathrm{O}_{3}$ & 16.72 & 16.96 & 16.54 & 16.83 & 16.73 & 16.31 & 16.11 \\
\hline $\mathrm{Fe}_{2} \mathrm{O}_{3} \mathrm{~T}$ & 11.68 & 11.96 & 11.92 & 11.74 & 11.68 & 11.58 & 12.64 \\
\hline MnO & 0.175 & 0.175 & 0.176 & 0.179 & 0.173 & 0.180 & 0.167 \\
\hline MgO & 5.71 & 5.58 & 5.67 & 5.71 & 5.70 & 5.55 & 5.16 \\
\hline $\mathrm{CaO}$ & 9.42 & 9.17 & 9.33 & 9.12 & 9.22 & 9.54 & 8.62 \\
\hline $\mathrm{Na}_{2} \mathrm{O}$ & 3.37 & 3.39 & 3.25 & 3.39 & 3.31 & 3.09 & 3.67 \\
\hline $\mathbf{K}_{2} \mathbf{O}$ & 1.69 & 1.65 & 1.65 & 1.67 & 1.65 & 1.69 & 2.13 \\
\hline $\mathbf{P}_{2} \mathbf{O}_{5}$ & 1.125 & 1.129 & 1.119 & 1.137 & 1.104 & 1.110 & 1.252 \\
\hline Total & 99.55 & 100.18 & 99.41 & 100.05 & 99.58 & 98.37 & 99.07 \\
\hline Mg\# & 53.26 & 52.10 & 52.56 & 53.14 & 53.21 & 52.76 & 48.73 \\
\hline V ppm & 185.7 & 184.8 & 179.0 & 175.3 & 180.9 & 189.7 & 221.6 \\
\hline Cr ppm & 87.4 & 78.0 & 71.0 & 78.5 & 88.0 & 69.0 & 63.9 \\
\hline Ni ppm & 20.6 & 33.0 & 27.1 & 19.6 & 20.0 & 22.5 & 66.3 \\
\hline Zn ppm & 152.1 & 165.2 & 147.7 & 133.6 & 149.8 & 153.4 & 99.0 \\
\hline Rb ppm & 16.7 & 16.7 & 15.5 & 16.5 & 15.8 & 13.9 & 18.0 \\
\hline Sr ppm & 1471.3 & 1440.5 & 1478.7 & 1458.7 & 1431.6 & 1456.1 & 1465.7 \\
\hline Y ppm & 30.1 & 38.7 & 29.4 & 27.7 & 28.1 & 27.9 & 29.6 \\
\hline Zr ppm & 388.1 & 370.7 & 380.3 & 402.9 & 390.6 & 391.4 & 384.7 \\
\hline Nb ppm & 31.3 & 30.7 & 32.7 & 35.4 & 34.9 & 28.3 & 26.9 \\
\hline Ba ppm & 1394.6 & 1527.6 & 1460.5 & 1363.2 & 1352.5 & 1546.8 & 1274.5 \\
\hline
\end{tabular}


Appendix 4.1. continued

\begin{tabular}{|c|c|c|c|c|c|c|c|c|}
\hline Sample & CF15FVP & LC7-18-94-5BMC & LC7-18-94-6BMC & LW148FVP & BC1FVP & BC2FVP & BC3FVP & BC4FVP \\
\hline Center & Little Cone SW & Little Cone SW & Little Cone SW & Little Cone SW & Black Cone & Black Cone & Black Cone & Black Cone \\
\hline $\mathrm{SiO}_{2}$ & 47.10 & 45.13 & 47.23 & 47.40 & 50.60 & 50.38 & 49.89 & 50.19 \\
\hline $\mathrm{TiO}_{2}$ & 2.175 & 2.078 & 2.209 & 2.206 & 1.427 & 1.502 & 1.495 & 1.490 \\
\hline $\mathrm{Al}_{2} \mathrm{O}_{3}$ & 16.05 & 15.29 & 16.27 & 16.28 & 17.19 & 17.32 & 17.02 & 17.22 \\
\hline $\mathrm{Fe}_{2} \mathrm{O}_{3} \mathrm{~T}$ & 11.77 & 11.30 & 11.73 & 12.05 & 10.37 & 10.69 & 10.57 & 10.69 \\
\hline $\mathrm{MnO}$ & 0.170 & 0.161 & 0.171 & 0.173 & 0.168 & 0.172 & 0.169 & 0.172 \\
\hline MgO & 5.35 & 5.01 & 5.28 & 5.11 & 5.17 & 5.15 & 5.09 & 5.22 \\
\hline $\mathrm{CaO}$ & 9.34 & 10.86 & 9.40 & 9.18 & 8.39 & 8.51 & 8.69 & 8.52 \\
\hline $\mathrm{Na}_{2} \mathrm{O}$ & 3.81 & 3.77 & 3.78 & 3.80 & 3.24 & 3.18 & 3.21 & 3.16 \\
\hline $\mathbf{K}_{2} \mathbf{O}$ & 2.00 & 1.99 & 2.03 & 2.11 & 1.55 & 1.84 & 1.81 & 1.78 \\
\hline $\mathbf{P}_{2} \mathbf{O}_{5}$ & 1.353 & 1.289 & 1.362 & 1.338 & 1.011 & 1.078 & 1.050 & 1.065 \\
\hline Total & 99.13 & 96.87 & 99.47 & 99.65 & 99.13 & 99.82 & 98.99 & 99.51 \\
\hline V ppm & 195.7 & 209.3 & 210.5 & 221.6 & 150.4 & 161.1 & 151.0 & 163.3 \\
\hline Cr ppm & 73.6 & 62.4 & 66.5 & 61.2 & 91.6 & 93.1 & 90.2 & 77.7 \\
\hline Ni ppm & 35.8 & 50.7 & 42.8 & 35.5 & 42.6 & 38.8 & 39.8 & 36.4 \\
\hline Zn ppm & 155.9 & 146.3 & 148.2 & 155.1 & 139.6 & 141.3 & 139.0 & 139.4 \\
\hline Rb ppm & 15.9 & 16.8 & 18.3 & 16.9 & 18.7 & 23.1 & 21.5 & 28.3 \\
\hline Sr ppm & 2187.6 & 2116.1 & 2212.8 & 2176.5 & 1253.4 & 1325.7 & 1326.2 & 1329.0 \\
\hline Y ppm & 28.9 & 27.5 & 24.4 & 27.9 & 26.4 & 30.3 & 34.4 & 21.5 \\
\hline Zr ppm & 427.6 & 419.0 & 420.6 & 432.1 & 386.0 & 389.0 & 388.0 & 386.2 \\
\hline Nb ppm & 31.7 & 25.6 & 33.7 & 35.0 & 34.2 & 27.7 & 27.3 & 27.8 \\
\hline Ba ppm & 1450.3 & 1433.4 & 1642.3 & 1480.7 & 1322.2 & 1464.4 & 1557.9 & 1493.8 \\
\hline
\end{tabular}


Appendix 4.1. continued

\begin{tabular}{|c|c|c|c|c|c|c|c|c|c|c|}
\hline Sample & BC5FVP & BC6FVP & BC7FVP & BC8FVP & BC9FVP & BC10FVP & BC11FVP & BC12FVP & BC13FVP & BC14FVP \\
\hline Center & Black Cone & Black Cone & Black Cone & Black Cone & Black Cone & Black Cone & Black Cone & Black Cone & Black Cone & Black Cone \\
\hline $\mathrm{SiO}_{2}$ & 49.84 & 50.19 & 49.87 & 49.75 & 50.14 & 50.38 & 50.09 & 51.03 & 50.88 & 51.30 \\
\hline $\mathrm{TiO}_{2}$ & 1.480 & 1.508 & 1.481 & 1.479 & 1.483 & 1.485 & 1.483 & 1.457 & 1.435 & 1.428 \\
\hline $\mathrm{Al}_{2} \mathrm{O}_{3}$ & 17.05 & 17.21 & 17.18 & 17.20 & 17.32 & 17.26 & 17.11 & 17.18 & 17.04 & 17.07 \\
\hline $\mathrm{Fe}_{2} \mathrm{O}_{3} \mathrm{~T}$ & 10.64 & 10.78 & 10.75 & 10.72 & 10.82 & 10.69 & 10.63 & 10.44 & 10.32 & 10.34 \\
\hline MnO & 0.172 & 0.171 & 0.172 & 0.175 & 0.175 & 0.168 & 0.167 & 0.163 & 0.167 & 0.168 \\
\hline MgO & 5.19 & 5.25 & 5.14 & 5.12 & 5.07 & 5.14 & 5.19 & 4.92 & 5.09 & 5.15 \\
\hline $\mathrm{CaO}$ & 8.58 & 8.53 & 8.66 & 8.53 & 8.60 & 8.48 & 8.79 & 8.37 & 8.47 & 8.39 \\
\hline $\mathrm{Na}_{2} \mathrm{O}$ & 3.24 & 3.32 & 3.17 & 3.24 & 3.19 & 3.21 & 3.28 & 3.16 & 3.16 & 3.15 \\
\hline $\mathbf{K}_{2} \mathbf{O}$ & 1.72 & 1.63 & 1.61 & 1.68 & 1.76 & 1.70 & 1.68 & 1.80 & 1.69 & 1.77 \\
\hline $\mathbf{P}_{2} \mathbf{O}_{5}$ & 1.077 & 1.046 & 1.075 & 1.069 & 1.059 & 1.058 & 1.048 & 0.985 & 0.991 & 0.986 \\
\hline Total & 98.98 & 99.63 & 99.11 & 98.96 & 99.63 & 99.58 & 99.46 & 99.50 & 99.24 & 99.76 \\
\hline Mg\# & 53.22 & 53.17 & 52.69 & 52.66 & 52.20 & 52.82 & 53.21 & 52.36 & 53.45 & 53.74 \\
\hline V ppm & 165.9 & 172.5 & 169.2 & 149.0 & 163.7 & 153.6 & 160.5 & 158.6 & 148.8 & 150.9 \\
\hline Cr ppm & 92.0 & 88.6 & 74.2 & 88.6 & 79.1 & 90.6 & 90.2 & 95.9 & 88.2 & 91.7 \\
\hline Ni ppm & 42.0 & 45.6 & 31.2 & 38.9 & 50.9 & 40.5 & 38.3 & 51.9 & 40.4 & 37.9 \\
\hline Zn ppm & 140.4 & 143.2 & 140.1 & 140.7 & 141.9 & 147.2 & 147.8 & 139.9 & 138.3 & 135.6 \\
\hline Rb ppm & 21.0 & 19.0 & 18.1 & 21.5 & 21.1 & 22.5 & 21.0 & 23.0 & 23.6 & 24.6 \\
\hline Sr ppm & 1308.7 & 1325.5 & 1337.6 & 1312.6 & 1320.8 & 1318.0 & 1306.0 & 1247.9 & 1263.7 & 1262.1 \\
\hline Y ppm & 16.0 & 29.3 & 27.3 & 31.9 & 24.3 & 30.7 & 24.6 & 35.9 & 28.4 & 36.1 \\
\hline Zr ppm & 391.1 & 397.5 & 397.1 & 387.0 & 401.0 & 394.9 & 386.8 & 383.4 & 379.1 & 391.0 \\
\hline Nb ppm & 30.3 & 29.8 & 26.0 & 27.4 & 26.4 & 30.1 & 24.6 & 29.8 & 30.8 & 28.8 \\
\hline Ba ppm & 1397.9 & 1442.5 & 1391.7 & 1398.4 & 1439.3 & 1385.3 & 1346.7 & 1407.8 & 1507.9 & 1341.3 \\
\hline
\end{tabular}


Appendix 4.1. continued

\begin{tabular}{|c|c|c|c|c|c|c|c|c|c|}
\hline Sample & MC7-18-94-1BMC & MC7-18-94-3АВМС & RC2FVP & RC3FVP & BB2FVP & BB3FVP & BB5FVP & CF10FVP & CF11FVP \\
\hline Center & Makani Cone & Makani Cone & Red Cone & Red Cone & Buckboard & Buckboard & Buckboard & $\overline{\text { SE Crater Flat }}$ & SE Crater Flat \\
\hline $\mathrm{SiO}_{2}$ & 49.07 & 48.62 & 51.29 & 50.60 & 52.37 & 53.36 & 53.04 & 47.82 & 48.34 \\
\hline $\mathrm{TiO}_{2}$ & 1.614 & 1.579 & 1.359 & 1.533 & 1.445 & 1.409 & 1.465 & 1.806 & 1.833 \\
\hline $\mathrm{Al}_{2} \mathbf{O}_{3}$ & 17.16 & 16.77 & 17.19 & 17.26 & 17.48 & 17.41 & 17.59 & 15.59 & 15.99 \\
\hline $\mathrm{Fe}_{2} \mathrm{O}_{3} \mathrm{~T}$ & 11.01 & 10.79 & 10.26 & 10.94 & 8.60 & 8.35 & 8.52 & 12.21 & 12.09 \\
\hline MnO & 0.170 & 0.168 & 0.173 & 0.175 & 0.139 & 0.129 & 0.134 & 0.176 & 0.169 \\
\hline MgO & 5.20 & 5.08 & 4.75 & 5.23 & 4.76 & 4.87 & 4.93 & 7.07 & 6.24 \\
\hline $\mathrm{CaO}$ & 8.70 & 9.31 & 8.68 & 8.61 & 7.15 & 6.81 & 6.90 & 9.37 & 9.57 \\
\hline $\mathrm{Na}_{2} \mathrm{O}$ & 3.35 & 3.29 & 3.46 & 3.27 & 3.90 & 3.78 & 3.92 & 2.95 & 3.08 \\
\hline $\mathbf{K}_{2} \mathbf{O}$ & 1.66 & 1.65 & 1.70 & 1.87 & 2.35 & 2.55 & 2.37 & 1.61 & 1.68 \\
\hline $\mathbf{P}_{2} \mathbf{O}_{5}$ & 1.138 & 1.117 & 1.012 & 1.101 & 1.084 & 1.012 & 1.016 & 0.699 & 0.727 \\
\hline Total & 99.06 & 98.39 & 99.87 & 100.59 & 99.28 & 99.68 & 99.90 & 99.31 & 99.73 \\
\hline Mg\# & 52.38 & 52.32 & 51.87 & 52.67 & 56.31 & 57.59 & 57.42 & 57.43 & 54.59 \\
\hline V ppm & 172.0 & 193.5 & 159.0 & 166.9 & 124.3 & 130.7 & 135.5 & 212.3 & 260.9 \\
\hline Cr ppm & 65.8 & 65.8 & 71.4 & 93.6 & 80.4 & 92.4 & 78.2 & 191.6 & 133.9 \\
\hline Ni ppm & 51.4 & 60.0 & 38.1 & 39.9 & 73.7 & 72.5 & 68.7 & 29.6 & 22.5 \\
\hline Zn ppm & 146.6 & 136.6 & 133.5 & 125.6 & 100.0 & 107.2 & 100.6 & 117.1 & 121.5 \\
\hline Rb ppm & 22.9 & 14.7 & 20.0 & 20.1 & 33.2 & 31.5 & 34.0 & 23.2 & 26.5 \\
\hline Sr ppm & 1396.9 & 1409.9 & 1833.4 & 1411.4 & 1310.8 & 1271.7 & 1320.4 & 950.5 & 980.8 \\
\hline Y ppm & 15.4 & 32.6 & 34.0 & 36.6 & 19.1 & 20.7 & 19.9 & 34.4 & 32.0 \\
\hline Zr ppm & 407.5 & 407.3 & 431.1 & 391.8 & 371.5 & 373.6 & 372.2 & 272.8 & 287.1 \\
\hline Nb ppm & 23.1 & 25.9 & 28.0 & 32.4 & 18.9 & 21.4 & 28.8 & 19.7 & 21.1 \\
\hline Ba ppm & 1405.3 & 1413.5 & 1713.1 & 1530.0 & 2159.3 & 2217.0 & 2207.9 & 942.6 & 973.0 \\
\hline
\end{tabular}


Appendix 4.1. continued

\begin{tabular}{|c|c|c|c|c|c|c|c|}
\hline Sample & CF12FVP & CF13FVP & CF14FVP & CF3-18-92-2BMC & CF3-18-92-3A-BMC & CF3-18-92-3B-BMC & CF3-18-92-4-BMC \\
\hline Center & SE Crater Flat & SE Crater Flat & SE Crater Flat & SE Crater Flat & SE Crater Flat & SE Crater Flat & SE Crater Flat \\
\hline $\mathrm{SiO}_{2}$ & 47.69 & 47.68 & 47.24 & 48.60 & 47.05 & 47.73 & 48.60 \\
\hline $\mathrm{TiO}_{2}$ & 1.856 & 1.766 & 1.627 & 1.782 & 1.618 & 1.627 & 1.777 \\
\hline $\mathrm{Al}_{2} \mathbf{O}_{3}$ & 15.32 & 15.36 & 14.87 & 15.93 & 15.01 & 15.07 & 15.69 \\
\hline $\mathrm{Fe}_{2} \mathrm{O}_{3} \mathbf{T}$ & 12.28 & 12.06 & 11.36 & 11.78 & 11.52 & 11.52 & 12.13 \\
\hline $\mathrm{MnO}$ & 0.175 & 0.172 & 0.167 & 0.169 & 0.166 & 0.169 & 0.172 \\
\hline MgO & 6.56 & 6.92 & 7.13 & 5.74 & 7.86 & 7.43 & 6.61 \\
\hline $\mathrm{CaO}$ & 9.36 & 9.04 & 10.44 & 9.40 & 9.66 & 9.70 & 8.72 \\
\hline $\mathrm{Na}_{2} \mathrm{O}$ & 2.93 & 2.94 & 2.78 & 3.04 & 2.76 & 2.79 & 3.07 \\
\hline $\mathbf{K}_{2} \mathbf{O}$ & 1.58 & 1.54 & 1.60 & 1.70 & 1.58 & 1.59 & 1.59 \\
\hline $\mathbf{P}_{2} \mathbf{O}_{5}$ & 0.697 & 0.683 & 0.608 & 0.701 & 0.609 & 0.606 & 0.798 \\
\hline Total & 98.45 & 98.17 & 97.83 & 98.84 & 97.83 & 98.23 & 99.17 \\
\hline Mg\# & 55.43 & 57.22 & 59.37 & 53.16 & 61.37 & 60.03 & 55.94 \\
\hline V ppm & 232.0 & 207.3 & 225.9 & 241.4 & 213.2 & 207.5 & 202.0 \\
\hline Cr ppm & 180.2 & 191.7 & 267.3 & 127.1 & 280.1 & 279.2 & 189.8 \\
\hline Ni ppm & 36.9 & 33.2 & 38.9 & 18.2 & 38.2 & 34.9 & 69.4 \\
\hline Zn ppm & 113.4 & 131.4 & 127.2 & 127.5 & 123.5 & 126.5 & 136.6 \\
\hline Rb ppm & 21.6 & 24.4 & 27.8 & 29.0 & 26.4 & 29.3 & 21.0 \\
\hline Sr ppm & 933.4 & 891.1 & 910.4 & 956.3 & 869.4 & 878.5 & 998.7 \\
\hline Y ppm & 32.0 & 30.3 & 20.8 & 38.4 & 32.9 & 30.2 & 28.9 \\
\hline Zr ppm & 273.4 & 273.4 & 255.3 & 282.4 & 261.3 & 257.6 & 308.2 \\
\hline Nb ppm & 22.7 & 22.5 & 20.2 & 20.5 & 18.4 & 20.5 & 25.7 \\
\hline Ba ppm & 905.1 & 937.7 & 882.8 & 951.7 & 868.8 & 840.9 & 972.9 \\
\hline
\end{tabular}


Appendix 4.1. continued

\begin{tabular}{|c|c|c|c|c|c|c|c|}
\hline Sample & CF3-18-92-6-BMC & CF3-18-92-7-BMC & NE-10-1-91-2BMC & TM1FVP & TM2FVP & TM3FVP & TM4FVP \\
\hline Center & SE Crater Flat & SE Crater Flat & Thirsty Mesa & Thirsty Mesa & Thirsty Mesa & Thirsty Mesa & Thirsty Mesa \\
\hline $\mathrm{SiO}_{2}$ & 47.44 & 47.66 & 50.90 & 50.77 & 50.89 & 50.96 & 50.36 \\
\hline $\mathrm{TiO}_{2}$ & 1.835 & 1.821 & 1.850 & 1.848 & 1.862 & 1.828 & 1.827 \\
\hline $\mathrm{Al}_{2} \mathrm{O}_{3}$ & 15.89 & 15.68 & 17.22 & 17.16 & 17.39 & 17.26 & 17.03 \\
\hline $\mathrm{Fe}_{2} \mathrm{O}_{3} \mathrm{~T}$ & 11.91 & 12.01 & 9.57 & 9.52 & 9.41 & 9.23 & 9.12 \\
\hline $\mathrm{MnO}$ & 0.159 & 0.177 & 0.157 & 0.166 & 0.166 & 0.160 & 0.154 \\
\hline MgO & 6.23 & 6.00 & 4.98 & 4.69 & 4.74 & 4.50 & 4.37 \\
\hline $\mathrm{CaO}$ & 9.64 & 9.58 & 6.97 & 7.08 & 7.10 & 7.22 & 7.55 \\
\hline $\mathrm{Na}_{2} \mathrm{O}$ & 2.88 & 3.00 & 4.24 & 4.22 & 4.23 & 4.09 & 3.98 \\
\hline $\mathbf{K}_{2} \mathbf{O}$ & 1.76 & 1.66 & 2.84 & 2.81 & 2.85 & 2.85 & 2.85 \\
\hline $\mathbf{P}_{2} \mathbf{O}_{5}$ & 0.728 & 0.716 & 0.970 & 0.976 & 0.978 & 0.975 & 1.094 \\
\hline Total & 98.47 & 98.31 & 99.71 & 99.25 & 99.61 & 99.08 & 98.34 \\
\hline Mg\# & 54.93 & 53.78 & 54.81 & 53.44 & 53.99 & 53.20 & 52.76 \\
\hline V ppm & 216.3 & 207.6 & 155.3 & 162.0 & 167.4 & 156.9 & 157.9 \\
\hline Cr ppm & 116.3 & 140.7 & 65.3 & 61.0 & 56.7 & 51.7 & 55.7 \\
\hline Ni ppm & 13.4 & 20.9 & 45.6 & 77.0 & 58.5 & 65.7 & 50.8 \\
\hline Zn ppm & 130.2 & 136.6 & 99.1 & 90.6 & 76.4 & 80.9 & 89.3 \\
\hline Rb ppm & 25.0 & 23.5 & 51.1 & 48.6 & 47.5 & 46.8 & 46.3 \\
\hline Sr ppm & 1011.0 & 948.2 & 971.1 & 952.3 & 949.4 & 975.4 & 978.2 \\
\hline Y ppm & 28.5 & 28.1 & 32.4 & 27.7 & 32.3 & 29.1 & 29.7 \\
\hline Zr ppm & 290.9 & 291.9 & 379.7 & 337.3 & 371.0 & 368.7 & 383.6 \\
\hline Nb ppm & 22.9 & 22.5 & 34.1 & 31.6 & 27.7 & 38.3 & 35.5 \\
\hline Ba ppm & 993.9 & 980.6 & 1511.9 & 1516.1 & 1389.6 & 1848.0 & 1820.7 \\
\hline
\end{tabular}


Appendix 4.2. Instrumental neutron activation trace-element analyses of basalts from the YMR

\begin{tabular}{|c|c|c|c|c|c|c|c|c|c|c|}
\hline Sample & HC1FVP & HC2FVP & HC3FVP & HC4FVP & HC5FVP & HC6FVP & HC7FVP & HC13FVP & HC15FVP & SB7-20-95-2BMC \\
\hline Center & $\begin{array}{c}\text { Hidden } \\
\text { Cone }\end{array}$ & $\begin{array}{c}\text { Hidden } \\
\text { Cone }\end{array}$ & $\begin{array}{c}\text { Hidden } \\
\text { Cone }\end{array}$ & $\begin{array}{c}\text { Hidden } \\
\text { Cone }\end{array}$ & $\begin{array}{c}\text { Hidden } \\
\text { Cone }\end{array}$ & $\begin{array}{c}\text { Hidden } \\
\text { Cone }\end{array}$ & $\begin{array}{c}\text { Hidden } \\
\text { Cone }\end{array}$ & $\begin{array}{c}\text { Hidden } \\
\text { Cone }\end{array}$ & $\begin{array}{c}\text { Hidden } \\
\text { Cone }\end{array}$ & Hidden Cone $\mathrm{N}$ \\
\hline Sc & 20.00 & 19.68 & 19.93 & 20.00 & 19.67 & 20.20 & 19.76 & 19.74 & 19.03 & 19.05 \\
\hline Co & 27.6 & 26.6 & 27.2 & 28.3 & 26.7 & 27.8 & 26.9 & 27.6 & 26.7 & 27.6 \\
\hline $\mathbf{R b}$ & 19.0 & 20.0 & 20.0 & 20.0 & 19.0 & 15.0 & 18.0 & 21.0 & 28.0 & 19 \\
\hline $\mathrm{Sr}$ & 1440 & 1440 & 1470 & 1430 & 1460 & 1460 & 1400 & 1390 & 1330 & 1380 \\
\hline $\mathbf{B a}$ & 1420 & 1430 & 1400 & 1430 & 1390 & 1470 & 1450 & 1440 & 1440 & 1430 \\
\hline $\mathbf{L a}$ & 114.7 & 114.7 & 111.6 & 114.9 & 110.3 & 112.9 & 110.5 & 119.7 & 113.1 & 114.1 \\
\hline $\mathrm{Ce}$ & 204.0 & 207.0 & 202.0 & 205.0 & 201.0 & 207.0 & 201.0 & 215.0 & 208.0 & 208 \\
\hline Sm & 12.60 & 12.50 & 12.53 & 12.40 & 12.34 & 12.60 & 12.51 & 12.65 & 12.27 & 12.48 \\
\hline Eu & 3.18 & 3.12 & 3.17 & 3.14 & 3.12 & 3.21 & 3.16 & 3.22 & 3.03 & 3.16 \\
\hline $\mathbf{T b}$ & 1.12 & 1.18 & 1.13 & 1.13 & 1.18 & 1.18 & 1.16 & 1.20 & 1.12 & 1.14 \\
\hline $\mathbf{Y b}$ & 2.46 & 2.34 & 2.48 & 2.45 & 2.40 & 2.44 & 2.34 & 2.41 & 2.38 & 2.32 \\
\hline $\mathbf{L u}$ & 0.353 & 0.341 & 0.361 & 0.343 & 0.351 & 0.365 & 0.362 & 0.355 & 0.364 & 0.345 \\
\hline Hf & 8.09 & 7.98 & 7.97 & 7.90 & 7.57 & 8.07 & 7.81 & 8.18 & 8.03 & 7.99 \\
\hline $\mathbf{T a}$ & 1.62 & 1.67 & 1.61 & 1.61 & 1.58 & 1.61 & 1.62 & 1.61 & 1.59 & 1.55 \\
\hline Th & 12.30 & 12.12 & 11.70 & 12.05 & 11.45 & 11.79 & 11.46 & 11.89 & 12.21 & 10.92 \\
\hline
\end{tabular}


Appendix 4.2. continued

\begin{tabular}{|c|c|c|c|c|c|c|c|c|}
\hline Sample & LBP1FVP & LBP2FVP & LBP3FVP & LBP4FVP & LBP5FVP & LBP6FVP & LBP7FVP & LBP8FVP \\
\hline Center & Little Black Peak & Little Black Peak & Little Black Peak & $\begin{array}{c}\text { Little Black } \\
\text { Peak }\end{array}$ & $\begin{array}{c}\text { Little Black } \\
\text { Peak }\end{array}$ & $\begin{array}{c}\text { Little Black } \\
\text { Peak }\end{array}$ & $\begin{array}{c}\text { Little Black } \\
\text { Peak }\end{array}$ & $\begin{array}{c}\text { Little Black } \\
\text { Peak }\end{array}$ \\
\hline Sc & 20.30 & 19.71 & 19.14 & 19.93 & 19.77 & 19.62 & 19.84 & 19.88 \\
\hline Co & 29.2 & 27.8 & 27.0 & 27.8 & 27.6 & 27.6 & 28.0 & 28.0 \\
\hline $\mathbf{R b}$ & 21.0 & 20.0 & 19.0 & 20.0 & 15.0 & 20.0 & 20.0 & 19.0 \\
\hline $\mathrm{Sr}$ & 1420 & 1360 & 1420 & 1400 & 1380 & 1430 & 1420 & 1430 \\
\hline $\mathbf{B a}$ & 1400 & 1440 & 1380 & 1450 & 1430 & 1440 & 1440 & 1480 \\
\hline La & 102.9 & 104.1 & 101.9 & 105.7 & 105.3 & 104.4 & 105.2 & 105.8 \\
\hline $\mathrm{Ce}$ & 192.2 & 194.4 & 191.5 & 196.7 & 196.7 & 195.0 & 195.8 & 198.9 \\
\hline Sm & 12.30 & 12.50 & 12.30 & 12.46 & 12.56 & 12.52 & 12.62 & 12.80 \\
\hline Eu & 3.22 & 3.24 & 3.13 & 3.22 & 3.25 & 3.22 & 3.26 & 3.28 \\
\hline $\mathbf{T b}$ & 1.14 & 1.17 & 1.13 & 1.20 & 1.14 & 1.18 & 1.17 & 1.19 \\
\hline $\mathbf{Y b}$ & 2.41 & 2.42 & 2.37 & 2.38 & 2.42 & 2.41 & 2.44 & 2.48 \\
\hline $\mathbf{L u}$ & 0.346 & 0.365 & 0.352 & 0.353 & 0.340 & 0.337 & 0.344 & 0.368 \\
\hline Hf & 7.73 & 7.75 & 7.56 & 7.95 & 7.79 & 7.72 & 7.80 & 7.79 \\
\hline $\mathbf{T a}$ & 1.46 & 1.45 & 1.53 & 1.46 & 1.54 & 1.52 & 1.52 & 1.54 \\
\hline Th & 8.06 & 8.42 & 8.37 & 8.80 & 8.86 & 8.62 & 8.49 & 8.87 \\
\hline
\end{tabular}


Appendix 4.2. continued

\begin{tabular}{|c|c|c|c|c|c|c|c|c|}
\hline Sample & LBP9FVP & LBP10FVP & LBP11FVP & $\begin{array}{c}\text { LC7-13-94- } \\
\text { 1BMC } \\
\end{array}$ & CF15FVP & LW148FVP & $\begin{array}{c}\text { LC7-18-94- } \\
\text { 5BMC } \\
\end{array}$ & $\begin{array}{c}\text { LC7-18-94- } \\
\text { 6BMC } \\
\end{array}$ \\
\hline Center & $\begin{array}{c}\text { Little Black } \\
\text { Peak }\end{array}$ & $\begin{array}{c}\text { Little Black } \\
\text { Peak }\end{array}$ & $\begin{array}{c}\text { Little Black } \\
\text { Peak }\end{array}$ & Little Cone NE & $\begin{array}{c}\text { Little Cone } \\
\text { SW }\end{array}$ & $\begin{array}{c}\text { Little Cone } \\
\text { SW }\end{array}$ & Little Cone SW & Little Cone SW \\
\hline Sc & 20.00 & 20.40 & 19.22 & 18.83 & 17.87 & 17.48 & 16.74 & 17.16 \\
\hline Co & 28.4 & 28.6 & 27.4 & 30.8 & 29.6 & 29.1 & 27.6 & 28.3 \\
\hline $\mathbf{R b}$ & 21.0 & 24.0 & 23.0 & 17.0 & 19.0 & 22.0 & 18.0 & 18.0 \\
\hline Sr & 1390 & 1400 & 1350 & 1390 & 2140 & 2040 & 2010 & 2030 \\
\hline $\mathbf{B a}$ & 1420 & 1400 & 1440 & 1180 & 1470 & 1440 & 1380 & 1400 \\
\hline $\mathbf{L a}$ & 104.4 & 104.2 & 102.9 & 89.7 & 134.3 & 130.7 & 126.4 & 129.3 \\
\hline $\mathrm{Ce}$ & 195.1 & 194.1 & 193.9 & 182.9 & 258.0 & 255.0 & 244.0 & 252.0 \\
\hline Sm & 12.56 & 12.35 & 12.18 & 13.40 & 16.08 & 16.29 & 15.35 & 15.90 \\
\hline Eu & 3.25 & 3.27 & 3.14 & 3.28 & 3.96 & 3.87 & 3.73 & 3.86 \\
\hline $\mathbf{T b}$ & 1.17 & 1.19 & 1.14 & 1.16 & 1.34 & 1.32 & 1.29 & 1.30 \\
\hline $\mathbf{Y b}$ & 2.44 & 2.42 & 2.36 & 2.16 & 2.30 & 2.26 & 2.22 & 2.23 \\
\hline Lu & 0.366 & 0.351 & 0.348 & 0.305 & 0.333 & 0.339 & 0.314 & 0.317 \\
\hline Hf & 8.00 & 7.76 & 7.67 & 7.67 & 7.88 & 8.03 & 7.53 & 7.78 \\
\hline $\mathbf{T a}$ & 1.57 & 1.53 & 1.46 & 1.37 & 1.67 & 1.58 & 1.51 & 1.59 \\
\hline Th & 8.43 & 8.11 & 8.42 & 5.68 & 9.65 & 9.76 & 9.24 & 9.60 \\
\hline
\end{tabular}


Appendix 4.2. continued

\begin{tabular}{|c|c|c|c|c|c|c|c|c|c|c|c|}
\hline Sample & BC1FVP & BC2FVP & BC3FVP & BC4FVP & BC5FVP & BC6FVP & BC7FVP & BC8FVP & BC9FVP & $\overline{\text { BC10FVP }}$ & BC11FVP \\
\hline \multirow[t]{2}{*}{ Center } & Black & Black & Black & Black & Black & Black & Black & Black & Black & Black & Black \\
\hline & Cone & Cone & Cone & Cone & Cone & Cone & Cone & Cone & Cone & Cone & Cone \\
\hline Sc & 18.44 & 18.71 & 18.48 & 18.01 & 18.36 & 18.46 & 18.07 & 18.58 & 18.28 & 18.43 & 18.34 \\
\hline Co & 27.0 & 27.9 & 27.7 & 26.8 & 27.5 & 28.2 & 27.0 & 27.7 & 26.9 & 27.7 & 27.4 \\
\hline $\mathbf{R b}$ & 24.0 & 22.7 & 24.0 & 22.0 & 21.7 & 22.4 & 22.0 & 24.0 & 22.0 & 22.2 & 23.5 \\
\hline $\mathbf{S r}$ & 1230 & 1300 & 1290 & 1240 & 1280 & 1300 & 1260 & 1280 & 1220 & 1300 & 1273 \\
\hline $\mathbf{B a}$ & 1360 & 1410 & 1520 & 1380 & 1390 & 1370 & 1340 & 1380 & 1370 & 1390 & 1360 \\
\hline $\mathbf{L a}$ & 112.5 & 117.4 & 115.9 & 113.7 & 115.6 & 115.4 & 115.3 & 117.4 & 115.1 & 116.2 & 114.8 \\
\hline $\mathrm{Ce}$ & 198.4 & 210.8 & 207.8 & 205.0 & 207.6 & 207.3 & 206.0 & 209.4 & 207.0 & 208.5 & 208.0 \\
\hline Sm & 11.45 & 12.04 & 11.77 & 11.86 & 11.94 & 11.88 & 12.11 & 12.01 & 11.92 & 12.08 & 11.94 \\
\hline Eu & 2.91 & 3.07 & 3.06 & 3.05 & 3.01 & 3.09 & 3.00 & 3.07 & 3.04 & 3.06 & 3.06 \\
\hline $\mathbf{T b}$ & 1.05 & 1.11 & 1.06 & 1.07 & 1.09 & 1.09 & 1.07 & 1.12 & 1.08 & 1.11 & 1.07 \\
\hline $\mathbf{Y b}$ & 2.35 & 2.38 & 2.33 & 2.29 & 2.36 & 2.36 & 2.35 & 2.42 & 2.34 & 2.43 & 2.38 \\
\hline Lu & 0.339 & 0.353 & 0.352 & 0.334 & 0.335 & 0.345 & 0.340 & 0.346 & 0.333 & 0.348 & 0.359 \\
\hline Hf & 7.57 & 7.89 & 7.77 & 7.56 & 7.77 & 7.70 & 7.57 & 7.75 & 7.68 & 7.72 & 7.81 \\
\hline $\mathbf{T a}$ & 1.44 & 1.49 & 1.43 & 1.44 & 1.45 & 1.47 & 1.44 & 1.50 & 1.41 & 1.47 & 1.48 \\
\hline Th & 11.48 & 11.85 & 11.75 & 11.72 & 11.69 & 11.78 & 11.73 & 11.81 & 11.44 & 11.84 & 11.92 \\
\hline
\end{tabular}


Appendix 4.2. continued

\begin{tabular}{|c|c|c|c|c|c|c|c|c|c|c|}
\hline$\overline{\text { Sample }}$ & BC12FVP & BC13FVP & BC14FVP & $\begin{array}{c}\text { MC7-18-94- } \\
\text { 1BMC } \\
\end{array}$ & $\begin{array}{c}\text { MC7-18-94- } \\
\text { 3АВMC } \\
\end{array}$ & RC2FVP & RC3FVP & BB2FVP & BB3FVP & CF10FVP \\
\hline$\overline{\text { Center }}$ & $\begin{array}{l}\text { Black } \\
\text { Cone }\end{array}$ & $\begin{array}{l}\text { Black } \\
\text { Cone }\end{array}$ & $\begin{array}{l}\text { Black } \\
\text { Cone }\end{array}$ & Makani Cone & Makani Cone & $\begin{array}{l}\text { Red } \\
\text { Cone }\end{array}$ & $\begin{array}{l}\text { Red } \\
\text { Cone }\end{array}$ & Buckboard & Buckboard & $\begin{array}{c}\text { SE Crater } \\
\text { Flat }\end{array}$ \\
\hline$\overline{\text { Sc }}$ & 18.00 & 18.24 & 18.12 & 18.34 & 17.73 & 17.39 & 18.22 & 14.14 & 14.10 & 26.60 \\
\hline Co & 25.6 & 26.8 & 26.8 & 27.9 & 26.9 & 24.6 & 27.2 & 24.0 & 23.1 & 38.9 \\
\hline $\mathbf{R b}$ & 28.0 & 26.0 & 26.3 & 17.0 & 19.0 & 26.0 & 24.0 & 33.0 & 36.0 & 27.0 \\
\hline $\mathbf{S r}$ & 1190 & 1230 & 1230 & 1360 & 1380 & 1720 & 1340 & 1210 & 1190 & 900 \\
\hline $\mathbf{B a}$ & 1320 & 1470 & 1360 & 1450 & 1460 & 1670 & 1410 & 2050 & 2140 & 910 \\
\hline $\mathbf{L a}$ & 110.6 & 112.0 & 110.9 & 115.8 & 112.0 & 137.6 & 114.6 & 84.5 & 83.5 & 69.0 \\
\hline $\mathrm{Ce}$ & 196.9 & 198.5 & 196.3 & 213.0 & 207.0 & 244.0 & 209.0 & 160.6 & 158.8 & 131.5 \\
\hline Sm & 11.48 & 11.38 & 11.39 & 12.72 & 12.49 & 13.35 & 12.31 & 9.36 & 9.08 & 9.70 \\
\hline $\mathbf{E u}$ & 2.83 & 2.87 & 2.86 & 3.20 & 3.12 & 3.25 & 3.12 & 2.60 & 2.52 & 2.51 \\
\hline $\mathbf{T b}$ & 1.01 & 1.03 & 1.05 & 1.09 & 1.13 & 1.13 & 1.09 & 0.81 & 0.76 & 1.04 \\
\hline $\mathbf{Y b}$ & 2.34 & 2.35 & 2.34 & 2.30 & 2.27 & 2.45 & 2.33 & 1.90 & 1.99 & 2.57 \\
\hline $\mathbf{L u}$ & 0.329 & 0.337 & 0.337 & 0.353 & 0.325 & 0.346 & 0.318 & 0.290 & 0.299 & 0.375 \\
\hline Hf & 7.51 & 7.61 & 7.53 & 7.79 & 7.56 & 7.42 & 7.56 & 7.48 & 7.41 & 5.83 \\
\hline $\mathbf{T a}$ & 1.45 & 1.47 & 1.42 & 1.50 & 1.46 & 1.41 & 1.41 & 1.16 & 1.17 & 1.00 \\
\hline Th & 11.39 & 11.67 & 11.50 & 10.82 & 10.37 & 14.20 & 11.62 & 8.81 & 8.55 & 6.16 \\
\hline
\end{tabular}


Appendix 4.2. continued

\begin{tabular}{|c|c|c|c|c|c|c|c|}
\hline Sample & CF11FVP & CF12FVP & CF13FVP & $\begin{array}{c}\text { CF3-18-92-2- } \\
\text { BMC }\end{array}$ & $\begin{array}{c}\text { CF3-18-92-3A- } \\
\text { BMC }\end{array}$ & $\begin{array}{c}\text { CF3-18-92-3B- } \\
\text { BMC }\end{array}$ & $\begin{array}{c}\text { CF3-18-92-4- } \\
\text { ВMC }\end{array}$ \\
\hline Center & $\begin{array}{c}\text { SE Crater } \\
\text { Flat }\end{array}$ & $\begin{array}{c}\text { SE Crater } \\
\text { Flat }\end{array}$ & $\begin{array}{c}\text { SE Crater } \\
\text { Flat }\end{array}$ & SE Crater Flat & SE Crater Flat & SE Crater Flat & SE Crater Flat \\
\hline Sc & 26.00 & 27.50 & 24.90 & 25.70 & 27.10 & 26.90 & 23.30 \\
\hline Co & 35.3 & 37.6 & 38.8 & 33.7 & 39.5 & 39.5 & 36.6 \\
\hline $\mathbf{R b}$ & 30.0 & 25.0 & 23.0 & 33.0 & 27.0 & 26.0 & 20.0 \\
\hline $\mathrm{Sr}$ & 970 & 980 & 860 & 950 & 840 & 880 & 1010 \\
\hline $\mathbf{B a}$ & 940 & 920 & 960 & 920 & 880 & 900 & 980 \\
\hline La & 71.5 & 70.0 & 68.3 & 70.1 & 63.0 & 63.2 & 82.4 \\
\hline $\mathrm{Ce}$ & 136.3 & 135.8 & 132.2 & 133.0 & 121.6 & 121.7 & 152.0 \\
\hline Sm & 9.94 & 9.82 & 9.41 & 9.71 & 8.81 & 8.93 & 10.12 \\
\hline $\mathbf{E u}$ & 2.60 & 2.61 & 2.46 & 2.52 & 2.31 & 2.26 & 2.60 \\
\hline $\mathbf{T b}$ & 1.07 & 1.07 & 1.00 & 1.00 & 0.94 & 0.94 & 0.99 \\
\hline $\mathbf{Y b}$ & 2.75 & 2.72 & 2.48 & 2.55 & 2.41 & 2.40 & 2.29 \\
\hline $\mathbf{L u}$ & 0.400 & 0.408 & 0.359 & 0.387 & 0.335 & 0.351 & 0.341 \\
\hline Hf & 5.99 & 6.11 & 5.88 & 5.92 & 5.59 & 5.50 & 6.33 \\
\hline $\mathbf{T a}$ & 1.08 & 0.99 & 1.08 & 1.05 & 1.00 & 1.00 & 1.22 \\
\hline Th & 6.45 & 6.07 & 5.98 & 6.53 & 6.04 & 6.03 & 6.47 \\
\hline
\end{tabular}


Appendix 4.2. continued

\begin{tabular}{lccccc}
\hline Sample & $\begin{array}{c}\text { CF3-18-92-7- } \\
\text { BMC }\end{array}$ & TM1FVP & TM2FVP & TM3FVP & TM4FVP \\
\hline Center & SE Crater Flat & Thirsty & Thirsty & Thirsty & Thirsty \\
& & Mesa & Mesa & Mesa & Mesa \\
\hline Sc & 25.80 & 15.38 & 14.97 & 14.62 & 14.32 \\
Co & 35.4 & 25.3 & 24.8 & 23.8 & 22.8 \\
Rb & 27.0 & 48.0 & 48.0 & 47.0 & 42.0 \\
Sr & 940 & 910 & 920 & 950 & 950 \\
Ba & 930 & 1470 & 1440 & 1850 & 1800 \\
La & 70.8 & 72.8 & 70.7 & 72.9 & 78.6 \\
Ce & 134.3 & 145.8 & 142.2 & 144.0 & 155.4 \\
Sm & 9.79 & 9.92 & 10.06 & 10.05 & 10.50 \\
Eu & 2.56 & 2.62 & 2.58 & 2.57 & 2.71 \\
Tb & 1.07 & 1.05 & 1.04 & 1.03 & 0.99 \\
Yb & 2.58 & 2.77 & 2.64 & 2.65 & 2.48 \\
Lu & 0.382 & 0.418 & 0.402 & 0.380 & 0.375 \\
Hf & 5.98 & 7.89 & 7.55 & 7.71 & 8.17 \\
Ta & 1.10 & 1.80 & 1.90 & 1.84 & 1.61 \\
Th & 6.41 & 4.34 & 4.47 & 4.50 & 4.99 \\
\hline
\end{tabular}




\title{
Physical Processes of Magmatism and Effects on the Potential Repository: Synthesis of Technical Work through Fiscal Year 1995
}

\author{
Greg A. Valentine \\ Giday WoldeGabriel \\ Nina D. Rosenberg \\ Karen E. Carter Krogh \\ Bruce M. Crowe \\ Phil Stauffer \\ Larry H. Auer \\ Carl W. Gable \\ Fraser Goff \\ Rick Warren \\ Frank V. Perry \\ Earth and Environmental Sciences Division, Los Alamos National Laboratory
}

\section{Summary}

This chapter summarizes data collection and model calculations through FY95 under Study Plan 8.3.1.8.1.2, "Physical Processes of Magmatism and Effects on the Potential Repository." The objective of this study plan is to gather information that ultimately constrains the consequences of small-volume, basaltic magmatic activity at or near a potential repository. We then couple this information with event-probability estimates, described elsewhere in this synthesis report, to yield a magmatic risk assessment.

Two basic classes of effects of magmatism are considered here: (1) eruptive effects, whereby rising magma intersects a potential repository, entrains radioactive waste, and erupts it onto the earth's surface and (2) subsurface effects, which include a wide range of processes such as hydrothermal flow, alteration of mineral assemblages in the potential repository system, and alteration of hydrologic flow properties of the rocks surrounding a potential repository.

- Eruptive (direct) effects - We present data on the possible entrainment of waste into eruptive magma. These data were collected from analog volcanoes and represent a range of eruption mechanisms including Strombolian, Hawaiian, and hydrovolcanic. Strombolian and Hawaiian eruptions generally entrain little wall-rock material and are unlikely to have a strong influence on total system performance assessments. Hydrovolcanic eruptions entrain $10^{3}-10^{4}$ times more wall rock debris and could influence performance assessments, depending mainly on the probability of such eruptions.

- $\quad$ Subsurface (indirect) effects - We present field data from analog sites at which the plumbing of small basaltic volcanoes is exposed and where the volcanoes penetrated silicic tuffs similar to those at Yucca Mountain. Geometry of shallow intrusions is determined by a complicated interplay between pre-existing structures, shallow stress field variations, and rock mechanical properties. The intrusion geometry, in turn, determines the alteration of the host rocks. 
Chemical and mineralogical studies of the host tuffs indicated that for shallow, small-volume basaltic intrusions, alteration is limited to within a few tens of meters of the intrusion itself. There is no evidence for extensive, long-lived hydrothermal systems. Numerical modeling studies suggest that the farthest reaching "hydrothermal" process in the vadose zone, which is convection of pore air, is limited to within $2.5 \mathrm{~km}$ of intrusions of relevant sizes.

- Magma system dynamics - examination of processes of magmatic activity from melt generation through storage, transport, and eruption - are important for providing some "deterministic" constraints on probability calculations. The low magma flux dynamics of the Yucca Mountain region are not well understood - we review what is known and recommend future directions of study.

\section{Introduction}

This chapter is a revision of Chapter 5 of Crowe et al. (1995). Here we synthesize work carried out as part of Study Plan 8.3.1.8.1.2, "Physical Processes of Magmatism and Effects on the Potential Repository." The study plan was not completed; therefore, this chapter should not be viewed as a final report on the study plan. Instead, it is a report on results obtained primarily during FY93 to FY95, and it includes approximately one-half of the work originally planned.

This chapter consists of three sections, corresponding to the three activities of the original study plan: Eruptive Effects, Subsurface Effects, and Magma System Dynamics. The data reported for the eruptive effects section were collected at analog volcanoes, for which the geologic settings allowed the quantity of debris entrained by rising magma to be constrained as a function of depth below the volcanoes. Data collected during these field studies provided critical information for determining how much radioactive waste could be entrained into magma and erupted onto the surface if a volcano was to form directly through the potential Yucca Mountain repository. The data provided bounds on the quantity of debris that can be entrained into rising magma per meter along the volcanic plumbing for a range of eruption mechanisms, including Strombolian, hydrovolcanic, and effusive. These data can be used directly in performance assessment calculations of waste erupted onto the earth's surface, given a volcanic event that intersects a potential repository. However, the implications of these data on performance of the potential repository cannot be fully stated until they have been used in rigorous, total performance assessments.

A more challenging problem is determining the effect of magma intrusions (whether accompanied by surface eruption or not) on potential repository performance, either by mechanical or chemical/mineralogical alteration of the potential repository system, or by hydrothermal flow. This subject comprises the subsurface effects portion of the study plan. Here, we report results of field research at two sites in which basaltic magmas intruded silicic tuffs at shallow depths. These results constrain the compositional and mineralogical effects of the intrusions on tuff wall rocks and factors governing the geometry of the intrusions. The implications of these data for performance of the potential repository cannot be quantitatively assessed until they have been incorporated into rigorous total system performance assessment. However, it appears that for the size and shape of intrusions that are relevant for the Yucca Mountain setting, alteration of the host rock is limited to at most a few tens of meters distance from the intrusions themselves. We also report on some of the first stages of a planned extensive modeling study aimed at predicting such processes for a variety of intrusion sizes and shapes. Most of the theory and modeling results are of such a preliminary nature that they cannot be used in total system performance assessments. 
However, results of preliminary calculations suggest that unless an intrusion is within about 2.5 $\mathrm{km}$ of the potential repository, it will not perturb the unsaturated zone of the repository system.

The magma system dynamics section of the study plan dealt with the physics of magmatism and the potentially unique processes driving volcanism in the Yucca Mountain region (YMR). Our original objective was to provide some deterministic predictions to supplement the probabilistic risk approach in this section. At this time, however, we only present a review of the current state of related literature.

\section{Eruptive Effects}

\section{A. Summary of Eruptive Effects Approach and Results}

As magma rises through the lithosphere, it may entrain wall rock debris, and, if the magma penetrates a potential radioactive waste repository, some waste material could be entrained as well. Here we describe a suite of field studies aimed at quantifying this entrainment process in a manner that can eventually be used in performance assessment. The entrainment process depends on the local hydrodynamic regime of the magma (e.g., velocity, temperature, bulk density), the extent of interaction of magma with groundwater, and the mechanical properties of the wall rocks. Wall-rock entrainment results in local flaring of dikes and conduits, which in turn affects the hydrodynamics of magma ascent and eruption. We studied upper-crustal xenoliths erupted from small-volume basaltic volcanoes of the Lucero volcanic field (west-central New Mexico; Valentine and Groves, 1996) and of the San Francisco volcanic field (north-central Arizona) to assess the relative importance of various entrainment mechanisms during a range of eruptive styles including strongly hydrovolcanic, Strombolian, and effusive processes. Total xenolith volume fractions range from 0.3-0.9 in hydrovolcanic facies to $<10^{-4}-10^{-2}$ in most Strombolian facies. The volcanoes erupted through thick, well-characterized sequences of Paleozoic and lower Mesozoic sedimentary rocks, so that, in some cases, erupted xenoliths can be correlated with sedimentary units and, hence, depth ranges. The abundance of xenoliths from a given subvolcanic unit is divided by that unit's thickness to obtain an average entrainment rate (xenolith volume fraction derived per unit depth in the conduit). Shallow (less than a few hundred meters) entrainment rates are very sensitive to the degree of hydrovolcanic activity. Deeper entrainment is more sensitive to the mechanical properties of the wall rocks and, in the cases studied here, is thought to depend mainly on brittle failure related to offshoot dikes, pore pressure buildup, and thermal stresses. The entrainment rate can be used as a source term in multiphase numerical models of conduit flow. Based on the data presented here, theoretical models of conduit flow and erosion are justified in neglecting the contribution of mass and momentum from entrained material during basaltic eruptions driven by magmatic volatiles, but not in eruptions driven by hydrovolcanic processes.

\section{B. Introduction and Review of the Literature}

The ascent and eruption of basaltic magmas through the upper lithosphere are governed by the initial volatile content and rheological properties of the magma, the pressure at the magma source, interaction between magma and external water, the solid mechanics of dike or conduit opening, and the geometry of the dike or conduit through which the magma travels. Numerous authors have studied the source pressure and the behavior of volatiles in ascending basaltic magmas and their role in accelerating the mixture (e.g., Szekely and Reitan, 1971; McGetchin and Ullrich, 1973; Wilson and Head, 1981; Spera, 1984; Vergniolle and Jaupart, 1986). Similarly, much research has been done on the physical processes associated with magma-water interaction (e.g., Wohletz and 
McQueen, 1984; Wohletz, 1986; Zimanowski et al., 1991; Dobran and Papale, 1993). The coupled solid and fluid mechanics of dike propagation, which is the dominant form of basaltic magma transport through the lithosphere, has been addressed by numerous researchers, as reviewed by Rubin (1993) and Lister and Kerr (1991). Delaney and Pollard (1981) and Bruce and Huppert (1990) addressed the transition from flow through dikes to flow through conduits that occurs in many basaltic eruptions (e.g., Richter et al., 1970) and is also evidenced in exposed neck and dike complexes. Many individuals have addressed the heat transfer between rising basaltic magmas and their wall rocks (e.g., Fedotov, 1978, 1981; Delaney and Pollard, 1982; Spence and Turcotte, 1985; Fabre et al., 1989; Bruce and Huppert, 1990; Carrigan et al., 1992).

An outstanding problem in our understanding of basaltic eruption dynamics has been the coupling between magma hydrodynamics and dike/conduit geometry at shallow depths. Conduit geometry partly determines the pressure and velocity distribution of the magma and, hence, the eruption dynamics and resulting facies, but the pressure and velocity also affect conduit geometry through various entrainment or erosion processes (for the remainder of the paper, unless otherwise specified, the term conduit is used to refer to the plumbing for a volcanic eruption in general, whether it is a dike or circular pipe). To date there have been two end-member approaches to the ascent of magma at shallow depths. One assumes that the conduit has a constant width (or diameter), in which case, for a given mass flux, the pressure and velocity distribution can be found (e.g., Dobran, 1992) and implies that the wall rocks are perfectly rigid. The second assumes that the conduit walls are very weak so that any local change in flow pressure relative to the lithostatic pressure in the country rock is immediately accommodated by wall failure. In this case the pressure in the rising magma is always equal to the lithostatic pressure, and for a given mass flux the velocity and conduit geometry can be calculated. This second approach has been the most commonly used for determining eruption conditions of both basaltic and silicic eruptions (Wilson et al., 1980; Wilson and Head, 1981).

In reality, wall rocks are neither perfectly rigid nor perfectly weak, but a more realistic theoretical treatment is very difficult and poorly constrained by a lack of knowledge of the various mechanisms by which wall rock can be eroded or entrained off conduit walls. Macedonio et al. (1994) formulated a theory that accounts for three erosion mechanisms: abrasion from pyroclasts impacting conduit walls, erosion due to shear stress at the wall, and conduit wall collapse where the magma pressure is sufficiently different from the lithostatic pressure. They used the two-phase hydrodynamic model of Dobran and Papale (1992) to compute conditions along the conduit and then used these conditions to calculate the contributions of the three erosion mechanisms. The next step in developing volcanic conduit models is to fully couple the hydrodynamic calculation with the resulting erosion so that the full feedback mechanism can be understood. However, as Macedonio et al. (1994) point out: "A much more comprehensive study (than existing field studies) of the origin of lithics within the conduit and their relationship with the eruption dynamics is badly needed for future progress in quantifying erosion processes" (parenthetical statement added).

The following entrainment mechanisms have also been identified: (1) Spalling of rock into the low-pressure cavity at the tip of a propagating dike (e.g., Rubin, 1993; Lister and Kerr, 1991). Variations in proportions of wall-rock types would be expected in the erupted xenolith assemblage due to the variations in mechanical properties. However, this mechanism is highly transitory and would only be reflected in early erupted materials. (2) Entrainment of xenoliths at levels in a conduit where explosive magma-water interaction fragments the wall rocks (e.g., Self et al., 1980; Wohletz and McQueen, 1984; Wohletz, 1986; Lorenz, 1986; Houghton and Schmincke, 1986; Barberi et al., 1988; Heiken et al., 1988; White, 1991; Zimanowski et al., 1991; Godchaux et al., 
1992). (3) Entrainment due to shear stresses exerted on the wall by the flowing magma. Macedonio et al. (1994) treated the case where roughness elements extend from the conduit wall into the flowing magma stream. Another type of shear erosion, which is most applicable where the wall rocks are unconsolidated sediments or pyroclastic material, is grain-by-grain entrainment. (4) Isolation of country rock blocks by small offshoot dikes that extend from main dikes. Such offshoot dikes can propagate some distance parallel to the main dike, and at some point may rejoin the main dike. In this case, the wall rock between the main and offshoot dikes is then included into the flowing magma. (5) Cracking by thermal stresses (McBirney, 1959) and pore pressure buildup (Delaney, 1982) and entrainment of fragments into the magma. (6) Interaction between rising magma and wet sediments, which can be a special case of (2) and (3) above (e.g., Kokelaar, 1982; Busby-Spera and White, 1987; Leat and Thompson, 1988; White, 1991). In such interactions the entrainment process is essentially that of two viscous fluids, variably complicated by vaporization of water in the wet sediments and quenching of parcels of magma.

\section{Analog Studies in the Lucero Volcanic Field, New Mexico}

1. Introduction. In this section, we present data pertaining to wall-rock entrainment from two small basaltic volcanoes in the Lucero volcanic field, New Mexico, that exhibit a range of eruptive mechanisms from hydromagmatic to Strombolian and effusive. Because of the wellconstrained stratigraphy of sedimentary rocks below the volcanoes, we are able to estimate quantitatively the fraction of debris eroded per meter depth down the conduits. From this information we can assess to some degree the relative importance of various wall-rock entrainment mechanisms for different rock types and for different eruptive mechanisms.

2. Geologic Setting. The Lucero volcanic field is a region of isolated basaltic cones, lava flows, flow-capped mesas, buttes (representing highly eroded volcanic centers), and associated shallow intrusive bodies that straddles the eastern edge of the tectonically stable Colorado Plateau and its transition to the Rio Grande rift (Figure 5.1). The volcanic field covers about $2000 \mathrm{~km}^{2}$ and is named after the adjacent Sierra Lucero, a monoclinal uplift. The field was defined by Baldridge et al. (1987) after being previously mapped and described in fragments for mineral resource evaluations that focused mainly on the subvolcanic sedimentary rocks (Jicha, 1958; Wengerd, 1958; Moench, 1964; Zilinski, 1976; Machette, 1978; Osburn, 1982, 1984). Baldridge et al. (1987) established the chronological and geochemical trends of the field, which includes a range of basaltic compositions from basanites to alkali-olivine basalts, tholeiites, and evolved alkali basalts. Eruptions took place during three phases of activity: 8.3-6.2, 4.3-3.3, and 1.1-0.3 Ma.

We chose two volcanic centers, Alkali Buttes and Volcano Hill (Figure 5.1), because of their wide range of eruptive facies and because a combination of field and petroleum well-log data constrains the country rock stratigraphy below them. Baldridge et al. (1987) report a K-Ar age of $0.8 \pm 0.1 \mathrm{Ma}$ for Volcano Hill and interpret Alkali Buttes to be roughly the same age based on regional geomorphic relations. The erupted magmas were nepheline-normative, alkali-olivine basalts (Baldridge et al., 1987). 


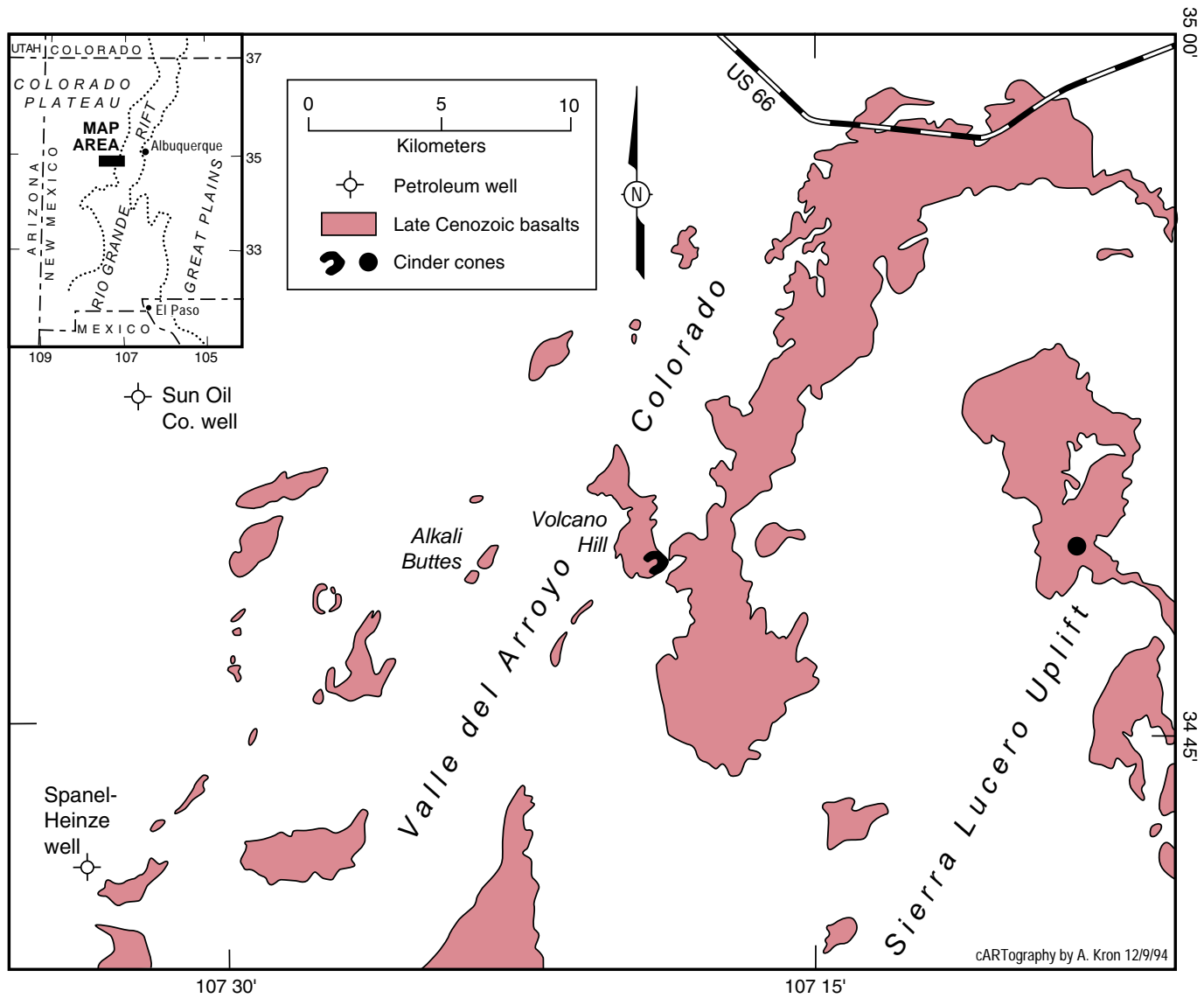

Figure 5.1. Simplified geologic map of the northern part of the Lucero volcanic field, showing late Cenozoic basalts, Alkali Buttes, and Volcano Hill. Also shown are the locations of the Sierra Lucero uplift and two petroleum wells, all of which provided stratigraphic control on subvolcanic stratigraphy. Inset shows location of map area within the New Mexico and relative to the Colorado Plateau and Rio Grande Rift. Adapted from Figures 1 and 2 of Baldridge et al. (1987).

The Colorado Plateau is an excellent setting for the detailed study of xenolith derivation as a function of depth because of its well-established, "layer cake" stratigraphy. Although the eruptive centers we describe here are only about $30 \mathrm{~km}$ from the eastern edge of the Plateau, the rocks beneath them are relatively unaffected by faulting. In addition to well-known stratigraphy, the various sedimentary units below the volcanoes are, for the most part, easily distinguished in hand sample. Stratigraphic descriptions and thicknesses were obtained mainly from Jicha's (1958) and Zilinski's (1976) reports; most of their data were obtained directly from exposures in the Sierra Lucero uplift. These thicknesses were confirmed in the vicinity of the Alkali Buttes and Volcano Hill from logs of two petroleum wells (Figure 5.1). The logs were obtained from the New Mexico Bureau of Mines and Mineral Resources: (1) Spanel-Heinze oil-well log, \#1-M Santa Fe Pacific 9612, Log No. F278, 5-5N-7W, total depth 4992 feet, drilled, 1959; (2) Sun Oil Company oil well log, \#1 Pueblo of Acoma, 2-7N-7W, total depth 4794 feet, drilled, 1960, logged by E. R. Hill. The stratigraphic units are, in descending order, with simplified descriptions:

Chinle Formation (Upper Triassic)-- c. 510 m thick below volcanoes. Mainly red to reddish brown and purple silty mudstone and clay shale with thin sandstone lenses. Lower $200 \mathrm{~m}$ has zones of feldspathic sandstone, and chert and limestone pebble conglomerates. 
San Andres Formation (Lower Permian) - c. 130 m thick. Mainly gray, fine-to medium-grained limestones, silty limestones, gypsum, and gypsiferous shale. Distinctive petroleum odor when broken.

Glorieta Sandstone (Lower Permian) - c. 60 m thick. Massive, pale yellow, finegrained, well-sorted quartzose sandstone with abundant cross bedding. Erosionally resistant formation.

Yeso Formation (Lower Permian) - c. 400 m thick. Alternating beds of pale red, yellow, and buff gypsiferous shale with grayish white to pink sandstone. Highly gypsiferous.

Abo Formation (Lower Permian) - c. 280 m thick. Mainly dark red, silty sandstones and shales with lenses of limestone.

Madera Formation (Pennsylvanian) - c. $230 \mathrm{~m}$ thick. Various combinations of tan, gray, white, and red dense limestone interbedded with white, coarse-grained sandstone and light gray to red-brown shale.

Sandia Formation (Pennsylvanian) - c. 75 m thick. Tan-white and tan-brown, dense, crystalline limestone interbedded with white coarse-grained sandstone and conglomerate.

Granite Wash Formation (Precambrian) - Coarsely crystalline granite.

We estimate the thicknesses to be accurate to within $10 \%$ of the thickness of each formation, based on combined outcrop and well data. Most observed xenolith fragments were from the Chinle, San Andres, or Glorieta formations (depths less than about $700 \mathrm{~m}$ ).

3. Alkali Buttes Volcanic Center. Alkali Buttes (Figure 5.2) are erosional remnants of an approximately $2-\mathrm{km}$ long, north-northeast trending chain of four to five vents that is subparallel to major structures in the region. This chain probably formed a single continuous landform prior to erosion. The absence of paleosols or reworked deposits indicates that the chain erupted over a relatively short time, although the erosional removal of deposits between South and North Alkali Buttes precludes any determination of relative timing of the two.

a. Description of South Alkali Butte. South Alkali Butte is the remnant of a tuff ring or tuff cone (only the inward-dipping, crater-filling deposits are preserved). The earliest preserved deposits (Figure 5.3) are massive tuffs containing abundant lapilli and block-sized xenolith clasts; these deposits are only exposed along the northeastern quadrant. Juvenile clasts in the tuffs range from ash to as large as $\sim 40 \mathrm{~cm}$ and occur both as scattered clasts throughout the tuff and as lapillirich, clast-supported lenses. The lenses are 0.5-2 $\mathrm{m}$ long and up to $0.3 \mathrm{~m}$ thick; some are reversegraded. Dense juvenile clasts are typically angular and blocky and, in some cases, have cauliflower bomb textures. Vesicular clasts in the tuff have ragged margins where basalt may extend as fingers into the tuff and vice versa, indicating that the clasts were still partly molten upon deposition. The ash matrix of the tuffs contains large proportions of disaggregated xenolithic material (discussed in detail below). The abundance of xenoliths and blocky nonvesicular juvenile clasts indicates that these tuff deposits probably represent hydrovolcanic activity at the early stages of eruption. We infer that these deposits are relatively massive due to constant churning and redeposition within or 
near the vent as opposed to fallout and pyroclastic surge deposits (not preserved here) outside the crater, which would typically be better bedded and show a variety of sedimentary structures.

The tuffs are overlain by beds of poorly vesicular basalt lapilli with much lower xenolith content than the tuffs (Figure 5.3). At South Alkali Butte, some of these lapilli beds contain an ash matrix that comprises less than $30 \%$ by volume of the deposits, whereas other beds have little or no ash and are clast supported. This facies is interpreted to represent explosive ejection of quenched magma in the upper part of the conduit, driven mainly by hydrovolcanic explosions, and records the transition from dominantly hydrovolcanic to Strombolian eruptions.

Overlying the lapilli beds are beds of coarse, vesicular scoria and small bombs, which are in turn overlain by variably agglutinated coarse spatter beds interlayered with thin lava-flow units (Figures 5.2 and 5.3). At South Alkali Butte, this part of the sequence tends to exhibit upward coarsening from coarse lapilli to large bombs. Spindle and ribbon bombs are common in these deposits. Bedding is crudely defined by coarse bombs. This facies, referred to as vesicular scoria and spatter, is interpreted to represent Strombolian eruptions driven by vesiculation.

Near the original crater center, the spatter beds are overlain by deposits consisting of a mixture of mud derived from the Chinle formation and large, highly vesicular, fluidal basalt clasts. The basalt clasts are highly altered so that they are blue-gray in color and are very soft (chalky), but vesicles and bomb textures are preserved. The lowest exposures of this unit are composed of approximately equal amounts of reddish mud matrix and basalt bombs, and the proportion of basalt clasts tends to increase upward in the deposit. Some of the larger bombs $(20-30 \mathrm{~cm})$ have yellow-green alteration zones (palagonite). The degree of alteration of basalt clasts decreases upward and the matrix gradually changes to a greenish-orange color. The deposit is thickest ( 3-4 $\mathrm{m}$, base not exposed) and basalt clasts tend to be subhorizontal near the inferred main vent of South Alkali Butte (Figure 5.2), the deepest part of the crater, and drapes up onto and pinches out over the vesicular scoria and spatter beds that form the rim of what remains of the crater (the original rim has been eroded away). This mixed Chinle mud-basalt clast deposit is capped by lavas. Near the original center of the crater, these lavas have pillow-like structures and may be pillow lavas; they locally protrude downward into the Chinle-basalt mixture.

b. Interpretation of South Alkali Butte Eruptive Sequence. We interpret this sequence of deposits as recording decreasing hydrovolcanic activity and increasing Strombolian activity through the main phases of eruption (lapilli and block-rich tuffs, poorly vesicular lapilli, scoria, and spatter/lava flow units). The initial hydrovolcanic eruptions were driven by interaction between rising magma, wet sediment, or free pore water. At Alkali Buttes it is likely that most of the magma-water interaction took place within the Chinle formation, as indicated by the abundance of Chinle-derived material in the ash matrix of the tuffs (see below). According to Jicha (1958) most wells in the region are drilled into and produce water from the Chinle formation, indicating that much of the formation is saturated. These wells produce water at very low rates (c. 4-8 liters per minute; Jicha, 1958), indicating low permeabilities. The generally low permeabilities indicate that mixing between magma and wet sediment may have been an important mechanism for initial hydrovolcanic activity at Alkali Buttes. The situation at Alkali Buttes is similar to that described by White (1991) for the Hopi Buttes hydrovolcanic eruptions which penetrated a surface unit (Bidahochi formation) that is similar in its characteristics to the Chinle formation. Magma-wet sediment interaction is evidenced by interfingering contacts between basalt clasts and surrounding xenolithic matrix material (White, 1991; Leat and Thompson, 1988). 


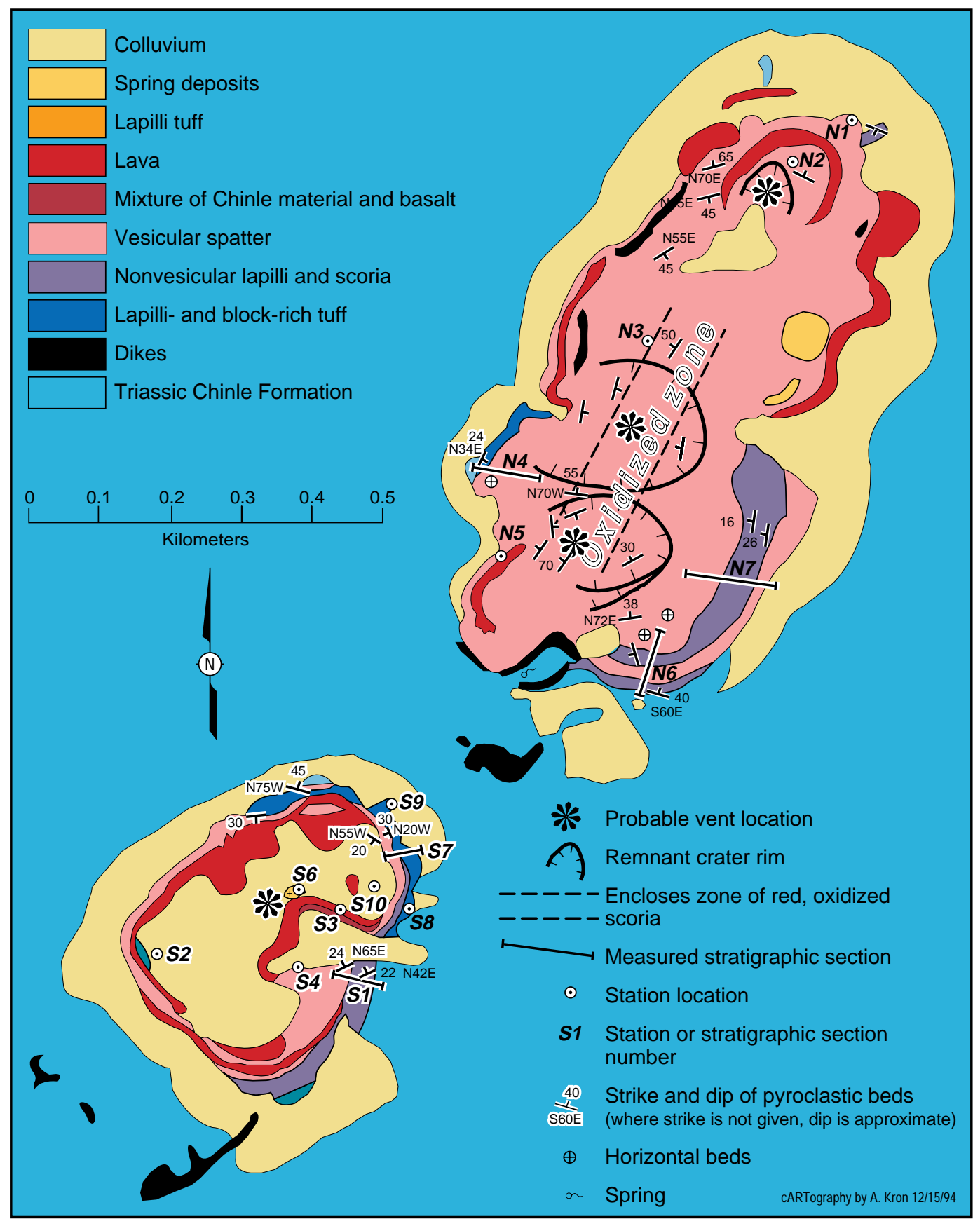

Figure 5.2. Geologic map of Alkali Buttes, showing distribution of volcanic facies, bed orientations, and station locations.

This main phase was followed by an extended period of weak lava effusion and mud boiling in the lowest parts of the crater (to produce the mixed Chinle mud-basalt clast unit) and, eventually, production of a small volume of lava that flowed onto and into the mixed Chinle mud-basalt clast unit. This mixed deposit can be thought of as having been emplaced as a weakly erupted peperite and was probably a water-saturated slurry at the time- an extremely muddy crater lake. This deposit was still very wet when subsequent lava flows were emplaced over and intruded down into it; hence the possible formation of pillows. 

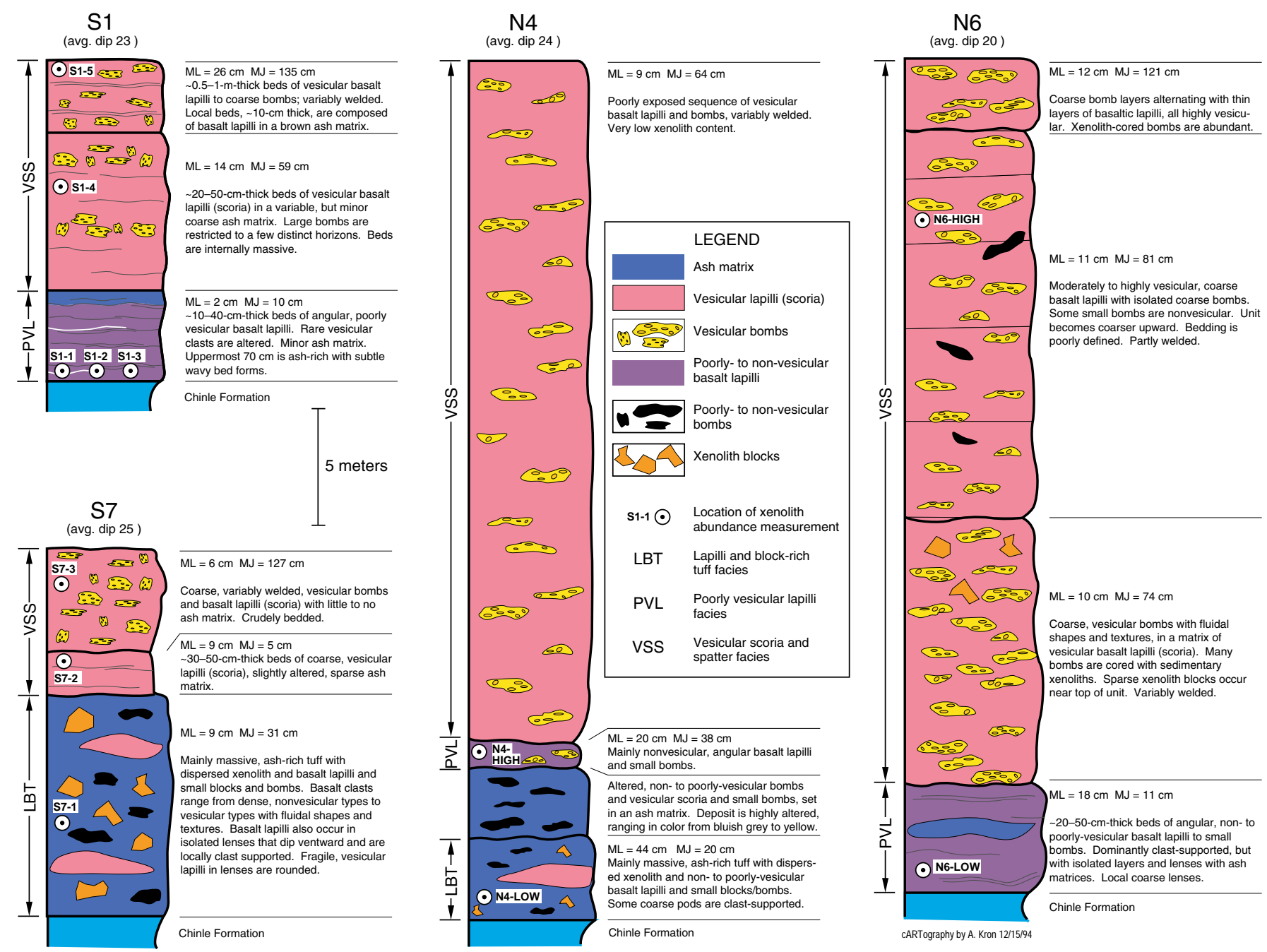

Figure 5.3. Four stratigraphic columns from Alkali Buttes (measured sections S1, S7, N4, N6 - see Figure 5.2 for map locations). Thicknesses have been corrected for the average dip at each measured section. The columns for stations S7 and N4 record the entire succession of pyroclastic facies at Alkali Buttes, with lapilli and block-rich tuff at the base. Stratigraphic locations of lithic abundance measurements (Table 5.1, Figures 5.6, 5.7, 5.9, 5.10) are shown. 
A small area, about $50 \mathrm{~m}$ in diameter, on the interior of the center is littered with large (decimeter to meter) xenolith and dense basalt blocks. The xenoliths are mainly Chinle, San Andres, and Glorieta rocks. These blocks are interpreted to record a late-stage phreatic explosion. Although many of the blocks originated at 510-700 m depth, we think that the locus of this phreatic explosion was probably high within the throat of the volcano. This is supported by the presence of large, dense basalt blocks and implies that the deeper-seated xenoliths were probably recycled from earlier stages of eruption. Possible spring deposits (gray to yellow carbonates with massive, vuggy, and laminated textures) cap the lava in the center of the original crater.

c. Description of North Alkali Butte. North Alkali Butte consists of the remnants of three scoria/spatter cones and associated craters (Figure 5.2). The southern two cones filled in a previously formed tuff ring or tuff cone, of which only the interior, inward-dipping deposits are preserved. As at South Alkali Butte, the lowest preserved deposits of this tuff ring/cone phase are lapilli tuffs (only exposed at station N4; Figures 5.2 and 5.3), overlain by poorly vesicular basalt lapilli beds. The latter deposits are dominantly clast supported with local thin layers and lenses that are richer in ash and matrix supported. Local coarse lenses may represent small grain avalanche deposits. This facies is overlain by vesicular scoria and spatter beds that are variably agglutinated and are associated with the three cones (Figure 5.3). Small lava flows were also erupted from the cones.

The northern part of North Alkali Butte is poorly exposed and contains only one outcrop indicative of hydrovolcanic activity (Station N1, Figure 5.2) - a deposit of coarse juvenile lapilli and blocks set in a shaley or mud matrix. Juvenile clasts in this deposit range from broken bombs and angular clasts to clasts with textures indicative of fluidal mixing with the wet-sediment matrix (White, 1991; Leat and Thompson, 1988).

Possible spring deposits, similar to those described at South Alkali Butte, occur on the northeastern flank of North Alkali Butte. An active spring is present at the southern end of North Alkali Butte; it is collinear with the possible spring deposits on North and South Alkali Buttes, along a north-northeasterly trend that, like the trend of the vents, is subparallel to regional structures. Spring deposits also occur about $0.5 \mathrm{~km}$ northeast of the northern end of North Alkali Butte along the same trend.

d. Interpretation of North Alkali Butte Eruptive Sequence. North Alkali Butte went through similar eruptive phases to South Alkali Butte but with a more dominant component of Strombolian eruption to produce the scoria and spatter cones. Treating Alkali Buttes as a single chain of vents, we suggest that hydrovolcanic activity was strongest near the southern end of the chain, possibly reflecting a local concentration of groundwater paths (e.g., fractures) and decreased northward.

e. Structural Control on Hydrovolcanic Activity at Alkali Buttes. As will be seen below, Volcano Hill, which erupted through the same sedimentary sequence as Alkali Buttes, shows little or no evidence of magma-water (or wet sediment) interaction. It is likely that the ascent path of magma beneath Alkali Buttes was controlled by a crustal structure that also affected groundwater, whereas the magma path beneath Volcano Hill was not. In addition to the presence of hydrovolcanic deposits, this is supported at Alkali Buttes by: (1) evidence such as possible pillow lavas that the original crater at South Alkali Butte was very wet (either with standing water or a mud slurry); (2) the persistence of springs both shortly after eruption and into present times along a trend that approximately coincides with the vent locations and extends beyond them; (3) the fact 
that structural control plays a role in determining quality of groundwater from the Chinle formation in modern wells and springs of the region, indicating its importance to groundwater flow (Jicha, 1958); and (4) the north-northeast trend of Alkali Buttes and other vents in the same valley indicates structural control-Baldridge et al. (1987) suggested that this is the location of a hinge line for the Sierra Lucero uplift. We think that there may be fractures at depth related to this hinge line, although there is not obvious evidence for significant faulting.

4. Volcano Hill. Volcano Hill (Figure 5.4) is a large scoria cone, rising about $180 \mathrm{~m}$ above the surrounding terrain; we estimate that the original cone extended about $50 \mathrm{~m}$ higher but has since been eroded. The cone is open to the west, where a lava flow extends from the central crater west and north to a distance of about $5 \mathrm{~km}$. It appears that the cone and lava flow formed simultaneously by lava fountain and Strombolian activity (similar to the, 1984 Puu Oo cone, Hawaii; Wolfe et al., 1987a). The volcano shows no evidence of major breaks in eruptive activity and is, therefore, considered to be monogenetic. It is composed almost entirely of variably welded, coarse spatter and scoria; there is no evidence of any substantial hydrovolcanic activity. Individual clasts are moderately to highly vesicular, and fluidal shapes and textures are very common in coarser clasts. Individual beds are moderately to poorly sorted, based on visual inspection, but contain virtually no pyroclasts smaller than lapilli size. Except in the innermost part of the crater, the crudely defined bedding dips radially outward from the center of the cone. Inward-dipping beds, typically $0.5-1 \mathrm{~m}$ thick, of alternating welded spatter and lava, occur in the deepest part of the crater and represent the near-vent facies of the volcano (Figure 5.4). These lava beds probably formed by complete coalescence of hot spatter clasts, and the alternation with noncoalesced spatter reflects variations in the local clast temperature and accumulation rate and, hence, magma discharge at the vent (Head and Wilson, 1987). A chain of three minor vents extends to the S-SW from this main vent. A highly altered, basaltic dike is exposed in a canyon to the north of the main cone. This dike lies on the projected trend of the other vents. The trend is subparallel to regional structures, as is the trend of vents at Alkali Buttes.

\section{Xenolith Data.}

a. Maximum Xenolith and Juvenile Clast Size. Maximum clast sizes were obtained by measuring the long axis of the three largest clasts (MJ - juvenile clasts, or ML - xenolith clasts), within a few $\mathrm{m}^{2}$ of outcrop area and taking the average at each station (Figure 5.5); they are discussed here in terms of the four main eruptive facies represented at Alkali Buttes and Volcano Hill (lapilli tuff, poorly vesicular lapilli, vesicular spatter and scoria, and lava). Overall, MJ is larger (typically $80-100 \mathrm{~cm}$ ) in the vesicular scoria and spatter facies than in the other two pyroclastic facies. The opposite is true, with some exceptions, for ML; lapilli and block-rich tuffs tend to have the largest xenolith clasts of the pyroclastic facies. The largest xenolith clasts measured in the tuffs are $2.2 \mathrm{~m}$ and $1.5 \mathrm{~m}$ in long dimension, and are from the San Andres and Glorieta formations, respectively. Other xenolith clasts of comparable size were found at one station (S4) in the vesicular spatter and scoria units at South Alkali Butte. These clasts are 2.7 and $3.0 \mathrm{~m}$ in long dimension and are both from gypsum beds that are characteristic of the topmost Yeso Formation. Thus, large meter-size blocks were erupted from depths of 500-700 m during both hydrovolcanic and magmatic eruptions.

\section{b. Xenolith Volume Fractions - Measurement Technique and Sources of Uncertainty.}

Many basaltic volcanic rocks are either lavas or very coarse-grained or consolidated (except for fallout tephra deposits) so that standard sieve techniques and component analyses are not very useful for determining volume fractions of xenoliths. Our method is as follows. An area (typically 
$1 \mathrm{~m}^{2}$ ) is marked off on the face of an exposure. All xenoliths (including those within juvenile clasts) with long dimensions greater than $1 \mathrm{~cm}$ are measured (long and short dimensions) and identified with their original formation - and, thus, depth range - in the subvolcanic sequence. Hand samples are collected from each measured area for analysis of smaller grain sizes with hand lens and microscope. The long and short dimensions of each clast are used to estimate its area in the exposure face, approximating the shape of the clasts as rectangles. Dividing the total clast areas for each subvolcanic unit by the exposure area yields area fractions represented by each unit. To convert these area fractions to volume fractions $(F)$ we use the following formula:

$$
F=(\text { area fraction })^{3 / 2} \times(1.18)^{3}
$$

The quantity 1.18 is applied to correct for the fact that individual clasts are not necessarily exposed such that their true long and short dimensions can be measured. This factor has been shown to account for random slices through spheres (Cashman and Marsh, 1988; Mangan et al., 1993). Strictly speaking, this factor does not apply to angular fragments such as most of the measured xenoliths described here. The error introduced by this simplified correction is small compared to other sources of error in the xenolith concentration estimates (see below). Samples from poorly vesicular lapilli facies and vesicular scoria and spatter facies contain virtually no material finer than lapilli size. Hand lens examination of samples from these facies confirmed that the field measurements described above account for virtually all of the xenoliths in them.

The block and lapilli rich tuff facies, on the other hand, contain appreciable quantities of ash (up to c. $90 \%$ volume), which was analyzed by standard point-counting techniques on a petrographic microscope. 500 points were counted on each thin section, with spacing of about 1 $\mathrm{mm}$ between traverses and $1 \mathrm{~mm}$ between points along traverses. There are four main types of matrix grains in the tuffs. The first type is juvenile basalt grains, which occur as black, poorly vesicular, relatively phenocryst-poor varieties and as amber brown, vesicular, phenocryst-rich clasts. The second type of matrix grain ranges in color from milky or purplish white to reddish brown, is massive, and appears the same under parallel and crossed polarizers. These features are typical of mudstones and claystones (e.g., Williams et al., 1954), and the general characteristics of the particles indicate that they are fragments of Chinle Formation. Some of these fragments may also contain zeolites. Quartz, the third important matrix grain, occurs mainly as individual grains, typically less than $1 / 3 \mathrm{~mm}$ in diameter, that are subangular to rounded and occasionally broken. Rare fragments of sandstone, about $1 \mathrm{~mm}$ in size, were found in a sample from site S9; the quartz grains in these clasts are rounded. Because most of the matrix quartz consists of individual grains, we interpret it to be derived mainly from the Chinle Formation, originating either as dispersed sand grains in the mudstones and shales, or from poorly cemented sand lenses within the formation. Some of the quartz grains and rare sandstone fragments were possibly derived from the Glorieta Formation, but this is less likely because of the strongly cemented nature of that unit. The final important type of matrix material is calcite (and some zeolite?), which lines void spaces and fractures in the matrix. This material formed after deposition of the tuffs. Detailed component data for matrix material from these tuffs are provided in the footnotes for Appendix 5.1.

Sources of error include, in addition to those mentioned above, the measured exposure area (less than $\sim 10 \%$ ), departure of the exposure surface from true two-dimensionality (probably $<10 \%$ ), irregular shapes of xenolith clasts (errors perhaps as high as 50\%), uncertainty in correlation of clasts with correct subvolcanic units, and uncertainty in unit thickness directly beneath the volcanoes. The unconsolidated, fine-grained nature of much of the Chinle Formation may result in its volume fraction being underestimated because (1) it may have mixed with magma 
and disaggregated into fine particles that are not recognizable; and (2) disaggregated Chinle material may have been deposited as fine ash in more distal pyroclastic deposits that are no longer preserved. Some bombs, especially at Volcano Hill, contain swirly patches of Chinle material, indicative of initial stages of the mixing into the magma. Because most sedimentary sections on the Colorado Plateau contain at least one formation that is composed of mudstone or fine shales, this problem is largely unavoidable. Similar studies at other areas where such units reside at different depths below the volcanoes are in progress; this will allow us to filter out such complications. Although these errors seem somewhat high, we think that most of the xenolith volume fraction estimates are accurate to within a factor of about two and almost certainly within an order of magnitude.

c. Xenolith Volume Fractions. Calculated volume fractions of each stratigraphic unit in the country rock are listed in Appendix 5.1, where they are grouped by facies (and thus by eruption mechanism). Total xenolith volume fractions vary somewhat systematically with facies (Figure 5.5), the hydrovolcanic tuffs having the highest xenolith contents (by volume), ranging from 0.32 to 0.91 . Poorly vesicular lapilli deposits range from 0 to $6 \times 10^{-3}$. Vesicular scoria and spatter facies have xenolith contents ranging from $2 \times 10^{-5}$ to $7 \times 10^{-3}$, with most sites ranging between $10^{-}$ ${ }^{4}$ and $10^{-3}$. These are consistent with data reported by Crowe et al. (1983a) from other scoria cones in the southwestern U.S. (Appendix 5.1). Only two sites in lava were analyzed for xenolith contents, and these are within the same range as the vesicular spatter and scoria deposits.

d. Entrainment Rates. The entrainment rate for each subvolcanic unit is obtained by dividing the volume fraction of xenoliths from a given unit by the unit's thickness. The value obtained is the average xenolith volume fraction derived per unit depth within each unit (see also Mastin, 1991). As average values, these entrainment rates do not account for local flaring or narrowing of conduits within individual subvolcanic units. We assume that feeder dikes/conduits retain near-vertical trajectories as they propagate though the various subvolcanic units, although it is possible that in some units dikes may bend and, therefore, effectively have a longer path through those units (e.g., Baer and Reches, 1991; Baer, 1991). Entrainment rates for each of the measured sites are listed in Appendix 5.1. We focus our discussion here on five stratigraphic sections: two at South Alkali Butte (sections S1, and S7 including site S8), two at North Alkali Butte (sections N4 and N6), and one at Volcano Hill (Figures 5.2 through 5.4).

Sections S1 and N6, which include poorly vesicular lapilli facies and vesicular spatter and scoria facies (Figures 5.6 and 5.7), do not show simple systematic variations in entrainment rates as a function of stratigraphic height in the eruptive sequence. Note that sites S1-1 (not plotted because it contained no xenoliths), S1-2, and S1-3, all of which were measured at the same level in the same lapilli layer, show as much variation as the entire vertical sequence at section $\mathrm{S} 1$, which includes variations in facies (see Figure 5.3 for stratigraphic locations of sites). Entrainment rates within the San Andres (510-640 m depth) and Glorieta (640-700 m depth) tend to be larger than the average entrainment rate in the overlying Chinle Formation (note that high entrainment rates at very shallow depths, associated with a flaring vent structure, would not be recorded on these plots because xenolith derivation is averaged over the entire thickness of a unit). The low apparent Chinle entrainment may also be due in part to disaggregation of unconsolidated Chinle material as it was entrained and subsequent dispersal as ash that is not preserved in these proximal deposits. However, entrainment rates for San Andres and, more consistently, Glorieta materials are relatively constant in all eruptive facies at Alkali Buttes and at Volcano Hill. 


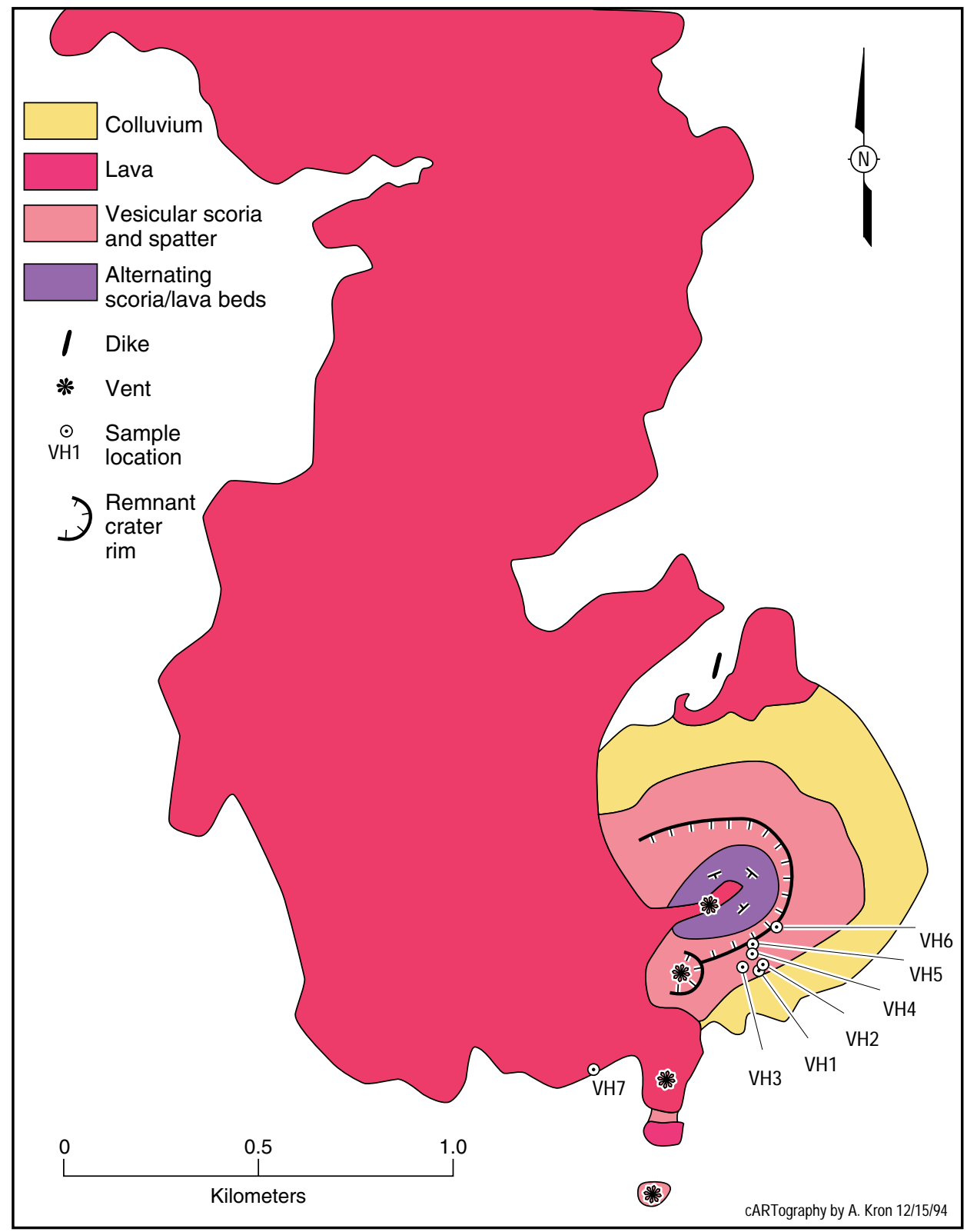

Figure 5.4. Geologic map of Volcano Hill, showing distribution of volanic facies, bed orientations, and station locations

The section measured at Volcano Hill consists only of vesicular scoria and spatter facies (Figure 5.8). All but one of the six measured sites contain xenoliths from the Glorieta Formation, which was typically entrained at a rate of between 10-6 and 10-5 volume fraction/m. Half of the sites also contain Chinle material, but at relatively low entrainment rates. There is no obvious systematic change in the pattern of wall-rock entrainment as a function of stratigraphic height in the cone. 


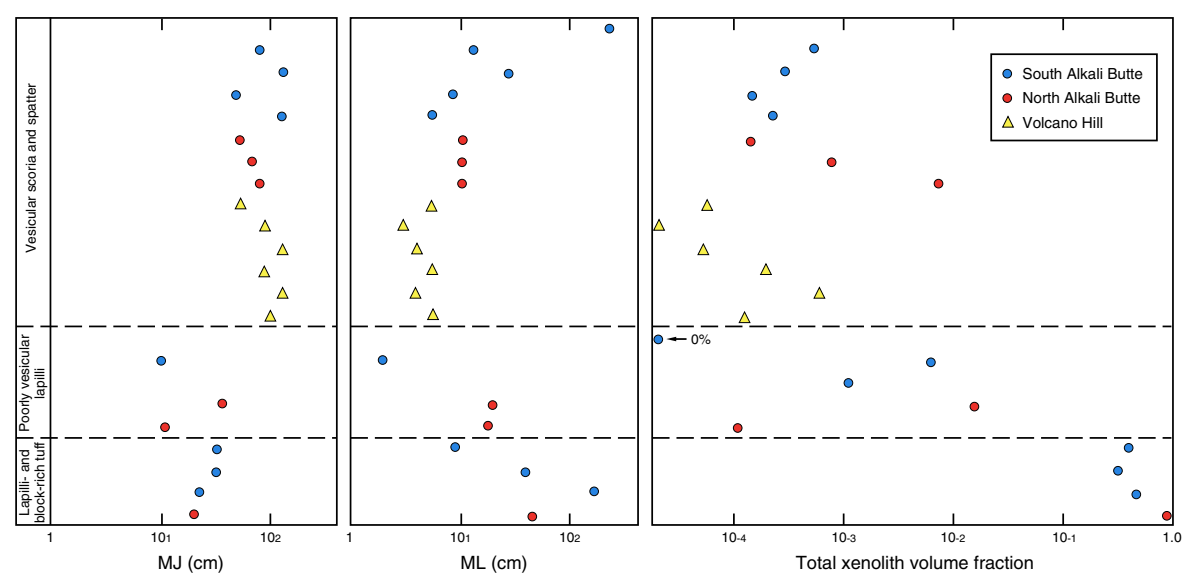

Figure 5.5. Maximum sizes of juvenile (MJ) and xenolith (ML) clasts and total volume fraction of xenoliths. The observations are arranged according to facies types. Note that the vesicular spatter and scoria facies has the largest values of $\mathrm{MJ}$, and that the highest xenolith volume fractions occur in the lapilli and block-rich tuff facies. One example of the poorly vesicular lapilli facies from South Alkali Butte, indicated with an arrow, lacks xenoliths and is arbitrarily plotted at a volume fraction of 10-5.

Sections that include block and lapilli-rich tuff facies show some systematic variation in entrainment rates (Figures 5.9 and 5.10). The two stratigraphically lowest sites at section S7 (including site S8) and the lowest site at section N4, all in the tuff facies, have large entrainment rates in the uppermost $510 \mathrm{~m}$ (Chinle Formation); this reflects the large quantity of xenolithic debris in the ash matrix of the tuffs. However, entrainment rates of the deeper San Andres and Glorieta formations are similar to estimates at other sites for the other three facies. Higher up in the sections, the vesicular scoria and spatter deposits are very poor in xenoliths and have much lower entrainment rates, especially of Chinle material.

In summary, the entrainment rate data indicate that there is a relatively consistent degree of wall-rock erosion at depths of 510-700 $\mathrm{m}$ and especially between 640-700 m (Glorieta Formation). Pyroclastic deposits interpreted as recording early hydrovolcanic phases at Alkali Buttes are fundamentally different only in that the shallow (0-510 m, Chinle Formation) entrainment rates are much larger than in other facies. The deeper entrainment rates are essentially the same in the tuffs as in other facies.

6. Interpretations and Conclusions from Lucero Volcanic Field.The width of dikes or conduits beneath volcanoes has two components: that produced by elastic deformation and that produced by erosion or entrainment of the dike walls. The xenolith data presented here allow us to assess the relative importance of the latter component. For example, the total eruptive volume of the Alkali Buttes volcanic center is estimated to be on the order of $108 \mathrm{~m} 3$ (about half of which is preserved). We estimate that about $6000 \mathrm{~m} 3$ of Glorieta xenoliths, which were entrained at a relatively consistent rate of about 10-6/m during all eruptive phases, were ejected at Alkali Buttes. Assuming that at depth the plumbing for Alkali Buttes was characterized by a dike of about $1.9 \mathrm{~km}$ length (the approximate length of the chain of vents), the average dike widening from entrainment was about $5 \mathrm{~cm}$. This estimate is consistent with maximum xenolith sizes in the vesicular scoria and spatter facies, most of which are between $5-10 \mathrm{~cm}$ in the long dimension. The local effects of entrainment could be much more dramatic, for example, where a meter-sized block of wall rock is entrained, but this would probably not have a large effect on eruption dynamics. 

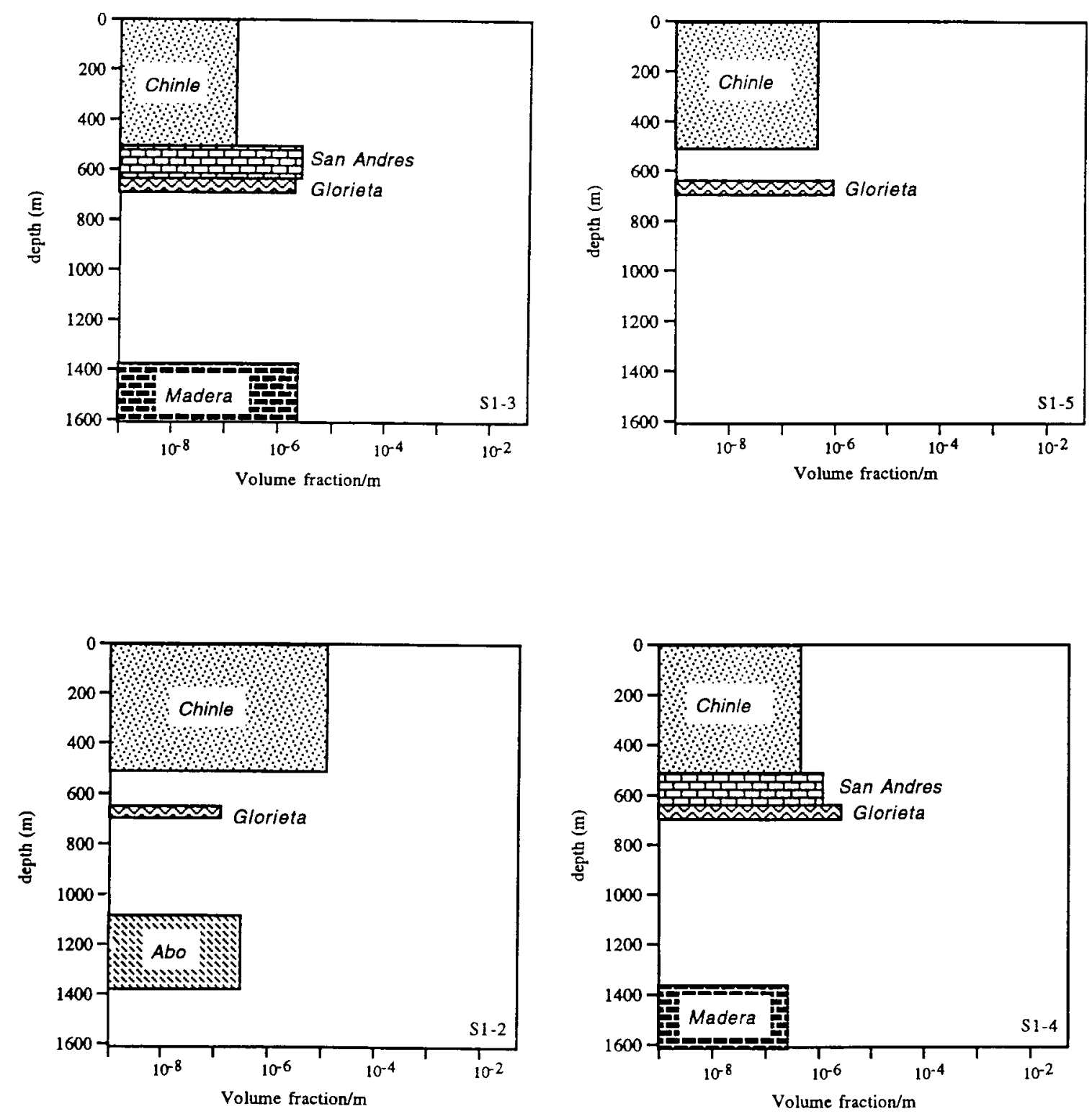

Figure 5.6. Entrainment rate plots for measured section $S 1$ at southern Alkali Butte. Site numbers identified in lower right-hand corners of plots (see Figure 5.3 for stratigraphic location of each site). S1-2 and S1-3 were measured in the same layer of poorly vesicular lapilli. S1-4 and S1-5 are from vesicular scoria and spatter facies.

During strongly hydrovolcanic phases of eruption, on the other hand, wall-rock entrainment can have a much larger effect on dike width. Although we cannot resolve entrainment variations within the uppermost $510 \mathrm{~m}$ below Alkali Buttes, it is likely that at very shallow depths, say less than $100 \mathrm{~m}$, the entrainment component of dike widening could have been even more significant. At depths below the Chinle Formation, though, the entrainment component during hydrovolcanic phases was similar to that during magmatic phases. 

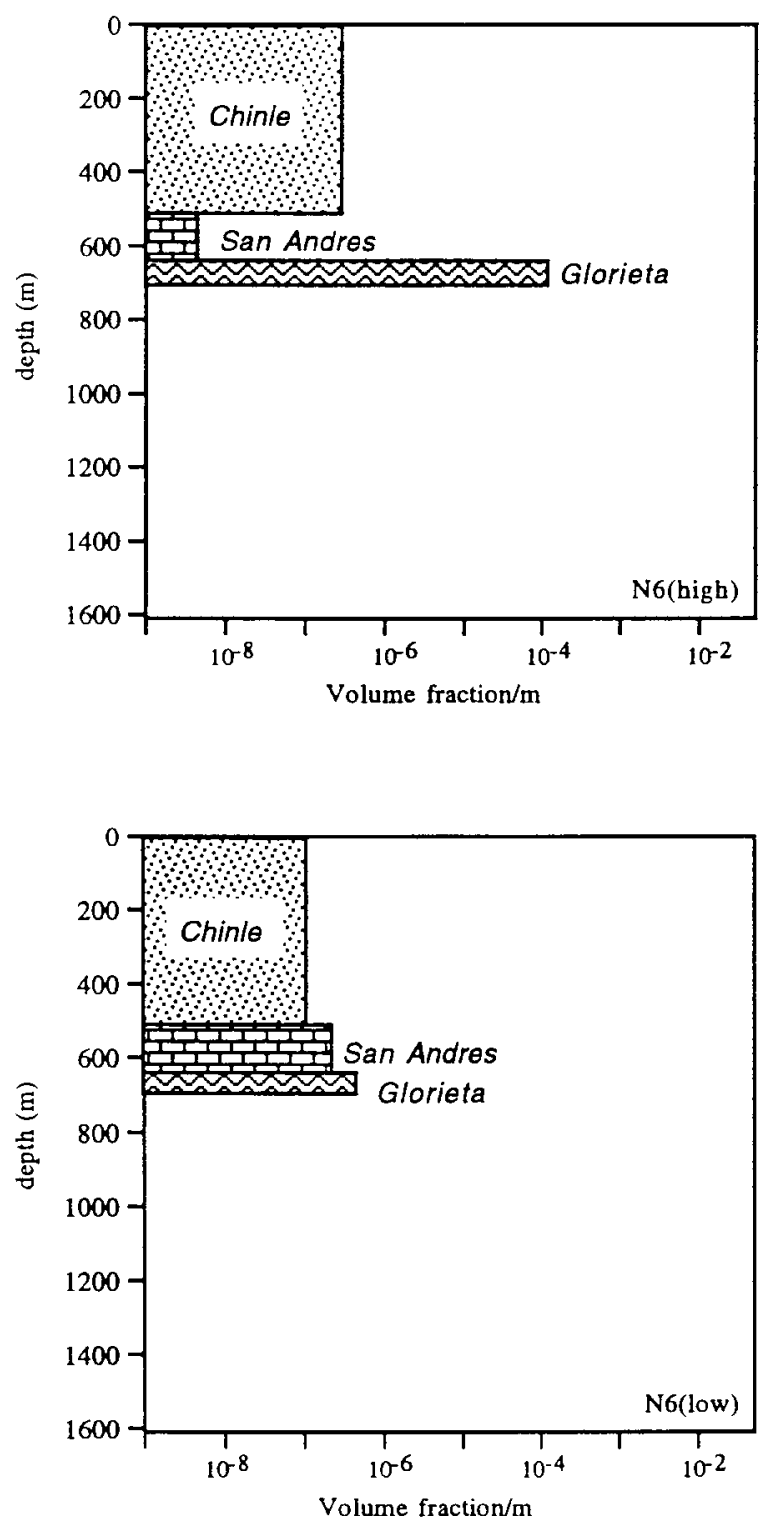

Figure 5.7. Entrainment rate plots for measured section N6 at northern Alkali Butte. Site numbers identified in lower right-hand corners of plots (see Figure 5.3 for stratigraphic location of each site). N6(low) is from poorly vesicular lapilli facies, N6(high) is from vesicular scoria and spatter facies.

The relationships between xenolith derivation data and facies (eruption mechanisms) allow us to assess the relative importance of the various entrainment mechanisms. For example, the xenolith data show that entrainment of Chinle material was much larger during hydrovolcanic phases than during magmatic phases. During the hydrovolcanic phases, explosive magma-water (or magma-wet sediment) interaction was the dominant entrainment mechanism. The relatively consistent entrainment of deeper Glorieta and, to a lesser extent, San Andres formations is more difficult to explain. One possibility is that the Glorieta Formation is an aquifer and that during magma ascent steam explosions occurred there causing wall-rock entrainment. The Glorieta Formation, however, is typically strongly cemented and probably has a very low matrix permeability. It is thin and tends to crop out as steep slopes or cliffs and, therefore, does not have a large recharge area in the region 
(Jicha, 1958). It is highly jointed and may have a high fracture permeability, but the volume of water that could flow through these fractures would be relatively small. While the possibility that entrainment of Glorieta xenoliths is caused by steam explosions cannot be ruled out, we do not think that this is the best explanation. Another mechanism for entrainment is abrasion of the conduit walls above the fragmentation level (where the volume fraction of gas in the vesiculating magma becomes sufficiently high that the magma fragments and the flow is characterized by magma clots entrained in a rapidly accelerating gas stream). However, it is unlikely that the fragmentation level of these basalts was deeper than about $400 \mathrm{~m}$, which is the approximate fragmentation depth for a basalt containing a large mass fraction of water (2\%). Also, this deep entrainment is recorded in lava flows that may have formed from purely effusive activity in which the magma did not fragment. Finally, the fact that the Glorieta Formation is the most competent of the subvolcanic stratigraphic units rules out the possibility that it was preferentially entrained by shear erosion.

The most likely mechanisms for entrainment of Glorieta xenoliths are (1) inclusion of wall rocks between the main dike(s) and small offshoot dikes, and (2) cracking of wall rocks due to thermal stresses (McBirney, 1959) and pore-pressure buildup (Delaney and Pollard, 1981; Delaney, 1982). Both of these mechanisms involve brittle failure of wall rocks, which addresses the apparent paradox that the Glorieta Formation is the most competent of the subvolcanic units and yet was preferentially entrained by the rising magmas. Ongoing studies of the type reported here are focusing on areas where competent and incompetent stratigraphic units reside at different depths below volcanoes in order to see if the pattern described here is similar at other sites.

A final point relates the xenolith data here to the conduit modeling approach of Macedonio et al. (1994). They modeled conduit flow in a rigid conduit, then used the flow field to estimate erosion of the conduit walls as a function of depth in the conduit. In their governing equations, the contribution of mass and momentum by entrained wall rock was neglected. Our data indicate that for basaltic eruptions driven by expansion of magmatic volatiles, this approximation is probably quite adequate. The volume fraction of xenoliths (relative to the total volume of solids) entrained per meter is so small that even under the most aggressive conditions of magmatic eruption that occurred at the Lucero volcanic centers, neglecting the xenolith mass and momentum contributions would result in very small errors compared to the other uncertainties inherent in modeling geologic processes. During hydrovolcanic phases, however, it would be critical to account for the effects of the added xenolith mass, momentum, and energy. The entrainment rate values in Appendix 5.1 can be used as a range of source terms for the governing equations of Macedonio et al. (1994; $\mathrm{C}_{\mathrm{w}}$ in their equations 3 and 5).

\section{Analog Studies in San Francisco Volcanic Field, Arizona}

1. Introduction. In this section we present data pertaining to wall-rock entrainment from three small basaltic volcanoes in the San Francisco volcanic field. These data are from Strombolian facies deposits. Up through the end of FY95, detailed field studies were being conducted in this volcanic field on four volcanoes and a wider variety of eruptive facies including strongly hydrovolcanic. These field-based studies are not yet complete and, therefore, are not reported here in detail. In general, the preliminary data from San Francisco volcanic field are quite consistent with those obtained in the Lucero volcanic field, indicating that similar conclusions would have been reached if the research had been carried to completion. 

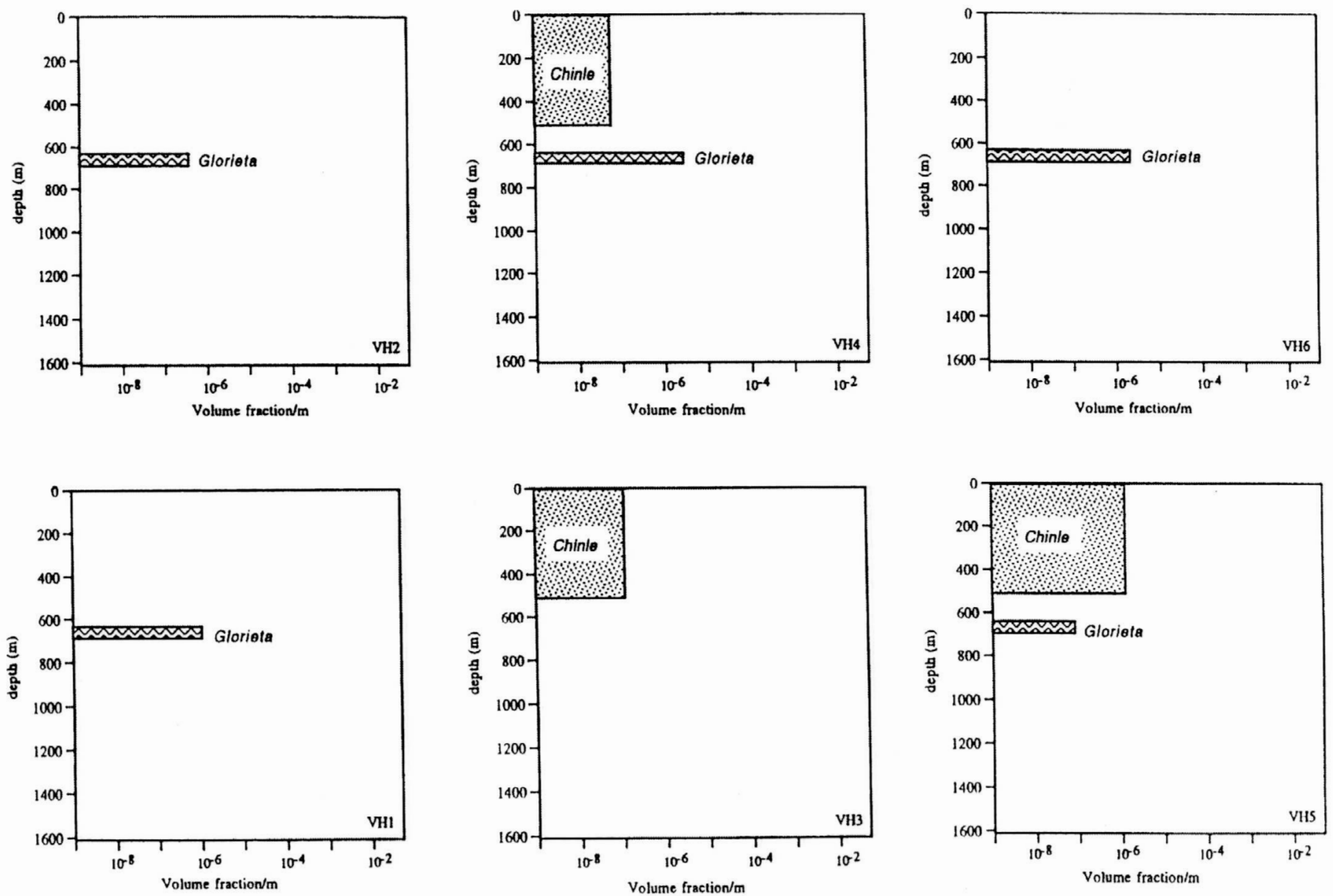

Figure 5.8. Entrainment rate plots for Volcano Hill. The entire section is vesicular scoria and spatter. Site numbers identified in lower right-hand corners of plots (see Figure 5.4 for map location of each site). Note the relatively consistent entrainment of Glorieta material. 

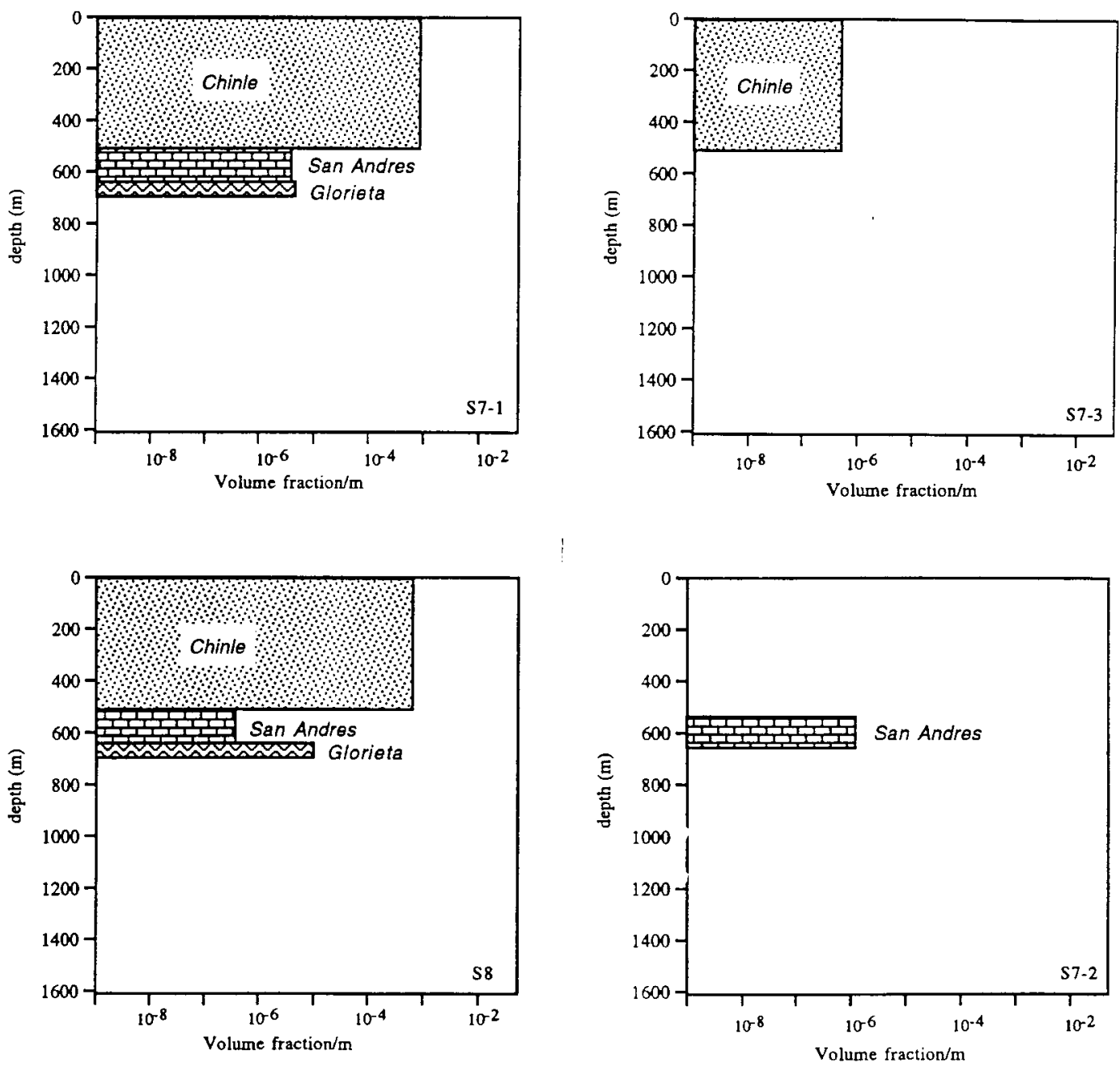

Figure 5.9. Entrainment rate plots for measured section $S 7$ (including site S8, which is stratigraphically lower than S7-1) at southern Alkali Butte. Site numbers identified in lower righthand corners of plots (see Figure 5.3 for stratigraphic location of each site). S8 and S7-1 are from lapilli and block rich tuff, S7-2 and S7-3 are from vesicular spatter and scoria facies. Note that the entrainment rates for Chinle material in the lapilli and block rich tuff are much higher than in other facies, entrainment of San Andres and Glorieta material is similar to other facies shown in previous figures.

2. Geologic Setting. The San Francisco volcanic field (SFVF; Figure 5.11) is located just north of the physiographic boundary between the tectonically-stable Colorado Plateau Province and the Basin and Range Province, which is characterized by extensional tectonics. About 600 vents are present in the field, and a wide range of lava and pyroclastic compositions occur there, including tholeiitic basalts to dacites and rhyolites as well as more alkaline compositions such as basanites, hawaiites, benmorites, and trachytes (Holm, 1986; Arculus and Gust, 1995). Most of the SFVF is covered by mafic lavas and cones with a few focal points for silicic volcanism (Figure 5.11). The most prominent silicic center is the composite cone known as San Francisco Peaks, which reaches an altitude of c. $4000 \mathrm{~m}$ above sea level (2000 $\mathrm{m}$ above the surrounding plateau). The youngest volcano in the field is the basaltic cone and lava flows of Sunset Crater, which erupted at c. 1064 A.D. (Smiley, 1958; Holm, 1986, 1987; Holm and Moore, 1987; Self, 1990). Volcanism began in the area about 9 million years ago (Damon et al., 1974; Ulrich et al., 1984). 

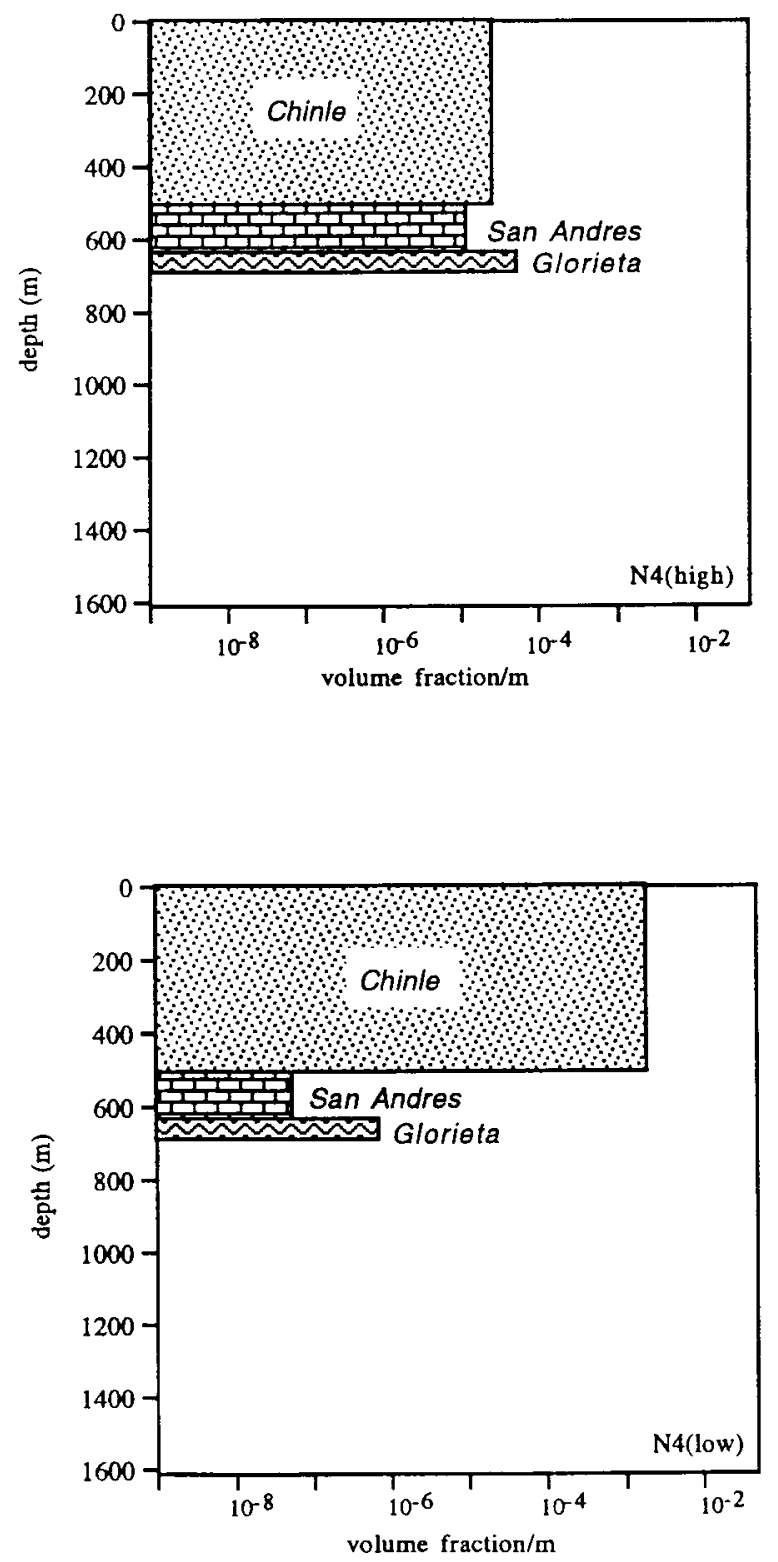

Figure 5.10. Entrainment rate plots for measured section N4 at northern Alkali Butte. Site numbers identified in lower right-hand corners of plots (see Figure 5.5 for stratigraphic location of each site). N4(low) is from lapilli and block rich tuff, while N4(high) is from poorly vesicular lapilli facies.

A wide variety of volcanic studies have been conducted in the SFVF, especially over the past two decades. A United States Geological Survey team has published a comprehensive base of geologic maps, geochemical analyses, radiometric ages, and paleomagnetic data (Moore et al., 1976; Ulrich et al., 1984; Tanaka et al., 1986; Ulrich and Bailey, 1987; Wolfe et al., 1987b, c; Newhall et al., 1987; Moore and Wolfe, 1987). Numerous studies have focused on xenoliths erupted in the volcanic field, but these have only been concerned with fragments of deep crust or mantle materials (Cummings, 1972; Stoeser, 1974; Pushkar and Stoeser, 1975; Chen and Arculus, 1995). 


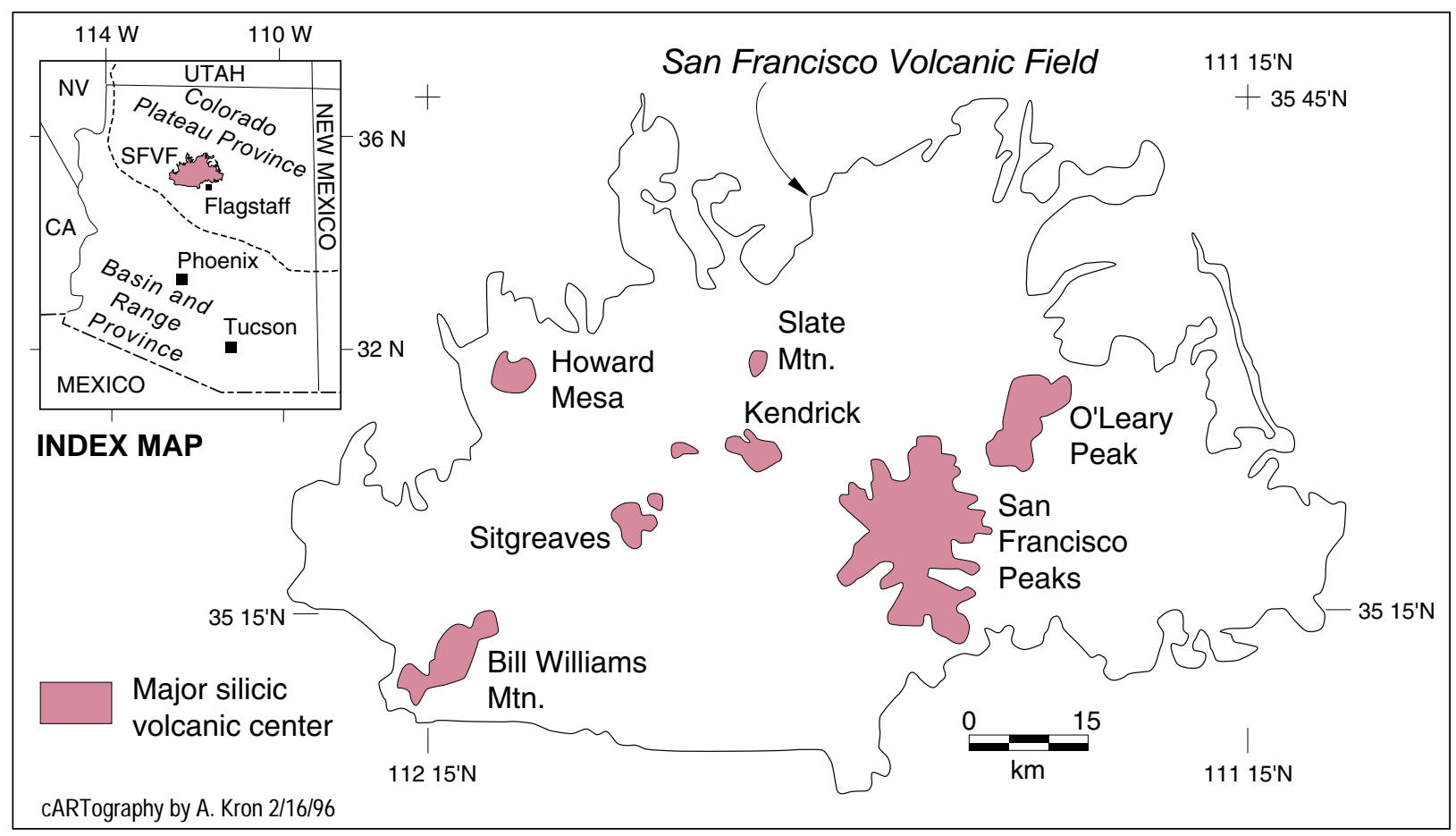

Figure 5.11. Outline of San Francisco Volcanic Field, northcentral Arizona. With the exception of the major silicic centers shown, most of the enclosed area is covered by basaltic rocks. Inset shows location within Arizona, and the approximate boundary between the Colorado Plateau and Basin and Range Provinces. Adapted from Arculus and Gust (1995).

We chose four basaltic volcanoes for detailed study (Dry Lake, South Sheep Hill, Rattlesnake Crater, and South Merriam; Figure 5.12) because they represent a range of eruptive mechanisms and because they sit either directly on sedimentary rocks or are separated from the sedimentary rocks by no more than $50 \mathrm{~m}$ of volcanic rocks. However, because the field studies are incomplete, data are only reported for part of the Dry Lake sequence and South Merriam. Based on Ulrich et al. (1984), we estimate the following stratigraphy beneath the selected volcanoes, listed in descending order from the surface:

Earlier volcanics - <50 m thick, mainly basaltic lava flows. Less than $9 \mathrm{Ma}$.

Kaibab Formation - 150 m thick, yellowish-gray to light gray silty dolomite, dolomitic sandstone, minor sandstone, and dolomitic limestone. Lower Permian.

Coconino Sandstone - $300 \mathrm{~m}$ thick, also includes Toroweap Formation. Light colored, orange-tan, fine-grained, cross stratified sandstone. Lower Permian.

"Red Beds" - 760 m thick, includes Hermit Shale, Supai Formation, Redwall Limestone, and Temple Butte Limestone. Dominantly red-colored shales, sandstones, and limestones. Middle Devonian through Lower Permian.

We do not differentiate the formations within the "Red Bed" category because it is difficult to distinguish them in hand-sized xenoliths studied here. 

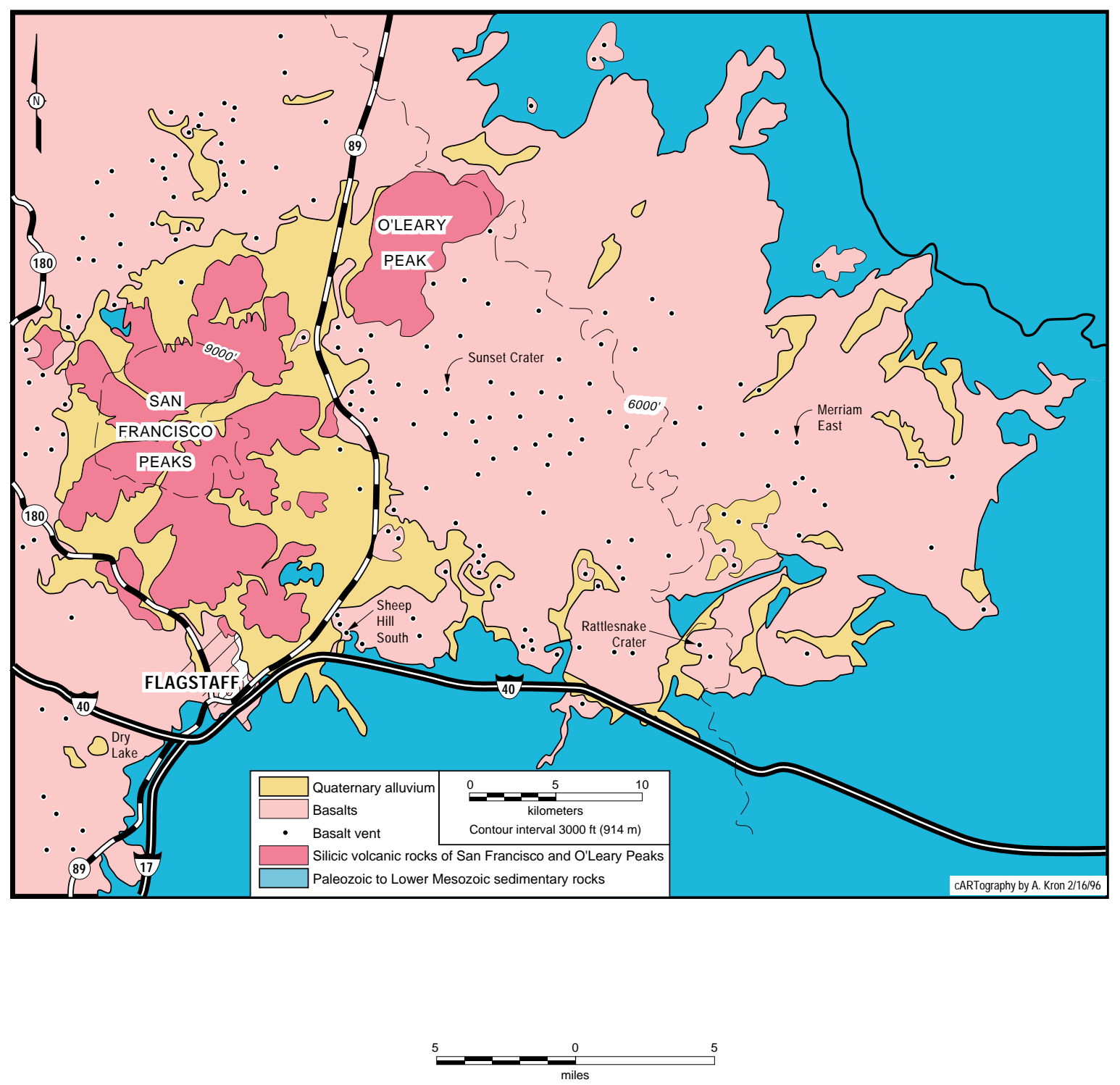

Figure 5.12. Geologic map of eastern SFVF, showing distribution of basaltic vents exposed at the surface. Locations of the four centers studied (Dry Lake, Sheep Hill South, Rattlesnake Crater, and Merriam East) are shown, as well as that of Sunset Crater (the youngest center in the volcanic field). Major highways indicated. Map based on Ulrich et al. (1984).

3. East Merriam Cone. East Merriam Cone is a partly quarried cone just east of the larger Merriam Cone (Figures 5.12 and 5.13). According to Moore and Wolfe (1987), the eruptive products of this cone (their vent 3036B) are microporphyritic olivine basalts with an age of $0.15 \pm$ $0.03 \mathrm{Ma}$. The quarry, where our data were collected, exposes massive, parallel-bedded, well-sorted scoria fall layers. The scoria clasts are highly vesicular and glassy, nearly to the point that they could be termed pumice. We interpret these deposits to have been laid down by very energetic, probably violent Strombolian eruptions. Due to inaccessibility of steep quarry walls, only two xenolith abundance measurements were taken near the base of the quarry. The results of these measurements are presented in Table 5.1. 


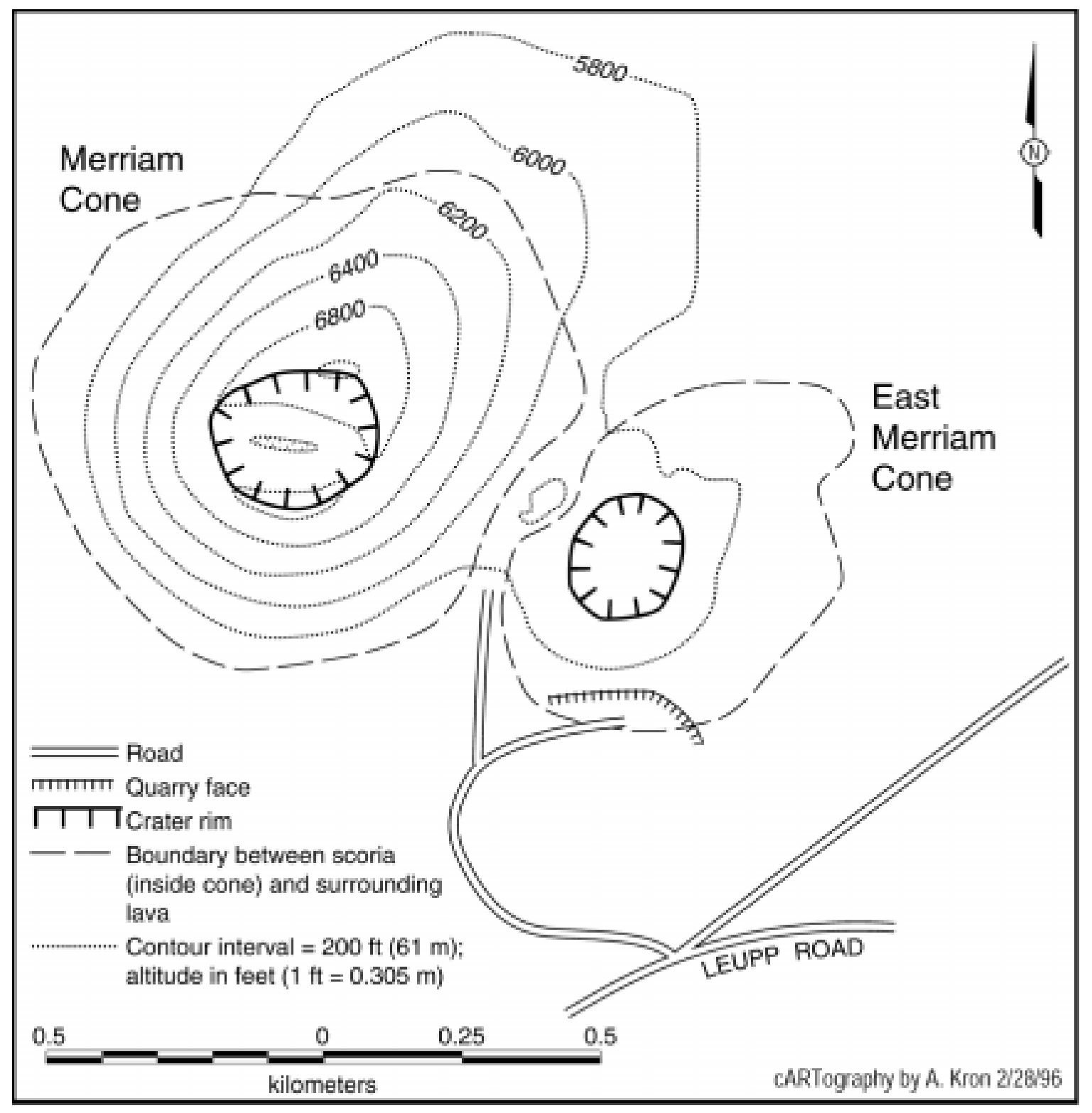

Figure 5.13. Simple geologic map of Merriam and East Merriam cones. Quarry is where lithic abundances were measured.

4. Dry Lake. Dry Lake volcano (Figures 5.12 and 5.14) is a complicated center that apparently began as a cluster of Strombolian scoria cones that were then partially truncated by maar-crater collapse during final hydrovolcanic phases (Mayr, 1994). The eruptive products are plagioclase phyric hawaiites with an age between 0.69 - 1.41 Ma (Wolfe et al., 1987c). Extensive quarrying has exposed a thick section through one of the scoria cones and its mantle of late-stage hydrovolcanic deposits. Xenolith contents in the scoria are provided in Table 5.1. The deposits in which these measurements were taken consist of massive, parallel, clast-supported beds of red scoria lapilli and small blocks. These beds record fallout from Strombolian eruptions. 


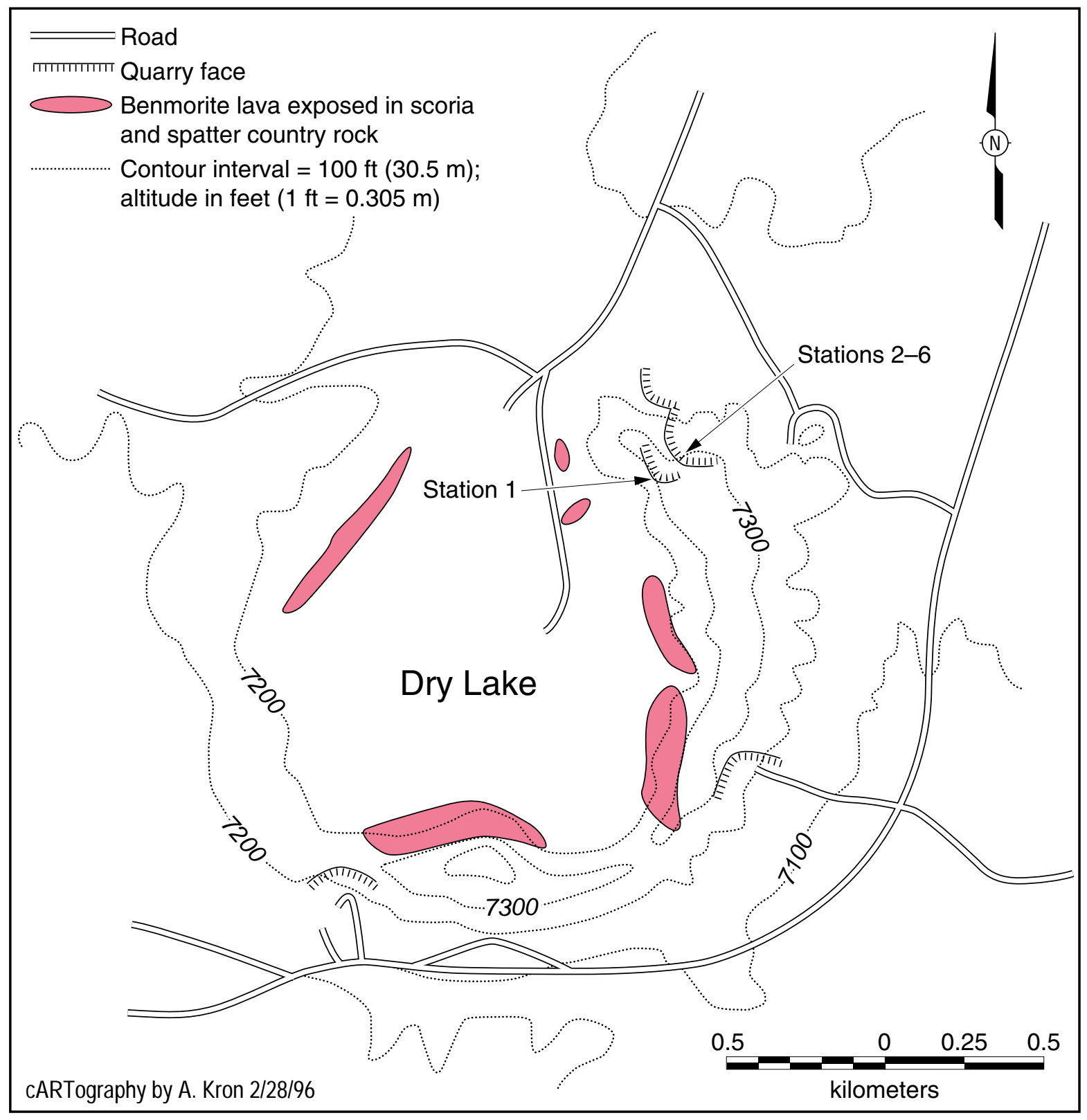

Figure 5.14. Simple geologic map of Dry Lake volcano, showing station locations. 
Table 5.1. Volume fractions of sedimentary xenoliths from South Merriam and Dry Lake volcanoes, Strombolian facies.*

\begin{tabular}{llll}
\hline South Merriam Cone** & & & \\
& Station MS-1 & Station MS-2 & \\
\hline Area fraction & $3.8 \times 10^{-4}$ & $1.6 \times 10^{-3}$ & \\
Volume fraction & $1.2 \times 10^{-5}$ & $1.1 \times 10^{-4}$ & \\
Dry Lake Volcano (Strombolian facies)*** & & Station 5 \\
\hline Area fraction & Station 3 & Station 4 & $1.5 \times 10^{-3}$ \\
Volume fraction & $9.3 \times 10-4$ & 0 & $9.6 \times 10^{-5}$ \\
\hline
\end{tabular}

*Area fraction and volume fractions determined for xenoliths $>1 \mathrm{~cm}$ (long dimension) at outcrop, as described in text.

**All xenoliths observed at this site were identified as Kaibab Limestone.

***All xenoliths observed at these stations were basaltic lava fragments, Kaibab Limestone, or Coconino Sandstone.

5. Discussion. The limited data that have been analyzed at San Francisco volcanic field are consistent with those reported above for vesicular scoria and spatter facies at the Lucero volcanic field and with data reported by Crowe et al. (1983a). Further field and laboratory work would be necessary to complete the suite of studies identified in the study plan. These would mainly consist of completion of field work and laboratory analysis of xenoliths from Rattlesnake Crater, South Sheep Hill, and the hydrovolcanic portion of Dry Lake. Preliminary data suggest that data from hydrovolcanic facies would be consistent with those from Alkali Buttes in the Lucero volcanic field, both in terms of overall xenolith content and derivation as a function of depth below the volcanoes.

\section{Subsurface Effects}

\section{A. Summary of Subsurface Effects Approach and Results}

To constrain the effects of magmatic intrusions on a potential repository, we took a combined approach applying field analog studies and numerical modeling. Field analog studies, emphasized during the first phases of the study plan implementation, focused on determining the factors that control shallow basaltic intrusion geometry and the geochemical and mineralogical effects of basaltic intrusions on silicic pyroclastic host rocks. These studies are reported here. Numerical modeling studies were due to be phased in during the final half of the project. As a result, only the very first stages of such modeling are reported here.

\section{B. Controls on Geometry of Shallow Basaltic Intrusions - Studies from Paiute Ridge Analog Site, Southern Nevada}

1. Summary. Late Miocene basaltic sills and dikes in the Paiute Ridge area of southern Nevada show evidence that their emplacement was structurally controlled. Basaltic dikes in this area formed by dilating pre-existing vertical to steeply E-dipping normal faults. Magma 
propagation along these faults must have required less energy than the creation of a selfpropagated fracture at dike tips, and the magma pressure must have been greater than the compressive stress perpendicular to the fault surface. N- to NE-trending en echelon dikes formed locally and are not obviously attached to the three main dikes in the area. The en echelon segments are probably pieces of deeper dikes, which are segmented perhaps as a result of a documented rotation of the regional stresses. Alternatively, changes in orientation of principal stresses in the vicinity of each en echelon dike could have resulted from local loads associated with paleotopographic highs or nearby structures. Sills locally branched off some dikes within $300 \mathrm{~m}$ of the paleosurface. These subhorizontal bodies occur consistently in the hanging-wall block of the dike-injected faults and intrude Tertiary tuffs near the Paleozoic-Tertiary contact. We suggest that the change in stresses near the earth's surface, the material strength of the tuff and Paleozoic rocks, and the Paleozoic bedding dip direction probably controlled the location of sill formation and direction of sill propagation. The two largest sills deflected the overlying tuffs to form lopoliths, indicating that the magma pressure exceeded vertical stresses at that location and that the shallow level and large size of the sills allowed interaction with the free (earth's) surface.

2. Introduction. Many studies report that dikes intrude normal to the regional direction of least principal stress or to the local direction of least principal stress in the vicinity of large structures such as volcanic centers (e.g., Delaney and Pollard, 1981). Recently, some attention has been given to the mechanics by which those dikes inject into the crust. Specifically, it has been suggested that the propagation of dikes occurs by dilation of pre-existing fracture surfaces (e.g., Delaney et al., 1986) and by generation of self-propagating tip fractures in advance of the magma (e.g., Rubin, 1993; Lister and Kerr, 1991). By analyzing the distribution and geometry of dikes and their structural setting, it should be possible to distinguish the dominant emplacement mechanisms and possible structural controls on those mechanisms.

In many cases, subvertical dikes feed subhorizontal sheet intrusions (loosely called sills in this paper, although the strict definition of a sill requires that it be concordant with bedding or foliation of the host rock). Currently, three main factors have been identified that determine whether a dike will feed a sill. (1) If dike propagation is being driven by its buoyancy relative to local wall rocks, then when a dike reaches a height in the lithosphere where its magma is no longer buoyant (the level of neutral buoyancy, or LNB), further upward propagation will cease. Further influx of magma is accommodated by lateral flow at the LNB. Depending on whether $\sigma_{3}$ (least principal stress) is horizontal or vertical at the LNB, the dike will become a bladed dike or a sill, respectively (Lister and Kerr, 1991). (2) The emplacement of a dike changes the stress field because a dike exerts pressure on its walls. Under some conditions (Parsons and Thompson, 1991) the vertical stress could become the least principal stress and sills could form by continued magma influx. This process is enhanced where dikes cross zones of ductile rocks in which ambient differential stresses are low, as discussed by Parsons et al. (1992). (3) If the host rock can behave as a fluid, then fracture propagation ceases and the dike magma simply spreads out laterally at its LNB as a density current. An example of this is where a propagating dike encounters another intrusive body which is still partially molten (Parsons et al., 1992; Valentine, 1993).

The first two factors for sill formation given above, which apply when the host rock behaves as an elastic solid, should have the following trademarks in the field. First, a dike that experiences these processes will likely experience them along most or all of its length. This is because the orientation of the stress field associated with a self-propagating dike can be assumed to be relatively constant at a given level along its plane, except in the immediate vicinity of its edges. Ideally, such a dike would form a sill along its entire length, and the sill would extend outward 
from both sides of the dike. Second, where a sill forms, its feeder dike should not extend above the level of the sill (except for a minor overshoot distance; Lister and Kerr (1991)). In essence, the entire dike would be deflected horizontally to form a sill. It is worth noting that both of these models for sill formation are most commonly applied to large-scale magma transport problems, for example, to explain horizontal reflectors (inferred to be sheet intrusions) at lower-crustal depths that are recorded by seismic surveys in extending terrains (see Parsons et al. (1992) for a brief review). Sill formation at smaller scales and shallower depths is not as well understood although it is commonly assumed that these large-scale models apply at all scales. For example, small-scale (tens of meters thick, hundreds of meters in plan dimension) sill formation at the Paiute Ridge intrusive complex, described in this paper, was attributed to an LNB mechanism by Crowe et al. $(1983 \mathrm{a}, \mathrm{b})$. By completing detailed analysis of the distribution and geometries of dikes and sills and their structural setting, it is possible to distinguish the dominant emplacement mechanism(s), thereby providing information about the local and regional stress state and possible structural controls on magma propagation during intrusion.

Here we describe the basaltic intrusive complex at Paiute Ridge, Nevada, which contains both dikes and sills emplaced at shallow depths. However, unlike sills produced by the mechanisms given above, the sills in this complex feed off short segments of much longer dikes, the sills extend only from one side of their feeder dikes, and the dikes extend significantly higher than the level of sill formation. The role of pre-existing structures on dike and sill formation is emphasized. This area provides a favorable setting in which to document and explain dike and sill emplacement mechanisms because the contact relations are generally well exposed.

3. Geologic Setting. The Paiute Ridge intrusive complex is composed of dikes, sills, and small remnants of scoria cones and lava flows of alkali basalt (hawaiite) composition (Table 5.2, Figure 5.15). The complex was originally mapped by Byers and Barnes (1967) and has briefly been described by Crowe et al. (1983a) and Valentine et al. (1992, 1993). Paleomagnetic evidence (Ratcliff, 1993; Ratcliff et al., 1994), radiometric age determinations (our data and Byers and Barnes, 1967), and petrologic studies (F.V. Perry, unpublished data) indicate that the basalts were emplaced during a single, brief magmatic pulse that had a total volume of a few tenths of a cubic kilometer. No cross-cutting relationships have been found in the intrusions. The ${ }^{40} \mathrm{Ar} /{ }^{39} \mathrm{Ar}$ age of this event is $8.59 \pm 0.07$ (2s) Ma; it is part of a group of alkali basalts that erupted within the southcentral Great Basin in the past $\sim 9 \mathrm{Ma}$, coinciding with the waning of silicic volcanism in the region (Vaniman et al., 1982).

The structural setting at the time of intrusion was that of a small horst and graben system that consisted dominantly of N- to NNW-trending normal faults. These faults, which formed from roughly E-directed extension during the early Tertiary (Minor, 1995), displace a sequence of middle Miocene silicic tuffs (from the Southwestern Nevada volcanic field located $25 \mathrm{~km}$ to the west, see Vogel and Byers (1989), Sawyer et al. (1994)), that had been deposited on rolling hills of Paleozoic carbonates. Eruptive lavas and scoria deposits occur only in the graben regions, whereas dikes and sills occur beneath the original floor. Most of the sills formed within the silicic tuffs (Figure 5.16) at original depths estimated between 150-250 m (based on the original topography, as reconstructed from erosional remnants of rocks that overlie the sills). 


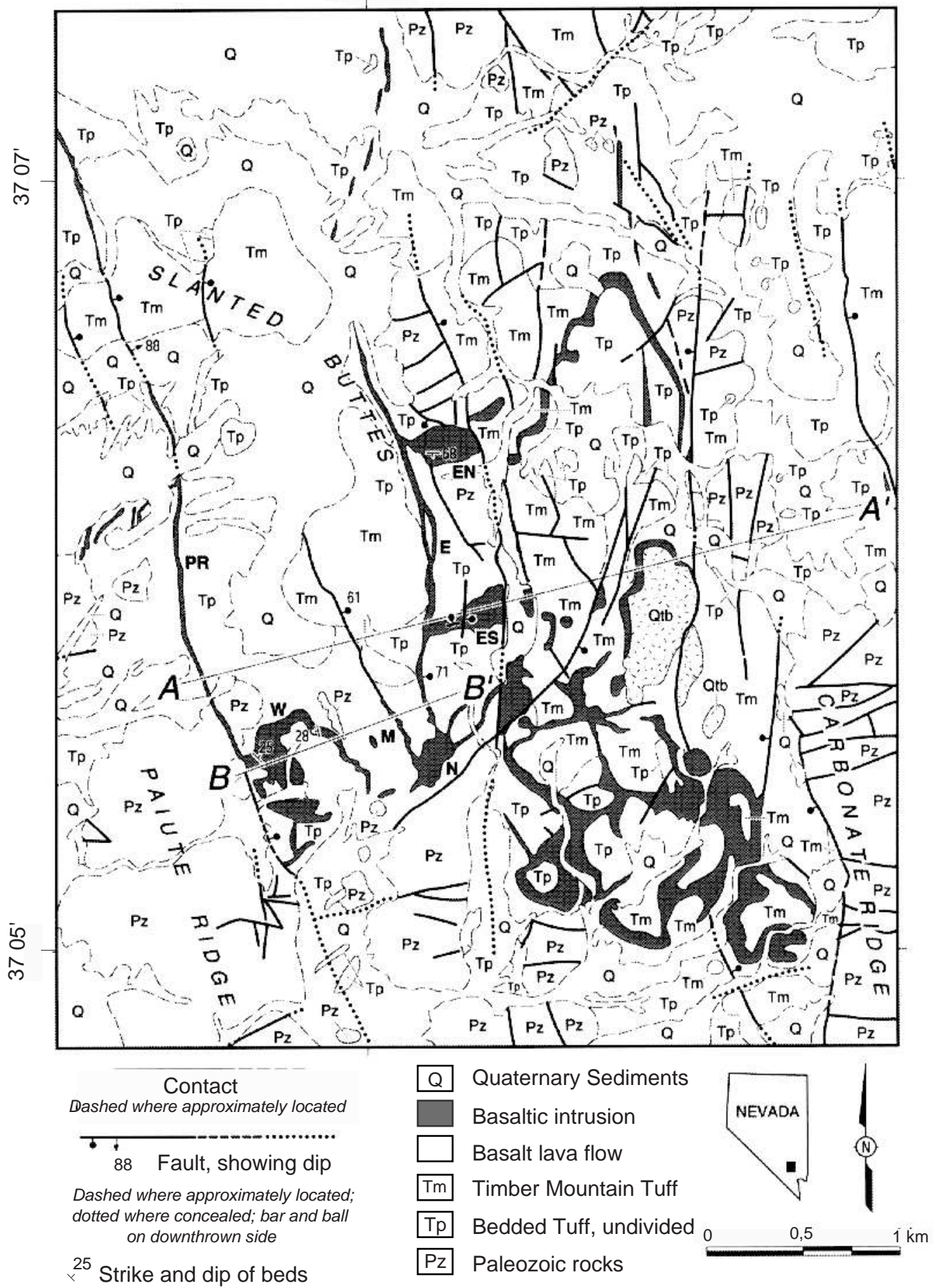

Figure 5.15. Simplified geologic map of the Paiute Ridge area, emphasizing basaltic rocks. Modified from Goff et al. (1995), Crowe et al. (1983) and Byers and Barnes (1967). Nomenclature of volcanic units follows Sawyer et al. [1994]. Cross section lines in Figure 5.2 are indicated. Pz - Paleozoic basement rocks (mainly carbonates) undivided; $\mathrm{Tp}$ - undivided bedded tuffs including units belonging to Tunnel Formation, Indian Trail Formation, Paintbrush group, comprised of fallout, pyroclastic flow deposits, and reworked nonwelded tuffs with varying degrees of zeolitic alteration; Tm - Timber Mountain tuffs, undivided (includes Rainier Mesa member); Qac - Quaternary alluvium and colluvium. PR - Paiute Ridge fault and dike; W - W sill; M - M dike and fault; E - E dike and fault; ES - ES sill along E dike near volcanic neck N; EN - EN sill along E dike. 
Table 5.2. Representative major element oxide composition of Paiute Ridge alkali basalt*, determined by $\mathrm{x}$-ray fluorescence analysis.

\begin{tabular}{||ll||}
\hline \hline Oxide & Weight \% \\
\hline $\mathrm{SiO}_{2}$ & 48.92 \\
$\mathrm{TiO}_{2}$ & 2.84 \\
$\mathrm{Al}_{2} \mathrm{O}_{3}$ & 17.35 \\
$\mathrm{FeO}$ & 10.95 \\
$\mathrm{MgO}$ & 5.28 \\
$\mathrm{CaO}$ & 8.12 \\
$\mathrm{Na}_{2} \mathrm{O}$ & 4.17 \\
$\mathrm{~K}_{2} \mathrm{O}$ & 1.70 \\
$\mathrm{P}_{2} \mathrm{O}$ & $\underline{0.58}$ \\
$\mathrm{TOTAL}_{5}$ & 99.92 \\
\hline \hline
\end{tabular}

* Sample B-13, reported in Appendix A of Crowe et al. [1986]

\section{Descriptions of Dikes and Sills at Paiute Ridge.}

a. Dikes. Basaltic dikes in the study area have intruded dominantly within a $2 \mathrm{~km}$-wide graben between the Carbonate and Paiute Ridges (Figure 5.15). The longest dikes occur along preexisting, NNW-trending, steeply E-dipping normal fault surfaces that cut Paleozoic sedimentary rocks and overlying Tertiary tuffs (Figure 5.15). There are many other faults in the area, including (1) those with similar (NNW) strikes that either dip more shallowly east or dip toward the west and (2) those with E to NE strikes. At the current depth of exposure, however, none of these faults is occupied by dikes. Additionally, there are a few small dikes that radiate out from the volcanic neck (Figure 5.15) and do not appear to follow pre-existing structures.

The three longest fault-entrenched dikes (PR, $\mathrm{M}$ and $\mathrm{E}$ on Figure 5.15) range in length and width from $400 \mathrm{~m}$ to nearly $5 \mathrm{~km}$ and from $1.2 \mathrm{~m}$ to $9 \mathrm{~m}$, respectively. The western-most, or Paiute Ridge (PR), dike varies in strike from $\mathrm{N}$ to NNW and intrudes Cambrian carbonates (Halfpint member of the Nopah Formation) in the south and nonwelded, bedded Tertiary tuffs (Tp in Figure 5.15) toward the north. The dike visibly occupies the steeply E-dipping Paiute Ridge fault at Slanted Buttes (Figure 5.15) and along the trend of the fault at its southern tip. Along the central segment, the dike does not reside along a mappable fault surface; however, it connects the faultentrenched tips and most likely occupies a fault surface as well. The dike nowhere appears displaced by the Paiute Ridge fault, which has a throw of less than $15 \mathrm{~m}$ across the Rainier Mesa member at Slanted Buttes. Dike widths are highly variable as they pinch and swell along strike. PR dike is thickest where it feeds the sill at its southern end (Figure 5.15) and along its longest $(100 \mathrm{~m})$ central segment.

The PR dike is composed of a main continuous dike and at least 24 dike-parallel segments that vary between 4 and $100 \mathrm{~m}$ in length. These segments are isolated and occur within tens of meters of the parent dike. In several places along strike, two segments diverge from the parent dike and enclose a lens of host tuff. In the northern half of the PR dike, where its shallowest intrusion level is preserved at Slanted Buttes, it splits into two parallel dikes and encloses fault breccia. The breccia is in smooth contact with the dike and contains vesiculated basalt and fused tuff. Also, at this tip, elongated vesicles in the dike are folded into an open fold with a nearly horizontal axis. 

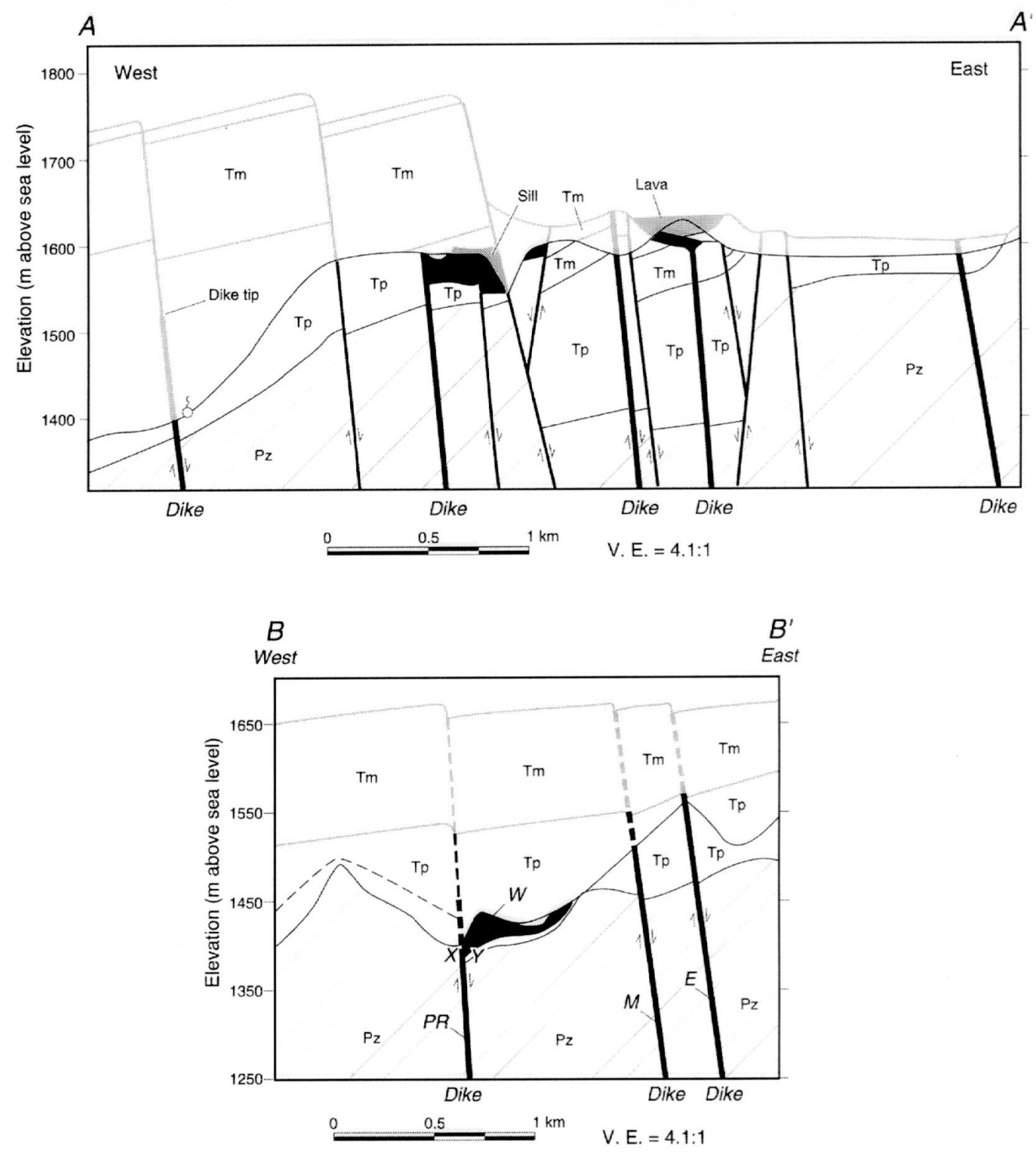

Figure 5.16. Cross sections through Paiute Ridge area (A-A' and B-B' in Figure 5.1) showing present-day topography and geology, with inferred topography (dashed) at the time of basaltic activity. Letters are the same as in Figure 5.1. Note that the sills (W sill in B-B' and ES sill in A-A') intrude Tertiary tuffs just above the Tertiary-Cambrian unconformity. X and $\mathrm{Y}$ (of section B-B') represent points at which vertical stresses are unequal (6-7.6 MPa and 5.2 MPa respectively based on estimated overburden; see Interpretation section) within the hangingwall and footwall of the Paiute Ridge fault.

The PR dike contains ubiquitous near-vertical joints that result in a pervasive platy texture with plates parallel to the dike-host contact. Conversely, with the exception of local cooling joints in fused wall rock (extending 10-20 cm into the wall rock, perpendicular to the dike margin), joints are never visible in the host rock along the length of the dike. The contact between basalt and the tuff host rock is consistently smooth and shows no brecciation. Along strike at this contact, the tuff host rock is fused or welded to varying degrees: in places the tuff is completely welded and forms black vitrophyre that grades rapidly away from the contact, over a distance of 
nonwelded tuff that is apparently unaffected by the dike. In other places the tuff is only partly welded at the contact, and black fiamme are elongated parallel to the contact. We infer that this "contact welding" is the combined result of heat from the dike and compressive stress exerted by the flowing magma on the wall rocks. Welded host rock commonly contains vesicles that are elongated vertically and parallel to the margin. In some places, welded tuff coats the basalt and displays rills or elongate smooth ridges (flutes). Most rills plunge nearly vertically; however, a subhorizontal rill is present in the central part of the dike. At the dike tip, exposed at Slanted Buttes, scoria patches crop out near the dike-host contact.

The two eastern dikes, $\mathrm{M}$ and $\mathrm{E}$ (Figure 5.15), show geometries and textures similar to those of PR; however, $\mathrm{M}$ dike is much shorter and does not feed a sill, and $\mathrm{E}$ dike was emplaced closest to the paleosurface and feeds two sills. M dike radiates out from a volcanic neck to the southeast (Figure 5.15) and, although poorly exposed, it visibly occupies a normal fault, oriented $\mathrm{N} 40^{\circ} \mathrm{W}$, $61^{\circ} \mathrm{E}$, that displaces the Rainier Mesa member and older tuffs (see Byers and Barnes, 1967). M dike varies in width between 2 and $4 \mathrm{~m}$ and has an exposed length of $400 \mathrm{~m}$. Its host rocks are only Tertiary tuffs, which show no brecciation or jointing near the dike contact. Near the neck, $\mathrm{M}$ dike is a single continuous dike; farther from the neck it is composed of several segments. The upper termination of the dike veers west, narrows, and terminates at an elevation of $1579 \mathrm{~m}$. Texture within the dike is characterized by a vertical platy fabric that parallels the dike margins.

The $\mathrm{E}$ dike is the eastern-most dike studied within the graben. Like $\mathrm{M}$ dike, it extends from the volcanic neck to the south and was emplaced into Tertiary tuffs in a N to NNW direction. Near the neck, the dike visibly occupies a NNW-trending, steeply E-dipping normal fault that displaces bedded tuffs $3.5 \mathrm{~m}$ and does not cut the dike. The exposed dike length is $2020 \mathrm{~m}$, and the width varies from $3 \mathrm{~m}$ near the northern tip to $6 \mathrm{~m}$ near the southern sill. The $\mathrm{E}$ dike is less segmented than the PR dike and is composed of fewer than a dozen segments. In at least three places near the contact with the Rainier Mesa tuff, (Figure 5.15), and one location near the volcanic neck, the dike locally diverges to form two segments that engulf an 8-m-wide lens of the tuff host rock.

The texture of $\mathrm{E}$ dike is characterized by the pervasive vertical platy fabric common to $\mathrm{M}$ and PR dikes. Adjacent host tuffs are not jointed nor brecciated, except for local vertical jointing of the Rainier Mesa tuff, which is intruded by the dike at its shallowest level. The contact of the dike and host tuff is preserved in places and varies from partly to completely welded in the same manner as described above for the PR dike. Where complete welding has occurred, vesicles are vertical and parallel the dike margin. Contact welding of the host tuffs formed oblate fiamme that parallel the dike-host contact. Visible thermal effects on the wall rocks disappear within one meter of the dike margin.

The southern termination of E dike, near the volcanic neck, shows subhorizontal rills on the near vertical dike-host contact, while the same contact at the northern termination shows vertical rills. At its northern termination, the dike ends in three left-stepping en echelon segments. The margins of these segments contain completely welded tuff host rock (black vitrophyre) and occasional patches of scoria.

b. Sills. Subhorizontal basaltic sheets (here loosely termed sills), which are roughly planar and locally conformable with bedding, have intruded nonwelded bedded tuffs (Tp, Figure 5.15) in the graben east of Paiute Ridge. Sills occur consistently as extensions off fault-conforming dikes into the hanging-wall block of the NNW-trending normal faults. The sills appear to inject 
exclusively into tuffs at positions near the contact between the Paleozoic sedimentary rocks and overlying tuffs; the sills do not inject into the Paleozoic rocks themselves.

The western-most sill, W, forms east of PR dike in the hanging wall of the Paiute Ridge fault. It is fed by PR dike, which widens near the sill and can be traced to within about three meters of the sill's western margin. Based on reconstructions (Figure 5.16), W sill was emplaced in nonwelded bedded tuffs within tens of meters above the presently buried Paleozoic-Tertiary contact. The minimum thickness of $\mathrm{W}$ sill is difficult to determine because of erosion of the uppermost part of the sill and overlying tuffs but is estimated at about three meters. Its maximum thickness appears to be less than $20 \mathrm{~m}$, and its maximum exposed plan dimension is ca. $600 \mathrm{~m}$. The depth of sill intrusion was at most $250 \mathrm{~m}$ below the earth's surface (Figure 5.16) and $160 \mathrm{~m}$ below the highest level reached by the parent PR dike.

The lower contact of $\mathrm{W}$ sill with nonwelded bedded tuffs is generally conformable with bedding as is the upper sill-tuff contact where it is preserved. Textures within the sill are highly variable. At the western margin, the base of the sill has a pervasive platy fabric in which the plates (a few $\mathrm{cm}$ thick) are parallel to the subhorizontal, S-dipping tuff-sill contact. Where this contact is irregular the basalt is either not jointed or has joints that follow the shape of the contact. Above the basal contact, the platy fabric alternates with thicker $(>10 \mathrm{~cm})$ subhorizontal seams of massive basalt. Just north or south of the point where the dike and sill connect, the subhorizontal platy fabric is absent: in two places, $1.5 \mathrm{~m}$ and $10 \mathrm{~m}$ above the basal contact, the basalt is either irregularly vertically jointed or has a chaotic, jumbled appearance. On the north side of the sill, where the sill and tuff dip on average $44^{\circ}$ toward the south, rills plunging toward $235^{\circ}$ are preserved on the under side of the sill. The margins of the sill dip moderately inward on all sides. Thin, discontinuous sills, $<1 \mathrm{~m}$ thick and $<10 \mathrm{~m}$ long, are locally present beneath the main $\mathrm{W}$ sill; these parallel the main sill and are separated from it by 2-3 $\mathrm{m}$ of country rock.

Two sills, ES and EN, inject into the hanging wall of the fault utilized by E-dike. The sills are fed by E dike, which widens near the sill contacts and can be traced directly into the sills. Based on reconstructions (Figure 5.16), the southernmost sill, ES, injects bedded tuffs (Figure 5.15) within $15 \mathrm{~m}$ of the presently buried Paleozoic-Tertiary contact. ES is approximately $450 \mathrm{~m}$ in the long dimension and is up to $24 \mathrm{~m}$ thick. The depth of intrusion was probably c. $175 \mathrm{~m}$ below the earth's surface, only $60 \mathrm{~m}$ below the shallowest level attained by the parent dike.

Along its lower contact with the nonwelded bedded tuffs, ES sill is parallel with the trend of bedding in some places and is disconformable elsewhere. Tuff host rock underlying the ES sill contains fractures normal to the sill-tuff contact. The fractures typically have sharp lower tips and extend into the host tuff less than 2.5 meters. Through the center of the sill, a set of steeply Edipping faults, comprising a $\mathrm{N}$-trending normal fault zone, displaces ES sill approximately 4 meters down to the east.

The EN sill, the northernmost sill attached to E dike (Figure 5.15), is emplaced in nonwelded bedded tuffs just above the Paleozoic-Tertiary contact and continues laterally toward the east to intersect a horst of fractured Ordovician limestones. The EN is approximately $380 \mathrm{~m}$ across the long dimension and as much as $46 \mathrm{~m}$ thick. The depth of intrusion was probably less than $100 \mathrm{~m}$ below the earth's surface, at approximately the same height as that attained by the parent dike at its northern tip. The EN sill appears generally discordant with bedding of the underlying tuff. Rills exposed on the underside of the basalt in contact with tuff plunge toward $227^{\circ}$ on an EW-striking, $68^{\circ} \mathrm{S}$ dipping surface (Figure 5.17). 


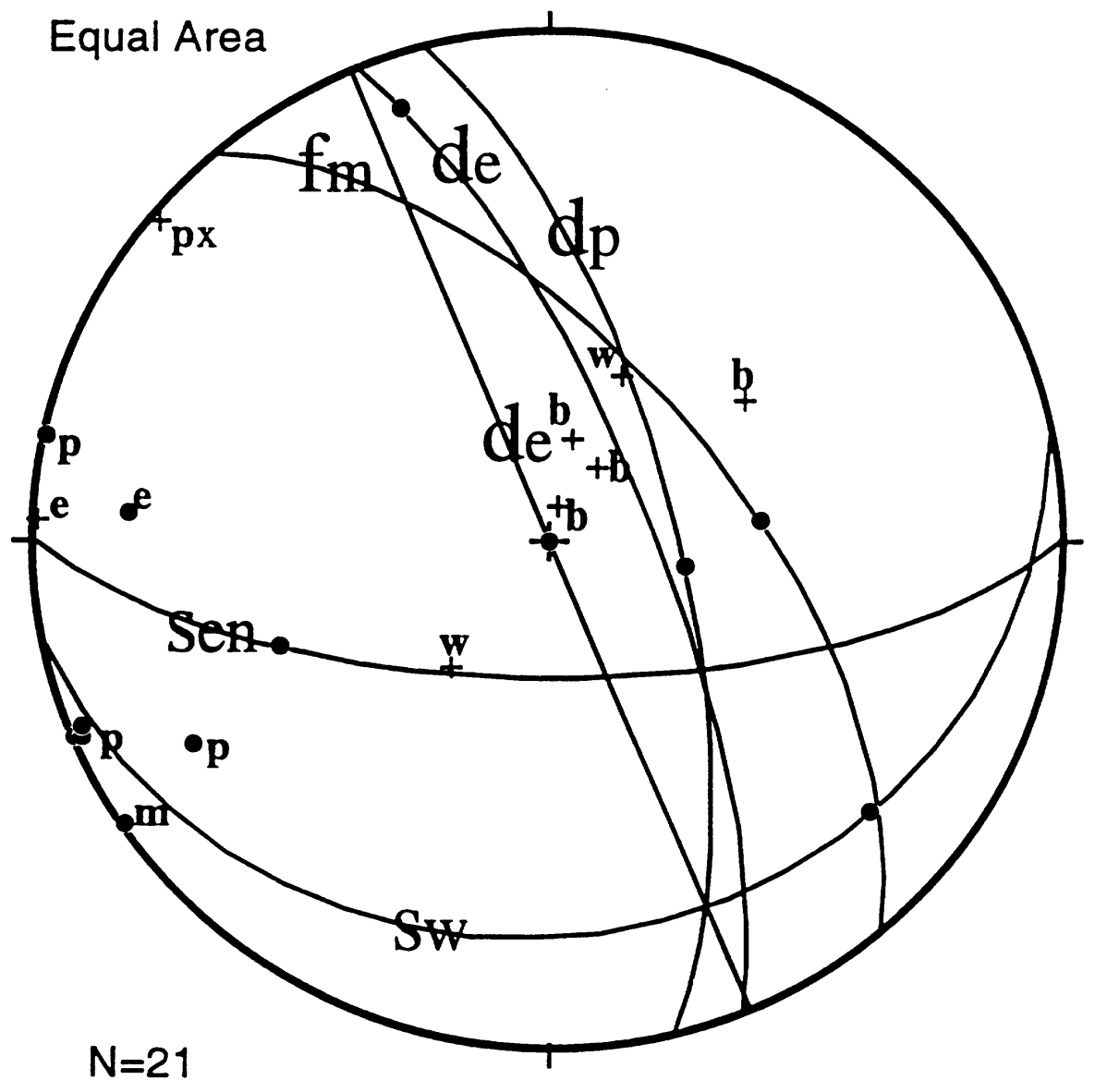

Figure 5.17. Lower hemisphere stereogram of structures at Paiute Ridge. Great circles show surfaces and kinematic indicators: $\mathrm{fm}=$ fault surface confining $\mathrm{m}$ dike and slickenside; de $=\mathrm{E}$ dike with flow indicator; $\mathrm{dp}=\mathrm{PR}$ dike with flow indicator, Sen = layering in $\mathrm{EN}$ sill, $\mathrm{Sw}=$ layering in $\mathrm{W}$ sill. Isolated dots represent poles to dike orientations: $\mathrm{p}=\mathrm{PR}$ dike, $\mathrm{e}=\mathrm{E}$ dike, $\mathrm{m}=\mathrm{M}$ dike; and + indicate layering: $\mathrm{w}=$ layering in $\mathrm{W}$ dike, $\mathrm{b}=$ layering in tuff adjacent to intrusive bodies, $\mathrm{e}=$ layering in $\mathrm{E}$ dike. px is an anomalous fabric within PR dike that is perpendicular to its strike. Fabric elsewhere along dikes is coplanar with the dike margin.

c. En Echelon Segments. En echelon segmented dikes occur in the area between Paiute Ridge and Carbonate Ridge; however, they were not examined in detail for this study, and so only their gross geometries are mentioned here. The en echelon dikes crop out west of PR dike and north and northeast of E dike. The two western dikes trend north and northeast and do not follow recognizable preexisting surfaces such as faults or lithologic contacts. The easternmost en echelon dike trends north, and although it does not inject any pre-existing structures, it does follow the trace of an inferred N-trending fault that terminates south of the dike's southern tip (Byers and Barnes, 1967). These dikes do not follow the NNW trend of the dikes discussed above and do not appear to be associated with any sills. 
5. Interpretation. The three major dikes in the Paiute Ridge region occupy fault surfaces and are not cut by those faults. Thus, the dikes appear to have utilized pre-existing fault surfaces with NNW strikes. This implies that the structurally controlled magma emplacement was energetically more favorable than if the magma had created its own path by fracturing intact rock at the upper dike tip. Sills fed by these dikes intrude into tuffs (except for the distal end of EN sill) and occur consistently in the hanging wall of dike-injected faults, close to and above the PaleozoicTertiary contact. The very shallow emplacement of sills (between $250 \mathrm{~m}$ and $100 \mathrm{~m}$ below the paleosurface) and deflection of overlying tuffs suggest that sills interacted with the earth's surface during intrusion. Below, we explore conditions under which such shallow emplacement could occur.

a. Dikes. Decades of observations of dike geometries have documented that, in the absence of local stress perturbations, dikes typically form normal to the direction of the least compressive stress, $\sigma_{3}$. More specifically, to propagate a vertical dike, $\sigma_{3}$ must be horizontal and the magma pressure within a dike, $P_{m}$, must exceed $\sigma_{3}$ (Pollard, 1987). If magma injects a pre-existing plane of weakness, then for a vertical plane, $P_{m}$ must exceed $\sigma_{3}$ and the friction across the crack surface. For a plane dipping less than $90^{\circ}$, magma pressure in the crack must exceed $\sigma_{3}$ plus a component of the vertical stress, $\sigma_{v}$. Furthermore, if the strike of the pre-existing planes is not normal to the direction of $\sigma_{3}$, magma pressures must be much greater than $\sigma_{3}$ in order to dilate them. Delaney et al. (1986) determined that if $P_{m}$ is only slightly greater than $\sigma_{3}$ or if differential stresses are high (Pollard, 1987), only cracks nearly perpendicular to $\sigma_{3}$ can be dilated. If, on the other hand, $P_{m}$ is greater than the greatest horizontal compressive stress, $\sigma_{H}$, a crack of any orientation can be dilated.

The normal and normal-oblique faults, dilated by dikes, formed between 11.45 Ma and 8.5 Ma under a stress field characterized by a SW- to WSW-directed $\sigma_{3}$ (Minor, 1995). Subsequent to this faulting event and into present times, the regional stress field underwent a gradual clockwise rotation of $65^{\circ}$, resulting in a NW-directed $\sigma_{3}$ (Haimson et al., 1974; McGarr and Gay, 1978; Minor, 1995). Basaltic dikes were probably emplaced near the end of the period characterized by the WSW-directed $\sigma_{3}$, before the $65^{\circ}$ rotation, based on the following information: (1) the age of the Paiute Ridge basalts is $8.59 \pm .07 \mathrm{Ma}$, which corresponds to the end of the period of WSWdirected $\sigma_{3}$; and (2) dikes were emplaced exclusively along NNW-striking faults. If NE-striking faults, and the associated NW-directed $\sigma_{3}$, had existed during the time of intrusion, dikes would have preferentially occupied the NE- rather than NNW-striking faults.

The dikes occupy only steeply dipping $\left(>60^{\circ}\right)$ planes even though other, more shallowly dipping planes of weakness existed during intrusion: (1) to the south, where the dip of the Paiute Ridge fault shallows to $50^{\circ}$, magma did not inject the fault; and (2) other preexisting fault surfaces, notably those with shallower or west dips (Byers and Barnes, 1967; Goff et al., 1996), were also not intruded. This suggests that although $P_{m}$ exceeded $\sigma_{3}$ plus a small component of vertical stress along steeply dipping faults, it was not great enough to overcome the additional component of $\sigma_{v}$ on shallowly dipping faults.

Some estimates of the physical conditions, such as driving pressure and energy requirements, that accompanied dike intrusion can be made based on the above qualitative analysis. For uniform loading stresses, and neglecting gravitational forces on the solid host rock, magma in a dike does not sense the density of the surrounding rock but only the ambient stresses on the dike plane (Rubin, 1995). Therefore, the width to length ratio $(w / l)$ of a dike is related to the pressure available to deform the dike walls and the resistance of the host rock to deformation, (Pollard, 1987; Rubin, 1995) as expressed by: 


$$
\frac{w}{l}=\frac{P_{d}}{\mu /(1-v)}
$$

where $P_{d}=P_{m^{-}} \sigma_{3}$ is the driving pressure, $\mu$ is the elastic shear modulus, and $v$ is Poisson's ratio. For the dike intruding the Paiute Ridge fault, the average width is $5 \mathrm{~m}$ and the length is $4.6 \mathrm{~km}$. Estimated average shear modulus and Poisson's ratio for Paleozoic host rocks are $1 \mathrm{GPa}$ and 0.25 , respectively, and for the Tertiary tuffs are $800 \mathrm{MPa}$ and 0.31 , respectively (Van Burkirk et al., 1978). Therefore, the driving pressure for the basaltic magma in these dikes was probably on the order of 1.4 to $2.6 \mathrm{MPa}$, which is within the range of 1 to $4 \mathrm{MPa}$ reported by others (e.g., Pollard, 1987). These low driving pressures might be the reason some of the dikes apparently did not intersect the earth's surface. Low driving pressures could have occurred for many reasons, including a decreasing magma supply with time, inhibited flow due to solidification of the magma, or lateral redirection of the magma into adjacent sills.

From these driving pressures, we can obtain a measure of the energy consumed in the fracture process associated with dike intrusion. $G$ is the mechanical energy release rate per unit increase in crack length. The propagation path of a dike will be that which minimizes $G$ (Delaney et al., 1986; Rubin, 1995). The amount of energy required to propagate the dike can be determined by assessing the critical energy release rate $^{1}, G_{C}$, using Equation 21 of Pollard (1987):

$$
G_{c}=\frac{\pi l P_{d}^{2}(1-v)}{4 \mu}
$$

Using the parameters specified above in Eq. (5-2), $G_{C}$ is approximately $6 \mathrm{MPa} \bullet \mathrm{m}$ for dikes that intruded intact rock. This value must be greater than the critical energy release rate for dilating a pre-existing plane of weakness because the latter does not require the additional energy needed to fracture intact rock at the dike tip. In other words, for dikes at Paiute Ridge, it was energetically favorable for magma to utilize pre-existing fault surfaces than to create new fractures in intact rock, and so $G_{C}$ can be used as an estimate of the minimum energy required for dikes to form by fracturing of intact rock and a maximum of that required for injecting pre-existing planes. At present, few other values of $G_{C}$, for dike formation, have been published. It will be interesting to compare energy requirements for different intrusion scenarios as they become available.

\footnotetext{
${ }^{1}$ Note that $K=K c$, where $K$ is the stress intensity factor and $K c$ is its critical value for crack propagation, is a commonly used proprogation criterion; however, its use in cases such as this is questionable. Rubin (1993) has shown that $K$, which is a measure of the stresses at the crack tip, cannot be considered solely a material property, but in fact, varies with confining pressure and, thus, is not a physically meaningful quantity. Additionally, the use of $K=K c$ as a propagation criterion is valid only if the region of inelastic deformation is small compared to crack length (see Rubin, 1995). For many dikes, zones of inelastic deformation at the dike tip are long, and a significant amout of energy could be dissipated by mechanisms other than simple extension of a crack surface (see Shlyapobersky and Chudnovsky, 1994). As such, if $K=K c$ is inadequate to determine conditions necessary for propagation, it is preferable to analyze the energy requirements of the system through the criterion $G_{c}$ because of its ability to incorporate the effects of the host rock as in addition to the crack configuration and loading.
} 
Flutes and rills on the dike/host-rock contact can be interpreted as flow direction indicators. Such features observed in the PR dike are dominantly vertical and, therefore, indicate vertical flow. No such features were observed in $\mathrm{M}$ dike. Indicators in $\mathrm{E}$ dike suggest that flow in the northern part of the dike was dominantly vertical, while toward its southern end flow was lateral. We suggest that the dike was emplaced first by flowing up along a fault plane. Flow gradually became focused at the southern end of the dike to form the volcanic neck or plug. As this conduit became established, magma flowing up the southern end of the dike was diverted toward the conduit, resulting in lateral flow indicators. As the conduit was established, it exerted pressure on its walls. Because of its roughly cylindrical shape, this pressure resulted in tension on the conduit walls and the formation of radial dikes (Figure 5.15). One of these radial dikes was "captured" by a preexisting fault as it propagated away from the plug to form $M$ dike. This sequence of events, in which magma rises in a dike but gradually becomes focused into a central conduit, is very common for basalts (e.g., Richter et al., 1970; Delaney and Pollard, 1981; Bruce and Huppert, 1990).

b. Sills. Sill geometries and spatial distributions in the Paiute Ridge area suggest that the recently proposed mechanisms for sill formation, (i.e., along the level of neutral buoyancy or LNB (Lister and Kerr, 1991) or at the point of dike-induced stress reorientation (Parsons et al., 1992; Parsons and Thompson, 1991), do not adequately explain their existence. The buoyancy force in an LNB mechanism depends on the integrated density of vertical columns through the dike and through adjacent wall rock to the surface, not on the local density contrast between magma and immediately adjacent wall rock. With this in mind, it seems unlikely that an LNB mechanism could have acted along such localized segments of the main dikes (which would imply local and abrupt variations in the integrated density of the rock column). In addition, along most of the dikes' lengths, there is evidence that magma continued to rise to a level significantly higher than the sills, and the sills propagated from only one side of the dikes. Similar arguments can be made against the mechanism of dike-induced stress reorientation (Parsons et al., 1992; Parsons and Thompson, 1991) for sills at Paiute Ridge. This mechanism would most likely have caused sills to form along most of the length of a dike, barring any externally (i.e., non-dike related) induced major stress heterogeneities along the length of the dike.

Considering that the magma senses and responds to the ambient stresses, the sills must have intruded at levels where the maximum vertical stress was lower than the maximum compressive horizontal stress. Additionally, at the point of injection, the magma pressure must have exceeded either the strength of the rock or the cohesive strength of a subhorizontal pre-existing plane of weakness, such as a bedding plane or lithologic contact, and also must have exceeded the vertical stresses at the level of sill injection $(<300 \mathrm{~m})$. Vertical stresses at this depth can be estimated, (using $\sigma_{v}=\rho g$ ), at roughly 5.2 MPa in the Tertiary tuffs, and ca. 6.5 MPa under the estimated volume of Cambrian rocks. Therefore, $P_{m}$ for the tuff-intruding sills must have been greater than 5.2 MPa. In the absence of any tectonic compression, vertical stresses exceed horizontal stresses at all depths below the earth's surface (see Figure 5.18 and compare $\sigma_{v}=\rho g h$ with $\left.\sigma_{h} \neq v / 1-v\right) \rho g$ ). For conditions to favor sill formation, therefore, some additional horizontal compressive stress must have existed along segments of PR and E dikes at points where the sills formed. If a small (3 to $4 \mathrm{MPa}$ ) horizontal stress had existed, the horizontal stresses would have exceeded the vertical stresses at depths shallower than $300 \mathrm{~m}$ (Figure 5.18). We suggest, therefore, that a horizontal compressive stress existed during sill formation along at least short segments of the dike-hosting faults. Such a stress regime would be similar to that reported for present-day horizontal stresses at a depth of $380 \mathrm{~m}$ near Paiute Ridge. Haimson et al. (1974) report in situ stresses that range from 8.8 (NE-directed $\sigma_{l}$ ) to $2.4 \mathrm{MPa}\left(\mathrm{NW}\right.$-directed $\sigma_{3}$ ), so the magnitude of compressive stress that we infer is reasonable. We emphasize, though, that because the sills formed only along very short 
dike-hosting faults. Such a stress regime would be similar to that reported for present-day horizontal stresses at a depth of $380 \mathrm{~m}$ near Paiute Ridge. Haimson et al. (1974) reportin situ stresses that range from 8.8 (NE-directed 1) to $2.4 \mathrm{MPa}$ (NW-directed 3), so the magnitude of compressive stress that we infer is reasonable. We emphasize, though, that because the sills formed only along very short segments of the dikes and their host faults, this compression was probably localized. This local phenomenon might be due to contrasting rock properties on different sides of the faults or local stress variations due to topographic effects.

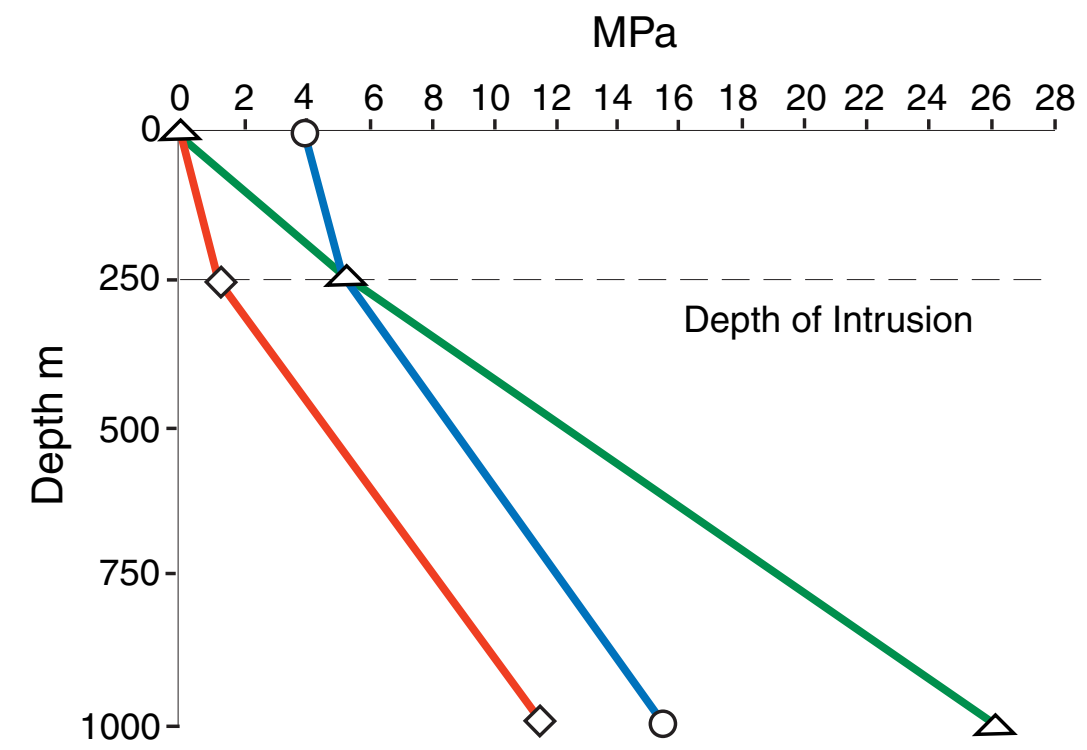

Figure 5.18. Possible stress gradients for conditions during intrusive activity in the Paiute Ridge area. Depth is from paleosurface. Diamond $=h, \mathrm{X}=v$, and Circle $=h^{+}$tectonic compression. Intrusion of sills would be favored at the depth where $v<h$. With a small tectonic compression (4 MPa) $h$ can exceed $v$ at depths shallower than approximately $300 \mathrm{~m}$ (depth $=250 \mathrm{~m}$ is approximateTertiaryPaleozoic boundary). Calculations for $v$ and $h$ are standard $(v=g h$ and $h=(/ 1-) g h:$ see e.g., Engelder [1993]). Rock properties are described in the text

If, indeed, ambient stresses are the dominant factor controlling the direction and geometry of magma injection, the consistency with which sills inject into a particular structural setting (intoTertiary tuffs within the hanging walls of faults, just above the contact with Cambrian carbonates) must be related to stresses in the vicinity of parent dikes. Magma migrating upwards along dikes would approach such a contact (T-Cambrian) and sense a drastic change in ambient stresses and a difference in those stresses on either side of the fault; vertical stresses on the western side of PR dike would have been roughly 6 to $7.6 \mathrm{MPa}$ in Cambrian carbonates (at about $250 \mathrm{~m}$ depth) and those on the eastern side, in Tertiary tuffs, would have been about 5.2 MPa (Figure 5.16). Furthermore, adjacent to PR dike, bedding planes areW-dipping in both the Cambrian and Tertiary rocks. The dip direction of these potential planes of weakness would favor the injection of sills upwards toward the east rather than downwards towards the west (Figure 5.16), similar to the fluid-filled cracks that seek the earth's surface analyzed by Weertman (1980). Based on an analogous structural setting, it is likely that the same mechanical configuration controlled the injection of the two sills fed by E dike. Thus, the consistent occurence of sills in particular geometric sitautions that are highly spacially localized suggests that their emplacement is controlled by the ambient stresses and rock type. These two factors were highly variable during intrusion 
because of the spatial distribution and orientation of tuff, Paleozoic rocks (that also formed paleohills), and major faults.

The W sill and the largest sill near Carbonate Ridge (Figure 5.15) have deflected the overlying tuffs and dip inward around their margins to form lopoliths. The collapsed top of these bodies suggests that the magma interacted with the overlying free (earth's) surface. This geometry is not shared by the two smaller sills (ES and EN) fed by E dike. We suggest, following results of the laccolith study by Pollard and Holzhausen (1979), that the size of the sills is an important factor in the formation of the lopolithic geometry at Paiute Ridge. Pollard and Holzhausen (1979) suggest that, because of tensile stresses over the central part of a sill, a large body of magma will interact with the earth's surface if it is close to the surface. We suggest that the same physical constraints control the formation of lopoliths: larger bodies that are closer to the earth's surface experience more interaction (i.e., bending of overlying strata) with that surface. Pollard and Holzhausen (1979) calculate that the transition from a sill to a laccolith occurs at a ratio of half-length to depth $(\mathrm{l} / \mathrm{d})$ of approximately 1.6. We support this theory with the ratios for lopoliths in the Paiute Ridge area: the $l / d$ of $\mathrm{W}$ sill is between 1.2 and 1.88 (depending on the estimated depth); the $l / d$ of the largest sill is approximately 8.5 . The smaller sills are not lopoliths and have $l / d$ ratios between 1 and 2. Notably, these sills have a much smaller area than the lopoliths and, therefore, could not exert as much force on the overlying rocks to cause bending. Therefore, the aerial extent of the sill, in addition to simply the $l / d$ ratio, must also be an important factor in whether it becomes a laccolith or lopolith. There are two reasons why the roofs of Paiute Ridge intrusions sag inward (forming lopoliths) rather than bow upward: (1) The magma may have been vesicular at these shallow depths during intrusion, so that while magma initially pushed the roof up, as the volatiles leaked out and the intrusion cooled, the roof gradually sagged downward. (2) The host rocks were originally nonwelded silicic tuffs, but the heat and pressure of the intrusions caused welding, pore collapse, and attendant decrease in rock volume adjacent to the intrusions. This accounts for inward sagging of both the roofs and floors of the lopoliths.

c. En Echelon Dikes. The mechanisms responsible for the formation of the en echelon dikes at Paiute Ridge are not known, but based on their geometries and the stress history, we offer two possible models. The trend of the line connecting the en echelon segments varies from $\mathrm{N}$ to NE, in contrast to the NW-trending dikes discussed previously. It is possible that these segments represent intrusion during the transition from the SSW- to NW-directed $\sigma_{3}$ around 8.5 Ma (see above). If these dikes intruded during a rotating stress field, their orientation would reflect a plane normal to the direction of the incremental $\sigma_{3}$ as it changed from SSW to NW. Additionally, the rotation of principal stresses about an axis parallel to the propagation direction of the dike, as described by Delaney and Pollard (1981) and Pollard (1987), could have resulted in segmentation of those dikes. In the Paiute Ridge area, rotation would have been clockwise about a vertical axis near the final extent of dike ascension (at depths $<250 \mathrm{~m}$ ), resulting in right-stepping $\mathrm{N}$-trending segments of NE-trending dikes (Figure 5.15). Alternatively, if the en echelon dikes formed in the same (nonrotating) stress field as did the other nonsegmented dikes, it is possible that surficial loads could be responsible for the near-surface segmentation. Structures, topographic relief, or intrusive bodies near the intruding dikes could have induced a rotation of local principal stresses, resulting in dike segmentation. It is possible that further age constraints could reveal which of the two models is most likely.

6. Conclusions. The location and geometry of Miocene basaltic intrusive bodies in the Paiute Ridge area are strongly controlled by pre-existing structures and regional stresses. The longest dikes intruded normal to $\sigma_{3}$ along pre-existing faults with critical dips and strikes; only 
NNW steeply dipping planes were injected. To achieve this geometry, magma pressures must have been greater than $\sigma_{3}$ and also have exceeded friction across the fault surfaces. Driving pressures were apparently not sufficient to intrude along faults of other orientations nor along selfpropagated paths. En echelon dikes trend at an angle to the fault-conforming dikes and could have formed during the documented $65^{\circ}$ stress-field rotation after ca. $8.5 \mathrm{Ma}$. Sills, which occur adjacent to dikes within $300 \mathrm{~m}$ of the paleosurface, consistently occur in the hanging-wall block of the dike-injected faults. We interpret their location in Tertiary tuffs, just above the PaleozoicTertiary contact, to indicate that intruding magma sensed a significant local change in ambient stresses along the fault planes. Additionally, we suggest that the dip of bedding surfaces helped localize the direction of sill injection; magma preferred to flow upwards towards the east rather than downward toward the west. The two largest sills formed lopoliths, indicating that the magma pressure exceeded the vertical stresses at that location and that the shallow level and large aerial extent of the sills allowed interaction with the free (Earth's) surface. We infer that sills at depths greater than those now exposed at the surface would be less likely to form lopoliths and would preferentially form in the Tertiary tuffs rather than in the Paleozoic sedimentary rocks. Finally, we speculate that the processes that governed dike propagation and local shallow sill formation at Paiute Ridge may operate in other shallow rift settings (e.g., continental rifts and rift zones of shield volcanoes as has recently been addressed by Johnson (1995), who notes the importance of structure-related stress variations in stalling dikes in the east rift zone at Kilauea volcano).

\section{Alteration of Silicic Tuffs Around Shallow Basaltic Intrusions}

1. Introduction. This section reports studies of alteration of silicic pyroclastic rocks by shallow basaltic intrusions. Two sites were chosen for study because combined they are good analogs for the various rocks in the vadose zone at Yucca Mountain and allow us to constrain the type and spatial scale of alteration that would accompany a basaltic intrusion into the potential repository. The two sites are (1) Paiute Ridge and the Slanted Buttes area of Paiute Ridge, eastern Nevada Test Site, where variably vitric and zeolitized silicic tuffs (some of which correlate to those at Yucca Mountain, some $40 \mathrm{~km}$ away) were intruded by basaltic dikes and sills, and (2) Grants Ridge, New Mexico. At Grants Ridge a thick sequence of unconsolidated rhyolite ignimbrite, fallout, and reworked volcaniclastic deposits were intruded by a basaltic plug that fed a scoria cone eruption. Erosion of the site has since produced a natural cross section through the scoria cone, its feeding system, and the pyroclastic host rocks. We gathered data to constrain geochemical and mineralogical alteration effects at both sites. The basic results are that alteration is quite limited, typically only found within 5-10 meters of the intrusions. The next phase of these studies is detailed numerical simulation of the thermal evolution of the sites, which would serve two purposes. The first would be a better understanding of the field-based observations and, therefore, more confident prediction of magmatic effects on potential repository performance. The second purpose would be for benchmarking numerical models of hydrothermal processes using these field examples that are at the same scale as the potential repository. This would lend confidence to engineering designs of thermal loading of the potential repository.

\section{Paiute Ridge/Slanted Buttes Analog Site.}

a. Summary. Vitric and zeolitized tuffs of middle Miocene age intruded by shallow highalumna alkali basalt magmas developed localized contact metamorphic zones at Slanted Buttes in the northeastern part of the Nevada Test Site, Nevada. This study was part of a natural analog investigation to evaluate the effects of volcanism on the performance of a potential high-level radioactive waste repository environment at Yucca Mountain. Despite the similarity in size 
between the two dikes ( $~ 9$ m wide), the contact metamorphic zones ranged from 0.5 to about $6 \mathrm{~m}$. The dike responsible for the localized thermal zone $(0.5 \mathrm{~m})$ is about $2 \mathrm{~km}$ from a possible source plug, whereas the other one is within $100 \mathrm{~m}$. The contact aureole beneath the $45-\mathrm{m}$ thick sill is also localized and extends to about $5 \mathrm{~m}$. The sill is an offshoot from a dike that is about $1 \mathrm{~km}$ away from a plug. Shallow emplacement into an unsaturated environment and loss of heat from the dikes and sill may be responsible for the localized nature of the contact metamorphic zones.

Devitrification is enhanced in the presence of aqueous solutions.

Silicic and zeolitized tuffs within the contact aureoles are either devitrified or fused and quenched to form vitrophyres. Within the contact zone, the vitric content of the Ammonia Tanks Tuff of the Timber Mountain Group was totally replaced by feldspar, quartz, and cristobalite. The Tiva Canyon Tuff of the Paintbrush Group beneath the sill contains a vitrophyre and a devitrified zone side by side, and a clinoptilolite-rich tuff occurs about $3 \mathrm{~m}$ away. Variations in major, trace, and rare earth elements are subtle except for water content.

Based on the natural analog studies, there is no indication for extensive hydrothermal circulation and alteration, brecciation and deformation related to magmatic intrusion, and vapor phase recrystallization during the magmatic intrusions into the vitric and zeolitized tuffs.

b. Introduction. We studied contact metamorphism of vitric and zeolitized tuffs intruded by basaltic dikes, sills, and plugs, in order to understand thermal, degassing, and volatilization effects on the host rocks. Contact aureoles form due to changes in (a) volatile contents, (b) mineralogic and isotopic compositions, (c) non-volatile major and trace-element compositions, and (d) textural modifications (Barton et al., 1991). Contact aureoles around shallow magmatic bodies provide information about the alteration processes related to thermal, hydrothermal (metasomatic), and structural modifications that are generally manifested by coarsening, recrystallization, mineralogical and chemical changes, anatexis, and deformation and brecciation (Barton et al., 1991; Kerrick, 1991). Although loss of volatiles can be reversed if there is an appropriate source, other processes such as mobilization of certain major, trace, and rare earth elements, loss of pore fluids, radiogenic argon, organic-derived components, and halogens can be irreversible. Such chemical and physical changes provide information on the thermal history of the host rocks and the spatial extent of the contact metamorphism. Here, we present results of field and laboratory studies that address the thermal effects of shallow basaltic dikes and a sill on vitric and zeolitized tuffs. We collected vitric and zeolitized silicic tuff samples within and outside contact aureoles to determine the physical and chemical modifications induced by the basaltic intrusions.

c. Geological Background and Field Study. The study site is located about $40 \mathrm{~km}$ northeast of Yucca Mountain along the northeastern part of the Nevada Test Site, Nevada, USA (Figure 5.19). The Slanted Buttes ridge north and northwest of Paiute Ridge is intruded by dikes, sills, and conduit plugs, representing a shallow (100-200 m depth) intrusive plumbing system for a small volume volcanic center (Crowe et al., 1986). Due to erosion and faulting, only a small part of the eruptive lavas and scoria remain perched on top of vitric and altered silicic tuffs of the southwest Nevada volcanic field. The alkali basalt intrusions are late Miocene in age (8.7 Ma) and intruded into host rocks consisting of massive and bedded middle Miocene Calico Hills Formation, Paintbrush, and Timber Mountain Group tuffs (Byers and Barnes, 1967; Crowe et al., 1986). According to Crowe et al. (1983a), the basaltic intrusions are confined to a series of gently tilted fault blocks that are within a north-northwest-trending graben system of $15-$ to $20-\mathrm{km}$ long and 4to $8-\mathrm{km}$ wide. Most of the faulting predates the basaltic intrusion in this area. 
The shallow basaltic plugs, dikes, and sills were intruded along pre-existing structural weaknesses except for few that terminate at fault boundaries (Crowe et al., 1983a). The sill-like bodies are mostly local offshoots of the elongate dikes (Figure 5.19). The scoria patches represent zones where pressure in the magma was reduced and volatiles exsolved, indicating that present exposures are very near to the original paleosurface. Some of the intrusion margins (e.g., plugs) also display intrusion breccias in which basaltic fragments are incorporated in a chaotic matrix of sintered to glassy hornfelsed tuff. The dikes cut across stratigraphic units, whereas most of the silllike intrusions were emplaced along stratigraphic contacts. In most cases, the dikes occur radially around conduit plugs composed of jointed basalt, scoria patches, and partially fused and stoped silicic tuff blocks of the Timber Mountain tuff. Thicker sills have coarser (diabase) texture. Phenocrysts of the high-alumna alkali basalts consist of plagioclase, clinopyroxene, and iddingsitized olivine. Local zones of reddish, vesicular scoria occur within and near plug boundaries and intrusion margins.

Samples were collected from thermally altered zones of vitric and zeolitized tuffs. A number of samples (PR95-1 to PR95-15) were collected transverse to a 9-m thick dike from about 30 and 6 $\mathrm{m}$ on the north and south sides, respectively, where the dike was intruded into the middle Miocene Ammonia Tanks Tuff (11.6 Ma; Sawyer et al., 1994) of the Timber Mountain Group located along the southeastern part of the Slanted Buttes (Figure 5.19, Location A). The ash flow is vitric and is matrix-supported, moderately welded, massive, pinkish brown, and pumice rich with cavernous weathering. Quartz, sanidine, and minor amounts of biotite are present as phenocrysts. The effect of the dike on the pumice-rich ash flow tuff is limited to about $4 \mathrm{~m}$ from the contact zone, and it is represented by change of color (i.e., from pinkish brown to dark pinkish orange and light to dark gray), hardness, degree of fusion and recrystallization, and foliation and jointing parallel to the strike of the dike. The dike along the contact zone is strongly jointed parallel to the axis of the dike and forms thin plates that are easily broken and eroded, creating a channel between resistant ledges of fused ash flow tuff. The dike is aphyric along the contact with the tuff while it is partially altered to smectite in the middle part.

Another suite of samples (PR95-18 to PR95-23) were collected beneath a 45-m thick sill that branches from a dike (Location B, Figure 5.19). The base of the sill has a sharp contact with the underlying tuff. No breccias, stoped country rock, or lithic fragments were noted along the contact. Similar to the dike, the base of the sill is jointed and forms thin plates parallel to the contact. The tuffs at this locale belong to the Paintbrush Tuff and the Calico Hills Formation, based on petrographic and major and trace-element chemical data.

The contact aureole below the sill is about 5-m thick and is represented by a $0.5-\mathrm{m}$ thick vitrophyre (PR95-18) that laterally changes to an orange-brownish baked and hardened tuff (PR95-21). This unit was identified as the Tiva Canyon Member of the Paintbrush Group based on petrographic and chemical data. A hornfelsic zone that contains a $10-\mathrm{cm}$ thick, light-green opaline layer of concretions (PR95-19) crops out about $1 \mathrm{~m}$ below the vitophyre. A baked tuff also occurs between the vitrophyre and the sill. About $3 \mathrm{~m}$ beneath the sill, a tuff (PR95-20) that is massive, pinkish, and moderately welded contains silicified clasts (pumice?), abundant obsidian fragments, welded pumice, and stretched vesicles. This tuff also belongs to the Paintbrush Group. The pinkish tuff grades to a poorly welded zone that also contains a greenish opaline layer like an overlying outcrop closer to the base of the sill. A light gray bedded tuff (PR95-23) with abundant lithic fragments crops out about $35 \mathrm{~m}$ below the base of the sill. The tuff contains abundant quartz with minor amounts of feldspar and biotite and was correlated to the Calico Hills Formation on the basis of mineralogy and major and trace-element chemistry. Fractures and joints within the contact 
aureole are filled with opal and minor calcite, whereas the joints at the base of the sill are devoid of secondary minerals.

Four samples were collected from a $0.7-\mathrm{m}$ thick poorly consolidated, coarse and fairly matrixfree pumice fall that was intruded by a 9-m wide dike at the south side of the northern part of the Slanted Buttes (Figure 5.19, Location C). The dike forms a resistant ledge along the contact with the host rock, whereas the middle section is altered and eroded and forms a deep erosional channel (>1.5-m deep) parallel to the strike of the joints and the dike. A sample from the dike (PR95-28) is partially altered and contains abundant amygdules of silica. The bedded pumice fall occurs below the Rainier Mesa Tuff and probably belongs to the Paintbrush Group (12.8-12.7 Ma, Sawyer et al., 1994). The contact aureole is about $0.5-\mathrm{m}$ wide and gradational. The tuff along the contact zone is fused and glassy. It is about 20 to $30-\mathrm{cm}$ wide, and a sample (PR95-24) from this zone is hard, glassy, dark gray, and generally foliated parallel to the strike of the dike. It also contains opaline nodules of altered pumice clasts. It grades to partially recrystallized pumice (PR95-25) where the incipient bedding is still preserved. Two more pumice fall samples collected about 1.3 (PR95-26) and $1.8 \mathrm{~m}$ (PR95-27) from the dike show no apparent thermal effect from the intrusion. They are friable and bedded with millimeter-thick laminations.

d. Analytical Methods. Bulk samples were pulverized and analyzed using X-ray diffraction (XRD) on an automated Siemens D-500 diffractometer using $\mathrm{Cu} K \alpha$ radiation, $0.02^{\circ} 2 \theta$ steps, and counting times of $1 \mathrm{~s}$ per step for all mounts $\left(2-36^{\circ} 2 \theta\right)$ to determine changes in mineralogy in the host rock during contact metamorphism. Quantitative mineralogic analyses were also conducted on select samples (Chipera and Bish, 1995). The major and trace-element compositions of bulk powders were analyzed using a Rigaku 3064 wavelength dispersive $\mathrm{x}$-ray fluorescence (XRF), and the intensities were processed to concentrations using XRF-11 to determine changes in bulk-rock compositions (metasomatism) due to fluid-rock interaction in a contact aureole. Analyses and statistics of the unknown samples are based on a model that uses intensities for 21 standard rocks.

Selected samples were analyzed for $\mathrm{F}, \mathrm{Cl}, \mathrm{B}, \mathrm{Br}, \mathrm{S}$, and $\mathrm{P}_{2} \mathrm{O}_{5}$ using an Ion Chromatograph Dionex 4000i with conductivity and UV/Vis detectors and other accessories to estimate volatile components gained or lost during contact metamorphism (Shevenell and Goff, 1993). Bulk samples were analyzed from within and outside the contact metamorphic zone. Standards that were lithologically similar to the unknown samples were also analyzed to determine the quality of the analytical work.

The effect of contact metamorphism on the rare earth-element compositions of vitric and zeolitized tuffs was also determined by instrumental neutron activation analysis (INAA) on selected samples at Washington University, St. Louis (Korotev, 1987). Two NBS standards were included with the unknown samples. 


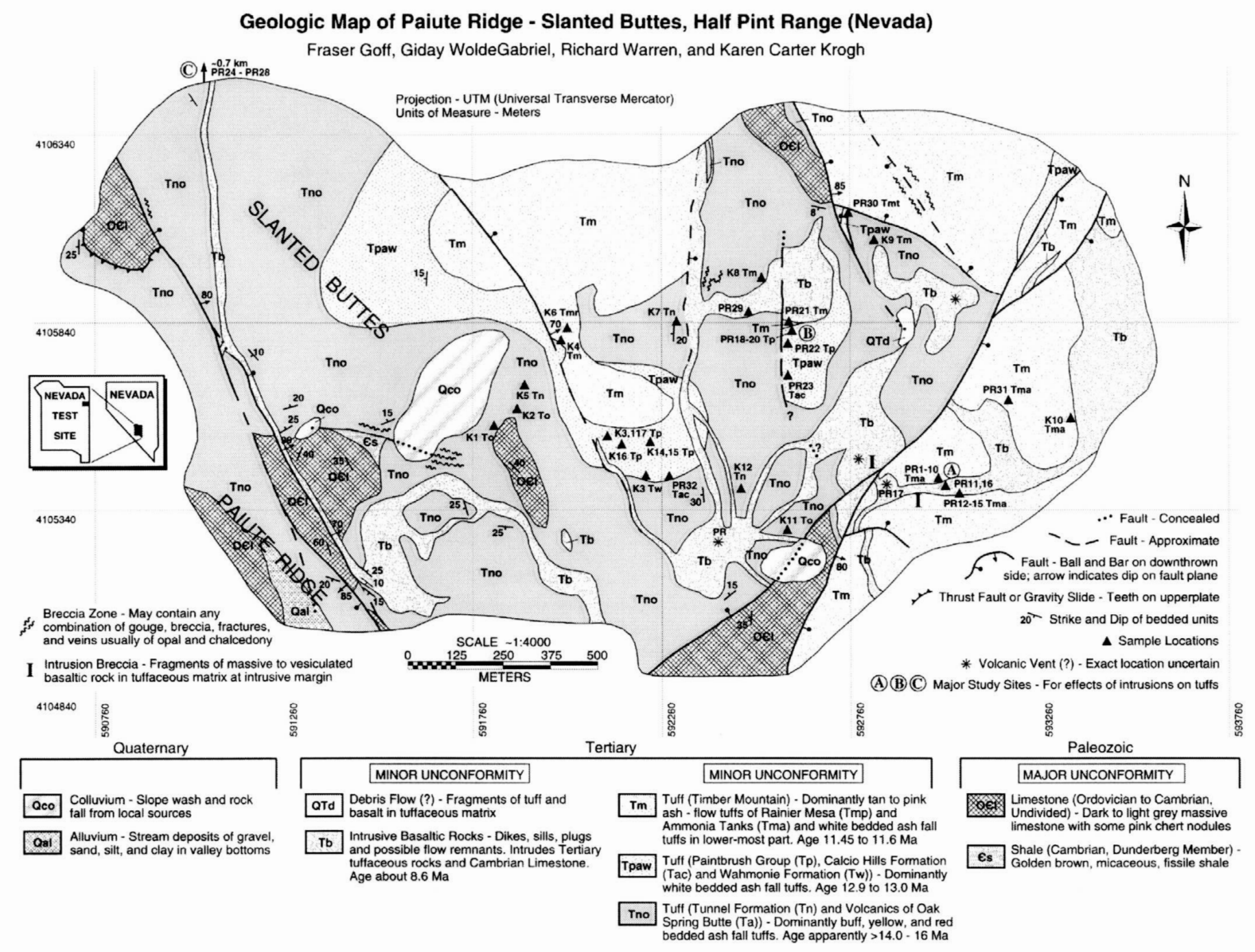

Figure 5.19. Geologic map of the Slanted Buttes, Half Pint Range, Nevada. Inset map shows the location of Slanted Buttes. The geologic map indicates the sample locations of tuffs intruded by dikes and a sill. 


\section{e. Analytical Results.}

(1) X-Ray Diffraction Analysis. Changes in mineralogical compositions were noted in the Ammonia Tank Tuff samples collected at different intervals on both sides of the 9-m wide basaltic dike (Figure 5.19 A). These results are presented in Table 5.3 and Figure 5.20. The silicic samples generally exhibit a trend of decreasing volcanic glass contents and increasing amounts of feldspar, quartz, and, cristobalite toward the dike (Figure 5.20). However, a sample closer to the dike $(\sim 3 \mathrm{~m})$ on the north side of the dike contains about $40 \%$ clinoptilolite, $4 \%$ of cristobalite, and a higher content of feldspar (Figure 5.20B). On the south side, samples collected within about $6 \mathrm{~m}$ of the dike do not contain volcanic glass (Figure 5.20F). Trace amounts of clinoptilolite are also present in one of the samples collected on the south side of the dike. Recrystallization and alteration within the dike is also noticeable because of the increased content of cristobalite and smectite in the basaltic samples collected along the contact zone with the tuff (Figure 5.20E). Based on the mineralogical composition, the effect of the dike is much more apparent in samples collected within about $2.0 \mathrm{~m}$ from the contact (Table 5.3). For example, the volcanic glass content systematically decreases from about $60 \%$ at about $15 \mathrm{~m}$ to none about $2 \mathrm{~m}$ away from the contact. Conversely, feldspar, quartz, and cristobalite contents increased from 45 to $69 \%, 4$ to $9 \%$, and 0.4 to $13 \%$, respectively. Physical changes in color and hardness, absence of volcanic glass, and the increase in quartz, feldspar, and cristobalite contents toward the dike are important indicators of the lateral extent of the contact metamorphic aureole.

There is no systematic mineralogic and volcanic glass variation in the altered Tiva Canyon Tuff within the contact aureole created beneath the $45-\mathrm{m}$ thick sill about $0.6 \mathrm{~km}$ northwest of the previous dike (Figure 5.19, Location B). Unlike the Ammonia Tank Tuff intruded by a dike, the older tuff beneath the sill indicates variable contact metamorphic effects (Figure 5.21, Table 5.3). The tuff (PR95-18) along the contact zone is fused and quenched and contains about $80 \%$ volcanic glass and 6\% clinoptilolite (Figure 5.21A), whereas another sample (PR95-21) of the same unit collected along the contact about $10 \mathrm{~m}$ west of the previous sample is baked and hardened and contains no glass but the same amount of clinoptilolite and higher contents of feldspar, quartz, and cristobalite (Table 5.3, Figure 5.21D). About $1.5 \mathrm{~m}$ beneath the sill, a greenish layer (PR95-19) parallel to the bedding of the tuff and the contact with the sill is enriched in quartz, feldspar, and opal (Figure 5.21B). However, about $3 \mathrm{~m}$ below the sill, another sample (PR95-20, Figure 5.21C) contains abundant volcanic glass ( $65 \mathrm{wt} \%)$, whereas two other samples collected at about 8 (PR95-22) and $35 \mathrm{~m}$ (PR95-23) have no volcanic glass (Figure 5.21E). Instead, these two samples belonging to the Paintbrush Group and the Calico Hills Formation, respectively, are dominated by clinoptilolite (Table 5.3).

More samples were collected from a pumice fall that was intruded by a 9-m thick dike along the northwestern extension of the dike system that disappears into the south side of the Slanted Buttes (Figure 5.19, Location C). All samples collected along the contact zone and about $1.8 \mathrm{~m}$ west of the dike contain about $80 \%$ volcanic glass (Table 5.3, Figure 5.22A,B). The sample along the contact is totally fused and hard with abundant spherical glass blebs, most of which are still intact. It is characterized by higher contents of quartz and cristobalite compared with samples collected farther from the dike (Table 5.3).

(2) Geochemical Results. Variations are noted in major and trace-element compositions of the various vitric and zeolitized tuff samples intruded by dikes and a sill. The Ammonia Tanks Tuff samples (PR95-1 to PR95-10 and PR95-12 to PR95-15) exhibit slight increase in $\mathrm{SiO}_{2}, \mathrm{~K}_{2} \mathrm{O}$, $\mathrm{Na}_{2} \mathrm{O}, \mathrm{TiO}_{2}$, and $\mathrm{Fe}_{2} \mathrm{O}_{3}$ contents toward the dike, whereas the loss-on-ignition (LOI) shows the 
the opposite trend (Appendix 5.2, Figures 5.23 and 5.24). $\mathrm{Al}_{2} \mathrm{O}_{3}$ and $\mathrm{MgO}$ are minimally affected (Figures 5.23C and 5.23F). Although within the error rangeof the analysis, the high-alumna basalt sample from the contact zone shows subtle depletions in most of the major elements compared to another sample collected from the middle of the dike. Depletion and enrichment of $\mathrm{Na}_{2} \mathrm{O}$ and LOI, respectively (Figures 5.23B and 5.23E), are noted in the basalt specimen from the contact zone.

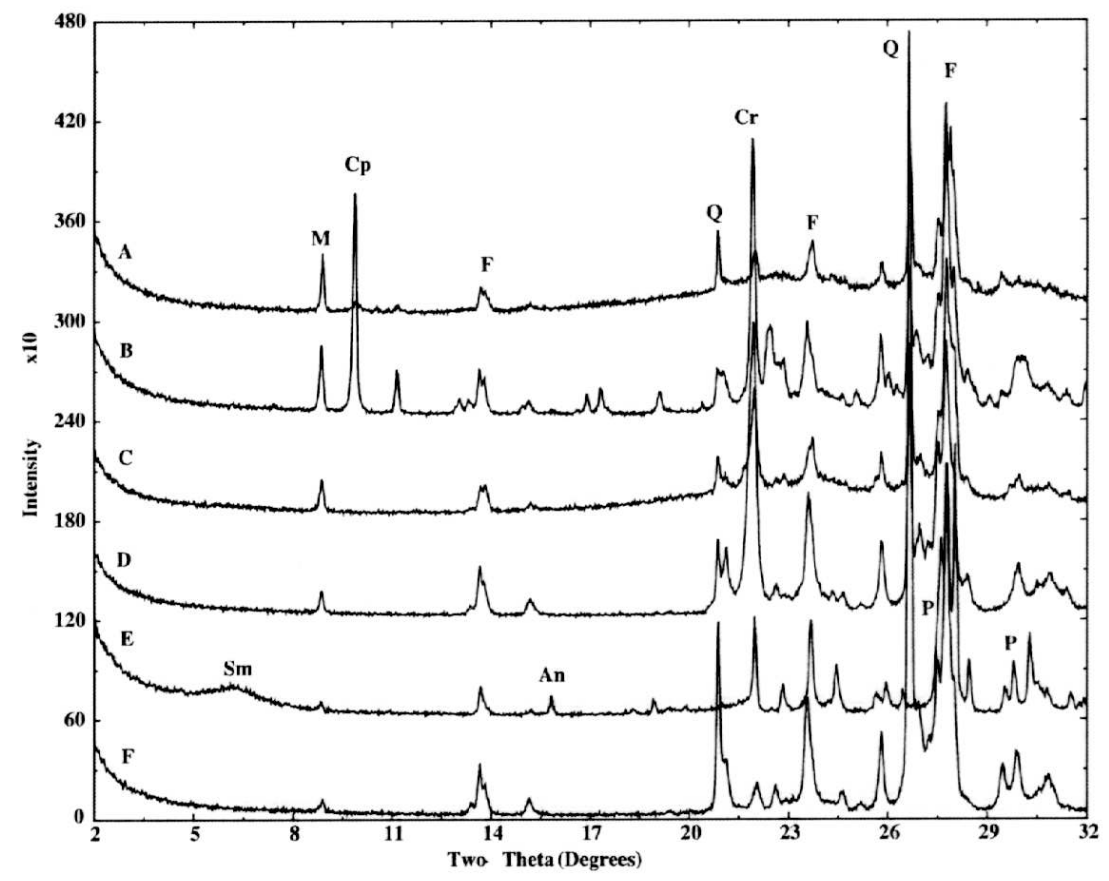

Figure 5.20. X-ray diffraction patterns of representative bulk samples from the Ammonia Tanks Tuff at the southeastern part of the Slanted Buttes. Samples collected at different intervals from the dike. For example at $34 \mathrm{~m}$ (A=PR95-1), $2.8 \mathrm{~m}$ (B=PR95-8), $2.4 \mathrm{~m}$ (C=PR95-9), $1.6 \mathrm{~m}$ ( $\mathrm{D}=\mathrm{PR} 95-10)$, recrystallized basalt from the contact $(\mathrm{E}=\mathrm{PR} 95-11)$, and $6 \mathrm{~m}(\mathrm{~F}=\mathrm{PR} 95-15)$. Patterns represent smectite $(\mathrm{Sm})$, mica $(\mathrm{M})$, clinoptilolite $(\mathrm{Cp})$, feldspar $(\mathrm{F})$, analcime $(\mathrm{An})$, quartz $(\mathrm{Q})$, cristobalite $(\mathrm{Cr})$, and pyroxene $(\mathrm{P})$.

The Ammonia Tanks Tuff shows insignificant variationsin its chondrite-normalized traceelement and rare-earth-element (REE) concentrations except for $\mathrm{Ba}, \mathrm{K}, \mathrm{Rb}, \mathrm{Sr}, \mathrm{Tb}$, and $\mathrm{Yb}$ (Figures 5.24A,B, Table 5.4). Except for $\mathrm{Eu}, \mathrm{Nb}$, and $\mathrm{Tb}$ enrichment, the basalt sample from the middle part of the dike contains lower trace element and REE contents compared with the Ammonia Tank Tuff(Figures 5.24A,B).

The major and trace-element compositions of the vitric and zeolitic tuffs beneath the sill are variable (Figure 5.23). The layer directly below the sill, the Tiva Canyon Tuff, is the uppermost unit of the Paintbrush Group and is partially fused and transformed to a $0.5-\mathrm{m}$ thick vitrophyre along the contact zone. It contains higher contents of major and trace elements and REE compared with the underlying opaline and zeolitized tuffs below it (Figures 5.23, 5.24). The vitrophyre has different major and trace elements compositions compared with the underlying samples (Appendices 5.1 and 5.2). For example, an opalized Tiva Canyon Tuff sample collected about a meter below the vitrophyre is enriched in silica (79.4\% wt), depleted in $\mathrm{Al}_{2} \mathrm{O}_{3}(8.8 \% \mathrm{wt})$ and $\mathrm{TiO}_{2}(0.79 \% \mathrm{wt})$, and contains lower content of LOI compared with the other samples collected above and below it (Appendix 5.2). This is also true for the trace elements and the REE contents except for Co and $\mathrm{Ba}$ (Table 5.4). Unlike the major, trace, and REE contents, the LOI generally appears to increase away from the sill (Figure 5.23E). 


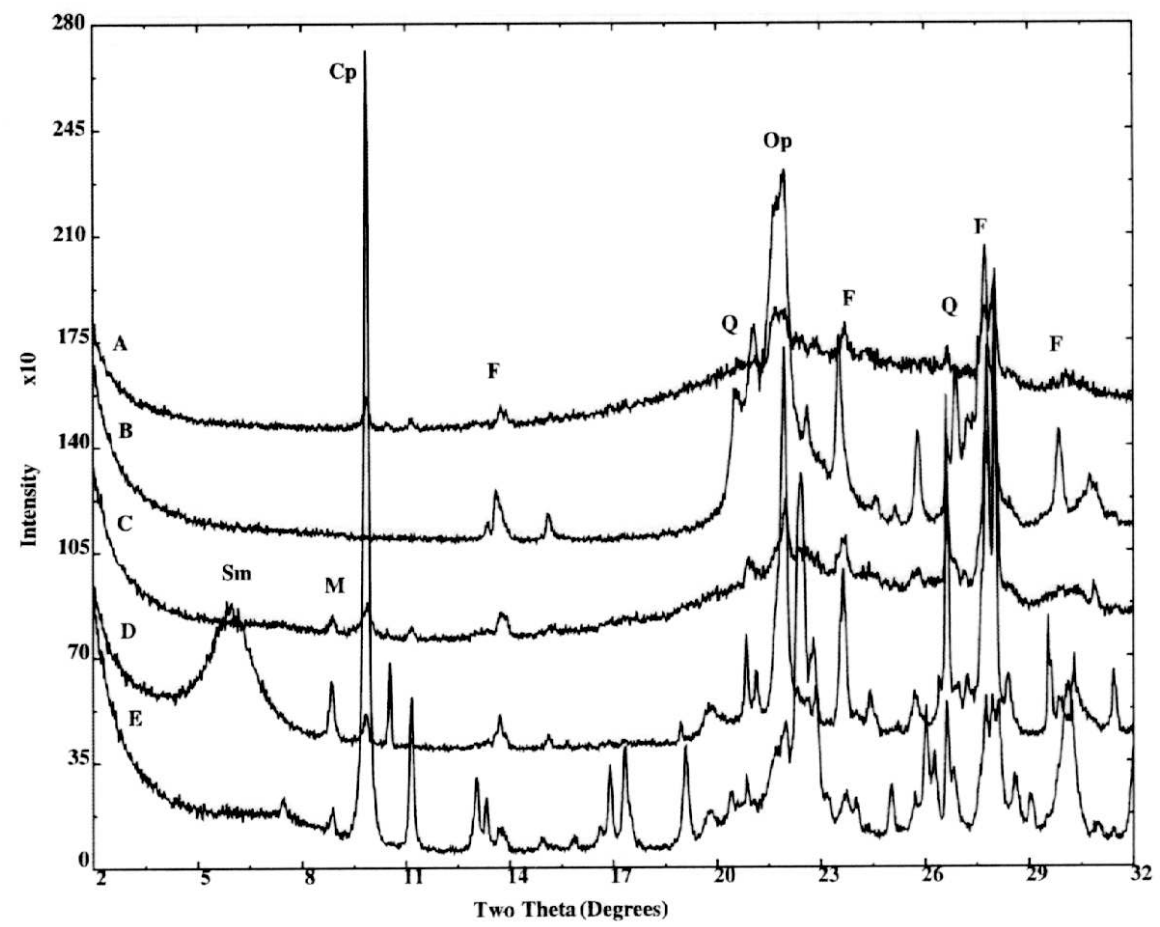

Figure 5.21. X-ray diffraction patterns of representative bulk samples from the Tiva Canyon Tuff at the southeastern part of the Slanted Buttes. The patterns ipresent a vitrophyre directly below the sill ( $A=P R 95-18)$, a meter below the vitrophyre ( $B=P R 95-19), 3 \mathrm{~m}(\mathrm{C}=\mathrm{PR} 95-20)$, devitrified tuff from the contact $(\mathrm{D}=\mathrm{PR} 95-21)$, and $8 \mathrm{~m}$ below the sill $(\mathrm{E}=\mathrm{PR} 95-22)$. Paterns represent smectite $(\mathrm{Sm})$, mica $(\mathrm{M})$, clinoptilolite $(\mathrm{Cp})$, feldspar $(\mathrm{F})$, quartz $(\mathrm{Q})$, cristobdite $(\mathrm{Cr})$, and opal (Op).

Samples from the virophyre and a tuff about $3 \mathrm{~m}$ below it were also analyzed for $\mathrm{B}, \mathrm{Br}, \mathrm{Cl}$, $\mathrm{F}, \mathrm{Li}, \mathrm{P}_{2} \mathrm{O} 5$, and $\mathrm{S}$ because these elements along with water form the bulk of volatile contents escaping during volcanic eruptions (Table 5.4). The vitrophyre sample contains slightly higher B, $\mathrm{Cl}$, and $\mathrm{S}$, whereas the sample furthest from the sill is enriched in $\mathrm{F}, \mathrm{Li}$, and $\mathrm{P}_{2} \mathrm{O}_{5}$ (Table 5.4).

Samples from the pumice fall beneath the Rainier Mesa Tuff intruded by a 9-m thick dike exhibit insignificant modifications in their major and trace-ement compositions like the other tuffs intruded by a sill and a dike along the eastern parto the Slanted Buttes. Except for $\mathrm{Na}_{2} \mathrm{O}$ and $\mathrm{Zr}$ contents that decrease away from the contact zone, there is no systematic geochemical variation with reference to the dike (Figure 5.23, Appendix 5.2).

\section{$f$ Discussion of Physical, Mineralogical, and Chemical Changeswithin the Contact}

Aureoles. The tuffs within the contact aureoles of the dikes and sill at Slanted Buttes exhibit variable physical and chemical changes although the intruding magmatic bodies have similar basaltic compositions (Table 5.3). For example, the volcanic glass in the dike-intruded Ammonia Tank Tuff was totally recrystallized to quartz, feldspar, and cristobalite within an asymmetrical contact aureole (Figure 5.19 A). Despite the thickness $(\sim 45 \mathrm{~m})$ and size of the sill, the contact aureole below the sill is not wider compared with the similar one developed adjacent to the $9-\mathrm{m}$ thick dike in the southeastern part of the Slanted Buttes. The Tiva Canyon Tuff beneath the sill is partially recrystallized into a quartz and feldspar-rich zone in one location and into a 0.5 -m-thick, dark brown and densely welded vitrophyre a few meters away $(\mathrm{ca} .10 \mathrm{~m})$. The contact aureole below the sill is about 5-m wide or less (Figure 5.19 B). 
Table 5.3. Quantitative X-ray diffraction data for Paiute Ridge samples.

\begin{tabular}{|c|c|c|c|c|c|c|c|c|c|c|c|}
\hline $\begin{array}{l}\text { Sample } \\
\text { Number }\end{array}$ & $\begin{array}{l}\text { Distance to } \\
\text { dike/sill (m) }\end{array}$ & $\begin{array}{l}\text { Volcanic } \\
\text { glass }\end{array}$ & Mica & Feldspar & Q Quartz & Cristobalite & Tridymite & Opal-CT & Clinoptilolite & Calcite & Smectite \\
\hline PR95-1P1 ${ }^{a}$ & 34.0 & 60 & 1.2 & 31.6 & 4.8 & 0.8 & & & & & \\
\hline PR95-2P1 ${ }^{\mathrm{a}}$ & 28.9 & 60 & 1.2 & 36.8 & 1.6 & 0.4 & & & & & \\
\hline PR95-3P1 ${ }^{a}$ & 22.4 & 60 & 0.8 & 35.6 & 3.2 & & & & & & \\
\hline PR95-4P1 ${ }^{\mathrm{a}}$ & 14.6 & 60 & 1.2 & 32.4 & 5.6 & 0.4 & & & & & \\
\hline PR95-5P1 ${ }^{\mathrm{a}}$ & 12.0 & 50 & 1.5 & 44.5 & 4.0 & & & & & & \\
\hline PR95-6P1 ${ }^{\mathrm{a}}$ & 7.8 & 50 & 2.0 & 41.0 & 7.5 & & & & & & \\
\hline PR95-7P1 ${ }^{\mathrm{a}}$ & 4.4 & 55 & 1.8 & 37.9 & 4.9 & 0.4 & & & & & \\
\hline PR95-8P1 ${ }^{\mathrm{a}}$ & 2.8 & & 2.0 & 50.0 & 5.0 & 4.0 & & & 40.0 & & \\
\hline PR95-9P1 ${ }^{a}$ & 2.4 & 31 & $2 \pm 1$ & $55 \pm 8$ & $7 \pm 1$ & $4 \pm 1$ & $1 \pm 1$ & & & & \\
\hline PR95-10P1 ${ }^{\mathrm{a}}$ & 1.6 & & $1 \pm 1$ & $69 \pm 10$ & $9 \pm 1$ & $13 \pm 1$ & $9 \pm 1$ & & & & \\
\hline PR95-11P1 & contact zone & & & 83.0 & & 1.0 & & & & & 16.0 \\
\hline PR95-12P1 ${ }^{\mathrm{a}}$ & contact zone & & & $69 \pm 10$ & $9 \pm 1$ & $9 \pm 4$ & & & & & \\
\hline PR95-13P1 ${ }^{\mathrm{a}}$ & 1.25 & & $1 \pm 1$ & $64 \pm 9$ & $13 \pm 1$ & $11 \pm 1$ & $12 \pm 1$ & & & & \\
\hline PR95-14P1 ${ }^{\mathrm{a}}$ & 2.85 & & $1 \pm 1$ & $62 \pm 9$ & $16 \pm 1$ & $10 \pm 1$ & $10 \pm 1$ & & $1 \pm 1$ & & \\
\hline PR95-15P1 ${ }^{a}$ & 6.0 & & $1 \pm 1$ & $57 \pm 8$ & $24 \pm 2$ & & & $6 \pm 3$ & $3 \pm 1$ & $9 \pm 2$ & \\
\hline PR95-18P1 ${ }^{b}$ & contact zone & 80.0 & & 13.4 & 0.4 & 0.8 & & & 5.6 & & \\
\hline PR95-19P1 ${ }^{b}$ & 1.5 & & & 34.0 & 9.0 & & & 57.0 & & & \\
\hline PR95-20P1 ${ }^{d}$ & 3.0 & 65.0 & 0.4 & 25.5 & 1.8 & 0.4 & & & 7.0 & & \\
\hline PR95-21P1 ${ }^{\mathrm{c}}$ & contact zone & & 1.0 & 49.0 & 3.0 & 9.0 & & & 5.0 & & 31.0 \\
\hline PR95-22P1 ${ }^{d}$ & 8.0 & & & 8.0 & 2.0 & 2.0 & & & 89.0 & & \\
\hline PR95-23P1 ${ }^{c}$ & 35.0 & & & 2.0 & 1.0 & & & 28.0 & 69.0 & & \\
\hline PR95-24P1 ${ }^{d}$ & contact zone & 80.0 & & 15.2 & 4.2 & 0.6 & & & & & \\
\hline PR95-27P1 ${ }^{d}$ & 1.8 & 80.0 & & 17.8 & 2.2 & & & & & & \\
\hline
\end{tabular}

a Ammonia Tanks Tuff

b Tiva Canyon Tuff and other Paintbrush Group

c Calico Hills Formation

d Pumice fall of Paintbrush Group 
Table 5.4. INAA and halogen data from Paiute Ridge, NTS, Nevada.

\begin{tabular}{|c|c|c|c|c|c|c|c|c|c|c|c|}
\hline Sample & PR95-1 & PR95-8 & PR95-10 & PR95-11 & PR95-16 & PR95-18 & PR95-19 & PR95-20 & PR95-21 & PR95-22 & PR95-29 \\
\hline $\mathrm{Na}_{2} \mathrm{O}$ & 3.15 & 2.73 & 3.92 & & 3.84 & 3.39 & 2.16 & 2.55 & 2.40 & 1.51 & 2.15 \\
\hline $\mathrm{K}_{2} \mathrm{O}$ & 5.20 & 5.50 & 5.90 & & 1.70 & 5.40 & 4.50 & 4.90 & 2.40 & 2.00 & 0.20 \\
\hline $\mathrm{CaO}$ & 2.70 & 1.57 & 0.67 & & 8.70 & 0.55 & 1.14 & 0.96 & 3.07 & 2.17 & 12.70 \\
\hline $\mathrm{Sc}$ & 2.44 & 2.49 & 2.42 & & 22.80 & 1.80 & 1.21 & 2.47 & 4.45 & 2.53 & 37.60 \\
\hline $\mathrm{Cr}$ & 0.00 & 0.00 & 0.00 & & 50.10 & 0.00 & 0.00 & 2.40 & 11.00 & 3.60 & 333.00 \\
\hline $\mathrm{FeO}$ & 1.19 & 1.26 & 1.27 & & 10.17 & 0.99 & 0.70 & 1.16 & 1.84 & 1.31 & 9.41 \\
\hline Co & 1.05 & 0.80 & 0.67 & & 33.30 & 0.14 & 0.53 & 1.01 & 2.96 & 1.52 & 48.80 \\
\hline $\mathrm{Ni}$ & 0.00 & 2.00 & 1.00 & & 31.00 & 0.00 & 1.00 & 5.00 & 0.00 & 6.00 & 157.00 \\
\hline $\mathrm{Zn}$ & 57.70 & 59.20 & 59.50 & & 104.00 & 91.70 & 68.70 & 92.00 & 54.70 & 94.50 & 99.00 \\
\hline As & 2.60 & 1.00 & 2.70 & & 0.80 & 2.90 & 1.11 & 2.58 & 1.23 & 0.76 & 1.90 \\
\hline $\mathrm{Br}$ & 1.29 & 0.00 & 0.42 & & 0.10 & 0.80 & 0.55 & 0.36 & 0.03 & 0.13 & 0.30 \\
\hline $\mathrm{Rb}$ & 143.50 & 85.50 & 174.90 & & 23.00 & 184.10 & 102.70 & 179.00 & 38.70 & 90.80 & 5.00 \\
\hline $\mathrm{Sr}$ & 270.00 & 728.00 & 99.00 & & 590.00 & 88.00 & 67.00 & 192.00 & 488.00 & 380.00 & 170.00 \\
\hline $\mathrm{Zr}$ & 295.00 & 302.00 & 289.00 & & 240.00 & 238.00 & 162.00 & 215.00 & 148.00 & 225.00 & 50.00 \\
\hline $\mathrm{Sb}$ & 0.38 & 0.18 & 0.38 & & 0.07 & 0.27 & 0.15 & 0.28 & 0.21 & 0.19 & 0.08 \\
\hline Cs & 3.30 & 1.13 & 2.61 & & 0.40 & 4.71 & 2.18 & 6.21 & 1.08 & 4.26 & 0.08 \\
\hline $\mathrm{Ba}$ & 701.00 & 717.00 & 551.00 & & 368.00 & 77.00 & 104.00 & 182.00 & 655.00 & 534.00 & 170.00 \\
\hline $\mathrm{La}$ & 68.70 & 67.90 & 66.70 & & 35.40 & 41.20 & 25.80 & 37.60 & 41.20 & 30.20 & 5.19 \\
\hline $\mathrm{Ce}$ & 125.60 & 127.80 & 128.40 & & 71.40 & 90.90 & 55.60 & 76.30 & 82.90 & 66.30 & 11.76 \\
\hline $\mathrm{Nd}$ & 41.00 & 42.30 & 42.00 & & 34.00 & 32.40 & 21.10 & 28.80 & 28.30 & 26.10 & 9.00 \\
\hline $\mathrm{Sm}$ & 7.18 & 7.36 & 7.48 & & 6.90 & 8.57 & 5.53 & 6.72 & 5.18 & 6.22 & 2.41 \\
\hline $\mathrm{Eu}$ & 0.83 & 0.83 & 0.79 & & 2.09 & 0.42 & 0.28 & 0.50 & 0.86 & 0.39 & 0.97 \\
\hline $\mathrm{Tb}$ & 0.81 & 0.84 & 0.94 & & 0.98 & 1.25 & 0.85 & 0.99 & 0.58 & 0.88 & 0.51 \\
\hline $\mathrm{Yb}$ & 3.09 & 2.99 & 3.39 & & 2.93 & 3.89 & 3.20 & 3.35 & 2.03 & 3.13 & 2.06 \\
\hline $\mathrm{Lu}$ & 0.47 & 0.45 & 0.49 & & 0.42 & 0.56 & 0.45 & 0.48 & 0.30 & 0.46 & 0.31 \\
\hline Hf & 8.21 & 7.95 & 8.14 & & 5.49 & 8.55 & 5.99 & 7.47 & 4.41 & 7.84 & 1.54 \\
\hline Ta & 1.64 & 1.72 & 1.85 & & 2.19 & 1.65 & 1.13 & 1.55 & 1.17 & 1.48 & 0.26 \\
\hline W & 1.00 & 0.60 & 0.60 & & 0.30 & 1.80 & 0.50 & 1.30 & 0.60 & 0.50 & 1.20 \\
\hline $\mathrm{Au}$ & 0.50 & 1.00 & 0.00 & & 1.00 & 0.00 & 1.50 & 2.00 & 0.30 & 0.80 & 7.10 \\
\hline Th & 22.40 & 24.10 & 25.40 & & 3.92 & 25.30 & 18.02 & 23.70 & 18.01 & 21.50 & 0.28 \\
\hline $\mathrm{U}$ & 4.01 & 2.62 & 5.16 & & 0.85 & 5.03 & 2.85 & 4.25 & 1.58 & 2.57 & 0.23 \\
\hline B & 21.00 & & & 14.00 & & 30.00 & & 20.00 & & & \\
\hline $\mathrm{Br}$ & 1.00 & & & 1.00 & & 1.00 & & 1.00 & & & \\
\hline $\mathrm{Cl}$ & 371.00 & & & 38.00 & & 134.00 & & 78.00 & & & \\
\hline $\mathrm{F}$ & 457.00 & & & 831.00 & & 641.00 & & 758.00 & & & \\
\hline $\mathrm{Li}$ & 16.00 & & & 8.00 & & 8.00 & & 13.00 & & & \\
\hline S & 93.00 & & & 65.00 & & 29.00 & & 21.00 & & & \\
\hline $\mathrm{P}_{2} \mathrm{O}_{5}$ & 422.00 & & & 4921.00 & & 93.00 & & 348.00 & & & \\
\hline
\end{tabular}




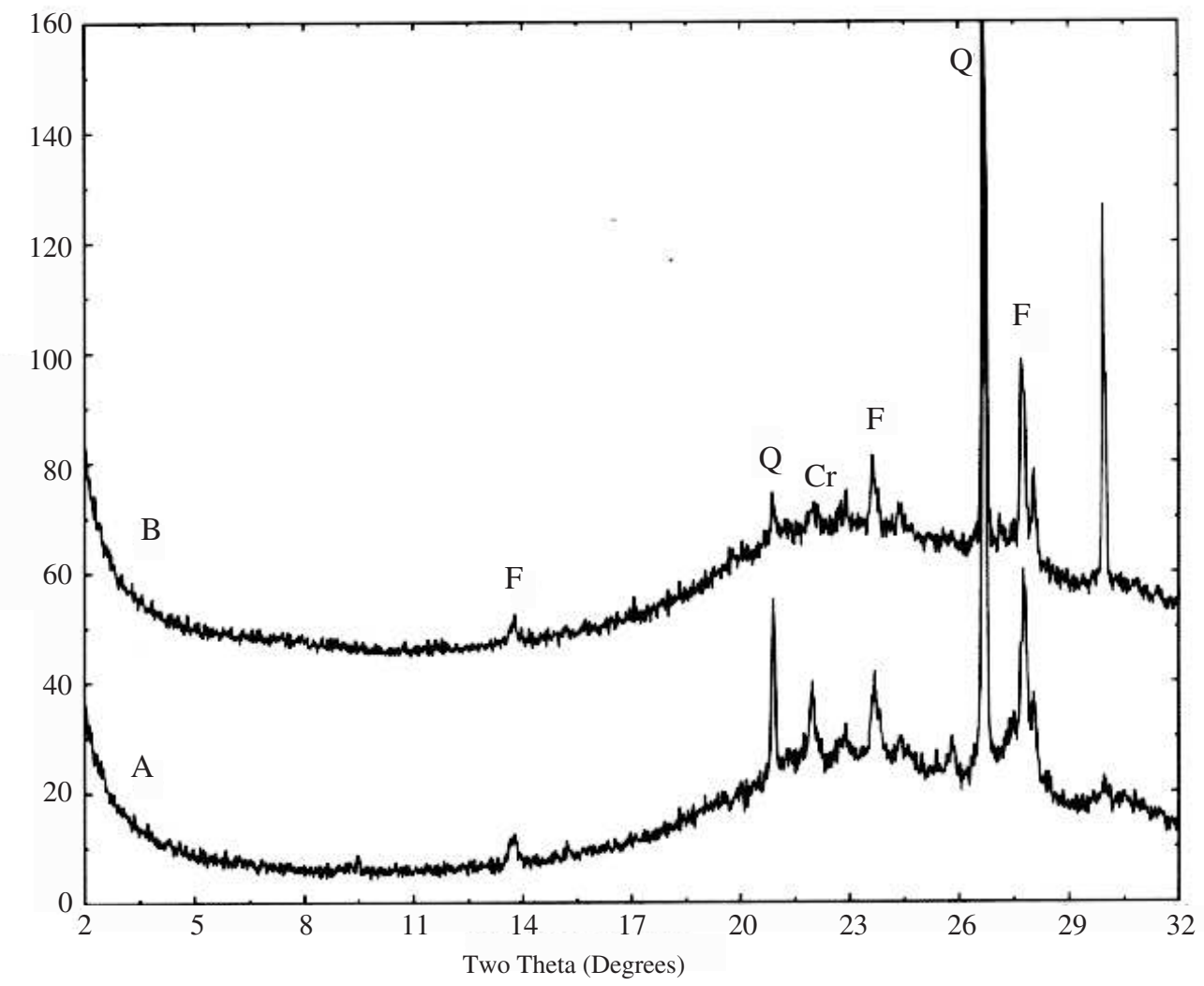

Figure 5.22. X-ray diffraction patterns of representative bulk samples from a pumice fall in the northern part of Slanted Buttes. Samples collected at the contact with the dike (A=PR95-24) and $1.8 \mathrm{~m}$ away (B=PR95-27). Patterns represent feldspar (F), quartz (Q), and cristobalite (Cr).

The poorly compacted but well-sorted pumice fall along the southern part of the Slanted Buttes was also fused to a light gray vitrophyre characterized by abundant and intact spherical glass blebs and recrystallized coarse quartz phenocrysts. Here, the contact aureole is less than a meter wide, although the dike is as wide as the other one from the eastern part of the Slanted Buttes.

Processes related to hydrothermal circulation and alteration appear to be minimally developed in the intruded country rocks. Brecciation or stoping beneath the sill and adjacent to the dikes where the samples were collected is minimal except around the plugs. The mafic intrusions along the contact are characterized by narrowly spaced joints that are parallel to the strike of the intrusive body.

The dike along the southeastern part of the Slanted Buttes (Figure 5.19A) is within $100 \mathrm{~m}$ from a plug, whereas the sill and the other dike are farthest from the plug area $(1 \mathrm{~km}$ and $2 \mathrm{~km}$ distant, respectively), which may explain the localized nature of the contact metamorphic aureoles. According to Delaney and Pollard (1982), insignificant contact metamorphic zones around dikes and sills may be attributed to shallow emplacement and higher cooling rates of these thin magmatic bodies. The absence of compositional variation in the basaltic rocks probably suggests minimal residence time, and rapid ascent and emplacement. Dikes generally exhibit compositional and textural zonations because of multiple injections of magma during dike intrusions (Delaney and Pollard, 1982). However, this is not the case in the dikes of the Slanted Buttes area. They generally exhibit homogeneous internal chemical compositions (i.e., edge versus center of dike), and there is little compositional variation between dikes, sills, flows, and plugs that are widely separated from each other (Crowe et al., 1986). Moreover, the dikes along the contact with the host tuffs are vesicular indicating the escape of volatiles, a possible evidence for shallow emplacement. 

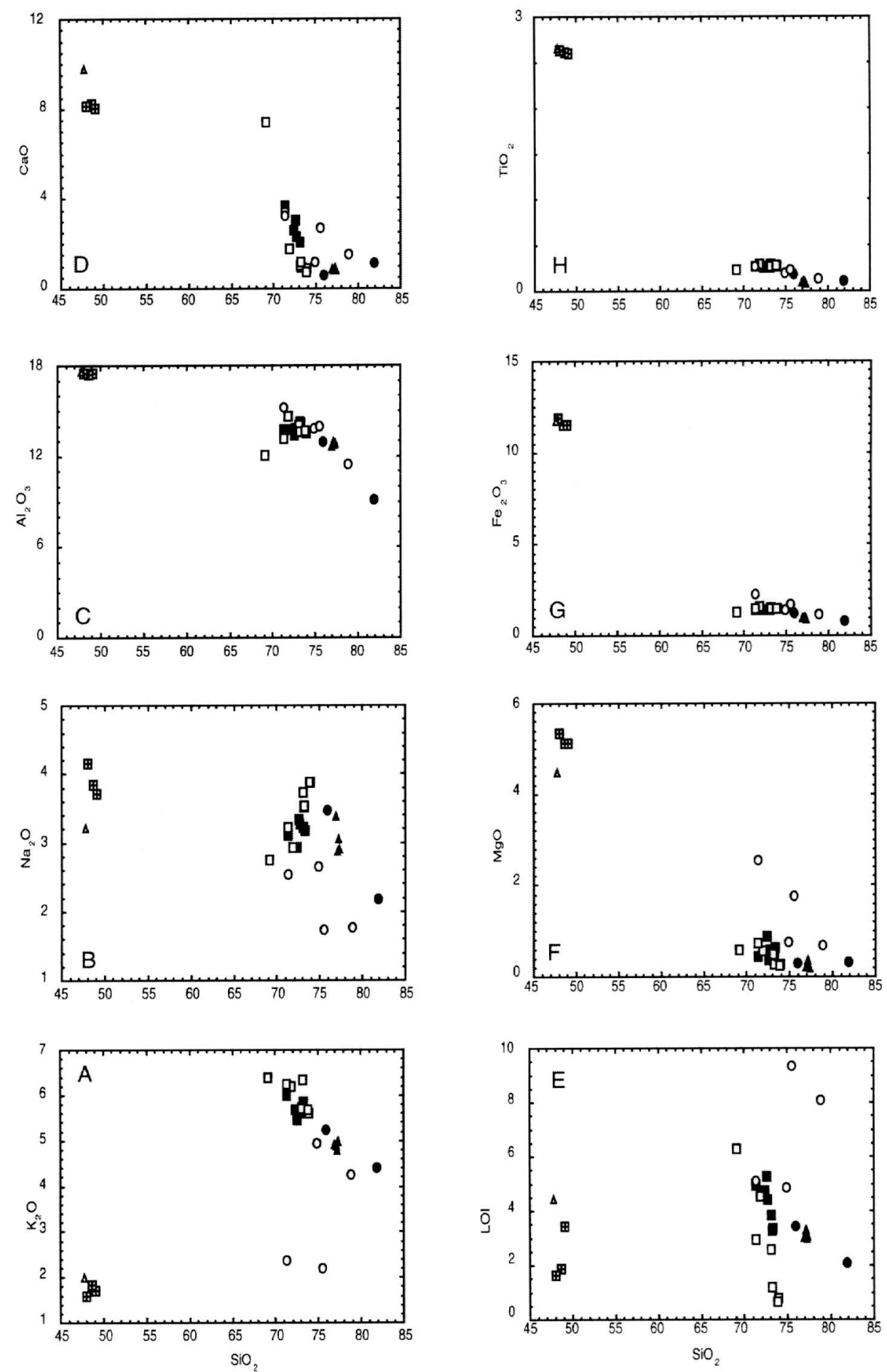

Figure 5.23. Variation diagrams of major elements (wt \%) versus $\mathrm{SiO}_{2}$. Analysis calculated to $100 \%$ volatile free. Symbols represent samples from the Ammonia Tanks Tuff (open squares=PR95-1 to 7; solid squares $=$ PR95-8 to 10 and 12 to 13), dike and plug samples n Ammonia Tank Tuff (open square filled with cross), Tiva Canyon Tuff (solid circle=PR95-18 and 19, open circle=PR95-20 to 23), pumice fall ( olid triangle=PR95-24 to 27), and dike in pumice fall (open triangle=PR95-28). 

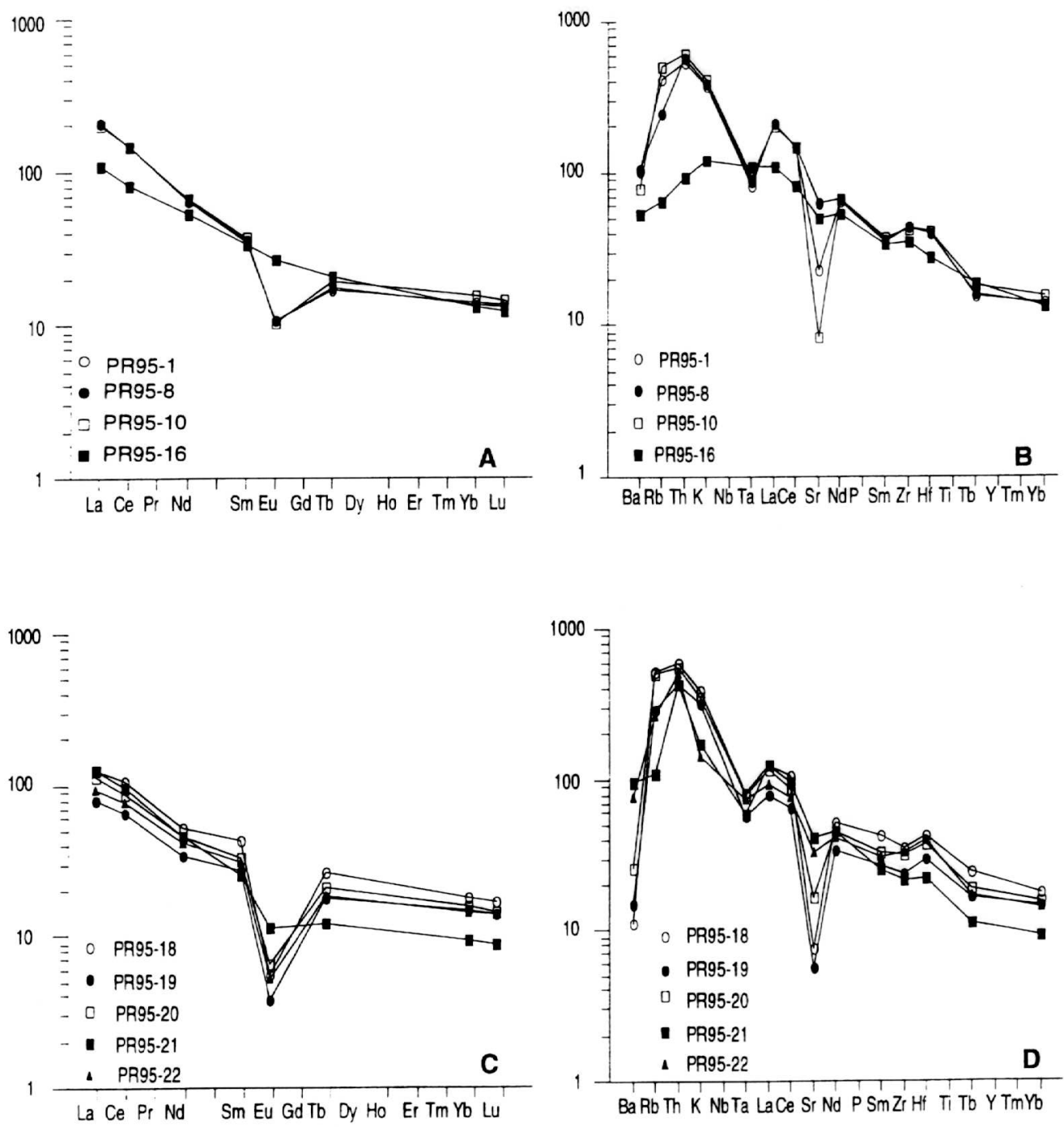

Figure 5.24. Conventional chondrite-normalized rare earth element plotof the Ammonia Tanks Tuff ( $\mathrm{A}=\mathrm{PR} 95-1,8$, and 10), a dike within the same tuff ( $\mathrm{A}=\mathrm{PR} 95-16)$, and the Tiva Canyon Tuff ( $C=$ PR95-18 to 22). Plots B and D represent multi-element chondrite-normalized spidergrams of the same samples plotted in A and C (Nakamura, 1974; Thompson et al., 1984).

Although the tuffs were intruded by the same high-alumna alkaline basalt magma, the effects of contact metamorphism were variable. For example, contact metamorphism of the Ammonia Tank Tuff is represented by a localized devitrified zone. However, the Tiva Canyon Tuff within the contact aureole is characterized by a devitified zone adjacent to a fused and quenched glass. Experimental studies indicate that the raeof devitrification of natural rhyolitic glass significantly increased in the presence of water and dkali-rich solutions (Lofgren, 1970). According to Lofgren $(1970,1971)$, the devitrification process involves hydration followed by devitrification. This process involves water diffusion through silicate glass forming hydroxide ions $\left(\mathrm{OH}^{-}\right)$that break the bridging of Si-O bonds by $\mathrm{OH}^{-}$and make available the newly freed $\mathrm{SiO}_{4}$ tetrahedra for the formation of quartz and feldspar crystals. The hydration and 
five orders of magnitude in the presence of $\mathrm{Na}$ and $\mathrm{K}$ compounds compared with pure water. Lofgren (1971) also recognized in his experimental runs the existence of a devitrification zone behind hydration fronts. He attributed this incomplete devitrification to the lack of sufficient water or alkalis or low temperature $\left(\sim 240^{\circ} \mathrm{C}\right)$ and pressure $(50 \mathrm{MPa})$ where nucleation ceased as the supply of water diminished. The limited devitrification processes noted in the host rocks in our study may be related to the intrusion of the basaltic magmas into an unsaturated environment.

The mineralogical and geochemical data indicate the extent of physical and chemical interactions between the intruding basaltic magmas and the vitric and zeolitic tuffs. The dikes and sill show a range of physical modifications represented by minor deformation features that include narrowly spaced joints parallel to the strike of dikes or sills, contact welding, vesiculation along the contact with the host rock, and alteration. The dikes along the contact zone are generally altered and break into thin plates of the same thickness and dimensions. Although the dikes intrude tuffs of different ages and compositions, the high-alumna alkali basalts exhibit minor chemical interaction with the host tuffs. Comparison between basaltic specimens from the edge and center of a dike and from a plug about $100 \mathrm{~m}$ to the south (Figure 5.19 A) shows minor variations in major and traceelement compositions. For example, the sample from the plug is less altered with lower $\mathrm{SiO}_{2}, \mathrm{~K}_{2} \mathrm{O}$, LOI, $\mathrm{Cr}, \mathrm{Ni}, \mathrm{Rb}$, and $\mathrm{Ba}$ and higher $\mathrm{Fe}_{2} \mathrm{O}_{3}, \mathrm{MgO}, \mathrm{Na}_{2} \mathrm{O}$, and $\mathrm{Zn}$ compared to the dike samples (Appendix 5.2). A basalt sample from the contact with the Ammonia Tank Tuff is partially altered and contains smectite and somewhat higher $\mathrm{LOI}, \mathrm{SiO}_{2}, \mathrm{~V}$, and $\mathrm{Zn}$ and lower $\mathrm{CaO}, \mathrm{Na}_{2} \mathrm{O}, \mathrm{K}_{2} \mathrm{O}, \mathrm{Ni}$, $\mathrm{Sr}, \mathrm{Y}$, and $\mathrm{Zr}$ compared with another sample from the center of the same dike (Appendix 5.2). Basalt specimens from the contact with the tuffs have higher LOI values (3.43-4.4\% wt) compared with samples collected more than $4 \mathrm{~m}$ away $(1.62-1.89 \% \mathrm{wt})$ from the basalt-tuff contact. The geochemical results suggest that there was some transfer of elements to and from the dike and the host tuff during the magmatic intrusion. For example, the fused tuff was dehydrated, whereas the basalt was hydrated. The basalt contains a slightly higher content of silica consistent with a devitrification process, whereas the adjacent tuff inherited minor amounts of $\mathrm{Ni}$ along with the recrystallization of volcanic glass to feldspar and silica.

In most places the host tuffs adjacent to the dikes are fused and massive with none of the platy jointing found in the adjacent basaltic intrusions. Moreover, there is no breccia zone developed at the sampling locations except for a narrow baked and fused zone. According to Delaney (1980), pore fluid pressure increases due to heating in impermeable rocks, such as shales and siltstone, during dike intrusion, resulting in higher effective stresses that possibly lead to brecciation. Hydraulic rupture related to hydrothermal brecciation triggered by boiling and rapid release of confining pressure of fluids in fractures and intergranular pores was documented in subsurface core samples obtained during the experimental Continental Scientific Drilling Project in the Valles caldera, Jemez Volcanic field, New Mexico (Hulen and Nielson, 1988). Thus, the absence of breccias around the dikes and sills at our sample sights may be related to the permeable nature of the host tuffs, absence of pore fluids, heat loss from the dikes and sill and short duration of heat transfer to the host rocks.

The insignificant difference in chemical compositions between the tuffs within and outside the contact aureole indicates minimal hydrothermal activity. The $\mathrm{B}, \mathrm{Br}, \mathrm{Cl}, \mathrm{F}, \mathrm{Li}, \mathrm{S}$, and $\mathrm{P}_{2} \mathrm{O}_{5}$ contents of samples from the Ammonia Tank Tuff outside the contact aureole and a recrystallized basalt from the contact with the tuff show variable enrichments in certain elements characteristic of silicic and basaltic rocks except for $\mathrm{S}$ and $\mathrm{F}$ contents (Table 5.4). The results cannot be used to assess the effect of contact metamorphism because the two samples are more than $30 \mathrm{~m}$ apart. However, two samples from the contact aureole beneath the sill show no apparent trend in their $\mathrm{B}, \mathrm{Br}, \mathrm{Cl}, \mathrm{F}, \mathrm{Li}$, 
$\mathrm{S}$, and $\mathrm{P}_{2} \mathrm{O}_{5}$ contents although these elements are generally sensitive to elevated temperatures. The vitrophyre (PR95-18) is directly beneath the sill and contains higher contents of $\mathrm{Cl}, \mathrm{B}$, and $\mathrm{S}$, whereas the other sample (PR95-20), which is about $3 \mathrm{~m}$ below it, has higher F (Appenidx 5.2).

Different processes operated during the intrusion of the sill into the Tiva Canyon Tuff compared with the changes observed in the Ammonia Tanks Tuff within the contact aureole. For example, mineralogic analyses of the Tiva Canyon Tuff beneath the sill suggest that the tuff along the contact was totally devitrified, while a few meters away $(\sim 10 \mathrm{~m})$ the same unit was altered into a $0.5-\mathrm{m}$ thick densely welded vitrophyre with about $80 \%$ volcanic glass (Table 5.3, Figure 5.21). The presence of minor amounts of clinoptilolite in the vitrophyre and devitrified tuff suggests that the Tiva Canyon Tuff was zeolitized before the intrusion. If this interpretation is correct, the clinoptilolite grains are remnants of a preintrusion alteration process within the contact aureole rather than postintrusion diagenetic phases. If the volcanic glass was destroyed by devitrification, there would be no raw material for clinoptilolite diagenesis after the basaltic intrusion. About a meter below the vitrophyre, the tuff (PR95-19) is banded with a greenish layer that is replaced by opal. The cristobalite probably formed by devitrification after original deposition of the tuff rather than from the effect of the sill. No volcanic glass is present in the lowermost two samples that are about $8 \mathrm{~m}$ and $35 \mathrm{~m}$ beneath the sill. These altered tuffs are dominated by secondary minerals such as clinoptilolite (69-89\%), opal-CT (28\%), and cristobalite (2\%). From the mineralogic and geochemical data of the Tiva Canyon Tuff below the sill, it appears that the volcanic glass was altered to clinoptilolite and opal-CT prior to the intrusion of the sill. The occurrence of a $10-\mathrm{cm}$ thick opaline zone about a meter below the vitrophyre corroborates this suggestion. Hydrolysis of glass raises the silica activity $\left(\mathrm{a}_{\mathrm{SiO} 2}\right), \mathrm{pH}$, and activity ratios of $\left(\mathrm{Na}^{+}+\mathrm{K}^{+}\right) / \mathrm{H}^{+}$creating a conducive environment for the crystallization of smectite, zeolites, opal-CT (Hay, 1995). Although the upper stability limit of clinoptilolite and opal-CT is about $100^{\circ} \mathrm{C}$ (Levy and O'Neil, 1989; Iijima and Ogihara, 1995), these secondary minerals exhibit no apparent effect from the sill. During burial diagenesis, clinoptilolite alters to analcime and to albite in the temperature ranges of $76^{\circ}-91^{\circ} \mathrm{C}$ and $120^{\circ}-124^{\circ} \mathrm{C}$, respectively (Iijima and Ogihara, 1995). However, clinoptilolite can alter to analcime in the presence of $\mathrm{Na}^{+}$cation as has been well documented in saline, alkaline-lake deposits (Surdam and Sheppard, 1978; Moncure et al., 1981). X-ray diffraction analysis of samples from the contact aureole indicates no analcime. Lack of $\mathrm{Na}^{+}$cation may be a possible explanation for the absence of analcime and albite in the altered tuffs within the contact aureole. In fact, devitrification rate is higher in the presence of alkali solutions compared with pure water (Lofgren, 1970), and this may explain the localized nature of the contact aureole below the 45-m thick sill. The alkali contents $\left(\mathrm{Na}_{2} \mathrm{O}\right.$ and $\left.\mathrm{K}_{2} \mathrm{O}\right)$ of the Tiva Canyon samples from the contact aureole are depleted except for a sample from the vitrophyre zone, and this may be related to loss of alkalis during zeolitization (Appendix 5.2; Hay, 1995). The abundance of clinoptilolite in the lowermost samples from the Paintbrush Group and the Calico Hills Formation tuffs suggests that thermal effect from the sill was minimal.

Although the dike-intruded Ammonia Tank Tuff within the contact aureole is completely devitrified, a similarly intruded pumice fall at the east side of Slanted Butte (Figure 5.19C) does not show the same kind of mineralogical modification. The insignificant alteration around the dike may be related to low temperature and insufficient fluids.

Implications for Magmatic Hazards and Potential Repository Heat at Yucca Mountain. The natural analog studies of magmatic intrusions are aimed at understanding the range of subsurface processes that may occur in a potential repository system. This includes the potential repository itself and the surrounding natural barriers. Subsurface processes can be divided into (a) 
magmatic intrusions and eruptions and related thermal perturbation associated with a magmatic intrusion (short term) and (b) those that occur over a long term as the hydrologic system is reestablished with altered hydrologic and mineralogical properties (Valentine et al., 1993). The long term effects include the possibility of perched water near low-permeability intrusive bodies (e.g., dikes and sills), possible fast paths along intrusion-induced fractures, and reduced chemical retardation properties of the country rock resulting from hydrothermal alteration. Results of field studies indicate the extent of alteration processes related to small and shallow basaltic intrusions into vitric and zeolitized tuffs. Such results are important for performance assessment of basaltic magma intrusions into or close to a potential repository environment. The field studies also provide data that can be used to evaluate the effects of heat from decay of radioactive waste in a potential repository environment. The field and laboratory data from the natural analog studies could be used to build confidence and intuition and to calibrate modeling of such processes with similar physical and chemical environments if the need arises (e.g., contact metamorphism from heat generated from a high-level radioactive waste in a potential repository environment).

The field and analytical data from the Slanted Buttes, located about $40 \mathrm{~km}$ northeast of Yucca Mountain, provide information about the contents of lithic fragments in the intrusive bodies, volatile contents and thermal and degassing effects of the dikes and sill, and degree of alteration of host rocks adjacent to the basaltic intrusions. The sill and dikes were possibly intruded into a shallow unsaturated environment a few hundred meters from the paleosurface as indicated by reconstruction of stratigraphy above the intrusions (Valentine et al., 1993; Ratcliff et al., 1994). This is consistent with the limited nature of the contact metamorphic aureole and devitrification and the presence of vesicles along the edges of the basaltic intrusions. The depth of intrusion may be comparable to the potential repository environment at Yucca Mountain. The Slanted Buttes sites can be used as natural analogs to delineate the different geologic processes that could be potentially initiated around a high-level radioactive waste if a basaltic magma intrudes into or close to a potential repository.

Based on these studies, there is no indication for extensive hydrothermal transfer from the basaltic intrusions into the host silicic and zeolitized tuffs. Field and analytical evidence from the localized contact metamorphic aureoles and devitrification of the silicic tuffs adjacent to the intrusion, minimal hydrothermal alteration, and presence of low-temperature minerals at close proximity to the intrusions suggest insignificant effects of the shallow basaltic intrusions on the vitric and zeolitized tuffs. In fluid-deficient systems, the rate and extent of water-rock interactions are significantly diminished (Esposito and Whitney, 1995). Although there are remnants of scoria deposits that suggest explosive eruptions, the host rocks adjacent to the sills and dikes do not record the effects of volatiles or water. If the field data are consistent with the emplacement of the intrusive bodies into unsaturated vitric and zeolitized tuffs, the volatile contents of the basaltic intrusions were insignificant. In fact, the absence of widespread devitrification of the tuffs along the contact zone appears to reflect lack of aqueous solutions (Lofgren, 1971). Fracture zones in the host rocks are filled with opal and calcite. These secondary minerals are possibly related to zeolitization processes that occurred prior to the basaltic intrusions.

Volatile contents of the basaltic intrusions (e.g., plugs, dikes, and sills) appear to have been small, consistent with the localized nature of the contact metamorphic zone. Planar joints developed within the basalt intrusions along the contacts are devoid of secondary minerals. Thermal and degassing effects related to the basaltic intrusions are also insignificant as indicated by the higher of $\mathrm{B}, \mathrm{Cl}, \mathrm{F}$, and $\mathrm{S}$ contents of samples within the contact aureole. This may be related 
to the limited nature of hydrothermal circulation and alteration developed around these basaltic bodies, consistent with intrusions into an unsaturated environment.

g. Conclusion. Localized contact metamorphic zones were developed in vitric and zeolitized tuffs intruded by high-alumna alkali basalt magma. The dikes are about 9-m wide, whereas the sill is about 45-m thick. The dikes were intruded into vitric tephra of the Ammonia Tanks Tuff of the Timber Mountain Group and units of the Paintbrush Group. The sill, which is an offshoot of a dike that is about $1 \mathrm{~km}$ from a plug, intruded into a zeolitized Tiva Canyon Tuff. The sizes of the contact aureoles around the intrusions are variable and range from about 0.5 to $6 \mathrm{~m}$. Although the tuffs are poorly consolidated and permeable, hydrothermal circulation and alteration related to the intrusions were not widespread. The localized nature of these processes may be related to rapid loss of heat from the intrusive bodies, shallow emplacement into an unsaturated environment, and lack of fluids within the intruded tuffs. Devitrification of tuffs is enhanced in the presence of aqueous solutions and alkalis.

Mineralogical modifications within the intruded tuffs indicate the extent of contact metamorphism. Volcanic glass in the Ammonia Tank Tuff is totally recrystallized to feldspar, quartz, and cristobalite within the contact zone. Major, trace, and rare earth element compositions are subtly modified compared with the mineralogy. Water content is clearly modified in the basalt and the adjacent tuffs. Unlike the Ammonia Tanks Tuff, a pumice fall intruded by a dike of the same size formed a fused glassy tuff with about $80 \%$ glass and with no apparent variation in chemistry and mineralogy compared with a sample collected outside the contact aureole. The Tiva Canyon Tuff below the sill was devitrified and also altered to a vitrophyre within a short distance directly below the sill.

Based on the field and laboratory results, the effect of the basaltic intrusions was confined to the immediate contact zone, and there were no widespread hydrothermal circulations and alterations in the poorly-welded tuffs. The occurrence of low-temperature clinoptilolite and opal also suggests that thermal transfer into the adjacent country rock was minimal. The lack of widespread brecciation around the dikes and sill may be consistent with intrusion into a shallow unsaturated environment. The natural analog studies at Slanted Buttes could be used to delineate the different geologic processes that could be initiated around a potential high-level radioactive waste repository if a basaltic magma intrudes into or close to a potential repository, or heat generated from a potential high-level radioactive waste repository alters the host rock.

\section{Grants Ridge Analog Site.}

a. Introduction. We studied contact metamorphic effects on poorly consolidated late Pliocene ash flow tuffs and overlying volcaniclastic layers that were intruded by a basaltic plug and capped by thick scoria deposits. The study site is located in west-central New Mexico within the southwest confines of the Pliocene Mt. Taylor volcanic field (Figure 5.25). The area is characterized by northeast-trending discontinuous mesa. The plug responsible for the widespread basaltic lavas capping the mesa is located in the northeastern part of this discontinuous mesa (termed East Grants Ridge) about $12 \mathrm{~km}$ southwest of Mt. Taylor.

Systematic studies of contact metamorphic processes require the understanding of hydrothermal activity, structural deformation, brecciation, thermal, degassing, and volatilization effects on the host rocks during magmatic intrusion. The East Grants Ridge site provides an ideal geologic section where a thick ( 150-m wide) basaltic plug intruded into vitric, unwelded, porous 
silicic rocks. We collected samples at different locations from the plug and the host rocks to map the aerial extent of alteration related to the intrusion. The effects of an intrusion on the host rocks are generally manifested by physical changes such as compaction and change in color. Moreover, such effects could be mapped by geochemical modifications that lead to enrichments and depletions in the host rocks due to recrystallization and hydrothermal activity. Widespread hydrothermal activity can develop in such an environment provided there is sufficient water. Deformation and brecciation of the host rocks caused by the intruding magmatic body create radial fracture systems that provide important fluid pathways.

Here, we present results of our field and laboratory studies. Mineralogical and geochemical data on bulk and pumice samples from within and outside the contact metamorphic zone provide information on the behavior of major, trace, rare earth element, and gaseous volatile contents of these rocks.

b. Geologic Background. East Grants Ridge is made up of basaltic and silicic rocks that are unconformably exposed on top of sandy shale and silty sandstone units of the Upper Cretaceous Mancos Shale (Kerr and Wilcox, 1963; Thadden et al., 1967). These rocks are well exposed along the east side of this northeast-trending discontinuous mesa (Figure 5.25). Initial volcanic activity at East Grants Ridge was represented by a pyroclastic eruption that was followed by dome-building felsite, obsidian, and perlite lavas. The silicic tephra is represented by crystal-poor ash flows, pumiceous falls, and surge deposits that are mostly exposed along the southwest flank of the rhyolite-obsidian-perlite dome complex. According to Kerr and Wilcox (1963), the lava dome has a crystal-poor rhyolite core surrounded by flow-banded obsidian and perlite flows that hydrated under magmatic conditions. The transition from a rhyolite core to an obsidian zone is gradational with no interruption in the flow banding, suggesting contemporaneous emplacement (Kerr and Wilcox, 1963). Vapor-phase crystallization is represented by the deposition of tridymite, topaz, and garnet in lithophysae within the rhyolite and obsidian flows. The silicic rocks of East Grants Ridge were classified as topaz rhyolites because of high concentrations of $\mathrm{F}(0.5 \%), \mathrm{Li}$, and $\mathrm{Rb}$, and the occurrences of vapor phase garnet, topaz, and tridymite in lithophysae in the rhyolite lavas (Christiansen et al., 1983). K/Ar dating of rhyolite from the dome complex yielded apparent ages of 3.3 Ma (Lipman and Mehnert, 1979).

The silicic tephra sequence of East Grants Ridge is covered by 0.5-2 $\mathrm{m}$ thick lithic-rich reworked and partially baked volcaniclastic sedimentary unit that contains lenses of coarse pebbles. This unit is poorly consolidated and sorted and exhibits graded bedding. However, the upper 20 to $30 \mathrm{~cm}$ of this orange sedimentary layer is moderately consolidated because of baking effects of the overlying scoria deposit. Although the volcaniclastic layer crops out on both sides of the plug, its lateral exposure is discontinuous because of talus and landslide accumulations from the overlying scoraceous deposit. A localized outcrop of this reworked tuff was identified and sampled about 300 $\mathrm{m}$ on the northeast side of the plug. The volcaniclastic unit is totally fused and brecciated adjacent to the plug (Figure 5.26, samples 5a and 5b inset map). 


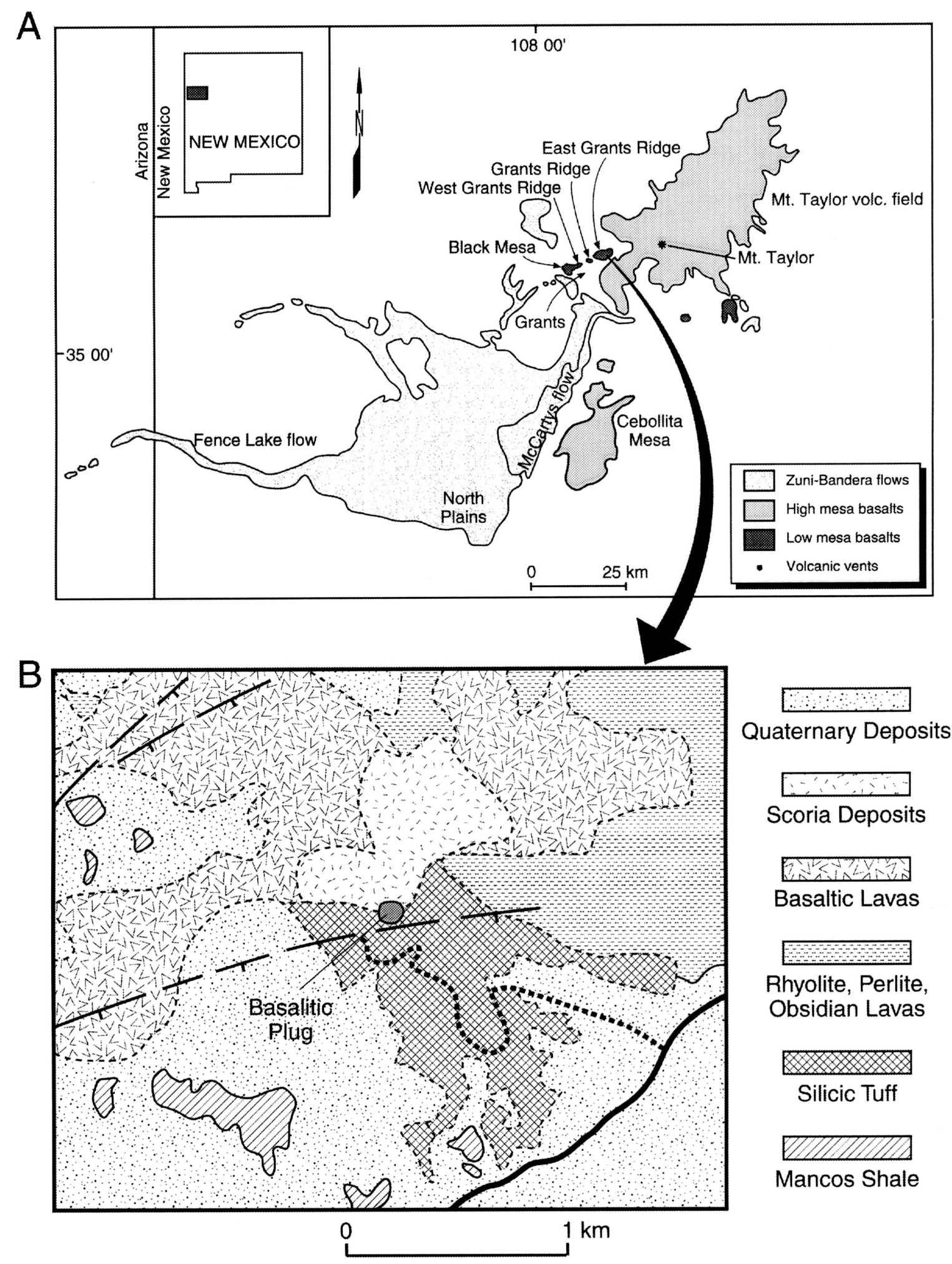

Figure 5.25. Distribution of volcanic rocks of the Pliocene Mt. Taylor and the Pleistocene ZuniBandera volcanic fields (A) of west-central New Mexico (Laughlin et al., 1994). A detailed geologic map of the East Grants Ridge located along the southeastern part of the Mt. Taylor volcanic field (A) is also given (B). The basaltic plug is located in the middle of the map (Thaden et al., 1967). 


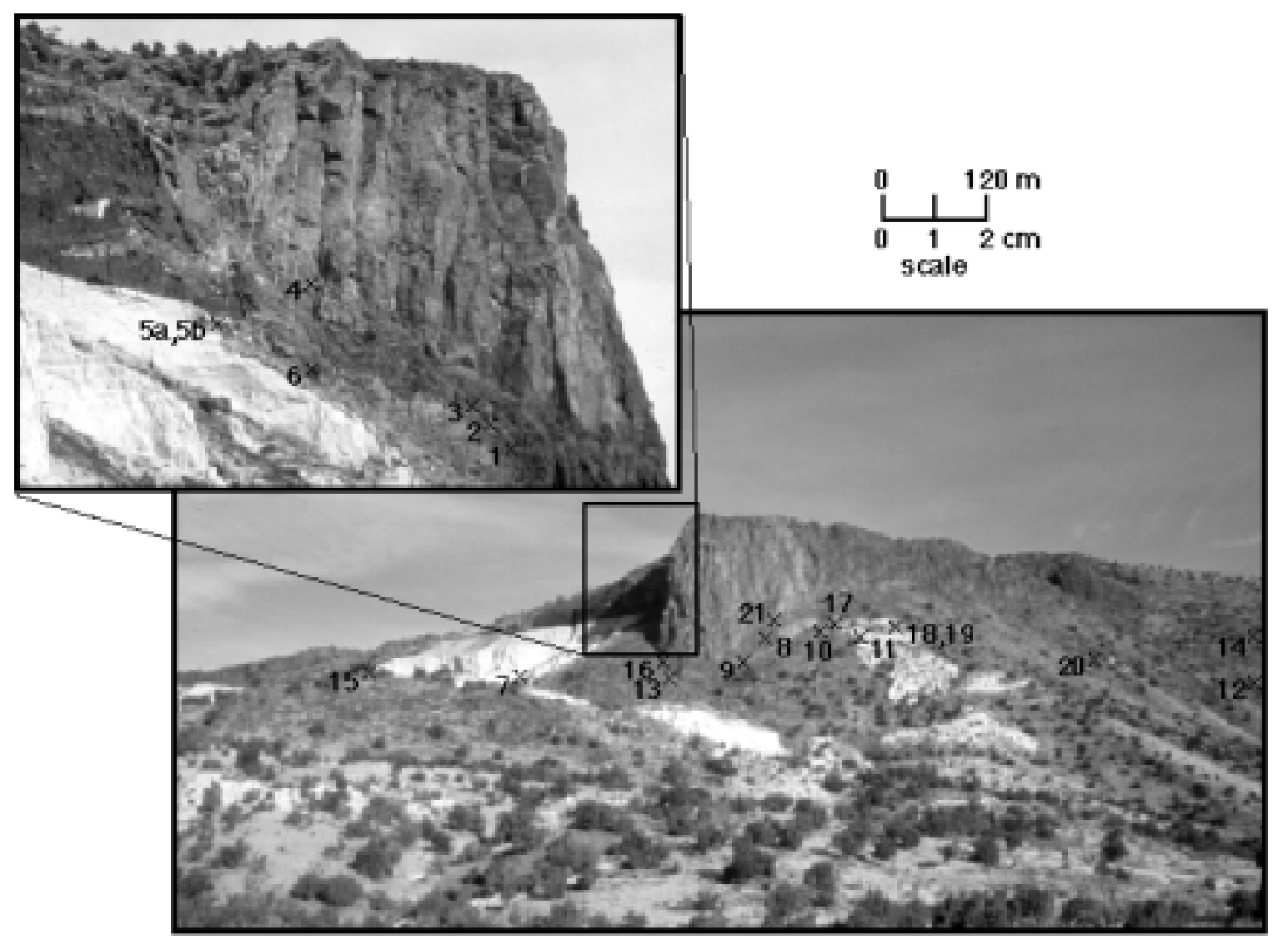

Figure 5.26. Panoramic view of the basaltic plug and the silicic ash flow tuff (White) of East Grants Ridge taken from the main highway looking northwest. Numbers represent sample locations of silicic tuffs and lavas, volcaniclastic sediments, and basalt flows from the plug.

The silicic pyroclastic deposit, rhyolite and perlite lavas, and the volcaniclastic unit at the southwest side of East Grants Ridge are overlain by basaltic lavas and thick scoria deposits (Figure 5.25b). The silicic pyroclastic and volcanic rocks are intruded by the 150-m thick basaltic plug that supplied lava and scoria to the surface. Essentially, the study area represents a scoria cone (with attendant lava flows) that has been dissected by erosion and possibly faulting. A cross section of the cone, its feeder plug, and the wall rocks (silicic pyroclastic and volcaniclastic deposits) is exposed in the steep flank of Grants Ridge. The plug is obscured at the base of the slope by talus (Figure 5.26). A localized contact metamorphic aureole formed around this vertically jointed basaltic plug. The contact aureole is partly obscured because of talus and landslide blocks from the overlying scoria deposit and from the spalling of the jointed plug wall.

The olivine basalt lava flows and scoria beds contain fused rhyolite and pumice clasts. These basaltic lavas cover a wide area and form flat mesa tops of the Grants Ridge, West Grants Ride, and Black Mesa (Figure 5.25a). According to Kerr and Wilcox (1963), the basaltic eruption culminated with the formation of several cones of basaltic scoria. These scoria cones are exposed above the plug and are intruded by sills and dikes (Figure 5.25b). Thick flows of bedded scoria deposits occur close to the vent area. Most of these scoria beds thin out and disappear within a short distance from the vents. The plug is surrounded by agglutinated scoria deposits, and the basaltic lavas exposed above the silicic tuffs occur about $100 \mathrm{~m}$ west of the plug. 
Although the basaltic flows from East Grants Ridge were not dated, K/Ar ranges of 2.9 to 1.6 Ma were reported from lavas of the Mt. Taylor volcanic field (Lipman and Mehnert, 1979) (Figure 5.25a). A K/Ar age of 2.57 Ma was reported on a basalt flow from Black Mesa, located along the southwestern part of Grants Ridge (Laughlin et al., 1994; Figure 5.25a). Intermediate to felsic rocks with similar apparent ages (3.73-2.01 Ma) were also reported from the Mt. Taylor volcanic field to the northeast of Grants Ridge (Perry et al., 1990).

c. Field Studies. Samples were systematically collected from the basaltic plug, silicic ignimbrite, and volcaniclastic unit on both sides and at different distances from the intrusive body located at the southwestern part of East Grants Ridge (Figure 5.26). The ash-flow tuff samples consist of matrix and pumice clasts from each location. Sampling was dictated by the availability of outcrops and accessibility because of steep cliffs and slopes created by pumice quarries and the accumulation of talus and landslides around the plug, respectively. As indicated in Figure 5.26, sample points are distributed from the contact zone to about $300 \mathrm{~m}$ away on both sides of the plug.

Four basaltic samples were collected from different parts of the plug (Figure 5.26). Two of the samples located on the west (GR95-4) and east (GR95-9) sides of the plug were within a few meters of the contacts with the silicic tuffs and the volcaniclastic layer. Here, the plug is sparsely porphyritic with plagioclase phenocrysts and coarse pyroxene crystals. Close to the contact zone, the plug is fractured, poorly jointed, and vesiculated. The other two samples (GR95-13 and GR9516) were collected from the central part of the plug away from the contact metamorphic zone. This part of the plug is moderately porphyritic with an aphyric matrix, massive, and vertically jointed.

Most of the samples for this study were collected from the ash flow tuff because the focus of this study was to evaluate the thermal effects of the basaltic intrusion on the poorly welded pumicerich pyroclastic rocks. The contact metamorphic zone around the approximately $150-\mathrm{m}$ wide plug is not extensive and may be less than $5 \mathrm{~m}$ wide. The ash flow and pumice clasts along the contact zone were fused and vesiculated, but only welded within about $1 \mathrm{~m}$ of the contact. The fused pumice clasts are characterized by large spherical vesicles that are held together by reddish fused matrix. The fused pumice and the matrix of the ash flow tuff formed a honeycomb-like mesh. A total of six samples were collected from the contact zone along the west (GR95-1a, GR95, 1b, GR95-2, and GR95-3) and east (GR95-8a and GR95-8b) sides of the plug. However, the pumice clasts (GR95-8a) from the east side of the contact zone are not fused like those from the western part of the aureole (GR95-1a). More ash flow tuff and pumice clasts were taken from the west side at about $25 \mathrm{~m}$ (GR95-6a and GR95-6b), $45 \mathrm{~m}$ (GR95-7) and about $300 \mathrm{~m}$ (GR95-15a and GR9515b) (Figure 5.26). A large pumice quarry exposed a section of the ash flow tuff 40 to $50 \mathrm{~m}$ west of the plug. No alteration effect was noted in the exposed walls of the quarry except for localized fusion of the tuff around a dike that intruded into the tuff. The quarry wall closest to the plug is pumice-rich, soft, and unconsolidated. Two of the samples came from the eastern (GR95-7) and western (GR95-15a and GR95-15b) walls of this abandoned open pit mine to determine signs of devitrification. Two more samples (GR95-5a and GR95-5b) were obtained from the volcaniclastic layer directly below the thick scoria deposit about $30 \mathrm{~m}$ west of the plug (inset map, Figure 5.26).

More samples were collected from the east side of the plug. The pumice-rich ash flow tuff (GR95-8a and GR95-8b) and the overlying volcaniclastic sediment (GR95-21) samples from the contact zone are fused, brecciated, and intruded by vesiculated basaltic lava. However, as described above, the pumice clasts exhibit minimal thermal effects compared to the ash flow matrix and the volcaniclastic unit. Two more ash flow tuff and pumice samples were collected at about 10 $\mathrm{m}$ (GR95-10) and $40 \mathrm{~m}$ (GR95-11) east of the plug. The baked volcaniclastic unit directly below 
the scoria deposits was traced to about $300 \mathrm{~m}$ east of the plug, and more samples were obtained along strike at about $10 \mathrm{~m}$ (GR95-17), $40 \mathrm{~m}$ (GR95-18 and GR95-19), and about $300 \mathrm{~m}$ (GR9520) away.

About 500 m east of the basaltic plug, a 240-m high fault section exposes silicic tephra and rhyolite, perlite, and vitrophyre lavas of the dome complex that are capped by basaltic lavas and scoria deposits. Samples of a rhyolite (GR95-12) and vitrophyre (GR95-14) lavas were collected from this section to compare the mineralogical and chemical composition of the silicic tuffs and lavas from the contact aureole, the poorly consolidated pumice-rich ash flow tuffs, and the rhyoliteobsidian-perlite lava dome.

d. Analytical Methods. Bulk ash-flow tuff matrix, pumice clasts, and volcaniclastic samples were pulverized and analyzed using x-ray diffraction (XRD) on an automated Siemens D-500 diffractometer using $\mathrm{Cu} \mathrm{K} \alpha$ radiation, $0.02^{\circ} 2 \theta$ steps, and counting times of $1 \mathrm{~s}$ per step for all mounts $\left(2-36^{\circ} 2 \theta\right)$ to determine mineralogic variations among the different samples collected around the plug and beyond.

The same powders were used to analyze for major and trace-element compositions using a Rigaku 3064 wavelength dispersive $x$-ray fluorescence (XRF). The intensities from each sample were processed to concentrations using XRF-11 to determine changes in bulk-rock compositions due to fluid-rock interaction during the basaltic intrusion. Analysis and statistics of the unknown samples are based on a model that uses intensities for 21 standard rocks. Volcanic glass chemistry was obtained on five samples using an automated SX50 Cameca electron microprobe. The probe was operated using an accelerating potential of $15 \mathrm{kV}, 15 \mathrm{nA}$ beam current and a fixed beam size of $10 \mathrm{~mm}$. Standards used for calibration include both natural silicic and basaltic glasses, a set of feldspars, iron oxide, pyroxene, and amphiboles.

Selected samples were analyzed for $\mathrm{F}, \mathrm{Cl}, \mathrm{B}, \mathrm{Br}, \mathrm{Li}, \mathrm{S}$, and $\mathrm{P}_{2} \mathrm{O}_{5}$ using an Ion Chromatograph Dionex 4000i with conductivity and UV/Vis detectors and other accessories to estimate volatile components gained or lost during the contact metamorphism (Shevenell and Goff, 1993). Bulk ash flow tuffs and pumice samples from within and outside the contact metamorphic zone were analyzed. Standards that were lithologically similar to the samples were also analyzed to determine the quality of the analytical work.

Finally, the effect of contact metamorphism on the rare earth element compositions of the basalt, ash flow tuffs, pumice clasts, and volcaniclastic unit were determined by instrumental neutron activation analysis (INAA) on selected samples at Washington University, St. Louis (Korotev, 1987). Two NBS standards were analyzed with the samples for controlling the quality of the analytical work.

\section{e. Mineralogical and Geochemical Results.}

(1) X-Ray Diffraction Analysis. The ash flow tuff, pumice, and volcaniclastic samples collected within the contact metamorphic aureole were modified in their mineralogic compositions compared with those samples collected outside this zone (Figure 5.27a). As indicated in Figure 5.27a, a rhyolite lava (Figure 5.27a-A) collected about 500 m east of the contact metamorphic aureole exhibits the same x-ray diffraction patterns as a pumice (Figure 5.27a-B), a bulk ash flow tuff (Figures 5.27a-D), and a volcaniclastic sediment (Figure 5.27a-F) collected from the contact metamorphic zone. The volcanic glass in the tuffaceous samples was totally recrystallized and the 
mineralogy is dominated by quartz, cristobalite, tridymite, and sanidine except for minor amounts of micaceous minerals in the rhyolite lava. Although the rhyolite and vitrophyre lavas are enriched in vapor phase topaz and garnet (Christiansen et al., 1983), none of these minerals were indicated by the x-ray diffraction patterns. Two other ash flow samples (Figures 5.27a-C and 5.27a-E) collected outside the contact aureole are dominated by volcanic glass except for minor amounts of phenocrystic quartz and feldspar and vapor phase tridymite and cristobalite crystallized during deposition. These poorly-consolidated and volcanic glass-dominated ash-flow tuff samples exhibit minimal physical or mineralogical effects from the basaltic intrusion represented by the plug.

In Figure 5.27b, a reworked tuff (Figure 5.27b-A), a vitrophyre lava (Figure 5.27b-B), and an ash flow tuff (Figure 5.27b-C) are plotted with three pumice samples (Figures 5.27b-D, E, and F) collected at different distances from the plug (Figure 5.26). An ash flow tuff and a volcaniclastic sediment from the contact aureole and from directly beneath the thick scoria deposit, respectively, are devoid of volcanic glass and are dominated by quartz, sanidine, cristobalite, and tridymite. Trace amounts of gypsum, micaceous, and clay minerals are present in these samples. The pumice samples are glassy except for small amounts of quartz and feldspar phenocrysts, cristobalite from devitrification during cooling, and secondary calcite in one of the samples (Figure 5.27b-F). The vitrophyre has identical x-ray diffraction patterns as the pumice samples. Although three of the pumice samples were collected along the contact with the plug, two of them (Figures 5.27a-B and $5.27 \mathrm{~b}-\mathrm{C}$ ) were totally recrystallized, whereas the other one (Figure 5.27b-E) is glassy like the pumice clasts collected outside the contact aureole and the vitrophyre lava. Although dominated by pumice clasts and fine ash matrix, the volcaniclastic sedimentary layer was recrystallized and contains no, or a minimal amount of, volcanic glass. These samples were collected either from the contact aureole of the plug or directly beneath the scoria deposit and were significantly altered by heat from the basaltic flows.

Outcrops around the plug are poor because of talus cover. However, the pinkish to orange color of the patchy outcrops of the ash flow tuff and the volcaniclastic sediment is one indicator of the zone of contact metamorphism. Although gradational, the abundance of volcanic glass in the ash flow tuff samples appears to generally indicate the aerial extent of the contact metamorphic aureole. For example, at about $10 \mathrm{~m}$ from the plug, the ash flow samples contain about 60 to 70 percent volcanic glass and this increases to more than 90 percent about $20 \mathrm{~m}$ away. The contact metamorphic zone is also moderately defined by the degree of compaction of the poorly consolidated ash flow and reworked tuffs. The compaction is gradational and consistent with the degree of devitrification of the volcanic glass. 


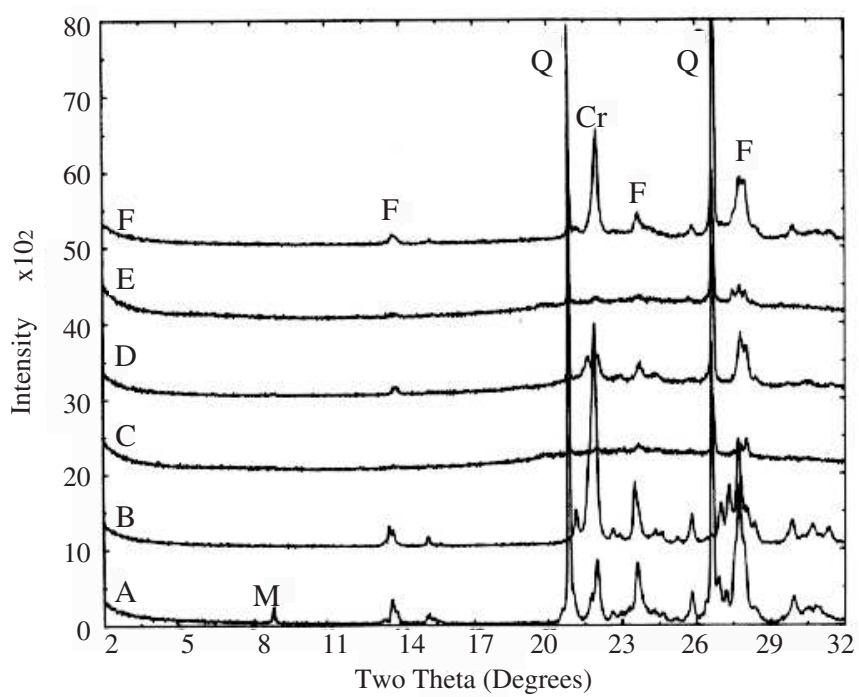

(a)

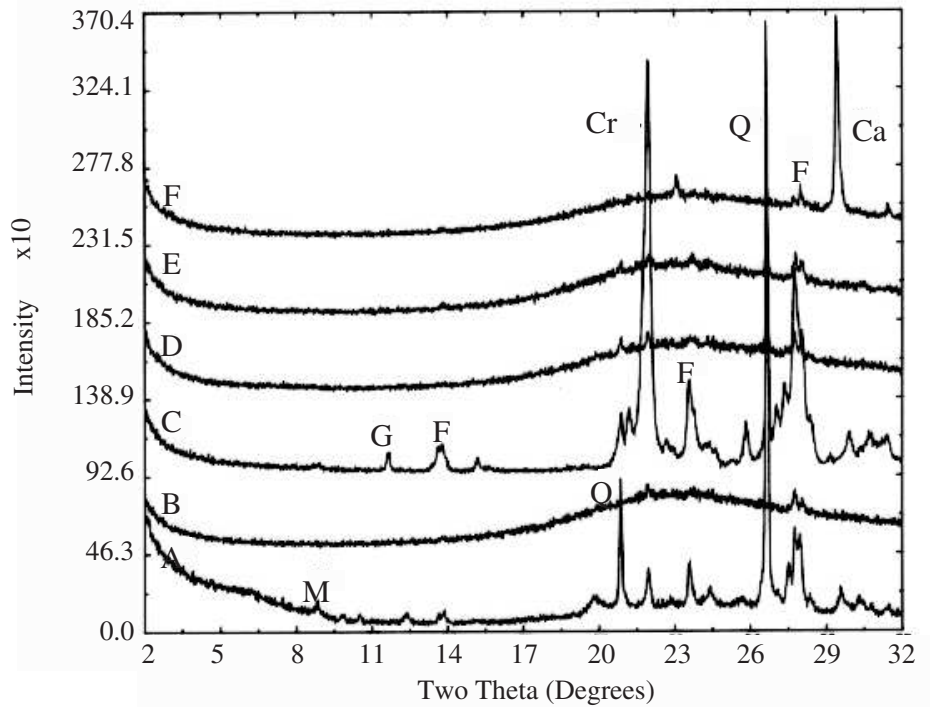

(b)

Figure 5.27. (a) X-ray diffraction patterns of representative silicic tuffs and lavas and volcaniclastic sediments collected at different distances from the plug. The patterns represent a rhyolite lava ( $\mathrm{A}=\mathrm{GR} 95-12$ ), pumice from the contact ( $\mathrm{B}=\mathrm{GR} 95-1 \mathrm{a})$, bulk tuff ( $\mathrm{C}=\mathrm{GR} 95-6 \mathrm{~b}, \mathrm{D}=\mathrm{GR} 95-8 \mathrm{a}$, and $\mathrm{E}=\mathrm{GR} 95-15 \mathrm{a})$, and a volcaniclastic sediment (F=GR95-21). Patterns represent mica (M), feldspar (F), quartz (Q), and cristobalite (Cr). Samples C and E were collected about 25 and $300 \mathrm{~m}$, respectively, away from the plug (Fig. 5.26). (b) X-ray diffraction patterns of representative silicic tuffs and lavas and volcaniclastic sediments collected at different distances from the plug. The patterns represent a volcaniclastic sediment ( $A=$ GR95-20), a virtophyre ( $B=$ GR95-14), bulk tuff ( $C=$ GR95-1b), pumice (D=GR95-6, E=GR95-8b, and F=GR95-15b). Patterns represent gypsum (G), mica (M), clinoptilolite $(\mathrm{Cp})$, feldspar $(\mathrm{F})$, quartz $(\mathrm{Q})$, cristobalite $(\mathrm{Cr})$, and calcite $(\mathrm{Ca})$.

(2) Geochemical Analysis. Major, trace, and rare earth element compositions of the basaltic, silicic, and volcaniclastic rocks indicate variations related to the thermal effects of the plug and the scoria deposit (Appendix 5.3). Although most of the samples show a linear trend, major oxides plotted against silica indicate notable scattering in their concentrations (Figure 5.28). Samples from the edge (contact zone) and the center of the plug indicate a range in major element concentrations. The two basalt samples from the center of the plug (Figure 5.26) are low in silica and $\mathrm{P} 2 \mathrm{O} 5$ and higher in $\mathrm{CaO}, \mathrm{Fe} 2 \mathrm{O} 3, \mathrm{MgO}, \mathrm{TiO}_{2}$ compared with the other two basalt 
zone with the silicic rocks (Appendix 5.3). The enrichment in silica, alkalies, and $\mathrm{P}_{2} \mathrm{O}_{5}$ is possibly related to alteration within the contact metamorphic aureole.

Similar major element variations are also noted within the volcaniclastic samples. Those from outside the contact aureole are enriched in $\mathrm{MgO}, \mathrm{TiO}_{2}, \mathrm{Fe}_{2} \mathrm{O}_{3}, \mathrm{CaO}, \mathrm{P}_{2} \mathrm{O}_{5}$, and $\mathrm{LOI}$ (loss on ignition) and depleted in $\mathrm{SiO}_{2}$ and the alkalies (Figure 5.28). Like the basalt specimen from the contact zone, the reworked tuffs appear to have gained silica and alkalies because of devitrification consistent with the recrystallization of the volcanic glass in these rocks.

The silicic ash flow tuff, lavas, and pumice clasts plot close to each other and show minor variation in their major element compositions (Figure 5.28). Except for higher alkalies and lower LOI contents in samples from the contact aureole, most of the ash flow tuff samples contain similar concentration of the major oxides (Appendix 5.3). The pumice clasts are more enriched in their silica and alkali contents but contain no, or minor amounts of, $\mathrm{Fe}_{2} \mathrm{O}_{3}, \mathrm{CaO}, \mathrm{TiO}_{2}, \mathrm{MgO}$, and $\mathrm{P}_{2} \mathrm{O}_{5}$ compared with the ash flow tuffs. Moreover, the LOI content is higher for the ash flow tuff samples regardless of their location. The rhyolite and vitrophyre samples generally plot within the range of the silicic tuff samples. For example, the vitrophyre is more chemically similar to the pumice clasts than the ash flow tuffs. The rhyolite lava has the highest silica content $(75.32 \mathrm{wt} \%)$ and lowest LOI $(0.4 \mathrm{wt} \%)$ than all the silicic rocks. For the rest of the oxides, the difference was insignificant.

The major element compositions from the microprobe analysis of volcanic glasses from five samples collected at different intervals away from the plug are generally consistent with the results of the bulk samples obtained using XRF (Appendix 5.4, Figure 5.29). The scattering in alkalies and water contents is similar to the major oxide plots shown in Figures 5.28 and 5.29. However, a distinct grouping is indicated by the $\mathrm{FeO}$ and $\mathrm{F}$ plots. A sample (GR95-15b) collected about $300 \mathrm{~m}$ west of the plug contains twice as much F compared to other samples collected with about $25 \mathrm{~m}$ from the intrusion (Appendix 5.4). Conversely, samples (GR95-6, 7, and 8) outside the contact aureole (Figure 5.26) are enriched in their FeO contents (Figure 5.29).

The effect of the basaltic intrusion on the volatile contents of the silicic ash flow tuffs were also checked on four samples (GR95-7, 8a, 8b, and 11) within about $50 \mathrm{~m}$ from the plug (Figure 5.26). These samples were checked for their $\mathrm{B}, \mathrm{Cl}, \mathrm{F}, \mathrm{Li}, \mathrm{P}_{2} \mathrm{O}_{5}$, and $\mathrm{S}$ concentrations (Table 5.5). The $\mathrm{F}$ content increases away from the plug consistent with the electron microprobe data (Figure 5.30). $\mathrm{Cl}$ also appears to show the same trend except for higher concentration in one of the samples from the contact aureole (Table 5.5). Although not by much, $\mathrm{S}$ content is higher in samples within the aureole, whereas $\mathrm{B}, \mathrm{Li}$, and $\mathrm{P}_{2} \mathrm{O}_{5}$ show no particular trend (Figure 5.30).

Unlike the silica and major element plots, no linear trends are indicated by the trace elements except for $\mathrm{Sr}$ (Figure 5.31). Moreover, the silica and trace element plots indicate more scattering compared to the major elements. The basalt samples from the center of the plug contain higher $\mathrm{Ni}$, $\mathrm{Cr}$, and $\mathrm{V}$ consistent with their elevated concentrations of $\mathrm{MgO}, \mathrm{TiO}_{2}, \mathrm{Fe}_{2} \mathrm{O}_{3}, \mathrm{CaO}, \mathrm{P}_{2} \mathrm{O}_{5}$ (Figure 5.28). Those basalt samples close to the contact zone have either similar or slightly higher $\mathrm{Ba}, \mathrm{Nb}$, $\mathrm{Rb}, \mathrm{Sr}, \mathrm{Zn}$, and $\mathrm{Zr}$ contents. Similar to the major element plots, the volcaniclastic sediments are also separated into two groups on the basis of their trace-element compositions. Those from outside the contact aureole are enriched in $\mathrm{Sr}$ and $\mathrm{Zr}$, whereas higher $\mathrm{Rb}, \mathrm{Nb}, \mathrm{Y}, \mathrm{Zn}$, and $\mathrm{Zr}$ concentrations are present in the thermally altered rocks (Figure 5.31). 

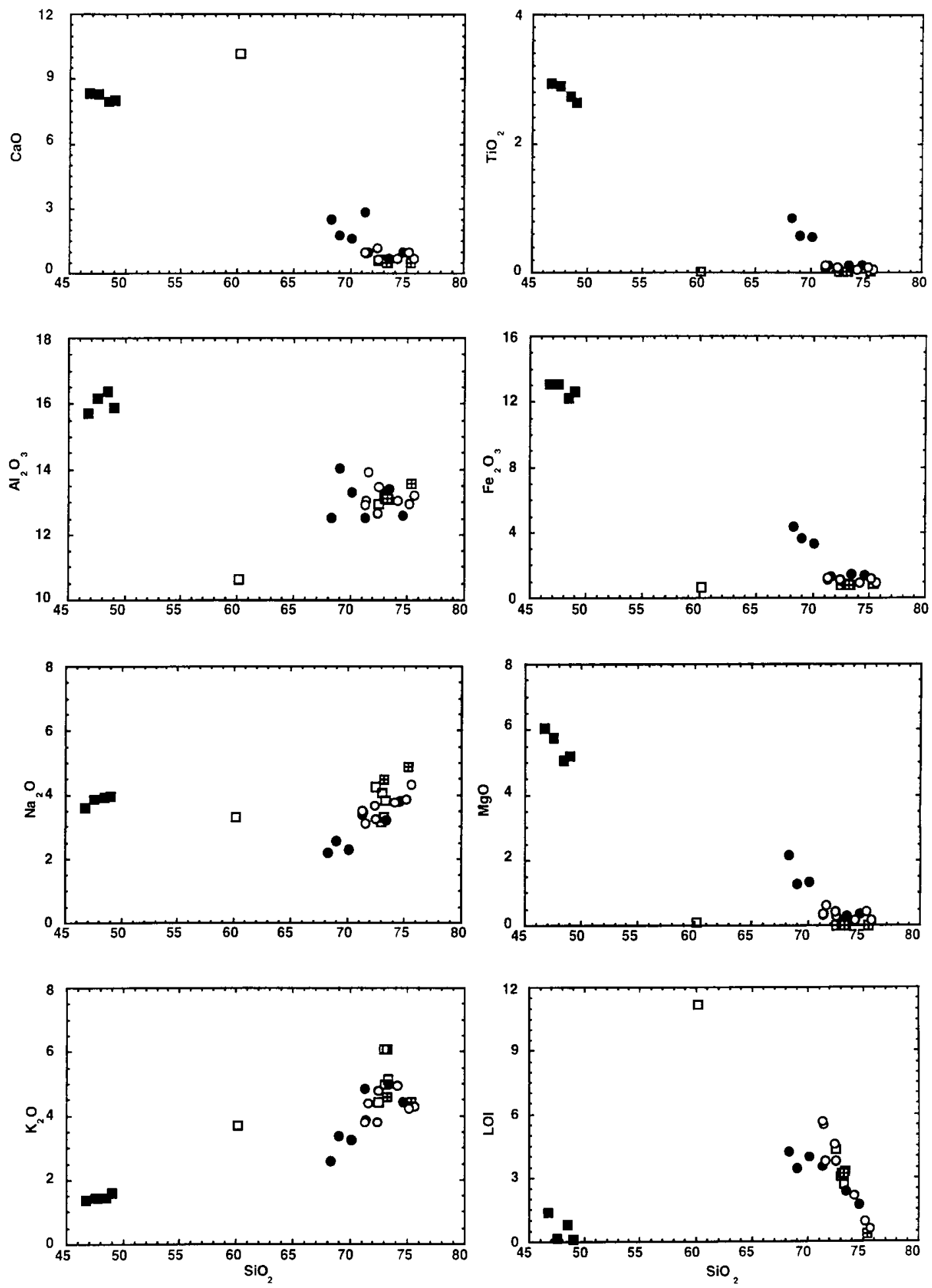

Figure 5.28. Variation diagrams of major elements versus $\mathrm{SiO}_{2}$ (wt \%). Analysis calculated to 100 $\%$ volatile free. Symbols represent samples of basalts (solid squares), pumice clasts (open squares), rhyolite lava (open square filled with cross), volcaniclastic sediments (solid circle), and ash flow tuff (open circle). 

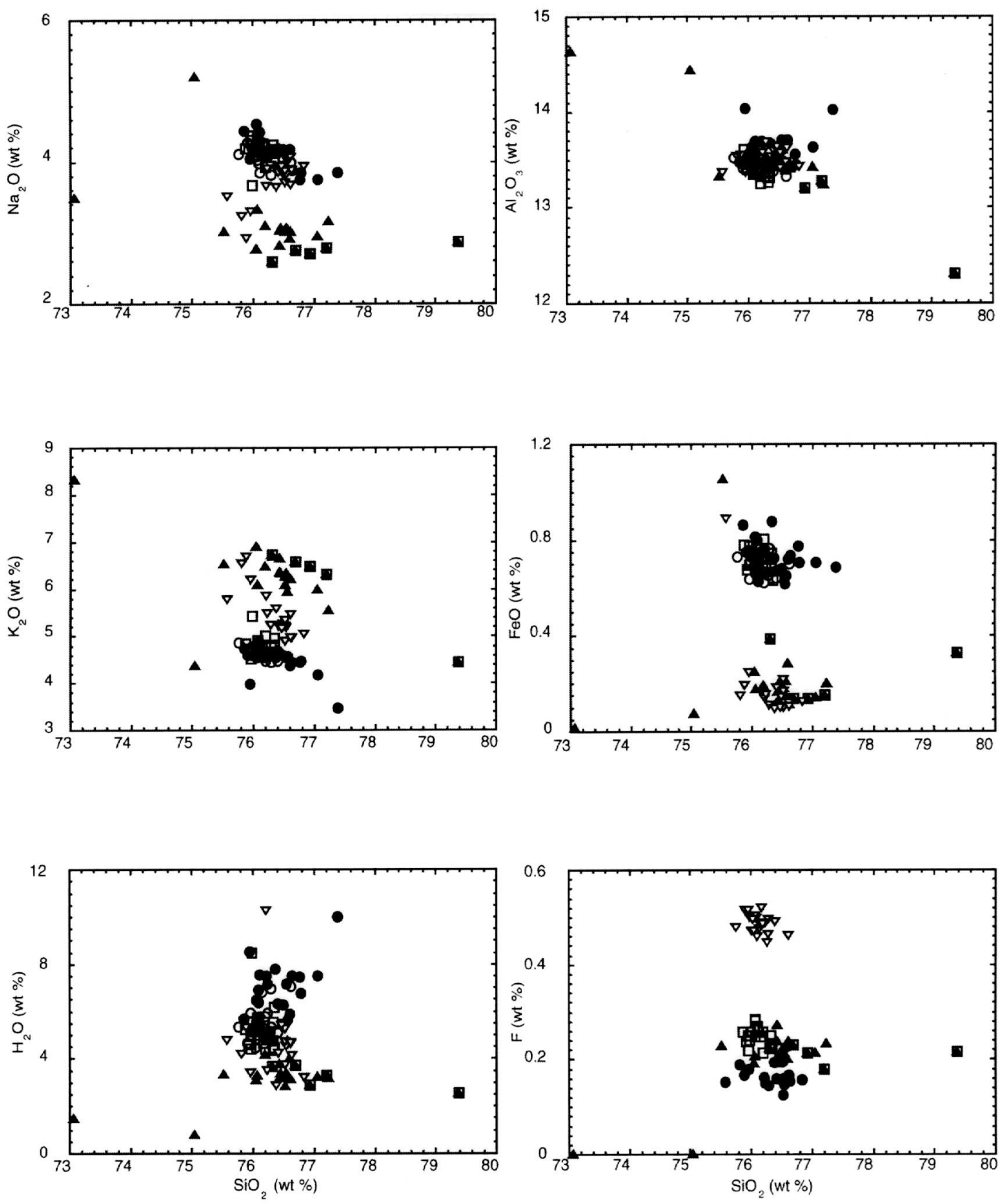

Figure 5.29. Variation diagrams of major elements compositions of volcanic glass from microprobe analyses versus $\mathrm{SiO}_{2}$ (wt \%). Analysis calculated to $100 \%$ volatile free. Symbols represent selected samples of silicic tuffs: GR95-1 (solid triangle), GR95-6 (open squares), GR95-7 (solid circle), GR95-8 (inverted open triangle), and GR95-15 (open circle). 

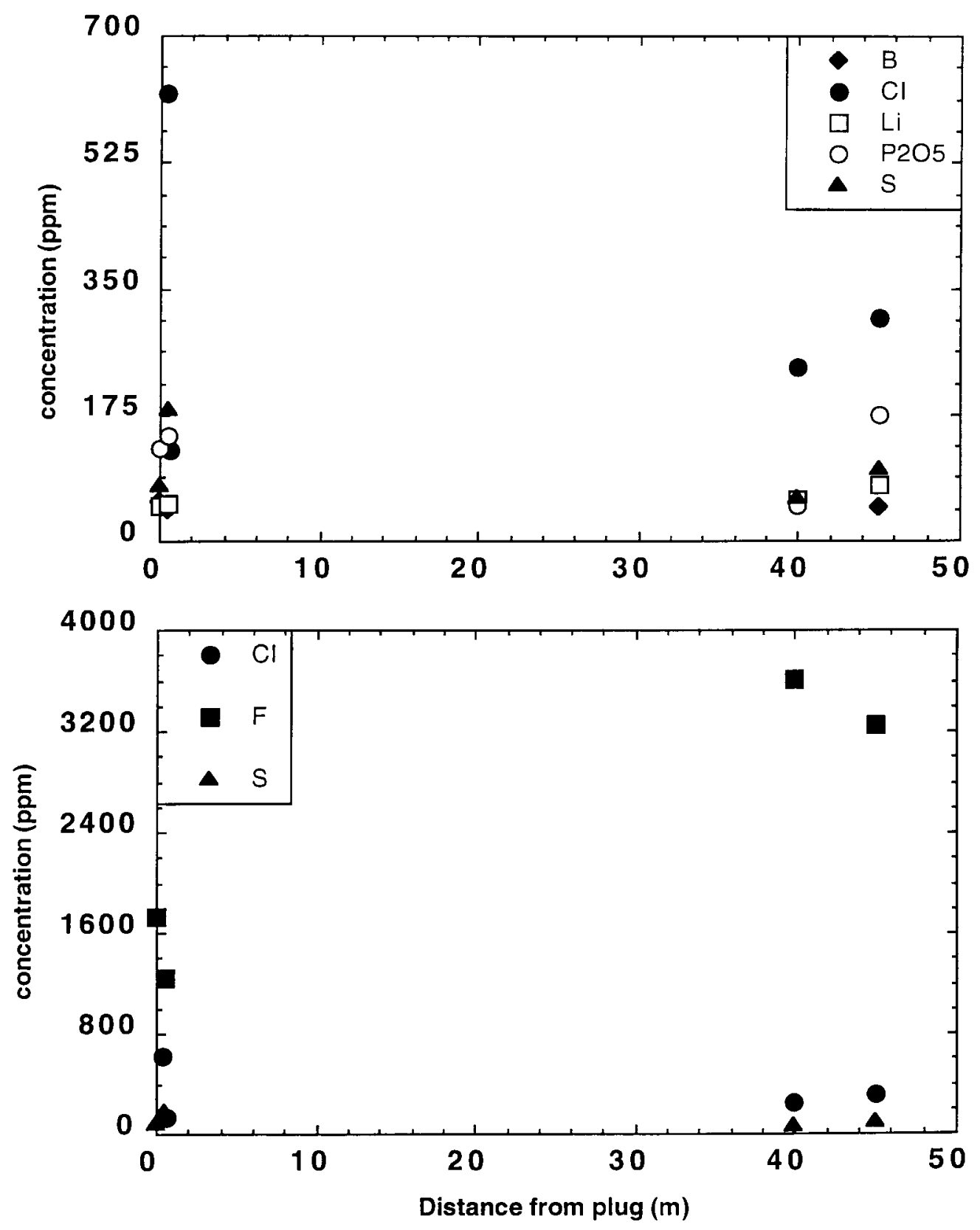

Figure 5.30. Plots of elemental concentrations of $\mathrm{B}, \mathrm{Cl}, \mathrm{F}, \mathrm{Li}, \mathrm{P}_{2} \mathrm{O}_{5}$, and $\mathrm{S}$ versus distance from the basaltic plug. Legends of symbols are given in boxes. 

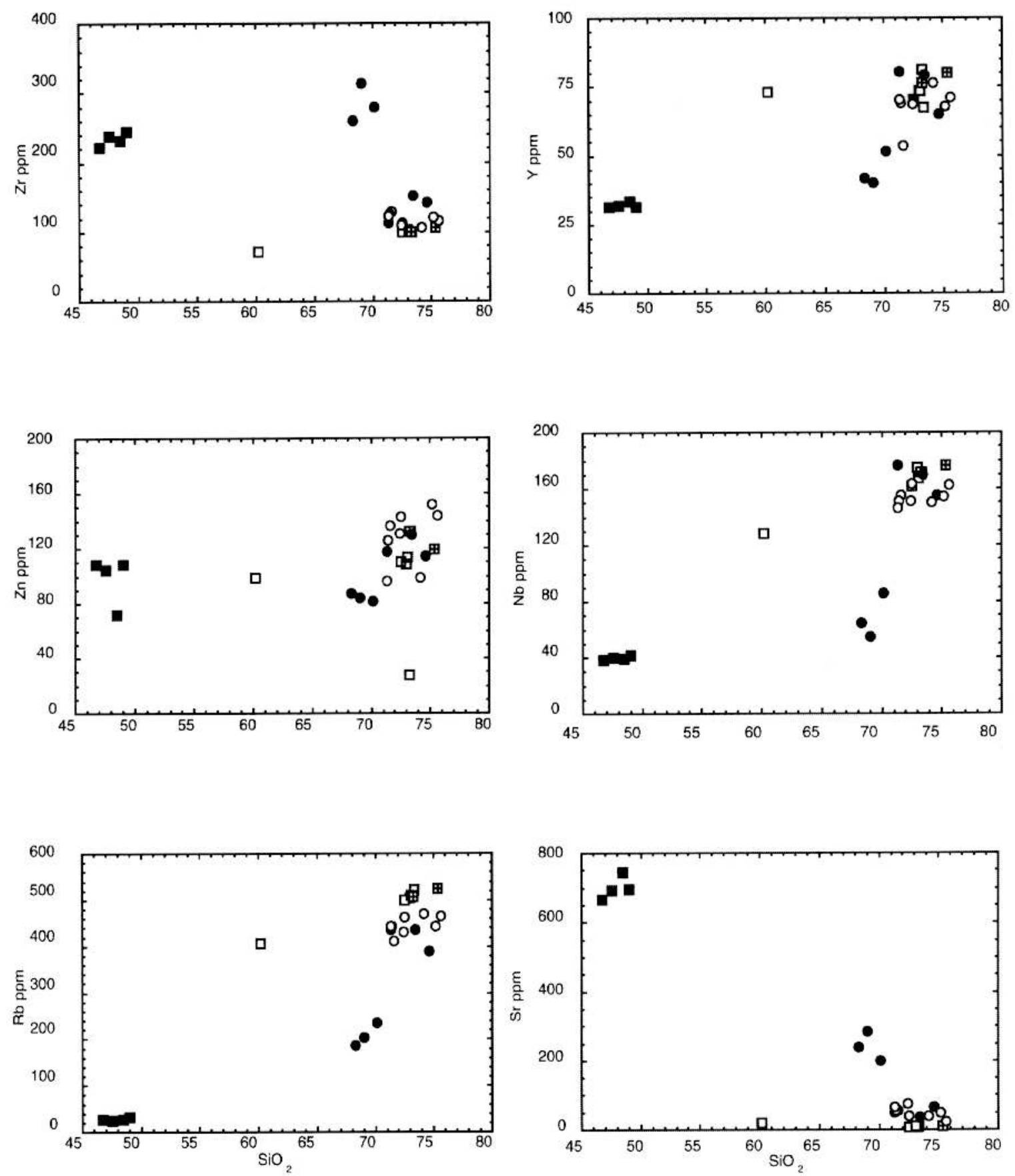

Figure 5.31. Variation diagrams of trace element compositions in parts per million versus $\mathrm{Si}_{2}$ (wt $\%$ ). Symbols represent samples of basalts (solid squares), pumice clasts (open squares), rhyolite lava (open square filled with cross), volcaniclastic sediments (solid circle), and ash flow tuff (open circle). 


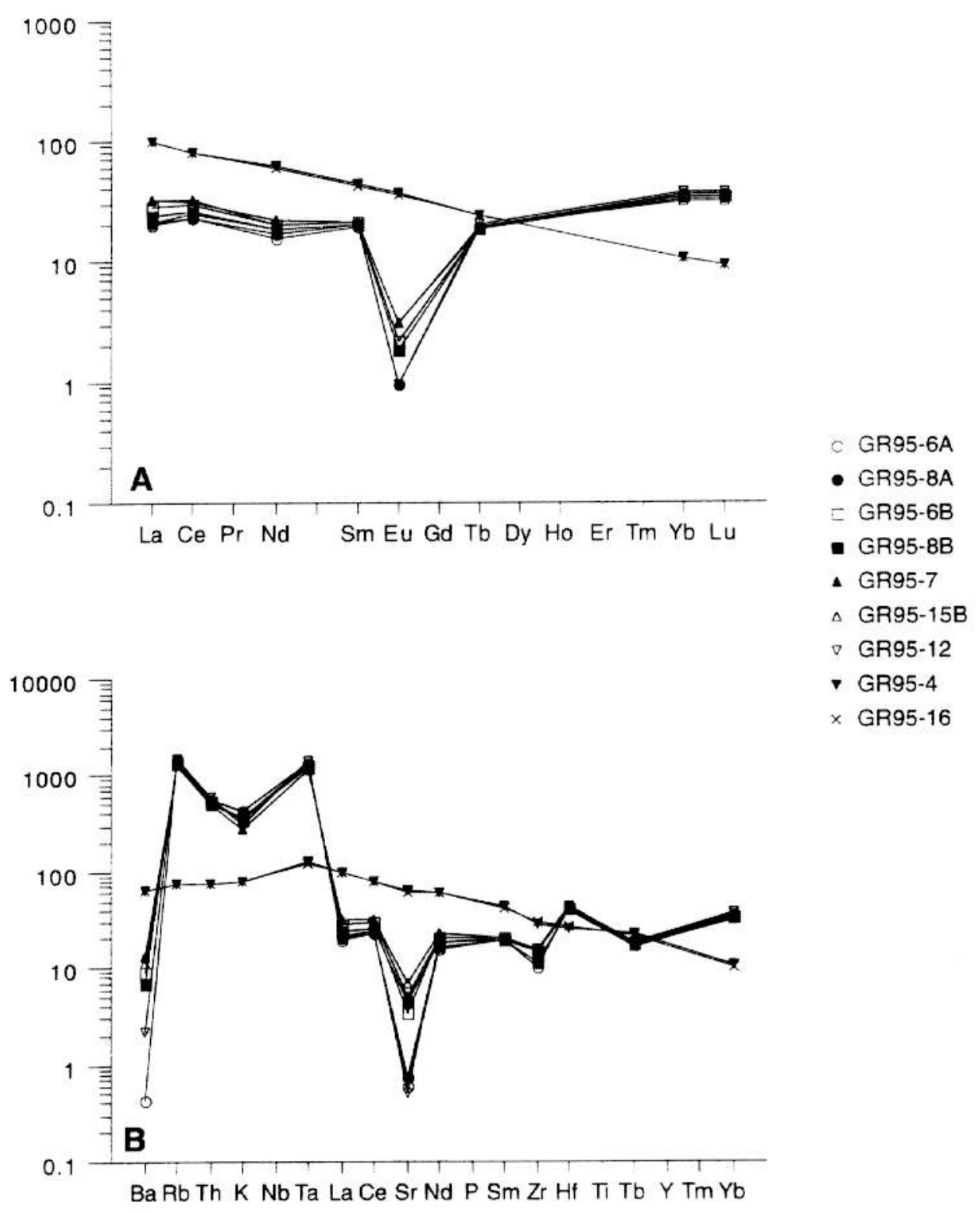

Figure 5.32. Chondrite-normalized rare earth element plots of silicic tuffs and basaltic lavas. Symbols and the corresponding samples are given in the legend. PlaB represents multi-element chondritenormalized spidergrams of the same samples plotted in A (Nakamura, 1974; Thompson et al., 1984).

The silicic rocks contain no $\mathrm{Cr}$ and $\mathrm{Ni}$, and the pumice clasts and lavas contain no $\mathrm{Ba}$ and $\mathrm{V}$. The ash flow tuffs and pumice clasts contain variable concentrations of trace elements. For example, the pumice clasts have slightly higher contents of $\mathrm{Rb}, \mathrm{Nb}$, and $\mathrm{Y}$, whereas the tuffs contain more Ba, Sr, Zn, and Zr contents (Appendix 5.3, Figure 5.31). The trace element compositions of the rhyolite and vitrophyre lavas are similar to the rest of the silicic tuff samples except for slightly higher $\mathrm{Rb}$ and insignificant amounts of Sr. In fact, the vitrophyre contains no $\mathrm{Sr}$. 
Table 5.5. Halogen data from Grants Ridge.

\begin{tabular}{|llllllll||}
\hline SAMPLE & $\mathrm{B}$ & $\mathrm{Br}$ & $\mathrm{Cl}$ & $\mathrm{F}$ & $\mathrm{Li}$ & $\mathrm{P}_{2} \mathrm{O}_{5}$ & $\mathrm{~S}$ \\
\hline GR95-7 & 36.00 & 0.50 & 314.00 & 3064.00 & 76.00 & 162.00 & 98.00 \\
GR95-7 & 55.00 & 1.00 & 301.00 & 3425.00 & 76.00 & 187.00 & 104.00 \\
GR95-8A & 46.00 & 0.50 & 106.00 & 1727.00 & 46.00 & 123.00 & 88.00 \\
GR95-8A & 63.00 & 1.00 & 144.00 & 1745.00 & 50.00 & 137.00 & 68.00 \\
GR95-8B & 34.00 & 1.30 & 618.00 & 1250.00 & 48.00 & 120.00 & 182.00 \\
GR95-8B & 50.00 & 1.30 & 621.00 & 1222.00 & 54.00 & 172.00 & 185.00 \\
GR95-11 & 51.00 & 0.50 & 242.00 & 3542.00 & 55.00 & 40.00 & 68.00 \\
GR95-11 & 55.00 & 1.00 & 237.00 & 3690.00 & 57.00 & 57.00 & 50.00 \\
Average values & & & & & & & \\
\hline GR95-7 & 45.50 & 0.75 & 307.50 & 3244.50 & 76.00 & 174.50 & 101.00 \\
GR95-8A & 54.50 & 0.75 & 125.00 & 1736.00 & 48.00 & 130.00 & 78.00 \\
GR95-8B & 42.00 & 1.30 & 619.50 & 1236.00 & 51.00 & 146.00 & 183.50 \\
GR95-11 & 53.00 & 0.75 & 239.50 & 3616.00 & 56.00 & 48.50 & 59.00 \\
\hline \hline
\end{tabular}

Finally, selected samples from different locations with reference to the basaltic plug were analyzed for their rare earth element (REE) concentrations to check for signs of enrichments or depletions because of the contact metamorphic effect (Figure 5.26). Chondrite-normalized REE and multi-element plots are given for the selected samples in Figure 5.32 (Nakamura, 1974; Thompson et al., 1984). Basalt samples from the contact zone (GR95-4) and the center of the plug (GR95-16) show no significant variations. However, the overlap is not perfect, and the sample from the contact zone appears to be slightly enriched (Figures 5.32a,b). The basalt samples are enriched in light REE, $\mathrm{Ba}$, and $\mathrm{Sr}$ contents compared with the silicic rocks, whereas $\mathrm{Yb}, \mathrm{Lu}, \mathrm{Rb}$, $\mathrm{Th}, \mathrm{K}$, and $\mathrm{Nb}$ are higher in the silicic rocks. Variations in the REE contents are more apparent in the silicic rocks. For example, the ash flow tuffs and pumice clasts from the contact aureole are depleted in light REE, whereas the opposite is indicated by the rhyolite (GR95-12). In the multielement plot (Figure 5.32b), the silicic rocks exhibit minimal variations in their $\mathrm{Rb}, \mathrm{Th}, \mathrm{Nb}, \mathrm{Ce}$, $\mathrm{Nd}, \mathrm{Sm}, \mathrm{Hf}$, and $\mathrm{Yb}$. Of all the elements, $\mathrm{Ba}, \mathrm{Eu}$, and $\mathrm{Sr}$ show the greatest variations.

f. Discussion. Despite the size of the basaltic plug ( 150-m wide), hydrothermal alteration in the silicic rocks of East Grants Ridge is minimal. Field and laboratory studies provide no evidence for hydrothermal activity in the poorly consolidated pyroclastic deposits intruded by the olivine-bearing basalt. In fact, because of the unwelded nature of the ash flow tuff near the basaltic plug, it was extensively mined for pumice (Figure 5.26). However, the effect of the basaltic intrusion and the thick scoria deposit is distinctly apparent in a narrow zone along the contact with the silicic tuffs. This is indicated by physical changes in brecciation, deformation, injection of basalt along bedding planes, compaction, and coloration. The pyroclastic rocks and volcaniclastic sediment below the scoria are brownish-orange because of baking. These same rocks adjacent to the plug show the effect of more heat than those below the scoria by being dark orange, fused, deformed, and brecciated. Although the silicic rocks are not fully exposed around the plug, the extent of the contact metamorphic aureole is about $5 \mathrm{~m}$ wide or less, based on the color transition from orange to light gray and degree of compaction.

An attempt was also made to define the aerial extent of the contact metamorphic aureole using mineralogical compositions of the different samples collected from both sides of the plug (Figures $5.27 \mathrm{a}, \mathrm{b})$. Generally, the volcanic glass of silicic rocks is recrystallized or devitrified at elevated 
temperatures in the presence of fluids (Lofgren, 1970), but devitrification is minimized in dry conditions or if the fluid is pure water. Unlike samples within the contact aureole, ash flow tuff and pumice clasts within $10 \mathrm{~m}$ of the plug are dominated by an elevated background of amorphous silica scattering which indicates the presence of abundant volcanic glass. Exceptions were noted to this observation. Pumice clasts on the west side of the contact zone were fused and totally devitrified, whereas on the east side, similar samples from the contact consist of volcanic glass. Variation in mineralogical composition of the silicic rocks was a useful diagnostic tool to trace the extent of the thermal effect because of the devitrification process. However, this was not the case with all the samples. The role of aqueous solutions appears to be an important factor in the recrystallization of volcanic glass intruded by basaltic magmas.

Variation in major element compositions among the basaltic and silicic rocks is not extensive and is consistent with a minimal amount of water-rock interaction during the basaltic intrusion. However, as indicated in Figure 5.28, the basalt samples from the same plug show minor variations because of localized interaction along the contact with the tuff. Increased silica and alkalies in the basalt samples from the contact zone suggest localized elemental exchanges between the mafic and silicic rocks. The volcaniclastic samples from the contact zone also show the same kind of enrichment. Despite higher porosity due to poor compaction in the volcaniclastic rocks, a sample $10 \mathrm{~m}$ away from the plug has the same major and trace element chemistry as a sample collected about $300 \mathrm{~m}$ away, reflecting the absence of hydrothermal alteration due to insufficient aqueous solutions during the intrusion.

Comparison of major element chemistry of volcanic glass obtained by electron microprobe analysis clearly indicates the effect of the intrusion on the silicic rocks (Figure 5.29). Localized water-rock interaction involving the silicic and basaltic rocks within the contact aureole is indicated by minor enrichments in alkalies of the silicic rocks while they were depleted in their $\mathrm{FeO}, \mathrm{H}_{2} \mathrm{O}$, and $\mathrm{F}$ contents. A similar approach using the volatile contents $\left(\mathrm{B}, \mathrm{Br}, \mathrm{Cl}, \mathrm{F}, \mathrm{Li}, \mathrm{P}_{2} \mathrm{O}_{5}\right.$, and $\mathrm{S}$ ) of bulk ash flow tuffs to map the aerial extent of the effect of the intrusion was also informative (Figure 5.30). The F data from this and the probe analyses are consistent with each other. With the exception of one sample, the $\mathrm{Cl}$ data show the same pattern as the $\mathrm{F}$ variation. The $\mathrm{S}$ content is higher in the silicic samples close to the basalt intrusion, although only slightly. This is because $S$ is the major volatile component of basaltic intrusion. Thus, microprobe data and wet analysis of volatile contents of pure glass separate appear to be useful tools to delineate the aerial extent of a contact metamorphic zone created by an intrusion.

The trace element and REE compositions of the basaltic, silicic, and volcaniclastic rocks corroborate the information provided by the major element data. This geochemical pattern is attributed to minimal water-rock interaction within the contact aureole and adjacent rocks. No mineralogical or chemical evidence was apparent that would suggest migration of sufficient aqueous solutions within the contact zone of the silicic and basaltic rocks and the adjacent poorlyconsolidated tuffs. Evidence is provided by the similarity in trace element and REE contents of samples collected within and outside the contact zone.

\section{g. Hydrothermal Systems Associated with Shallow Intrusions and Volcanic Centers.} Major Quaternary geothermal systems have developed around shallow intrusions (e.g., The Geysers-Clear Lake geothermal field, California) and in caldera-forming silicic centers such as the Valles caldera of the Jemez volcanic field in north-central New Mexico. The effect of hydrothermal alteration related to magmatic intrusion and volcanic eruptions can be delineated from the geochronological data of the hydrothermally-altered host rocks. The fluids responsible for the 
widespread hydrothermal alterations are generally of meteoric and magmatic origins. In the Geysers geothermal field, the graywackes and argillites are intruded by northwest-trending felsic plutons and other volcanics (Schriener and Suemnicht, 1981). Geochronologic data on volcanic flows and plutonic intrusions from The Geysers-Clear Lake region range in age from 2.4-0.57 Ma (Schriener and Suemnicht, 1981; Donnelly-Nolan et al., 1981; Pulka, 1991; Dalrymple, 1992; Hulen et al., 1997). Hulen et al. (1997) reported ${ }^{40} \mathrm{Ar} /{ }^{39} \mathrm{Ar}$ crystallization ages of 1.09, 1.1, and $0.57 \mathrm{Ma}$, respectively, for the granodiorite intrusion underlying the steam field, a microgranite porphyry dike from beneath Cobb Mountain, and from vein adularia in a core sample from The Geysers Coring Project corehole SB-15-D. Temperature data (Hulen and Nielson, 1996) from the modern reservoir of corehole SB-15-D $\left(180-235{ }^{\circ} \mathrm{C}\right)$, fluid inclusion $\left(195-304{ }^{\circ} \mathrm{C}\right)$, and vitrinite reflectance $\left(283-311^{\circ} \mathrm{C}\right)$ are high enough to reset the Ar contents of minerals and clay fractions during hydrothermal alteration. However, despite the high-temperature water- and steamdominated environments of The Geysers-Clear Lake geothermal field, most of the clays were not totally reset and represented mixed ages of hydrothermal clays of Quaternary diagenesis and older clays of detrital and metamorphic origins related to subduction (WoldeGabriel et. al., in review). The dates have no geological significance other than to indicate that the preexisting metamorphic and detrital clays were not totally degassed even though the host rocks were subjected to a hightemperature geothermal environment for more than a million years. Low permeability and slow diagenetic reactions in the metagraywacke and argillite may be responsible for the partial resetting of the Ar in the mixed-layered illite/smectite (WoldeGabriel et al., in review).

The Experimental Continental Scientific Drilling Project drilled in and around the Valles caldera retrieved more than $3.1 \mathrm{~km}$ of continuous core samples and valuable subsurface information related to stratigraphy, structure, hydrothermal alteration, mineralization, and chemistry of hydrothermal fluids (Goff and Nielson, 1986; Goff and Gardner, 1988, 1994; Hulen and Nielson 1988; Hulen and Gardner, 1989; Hulen et al., 1989). Hydrothermal alteration related to the Valles and the Cerro-Toledo calderas are widespread in the volcanic field because the Jemez volcanic field is cut by numerous fault zones that created conduits for hydrothermal fluid circulation. Hydrothermal fluids channeled through these tectonically-disrupted lavas, silicic tephra, and interbedded volcaniclastic sediments were responsible for surface and subsurface argillic and propylitic alterations. The types and timing of hydrothermal alteration and mineralization in and around the caldera are mostly consistent with and related to the silicic volcanic eruptions of the Jemez volcanic field (WoldeGabriel, 1990; WoldeGabriel and Goff, 1989, 1992).

In contrast, although hydraulically-significant fractures were probably generated in the nonwelded tuffs, sediments, and underlying Mesozoic sedimentary rocks during the basaltic intrusion and post-intrusion faulting at Grants Ridge in west-central New Mexico, lack of fluids appears to have been the main reason for the minimal development of hydrothermal system around the 150-wide basaltic intrusion. Esposito and Whitney (1995) reported that the distance of hydrothermal alteration around thin igneous intrusions into a lithologically heterogeneous Tertiary sedimentary basin in southwestern Washington was equivalent to the thickness of the sill. According to the authors, hydrothermal alteration of the host rock was dictated by solution chemistry, water availability, and starting mineralogy. Thus, in the absence of fluids, magmatic intrusions have minimal effect on the country rocks beyond the immediate contact.

h. Implications of the natural analog studies to magmatic hazards and repository heat at Yucca Mountain. The natural analog study of the contact metamorphic effects of the 150-m wide Grants Ridge basaltic intrusion into a nonwelded silicic tuff was aimed at understanding the extent 
of subsurface processes related to internal and external heat sources that may occur in a potential repository environment. Subsurface magmatic processes can affect both the repository itself and the surrounding natural barriers as discussed in Section IV.C.2.g.

Despite the size of the basaltic plug and the nonwelded nature of the silicic tephra, the field and analytical data from the Grants Ridge natural analog site located in west-central New Mexico suggest the absence of a hydrothermal system except for localized recrystallization of volcanic glass within the contact zone. The plug was possibly intruded into a shallow, probably unsaturated, environment, similar to the potential Yucca Mountain repository. Therefore by analogy we suggest that an intrusion at Yucca Mountain would not result in large amounts of hydrothermally-driven mass transfer.

i. Summary and Conclusions. Physical features (e.g., color variation and degree of compaction), mineralogical, and chemical data from the silicic tuffs around the basaltic plug indicate variable thermal effects. Despite the size of the basaltic intrusion ( $150 \mathrm{~m}$ wide), the contact metamorphic zone developed around the basaltic plug is confined to a narrow zone of about $5 \mathrm{~m}$ wide. This is similar in size to the contact aureoles developed in vitric and zeolitized tuffs intruded by dikes and a sill at Paiute Ridge along the northeastern boundary of the Nevada Test Site (Section IV.C). The ash flow tuff along the contact aureole is baked, fused, deformed, and injected with basalt lava. This thermal effect gradationally decreases away from the intrusion. Variation in color and the degree of compaction of the silicic ash flow tuff provide evidence for the localized nature of the thermal effect.

Variations in mineralogical and geochemical compositions are consistent with the changes in color and compaction of the silicic rocks. The volcanic glass, water composition, fluorine, chlorine, and iron contents increase away from the intrusion. Conversely, the amount of recrystallized minerals and the alkali contents are higher along the contact.

The field and laboratory data suggest that the effect of the intrusion on the unwelded pumicerich ash flow tuff was minimal. Pumice was mined at close proximity on both sides of the plug indicating insignificant contact welding and hydrothermal alteration. Intrusion into an unsaturated environment appears to be the most probable cause for the limited water-rock interaction in the porous ash flow tuffs. Because devitrification is generally enhanced by aqueous solution, the abundance of volcanic glass within a short distance $(\sim 5 \mathrm{~m})$ from the intrusion suggests a dry environment. Thus, in the absence of aqueous solutions, the width of the contact metamorphic aureole is generally confined to a narrow zone regardless of the size of the intrusion.

\section{Theoretical and Modeling Studies of Hydrothermal Processes}

1. Introduction. This section describes results from the first stage of theoretical and modeling studies that were conducted for the magmatic effects study plan. The results shown here comprise some of the first steps toward a more comprehensive set of numerical simulation studies that were planned for the latter half of the effects project. First, we describe analysis of the onset of convection of a compressible gas in porous media. This was a necessary first step because hydrothermal effects of interest for the potential Yucca Mountain repository would occur in the vadose zone, which differs from the classical hydrothermal system in saturated media. The theoretical analysis below shows how the different fluid properties of air (vadose zone) and liquid water affect convection. This analysis was also used to verify the computer code FEHM and is being published as a separate paper (Stauffer et al., 1997). Described below are preliminary 
numerical simulations aimed at determining the maximum distance that effects (in this case, perturbed flow fields) extend from a shallow basaltic dike or sill. This problem is important because it defines the area surrounding the potential repository within which an intrusion might affect potential repository performance even if the intrusion does not directly intersect the potential repository.

\section{Finite Amplitude Analysis of Natural Convection of Compressible Gas in Porous}

\section{Media.}

a. Summary. The theory of thermally driven convection of dry air in a porous medium is reviewed. The critical Rayleigh number $(R a)$ for air is the same as for liquid, $4 \pi^{2}$, but the thermal gradient used is decreased by the adiabatic gradient of air. Because of the differences in the physical properties of air and water, initiation of convection requires the product of gradient and permeability to be thousands of times greater for air than for water. Finite amplitude analysis of the problem for $R a<300$ show that (1) the code predicts the onset of convection in an air-filled porous medium, (2) at low thermal gradient, $R a$ vs. $\mathrm{Nu}$ (Nusselt number) curves are nearly the same for air and water, (3) the slope of the $R a$ vs. Nu curve matches well with experimental data reported by others for water, and (4) time to steady state decreases approximately as the square root of Nusselt number.

\section{b. Nomenclature for Section 2.}

\begin{tabular}{|c|c|c|}
\hline & & Greek symbols \\
\hline & & fluid thermal expansivity \\
\hline$c_{p}$ & heat capacity of fluid at constant pressure & isothermal compressibility \\
\hline$g$ & gravitational constant & porosity \\
\hline$\Gamma$ & $\Delta \mathrm{T} / \mathrm{H}$, temperature gradient & equivalent thermal conductivity \\
\hline$H$ & thickness of system & viscosity of fluid \\
\hline$K$ & permeability & fluid density \\
\hline$N u$ & Nusselt Number & \\
\hline$P$ & pressure of fluid & $\underline{\text { Subscripts }}$ \\
\hline$Q$ & heat content & \\
\hline$R a$ & Rayleigh Number & critical \\
\hline$R e_{p}$ & Porous Reynolds Number & effective \\
\hline$T$ & temperature of gas and matrix (Kelvin) & matrix \\
\hline$\Delta T$ & change in temperature across system & steady state \\
\hline$t$ & time & \\
\hline$U$ & internal energy & $\underline{\text { Superscript }}$ \\
\hline $\mathbf{v}$ & Darcy fluid flux & Total derivative with respect to time \\
\hline$W$ & work & \\
\hline $\mathbf{z}$ & downward unit vector & \\
\hline
\end{tabular}

c. Introduction. The onset of convection in incompressible liquid in a porous media has been considered many times, and a comprehensive treatment of this subject can be found in Nield and Bejan (1992). Much less work has been done, however, on the problem of ideal gas convection in porous media. Strauss and Schubert (1977) include the compressibility term in their linear 
stability analysis (LSA) but restrict their analysis to steam-saturated water (i.e. no free vapor phase). Saatdjain (1980) neglects the pressure/volume contribution to the energy equation in his treatment of ideal gas porous convection. Nield (1982) corrects Saatdjain and provides many insights into the differences between air and water but provides only a brief LSA. Zhang et al. (1994) present a complete LSA for moist gas convection in porous media that reduces to the solution of Nield when moisture content is set to zero. The reader is referred to this work for further details.

Nield (1982) and Zhang et al. (1994) both show that the onset of convection in an ideal gas can be characterized by a critical Rayleigh number $(R a)$. The exact form of the definition of the Rayleigh numbers, however, is altered because of the effects of compressibility. To first order, the only difference is that for an incompressible fluid like water, we have the Rayleigh number:

$$
R a_{\text {liquid }}=\frac{\alpha H^{2} K g c_{p} \Gamma \rho^{2}}{\mu \kappa}
$$

whereas for air, we have a slightly different definition of the Rayleigh number:

$$
R a_{\text {air }}=\frac{H^{2} K g\left(c_{p} \Gamma-g\right) \rho^{2}}{T \mu \kappa}
$$

The two definitions of the Rayleigh numbers are almost identical. For an ideal gas, $\alpha=1 / \mathrm{T}$. The $c_{p} \Gamma$ term in $R a_{\text {liquid }}$ is replaced by $\left(c_{p} \Gamma-g\right)$ in the $R a_{a i r}$ definition. This result is analogous to Jeffrey's (1930) conclusion that the $R a$ for compressible fluid convection (no porous medium) must be modified to account for the adiabatic gradient. The change in the effective temperature gradient arises from the pressure dependence of the heat content of a fluid parcel. In an incompressible fluid, the internal energy depends only on the temperature. In a compressible gas, if a packet moves into a lower pressure region, it expands and cools adiabatically, reducing the effective temperature gradient. This means that for air, $\Gamma$ must be larger than an adiabatic gradient, $g / c_{p} 10^{-2^{\circ}} \mathrm{K} / \mathrm{m}$, before the Rayleigh number even has a positive value. Below the adiabatic gradient, air convection is not possible for any values of system height $(H)$ or permeability $(K)$. Thus if we use $R a_{\text {liquid }}$ but substitute an effective temperature gradient

$$
\Gamma_{e f f}=\Gamma-\frac{g}{c_{p}}
$$

for $\Gamma$ and $1 / T$ for $\alpha$, the two Rayleigh numbers are identical (Nield, 1982).

It is the values of the physical quantities appearing in the two Rayleigh number definitions that dominate the difference between the convective stability of subsurface water and air. Simple algebra shows that for a given geothermal gradient the critical permeability for onset of convection in a typical porous medium is three orders of magnitude greater for dry air than liquid water (Table 5.6).

The dramatic increase in the permeability needed to initiate convection in air is explained by the factors noted previously. While the lower viscosity and higher thermal expansion coefficient favor convection in air, these are more than offset by the $\rho^{2}$ factor present in Eqs. (5-4a) and (5$4 b)$. Convection occurs when it is more efficient to move energy by the physical exchange of matter than by conduction of heat. While it is easy to convect large volumes of air, those volumes of air 
carry very little heat energy, and the heat is rapidly dissipated by the conduction through the matrix, damping the convective motion.

The purpose of this section is to examine convective flow in a porous medium filled with dry air heated from below. We present the theory, report finite amplitude results for Rayleigh numbers $R a$ up to 300, discuss the relationship between time to steady state, Nusselt number ( $\mathrm{Nu}$ ) and $R a$ for these systems, and compare the results to those for similar systems saturated with liquid.

Table 5.6. Physical Properties of Air and Water at 293K and 373 K.

\begin{tabular}{|lll|lll||}
\hline \hline & Air & & Water & & \\
\hline & $293 \mathrm{~K}$ & $373 \mathrm{~K}$ & $293 \mathrm{~K}$ & $373 \mathrm{~K}$ & \\
\hline$\rho$ & 1.205 & 0.946 & 998.2 & 958.4 & $\mathrm{~kg} / \mathrm{m}^{3}$ \\
$\alpha$ & $3 \times 10^{-4}$ & $2.7 \times 10^{-3}$ & $2.1 \times 10^{-4}$ & $7.1 \times 10^{-4}$ & $\mathrm{~K}^{-1}$ \\
$\kappa$ & $2.5 \times 10^{-2}$ & $3.2 \times 10^{-2}$ & 0.6 & 0.68 & $\mathrm{~W} / \mathrm{mK}$ \\
$c_{p}$ & 1006 & 1011 & 4182 & 4216 & $\mathrm{~J} / \mathrm{kgK}$ \\
$\mu$ & $1.81 \times 10^{-5}$ & $2.18 \times 10^{-5}$ & $1.0 \times 10^{-3}$ & $2.83 \times 10^{-4}$ & $\mathrm{~Pa} \cdot \mathrm{s}$ \\
\hline
\end{tabular}

Values from appendix C, Bejan (1993).

The motivation for this work comes from our study of the effects of volcanic intrusions into partially saturated rock. We seek to understand the spatial and temporal scale over which an intrusive event can have a significant effect on the transport of gases, both from the intrusion itself (e.g., $\mathrm{SO}_{2}$ ) or at some distance from the intrusion.

First, we review the governing equations and verify the ability of the numerical code we use for our finite amplitude calculations to reproduce the critical Rayleigh number.

d. Governing Equations. The basic equations that govern low velocity (Darcy flow regime) convective flow in porous media are well developed in the literature (e.g., Nield and Bejan, 1992; Strauss and Schubert, 1977; and Nield, 1982). In the following form, rewritten from Nield and Bejan (1992), Strauss and Schubert (1977), and Nield (1982) for clarity, the equations apply to single phase compressible as well as Bousinesq approximate incompressible fluids.

$$
\begin{gathered}
\phi \frac{\partial \rho}{\partial t}+\nabla \bullet \mathbf{v}=0 \\
\mathrm{v}=\frac{K}{\mu}(\nabla P-\rho g \mathbf{z}) \\
\left(\rho c_{p}\right)_{m} \frac{\partial T}{\partial t}+\left(\rho Q^{\prime}\right)_{f}=\kappa \nabla^{2} T
\end{gathered}
$$

where the matrix density, $\rho_{m}$, includes a correction for porosity. Equation (5-5c) can be reformatted in the more traditional form of Nield (1982). By substitution of $Q^{\prime}=U^{\prime}-W^{\prime}$, and bearing in mind the total derivative of a quantity (Q) includes an advective transport contribution as 


$$
Q^{\prime}=\frac{\partial Q}{\partial t}+\mathbf{v} \bullet \nabla Q
$$

We arrive, after some algebraic manipulation and thermodynamic substitutions, at:

$$
\left(\rho c_{p}\right)_{m} \frac{\partial T}{\partial t}+\left(\rho c_{p}\right)_{f} T^{\prime}-\alpha T P^{\prime}=\kappa_{e f f} \nabla^{2} T
$$

The difference between the convection of an incompressible liquid and the convection of a compressible gas arises from three basic causes. The first is the significantly smaller amount of energy contained in a given volume of gas compared to the same volume of liquid. The advective heat transport term, $\rho Q$ ', of Eq. (5-5c) is directly proportional to the density, $\rho$. For example, even though the rate of change per unit mass, $Q$ ', is roughly the same for both water and gas, the fact that the density of air is three orders of magnitude lower makes convection in air much less efficient. The second cause is the much smaller buoyancy force ( $\rho g$, Eq. (5-5b) for air, again due to the very large difference in the densities. For air,

$$
\delta \rho g=\rho g\left(\frac{\delta P}{P}-\frac{\delta T}{T}\right)
$$

where the first term on the right-hand side corresponds to the isothermal compressibility, $\beta$. For the incompressible case, only the thermal expansion term is retained as:

$$
\delta \rho g=\rho g \alpha \delta T
$$

The third is that the energy content of a given volume of air is pressure dependent, whereas the energy content of a given volume of liquid is not. For air,

$$
\rho Q^{\prime}=c_{p} \rho T^{\prime}-P^{\prime}
$$

In contrast, for a Boussinesq liquid,

$$
\rho Q^{\prime}=c_{p} \rho T^{\prime}
$$

Secondary factors that lead to real gases being more stable than an ideal gas include variations in $\alpha, c_{p}$ and $\mu$ with temperature (Nield, 1982). Comparison between air and water material properties and their derivatives with temperature can be located in Nield and Bejan (1992) and Bejan (1993).

e. Finite Amplitude Analysis. In order to consider finite amplitude convection in air, one must go beyond the assumptions used in the linear stability analysis. This is especially important with air because the strong temperature dependence of the thermodynamic properties of air leads to large differences in the Rayleigh number calculated at the hot versus cold ends of the convective cell. Note that in this paper, we will report all $R a$ values calculated at the mean temperature of the system after Davidson (1986).

For the numerical analysis of the convection problem we have used the finite element heat and mass transfer code FEHM (Zyvoloski et al., 1995a,b). Originally developed for use in geothermal 
reservoir modeling, FEHM is capable of simulating multiphase transport of air, water, water vapor, and dilute solutes in fractured and porous media. FEHM solves these equations for the highly nonlinear equations for air convection using the Galerkin technique to discretize the spatial derivative and a standard first-order approach to the time discretization. Lobbato integration is used to evaluate integrals in the finite element equations, and a modified Newton-Raphson iterative procedure is used to solve the resulting system of equations. Dependence of material properties on pressure and temperature is represented as a cubic polynomial. The polynomial fits are based on National Bureau of Standards steam tables (Haar et al., 1984).

In our calculations, we assume that (1) flow is not affected by quadratic drag or boundary phenomenon (i.e., the creeping Darcy regime), and that (2) thermal equilibrium exists between the air and rock. The violation of either of these would require extra terms to modify the treatment of the heat transfer. We address (1) first. The transition from creeping Darcy flow to inertial flow is determined by the value of the porous Reynolds number, $\operatorname{Re}_{\mathrm{p}}$. If $\mathrm{Re}_{\mathrm{p}}<<1$, all inertial and boundary effects are negligible. Even under the liberal assumption that our pore diameter is as large as $10^{-3}$ $\mathrm{m}, \mathrm{Re}_{\mathrm{p}}$ approaches unity only if the air velocity is above $0.015 \mathrm{~m} / \mathrm{s}$. Maximum air velocities reached during this study were $210^{-4} \mathrm{~m} / \mathrm{s}$ at $R a=300$. With respect to issue (2), thermal equilibrium is reached if a temperature perturbation in the convective cell moves slowly compared to the time required to exchange energy over pore-scale lengths. Computations of energy transfer rates for FEHM (Zyvoloski et al., 1995a) show that thermal equilibrium is valid for water velocities below $10^{-5} \mathrm{~m} / \mathrm{s}$. Scaling the water results to air by the product of relative heat capacity, thermal conductivity, and density (Table 5.6), we come to the conclusion that a typical porous medium should be in approximate thermal equilibrium at air velocities below $1.7 \mathrm{e}-3 \mathrm{~m} / \mathrm{s}$.

A simple two dimensional regular grid representing a $200 \mathrm{~m}$ square, broken into $49 \times 49$ rectangular elements, has been used for the simulations. Top and bottom boundaries have fixed temperatures while the side boundaries permit no flow with respect to either mass or energy (Figure 5.33). Note that this choice of no flow lateral boundaries restricts the horizontal motion and limits the possible planforms. For all the simulations presented here, we use an initial middomain temperature of $60^{\circ} \mathrm{C}$. Top and bottom boundaries are set to $60^{\circ} \mathrm{C} \pm 1 / 2 \Delta \mathrm{T}$. For each case, a non-flow calculation was used to generate the initial temperature-pressure distributions as input for the stability test. Convection was set in motion by finite temperature perturbations $\left(0.1-1^{\circ} \mathrm{C}\right)$ at selected bottom nodes.

Our major measure of the dynamics of convection in these systems is the computed Nusselt number, $\mathrm{Nu}$, which is the ratio of the total flux to the purely conductive flux implied by the temperature gradient. We calculate $\mathrm{Nu}$ at the top and the bottom of the system numerically after the system has reached steady state. The criterion for determining a steady state is that a small rate of change in the temperature has been achieved. As one can see in Figure 5.34, this time is welldetermined. Error in the calculation of $\mathrm{Nu}$ is estimated to be between 2 and $3 \%$.

f. FEHM Results. We begin by validating FEHM's ability to predict the onset of convection in air. As we show below, FEHM reproduces the critical Rayleigh number remarkably well (Figure 5.35). We determined $R a_{c}$ by a straight line fit through the results for four calculations at low Rayleigh number extrapolated to $\mathrm{Nu}=1$. Nonlinear effects decrease with temperature gradient, so we used a low thermal gradient of $20^{\circ} \mathrm{C} / \mathrm{km}$ for this analysis. By definition at $R a_{c}$ the time to set up convection is infinitely long, so we must extrapolate the finite amplitude results to estimate the threshold value. The $R a_{c}$ determined from these FEHM results is 39 , which is remarkably close to the linear stability prediction of $4 \pi^{2}$. 
Figure 5.36 shows all our finite amplitude results for air and for water on a Ra vs. Nu plot. As Figure 5.5 shows, the results for air and water are nearly identical (see Table 5.6 for property values used in these simulations). The thermal gradient for these simulations was $20^{\circ} \mathrm{C} / \mathrm{km}$ for air and $300^{\circ} \mathrm{C} / \mathrm{km}$ for water. These results are in good agreement with ascaling analysis reported by Nield and Bejan (1992) for systems saturated with water and experimental data reported by Kaneko et al. (1974) and Elder (1967).

$$
T_{\text {top }}=60^{\circ}-1 / 2 \Delta T
$$

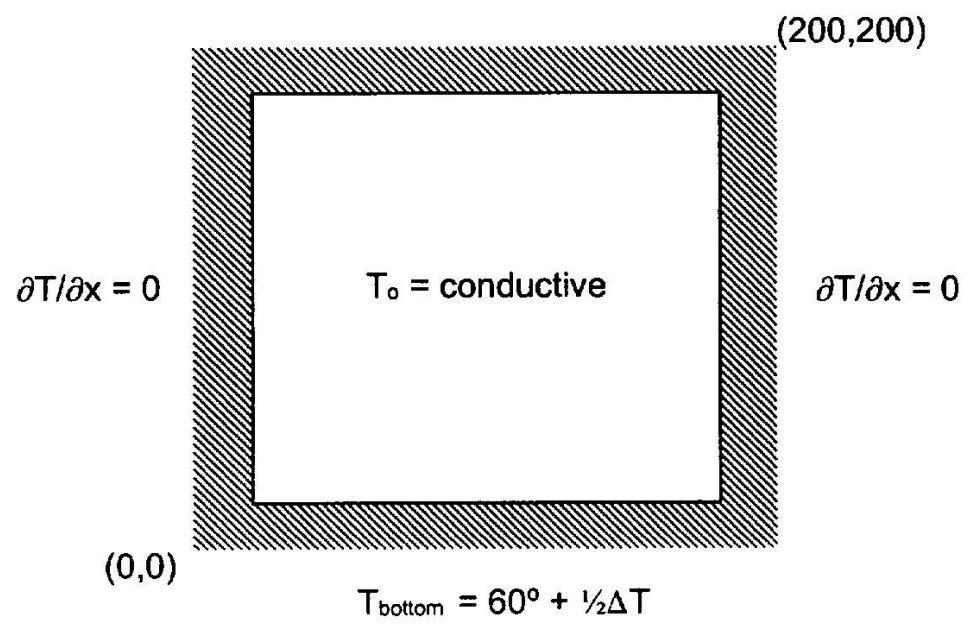

Figure 5.33. Domain, boundary and initial conditions for finite amplitude numerical simulations reported in this study.

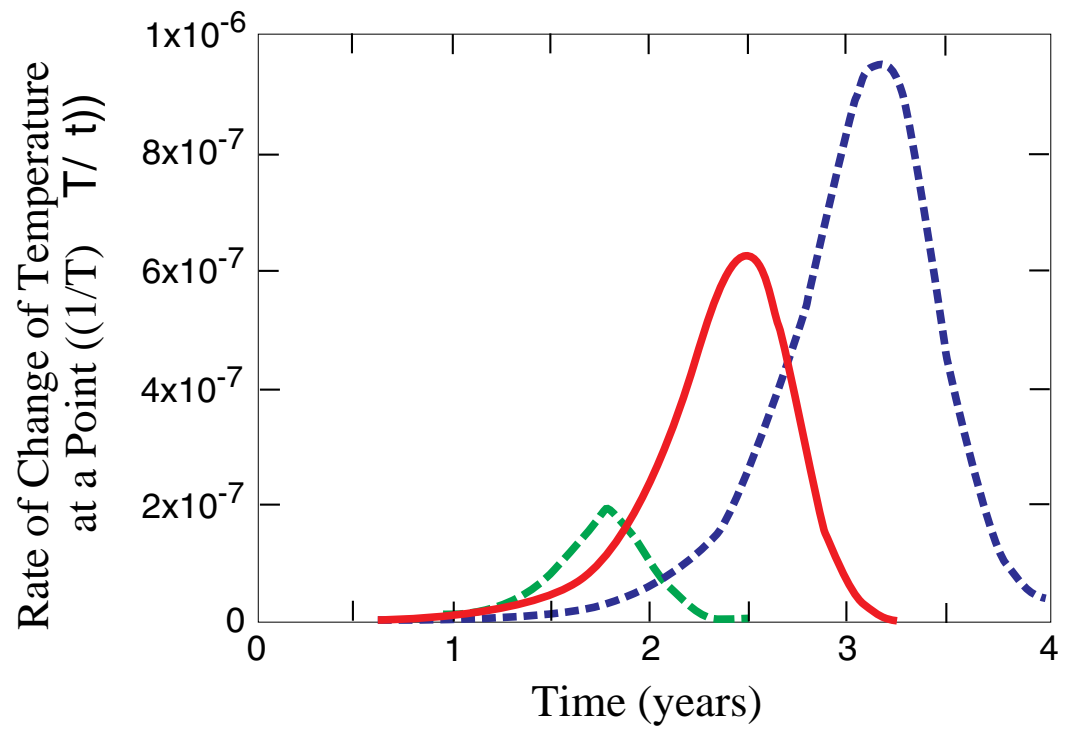

Figure 5.34. Rate of change of temperature at a point vs. time. We defined steady-state approximately the $95 \%$ percentile of these curves. 
The relationship between $\mathrm{Nu}$ and time to steady state $\left(\mathrm{t}_{\mathrm{s}}\right)$ is shown in Figure 5.37. As this figure shows, the time to establish the convective flow is on the order of 1000 years for the system simulated here, and decreases as the strength of the convection increases. The value of $t_{s}$ scales in a simple way, decreasing in approximately direct proportion to the square root of $\mathrm{Nu}$. This is true for a variety of thermal gradients and different system heights, scaled in Figure 5.37 such that the product, $(K H \Gamma)$, remains constant. Scaling to determine times needed to reach steady state has proved useful in our current work. Another point of interest is that as the Nusselt number approaches 1 from above, time to steady state quickly exceeds the time for a conductive profile to equilibrate, which is in agreement with observations reported by Elder (1967).

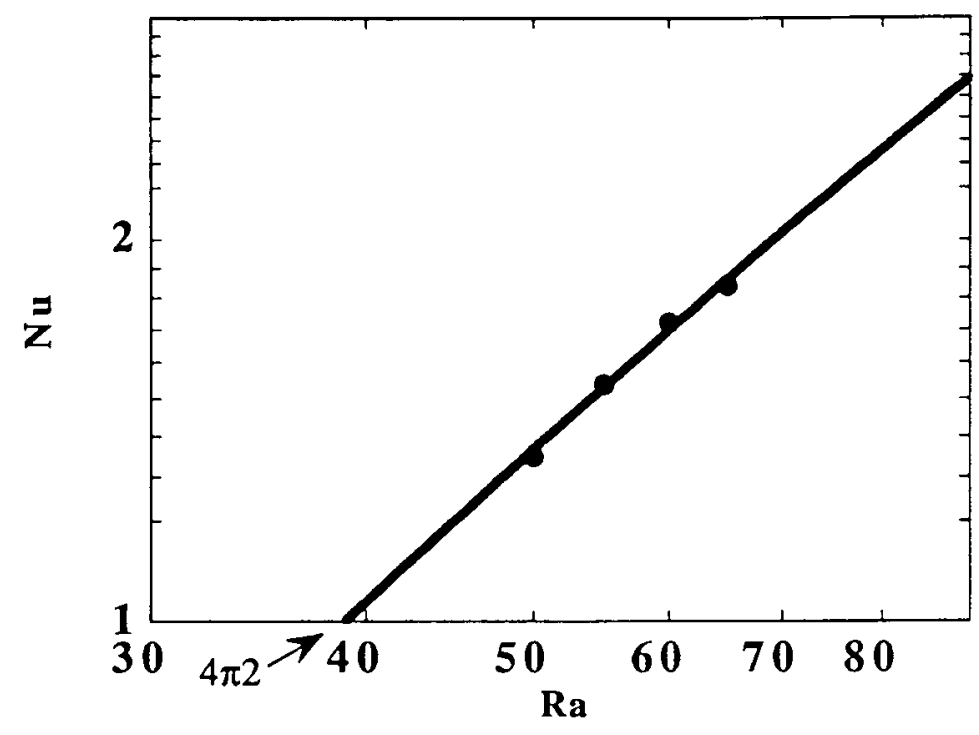

Figure 5.35. Nu vs. Ra for air from low Ra FEHM simulations. 


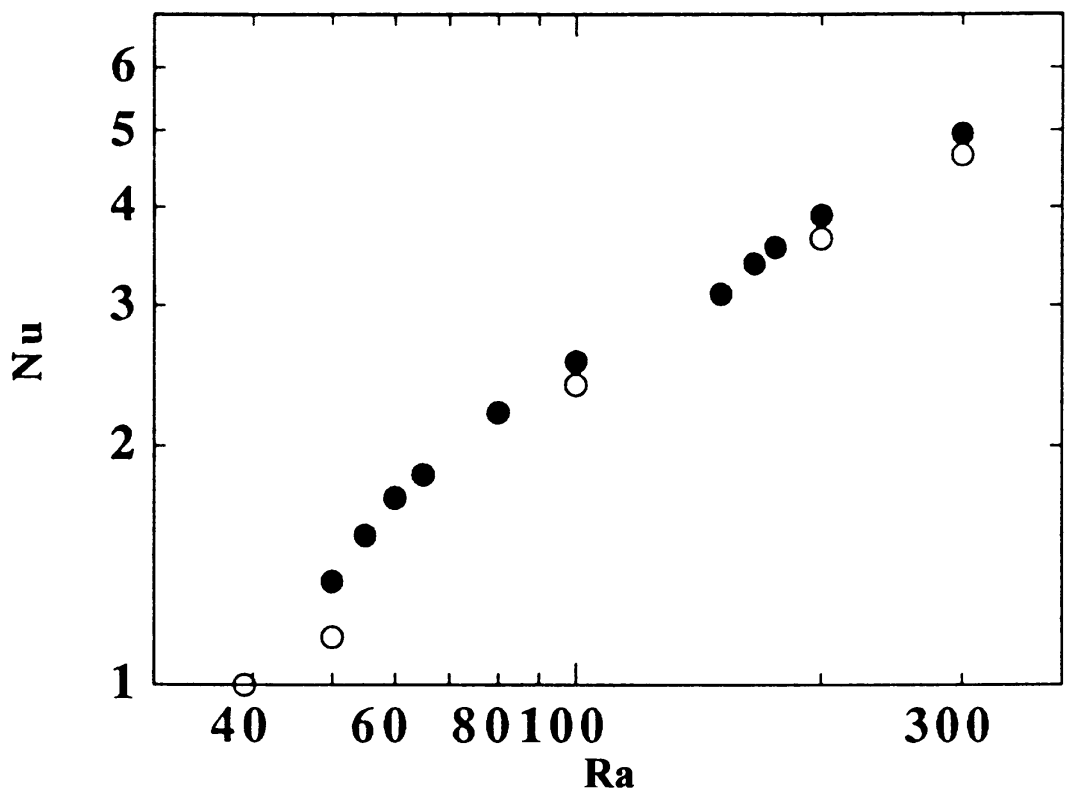

Figure 5.36. $\mathrm{Nu}$ vs. Ra for air and water from FEHM simulations. Filled circles represent results for air convection. Open circles represent results for water convection.

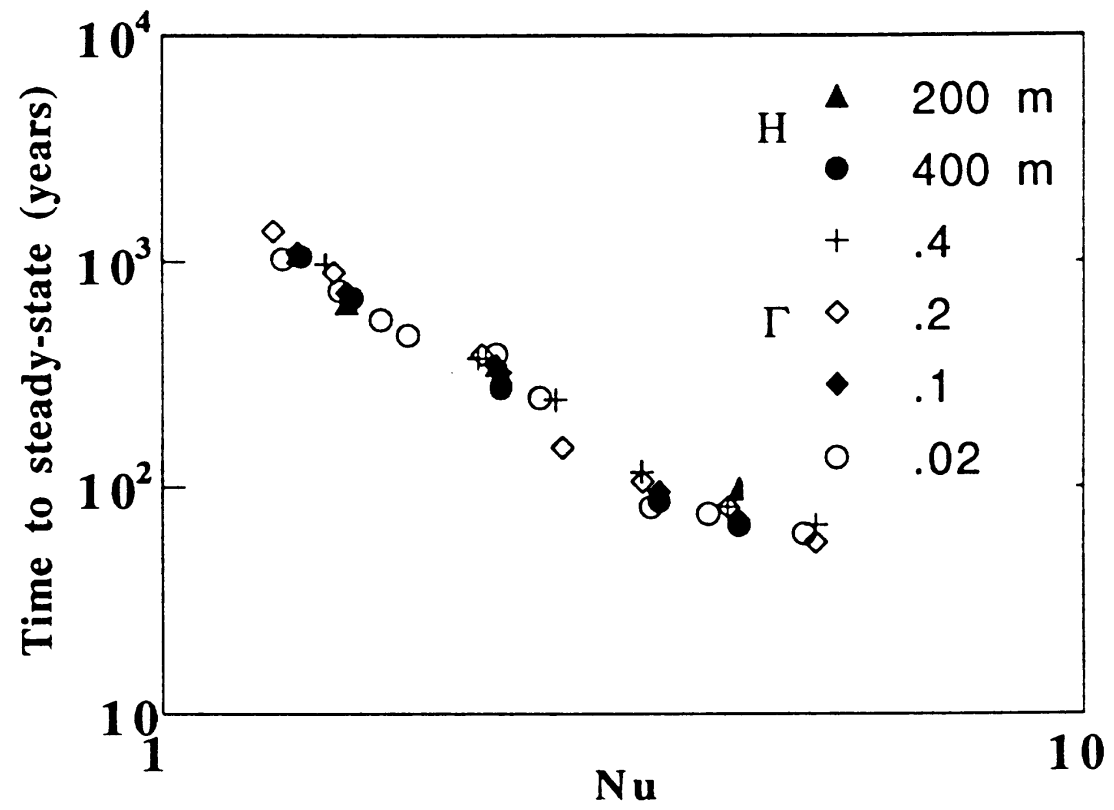

Figure 5.37. Time to steady-state vs. Nu for air from FEHM simulations for systems with several different thermal gradients and different heights.

We use Nu rather than $R a$ to bypass the problems of $R a_{a i r}$ varying so greatly in value from the top to the bottom of the system. Instead of using a mean value for the system temperature and plotting $R a$ versus $\mathrm{t}_{\mathrm{s}}$ after Davidson (1986), we have chosen to examine time to steady state as a function of the Nusselt number. Solution of the LSA equations for stability of integer wavelength cells predicts that multiple planforms are stable for a given $R a$, each with a unique $\mathrm{Nu}(\mathrm{Nield}$ and 
Bejan, 1992). Final planform pattern depends solely on initial conditions; thus, a plot of $R a$ versus $\mathrm{t}_{\mathrm{s}}$ would have several time points for a given $R a$. The Nusselt number provides a single value for energy transport across a system at steady state and is, therefore, a more consistent parameter to plot versus time to steady state.

g. Conclusions. The equations governing convection of air in a porous medium are very similar to those of water. The compressibility of the air, however, does affect the apparent temperature gradient. Because the air cools adiabatically when it rises, the effective temperature gradient is correspondingly reduced. By including this term it is possible to define a Rayleigh number appropriate for the prediction of the onset of convection in air. The resulting critical Rayleigh number for air is the same as for water, $4 \pi^{2}$, when the gradient in the incompressible Rayleigh number is lowered by the adiabatic gradient of the gas. Even though the critical numbers are identical, it is much more difficult to induce convection in air than in water. In fact, the product of gradient and permeability must be thousands of times larger because of the very much lower density of the gas, which makes convection in air much less efficient in transporting energy than in water.

Finite amplitude analysis of the problem using the FEHM computer code shows that (1) the numerical code predicts the onset of convection in air very well, (2) the $R a$ vs. Nu curves for air (at low thermal gradients) and water are nearly identical, (3) the slope of this $R a$ vs. Nu curve matches well with theory and experimental data reported by others for water, and (4) time to steady state decreases approximately as the square root of $\mathrm{Nu}$.

\section{Spatial Scales of Effects on the Potential Yucca Mountain Repository Due to Convective Air Flow Induced by Igneous Intrusions.}

a. Summary. The purpose of this study is to provide information that will influence the calculations of $E 2$ by defining the spatial scale over which an intrusive event can have a significant effect on the potential Yucca Mountain repository. Our approach is based on numerical simulations of thermally induced convective flow of air where the thermal driving force is the heat from magmatic intrusions. Based on a series of simulations of highly simplified systems that represent Yucca Mountain, we conclude that the spatial scale over which an intruded dike or sill can have a significant effect on a potential repository is on the order of kilometers. "Intrusion" gas travels less than about $500 \mathrm{~m}$ and the horizontal distance over which an intrusion affects convective air flow is less than $2.5 \mathrm{~km}$. Future calculations will address the role of more realistic stratigraphy, dual permeability fracture models, and topography; consider 3D domains and the flow of water (liquid and vapor) in addition to air flow; and include more complete parameter and sensitivity analyses.

b. Introduction. The following probabilistic framework is being used to estimate the risk of magmatic activity to the potential Yucca Mountain repository:

$$
\mathrm{R}_{\text {mag }}=[\operatorname{Pr}(\mathrm{E} 2 \text { given } \mathrm{E} 1) \operatorname{Pr}(\mathrm{E} 1)] \times \mathrm{C}_{\text {mag }}
$$

where $R_{\text {mag }}$ is the risk posed by magmatic activity. $E 1$ is the recurrence rate of magmatic events in the region surrounding Yucca Mountain (based on the estimated recurrence rate during the Quaternary and Pliocene), E2 is the probability that a future magmatic event intersects the potential repository or is close enough to it to have a significant effect on its performance, and $C_{m a g}$ 
is the sum of all consequences associated with a magmatic event that is sufficiently close to a potential repository to have an adverse effect on it.

The purpose of the present study is to provide information that will influence the calculations of $E 2$ by defining the spatial scale over which an intrusive event can have a significant effect on a repository. Our approach is based on numerical simulations of thermally induced convective flow of air at Yucca Mountain where the thermal driving force is the heat from magmatic intrusions. At this point, the definition of "a significant effect" is unclear. For the purposes of this study, we are examining the spatial scales associated with two effects. The first is arrival of "intrusion" gas, which might contain corrosive gases such as $\mathrm{SO}_{2}$, at the potential repository. The second is a change in air flow at the potential repository.

Previous modeling studies have examined the effects of thermally induced convective flow at Yucca Mountain where the thermal driving force is provided by radioactive waste buried in the potential repository (Tsang and Pruess, 1987; Lu and Ross, 1993; Buscheck and Nitao, 1993). While these studies are relevant in terms of the flow and transport processes involved, they address a very different problem. One difference is the magnitude and duration of the thermal driving force. In the hot repository case, the thermal source lasts thousands of years and maximum temperatures are about $100^{\circ} \mathrm{C}$. A dike or sill intrudes at magmatic temperatures, about $1200^{\circ} \mathrm{C}$, but heat input lasts only a few years after which the intrusion gradually cools. More important is the difference in the questions being asked in these two cases. The concern in the hot repository problem is the transport of vapor-phase contaminants from the repository to the surface or water table; therefore, the focus is on flow and transport in the vertical direction. The concern in the magmatic intrusion problem is primarily one of flow and transport in the horizontal direction.

c. Modeling Approach. The FEHM computer code is used to perform the series of simulations of air convection reported here. FEHM is a nonisothermal, multiphase flow and transport code that was developed by George Zyvoloski and others at Los Alamos National Laboratory with the support of a variety of sponsors, primarily the Yucca Mountain Site Characterization Project (YMP). For details on FEHM, see Zyvoloski et al. (1992; 1995a,b).

We have made several simplifying assumptions. Our domain is a 2-D box of homogeneous materials. An equivalent continuum model is used for the permeability. The role of more realistic stratigraphy, dual permeability fracture models, and topography was to be considered in the future. Our simulations account for the flow of air only. Simulations that include liquid water and water vapor were also planned for future work. Comparisons of simulations using linear expressions for air properties to those using real air properties show no significant differences. Because "linear" air simulations run much faster, we used this approach in this study.

Our model domain is a 2-D box of homogeneous material with the properties of Topopah Springs Tuff (unit TSW2), the rock in which the potential repository at Yucca Mountain would be located. A few simulations were performed to investigate the model sensitivity to values chosen for porosity and permeability. The domain is $700 \mathrm{~m}$ in height, which represents the nominal distance from the surface to the water table at Yucca Mountain, and $6 \mathrm{~km}$ in length, depending on the problem. The grid is in Cartesian coordinates and contains 3600 nodes. A typical grid is shown in Figure 5.38. Due to the symmetry of the problem, simulations are performed in a box only $3 \mathrm{~km}$ in length with the dike or sill located at the left wall. 


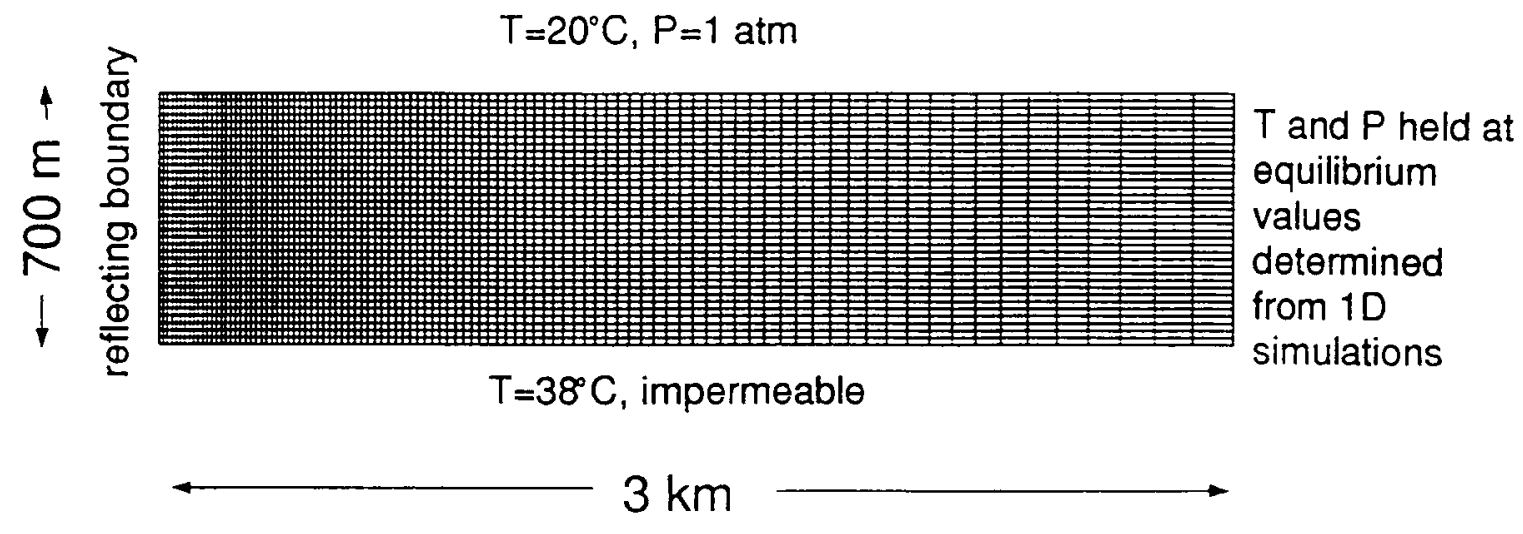

Figure 5.38. Domain and boundary conditions.

Properties of TSW2

$\begin{array}{ll}\text { permeability } & 10^{-12} \mathrm{~m}^{2} \\ \text { porosity }^{\mathrm{a}} & 0.14 \\ \text { rock density } & 2200 \mathrm{~kg} / \mathrm{m}^{3} \\ \text { rock heat capacity } & 1000 \\ \text { rock thermal conductivity } & 2.7 \mathrm{~W} / \mathrm{m}^{\circ} \mathrm{C}\end{array}$

${ }^{a}$ Wilson, M. L. et al. (1994), other values are broadly representative of variably welded silicic tuffs. 
The following boundary conditions and initial conditions were used. The left wall represents a symmetry line in this problem and is, therefore, impermeable to air flow and heat transport. The bottom boundary represents the water table. It is an impermeable boundary with a constant temperature of $38^{\circ} \mathrm{C}$. The top boundary is set to $1 \mathrm{~atm}$ pressure, allowing for air to flow into or out of the top. Air that leaves the system through the top wall is allowed to carry its heat with it. The boundary is otherwise set to $20^{\circ} \mathrm{C}$, and air that enters the system is constrained to be $20^{\circ} \mathrm{C}$. Equilibrium values of pressure and temperature, obtained from 1-D background simulations before an intrusive event, are maintained at the right boundary. These 1-D equilibrium temperature and pressure values were used as initial values for the 2-D domain as well.

The dike or sill is modeled by setting "dike" or "sill" nodes to $300^{\circ} \mathrm{C}$ for 4 years beginning at time equal to 0. Calculations based on equations given in Turcotte and Schubert (1982) for total heat into a semi-infinite half-space and the heat flux from a cooling dike or sill show that the total heat input in this way is approximately equivalent to that from a $1-\mathrm{m}$-thick $1200^{\circ} \mathrm{C}$ intrusion. We believe this simplification is adequate for the far-field calculations considered here. Simulations are run out to 1,000 years by which time the perturbations in the temperature field introduced by the magmatic intrusions have (or have very nearly) disappeared. A dike is modeled as a series of nodes along the left wall beginning at the water and extending upwards. Dikes of various heights above the water table $(180 \mathrm{~m}, 360 \mathrm{~m}, 560 \mathrm{~m}$, and $680 \mathrm{~m})$ are considered. A sill is modeled as a one-node thick zone of material extending $100 \mathrm{~m}$ from the left wall at various distances above the water table $(0 \mathrm{~m}, 360 \mathrm{~m}$ and $520 \mathrm{~m})$. Both permeable and impermeable intrusions are modeled for intrusions not along a side boundary.

A particle tracking routine is used to display the advective transport. To estimate the spatial scale for the arrival of air that has been in contact with the intrusion, particles are introduced at the "dike" or "sill" nodes (adjacent to the "sill" nodes for the impermeable sill cases). The initial particle field contained 10,000 particles. The paths of these particles are evaluated throughout the simulation and the maximum horizontal distance traveled is noted. To assess the spatial scale for a change in air flow at the potential repository location as a result of convection induced by the magmatic intrusion, particles are introduced along a line at the potential repository horizon (halfway between the ground surface and the water table) beginning $\sim 600 \mathrm{~m}$ from the left boundary on day one of the simulation. We use the spread of the particles as a function of distance after 1,000 years as a measure of the magnitude and direction of the air flow at that distance.

d. Results. The results of the dike and sill simulations using the parameters given above are shown in the form of temperature and particle fields at 1 day, 4 years, 100 years, 500 years, and 1000 years (Figures 5.39-5.45). These plots show that the horizontal distance over which an intrusion affects convective air flow is always less than $2.5 \mathrm{~km}$, and that the "dike" or "sill" particles, representing magmatic volatiles, never travel more than $\sim 500 \mathrm{~m}$ horizontally. The sensitivity of these results to values of porosity and permeability was investigated for one case, the $560 \mathrm{~m}$ dike, by running simulations with the porosity changed by $+/-50 \%$ and the permeability changed by $+/-$ a factor of 2 from the values given above (Figures 5.46, 5.47). These simulations show that the distance the "potential repository horizon" is affected by the dike increases with increasing porosity and increasing permeability, but the zone of influence for effects on air flow and "intrusion" air are still less than $2.5 \mathrm{~km}$ and $500 \mathrm{~m}$, respectively. Maximum flow velocities in our simulations are on the order of millimeters per day. 
PARTICLE FIELD
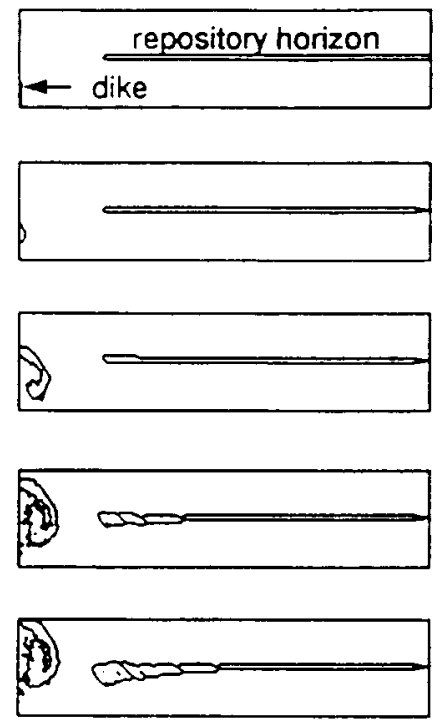

$3 \mathrm{~km}$

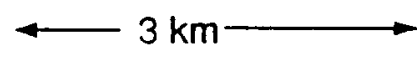

TEMPERATURE FIELD
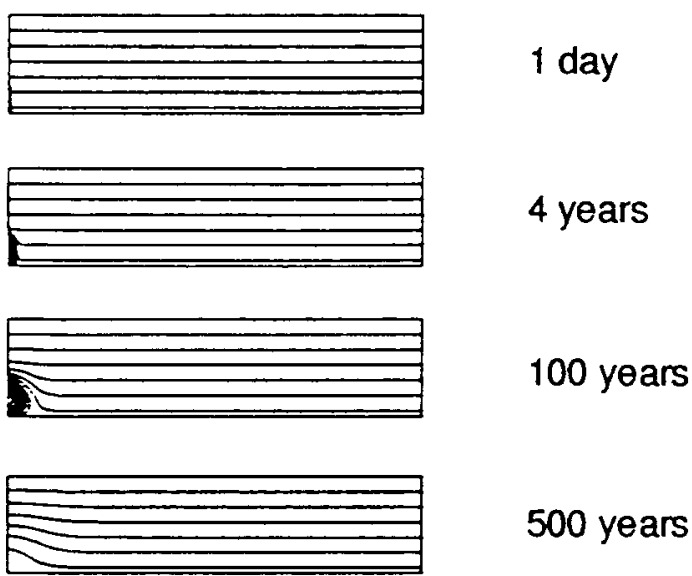

500 years

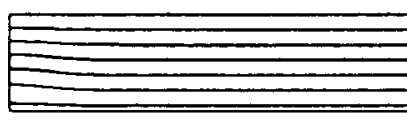

1000 years

$3 \mathrm{~km}$

Figure 5.39. Particle and temperature fields for $180 \mathrm{~m}$ dike at various times. The particle contour separates the region with particles present from the region with no particles present.

PARTICLE FIELD
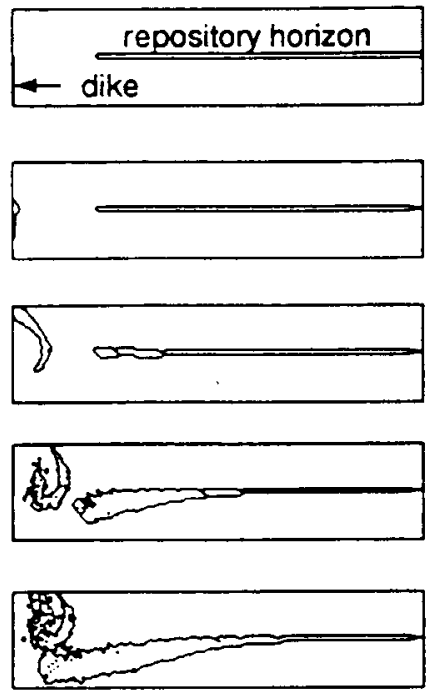

$3 \mathrm{~km}$

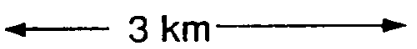

\section{TEMPERATURE FIELD}

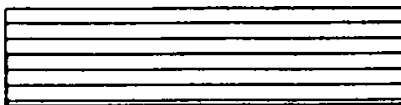

1 day
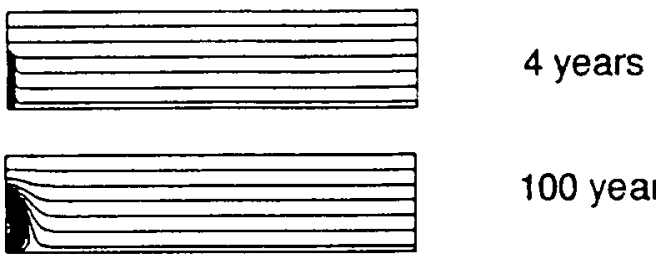

100 years

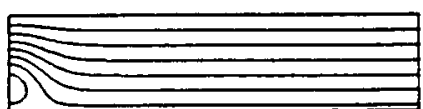

500 years

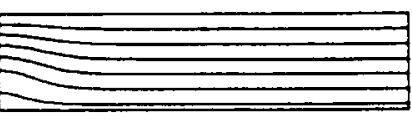

1000 years

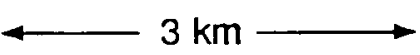

Figure 5.40. Particle and temperature fields for $360 \mathrm{~m}$ dike at various times. The particle contour separates the region with particles present from the region with no particles present. 
PARTICLE FIELD
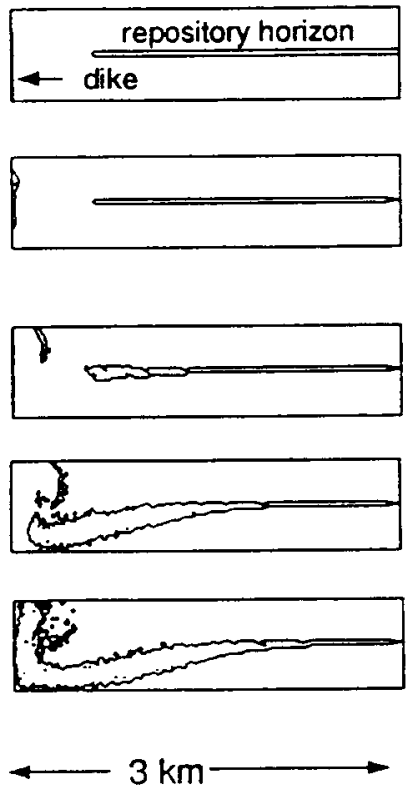

\section{TEMPERATURE FIELD}

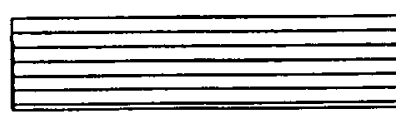

1 day

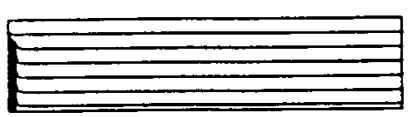

4 years

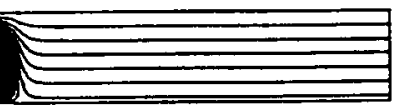

100 years

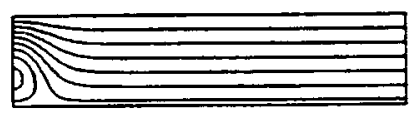

500 years

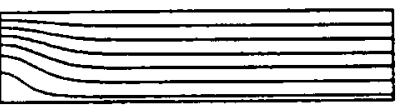

1000 years

$3 \mathrm{~km}$

Figure 5.41. Particle and temperature fields for $560 \mathrm{~m}$ dike at various times. The particle contour separates the region with particles present from the region with no particles present.

PARTICLE FIELD
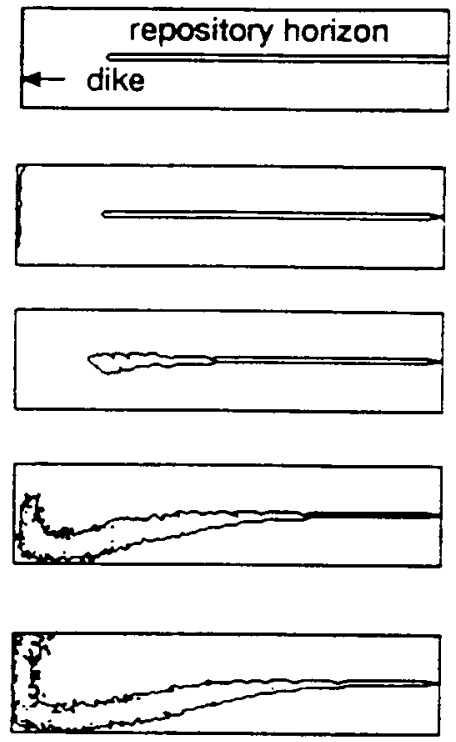

$3 \mathrm{~km}$

\section{TEMPERATURE FIELD}

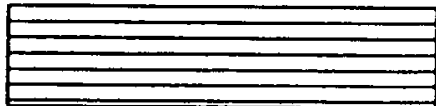

1 day

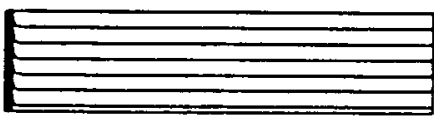

4 years

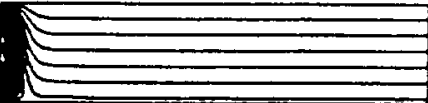

100 years

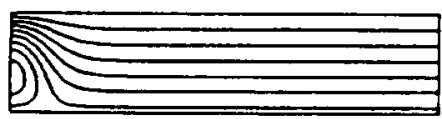

500 years

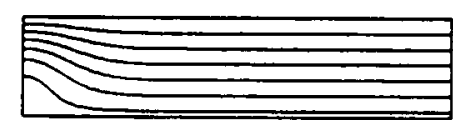

1000 years

\section{$3 \mathrm{~km}$}

Figure 5.42. Particle and temperature fields for $680 \mathrm{~m}$ dike at various times. The particle contour separates the region with particles present from the region with no particles present 


\section{PARTICLE FIELD TEMPERATURE FIELD}
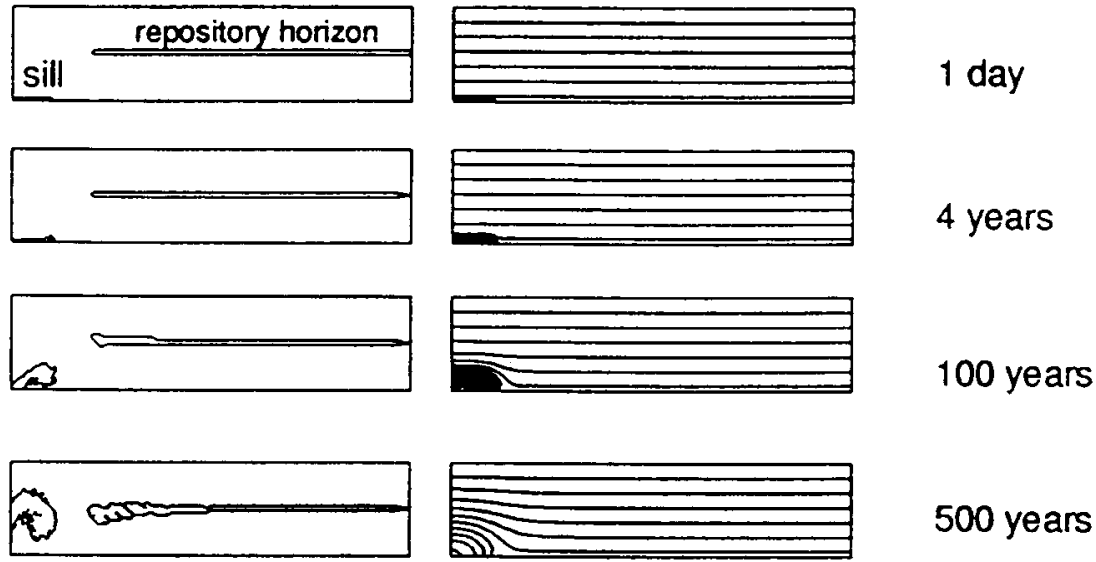

500 years
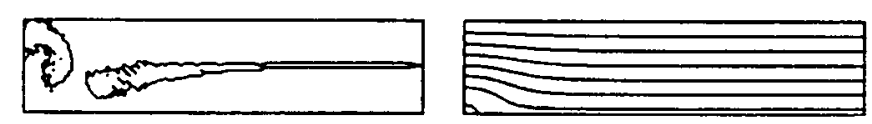

1000 years

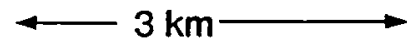

\section{$3 \mathrm{~km}$}

Figure 5.43. Particle and temperature fields for a sill at the water table at various times. The particle contour separates the region with particles present from the region with no particles present.

\section{PARTICLE FIELD (permeable sill)}
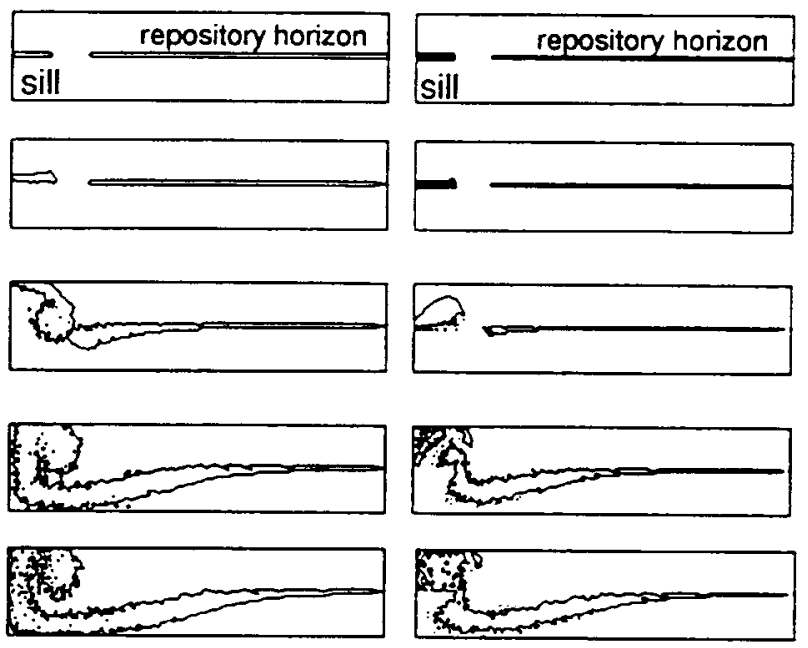

$3 \mathrm{~km}$

PARTICLE FIELD (impermeable sill)
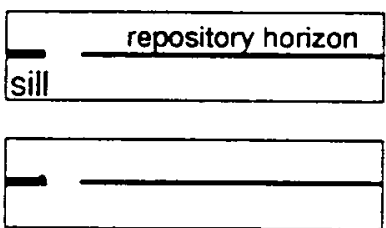

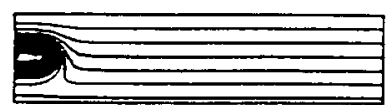

100 years

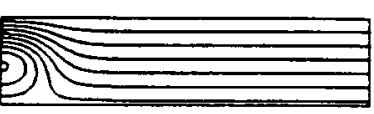

500 years

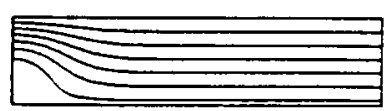

1000 years

1 day

4 years

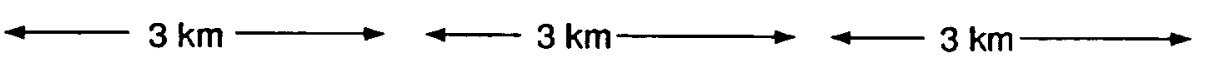

Figure 5.44. Particle and temperature fields for a permeable and an impermeable sill at $360 \mathrm{~m}$ at various times. The particle contour separates the region with particles present from the region with no particles present. The temperature fields for these two simulations appear identical. 

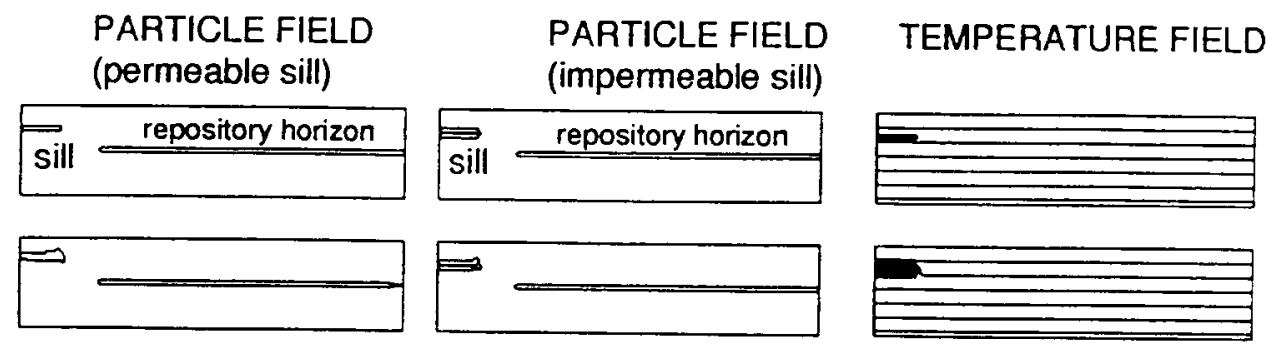

1 day

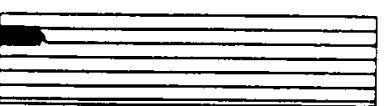

4 years
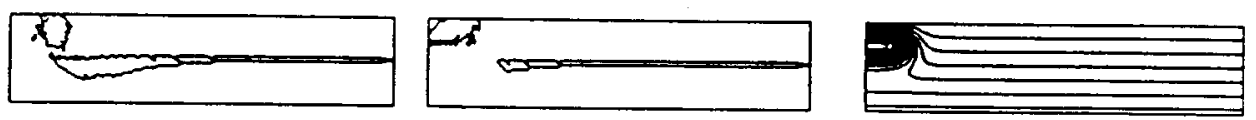

100 years
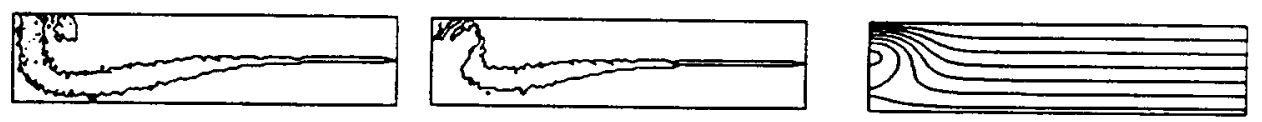

500 years
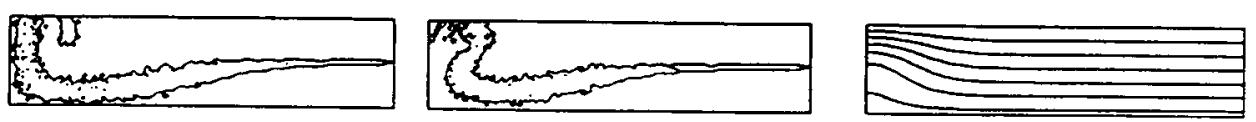

1000 years

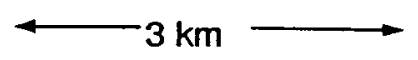

$3 \mathrm{~km}$

$3 \mathrm{~km}$

Figure 5.45. Particle and temperature fields for a permeable and an impermeable sill at $520 \mathrm{~m}$ at various times. The particle contour separates the region with particles present from the region with no particles present. The temperature fields for these two simulations appear identical.

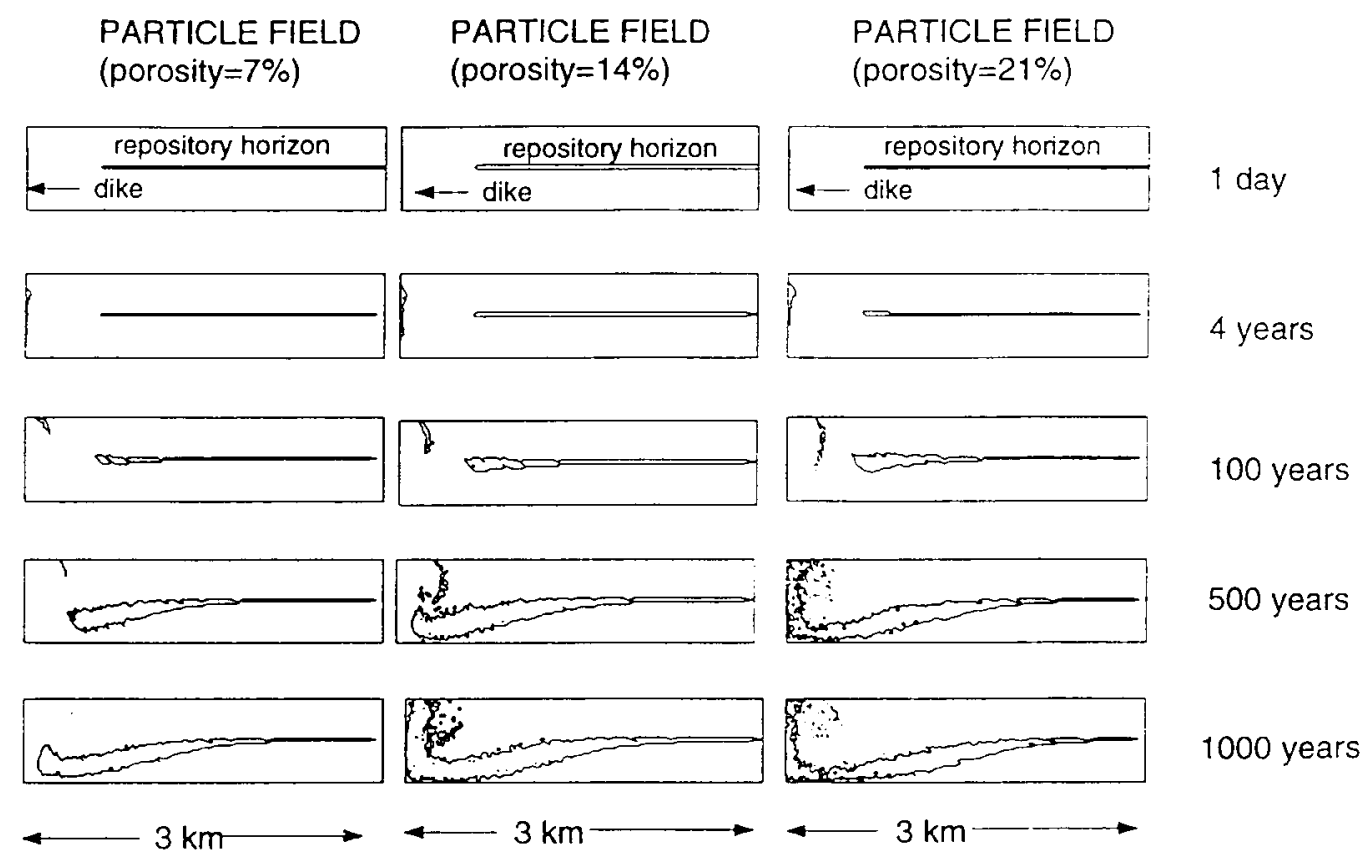

Figure 5.46. Particle fields for a $560 \mathrm{~m}$ dike at various times for different porosity values. The particle contour separates the region with particles present from the region with no particles present. 
PARTICLE FIELD PARTICLE FIELD PARTICLE FIELD

(permeability $=0.5 \times 10-12 \mathrm{~m} 2) \quad$ (permeability $=10-12 \mathrm{~m} 2) \quad$ (permeability $=2 \times 10-12 \mathrm{~m} 2)$

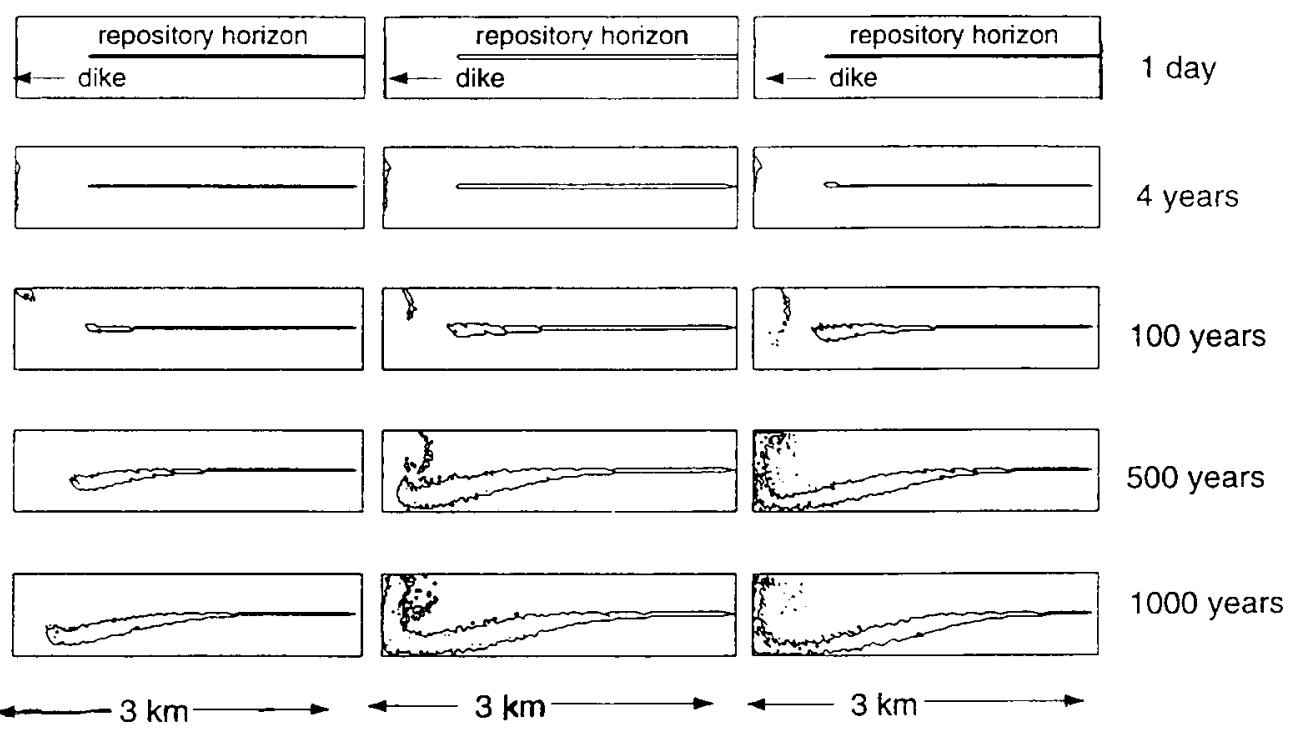

Figure 5.47. Particle fields for a $560 \mathrm{~m}$ dike at various times for different permeability values. The particle contour separates the region with particles present from the region with no particles present.

e. Discussion and Conclusions. Our basic result is that magmatic intrusions at Yucca Mountain would not cause significant large scale convection at horizontal distances greater than a few kilometers. "Intrusion" gas travels less than about $500 \mathrm{~m}$ laterally, and the horizontal distance over which an intrusion affects convective air flow is less than $2.5 \mathrm{~km}$. This makes sense considering that while it is easy to move large volumes of air, because of the very low density of air, those volumes carry very little energy. Further, the small amount of heat being physically transported by the air is dissipated by conduction through the matrix, which rapidly damps the convective motion. We stress, however, that these calculations are limited to highly simplified systems. Future work should address the role of more realistic stratigraphy, dual permeability fracture models, and topography; consider 3-D domains and the flow of water (liquid and vapor) in addition to air flow; and include more complete parameter and sensitivity analyses.

\section{Magma System Dynamics: Segregation, Transport, and Local Storage of Basaltic Magma}

\section{A. Summary}

Basaltic magma of the YMR originates in the upper mantle probably by processes of decompression melting. Once a melt is formed, it segregates from its solid mantle residue through a process of two-phase flow involving buoyant rise of the melt accompanied by deformation and compaction of the matrix. The mechanics of melt segregation are controlled by the equations of conservation of mass and momentum. The form of melt-matrix equations has been determined but not for all assumptions of boundary conditions. A controversial aspect of computer modeling of the melt segregation equations is the existence of solitary wave solutions called solitons. Some workers argue that the formation of solitons may lead to spatial and temporal episodicity of melt 
segregation. Alternatively, the features may be short-lived and incapable of affecting surface volcanic patterns. Small-volume basaltic magmatism in the YMR is probably a product of relict mantle instability from asthenospheric upwelling in the Miocene or continuing low rates of extensional deformation. There is nearly complete agreement that basalt magma ascends via fluidassisted fracture propagation as dikes. The formation and form of magma transport in dikes have been described by many authors using different assumptions dependent on whether the shapes of magma-formed fractures are controlled by the rock properties or the dynamics of flowing magma. The latter view requires assessment of elastic deformation of the country rock and fracture, flow, and gas properties at the dike tip. Field evidence shows that dikes can be modeled as planar cracks formed in brittle solids by pressurization and dilation associated with magma injection. Magma in dikes will rise until it erupts, solidifies, or reaches the level of neutral buoyancy (LNB). The position of the LNB in the Yucca Mountain area may be influenced by the density interface between low-density basin fill and the Paleozoic rocks. Other processes, such as crack-rate propagation, wall-rock permeability, magma-gas content, or mechanisms of volatile concentration in a dike tip, could negate the controls of the LNB. One additional issue is the control of dike orientations by preexisting fractures. Field observations show that dikes can both fill fractures or fault planes or propagate by magma-induced fracture in directions controlled by the stress field. The structural controls of basaltic centers in the YMR suggest that feeder dikes may follow northwest-trending structure at depth but divert at shallow levels to north-northeast trending strikes perpendicular to the least compressive stress direction.

\section{B. Introduction}

This section provides a brief overview of the processes of accumulation and ascent of basalt magma in a continental extensional setting and emphasizes the mechanisms of melt segregation and transport of magma via magma-driven fracture through the mantle and crust. Consideration is given as well to storage of basalt in the mantle and crust and at its LNB, where magma may propagate laterally. There has been substantial progress, particularly in the, 1980s, in mathematically describing the processes of segregation, migration, and eruption of magma. We review the relevant aspects of these processes, focusing primarily on the constraints that can be developed for the physical dimensions of magma systems, the mechanical interactions of magma and country rock, and the rates of operation of magmatic processes. These constraints are applied where possible in attempting to understand the time-space patterns of basaltic volcanism in the YMR.

\section{Melt Generation And Segregation}

We assume, first, that partial melt of basaltic composition originates in the upper mantle at depths of 45 to $70 \mathrm{~km}$. There is a wealth of petrologic information on the geochemical processes of melt formation constrained mostly by the major, trace-element, and isotopic composition of erupted basalt (see Chapter 4).

The processes controlling the formation of the magma are perhaps best known for the generation of mid-ocean ridge basalt (MORB). Melting of oceanic mantle almost certainly occurs because of adiabatic upwelling beneath mid-ocean ridge spreading centers. Here, oceanic lithosphere is upheld on a reservoir of convecting asthenospheric mantle of probable uniform composition. Recent reviews of processes controlling melting in the upper mantle are provided by Kinzler and Grove (1992), Eggins (1992), and Cordery and Morgan (1993). They note that decompression melting results when mantle rises faster than it can exchange heat with the 
surrounding rocks (adiabatically). Excess heat is lost through melt production, and that loss is controlled by the latent heat of fusion of mantle peridotite, the heat capacity, the ambient mantle temperature, and the pressure and compositional fields of the mantle solidus (Kinzler and Grove, 1992). The degree of melting generally increases with continuing decompression. Melting continues until either conductive cooling from above lowers the temperature below the solidus or a basaltic component is extracted. The extracted melt may migrate through the matrix or move preferentially in channels but most probably moves by porous flow (D'Arcy flow). Melt velocities are assumed to be much higher than the velocity of upwelling mantle (Cordery and Morgan, 1993). Percolation allows the melt to maintain equilibrium with the matrix; channel segregation isolates the melt from the matrix (Eggins, 1992). The two processes have different effects on the resulting melt geochemistry.

Melt production in the mantle below the YMR is constrained by the unique upper mantle of the southern Great Basin. First, the area is located on the north edge of the amagmatic gap (see Chapter 3; Farmer et al., 1989; Jones et al., 1992). The region south of Yucca Mountain exhibited no magmatism during the Mesozoic and Cenozoic despite major plutonic episodes in the late Mesozoic (Farmer and DePaolo, 1983), and profound mid-Cenozoic extension (Jones et al., 1992). Second, the isotopic composition of strontium and neodymium in basalt in the YMR shows that it is underlain by preserved lithospheric mantle (Farmer et al., 1989). The isotopic characteristics of basalt generated in the lithospheric mantle have remained uniform for basalt melts for the past 10 Ma in the YMR (Farmer et al., 1989). The presence of thick and cold lithospheric mantle reduces significantly the ability of asthenospheric upwelling to penetrate the crust and generate magma that feeds surface volcanism (Nicolas, 1990). Finally, while initiation of a melting anomaly probably occurs in the asthenospheric mantle, the isotopic composition of the basalt of the YMR requires that the erupted melt component was derived from or equilibrated with the lithospheric mantle (Farmer et al., 1989). For these reasons it is unlikely that the theories developed for melt percolation in mid-ocean ridge settings, discussed above, can be directly applied to YMR basaltic volcanism. However, as a starting point for future analysis, we review these theories below in some detail.

Once a melt is formed by decompression melting, it must segregate from its solid residue and remain mostly molten during ascent in order to erupt eventually at the surface. Sleep (1974) noted melt can move as a two-phase flow involving the solid rock and the melt that exists in the matrix at grain intersections. The melt-filled grain intersections form a porous three-dimensional network in the rock. The basic dynamic process is that when melt is formed; it will tend to rise and segregate driven by buoyancy. A relatively new aspect of understanding of buoyant magma transport is that movement of melt in a porous rock matrix needs to account for the effects of compaction of the solid matrix. The equations for a two-phase flow system rising through the buoyancy of the melt phase accompanied by deformation and compaction of the matrix have been described by many workers (for example, Scott and Stevenson, 1984; McKenzie, 1984; Fowler, 1984; Scott and Stevenson, 1986, 1989).

Ribe (1987), Scott and Stevenson (1989), Fowler (1990a), and Cordery and Morgan (1993) provided the most recent reviews of the basic equations of melt segregation and compaction. They noted that the mechanics of melt segregation are controlled by conservation of mass and momentum. Summarizing and using the form of the compaction-migration equations of Fowler (1990a), conservation of mass for the melt requires: 


$$
\chi_{t}+\nabla \bullet\left[\chi u^{l}\right]=S
$$

where $\chi$ is the liquid mass fraction, $u^{l}$ is the liquid velocity, and $S$ is the melting rate. Darcy's law for the melt velocity is:

$$
u^{l}-u^{s}=-k \chi \nabla\left[p_{l}+\rho_{l} g y\right]
$$

where $u^{s}$ is the solid velocity, $k$ is the permeability coefficient, $p_{l}$ is the liquid pressure, $\rho_{l}$ is the liquid density, $g$ is gravity, and $y$ is the vertical coordinate. The viscous compaction relation requires:

$$
p_{s}-p_{l}=-\left(\frac{\eta_{m}}{\chi}\right)\left[\frac{\tau_{m}}{p_{s}-p_{l}}\right]^{n-l} \nabla \cdot u^{s}
$$

where $p_{s}$ is the solid pressure, $\eta_{\mathrm{m}}$ is the mantle viscosity scale, and $\tau_{\mathrm{m}}$ is the mantle deviatoric stress scale. Conservation of energy requires:

$$
\begin{gathered}
\rho_{s} L S+\rho_{s} c_{p} \frac{d T}{d t}-\beta T\left[\frac{\rho_{s}}{\rho_{l}} \chi\left(\frac{\partial p_{l}}{\partial t}+u^{l} \bullet \nabla p_{l}\right)+\right. \\
\left.\left(\frac{1-\chi}{1+r_{\chi}}\right)\left(\frac{\partial p_{s}}{\partial t}+u^{s} \bullet \nabla p_{s}\right)\right]=k \nabla^{2} T
\end{gathered}
$$

where $L$ is the latent heat, $c_{p}$ is the specific heat at constant pressure, $T$ is the temperature, $\beta$ is the thermal expansion coefficient, $d / d t$ is the material derivative, $r$ is the shrinkage ratio, and $k$ is the thermal conductivity. Finally, the Clapeyron relation requires:

$$
T=T_{0}+\Gamma p_{1}
$$

where $T_{0}$ is a reference temperature and $\Gamma$ is the slope of the Clapeyron curve.

The equations for matrix flow include conservation of mass:

$$
\nabla \bullet u^{s}=-\nabla \bullet\left[\chi\left(u^{l}-u^{s}\right)\right]
$$

conservation of momentum:

$$
-\nabla p_{s}+\nabla \bullet \tau+\nabla\left[\left(\rho_{s} / \rho_{l}\right) \chi\left(p_{s}-p_{l}\right)\right]+\rho g=0
$$

and the stress/strain rate relation:

$$
\tau_{i j}=\eta\left(\frac{\partial u_{s}^{i}}{\partial_{x_{j}}}+\frac{\partial u_{s}^{i}}{\partial x_{i}}\right)
$$


Fowler (1990a) notes that there is general agreement on the form of the matrix and melt flow equations but there are widely varying assumptions concerning the boundary conditions of the modeled processes. There are two areas of concern. First, a common assumption is that all the segregated magma ascends through the lithosphere via dike propagation. This is most significant for the YMR region with its lithospheric mantle. Second, the dynamics of melting are often neglected by assuming the melting rate $\mathbf{S}$ to be zero and ignoring the energy equation. A proposed alternative (Fowler, 1990a) is to establish the boundary conditions by applying mass conservation, force balance, surface energy balance, and the continuity of temperature and free energy. Cordery and Morgan (1993) assume that the percentage of melt present is small (less than a few percent), and melt is extracted as a steady state process.

A number of workers (Scott and Stevenson, 1984, 1986, 1989; Richter and McKenzie, 1984; Scott et al., 1986; Scott, 1988) have examined, through computer modeling and laboratory experiments, flow through compacting media using modified forms of these equations. Their results reveal the somewhat surprising existence of solitary wave solutions called solitons or magmons (Scott and Stevenson, 1984, 1986). Solitons are waves that propagate through the compacting media as a porosity pulse responding to pressure gradients. Assignment of reasonable permeability and rheological properties to these features gives wavelengths of kilometers and velocities of centimeters per year. The volume of liquid within a magmon of this size is about $1 \mathrm{~km}^{3}$ (Scott and Stevenson, 1986). Most authors have been cautious about applying concepts of solitary waves to surface volcanic patterns but this phenomenon could lead to spatial and temporal episodicity of melt segregation if the patterns are not removed or obscured by processes of crustal transport. Cordery and Morgan (1993), for example, note that an assumption of steady-state extraction eliminates the existence of magmons.

Fowler (1990b) examined applications of a compaction model for melt transport. He argued that solitary waves can propagate primarily under conditions of zero melting $(\mathbf{S}=0)$. Under conditions when $\mathbf{S} \neq 0$, solitary waves move at a nonconstant speed of $2 z^{1 / 2} / \zeta$, where $z$ is the vertical coordinate ( $z=0$ at the base of the melt zone) and $\zeta$ is the compaction height. The amplitude of the solitary waves decays according to $1 / z^{1 / 2}$ and may exhibit nonlinearity and diffusion leading to degrading. Fowler (1990b, his Appendix B) also obtained nonlinear equations for solitary waves by adding other melting variables and argued that the waves are only short-term features. He verified the concept of compaction length but argued that other complications such as bulk viscosity, melt refreezing, and fracturing need to be considered. Scott and Stevenson (1989) agree that solitary waves are probably not important under conditions of high melt production (fast-spreading). They suggest. however, that solitary waves could provide a mechanism for explaining oscillating magmatic rates at slow spreading ridges. This suggests the wave phenomenon could be important for areas of low melt production associated with small-volume continental basaltic volcanism typical of the YMR. The exceptionally small volume of Pliocene and Quaternary basaltic volcanism of the YMR may be especially appropriate. However, this requires that the episodic nature of solitary wave phenomena be preserved through the processes of ascent and eruption of magma. An interesting but highly speculative concept is that the episodic nature of polygenetic eruptive models may originate or be influenced by oscillatory solitary waves. Scott and Stevenson (1989) point out that the existence of solitary waves has only been indicated from oneand two-dimensional modeling; it has not been explored yet for three-dimensional modeling. The issue of three-dimensional modeling of melt migration has been addressed by Spiegelman and Wiggins (1993). They suggest the form of melt migration in three dimensions is in spherical waves of melt fraction. These waves form from perturbations to steady-state flow and can link to form a 
channel network aiding melt propagation. Spiegelman and Wiggins (1993) note that solitary waves may contribute to episodicity of magmatism derived from the mantle.

While it is tempting to apply the solitary wave, or magmon, concept to YMR basaltic volcanism as an explanation for episodicity, we again point out that these concepts were developed for mid-ocean ridge settings where asthenospheric processes dominate. In the YMR the lithospheric mantle is likely to behave differently and to have a strong influence on behavior of the volcanic system.

Nicolas $(1986,1990)$ considered constraints on the depth of melting and melt extraction of basaltic magma. While most of the considerations are for MORB, they can be applied by inference to continental settings. First, the melting process is thought to occur primarily in the asthenosphere, which corresponds to the convecting mantle where heat is transferred by convective flow and the system is adiabatic (Nicolas, 1990). Second, in general, a diapir initiated in the asthenosphere will rise, accompanied by melting, until it reaches the lithosphere. Here it may keep rising but melting ceases (McKenzie, 1984; Nicolas, 1990). If the asthenosphere diapir has a slow ascent rate, it will barely penetrate the lithosphere. Again, we note the presence of the thick, largely unmodified and presumably cool lithospheric mantle beneath the YMR (Farmer et al., 1989). This cold upper mantle should inhibit the development of large zones of upwelling in the region. The diapirs under these conditions are probably less energetic with low upward velocities, low degree of extracted melt (<7\%), and limited penetration of the lithosphere (Nicolas et al., 1987; Nicolas, 1990).

A pertinent question to consider is the mechanisms responsible for the generation of the volcanic rocks in the YMR. The setting of the Yucca Mountain site in the Basin and Range province, the tectonic association with intense episodes of Miocene extensional faulting, and the exceptionally large volume of Miocene volcanism in the Southwest Nevada Volcanic Field almost certainly require a genetic link between volcanism and large-scale asthenospheric upwelling (for example, Eaton et al., 1978; Christiansen and McKee, 1978; Lachenbruch and Sass, 1978; Eaton, 1982; Jones et al., 1992). The peak of upwelling must have coincided with the peak of tectonism and volcanism (12 Ma) (see Chapter 3) and may have significantly eroded and induced melting in the lower lithospheric mantle; a similar process was suggested in the Rio Grande Rift by Bussod and Williams (1991). The dramatic decrease in the volume of volcanism in the late Miocene in the YMR must have been in response to a decrease in the rate of asthenospheric upwelling. The smallvolume episode of postcaldera basaltic volcanism that has continued from the Miocene to the Quaternary clearly must not be associated with earlier large-scale asthenospheric upwelling. Instead the basalts may be formed by two alternative processes (or a combination of processes): (1) discontinuous melting of hydrous heterogeneities in what is presently the lower lithospheric mantle, and (2) continuing extensional deformation in the Basin and Range province, but at diminished rates. Tectonism, as recorded in rates of extensional faulting, has waned dramatically in the YMR since the Miocene but continues to be active (see Chapter 3). The modern low rates of extensional faulting are compatible with the generation of only small volumes of basaltic magma $\left(<0.5 \mathrm{~km}^{3}\right.$ in the YMR in the Quaternary). Generation and eruption of larger volumes of basaltic magma in the YMR is probably inhibited by the presence of cool lithospheric mantle (Farmer et al., 1989) and waning tectonism.

\section{Magma Ascent}

Once basaltic melt is segregated, it must move to the surface rapidly to avoid solidification with decreasing temperature. There is nearly complete agreement that transport occurs through 
fluid-assisted fracture propagation. This conclusion is based on the global observation of basalt dikes in a range of tectonic settings in both oceanic and continental crust. Fissure eruptions at many volcanoes prove that magma is fed from linear dikes. Dikes are exposed commonly in the vent facies of dissected volcanoes. Dikes are exposed in country rock beneath and adjacent to deeply dissected volcanoes. Dike swarms are commonly observed crosscutting cratonic and ultramafic rocks. Flow of basaltic magma through fractures provides the most compelling mechanism for transmitting magma through cool country rock without temperature loss resulting in solidification (Lister and Kerr, 1991).

Extraction of magma into conduits opened by melt-fracture requires that the melt pressure exceed the yield pressure of mantle peridotite; evidence of fractures in peridotite is found in peridotite massifs and in xenoliths erupted onto the surface (Bussod and Williams, 1991). The depth of this process can be constrained best by the depth of earthquakes and deep harmonic tremor; this information is known only for oceanic island basalt. Aki and Koyanagi (1981) examined the depth distribution of harmonic tremor below Kilauea Volcano, Hawaii. They distinguished tremor from earthquakes by the duration and period of the former. The amplitude of tremor is sustained longer than earthquakes, and distant stations show the same period as close stations. Deep tremor is separated from shallow tremor by a uniform distribution of amplitude over distance for the latter. Aki and Koyanagi (1981) found seismic evidence of deep tremor to a depth of about $55 \mathrm{~km}$ that may mark the depth of onset of magma transport by magma-fracture. They also noted that the reduced displacement of tremor (directly proportional to the rate of magma flow) is an order of magnitude smaller than estimates of magma supply for Kilauea (Swanson, 1972; Shaw, 1980, 1987). Aki and Koyanagi (1981) suggested, based on this discrepancy, that a significant component of magma is transported through dikes that may propagate aseismically. Ryan (1988) showed that the seismicity patterns below Kilauea Volcano reveal the presence of a primary magma conduit that is concentrically zoned to $34 \mathrm{~km}$ depth. He interprets the zonal structure to be a central region of higher permeability surrounded by a region of numerous dikes.

The formation and form of magma transport in dikes have been described by many authors. Pollard (1976, 1987), Pollard and Muller (1976), and Delaney and Pollard (1981) described theoretical studies of dikes and calculated solutions for the equilibrium shapes of magma-formed fractures largely from a perspective of rock mechanics. Lister and Kerr (1991) note that these analyses are valid only if the intrusion shapes are determined after the magma stops flowing but has not solidified. Moreover, they suggest the dynamics of magma fracture must incorporate properties of the flowing magma, including elastic and inelastic deformation (Rubin, 1993) of the country rock and fracture at the dike tip.

Spence et al. (1987) derived equations governing the steady, vertical propagation of a twodimensional dike driven by buoyancy from a linear source. Lister (1990) extended their analysis and showed that elastic deformation and country rock strength are important primarily at the dike tip. The most recent review of fracture propagation and magma transport in dikes is by Lister and Kerr (1991). We draw heavily from their work in the following summary.

Field observations of dikes show that country rock around intrusions moved apart; there has been little sliding or offset parallel to the dike margins (Pollard, 1987, p. 14). This suggests that dike intrusions can be modeled as planar cracks formed in brittle solids by pressurization and dilation associated with injection of magma (Lister and Kerr, 1991). This treatment requires consideration of elastic pressures, stresses at the fracture tip, density-driven buoyancy, viscous 
pressure drop associated with flowage of magma, deviatoric tectonic stress normal to the dike, and the overpressure of the magma (Lister and Kerr, 1991).

The response of mantle and crustal rocks to fracture is dependent on the stresses applied and the time scale of rock response. Observed and inferred propagation velocities of magma in dikes (tens of $\mathrm{cm}$ to $\mathrm{m} \mathrm{sec}^{-1}$ ) suggest a short time scale of rock response. The strain imparted to the rock by dike emplacement is measured by the ratio of dike thickness to length (Pollard, 1987); it is typically $<10^{-3}$ to $10^{-4}$. These conditions suggest rock response can be modeled as an elastic response (Lister and Kerr, 1991). Rubin (1993) noted the zones of inelastic deformation are produced at the tips of propagating dikes.

Elastic response in rocks is measured by the shear modulus $u$ and the Poisson's ratio $v$; typical values are 25-35 GPa and 0.22-0.28 for basalt, respectively (Lister and Kerr, 1991). Dike geometry can rarely be established from field relations but can be approximated as a twodimensional, blade-shaped crack or a three-dimensional penny-shaped crack (Maaloe, 1987; Pollard, 1987). Representative lengths of dikes are about $2 \mathrm{~km}$ long and a meter wide (Maaloe, 1987).

Fractures propagate primarily by extension of preexisting microcracks governed by the stress field and bond strength near the crack tip (Lister and Kerr, 1991). The stress field near the tip of a crack has the form (Lister and Kerr, 1991):

$$
\sigma_{i j}=K f_{i j}(\theta) /(2 r)^{1 / 2}
$$

where $r$ and $\theta$ are plane polar coordinates centered on the crack tip, $f_{i j}$ are a function of $\theta$, and $K$ is a coefficient known as the stress intensity factor. Crack propagation is governed by a critical stress intensity factor called the fracture toughness $K_{c}$ (Pollard, 1987).

Magma will tend to rise by buoyancy if its density is less than the density of the surrounding rock. The LNB is the level of neutral buoyancy where magma is neither positively nor negatively buoyant. The position of this zone in the crust will determine whether, and at what depth, magma may form lateral intrusions or magma chambers (Walker, 1989). The difference in gravitation force on a magma body is equivalent to a hydrostatic pressure gradient on the magma given by (Lister and Kerr, 1991):

$$
\frac{d P_{h}}{d z}=\left(\rho_{r}-\rho_{m}\right) g
$$

where $\rho_{m}(z)$ and $\rho_{r}(z)$ are the densities of magma and rock at a depth $z$ below the surface. If the density difference is assigned a general value of $\Delta \rho$, during ascent of magma, then the total hydrostatic pressure is $\Delta P_{h} \approx \Delta \rho g h$ where $h$ is the height of rise. Generally, magma is less dense than the mantle and the lower crust. The LNB in Hawaii is on the order of 3 to $6 \mathrm{~km}$ below the surface (Walker, 1989).

The mean velocity of magma averaged across a dike width (w) depends on $\nabla p$, the spatial gradient in the fluid pressure. For laminar flow the velocity $u$ is: 


$$
u=-\frac{w^{2}}{3 \eta} \nabla p
$$

where $\eta$ is the magma viscosity. Conservation of fluid volume shows that the thickness of a dike-induced fracture varies with time (Lister and Kerr, 1991):

$$
\frac{\partial w}{\partial t}=\nabla \bullet(u w)
$$

An approximation of the flow velocity $u$ in a fracture is

$$
u \sim \frac{l}{t}
$$

where $l$ is the length of the fracture and $t$ is the time since initiation of the fracture (see Lister and Kerr (1991), Figure 5.1, for the definition of $h, l$, and $w$ for fractures of different geometry). A typical pressure drop in laminar flow along a fracture of length $l$ may be estimated from combining the preceding two equations:

$$
\Delta P_{v} \sim \frac{\eta l^{2}}{w^{2} t}
$$

The crust of the earth is in a complex state of stress and the regional lithospheric stress deviates from the lithostatic value dependent on location. If the tectonic stress perpendicular to a dike is $\sigma$ then the shape of a dike depends on $\sigma$ by an effective normal stress $\sigma-\Delta P_{i}$. For most cases the effective overpressure $\Delta P_{o}=\Delta P_{i}-\sigma$ (where $\Delta P_{i}$ is the internal pressure). Lister and Kerr (1991) argue that $\sigma$ does not vary significantly with depth; $\Delta P_{o}$ can be assumed to be constant.

Lister and Kerr (1991) evaluated the balance between $\Delta P_{e}, \Delta P_{f}, \Delta P_{h}, \Delta P_{v}$, and $\Delta P_{o}$. The $\Delta P_{e}$ is approximately equal to $m w / l$ where $m$ is the shear modulus divided by 1 - Poisson's ratio, $w$ is fracture thickness, and $l$ is shorter than the other two dimensions. The $\Delta P_{f}$ is the internal pressure required to propagate a magma fracture, $\Delta P_{h}$ is hydrostatic pressure, and $\Delta P_{v}$ is the pressure drop by laminar flow along the length of a fracture. They used the following equations from Weertman (1971) and Pollard and Muller (1976) assuming a constant $\Delta p$ :

$$
p(z)=\Delta P_{o}+\Delta \rho g z
$$

where $p(z)$ is the magmatic pressure and

$$
w(z)=\frac{h}{m}\left(\Delta P_{o}+\frac{1}{2} \Delta \rho g z\right)\left(1-\frac{z^{2}}{h^{2}}\right)^{1 / 2}
$$

where $w(z)$ is the dike width, and $K$, the stress intensity at the dike tips, is 


$$
K( \pm h)=h^{1 / 2}\left(\Delta P_{o} \pm \frac{1}{2} \Delta \rho g h\right)
$$

Lister and Kerr (1991) examined the relations among the last three equations to evaluate the closure of ends of dikes and the conditions of dike propagation. They note that a dike must exceed a vertical extent of $100 \mathrm{~m}$ and a width of $2 \mathrm{~mm}$ to propagate upwards by buoyancy (p. 10,055). Further, as $h$ increases $\Delta P_{h}$ increases and $\Delta P_{f}$ decreases. This requires that as $h$ gets large $\Delta P_{f}<<$ $\Delta P_{h}$ and demonstrates that rock toughness or resistance to fracture is much less important than the hydrostatic pressures (however, see Rubin, 1993 for alternative views based on field observations). A dike will propagate until it reaches the LNB or solidifies. The relation between $\Delta P_{f}$ and $\Delta P_{h}$ suggests that there is limited advantage gained by magma ascending along preexisting fractures (Lister and Kerr, 1991), a conclusion that is not always consistent with field observations (Delaney et al., 1986; Pollard, 1987; Rubin, 1993). An exception to this conclusion would be if the dike tip is deflected by existing fractures or joints and therefore preferentially follows fractures or if inelastic deformation depends upon the near-tip stress field. Lister and Kerr (1991) argue that the rate of propagation of magma is controlled primarily by viscous resistance of the flow of magma into the dike tip and that a dike is unable to close from the bottom upwards because it is difficult to expel viscous magma from a closing crack.

Lister and Kerr (1991) note that $\Delta P_{h} \approx \Delta P_{e}$ when:

$$
\frac{h^{2}}{w} \sim \frac{m}{\Delta \rho g}
$$

Since dikes are generally only one or two meters wide, $h^{2} / w>>m / \Delta \rho g$, and therefore $\Delta P_{h} \gg>$ $\Delta P_{e}$. They conclude that the transport of magma in feeder dikes is dominated by the balance between buoyancy forces and viscous drag. They also argue that the local hydrostatic pressure gradient does not need to be positive throughout ascent. It needs to be positive only when averaged over the length of the conduit. Other considerations are that a dike is held open against elastic stresses $\Delta P_{e}$ by a small fluid overpressure $\Delta P_{o}$. The latter is determined by the supply rate of magma from below, a variable that has not been well defined in magma transport models. The elastic pressures are large at the dike tip. Overall, propagation and transport of a feeder dike are controlled by the balance between $d P_{h} / d z \approx d P_{v} / d z$ (Lister and Kerr, 1991). This allows the derivation (Lister and Kerr, 1991; see also Spence and Turcotte, 1990, their equation [1]):

$$
\frac{\partial w}{\partial t}+\frac{\partial}{\partial z}\left(\frac{\rho_{r}-\rho_{m} g w^{3}}{3 \eta}\right)=0
$$

\section{E. Eruption or Intrusion of Basaltic Magma}

The preceding equation shows that (neglecting temperature effects) magma will rise through the crust to be erupted at the surface or will stagnate and can spread laterally at the LNB. Ryan and Blevins (1987) and Walker (1989) discussed the importance of the LNB, particularly for the Hawaiian volcanoes. Important problems related to these concepts are the degree of overshoot of ascending magma beyond the LNB and the lateral spread of magma at the LNB. Both could lead to eruption: the former if the LNB is located at a shallow level in the crust; the latter if the combination of lateral propagation of dikes and topographic irregularity lead to breaching of the 
surface. The controls of lateral movement of magma at the LNB forming blade-like dikes have been discussed extensively for Kilauea Volcano, Hawaii, and Krafla Volcano, Iceland, by Rubin and Pollard (1987).

Buoyancy-driven magma ascent following the concepts of Lister and Kerr (1991) has several important applications to the YMR. The shallow structure of the region is characterized by lowdensity (basin-fill) deposits in Crater Flat and possibly beneath Yucca Mountain. The density interface between these deposits and underlying higher density deposits (Paleozoic rocks) may be about 2 to $4 \mathrm{~km}$ below the Yucca Mountain area based on interpretations of gravity and seismic refraction data (Snyder and Carr, 1984). This density interface could control the depth of the LNB. In this case, the depth of the density interface suggests the LNB may be deep beneath the region, perhaps considerably below the depth of the potential repository. However, an unknown variable is the degree of magma overshoot through and above the LNB. Additionally, if the LNB was a completely effective barrier to ascent of magma, the basaltic rocks of the Crater Flat area would not be present. Either the LNB is not an effective barrier or other processes such as crackpropagation rate, wall-rock permeability, or initial gas content of magma may locally or temporally be more important. If the LNB is an important barrier to magma ascent, the depth of the density interface suggests that magma should not propagate to the surface but instead spread laterally at the LNB. Consideration of the significance of this phenomenon may be important, mostly for evaluating the effect of intrusions on the waste isolation system of the YMR.

The concept of an LNB could provide a means of explaining the length of propagation of the longest cluster of basalt centers in the YMR, the Quaternary basalt of central Crater Flat. The length of this aligned chain is $12 \mathrm{~km}$, significantly longer than typical dike lengths (Crowe et al., 1983b; Maaloe, 1987; Pollard, 1987; Rubin and Pollard, 1987). An alternative interpretation is that the chain represents magma that upwelled beneath the Red Cone and Black Cone centers and propagated laterally as a bladed dike at a shallow level. Note, however, that topography in the Crater Flat basin would not favor the formation of bladed dikes. However, if dike propagation did occur, it would follow the direction of the maximum compressive stress direction. Makani Cone and the Little Cone centers may represent eruptive centers formed at the ends of a propagated dike system. This would require the length of dike propagation to be only $6 \mathrm{~km}(1 / 2$ the cone cluster length). Additionally, it could explain the small volume of the end centers (Little and Makani Cones) compared to the Red Cone and the Black Cone centers. This interpretation may be tested by examination of petrology data and modeling of aeromagnetic data for Crater Flat. The basalt magma of the centers is distinctly more magnetic than the alluvial fill of Crater Flat (Kane and Bracken, 1983), and it may be possible to model the aeromagnetic data, enhanced with ground magnetic data, to test for the presence and geometry of lateral feeder systems beneath the centers.

The presence of sills and lopolithic centers at the Paiute Ridge area is possibly consistent with trapping of magma at the LNB. These intrusions formed just above the interface between the Paleozoic carbonates and the primary and reworked pyroclastics of the Paintbrush Tuff (distal facies of the units exposed at Yucca Mountain), a potential density contrast and possible zone of weakness (Crowe et al., 1983b). Support for this interpretation is provided by the lopolithic structure of some intrusions (Byers and Barnes, 1967; Crowe et al., 1983b). Sagging of the floor of some intrusions may have been caused by emplacement of magma with a density greater than the density of the underlying country rock. Alternative interpretations other than the LNB control of the intrusions of the Paiute Ridge area are possible. Perhaps the most convincing evidence against LNB control of intrusion depth is that many intrusions were fed by dikes that propagated to the surface. If the LNB had been an effective barrier, the magma would not have reached the 
surface. In some cases, the intrusions formed locally above the carbonate-pyroclastic interface and not at the density interface (Valentine et al., 1992). The local formation of intrusions may be controlled by asperities along fault planes that the dikes occupy (Valentine et al., 1993). The sagging of the floor of intrusions to form lopoliths may be associated with locally intense welding of the country rock and the attendant porosity reduction, and not density sagging.

An additional mechanism that may be important for the transport of magma in dikes is the possibility of exsolution of volatiles at the tips of the dikes. Lister and Kerr (1991) note that the width $w$ of a dike approaches 0 at the crack tip. This requires the mean velocity to be very small or the pressure gradient very large. Extension of a fluid-filled crack requires low fluid pressure in the tip promoting exsolution of volatiles. Using assumptions of thermodynamic equilibrium, Lister (1990) has evaluated numerically the effects of volatiles on the dike tip. He uses the equation for the solubility of water in a basalt melt from Wilson and Head (1981) and notes that magmas are saturated in volatiles at pressures corresponding to a lithostatic overburden of at most a few $\mathrm{km}$ and probably not more than a few hundred meters. When $p_{v o l}$ is large under a lithostatic overburden exceeding the volatile saturation pressure, volatiles should occupy only a small region of the tip. The length of this volatile-filled region extends as the dike propagates toward the level of $p_{v o l}=0$ and the magma is saturated in volatiles (Lister and Kerr, 1991). At this volatile saturation level, the rate of bubble nucleation from the magma will be too large to maintain thermodynamic equilibrium between the volatiles in the dike tip and the magma. Volatile exsolution will extend throughout the melt and the system would have to be modeled as a two-phase compressible flow. This mechanism would decrease the density and propagate dikes above the LNB of a volatile undersaturated melt (Lister and Kerr, 1991; p. 10,070). Lister (1990) approximated the length of the volatile-filled region and noted that it can become surprising large below the depth of volatile saturation (Lister and Kerr, 1991; their Figure18). This, again, may be a critically important mechanism to promote overshooting of the LNB and eruption of magma at the surface.

The viscosity of basalt magma is strongly temperature dependent (Ryan and Blevins, 1987). A small drop in temperature caused by heat loss to the country rock promotes a viscosity increase and an increase in viscous pressure. Delaney and Pollard (1982) note that a magma traveling more than a few kilometers from an upper crustal source at typical propagation velocities will solidify in a few hours (assuming a 2-m dike thickness). The time for complete solidification of a dike can be approximated by (Lister and Kerr, 1991):

$$
t_{s}=\frac{w^{2}}{\lambda k}
$$

where $\lambda$ is a numerical coefficient dependent on the solidification temperature and thermal properties of the magma and solidification layer and $k$ is the thermal diffusivity of the magma. This calculation neglects the advective supply of heat caused by the flow of the magma and overestimates the likelihood of dike solidification. Bruce and Huppert (1990) emphasized the importance of latent heat of solidification and the effect of thermal advection of magma on the temperature profile of a dike. They used two-dimensional modeling to show that for dike widths of greater than about $1 \mathrm{~m}$, flow blockage from solidification will be reversed by continued supply of heat through magma flow. This reversal can exceed heat loss into the country rock and result in melting and expansion of dike widths. Bruce and Huppert (1990) also described preliminary threedimensional modeling of a range of other effects, the most important being the well-described localization of fissure eruptions in distinct conduits through the duration of a fissure eruption. An 
unconsidered implication of the Bruce-Huppert model, however, is the effect of melting on magma composition. Geochemical and isotopic studies of basalt magmas in a range of settings show that it is rare for basalt to be contaminated with country rock, particularly shallow country rock. If the advective supply of heat is significant over a depth range, country-rock contaminated basalt should be observed more commonly.

Lister and Kerr (1991) conclude that a dike cannot propagate further than a critical length approximated by:

$$
l_{s} \sim P_{e} w
$$

where $P_{e}$ is the Peclet number. They suggest that while models are not yet capable of incorporating the mechanics of dike propagation and effects of solidification, several important conclusions can be drawn. First, solidification rates are significant for narrow dikes (tens of cms) over distances of a few kilometers. Narrow dike regions freeze and become narrower, and wide regions tend to melt and become wider. Second, loss of heat from the narrow dike tip will cool the magma and increase viscosity, increasing the need for source pressure to maintain flow into the dike tip. This can lead to inflation of a dike behind a blocked dike tip. It may provide a mechanism for observed large dike widths in frozen magma conduits beneath eruptive centers. Third, the earlier discussions of the unimportance of elastic stresses associated with dike propagation suggest the growth of a chilled layer may be easily overcome by dike expansion.

A final problem for this section is the issue of whether a dike path follows a preexisting fracture or fracture system or the dike propagation direction is determined by the stress field. To examine this question, basic data have to be gathered on the geometry of dike systems, their relation to local fractures, and the relationship to other features such as magma reservoirs. Pollard (1987) has noted that many dikes display minor irregularities called cusps, steps, buds, and segments. He notes that these irregularities have a length scale that is much less than the dike length and are not important unless they are near the dike tip. Pollard (1987; his Figure 5.9) showed that the principal direction of dike propagation is parallel to the long dimension of these features.

The geometry of a dike is determined at least in part by the path established by the dike tip. A long recognized feature of dikes is that they are emplaced commonly perpendicular to the least compressive stress direction (Pollard, 1987). Delaney et al. (1986) described mafic dikes that intruded sedimentary rocks on the Colorado Plateau. These dikes are associated with joint sets in country rock that are closely spaced near the dikes but increase in spacing away from the dikes. They suggest that the joints are formed by fracturing of the host rock by tensile stress generated by magmatic pressure beyond the tips of propagating dikes. The joints become juxtaposed with the dike body with continued propagation. Delaney et al. (1986) contrast dikes with self-generated fractures propagated perpendicular to the least compressive stress direction with dikes that parallel regional joint sets. They suggest that magma can invade older or existing joints if the magmatic pressure exceeds the horizontal stress acting across the joint plane. This may be optimized by two situations. First, it may occur if the horizontal principal stress difference is small compared to the magmatic driving pressure. Second, it may also occur if joints are nearly perpendicular to the direction of least compressive stress.

Delaney et al. (1986; their appendix A) developed criteria for identifying dikes intruded along older joints. These include field evidence for slip that is substantial in comparison to dilation and 
formation of crack splays if the dike propagates beyond the ends of the joint. In the latter case, magma must create its own fracture and would turn or splay toward the direction of maximum principal stress.

Pollard (1987) recognized three fracture modes for the orientation of dikes. The first is a planar dike that follows a fracture produced by the least compressive stress acting perpendicular to the dike plan. The second is a curved dike. This is produced by a spatial rotation of the least compressive stress about an axis parallel to the dike periphery. The third is a segmented dike produced by a spatial rotation of the least compressive stress about an axis parallel to the propagation direction. Pollard (1987) presented criteria needed to verify control of dike paths by preexisting fractures that are not parallel to the least compressive stress direction. These criteria are that, first, the fractures must be older than the dikes and have comparable planar dimensions. Second, shear displacements must be found along the dike indicating that dilations were accompanied by slip induced by the resolved shear stress across the dike.

Baer and Reches (1991) examined dike propagation mechanisms for a dike swarm crossing different rock units. They noted that intrusion mechanisms were different for each rock unit, indicating that host rock properties played a role in controlling dike propagation mechanisms, directions, and detailed geometry. Dikes in a stratified sequence formed segments contained within distinct stratified layers. Dikes in massive sandstones formed smaller segments and had associated dike fingers with intermittent smooth portions and patches with slickensides. The dike propagation through the massive sandstones was inferred to form through alternating stages of fluidization, viscous flow, and brittle deformation. These dike systems were emplaced horizontally, along dikegenerated fractures. Baer (1991) suggests that the dikes propagated at the LNB and were driven by the density difference between the magma and host rock.

We have limited information about the geometry and relationship of feeder dikes for Pliocene and Quaternary basalt centers in the YMR because of the minor degree of erosional modification of the centers. The primary exposure of dikes is in cone scoria where the dikes exhibit highly irregular geometry that is unrelated to the regional stress field (Crowe et al., 1983b).

Several inferences can be offered on the probable form of subsurface dikes in the area. First, the regional alignment of major vents for all Pliocene and Quaternary basalt centers of Crater Flat are northwest (see Chapter 3). This alignment is inferred to be controlled by structural features at depth and may not be controlled by the shallow stress field. This inference is based on the repeated appearance of basalt centers ranging in age from 4.8 to $<0.1$ Ma along a preferential northwest trend. The recurrence of temporally distinct events (contrasted with coeval cone clusters) on the same directional trends suggests the presence of a long-lived subsurface structural control of the ascent of magma. Additionally, as shown in Chapter 3, the direction of alignment of Pliocene and Quaternary volcanic centers coincides with the surface of maximum magma eruption volumes. The strong correlation between center alignment and eruption volumes provides significant support for the rise of magma at depth along northwest-trending structures. This conclusion is in strong contrast with Lister and Kerr (1991) who, as noted earlier, conclude that rock is weak and preexisting fractures are not important in dike propagation. Rubin (1993) presented arguments that the mechanical properties of country rock are important. The most compelling argument is the apparent discrepancy between laboratory measurements of fracture energy compared with field observations of country rock effects from dike propagation. Field evidence demonstrates that inelastic deformation at dike tips can be much larger than those produced at the tips of tensil cracks 
in laboratory experiments. Moreover, deformation of country rock is observable adjacent to dikes for a range of rock types.

An alignment of clusters of scoria cones of probable similar age provide probably the best indicator of the local trend of shallow feeder dikes (e.g., Nakamura, 1977). These alignments, in the YMR, include the north-south cluster of the 3.7 Ma centers, the north-northeast cluster of the Quaternary basalt of Crater Flat, and the north-northeast cluster of the basalt of Sleeping Butte. These directions are perpendicular or near-perpendicular to the least compressive stress direction (Stock et al., 1985). The Lathrop Wells volcanic center consists of only one scoria cone, and no structural trend can be assigned to a single cone. However, the predominant direction of fissure systems in the center are northwest. The two distinct structural settings of basalt centers in Crater Flat (northwest-trending localization of vents of different ages; northeast-trending, coeval cone clusters) probably requires reorientation of dikes at a shallow depth.

A preferred model for dike emplacement in the Yucca Mountain area is ascent of pulses of basalt magma at depth along northwest-trending structures followed by a shallow north-northeast reorientation of dikes (90 degrees) parallel to the maximum compressive stress direction. This is consistent with the lengths of the different structures. The northwest-trending Crater Flat volcanic field (Crowe and Perry, 1989) extends for over 50 kilometers. This exceeds the maximum length of known dikes, except bladed dikes, propagating laterally from a shallow magma reservoir. Northeast-trending cone alignments range from 2.6 to $12 \mathrm{~km}$, consistent with formation from individual feeder dikes. The dike model may be tested with geophysical data, particularly aeromagnetic data. It may be possible to use geophysical methods to determine if there is a change in dike orientation from north-northwest to northwest with depth. If this reorientation is recognized, the depth of the reorientation compared with the depth of the potential repository at Yucca Mountain may provide key information on the likely depth of occurrence of basalt intrusions. This dike reorientation could coincide with a reduction in confining pressure for two regimes of dike propagation (Rubin, 1993): northwest following structure at higher confining pressure, and northeast associated with magma-induced fractures at lower confining pressures.

Finally, it is difficult to establish a relation between vent alignments and local structure for individual basalt centers in the YMR. Alignments of fissures, vents, scoria mounds, and scoria cones define conjugate northwest and north-northeast trends (Crowe and Carr, 1980; Vaniman et al., 1982; Crowe et al., 1983b; Crowe, 1990; Smith et al., 1990; Ho et al., 1991). These directions parallel the expected directions of dike and structural trends. But the data sets are inconsistent (see Chapter 3). Some basalt centers are located along structures or intersections of multiple structures; others appear independent of structure. Exposure of dikes in country rock associated with the Pliocene and Quaternary basalt centers is insufficient to identify structurally controlled or stresscontrolled dike features using the criteria of Delaney et al. (1986) and Pollard (1987). If these features could be identified, northwest-trending dikes would be expected to be structurally controlled (fracture controlled), and north-northeast trending dikes would be stress-controlled.

\section{References}

Aki, K., and R. Koyanagi, "Deep Volcanic Tremor and Magma Ascent Mechanism under Kilauea, Hawaii,” Journal Geophysical Research 86, 7095-7109 (1981).

Arculus, R.J., and D. Gust, "Regional petrology of the San Francisco Volcanic Field, Arizona, USA," Journal of Petrology 36, 827-861 (1995). 
Baer, G. "Mechanisms of Dike Propagation in Layered Rocks and Massive, Porous Sedimentary Rocks," Journal Geophysical Research 96, 11911-11929 (1991).

Baer, G., and Z. Reches, "Mechanics of Emplacement and Tectonic Implications of the Ramon Dike Systems, Israel," Journal Geophysical Research 96, 11895-11910 (1991).

Baldridge, W.S., F.V. Perry, and M. Shafiqullah, "Late Cenozoic Volcanism of the Southeastern Colorado Plateau: I. Volcanic geology of the Lucero area, New Mexico," Geological Society America Bulletin 99, 463-470 (1987).

Barberi, F., J.M. Navarro, M. Rosi, R. Santacroce, and A. Sbrana, "Explosive Interaction of Magma with Ground Water: Insights from Xenoliths and Geothermal Drillings," Rend. Soc. Ital. Mineralogy and Petrology 43, 901-926 (1988).

Barton, M. D., Ilchik, and M.A. Marikos, "Metasomatism," In Contact Metamorphism, D. M. Kerrick, Ed., Reviews in Mineralogy, (Mineralogical Society of America, BookCrafters, Chelsea, 1991), vol. 26, pp. 321-350.

Bejan, A. Heat Transfer, (Wiley, 1993).

Bruce, P.M., and H.E. Huppert, "Solidification and Melting Along dykes by the Laminar flow of Basaltic Magma," in Magma Transport and Storage, M.P. Ryan, Ed., (John Wiley \& Sons Ltd., 1990), pp. 87-101.

Buretta, F.J., and A.S. Berman, "Convective heat Transfer in a Liquid Saturated Porous Layer," Journal of Applied Mechanics 98, 249-253 (1976).

Busby-Spera, C.J., and J.D.L. White, "Variation in Peperite Textures Associated with Differing hostSediment Properties," Bulletin of Volcanology 49, $765-775$ (1987).

Buscheck, T.A., and J.J. Nitao, "The Impact of Repository heat on Thermo-Hydrological Performance at Yucca Mountain," in Proceedings: Site Characterization and Model Validation Focus '93 (American Nuclear Society La Grange Park, Illinois, 1993), pp. 103-109.

Bussod, G.Y.A., and Williams, D.R., "Thermal and kinematic model of the southern Rio Grande rift: inferences from crustal and mantle xenoliths from Kilbourne Hole, New Mexico," Tectonophysics 197, 373-389 (1991).

Byers, F. M., Jr., and H. Barnes, "Geologic map of the Paiute Ridge Quadrangle, Nye and Lincoln Counties, Nevada,” U.S. Geological Survey Quadrangle Map GQ-577 (1967).

Carrigan, C.R., G. Schubert, and J.C. Eichelberger, "Thermal and Dynamical Regimes of Single- and Two-Phase Magmatic flow in dikes," Journal of Geophysical Research 97, 17377-17392 (1992).

Cashman, K., and B.M. Marsh, "Crystal size Distribution (CSD) in rocks and the Kinetics and Dynamics of Crystallization: II. Makaopuhi lava lake," Contributions to Mineralogy and Petrology 99, 292-305 (1988).

Chen, W., and R.J. Arculus, "Geochemical and Isotopic Characteristics of Lower Crustal Xenoliths, San Francisco Volcanic Field, Arizona, U.S.A,” Lithos 36, 203-225 (1995).

Chipera, S. J., and D.L. Bish, "Multireflection RIR and Intensity Normalization for Quantitative Analyses: Application to Feldspars and Zeolites," Powder Diffraction 10, 47-55 (1995). 
Christiansen, E. H., Burt, D.M., Sheridan, M.F., and R.T. Wilson, "The Petrogenesis of Topaz Rhyolites from the Western United States," Contributions to Mineralogy and Petrology 83, 16-30 (1983).

Christiansen, T. L., and E. H. McKee, "Late Cenozoic Volcanic and Tectonic Evolution of the Great Basin and Columbia Intermontane Regions," in Geological Society America Memoir 152: Cenozoic Tectonics and Regional Geophysics of the Western Cordillera, R. B. Smith, and G. P. Eaton, Eds. (Geological Society America, Boulder, Colorado, 1978), pp. 283-311.

Cordery, M. J., and J. P. Morgan, "Convection and Melting at Mid-Ocean Ridges," Journal Geophysical Research 98, 19477-19503 (1993).

Crowe, B. M., "Basaltic Volcanic Episodes of the Yucca Mountain region," in Proceedings High-Level Radioactive Waste Management Conference, Las Vegas, Nevada (American Nuclear Society, La Grange Park Illinois, 1990), Vol. 1, pp. 65-73.

Crowe, B. M., and F. V. Perry, "Volcanic Probability Calculations for the Yucca Mountain Site: Estimation of Volcanic Rates," in Proceedings Nuclear Waste Isolation in the Unsaturated Zone, Focus '89 (American Nuclear Society, La Grange Park, Illinois, 1989) pp. 326-334.

Crowe, B. M., and W. J. Carr, "Preliminary Assessment of the Risk of Volcanism at a Proposed Nuclear Waste Repository in the Southern Great Basin," U.S. Geological Survey Open-File report 80-375, 15 pp. (1980).

Crowe, B. M., S. Self, D. Vaniman, R. Amos, and F. Perry, "Aspects of Potential Magmatic Disruption of a High-Level Radioactive Waste Repository in Southern Nevada," Journal Geology 91, 259-276 (1983a).

Crowe, B. M., D. T. Vaniman, and W. J. Carr, "Status of Volcanic Hazard Studies for the Nevada Nuclear Waste Storage Investigations," Los Alamos National Laboratory report LA-9325-MS 47 pp. (1983b).

Crowe, B.M., K.H. Wohletz, D.T. Vaniman, E. Gladney, and N. Bower, "Status of Volcanic Hazard Studies for the Nevada Nuclear Waste Storage Investigations," Los Alamos National Laboratory report, LA-9325-MS, vol. II (1986).

Crowe, B.M., Perry, F., Geissman, J., McFadden, L., Wells, S., Murrell, M., Poths, J., Valentine, G.A., Bowker, L., and K. Finnegan, "Status of Volcanism Studies for the Yucca Mountain Site Characterization Project," Los Alamos National Laboratory report LA-12908-MS (1995).

Cummings, D., "Mafic and Ultramafic Inclusions, Crater 160, San Francisco Volcanic Field, Arizona," U.S. Geological Survey Professional Paper 800-B, B95-104 (1972).

Dalrymple, G. B. "Preliminary report on 40Ar/39Ar incremental heating experiments on feldspar samples from the felsite unit, Geysers geothermal field, California." US Geological Survey, Open-File Report, 92-407, 15 p., (1992).

Damon, P.E., Shafiqullah, M., and J.S. Leventhal, "K-Ar Chronology for the San Francisco Volcanic Field and Rate of Erosion of the Little Colorado River," in Geology of Northern Arizona, Karlstrom, T.N.V., Swann, G.A., and Eastwood, R.L. Eds., Geological Society of America Guidebook for Rocky Mountain Section Meeting 6(5), 221-235 (1974).

Davidson, M.R., "Natural Convection of Gas/Vapor Mixtures Heated from Below," International Journal of Heat and Mass Transfer 9, 1371-1386 (1986). 
Delaney, P. T., "Expansion and Pressurization of Groundwater during Heating from an Igneous Intrusion: A Mechanism for Brecciation of host rocks," Abstract, American Geophysical Union Transactions 61, 1146 (1980).

Delaney, P. T., "Rapid Intrusion of Magma into Wet Rock: Groundwater Flow Due to Pore Pressure Increases," Journal of Geophysical Research 87, 7739-7756 (1982).

Delaney, P. T., and D. D. Pollard, "Deformation of Host Rocks and Flow of Magma During Growth of Minette Dykes and Breccia-Bearing Intrusions near Ship Rock New Mexico," U.S. Geological Survey Professional Paper 1202, 61 pp. (1981).

Delaney, P. T. and D. D. Pollard, "Solidification of basaltic magma during flow in a dike," American Journal of Science 282, 856-885 (1982).

Delaney, P. T., "Expansion and Pressurization of Groundwater During Heating from an Igneous Intrusion: A Mechanism for Brecciation of Host Rocks," Abs., American Geophysical Union Transactions 61, p. 1146 (1980).

Delaney, P. T., D. D. Pollard, J. I. Ziony, and E. H. McKee, "Field Relations Between Dikes and Joints: Emplacement Processes and Paleostress Analysis," Journal Geophysical Research 91, 4920-4938 (1986).

Dobran, F., "Nonequilibrium flow in Volcanic Conduits and Application to the Eruptions of Mt. St. Helens on May 18 1980, and Vesuvius in AD 79," Journal of Volcanology and Geothermal Research 49, 285-311 (1992).

Dobran, F., and P. Papale, "CONDUIT2: A Computer Program for Modeling Steady State Two-Phase Flows in Volcanic Conduits," VSG report 92-5, Giardini (1992).

Dobran, F.,and P.Papale, "Magma-Water Interaction in Closed Systems and Application to Lava Tunnels and Volcanic Conduits," Journal of Geophysical Research 98, 14041-14058 (1993).

Donnelly-Nolan, J. M., Hearn, B. C., Jr., Curtis, G. H., and Drake, R. E., "Geochronology and evolution of the Clear Lake Volcanics." In Research in The Geysers-Clear Lake geothermal area, northern California (eds. McLaughlin, R.J. and Donnelly-Nolan, J.M.), U.S. Geological Survey, Professional Paper 1141, 47-60 (1981).

Eaton, G. P., "The Basin and Range Province; Origin and Tectonic Significance," Annual Reviews Earth Planetary Science 10, 409-440 (1982).

Eaton, G. P., R. R. Wahl, H. J. Prostka, D. R. Mabey, and M. D. Kleinkopf, "Regional Gravity and Tectonic Patterns: their Relation to Late Cenozoic Epirogeny and Lateral Spreading in the Western Cordillera," in Geological Society America Memoir 152: Cenozoic Tectonics and Regional Geophysics of the Western Cordillera, R.B. Smith, and G.P. Eaton, Eds. (Geological Society America Boulder, Colorado, 1978), pp. 51-91.

Eggins, S.M., "Petrogenesis of Hawaiian Tholeiites: II, Aspects of Dynamic Melt Segregation," Contributations Mineralogy Petrology 110, 398-410 (1992).

Elder, J.W., "Steady free Convection in a Porous Medium Heated from Below," Journal of Fluid Mechanics 27, 29-48 (1967).

Engelder, T., "Stress Regimes in the Lithosphere," Princeton University Press, (1993). 
Esposito, K. J., and G. Whitney, "Thermal Effects of Thin Igneous Intrusions on Diagenetic Reactions in a Tertiary Basin of Southwestern Washington," U. S. Geological Survey Bulletin 2085-C, 40 pp. (1995).

Fabre, P., Y. Kast, and M. Girod, "Estimation of flow Duration of Basaltic Magma in Fissures," Journal of Volcanology and Geothermal Research 37, 167-186 (1989).

Farmer, G. L., and D. J. DePaolo, "Origin of Mesozoic and Tertiary Granite in the Western United States and Implications for Pre-Mesozoic Crustal Structure, 1, Nd and Sr Isotopic Studies in the Geocline of the Northern Great Basin,” Journal Geophysical Research 88, 3379-3401 (1983).

Farmer, G. L., Perry, F. V., Semken, S., Crowe, B., Curtis, D. and DePaolo, D. J., "Isotopic Evidence on the Structure and Origin of Subcontinental Lithospheric Mantle in Southern Nevada," Journal Geophysical Research 94, 7885-7898 (1989).

Fedotov, S.A., "Ascent of Basic Magmas in the Crust and the Mechanism of Basaltic Fissure Eruptions," Int. Geol. Rev. 20, 33-48 (1978).

Fedotov, S.A., "Magma Rates in Feeding Conduits of Different Volcanic Centres," Journal of Volcanology and Geothermal Research 8, 379-394 (1981).

Fowler, A.C., "A Compaction Model for Melt Transport in the Earth's Asthenosphere. Part I: The Basic Model," in Magma Transport and Storage, M.P. Ryan, Ed., (John Wiley \& Sons, England, 1990a), pp. 3-14.

Fowler, A.C., "A Compaction Model for Melt Transport in the Earth's Asthenosphere. Part II: Applications," in Magma Transport and Storage, M.P. Ryan, Ed. (John Wiley \& Sons, Chichester, 1990b), Chapter 1, pp. 15-32.

Fowler, A. C., "Mantle and Magma Dynamics," in Dynamic Differentiation, Notes of the GFD Summer Program, Woods Hole Oceanographic Institution, W. Malkus, Ed., (Woods Hole MA, WHOI 84-44), 7477 (1984).

Godchaux, M. M., B. Bonnichsen, and M.D. Jenks, "Types of Phreatomagmatic Volcanoes in the Western Snake River Plain, Idaho, USA,” Journal of Volcanology and Geothermal Research 52, 1-25 (1992).

Goff, F. and J.N. Gardner, "Evolution of mineralized geothermal system, Valles caldera, New Mexico," Economic Geology 89, 1803-1832 (1994).

Goff, F. and Gardner, J. N., "Valles caldera region, New Mexico, and the emerging Continental Scientific Drilling Program,” Journal of Geophysical Research 93, 5997-5999 (1988).

Goff, F. and D.L. Nielsen, "Caldera Processes and Magma-Hydrothermal Systems: Continental Scientific Drilling Program—Thermal Regimes, Valles Caldera Research, Scientific, and Management plan," Los Alamos National Laboratory report LA-10737-OBES, 163 pp., (1986).

Goff, F., G. WoldeGabriel, R. Warren, and K.E. Carter Krogh, "Geologic Map, Paiute-Ridge-Slanted Buttes, Half-Pint Range, Nevada,” Los Alamos National Laboratory report, (in press, 1996).

Haar, L., J. S. Gallagher, and G.S. Kell, NBS/NRC Steam Tables, (Hemisphere Publishing Corporation, New York 1984). 
Haimson, B.C., J. Lacomb, A. H. Jones, and S.J. Green, "Deep Stress Measurements in Tuff at the Nevada Test Site," in Advances in Rock Mechanics, v.IIa, (National Academy of Sciences, Washington D.C., 1974) pp. 557-561.

Hay, R. L., "New developments in the geology of natural zeolites," in Natural Zeolites'93, Occurrence, Properties, and Use, D.W. Ming and F. A. Mumpton, Eds., (International Committee on Natural Zeolites, Brockport, N. Y., 1995), pp. 3-13.

Head III, J.W. and L. Wilson, "Basaltic Pyroclastic Eruptions: Influence of Gas-Release Patterns and Volume Fluxes on Fountain Structure, and the Formation of Cinder cones, Spatter cones, Rootless flows, Lava Ponds and Lava Flows," Journal of Volcanology and Geothermal Research 37, 261-271 (1987).

Heiken, G., K. Wohletz, and J. Eichelberger, "Fracture Fillings and Intrusive Pyroclasts, Inyo Domes, California," Journal of Geophysical Research 93, 4335-4350 (1988).

Ho, C. H., E. I. Smith, and D. L. Feuerbach, and T. R. Naumann, "Eruptive Probability Calculations for the Yucca Mountain Site, USA: Statistical Estimation of Recurrence Rates," Bulletin Volcanology 54, 5056 (1991).

Holm, R. F., and R. B. Moore, "Holocene Scoria Cone and Lava Flows at Sunset Crater, Northern Arizona," Geological Society of America Centennial Field Guide--Rocky Mountain Section, Denver, pp. 393-397 (1987).

Holm, R.F., "Field Guide to the Geology of the Central San Francisco Volcanic Field, Northern Arizona," in Geology of Northern Arizona, Nations, J.D., Conway, C.M., and Swann, G.A. Eds., Geological Society of America Guidebook for Rocky Mountain Section Meeting, Field Trip Guidebook, pp. 27-42 (1986).

Holm, R.F., "Significance of Agglutinate Mounds on Lava Flows Associated with Monogenetic Cones: An Example at Sunset Crater, Northern Arizona," Geological Society of America Bulletin 99, 319-324 (1987).

Houghton, B .F. and Schmincke, H. -U., "Mixed Deposits of Simultaneous Strombolian and Phreatomagmatic Volcanism: Rothenberg Volcano, East Eifel Volcanic Field," Journal of Volcanology and Geothermal Research 30, 117-130 (1986).

Hulen, J. B. and Nielson, D. L., "The Geysers felsite." Transactions of the Geothermal Resources Council 20, 295-306 (1996).

Hulen, J. B., Heizler, M. T., Stimac, J. A., Moore, J. N., and Quick, J. C., "New Constraints on the Timing of Magmatism, Volcanism, and the Onset of Vapor-Dominated Conditions of the Geysers Steam Field, California," Proc. Twenty-second Workshop on Geothermal Reservoir Engineering, Stanford University, California, 27-29 January, (1997).

Hulen, J.B. and D.L. Nielson, "Hydrothermal Brecciation in the Jemez Fault Zone, Valles Caldera, New Mexico -- Results from Continental Scientific Dilling Program Core Hole VC-1," Journal of Geophysical Research 93, 6077-6089 (1988).

Hulen, J. B. and Gardner, J. N. "Field geologic log for Continental Scientific Drilling Program Core Hole VC-2B, Valles caldera, New Mexico,” DOE/ER/13196-4, ESL-89025-TR, 21 p. (1989). 
Hulen, J. B., Gardner, J. N., Goff, F., Nielsen, D. L., Moore, J. N., Musgrave, J. A., Lemieux, M. M., Meeker, K., and Snow, M. G., "The Sulphur Springs hydrothermal system, past and present: Initial results from Continental Scientific Drilling Program core hole VC-2B, Valles caldera, New Mexico," Trans. Geotherm. Resour. Council 13, 149-156 (1989).

Iijima, A., and S. Ogihara, S., "Temperature-Time Relationships of Zeolitic Reactions During Burial Diagenesis in Marine Sequences," in Natural Zeolites'93, Occurrence, Properties, and Use, D.W. Ming and F.A. Mumpton, Eds., (International Committee on Natural Zeolites, Brockport, N.Y., 1995), pp. 115123.

Jeffrey, H., "The Instability of a Compressible Fluid Heated from Below," Proceedings of the Cambridge Philosophical Society 26, 170-172 (1930).

Jicha, H.L., Jr., "Geology and Mineral Resources of Mesa del Oro Quadrangle, Socorro and Valencia Counties, New Mexico," New Mexico Bureau Mines Mineral Resources Bulletin 56, 67 pp. (1958).

Johnson, D.J., "Molten core Model for Hawaiian rift Zones," Journal of Volcanoljogy and Geothermal Research 66, 27-35 (1995).

Jones, J. H., B. P. Wernicke, G. L. Farmer, J. D. Walker, D. S. Colman, L. W. McKenna, and F. V. Perry, "Variations Across and Along a Major Continental Rift: an Interdisciplinary Study of the Basin and Range Province, Western USA,” Tectonophysics 213, pp. 57-96 (1992).

Kane, M. F., and R. E. Bracken, "Aeromagnetic Map of Yucca Mountain and Surrounding Regions, Southwest Nevada," U.S. Geological Survey, Open-File report 83-616, 19 pp. (1983).

Kaneko, T., M. F. Mohtadi, and K. Aziz, "An Experimental Study of Natural Convection in Inclined Porous Media," International Journal of Heat and Mass Transfer 17, 129-138 (1974).

Kerr, P. F., and J. T. Wilcox, "Structure and Volcanism, Grants Ridge Area, New Mexico," New Mexico Bureau of Mines and Mineral Resources, Memoir 15, 205-213 (1963).

Kerrick, D.M., "Overview of Contact Metamorphism," in Contact Metamorphism, D. M. Kerrick, Ed., Reviews in Mineralogy, Mineralogical Society of America 26, (BookCrafters, Chelsea, 1991), pp. 1-12.

Kinzler, R. and T. L. Grove, "Primary Magmas of Mid-ocean Ridge Basalts 2. Applications," Journal Geophysical Research 97, 6907-6926 (1992).

Kokelaar, B.P., "Fluidization of Wet Sediments During the Emplacement and Cooling of Various Igneous Bodies," Journal of the Geological Society London 139, 21-33 (1982).

Korotev, R.L., "National Bureau of Standards Coal Flyash (SRM1633a) as a Multielement Standard for Instrumental Neutron Activation Analysis," Journal of Radioanalytical and Nuclear Chemistry 110, 159177 (1987)

Lachenbruch, A.H., and J.H. Sass, "Models of an Extending Lithosphere and Heat Flow in the Basin and Range Province," in Geological Society America Memoir 152: Cenozoic Tectonics and Regional Geophysics of the Western Cordillera, R.B. Smith, and G.P. Eaton, Eds. (Geological Society America, Boulder, Colorado, 1978), pp. 209-250.

Laughlin, A. W., Perry, F. V., Damon, P. E., Shafiqullah, M., WoldeGabriel, G., McIntosh, W., Harrington, C. D., Wells, S. G., and Drake, P. G., "Geochronology of Mount Taylor, Cebollita Mesa, and Zuni-Bandera volcanic fields, Cibola County, New Mexico," Geology 15, 81-92 (1994). 
Leat, P. T. and R. N. Thompson, "Miocene Hydrovolcanism in NW Colorado, USA, Fuelled by Explosive Mixing of Basic Magma and wet Unconsolidated Sediment," Bulletin of Volcanology 50, 229-243 (1988).

Levy, S. S. and J. R. O'Neil, "Moderate Temperature Zeolite Alteration in a Cooling Pyroclastic Deposit," Chemical Geology 76, 321-326 (1989).

Lipman, P. W., and H. H. Mehnert, "Potassium-Argon Ages from the Mount Taylor Volcanic Field, New Mexico," U.S. Geological Survey Professional Paper 1124-B, 8 pp. (1979).

Lister, J. R. and R. C. Kerr, "Fluid-Mechanical Models of Crack Propagation and their Application to Magma Transport in dykes," Journal of Geophysical Research 96, 10049-10077 (1991).

Lister, J. R., "Buoyancy-driven Fluid Fracture: Similarity Solutions for the Horizontal and Vertical Propagation of Fluid-filled Cracks," Journal Fluid Mechanics 217, 213-239 (1990).

Lofgren, G., "Experimental Devitrification Rate of Rhyolite Glass," Geological Society of America Bulletin 81, 553-560 (1970).

Lofgren, G., "Experimentally Produced Devitrification Textures in Natural Rhyolitic Glass," Geological Society of America Bulletin 82, 111-124 (1971).

Lorenz, V., "On the Growth of Maars and Diatremes and its Relevance to the Formation of Tuff Rings," Bulletin of Volcanology 48, 265-274 (1986).

Lu, N. and B. Ross, "Mountain Scale Modeling of Transient, Coupled Gas Flow, Heat Transfer and Carbon-14 Migration," in Proceedings: Site Characterization and Model Validation Focus '93, (American Nuclear Society, La Grange Park, Illinois, 1993), pp. 103-109.

Maaloe, S., "The Generation and Shape of Feeder Dykes from Mantle Sources," Contributions Mineralogy Petrology 96, 47-55 (1987).

Macedonio, G., F. Dobran, and A. Neri, "Erosion Processes in Volcanic Conduits and Application to the AD 79 Eruption of Vesuvius," Earth and Planetary Science Letters 121, 137-152 (1994).

Machette, M. N., "Preliminary Geologic Map of the Socorro $1^{\circ} \times 2^{\circ}$ Quadrangle, Central New Mexico," U.S. Geological Survey Open-File report 78-607 (1978).

Mangan, M. T., K. V. Cashman, and S. Newman, "Vesiculation of Basaltic Magma During Eruption," Geology 21, 157-160 (1993).

Mastin, L. G., "The Roles of Magma and Groundwater in the Phreatic Eruptions at Inyo Craters, Long Valley Caldera, California," Bulletin of Volcanology 53, 579-596 (1991).

Mayr, A., "Volcanic Processes and Eruption History of Dry Lake Volcano, San Francisco Volcanic Field, Arizona," unpublished M.S. thesis, Northern Arizona University, 76 pp. (1994).

McBirney, A.R., "Factors Governing the Emplacement of Volcanic Necks," American Journal of Science 257, 431-448 (1959).

McGarr, A., and Gay, N.C., "State of Stress in the Earth's Crust," Annual Review of Earth and Planetary Sciences 6, 405-436 (1978). 
McGetchin, T. R. and G. W. Ullrich, "Xenoliths in Maars and Diatremes with Inferences for the Moon, Mars, and Venus," Journal of Geophysical Research 78, 1833-1853 (1973).

McKenzie, D. P., "The Generation and Compaction of Partial Melts," Journal Petrology 25, 713-765 (1984).

Minor, S. A., "Superposed Local and Regional Paleostresses: Fault-Slip Analysis of Neogene Extensional Faulting near Coeval Caldera Compleses, Yucca Flat, Nevada," Journal of Geophysical Research 100, 10507-10528 (1995).

Moench, R. H., "Geology of the Dough Mountain Quadrangle, New Mexico," U.S. Geological Survey Map GQ-354 (1964).

Moncure, G. K., Surdam, R. C., and H. L. McKague, "Zeolite Diagenesis Below Pahute Mesa, Nevada Test Site," Clays and Clay Minerals 29, 385-396 (1981).

Moore, R. B., and E. W. Wolfe, "Geologic Map of the East Part of the San Francisco Volcanic Field, North-Central Arizona,” U.S. Geological Survey Map MF-1960 (1987).

Moore, R. B., Wolfe, E. W., and G. E. Ulrich, "Volcanic Rocks of the Eastern and Northern Parts of the San Francisco Volcanic Field, Arizona," U.S. Geological Survey Journal of Research 4, 549-560 (1976)

Nakamura, K., "Volcanoes as Possible Indicators of Tectonic Stress Orientation: Principle and Proposal," Journal Volcanology Geothermal Research 2, 1-16 (1977).

Nakamura, N., "Determination of REE, $\mathrm{Ba}, \mathrm{Mg}, \mathrm{Na}$, and $\mathrm{K}$ in Carbonaceous and Ordinary Chondrites," Geochimica et Cosmochimica Acta 38, 757-775 (1974).

Newhall, C. G., Ulrich, G. E., and E. W. Wolfe, "Geologic Map of the Southwest Part of the San Francisco Volcanic Field, North-Central Arizona,” U.S. Geological Survey Map MF-1958 (1987).

Nicolas, A., "A Melt Extraction Model Based on Structural Studies in Mantle Peridotites," Journal Petrology 27, 999-1022 (1986).

Nicolas, A., "Melt Extraction from Mantle Peridotites: Hydrofracturing and Porous Flow, with Consequences for Oceanic Ridge," in Magma Transport and Storage, M. P. Ryan, Ed. (John Wiley \& Sons, Chichester, 1990) Chapter 10, pp. 159- 174.

Nicolas, A., G., F. Lucazeau, and R. Bayer, "Peridotite Xenoliths in Massif Central Basalts, France: Textural and Geophysical Evidence for Asthenospheric Diapirism," in Mantle Xenoliths, P. Nixon, Ed. (John Wiley, \& Sons, Chichester, 1987), p. 844.

Nield, D.A. and A. Bejan, Convection in Porous Media, (Springer-Berlin,1992).

Nield, D.A., "Onset of Convection in a Porous Layer Saturated by an Ideal gas," International Journal of Heat and Mass Transfer 25, 1605-1606 (1982).

Osburn, J.C., "Geology and Coal Resources of Three Quadrangles in the Central Datil Mountains coal Field, Socorro County, New Mexico," New Mexico Bureau of Mines and Mineral Resources Open-File report 164 (1982).

Osburn, J.C., "Geology of Pueblo Viejo Mesa Quadrangle, Socorro and Cibola Counties, New Mexico," New Mexico Bureau of Mines and Mineral Resources Geologic Map 55 (1984). 
Parsons, T., and G.A. Thompson, "The role of Magma Overpressure in Suppressing Earthquakes and Topography: Worldwide Examples," Science 253, 1399-1402 (1991).

Parsons, T., Sleep, N. H., and G. A. Thompson, "Host rock Rheology Controls on the Emplacement of Tabular Intrusions: Implications for the Underplating of Extending Crust," Tectonics 11, 1348-1356 (1992).

Perry, F. V., Baldridge, W. S., DePaolo D. J., and M. Shafiqullah, "Evolution of a Magmatic System During Continental Extension: the Mount Taylor Volcanic Field, New Mexico," Journal of Geophysical Research 95, 19327-19348 (1990).

Pollard, D. D., "Elementary Fracture Mechanic Applied to the Structural Interpretation of Dykes," Geological Association Canada Special Paper 34, 5-24 (1987).

Pollard, D. D., "On the Form and Stability of Open Hydraulic Fractures in the Earths's Crust," Geophysical Research Letter 3, 513-516 (1976).

Pollard, D. D., and G. Holzhausen, "On the Mechanical Interaction between a Fluid-Filled Fracture and the Earth's Surface," Tectonophysics 53, 27-57 (1979).

Pollard, D. D., and O. H. Muller, "The Effects of Gradients in Regional Stress and Magma Pressure on the Form of Sheet Intrusions in Cross Section," Journal Geophysical Research 81, 975-984 (1976).

Pulka, F. S., "Subsurface geology at Ford Flat, Geysers geothermal field, northern California," M.S. Thesis, Michigan Tech. Univ., Houghton, 324 p., (1991).

Pushkar, P., and Stoeser, D. B., "87Sr/86Sr Ratios in some Volcanic Rocks and some Semifused Inclusions of the San Francisco Volcanic Field," Geology 3, 669-671 (1975).

Ratcliff, C. D., "Paleomagnetic and rock Magnetic Study of the Paiute Ridge Subvolcanic Center, Southern Nevada," unpub. M.S. Thesis, University of New Mexico, 69 pp., (1993).

Ratcliff, C. D., Geissman, J. W., Perry, F. V., Crowe, B. M., and P. K. Zeitler, "Paleomagnetic Record of a Geomagnetic-Field Reversal from late Miocene Mafic Intrusions, Southern Nevada," Science 266, 412416 (1994).

Ribe, N. M., "Theory of Melt Segregation - a Review," Journal Volcanology Geothermal Research 33, 241-253 (1987).

Richter, D. H., J. P. Eaton, K. J. Murata, W. U. Ault, and H. L. Krivoy, "Chronological Narrative of the 1959-1960 Eruption of Kilauea Volcano, Hawaii,” U.S. Geological Survey Professional Paper 537-E, pp. E1-E73, (1970).

Richter, F. M., and D. P. McKenzie, "Dynamical Models for Melt Segregation from a Deformable Matrix," Journal Geology 92, 729-240 (1984).

Rubin, A. M., "Propagation of magma-filled cracks," Annual Review of Earth and Planetary Sciences 23, 287-336 (1995).

Rubin, A. M., "Tensile Fracture of Rock at High Confining Pressure: Implications for Dike Propagation," Journal of Geophysical Research 98, 15919-15936 (1993). 
Rubin, A. M., and D. D. Pollard, "Origins of Blade-like Dikes in Volcanic Rift Zones," U.S. Geological Survey Professional Paper 1350, 1449-1470 (1987).

Ryan, M. P., "The Mechanics and Three-dimensional Internal Structure of Active Magmatic Systems: Kilauea Volcano, Hawaii,” Journal Geophysical Research 93, 4213-4248 (1988).

Ryan, M. P., and J. Y. K. Blevins, "Viscosity of Synthetic and Natural Silicate Melts and Glasses at High Temperatures and 1 Bar (10 $10^{5}$ Pascals) Pressure and at High Pressures," U.S. Geological Survey Bulletin 1764, pp. 1-563 (1987).

Saatdjian, E., "Natural Convection in a Porous Layer Saturated with a Compressible Ideal gas," International Journal of Heat and Mass Transfer 23, 1681-1693 (1980).

Sawyer, D. A., R. J. Fleck, M. A. Lanphere, R. G. Warren, D. E. Broxton, and M. R. Hudson, "Episodic Caldera Volcanism in the Miocene Southwestern Nevada Volcanic Field: Revised Stratigraphic Framework, ${ }^{40} \mathrm{Ar}{ }^{39} \mathrm{Ar}$ Geochronology, and Implications for Magmatism and Extension," Geological Society of America Bulletin 106, 1304-1318 (1994).

Schriener, A. and Suemnicht, G.A., "Subsurface intrusive rocks in The geysers geothermal area, California," in Proc. Symp. on Mineral Deposits of the Pacific Northwest, M.L. Silberman, C.W. Field, and A.L. Berry, Eds., U. S. Geological Survey Open-File report 81-355, 295-302 (1981).

Scott, D.R., "The Competition between Percolation and Circulation in a Deformable Porous Medium," Journal Geophysical Research 93, 6451-6462 (1988).

Scott, D.R., and D.J. Stevenson, "A Self-consistent Model of Melting, Magma Migration and Buoyancydriven Circulation Beneath Mid-ocean Ridges," Journal Geophysical Research 94, 2973-2988 (1989).

Scott, D. R., and D. J. Stevenson, "Magma Ascent by Porous Flow," Journal Geophysical Research 91, 9283-9296 (1986).

Scott, D. R., and D. J. Stevenson, “Magma Solitons,” Geophysical Research Letter 11, 1161-1164 (1984).

Scott, D.R., D.J. Stevenson, and J.A. Whitehead, "Observations of Solitary Waves in a Viscously Deformable Pipe," Nature 319, 759-761 (1986).

Self, S., Kienle, J., and J.-P. Huot, "Ukinrek Maars, Alaska, II. Deposits and Formation of the 1977 Craters," Journal of Volcanology Geothermal Research 7, 39-65 (1980).

Self, S., "Sunset Crater," In Volcanoes of North America: United States and Canada, C.A. Wood and J. Kienle Eds. (Cambridge University Press, 1990), pp. 280-281.

Shaw, H.R., "The Fracture Mechanisms of Magma Transport from the Mantle to the Surface," in Physics of Magmatic Processes, R. B. Hargraves, Ed. (Princeton University Press, Princeton, New Jersey 1980) pp. 201-264.

Shaw, H. R., "Uniqueness of Volcanic Systems," in Volcanism in Hawaii, R. W. Decker, T. L. Wright, and P. H. Stauffer, Eds., U.S. Geological Survey Professional Paper 1350, 2, 1357-1394 (1987).

Shevenell, L., and F. Goff, "Addition of Magmatic Volatiles into the Hot Spring Waters of Loowit Canyon, Mount St Helens, Washington, USA,” Bulletin of Volcanology 55, 489-503 (1993). 
Shylapobersky, J., and A. Chudnovsky, "Review of Recent Developments in Fracture Mechanics with Petroleum Engineering Applications," Proceedings of the Euroch Symposium on Rock Mechanics in Petroleum Engineering, 381-389 (1994).

Sleep, N. H., "Segregation of Magma from a Mostly Crystalline Mush," Geological Society America Bulletin 85, 1225-1232 (1974).

Smiley, T.L., "The Geology and Dating of Sunset Crater, Flagstaff, Arizona," 9th Field Conference Guidebook, New Mexico Geological Society, Socorro, New Mexico, pp. 186-190 (1958).

Smith, E.I., D.L. Feuerbach, T.R. Naumann, and J.E. Faulds, "The Area of Most Recent Volcanism Near Yucca Mountain, Nevada: Implications for Volcanic Risk Assessment," in Proceedings High-Level Radioactive Waste Management Conference, Las Vegas, Nevada (American Nuclear Society, La Grange Park Illinois, 1990), 81-90 (1990).

Snyder D.B. and W.J. Carr, "Interpretation of Gravity Data in a Complex Volcanotectonic Setting, Southwestern Nevada," Journal Geophysical Research, 89, 10, 193-10, 206 (1984).

Spence, D. A. and D. L. Turcotte, "Magma-Driven Propagation of Cracks," Journal of Geophysical Research 90, 575-580 (1985).

Spence, D.A., and D.L. Turcotte, "Buoyancy-driven Magma Fracture: a Mechanism for Ascent through the Lithosphere and the Emplacement of Diamonds," Journal Geophysical Research 95, 5133-5139 (1990).

Spence, D. A., P. W. Sharp, and E. L. Turcotte, "Buoyancy-driven Crack Propagation: A Mechanism for Magma Migration," Journal Fluid Mechanics 174, 135-153 (1987).

Spera, F.J., "Carbon Dioxide in Petrogenesis III: Role of Volatiles in the Ascent of Alkaline Magma with Special Reference to Xenolith-Bearing Mafic Lavas," Contributions to Mineralogy and Petrology 88, 217-232 (1984).

Spiegelman, M., and C. Wiggings, "Great Balls of Fire: Magma Migration and Magma Solitary Waves in 3-D," EOS, Transactions American Geophysical Union 74, 684 (1993).

Stauffer, P.H., L.A. Auer, N.D. Rosenberg, "Compressible Gas in Porous Media: A Finite Element Analysis of Natural Convection," International Journal of Heat and Mass Transfer 40, 1585-1589 (1997)

Stock, J. M., Healy, J. H., Hickman, S. H., and Zoback, M. D., "Hydraulic Fracturing Stress Measurements at Yucca Mountain, Nevada, and Relationship to the Regional Stress Field," Journal Geophysical Research 90, 8691-8708 (1985).

Stoeser, D.B., "Xenoliths of the San Francisco Volcanic Field, Northern Arizona," in Geology of Northern Arizona, with Notes on Archeology and Paleoclimate: Part II, Area Studies and Field Guides, Karlstrom, T.N.V., G.A Swann and R.L Eastwood Eds., (Geological Society of America, Rocky Mountain Section, 1974), 530-545.

Strauss, J. M. and G. Schubert, "Thermal Convection of Water in a Porous Medium: Effects of Temperature and Pressure Dependent Thermodynamic and Transport Properties," Journal of Geophysical Research 82, 325-333 (1977). 
Surdam, R. C. and R. A. Sheppard, “Zeolites in Saline, Alkaline Lake-Deposits,” In Natural Zeolites: Occurrence, Properties, and Use, L.B. Sand and F.A. Mumpton Eds., Pergamon Press, Elmsford, N. Y., 145-174 (1978).

Swanson, D. A., “Magma Supply Rate at Kilauea Volcano, 1952-1971,” Science 1975, 169-170 (1972).

Szekely, J. and P. H. Reitan, "Dike Filling by Magma Intrusion and by Explosive Entrainment of Fragments," Journal of Geophysical Research 76, 2602-2607 (1971).

Tanaka, K. L., Shoemaker, E. M., Ulrich, G. E., and E. W. Wolfe, "Migration of Volcanism in the San Francisco Volcanic Field, Arizona" Geological Society of America Bulletin 97, 129-141 (1986).

Thadden, R.E., Santos, E.S., and O.B. Raup, "Geologic Map of the Grants Quadrangle, Valencia County, New Mexico,” U.S. Geological Survey Map GQ-681 (1967).

Thompson, R. N., Morrison, M. A., Hendry, G. L., and S. J. Parry, "An Assessment of the Relative Roles of Crust and Mantle in Magma Genesis: An Elemental Approach," Philosophical Transactions of the Royal Philosophical Society of London 310, 549-590 (1984).

Tsang, Y.W. and K. Pruess, “A Study of Thermally Induced Convection near a High-Level Nuclear Waste Repository in Partially Saturated Fractured Tuff,” Water Resources Research 23, 1958-1966 (1987).

Turcotte, D.L. and G. Schubert, Geodynamics: Applications of Continuum Physics to Geological Problems, (John Wiley and Sons, New York, 1982.)

Ulrich, G.E., and N.G. Bailey, "Geologic Map of the SP Mountain Part of the San Francisco Volcanic Field, North-Central Arizona,” U.S. Geological Survey Map MF-1956 (1987).

Ulrich, G.E., Billingsley, G.H., Hereford, R., Wolfe, E.W., Nealey L.D., and R.L. Sutton, "Map Showing Geology, Structure, and Uranium Deposits of the Flagstaff $1^{\circ}$ x $2^{\circ}$ Quadrangle, Arizona," U.S. Geological Survey Map I-1446 (1984).

Valentine, G.A., "Note on the Distribution of Basaltic Volcanism Associated with Large Silicic Centers," Journal of Volcanology and Geothermal Research 56, 167-170 (1993).

Valentine, G.A., and KR. Groves, "Entrainment of Country Rock during Basaltic Eruptions of the Lucero Volcanic Field, New Mexico," Journal of Geology 104, 71-90 (1996).

Valentine, G.A., B.M. Crowe, And F.V. Perry, "Physical Processes and Effects of Magmatism in the Yucca Mountain Region," in Proceedings High Level Radioactive Waste Management Conference Las Vegas, Nevada (American Nuclear Society, La Grange, Illinois, 1992), 3, pp. 2344-2355.

Valentine, G.A., K.R. Groves, C.W. Gable, F.V. Perry, and B.M. Crowe, "Effects of Magmatic Processes on the Potential Yucca Mountain Repository: Field and Computational Studies," in Proceedings: Site Characterization and Model Validation Focus '93 (American Nuclear Society La Grange Park, Illinois, 1993), pp. 167-173.

Van Burkirk, R. G., D. S. Gardiner, and S. W. Butters, "Characterization of Yucca Flat Materials," Terra Tek Report 78-67, Salt Lake City, Utah, Terra Tek Inc., (1978).

Vaniman, D. T., and B. M. Crowe, "Geology and Petrology of the Basalts of Crater Flat: Applications to Volcanic Risk Assessment for the Nevada Nuclear Waste Storage Investigations," Los Alamos National Laboratory report LA-8845-MS, 67 pp. (1981). 
Vaniman, D.T., B.M. Crowe, and E.S. Gladney, "Petrology and Geochemistry of Hawaiite Lavas from Crater Flat, Nevada," Contributions Mineralology Petrology 80, 341-357 (1982).

Vergniolle, S.C. and Jaupart, "Separated Two-Phase flow and Basaltic Eruptions," Journal of Geophysical Research 91, 12842-12860 (1986).

Vogel, T. A., and F. M. Byers, "Introduction to the Special Section on the Southwestern Nevada Volcanic Field," Journal of Geophysical Research 94, 5907 (1989).

Walker, G. P. L., "Gravitational (Density) Controls on Volcanism, Magma Chambers and Intrusions," U.S. Geological Survey Professional Paper 1350, 1449-1470 (1989).

Weertman, J., "The Stopping of a Rising, Liquid-Filled Crack in the Earth's Crust by a Freely Slipping Horizontal Joint," Journal of Geophysical Research 85, 967-976 (1980).

Weertman, J., "Theory of Fluid-filled Crevasses in Glaciers Applied to Vertical Magma Transport Beneath Ridges," Journal Geophysical Research 76, 1171-1183 (1971).

Wengerd, S. A., "Lucero Basin Attracts Wildcatters," Oil and Gas Journal (1958).

White, J. D. L., "Maar-Diatreme Phreatomagmatism at Hopi Buttes, Navajo Nation (Arizona), USA," Bulletin of Volcanology 53, 239-258 (1991).

Williams, H., F. J. Turner, and C. M. Gilbert, Petrography: An Introduction to the Study of rocks in thin Sections, (W.H. Freeman and Co., New York, 1954), 626 pp.

Wilson, L., and J. W., Head III, "Ascent and Eruption of Basaltic Magma on the Earth and Moon," Journal of Geophysical Research 86, 2971-3001 (1981).

Wilson, L., R. S. J. Sparks, and G. P. L. Walker, "Explosive Volcanic Eruptions-IV. The Control of Magma Properties and Conduit Geometry on Eruption Column Behavior,"Geophysical Journal of the Royal Astronomical Society 63, 117-148 (1980).

Wilson, M. L. et al., "Total-System Performance Assessment for Yucca Mountain--SNL Second Iteration (TSPA-1993)," Sandia National Laboratories report SAND93-2675 (1994).

Wohletz, K. H. and R. G. McQueen, "Experimental Studies of Hydromagmatic Volcanism," in Explosive Volcanism: Inception, Evolution, and Hazards (National Academy Press, 1984), pp. 158-169.

Wohletz, K.H., "Explosive Magma-Water Interactions: Thermodynamics, Explosion Mechanisms, and Field Studies," Bulletin of Volcanology 48, 245-264 (1986).

WoldeGabriel, G. and Goff, F., "K/Ar dates of hydrothermal clays from corehole VC-2B, Valles caldera, New Mexico and their relation to alteration in a large hydrothermal system." Journal of Volcanology Geothermal Research 50, 207-230 (1992).

WoldeGabriel, G. and Goff, F., "Temporal relations of volcanism and hydrothermal systems in two areas of the Jemez volcanic field, New Mexico," Geology 17, 986-989 (1989).

WoldeGabriel, G., "Hydrothermal alteration in core hole VC-1 and the Valles caldera ring fracture: Evidence for multiple hydrothermal systems," Journal of Volcanology and Geothermal Research 40, 105-122 (1990). 
WoldeGabriel, G., Goff, F., Hulen, J. B., Aronson, J. L., "Mineralogical and K-Ar geochronology of mixed-layered illite/smectite from the Geysers coring project, California," Geothermics (in review).

Wolfe, E. W., M. O. Garcia, D. B. Jackson, R. Y. Koyanagi, C. A. Neal, and A. T. Okamura, "The Puu Oo eruption of Kilauea Volcano, Episodes 1-20, January 3 1983, to June 8 1984," U.S. Geological Survey Professional Paper 1350, 471-508 (1987a).

Wolfe, E. W., Ulrich, G. E., and C. G. Newhall, "Geologic Map of the Northwest Part of the San Francisco Volcanic Field, North-Central Arizona,” U.S. Geological Survey Map MF-1957 (1987b).

Wolfe, E. W., Ulrich, G. E., Holm, R. F., Moore, R .B., and C. G. Newhall, "Geologic map of the central part of the San Francisco Volcanic Field, north-central Arizona," U.S. Geological Survey Map MF-1959 $(1987 \mathrm{c})$.

Zhang, Y., N. Lu and B. Ross, "Convective Instability of Moist gas in a Porous Medium," International Journal of Heat and Mass Transfer 37, 129-138 (1994).

Zilinski, R. E., Jr., "Geology of the Central part of the Lucero Uplift, Valencia County, New Mexico," MS Thesis, University of New Mexico, 69 p. (1976).

Zimanowski, B., G. Frölich, and V. Lorenz, "Quantitative Experiments on Phreatomagmatic Explosions," Journal of Volcanology and Geothermal Research 48, 341-358 (1991).

Zoback, M. I., R. E. Anderson, and B. A. Thompson, "Cainozoic Evolution of the State of Stress and Style of Tectonism of the Basin and Range Province of the Western United States," Philosophical Transactions Royal Society London Series A 300, 407-434 (1981).

Zyvoloski, G. A., B. A. Robinson, Z. V. Dash and L. L. Trease, "Models and Methods Summary for the FEHMN Application," Los Alamos National Laboratory document LA-UR-94-3787 Rev. 1 (1995a).

Zyvoloski, G. A., B.A. Robinson, Z.V. Dash and L.L. Trease, "Users Manual for the FEHMN application," Los Alamos National Laboratory document LA-UR-94-3788 Rev. 1 (1995b).

Zyvoloski, G. A., Z. V. Dash, and S. Kelkar, "FEHMN 1.0: Finite Element Heat and Mass Transfer Code," Los Alamos National Laboratory report LA-12062-MS, Rev. 1. (1992). 
Appendix 5.1. Xenolith Abundance Data for Lucero Volcanic Field

\begin{tabular}{|c|c|c|c|c|c|c|c|c|}
\hline $\begin{array}{l}\text { Facies } \\
\text { Type }\end{array}$ & Site ${ }^{a}$ & Parameter ${ }^{\mathrm{b}}$ & Chinle & San Andres & Glorieta & Abo & Madera & $\begin{array}{l}\text { Total Volume } \\
\text { Fraction }\end{array}$ \\
\hline $\begin{array}{l}\mathrm{L} \\
\mathrm{A}\end{array}$ & N5 & $\begin{array}{l}\mathrm{AF} \\
\mathrm{VF} \\
\mathrm{VF} / \mathrm{m}\end{array}$ & $\begin{array}{l}1.6 \times 10^{-3} \\
1.1 \times 10^{-4} \\
2.2 \times 10^{-7}\end{array}$ & $\begin{array}{l}1.2 \times 10^{-3} \\
6.8 \times 10^{-5} \\
5.2 \times 10^{-7}\end{array}$ & $\cdots$ & $\cdots$ & $\cdots$ & $1.8 \times 10^{-4}$ \\
\hline $\begin{array}{l}\mathrm{V} \\
\mathrm{A}\end{array}$ & VH7 & $\begin{array}{l}\mathrm{AF} \\
\mathrm{VF} \\
\mathrm{VF} / \mathrm{m}\end{array}$ & $\cdots$ & $\ldots$ & $\begin{array}{l}3.4 \times 10^{-3} \\
3.3 \times 10^{-4} \\
5.5 \times 10^{-6}\end{array}$ & $\cdots$ & $\cdots$ & $3.3 \times 10^{-4}$ \\
\hline $\begin{array}{l}\text { V } \\
\text { E } \\
\text { S }\end{array}$ & $\mathrm{S} 1-4^{\mathrm{c}}$ & $\begin{array}{l}\mathrm{AF} \\
\mathrm{VF} \\
\mathrm{VF} / \mathrm{m}\end{array}$ & $\begin{array}{l}2.7 \times 10^{-3} \\
2.3 \times 10^{-4} \\
4.5 \times 10^{-7}\end{array}$ & $\begin{array}{l}2.0 \times 10^{-3} \\
1.5 \times 10^{-4} \\
1.2 \times 10^{-6}\end{array}$ & $\begin{array}{l}2.1 \times 10^{-3} \\
1.6 \times 10^{-4} \\
2.6 \times 10^{-6}\end{array}$ & $\cdots$ & $\begin{array}{l}1.1 \times 10^{-3} \\
5.8 \times 10^{-5} \\
2.5 \times 10^{-7}\end{array}$ & $6.0 \times 10^{-4}$ \\
\hline $\begin{array}{l}\mathrm{I} \\
\mathrm{C} \\
\mathrm{U}\end{array}$ & $\mathrm{S} 1-5^{\mathrm{c}}$ & $\begin{array}{l}\text { AF } \\
\mathrm{VF} \\
\mathrm{VF} / \mathrm{m}\end{array}$ & $\begin{array}{l}2.7 \times 10^{-3} \\
2.3 \times 10^{-4} \\
4.5 \times 10^{-7} \\
\end{array}$ & $\cdots$ & $\begin{array}{l}1.1 \times 10^{-3} \\
5.9 \times 10^{-5} \\
9.8 \times 10^{-7}\end{array}$ & $\cdots$ & $\cdots$ & $2.9 \times 10^{-4}$ \\
\hline $\begin{array}{l}\mathrm{L} \\
\mathrm{A} \\
\mathrm{R}\end{array}$ & S7-2 & $\begin{array}{l}\mathrm{AF} \\
\mathrm{VF} \\
\mathrm{VF} / \mathrm{m}\end{array}$ & $\cdots$ & $\begin{array}{l}2.1 \times 10^{-3} \\
1.6 \times 10^{-4} \\
1.2 \times 10^{-6}\end{array}$ & $\cdots$ & $\cdots$ & $\cdots$ & $1.6 \times 10^{-4}$ \\
\hline $\begin{array}{l}\mathrm{S} \\
\mathrm{C}\end{array}$ & S7-3 & $\begin{array}{l}\mathrm{AF} \\
\mathrm{VF} \\
\mathrm{VF} / \mathrm{m}\end{array}$ & $\begin{array}{l}2.8 \times 10^{-3} \\
2.4 \times 10^{-4} \\
4.8 \times 10^{-7} \\
\end{array}$ & $\cdots$ & $\cdots$ & $\cdots$ & $\cdots$ & $2.4 \times 10^{-4}$ \\
\hline $\begin{array}{l}\mathrm{O} \\
\mathrm{R} \\
\mathrm{I} \\
\mathrm{A}\end{array}$ & $\mathrm{N} 2$ & $\begin{array}{l}\text { AF } \\
\text { VF } \\
V F / m\end{array}$ & $\begin{array}{l}6.9 \times 10^{-4} \\
3.0 \times 10^{-5} \\
5.9 \times 10^{-8}\end{array}$ & $\begin{array}{l}4.2 \times 10^{-4} \\
1.4 \times 10^{-5} \\
1.1 \times 10^{-7}\end{array}$ & $\begin{array}{l}1.6 \times 10^{-3} \\
1.1 \times 10^{-4} \\
1.8 \times 10^{-6}\end{array}$ & $\cdots$ & $\cdots$ & $1.5 \times 10^{-4}$ \\
\hline
\end{tabular}


Appendix 5.1. continued

\begin{tabular}{|c|c|c|c|c|c|c|c|c|}
\hline $\begin{array}{l}\text { Facies } \\
\text { Type }\end{array}$ & Site $^{\mathrm{a}}$ & Parameter $^{\mathrm{b}}$ & Chinle & San Andres & Glorieta & Abo & Madera & $\begin{array}{l}\text { Total Volume } \\
\text { Fraction }\end{array}$ \\
\hline & N3 & $\begin{array}{l}\mathrm{AF} \\
\mathrm{VF} \\
\mathrm{VF} / \mathrm{m}\end{array}$ & $\begin{array}{l}6.4 \times 10^{-3} \\
8.4 \times 10^{-4} \\
1.6 \times 10^{-6}\end{array}$ & $\ldots$ & $\cdots$ & $\ldots$ & $\ldots$ & $8.4 \times 10^{-4}$ \\
\hline $\begin{array}{l}\text { A } \\
\mathrm{N} \\
\mathrm{D}\end{array}$ & N6 (high) & $\begin{array}{l}\mathrm{AF} \\
\mathrm{VF} \\
\mathrm{VF} / \mathrm{m}\end{array}$ & $\begin{array}{l}1.8 \times 10^{-3} \\
1.3 \times 10^{-4} \\
2.5 \times 10^{-7}\end{array}$ & $\begin{array}{l}5.0 \times 10^{-5} \\
5.8 \times 10^{-7} \\
4.5 \times 10^{-9}\end{array}$ & $\begin{array}{l}2.6 \times 10^{-2} \\
6.9 \times 10^{-3} \\
1.2 \times 10^{-4}\end{array}$ & $\cdots$ & $\cdots$ & $7.0 \times 10^{-3}$ \\
\hline $\begin{array}{l}\mathrm{S} \\
\mathrm{P} \\
\mathrm{A}\end{array}$ & VH1 & $\begin{array}{l}\mathrm{AF} \\
\mathrm{VF} \\
\mathrm{VF} / \mathrm{m}\end{array}$ & $\ldots$ & $\ldots$ & $\begin{array}{l}1.1 \times 10^{-3} \\
6.1 \times 10^{-5} \\
1.0 \times 10^{-6}\end{array}$ & $\ldots$ & $\ldots$ & $6.1 \times 10^{-5}$ \\
\hline $\begin{array}{l}\mathrm{T} \\
\mathrm{T} \\
\mathrm{E}\end{array}$ & $\mathrm{VH} 2$ & $\begin{array}{l}\mathrm{AF} \\
\mathrm{VF} \\
\mathrm{VF} / \mathrm{m}\end{array}$ & $\ldots$ & $\ldots$ & $\begin{array}{l}5.3 \times 10^{-4} \\
2.0 \times 10^{-5} \\
3.4 \times 10^{-7}\end{array}$ & $\ldots$ & $\cdots$ & $2.0 \times 10^{-5}$ \\
\hline \multirow[t]{4}{*}{$\mathrm{R}$} & VH3 & $\begin{array}{l}\mathrm{AF} \\
\mathrm{VF} \\
\mathrm{VF} / \mathrm{m}\end{array}$ & $\begin{array}{l}1.1 \times 10^{-3} \\
5.6 \times 10^{-5} \\
1.1 \times 10^{-7}\end{array}$ & $\ldots$ & $\ldots$ & $\cdots$ & $\ldots$ & $5.6 \times 10^{-5}$ \\
\hline & VH4 & $\begin{array}{l}\mathrm{AF} \\
\mathrm{VF} \\
\mathrm{VF} / \mathrm{m}\end{array}$ & $\begin{array}{l}6.7 \times 10^{-4} \\
2.8 \times 10^{-5} \\
5.5 \times 10^{-8}\end{array}$ & $\cdots$ & $\begin{array}{l}2.2 \times 10^{-3} \\
1.7 \times 10^{-4} \\
2.8 \times 10^{-6}\end{array}$ & $\ldots$ & $\cdots$ & $2.0 \times 10^{-4}$ \\
\hline & VH5 & $\begin{array}{l}\mathrm{AF} \\
\mathrm{VF} \\
\mathrm{VF} / \mathrm{m}\end{array}$ & $\begin{array}{l}5.4 \times 10^{-3} \\
6.5 \times 10^{-4} \\
1.3 \times 10^{-6}\end{array}$ & $\cdots$ & $\begin{array}{l}2.0 \times 10^{-4} \\
4.6 \times 10^{-6} \\
7.7 \times 10^{-8}\end{array}$ & $\ldots$ & $\ldots$ & $6.5 \times 10^{-4}$ \\
\hline & VH6 & $\begin{array}{l}\mathrm{AF} \\
\mathrm{VF} \\
\mathrm{VF} / \mathrm{m}\end{array}$ & $\ldots$ & $\ldots$ & $\begin{array}{l}1.8 \times 10^{-3} \\
1.3 \times 10^{-4} \\
2.1 \times 10^{-6}\end{array}$ & $\ldots$ & $\ldots$ & $1.3 \times 10^{-4}$ \\
\hline
\end{tabular}


Appendix 5.1. continued

\begin{tabular}{|c|c|c|c|c|c|c|c|c|c|}
\hline $\begin{array}{l}\text { Facies } \\
\text { Type }\end{array}$ & & Site $^{\mathrm{a}}$ & Parameter ${ }^{\mathrm{b}}$ & Chinle & San Andres & Glorieta & Abo & Madera & $\begin{array}{l}\text { Total Volume } \\
\text { Fraction }\end{array}$ \\
\hline $\begin{array}{l}\mathrm{P} \\
\mathrm{O} \\
\mathrm{O}\end{array}$ & & S1-1 & $\begin{array}{l}\mathrm{AF} \\
\mathrm{VF} \\
\mathrm{VF} / \mathrm{m}\end{array}$ & $\ldots$ & $\cdots$ & $\cdots$ & $\cdots$ & $\cdots$ & 0 \\
\hline $\begin{array}{l}\mathrm{R} \\
\mathrm{L} \\
\mathrm{Y}\end{array}$ & $\begin{array}{l}\mathrm{L} \\
\mathrm{A} \\
\mathrm{P}\end{array}$ & $\mathrm{S} 1-2^{\mathrm{c}}$ & $\begin{array}{l}\mathrm{AF} \\
\mathrm{VF} \\
\mathrm{VF} / \mathrm{m}\end{array}$ & $\begin{array}{l}2.7 \times 10^{-2} \\
6.1 \times 10^{-3} \\
1.2 \times 10^{-5}\end{array}$ & $\cdots$ & $\begin{array}{l}2.9 \times 10^{-4} \\
8.0 \times 10^{-6} \\
1.3 \times 10^{-7}\end{array}$ & $\begin{array}{l}1.4 \times 10^{-3} \\
8.5 \times 10^{-5} \\
3.0 \times 10^{-7}\end{array}$ & $\cdots$ & $6.2 \times 10^{-3}$ \\
\hline $\begin{array}{l}\mathrm{V} \\
\mathrm{E}\end{array}$ & $\begin{array}{l}\mathrm{I} \\
\mathrm{L} \\
\mathrm{L}\end{array}$ & $\mathrm{S} 1-3^{\mathrm{c}}$ & $\begin{array}{l}\mathrm{AF} \\
\mathrm{VF} \\
\mathrm{VF} / \mathrm{m}\end{array}$ & $\begin{array}{l}1.3 \times 10^{-3} \\
8.1 \times 10^{-5} \\
1.6 \times 10^{-7} \\
\end{array}$ & $\begin{array}{l}3.6 \times 10^{-3} \\
3.6 \times 10^{-4} \\
2.7 \times 10^{-6}\end{array}$ & $\begin{array}{l}1.6 \times 10^{-3} \\
1.1 \times 10^{-4} \\
1.8 \times 10^{-6} \\
\end{array}$ & $\cdots$ & $\begin{array}{l}4.7 \times 10^{-3} \\
5.4 \times 10^{-4} \\
2.3 \times 10^{-6} \\
\end{array}$ & $1.1 \times 10^{-3}$ \\
\hline $\begin{array}{l}\mathrm{S} \\
\mathrm{I} \\
\mathrm{C}\end{array}$ & I & N4 (high) ${ }^{\mathrm{d}}$ & $\begin{array}{l}\mathrm{AF} \\
\mathrm{VF} \\
\mathrm{VF} / \mathrm{m}\end{array}$ & $\begin{array}{l}3.7 \times 10^{-2} \\
1.2 \times 10^{-2} \\
2.3 \times 10^{-5}\end{array}$ & $\begin{array}{l}9.0 \times 10^{-3} \\
1.4 \times 10^{-3} \\
1.1 \times 10^{-5} \\
\end{array}$ & $\begin{array}{l}1.4 \times 10^{-2} \\
2.8 \times 10^{-3} \\
4.7 \times 10^{-5}\end{array}$ & $\cdots$ & $\cdots$ & $1.6 \times 10^{-2}$ \\
\hline $\begin{array}{l}\mathrm{U} \\
\mathrm{L} \\
\mathrm{A} \\
\mathrm{R}\end{array}$ & & N6 (low) & $\begin{array}{l}\mathrm{AF} \\
\mathrm{VF} \\
\mathrm{VF} / \mathrm{m}\end{array}$ & $\begin{array}{l}1.0 \times 10^{-3} \\
5.3 \times 10^{-5} \\
1.0 \times 10^{-7}\end{array}$ & $\begin{array}{l}6.5 \times 10^{-4} \\
2.7 \times 10^{-5} \\
2.1 \times 10^{-7}\end{array}$ & $\begin{array}{l}6.6 \times 10^{-4} \\
2.8 \times 10^{-5} \\
4.6 \times 10^{-7}\end{array}$ & $\cdots$ & $\cdots$ & $1.1 \times 10^{-4}$ \\
\hline
\end{tabular}


Appendix 5.1. continued

\begin{tabular}{|c|c|c|c|c|c|c|c|c|c|}
\hline \multicolumn{2}{|c|}{$\begin{array}{l}\text { Facies } \\
\text { Type }\end{array}$} & Site $^{\mathrm{a}}$ & Parameter $^{\mathrm{b}}$ & Chinle & $\begin{array}{l}\text { San } \\
\text { Andres }\end{array}$ & Glorieta & Abo & Madera & $\begin{array}{l}\text { Total Volume } \\
\text { Fraction }\end{array}$ \\
\hline \multicolumn{2}{|l|}{$\begin{array}{l}\mathrm{L} \\
\mathrm{A} \\
\mathrm{P} \\
\mathrm{I}\end{array}$} & $S 7-1^{e}$ & $\begin{array}{l}\mathrm{AF} \\
\mathrm{VF} \\
\mathrm{VF} / \mathrm{m}\end{array}$ & $\begin{array}{l}5.4 \times 10^{-3} \\
6.5 \times 10^{-4}(0.41) \\
8.1 \times 10^{-4}\end{array}$ & $\begin{array}{l}4.4 \times 10^{-3} \\
4.8 \times 10^{-4} \\
3.7 \times 10^{-6}\end{array}$ & $\begin{array}{l}2.9 \times 10^{-3} \\
2.6 \times 10^{-4} \\
4.3 \times 10^{-6}\end{array}$ & $\cdots$ & $\ldots$ & .41 \\
\hline \multicolumn{2}{|l|}{$\begin{array}{l}\text { L } \\
\mathrm{L} \\
\mathrm{I}\end{array}$} & $\mathrm{S} 8^{\mathrm{e}}$ & $\begin{array}{l}\mathrm{AF} \\
\mathrm{VF} \\
\mathrm{VF} / \mathrm{m}\end{array}$ & $\begin{array}{l}7.3 \times 10^{-2} \\
3.2 \times 10^{-2}(0.30) \\
6.5 \times 10^{-4}\end{array}$ & $\begin{array}{l}9.3 \times 10^{-4} \\
4.6 \times 10^{-5} \\
3.6 \times 10^{-7}\end{array}$ & $\begin{array}{l}5.1 \times 10^{-3} \\
6.0 \times 10^{-4} \\
1.0 \times 10^{-5}\end{array}$ & $\cdots$ & $\ldots$ & .32 \\
\hline $\begin{array}{l} \\
\text { B } \\
\text { L }\end{array}$ & $\begin{array}{l}\mathrm{T} \\
\mathrm{U} \\
\mathrm{F}\end{array}$ & $\mathrm{S} 9^{\mathrm{e}}$ & $\begin{array}{l}\mathrm{AF} \\
\mathrm{VF} \\
\mathrm{VF} / \mathrm{m}\end{array}$ & $\begin{array}{l}5.7 \times 10^{-3} \\
7.1 \times 10^{-4}(0.46) \\
9.0 \times 10^{-4}\end{array}$ & $\begin{array}{l}3.0 \times 10^{-3} \\
2.7 \times 10^{-4} \\
2.1 \times 10^{-6}\end{array}$ & $\begin{array}{l}4.9 \times 10^{-3} \\
5.6 \times 10^{-4} \\
9.3 \times 10^{-6}\end{array}$ & $\cdots$ & $\ldots$ & .46 \\
\hline & N4 (low) & $\begin{array}{l}\mathrm{AF} \\
\mathrm{VF} \\
\mathrm{VF} / \mathrm{m}\end{array}$ & $\begin{array}{l}1.3 \times 10^{-2} \\
2.5 \times 10^{-3}(0.91) \\
1.8 \times 10^{-3}\end{array}$ & $\begin{array}{l}2.6 \times 10^{-4} \\
6.9 \times 10^{-6} \\
5.3 \times 10^{-8}\end{array}$ & $\begin{array}{l}8.8 \times 10^{-4} \\
4.3 \times 10^{-5} \\
7.2 \times 10^{-7}\end{array}$ & $\cdots$ & $\ldots$ & .91 \\
\hline \multicolumn{2}{|c|}{$\begin{array}{l}\text { Facies } \\
\text { Type }\end{array}$} & Site $^{\mathrm{a}}$ & Parameter $^{b}$ & Chinle & $\begin{array}{l}\text { San } \\
\text { Andres }\end{array}$ & Glorieta & Abo & Madera & $\begin{array}{l}\text { Total Volume } \\
\text { Fraction }\end{array}$ \\
\hline $\begin{array}{l}\mathrm{O} \\
\mathrm{T} \\
\mathrm{H} \\
\mathrm{E} \\
\mathrm{R}\end{array}$ & \begin{tabular}{|l}
$\mathrm{C}$ \\
$\mathrm{O}$ \\
$\mathrm{N}$ \\
$\mathrm{E}$ \\
$\mathrm{S}$
\end{tabular} & $\begin{array}{l}\text { Lathrop Wells }{ }^{f} \\
\text { Lathrop Wells } \\
\text { Lathrop Wells } \\
\text { Lathrop Wells }^{f} \\
\text { SFF }^{f}\end{array}$ & $\cdots$ & $\ldots$ & $\cdots$ & $\ldots$ & $\ldots$ & $\cdots$ & $\begin{array}{r}9 \times 10^{-5} \\
2.2 \times 10^{-4} \\
3.2 \times 10^{-4} \\
3.8 \times 10^{-4} \\
6.0 \times 10^{-4}\end{array}$ \\
\hline
\end{tabular}


a Site nomenclature - S, South Alkali Butte; N, North Alkali Butte; VH, Volcano Hill. First numeral is site number. Numeral after dash is measured area number where several areas were studied at a single site.

$\mathrm{b}$ AF is the calculated area fraction of xenoliths; VF is calculated volume fraction; $\mathrm{VF} / \mathrm{m}$ is entrainment rate of xenoliths (volume fraction derived per meter in dike/conduit).

${ }^{c}$ Varying proportions of xenoliths at these measured areas were difficult to correlate with a subvolcanic stratigraphic unit, mainly because these measurements were made early in the study before we were familiar with detailed characteristics of subvolcanic units. Uncorrelated xenoliths make up the following portions of these sites: S1-4, 63\%; S1-5, 91\%, S1-2, 6\%; S1-3, 21\%. Total volume fraction estimates for these sites are accurate, but entrainment rates for individual formations should be viewed with caution. Shales were assumed to be derived from Chinle Fm., limestones from San Andres Fm., and sandstones from Glorieta Fm., for entrainment rate calculation.

d Highly friable sandstone clasts were not correlated with a subvolcanic unit when data were collected. We assume here that these were derived from similar sandstone horizons within the Chinle Fm.

e AF values were determined for xenoliths $>1 \mathrm{~cm}$ (long dimension) at the outcrop, as described in text. VF values not in parentheses correspond to the field data, while values inside parentheses are the volume fractions within the matrix $(<1 \mathrm{~cm}$ size grains) determined by point counting of thin sections. The two main matrix constituents not listed in the table are calcite, which lines and/or fills pore spaces, and juvenile basalt fragments. These comprise the following volume fractions: site S7-1 - 0.55 basalt, 0.04 calcite; site S8 - 0.59 basalt, 0.11 calcite; site S9 - 0.49 basalt, 0.05 calcite; site N4(low) - 0.05 basalt, 0.04 calcite. See text for discussion of stratigraphic correlation of matrix xenolith grains.

f Data from the other scoria cones in Arizona and Nevada, reported in Crowe et. al. (1983). These would fall under vesicular scoria and spatter facies in the present report. SFF - San Francisco Field, Arizona. 
Appendix 5.2. Major and trace element data for Paiute Ridge samples.

\begin{tabular}{|c|c|c|c|c|c|c|c|c|c|c|}
\hline Sample \# & PR95-1 & PR95-2 & PR95-3 & PR95-4 & PR95-5 & PR95-6 & PR95-7 & PR95-8 & PR95-9 & PR95-10 \\
\hline $\mathrm{SiO} 2$ & 68.84 & 70.65 & 69.14 & 70.44 & 67.38 & 70 & 68.38 & 67.93 & 71.06 & 73.15 \\
\hline TiO2 & 0.256 & 0.281 & 0.259 & 0.254 & 0.254 & 0.269 & 0.25 & 0.273 & 0.268 & 0.265 \\
\hline $\mathrm{Al} 2 \mathrm{O} 3$ & 12.72 & 13.75 & 13.13 & 13.09 & 12.96 & 13.56 & 12.98 & 13.83 & 13.61 & 13.41 \\
\hline Fe2O3 & 1.36 & 1.46 & 1.33 & 1.35 & 1.33 & 1.43 & 1.34 & 1.49 & 1.42 & 1.44 \\
\hline $\mathrm{MnO}$ & 0.077 & 0.089 & 0.082 & 0.081 & 0.077 & 0.086 & 0.083 & 0.087 & 0.089 & 0.087 \\
\hline $\mathrm{MgO}$ & 0.35 & 0.46 & 0.56 & 0.48 & 0.42 & 0.61 & 0.84 & 0.54 & 0.47 & 0.25 \\
\hline $\mathrm{CaO}$ & 2.9 & 0.93 & 2.19 & 1.97 & 3.47 & 0.92 & 2.46 & 1.67 & 1.02 & 0.89 \\
\hline $\mathrm{Na2O}$ & 3.17 & 3.38 & 3.11 & 3.1 & 2.94 & 3.02 & 2.76 & 2.77 & 3.63 & 3.83 \\
\hline $\mathrm{K} 2 \mathrm{O}$ & 5.17 & 5.41 & 5.33 & 5.52 & 5.66 & 5.58 & 5.38 & 5.86 & 5.54 & 5.54 \\
\hline P2O5 & 0.048 & 0.044 & 0.042 & 0.057 & 0.06 & 0.046 & 0.063 & 0.057 & 0.043 & 0.043 \\
\hline LOI \% & 5.25 & 3.26 & 4.42 & 3.85 & 4.93 & 3.35 & 4.75 & 4.53 & 2.57 & 0.77 \\
\hline Total & 94.89 & 96.45 & 95.18 & 96.34 & 94.54 & 95.52 & 94.55 & 94.5 & 97.16 & 98.91 \\
\hline $\mathrm{V}$ & 18.6 & 14.8 & 15.1 & 14.5 & 14.3 & 16.4 & 24.7 & 34.6 & 10.4 & 13.7 \\
\hline \multicolumn{11}{|l|}{$\mathrm{Cr}$} \\
\hline $\mathrm{Ni}$ & & 5.9 & 6.1 & & 6.6 & & & & & 7.6 \\
\hline $\mathrm{Zn}$ & 47.5 & 52.9 & 46.3 & 44 & 42.2 & 49.5 & 47 & 58.2 & 46 & 49.4 \\
\hline $\mathrm{Rb}$ & 147.7 & 169 & 165 & 173.1 & 171.3 & 171.6 & 169.2 & 86.1 & 155.9 & 171.9 \\
\hline $\mathrm{Sr}$ & 258.6 & 116.3 & 108.9 & 117.9 & 135.4 & 113.4 & 146 & 718.8 & 119 & 93.6 \\
\hline$Y$ & 32.5 & 28.4 & 27 & 31.1 & 35.8 & 35.6 & 32.1 & 31 & 32.5 & 30 \\
\hline $\mathrm{Zr}$ & 265 & 316.8 & 262 & 271.1 & 261.3 & 282.6 & 272.2 & 315.9 & 288.1 & 278.3 \\
\hline $\mathrm{Nb}$ & 26.2 & 27.6 & 28.1 & 24.5 & 27.3 & 30 & 28.8 & 25.7 & 26.9 & 28.6 \\
\hline $\mathrm{Ba}$ & 712.4 & 564.2 & 487.4 & 556.2 & 511.5 & 483 & 444.7 & 689.3 & 527.2 & 532.3 \\
\hline
\end{tabular}


Appendix 5.2. continued

\begin{tabular}{|c|c|c|c|c|c|c|c|c|c|c|}
\hline Sample \# & PR95-11 & PR95-12 & PR95-13 & PR95-14 & PR95-15 & PR95-17 & PR95-18 & PR95-19 & PR95-20 & PR95-21 \\
\hline $\mathrm{SiO} 2$ & 47.28 & 71.98 & 72.84 & 68.75 & 64.58 & 46.78 & 72.6 & 79.38 & 70.4 & 67.04 \\
\hline TiO2 & 2.508 & 0.268 & 0.277 & 0.259 & 0.224 & 2.564 & 0.176 & 0.109 & 0.189 & 0.254 \\
\hline $\mathrm{Al2O}$ & 16.84 & 13.38 & 13.51 & 12.71 & 11.29 & 17.08 & 12.4 & 8.81 & 12.97 & 14.33 \\
\hline Fe2O3 & 11.09 & 1.47 & 1.47 & 1.42 & 1.19 & 11.59 & 1.14 & 0.79 & 1.33 & 2.13 \\
\hline $\mathrm{MnO}$ & 0.167 & 0.09 & 0.082 & 0.072 & 0.067 & 0.171 & 0.116 & 0.075 & 0.108 & 0.067 \\
\hline $\mathrm{MgO}$ & 4.92 & 0.27 & 0.24 & 0.72 & 0.55 & 5.19 & 0.29 & 0.31 & 0.72 & 2.38 \\
\hline $\mathrm{CaO}$ & 7.77 & 1.15 & 0.72 & 3.28 & 6.89 & 7.93 & 0.56 & 1.1 & 1.11 & 3.05 \\
\hline $\mathrm{Na2O}$ & 3.57 & 3.48 & 3.83 & 3.1 & 2.57 & 4.06 & 3.3 & 2.11 & 2.49 & 2.39 \\
\hline $\mathrm{K} 2 \mathrm{O}$ & 1.65 & 6.24 & 5.61 & 6.02 & 5.96 & 1.55 & 5.02 & 4.28 & 4.66 & 2.24 \\
\hline P2O5 & 0.567 & 0.046 & 0.049 & 0.051 & 0.098 & 0.581 & & & 0.035 & 0.063 \\
\hline LOI \% & 3.44 & 1.18 & 0.65 & 2.94 & 6.28 & 1.62 & 3.43 & 2.1 & 4.88 & 5.12 \\
\hline Total & 96.35 & 98.37 & 98.63 & 96.37 & 93.42 & 97.5 & 95.61 & 96.96 & 94.02 & 93.95 \\
\hline Sample \# & PR95-11 & PR95-12 & PR95-13 & PR95-14 & PR95-15 & PR95-17 & PR95-18 & PR95-19 & PR95-20 & PR95-21 \\
\hline $\mathrm{V}$ & 266.1 & 23 & 11.1 & 18.5 & 14 & 248.1 & & & & 19.5 \\
\hline $\mathrm{Cr}$ & 47 & & & & & 32.4 & & & & 10.8 \\
\hline $\mathrm{Ni}$ & 48.1 & 11.1 & & & 9.6 & 45.5 & 8.7 & 14.6 & 6.9 & 7.9 \\
\hline $\mathrm{Zn}$ & 55.8 & 35.6 & 42.6 & 42.3 & 23 & 69.7 & 72 & 49.2 & 60.7 & 38.8 \\
\hline $\mathrm{Rb}$ & 20 & 183 & 172.7 & 132.3 & 144 & 15.8 & 187.9 & 99.7 & 179.7 & 38.6 \\
\hline $\mathrm{Sr}$ & 563.6 & 79.6 & 100.7 & 146.3 & 166.7 & 593.9 & 80.8 & 63.2 & 187.8 & 497.3 \\
\hline $\mathrm{Y}$ & 34.1 & 32.8 & 37.5 & 29.1 & 30.2 & 34.3 & 44.8 & 28.4 & 41.4 & 18.2 \\
\hline $\mathrm{Zr}$ & 249.6 & 284.5 & 297.6 & 265.5 & 236.9 & 250.6 & 235.3 & 162 & 212.3 & 155.1 \\
\hline $\mathrm{Nb}$ & 36.1 & 31.2 & 30 & 23.8 & 23.7 & 36.8 & 26.1 & 21.8 & 25.9 & 16.1 \\
\hline $\mathrm{Ba}$ & 371.5 & 500.1 & 585.3 & 538.3 & 501.7 & 330 & 85.5 & 77.5 & 179.7 & 653.2 \\
\hline
\end{tabular}


Appendix 5.2. continued

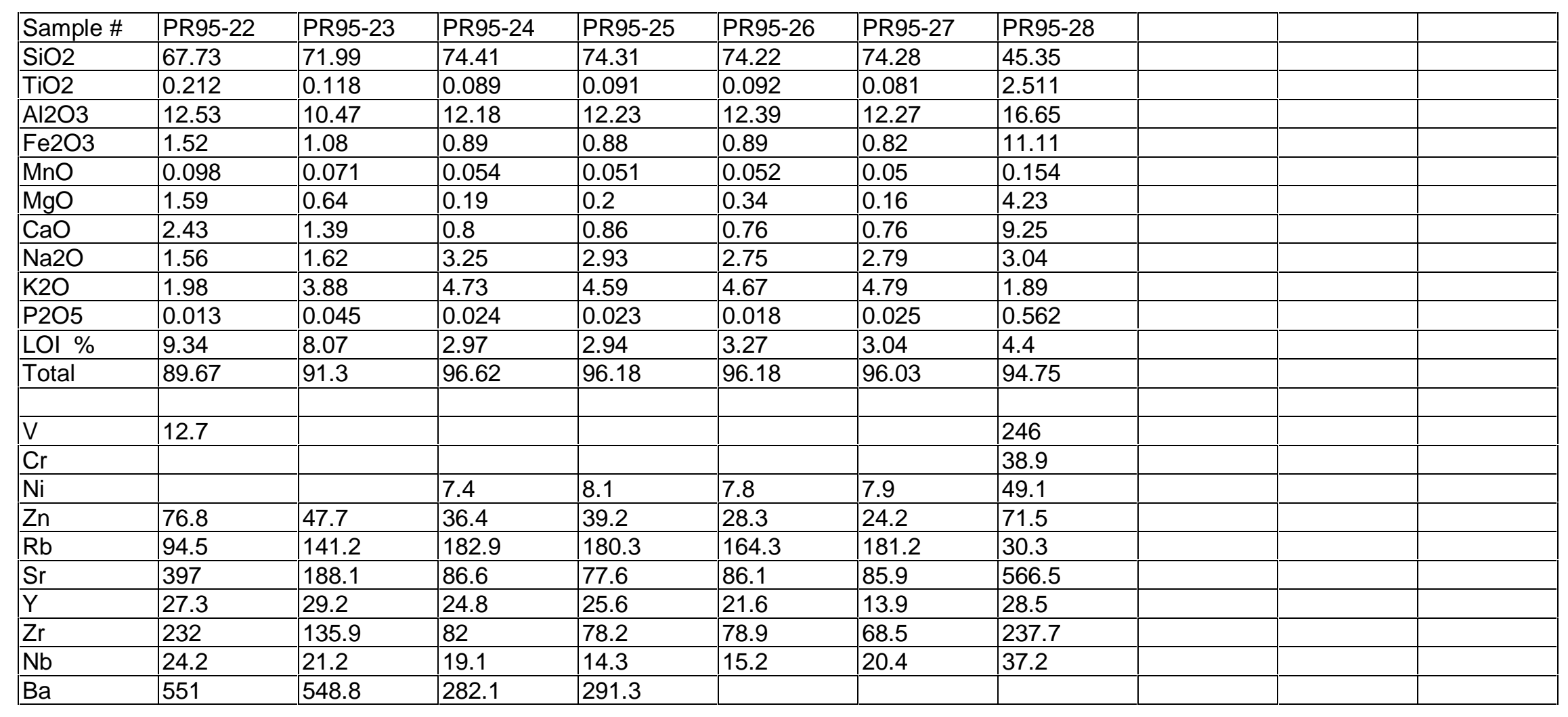


Appendix 5.3. Major and trace-element data for Grants Ridge samples

\begin{tabular}{|c|c|c|c|c|c|c|c|c|}
\hline Sample & |GR95-1A & |GR95-1B & |GR95-2 & |GR95-3 & |GR95-4 & |GR95-5A & GR95-5B & GR95-6A \\
\hline $\mathrm{SiO}_{2}$ & 72.44 & 71.23 & 75.53 & 74.67 & 48.34 & 73.01 & 70.78 & 72.83 \\
\hline $\mathrm{TiO}_{2}$ & 0.02 & 0.11 & 0.05 & 0.08 & 2.72 & 0.12 & 0.07 & 0.02 \\
\hline $\mathrm{Al}_{2} \mathrm{O}_{3}$ & 13.08 & 13.86 & 13.19 & 12.88 & 16.33 & 13.33 & 12.43 & 12.99 \\
\hline$\overline{\mathrm{Fe}_{2} \mathrm{O}_{3} \mathrm{~T}}$ & 0.82 & 1.31 & 0.95 & 1.19 & 12.21 & 1.45 & 1.10 & 0.77 \\
\hline $\mathrm{MnO}$ & 0.12 & 0.11 & 0.12 & 0.12 & 0.17 & 0.09 & 0.08 & 0.12 \\
\hline $\mathrm{MgO}$ & $\mid-0.07$ & 0.63 & 0.16 & 0.42 & 5.05 & 0.28 & 0.33 & \\
\hline $\mathrm{CaO}$ & 0.57 & 0.99 & 0.70 & 0.99 & 7.94 & 0.67 & 2.80 & 0.47 \\
\hline $\mathrm{Na}_{2} \mathrm{O}$ & 3.12 & 3.09 & 4.33 & 3.85 & 3.91 & 3.19 & 3.33 & 3.79 \\
\hline $\mathrm{K}_{2} \mathrm{O}$ & 6.02 & 4.35 & 4.27 & 4.20 & 1.44 & 4.94 & 4.81 & 5.08 \\
\hline $\mathrm{P}_{2} \mathrm{O}_{5}$ & 0.03 & 0.11 & 0.02 & 0.03 & 0.85 & 0.04 & 0.04 & \\
\hline LOI & 3.02 & 3.74 & 0.59 & 0.95 & 0.77 & 2.35 & 3.49 & 3.24 \\
\hline Total & 96.23 & 95.82 & 99.33 & 98.44 & 98.96 & 97.11 & 95.77 & 96.08 \\
\hline $\mathrm{V}$ & & 16.42 & & 7.74 & 176.40 & 14.40 & 8.40 & \\
\hline $\mathrm{Cr}$ & & & & & 53.50 & & & \\
\hline $\mathrm{Ni}$ & & 8.93 & & & 51.23 & & & \\
\hline $\mathrm{Zn}$ & 108.30 & 136.65 & 143.52 & 152.07 & 71.83 & 129.84 & 117.78 & 132.15 \\
\hline $\mathrm{Rb}$ & 504.59 & 411.86 & 465.06 & 443.63 & 26.13 & 435.57 & 435.69 & 521.14 \\
\hline$\overline{\mathrm{Sr}}$ & 7.13 & 55.84 & 24.13 & 48.08 & 744.19 & 36.83 & 48.15 & 8.59 \\
\hline$Y$ & 73.62 & 53.36 & 71.24 & 67.86 & 33.52 & 79.20 & 80.25 & 67.20 \\
\hline $\mathrm{Zr}$ & 102.59 & 128.56 & 115.54 & 120.70 & 232.57 & 151.88 & 112.96 & 99.64 \\
\hline $\mathrm{Nb}$ & 175.17 & 154.89 & 162.32 & 154.46 & 38.93 & 169.69 & 176.75 & 171.46 \\
\hline $\mathrm{Ba}$ & & 113.38 & 72.48 & 95.10 & 430.17 & 142.04 & 88.00 & \\
\hline Sample & GR95-6B & GR95-7 & GR95-8A & GR95-8B & GR95-9 & GR95-10 & GR95-11 & GR95-12 \\
\hline $\mathrm{SiO}_{2}$ & 71.72 & 70.47 & 72.40 & 73.56 & 48.64 & 71.53 & 71.90 & 74.50 \\
\hline $\mathrm{TiO}_{2}$ & 0.07 & 0.10 & 0.02 & 0.05 & 2.62 & 0.08 & 0.02 & 0.02 \\
\hline $\mathrm{Al}_{2} \mathrm{O}_{3}$ & 13.33 & 12.87 & 13.07 & 12.95 & 15.77 & 12.50 & 12.84 & 13.42 \\
\hline $\mathrm{Fe}_{2} \mathrm{O}_{3} \mathrm{~T}$ & 1.07 & 1.22 & 0.77 & 0.93 & 12.51 & 1.09 & 0.79 & 0.83 \\
\hline $\mathrm{MnO}$ & 0.12 & 0.11 & 0.13 & 0.14 & 0.18 & 0.12 & 0.12 & 0.13 \\
\hline $\mathrm{MgO}$ & 0.29 & 0.35 & & 0.16 & 5.16 & 0.44 & & \\
\hline $\mathrm{CaO}$ & 0.62 & 0.94 & 0.52 & 0.67 & 7.91 & 1.15 & 0.60 & 0.47 \\
\hline $\mathrm{Na}_{2} \mathrm{O}$ & 3.21 & 3.43 & 3.25 & 3.72 & 3.92 & 3.63 & 4.21 & 4.82 \\
\hline $\mathrm{K}_{2} \mathrm{O}$ & 4.73 & 3.81 & 5.99 & 4.88 & 1.60 & 3.73 & 4.36 & 4.36 \\
\hline $\mathrm{P}_{2} \mathrm{O}_{5}$ & & 0.02 & & & 0.86 & 0.02 & & \\
\hline LOI & 3.75 & 5.41 & 2.69 & 2.15 & 0.11 & 4.52 & 4.28 & 0.36 \\
\hline Total & 95.16 & 93.31 & 96.15 & 97.05 & 99.16 & 94.28 & 94.84 & 98.56 \\
\hline $\mathrm{V}$ & 8.11 & 9.90 & & & 196.11 & 8.89 & & \\
\hline $\mathrm{Cr}$ & & & & & 74.91 & & & \\
\hline $\mathrm{Ni}$ & & 6.47 & 6.42 & & 56.36 & & & 6.03 \\
\hline $\mathrm{Zn}$ & 142.98 & 125.69 & 28.22 & 99.05 & 108.66 & 130.71 & 109.97 & 119.59 \\
\hline $\mathrm{Rb}$ & 463.92 & 442.51 & 509.51 & 470.91 & 31.42 & 432.44 & 500.05 & 524.81 \\
\hline $\mathrm{Sr}$ & 39.56 & 55.83 & 7.73 & 39.47 & 697.36 & 75.25 & 5.99 & 9.27 \\
\hline $\mathrm{Y}$ & 69.35 & 68.97 & 81.38 & 76.28 & 31.62 & 68.42 & 70.25 & 80.11 \\
\hline $\mathrm{Zr}$ & 112.58 & 125.83 & 99.41 & 106.41 & 245.07 & 110.13 & 100.41 & 107.03 \\
\hline $\mathrm{Nb}$ & 163.29 & 150.81 & 169.85 & 150.61 & 41.91 & 150.90 & 161.59 & 176.15 \\
\hline $\mathrm{Ba}$ & 64.14 & 91.16 & & & 428.20 & 56.96 & & \\
\hline
\end{tabular}


Appendix 5.3. continued

\begin{tabular}{|c|c|c|c|c|c|}
\hline Sample & GR95-13 & GR95-14 & GR95-15A & GR95-15B & GR95-16 \\
\hline $\mathrm{SiO}_{2}$ & 46.14 & 72.17 & 59.62 & 70.48 & 47.00 \\
\hline $\mathrm{TiO}_{2}$ & 2.88 & 0.02 & 0.02 & 0.11 & 2.86 \\
\hline$\overline{\mathrm{Al}_{2} \mathrm{O}_{3}}$ & 15.53 & 12.93 & 10.51 & 12.75 & 15.99 \\
\hline $\mathrm{Fe}_{2} \mathrm{O}_{3} \mathrm{~T}$ & 12.89 & 0.78 & 0.64 & 1.25 & 12.92 \\
\hline $\mathrm{MnO}$ & 0.17 & 0.12 & 0.09 & 0.11 & 0.17 \\
\hline $\mathrm{MgO}$ & 5.96 & -0.07 & 0.09 & 0.35 & 5.68 \\
\hline $\mathrm{CaO}$ & 8.23 & 0.46 & 10.05 & 0.95 & 8.17 \\
\hline $\mathrm{Na}_{2} \mathrm{O}$ & 3.57 & 4.41 & 3.28 & 3.44 & 3.80 \\
\hline $\mathrm{K}_{2} \mathrm{O}$ & 1.37 & 4.50 & 3.66 & 3.76 & 1.41 \\
\hline $\mathrm{P}_{2} \mathrm{O}_{5}$ & 0.65 & -0.01 & -0.01 & 0.02 & 0.72 \\
\hline LOI & 1.37 & 3.16 & 11.05 & 5.59 & 0.14 \\
\hline Total & 97.40 & 95.39 & 87.97 & 93.21 & 98.73 \\
\hline $\mathrm{V}$ & 225.08 & & & 10.72 & 219.47 \\
\hline $\mathrm{Cr}$ & 74.91 & & & & 72.22 \\
\hline $\mathrm{Ni}$ & 69.52 & & & 10.76 & 64.74 \\
\hline $\mathrm{Zn}$ & 108.48 & 132.65 & 99.05 & 96.25 & 104.29 \\
\hline $\mathrm{Rb}$ & 26.15 & 508.20 & 406.61 & 444.69 & 24.29 \\
\hline $\mathrm{Sr}$ & 666.88 & & 20.23 & 66.82 & 693.27 \\
\hline $\bar{Y}$ & 31.53 & 76.56 & 73.13 & 70.40 & 32.00 \\
\hline $\mathrm{Zr}$ & 221.68 & 99.43 & 72.70 & 122.31 & 238.19 \\
\hline $\mathrm{Nb}$ & 38.28 & 171.13 & 128.08 & 146.30 & 40.43 \\
\hline $\mathrm{Ba}$ & 425.18 & & & 79.82 & 405.62 \\
\hline Sample & GR95-17 & GR95-18 & GR95-19 & GR95-20 & GR95-21 \\
\hline $\mathrm{SiO}_{2}$ & 68.58 & 72.55 & 69.60 & 67.55 & 73.79 \\
\hline $\mathrm{TiO}_{2}$ & 0.57 & 0.02 & 0.55 & 0.83 & 0.12 \\
\hline $\mathrm{Al}_{2} \mathrm{O}_{3}$ & 13.91 & 13.00 & 13.19 & 12.36 & 12.46 \\
\hline $\mathrm{Fe}_{2} \mathrm{O}_{3} \mathrm{~T}$ & 3.66 & 0.79 & 3.34 & 4.32 & 1.34 \\
\hline $\mathrm{MnO}$ & 0.09 & 0.12 & 0.09 & 0.10 & 0.08 \\
\hline $\mathrm{MgO}$ & 1.28 & 0.08 & 1.32 & 2.14 & 0.34 \\
\hline $\mathrm{CaO}$ & 1.77 & 0.63 & 1.60 & 2.48 & 0.95 \\
\hline $\mathrm{Na}_{2} \mathrm{O}$ & 2.54 & 4.02 & 2.27 & 2.17 & 3.75 \\
\hline $\mathrm{K}_{2} \mathrm{O}$ & 3.35 & 4.94 & 3.20 & 2.56 & 4.36 \\
\hline $\mathrm{P}_{2} \mathrm{O}_{5}$ & 0.17 & -0.01 & 0.16 & 0.16 & 0.02 \\
\hline LOI & 3.39 & 3.18 & 3.95 & 4.18 & 1.71 \\
\hline Total & 95.93 & 96.16 & 95.31 & 94.68 & 97.22 \\
\hline $\mathrm{V}$ & 52.41 & & 65.56 & 68.00 & 8.42 \\
\hline $\mathrm{Cr}$ & 28.69 & & 26.81 & 37.63 & \\
\hline $\mathrm{Ni}$ & 8.81 & 6.09 & 14.64 & 21.91 & 7.88 \\
\hline $\mathrm{Zn}$ & 83.82 & 113.95 & 81.33 & 87.84 & 114.58 \\
\hline $\mathrm{Rb}$ & 204.07 & 509.51 & 235.74 & 186.10 & 390.43 \\
\hline $\mathrm{Sr}$ & 285.85 & 8.84 & 198.99 & 239.35 & 64.75 \\
\hline $\mathrm{Y}$ & 39.94 & 73.57 & 51.36 & 41.65 & 64.86 \\
\hline $\mathrm{Zr}$ & 313.33 & 99.13 & 278.59 & 259.13 & 142.11 \\
\hline $\mathrm{Nb}$ & 54.93 & 167.51 & 85.97 & 64.66 & 155.34 \\
\hline $\mathrm{Ba}$ & 692.07 & & 399.00 & 386.38 & 131.08 \\
\hline
\end{tabular}


Appendix 5.4. Electron Microprobe data from Grants Ridge

\begin{tabular}{|c|c|c|c|c|c|c|c|c|c|c|c|c|c|c|}
\hline SAMPLE & $\mathrm{SiO}_{2}$ & $\mathrm{TiO}_{2}$ & $\mathrm{AL}_{2} \mathrm{O}_{3}$ & $\mathrm{FeO}$ & $\mathrm{CaO}$ & $\mathrm{MgO}$ & $\mathrm{MnO}$ & $\mathrm{K}_{2} \mathrm{O}$ & $\mathrm{Na}_{2} \mathrm{O}$ & $\mathrm{SrO}$ & $\mathrm{BaO}$ & $\mathrm{P}_{2} \mathrm{O}_{5}$ & $\mathrm{~F}$ & TOTAL \\
\hline gr95_1 & 74.00 & 0.04 & 13.00 & 0.13 & 0.24 & 0.00 & 0.06 & 6.44 & 2.73 & 0.02 & 0.00 & 0.01 & 0.26 & 96.81 \\
\hline gr95_1 & 74.23 & 0.00 & 12.97 & 0.11 & 0.30 & 0.00 & 0.10 & 6.02 & 2.93 & 0.01 & 0.03 & 0.06 & 0.23 & 96.88 \\
\hline gr95_1 & 73.87 & 0.01 & 12.97 & 0.20 & 0.27 & 0.00 & 0.06 & 6.11 & 2.97 & 0.06 & 0.01 & 0.00 & 0.19 & 96.63 \\
\hline gr95_1 & 74.76 & 0.00 & 12.81 & 0.20 & 0.36 & 0.00 & 0.07 & 5.38 & 3.06 & 0.04 & 0.00 & 0.00 & 0.23 & 96.79 \\
\hline gr95_1 & 73.95 & 0.05 & 13.03 & 0.15 & 0.16 & 0.00 & 0.07 & 6.12 & 2.96 & 0.01 & 0.00 & 0.00 & 0.21 & 96.62 \\
\hline gr95_1 & 72.98 & 0.03 & 12.87 & 1.02 & 0.22 & 0.00 & 0.18 & 6.30 & 2.91 & 0.01 & 0.00 & 0.00 & 0.22 & 96.64 \\
\hline gr95_1 & 74.09 & 0.03 & 13.02 & 0.18 & 0.25 & 0.00 & 0.08 & 6.05 & 2.91 & 0.06 & 0.00 & 0.02 & 0.22 & 96.81 \\
\hline gr95_1 & 72.01 & 0.00 & 14.41 & 0.02 & 0.10 & 0.19 & 0.02 & 8.21 & 3.43 & 0.05 & 0.01 & 0.08 & 0.00 & 98.53 \\
\hline gr95_1 & 74.35 & 0.04 & 13.03 & 0.21 & 0.36 & 0.02 & 0.11 & 5.91 & 2.93 & 0.05 & 0.03 & 0.00 & 0.20 & 97.15 \\
\hline gr95_1 & 73.55 & 0.02 & 13.23 & 0.17 & 0.37 & 0.00 & 0.09 & 5.88 & 3.21 & 0.07 & 0.00 & 0.00 & 0.20 & 96.69 \\
\hline gr95_1 & 73.03 & 0.00 & 12.91 & 0.18 & 0.20 & 0.00 & 0.03 & 6.22 & 2.97 & 0.09 & 0.04 & 0.03 & 0.24 & 95.85 \\
\hline gr95_1 & 73.54 & 0.08 & 12.99 & 0.16 & 0.15 & 0.00 & 0.07 & 6.12 & 2.92 & 0.05 & 0.00 & 0.00 & 0.23 & 96.21 \\
\hline gr95_1 & 73.70 & 0.07 & 13.04 & 0.24 & 0.25 & 0.00 & 0.06 & 6.68 & 2.68 & 0.02 & 0.04 & 0.02 & 0.19 & 96.90 \\
\hline gr95_1 & 72.92 & 0.01 & 12.96 & 0.20 & 0.21 & 0.00 & 0.15 & 5.66 & 2.90 & 0.11 & 0.00 & 0.01 & 0.22 & 95.25 \\
\hline gr95_1 & 74.55 & 0.00 & 12.99 & 0.14 & 0.21 & 0.00 & 0.05 & 5.79 & 2.85 & 0.04 & 0.03 & 0.00 & 0.21 & 96.76 \\
\hline gr95_1 & 73.52 & 0.02 & 12.92 & 0.27 & 0.19 & 0.00 & 0.10 & 5.95 & 2.80 & 0.02 & 0.05 & 0.03 & 0.19 & 95.98 \\
\hline gr95_1 & 73.48 & 0.00 & 13.02 & 0.37 & 0.23 & 0.00 & 0.06 & 6.48 & 2.49 & 0.03 & 0.00 & 0.01 & 0.22 & 96.30 \\
\hline gr95_1 & 74.70 & 0.01 & 12.82 & 0.14 & 0.18 & 0.01 & 0.14 & 6.29 & 2.62 & 0.06 & 0.02 & 0.02 & 0.21 & 97.11 \\
\hline gr95_1 & 73.85 & 0.00 & 12.92 & 0.13 & 0.13 & 0.00 & 0.09 & 6.34 & 2.65 & 0.03 & 0.00 & 0.01 & 0.22 & 96.29 \\
\hline gr95_1 & 74.65 & 0.00 & 12.84 & 0.15 & 0.13 & 0.00 & 0.02 & 6.11 & 2.69 & 0.00 & 0.00 & 0.01 & 0.17 & 96.69 \\
\hline gr95_1 & 77.37 & 0.00 & 11.99 & 0.32 & 0.34 & 0.00 & 0.14 & 4.33 & 2.79 & 0.06 & 0.01 & 0.01 & 0.21 & 97.47 \\
\hline gr95-6b & 71.88 & 0.03 & 12.82 & 0.74 & 0.44 & 0.00 & 0.14 & 4.58 & 3.97 & 0.01 & 0.00 & 0.00 & 0.24 & 94.73 \\
\hline gr95-6b & 72.42 & 0.01 & 12.97 & 0.65 & 0.44 & 0.00 & 0.14 & 4.48 & 3.99 & 0.04 & 0.07 & 0.04 & 0.23 & 95.39 \\
\hline gr95-6b & 72.26 & 0.08 & 12.68 & 0.64 & 0.40 & 0.00 & 0.11 & 4.67 & 3.95 & 0.00 & 0.06 & 0.00 & 0.24 & 94.98 \\
\hline gr95-6b & 72.60 & 0.10 & 12.88 & 0.74 & 0.49 & 0.00 & 0.12 & 4.32 & 4.17 & 0.04 & 0.01 & 0.00 & 0.21 & 95.57 \\
\hline gr95-6b & 72.63 & 0.02 & 12.88 & 0.64 & 0.45 & 0.01 & 0.13 & 4.40 & 4.05 & 0.00 & 0.00 & 0.02 & 0.24 & 95.35 \\
\hline gr95-6b & 71.61 & 0.06 & 12.48 & 0.60 & 0.41 & 0.00 & 0.10 & 4.65 & 3.77 & 0.00 & 0.00 & 0.00 & 0.21 & 93.81 \\
\hline gr95-6b & 69.54 & 0.09 & 12.27 & 0.65 & 0.37 & 0.00 & 0.10 & 4.97 & 3.36 & 0.05 & 0.00 & 0.01 & 0.22 & 91.54 \\
\hline gr95-6b & 72.68 & 0.00 & 12.74 & 0.67 & 0.44 & 0.00 & 0.09 & 4.37 & 4.04 & 0.06 & 0.00 & 0.00 & 0.24 & 95.23 \\
\hline gr95-6b & 72.83 & 0.12 & 12.66 & 0.77 & 0.44 & 0.00 & 0.11 & 4.79 & 3.76 & 0.00 & 0.00 & 0.00 & 0.20 & 95.58 \\
\hline
\end{tabular}


Appendix 5.4. continued

\begin{tabular}{|c|c|c|c|c|c|c|c|c|c|c|c|c|c|c|}
\hline SAMPLE & $\mathrm{SiO}_{2}$ & $\mathrm{TiO}_{2}$ & $\mathrm{AL}_{2} \mathrm{O}_{3}$ & $\mathrm{FeO}$ & $\mathrm{CaO}$ & $\mathrm{MgO}$ & $\mathrm{MnO}$ & $\mathrm{K}_{2} \mathrm{O}$ & $\mathrm{Na}_{2} \mathrm{O}$ & SrO & $\mathrm{BaO}$ & $\mathrm{P}_{2} \mathrm{O}_{5}$ & $\mathrm{~F}$ & TOTAL \\
\hline gr95-6b & 72.09 & 0.01 & 12.81 & 0.72 & 0.45 & 0.00 & 0.12 & 4.47 & 4.03 & 0.03 & 0.00 & 0.00 & 0.24 & 94.85 \\
\hline gr95-6b & 72.93 & 0.08 & 12.72 & 0.60 & 0.44 & 0.00 & 0.16 & 4.60 & 3.81 & 0.00 & 0.05 & 0.01 & 0.22 & 95.53 \\
\hline gr95-6b & 72.17 & 0.05 & 12.74 & 0.74 & 0.45 & 0.00 & 0.11 & 4.37 & 3.99 & 0.05 & 0.01 & 0.02 & 0.27 & 94.87 \\
\hline gr95-6b & 72.45 & 0.04 & 12.84 & 0.68 & 0.46 & 0.01 & 0.09 & 4.37 & 4.06 & 0.00 & 0.04 & 0.01 & 0.26 & 95.20 \\
\hline gr95-6b & 72.10 & 0.00 & 12.62 & 0.64 & 0.48 & 0.01 & 0.09 & 4.41 & 3.92 & 0.05 & 0.02 & 0.00 & 0.22 & 94.46 \\
\hline gr95-6b & 72.20 & 0.09 & 12.85 & 0.66 & 0.44 & 0.00 & 0.05 & 4.43 & 4.09 & 0.03 & 0.04 & 0.04 & 0.24 & 95.05 \\
\hline gr95-6b & 71.73 & 0.01 & 12.70 & 0.68 & 0.46 & 0.00 & 0.06 & 4.36 & 4.10 & 0.00 & 0.03 & 0.00 & 0.27 & 94.28 \\
\hline gr95-6b & 73.00 & 0.03 & 12.69 & 0.71 & 0.47 & 0.00 & 0.13 & 4.47 & 3.99 & 0.03 & 0.00 & 0.00 & 0.22 & 95.64 \\
\hline gr95-6b & 72.42 & 0.00 & 12.67 & 0.69 & 0.46 & 0.00 & 0.09 & 4.53 & 3.94 & 0.04 & 0.09 & 0.00 & 0.25 & 95.05 \\
\hline gr95-6b & 69.31 & 0.00 & 12.38 & 0.63 & 0.44 & 0.00 & 0.07 & 4.22 & 4.01 & 0.01 & 0.01 & 0.00 & 0.24 & 91.22 \\
\hline gr95-6b & 72.37 & 0.04 & 12.92 & 0.75 & 0.46 & 0.00 & 0.15 & 4.32 & 4.05 & 0.00 & 0.02 & 0.03 & 0.25 & 95.26 \\
\hline gr95-6b & 72.53 & 0.00 & 12.75 & 0.76 & 0.45 & 0.01 & 0.06 & 4.34 & 3.92 & 0.00 & 0.00 & 0.00 & 0.26 & 94.97 \\
\hline gr95-6b & 71.28 & 0.01 & 12.65 & 0.71 & 0.43 & 0.00 & 0.10 & 4.54 & 4.00 & 0.02 & 0.00 & 0.00 & 0.25 & 93.89 \\
\hline gr95_7 & 71.58 & 0.01 & 12.61 & 0.63 & 0.45 & 0.00 & 0.10 & 4.41 & 3.86 & 0.01 & 0.04 & 0.01 & & 93.70 \\
\hline gr95_7 & 71.14 & 0.00 & 12.68 & 0.62 & 0.43 & 0.00 & 0.18 & 4.52 & 3.90 & 0.01 & 0.07 & 0.00 & & 93.54 \\
\hline gr95_7 & 71.69 & 0.02 & 12.59 & 0.64 & 0.44 & 0.00 & 0.11 & 4.31 & 3.91 & 0.01 & 0.00 & 0.00 & & 93.73 \\
\hline gr95_7 & 71.23 & 0.03 & 12.71 & 0.75 & 0.47 & 0.00 & 0.11 & 4.41 & 3.86 & 0.00 & 0.00 & 0.05 & & 93.61 \\
\hline gr95_7 & 70.76 & 0.00 & 12.69 & 0.62 & 0.46 & 0.00 & 0.14 & 4.31 & 3.81 & 0.01 & 0.02 & 0.00 & & 92.82 \\
\hline gr95_7 & 72.24 & 0.00 & 12.72 & 0.62 & 0.44 & 0.00 & 0.15 & 4.31 & 3.84 & 0.01 & 0.00 & 0.01 & & 94.34 \\
\hline gr95_7 & 70.85 & 0.02 & 12.71 & 0.59 & 0.44 & 0.00 & 0.06 & 4.27 & 4.11 & 0.05 & 0.00 & 0.01 & & 93.11 \\
\hline gr95_7 & 70.36 & 0.00 & 12.66 & 0.58 & 0.47 & 0.00 & 0.19 & 4.25 & 3.94 & 0.00 & 0.00 & 0.00 & & 92.44 \\
\hline gr95_7 & 72.70 & 0.00 & 12.78 & 0.84 & 0.40 & 0.01 & 0.09 & 4.45 & 3.98 & 0.00 & 0.00 & 0.00 & & 95.25 \\
\hline gr95_7 & 70.41 & 0.01 & 12.60 & 0.67 & 0.47 & 0.00 & 0.04 & 4.18 & 3.82 & 0.01 & 0.00 & 0.00 & & 92.21 \\
\hline gr95_7 & 72.09 & 0.06 & 12.63 & 0.68 & 0.44 & 0.00 & 0.11 & 4.11 & 3.92 & 0.01 & 0.04 & 0.02 & & 94.10 \\
\hline gr95_7 & 70.50 & 0.02 & 12.67 & 0.70 & 0.45 & 0.00 & 0.09 & 4.24 & 3.80 & 0.03 & 0.02 & 0.00 & & 92.50 \\
\hline gr95_7 & 71.60 & 0.07 & 12.54 & 0.66 & 0.45 & 0.00 & 0.11 & 4.18 & 3.59 & 0.04 & 0.00 & 0.01 & & 93.24 \\
\hline gr95_7 & 69.47 & 0.08 & 12.83 & 0.69 & 0.92 & 0.00 & 0.04 & 3.64 & 3.70 & 0.03 & 0.06 & 0.00 & & 91.47 \\
\hline gr95_7 & 71.84 & 0.02 & 12.87 & 0.77 & 0.21 & 0.00 & 0.08 & 4.29 & 4.28 & 0.02 & 0.05 & 0.03 & & 94.45 \\
\hline gr95_7 & 71.55 & 0.10 & 12.71 & 0.81 & 0.40 & 0.00 & 0.07 & 4.47 & 4.18 & 0.04 & 0.00 & 0.00 & & 94.32 \\
\hline gr95_7 & 71.07 & 0.05 & 12.73 & 0.57 & 0.45 & 0.00 & 0.12 & 4.21 & 3.62 & 0.01 & 0.00 & 0.02 & & 92.85 \\
\hline
\end{tabular}


Appendix 5.4. continued

\begin{tabular}{|c|c|c|c|c|c|c|c|c|c|c|c|c|c|c|}
\hline SAMPLE & $\mathrm{SiO}_{2}$ & $\mathrm{TiO}_{2}$ & $\mathrm{AL}_{2} \mathrm{O}_{3}$ & $\mathrm{FeO}$ & $\mathrm{CaO}$ & $\mathrm{MgO}$ & $\mathrm{MnO}$ & $\mathrm{K}_{2} \mathrm{O}$ & $\mathrm{Na}_{2} \mathrm{O}$ & $\mathrm{SrO}$ & $\mathrm{BaO}$ & $\mathrm{P}_{2} \mathrm{O}_{5}$ & $\mathrm{~F}$ & TOTAL \\
\hline gr95_7 & 71.03 & 0.08 & 12.54 & 0.72 & 0.45 & 0.00 & 0.12 & 4.11 & 3.46 & 0.02 & 0.00 & 0.00 & & 92.53 \\
\hline gr95_7 & 70.90 & 0.02 & 12.68 & 0.68 & 0.42 & 0.00 & 0.09 & 4.11 & 3.59 & 0.01 & 0.01 & 0.02 & & 92.52 \\
\hline gr95_7 & 71.29 & 0.00 & 12.61 & 0.65 & 0.42 & 0.00 & 0.11 & 3.86 & 3.47 & 0.03 & 0.05 & 0.03 & & 92.51 \\
\hline gr95_7 & 71.69 & 0.00 & 12.75 & 0.70 & 0.42 & 0.00 & 0.07 & 4.31 & 4.16 & 0.05 & 0.04 & 0.01 & & 94.20 \\
\hline gr95_7 & 69.63 & 0.03 & 12.62 & 0.62 & 0.43 & 0.01 & 0.06 & 3.13 & 3.46 & 0.00 & 0.00 & 0.01 & & 89.98 \\
\hline GR95_8 & 73.21 & 0.04 & 13.02 & 0.17 & 0.47 & 0.00 & 0.10 & 4.98 & 3.68 & 0.02 & 0.01 & 0.01 & 0.15 & 95.80 \\
\hline GR95_8 & 72.29 & 0.04 & 12.83 & 0.14 & 0.46 & 0.00 & 0.05 & 4.98 & 3.62 & 0.00 & 0.02 & 0.00 & 0.15 & 94.51 \\
\hline GR95_8 & 71.97 & 0.04 & 12.73 & 0.85 & 0.49 & 0.00 & 0.16 & 5.49 & 3.34 & 0.05 & 0.00 & 0.05 & 0.15 & 95.24 \\
\hline GR95_8 & 72.46 & 0.01 & 12.99 & 0.10 & 0.41 & 0.00 & 0.10 & 4.98 & 3.74 & 0.05 & 0.05 & 0.01 & 0.14 & 94.97 \\
\hline GR95_8 & 73.11 & 0.07 & 12.93 & 0.11 & 0.47 & 0.00 & 0.13 & 4.95 & 3.64 & 0.00 & 0.01 & 0.00 & 0.14 & 95.51 \\
\hline GR95_8 & 68.40 & 0.00 & 12.09 & 0.12 & 0.46 & 0.00 & 0.06 & 5.25 & 3.27 & 0.00 & 0.01 & 0.00 & 0.15 & 89.74 \\
\hline GR95_8 & 74.39 & 0.00 & 13.00 & 0.12 & 0.45 & 0.00 & 0.07 & 4.87 & 3.80 & 0.02 & 0.00 & 0.01 & 0.15 & 96.82 \\
\hline GR95_8 & 73.70 & 0.10 & 13.02 & 0.21 & 0.48 & 0.00 & 0.11 & 4.71 & 3.80 & 0.00 & 0.08 & 0.00 & 0.15 & 96.30 \\
\hline GR95_8 & 73.59 & 0.04 & 13.10 & 0.15 & 0.31 & 0.00 & 0.14 & 5.29 & 3.75 & 0.05 & 0.00 & 0.04 & 0.14 & 96.54 \\
\hline GR95_8 & 73.49 & 0.06 & 13.05 & 0.12 & 0.45 & 0.00 & 0.11 & 4.75 & 3.72 & 0.05 & 0.00 & 0.00 & 0.15 & 95.89 \\
\hline GR95_8 & 74.19 & 0.10 & 13.02 & 0.09 & 0.47 & 0.01 & 0.08 & 5.42 & 3.54 & 0.05 & 0.06 & 0.01 & 0.19 & 97.13 \\
\hline GR95_8 & 72.51 & 0.00 & 12.71 & 0.16 & 0.50 & 0.00 & 0.10 & 5.05 & 3.51 & 0.07 & 0.02 & 0.02 & 0.19 & 94.76 \\
\hline GR95_8 & 72.91 & 0.04 & 12.93 & 0.09 & 0.48 & 0.00 & 0.08 & 4.97 & 3.69 & 0.02 & 0.00 & 0.00 & 0.12 & 95.28 \\
\hline GR95_8 & 71.89 & 0.03 & 12.84 & 0.18 & 0.47 & 0.00 & 0.08 & 6.32 & 2.77 & 0.01 & 0.03 & 0.02 & 0.16 & 94.73 \\
\hline GR95_8 & 73.10 & 0.00 & 12.83 & 0.11 & 0.47 & 0.00 & 0.10 & 5.20 & 3.50 & 0.00 & 0.00 & 0.00 & 0.16 & 95.40 \\
\hline GR95_8 & 73.05 & 0.03 & 12.84 & 0.10 & 0.47 & 0.00 & 0.11 & 4.73 & 3.87 & 0.03 & 0.02 & 0.00 & 0.16 & 95.34 \\
\hline GR95_8 & 72.68 & 0.02 & 12.97 & 0.14 & 0.45 & 0.00 & 0.07 & 6.26 & 3.09 & 0.01 & 0.04 & 0.03 & 0.18 & 95.85 \\
\hline GR95_8 & 73.39 & 0.05 & 12.91 & 0.24 & 0.45 & 0.00 & 0.16 & 5.98 & 3.18 & 0.05 & 0.04 & 0.05 & 0.17 & 96.61 \\
\hline GR95_8 & 72.34 & 0.00 & 12.89 & 0.09 & 0.43 & 0.00 & 0.09 & 4.88 & 3.72 & 0.00 & 0.02 & 0.01 & 0.20 & 94.59 \\
\hline GR95-15 & 72.05 & 0.01 & 12.86 & 0.69 & 0.45 & 0.00 & 0.05 & 4.38 & 3.96 & 0.01 & 0.06 & 0.00 & 0.45 & 94.78 \\
\hline GR95-15 & 72.38 & 0.04 & 12.63 & 0.62 & 0.44 & 0.00 & 0.13 & 4.36 & 3.97 & 0.07 & 0.02 & 0.00 & 0.42 & 94.91 \\
\hline GR95-15 & 72.07 & 0.01 & 12.76 & 0.70 & 0.42 & 0.00 & 0.13 & 4.58 & 3.65 & 0.01 & 0.09 & 0.03 & 0.43 & 94.70 \\
\hline GR95-15 & 72.23 & 0.00 & 12.73 & 0.72 & 0.45 & 0.00 & 0.13 & 4.20 & 3.93 & 0.00 & 0.00 & 0.00 & 0.47 & 94.67 \\
\hline GR95-15 & 72.51 & 0.06 & 12.70 & 0.61 & 0.43 & 0.01 & 0.10 & 4.24 & 3.97 & 0.00 & 0.00 & 0.01 & 0.47 & 94.91 \\
\hline
\end{tabular}


Appendix 5.4. continued

\begin{tabular}{|c|c|c|c|c|c|c|c|c|c|c|c|c|c|c|}
\hline SAMPLE & $\mathrm{SiO}_{2}$ & $\mathrm{TiO}_{2}$ & $\mathrm{AL}_{2} \mathrm{O}_{3}$ & $\mathrm{FeO}$ & $\mathrm{CaO}$ & $\mathrm{MgO}$ & $\mathrm{MnO}$ & $\mathrm{K}_{2} \mathrm{O}$ & $\mathrm{Na}_{2} \mathrm{O}$ & $\mathrm{SrO}$ & $\mathrm{BaO}$ & $\mathrm{P}_{2} \mathrm{O}_{5}$ & $\mathrm{~F}$ & TOTAL \\
\hline GR95-15 & 72.01 & 0.06 & 12.64 & 0.66 & 0.44 & 0.00 & 0.12 & 4.62 & 3.77 & 0.04 & 0.02 & 0.00 & 0.47 & 94.65 \\
\hline GR95-15 & 70.99 & 0.00 & 12.48 & 0.71 & 0.42 & 0.00 & 0.13 & 4.49 & 3.55 & 0.01 & 0.01 & 0.01 & 0.43 & 93.05 \\
\hline GR95-15 & 72.07 & 0.05 & 12.67 & 0.69 & 0.45 & 0.00 & 0.08 & 4.60 & 3.81 & 0.01 & 0.03 & 0.00 & 0.48 & 94.74 \\
\hline GR95-15 & 70.95 & 0.00 & 12.47 & 0.70 & 0.46 & 0.00 & 0.11 & 4.37 & 3.87 & 0.00 & 0.00 & 0.00 & 0.44 & 93.17 \\
\hline GR95-15 & 72.06 & 0.06 & 12.78 & 0.67 & 0.46 & 0.00 & 0.09 & 4.50 & 3.87 & 0.00 & 0.00 & 0.02 & 0.45 & 94.76 \\
\hline GR95-15 & 72.36 & 0.07 & 12.78 & 0.71 & 0.42 & 0.00 & 0.13 & 4.39 & 4.08 & 0.06 & 0.02 & 0.03 & 0.49 & 95.34 \\
\hline GR95-15 & 72.46 & 0.00 & 12.76 & 0.71 & 0.47 & 0.00 & 0.08 & 4.45 & 3.87 & 0.01 & 0.03 & 0.01 & 0.49 & 95.13 \\
\hline GR95-15 & 72.12 & 0.05 & 12.65 & 0.68 & 0.44 & 0.00 & 0.12 & 4.30 & 4.02 & 0.02 & 0.01 & 0.03 & 0.46 & 94.69 \\
\hline GR95-15 & 71.72 & 0.00 & 12.66 & 0.65 & 0.43 & 0.00 & 0.13 & 4.35 & 3.83 & 0.00 & 0.05 & 0.00 & 0.46 & 94.07 \\
\hline GR95-15 & 71.72 & 0.05 & 12.71 & 0.70 & 0.46 & 0.00 & 0.08 & 4.35 & 3.95 & 0.06 & 0.00 & 0.05 & 0.47 & 94.40 \\
\hline GR95-15 & 71.20 & 0.04 & 12.38 & 0.65 & 0.41 & 0.00 & 0.11 & 4.12 & 3.71 & 0.00 & 0.03 & 0.01 & 0.43 & 92.92 \\
\hline GR95-15 & 72.62 & 0.09 & 12.82 & 0.66 & 0.45 & 0.00 & 0.05 & 4.55 & 3.96 & 0.03 & 0.03 & 0.00 & 0.47 & 95.52 \\
\hline GR95-15 & 72.31 & 0.04 & 12.76 & 0.59 & 0.44 & 0.01 & 0.16 & 4.24 & 4.01 & 0.04 & 0.00 & 0.04 & 0.46 & 94.90 \\
\hline GR95-15 & 71.47 & 0.01 & 12.70 & 0.60 & 0.46 & 0.00 & 0.07 & 4.48 & 3.99 & 0.03 & 0.00 & 0.00 & 0.48 & 94.09 \\
\hline GR95-15 & 71.78 & 0.07 & 12.59 & 0.69 & 0.45 & 0.00 & 0.13 & 4.31 & 3.86 & 0.02 & 0.04 & 0.00 & 0.46 & 94.21 \\
\hline GR95-15 & 71.70 & 0.02 & 12.79 & 0.69 & 0.48 & 0.00 & 0.17 & 4.59 & 3.88 & 0.05 & 0.00 & 0.01 & 0.45 & 94.64 \\
\hline
\end{tabular}




\title{
CHAPTER SIX
}

\section{Probabilistic Modeling of Volcanism Data: Final Volcanic Hazard Studies for the Yucca Mountain Site}

\author{
Bruce M. Crowe \\ Earth and Environmental Sciences Division, Los Alamos National Laboratory \\ Peter Wallmann ${ }^{1}$ \\ Golder Associates Inc., Seattle \\ Lynn M. Bowker \\ College of Law, University of Wyoming
}

\section{Summary}

This chapter extends the results of probabilistic modeling reported in "Status of Volcanism Studies for the Yucca Mountain Site Characterization Project" (Crowe et al., 1995). Crowe et al. (1995), which has been commonly referred to as the "volcanism status report," will be hereafter referred to as the VSR. This chapter describes the results of continuing probabilistic modeling of volcanism data used in volcanic hazard studies. It is the final phase of probabilistic studies for the Yucca Mountain Project by the Los Alamos National Laboratory. The report complements and applies results from an expert judgment study on probabilistic volcanic hazard assessment (PVHA) for the Yucca Mountain site.

Small volume $\left(<1 \mathrm{~km}^{3}\right)$ Pliocene and Quaternary basaltic volcanic centers in the Yucca Mountain region (YMR) were formed by mixed Hawaiian and strombolian eruptions with minor accompanying hydrovolcanic activity; these same types of eruptions are the expected nature of future volcanic activity in the YMR. The occurrence probability of future volcanic events with a major hydrovolcanic eruptive component is $<10^{-8}$ year $^{-1}$.

The final interpretations of the past record of Pliocene and Quaternary volcanic activity in the YMR are presented for PVHA. The intervals for assessing volcanic recurrence rates are based on recognized cycles in the geologic record of the YMR and accordingly, two volcanic cycles are used for probabilistic assessments: post-4.8 and post-1.1 Ma ( $\pm 0.1 \mathrm{Ma})$. Polygenetic volcanism, an alternative to a conventional monogenetic eruption model of small volume basaltic volcanic centers of the YMR, is judged not to be important for PVHA. The past record of volcanic events is described for each Pliocene and Quaternary volcanic center of the YMR, and four distributions are used in combination with simulation modeling to evaluate contrasting assumptions of the number of volcanic events. Sensitivity studies of PVHA are evaluated for E2, the disruption probability, and E1, the recurrence rate. The E2 studies are based on the concept of identifying volcanic zones that are assumed to be preferential sites of Pliocene and Quaternary basaltic volcanism in the southern Great Basin. Two zone types are recognized: spatial and structural. Spatial zones are established from the distribution of volcanic centers for the Quaternary and the Pliocene and Quaternary and include the Crater Flat volcanic zone and the YMR; structural zones are the Quaternary pull-apart basin, the Pliocene-Quaternary pull-apart basin, the Walker Lane shear

${ }^{1}$ Deceased 
zone, and the northeast-trending structural zone. The defined zones represent a range of alternative models; identification of other zones is possible given the limited record of Pliocene and Quaternary volcanic events in the YMR. The E2 is assessed using simulation modeling for the seven spatial and structural zones in which volcanic events are described using probability distributions that define the dimensions of basaltic feeder dikes. The results show that E2 is related systematically to the area and geometry of volcanic zones and a newly defined factor, the critical intersection volume (CIV), that is unique for each zone. Sensitive parameters for E2 are dike length, dike orientation, the geometry of volcanic zones relative to the location of the Yucca Mountain site, and models of event distributions within zones.

Assessments of repose patterns show that there have been both short- and long-duration repose intervals, and the short-repose intervals are equivalent to recurrence rates of 2 to $3 \times 10^{-6}$ events year ${ }^{-1}$. Homogeneous Poisson probabilistic models are used in combination with simulation modeling of event counts and are applied to specific volcanic zones to further evaluate variability in E1. The event counts include possible undetected volcanic events in the distribution models.

Lower or minimum probability bounds for the Yucca Mountain site are established by evaluating regional background rates for $\operatorname{Pr}(\mathrm{E} 1), \operatorname{Pr}(\mathrm{E} 2)$ and $\operatorname{Pr}([\mathrm{E} 2$ given $\mathrm{E} 1] \operatorname{Pr}[\mathrm{E} 1])$ for the southern Great Basin. These bounds are compared with similar rates for spatial and structural volcanic zones assuming random location of representative repository areas in the zones (maximum bounds). The minimum probability bounds for the southern Great Basin are about $7 \times 10^{-10}$ to $3 \times 10^{-9}$ events $\mathrm{yr}^{-1}$; maximum probability bounds for volcanic zones approach $10^{-7}$ events year ${ }^{-1}$. The probability of magmatic disruption of the Yucca Mountain site must be between these bounds.

A programmatic decision not to investigate aeromagnetic anomalies in the Amargosa Valley through exploratory drilling has limited impact on PVHA assuming the aeromagnetic anomalies are from buried basalt centers, not intrusions. A decision not to investigate a positive aeromagnetic anomaly south of Little Cones has limited impact on PVHA but results in greater uncertainty from incomplete characterization of the record of basaltic volcanism in Crater Flat. Sensitivity studies of changes in the location of the eastern boundaries of volcanic zones are assessed through analysis of the results of simulation modeling of the disruption ratio, in which the lengths of feeder dikes are varied systematically.

Using the Repository Integration Program (RIP), the sensitivity of radiological releases from future magmatic disruption of a repository and repository system were simulated. The results indicated that volcanism is not a priority issue for total system performance studies of the Yucca Mountain site.

\section{Introduction}

This update of the VSR (Crowe et al., 1995) presents the results of probabilistic modeling of volcanism data for probabilistic volcanic hazard assessment (PVHA) and limited probabilistic volcanic risk assessment (PVRA) for the Yucca Mountain site. The primary purpose of this report is to update the VSR, adding information obtained since completion of the latter report in midcalendar year 1995. The new information includes a series of milestone reports completed in fiscal year 1995 (Crowe, 1995a,b; Crowe and Perry, 1995; Golder Associates, 1995) and the results of an external expert judgment study of PVHA summarized in a report issued by the organization that convened, conducted and presented the results of that study (Geomatrix, 1996). The expert 
judgment PVHA results are very similar to the PVHA results summarized in Crowe et al. (1995, see Chapter 7) and for this reason, the overall organization and some of the content of Chapter 7 of the VSR are preserved in this report. New information is added only where it extends the scope of the VSR and/or the expert judgment report. The overlap between the VSR and this report is intentional. The primary purpose of this report, like the VSR, is to provide a reference document for use by the Department of Energy (DOE) in their continuing assessment of the volcanism issue for the Yucca Mountain site.

This report builds on the data and methods for probability estimates from published studies (Crowe and Carr, 1980; Crowe et al., 1982, 1983a; Crowe, 1986; Crowe et al., 1989; Crowe and Perry, 1989; Smith et al., 1990; Ho, 1991; Ho et al., 1991; Crowe et al., 1992; Ho, 1992, 1995, Connor and Hill, 1993, 1995; Wallmann et al., 1993; Crowe et al., 1993; Crowe et al., 1995; Golder Associates, 1995). We have modified the terms used in the previous VSR (Crowe et al., 1995) that refer to PVHA to be consistent with the report by Geomatrix (1996). In this report, the term volcanic hazard refers to the occurrence probability of a future volcanic event. The term volcanic risk is used to denote a combination of the occurrence probability and the effects of a future volcanic event; volcanic risk assessment denotes the process of formal evaluation of volcanic risk. Most volcanism studies for the Yucca Mountain site have focused on estimating volcanic hazards or the occurrence probability of magmatic disruption of a repository; only a few studies have combined the occurrence probability with assessments of the consequences of a volcanic event (probabilistic volcanic risk assessment). We use the formal definitions of these terms throughout this chapter to avoid confusion and to discriminate between hazard assessment (studies of the occurrence probability) and risk assessment (occurrence probability combined with event consequences). Volcanism studies through the Los Alamos program are concerned primarily with PVHA, although some work has been completed on the effects of eruptive and intrusive activity on a repository (Valentine et al., 1992; 1996). The formal PVRA is being conducted as part of the total systems performance assessment (TSPA) for the Yucca Mountain Site Characterization Project (YMP; see Andrews, 1994).

Probability estimations of the likelihood of magmatic disruption of a potential repository were assembled in the VSR for a range of alternative recurrence models and models of the spatial and structural controls of basaltic volcanism in the YMR (Crowe et al., 1995). Cumulative probability distributions of the magmatic disruption of a repository and repository system were established using simulation modeling. These probability distributions represent the best approximations of the probability of magmatic disruption of the Yucca Mountain site using equally weighted, multiple alternative models of the recurrence rate and the disruption ratio for specified areas of the YMR. In contrast, the expert judgment studies of the volcanism issue (Geomatrix, 1996) used multiple alternative models for the recurrence rate and disruption probability and individual experts weighted the applicability of alternative models using subjective judgment. In both cases (volcanism status and expert judgment reports), the limited database of Pliocene and Quaternary volcanic events in the YMR make it nearly impossible to develop a single or even a most acceptable set of models for PVHA. Despite the diversity and uncertainty of alternative models used in PVHA, the results of nearly all studies are strikingly similar. A decision in the fall of 1995 to end volcanism work was made independently by the DOE. The decision can be justified partly on the basis of no significant differences between the results of PVHA for the YMR for studies conducted by Los Alamos National Laboratory on behalf of the DOE $\left(1.9 \times 10^{-8}\right.$ events year ${ }^{-1}$, Crowe et al., 1995), by contractors of the Nuclear Regulatory Commission ( 1 to $5 \times 10^{-8}$ events year ${ }^{-1}$, Connor and Hill, 1995), or by a panel of experts on volcanism and tectonics $\left(1.5 \times 10^{-8}\right.$ events year ${ }^{-1}$, Geomatrix, 1996). 
This report focuses on sensitivity studies of the occurrence probability for magmatic disruption of a potential repository and an area surrounding a potential repository system that could be adversely affected by a volcanic or magmatic event. We continue to use a slightly different perspective than that of earlier studies, including those by other researchers and by ourselves. Earlier volcanism studies attempted primarily to bound the occurrence probability of volcanic events by identifying a range of values that could be assigned to attributes of the probabilistic assessment. If there was uncertainty involving assignment of data values, conservative values or values that would not underestimate hazards or risk were used (Crowe and Carr, 1980; Crowe et al., 1982). Many assessments emphasized worst case or maximum estimates of volcanic occurrence probabilities (for example, Crowe and Carr, 1980; Crowe et al., 1982; Smith et al., 1990; Ho et al., 1991; Ho, 1992, 1995; Connor and Hill, 1993, 1995). In contrast, in the VSR we initiated a perspective of assessing attribute values for probabilistic hazard assessment that includes most likely, minimum, and maximum values for alternative models of the geologic record of basaltic volcanism in the YMR. Identification of most likely values (midpoint estimates) avoids the addition of nonsystematic bias toward worse-case calculations that are built unavoidably into assessments when only conservative attribute values are used. Conservative attribute values systematically bias probabilistic assessments toward worse case assessments, but the magnitude of the bias is nonsystematic. This bias results primarily from the absence of a standard definition of "conservatism" in the assignment of probability values. In contrast, the probability distributions presented in this report were constructed to represent unbiased descriptors of the central tendency and uncertainty of data distributions.

This report, for four specific topics, presents the results of probabilistic sensitivity studies in which conservative data assumptions are used to evaluate issue sensitivity. A comparative assessment of probability bounds is evaluated by contrasting regional background rates of volcanism with rates in Pliocene and Quaternary volcanic zones. The impact on PVHA of incomplete characterization of aeromagnetic anomalies is assessed for both the Amargosa Valley and Crater Flat areas, and sensitivity studies are presented of the impact of changes in the location of boundaries of volcanic zones adjacent to the Yucca Mountain site. Modeling of radiological releases from the Yucca Mountain sites with and without volcanic events are evaluated to assess the significance of volcanism on TSPA.

\section{A. Probabilistic Approach to Volcanism Studies}

The traditional and most common approach to defining volcanic hazards is to study the past record of volcanism at and around a site of interest. These studies employ standard geological methods (field mapping, geochronology, petrology, geochemistry, and geophysics). Information from the conventional studies is used to make subjective judgments about the hazards of future volcanism. This generally involves identifying the eruptive styles of past volcanic events, the area affected by past volcanic activity, and the range of hazards represented by similar future events. A general but not universal assumption of these studies is that future volcanic activity will follow the same patterns as past volcanic activity.

The conventional approaches to volcanic hazard studies are not easily applied to the issue of assessing hazards for long-term isolation of high-level radioactive waste through underground storage. Here, the task of identifying the nature of a future volcanic hazard is simply the recognition that volcanic activity could disrupt a repository and spread radionuclides, either directly or indirectly, to the accessible environment. A more pertinent and difficult question is how can the risk of the perceived volcanic hazard be quantified? The hazard in most cases is not from 
another eruption at an existing volcano but from the birth of a new volcano that could erupt through or near a repository. The added uncertainties are that the timing and location of a future volcanic event are difficult to constrain, and both the hazard and risk of future volcanism must be defined for 10,000 years.

The most likely future volcanic event from the perspective of volcanic hazards for a potential repository at YM is the formation of a new pulse of magma that ascends through country rock beneath the YMR and intrudes or erupts at an uncertain location in the region. This event creates some unique problems in forecasting recurrence rates and disruption probabilities for PVHA:

1. There are a limited number of past volcanic events (five, possibly six, Quaternary volcanic centers within a circle of $25-\mathrm{km}$ radius centered at the Yucca Mountain site). The location and identification of volcanic centers is described in the VSR (Crowe et al., 1995). This small number of events is insufficient to discriminate different temporal or spatial hypotheses using standard statistical tests for significance. We can only approximate time-distribution and spatial models and attempt to construct probability distributions that adequately represent the uncertainty of the probability models (Crowe et al., 1993).

2. While there are a range of models that can be applied to the spatial distribution of sites of basaltic volcanism in the YMR, all but one of the Pliocene and Quaternary volcanic centers are located in a narrow northwest-trending zone called the Crater Flat volcanic zone (CFVZ; Crowe and Perry, 1989). Accordingly, the most likely location of a future event should be in this zone. During the last $4.8 \mathrm{Ma}$, there were 15 volcanic events in the CFVZ (event definition = most likely event counts), and only one event outside of the zone (definitions of most likely event counts are presented in section VI and in Tables 6.4 through 6.10 of a following section). The 3.0 Ma basalt of Buckboard Mesa is located in the Timber Mountain caldera about $37 \mathrm{~km}$ northeast of the center of the Yucca Mountain site; it is the only Plio-Quaternary center that occurs outside of the CFVZ. This raises a finite possibility that events could occur outside the CFVZ in some other defined volcanic zone (see for example, Smith et al., 1990; Geomatrix, 1996) and possibly within Yucca Mountain.

3. The location of volcanic events, in which the defined event is the formation of a new volcanic center, shows no systematic relation to the location of preceding volcanic events (Crowe et al., 1993,1995; Golder Associates, 1995). Sites of successive "new" events jump to unique locations and their jump directions and lengths appear similar to a Brownian process with a component of west or southwest drift through time (Golder Associates, 1995).

4. New volcanic events occur either as individual centers or as clusters of centers (Crowe and Perry, 1989; Connor and Hill, 1995; Golder Associates, 1995) and the lengths of the clusters vary from 2 to $13 \mathrm{~km}$. The scale and sequence of cluster events are fractal (Golder Associates, 1995) and the clusters tend to be aligned northeast, parallel to the maximum compressive-stress direction (Crowe et al., 1986; Crowe, 1990). Locally, this alignment direction is sub-parallel to faults in Yucca Mountain (Smith et al., 1990). 
The emphasized strategy for attempting to quantify the hazard and the risk of future volcanic events is to use a probabilistic approach; it has several distinct advantages over standard approaches used in studies of volcanic hazards:

1. Using a probabilistic approach, one attempts to quantify a problem and provide a more objective basis for judging acceptable or unacceptable risks. In contrast, conventional hazard studies identify zones in which future volcanic events might occur with subjective descriptions of the nature of the hazard (for example, high, intermediate, low).

2. A probabilistic approach brings a structured formalism to the problem. This allows a complex issue like predicting the risk of future volcanism to be subdivided into logical components with established rules for combining the results of each component. Precise answers cannot always be given for each aspect of a probabilistic approach, but the probabilities can generally be bounded and decisions made whether the bounding data are acceptable or unacceptable.

3. An often-unappreciated advantage of a probabilistic approach is flexibility. The importance of alternative models or different data interpretations can be assessed by examining how they change the probability distributions (Crowe et al., 1995). Volcanic studies for the Yucca Mountain site require working with a small data set and the limitations of the data set make it likely, if not expected, that there will be alternative perspectives or models of the nature and hazards of future volcanic activity. Moreover, by virtue of the limited data, it is very difficult to conclusively prove or disprove alternative models.

4. Probabilistic studies are iterative. Once formulated, they can be readily refined with the addition of new data resulting in a continuous upgrading of PVHA. In fact, the test for judging the importance of new data is to determine whether the new data change the probability distributions.

5. The most important advantage of a probabilistic approach is that it allows the data to be more readily assessed against the regulatory requirements for licensing a repository.

This report describes and updates probability models for volcanism studies using current information from site characterization studies. These new data are assessed for their importance with respect to PVHA for the Yucca Mountain site. The new data sets are applied to sensitivity studies of variables of the conditional probability of magmatic disruption of a repository and repository system. Revised estimates of the probability of magmatic disruption of a potential repository at the Yucca Mountain site are not presented in this report. The expert judgment study (Geomatrix, 1996) provides the most comprehensive compilation of the probability of magmatic disruption of a repository and is the emphasized source for final PVHA estimates. We have focused our final studies on examination of the sensitivity of estimates of: 1) the recurrence rate (E1) using revised event counts from volcanism studies and the expert judgment study that accounted for undetected volcanic events and 2) revised assessments of the disruption probability (E2) using simulation modeling that incorporates the dimensions of feeder dike systems associated with volcanic centers. We also briefly describe a simple approach to bounding estimates of the probability of magmatic disruption of the Yucca Mountain site, and we provide the results of simulation modeling of the effects of magmatic events on the performance of a repository and repository system. This report is the final product of Los Alamos volcanism studies and concludes 
the systematic process of probabilistic studies described in Study Plan 8.3.1.8.1.1, "Probability of Magmatic Disruption of the Repository" (Los Alamos, 1996).

\section{Probability Model}

The probability of magmatic disruption of a repository or repository system $\left(P r_{d r}\right)$ is defined as a conditional probability:

$$
\operatorname{Pr}_{d r}=\operatorname{Pr}(\text { E2 given E1 }) \operatorname{Pr}(E 1),
$$

where $E 1$ denotes the recurrence rate of volcanic events in the YMR, and E2 denotes the probability that a future magmatic event intersects a specified area. This probability can be expressed mathematically (Crowe et al., 1982):

$$
\operatorname{Pr}[\text { no eruptive event before time } t]=\exp ^{(-\lambda t p)},
$$

where $\lambda$ is the recurrence rate of volcanic events, $t$ is time and $p$ is the probability that an event is disruptive. The $\lambda$ can be defined in a number of ways (see following section on the definition of volcanic events). For this report, the volcanic event of emphasis is defined as the rate of formation of a new volcanic center, volcanic cluster, or magmatic intrusion. In previous studies the $p$ was defined as $a / A$ where $a$ is the area of concern (repository or repository system) and $A$ was the area of the established volcanic rate or $\lambda$ (Crowe et al., 1982; 1995). In this study, $p$ is defined as the intersection probability of a repository or repository system by a volcanic event or feeder dike(s) associated with that volcanic event (Crowe, 1995; Golder Associates, 1995).

The basic assumption used in most applications of the probability model is a homogeneous or modified homogeneous Poisson distribution of the volcanic events in time and space (Crowe et al., 1982; Crowe, 1986). A Poisson random variable with parameter $\lambda>0$ has a probability density function (Devore, 1987; Tuckwell, 1988; Evans et al., 1993)

$$
f(x)=\frac{e^{-\lambda} \lambda^{x}}{x !}
$$

The probability density function can be integrated over $(x 1, x 2)$ to obtain the probability of $X$

$$
\operatorname{Pr}\left\{x_{1}<X<x_{2}\right\}=\int_{x_{1}}^{x_{2}} f(x) d x .
$$

A Poisson random variable has mean $E(X)=\lambda$ and variance $=\lambda$, (Tuckwell, 1988; Evans et al., 1993), and the Poisson distribution can be viewed as a special case of the binomial distribution when $n$, the number of trials, becomes very large, and $p$, the event probability, becomes very small. The Poisson distribution is easier to calculate than the binomial distribution because for the former $n p=\lambda$, where $\lambda$ is the rate of occurrence of events (Davis, 1986). Critical assumptions of the Poisson distribution are that the events occur independently, they are exponentially distributed through time $t$, and the probability of more than one event occurring at the same time is vanishingly small (Davis, 1986; Devore, 1987). The rate parameter or intensity $(\lambda)$ of a homogeneous Poisson process (HPP) is assumed to be independent of its interval or time; for a nonhomogeneous Poisson 
process (NHPP), $\lambda$ is assumed to be a function of $t$, denoted as $\lambda$ t (Tuckwell, 1988; Ho, 1991). The versatility of application of the Poisson process is that individual nonPoissonian processes often become Poisson when considered together (Tuckwell, 1988; Olkin et al., 1994).

Crowe et al. (1992) reviewed recurrence models for volcanic events and discussed the rationale for choosing a simple Poisson model for PVHA for the YMR. Briefly, the model is conceptually simple, assumptions using this model are well defined, and potential errors can be constrained. The simple Poisson model is widely used in many volcanism studies (for example, De la Cruz-Reyna, 1991; Scandone et al., 1993; Geomatrix, 1996). The Poisson model is particularly appropriate and may be conservative for the case of the YMR where multiple lines of evidence indicate patterns of volcanism may be waning over the last 4.8 Ma (Vaniman and Crowe, 1981; Crowe et al., 1982; Crowe et al., 1992; Perry and Crowe, 1992). Finally, a homogeneous Poisson distribution is used because the data set for the YMR (number of past volcanic events) is too limited to apply convention statistical tests to the selection of distribution models. Basically, a homogeneous Poisson model is used because it is applied traditionally in most probabilistic studies using event rates, and this approach requires the fewest assumptions for probabilistic modeling.

There has been and continues to be debate in the geologic literature concerning the suitability of the use of homogeneous Poisson distribution for temporal and spatial models of volcanic events. Clearly, this debate will not be resolved using the limited data set of Pliocene and Quaternary volcanic events in the YMR. A far more important issue than a debate over a choice of distribution models is whether probabilistic assessments can be structured using a homogeneous Poisson model (or any other model) so that the hazard or risk of volcanism is adequately represented. To minimize this debate, we continue the approach adopted by Crowe et al. (1995) and consider both homogeneous and nonhomogeneous Poisson recurrence rates. Additionally, we incorporate data using the nonhomogeneous spatial and temporal models of Connor and Hill (1995) and the volcanism expert judgment panel (Geomatrix, 1996).

Multiple geologic assumptions are required to apply a probabilistic approach to assessing volcanic hazards for the Yucca Mountain site:

1. The past record of basaltic volcanic activity in the YMR is assumed to be the most reliable indicator of the recurrence rates, the spatial patterns of volcanic events, and the nature of future volcanic events. This assumption is supported by the consistency of the record of volcanism in the region for the last $10 \mathrm{Ma}$. All post-late Miocene volcanic centers of the postcaldera basaltic episode formed from the eruption of small volumes $(\leq 1$ $\mathrm{km}^{3}$ ) of basaltic magma (Crowe, 1990), except for the basalt of Thirsty Mesa $\left(3 \mathrm{~km}^{3}\right)$. The small-volume volcanic activity formed spatially isolated centers comprising scoria and spatter cones, fissure systems, and associated lava flows. The spatial and temporal patterns of sporadic volcanic events forming spatially scattered basaltic volcanic centers have persisted in the YMR for the last 10.0 Ma (Crowe, 1990; Golder Associates, 1995).

2. We assume there has been a sufficiently detailed study of the YMR to identify all significant Pliocene and Quaternary volcanic centers. Quaternary basaltic volcanic centers are conspicuous geomorphic forms in arid regions of the southwest United States (Dohrenwend et al., 1986) and persist as prominent forms for long periods of time. For example, Pliocene basalt centers in Crater Flat (3.7 Ma) are readily identified by the presence of scoria deposits with exposed feeder dikes (Vaniman and Crowe, 1981; Crowe et al., 1983b). The Pliocene and Quaternary basalt centers in the YMR can be identified 
through visual inspection of aerial photographs and even satellite photographs. The presence and location of Quaternary volcanic centers in the region have been recognized for several decades.

3. Detailed drape aeromagnetic surveys were completed for the YMR (Kane and Bracken, 1983; Langenheim et al., 1991, 1993; Langenheim, 1995). Basaltic volcanic rocks have high magnetic susceptibility and are identified easily among the generally nonmagnetic Paleozoic rocks, and the alluvial fill of the basins flanking Yucca Mountain (Kane and Bracken, 1983). Surface Pliocene and Quaternary volcanic centers form prominent anomalies in aeromagnetic data (Crowe and Carr, 1980; Kane and Bracken, 1983; Crowe et al., 1986; Langenheim et al., 1991; 1993; Langenheim, 1995).

4. The detection of buried basalt centers or basalt intrusions may be more difficult in volcanic bedrock in which the country rock has higher magnetic susceptibility, and the possibility of undetected intrusions in these settings cannot be ruled out. However, undetected basalt centers are probably not a major source of uncertainty. A basaltic event must ascend to depths at or near a repository (300 m below the surface) to adversely affect a repository or repository system. Basalt magmas at these depths exsolve volatiles, and the volatile expansion provides a strong driving force for eruption (Wilson and Head, 1981). We have examined basalt intrusions at all known sites of intrusions in the YMR (Crowe et al., 1986; Crowe, 1990; Valentine et al., 1992). Every known site in the YMR where intrusions are observed is associated with a site or sites of contemporaneous surface volcanic rocks. Thus, the geologic record of small volume basaltic volcanism in the YMR supports the inference that basaltic magma in dike form is unlikely to ascend to a shallow depth beneath the YMR without erupting at some point along the length of the dike. The existence of undetected basalt intrusions requires that they are deep, small, or a combination of both. As the depth of an intrusion below the surface increases and the size decreases, the potential impact of these bodies on a waste isolation system decreases.

5. The possibility of undetected intrusions and their introduced uncertainty is assessed in probability distributions used for PVHA.

The issue of undetected basaltic intrusions has remained controversial and is a topic of continuing comment by the Nuclear Regulatory Commission (NRC) in their reviews of volcanism studies. In an attempt to reduce this controversy, modifications have been made in this report that change somewhat the approach used by Crowe et al. (1995). There has been continuing confusion over the definition of undetected magmatic events. We have not stated that undetected intrusions do not occur or are not possible. Instead, the position taken is that it is unlikely for magma to rise to shallow levels without erupting at some point along the length of a feeder dike or dike system. We argue, therefore, that undetected events can occur in association with volcanic eruptions, but it is very unlikely that magma will rise to levels where it could adversely affect a repository or repository system without an accompanying eruption. Thus, one source of confusion concerning undetected intrusions is a semantics issue involving the distinction between undetected events associated with a known Pliocene or Quaternary volcanic center and an undetected shallow basaltic intrusion that ascended to shallow levels $(\sim 300 \mathrm{~m})$ but never erupted. Such an event would be separate in time and space from recognized volcanic centers of the YMR.

The possibility of an undetected event consisting of a shallow magmatic intrusion without an associated eruption site is judged to be very unlikely in areas of alluvium or nonmagmatic 
Paleozoic rocks. The extensive and high-quality drape aeromagnetic data for the YMR (Oliver et al., 1995) and the strong contrasts in magnetization of a shallow basalt intrusion compared to alluvium or Paleozoic rocks make detection likely. Moreover, exploratory drilling of several of the aeromagnetic anomalies recognized by Kane and Bracken (1983) has verified interpretations that the anomalies are produced by buried basalt centers (see for example, Carr, 1984; Crowe et al., 1986; Langenheim, 1995). However, a small basaltic intrusion could be present in volcanic country rock and remain undetected. This is particularly true for areas of extensive coverage by the Topopah Springs Tuff of the Paintbrush Group, a unit that dominates the near-surface magnetic field (Oliver et al., 1995).

We have changed two things found in the VSR in an attempt to reduce the past controversies concerning undetected intrusions. First, the possibility of undetected intrusions associated with Pliocene and Quaternary volcanic centers is now included in estimates of many of the event counts in the development of probability distributions. Second, a range of opinions was obtained from the expert judgment panel on the possibility of undetected shallow intrusions including events associated or not associated with volcanic centers. These opinions, where they can be translated into estimates of potential increases in event counts from undetected intrusions, are included in revised estimates of recurrence rates. This does not eliminate the issue of undetected events but does allow assessment of the sensitivity of this issue for PVHA (see also Geomatrix, 1996).

We assume that the observations and interpretations of the geologic record are reliable, an assumption that is difficult to quantify. Here there are four sources of uncertainty:

1. The largest source of uncertainty is from the limited database of past volcanic events that must be used to forecast future volcanic events.

2. An additional significant area of uncertainty is the different opinions expressed by individual researchers concerning interpretations of the geologic record. Experience has shown that there is a range of alternative interpretations of the record of basaltic volcanism, and many of these alternatives are recorded in the elicitation of individual members of the volcanism expert judgment panel (Geomatrix, 1996). The perspective used in this report is that differences of opinion are expected, and the resulting alternative models often cannot be discriminated with the limited data. Opinion differences are considered significant only if they result in different probability distributions for the PVHA.

3. The primary method for dating of Quaternary basaltic volcanic rocks is the K-Ar method, and this method becomes increasingly less precise with decreasing age of the dated rocks for rocks younger than about $1 \mathrm{Ma}$. Using multiple chronology methods mitigates this problem at least partly, and we assign multiple models for the age of volcanic events where there is uncertainty in age determinations. While debate will continue over the interpretation of geochronology data, experience has shown that different chronology models are not a major source of uncertainty (Crowe et al., 1995; Geomatrix, 1996).

4. The reliability of interpreting the record of basaltic volcanism decreases with increasing age of the volcanic centers. This is primarily because older centers are progressively more modified and parts of the record of volcanic events are eroded or covered. The resulting uncertainty primarily affects counts of volcanic events, and we treat event counts as probability distributions to describe this uncertainty. 


\section{Strategy for Assessing the Volcanism Issue}

A strategy for assessing the volcanism issue was developed primarily as a tool to establish priorities for carrying out volcanism studies. With the termination of volcanism studies, the characterization strategy presented in the VSR (Crowe et al., 1995) is no longer applicable and accordingly this section is greatly reduced. The characterization strategy for assessing the volcanism issue should now be replaced by a strategy developed by the DOE for suitability and licensing considerations. The only strategy discussions included in this report are for topics where contributions from the expert judgment study (Geomatrix, 1996) provide new information that may aid the DOE in developing their resolution strategy.

What is the nature of expected future volcanic activity? This question is answered primarily by an examination of the volcanic record. Table 6.1 is a compilation of the predominant eruptive style of Pliocene and Quaternary basaltic volcanic centers in the YMR (Crowe et al., 1983b; 1995). Eruptive activity at basaltic volcanic centers in the YMR has been of mostly mixed Hawaiian and strombolian style, with locally important hydrovolcanic eruptions (Crowe et al., 1983b; 1995). Further, there are some general patterns, in time and space, to the occurrence of different types of volcanic eruptions. Pliocene volcanic eruptions were mostly of Hawaiian type, with higher eruption volumes $\left(>0.5 \mathrm{~km}^{3}\right)$ and a low ratio of pyroclastic deposits/lava compared to the total erupted volume (Crowe et al., 1983b). Quaternary eruptions were of mixed Hawaiianstrombolian type, volumes were low $\left(<0.1 \mathrm{~km}^{3}\right)$, the morphology of lava flows are consistent with low effusion rates, and the ratio of pyroclastic deposits/lava volumes for these eruptions was greater than for the Pliocene eruptions. Hydrovolcanic eruptions occurred at one center (Lathrop Wells center) and are possible at some of the Quaternary and Pliocene basalt centers of Crater Flat (Smith et al., 1990). The volume of hydrovolcanic deposits is minor at all centers $\left(<0.05 \mathrm{~km}^{3}\right)$.

Table 6.1. Eruption characteristics of Pliocene and Quaternary volcanic centers in the YMR.

\begin{tabular}{|c|c|c|c|c|c|c|}
\hline $\begin{array}{l}\text { Volcanic } \\
\text { Center }\end{array}$ & $\begin{array}{l}\text { Event } \\
\text { Counts }\end{array}$ & $\begin{array}{l}\text { Lava } \\
\text { Eruptions }\end{array}$ & $\begin{array}{l}\text { Effusion } \\
\text { Rate }\end{array}$ & Hawaiian & $\begin{array}{l}\text { Pyroclastic } \\
\text { Strombolian }\end{array}$ & $\begin{array}{l}\text { Eruptions } \\
\text { Hydrovolcanic }\end{array}$ \\
\hline $\begin{array}{l}\text { Basalt of } \\
\text { Thirsty Mesa }\end{array}$ & 1 & $\begin{array}{l}\text { Mesa or } \\
\text { Shield }\end{array}$ & High & $90 \%$ & $10 \%$ & None \\
\hline $\begin{array}{l}\text { Pliocene } \\
\text { basalt, SE } \\
\text { Crater Flat }\end{array}$ & 2 & $\begin{array}{l}\text { Aa lava } \\
\text { sheets }\end{array}$ & Moderate & $70 \%$ & $30 \%$ & Minor? or None \\
\hline $\begin{array}{l}\text { Basalt of } \\
\text { Buckboard } \\
\text { Mesa }\end{array}$ & 1 & $\begin{array}{l}\text { Mesa/aa } \\
\text { lava sheet }\end{array}$ & High & $70 \%$ & $30 \%$ & None \\
\hline $\begin{array}{l}\text { Quaternary } \\
\text { Crater Flat }\end{array}$ & 3 & Blocky aa & Low & $30 \%$ & $70 \%$ & Minor? or None \\
\hline $\begin{array}{l}\text { Sleeping } \\
\text { Butte }\end{array}$ & 2 & Blocky aa & Low & $30 \%$ & $70 \%$ & None \\
\hline $\begin{array}{l}\text { Lathrop } \\
\text { Wells }\end{array}$ & 1 & Blocky aa & Low & $20 \%$ & $75 \%$ & $5 \%$ \\
\hline
\end{tabular}


Future eruptions in the YMR would be expected to form small volumes of predominantly blocky $a a$ lava, and the pyroclastic component would be expected to be of mixed Hawaiianstrombolian type with strombolian eruptions dominating. The percentage of hydrovolcanic eruptions is estimated to be $<10 \%$ (very approximate estimate) and may be even less for areas of deep groundwater, like Yucca Mountain $(<<10 \%)$. Smith and Luedke (1984) estimated that hydrovolcanic eruptions occur in about $10 \%$ of volcanic eruptions in the western United States. Hasenaka and Carmichael (1985) noted that hydrovolcanic centers (tuff rings or tuff cones) form $<3 \%$ of the Michoacan-Guanajuao volcanic field of central Mexico (22 of 913 basaltic volcanic centers). Estimates provided by the volcanism expert judgment panel of the likelihood of a hydrovolcanic event at the Yucca Mountain site ranged from <1 to $6.7 \%$ with a mean value of about 1-to-2\% (1 to 2 hydrovolcanic events in 100 volcanic events) (Geomatrix, 1996).

The distribution of Pliocene and Quaternary volcanic events is used as a best indicator of the distribution of future volcanic events, recognizing that the past record allows forecasting of only an approximate area where an event might occur. Unfortunately, a specific event location cannot be identified (Figure 6.1; see also Crowe et al., 1995; Golder Associates, 1995). Probability estimates are assembled by establishing a range of spatial and structural models and then using the volcanic record for individual models to constrain and forecast future events. Figure 6.1 illustrates the basis for this approach. A spatial area corresponding to the CFVZ can be defined by the sequence of three sets of Pliocene volcanic events in the YMR (Event 1 in Figure 6.1). These events outline a northwest-trending elliptical zone bounded on the northwest by the basalt of Thirsty Mesa, on the south and southeast by the aeromagnetic anomalies in the Amargosa Valley including the basalt centers of the 3.7 Ma basalt of southeast Crater Flat.

All but one subsequent volcanic event ( 3 sets of Quaternary volcanic events) occurred adjacent to or within the bounds of the area defined by the distribution of Pliocene basaltic volcanic centers (Events 3 and 4 in Figure 6.1). The one exception is the Pliocene basalt center of Buckboard Mesa that is located about 40-km northeast of the CFVZ (Event 2 in Figure 6.1). The area encompassed by the distribution of all Pliocene and Quaternary volcanic events shown on Figure 6.1 has been designated as the YMR (Crowe et al., 1995). It is slightly larger than but similar to the Area of Most Recent Volcanism (AMRV) of Smith et al. (1990). Based on the distribution patterns of past volcanic events, there is a relatively high probability (estimated to be > $90 \%$ since there have been about 16 past events) that any future volcanic event will occur within the boundaries of the YMR. The utility of choosing alternative event areas within the YMR can be evaluated approximately by systematically assessing the percentage of the past events that are contained in the event areas relative to the event totals contained in the YMR. This approach is divided into separate estimates for Quaternary and Pliocene and Quaternary volcanic event counts and the results are summarized in Table 6.2. The event-count assignments are the most likely estimates from descriptions of volcanic centers in a following section and do not include undetected events. 


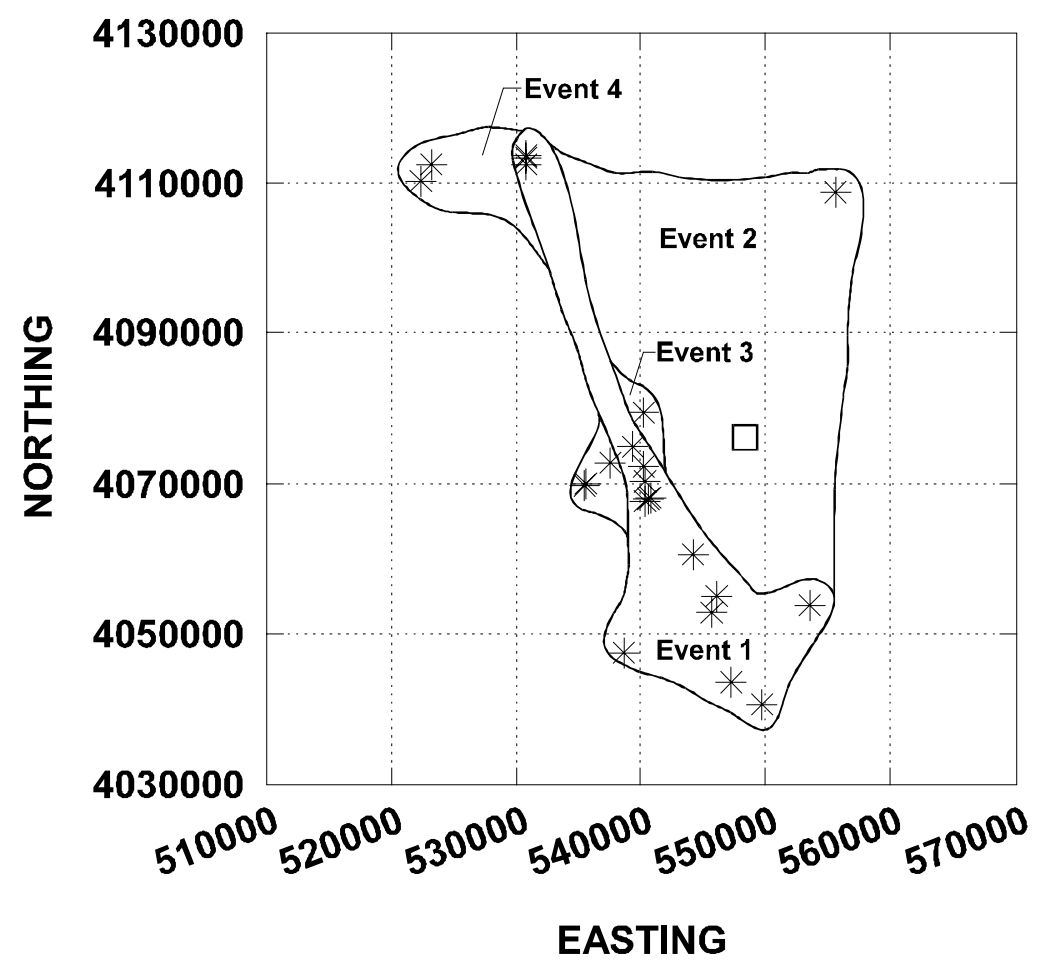

Figure 6.1. Distribution areas defined by Pliocene and Quaternary volcanic events in the YMR, including aeromagnetic anomalies of Crater Flat and the Amargosa Valley assumed to be buried volcanic centers. The areas that enclose the distribution of volcanic events are labeled in the chronological sequence of the events ( $1=$ oldest; $4=$ youngest). The locations of the three Pliocene volcanic events (aeromagnetic anomalies of Amargosa Valley, the 3.7 Ma basalt of southeast Crater Flat, and the basalt of Thirsty Mesa) form a distribution area that is enclosed by an elongate polygon labeled as event 1; the geometry of the area is similar to but larger than the CFVZ of Crowe and Perry (1989). The location of all subsequent volcanic events is in or adjacent to the event 1 polygon including the Quaternary basalt of Crater Flat (Event 3), the basalt of Sleeping Butte (Event 4) and the Lathrop Wells center. The latter center is not labeled as an event because it is contained within the Event 1 polygon. The basalt of Buckboard Mesa (Event 2) is the only event that is located a significant distance outside of the Event 1 polygon. The square marks the location of the Yucca Mountain site.

On the basis of the past record of basaltic volcanic events in the YMR, there is $>90 \%$ probability that a future volcanic event will occur within the CFVZ or the Walker Lane structural zone (WLSZ) (Table 6.2; Figure 6.1). There have been 16 volcanic events where the event numbers are the most likely event counts in the YMR during the Pliocene and Quaternary. One volcanic event, or about $6 \%$, occurred outside the CFVZ or WLSZ. A northeast trending structural zone (NESZ; Crowe, 1995a) includes 67\% of Quaternary events and 87\% of all Pliocene and Quaternary events. The Quaternary and Pliocene-Quaternary pull-apart models (Crowe, 1995a) include $67 \%$ of the Quaternary events and $75 \%$ of Pliocene and Quaternary volcanic events, respectively.

The distribution of past events suggests that a future volcanic event is about seven times more likely to occur in an alluvial valley or along a range edge than in a range interior $(75 \%$ of the Pliocene and Quaternary volcanic centers occur in alluvial basins, $12.5 \%$ along range fronts, and $12.5 \%$ occur in a range interior) as can be seen in Table 6.3 . 


\section{Additional features of Figure 6.1 are}

1. The tendency for volcanic centers to occur as event clusters (Crowe and Perry, 1989; Connor and Hill, 1995). These clusters include, for the YMR, a Crater Flat cluster, an Amargosa cluster and a cluster in the Sleeping Butte-Thirsty Mesa area.

2. There has been a notable concentration of Pliocene and Quaternary volcanic activity in southwest and southern Crater Flat. This concentration is even more pronounced if vent locations for Miocene basaltic volcanic centers are included on the event distribution map (Crowe, 1990; Crowe et al., 1986; 1995).

3. The most likely site of a future volcanic event, based on a simple examination of the past record of volcanic events, is in southwestern Crater Flat.

\section{Assumptions and Physical Models}

This part of the report attempts to define the current understanding of the record of basaltic volcanism in the YMR so it can be applied consistently to probabilistic assessments of the recurrence rate (E1), the disruption probability (E2), and the probability of magmatic disruption of the repository and related areas $(\operatorname{Pr}[(\mathrm{E} 2$ given $\mathrm{E} 1) \operatorname{Pr}(\mathrm{E} 1)])$. The data are from two sources: 1) external publications outside of the YMP and 2) site characterization studies for the YMP current to the completion of this report (August 1996). The data compilations include qualified and non-qualified data from the perspective of the quality assurance program for the YMP, and therefore the information in this report must be regarded as non-qualified.

We acknowledge that there is not a single accepted definition of the number of past volcanic events in the YMR and, therefore, use multiple models of E1 in the sensitivity studies for this report. Likewise, there is not a consensus model for the spatial or structural controls of the location of basaltic volcanic events. We take the approach that it is more important to identify and evaluate the minimum, maximum, and most likely values for variables used in PVHA. For E1, minimum values are defined as one minus the smallest number of volcanic events required to produce the record of observed Pliocene and Quaternary volcanic activity. Maximum values of E1 are defined as one plus the largest number of volcanic events required for producing the observed volcanic record. For most cases, this definition includes estimates of possible undetected events. The most likely values are defined as the number of volcanic events required to produce the volcanic record using subjective judgments of the most reasonable event assignments based on multiple lines of geologic, geochemical, and geophysical evidence. The selections used for the event counts for minimum and maximum are somewhat subjective and selections of the most likely values are highly subjective (interpretation of data sets); all can be slightly different for different individuals (Geomatrix, 1996). 
Table 6.2. Distribution and Event Percentages of Pliocene and Quaternary Volcanic Events in the YMR by Spatial and Structural Models ${ }^{*}$

\begin{tabular}{|c|c|c|c|c|c|c|c|}
\hline Volcanic Center & $\begin{array}{l}\text { CFVZ- } \\
\text { Quat }\end{array}$ & $\begin{array}{c}\text { CFVZ- } \\
\text { Plio- } \\
\text { Quat }\end{array}$ & NESZ & WLSZ & $\begin{array}{l}\text { Yucca } \\
\text { Mountain } \\
\text { Region }\end{array}$ & $\begin{array}{l}\text { Pull-Apart } \\
\text { Quaternary }\end{array}$ & $\begin{array}{c}\text { Pull-Apart } \\
\text { Plio- } \\
\text { Quaternar } \\
\text { y }\end{array}$ \\
\hline Thirsty Mesa & - & 1 & - & 1 & 1 & - & - \\
\hline Crater Flat $\mathrm{A}$ & - & 1 & 1 & 1 & 1 & - & 1 \\
\hline Amargosa Valley B & - & 1 & 1 & 1 & 1 & - & 1 \\
\hline Amargosa Valley C & - & 1 & 1 & 1 & 1 & - & 1 \\
\hline Amargosa Valley D & - & 1 & 1 & 1 & 1 & - & 1 \\
\hline Amargosa Valley E & - & 1 & 1 & 1 & 1 & - & 1 \\
\hline Amargosa Valley F & - & 1 & 1 & 1 & 1 & - & 1 \\
\hline $\begin{array}{c}\text { Southeast Crater } \\
\text { Flat } 1\end{array}$ & - & 1 & 1 & 1 & 1 & - & 1 \\
\hline $\begin{array}{c}\text { Southeast Crater } \\
\text { Flat } 2\end{array}$ & - & 1 & 1 & 1 & 1 & - & 1 \\
\hline Buckboard Mesa & - & - & 1 & - & 1 & - & - \\
\hline Makani Cone & 1 & 1 & 1 & 1 & 1 & 1 & 1 \\
\hline $\begin{array}{l}\text { Black Cone-Red } \\
\text { Cone }\end{array}$ & 1 & 1 & 1 & 1 & 1 & 1 & 1 \\
\hline Little Cones & 1 & 1 & 1 & 1 & 1 & 1 & 1 \\
\hline $\begin{array}{l}\text { Little Black Peak } \\
\text { Cone }\end{array}$ & 1 & 1 & - & 1 & 1 & - & - \\
\hline Hidden Cone & 1 & 1 & - & 1 & 1 & - & - \\
\hline Lathrop Wells center & 1 & 1 & 1 & 1 & 1 & 1 & 1 \\
\hline Totals & 6 & 15 & 13 & 15 & 16 & 4 & 12 \\
\hline Quaternary \% & $100 \%$ & $100 \%$ & $67 \%$ & $100 \%$ & $100 \%$ & $67 \%$ & $67 \%$ \\
\hline Plio-Quaternary \% & - & $94 \%$ & $87 \%$ & $94 \%$ & $100 \%$ & - & $75 \%$ \\
\hline
\end{tabular}

*Assumptions:

1. Labeling of the aeromagnetic anomalies follows the identifications used in Geomatrix (1996).

2. Event definitions are from Crowe et al., 1995.

3. Event assignments are taken from the most likely event counts of Sections VI, E and D of this report.

4. Event percentages are calculated relative to the event totals for the Quaternary YMR and the PlioQuaternary YMR.

5. Spatial and structural models are from Crowe (1995) and Chapter 3 of this report.

6. A Quaternary YMR is not listed because it is identical to the Quaternary CFVZ. 
Table 6.3. Topographic Setting of Pliocene and Quaternary Volcanic Events in the YMR*

\begin{tabular}{|c|c|c|c||}
\hline \hline Volcanic Event & Alluvial Valley & Range Edge & Range Interior \\
\hline Thirsty Mesa & & & 1 \\
\hline Crater Flat A & 1 & & \\
\hline Amargosa Valley B & 1 & & \\
\hline Amargosa Valley C & 1 & & \\
\hline Amargosa Valley D & 1 & & \\
\hline Amargosa Valley E & 1 & & \\
\hline Amargosa Valley F & 1 & & \\
\hline Southeast Crater Flat 1 & 1 & & \\
\hline Southeast Crater Flat 2 & 1 & & \\
\hline Buckboard Mesa & 1 & & \\
\hline Makani Cone & 1 & & \\
\hline Black Cone-Red Cone & 1 & & $12.5 \%$ \\
\hline Little Cones & 1 & 1 & \\
\hline Little Black Peak Cone & & & \\
\hline Hidden Cone & & $12.5 \%$ & \\
\hline Lathrop Wells & 12 & & \\
\hline Totals & $75 \%$ & & \\
\hline \% of Total & & & \\
\hline \hline
\end{tabular}

* Assumptions:

1. Labeling of the aeromagnetic anomalies follows the identifications used in Geomatrix (1996).

2. Volcanic centers are converted to volcanic events using the event definitions of Crowe et al., 1995.

3. Event assignments are from the most likely event models of Sections VI, E and D of this report.

The best perspective for judging the results of probability assessments and ensuring they are neither underestimated nor overestimated is through comparison with the geologic record. Three approaches are used to constrain the variability in judgmental options for estimating probabilities.

1. The methods and approaches used for the calculations must be compatible with the record of volcanic activity in the YMR.

2. The assumptions used for probability estimations must be consistent with and supported by conceptual understanding of the physical processes of volcanic activity.

3. We emphasize the numerical range of probability estimates, not the different ways of making the calculations. It is not necessary to discriminate alternative model assumptions if they result in similar ranges of probability estimates.

\section{B. Time Perspective of Probability Estimations.}

The first aspect of assembling probability estimations is identifying a time criterion for the probabilistic assessment. Regulatory guidelines by the NRC require an assessment of disruptive events during the Quaternary (1.6 Ma geologic definition; 2 Ma NRC definition). However, an arbitrarily imposed time interval affects estimations non-systematically of volcanic recurrence rates using either a homogeneous or nonhomogeneous Poisson distribution (Crowe et al., 1995). A more 
consistent and defensible approach is to use a geologic perspective and assess the record of volcanism for intervals corresponding to volcanic cycles (Crowe et al., 1995). The suggested intervals for examining the record of volcanic events for PVHA in the YMR are twofold: post-4.8 million years and post-1.1 million years. The former corresponds to a 2.5 million year time gap ${ }^{1}$ between the Older postcaldera and Younger postcaldera basalt episodes (Crowe, 1990; Crowe et al., 1995; also see age assignments in section VI of this report) and coincides with the age of the basalt of Thirsty Mesa (4.7 Ma) combined with an approximation of the uncertainty in establishing that age $( \pm 100 \mathrm{ka})$. The latter interval corresponds to a $2.0 \mathrm{Ma}$ time gap within the Younger postcaldera basalt between the 1.0 Ma Quaternary basalt of Crater Flat and the preceding event, the 3.0 Ma basalt of Buckboard Mesa. An interval of 1.1 Ma is used in PVHA that combines the 1.0 Ma age of the Quaternary basalt of Crater Flat and an approximate $\pm 100 \mathrm{ka}$ interval that represents the uncertainty of the age assignment.

An area of misunderstanding or misinterpretation in past assessments of recurrence rates (E1) for the YMR is the use of an arbitrary or undocumented period of time, $t$, for the probability assessment. During the past 4.8 Ma, volcanic activity in the YMR has occurred episodically. There have been brief periods of volcanic activity separated by long periods of inactivity. Unrealistically short recurrence intervals or high recurrence rates can result from narrowing the period of assessment to intervals closely bracketing the time or times of volcanic activity. Equally, extremely long recurrence intervals or low recurrence rates can be obtained by estimating recurrence rates during times of limited or no volcanic activity. Neither approach gives realistic or representative recurrence rates. What is more important, and a fundamental requirement for making probability estimations, is to provide justification for selection of the interval used for the estimations. Ideally, the justification should be based on volcanic processes or on the geologic record. The panel members of the expert judgment study were nearly unanimous in choosing volcanic cycles for estimates of E1; nearly all the panel members chose intervals of post-1 Ma and post-5 Ma for establishing recurrence rates (Geomatrix, 1996). Two panel members used $2.0 \mathrm{Ma}$ in addition to 1.0 Ma and three members used the above intervals and a longer interval of 9-11 Ma (Geomatrix 1996).

Conclusion: We use the last 4.8 and $1.1 \mathrm{Ma}$ as the standard intervals for estimating volcanic recurrence rates because these intervals correspond to established volcanic cycles in the record of volcanism in the YMR. We do not use definitions of the Quaternary (contrast with Crowe et al., 1995) because the Quaternary is an arbitrary interval relative to the volcanic record of the YMR.

\section{Definition of Volcanic Events.}

The second aspect of assessing the volcanic record, and an additional source of confusion in published estimates of the probabilistic assessment of volcanism is defining the nature of a volcanic event. The definition of volcanic events used in the probability assessment conducted for this report includes $\lambda_{\mathrm{v}}, \lambda_{\mathrm{c}}$, and $\lambda_{\mathrm{i}}$, where $\lambda_{\mathrm{v}}$ is the rate of formation of volcanic events, $\lambda_{\mathrm{c}}$ is the rate of formation of volcanic clusters, and $\lambda_{\mathrm{i}}$ is the rate of formation of volcanic intrusions. Each involves the birth of a new volcanic center, a cluster of volcanic centers or an episode of intrusion of

\footnotetext{
${ }^{1}$ Based on a revised age of 7.2 Ma for the basalt of Nye Canyon (Dennis Gustafason, personal communication 1996).
} 
basaltic magma in the shallow crust. These events have spatial variability in their locations and therefore represent a finite hazard of forming at or near the Yucca Mountain site.

A volcanic event is defined from the perspective of the geometry of an underground repository. The primary magmatic event of concern is the rise of a new pulse of magma through a repository. Ascending magma moves upward, driven primarily by buoyancy along a near-vertical, sheet-like dike or dikes. As magma nears the surface, it begins to exsolve volatiles, and when the volatile bubble pressure exceeds a critical level controlled by the confining pressure and the yield strength of the melt, the magma fragments and erupts. The maximum flux of magma flow is concentrated in a near-circular conduit that becomes the predominant eruptive site or main vent. Multiple conduit sites can occur along the fissure, and dikes can branch from the main dike at depth and form separate vents at the surface. From the perspective of an underground repository, the key variables for a volcanic event are the depth of branching of dikes, the depth of expansion of dikes into conduits, and the depth of magma fragmentation associated with an eruptive event. Events occurring well above the depth of a repository will have a smaller effect on a repository with respect to the incorporation and surface dispersal of radioactive waste. Events occurring below a repository could increase the geometric area of waste-magma contact, and potentially, the volume of dispersed radioactivity either through eruptions or through secondary or subsurface effects.

The rise and eruption of magma can lead to the formation of a single volcanic center such as the Lathrop Wells volcanic center or a cluster of multiple centers like the basalt of Sleeping Butte (Crowe and Perry, 1991; Crowe et al., 1995). A basaltic volcanic center is defined as a group of discrete or closely spaced volcanic vents that form a spatially distinct volcanic landform. Generally, a volcanic center consists of one main eruptive vent with a moderate-sized scoria cone and multiple satellite vents of smaller dimensions associated with the main cone (Crowe, 1986). For the purposes of PVHA, we use the term volcanic center to correspond to a single volcanic event. While this is a simple definition of a volcanic event, there can be uncertainty in identifying and separating volcanic events when a center consists of more than one spatially separate scoria cone. Multiple approaches are used in an attempt to constrain the uncertainty of identifying volcanic events. Volcanic events are assumed to have occurred in relatively short-lived volcanic eruptions (years to decades) corresponding to their classification as monogenetic centers. An alternative model which assumes that some volcanic centers may have formed during multiple, time-distinct volcanic events (polygenetic centers) has been controversial. The model has been carefully investigated as a possible eruption model for the Pliocene and Quaternary volcanic centers of the YMR to ensure that all alternative models are included in assessments of volcanic hazards for the Yucca Mountain site (for example, Wells et al., 1990; Crowe et al., 1992; 1995).

The separation distance of volcanic events should be related to the lengths of feeder dikes. A separation distance of two volcanic centers by $\sim 4-5 \mathrm{~km}$ would suggest the centers could represent separate volcanic events; a separation of centers by $10-12 \mathrm{~km}$ would strongly suggest they represent separate volcanic events, regardless of the results of chronology or geochemical data. A volcanic event should be formed by a single pulse or batch of magma, and the geochemical composition of the deposits from the event should be similar or be related by magmatic processes of fractionation or contamination. Alternatively, if there are significant differences in the geochemical composition of the volcanic deposits, the deposits could be judged to have formed from two volcanic events. In practice, there may not be a complete understanding of all possible mechanism for producing geochemical diversity in the deposits of a volcanic center and geochemical differences between volcanic units do not necessarily imply time differences in 
eruptive units. Thus, interpretations based on geochemical data are used somewhat cautiously, and differences in chemistry, by themselves, are not sufficient evidence to require separate volcanic events.

These definitions are generally useful but cannot always uniquely discriminate the number of volcanic events. The resulting ambiguities in temporal, spatial, and geochemical aspects of volcanic events can lead to uncertainty in event definitions. In ambiguous cases, multiple approaches are used to define volcanic events. For example, the Quaternary basalt of Crater Flat consists of four separate volcanic centers. These could be identified as four distinct volcanic events, a single cluster event, or combinations of volcanic events and cluster events. We attempt to carefully define the usage and assumptions in the definitions of volcanic events in the following probability estimations, recognizing that there will not be complete agreement with all assumptions. The uncertainty in event definitions is defined by treating volcanic events as probability distributions.

The rise and eruption of a pulse of magma from single or multiple contemporaneous dikes form individual volcanic centers. Multiple feeder dikes are probably required because commonly a single dike cannot fit the spatial geometry of vents, vent zones, or fissures at volcanic centers. This is illustrated by the distribution of fissure vents associated with the oldest stratigraphic unit of the Lathrop Wells volcanic center. The surface vents associated with this unit define three partly overlapping fissure systems (Crowe et al., 1995; Chapter 2) and require eruption from multiple dikes; a single feeder dike could not have produced the three fissures. Moreover, geochemical data show that magma erupted from individual fissures is of different geochemical composition and cannot be related by processes of fractionation or assimilation (Crowe et al., 1995; Chapters 2 and 4 , this report). This may require that individual fissures were formed by geochemically distinct magma batches.

Conclusion: We assume a volcanic event (new volcanic center) is formed from the rapid emplacement of 1 to 3 dikes that feed surface volcanic eruptions.

\section{Polygenetic Volcanism.}

Polygenetic volcanism (Crowe et al., 1989; Wells et al., 1990; Perry and Crowe, 1992) represents a special sub-case of volcanic events. A polygenetic episode is defined as an eruption at a preexisting volcanic center that is separated in time from the preceding event by an interval exceeding the residence time of basaltic magma in the shallow crust. The interval duration is open to interpretation but may be decades or centuries. By definition, polygenetic episodes represent eruptions of discrete pulses of magma. Dike cooling times in the shallow crust, assuming dike widths of $5 \mathrm{~m}$ or less, are no more than 10 years (Bruce and Hubbert, 1990; Lister and Kerr, 1991). The uncertainty in establishing eruption ages using paleomagnetic data is at best decades to centuries (Champion, 1991; Radcliff et al., 1994). Thus, a polygenetic episode is regarded as the recurrence of an eruption at an existing center where there has been no activity for several decades to centuries. The existence and significance of polygenetic eruptions have been investigated carefully as part of volcanism studies because consideration of multiple alternative models is critical to a comprehensive PVHA. The model has been controversial (Whitney and Shroba, 1991; Champion, 1991; Turrin et al., 1991, 1992;) but remains difficult to disprove conclusively (Crowe et al., 1989; Wells et al., 1990; Wells et al., 1992; Crowe et al., 1992; 1995). Polygenetic volcanism was discussed but not applied to PVHA in previous studies (Crowe et al., 1995), and it was anticipated that these events would be assessed in future revisions of PVHA. However, polygenetic volcanism is not considered in this final report for the following reasons: 
1. Polygenetic volcanism does not apply to PVHA for the Yucca Mountain site. The event of significance for PVHA is the formation of a new volcanic center in which there is uncertainty in the location and recurrence time of a future event. Polygenetic volcanism refers to the recurrence of a volcanic event at an existing volcanic center. The youngest volcanic center in the YMR is the $75 \mathrm{ka}$ Lathrop Wells center and it is located $20 \mathrm{~km}$ south of the Yucca Mountain site. This distance is considerably greater than the length of feeder dikes for basaltic volcanic centers. Therefore, the polygenetic model is judged not to be significant for the site.

2. There have been extensive reviews of the field and geochronology evidence of polygenetic volcanism at the Lathrop Wells volcanic center and other Pliocene and Quaternary volcanic centers in the YMR. While a polygenetic classification of the volcanic centers cannot be disproved, it has received only limited acceptance. Moreover, the NRC and contractors for the NRC continue to argue against data and interpretations that support the polygenetic model, and their strong opposition suggests, therefore, that this alternative model may not be important for regulatory assessments of future magmatic activity.

3. Several findings provide increased support for the monogenetic model. These results include trenching in the summit crater of the main scoria cone of the Lathrop Wells volcanic center, consistent and reproducible ${ }^{40} \mathrm{Ar} /{ }^{39} \mathrm{Ar}$ age measurements for most eruptive units, and revised results of geochemical modeling of the possible Holocene tephra deposits of the center. The new data do not refute the polygenetic model, but they provide the first definitive data set that is consistent with a preference for the monogenetic model over the polygenetic model.

4. Paleomagnetic studies designed to test the monogenetic-polygenetic models at the late Miocene Paiute Ridge basalt center provided definitive evidence supporting the monogenetic model. This center, consisting of multiple eruptive vents, conduit plugs, and sill-and-dike intrusions, formed during a brief interval estimated to be only a few hundred years based on the documentation of a high-quality paleomagnetic record of a geomagnetic field reversal in the intrusive and volcanic rocks (Ratcliff et al., 1994).

5. The probability of magmatic disruption of the Yucca Mountain site is $\sim 1.5 \times 10^{-8}$ events year $^{-1}$ (Crowe et al., 1995; Geomatrix, 1996). The likelihood of a polygenetic event at a volcanic center is certainly $<1$ and most likely $<0.1$ (see individual elicitations in Geomatrix, 1996). The likelihood of the conditional probability of a new volcanic center forming $\left(1.5 \times 10^{-8} \mathrm{yr}^{-1}\right)$ and the new center being polygenetic $\left(<0.1 \mathrm{yr}^{-1}\right)$ is $<1$ chance in 10,000 in 10,000 years. This probability is low and may not require consideration in regulatory assessments for underground storage of high-level radioactive waste.

The DOE has the final responsibility concerning the importance of the polygenetic model in the application for licensing of the potential Yucca Mountain repository. The logic of not using this model is compelling for PVHA, in which the event is not significant for the occurrence probability of magmatic disruption of the Yucca Mountain site. There is increased ambiguity about choosing not to use the model in studies of the effects of volcanism because the event probability of $<1$ in 10,000 in 10,000 years from 10 CRF 191 may no longer apply. Moreover, the polygenetic model may require consideration if the regulatory standards for a repository are dose- or risk-based in contrast to a release-based standard (National Research Council, 1995). 
Conclusion: We estimate that there is a $70 \%$ likelihood that the monogenetic model is the correct model for the eruptive behavior of small volume basaltic volcanic centers in the YMR, an estimation that is generally consistent with the event count assignments of individual members of the volcanism expert judgment panel. We do not consider the polygenetic model significant in terms of volcanic hazard to the potential repository and do not include it in PVHA.

\section{Volcanic Events at Volcanic Centers in the Yucca Mountain Region}

The following sections describe the data sets used for probability revisions, the alternative event counts and simulation modeling of event counts using different probability distributions and data assumptions. These data are regarded as the best estimates of existing information from site characterization studies. Event counts are established using four alternative approaches that directly reflect contrasting levels of required information for the simulation modeling. These alternative approaches use different probability distributions, which are ordered by increasing levels of information required for the parameters that describe the distributions (starting with the minimal data assumptions):

1. Uniform: A probability distribution in which every value across the range of the distribution has an equal likelihood of occurrence, and the distribution parameters are the minimum and maximum. The distribution corresponds to the case where only bounding estimates of event counts are known or estimated and there is no information on the shape of the distribution between the bounding values. The minimum and maximum bounds for the uniform distribution have a zero probability of occurrence and therefore must be located outside of the distribution (Newendorp, 1974; Megill, 1984).

2. Triangular: A probability distribution specified by three points corresponding to the minimum, maximum, and most likely distribution parameters. The minimum and maximum parameters, like the uniform distribution, have a zero probability of occurrence. The triangular distribution requires the same data as the uniform distribution, plus it must include the location of the most likely value or mode of a probability distribution. The skew of the triangular distribution is established by the location of the most likely value relative to the minimum and maximum values.

3. Trigen: A trigen distribution is a special distribution type used with the @RISK simulation software (Palisade Corporation, 1996) in which minimum, most likely and maximum distribution parameters are required to define the probability distribution. The percentile values of the minimum and maximum parameters for the distribution are specified and can be within the distribution. For this report, all event counts using a trigen distribution are assigned a minimum value corresponding to the 10-percentile and a maximum value corresponding to the 90 -percentile. This distribution applies to the case where it is assumed to be easier to estimate a percentile value within a distribution than to estimate bounds that are outside of the distribution. The trigen distribution, as used in this report, does not include assessments of undetected events, and thus, the sensitivity of undetected events can be evaluated by comparing the simulation results for the triangular and trigen distributions.

4. Normal: A probability distribution that corresponds to the standard bell-shaped curve and requires the mean and the standard deviation as distribution parameters. For most event counts for the volcanic record of the YMR, there is insufficient information to establish a mean and standard deviation. However, we combined the event counts from 
the expert judgment study (Geomatrix, 1996) for all members of the panel to estimate the mean and standard deviation for this distribution-type (see following section and Table 6-13).

\section{A. Quaternary Volcanic Centers (Oldest to Youngest)}

The Quaternary volcanic centers in the YMR and the event counts assigned to the centers are summarized below from oldest to youngest. Events are treated as discrete variables in the event assignments because an event either occurs or does not occur-there is no physical meaning, for example, to a " 0.5 " volcanic event. This requires extrapolation for some percentile assignments, and in these cases the assignments are rounded to an integer event number. This difficulty is avoided in the simulation modeling where event counts are combined for different spatial and structural models and treated as continuous distributions. The assessments of the event counts for the cases described above are somewhat subjective, and past experience has shown that there can be differences in the counts from investigator to investigator. However, past experience has also shown that these differences tend not to be significant when translated into probability distributions (Crowe et al., 1995; Geomatrix, 1996). This continues to be the case for data summarized in this report, and the simulation tables for each volcanic center are included to document the sensitivity of the event counts to subjective judgments. The cited ages for the following event assignments are based on compilations of all available geochronology information for the volcanic centers. Some of the geochronology and geophysical data were obtained from published work outside of the YMP, and accordingly, resulting calculations using these data are not qualified under the YMP.

1. The 1.0 Ma Centers: Quaternary basalt of Crater Flat. The Quaternary basalt of Crater Flat consists of four volcanic centers including the Little Cones, Red Cone, Black Cone and the Makani Cone. The centers have been described by Vaniman and Crowe (1981), Vaniman et al. (1982), Smith et al. (1990), Ho et al. (1991), and the data are summarized in Crowe et al. (1995). The mean age of all the centers is estimated to be $1.0 \pm 0.1 \mathrm{Ma}$, and existing data support an age of 1.0 Ma for each center (Chapter 2, this report). Fleck et al. (1996) reported an age of $1.069 \pm$ 0.020 for the Quaternary basalt of Crater Flat but did not include data from Red Cone in their study. An alternative age of about $0.75 \mathrm{Ma}$ (Crowe et al., 1995; Chapter 2, this report) is permissible for the Little Cones center. One event or as many as 7 events are possible on the basis of the geologic and geochronologic data for the centers; a 3-event scenario is given the highest weighting (most likely estimate).

The one-event scenario emphasizes the alignment and relatively close proximity of each center, the consistency in the results of age determinations obtained for the centers (Crowe et al., 1995; Chapter 2), and the inferred uniformity of their field magnetization directions (Champion, 1991). Weaknesses of this interpretation are incompletely documented paleomagnetic data, some divergence in the results of geochronology data (Crowe et al., 1995; Chapter 2 this report) and the alignment length of the basalt centers $(12.6 \mathrm{~km})$ exceeds the likely dimension of a single feeder dike.

The most likely three-event scenario assumes that Red Cone and Black Cone formed from a single pulse of magma (1-event; see geochemical data of Bradshaw and Smith, 1994), and the Little Cones and Makani centers each formed as separate events. This is supported by the observation that the Little Cones center can be discriminated petrographically and geochemically from the Red Cone and Black Cone centers (Vaniman et al., 1982; Fleck et al., 1996), and both 
Little Cones and Makani Cone are spatially separate (3-4 km separation) from, respectively, the Red Cone and Black Cone centers.

The 7-event scenario assumes each center represents a separate volcanic event, the Little Cones center is two events (Connor and Hill, 1993), and there are as many as two undetected events associated with the Quaternary basalt of Crater Flat. This scenario assumes also that there is sufficient uncertainty in geochronology data to permit the interpretation that each center is a separate event, and the paleomagnetic data are either incomplete or do not represent the temporal complexity of the volcanic events.

The assignment of two undetected events is based on the presence of an unexplored positive magnetic anomaly about $1 \mathrm{~km}$ south of the Little Cones and the presence of a still unexplained positive aeromagnetic anomaly in the middle of Crater Flat (Kane and Bracken, 1983). The latter interpretation is considered unlikely based on the results of the $\mathrm{VH}-1$ exploratory drill hole (Carr, 1984). The possibility of other undetected events is discounted because of multiple lines of evidence including: 1) high quality drape aeromagnetic data for the Crater Flat basin, 2) the setting of the basalt centers in alluvial deposits, 3) the availability of subsurface data from two nearby drill holes (VH-1 and VH-2), and 4) data interpretations from high quality seismic reflection/refraction lines located near the centers (Brocher et al., 1996). The volume of the basalt centers was presented in Crowe et al. (1995); no revisions of the volume estimations have been made because of the insensitivity of the volume data to the PVHA (Crowe et al., 1995). The alternative probability distributions for the event counts are shown on Figure 6.2 and the results of simulation modeling using the distributions are summarized in Table 6.4.

The modeling used the @ RISK simulation software (Version 3.5) with 10,000 iterations per simulation using latin hypercube sampling. Distribution parameters were derived from the event assignments described below for the Quaternary basalt of Crater Flat. The distribution parameters (mean, standard deviation) for the normal were obtained from the event count assignments of the volcanism expert judgment study (Geomatrix, 1996). In some cases for the trigen and normal distributions, the event assignments resulted in negative event counts for the minimum events. These negative counts are not realistic physically and can be removed by using a zero-truncated probability distribution. We do not use truncated distributions, however, because the effect on the cumulative probability distributions is small. Negative values for event counts have been rounded to zero in the accompanying tables.

Minimum Event Bound: 0 events 10-Percentile Event Model: 1 event Most Likely Event Model: 3 events

Normal Distribution Event Model: $2.3 \pm 1.1$ events

90-Percentile Event Model: 5 events

Maximum Event Bound: 8 events

Polygenetic Episodes: not applicable for the revised PVHA 
Table 6.4. Univariate Statistics and Percentiles from Simulation Modeling of Event Counts Using Alternative Probability Distributions for the Quaternary Basalt of Crater Flat

\begin{tabular}{|c|c|c|c|c|c|c|c|}
\hline \multirow[b]{2}{*}{ Event Counts $=$} & Minimum & $10 \%$ & $\begin{array}{l}\text { Most } \\
\text { Likely }\end{array}$ & $90 \%$ & Maximum & Mean & Std Dev \\
\hline & 0.0 & 1.0 & 3.0 & 5.0 & 8.0 & 2.3 & 1.1 \\
\hline \multicolumn{8}{|c|}{ Probability Distributions } \\
\hline & Uniform & Triangular & Trigen & Normal & & & \\
\hline \multirow[t]{29}{*}{ Exp Value $=$} & 4.0 & 3.7 & 3.0 & 2.3 & & & \\
\hline & & & Uniform & Triangle & Trigen & Normal & \\
\hline & & Minimum = & 0.0 & 0.0 & 0.0 & 0.0 & \\
\hline & & Maximum = & 8.0 & 8.0 & 6.6 & 6.4 & \\
\hline & & Mean $=$ & 4.0 & 3.7 & 3.0 & 2.3 & \\
\hline & & Std Deviation = & 2.3 & 1.6 & 1.5 & 1.1 & \\
\hline & & Variance $=$ & 5.3 & 2.7 & 2.2 & 1.2 & \\
\hline & & Skewness $=$ & 0.0 & 0.2 & 0.0 & 0.0 & \\
\hline & & Kurtosis $=$ & 1.8 & 2.4 & 2.4 & 3.0 & \\
\hline & & Mode $=$ & 3.4 & 3.0 & 3.0 & 2.3 & \\
\hline & & $5 \%$ Perc $=$ & 0.4 & 1.1 & 0.5 & 0.5 & \\
\hline & & $10 \%$ Perc $=$ & 0.8 & 1.5 & 1.0 & 0.9 & \\
\hline & & $15 \%$ Perc $=$ & 1.2 & 1.9 & 1.4 & 0.9 & \\
\hline & & $20 \%$ Perc $=$ & 1.6 & 2.2 & 1.7 & 1.2 & \\
\hline & & $25 \%$ Perc $=$ & 2.0 & 2.4 & 1.9 & 1.6 & \\
\hline & & $30 \%$ Perc $=$ & 2.4 & 2.7 & 2.2 & 1.7 & \\
\hline & & $35 \%$ Perc $=$ & 2.8 & 2.9 & 2.4 & 1.9 & \\
\hline & & $40 \%$ Perc $=$ & 3.2 & 3.1 & 2.6 & 2.0 & \\
\hline & & $45 \%$ Perc $=$ & 3.6 & 3.3 & 2.8 & 2.2 & \\
\hline & & $50 \%$ Perc $=$ & 4.0 & 3.5 & 3.0 & 2.3 & \\
\hline & & $55 \%$ Perc $=$ & 4.4 & 3.8 & 3.2 & 2.4 & \\
\hline & & $60 \%$ Perc $=$ & 4.8 & 4.0 & 3.4 & 2.6 & \\
\hline & & $65 \%$ Perc $=$ & 5.2 & 4.3 & 3.6 & 2.7 & \\
\hline & & $70 \%$ Perc $=$ & 5.6 & 4.5 & 3.8 & 2.9 & \\
\hline & & $75 \%$ Perc $=$ & 6.0 & 4.8 & 4.1 & 3.0 & \\
\hline & & $80 \%$ Perc $=$ & 6.4 & 5.2 & 4.3 & 3.2 & \\
\hline & & $85 \%$ Perc $=$ & 6.8 & 5.5 & 4.6 & 3.4 & \\
\hline & & $90 \%$ Perc $=$ & 7.2 & 6.00 & 5.0 & 3.7 & \\
\hline & & $95 \%$ Perc $=$ & 7.6 & 6.6 & 5.5 & 4.1 & \\
\hline
\end{tabular}




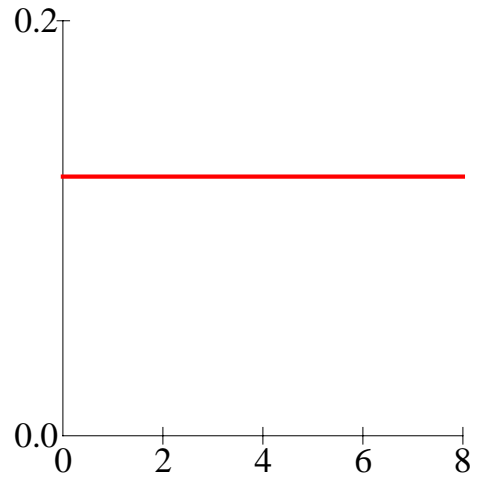

Event Counts: Uniform

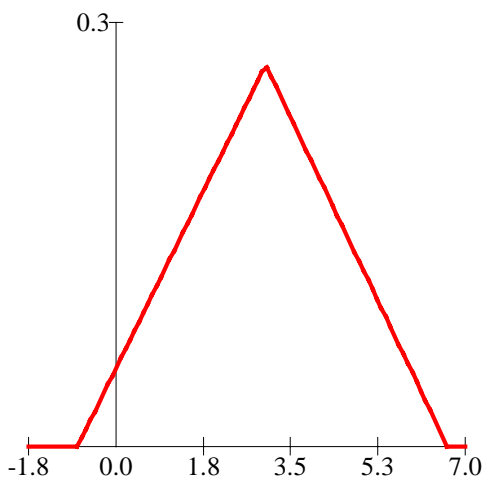

Event Counts: Trigen

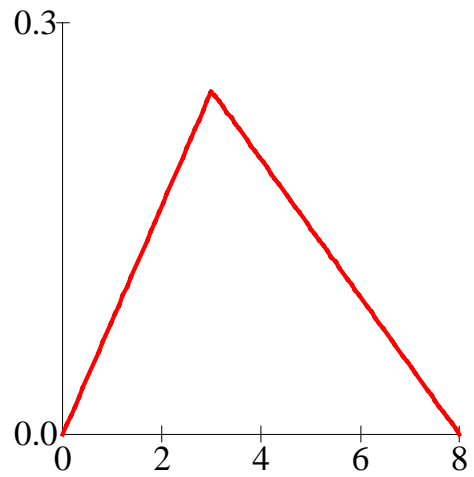

Event Counts: Triangle

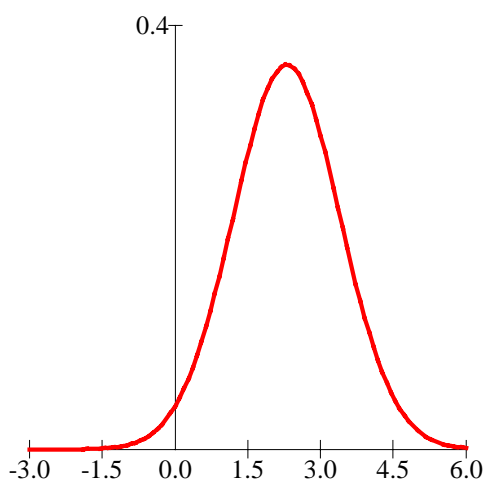

Events Counts: Normal

Figure 6.2. Alternative probability distributions used for the event-count simulations, Quaternary basalt of Crater Flat.

2. The 0.38 Ma Centers: Basalt of Sleeping Butte. Crowe and Perry (1991) have described the basalt of Sleeping Butte, consisting of the Little Black Peak and Hidden Cone centers, and the geology of the center is summarized in Crowe et al. (1995), Crowe and Perry (1995), and Fleck et al. (1996). We have obtained new whole-rock ${ }^{40} \mathrm{Ar} /{ }^{39} \mathrm{Ar}$ ages of $0.56 \pm 0.10$ and $0.32 \pm 0.03 \mathrm{ka}$ for Hidden Cone and $0.39 \pm 0.03$ and $0.36 \pm 0.04 \mathrm{ka}$ for Little Black Peak. Fleck et al. (1996) reported an age of $0.35 \pm 0.20 \mathrm{Ma}(2 \sigma)$ for the Sleeping Butte centers using K-Ar data from multiple laboratories. The differences between these ages are not significant statistically, and we use an age of $0.38 \mathrm{Ma}$ for the Sleeping Butte center, which is the arithmetic average of our Ar/Ar ages and the pooled age reported by Fleck et al. (1996). One event and as many as 3 volcanic events could be represented by the deposits of the Sleeping Butte center. For the 1-event scenario, Little Black Peak and Hidden Cone are assumed to be fed by a single, continuous feeder dike, an inference that is supported by paleomagnetic data (Champion, 1991). The 2-event scenario assumes each center is a separate event based on the $2.6 \mathrm{~km}$ separation of the centers, the different field magnetic directions obtained at the northwest flow lobe of the Hidden Cone center (Champion, 1995), and differences in geochemical composition of the deposits of the centers (Fleck et al., 
1996). The 3-event scenario assumes an undetected event could be associated with the Hidden Cone center primarily because of the absence of detailed geophysical data for the centers.

Additionally, the setting of the centers in magnetic country rock of Miocene tuff and the adjacent outcrops of extensive basaltic lava flows of Miocene age could make detection of other volcanic events difficult. The results of simulation modeling of alternative event counts for the Quaternary basalt of Sleeping Butte are summarized in Table 6.5 and the alternative probability distributions for the event counts are plotted in Figure 6.3. The simulation parameters are the same as in Figure 6.2 .

Minimum Event Bound: 0 events

10-Percentile Event Model: 1 event

Most Likely Event Model: 2 events

Normal Distribution Model: $2.1 \pm 0.9$ events

90-Percentile Event Model: 3 events

Maximum Probability Bound: 4 events

Polygenetic Episodes: not applicable for the revised PVHA 
Table 6.5. Univariate Statistics and Percentiles from Simulation Modeling of Event Counts Using Alternative Probability Distributions for the Basalt of Sleeping Butte

\begin{tabular}{|c|c|c|c|c|c|c|c|}
\hline \multirow[b]{2}{*}{ Event Counts = } & \multirow{2}{*}{$\begin{array}{c}\text { Minimum } \\
0.0\end{array}$} & $10 \%$ & \multirow{2}{*}{$\begin{array}{c}\text { Most } \\
\text { Likely } \\
2.0\end{array}$} & \multirow{2}{*}{$\begin{array}{c}90 \% \\
3.0\end{array}$} & \multirow{2}{*}{$\begin{array}{c}\text { Maximum } \\
4.0\end{array}$} & \multirow{2}{*}{$\begin{array}{c}\text { Mean } \\
2.1\end{array}$} & \multirow{2}{*}{$\begin{array}{c}\text { Std Dev } \\
0.9\end{array}$} \\
\hline & & 1.0 & & & & & \\
\hline \multirow{31}{*}{ Exp Value $=$} & \multicolumn{2}{|c|}{ Probability Distributions } & & & & & \\
\hline & Uniform & Triangular & Trigen & Normal & & & \\
\hline & 2.0 & 2.0 & 2.0 & 2.1 & & & \\
\hline & & & Uniform & Triangle & Trigen & Normal & \\
\hline & & Minimum = & 0.0 & 0.0 & 0.2 & 0.0 & \\
\hline & & Maximum = & 4.0 & 4.0 & 3.8 & 5.5 & \\
\hline & & Mean = & 2.0 & 2.0 & 2.0 & 2.1 & \\
\hline & & Std Deviation = & 1.1 & 0.8 & 0.7 & 0.9 & \\
\hline & & Variance $=$ & 1.3 & 0.7 & 0.5 & 0.8 & \\
\hline & & Skewness = & 0.0 & 0.0 & 0.0 & 0.0 & \\
\hline & & Kurtosis $=$ & 1.8 & 2.4 & 2.4 & 2.9 & \\
\hline & & Mode $=$ & 1.3 & 2.0 & 2.0 & 2.1 & \\
\hline & & $5 \%$ Perc $=$ & 0.2 & 0.6 & 0.8 & 0.6 & \\
\hline & & $10 \%$ Perc $=$ & 0.4 & 0.9 & 1.0 & 0.9 & \\
\hline & & $15 \%$ Perc $=$ & 0.6 & 1.1 & 1.2 & 1.2 & \\
\hline & & $20 \%$ Perc $=$ & 0.8 & 1.3 & 1.3 & 1.3 & \\
\hline & & $25 \%$ Perc $=$ & 1.0 & 1.4 & 1.5 & 1.5 & \\
\hline & & $30 \%$ Perc $=$ & 1.2 & 1.5 & 1.6 & 1.6 & \\
\hline & & $35 \%$ Perc $=$ & 1.4 & 1.7 & 1.7 & 1.7 & \\
\hline & & $40 \%$ Perc $=$ & 1.6 & 1.8 & 1.8 & 1.9 & \\
\hline & & $45 \%$ Perc $=$ & 1.8 & 1.9 & 1.9 & 2.0 & \\
\hline & & $50 \%$ Perc $=$ & 2.0 & 2.0 & 2.0 & 2.1 & \\
\hline & & $55 \%$ Perc $=$ & 2.2 & 2.1 & 2.1 & 2.2 & \\
\hline & & $60 \%$ Perc $=$ & 2.4 & 2.2 & 2.2 & 2.3 & \\
\hline & & $65 \%$ Perc $=$ & 2.6 & 2.3 & 2.3 & 2.5 & \\
\hline & & $70 \%$ Perc $=$ & 2.8 & 2.4 & 2.4 & 2.6 & \\
\hline & & $75 \%$ Perc $=$ & 3.0 & 2.6 & 2.5 & 2.7 & \\
\hline & & $80 \%$ Perc $=$ & 3.2 & 2.7 & 2.7 & 2.9 & \\
\hline & & $85 \%$ Perc $=$ & 3.4 & 2.9 & 2.8 & 3.0 & \\
\hline & & $90 \%$ Perc $=$ & 3.6 & 3.1 & 3.0 & 3.2 & \\
\hline & & $95 \%$ Perc $=$ & 3.8 & 3.4 & 3.2 & 3.6 & \\
\hline
\end{tabular}




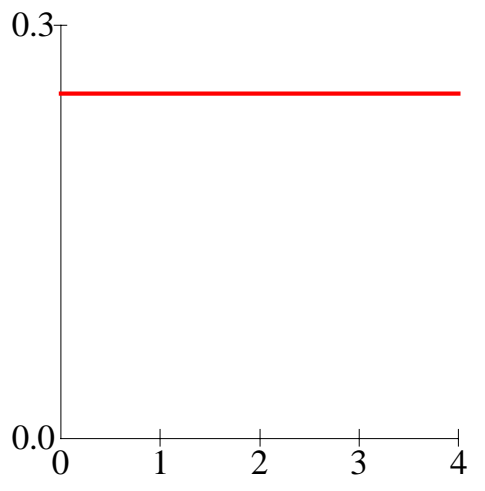

Event Counts: Uniform

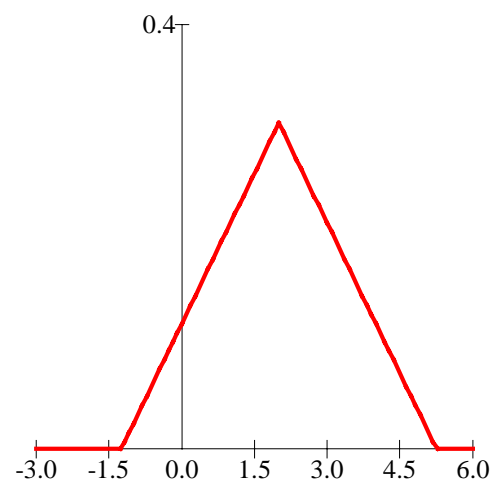

Event Counts: Trigen

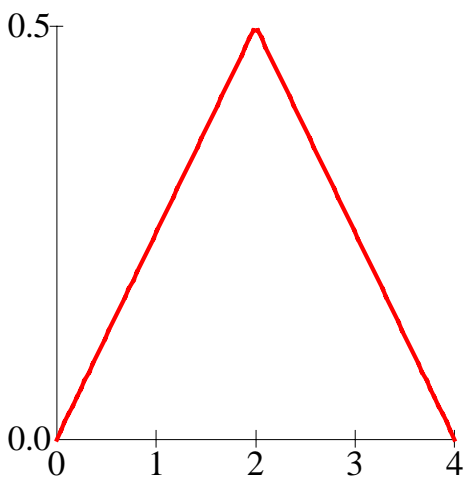

Event Counts: Triangle

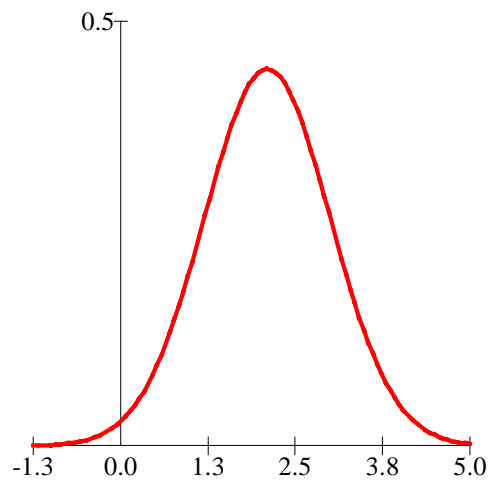

Event Counts: Normal

Figure 6.3. Probability distributions used for the event-count simulations, basalt of Sleeping Butte

3. The 75 ka Center: Lathrop Wells Center. The Lathrop Wells center has been described by Crowe and Carr (1980), Vaniman and Crowe (1981), Vaniman et al. (1982), Crowe et al. (1986), Wells et al. (1990), Turrin et al. (1991), Crowe et al. (1992; 1995) and Fleck et al. (1996). The chronology of the center has been controversial. Our judgment of the most reasonable geochronology model for the center is an age of about $75 \mathrm{ka}$. This age is based on the consistency among multiple alternative chronology methods including replicate high-quality ${ }^{40} \mathrm{Ar} /{ }^{39} \mathrm{Ar}$ ages from lithic fragments of tuff and lava samples (Chapter 2, this report). Alternatively, Turrin et al. (1991) and Fleck et al. (1996) have reported ages ranging from 116 to $133 \mathrm{ka}$ for lava units of the Lathrop Wells center. Their chronology model requires somewhat older ages than our suggested age of 75 $\mathrm{ka}$, and it is unlikely that the differences in the alternative chronology models will be resolved (Turrin et al., 1991; 1992; Wells et al., 1992). The primary appeal of an age of $75 \mathrm{ka}$ is that it 
allows resolution of the geomorphic and soils characteristics of the main cone and the associated lava flows (Chapter 2, this report). Thus, while we use an age of $75 \mathrm{ka}$ for the Lathrop Wells center for all PVHA models, we recognize that the adoption of any chronology model will be strongly dependent on interpretations of what constitute a "best or most reliable" chronology method. Multiple alternative chronology models are clearly permissible, and the important point is that they do not have a significant effect on PVHA (Crowe et al., 1995; Geomatrix, 1996). One event and as many as 4 events could be represented at the Lathrop Wells center. One event is emphasized both because a polygenetic model for the center is controversial and because polygenetic events are not used in PVHA. As many as three undetected events are possible but are judged to be unlikely. The possibility of undetected events is allowed on the basis of the complex structural setting of the center and the local presence of Miocene tuff beneath the deposits of the center. The inferred low event-weightings for undetected events came about because of the high quality of aeromagnetic coverage for the center. At least part of the deposits of the center overlie alluvial deposits. The results of simulation modeling of alternative event counts for the Quaternary Lathrop Wells volcanic center are summarized in Table 6.6, and the alternative probability distributions for event counts are plotted in Figure 6.4. The trigen distribution could not be simulated because the limited variability in event counts does not allow assignment of required parameters for this distribution. The simulation parameters for the uniform, triangular and normal distributions are the same as Figure 6.2.

\author{
Minimum Event Bound: 0 events \\ 10-Percentile Event Model: 1 event \\ Most Likely Event Model: 1 event \\ Normal Distribution Event Model: $1.5 \pm 0.4$ events \\ 90-Percentile Event Model: 1 event \\ Maximum Event Bound: 4 events \\ Polygenetic Episodes: not applicable for the revised PVHA
}


Table 6.6. Univariate Statistics and Percentiles from Simulation Modeling of Event Counts Using Alternative Probability Distributions for the Lathrop Wells Volcanic Center.

\begin{tabular}{|c|c|c|c|c|c|c|c|}
\hline & Minimum & $10 \%$ & $\begin{array}{l}\text { Most } \\
\text { Likely }\end{array}$ & $90 \%$ & Maximum & Mean & Std Dev \\
\hline \multirow[t]{3}{*}{ Event Counts $=$} & 0.0 & 1.0 & $1.0^{\circ}$ & 1.0 & 4.0 & 1.5 & 0.4 \\
\hline & Probability & istributions & & & & & \\
\hline & Uniform & Triangular & Normal & & & & \\
\hline \multirow[t]{29}{*}{ Exp Value $=$} & 2.0 & 1.7 & 1.5 & & & & \\
\hline & & & Uniform & Triangle & Normal & & \\
\hline & & Minimum = & 0.0 & 0.0 & 0.0 & & \\
\hline & & Maximum = & 4.0 & 4.0 & 3.0 & & \\
\hline & & Mean = & 2.0 & 1.7 & 1.5 & & \\
\hline & & Std Deviation = & 1.1 & 0.8 & 0.4 & & \\
\hline & & Variance $=$ & 1.3 & 0.7 & 0.2 & & \\
\hline & & Skewness = & 0.0 & 0.4 & 0.0 & & \\
\hline & & Kurtosis $=$ & 1.8 & 2.4 & 3.0 & & \\
\hline & & Mode $=$ & 0.5 & 1.0 & 1.5 & & \\
\hline & & $5 \%$ Perc $=$ & 0.2 & 0.4 & 0.8 & & \\
\hline & & $10 \%$ Perc $=$ & 0.4 & 0.6 & 1.0 & & \\
\hline & & $15 \%$ Perc = & 0.6 & 0.8 & 1.1 & & \\
\hline & & $20 \%$ Perc $=$ & 0.8 & 0.9 & 1.2 & & \\
\hline & & $25 \%$ Perc $=$ & 1.0 & 1.0 & 1.2 & & \\
\hline & & $30 \%$ Perc = & 1.2 & 1.1 & 1.3 & & \\
\hline & & $35 \%$ Perc = & 1.4 & 1.2 & 1.4 & & \\
\hline & & $40 \%$ Perc = & 1.6 & 1.3 & 1.4 & & \\
\hline & & $45 \%$ Perc $=$ & 1.8 & 1.4 & 1.5 & & \\
\hline & & $50 \%$ Perc $=$ & 2.0 & 1.5 & 1.5 & & \\
\hline & & $55 \%$ Perc = & 2.2 & 1.7 & 1.5 & & \\
\hline & & $60 \%$ Perc $=$ & 2.4 & 1.8 & 1.6 & & \\
\hline & & $65 \%$ Perc $=$ & 2.6 & 1.9 & 1.6 & & \\
\hline & & $70 \%$ Perc = & 2.8 & 2.1 & 1.7 & & \\
\hline & & $75 \%$ Perc = & 3.0 & 2.3 & 1.8 & & \\
\hline & & $80 \%$ Perc $=$ & 3.2 & 2.4 & 1.8 & & \\
\hline & & $85 \%$ Perc $=$ & 3.4 & 2.7 & 1.9 & & \\
\hline & & $90 \%$ Perc = & 3.6 & 2.9 & 2.0 & & \\
\hline & & $95 \%$ Perc = & 3.8 & 3.2 & 2.2 & & \\
\hline
\end{tabular}




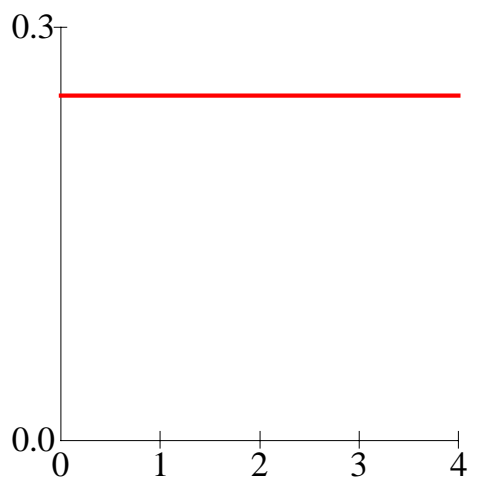

Event Counts: Uniform

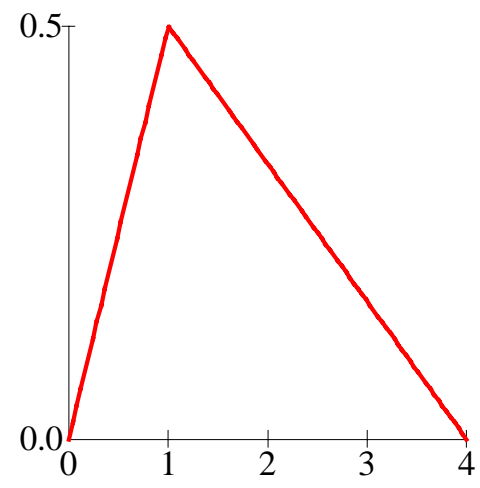

Event Counts: Triangle

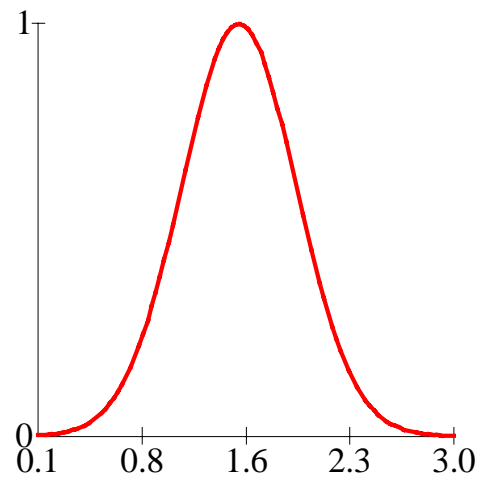

Event Counts: Normal

Figure 6.4. Probability distributions used for the event-count simulations, Lathrop Wells volcanic center.

\section{B. Pliocene Volcanic Events in the Yucca Mountain Region (Oldest to Youngest):}

1. The 4.7 Ma Centers: Basalt of Thirsty Mesa. The basalt of Thirsty Mesa was first recognized as a Pliocene volcanic center by Fleck et al. (1991), and the volcanic unit has been described by Crowe et al. (1995) and Fleck et al. (1996). Fleck et al. (1996) reported a weighted mean age of $4.63 \pm 0.02 \mathrm{Ma}$ for the basalt of Thirsty Mesa, and Crowe et al. (1995) reported ${ }^{40} \mathrm{Ar} /{ }^{39} \mathrm{Ar}$ ages of $4.68 \pm 0.03 \mathrm{Ma}$ for a lava collected from the west base of the mesa and $4.88 \pm$ $0.04 \mathrm{Ma}$ for a sample collected from a dike exposed in the summit scoria cone. We prefer the $\mathrm{Ar} / \mathrm{Ar}$ ages for the center but assign an age of $4.70 \mathrm{Ma}$ for PVHA that is the arithmetic average of our age determinations and the results of Fleck et al. (1996). A 1-event model is supported by the similarity in age determinations of samples collected from sites that span the stratigraphic section of the lava mesa of the basalt center. Paleomagnetic data reported in Fleck et al. (1996) are consistent with a single event. Geochemical data show no evidence of compositional variation that cannot be explained by a 1-event eruptive history (Crowe et al., 1986; 1995). The 2- and 3-event 
models are based on reconnaissance geologic mapping that shows the vent area for the center consists of three partly coalesced scoria/spatter cones. The likelihood of undetected events from burial is judged to be extremely low because the center is a high-standing topographic feature. The volume of the basalt of Thirsty Mesa was estimated to be $3.4 \mathrm{~km}^{3}$ by Fleck et al. (1996) and 3.0 $\mathrm{km}^{3}$ by Crowe et al. (1995); the difference in the estimates is not significant. The results of simulation modeling of the event counts for the basalt of Thirsty Mesa are summarized in Table 6.7, and the probability distributions for the alternative event-count models are plotted in Figure 6.5. The trigen and normal distributions could not be simulated because the limited variability in event counts does not allow assignment of required parameters for the distributions. The simulation parameters for the uniform and triangular distributions are the same as Figure 6.2.

\author{
Minimum Event Bound: 0 events \\ 10-Percentile Event Model: 1 event \\ Most Likely Event Model: 1 event \\ 90-Percentile Event Model: 1 event \\ Maximum Event Bound: 4 events \\ Polygenetic Episodes: not applicable for the revised PVHA
}


Table 6.7. Univariate Statistics and Percentiles from Simulation Modeling of Event Counts Using Alternative Probability Distributions for the Basalt of Thirsty Mesa

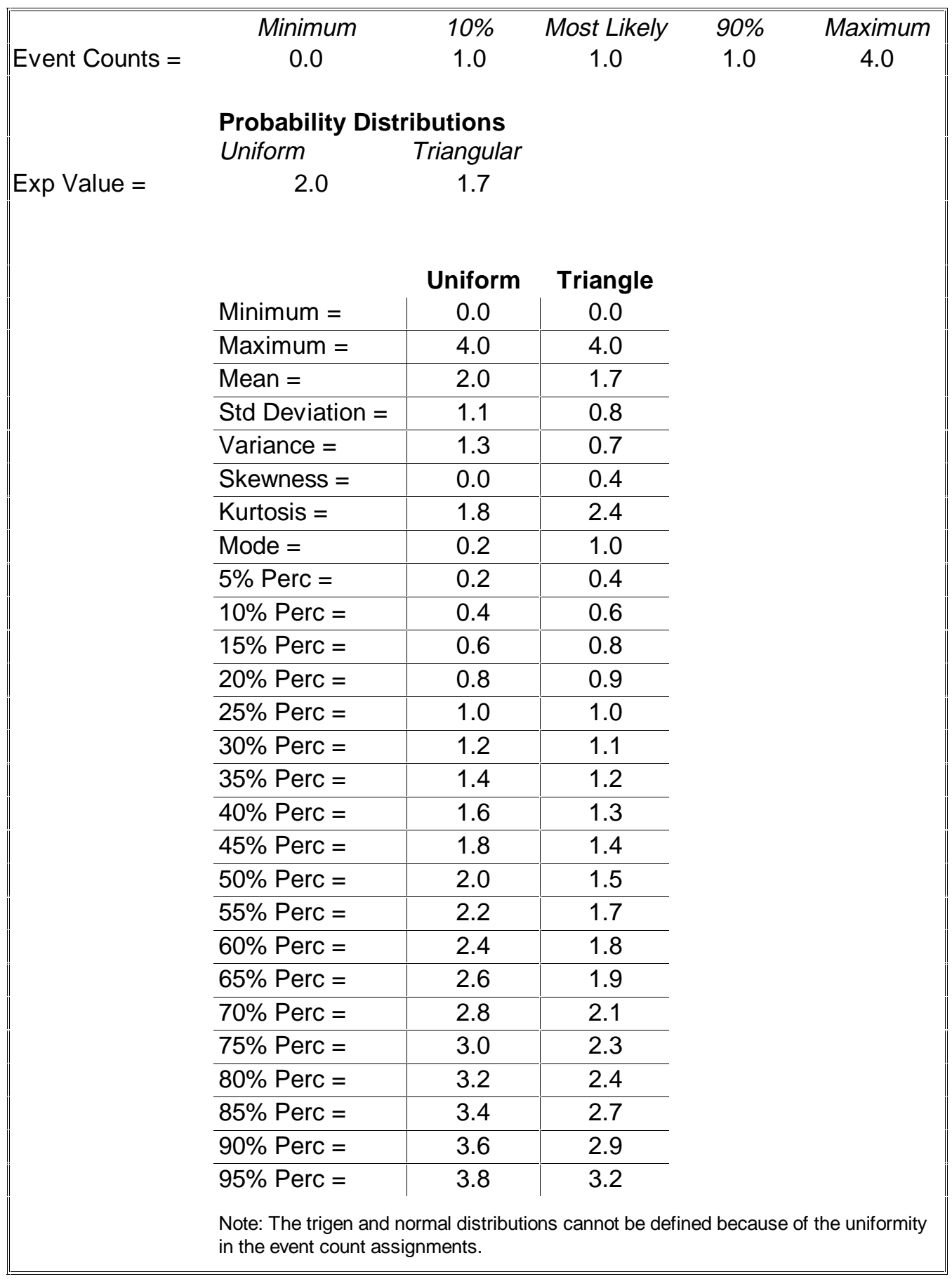




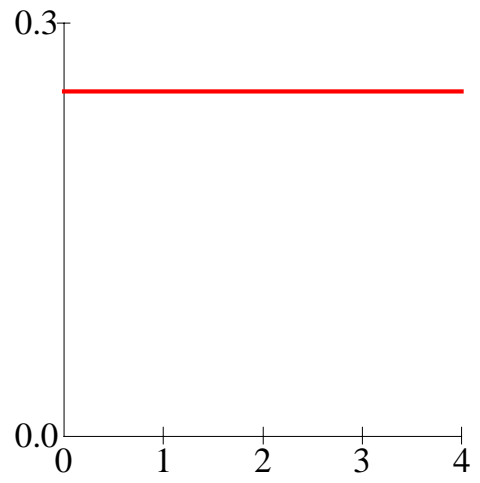

Event Counts: Uniform

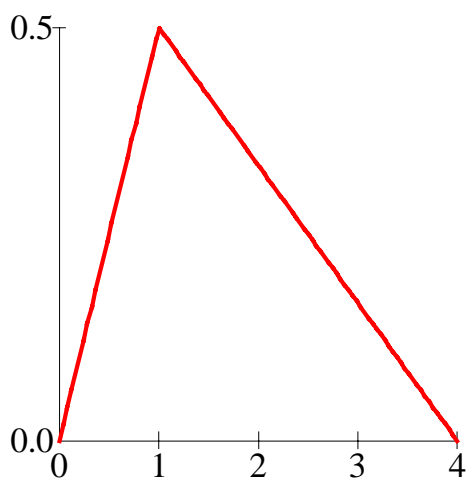

Event Counts: Triangle

Figure 6.5. Probability distributions used for the event-count simulations, basalt of Thirsty Mesa.

2. The 3.8 Ma Aeromagnetic Anomalies of Crater Flat and the Amargosa Valley. Aeromagnetic anomalies suspected to represent buried basaltic volcanic centers are included in event counts for PVHA. The anomalies are identified from the drape aeromagnetic surveys and interpretations of Kane and Bracken (1983), with the addition of data and interpretations for areas of the Amargosa Valley described by Langenheim et al. (1991) and Langenheim (1995). The labeling of the aeromagnetic anomalies follows the format used in the volcanism expert judgment report (labeled A through F; Geomatrix, 1996). Anomaly A is located in Crater Flat about $1 \mathrm{~km}$ south of the Little Cones (Crowe and Carr, 1980; Crowe et al., 1986; Langenheim, 1995). Anomaly B is located in the Amargosa Valley several kilometers south of the town of Amargosa Valley and is the only anomaly site that has been investigated through exploratory drilling (Harris et al., 1992; Langenheim, 1995; Crowe et al., 1995). Cuttings recovered from the exploratory drill hole yielded an age of $3.85 \pm 0.05 \mathrm{Ma}$ (Crowe et al., 1992). The age and geometry of the aeromagnetic anomaly are consistent with burial of a former surface volcanic center by alluvial sedimentation in the Amargosa Valley. Five additional aeromagnetic anomalies have been identified in the Amargosa Valley (C through F; see Geomatrix, 1996), and anomaly D may be related to basalt intersected in a water well at the 190-m depth (Langenheim, 1995). The minimum (10percentile model) for the aeromagnetic anomalies assumes 4 volcanic events assigning single events to anomalies $\mathrm{A}, \mathrm{B}$, and $\mathrm{E}$ with anomaly sites $\mathrm{C}$ and $\mathrm{D}$ assigned as one event because of their close spacing. This model also assumes anomalies $\mathrm{G}$ and $\mathrm{F}$ are produced by Miocene basalt or buried silicic volcanic rocks of Miocene age. The most likely event count is a 6-event scenario and infers that anomalies A, B, C, D, E each represents individual events with anomalies F and G combined into a single event because of close spacing. The separation of anomalies $\mathrm{C}$ and $\mathrm{D}$ into individual events is based on their inferred different magnetic polarities based on the drape aeromagnetic data (Langenheim, 1995). The 90-percentile event model assumes 8 events with anomalies $\mathrm{F}$ and $\mathrm{G}$ counted as separate events and anomaly B assigned as two events because of the large area of the anomaly. The maximum event bound is 13 events and assumes as many as 4 undetected volcanic events. The results of simulation modeling using the alternative event counts for the aeromagnetic anomalies are summarized in Table 6.8, and the probability distributions for the event counts are plotted in Figure 6.6. The simulation parameters for the distributions are the same as Figure 6.2. 
Minimum Event Bound: 3 events

10-Percentile Event Model: 4 events

Most Likely Event Model: 6 events

Normal Distribution Model: $5.4 \pm 1.7$ events

90-Percentile Event Model: 8 events

Maximum Probability Bound: 13 events

Polygenetic Episodes: not applicable for the revised PVHA

Table 6.8. Univariate Statistics and Percentiles from Simulation Modeling of Event Counts Using Alternative Probability Distributions for the Aeromagnetic Anomalies of Crater Flat and Amargosa Valley.

\begin{tabular}{|c|c|c|c|c|c|c|c|}
\hline \multirow[b]{2}{*}{ Event Counts = } & \multirow{2}{*}{$\begin{array}{c}\text { Minimum } \\
3.0\end{array}$} & $10 \%$ & \multirow{2}{*}{$\begin{array}{c}\text { Most } \\
\text { Likely } \\
6.0\end{array}$} & \multirow{2}{*}{$\begin{array}{l}90 \% \\
8.0\end{array}$} & \multirow{2}{*}{$\begin{array}{c}\text { Maximum } \\
13.0\end{array}$} & \multirow{2}{*}{$\begin{array}{c}\text { Mean } \\
5.4\end{array}$} & \multirow{2}{*}{$\begin{array}{c}\text { Std Dev } \\
1.7\end{array}$} \\
\hline & & 4.0 & & & & & \\
\hline & \multicolumn{2}{|c|}{ Probability Distributions } & & & & & \\
\hline & Uniform & Triangular & Trigen & Normal & & & \\
\hline \multirow[t]{29}{*}{ Exp Value $=$} & 8.0 & 7.3 & 6.0 & 5.4 & & & \\
\hline & & & Uniform & Triangle & Trigen & Normal & \\
\hline & & Minimum = & 3.0 & 3.0 & 2.4 & 0.0 & \\
\hline & & Maximum = & 13.0 & 13.0 & 9.6 & 12.1 & \\
\hline & & Mean = & 8.0 & 7.3 & 6.0 & 5.4 & \\
\hline & & Std Deviation = & 2.9 & 2.1 & 1.5 & 1.7 & \\
\hline & & Variance $=$ & 8.3 & 4.4 & 2.2 & 2.9 & \\
\hline & & Skewness $=$ & 0.0 & 0.4 & 0.0 & 0.0 & \\
\hline & & Kurtosis $=$ & 1.8 & 2.4 & 2.4 & 3.0 & \\
\hline & & Mode $=$ & 5.8 & 6.0 & 6.0 & 5.3 & \\
\hline & & $5 \%$ Perc $=$ & 3.5 & 4.2 & 3.5 & 2.6 & \\
\hline & & $10 \%$ Perc $=$ & 4.0 & 4.7 & 4.0 & 3.2 & \\
\hline & & $15 \%$ Perc $=$ & 4.5 & 5.1 & 4.4 & 3.6 & \\
\hline & & $20 \%$ Perc $=$ & 5.0 & 5.4 & 4.7 & 4.0 & \\
\hline & & $25 \%$ Perc $=$ & 5.5 & 5.7 & 4.9 & 4.2 & \\
\hline & & $30 \%$ Perc $=$ & 6.0 & 6.0 & 5.2 & 4.5 & \\
\hline & & $35 \%$ Perc $=$ & 6.5 & 6.2 & 5.4 & 4.7 & \\
\hline & & $40 \%$ Perc $=$ & 7.0 & 6.5 & 5.6 & 5.0 & \\
\hline & & $45 \%$ Perc $=$ & 7.5 & 6.8 & 5.8 & 5.2 & \\
\hline & & $50 \%$ Perc $=$ & 8.0 & 7.1 & 6.0 & 5.4 & \\
\hline & & $55 \%$ Perc $=$ & 8.5 & 7.4 & 6.2 & 5.6 & \\
\hline & & $60 \%$ Perc $=$ & 9.0 & 7.7 & 6.4 & 5.8 & \\
\hline & & $65 \%$ Perc $=$ & 9.5 & 8.0 & 6.6 & 6.0 & \\
\hline & & $70 \%$ Perc $=$ & 10.0 & 8.4 & 6.8 & 6.3 & \\
\hline & & $75 \%$ Perc $=$ & 10.5 & 8.8 & 7.1 & 6.5 & \\
\hline & & $80 \%$ Perc $=$ & 11.0 & 9.3 & 7.3 & 6.8 & \\
\hline & & $85 \%$ Perc $=$ & 11.5 & 9.8 & 7.6 & 7.2 & \\
\hline & & $90 \%$ Perc $=$ & 12.0 & 10.3 & 8.0 & 7.6 & \\
\hline & & $95 \%$ Perc $=$ & 12.5 & 11.1 & 8.5 & 8.2 & \\
\hline
\end{tabular}




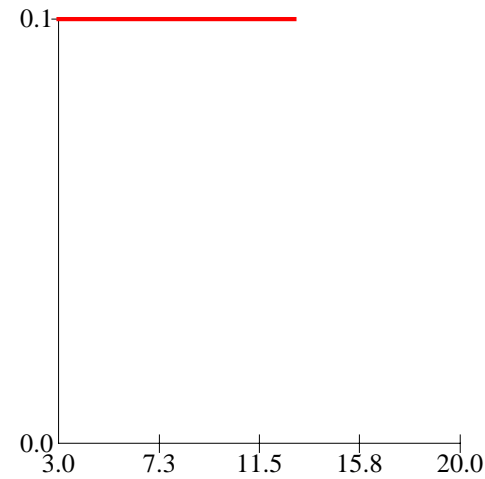

Event Counts: Uniform

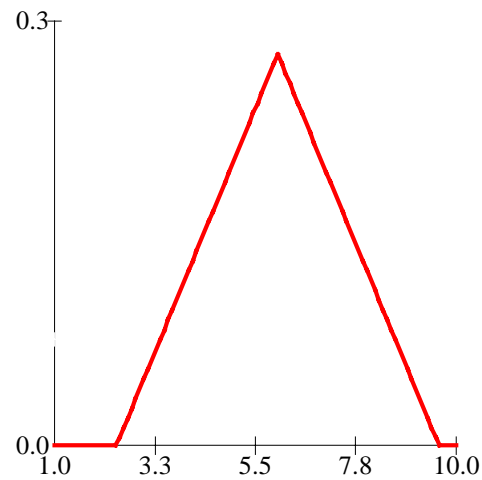

Event Counts: Trigen

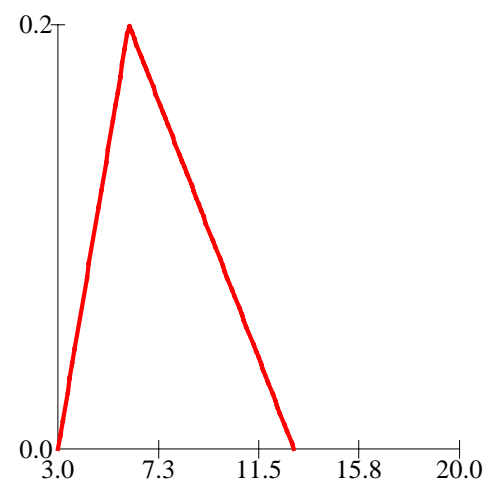

Event Counts: Triangle

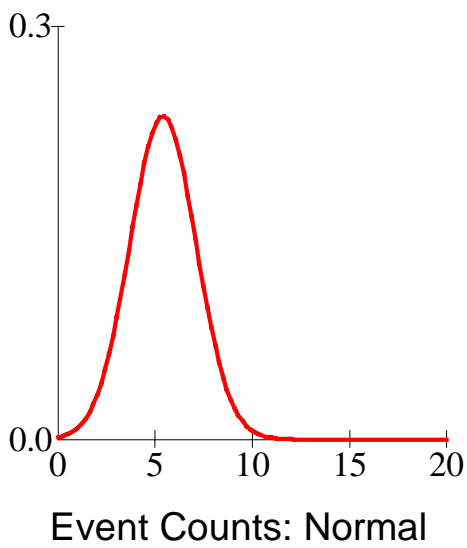

Figure 6.6. Probability distributions for the event-count simulations, aeromagentic anomalies of Crater Flat and Amargosa Valley.

3. The 3.7 Ma Centers: Basalt of Southeast Crater Flat. The 3.7 Ma basalt of southeast Crater Flat has been described by Vaniman and Crowe (1981), Vaniman et al. (1982), and is summarized in Crowe et al. (1995). The age of the centers is $3.74 \pm 0.10 \mathrm{Ma}$ (average of $2 s$ errors) using replicate, high-precision ${ }^{40} \mathrm{Ar} /{ }^{39} \mathrm{Ar}$ age determinations (Crowe et al., 1995) and this age has been reproduced at multiple K-Ar analytical laboratories (see for example, Fleck et al., 1996). The basalt of southeast Crater Flat is inferred to range from 1 event to as many as 8 events, with the most likely event counts assigned to the 2- or 3-event models. The 1-event, 10-percentile model is assumed on the basis of vent zones forming a N-S trending, en echelon fissure system (Crowe et al., 1995); the consistent geochronology data obtained for the unit (Crowe et al., 1995); and the apparent uniform field magnetization directions for the deposits (Champion, 1991). The 2event model is judged the most likely model because a minimum of two feeder dikes is needed to explain the vent distribution over a length of $4.8 \mathrm{~km}$. A 3-event model is given equal weighting because of the geometric requirement of two feeder dikes and the presence of a large eroded center at the north end of the vent alignment (Vaniman and Crowe, 1981) that probably represents a 
spatially separate volcanic center. The 90-percentile model (6 volcanic events) assumes each identified vent area or center represents a volcanic event and the maximum event count (8 volcanic events) assumes two undetected events. The undetected events are inferred to be concealed beneath the extensive alluvial cover of the eastern outcrops of the basalt unit. Crowe et al. (1995) reported an estimated volume of $0.7 \mathrm{~km}^{3}$ (DRE), whereas Fleck et al. (1996) reported a volume of $1.5 \mathrm{~km}^{3}$. This is a relatively large discrepancy in volume estimates and may be attributed partly to the density correction used by Crowe et al. (1995), as well as to different assumptions made concerning the subsurface distribution of the basalt of southeast Crater Flat. We base our interpretations of the distribution of the 3.7 Ma basalt of southeast Crater Flat on aeromagnetic data, results from drill hole USW-VH-1 and surface mapping. The reflector attributed to the 3.7 Ma basalt center by Brocher et al. (1996, submitted) and applied by Fleck et al. (1996) is too deeply buried to be associated with this basalt unit. Fleck et al. (1996) do not describe all assumptions used in their volume estimate. The results of simulation modeling of the event-count models for the 3.7 Ma basalt of southeast Crater Flat are summarized in Table 6.9, and the probability distributions for the event counts are plotted in Figure 6.7. The simulation parameters for the distributions are the same as Figure 6.2.

Minimum Event Bound: 0 events

10-Percentile Event Model: 1 event

Most Likely Event Model: 2 events

Normal Distribution Model: $2.0 \pm 0.9$ events

90-Percentile Event Model: 6 events

Maximum Event Bound: 8 events

Polygenetic Episodes: not applicable for the revised PVHA 
Table 6.9. Univariate Statistics and Percentiles from Simulation Modeling of Event Counts Using Alternative Probability Distributions for the 3.7 Ma Basalt of Crater Flat.

\begin{tabular}{|c|c|c|c|c|c|c|c|}
\hline \multirow{5}{*}{ Event Counts = } & Minimum & $10 \%$ & $\begin{array}{l}\text { Most } \\
\text { Likely }\end{array}$ & $90 \%$ & Maximum & Mean & Std Dev \\
\hline & 0.0 & 1.0 & 2.0 & 6.0 & 8.0 & 2.0 & 0.9 \\
\hline & \multicolumn{7}{|c|}{ Probability Distributions } \\
\hline & \multirow{3}{*}{$\begin{array}{r}\text { Uniform } \\
4.0\end{array}$} & Triangular & Trigen & Normal & & & \\
\hline & & 3.3 & 3.3 & 2.0 & & & \\
\hline & & Uniform & Triangle & Trigen & Normal & & \\
\hline & \multirow{5}{*}{$\begin{array}{l}\text { Minimum = } \\
\text { Maximum = } \\
\text { Mean }= \\
\text { Std Deviation = } \\
\text { Variance = }\end{array}$} & 0.0 & 0.0 & 0.0 & 0.0 & & \\
\hline & & 8.0 & 8.0 & 8.3 & 5.5 & & \\
\hline & & 4.0 & 3.3 & 3.3 & 2.0 & & \\
\hline & & 2.3 & 1.7 & 1.9 & 0.9 & & \\
\hline & & 5.3 & 2.9 & 3.5 & 0.8 & & \\
\hline & \multirow{2}{*}{$\begin{array}{l}\text { Skewness = } \\
\text { Kurtosis = }\end{array}$} & 0.0 & 0.4 & 0.4 & 0.0 & & \\
\hline & & 1.8 & 2.4 & 2.4 & 3.0 & & \\
\hline & Mode $=$ & 7.2 & 2.0 & 2.0 & 1.9 & & \\
\hline & $5 \%$ Perc $=$ & 0.4 & 0.9 & 0.6 & 0.5 & & \\
\hline & $10 \%$ Perc $=$ & 0.8 & 1.3 & 1.0 & 0.8 & & \\
\hline & $15 \%$ Perc $=$ & 1.2 & 1.5 & 1.3 & 1.1 & & \\
\hline & $20 \%$ Perc $=$ & 1.6 & 1.8 & 1.6 & 1.2 & & \\
\hline & $25 \%$ Perc $=$ & 2.0 & 2.0 & 1.9 & 1.4 & & \\
\hline & $30 \%$ Perc $=$ & 2.4 & 2.2 & 2.1 & 1.5 & & \\
\hline & $35 \%$ Perc $=$ & 2.8 & 2.4 & 2.3 & 1.6 & & \\
\hline & $40 \%$ Perc $=$ & 3.2 & 2.6 & 2.5 & 1.8 & & \\
\hline & $45 \%$ Perc = & 3.6 & 2.9 & 2.8 & 1.9 & & \\
\hline & $50 \%$ Perc $=$ & 4.0 & 3.1 & 3.1 & 2.0 & & \\
\hline & $55 \%$ Perc $=$ & 4.4 & 3.3 & 3.3 & 2.1 & & \\
\hline & $60 \%$ Perc $=$ & 4.8 & 3.6 & 3.6 & 2.2 & & \\
\hline & $65 \%$ Perc $=$ & 5.2 & 3.9 & 3.9 & 2.3 & & \\
\hline & $70 \%$ Perc $=$ & 5.6 & 4.2 & 4.3 & 2.5 & & \\
\hline & $75 \%$ Perc $=$ & 6.0 & 4.5 & 4.6 & 2.6 & & \\
\hline & $80 \%$ Perc $=$ & 6.4 & 4.9 & 5.0 & 2.8 & & \\
\hline & $85 \%$ Perc $=$ & 6.8 & 5.3 & 5.5 & 2.9 & & \\
\hline & $90 \%$ Perc $=$ & 7.2 & 5.8 & 6.0 & 3.1 & & \\
\hline & $95 \%$ Perc = & 7.6 & 6.4 & 6.7 & 3.5 & & \\
\hline
\end{tabular}




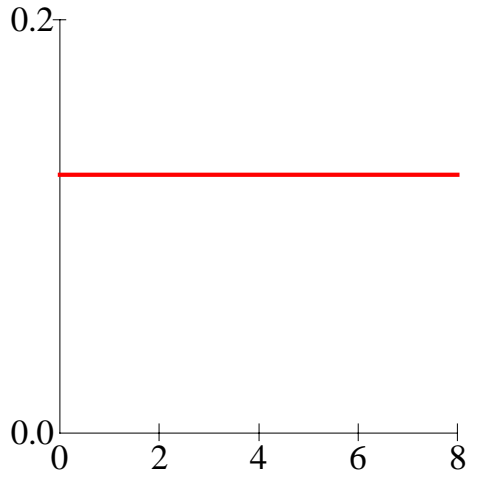

Event Counts: Uniform

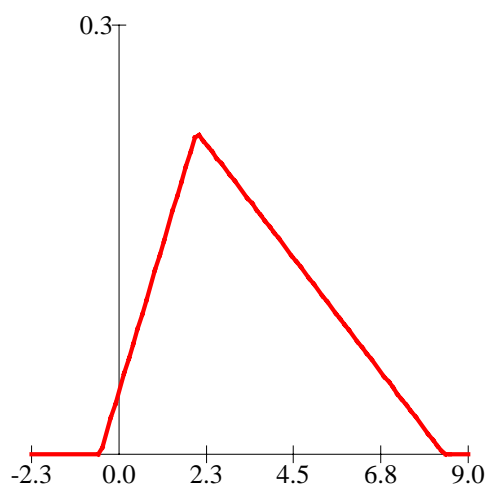

Event Counts: Trigen

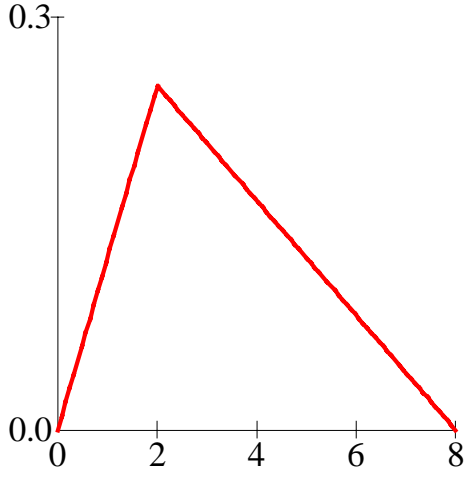

Event Counts: Triangle

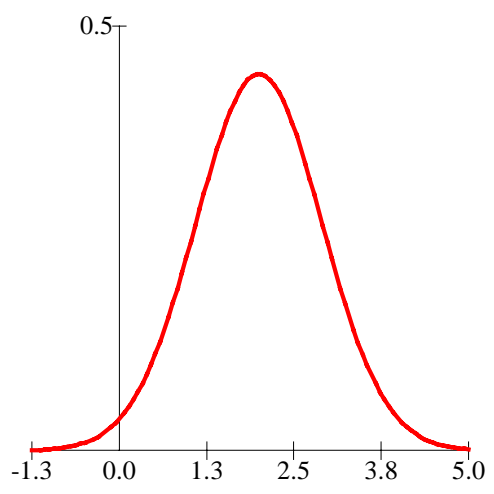

Event Counts: Normal

Figure 6.7. Probability distributions used for the event-count simulations, 3.7 Ma basalt of Crater Flat.

4. The 3.0 Ma Basalt of Buckboard Mesa. The U.S. Geological Survey has mapped the basalt of Buckboard Mesa, and the field contact relations for the center have been compiled at a scale of 1:24,000 on multiple geologic quadrangle maps. The geology of the center was described by Lutton (1968) and summarized in Crowe et al. (1995), Crowe and Perry (1995), and Fleck et al. (1996). Crowe and Perry (1995) reported whole rock ${ }^{40} \mathrm{Ar} /{ }^{39} \mathrm{Ar}$ ages of $3.08 \pm 0.02$ and $3.15 \pm 0.04$ Ma for samples collected from the basalt of Buckboard Mesa. Fleck et al. (1996) reported ages ranging from the 2.71 to $3.42 \mathrm{Ma}$ for the basalt of Buckboard Mesa and obtained a weighted mean age of $2.85 \pm 0.05$ Ma but discarded one sample (NNTS 15-86; see Fleck et al., 1996; their Table 6.1). We again prefer the Ar/Ar age determinations over the conventional K-Ar ages. However, the ages are similar and for this reason, we use an age of 3.0 Ma for the center, which is the arithmetic average of the Ar/Ar ages and the arithmetic mean reported by Fleck et al. (1996). The 10percentile and most likely event models for the center are a single-event model, and this model is based on the consistency in age determinations; the compositional uniformity of the basalt lavas in outcrop and in drill holes (Lutton, 1968; Crowe et al., 1986; 1995); and the presence of only a single, connected scoria cone and fissure system at the center (Scrugham Peak; Lutton, 1968; Crowe et al., 1995). A 2-event scenario is assigned for the 90-percentile model on the basis of the 
presence of an upper kaersutite-bearing lava flow northwest of Scrugham Peak, which can be mapped separately using geomorphology and phenocryst content to distinguish lava-flow units. An additional volcanic event is added to allow for an undetected event. However, this model is judged to have a low likelihood because of the results from extensive mapping and drill hole exploration in the Timber Mountain caldera as part of the investigations of the Nevada Test Site region and the observation that the basalt of Buckboard Mesa filled a topographic low and is now a topographic high (inverse topography). The volume of the basalt of Buckboard Mesa was estimated by Crowe et al. (1995) as $0.92 \mathrm{~km}^{3}$ (DRE); Fleck et al. (1996) reported a volume estimated of $1.3 \mathrm{~km}^{3}$. The minor differences in the volume estimations may be from different assumptions used to correct volumes to magma densities; Fleck et al. (1996) did not note whether their estimate was corrected to magma density. The results of simulation modeling for the event-count models for the basalt of Buckboard Mesa are summarized in Table 6.10, and the probability distributions for the event counts are plotted in Figure 6.8. The trigen and normal distributions could not be simulated because the limited variability in event counts does not allow assignment of required parameters for the distributions. The simulation parameters for the uniform and triangular distributions are the same as Figure 6.2.

Minimum Event Bound: 0 events

10-Percentile Model: 1 event

Most Likely Event Model: 1 events

90-Percentile Event Model: 2 events

Maximum Event Bound: 4 events

Polygenetic Episodes: not applicable for the revised PVHA 
Table 6.10. Univariate Statistics and Percentiles from Simulation Modeling of Event Counts Using Alternative Probability Distributions for the Basalt of Buckboard Mesa.

\begin{tabular}{|c|c|c|c|c|c|}
\hline \multirow[b]{2}{*}{ Event Counts = } & Minimum & $10 \%$ & $\begin{array}{l}\text { Most } \\
\text { Likely }\end{array}$ & $90 \%$ & Maximum \\
\hline & 0.0 & 1.0 & 1.0 & 2.0 & 4.0 \\
\hline \multicolumn{6}{|c|}{ Probability Distributions } \\
\hline & Uniform & Triangular & & & \\
\hline \multirow[t]{29}{*}{ Exp Value $=$} & 2.0 & 1.7 & & & \\
\hline & & Uniform & Triangle & & \\
\hline & Minimum = & 0.0 & 0.0 & & \\
\hline & Maximum = & 4.0 & 4.0 & & \\
\hline & Mean = & 2.0 & 1.7 & & \\
\hline & Std Deviation = & 1.1 & 0.8 & & \\
\hline & Variance $=$ & 1.3 & 0.7 & & \\
\hline & Skewness = & 0.0 & 0.4 & & \\
\hline & Kurtosis $=$ & 1.8 & 2.4 & & \\
\hline & Mode $=$ & 1.3 & 1.0 & & \\
\hline & $5 \%$ Perc $=$ & 0.2 & 0.4 & & \\
\hline & $10 \%$ Perc $=$ & 0.4 & 0.6 & & \\
\hline & $15 \%$ Perc $=$ & 0.6 & 0.8 & & \\
\hline & $20 \%$ Perc = & 0.8 & 0.9 & & \\
\hline & $25 \%$ Perc = & 1.0 & 1.0 & & \\
\hline & $30 \%$ Perc $=$ & 1.2 & 1.1 & & \\
\hline & $35 \%$ Perc $=$ & 1.4 & 1.2 & & \\
\hline & $40 \%$ Perc $=$ & 1.6 & 1.3 & & \\
\hline & $45 \%$ Perc $=$ & 1.8 & 1.4 & & \\
\hline & $50 \%$ Perc $=$ & 2.0 & 1.5 & & \\
\hline & $55 \%$ Perc $=$ & 2.2 & 1.7 & & \\
\hline & $60 \%$ Perc $=$ & 2.4 & 1.8 & & \\
\hline & $65 \%$ Perc $=$ & 2.6 & 1.9 & & \\
\hline & $70 \%$ Perc = & 2.8 & 2.1 & & \\
\hline & $75 \%$ Perc = & 3.0 & 2.3 & & \\
\hline & $80 \%$ Perc $=$ & 3.2 & 2.4 & & \\
\hline & $85 \%$ Perc = & 3.4 & 2.7 & & \\
\hline & $90 \%$ Perc = & 3.6 & 2.9 & & \\
\hline & $95 \%$ Perc = & 3.8 & 3.2 & & \\
\hline
\end{tabular}




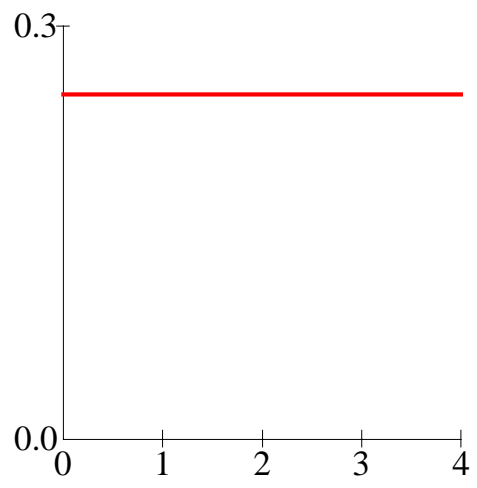

Event Counts: Uniform

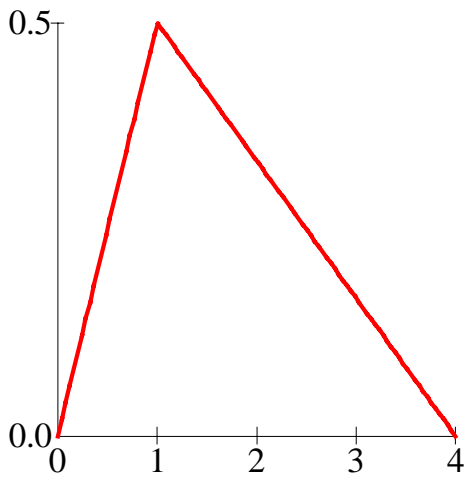

Event Counts: Triangle

Figure 6.8. Probability distributions used for the event-counts simulations, basalt of Buckboard Mesa.

The following observations are derived from examination of the data in Tables 6.4-6.10 and Figures 6.2-6.8:

1. There is very limited variability in event counts from different model assumptions for volcanic events marked by a single volcanic center (Thirsty Mesa, Buckboard Mesa).

2. The maximum variability in event counts from different model assumptions is for the aeromagnetic anomalies of the Amargosa Valley, the 3.7 Ma basalt of Crater Flat, and the 1.0 Ma Quaternary basalt of Crater Flat. The variability reflects increased options in interpreting volcanic events from combinations of burial, erosional removal of parts of volcanic center, or the presence of multiple spatial centers of probable similar age.

3. The treatment of event counts as probability distributions that incorporate a range of model assumptions removes or minimizes the interpretative issues concerning event counts that have been debated excessively and cannot be resolved with existing data. The limited variability in even-count distributions continue to support the judgment that alternative event-count models are not a major source of variance in PVHA (Crowe et al., 1995; Geomatrix, 1996).

4. The mean and standard deviation of event counts decreases generally in systematic order consisting of: Uniform>Triangular >Trigen>Normal. The one exception is the basalt of Sleeping Butte where the mean and standard deviation are higher for the normal distribution. Note that the higher mean and standard deviation values for the uniform and triangular distributions are controlled partly by bounding values outside the distributions and incorporation of estimates of undetected events (estimates of undetected events are also included in the normal distributions).

5. The smallest mean and standard deviations of the event counts are for the normal distribution with the exception of the basalt of Sleeping Butte; these results are from limited variance in event counts among individual members of the expert judgment panel and different treatment in the parameters assigned to the distributions (compared to the 
uniform, triangular and trigen distributions; see following sections and Table 6.13 for further discussion of the normal distributions).

6. The event distributions are used in modeling of probability estimates for $\mathrm{E} 1$ and $\operatorname{Pr}[(\mathrm{E} 2$ given $\mathrm{E} 1) \operatorname{Pr}(\mathrm{E} 1)]$ in following sections of this report.

\section{Revised Probability Modeling}

This section presents results of probabilistic modeling of variables of the PVHA and does not result in revised probability estimates. These estimates are provided by the PVHA study, which used formal methods of expert judgment and integrated the results of many years of volcanic hazard studies (Geomatrix, 1996). The purposes of this section are to continue to explore the scientific basis for probabilistic assessments, continue examinations of alternative temporal and spatial models for PVHA and provide an additional reference document for future suitability and regulatory assessments by the DOE.

Several important modifications have been made to the VSR (Crowe et al., 1995) in this chapter. Multiple reports (Sheridan, 1992; Wallmann, 1993; Crowe et al., 1993, 1995; Golder Associates, 1995) show that there is a large number of alternative models for E2, the disruption probability. Furthermore the probability distributions for E2 are somewhat more sensitive to alternative models than are the probability distributions for E1, the recurrence rate (Crowe et al., 1995). The revised PVHA for this report provides evaluations of the importance of alternative models on estimates of the probability of magmatic disruption of the Yucca Mountain site. These evaluations apply a concept of volcanic zones (assuming zones can be identified) that enclose the distribution of Pliocene and Quaternary volcanic events in the southern Great Basin. A significant inferred characteristic of an identified volcanic zone is that the recurrence rate of volcanic events inside the zone is greater than the recurrence rate outside the zone. Thus a probability step or gradient must bound a volcanic zone; the nature of the boundary is dependent on the zone type (spatial or structural zone) and the data used to define the boundary geometry. In practice, volcanic zones can be identified using a combination of assessments of the spatial distribution of volcanic centers and the tectonic-structural features of both the regional and local setting. The resulting volcanic zones can have distinct and abrupt structural boundaries that can be readily identified and mark an abrupt probability decrease at the zone boundary.

Alternatively, some zone boundaries may be difficult to identify and there is uncertainty in their location. A particularly important aspect of assessment of volcanic zones involves the location of the Yucca Mountain site relative to the boundaries of the volcanic zones. The Yucca Mountain site is located outside of but near to the boundaries of most volcanic zones established using spatial and structural criteria (Crowe et al., 1995; Geomatrix, 1996). A weakness of past PVHA was in how the probability of magmatic disruption was assessed when the Yucca Mountain site was located outside of a volcanic zone. The general approach, in these cases, was to expand somewhat arbitrarily the boundaries of volcanic zones so that the site was included in the zones (see Connor and Hill 1995 for an alternative solution to this problem). To address this weakness, we have revised the methods of assessing E2 and used a modification of the approaches of Sheridan (1992) and Wallmann (1993). These revised studies have been implemented using simulation modeling, where volcanic events are assigned dimensions of feeder dike systems associated with volcanic centers. Intersection of the Yucca Mountain site, through the simulation modeling, can occur either from direct intersection of a repository by a volcanic event (point source), or by intersection of a repository or identified area of a repository system by a subsurface feeder dike. 
An important and major result of PVHA from Crowe et al. (1995, Chapter 7) is the recognition that the spatial and structural models of basaltic volcanism used to assess the disruption ratio (E2) also provide indirect controls on the recurrence rate of volcanic events (E1). The primary effect is that the individual models of E2 are used to establish whether specific volcanic events should or should not be included in estimates of E1. The effects on E1 are nonsystematic and vary according to individual spatial or structural models (Crowe et al., 1995). To better account for this linkage between E2 and E1, we have reversed the order of discussion of parameters of the conditional probability of magmatic disruption. Spatial and structural aspects of the conditional probability (E2) are considered first followed by an evaluation of recurrence rates (E1) for specific models of E2.

\section{A. Revised Estimations of E2: the Disruption Probability}

The region of interest for PVHA is the southern Great Basin with the Yucca Mountain site located in an interior part of the southern Great Basin. This region is characterized by lower rates of extensional tectonism and Quaternary volcanism compared to the active margins of the Great Basin (Best and Brimhall, 1974; Smith and Luedke, 1984; Crowe et al., 1995). The definition of the geometry of the region of interest in the southern Great Basin is variable and depends on the criteria used to identify the regional boundaries (for example, tectonic, chronology, or geochemical data). Generally, the defined area of interest is within the region located east of Death Valley, south of the southern end of the Reveille Range, north of the south end of the Amargosa Valley, and east of the eastern boundary of the Nevada Test Site. A comprehensive set of alternative definitions of the area of interest for application to PVHA was presented in the volcanism expert judgment report (Geomatrix, 1996). These areas were not used directly in PVHA (Geomatrix, 1996) but are important for establishing background rates of volcanic activity that can be used to bound the probability of magmatic disruption of a potential repository (Crowe, 1995b; see also a following section on bounding probability estimates).

Individual volcanic zones can be drawn that enclose and define areas of higher recurrence rates of small volume basaltic volcanic centers within the broadly defined region of interest. Many different zones can be identified, and multiple alternative models of spatial and structural zones have been proposed by numerous investigators including Crowe et al. (1982, 1993, 1995), Ho et al. (1991), Sheridan (1992), Wallmann (1993), Connor and Hill (1995), Golder Associates (1995) and Geomatrix (1996).

The purpose of this section is to describe the results of studies that were conducted during FY95 using the discrete feature simulation and analysis capabilities of the FracMan code (Dershowitz et al., 1995). This computer code, which is primarily a rock mechanics code, was used as a tool to estimate the probability of magmatic disruption of the Yucca Mountain site for specific spatial and structural zones (Crowe, 1995a; Golder Associates, 1995). The FracMan code was used to generate discrete planar features as a means for simulating the formation of dikes in a three-dimensional volume that enclosed the Yucca Mountain site (Golder Associates, 1995). Dikes were distributed within a FracMan sub-volume and each sub-volume corresponds to defined spatial and structural volcanic zones. Dikes in the simulations were treated as rectangular and circular features with specified parameters of length, height, and orientation. The volcanic zones used in the FracMan simulations are from spatial and structural models developed for the YMR and summarized in Crowe et al. (1995; Tables 7.13-7.15). 
Several changes were made to the models. First, models involving detachment or caldera systems were eliminated on the basis of the data summarized in Crowe et al. (1995; Chapter 3) and Brocher et al. (1996). Second, related models were combined resulting in the definition of seven zones and these zones were used for the simulation modeling of magmatic disruption of a repository and repository system. The volcanic zones included in the simulations do not represent every possible volcanic zone that can be identified for the YMR and instead were chosen to represent a spectrum of possible spatial and structural zones.

1. Spatial Zone. The Quaternary CFVZ of Crowe and Perry (1989). This volcanic zone is an irregular polygon drawn by enclosing the area defined by the distribution of all Quaternary volcanic centers in the YMR (Golder Associates, 1995; their Figure 2.2). Boundaries of the zones cannot be consistently identified from structural, topographic, or geophysical features but are uniquely constrained from the distribution and locations of Quaternary volcanic centers. The trend of the spatial zone is NNW, and concealed features of the Walker Lane structural zone may control its location and orientation. The Yucca Mountain site is adjacent to but outside of the CFVZ. The boundaries of the zone are fixed by the distribution of Quaternary basalt centers and are unlikely to change with additional site characterization data.

2. Spatial Zone. The Pliocene and Quaternary CFVZ of Crowe and Perry (1989). This volcanic zone is drawn by enclosing the area defined by the distribution of all Pliocene and Quaternary volcanic centers and aeromagnetic anomalies inferred to represent buried Pliocene volcanic centers in the YMR, excluding the basalt of Buckboard Mesa (Golder Associates; their Figure 2.3). Boundaries of the zone cannot be defined consistently by structural, topographic or geophysical features. The trend of the spatial zone is NNW, parallel to structural features of the Walker Lane system. The southern boundaries of the volcanic zone in the Amargosa Valley are defined assuming all aeromagnetic anomalies of Crater Flat and the Amargosa Valley are produced from buried volcanic centers of Pliocene age or younger. The Yucca Mountain site is adjacent to but outside of the volcanic zone. The boundaries of the Pliocene-Quaternary CFVZ are uniquely fixed by the distribution and location of volcanic centers except on the southeast part of the zone, where the anomalies have not been investigated through exploratory drilling. The geometry of the southern part of the zone could change if, for example, all the aeromagnetic anomalies of the Amargosa Valley are not of Pliocene age. (Note: During final editing of this report and after completion of the simulation modeling described in the following section, we discovered that not all the aeromagnetic anomalies of the Amargosa Valley were included in this spatial zone. Inclusion of all anomaly sites would slightly increase E1 but significantly decrease E2 because the added area is distant from the Yucca Mountain site).

3. Spatial Zone. The Pliocene and Quaternary YMR. This volcanic zone is drawn by enclosing the area defined by the distribution of all Pliocene and Quaternary volcanic centers and aeromagnetic anomalies inferred to represent buried Pliocene volcanic centers in the YMR (Golder Associates; their Figure 2.4). It is nearly identical in concept and boundaries to the Case 1a model of Crowe et al. (1982) and the AMRV of Smith et al. (1990). Boundaries of the YMR, like other spatial volcanic zones do not correspond directly to structural, topographic or geophysical zones. A separate YMR zone defined by the distribution of Quaternary volcanic centers in the YMR is not included in the simulation modeling because the zone is identical to the Quaternary CFVZ. The Yucca Mountain site is included in the YMR zone. The boundaries of the YMR zone are uniquely defined by the distribution of Pliocene and Quaternary volcanic centers and aeromagnetic anomalies inferred to represent buried basalt centers. The only uncertainty in the zone boundaries is 
on the south end, where aeromagnetic anomalies have not been investigated through exploratory drilling.

4. Structural Zone. The Quaternary Crater Flat Pull-Apart basin. This structural zone is drawn to include the topographic basin of Crater Flat and the area immediately surrounding the Lathrop Wells volcanic center; the zone is based on the structural model of the Crater Flat basin by Fridrich (in press; Golder Associates, their Figure 2.5). The zone boundaries coincide partly with the physiographic boundaries of the Crater Flat basin and with a composite of structural features. The western margin of the pull-apart basin is defined by the frontal fault system of Bare Mountain and the extrapolated continuation of this structure to the southeast following linear gravity gradients in the Amargosa Valley. The eastern boundary of the pull-apart basin is not well defined and is drawn using a combination of changes in topography, paleomagnetic data, and the location of the eastern-hinge line of the Crater Flat basin (Fridrich, in press). The location and geometry of the bounding features of the basin have been confirmed in the central part of the basin using the results of seismic reflection and refraction studies (Brocher et al., 1996, in press) and are partly confirmed in other areas though gravity data (Oliver and Ponce, 1995). The Quaternary Crater Flat basin is inferred to be an area of continuing extension, where basaltic volcanic centers occur preferentially above the deepest, and presumably, most rapidly extending part of the Crater Flat basin (Fridrich, in press). Additionally, the southeast part of Yucca Mountain is inferred to be an area of continuing extension (Menges et al., 1994; Fridrich, in press; see expert judgment elicitation of George Thompson in Geomatrix, 1996). The Yucca Mountain site is located adjacent to but outside of the Crater Flat pull-apart basin.

5. Structural Zone. The Pliocene and Quaternary Crater Flat Pull-Apart basin. This volcanic zone is identical to the Quaternary pull-apart basin but is extended to the south to include the aeromagnetic anomalies of the Amargosa Valley (Langenheim, 1995; Golder Associates, their Figure 2.6). The constraints on the location of the zone boundaries are identical to the Quaternary pull-apart model for the Crater Flat basin. South of Crater Flat, the zone boundaries are bounded by the projection of the Bare Mountain range fault, the south projection of the gravity fault of Jackass Flats (Fridrich, in press), and the distribution of aeromagnetic anomalies in the Amargosa Valley (Langenheim, 1995). The Yucca Mountain site is located adjacent to but outside the northeast boundary of the Pliocene and Quaternary pull-apart basin.

6. Structural Zone. The Walker Lane shear zone (WLSZ). The WLSZ is a volcanic zone defined by largely inferred structural features of the Walker Lane system (Golder Associates, their Figure 2.6). Its boundaries are drawn parallel to NW trending structural features of the WLSZ, which are inferred to be present in the YMR largely on the basis of analogy with other areas of the WLSZ and also from the identification and geometry of magnetotelluric conductor zones (Klein, 1995). The zone has similar boundaries on the southeast as the Pliocene and Quaternary pull-apart basin. On the north, its boundaries are marked by the topographic basin of Sarcobatus Flat that is contiguous with the location of the basalt centers of Sleeping Butte. Extension of the zone northwest of the Crater Flat basin is somewhat speculative but is drawn to largely follow basin topography. Zone boundaries are largely inferential and are drawn to enclose the Crater Flat basin and part of the basins of Amargosa Valley and Sarcobatus Flats. This model assumes that basalt magma ascends preferentially along largely hidden structures of the Walker Lane structural system. The Yucca Mountain site is outside of but adjacent to the northeast edge of the WLSZ.

7. Structural Zone. Northeast-trending structural zone (NESZ). The northeast-trending structural zone is a composite zone of the models of Wright (1989), Smith et al. (1990), and Carr 
(1990) as shown in Golder Associates (1995), their figure 2.8. The northern boundary of the zone is defined by sets of closely spaced faults of Pahute Mesa (Carr, 1990), and the zone includes the basalt of Buckboard Mesa (Smith, 1990). It is extended to the south across largely crosscutting structure of the Timber Mountain-Oasis Valley complex. The eastern boundary follows Fortymile Wash and the gravity structure; the western boundary is defined by the Bare Mountain fault. The boundaries of the zone on the south are drawn to include the aeromagnetic anomalies of the Amargosa Valley, with the southwest boundary drawn parallel to steep linear gradients in the Bouguer gravity field that extend from and parallel the Bare Mountain fault. The Yucca Mountain site is included in the structural zone. The south end of the zone is constrained by the location of aeromagnetic anomalies in the Amargosa Valley.

\section{B. Simulation Modeling for E2, the Probability of Magmatic Disruption of the Yucca Mountain site.}

Golder Associates (1995) used simulation modeling to assess sensitivity in E2 for individual volcanic zones and for the geometry of basaltic volcanic events that could disrupt a potential repository site. Each volcanic zone used in the modeling is assumed to be $2000 \mathrm{~m}$ thick extending downward from the surface. Dike generation occurs at random sites within the volume defined by the volcanic zones described in the previous section. Three sub-volumes within the simulation volume are monitored for intersection by dikes during the simulations. They are 1) an area corresponding to a high-temperature repository (Hrep), 2) an area corresponding to a lowtemperature repository (Lrep) and 3) an area surrounding a repository that would be affected by emplacement of a basaltic dike (Srep). The areas of the high- and low- temperature potential repository outlines are treated as squares in the simulations and the area estimates are from Wilson et al. (1994) $\left(2.3 \mathrm{~km}^{2}\right.$ for the high-temperature repository and $4.6 \mathrm{~km}^{2}$ for the low-temperature repository). The area surrounding a repository is treated as a square whose boundaries are drawn $2.5 \mathrm{~km}$ from each edge of the outline of the low-temperature repository. The $2.5-\mathrm{km}$ boundary is a maximum standoff distance established from modeling studies of the effects of volcanic eruptions and magmatic intrusion on a potential repository system (Rosenberg et al., 1995). This standoff zone (Srep), coupled to the dimensions of the Lrep, give an area of $51 \mathrm{~km}^{2}$ that is monitored for dike intrusion during simulations.

Dikes are approximated as planar, rectangular features with dimensions of length, height, and orientation (Golder Associates, 1995). Three distribution types were used for selecting dike lengths: uniform, normal, and lognormal; dikes were also classified as simple and complex. Simple dikes are represented as single-continuous features; complex dikes are represented in the simulations by a single feature that represents a swarm of dikes that may or may not be interconnected. The dike lengths for the dike simulations are summarized in Tables 2-1 to 2-3 of Golder Associates (1995). Minimum and maximum dike lengths for uniform distributions range from 0.5 to $7 \mathrm{~km}$ for simple dikes and 0.5 to $14.6 \mathrm{~km}$ for complex dikes. Dike lengths for normal distributions were simulated with respectively, means and standard deviations of $2.0 \pm 2.0 \mathrm{~km}$ for simple dikes and $2.0 \pm 4.0 \mathrm{~km}$ for complex dikes. Dike lengths for lognormal distributions vary from means of 1.5 to $3.5 \mathrm{~km}$ with standard deviations of 1.0 to $3.0 \mathrm{~km}$ for simple dikes and means of 1.6 to $3.6 \mathrm{~km}$ with standard deviations of 3.0 to $5.0 \mathrm{~km}$ for complex dikes. A minimum dike length of $500 \mathrm{~m}$ was used for both the normal and lognormal distributions. A base case was established for each distribution type on the basis of an analysis of the spacing of volcanic centers in volcanic clusters for Pliocene and Quaternary volcanic centers of the YMR. Alternative dike dimensions that are different from the base case were used in the simulation modeling as a tool to assess the sensitivity of the disruption probability; the assigned values are not necessarily supported or required by data for the YMR. 
Dike height is not well constrained by field observations, and a uniform distribution was used for the simulation modeling with dike heights ranging from 0.5 to $3.0 \mathrm{~km}$ (Golder Associates; their Table 2-4). Dike orientations were treated as a bivariate normal distribution with a mean pole trend of $(115,0)$ and a standard deviation of $10^{\circ}$ for both trend and plunge (Wallmann, 1993). All sets of combinations of data values and distribution types for combinations of dike parameters are summarized in Table 2-5 of Golder Associates (1995).

Two hundred ninety-four simulation sets were run using different combinations of volcanic zones and dike parameters for the sensitivity studies of E2 (42 assigned parameter sets for dikes for each of the seven volcanic zones). Each simulation run involved 100 realizations with 10,000 dikes randomly generated for each realization. These data are summarized in a data report with an accompanying data appendix that presents summary graphs for all the simulation data (Golder Associates, 1995). The following general comments and observations are from assessment of the simulation data (modified from Golder Associates, 1995):

1. Some combinations of parameter sets for individual volcanic zones do not result in intersection of the repository areas and give disruption probabilities of $<10^{-4}$ (no intersections in 10,000 iterations). Generally these cases are for shorter dike lengths and/or small standard deviations for dike lengths and apply to volcanic source zones that do not include the Yucca Mountain site.

2. There is a logical ordering of disruption probabilities that follows directly the intersection area of a repository or repository system. This ordering is Hrep $\leq$ Lrep $\leq$ Srep.

3. The disruption probability for the seven defined volcanic zones follows generally the relationship: Quat CFVZ $\leq$ Plio-Quat CFVZ $\leq$ WLSZ $\leq$ Plio-Quat Pull-Apart $\leq$ Quat Pull-Apart $\leq \mathrm{NESZ} \cong \mathrm{YMR}$.

4. The YMR and NESZ volcanic zones generally give the greatest number of intersections (highest disruption probability) because a repository and repository system are included in the volcanic zones. The next highest number of intersections is for zones that do not include a repository or repository system but have eastern boundaries that are closest to repository boundaries.

5. The Quaternary pull-apart model generally yields the largest disruption probabilities for volcanic zones that do not include a repository or repository system. This relationship is explained by the observation that the volcanic zone is near the Hrep, Lrep, and Srep zones, and the pull-apart models occupy a small volume compared to other volcanic zones that do not include the Yucca Mountain site. Thus, dike generation is focused in a volume region that has a higher chance of intersection of the Hrep, Lrep, and Srep.

6. Conceptually, the intersection probability is generally proportional to the ratio of the volume of a zone where a disruptive dike can be generated (critical intersection volume [CIV]) to the total volume of the volcanic zone. This ratio cannot be established $a$ priori because it is dependent on dike lengths and dike orientation. This is an important new observation developed from assessing the geometry of a volcanic event through simulation modeling. Previous studies used a point source representation of 
events and attempted to account for the dimensions of an event by expanding a repository area. By assigning event lengths, event heights, and event orientations to disruptive volcanic events, the probability of disruption for a point $(\mathrm{x}, \mathrm{y})$ varies with distance from the monitored intersection area, dike orientation and dike height.

7. The concept of a CIV developed from the simulation modeling is similar to the observation by Geomatrix (1996) that the probability of repository intersection for a dike of length $(l)$ is determined by the azimuth range of the dike orientation. Geomatrix (1996) used a geometrical solution for calculating the probability of intersection of a repository and repository system that was conditioned on distributions for event lengths and event locations obtained through expert judgment.

8. Simulation modeling using uniform distributions reveals that simple dikes show a nonlinear increase in disruptive probability with increased length and height for the Hrep and Lrep whereas the probability of disruption of a repository system varies linearly with the same dike parameters. Modeling of complex dikes shows linear variability for the probability of disruption of the Hrep, Lrep, Srep; and simulations that used complex dikes with lognormal distributions show increased sensitivity to dike height. Generally, the greatest parameter sensitivity in the modeling results from increasing dike length and/or the standard deviation of dike length. These changes can result in an order of magnitude increase in the disruption probability.

9. The importance of using different volcanic zones in the simulation modeling can be large, and comparison of minimum and maximum disruption probabilities from all simulations can vary by more than two orders of magnitude. These differences persist but are reduced when event rates are coupled with the disruption probability, and they illustrate the importance of ensuring that event rates are applied for specific models of volcanic zones.

10. Dike lengths used in the simulation modeling (Golder Associates, 1995) are based on the observed spacing of volcanic centers in the YMR. These lengths tend to be shorter than the dike-length estimations of the expert panel described in the report by Geomatrix (1996). These differences should be considered when comparisons are made of the results from the different studies.

Figures 6.9 through 6.11 are plots of the mean estimates with one $\sigma$ error bars generated from the 10,000 iterations of dike generation for the probability of disruption of, respectively, the Hrep, Lrep, and Srep. The data are separated into categories corresponding to the seven volcanic zones. These plots were assembled with a subset of the simulation data (simple dike forms) and illustrate the major patterns of data variation in the disruption probability for the volcanic zones. The asymmetry and large error bars for the minimum values of the plotted disruption ratios are from the limitation in the number of realizations used in the simulations. The estimates of the probability of disruption follow the general ordering described above (Quat CFVZ $\leq$ Plio-Quat CFVZ $\leq$ WLSZ $\leq$ Plio-Quat Pull-Apart $\leq$ Quat Pull-Apart $\leq \mathrm{NESZ \cong YMR).} \mathrm{The} \mathrm{shape} \mathrm{of} \mathrm{the} \mathrm{curve}$ obtained by connecting the mean estimates of ordered volcanic zones is generally similar for the three plots. The only significant variability in the plots is for the Quaternary pull-apart 


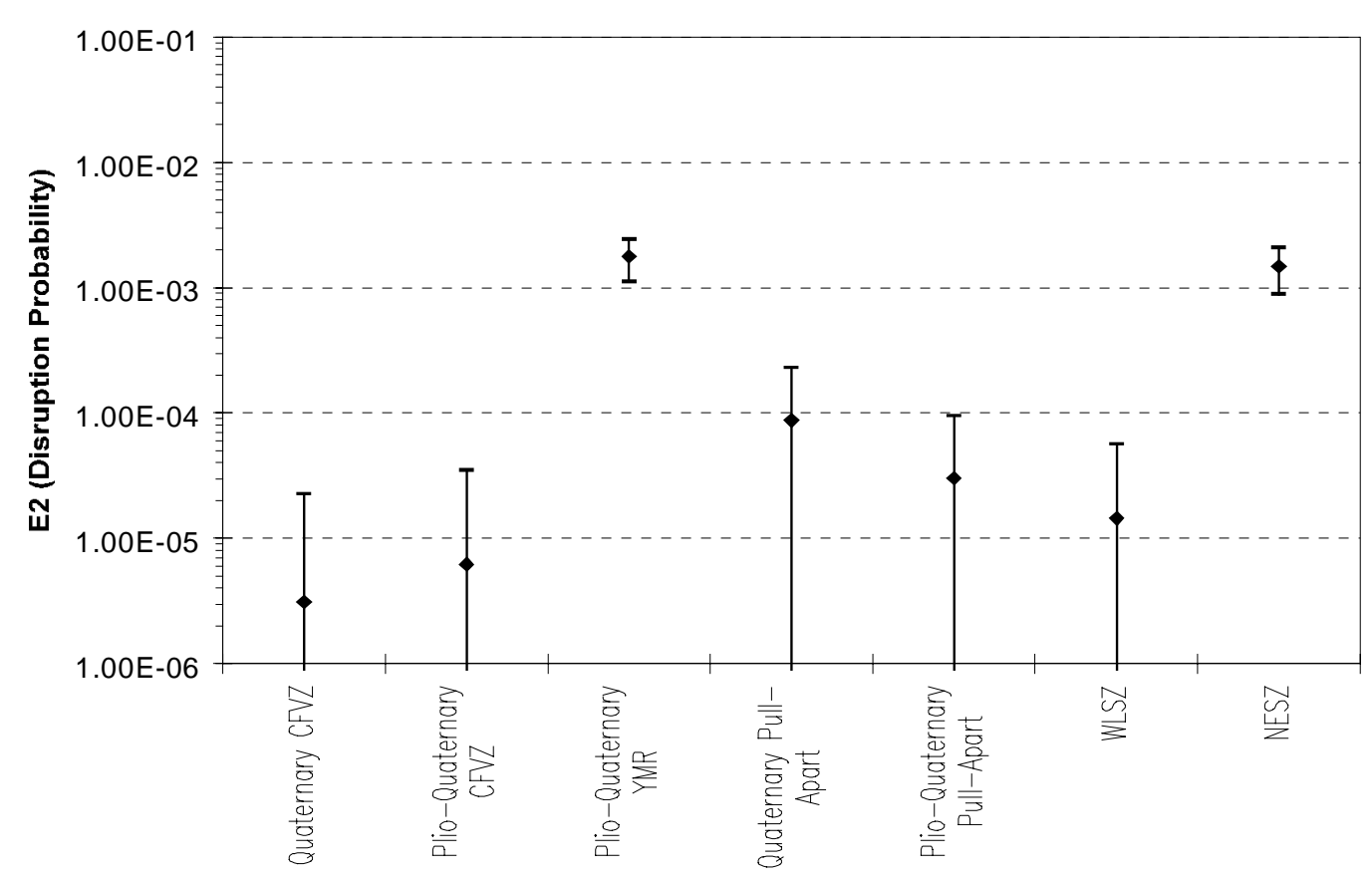

Figure 6.9 Simulated Disruption Probabilities (E2) for the High Temperature Repository (data from simulations using simple dike forms).

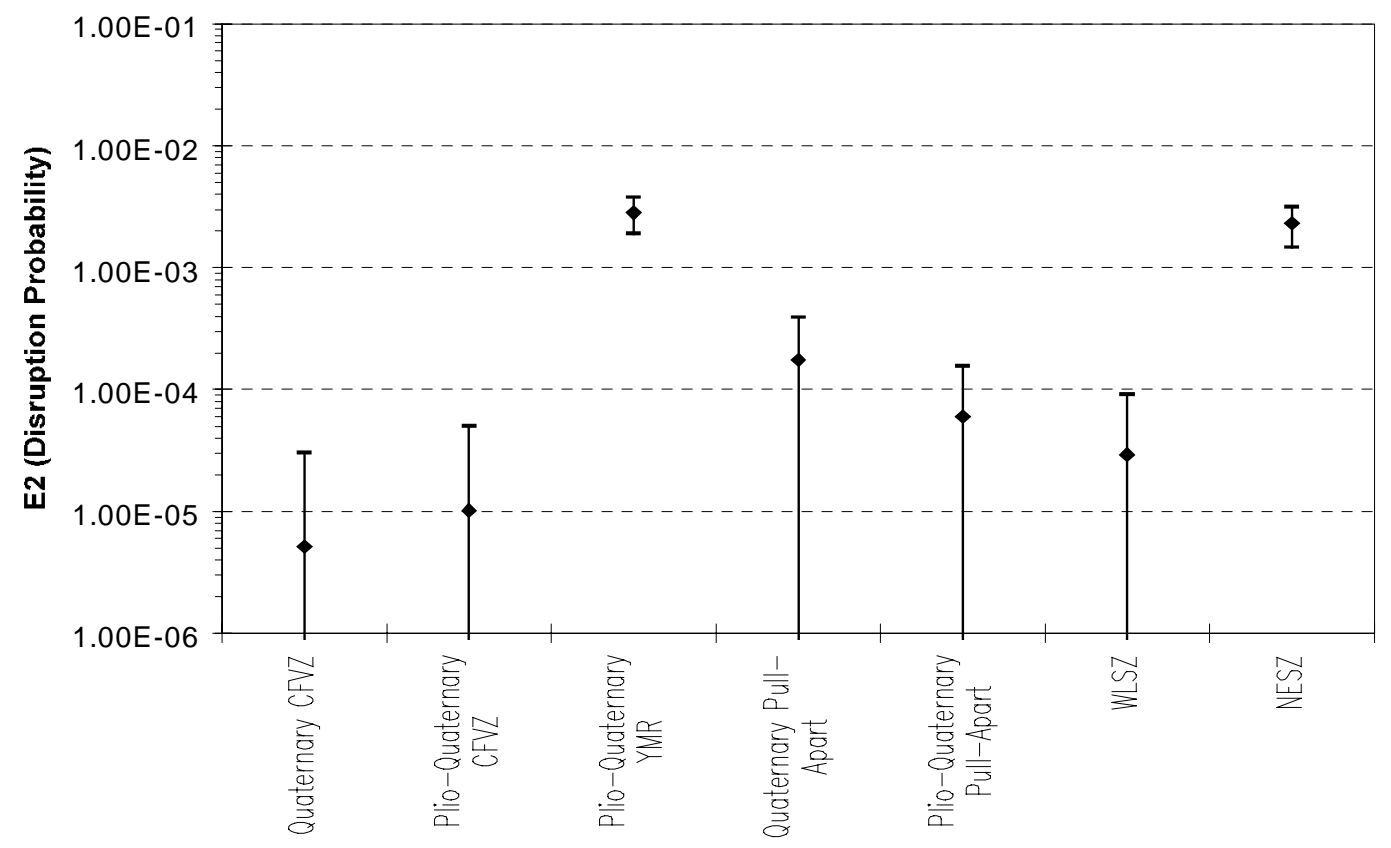

Figure 6.10 Simulated Disruption Probabilities (E2) for the Low Temperature Repository(data from simulations using simple dike forms). 


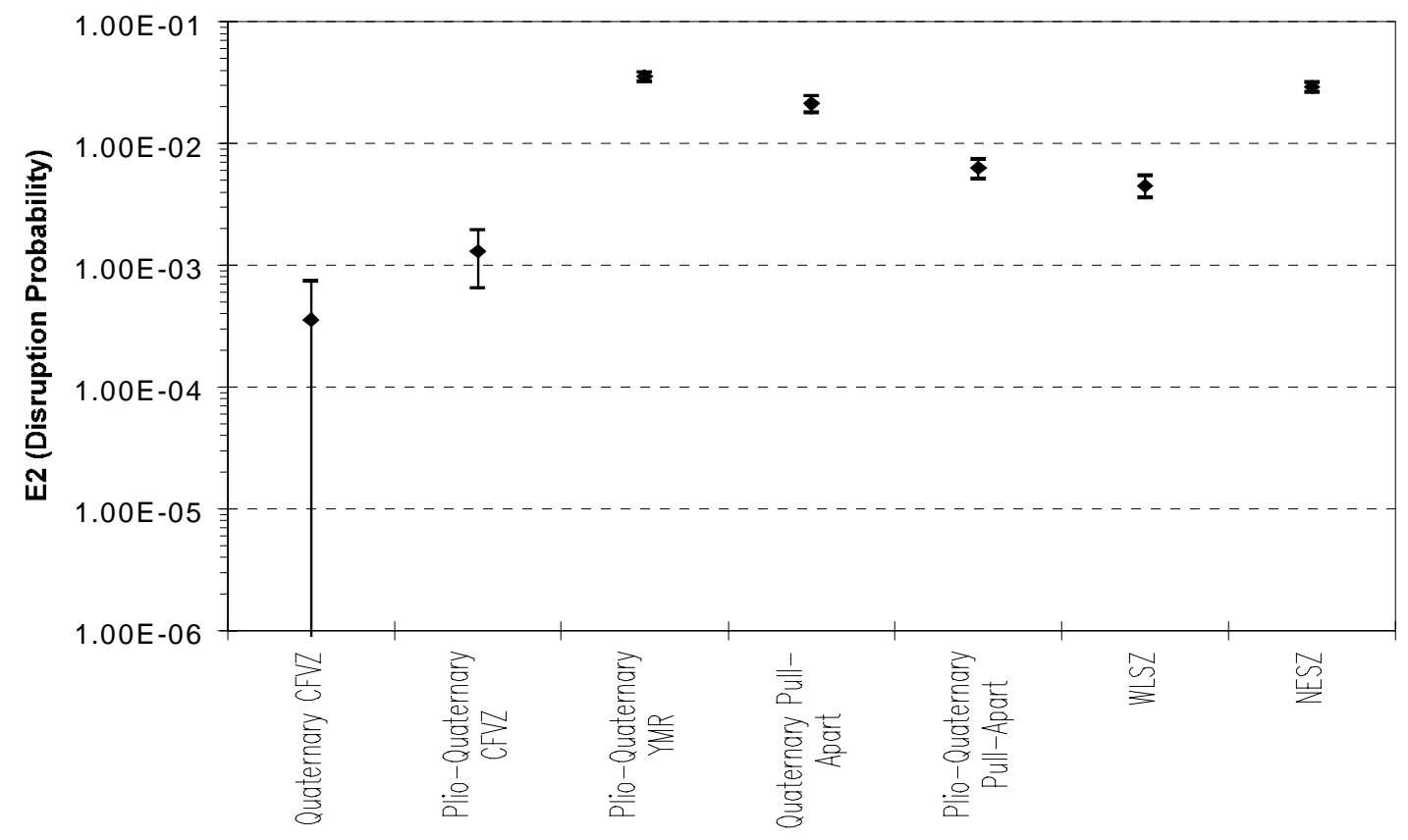

Figure 6.11. Simulated Disruption Probabilities (E2) for the Repository System (data from simulations using simple dike forms).

model. Here, the disruption probability is shifted closer to the values for the volcanic source models that include repository and repository zones for the Srep and this shift is caused by two features (Golder Associates, 1995):

1. The close proximity and overlap of the northeast boundary of the Quaternary pullapart mode with the outlines of the Srep.

2. The large CIV of the Quaternary pull-apart model.

Table 6.11 summarizes the mean estimates of the probability of disruption for the Hrep, Lrep, and Srep by volcanic zone using all simulation sets from the FracMan simulations. Mean estimates of the probability of magmatic disruption range from $1.9 \times 10^{-5}$ to $2.4 \times 10^{-3}$ for the Hrep, $3.1 \times 10^{-}$ ${ }^{5}$ to $3.7 \times 10^{-3}$ for the Lrep and $2.0 \times 10^{-3}$ to $4.0 \times 10^{-2}$ for the Srep. Mean estimates for all volcanic zones (equally weighted) are $7.8 \times 10^{-4}$ for the Hrep, $1.2 \times 10^{-3}$ for the Lrep, and $1.8 \times 10^{-2}$ for the Srep (dimensionless ratios; see Table 6.11).

\section{Uncertainty in E2: Completeness of Alternative Probabilistic Models.}

This section examines the completeness of alternative models used in probabilistic assessments of E2 and emphasizes data variables identified to be sensitive to input values from probabilistic modeling (Crowe et al., 1993, 1995; Geomatrix, 1996). An event geometry for disruptive volcanic events is used coupled with probabilistic definitions of data variables (Sheridan, 1992; Wallmann, 1993; Golder Associates, 1995). This approach provides a significant improvement over previous studies that treated volcanic events as a point source (Crowe et al., 
1995; Connor and Hill, 1995). Results from the simulation modeling (Golder Associates, 1995) and PVHA show conclusively that the sensitive parameters for the probability of disruption of a repository and repository system are dike lengths, dike orientations, models of volcanic source zones, and event locations and distributions within volcanic source zones. This section assesses the completeness of alternative models used to assess these variables.

Table 6.11. Mean Estimates of the Probability of Magmatic Disruption of the Potential Repository and Repository System Based on the FracMan Simulations.

\begin{tabular}{|c|c|c|c|c|c|c|c|}
\hline \multicolumn{4}{|c|}{ Quaternary Crater Flat Volcanic Zone } & \multicolumn{4}{|c|}{ Pliocene-Quaternary Pull-Apart } \\
\hline & HiTempRep & Low TempRep & RepSystem & \multirow{3}{*}{$\begin{array}{l} \\
\text { average } \\
\text { std dev }\end{array}$} & \multicolumn{3}{|c|}{ |HiTempRep Low TempRep RepSystem } \\
\hline Average & 1.9E-05 & $3.1 \mathrm{E}-05$ & $2.0 \mathrm{E}-03$ & & $2.1 \mathrm{E}-04$ & 3.6E-04 & 8.7E-03 \\
\hline Std dev & 5.7E-05 & 7.8E-05 & 2.3E-03 & & 3.3E-04 & $5.2 \mathrm{E}-04$ & 3.7E-03 \\
\hline \multicolumn{4}{|c|}{ Pliocene and Quaternary Crater Flat Volcanic Zone } & \multicolumn{4}{|c|}{ Walker Lane Shear Zone } \\
\hline & HiTempRep & Low TempRep & RepSystem & & HiTempRep & Low TempRep & RepSystem \\
\hline Average & 4.1E-05 & 7.3E-05 & $3.6 \mathrm{E}-03$ & average & 1.4E-04 & $2.3 \mathrm{E}-04$ & $6.4 \mathrm{E}-03$ \\
\hline Std dev & $8.2 \mathrm{E}-05$ & 1.3E-04 & $3.2 \mathrm{E}-03$ & std dev & 2.3E-04 & 3.6E-04 & 2.8E-03 \\
\hline \multicolumn{4}{|c|}{ Pliocene and Quaternary Yucca Mountain Region } & \multicolumn{4}{|c|}{ Northeast-trending Structural Zone } \\
\hline & HiTempRep & Low TempRep & RepSystem & & HiTempRep & Low TempRep & RepSystem \\
\hline Average & $2.4 \mathrm{E}-03$ & 3.7E-03 & $4.0 \mathrm{E}-02$ & average & $2.0 \mathrm{E}-03$ & 3.0E-03 & 3.3E-02 \\
\hline Std dev & 1.3E-03 & $1.9 \mathrm{E}-03$ & 2.1E-02 & std dev & 1.1E-03 & 1.1E-03 & $6.5 \mathrm{E}-03$ \\
\hline \multicolumn{4}{|c|}{ Quaternary Pull-Apart } & \multicolumn{4}{|c|}{ All Zones } \\
\hline & HiTempRep & Low TempRep & RepSystem & & HiTempRep & Low TempRep & RepSystem \\
\hline Average & $6.9 \mathrm{E}-04$ & $1.1 \mathrm{E}-03$ & 3.0E-02 & average & $7.8 \mathrm{E}-04$ & $1.2 \mathrm{E}-03$ & $1.8 \mathrm{E}-02$ \\
\hline Std dev & $1.0 \mathrm{E}-03$ & 1.6E-03 & 1.3E-02 & std dev & $5.3 \mathrm{E}-04$ & $7.4 \mathrm{E}-04$ & $7.1 \mathrm{E}-03$ \\
\hline
\end{tabular}

Note: The mean and standard deviation are calculated from all realizations of the simulations of the disruption probability using all spatial and structural volcanic zones.

1. Dike Lengths: Sheridan (1992) used dike lengths of $2.5 \pm 0.5 \mathrm{~km}$ for three volcanic zones defined for the YMR in his Monte Carlo simulations of disruption of the Yucca Mountain site. Wallmann (1993) described dike lengths with a uniform distribution for simulation modeling of repository disruption, and the defined dike dimensions of $7.5 \pm 6.5 \mathrm{~km}$ for a base case. These lengths were defined as $2 l$, where $l$ is the dike length, to reflect the uncertainty in direction of dike propagation (see following section). Dike lengths were varied systematically about the base case, and parametric studies of repository disruption were conducted for three volcanic zones using the FracMan computer code. Golder Associates (1995) extended the work of Wallmann (1993). Lengths of volcanic dikes were represented as simple and complex features and they were modeled as uniform, normal, and lognormal distributions in simulation modeling using the FracMan computer code. Dike lengths were allowed to vary from 0.5 to $14.6 \mathrm{~km}$, with different lengths assigned for each distribution model and for simple and complex dike forms. Dike length was recognized as an important data variable and treated as the first of two nodes on the logic tree structure for the PVHA study by Geomatrix (1996). Magmatic events were modeled as point events, as events centered along the length of a dike and as events randomly located along a dike. 
Event lengths were treated as cumulative distributions and as density functions that were derived from elicitation results for members of the volcanism expert judgment panel. A range of dike lengths were considered by the panel $(<1.0 \mathrm{~km}$ to 30 to $40 \mathrm{~km})$; mean or most likely values were generally in the range of 3 to $7 \mathrm{~km}$, and the uncertainty in dike lengths was defined as a probability distribution of dike length or in the form of a subjectively defined cumulative density function of dike length (Geomatrix, 1996). Each expert identified dike-length distributions based on their understanding of geologic literature, data from the YMR, and analog data from eroded basalt centers and concepts of magma dynamics.

Conclusion: A range of models of dike lengths has been considered in PVHA for the Yucca Mountain site. The sensitivity of PVHA for variable dike lengths is well represented in studies by Golder Associates (1995) and in the expert judgment PVHA (Geomatrix, 1996).

2. Dike Orientations: Sheridan (1992) used dike orientations selected on the basis of the regional stress field, and he allowed the orientations to vary with different models of volcanic source zones. Wallmann (1993) provided the most comprehensive survey of the effects of dike orientations on magmatic disruption of the Yucca Mountain site. He emphasized that dike models used in disruption simulations are concerned with dike propagation away from a point source, not simply with dike orientation. He argued that the direction of dike orientation follows the maximum regional compressive stress direction $\left(\mathrm{N} 20^{\circ} \mathrm{E}\right)$, but a dike would be equally likely to propagate in either a NE or SW direction. Wallmann (1993) also included variations in dike plunge and dip in his assessments. Golder Associates (1995) argued that the effects of dike orientations on magmatic disruption of a repository were well defined in the study by Wallmann (1993) and did not require re-investigation. They used a bivariate normal distribution for dike orientation, with a mean pole of $(115,0)$ and a standard deviation of $10^{\circ}$ for trend and plunge. Geomatrix (1996) used dike orientations defined by individual experts on the volcanism panel, where the orientation was defined as a distribution with a specified mean and standard deviation. These distributions were modeled as doubly truncated, normal density functions with truncation points at $\pm 90^{\circ}$ from the mean (Geomatrix, 1996; p. 3-15). Two members of the expert judgment panel defined bimodal dike orientations that were modeled as a symmetric density function (Geomatrix, 1996). The expert panel assigned dike orientations based on a range of considerations; they included stress field controls, variations in the stress field with depth, results of borehole hydro-fracturing studies, local structural control, the orientation of aligned clusters of volcanic centers, and the orientation of fissures in individual volcanic centers.

Conclusion: A wide range of selection criteria and orientation data for basalt dikes have been used in PVHA studies for the Yucca Mountain site. These assumptions and data are best described in the report by Wallmann (1993) and were represented in the expert judgment PVHA studies (Geomatrix, 1996).

3. Models of Volcanic Source Zones: There have been lengthy discussions in multiple publications concerning the development of volcanic source zones for PVHA; an extensive discussion is beyond the scope of this report. The focus of this evaluation is on volcanic source models that incorporate event geometry into PVHA for the Yucca Mountain site. Sheridan (1992) used three models of volcanic source zones in his Monte Carlo simulations of magmatic disruption of a repository site. His model A used a northwest-trending volcanic source zone equivalent to a Crater Flat volcanic field and identical to the Quaternary pull-apart model for Crater Flat. His model B used the same distribution area as model A, but it assumed a northeast trend to the source zone. The model C used by Sheridan (1992) assumed that a source zone for renewed volcanic 
activity would be centered at the Lathrop Wells center and oriented directly toward the Yucca Mountain site. Wallmann (1993) used four models for volcanic source zones including: 1) the ARMV defined by Smith et al. (1990), 2) a Lathrop Wells zone that is similar to Model C of Sheridan (1992), 3) a high-risk rectangle defined by Smith et al. (1990) and 4) the CFVZ of Crowe and Perry (1989). The volcanic source models used by Golder Associates (1995) were described in a preceding section of this report. The expert judgment panel used a diverse range of alternative models of volcanic source zones, and every expert used a unique perspective for specifying and justifying their source zone models (Geomatrix, 1996). The geometry of each source zone was presented in figures and the assumptions used to select source zones were included in the elicitation summaries provided by each member of the expert judgment panel (Geomatrix, 1996). This diversity of views reflects the uncertainty introduced by the limited record of volcanic events in the YMR.

The question about completeness of volcanic source models can never be answered with certainty. Developed models are dependent on current concepts of magma processes and on current understanding of the tectonic setting and tectonic features of the YMR. Both relate to the state of knowledge of geological sciences and could, of course, change if there are significant new concepts developed that change understanding of magmatic or tectonic processes as applied to the YMR. However, a partial answer to this question can be provided by three assessments.

First, Geomatrix (1996) developed aggregate distributions of the annual probability of magmatic disruption of the Yucca Mountain site. The distributions span approximately three orders of magnitude, a direct reflection of the uncertainty in the PVHA (Geomatrix, 1996; their Figure 4-44). The means of the probability of magmatic disruption for individual experts from the volcanism panel vary by about 1.5 orders of magnitude. Geomatrix (1996) noted that this expert uncertainty represents only about $30 \%$ of the total variance, with uncertainty from volcanic source zones contributing about $14 \%$ of the total variance (Geomatrix, 1996; p. 4-12 to 4-13). Thus, the uncertainty in source models, while significant, is not the major contributor to the total uncertainty of the PVHA.

Second, Geomatrix (1996) used two methods to assess the variability of results of the expert judgment study (p. 4-13 to 4-14), and both methods indicate relative stability of the aggregate results. While their stability analyses did not assess individual components of uncertainty, the results are consistent with limited sensitivity to variations in source models.

Third, individual experts of the volcanism panel expressed considerable uncertainty in locating the boundaries of their volcanic source zones. The diversity of source models used in PVHA suggests that minor changes in any source boundary should not result in significant changes in the probability estimates. However, the simulation studies by Golder Associates (1995) show some sensitivity in the estimates of the probability of magmatic intersection for volcanic source models that are close to the Yucca Mountain site, particularly those models that are near to or intersect the Srep. This increased sensitivity compared to other source-zone models indicates that the probability of magmatic disruption of some zones might require reassessment if future results from continuing site characterization or geophysical studies move critical volcanic source zone boundaries closer to the Yucca Mountain site. Examples of volcanic source models that could be sensitive include the Quaternary pull-apart basin model (elicitation of B. Crowe), the Crater Flat field (elicitation of R. Fisher and M. Sheridan), and the volcanic domain model (elicitation of G. Thompson) (elicitation citations all from Geomatrix, 1996). 
Conclusion: A very wide range of volcanic source models has been used in PVHA for the Yucca Mountain site and reflects the limited record of past volcanic events. The diversity of models has been captured well in the volcanism expert judgment study (Geomatrix, 1996). The remaining uncertainty is for volcanic source models with boundaries close to the Yucca Mountain site or the dike standoff area surrounding the Yucca Mountain site. These models might require reassessment if new data are obtained that moves source zone boundaries closer to the Yucca Mountain site.

4. Event Distributions within Volcanic Source Zones: The final area of uncertainty requiring assessment for E2 is the event distribution models used to assess spatial patterns of volcanic events within or associated with volcanic source zones. There has been considerable debate concerning these models, and the debate focuses on two alternative models: homogeneous and nonhomogeneous event distributions. Crowe et al. (1992; 1995) used a random or homogeneous Poisson model for the spatial distribution of volcanic events in assessments of the probability of magmatic disruption of the Yucca Mountain site. The primary basis for this approach is the limited record of volcanic events in the YMR; the data are too sparse to allow description using traditional statistical methods of hypothesis testing. Moreover, the Poisson model has been used extensively in probabilistic seismic hazard studies (Cornell, 1968, 1971) and the Poisson model has been shown to be a reasonable approximation for representing a combination of separate non-Poisson processes (Tuckwell, 1988; Crowe et al., 1995). Connor and Hill (1993, 1995) applied a combination of a Clark-Evans and Hopkins F test to reject the null hypothesis that basaltic volcanic centers are randomly distributed in the YMR, and they used three nonhomogeneous spatial distribution models to assess the probability of magmatic disruption of the Yucca Mountain site. Golder Associates (1995) reviewed models used to assess the spatial distribution of volcanic events in the YMR. Golder analyzed the $x, y$ data for the location of volcanic centers of the Postcaldera basalt and incorporated age information that allowed assessment of the sequence of volcanic events. They concluded that while that spatial data are sparse, there is evidence of two volcanic processes operating at two scales. These include smaller scale processes $(<10 \mathrm{~km})$, which can be characterized by a fractal distribution, and larger scale processes, which show Brownian spatial and random temporal patterns.

The debate concerning the application of homogeneous or nonhomogeneous spatial models of basaltic volcanism in the YMR will likely continue, given the limited database for analyses. While there is disagreement over which model is more or most appropriate, the fundamental issue cannot be resolved given the limited data. What is more important, is that both models give similar results for PVHA and thus distinctions between the models are not significant (Crowe et al., 1995).

The volcanism expert judgment panel used a range of models for the spatial distribution of volcanic events, and each panel member weighted models using their subjective judgment about the applicability of the model to the YMR. Homogeneous spatial models were implemented from volcanic zones established by individual experts by dividing a region of interest into nonoverlapping zones and by assuming a uniform spatial density of volcanic events in these zones (Geomatrix, 1996). The boundaries between any two zones represent a line in which there is a change or step in the volcanic recurrence rate. This step can correspond to background recurrence rates when the bounding zone is of regional extent, or to a separate volcanic zone when the bounding zone is local. The boundary between the zones can be treated as an abrupt probability step or as a gradual transition, which can be described with a smoothing function in places where the recurrence rate decays to a background or local rate over a specified distance from the zone boundary (Geomatrix, 1996). 
Members of the expert judgment panel used two approaches for homogeneous event models. They are: 1) volcanic events were randomly distributed within source zone boundaries, but feeder dikes for the events were allowed to extend beyond the zone boundaries; 2) volcanic events were randomly distributed within source zones, and the rate density was allowed to decay linearly with distance from a zone boundary (Geomatrix, 1996). Two types of nonhomogeneous models were used by the expert judgment panel. The first is a parametric model, which is a modification of the approach of Sheridan (1992), in which the spatial density of events was represented by a bivariate Gaussian distribution with five parameters: the $\mathrm{x}, \mathrm{y}$ coordinates of the center of the field, the length of the major and minor axes, and the orientation of the axes (Geomatrix, 1996). Data for the YMR was used to estimate the parameters of the bivariate Gaussian distribution. The second, which was used by several panel members, used nonparametric spatial density models based on the work by Connor and Hill (1995), and these panel members applied a kernel-density estimation technique to model the distribution of volcanic events. The fundamental difference between the two models is that the latter model assumes that future events are conditioned on and will occur near previous events, whereas the former model is conditioned on the shape parameters of a volcanic field, not the location of events.

Conclusion: A range of distribution models has been used to describe the distribution of past volcanic events in the YMR and to estimate or constrain the location of future volcanic events. This range of models is well represented in the approaches used for PVHA by the volcanism expert judgment panel (Geomatrix, 1996).

\section{Revised Estimations of E1: The Recurrence Rate}

Crowe et al. (1995) used a combination of times-series analyses, assessment of homogeneous Poisson models (events counts where $\lambda$ is constant), nonhomogeneous Poisson models (event counts where $\lambda$ is a function of time) and volume-predictable recurrence rates to examine variability in E1. The major conclusions of this work include

1. Time-series analysis is limited by the small number of past events and can only provide bounds on minimum repose intervals.

2. The mean recurrence rate using a homogeneous Poisson temporal model is $3.5 \pm 1.3 \times$ $10^{-6}$ events year $^{-1}$ (data from the VSR). The Poisson model is sensitive to the intervals used to establish event counts, and the recommended approach is to use intervals that correspond to volcanic cycles.

3. Nonhomogeneous Poisson temporal models are also sensitive to the time intervals used to establish event counts. The $\beta$, a fitting parameter for the Weibull distribution, gives values of $<1$ for nonhomogeneous Poisson models using intervals based on volcanic cycles; $\beta$ values of $>1$ can be obtained for models using fixed time intervals (Crowe et al., 1995; Geomatrix, 1996). The values for volcanic cycles are consistent with waning basaltic volcanism in the YMR during the Pliocene and Quaternary. Nonhomogeneous Poisson temporal models (using intervals from volcanic cycles) give recurrence rates that are generally lower than recurrence rates using homogeneous Poisson models.

4. The volume of Quaternary basaltic events in the YMR has decreased by a factor of 30 relative to Pliocene eruption volumes. Application of volume-predictable models to recurrence-rate estimations requires assumptions of a representative volume of a 
basaltic volcanic eruptions. Because of the exponential decline in magma volumes with time, linear regression models of magma volume versus time give unsatisfactory fits and result in very long or maximum recurrence rates. The volume-predictable model provides limited information and can only be used to bound maximum estimations of E1.

In this section, we examine the past approaches used to assess recurrence rates from the perspective of new information available since completion of the VSR including the results of the expert judgment study. A major part of the revised estimates of $\mathrm{E} 1$ are an assessment of recurrence rates for volcanic zones used for alternative spatial and structural models of E2.

Time-Series Analyses: The constraints we face because of a limited record of past volcanic events continues to affect our attempts to apply time-series analyses to assessments of the recurrence rate (Crowe et al., 1995). The only changes from previous assessments are minor refinements in the chronology of events. We originally anticipated that refinements in estimates of magma volume for volcanic units would affect time-series analyses. However, the exponential decline in magma-output rate (Crowe et al., 1995) swamps any uncertainty introduced by estimates of magma volumes; estimations incorporating magma volume were not considered for the revised time-series analyses.

The minor changes in the chronology of volcanic events described in a previous section are included in Table 6.12, a revision of Table 7.4 of Crowe et al. (1995). We have also adjusted the volume by adding estimates for the aeromagnetic anomalies of the Amargosa Valley using data from Langenheim (1995), modifying the volume of the Sleeping Butte center based on new field studies, and assuming the ages of unstudied anomalies are the same as anomaly A (3.85 Ma). The latter assumption is speculative because all the aeromagnetic anomalies have not been explored by drilling and therefore the chronology data are very limited. Because of the limited data, the only choice is to assume event ages similar to the studied anomaly. The revised table and data plots also include the aeromagnetic anomalies in the estimates of the repose intervals. The positive aeromagnetic anomaly of Crater Flat has not been added to the table or data plots because its age is unconstrained.

Figure 6.12 is plot of the cumulative volume of erupted magma (DRE) versus time for the Pliocene and Quaternary volcanic events of the YMR; it is an update of Figure 7.6 of the VSR. The stars on the plot denote volcanic events and the dashed lines connect successive volcanic events. The dashed lines have two slope segments corresponding to volcanic events $\geq 3.0 \mathrm{Ma}$ (steeper slope segment) and volcanic events $\leq 1.0 \mathrm{Ma}$. Figure 6.13 is a plot of the repose interval versus age for Pliocene and Quaternary volcanic events of the YMR and is an update of Figure 7.7 of the VSR ${ }^{2}$. The solid line is a linear regression fit to the data points, and the curved solid lines are the $95 \%$ confidence intervals for the location of the regression line. The y-intercept of the regression line $(\mathrm{t}=0)$ is about $0.7 \mathrm{Ma}$, but the confidence intervals for the line show that the intercept is poorly constrained. The mean repose interval is $0.96 \pm 0.77 \mathrm{Ma}$ (Table 6.12), an estimate that is similar to the recurrence interval of Fleck et al. (1996) of $0.90 \pm 0.27$ Ma obtained from evaluations of K-Ar age data. Neither of these numbers is significant given the variability of

\footnotetext{
${ }^{2}$ The first repose interval is not adjusted for the revised age of the basalt of Nye Canyon because the new chronology data were obtained after completion of the figures for this report.
} 
the past repose intervals. The significant observations from Figure 6.13 are 1) the slope of the regression-fit line is consistent with declining repose intervals through time (Vaniman and Crowe, 1981) and 2) there is a somewhat cyclical form to the repose patterns. The dashed line of Figure 6.13 is the distance-weighted regression fit of the data points and illustrates the sinusoidal form of this fit. The data are extremely limited but show an apparent temporally cyclical pattern of closely spaced events followed by a long-interval between events. The data are inadequate to allow inferences of where the present time $(t=0)$ is in this cyclical pattern. If the $t=0$ is in a short duration pattern, the repose pattern may be best described either by the interval between the Sleeping Butte and Lathrop Wells volcanic events (300 ka from Table 6.12) or the mean of the short-duration events $(525 \pm 320 \mathrm{ka}$; data from Table 6.12). These estimates are equivalent, respectively, to a recurrence rate of $3.3 \times 10^{-6}$ events year $^{-1}$ and $1.9 \times 10^{-6}$ events year-1 and are similar to the range of most likely events using homogeneous and nonhomogeneous Poisson event counts (Crowe et al., 1995; Geomatrix, 1996). Alternatively, if the YMR is in a long-interval pattern, the interval to the next volcanic event would be about 2.0 Ma, equivalent to a recurrence rate of $5.0 \times 10^{-7}$ events year ${ }^{-1}$, a significantly longer recurrence rate than rate estimates using homogeneous and nonhomogeneous Poisson models. Comparison of Figures 6.12 and 6.13 show that there is no relation between the volume of a volcanic event and the duration of the preceding repose interval.

Table 6.12. Age, volume, cumulative volume and repose intervals for Pliocene and Quaternary volcanic events of the YMR.

\begin{tabular}{|c|c|c|c|c|}
\hline Volcanic Center & $\begin{array}{l}\text { Age } \\
(\mathrm{Ma})\end{array}$ & $\begin{array}{c}\text { Volume } \\
\left(\mathrm{km}^{3}\right)\end{array}$ & $\begin{array}{c}\text { Cumulative } \\
\text { Volume } \\
\left(\mathrm{km}^{3}\right)\end{array}$ & $\begin{array}{c}\text { Repose } \\
\text { Interval } \\
\text { (Ma) }\end{array}$ \\
\hline Basalt of Thirsty Mesa & 4.7 & 3.0 & 3.0 & 2.1 \\
\hline Amargosa Aeromagnetic Anomalies & 3.8 & $0.8^{*}$ & 3.8 & $0.9^{* * *}$ \\
\hline Basalt of Southeast Crater Flat & 3.7 & 0.68 & 4.6 & 0.1 \\
\hline Basalt of Buckboard Mesa & 3.0 & .92 & 5.5 & 0.7 \\
\hline Quaternary Basalt of Crater Flat & 1.0 & .23 & 5.8 & 2.0 \\
\hline Basalt of Sleeping Butte & 0.4 & $.08^{* *}$ & 5.9 & 0.6 \\
\hline Lathrop Wells Volcanic Center & .08 & .14 & 6.1 & 0.3 \\
\hline $\begin{array}{l}\text { Mean } \\
\text { Std deviation }\end{array}$ & & $\begin{array}{l}0.84 \\
0.11\end{array}$ & & $\begin{array}{l}0.96 \\
0.77\end{array}$ \\
\hline $\begin{array}{l}{ }^{*} \text { volume estimates from Langenheim } \\
(1995) \\
{ }^{* *} \text { volume increased from Crowe et al. } \\
(1995) \text { to account for the western flow lobe } \\
{ }_{\star \star *} \text { aeromagnetic anomalies of Amargosa } \\
\text { are included in repose intervals }\end{array}$ & & & & \\
\hline
\end{tabular}




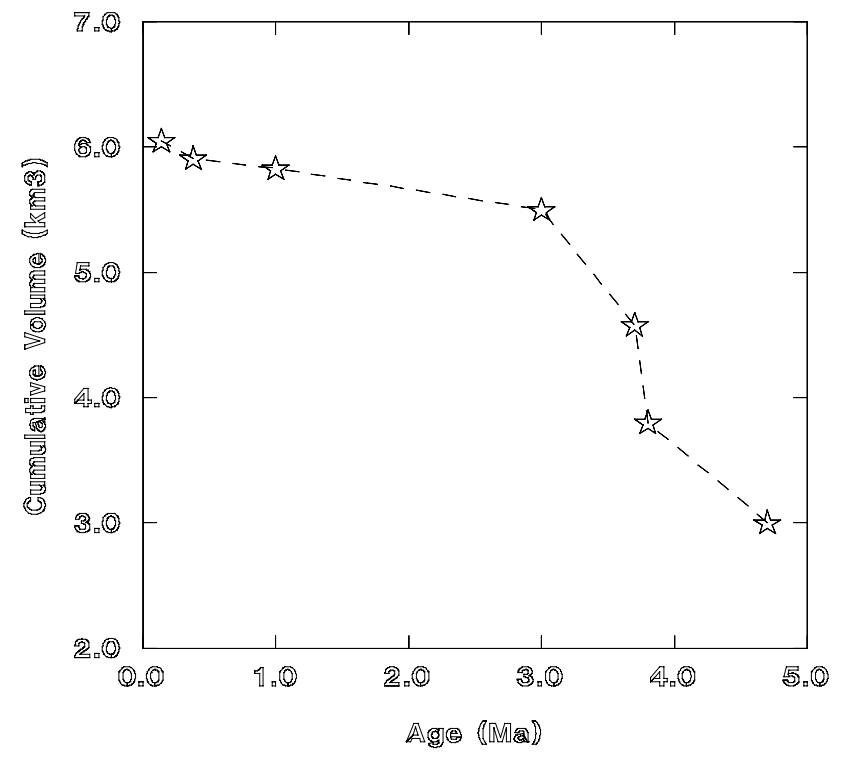

Figure 6.12. Plot of magma volume versus the event age for the Pliocene and Quaternary volcanic centers of the YMR. The stars denote volcanic events and the dashed line connects successive volcanic events.

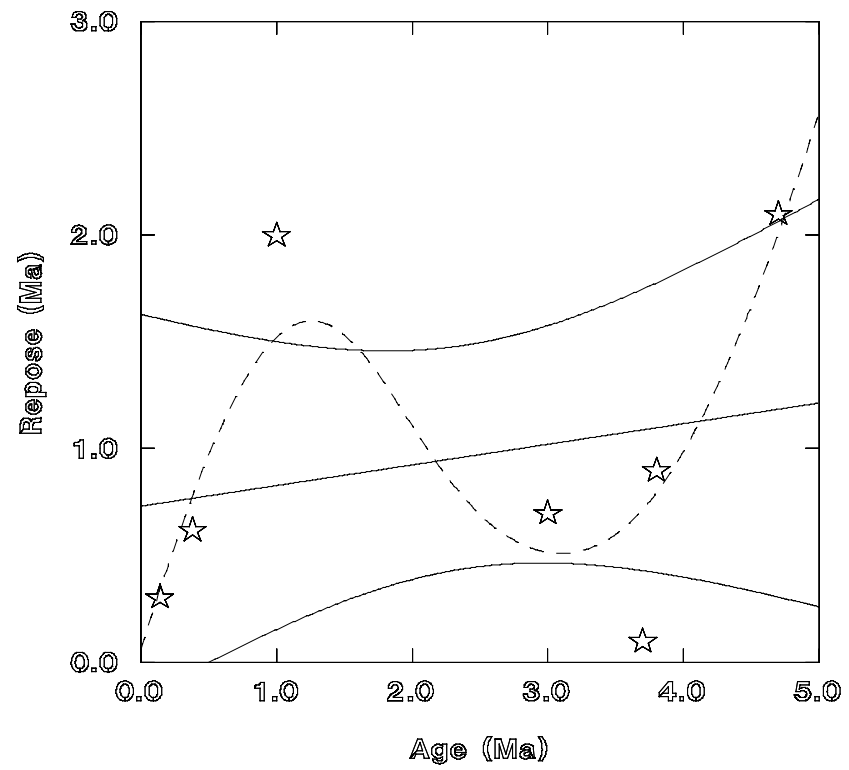

Figure 6.13. Plot of the duration between volcanic events (repose) versus the age of volcanic events for the Pliocene and Quaternary volcanic events of the YMR. The stars are the individual volcanic events. The solid line and associated solid curved lines are, respectively, the regression fit to the data and the $95 \%$ confidence intervals for the location of the regression line. The dashed line is a distanceweighted regression fit to the event data. 
Homogeneous Poisson Models (Event Counts). Event counts using a homogeneous Poisson model were summarized in Crowe et al. (1995). All members of the volcanism expert judgment study used homogeneous Poisson models for event counts, and three members also examined nonhomogeneous Poisson models. (Geomatrix, 1966). The recurrence rates (E1) using homogeneous and nonhomogeneous Poisson event counts are so similar that further consideration of nonhomogeneous Poisson event counts is unnecessary. The mean values for the $\beta$ parameter for nonstationary event models (using multiple sets of alternative geochronology data for volcanic events corresponding to volcanic cycles in the YMR) are $<1.0$ and, therefore, give recurrence rates that are smaller than stationary models. This calculation is, however, not consistent with the cyclic repose pattern of Fig. 6-13 that indicates decreasing repose intervals through time (see also Vaniman and Crowe, 1981).

This section summarizes and compares event counts used in the volcanism expert judgment study that incorporated the undetected events in the distributions and is applied to the spatial and structural zones (Table 6.13). The following assumptions were used to construct the table:

1. Event counts assignments are applied to the minimum, maximum, $10 \%, 90 \%$, and most likely, and mean estimates of a probability distribution. The minimum and maximum assignments are used for the uniform and triangular distributions and are, by definition, outside the probability distribution.

2. The mean minimum event counts cannot be estimated using standard statistics because the minimum events for many volcanic centers are equal to 0 . In these cases the mean minimum event counts are equal to the number of centers minus 1 so that the minimum assignment is outside the distribution. For example, the mean minimum event count for the Quaternary Crater Flat volcanic zone is equal to 2 [the Quaternary basalt of Crater Flat (one event) plus the basalt of Sleeping Butte (one event) plus the Lathrop Wells center (one event) minus 1]. This approach is used for all spatial and structural zones except for those zones that include the aeromagnetic anomalies of Crater Flat, where the minimum event assignments are $>0$.

3. The event counts are treated as discrete variables and rounded to the nearest integer corresponding to the probability assignment. For cases where event counts are equally spaced between assignments, a random look-up table was used to round the event count.

4. Non-integer event counts in Table 6.13 result from multiplication of the event counts by a factor that accounts for the possibility of undetected volcanic events. Each expert used a unique approach or multiplication factor to account for undetected events. This non-integer conversion requires the data to be treated as continuous variables in the simulation modeling.

5. Some experts chose intervals for event counts that did not include Pliocene events; event counts for Pliocene volcanic events are established from a subset of the members of the expert panel.

Events counts cannot be compared meaningfully without adjusting the event count assignments of Table 6.13 to the age interval of the events included in the spatial and structural zones. Tables 6.14 through 6.20 make these adjustments and include the results of simulation 
modeling to describe the uncertainty in E1 for spatial and structural zone. Simulation modeling is again used with varying probability distributions to contrast different data approaches. The following assumptions were used for Tables 6.14 through 6.20:

1. The most likely estimate of the event counts for the spatial and structural zones is the mode of probability distributions and is determined from statistical analysis of data from the simulation modeling of the events counts presented in Tables 6.4 through 6.10 .

2. The mean and standard deviation of the normal distribution used in Table 6.14 through 6.20 are determined from statistical analysis of data from the simulation modeling of the event counts presented in Tables 6.4 through 6.10.

3. The uniform and triangular distribution use minimum and maximum event counts and incorporate undetected events; the minimum event counts use the constraints of Table 6.13 and are not the sum of the percentiles; the trigen distribution uses the $10 \%$ and $90 \%$ event count assignments and does not include undetected events.

4. The percentile values for the simulations are the mean of the percentile assignments from the expert judgment study. An alternative method for these simulations would be to use a composite distribution of the expert judgment data, which would probably result in larger variances. This should be considered in future simulation modeling of volcanism data.

5. The probability of magmatic disruption $[\operatorname{Pr}(\mathrm{E} 2$ given $\mathrm{E} 1)(\operatorname{Pr}(\mathrm{E} 1)]$ is estimated from the data obtained using simulation modeling. The values of E2 used in the modeling are the means for the Hrep and Lrep for spatial and structural zones from Table 6.11.

The following observations are derived from examination of Tables 6.14 through 6.20 and Figures 6.14 through 6.20:

1. The mean and standard deviation of the recurrence rate decreases with distribution type following the order Uniform > Triangular > Trigen > Normal.

2. The difference in the mean estimates of the recurrence rate between the uniform and normal distributions are less than a factor of two for all spatial and structural zones. This difference provides a general approximation of the value of information gathered through site characterization studies (uniform $=$ minimal data; normal $=$ maximal data).

3. There is about an order of magnitude variation between minimum and maximum estimates of E1 for all spatial and structural zones.

4. Sensitivity studies continue to support the observation that uncertainty in E1 is not a key factor in PVHA (Crowe et al., 1995).

5. The differences between the triangular and trigen probability distributions largely is a reflection of incorporating estimates of undetected events in the triangular distributions. 
Table 6.13. Event Counts Applied to Volcanic Zones: Assignments of the Volcanism Expert Judgment Panel.

\begin{tabular}{|c|c|c|c|c|c|c|c|c|c|c|c|c|c|c|c|}
\hline \multicolumn{16}{|c|}{ Quaternary Crater Flat Volcanic Zone } \\
\hline \multirow{2}{*}{$\begin{array}{l}\text { Spatial Model } \\
\text { CFVZ } \\
\text { Quaternary }\end{array}$} & \multicolumn{5}{|c|}{ 1.0 Basalt } & \multicolumn{5}{|c|}{ Sleeping Butte } & \multicolumn{5}{|l|}{ Lathrop } \\
\hline & \begin{tabular}{|l} 
Events \\
Min
\end{tabular} & $\begin{array}{l}\text { Events } \\
10 \%\end{array}$ & $\begin{array}{l}\text { Most } \\
\text { Likely }\end{array}$ & $\begin{array}{l}\text { Events } \\
90 \%\end{array}$ & $\begin{array}{l}\text { Events } \\
\text { Max }\end{array}$ & \begin{tabular}{|l} 
Events \\
Min
\end{tabular} & $\begin{array}{l}\text { Events } \\
10 \%\end{array}$ & $\begin{array}{l}\text { Most } \\
\text { Likely }\end{array}$ & $\begin{array}{l}\text { Events } \\
90 \%\end{array}$ & $\begin{array}{l}\text { Events } \\
\text { Max }\end{array}$ & \begin{tabular}{|l} 
Events \\
Min
\end{tabular} & $\begin{array}{l}\text { Events } \\
10 \%\end{array}$ & $\begin{array}{l}\text { Most } \\
\text { Likely }\end{array}$ & $\begin{array}{l}\text { Events } \\
90 \%\end{array}$ & $\begin{array}{l}\text { Events } \\
\text { Max }\end{array}$ \\
\hline Carlson & 0.0 & 1.1 & 1.1 & 3.3 & 5.5 & 0.0 & 1.1 & 1.1 & 2.2 & 4.4 & 0.0 & 1.1 & 1.1 & 1.0 & 3.3 \\
\hline Crowe & 0.0 & 1.0 & 3.0 & 4.0 & 8.0 & 0.0 & 1.0 & 2.0 & 3.0 & 4.0 & 0.0 & 1.0 & 1.0 & 1.0 & 4.0 \\
\hline ||Duffield & 0.0 & 1.0 & 3.0 & 5.0 & 6.0 & 0.0 & 2.0 & 2.0 & 2.0 & 3.0 & 0.0 & 1.0 & 1.0 & 2.0 & 3.0 \\
\hline Fisher & 0.0 & 1.5 & 1.5 & 6.0 & 7.5 & 0.0 & 1.5 & 1.5 & 4.5 & 6.0 & 0.0 & 1.5 & 1.5 & 3.0 & 7.5 \\
\hline |Hackett & | 0.0 & 1.0 & 3.0 & 5.0 & 7.0 & 0.0 & 1.0 & 2.0 & 3.0 & 4.0 & 0.0 & 1.0 & 2.0 & 3.0 & 6.0 \\
\hline Kuntz & 0.0 & 1.5 & 1.5 & 4.5 & 7.5 & 0.0 & 1.5 & 1.5 & 4.5 & 6.0 & 0.0 & 1.5 & 1.5 & 1.5 & 7.5 \\
\hline McBirney & 0.0 & 1.0 & 1.0 & 1.0 & 6.0 & 0.0 & 1.0 & 2.0 & 3.0 & 4.0 & 0.0 & 1.0 & 2.0 & 4.0 & 5.0 \\
\hline Sheridan & 0.0 & 1.5 & 1.5 & 3.0 & 4.0 & 0.0 & 1.5 & 1.5 & 3.0 & 4.5 & 0.0 & 1.5 & 1.5 & 3.0 & 4.5 \\
\hline Thompson & 0.0 & 1.5 & 4.5 & 6.0 & 9.0 & 0.0 & 1.5 & 3.0 & 3.0 & 6.0 & 0.0 & 1.5 & 1.5 & 3.5 & 7.5 \\
\hline Walker & 0.0 & 2.0 & 3.0 & 6.0 & 10.0 & 0.0 & 2.0 & 4.0 & 4.0 & 6.0 & 0.0 & 2.0 & 2.0 & 2.0 & 10.0 \\
\hline Mean & 0.0 & 1.3 & 2.3 & 4.4 & 7.1 & 0.0 & 1.4 & 2.1 & 3.2 & 4.8 & 0.0 & 1.3 & 1.5 & 2.4 & 5.8 \\
\hline std deviation & 0.0 & 0.3 & 1.1 & 1.6 & 1.8 & 0.0 & 0.4 & 0.9 & 0.9 & 1.1 & 0.0 & 0.3 & 0.4 & 1.0 & 2.3 \\
\hline Mean Events & Min & $10 \%$ & $M L$ & $90 \%$ & $\operatorname{Max}$ & & & & & & & & & & \\
\hline All Experts & 2.0 & 4.0 & 5.9 & 10.0 & 17.7 & & & & & & & & & & \\
\hline
\end{tabular}

Note: Minimum values are 1 minus the number of events in the volcanic zone except for zones that include the aeromagnetic anomalies of the Amargosa Valley. 
Table 6.13. (cont.) Event Counts for the Pliocene-Quaternary Crater Flat Volcanic Zone

\begin{tabular}{|c|c|c|c|c|c|c|c|c|c|c|c|c|c|c|c|}
\hline \multicolumn{16}{|c|}{ Pliocene-Quaternary Crater Flat Volcanic Zone } \\
\hline \multirow{2}{*}{$\begin{array}{l}\text { Spatial Model } \\
\text { CFVZ } \\
\text { Plio-Quaternary }\end{array}$} & \multicolumn{5}{|c|}{ Thirsty Mesa } & \multicolumn{5}{|c|}{ Aeromagnetic Anomalies } & \multicolumn{5}{|c|}{ 3.7 Ma Basalt } \\
\hline & \begin{tabular}{|l} 
Events \\
Min
\end{tabular} & $\begin{array}{l}\text { Events } \\
10 \%\end{array}$ & $\begin{array}{l}\text { Most } \\
\text { Likely }\end{array}$ & $\begin{array}{l}\text { Events } \\
90 \%\end{array}$ & $\begin{array}{l}\text { Events } \\
\text { Max }\end{array}$ & \begin{tabular}{|l} 
Events \\
Min
\end{tabular} & $\begin{array}{l}\text { Events } \\
10 \%\end{array}$ & $\begin{array}{l}\text { Most } \\
\text { Likely }\end{array}$ & $\begin{array}{l}\text { Events } \\
90 \%\end{array}$ & $\begin{array}{l}\text { Events } \\
\text { Max }\end{array}$ & \begin{tabular}{|l} 
Events \\
Min
\end{tabular} & $\begin{array}{l}\text { Events } \\
10 \%\end{array}$ & $\begin{array}{l}\text { Most } \\
\text { Likely }\end{array}$ & $\begin{array}{l}\text { Events } \\
90 \%\end{array}$ & $\begin{array}{l}\text { Events } \\
\text { Max }\end{array}$ \\
\hline Carlson & 0.0 & 1.1 & 1.1 & 1.1 & 3.3 & 2.2 & 3.3 & 3.3 & 5.5 & 7.7 & 0.0 & 1.1 & 1.1 & 2.2 & 7.7 \\
\hline Crowe & 0.0 & 1.0 & 1.0 & 2.0 & 4.0 & 2.0 & 2.0 & 6.0 & 8.0 & 13.0 & 0.0 & 1.0 & 3.0 & 7.0 & 9.0 \\
\hline Hackett & 0.0 & 1.0 & 1.0 & 2.0 & 4.0 & 1.0 & 2.0 & 3.0 & 6.0 & 8.0 & 0.0 & 2.0 & 3.0 & 6.0 & 9.0 \\
\hline Kuntz & 0.0 & 1.5 & 1.5 & 1.5 & 6.0 & 0.0 & 3.0 & 4.5 & 6.0 & 10.5 & 0.0 & 1.5 & 1.5 & 4.5 & 10.5 \\
\hline McBirney & 0.0 & 1.1 & 1.1 & 1.1 & 3.3 & 1.1 & 4.4 & 5.5 & 7.7 & 9.9 & 0.0 & 1.1 & 1.1 & 4.4 & 7.7 \\
\hline Sheridan & 0.0 & 1.5 & 1.5 & 1.5 & 7.5 & 6.0 & 7.5 & 7.5 & 10.5 & 12.0 & 0.0 & 1.5 & 3.0 & 4.5 & 7.5 \\
\hline Thompson & na & na & na & na & na & 6.0 & 7.5 & 7.5 & 7.5 & 12.0 & 0.0 & 1.0 & 1.0 & 1.0 & 7.0 \\
\hline Walker & 0.0 & 2.0 & 2.0 & 2.0 & 8.0 & 2.0 & 4.0 & 6.0 & 12.0 & 14.0 & 0.0 & 2.0 & 2.0 & 8.0 & 12.0 \\
\hline Mean & 0.0 & 1.3 & 1.3 & 1.6 & 5.2 & 2.5 & 4.2 & 5.4 & 7.9 & 10.9 & 0.0 & 1.4 & 2.0 & 4.7 & 8.8 \\
\hline \multirow[t]{3}{*}{ std deviation } & 0.0 & 0.4 & 0.4 & 0.4 & 2.0 & 2.3 & 2.2 & 1.7 & 2.3 & 2.3 & 0.0 & 0.4 & 0.9 & 2.3 & 1.7 \\
\hline & \multicolumn{5}{|c|}{ 1.0 Basalt of Crater Flat } & \multicolumn{5}{|c|}{ Sleeping Butte } & \multicolumn{5}{|l|}{ Lathrop } \\
\hline & $\begin{array}{l}\text { Events } \\
\text { Min }\end{array}$ & $\begin{array}{l}\text { Events } \\
10 \%\end{array}$ & $\begin{array}{l}\text { Most } \\
\text { Likely } \\
\end{array}$ & $\begin{array}{l}\text { Events } \\
90 \%\end{array}$ & $\begin{array}{l}\text { Events } \\
\text { Max }\end{array}$ & $\begin{array}{l}\text { Events } \\
\text { Min }\end{array}$ & $\begin{array}{l}\text { Events } \\
10 \%\end{array}$ & $\begin{array}{l}\text { Most } \\
\text { Likely }\end{array}$ & $\begin{array}{l}\text { Events } \\
90 \%\end{array}$ & $\begin{array}{l}\text { Events } \\
\text { Max }\end{array}$ & $\begin{array}{l}\text { Events } \\
\text { Min }\end{array}$ & $\begin{array}{l}\text { Events } \\
10 \%\end{array}$ & $\begin{array}{l}\text { Most } \\
\text { Likely }\end{array}$ & $\begin{array}{l}\text { Events } \\
90 \%\end{array}$ & $\begin{array}{l}\text { Events } \\
\text { Max }\end{array}$ \\
\hline Mean & 0.0 & 1.3 & 2.3 & 4.4 & 7.1 & 0.0 & 1.4 & 2.1 & 3.2 & 4.8 & 0.0 & 1.3 & 1.5 & 2.4 & 5.8 \\
\hline Mean Events & Min & $10 \%$ & $M L$ & $90 \%$ & $\operatorname{Max}$ & & & & & & & & & & \\
\hline Expert Subset & 7.5 & 11.0 & 14.6 & 24.2 & 42.5 & & & & & & & & & & \\
\hline
\end{tabular}


Table 6.13. (cont.) Event Counts for the Pliocene-Quaternary Yucca Mountain Region.

\begin{tabular}{|c|c|c|c|c|c|c|c|c|c|c|c|c|c|c|c|}
\hline \multicolumn{16}{|c|}{ Plio-Quaternary Yucca Mountain Region } \\
\hline \multirow{2}{*}{$\begin{array}{l}\text { Spatial Model } \\
\text { YMR } \\
\text { Plio-Quaternary }\end{array}$} & \multicolumn{5}{|c|}{ Buckboard Mesa } & \multicolumn{5}{|c|}{ Thirsty Mesa } & \multicolumn{5}{|c|}{ 3.7 Ma Basalt } \\
\hline & \begin{tabular}{|l} 
Events \\
Min
\end{tabular} & $\begin{array}{l}\text { Events } \\
10 \%\end{array}$ & $\begin{array}{l}\text { Most } \\
\text { Likely }\end{array}$ & $\begin{array}{l}\text { Events } \\
90 \%\end{array}$ & $\begin{array}{l}\text { Events } \\
\text { Max }\end{array}$ & \begin{tabular}{|l} 
Events \\
Min
\end{tabular} & $\begin{array}{l}\text { Events } \\
10 \%\end{array}$ & $\begin{array}{l}\text { Most } \\
\text { Likely }\end{array}$ & $\begin{array}{l}\text { Events } \\
90 \%\end{array}$ & $\begin{array}{l}\text { Events } \\
\text { Max }\end{array}$ & \begin{tabular}{|l} 
Events \\
Min
\end{tabular} & $\begin{array}{l}\text { Events } \\
10 \%\end{array}$ & $\begin{array}{l}\text { Most } \\
\text { Likely }\end{array}$ & $\begin{array}{l}\text { Events } \\
90 \%\end{array}$ & $\begin{array}{l}\text { Events } \\
\text { Max }\end{array}$ \\
\hline Carlson & $\overline{0.0}$ & 1.0 & 1.0 & 2.0 & 3.0 & $\overline{0.0}$ & 1.3 & 1.3 & 1.6 & 5.2 & 0.0 & 1.4 & 2.0 & 4.7 & 8.8 \\
\hline Crowe & 0.0 & 1.0 & 1.0 & 2.0 & 4.0 & & & & & & & & & & \\
\hline Hackett & 0.0 & 1.0 & 1.0 & 2.0 & 3.0 & & & & & & & & & & \\
\hline Kuntz & 0.0 & 1.0 & 1.0 & 1.0 & 3.0 & & & & & & & & & & \\
\hline McBirney & 0.0 & 0.0 & 0.0 & 1.0 & 3.0 & & & & & & & & & & \\
\hline Sheridan & 0.0 & 1.0 & 1.0 & 4.0 & 7.0 & & & & & & & & & & \\
\hline Thompson & 0.0 & 1.0 & 1.0 & 2.0 & 3.0 & & & & & & & & & & \\
\hline Walker & 0.0 & 1.0 & 1.0 & 2.0 & 3.0 & & & & & & & & & & \\
\hline \multirow{4}{*}{$\begin{array}{l}\text { Mean } \\
\text { std deviation }\end{array}$} & 0.0 & 0.9 & 0.9 & 2.0 & 3.6 & & & & & & & & & & \\
\hline & 0.0 & 0.4 & 0.4 & 0.9 & 1.4 & & & & & & & & & & \\
\hline & \multicolumn{5}{|c|}{ Aeromagnetic Anomalies } & \multicolumn{5}{|c|}{ 1.0 Ma Basalt } & \multicolumn{5}{|c|}{ Sleeping Butte } \\
\hline & $\begin{array}{l}\text { Events } \\
\text { Min }\end{array}$ & $\begin{array}{l}\text { Events } \\
10 \%\end{array}$ & $\begin{array}{l}\text { Most } \\
\text { Likely }\end{array}$ & $\begin{array}{l}\text { Events } \\
90 \%\end{array}$ & $\begin{array}{l}\text { Events } \\
\text { Max }\end{array}$ & $\begin{array}{l}\text { Events } \\
\text { Min }\end{array}$ & $\begin{array}{l}\text { Events } \\
10 \%\end{array}$ & $\begin{array}{l}\text { Most } \\
\text { Likely }\end{array}$ & $\begin{array}{l}\text { Events } \\
90 \%\end{array}$ & $\begin{array}{l}\text { Events } \\
\text { Max }\end{array}$ & $\begin{array}{l}\text { Events } \\
\text { Min }\end{array}$ & $\begin{array}{l}\text { Events } \\
10 \%\end{array}$ & $\begin{array}{l}\text { Most } \\
\text { Likely }\end{array}$ & $\begin{array}{l}\text { Events } \\
90 \%\end{array}$ & $\begin{array}{l}\text { Events } \\
\text { Max }\end{array}$ \\
\hline \multirow[t]{3}{*}{ Mean } & 2.5 & 4.2 & 5.4 & 7.9 & 10.9 & 0.0 & 1.3 & 2.3 & 4.4 & 7.1 & 0.0 & 1.4 & 2.1 & 3.2 & 4.8 \\
\hline & \multicolumn{5}{|l|}{ Lathrop } & & & & & & & & & & \\
\hline & $\begin{array}{l}\text { Events } \\
\text { Min }\end{array}$ & $\begin{array}{l}\text { Events } \\
10 \%\end{array}$ & $\begin{array}{l}\text { Most } \\
\text { Likely }\end{array}$ & $\begin{array}{l}\text { Events } \\
90 \%\end{array}$ & $\begin{array}{l}\text { Events } \\
\text { Max }\end{array}$ & & & & & & & & & & \\
\hline Mean & 0.0 & 1.3 & 1.5 & 2.4 & 5.8 & & & & & & & & & & \\
\hline Mean Events & Min & $10 \%$ & $M L$ & $90 \%$ & $\operatorname{Max}$ & & & & & & & & & & \\
\hline Expert Set & 7.5 & 11.8 & 15.5 & 26.2 & 46.2 & & & & & & & & & & \\
\hline
\end{tabular}

Note: The unusual event counts for the basalt of Buckboard Mesa result from the strong views of one expert that the basalt of Buckboard Mesa should not be used in PVHA. He assumed 0 event counts for this center for all event count assignments except the $90 \%$ and maximum assignments. 
Table 6.13. (cont.) Event Counts for the Pliocene-Quaternary Yucca Mountain Region.

\begin{tabular}{|c|c|c|c|c|c|c|c|c|c|c|c|c|c|c|c|}
\hline \multicolumn{16}{|c|}{ Quaternary Pull-Apart Basin } \\
\hline \multirow{2}{*}{\begin{tabular}{|l} 
Structural Zone \\
Pull-Apart Basin \\
Quaternary
\end{tabular}} & \multicolumn{5}{|c|}{1.0 Basalt } & \multicolumn{5}{|l|}{ Lathrop } & & & & & \\
\hline & \begin{tabular}{|l} 
Events \\
Min
\end{tabular} & $\begin{array}{l}\text { Events } \\
10 \%\end{array}$ & $\begin{array}{l}\text { Most } \\
\text { Likely }\end{array}$ & $\begin{array}{l}\text { Events } \\
90 \%\end{array}$ & $\begin{array}{l}\text { Events } \\
\text { Max }\end{array}$ & \begin{tabular}{|l} 
Events \\
Min
\end{tabular} & $\begin{array}{l}\text { Events } \\
10 \%\end{array}$ & $\begin{array}{l}\text { Most } \\
\text { Likely }\end{array}$ & $\begin{array}{l}\text { Events } \\
90 \%\end{array}$ & $\begin{array}{l}\text { Events } \\
\text { Max }\end{array}$ & & & & & \\
\hline Mean & 0.0 & 1.3 & 2.3 & 4.4 & 7.1 & 0.0 & 1.3 & 1.5 & 2.4 & 5.8 & & & & & \\
\hline Mean Events & Min & $10 \%$ & $50 \%$ & $90 \%$ & $\operatorname{Max}$ & & & & & & & & & & \\
\hline Expert Set & 1.0 & 2.6 & 3.8 & 6.8 & 12.9 & & & & & & & & & & \\
\hline \multicolumn{16}{|c|}{ Plio-Quaternary Pull-Apart Basin } \\
\hline \multirow{2}{*}{$\begin{array}{l}\text { Structural Zone } \\
\text { Pull-Apart Basin } \\
\text { Plio-Quaternary }\end{array}$} & \multicolumn{5}{|c|}{ Aeromagnetic Anomalies } & \multicolumn{5}{|c|}{ 3.7 Ma Basalt } & \multicolumn{5}{|c|}{$1.0 \mathrm{Ma}$ Basalt } \\
\hline & \begin{tabular}{|l} 
Events \\
Min \\
\end{tabular} & $\begin{array}{l}\text { Events } \\
10 \%\end{array}$ & $\begin{array}{l}\text { Most } \\
\text { Likely }\end{array}$ & $\begin{array}{l}\text { Events } \\
90 \%\end{array}$ & $\begin{array}{l}\text { Events } \\
\text { Max }\end{array}$ & \begin{tabular}{|l} 
Events \\
Min
\end{tabular} & $\begin{array}{l}\text { Events } \\
10 \%\end{array}$ & $\begin{array}{l}\text { Most } \\
\text { Likely }\end{array}$ & $\begin{array}{l}\text { Events } \\
90 \%\end{array}$ & $\begin{array}{l}\text { Events } \\
\text { Max }\end{array}$ & \begin{tabular}{|l} 
Events \\
Min
\end{tabular} & $\begin{array}{l}\text { Events } \\
10 \%\end{array}$ & $\begin{array}{l}\text { Most } \\
\text { Likely }\end{array}$ & $\begin{array}{l}\text { Events } \\
90 \%\end{array}$ & $\begin{array}{l}\text { Events } \\
\text { Max }\end{array}$ \\
\hline \multirow[t]{4}{*}{ Mean } & 2.5 & 4.2 & 5.4 & 7.9 & 10.9 & 0.0 & 1.4 & 2.0 & 4.7 & 8.8 & 0.0 & 1.3 & 2.3 & 4.4 & 7.1 \\
\hline & \multicolumn{5}{|c|}{ Lathrop Wells center } & & & & & & & & & & \\
\hline & Events & Events & Most & Events & Events & & & & & & & & & & \\
\hline & Min & $10 \%$ & Likely & $90 \%$ & $\operatorname{Max}$ & & & & & & & & & & \\
\hline Mean & 0.0 & 1.3 & 1.5 & 2.4 & 5.8 & & & & & & & & & & \\
\hline Mean Events & Min & $10 \%$ & $M L$ & $90 \%$ & $\operatorname{Max}$ & & & & & & & & & & \\
\hline Expert Set & 5.5 & 8.2 & 11.2 & 19.4 & 32.6 & & & & & & & & & & \\
\hline
\end{tabular}


Table 6.13. (cont.) Event Counts for the Pliocene-Quaternary Yucca Mountain Region.

\begin{tabular}{|c|c|c|c|c|c|c|c|c|c|c|c|c|c|c|c|}
\hline \multicolumn{16}{|c|}{ Walker Lane Shear Zone } \\
\hline \multirow{2}{*}{\begin{tabular}{|l} 
Structural Zone \\
WLSZ \\
Plio-Quaternary
\end{tabular}} & \multicolumn{5}{|c|}{ Thirsty Mlesa } & \multicolumn{5}{|c|}{$3.7 \mathrm{Ma}$ Basalt } & \multicolumn{5}{|c|}{ Aeromagnetic Anomalies } \\
\hline & \begin{tabular}{|l} 
Events \\
Min \\
\end{tabular} & $\begin{array}{l}\text { Events } \\
10 \% \\
\end{array}$ & $\begin{array}{l}\text { Most } \\
\text { Likely }\end{array}$ & $\begin{array}{l}\text { Events } \\
90 \%\end{array}$ & $\begin{array}{l}\text { Events } \\
\text { Max }\end{array}$ & \begin{tabular}{|l|} 
Events \\
Min \\
\end{tabular} & $\begin{array}{l}\text { Events } \\
10 \%\end{array}$ & $\begin{array}{l}\text { Most } \\
\text { Likely } \\
\end{array}$ & $\begin{array}{l}\text { Events } \\
90 \%\end{array}$ & $\begin{array}{l}\text { Events } \\
\text { Max }\end{array}$ & \begin{tabular}{|l|} 
Events \\
Min \\
\end{tabular} & $\begin{array}{l}\text { Events } \\
10 \%\end{array}$ & $\begin{array}{l}\text { Most } \\
\text { Likely }\end{array}$ & $\begin{array}{l}\text { Events } \\
90 \% \\
\end{array}$ & $\begin{array}{l}\text { Events } \\
\text { Max }\end{array}$ \\
\hline \multirow[t]{3}{*}{ Mean } & 0.0 & 1.3 & 1.3 & 1.6 & 5.2 & 0.0 & 1.4 & 2.0 & 4.7 & 8.8 & 2.5 & 4.2 & 5.4 & 7.9 & 10.9 \\
\hline & \multicolumn{5}{|c|}{1.0 Basalt } & \multicolumn{5}{|c|}{ Sleeping Butte } & \multicolumn{5}{|l|}{ Lathrop } \\
\hline & \begin{tabular}{|l} 
Events \\
Min \\
\end{tabular} & $\begin{array}{l}\text { Events } \\
10 \% \\
\end{array}$ & $\begin{array}{l}\text { Most } \\
\text { Likely }\end{array}$ & $\begin{array}{l}\text { Events } \\
90 \%\end{array}$ & $\begin{array}{l}\text { Events } \\
\text { Max }\end{array}$ & \begin{tabular}{|l|} 
Events \\
Min \\
\end{tabular} & $\begin{array}{l}\text { Events } \\
10 \% \\
\end{array}$ & $\begin{array}{l}\text { Most } \\
\text { Likely } \\
\end{array}$ & $\begin{array}{l}\text { Events } \\
90 \% \\
\end{array}$ & $\begin{array}{l}\text { Events } \\
\text { Max }\end{array}$ & \begin{tabular}{|l|} 
Events \\
Min \\
\end{tabular} & $\begin{array}{l}\text { Events } \\
10 \% \\
\end{array}$ & $\begin{array}{l}\text { Most } \\
\text { Likely }\end{array}$ & $\begin{array}{l}\text { Events } \\
90 \% \\
\end{array}$ & $\begin{array}{l}\text { Events } \\
\text { Max }\end{array}$ \\
\hline Mean & 0.0 & 1.3 & 2.3 & 4.4 & 7.1 & 0.0 & 1.4 & 2.1 & 3.2 & 4.8 & 0.0 & 1.3 & 1.5 & 2.4 & 5.8 \\
\hline Mean Events & Min & $10 \%$ & $M L$ & $90 \%$ & Max & & & & & & & & & & \\
\hline Expert Set & 7.5 & 11.0 & 14.6 & 24.2 & 42.5 & & & & & & & & & & \\
\hline \multicolumn{16}{|c|}{ Plio-Quaternary Northeast-trending Structural Zone } \\
\hline Structural Zone & \multicolumn{5}{|c|}{3.7 Ma Basalt } & \multicolumn{5}{|c|}{ Aeromagnetic Anomalies } & \multicolumn{5}{|c|}{ Buckboard Mesa } \\
\hline \begin{tabular}{|l} 
NESZ \\
Plio-Quaternary \\
\end{tabular} & \begin{tabular}{|l|} 
Events \\
Min \\
\end{tabular} & $\begin{array}{l}\text { Events } \\
10 \% \\
\end{array}$ & $\begin{array}{l}\text { Most } \\
\text { Likely }\end{array}$ & $\begin{array}{l}\text { Events } \\
90 \%\end{array}$ & $\begin{array}{l}\text { Events } \\
\text { Max } \\
\end{array}$ & \begin{tabular}{|l|} 
Events \\
Min \\
\end{tabular} & $\begin{array}{l}\text { Events } \\
10 \% \\
\end{array}$ & $\begin{array}{l}\text { Most } \\
\text { Likely } \\
\end{array}$ & $\begin{array}{l}\text { Events } \\
90 \% \\
\end{array}$ & $\begin{array}{l}\text { Events } \\
\text { Max }\end{array}$ & \begin{tabular}{|l|} 
Events \\
Min \\
\end{tabular} & $\begin{array}{l}\text { Events } \\
10 \% \\
\end{array}$ & $\begin{array}{l}\text { Most } \\
\text { Likely }\end{array}$ & $\begin{array}{l}\text { Events } \\
90 \% \\
\end{array}$ & $\begin{array}{l}\text { Events } \\
\text { Max }\end{array}$ \\
\hline \multirow[t]{3}{*}{ Mean } & 0.0 & 1.5 & 2.0 & 4.8 & 9.2 & 2.5 & 4.2 & 5.4 & 7.9 & 10.9 & 0.0 & 0.9 & 0.9 & 2.0 & 3.6 \\
\hline & \multicolumn{5}{|c|}{1.0 Ma Basalt } & \multicolumn{5}{|l|}{ Lathrop } & & & & & \\
\hline & \begin{tabular}{|l|} 
Events \\
Min
\end{tabular} & $\begin{array}{l}\text { Events } \\
10 \%\end{array}$ & $\begin{array}{l}\text { Most } \\
\text { Likely }\end{array}$ & $\begin{array}{l}\text { Events } \\
90 \%\end{array}$ & $\begin{array}{l}\text { Events } \\
\text { Max }\end{array}$ & \begin{tabular}{|l|} 
Events \\
Min
\end{tabular} & $\begin{array}{l}\text { Events } \\
10 \%\end{array}$ & $\begin{array}{l}\text { Most } \\
\text { Likely }\end{array}$ & $\begin{array}{l}\text { Events } \\
90 \%\end{array}$ & $\begin{array}{l}\text { Events } \\
\text { Max }\end{array}$ & & & & & \\
\hline Mean & 0.0 & 1.3 & 2.3 & 4.4 & 7.1 & 0.0 & 1.3 & 1.5 & 2.4 & 5.8 & & & & & \\
\hline Mean Events & Min & $10 \%$ & $M L$ & $90 \%$ & Max & & & & & & & & & & \\
\hline Expert Set & 6.5 & 9.2 & 12.1 & 21.4 & 36.6 & & & & & & & & & & \\
\hline
\end{tabular}


Table 6.14. Univariate Statistics and Percentiles from Event Count Simulation Modeling for the Quaternary Crater Flat Volcanic Zone: E1 and E2 Given E1.

\begin{tabular}{|c|c|c|c|c|c|c|c|c|c|}
\hline $\begin{array}{l}\text { Event } \\
\text { Counts from } \\
\text { Table } 6.13\end{array}$ & $\begin{array}{c}\text { Zone } \\
\text { Minimum }\end{array}$ & Zone 10\% & $\begin{array}{l}\text { Zone } \\
\text { Most } \\
\text { Likely }\end{array}$ & $\begin{array}{l}\text { Zone } \\
90 \%\end{array}$ & $\begin{array}{c}\text { Zone } \\
\text { Maximum }\end{array}$ & & & $\begin{array}{c}\text { Simulation } \\
\text { Results }\end{array}$ & \\
\hline & 2.0 & 4.0 & 5.5 & 10.0 & 17.7 & Zone & mean & 5.9 & \\
\hline \multicolumn{6}{|c|}{ Distribution Parameters for Simulation Modeling } & Zone & std dev & 1.5 & \\
\hline $\begin{array}{l}\text { Distribution } \\
\text { Type }\end{array}$ & Uniform & Triangular & Trigen & Normal & & Zone & mode & 5.5 & \\
\hline $\begin{array}{l}\text { Expected } \\
\text { Value }\end{array}$ & 9.8 & 8.4 & 6.8 & 5.9 & E2 Hrep & $1.9 \mathrm{E}-5$ & & & \\
\hline \begin{tabular}{|l} 
Distribution \\
Type
\end{tabular} & Uniform & Triangular & Trigen & Normal & & Uniform & Triangular & Trigen & Normal \\
\hline E1 expected & 8.9E-6 & 7.6E-6 & $6.2 E-6$ & $5.4 \mathrm{E}-6$ & $\begin{array}{l}\text { E2 given } \\
\text { E1 }\end{array}$ & $1.7 \mathrm{E}-10$ & $1.5 \mathrm{E}-10$ & $1.2 \mathrm{E}-10$ & $1.0 \mathrm{E}-10$ \\
\hline \multicolumn{10}{|c|}{ Simulation Results } \\
\hline Minimum & $1.8 \mathrm{E}-6$ & $1.8 \mathrm{E}-6$ & $1.9 \mathrm{E}-6$ & $5.3 E-8$ & & $3.5 \mathrm{E}-11$ & $3.5 \mathrm{E}-11$ & 3.7E-11 & $1.0 \mathrm{E}-12$ \\
\hline Maximum & $1.6 \mathrm{E}-5$ & $1.6 \mathrm{E}-5$ & $1.1 \mathrm{E}-5$ & $1.0 \mathrm{E}-5$ & & $3.1 \mathrm{E}-10$ & $3.1 \mathrm{E}-10$ & $2.2 \mathrm{E}-10$ & $2.0 \mathrm{E}-10$ \\
\hline Mean & $8.9 \mathrm{E}-6$ & $7.6 \mathrm{E}-6$ & $6.2 \mathrm{E}-6$ & $5.4 \mathrm{E}-6$ & & 1.7E-10 & $1.5 \mathrm{E}-10$ & $1.2 \mathrm{E}-10$ & $1.0 \mathrm{E}-10$ \\
\hline Std Deviation & $4.1 \mathrm{E}-6$ & $3.1 \mathrm{E}-6$ & $2.0 \mathrm{E}-6$ & $1.3 \mathrm{E}-6$ & & $7.9 \mathrm{E}-11$ & $5.9 \mathrm{E}-11$ & $3.9 \mathrm{E}-11$ & $2.6 \mathrm{E}-11$ \\
\hline Variance & $1.7 \mathrm{E}-11$ & $9.3 \mathrm{E}-12$ & $4.1 \mathrm{E}-12$ & $1.8 \mathrm{E}-12$ & & $6.3 \mathrm{E}-21$ & $3.4 \mathrm{E}-21$ & $1.5 \mathrm{E}-21$ & $6.6 \mathrm{E}-22$ \\
\hline Skewness & 0.0 & 0.4 & 0.3 & 0.0 & & 0.0 & 0.4 & 0.3 & 0.0 \\
\hline Kurtosis & 1.8 & 2.4 & 2.4 & 3.0 & & 1.8 & 2.4 & 2.4 & 3.0 \\
\hline Mode & $3.6 \mathrm{E}-6$ & $5.0 \mathrm{E}-6$ & $5.0 \mathrm{E}-6$ & $5.6 \mathrm{E}-6$ & & $6.9 \mathrm{E}-11$ & $9.6 \mathrm{E}-11$ & $9.7 \mathrm{E}-11$ & $1.1 \mathrm{E}-10$ \\
\hline $5 \%$ & $2.5 \mathrm{E}-6$ & $3.3 \mathrm{E}-6$ & $3.1 \mathrm{E}-6$ & $3.2 \mathrm{E}-6$ & & $4.9 \mathrm{E}-11$ & $6.4 \mathrm{E}-11$ & $6.0 \mathrm{E}-11$ & $6.1 \mathrm{E}-11$ \\
\hline $10 \%$ & $3.2 \mathrm{E}-6$ & $4.0 \mathrm{E}-6$ & $3.6 \mathrm{E}-6$ & $3.6 \mathrm{E}-6$ & & $6.2 \mathrm{E}-11$ & $7.6 \mathrm{E}-11$ & $7.0 \mathrm{E}-11$ & 7.0E-11 \\
\hline $15 \%$ & $4.0 \mathrm{E}-6$ & $4.4 \mathrm{E}-6$ & $4.0 \mathrm{E}-6$ & $4.0 \mathrm{E}-6$ & & $7.60 \mathrm{E}-11$ & $8.5 \mathrm{E}-11$ & 7.7E-11 & 7.6E-11 \\
\hline $20 \%$ & 4.7E-6 & 4.8E-6 & $4.4 \mathrm{E}-6$ & $4.2 \mathrm{E}-6$ & & $9.0 \mathrm{E}-11$ & $9.3 \mathrm{E}-11$ & $8.4 \mathrm{E}-11$ & $8.1 \mathrm{E}-11$ \\
\hline $25 \%$ & $5.4 \mathrm{E}-6$ & 5.2E-6 & $4.7 \mathrm{E}-6$ & $4.5 \mathrm{E}-6$ & & $1.0 \mathrm{E}-10$ & $1.0 \mathrm{E}-10$ & $8.9 \mathrm{E}-11$ & 8.6E-11 \\
\hline $30 \%$ & $6.1 \mathrm{E}-6$ & 5.6E-6 & $4.9 \mathrm{E}-6$ & $4.7 \mathrm{E}-6$ & & $1.2 \mathrm{E}-10$ & $1.1 \mathrm{E}-10$ & $9.4 \mathrm{E}-11$ & $8.9 \mathrm{E}-11$ \\
\hline $35 \%$ & $6.8 \mathrm{E}-6$ & 6.0E-6 & $5.2 \mathrm{E}-6$ & $4.8 \mathrm{E}-6$ & & 1.3E-10 & $1.1 \mathrm{E}-10$ & $9.9 \mathrm{E}-11$ & $9.31 \mathrm{E}-11$ \\
\hline $40 \%$ & $7.5 \mathrm{E}-6$ & 6.4E-6 & $5.4 \mathrm{E}-6$ & $5.0 \mathrm{E}-6$ & & $1.4 \mathrm{E}-10$ & $1.2 \mathrm{E}-10$ & $1.0 \mathrm{E}-10$ & $9.6 \mathrm{E}-11$ \\
\hline $45 \%$ & $8.2 E-6$ & $6.8 \mathrm{E}-6$ & $5.7 \mathrm{E}-6$ & $5.2 \mathrm{E}-6$ & & $1.6 \mathrm{E}-10$ & $1.3 \mathrm{E}-10$ & $1.1 \mathrm{E}-10$ & $10.0 \mathrm{E}-11$ \\
\hline $50 \%$ & 8.9E-6 & 7.2E-6 & $6.0 \mathrm{E}-6$ & $5.4 \mathrm{E}-6$ & & 1.7E-10 & $1.4 \mathrm{E}-10$ & $1.1 \mathrm{E}-10$ & $1.0 \mathrm{E}-10$ \\
\hline $55 \%$ & $9.7 \mathrm{E}-6$ & 7.7E-6 & $6.2 \mathrm{E}-6$ & $5.5 \mathrm{E}-6$ & & $1.9 \mathrm{E}-10$ & $1.5 \mathrm{E}-10$ & $1.2 \mathrm{E}-10$ & $1.1 \mathrm{E}-10$ \\
\hline $60 \%$ & $1.0 \mathrm{E}-5$ & $8.1 \mathrm{E}-6$ & $6.6 \mathrm{E}-6$ & $5.7 \mathrm{E}-6$ & & $2.0 \mathrm{E}-10$ & $1.6 \mathrm{E}-10$ & $1.3 \mathrm{E}-10$ & $1.1 \mathrm{E}-10$ \\
\hline $65 \%$ & $1.1 \mathrm{E}-5$ & 8.7E-6 & $6.9 \mathrm{E}-6$ & $5.9 \mathrm{E}-6$ & & $2.1 \mathrm{E}-10$ & $1.7 \mathrm{E}-10$ & $1.3 \mathrm{E}-10$ & $1.1 \mathrm{E}-10$ \\
\hline $70 \%$ & $1.2 \mathrm{E}-5$ & $9.2 \mathrm{E}-6$ & $7.2 \mathrm{E}-6$ & $6.1 \mathrm{E}-6$ & & $2.3 \mathrm{E}-10$ & $1.8 \mathrm{E}-10$ & $1.4 \mathrm{E}-10$ & $1.2 \mathrm{E}-10$ \\
\hline $75 \%$ & $1.2 \mathrm{E}-5$ & $9.8 \mathrm{E}-6$ & $7.6 \mathrm{E}-6$ & $6.3 \mathrm{E}-6$ & & $2.4 \mathrm{E}-10$ & $1.9 \mathrm{E}-10$ & $1.5 \mathrm{E}-10$ & $1.2 \mathrm{E}-10$ \\
\hline $80 \%$ & $1.3 \mathrm{E}-5$ & $1.0 \mathrm{E}-5$ & $8.0 \mathrm{E}-6$ & $6.5 \mathrm{E}-6$ & & $2.5 \mathrm{E}-10$ & $2.0 \mathrm{E}-10$ & $1.5 \mathrm{E}-10$ & $1.2 \mathrm{E}-10$ \\
\hline $85 \%$ & $1.4 \mathrm{E}-5$ & 1.1E-5 & $8.5 \mathrm{E}-6$ & $6.7 \mathrm{E}-6$ & & $2.7 \mathrm{E}-10$ & $2.2 \mathrm{E}-10$ & $1.6 \mathrm{E}-10$ & 1.3E-10 \\
\hline $90 \%$ & $1.5 \mathrm{E}-5$ & $1.2 \mathrm{E}-5$ & $9.1 \mathrm{E}-6$ & $7.1 \mathrm{E}-6$ & & $2.8 \mathrm{E}-10$ & $2.3 \mathrm{E}-10$ & $1.7 \mathrm{E}-10$ & $1.4 \mathrm{E}-10$ \\
\hline $95 \%$ & $1.5 \mathrm{E}-5$ & 1.3E-5 & $9.8 \mathrm{E}-6$ & $7.6 \mathrm{E}-6$ & & $2.9 \mathrm{E}-10$ & $2.5 \mathrm{E}-10$ & $1.9 \mathrm{E}-10$ & $1.4 \mathrm{E}-10$ \\
\hline \multicolumn{10}{|c|}{$\begin{array}{l}\text { Notes: } \\
\text { Simulation modeling using @RISK Version 3.5, 10,000 iterations and Latin Hypercube Sampling } \\
\text { Zone most likely value is the mode derived from simulation modeling using the event counts of Table 6.13. } \\
\text { Zone standard deviation is derived from simulation modeling using the event counts of Table 6.13. } \\
\text { Pr(E2 given E1)Pr(Ed1) uses the high temperature repository area and the mean disruption probability from Table 6.11. } \\
\text { Event Rates are adjusted for undetected events }\end{array}$} \\
\hline
\end{tabular}




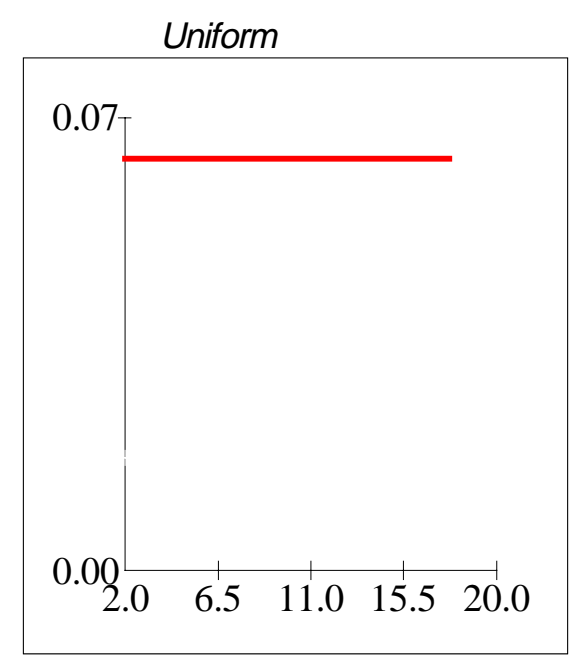

Triangle

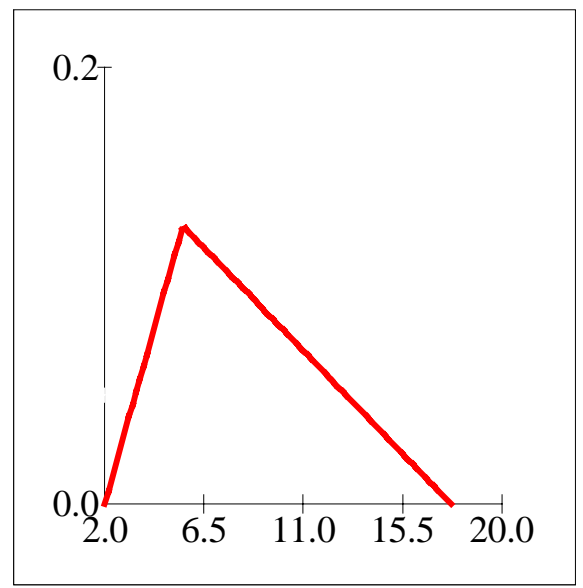

Trigen

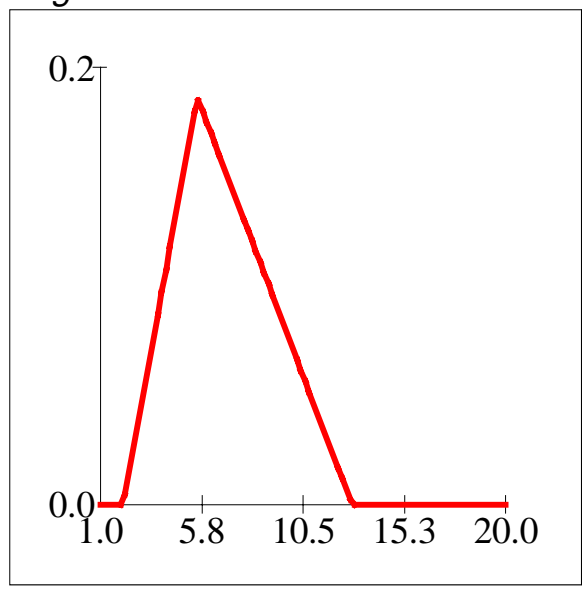

Normal

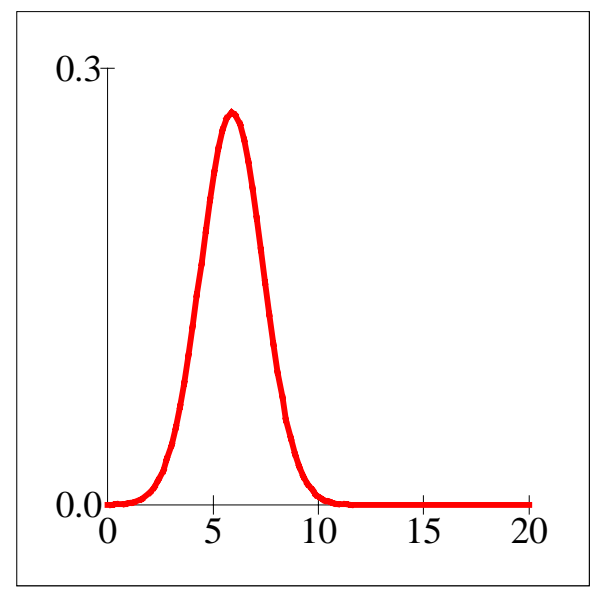

Figure 6.14. Probability distributions used in event-count simulations, Quaternary Crater Flat volcanic zone ( $\mathrm{x}$-axes are the event counts). 
Table 6.15. Univariate Statistics and Percentiles From Event Count Simulation Modeling for the Pliocene and Quaternary Crater Flat Volcanic Zone: E1 and E2 Given E1.

\begin{tabular}{|c|c|c|c|c|c|c|c|c|c|}
\hline \multirow[t]{2}{*}{$\begin{array}{l}\text { Event } \\
\text { Counts from } \\
\text { Table } 6.13\end{array}$} & $\begin{array}{c}\text { Zone } \\
\text { Minimu } \\
\mathrm{m}\end{array}$ & Zone 10\% & $\begin{array}{l}\text { Zone } \\
\text { Most } \\
\text { Likely }\end{array}$ & $\begin{array}{l}\text { Zone } \\
90 \%\end{array}$ & $\begin{array}{c}\text { Zone } \\
\text { Maximum }\end{array}$ & & & & $\begin{array}{l}\text { Simulation } \\
\text { Results }\end{array}$ \\
\hline & 7.5 & 11.0 & 14.8 & 24.2 & 42.5 & & Zone & mean & 14.6 \\
\hline \multicolumn{7}{|c|}{ Distribution Parameters for Simulation Modeling } & Zone & std dev & 3.0 \\
\hline $\begin{array}{l}\text { Distribution } \\
\text { Type }\end{array}$ & Uniform & Triangular & Trigen & Normal & & & Zone & mode & 14.8 \\
\hline $\begin{array}{l}\text { Expected } \\
\text { Value }\end{array}$ & 25.0 & 21.6 & 17.2 & 14.6 & E2 Lrep & $7.3 E-5$ & & & \\
\hline \begin{tabular}{|l} 
Distribution \\
Type
\end{tabular} & Uniform & Triangular & Trigen & Normal & & Uniform & Triangular & Trigen & Normal \\
\hline $\mathrm{E} 1$ & $5.2 \mathrm{E}-6$ & $4.5 \mathrm{E}-6$ & $3.6 \mathrm{E}-6$ & 3.0E-6 & $\begin{array}{c}\text { E2 given } \\
\text { E1 }\end{array}$ & $3.8 \mathrm{E}-10$ & $3.3 E-10$ & $2.6 \mathrm{E}-10$ & $2.2 \mathrm{E}-10$ \\
\hline \multicolumn{10}{|c|}{ Simulation Results } \\
\hline Minimum & $1.6 \mathrm{E}-6$ & $1.6 \mathrm{E}-6$ & $1.4 \mathrm{E}-6$ & $7.0 \mathrm{E}-7$ & & $1.1 \mathrm{E}-10$ & $1.16 \mathrm{E}-10$ & $1.02 \mathrm{E}-10$ & $5.13 \mathrm{E}-11$ \\
\hline Maximum & $8.8 \mathrm{E}-6$ & $8.8 \mathrm{E}-6$ & $6.3 \mathrm{E}-6$ & $5.7 \mathrm{E}-6$ & & $6.5 \mathrm{E}-10$ & $6.46 \mathrm{E}-10$ & $4.60 \mathrm{E}-10$ & $4.19 \mathrm{E}-10$ \\
\hline Mean & $5.2 \mathrm{E}-6$ & $4.5 \mathrm{E}-6$ & $3.6 \mathrm{E}-6$ & $3.0 \mathrm{E}-6$ & & $3.8 \mathrm{E}-10$ & $3.31 \mathrm{E}-10$ & $2.64 \mathrm{E}-10$ & $2.24 \mathrm{E}-10$ \\
\hline Std Deviation & $2.1 \mathrm{E}-6$ & $1.6 \mathrm{E}-6$ & $1.0 \mathrm{E}-6$ & $6.2 \mathrm{E}-7$ & & $1.5 \mathrm{E}-10$ & $1.15 \mathrm{E}-10$ & $7.51 \mathrm{E}-11$ & $4.57 \mathrm{E}-11$ \\
\hline Variance & $4.4 \mathrm{E}-12$ & $2.5 \mathrm{E}-12$ & $1.0 \mathrm{E}-12$ & $3.9 \mathrm{E}-13$ & & $2.4 \mathrm{E}-20$ & 1.33E-20 & $5.64 \mathrm{E}-21$ & $2.09 \mathrm{E}-21$ \\
\hline Skewness & 0.0 & 0.4 & 0.3 & 0.0 & & 0.0 & 0.47 & 0.29 & 0.00 \\
\hline Kurtosis & 1.8 & 2.4 & 2.4 & 3.0 & & 1.8 & 2.40 & 2.40 & 3.00 \\
\hline Mode & $2.5 \mathrm{E}-6$ & $3.2 \mathrm{E}-6$ & $3.2 \mathrm{E}-6$ & $3.1 \mathrm{E}-6$ & & $1.8 \mathrm{E}-10$ & $2.35 \mathrm{E}-10$ & $2.36 \mathrm{E}-10$ & $2.26 \mathrm{E}-10$ \\
\hline $5 \%$ & $1.9 \mathrm{E}-6$ & $2.3 \mathrm{E}-6$ & $2.0 \mathrm{E}-6$ & $2.0 \mathrm{E}-6$ & & $1.4 \mathrm{E}-10$ & $1.69 \mathrm{E}-10$ & $1.49 \mathrm{E}-10$ & $1.48 \mathrm{E}-10$ \\
\hline $10 \%$ & $2.3 \mathrm{E}-6$ & $2.6 \mathrm{E}-6$ & $2.3 \mathrm{E}-6$ & $2.2 \mathrm{E}-6$ & & $1.7 \mathrm{E}-10$ & $1.92 \mathrm{E}-10$ & $1.68 \mathrm{E}-10$ & $1.65 \mathrm{E}-10$ \\
\hline $15 \%$ & $2.7 \mathrm{E}-6$ & $2.8 \mathrm{E}-6$ & $2.5 \mathrm{E}-6$ & $2.4 \mathrm{E}-6$ & & $1.9 \mathrm{E}-10$ & $2.09 \mathrm{E}-10$ & $1.84 \mathrm{E}-10$ & $1.76 \mathrm{E}-10$ \\
\hline $20 \%$ & $3.0 \mathrm{E}-6$ & $3.0 \mathrm{E}-6$ & $2.7 \mathrm{E}-6$ & $2.5 \mathrm{E}-6$ & & $2.2 \mathrm{E}-10$ & $2.24 \mathrm{E}-10$ & $1.96 \mathrm{E}-10$ & $1.85 \mathrm{E}-10$ \\
\hline $25 \%$ & $3.4 \mathrm{E}-6$ & $3.2 \mathrm{E}-6$ & $2.8 \mathrm{E}-6$ & $2.6 \mathrm{E}-6$ & & $2.5 \mathrm{E}-10$ & $2.38 \mathrm{E}-10$ & $2.08 \mathrm{E}-10$ & $1.93 \mathrm{E}-10$ \\
\hline $30 \%$ & $3.7 \mathrm{E}-6$ & $3.4 \mathrm{E}-6$ & $3.0 \mathrm{E}-6$ & $2.7 \mathrm{E}-6$ & & $2.8 \mathrm{E}-10$ & $2.52 \mathrm{E}-10$ & $2.18 \mathrm{E}-10$ & $2.00 \mathrm{E}-10$ \\
\hline $35 \%$ & $4.1 \mathrm{E}-6$ & $3.6 \mathrm{E}-6$ & $3.1 \mathrm{E}-6$ & $2.8 \mathrm{E}-6$ & & $3.0 \mathrm{E}-10$ & $2.66 \mathrm{E}-10$ & $2.27 \mathrm{E}-10$ & $2.06 \mathrm{E}-10$ \\
\hline $40 \%$ & $4.5 \mathrm{E}-6$ & $3.8 \mathrm{E}-6$ & $3.21 \mathrm{E}-6$ & $2.9 \mathrm{E}-6$ & & $3.3 \mathrm{E}-10$ & $2.81 \mathrm{E}-10$ & $2.36 \mathrm{E}-10$ & $2.12 \mathrm{E}-10$ \\
\hline $45 \%$ & $4.8 \mathrm{E}-6$ & $4.0 \mathrm{E}-6$ & $3.3 \mathrm{E}-6$ & $3.0 \mathrm{E}-6$ & & $3.6 \mathrm{E}-10$ & $2.97 \mathrm{E}-10$ & $2.46 \mathrm{E}-10$ & $2.18 \mathrm{E}-10$ \\
\hline $50 \%$ & $5.2 \mathrm{E}-6$ & $4.3 \mathrm{E}-6$ & $3.5 \mathrm{E}-6$ & $3.0 \mathrm{E}-6$ & & $3.8 \mathrm{E}-10$ & $3.13 \mathrm{E}-10$ & $2.56 \mathrm{E}-10$ & $2.24 \mathrm{E}-10$ \\
\hline $55 \%$ & $5.6 \mathrm{E}-6$ & $4.5 \mathrm{E}-6$ & $3.6 \mathrm{E}-6$ & $3.1 \mathrm{E}-6$ & & $4.1 \mathrm{E}-10$ & $3.31 \mathrm{E}-10$ & $2.67 \mathrm{E}-10$ & $2.29 \mathrm{E}-10$ \\
\hline $60 \%$ & $5.9 \mathrm{E}-6$ & 4.7E-6 & $3.8 \mathrm{E}-6$ & $3.2 \mathrm{E}-6$ & & $4.4 \mathrm{E}-10$ & $3.49 \mathrm{E}-10$ & $2.78 \mathrm{E}-10$ & $2.35 \mathrm{E}-10$ \\
\hline $65 \%$ & 6.3E-6 & $5.0 \mathrm{E}-6$ & $3.9 \mathrm{E}-6$ & 3.3E-6 & & $4.6 \mathrm{E}-10$ & $3.69 \mathrm{E}-10$ & $2.90 \mathrm{E}-10$ & $2.41 \mathrm{E}-10$ \\
\hline $70 \%$ & $6.7 \mathrm{E}-6$ & $5.3 \mathrm{E}-6$ & $4.1 \mathrm{E}-6$ & $3.4 \mathrm{E}-6$ & & $4.9 \mathrm{E}-10$ & $3.89 \mathrm{E}-10$ & $3.03 \mathrm{E}-10$ & $2.48 \mathrm{E}-10$ \\
\hline $75 \%$ & $7.0 \mathrm{E}-6$ & $5.6 \mathrm{E}-6$ & $4.3 \mathrm{E}-6$ & $3.5 \mathrm{E}-6$ & & $5.2 \mathrm{E}-10$ & $4.12 \mathrm{E}-10$ & $3.17 \mathrm{E}-10$ & $2.54 \mathrm{E}-10$ \\
\hline $80 \%$ & 7.4E-6 & $5.9 \mathrm{E}-6$ & $4.5 \mathrm{E}-6$ & $3.6 \mathrm{E}-6$ & & $5.4 \mathrm{E}-10$ & $4.37 \mathrm{E}-10$ & $3.32 \mathrm{E}-10$ & $2.62 \mathrm{E}-10$ \\
\hline $85 \%$ & $7.8 \mathrm{E}-6$ & $6.3 \mathrm{E}-6$ & $4.8 \mathrm{E}-6$ & $3.7 \mathrm{E}-6$ & & $5.7 \mathrm{E}-10$ & $4.66 \mathrm{E}-10$ & $3.50 \mathrm{E}-10$ & $2.71 \mathrm{E}-10$ \\
\hline $90 \%$ & $8.1 \mathrm{E}-6$ & $6.8 \mathrm{E}-6$ & $5.0 \mathrm{E}-6$ & $3.8 \mathrm{E}-6$ & & $6.0 \mathrm{E}-10$ & $5.00 \mathrm{E}-10$ & $3.71 \mathrm{E}-10$ & $2.82 \mathrm{E}-10$ \\
\hline $95 \%$ & $8.5 \mathrm{E}-6$ & 7.4E-6 & $5.4 \mathrm{E}-6$ & $4.1 \mathrm{E}-6$ & & $6.2 \mathrm{E}-10$ & $5.44 \mathrm{E}-10$ & $3.98 \mathrm{E}-10$ & $2.99 \mathrm{E}-10$ \\
\hline \multicolumn{10}{|c|}{$\begin{array}{l}\text { Notes: } \\
\text { Simulation modeling using @RISK Version 3.5, 10,000 iterations and Latin Hypercube Sampling } \\
\text { Zone most likely value is the mode is derived from simulation modeling using the event counts of Table 6.13. } \\
\text { Zone standard deviation is derived from simulation modeling using the event counts of Table 6.13. } \\
\text { Pr(E2 given E1)Pr(Ed1) uses the low temperature repository area and the mean disruption probability from Table 6.11. } \\
\text { Event Rates are adjusted for undetected events }\end{array}$} \\
\hline
\end{tabular}



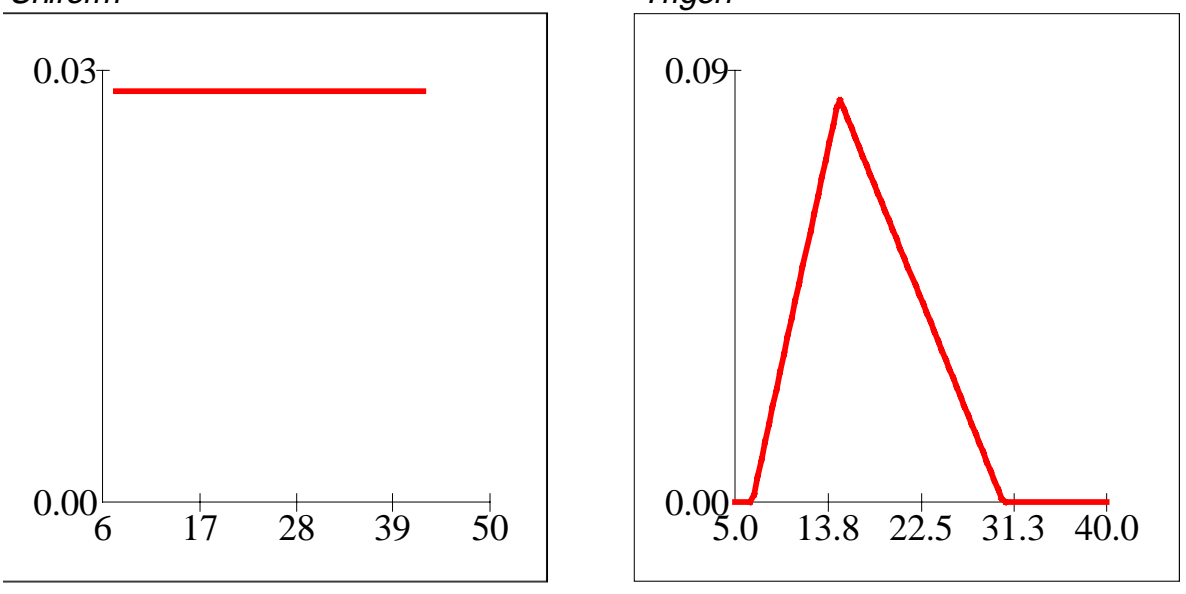

\section{Triangle}

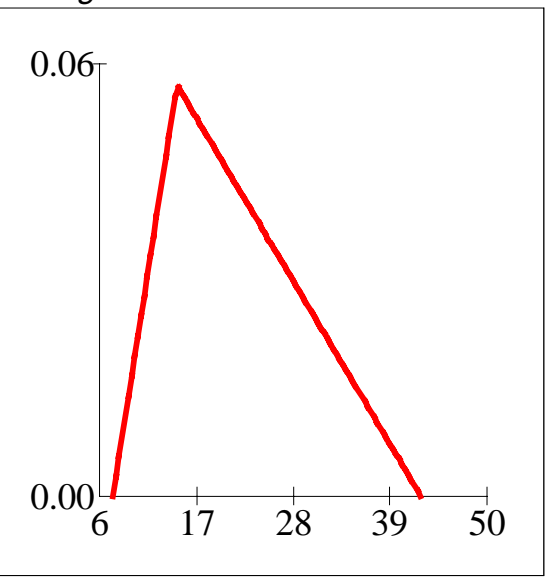

Normal

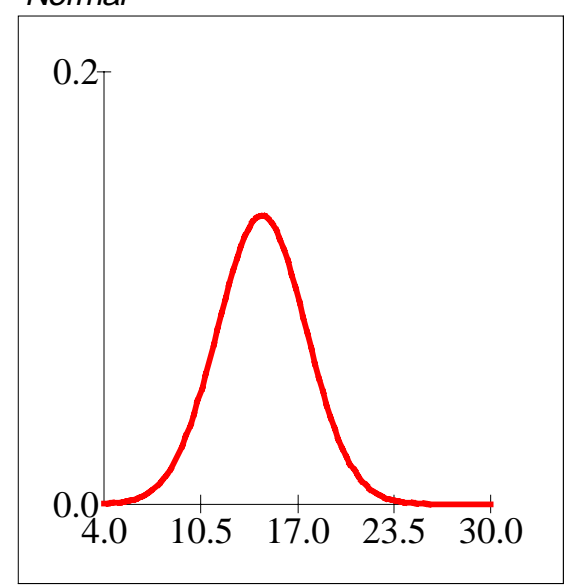

Figure 6.15. Probability distributions used in event-count simulations, Pliocene-Quaternary Crater Flat volcanic zone ( $\mathrm{x}$-axes are the event counts). 
Table 6.16. Univariate Statistics and Percentiles From Event Count Simulation Modeling for the YMR: E1 and E2 Given E1.

\begin{tabular}{|c|c|c|c|c|c|c|c|c|c|}
\hline $\begin{array}{l}\text { Event } \\
\text { Counts from } \\
\text { Table } 6.13\end{array}$ & $\begin{array}{c}\text { Zone } \\
\text { Minimum }\end{array}$ & Zone 10\% & $\begin{array}{c}\text { Zone Most } \\
\text { Likely }\end{array}$ & Zone 90\% & $\begin{array}{c}\text { Zone } \\
\text { Maximu } \\
m\end{array}$ & & & & $\begin{array}{l}\text { Zone } \\
\text { Simulation } \\
\text { Results }\end{array}$ \\
\hline & 7.5 & 11.8 & 15.8 & 26.2 & 46.1 & & Zone & mean & 15.5 \\
\hline \multicolumn{7}{|c|}{ Distribution Parameters for Simulation Modeling } & Zone & std dev & 3.0 \\
\hline \begin{tabular}{|l} 
Distribution \\
Type
\end{tabular} & Uniform & Triangular & Trigen & Normal & & & Zone & mode & 15.8 \\
\hline $\begin{array}{l}\text { Expected } \\
\text { Value }\end{array}$ & 27.3 & 23.5 & 18.6 & 15.5 & E2 Hrep & $2.4 \mathrm{E}-3$ & & & \\
\hline \begin{tabular}{|l} 
Distribution \\
Type
\end{tabular} & Uniform & Triangular & Trigen & Normal & & Uniform & Triangular & Trigen & Normal \\
\hline E1 & 5.E-6 & $4.9 \mathrm{E}-6$ & $3.9 \mathrm{E}-6$ & $3.2 \mathrm{E}-6$ & $\begin{array}{l}\text { E2 given } \\
\text { E1 }\end{array}$ & 1.3E-8 & $1.2 \mathrm{E}-8$ & $9.2 \mathrm{E}-9$ & 7.7E-9 \\
\hline \multicolumn{10}{|c|}{ Simulation Results } \\
\hline Minimum & $1.8 \mathrm{E}-6$ & $1.8 \mathrm{E}-6$ & $1.5 \mathrm{E}-6$ & 6.7E-7 & & $4.2 \mathrm{E}-9$ & $4.2 \mathrm{E}-9$ & $3.6 \mathrm{E}-9$ & $1.6 \mathrm{E}-9$ \\
\hline Maximum & $9.6 \mathrm{E}-6$ & $9.6 \mathrm{E}-6$ & $6.8 \mathrm{E}-6$ & $5.7 \mathrm{E}-6$ & & $2.3 \mathrm{E}-8$ & $2.3 \mathrm{E}-8$ & $1.6 \mathrm{E}-8$ & $1.4 \mathrm{E}-8$ \\
\hline Mean & $5.7 \mathrm{E}-6$ & $4.9 \mathrm{E}-6$ & $3.9 \mathrm{E}-6$ & $3.2 \mathrm{E}-6$ & & $1.35 \mathrm{E}-8$ & $1.2 \mathrm{E}-8$ & $9.2 \mathrm{E}-9$ & 7.7E-9 \\
\hline Std Deviation & $2.3 \mathrm{E}-6$ & $1.7 \mathrm{E}-6$ & $1.1 \mathrm{E}-6$ & 6.3E-7 & & $5.4 \mathrm{E}-9$ & $4.0 \mathrm{E}-9$ & $2.6 \mathrm{E}-9$ & $1.5 \mathrm{E}-9$ \\
\hline Variance & $5.1 \mathrm{E}-12$ & $2.9 \mathrm{E}-12$ & $1.2 \mathrm{E}-12$ & $3.9 \mathrm{E}-13$ & & $2.9 \mathrm{E}-17$ & $1.6 \mathrm{E}-17$ & $7.0 \mathrm{E}-18$ & $2.2 \mathrm{E}-18$ \\
\hline Skewness & 0.0 & 0.5 & 0.3 & 0.0 & & 0.0 & 0.5 & 0.3 & 0.0 \\
\hline Kurtosis & 1.8 & 2.4 & 2.4 & 3.0 & & 1.8 & 2.4 & 2.4 & 3.0 \\
\hline Mode & $2.0 \mathrm{E}-6$ & $3.5 \mathrm{E}-6$ & $3.2 \mathrm{E}-6$ & $3.3 \mathrm{E}-6$ & & $4.7 \mathrm{E}-9$ & $8.4 \mathrm{E}-9$ & $7.7 \mathrm{E}-9$ & $7.9 \mathrm{E}-9$ \\
\hline $5 \%$ & $2.2 \mathrm{E}-6$ & $2.5 \mathrm{E}-6$ & $2.2 \mathrm{E}-6$ & $2.2 \mathrm{E}-6$ & & $5.1 \mathrm{E}-9$ & $6.0 \mathrm{E}-9$ & $5.2 \mathrm{E}-9$ & $5.2 \mathrm{E}-9$ \\
\hline $10 \%$ & $2.5 \mathrm{E}-6$ & $2.9 \mathrm{E}-6$ & $2.5 \mathrm{E}-6$ & $2.4 \mathrm{E}-6$ & & $6.1 \mathrm{E}-9$ & $6.8 \mathrm{E}-9$ & $5.8 \mathrm{E}-9$ & $5.8 \mathrm{E}-9$ \\
\hline $15 \%$ & $2.9 \mathrm{E}-6$ & $3.1 \mathrm{E}-6$ & $2.7 \mathrm{E}-6$ & $2.6 \mathrm{E}-6$ & & $7.0 \mathrm{E}-9$ & 7.E-9 & $6.4 \mathrm{E}-9$ & $6.1 \mathrm{E}-9$ \\
\hline $20 \%$ & $3.3 E-6$ & 3.3E-6 & $2.9 \mathrm{E}-6$ & $2.7 \mathrm{E}-6$ & & $7.9 \mathrm{E}-9$ & 7.9E-9 & $6.8 \mathrm{E}-9$ & $6.4 \mathrm{E}-9$ \\
\hline $25 \%$ & $3.7 \mathrm{E}-6$ & $3.5 \mathrm{E}-6$ & $3.0 \mathrm{E}-6$ & $2.8 \mathrm{E}-6$ & & $8.9 \mathrm{E}-9$ & $8.4 \mathrm{E}-9$ & $7.2 \mathrm{E}-9$ & $6.7 \mathrm{E}-9$ \\
\hline $30 \%$ & $4.1 \mathrm{E}-6$ & 3.7E-6 & $3.2 \mathrm{E}-6$ & $2.9 \mathrm{E}-6$ & & $9.8 \mathrm{E}-9$ & 8.8E-09 & $7.6 \mathrm{E}-9$ & $6.9 \mathrm{E}-9$ \\
\hline $35 \%$ & $4.5 \mathrm{E}-6$ & $3.9 \mathrm{E}-6$ & $3.3 \mathrm{E}-6$ & $3.0 \mathrm{E}-6$ & & $1.1 \mathrm{E}-8$ & 9.4E-09 & $7.9 \mathrm{E}-9$ & $7.1 \mathrm{E}-9$ \\
\hline $40 \%$ & $4.9 \mathrm{E}-6$ & $4.3 \mathrm{E}-6$ & $3.5 \mathrm{E}-6$ & $3.1 \mathrm{E}-6$ & & $1.2 \mathrm{E}-8$ & 9.9E-09 & $8.2 \mathrm{E}-9$ & $7.3 \mathrm{E}-9$ \\
\hline $45 \%$ & $5.3 \mathrm{E}-6$ & $4.4 \mathrm{E}-6$ & $3.6 \mathrm{E}-6$ & $3.1 \mathrm{E}-6$ & & $1.3 \mathrm{E}-8$ & $1.0 \mathrm{E}-08$ & 8.6E-9 & $7.5 \mathrm{E}-9$ \\
\hline $50 \%$ & $5.7 \mathrm{E}-6$ & $4.6 \mathrm{E}-6$ & $3.7 \mathrm{E}-6$ & $3.2 \mathrm{E}-6$ & & $1.3 \mathrm{E}-8$ & $1.1 \mathrm{E}-08$ & 8.9E-9 & 7.7E-9 \\
\hline $55 \%$ & $6.2 \mathrm{E}-6$ & $4.9 \mathrm{E}-6$ & $3.9 \mathrm{E}-6$ & $3.3 \mathrm{E}-6$ & & $1.4 \mathrm{E}-8$ & $1.2 \mathrm{E}-08$ & $9.3 \mathrm{E}-9$ & $7.9 \mathrm{E}-9$ \\
\hline $60 \%$ & $6.5 \mathrm{E}-6$ & $5.2 \mathrm{E}-6$ & $4.1 \mathrm{E}-6$ & $3.4 \mathrm{E}-6$ & & $1.5 \mathrm{E}-8$ & $1.2 \mathrm{E}-08$ & $9.7 \mathrm{E}-9$ & $8.1 \mathrm{E}-9$ \\
\hline $65 \%$ & $6.9 \mathrm{E}-6$ & $5.4 \mathrm{E}-6$ & 4.3E-6 & $3.5 \mathrm{E}-6$ & & $1.6 \mathrm{E}-8$ & 1.3E-08 & $1.0 \mathrm{E}-8$ & $8.3 \mathrm{E}-9$ \\
\hline $70 \%$ & $7.2 \mathrm{E}-6$ & $5.7 \mathrm{E}-6$ & $4.4 \mathrm{E}-6$ & $3.6 \mathrm{E}-6$ & & $1.7 \mathrm{E}-8$ & $1.4 \mathrm{E}-08$ & $1.1 \mathrm{E}-8$ & $8.5 \mathrm{E}-9$ \\
\hline $75 \%$ & $7.6 \mathrm{E}-6$ & $6.1 \mathrm{E}-6$ & $4.7 \mathrm{E}-6$ & $3.6 \mathrm{E}-6$ & & $1.8 \mathrm{E}-8$ & $1.4 \mathrm{E}-08$ & $1.1 \mathrm{E}-8$ & 8.7E-9 \\
\hline $80 \%$ & 8.0E-6 & $6.5 \mathrm{E}-6$ & $4.9 \mathrm{E}-6$ & $3.8 \mathrm{E}-6$ & & $1.9 \mathrm{E}-8$ & $1.5 \mathrm{E}-08$ & $1.2 \mathrm{E}-8$ & $8.9 \mathrm{E}-9$ \\
\hline $85 \%$ & $8.4 \mathrm{E}-6$ & $6.9 \mathrm{E}-6$ & $5.1 \mathrm{E}-6$ & $3.9 \mathrm{E}-6$ & & $2.0 \mathrm{E}-8$ & $1.6 \mathrm{E}-08$ & $1.2 \mathrm{E}-8$ & $9.2 \mathrm{E}-9$ \\
\hline $90 \%$ & $8.8 \mathrm{E}-6$ & $7.4 \mathrm{E}-6$ & $5.5 \mathrm{E}-6$ & $4.0 \mathrm{E}-6$ & & $2.1 \mathrm{E}-8$ & $1.8 \mathrm{E}-08$ & $1.3 \mathrm{E}-8$ & $9.6 \mathrm{E}-9$ \\
\hline $95 \%$ & $9.2 \mathrm{E}-6$ & $8.0 \mathrm{E}-6$ & $5.9 \mathrm{E}-6$ & $4.3 \mathrm{E}-6$ & & $2.2 \mathrm{E}-8$ & $1.9 \mathrm{E}-08$ & $1.4 \mathrm{E}-8$ & $1.0 \mathrm{E}-8$ \\
\hline \multicolumn{10}{|c|}{$\begin{array}{l}\text { Notes: } \\
\text { Simulation modeling using @RISK Version 3.5, 10,000 iterations and Latin Hypercube Sampling } \\
\text { Zone most likely value is the mode is derived from simulation modeling using the event counts of Table 6.13. } \\
\text { Zone standard deviation is derived from simulation modeling using the event counts of Table 6.13. } \\
\text { Pr(E2 given E1)Pr(Ed1) uses the high temperature repository area and the mean disruption probability from Table 6.11. } \\
\text { Event Rates are adjusted for undetected events }\end{array}$} \\
\hline
\end{tabular}


Uniform

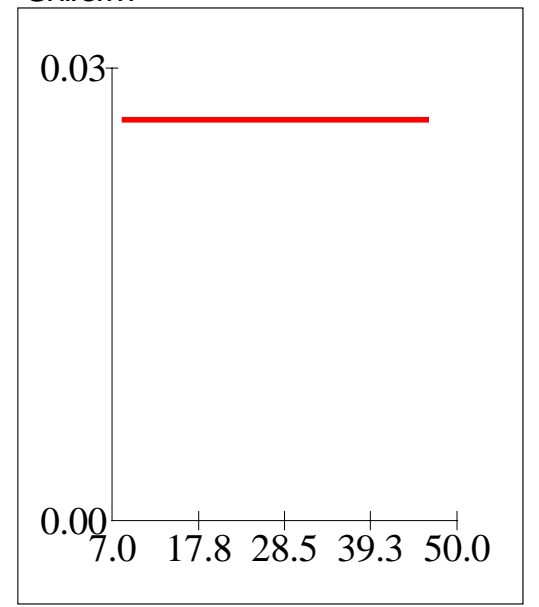

Triangle

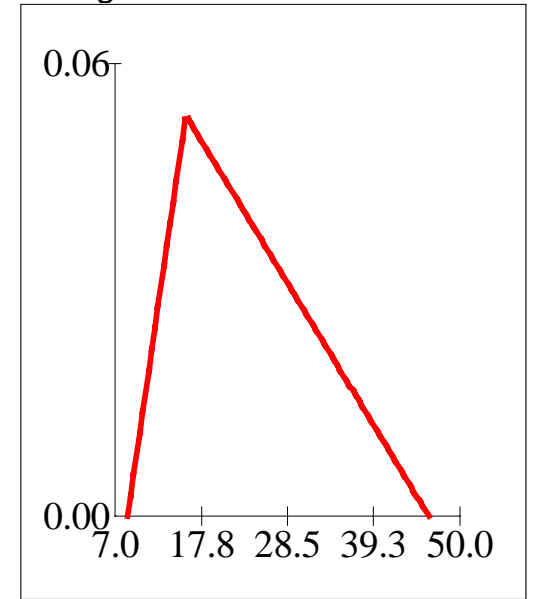

Trigen

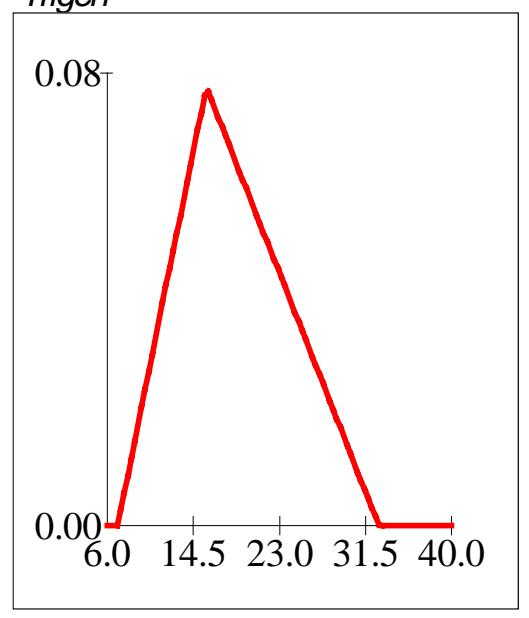

Normal

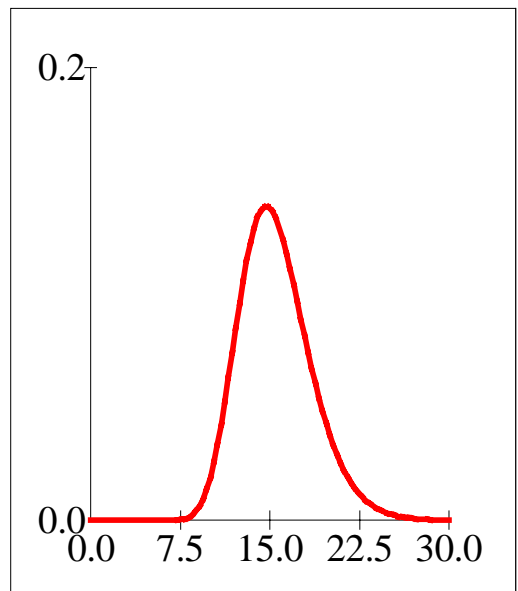

Figure 6.16. Probability distributions used in event-count simulations, Pliocene-Quaternary YMR (x-axes are the event counts). 
Table 6.17. Univariate Statistics and Percentiles From Event Count Simulation Modeling for the Quaternary Pull-Apart Basin: E1 and E2 Given E1.

\begin{tabular}{|c|c|c|c|c|c|c|c|c|c|}
\hline $\begin{array}{l}\text { Event } \\
\text { Counts from } \\
\text { Table } 6.13 \\
\end{array}$ & $\begin{array}{c}\text { Zone } \\
\text { Minimum }\end{array}$ & Zone 10\% & $\begin{array}{c}\text { Zone Most } \\
\text { Likely }\end{array}$ & Zone $90 \%$ & $\begin{array}{c}\text { Zone } \\
\text { Maximum }\end{array}$ & & & & $\begin{array}{l}\text { Zone } \\
\text { Simulation } \\
\text { Results } \\
\end{array}$ \\
\hline & 1.0 & 2.6 & 3.7 & 6.8 & 12.9 & & Zone & mean & 3.8 \\
\hline \multicolumn{7}{|c|}{ Distribution Parameters for Simulation Modeling } & Zone & std dev & 1.2 \\
\hline $\begin{array}{l}\text { Distribution } \\
\text { Type }\end{array}$ & Uniform & Triangular & Trigen & Normal & & & Zone & mode & 3.7 \\
\hline $\begin{array}{l}\text { Expected } \\
\text { Value }\end{array}$ & 6.9 & 5.9 & 4.6 & 3.8 & E2 Lrep & $1.1 \mathrm{E}-3$ & & & \\
\hline $\begin{array}{l}\text { Distribution } \\
\text { Type }\end{array}$ & Uniform & Triangular & Trigen & Normal & & Uniform & Triangular & Trigen & Normal \\
\hline $\mathrm{E} 1$ & $6.3 \mathrm{E}-6$ & 5.3E-6 & 4.1E-6 & $3.4 \mathrm{E}-6$ & $\begin{array}{l}\text { E2 given } \\
\text { E1 }\end{array}$ & 7.3E-9 & $6.1 \mathrm{E}-9$ & $4.8 \mathrm{E}-9$ & 4.0E-9 \\
\hline \multicolumn{10}{|c|}{ Simulation Results } \\
\hline Minimum & $9.1 \mathrm{E}-7$ & $9.6 \mathrm{E}-7$ & $1.1 \mathrm{E} 6$ & $0.0 \mathrm{E} 0$ & & $1.0 \mathrm{E}-9$ & $1.1 \mathrm{E}-9$ & $1.3 \mathrm{E}-9$ & $0.0 \mathrm{E} 0$ \\
\hline Maximum & $1.2 \mathrm{E}-5$ & $1.2 \mathrm{E}-5$ & $7.9 \mathrm{E}-6$ & $7.6 \mathrm{E}-6$ & & $1.3 \mathrm{E}-8$ & $1.3 \mathrm{E}-8$ & $9.1 \mathrm{E}-9$ & 8.7E-9 \\
\hline Mean & $6.3 \mathrm{E}-6$ & $5.3 \mathrm{E}-6$ & $4.1 \mathrm{E}-6$ & $3.4 \mathrm{E}-6$ & & 7.3E-9 & $6.1 \mathrm{E}-9$ & $4.8 \mathrm{E}-9$ & $4.0 \mathrm{E}-9$ \\
\hline Std Deviation & $3.1 \mathrm{E}-6$ & $2.3 \mathrm{E}-6$ & $1.4 \mathrm{E}-6$ & $1.1 \mathrm{E}-6$ & & $3.6 \mathrm{E}-9$ & 2.7E-9 & $1.6 \mathrm{E}-9$ & $1.2 \mathrm{E}-9$ \\
\hline Variance & $9.7 \mathrm{E}-12$ & $5.4 \mathrm{E}-12$ & $2.0 \mathrm{E}-12$ & $1.1 \mathrm{E}-12$ & & $1.3 \mathrm{E}-17$ & $7.1 \mathrm{E}-18$ & $2.7 \mathrm{E}-18$ & $1.5 \mathrm{E}-18$ \\
\hline Skewness & 0.0 & 0.45 & 0.32 & 0.0 & & 0.0 & 0.5 & 0.3 & 0.0 \\
\hline Kurtosis & 1.8 & 2.40 & 2.40 & 3.0 & & 1.8 & 2.0 & 2.4 & 3.0 \\
\hline Mode & $6.6 \mathrm{E}-6$ & $3.4 \mathrm{E}-6$ & $3.3 \mathrm{E}-6$ & $3.2 \mathrm{E}-6$ & & 7.5E-09 & $3.9 \mathrm{E}-9$ & $3.9 \mathrm{E}-9$ & $3.7 \mathrm{E}-9$ \\
\hline $5 \%$ & $1.4 \mathrm{E}-6$ & $2.0 \mathrm{E}-6$ & $2.0 \mathrm{E}-6$ & $1.7 \mathrm{E}-6$ & & & $2.4 \mathrm{E}-9$ & 2.3E-9 & $2.0 \mathrm{E}-9$ \\
\hline $10 \%$ & $2.0 \mathrm{E}-6$ & $2.5 \mathrm{E}-6$ & $2.4 \mathrm{E}-6$ & $2.1 \mathrm{E}-6$ & & $2.3 \mathrm{E}-9$ & $2.9 \mathrm{E}-9$ & $2.7 \mathrm{E}-9$ & $2.4 \mathrm{E}-9$ \\
\hline $15 \%$ & $2.5 \mathrm{E}-6$ & $2.9 \mathrm{E}-6$ & $2.6 \mathrm{E}-6$ & $2.3 \mathrm{E}-6$ & & $2.9 \mathrm{E}-9$ & 3.3E-9 & $3.0 \mathrm{E}-9$ & $2.7 \mathrm{E}-9$ \\
\hline $20 \%$ & $3.1 \mathrm{E}-6$ & $3.2 \mathrm{E}-6$ & $2.9 \mathrm{E}-6$ & $2.6 \mathrm{E}-6$ & & $3.5 \mathrm{E}-9$ & $3.7 \mathrm{E}-9$ & $3.3 \mathrm{E}-9$ & $2.9 \mathrm{E}-9$ \\
\hline $25 \%$ & $3.6 \mathrm{E}-6$ & $3.5 \mathrm{E}-6$ & $3.1 \mathrm{E}-6$ & $2.7 \mathrm{E}-6$ & & $4.2 \mathrm{E}-9$ & $4.0 \mathrm{E}-9$ & $3.5 \mathrm{E}-9$ & $3.1 \mathrm{E}-9$ \\
\hline $30 \%$ & $4.1 \mathrm{E}-6$ & $3.8 \mathrm{E}-6$ & 3.3E-6 & $2.9 \mathrm{E}-6$ & & $4.8 \mathrm{E}-9$ & 4.3E-9 & 3.7E-9 & $3.3 \mathrm{E}-9$ \\
\hline $35 \%$ & 4.7E-6 & $4.0 \mathrm{E}-6$ & $3.4 \mathrm{E}-6$ & $3.0 \mathrm{E}-6$ & & $5.4 \mathrm{E}-9$ & $4.6 \mathrm{E}-9$ & $3.9 \mathrm{E}-9$ & $3.5 \mathrm{E}-9$ \\
\hline $40 \%$ & $5.2 \mathrm{E}-6$ & 4.3E-6 & $3.6 \mathrm{E}-6$ & $3.2 \mathrm{E}-6$ & & $6.0 \mathrm{E}-9$ & $5.0 \mathrm{E}-9$ & $4.1 \mathrm{E}-9$ & $3.7 \mathrm{E}-9$ \\
\hline $45 \%$ & $5.8 \mathrm{E}-6$ & 4.7E-6 & $3.8 \mathrm{E}-6$ & $3.3 \mathrm{E}-6$ & & $6.6 \mathrm{E}-9$ & $5.4 \mathrm{E}-9$ & 4.4E-9 & $3.8 \mathrm{E}-9$ \\
\hline $50 \%$ & $6.3 \mathrm{E}-6$ & $5.0 \mathrm{E}-6$ & $4.0 \mathrm{E}-6$ & $3.4 \mathrm{E}-6$ & & $7.3 \mathrm{E}-9$ & 5.7E-9 & 4.6E-9 & $4.0 \mathrm{E}-9$ \\
\hline $55 \%$ & $6.9 \mathrm{E}-6$ & $5.3 \mathrm{E}-6$ & $4.2 \mathrm{E}-6$ & $3.6 \mathrm{E}-6$ & & 7.9E-9 & $6.1 \mathrm{E}-9$ & $4.8 \mathrm{E}-9$ & $4.1 \mathrm{E}-9$ \\
\hline $60 \%$ & $7.4 \mathrm{E}-6$ & 5.7E-6 & 4.4E-6 & $3.7 \mathrm{E}-6$ & & 8.5E-9 & $6.6 \mathrm{E}-9$ & $5.1 \mathrm{E}-9$ & 4.3E-9 \\
\hline $65 \%$ & $7.9 \mathrm{E}-6$ & $6.1 \mathrm{E}-6$ & 4.6E-6 & $3.9 \mathrm{E}-6$ & & $9.1 \mathrm{E}-9$ & $7.0 \mathrm{E}-9$ & $5.3 \mathrm{E}-9$ & $4.4 \mathrm{E}-9$ \\
\hline $70 \%$ & $8.5 \mathrm{E}-6$ & $6.5 \mathrm{E}-6$ & $4.9 \mathrm{E}-6$ & $4.0 \mathrm{E}-6$ & & 9.7E-9 & 7.5E-9 & $5.6 \mathrm{E}-9$ & $4.6 \mathrm{E}-9$ \\
\hline $75 \%$ & $9.0 \mathrm{E}-6$ & $7.0 \mathrm{E}-6$ & $5.1 \mathrm{E}-6$ & $4.2 \mathrm{E}-6$ & & $1.0 \mathrm{E}-8$ & $8.0 \mathrm{E}-9$ & $5.9 \mathrm{E}-9$ & $4.8 \mathrm{E}-9$ \\
\hline $80 \%$ & $9.6 \mathrm{E}-6$ & $7.45 \mathrm{E}-6$ & $5.4 \mathrm{E}-6$ & 4.3E-6 & & $1.1 \mathrm{E}-8$ & 8.6E-9 & $6.3 \mathrm{E}-9$ & $5.0 \mathrm{E}-9$ \\
\hline $85 \%$ & $1.0 \mathrm{E}-5$ & $8.0 \mathrm{E}-6$ & $5.8 \mathrm{E}-6$ & 4.6E-6 & & $1.2 \mathrm{E}-8$ & $9.2 \mathrm{E}-9$ & $6.6 \mathrm{E}-9$ & $5.2 \mathrm{E}-9$ \\
\hline $90 \%$ & $1.1 \mathrm{E}-5$ & 8.7E-6 & $6.2 \mathrm{E}-6$ & $4.8 \mathrm{E}-6$ & & $1.2 \mathrm{E}-8$ & $1.0 \mathrm{E}-8$ & $7.1 \mathrm{E}-9$ & $5.5 \mathrm{E}-9$ \\
\hline $95 \%$ & $1.1 \mathrm{E}-5$ & $9.6 \mathrm{E}-6$ & 6.7E-6 & $5.2 \mathrm{E}-6$ & & $1.3 \mathrm{E}-8$ & $1.1 \mathrm{E}-8$ & 7.7E-9 & $6.0 \mathrm{E}-9$ \\
\hline \multicolumn{10}{|c|}{$\begin{array}{l}\text { Notes: } \\
\text { Simulation modeling using @RISK Version 3.5, 10,000 iterations and Latin Hypercube Sampling } \\
\text { Zone most likely value is the mode is derived from simulation modeling using the event counts of Table 6.13. } \\
\text { Zone standard deviation is derived from simulation modeling using the event counts of Table } 6.13 . \\
\text { Pr(E2 given E1)Pr(Ed1) uses the low temperature repository area and the mean disruption probability from Table 6.11. } \\
\text { Event Rates are adjusted for undetected events }\end{array}$} \\
\hline
\end{tabular}



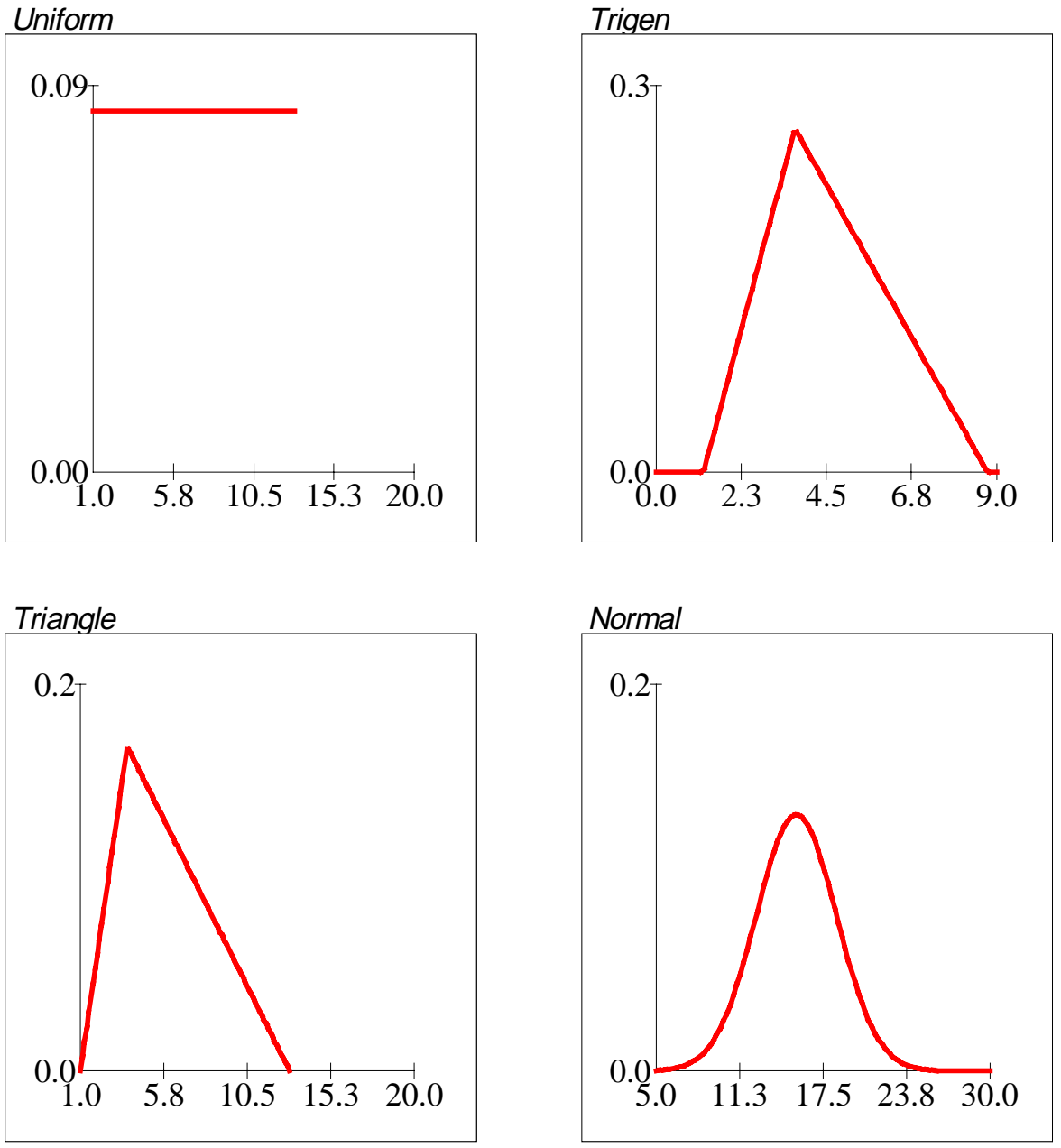

Figure 6.17. Probability distributions used in event-count simulations, Quaternary pull-apart basin (x-axes are the event counts). 
Table 6.18. Univariate Statistics and Percentiles From Event Count Simulation Modeling for the Pliocene and Quaternary Pull-Apart Basin: E1 and E2 Given E1.

\begin{tabular}{|c|c|c|c|c|c|c|c|c|c|}
\hline $\begin{array}{l}\text { Event } \\
\text { Counts from } \\
\text { Table } 6.13\end{array}$ & $\begin{array}{c}\text { Zone } \\
\text { Minimum }\end{array}$ & Zone $10 \%$ & $\begin{array}{l}\text { Zone } \\
\text { Most } \\
\text { Likely }\end{array}$ & $\begin{array}{l}\text { Zone } \\
90 \%\end{array}$ & $\begin{array}{c}\text { Zone } \\
\text { Maximum }\end{array}$ & & & & $\begin{array}{l}\text { Zone } \\
\text { Simulation } \\
\text { Results }\end{array}$ \\
\hline & 5.5 & 8.2 & 11.7 & 19.4 & 32.6 & & Zone & mean & 11.2 \\
\hline \multicolumn{7}{|c|}{ Distribution Parameters for Simulation Modeling } & Zone & std dev & 2.3 \\
\hline $\begin{array}{l}\text { Distribution } \\
\text { Type }\end{array}$ & Uniform & Triangular & Trigen & Normal & & & Zone & mode & 11.7 \\
\hline Exp Value & 18.0 & 15.9 & 13.5 & 11.2 & E2 Lrep & $3.6 \mathrm{E}-4$ & & & \\
\hline $\begin{array}{l}\text { Distribution } \\
\text { Type }\end{array}$ & Uniform & Triangular & Trigen & Normal & & Uniform & Triangular & Trigen & Normal \\
\hline $\mathrm{E} 1$ & $4.6 \mathrm{E}-6$ & $4.0 \mathrm{E}-6$ & $3.4 \mathrm{E}-6$ & $2.8 \mathrm{E}-6$ & $\begin{array}{l}\text { E2 given } \\
\text { E1 }\end{array}$ & $1.6 \mathrm{E}-9$ & $1.5 \mathrm{E}-9$ & $1.2 \mathrm{E}-9$ & $1.0 \mathrm{E}-9$ \\
\hline \multicolumn{10}{|c|}{ Simulation Results } \\
\hline Minimum & $8.7 \mathrm{E}-7$ & $9.1 \mathrm{E}-7$ & $1.1 \mathrm{E}-6$ & $4.5 \mathrm{E}-7$ & & $3.2 \mathrm{E}-10$ & 3.3E-10 & $4.1 \mathrm{E}-10$ & $1.6 \mathrm{E}-10$ \\
\hline Maximum & $8.2 \mathrm{E}-6$ & $8.2 \mathrm{E}-6$ & $6.2 \mathrm{E}-6$ & $5.0 \mathrm{E}-6$ & & 3.0E-09 & $3.0 \mathrm{E}-9$ & $2.2 \mathrm{E}-09$ & $1.8 \mathrm{E}-9$ \\
\hline Mean & $4.6 \mathrm{E}-6$ & $4.0 \mathrm{E}-6$ & $3.4 \mathrm{E}-6$ & $2.8 \mathrm{E}-6$ & & 1.6E-09 & $1.5 \mathrm{E}-9$ & $1.2 \mathrm{E}-09$ & $1.0 \mathrm{E}-9$ \\
\hline Std Deviation & $2.1 \mathrm{E}-6$ & $1.5 \mathrm{E}-6$ & $1.0 \mathrm{E}-6$ & $5.7 \mathrm{E}-7$ & & 7.7E-10 & $5.6 \mathrm{E}-10$ & $3.8 \mathrm{E}-10$ & $2.1 \mathrm{E}-10$ \\
\hline Variance & $4.5 \mathrm{E}-12$ & $2.4 \mathrm{E}-12$ & $1.1 \mathrm{E}-12$ & $3.3 \mathrm{E}-13$ & & $5.9 \mathrm{E}-19$ & $3.1 \mathrm{E}-19$ & $1.4 \mathrm{E}-19$ & $4.2 \mathrm{E}-20$ \\
\hline Skewness & 0.0 & 0.4 & 0.2 & 0.0 & & 0.0 & 0.4 & 0.2 & 0.0 \\
\hline Kurtosis & 1.8 & 2.4 & 2.4 & 3.0 & & 1.8 & 2.4 & 2.4 & 3.0 \\
\hline Mode & $2.5 \mathrm{E}-6$ & $2.9 \mathrm{E}-6$ & $3.0 \mathrm{E}-6$ & $2.8 \mathrm{E}-6$ & & $9.2 \mathrm{E}-10$ & $1.1 \mathrm{E}-9$ & $1.1 \mathrm{E}-9$ & $1.0 \mathrm{E}-9$ \\
\hline $5 \%$ & $1.2 \mathrm{E}-6$ & $1.8 \mathrm{E}-6$ & $1.8 \mathrm{E}-6$ & $1.9 \mathrm{E}-6$ & & $4.5 \mathrm{E}-10$ & $6.4 \mathrm{E}-10$ & $6.5 \mathrm{E}-10$ & $6.8 \mathrm{E}-10$ \\
\hline $10 \%$ & $1.6 \mathrm{E}-6$ & $2.1 \mathrm{E}-6$ & $2.1 \mathrm{E}-6$ & $2.1 \mathrm{E}-6$ & & $5.9 \mathrm{E}-10$ & $7.7 \mathrm{E}-10$ & $7.5 \mathrm{E}-10$ & $7.6 \mathrm{E}-10$ \\
\hline $15 \%$ & $2.0 \mathrm{E}-6$ & $2.4 \mathrm{E}-6$ & $2.3 \mathrm{E}-6$ & $2.2 \mathrm{E}-6$ & & $7.2 \mathrm{E}-10$ & 8.7E-10 & $8.3 \mathrm{E}-10$ & $8.1 \mathrm{E}-10$ \\
\hline $20 \%$ & $2.4 \mathrm{E}-6$ & $2.6 \mathrm{E}-6$ & $2.5 \mathrm{E}-6$ & $2.3 \mathrm{E}-6$ & & 8.5E-10 & $9.5 \mathrm{E}-10$ & $8.9 \mathrm{E}-10$ & $8.5 \mathrm{E}-10$ \\
\hline $25 \%$ & 2.7E-6 & $2.8 \mathrm{E}-6$ & $2.6 \mathrm{E}-6$ & $2.4 \mathrm{E}-6$ & & $9.8 \mathrm{E}-10$ & $1.0 \mathrm{E}-9$ & $9.5 \mathrm{E}-10$ & $8.8 \mathrm{E}-10$ \\
\hline $30 \%$ & $3.1 \mathrm{E}-6$ & $3.0 \mathrm{E}-6$ & $2.8 \mathrm{E}-6$ & $2.5 \mathrm{E}-6$ & & $1.1 \mathrm{E}-9$ & $1.1 \mathrm{E}-9$ & $1.0 \mathrm{E}-9$ & $9.1 \mathrm{E}-10$ \\
\hline $35 \%$ & $3.5 \mathrm{E}-6$ & $3.2 \mathrm{E}-6$ & $2.9 \mathrm{E}-6$ & $2.6 \mathrm{E}-6$ & & $1.2 \mathrm{E}-9$ & $1.2 \mathrm{E}-9$ & $1.1 \mathrm{E}-9$ & $9.4 \mathrm{E}-10$ \\
\hline $40 \%$ & $3.8 \mathrm{E}-6$ & $3.4 \mathrm{E}-6$ & $3.0 \mathrm{E}-6$ & $2.7 \mathrm{E}-6$ & & $1.4 \mathrm{E}-9$ & $1.2 \mathrm{E}-9$ & $1.1 \mathrm{E}-9$ & $9.7 \mathrm{E}-10$ \\
\hline $45 \%$ & $4.2 \mathrm{E}-6$ & $3.6 \mathrm{E}-6$ & $3.2 \mathrm{E}-6$ & $2.8 \mathrm{E}-6$ & & $1.5 \mathrm{E}-9$ & $1.3 \mathrm{E}-9$ & $1.1 \mathrm{E}-9$ & $10.0 \mathrm{E}-10$ \\
\hline $50 \%$ & $4.6 \mathrm{E}-6$ & $3.8 \mathrm{E}-6$ & $3.3 \mathrm{E}-6$ & $2.8 \mathrm{E}-6$ & & $1.6 \mathrm{E}-9$ & $1.4 \mathrm{E}-9$ & $1.2 \mathrm{E}-9$ & $1.0 \mathrm{E}-9$ \\
\hline $55 \%$ & $4.9 \mathrm{E}-6$ & $4.1 \mathrm{E}-6$ & $3.5 \mathrm{E}-6$ & $2.9 \mathrm{E}-6$ & & $1.8 \mathrm{E}-9$ & $1.5 \mathrm{E}-9$ & $1.2 \mathrm{E}-9$ & $1.0 \mathrm{E}-9$ \\
\hline $60 \%$ & $5.3 \mathrm{E}-6$ & 4.3E-6 & $3.6 \mathrm{E}-6$ & $3.0 \mathrm{E}-6$ & & $1.9 \mathrm{E}-9$ & $1.6 \mathrm{E}-9$ & $1.3 \mathrm{E}-9$ & $1.1 \mathrm{E}-9$ \\
\hline $65 \%$ & $5.7 \mathrm{E}-6$ & $4.6 \mathrm{E}-6$ & $3.8 \mathrm{E}-6$ & $3.1 \mathrm{E}-6$ & & $2.0 \mathrm{E}-9$ & $1.6 \mathrm{E}-9$ & $1.4 \mathrm{E}-9$ & $1.1 \mathrm{E}-9$ \\
\hline $70 \%$ & $6.0 \mathrm{E}-6$ & $4.8 \mathrm{E}-6$ & $4.0 \mathrm{E}-6$ & $3.1 \mathrm{E}-6$ & & $2.2 \mathrm{E}-9$ & $1.7 \mathrm{E}-9$ & $1.4 \mathrm{E}-9$ & $1.1 \mathrm{E}-9$ \\
\hline $75 \%$ & $6.4 \mathrm{E}-6$ & $5.1 \mathrm{E}-6$ & $4.2 \mathrm{E}-6$ & $3.2 \mathrm{E}-6$ & & 2.3E-9 & $1.8 \mathrm{E}-9$ & $1.5 \mathrm{E}-9$ & $1.2 \mathrm{E}-9$ \\
\hline $80 \%$ & $6.8 \mathrm{E}-6$ & $5.5 \mathrm{E}-6$ & $4.4 \mathrm{E}-6$ & $3.3 \mathrm{E}-6$ & & $2.4 \mathrm{E}-9$ & $2.0 \mathrm{E}-9$ & $1.5 \mathrm{E}-9$ & $1.2 \mathrm{E}-9$ \\
\hline $85 \%$ & $7.1 \mathrm{E}-6$ & $5.8 \mathrm{E}-6$ & $4.6 \mathrm{E}-6$ & $3.4 \mathrm{E}-6$ & & 2.6E-9 & $2.1 \mathrm{E}-9$ & $1.7 \mathrm{E}-9$ & $1.2 \mathrm{E}-9$ \\
\hline $90 \%$ & $7.5 \mathrm{E}-6$ & $6.3 \mathrm{E}-6$ & $4.9 \mathrm{E}-6$ & $3.6 \mathrm{E}-6$ & & 2.7E-9 & $2.3 \mathrm{E}-9$ & $1.8 \mathrm{E}-9$ & $1.3 \mathrm{E}-9$ \\
\hline $95 \%$ & $7.9 \mathrm{E}-6$ & $6.9 \mathrm{E}-6$ & $5.3 \mathrm{E}-6$ & $3.8 \mathrm{E}-6$ & & $2.8 \mathrm{E}-9$ & $2.5 \mathrm{E}-9$ & $1.9 \mathrm{E}-9$ & $1.4 \mathrm{E}-9$ \\
\hline \multicolumn{10}{|c|}{$\begin{array}{l}\text { Notes: } \\
\text { Simulation modeling using @RISK Version 3.5, 10,000 iterations and Latin Hypercube Sampling } \\
\text { Zone most likely value is the mode is derived from simulation modeling using the event counts of Table 6.13. } \\
\text { Zone standard deviation is derived from simulation modeling using the event counts of Table 6.13. } \\
\text { Pr(E2 given E1)Pr(Ed1) uses the low temperature repository area and the mean disruption probability from Table 6.11. } \\
\text { Event Rates are adjusted for undetected events }\end{array}$} \\
\hline
\end{tabular}



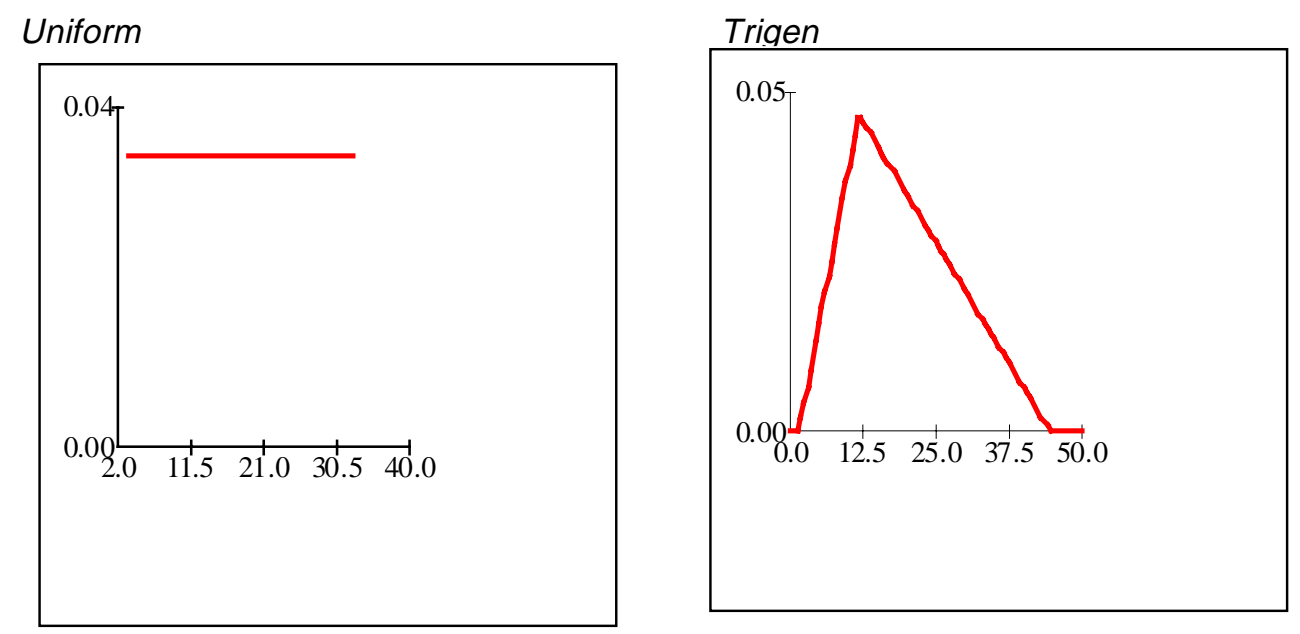

Triangle
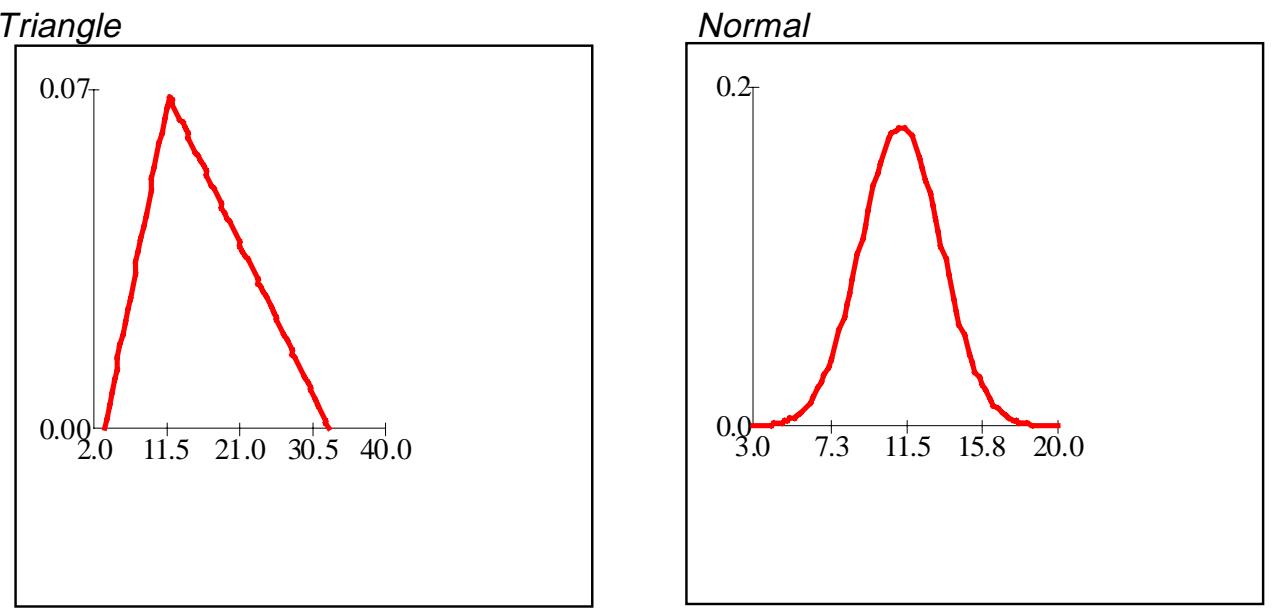

Figure 6.18. Probability distributions used for event-count simulations, Pliocene and Quaternary pull-apart basin ( $\mathrm{x}$-axes are the event counts). 
Table 6.19. Univariate Statistics and Percentiles From Event Count Simulation Modeling for the Walker Lane Structural Zone: E1 and E2 Given E1.

\begin{tabular}{|c|c|c|c|c|c|c|c|c|c|}
\hline \multirow[t]{2}{*}{$\begin{array}{l}\text { Event } \\
\text { Counts } \\
\text { From Table } \\
6.13 \\
\end{array}$} & $\begin{array}{c}\text { Zone } \\
\text { Minimum }\end{array}$ & Zone $10 \%$ & $\begin{array}{c}\text { Zone Most } \\
\text { Likely }\end{array}$ & $\begin{array}{c}\text { Zone } \\
90 \%\end{array}$ & $\begin{array}{c}\text { Zone } \\
\text { Maximum }\end{array}$ & & & & $\begin{array}{l}\text { Zone } \\
\text { Simulation } \\
\text { Results }\end{array}$ \\
\hline & 7.5 & 11.0 & 14.1 & 24.2 & 42.5 & & Zone & mean & 14.6 \\
\hline \multicolumn{7}{|c|}{ Distribution Parameters for Simulation Modeling } & Zone & std dev & 3.0 \\
\hline $\begin{array}{l}\text { Distribution } \\
\text { Type }\end{array}$ & Uniform & Triangular & Trigen & Normal & & & Zone & mode & 14.1 \\
\hline Exp Value & 25.0 & 21.3 & 17.1 & 14.6 & E2 Hrep & $1.4 \mathrm{E}-4$ & & & \\
\hline Distrib & Uniform & Triangular & Trigen & Normal & & Uniform & Triangular & Trigen & Normal \\
\hline E1 & $5.2 \mathrm{E}-6$ & $4.4 \mathrm{E}-6$ & $3.6 \mathrm{E}-6$ & $3.0 \mathrm{E}-6$ & $\begin{array}{l}\text { E2 given } \\
\text { E1 }\end{array}$ & $7.2 \mathrm{E}-10$ & $6.2 \mathrm{E}-10$ & $5.0 \mathrm{E}-10$ & $4.2 \mathrm{E}-10$ \\
\hline \multicolumn{10}{|c|}{ Simulation Results } \\
\hline Minimum & $1.6 \mathrm{E}-6$ & $1.6 \mathrm{E}-6$ & $1.4 \mathrm{E}-6$ & $6.7 \mathrm{E}-7$ & & $2.2 \mathrm{E}-10$ & $2.2 \mathrm{E}-10$ & $2.0 \mathrm{E}-10$ & $9.5 \mathrm{E}-11$ \\
\hline Maximum & $8.8 \mathrm{E}-6$ & $8.8 \mathrm{E}-6$ & $6.3 \mathrm{E}-6$ & $5.3 \mathrm{E}-6$ & & $1.2 \mathrm{E}-9$ & $1.2 \mathrm{E}-9$ & $8.8 \mathrm{E}-10$ & 7.4E-10 \\
\hline Mean & $5.2 \mathrm{E}-6$ & $4.4 \mathrm{E}-6$ & $3.6 \mathrm{E}-6$ & $3.0 \mathrm{E}-6$ & & $7.2 \mathrm{E}-10$ & $6.2 \mathrm{E}-10$ & $5.0 \mathrm{E}-10$ & $4.2 \mathrm{E}-10$ \\
\hline Std Deviation & $2.1 \mathrm{E}-6$ & $1.6 \mathrm{E}-6$ & $1.0 \mathrm{E}-6$ & $6.2 \mathrm{E}-7$ & & $2.9 \mathrm{E}-10$ & $2.2 \mathrm{E}-10$ & $1.42 \mathrm{E}-10$ & $8.6 \mathrm{E}-11$ \\
\hline Variance & $4.4 \mathrm{E}-12$ & $2.5 \mathrm{E}-12$ & $1.0 \mathrm{E}-12$ & $3.8 \mathrm{E}-13$ & & 8.6E-20 & $4.8 \mathrm{E}-20$ & $2.0 \mathrm{E}-20$ & 7.4E-21 \\
\hline Skewness & 0.0 & 0.5 & 0.3 & 0.0 & & 0.0 & 0.5 & 0.3 & 0.0 \\
\hline Kurtosis & 1.8 & 2.4 & 2.4 & 3.0 & & 1.8 & 2.4 & 2.4 & 3.0 \\
\hline Mode & $4.7 \mathrm{E}-6$ & $3.2 \mathrm{E}-6$ & $3.0 \mathrm{E}-6$ & $3.1 \mathrm{E}-6$ & & $6.5 \mathrm{E}-10$ & $4.5 \mathrm{E}-10$ & $4.2 \mathrm{E}-10$ & $4.3 \mathrm{E}-10$ \\
\hline $5 \%$ & $1.9 \mathrm{E}-6$ & $2.3 \mathrm{E}-6$ & $2.0 \mathrm{E}-6$ & $2.0 \mathrm{E}-6$ & & $2.7 \mathrm{E}-10$ & $3.1 \mathrm{E}-10$ & $2.8 \mathrm{E}-10$ & $2.8 \mathrm{E}-10$ \\
\hline $10 \%$ & $2.3 \mathrm{E}-6$ & $2.6 \mathrm{E}-6$ & $2.3 \mathrm{E}-6$ & $2.2 \mathrm{E}-6$ & & $3.2 \mathrm{E}-10$ & $3.6 \mathrm{E}-10$ & $3.2 \mathrm{E}-10$ & $3.1 \mathrm{E}-10$ \\
\hline $15 \%$ & $2.7 \mathrm{E}-6$ & $2.8 \mathrm{E}-6$ & $2.5 \mathrm{E}-6$ & $2.4 \mathrm{E}-6$ & & 3.7E-10 & $3.8 \mathrm{E}-10$ & $3.4 \mathrm{E}-10$ & 3.3E-10 \\
\hline $20 \%$ & $3.0 \mathrm{E}-6$ & $3.0 \mathrm{E}-6$ & $2.6 \mathrm{E}-6$ & $2.5 \mathrm{E}-6$ & & $4.2 \mathrm{E}-10$ & $4.1 \mathrm{E}-10$ & 3.7E-10 & $3.5 \mathrm{E}-10$ \\
\hline $25 \%$ & $3.4 \mathrm{E}-6$ & $3.2 \mathrm{E}-6$ & $2.8 \mathrm{E}-6$ & $2.6 \mathrm{E}-6$ & & $4.7 \mathrm{E}-10$ & $4.4 \mathrm{E}-10$ & $3.9 \mathrm{E}-10$ & 3.6E-10 \\
\hline $30 \%$ & $3.7 \mathrm{E}-6$ & $3.3 \mathrm{E}-6$ & $2.9 \mathrm{E}-6$ & $2.7 \mathrm{E}-6$ & & $5.2 \mathrm{E}-10$ & $4.7 \mathrm{E}-10$ & $4.1 \mathrm{E}-10$ & $3.8 \mathrm{E}-10$ \\
\hline $35 \%$ & $4.1 \mathrm{E}-6$ & $3.5 \mathrm{E}-6$ & $3.0 \mathrm{E}-6$ & $2.8 \mathrm{E}-6$ & & 5.7E-10 & $4.9 \mathrm{E}-10$ & $4.2 \mathrm{E}-10$ & $3.9 \mathrm{E}-10$ \\
\hline $40 \%$ & $4.5 \mathrm{E}-6$ & $3.8 \mathrm{E}-6$ & $3.2 \mathrm{E}-6$ & $2.9 \mathrm{E}-6$ & & $6.2 \mathrm{E}-10$ & $5.2 \mathrm{E}-10$ & $4.4 \mathrm{E}-10$ & 4.0E-10 \\
\hline $45 \%$ & $4.8 \mathrm{E}-6$ & $4.0 \mathrm{E}-6$ & $3.3 \mathrm{E}-6$ & $3.0 \mathrm{E}-6$ & & $6.7 \mathrm{E}-10$ & $5.5 \mathrm{E}-10$ & $4.6 \mathrm{E}-10$ & $4.1 \mathrm{E}-10$ \\
\hline $50 \%$ & $5.2 \mathrm{E}-6$ & $4.2 \mathrm{E}-6$ & $3.4 \mathrm{E}-6$ & $3.0 \mathrm{E}-6$ & & $7.2 \mathrm{E}-10$ & $5.8 \mathrm{E}-10$ & $4.8 \mathrm{E}-10$ & $4.2 \mathrm{E}-10$ \\
\hline $55 \%$ & $5.6 \mathrm{E}-6$ & 4.4E-6 & $3.6 \mathrm{E}-6$ & $3.1 \mathrm{E}-6$ & & 7.7E-10 & $6.2 \mathrm{E}-10$ & $5.0 \mathrm{E}-10$ & 4.3E-10 \\
\hline $60 \%$ & $5.9 \mathrm{E}-6$ & 4.7E-6 & $3.7 \mathrm{E}-6$ & $3.2 \mathrm{E}-6$ & & $8.2 \mathrm{E}-10$ & $6.5 \mathrm{E}-10$ & $5.2 \mathrm{E}-10$ & 4.4E-10 \\
\hline $65 \%$ & $6.3 \mathrm{E}-6$ & $5.0 \mathrm{E}-6$ & $3.9 \mathrm{E}-6$ & $3.3 \mathrm{E}-6$ & & $8.8 \mathrm{E}-10$ & $6.9 \mathrm{E}-10$ & $5.4 \mathrm{E}-10$ & 4.6E-10 \\
\hline $70 \%$ & $6.7 \mathrm{E}-6$ & $5.2 \mathrm{E}-6$ & $4.1 \mathrm{E}-6$ & $3.4 \mathrm{E}-6$ & & $9.3 \mathrm{E}-10$ & $7.3 \mathrm{E}-10$ & $5.7 \mathrm{E}-10$ & 4.7E-10 \\
\hline $75 \%$ & $7.0 \mathrm{E}-6$ & $5.6 \mathrm{E}-6$ & $4.3 \mathrm{E}-6$ & $3.5 \mathrm{E}-6$ & & $9.8 \mathrm{E}-10$ & 7.7E-10 & $6.0 \mathrm{E}-10$ & $4.8 \mathrm{E}-10$ \\
\hline $80 \%$ & $7.4 \mathrm{E}-6$ & $5.9 \mathrm{E}-6$ & $4.5 \mathrm{E}-6$ & $3.6 \mathrm{E}-6$ & & $1.0 \mathrm{E}-9$ & $8.2 \mathrm{E}-10$ & $6.3 \mathrm{E}-10$ & $4.9 \mathrm{E}-10$ \\
\hline $85 \%$ & $7.8 \mathrm{E}-6$ & $6.3 \mathrm{E}-6$ & $4.7 \mathrm{E}-6$ & $3.7 \mathrm{E}-6$ & & $1.1 \mathrm{E}-9$ & $8.8 \mathrm{E}-10$ & $6.6 \mathrm{E}-10$ & $5.1 \mathrm{E}-10$ \\
\hline $90 \%$ & $8.1 \mathrm{E}-6$ & 6.8E-6 & $5.0 \mathrm{E}-6$ & $3.8 \mathrm{E}-6$ & & $1.1 \mathrm{E}-9$ & $9.4 \mathrm{E}-10$ & $7.0 \mathrm{E}-10$ & 5.3E-10 \\
\hline $95 \%$ & $8.5 \mathrm{E}-6$ & 7.4E-6 & $5.4 \mathrm{E}-6$ & $4.1 \mathrm{E}-6$ & & $1.2 \mathrm{E}-9$ & $1.0 \mathrm{E}-9$ & $7.5 \mathrm{E}-10$ & $5.6 \mathrm{E}-10$ \\
\hline \multicolumn{10}{|c|}{$\begin{array}{l}\text { Notes: } \\
\text { Simulation modeling using @RISK Version 3.5, 10,000 iterations and Latin Hypercube Sampling } \\
\text { Zone most likely value is the mode is derived from simulation modeling using the event counts of Table 6.13. } \\
\text { Zone standard deviation is derived from simulation modeling using the event counts of Table 6.13. } \\
\text { Pr(E2 given E1)Pr(Ed1) uses the high temperature repository area and the mean disruption probability from Table 6.11. } \\
\text { Event Rates are adjusted for undetected events }\end{array}$} \\
\hline
\end{tabular}



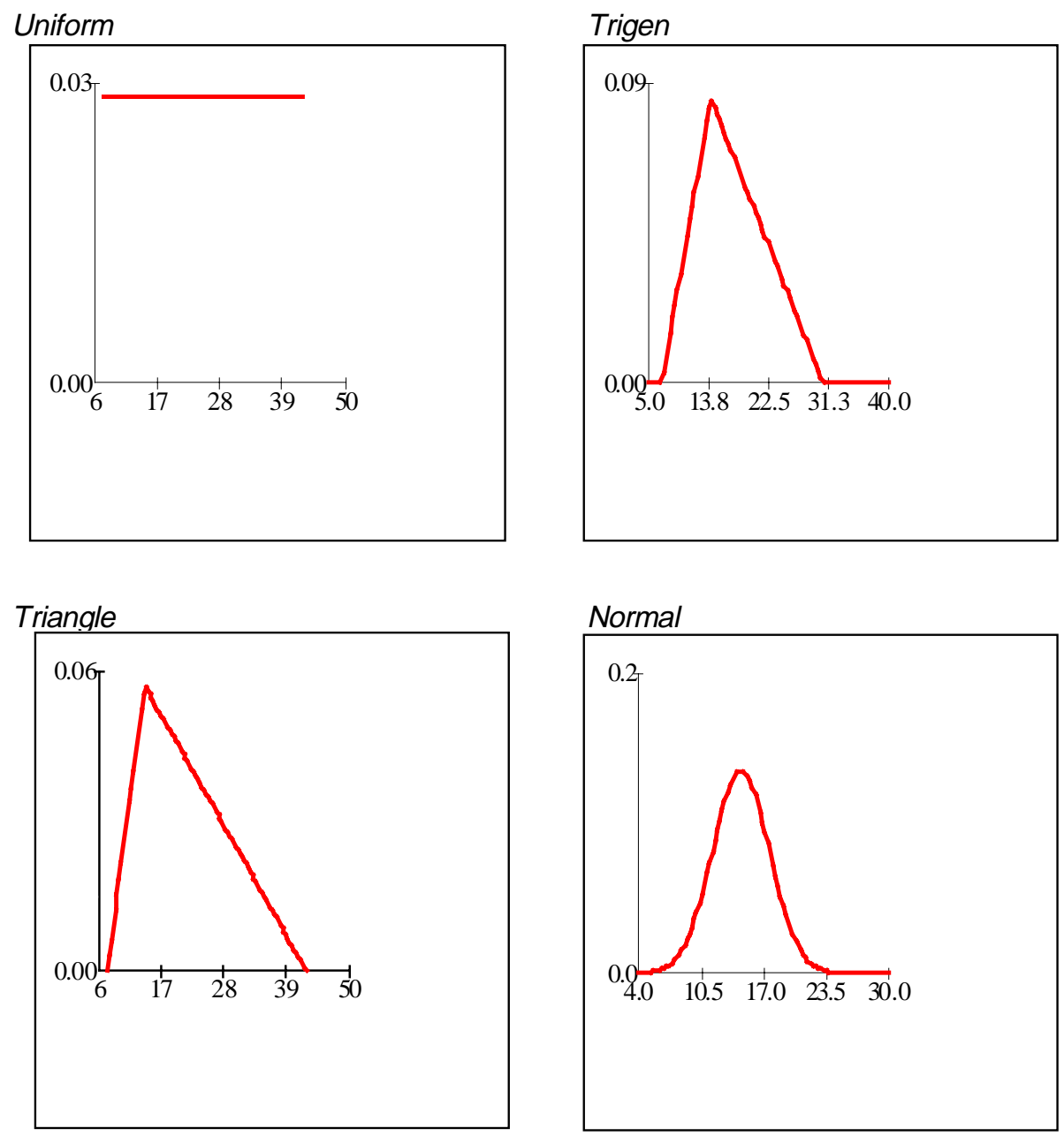

Figure 6.19. Probability distributions used in event-count simulations, Walker Lane structural zone (x-axes are the event counts). 
Table 6.20. Univariate Statistics and Percentiles From Event Count Simulation Modeling for the Northeast-trending Structural Zone: E1 and E2 Given E1.

\begin{tabular}{|c|c|c|c|c|c|c|c|c|c|}
\hline $\begin{array}{l}\text { Event } \\
\text { Counts from } \\
\text { Table } 6.13 \\
\end{array}$ & $\begin{array}{c}\text { Zone } \\
\text { Minimum }\end{array}$ & Zone 10\% & $\begin{array}{c}\text { Zone Most } \\
\text { Likely }\end{array}$ & $\begin{array}{c}\text { Zone } \\
90 \%\end{array}$ & $\begin{array}{c}\text { Zone } \\
\text { Maximum }\end{array}$ & & & & $\begin{array}{l}\text { Zone } \\
\text { Simulation } \\
\text { Results }\end{array}$ \\
\hline & 6.5 & 9.2 & 11.9 & 21.4 & 36.6 & & Zone & mean & 12.1 \\
\hline \multicolumn{7}{|c|}{ Distribution Parameters for Simulation Modeling } & Zone & std dev & 2.3 \\
\hline $\begin{array}{l}\text { Distribution } \\
\text { Type }\end{array}$ & Uniform & Triangular & Trigen & Normal & & & Zone & mode & 11.9 \\
\hline $\begin{array}{l}\text { Expected } \\
\text { Value }\end{array}$ & 21.5 & 18.3 & 14.8 & 12.1 & E2 Lrep & $3.0 \mathrm{E}-3$ & & & \\
\hline $\begin{array}{l}\text { Distribution } \\
\text { Type }\end{array}$ & Uniform & Triangular & Trigen & Normal & & Uniform & Triangular & Trigen & Normal \\
\hline $\mathrm{E} 1$ & $5.5 \mathrm{E}-6$ & $4.6 \mathrm{E}-6$ & $3.8 \mathrm{E}-6$ & $3.1 \mathrm{E}-6$ & $\begin{array}{l}\text { E2 given } \\
\text { E1 }\end{array}$ & $1.7 \mathrm{E}-8$ & $1.4 \mathrm{E}-8$ & $1.1 \mathrm{E}-8$ & $9.3 E-9$ \\
\hline \multicolumn{10}{|c|}{ Simulation Results } \\
\hline Minimum & $1.6 \mathrm{E}-6$ & $1.7 \mathrm{E}-6$ & $1.4 \mathrm{E}-6$ & $8.4 \mathrm{E}-7$ & & $5.0 \mathrm{E}-9$ & $5.1 \mathrm{E}-9$ & $4.3 \mathrm{E}-9$ & $2.6 \mathrm{E}-9$ \\
\hline Maximum & $9.3 \mathrm{E}-6$ & $9.2 \mathrm{E}-6$ & $6.8 \mathrm{E}-6$ & $5.2 \mathrm{E}-6$ & & $2.8 \mathrm{E}-8$ & $2.8 \mathrm{E}-8$ & $2.1 \mathrm{E}-8$ & $1.6 \mathrm{E}-8$ \\
\hline Mean & $5.5 \mathrm{E}-6$ & $4.6 \mathrm{E}-6$ & $3.8 \mathrm{E}-6$ & $3.1 \mathrm{E}-6$ & & $1.7 \mathrm{E}-8$ & $1.4 \mathrm{E}-8$ & $1.1 \mathrm{E}-8$ & $9.3 \mathrm{E}-9$ \\
\hline Std Deviation & $2.2 \mathrm{E}-6$ & $1.7 \mathrm{E}-6$ & $1.1 \mathrm{E}-6$ & $5.8 \mathrm{E}-7$ & & $6.7 \mathrm{E}-9$ & $5.0 \mathrm{E}-9$ & $3.5 \mathrm{E}-9$ & $1.8 \mathrm{E}-9$ \\
\hline Variance & $4.8 \mathrm{E}-12$ & 2.7E-12 & $1.3 \mathrm{E}-12$ & $3.4 \mathrm{E}-13$ & & $4.5 \mathrm{E}-17$ & $2.5 \mathrm{E}-17$ & $1.2 \mathrm{E}-17$ & $3.12 \mathrm{E}-18$ \\
\hline Skewness & 0.0 & 0.5 & 0.4 & 0.0 & & 0.0 & 0.5 & 0.4 & 0.0 \\
\hline Kurtosis & 1.8 & 2.4 & 2.4 & 3.0 & & 1.8 & 2.4 & 2.4 & 3.0 \\
\hline Mode & $1.8 \mathrm{E}-6$ & $3.0 \mathrm{E}-6$ & $3.2 \mathrm{E}-6$ & $3.1 \mathrm{E}-6$ & & $5.6 \mathrm{E}-9$ & $9.1 \mathrm{E}-9$ & $9.6 \mathrm{E}-9$ & $9.5 \mathrm{E}-9$ \\
\hline $5 \%$ & $2.0 \mathrm{E}-6$ & $2.4 \mathrm{E}-6$ & $2.0 \mathrm{E}-6$ & $2.1 \mathrm{E}-6$ & & $6.2 \mathrm{E}-9$ & $7.2 \mathrm{E}-9$ & $6.2 \mathrm{E}-9$ & $6.4 \mathrm{E}-9$ \\
\hline $10 \%$ & $2.4 \mathrm{E}-6$ & $2.7 \mathrm{E}-6$ & $2.3 \mathrm{E}-6$ & $2.3 \mathrm{E}-6$ & & $7.3 \mathrm{E}-9$ & $8.1 \mathrm{E}-9$ & $7.1 \mathrm{E}-9$ & $7.0 \mathrm{E}-9$ \\
\hline $15 \%$ & $2.8 \mathrm{E}-6$ & $2.9 \mathrm{E}-6$ & $2.5 \mathrm{E}-6$ & $2.5 \mathrm{E}-6$ & & $8.5 \mathrm{E}-9$ & $8.8 \mathrm{E}-9$ & 7.7E-9 & $7.5 \mathrm{E}-9$ \\
\hline $20 \%$ & $3.2 \mathrm{E}-6$ & $3.1 \mathrm{E}-6$ & $2.7 \mathrm{E}-6$ & $2.6 \mathrm{E}-6$ & & $9.6 \mathrm{E}-9$ & $9.4 \mathrm{E}-9$ & 8.3E-9 & $7.8 \mathrm{E}-9$ \\
\hline $25 \%$ & $3.5 \mathrm{E}-6$ & $3.3 \mathrm{E}-6$ & $2.9 \mathrm{E}-6$ & 2.7E-6 & & $1.1 \mathrm{E}-8$ & $1.0 \mathrm{E}-8$ & $8.8 \mathrm{E}-9$ & $8.1 \mathrm{E}-9$ \\
\hline $30 \%$ & $3.9 \mathrm{E}-6$ & $3.5 \mathrm{E}-6$ & $3.0 \mathrm{E}-6$ & $2.8 \mathrm{E}-6$ & & $1.2 \mathrm{E}-8$ & $1.1 \mathrm{E}-8$ & $9.2 \mathrm{E}-9$ & $8.4 \mathrm{E}-9$ \\
\hline $35 \%$ & $4.3 \mathrm{E}-6$ & 3.7E-6 & $3.2 \mathrm{E}-6$ & $2.8 \mathrm{E}-6$ & & $1.3 \mathrm{E}-8$ & $1.1 \mathrm{E}-8$ & $9.6 \mathrm{E}-9$ & $8.6 \mathrm{E}-9$ \\
\hline $40 \%$ & $4.7 \mathrm{E}-6$ & $3.9 \mathrm{E}-6$ & $3.3 \mathrm{E}-6$ & $2.9 \mathrm{E}-6$ & & $1.4 \mathrm{E}-8$ & $1.2 \mathrm{E}-8$ & $1.0 \mathrm{E}-8$ & $8.9 \mathrm{E}-9$ \\
\hline $45 \%$ & $5.1 \mathrm{E}-6$ & $4.1 \mathrm{E}-6$ & $3.5 \mathrm{E}-6$ & $3.0 \mathrm{E}-6$ & & $1.5 \mathrm{E}-8$ & $1.3 \mathrm{E}-8$ & $1.0 \mathrm{E}-8$ & $9.1 \mathrm{E}-9$ \\
\hline $50 \%$ & $5.5 \mathrm{E}-6$ & $4.4 \mathrm{E}-6$ & $3.6 \mathrm{E}-6$ & $3.1 \mathrm{E}-6$ & & $1.7 \mathrm{E}-8$ & $1.3 \mathrm{E}-8$ & $1.1 \mathrm{E}-8$ & $9.3 \mathrm{E}-9$ \\
\hline $55 \%$ & $5.8 \mathrm{E}-6$ & $4.6 \mathrm{E}-6$ & $3.8 \mathrm{E}-6$ & $3.1 \mathrm{E}-6$ & & $1.8 \mathrm{E}-8$ & $1.4 \mathrm{E}-8$ & $1.1 \mathrm{E}-8$ & $9.5 \mathrm{E}-9$ \\
\hline $60 \%$ & $6.2 \mathrm{E}-6$ & $4.9 \mathrm{E}-6$ & $4.0 \mathrm{E}-6$ & $3.2 \mathrm{E}-6$ & & $1.9 \mathrm{E}-8$ & $1.5 \mathrm{E}-8$ & $1.2 \mathrm{E}-8$ & $9.8 \mathrm{E}-9$ \\
\hline $65 \%$ & $6.6 \mathrm{E}-6$ & $5.2 \mathrm{E}-6$ & $4.1 \mathrm{E}-6$ & 3.3E-6 & & $2.0 \mathrm{E}-8$ & $1.6 \mathrm{E}-8$ & $1.3 \mathrm{E}-8$ & $1.0 \mathrm{E}-8$ \\
\hline $70 \%$ & $7.0 \mathrm{E}-6$ & $5.5 \mathrm{E}-6$ & $4.3 \mathrm{E}-6$ & $3.4 \mathrm{E}-6$ & & $2.1 \mathrm{E}-8$ & $1.7 \mathrm{E}-8$ & $1.3 \mathrm{E}-8$ & $1.0 \mathrm{E}-8$ \\
\hline $75 \%$ & $7.4 \mathrm{E}-6$ & $5.8 \mathrm{E}-6$ & $4.6 \mathrm{E}-6$ & $3.4 \mathrm{E}-6$ & & $2.2 \mathrm{E}-8$ & $1.8 \mathrm{E}-8$ & $1.4 \mathrm{E}-8$ & $1.0 \mathrm{E}-8$ \\
\hline $80 \%$ & 7.7E-6 & $6.2 \mathrm{E}-6$ & $4.8 \mathrm{E}-6$ & $3.5 \mathrm{E}-6$ & & $2.3 \mathrm{E}-8$ & $1.9 \mathrm{E}-8$ & $1.5 \mathrm{E}-8$ & $1.1 \mathrm{E}-8$ \\
\hline $85 \%$ & $8.1 \mathrm{E}-6$ & $6.6 \mathrm{E}-6$ & $5.1 \mathrm{E}-6$ & 3.7E-6 & & $2.5 \mathrm{E}-8$ & $2.0 \mathrm{E}-8$ & $1.5 \mathrm{E}-8$ & $1.1 \mathrm{E}-8$ \\
\hline $90 \%$ & 8.5E-6 & $7.1 \mathrm{E}-6$ & $5.4 \mathrm{E}-6$ & $3.8 \mathrm{E}-6$ & & $2.6 \mathrm{E}-8$ & $2.1 \mathrm{E}-8$ & $1.6 \mathrm{E}-8$ & $1.2 \mathrm{E}-8$ \\
\hline $95 \%$ & $8.9 \mathrm{E}-6$ & 7.7E-6 & $5.8 \mathrm{E}-6$ & $4.0 \mathrm{E}-6$ & & $2.7 \mathrm{E}-8$ & $2.3 \mathrm{E}-8$ & $1.8 \mathrm{E}-8$ & $1.2 \mathrm{E}-8$ \\
\hline \multicolumn{10}{|c|}{$\begin{array}{l}\text { Notes: } \\
\text { Simulation modeling using @RISK Version 3.5, 10,000 iterations and Latin Hypercube Sampling } \\
\text { Zone most likely value is the mode is derived from simulation modeling using the event counts of Table 6.13. } \\
\text { Zone standard deviation is derived from simulation modeling using the event counts of Table 6.13. } \\
\text { Pr(E2 given E1)Pr(Ed1) uses the low temperature repository area and the mean disruption probability from Table 6.11. } \\
\text { Event Rates are adjusted for undetected events }\end{array}$} \\
\hline
\end{tabular}



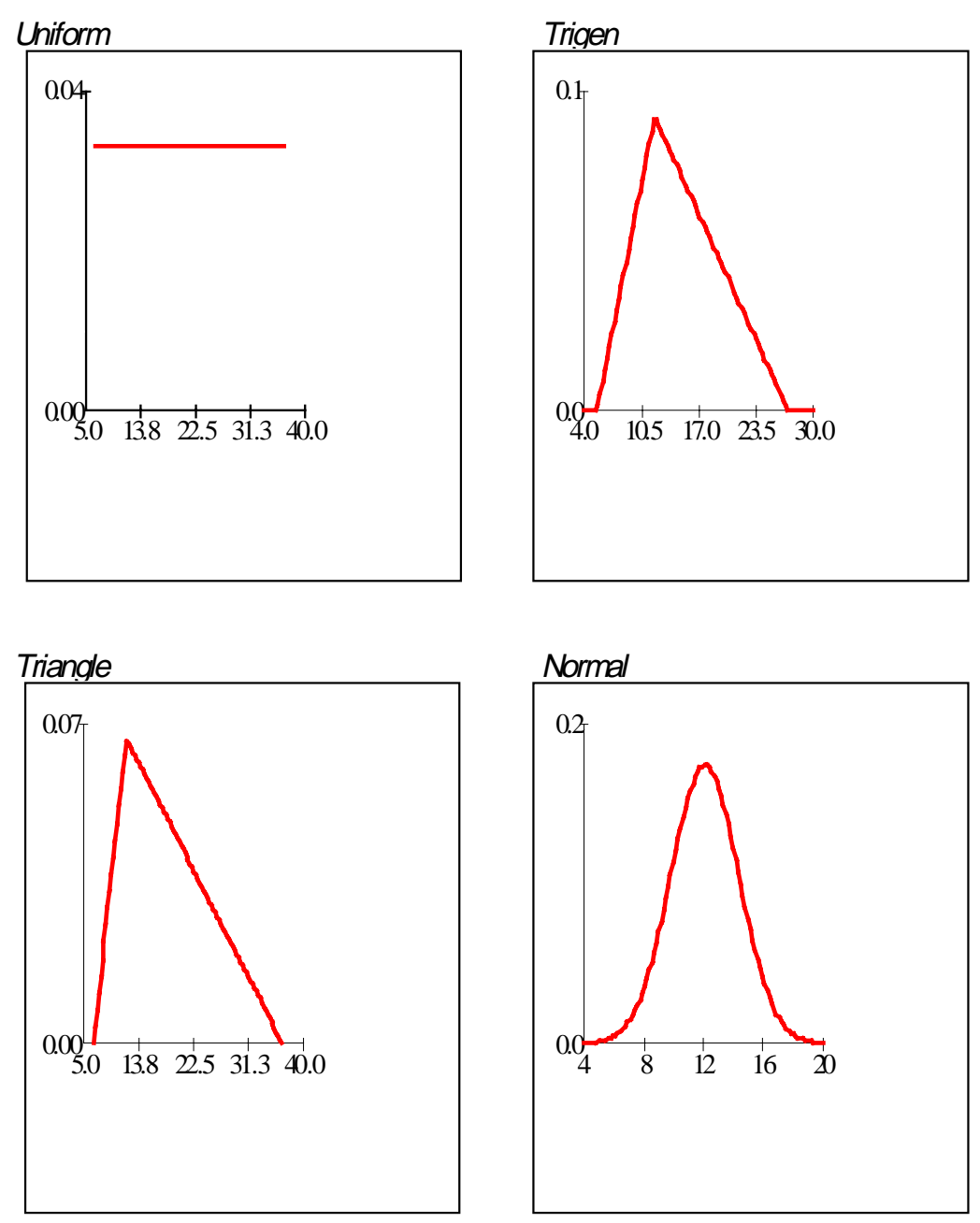

Figure 6.20. Probability distributions used in event-count simulations, Northeast-trending structural zone (x-axes are the event counts).

\section{E. Probability of Magmatic Disruption of a Repository}

Crowe et al. (1993; 1995), Connor and Hill (1995), and Geomatrix (1996) established probability distributions for magmatic disruption of a repository (PVHA). The mean probability estimates from these studies are very similar and do not require further discussion. Brief discussions are provided on the sensitivity of E2 and E2, given E1, for three topics:

1. Bounding probability estimates which were established by comparing the probability of magmatic disruption for background regional zones versus that for local spatial and structural zones in the YMR.

2. The sensitivity, with respect to PVHA, of changes in location of the eastern edge of spatial and structural zones that lie adjacent to the Yucca Mountain site.

3. The potential sensitivity, with respect to PVHA, of the recent decision by the DOE not to study the aeromagnetic anomalies in the Amargosa Valley using exploratory drilling. 
Bounding Estimates of the Probability of Magmatic Disruption. Bounding estimates for PVHA can be obtained for the YMR by applying two relatively straightforward assumptions. First, there is a low background recurrence rate of the formation of small-volume basalt centers of Quaternary age within the relatively inactive areas of the interior parts of the southern Great Basin (Crowe et al., 1995). Simple logic requires therefore, that recurrence rates in volcanic zones of the YMR should be greater than these background rates. Second, volcanic zones of the YMR should be areas of preferential occurrence of Pliocene and Quaternary volcanic events and therefore areas with higher volcanic hazards. Bounds on the probability of magmatic disruption of a repository for the YMR can be obtained by comparing the probability estimates for an area equal to the dimensions of a repository in spatial and structural volcanic zones, with similar probability estimations for regional background zones. The Yucca Mountain site is located near to but outside of most of the defined volcanic zones. Logically, the recurrence rates and disruption probabilities for the Yucca Mountain site must be greater than similar estimates for background regions and somewhat less than the probability estimates for locating a repository in a volcanic zone.

Quaternary recurrence rates have been obtained for three different regional background zones by estimating event counts. These areas are the southern Great Basin (SGB), the Amargosa Valley isotopic province (AVIP), and the area of the Postcaldera basalt episode in the YMR (PCB) (see Crowe 1990; also see elicitation of Bruce Crowe in Geomatrix 1996). The event counts used for the minimum probability bounds are the most likely event counts for the YMR from this report, as well as the most likely event counts for regional background zones from Geomatrix (1996). The interval used for the event counts is restricted to the Quaternary (1.6 Ma) because the events counts are poorly known for the pre-Quaternary outside of the YMR. The probability of magmatic disruption of a repository is established by assessing the Quaternary event counts (E1) combined with the regional disruption probability (E2, or the area of the repository divided by the area of the background zones; Table 6.21). The resulting estimates are $1.7 \times 10^{-9}$ to $7.2 \times 10^{-10}$ events year ${ }^{-1}$ for the Hrep, 3.4 to $1.4 \times 10^{-9}$ events year $^{-1}$ for the Lrep, and about 3.8 to $1.6 \times 10^{-8}$ events year $^{-1}$ for the Srep.

Maximum probability bounds are established by assuming random location of an area equal to the Hrep, the Lrep and the Srep within the seven spatial and structural zones of the YMR. The areas of these zones and the maximum probability bounds are listed on Table 6.22 (zone areas are from Geomatrix, 1996). The event counts for the zones are the maximum values from Table 6.13 and the disruption probability for individual zones is the representative repository area divided by the zone area. 
Table 6.21. Minimum Probability Bounds for Regional Volcanic Zones

\begin{tabular}{|c|c|c|c|c|c|c|}
\hline $\begin{array}{c}\text { Volcanic } \\
\text { Zones }\end{array}$ & $\begin{array}{c}\text { Zone } \\
\text { Area } \\
\left(\mathrm{km}^{2}\right) \\
\end{array}$ & $\begin{array}{l}\text { Event } \\
\text { Counts } \\
(1.6 \mathrm{Ma}) \\
\end{array}$ & $\begin{array}{c}\text { Recurrence } \\
\text { Rates } \\
\text { E1 } \\
\text { (events yr }{ }^{-1} \text { ) } \\
\end{array}$ & $\begin{array}{c}\text { Hrep } \\
\text { Disruption } \\
\text { Hrep } \\
\text { (events yr } r^{-1} \text { ) }\end{array}$ & $\begin{array}{c}\text { Lrep } \\
\text { Disruption } \\
\text { Lrep } \\
\text { (events yr }{ }^{-1} \text { ) } \\
\end{array}$ & $\begin{array}{c}\text { Srep } \\
\text { Disruption } \\
\text { Srep } \\
\text { (events yr }^{-1} \text { ) } \\
\end{array}$ \\
\hline $\begin{array}{l}\text { Southern. } \\
\text { Great Basin }\end{array}$ & 19874 & 10 & $6.2 E-6$ & $7.2 \mathrm{E}-10$ & $1.4 \mathrm{E}-9$ & $1.6 \mathrm{E}-8$ \\
\hline $\begin{array}{l}\text { Amargosa } \\
\text { Isotopic } \\
\text { Province }\end{array}$ & 7636 & 9 & $5.6 \mathrm{E}-6$ & $1.7 \mathrm{E}-9$ & $3.4 \mathrm{E}-9$ & $3.8 E-8$ \\
\hline $\begin{array}{l}\text { Postcaldera } \\
\text { Basalt Episode }\end{array}$ & 5649 & 6 & $3.7 E-6$ & $1.5 E-9$ & $3.0 \mathrm{E}-9$ & $3.4 \mathrm{E}-8$ \\
\hline \multicolumn{7}{|c|}{$\begin{array}{l}\text { Notes: } \\
\text { Zone Areas are from Geomatrix (1996) } \\
\text { Event counts are the } 50 \% \text { BC-15 to BC-25 in Geomatrix (1996) } \\
\text { Hrep }=2.3 \mathrm{~km}^{2} \\
\text { Lrep }=4.6 \mathrm{~km}^{2} \\
\text { Srep }=51 \mathrm{~km}^{2} \\
\text { Estimations assume random location of repository areas in volca }\end{array}$} \\
\hline
\end{tabular}

Table 6.22. Maximum Probability Bounds for PVHA for the YMR

\begin{tabular}{|c|c|c|c|c|c|c|}
\hline Volcanic Zones & $\begin{array}{c}\text { Zone } \\
\text { Area } \\
\left(\mathrm{km}^{2}\right) \\
\end{array}$ & $\begin{array}{l}\text { Event } \\
\text { Counts } \\
(1.6 \mathrm{Ma}) \\
\end{array}$ & 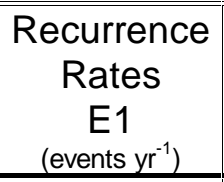 & $\begin{array}{c}\text { Hrep } \\
\text { Disruption } \\
\text { Hrep } \\
\text { (events yr } r^{-1} \text { ) } \\
\end{array}$ & $\begin{array}{c}\text { Lrep } \\
\text { Disruption } \\
\text { Lrep } \\
\text { (events yr } \mathrm{rr}^{-1} \text {. }\end{array}$ & $\begin{array}{c}\text { Srep } \\
\text { Disruption } \\
\text { Srep } \\
\text { (events yr }{ }^{-1} \text { ) } \\
\end{array}$ \\
\hline Quat CFVZ & 514 & 17.7 & $1.1 \mathrm{E}-5$ & $4.9 \mathrm{E}-8$ & $9.9 \mathrm{E}-8$ & $1.1 \mathrm{E}-6$ \\
\hline Plio-Quat CFVZ & 1068 & 42.5 & 2.7E-5 & $5.7 E-8$ & $1.1 \mathrm{E}-7$ & $1.3 \mathrm{E}-6$ \\
\hline Plio-Quat YMR & 1884 & 46.2 & $2.9 \mathrm{E}-5$ & $3.5 E-8$ & $7.0 \mathrm{E}-8$ & $7.8 \mathrm{E}-7$ \\
\hline Quat-Pull Apart & 242 & 12.9 & 8.1E-6 & 7.7E-8 & $1.5 \mathrm{E}-7$ & $1.7 \mathrm{E}-6$ \\
\hline $\begin{array}{l}\text { Plio-Quat Pull } \\
\text { Apart }\end{array}$ & 506 & 32.6 & $2.0 \mathrm{E}-5$ & $9.3 \mathrm{E}-8$ & $1.8 \mathrm{E}-7$ & 2.0E-6 \\
\hline WLSZ & 1452 & 42.5 & 2.7E-5 & $4.2 \mathrm{E}-8$ & $8.4 \mathrm{E}-8$ & 9.3E-7 \\
\hline NESZ & 2176 & 36.6 & $2.3 E-5$ & 2.4E-8 & $4.8 \mathrm{E}-8$ & $5.4 \mathrm{E}-7$ \\
\hline \multicolumn{7}{|c|}{$\begin{array}{l}\text { Notes: } \\
\text { Zone Areas are from Geomatrix (1996) } \\
\text { Event counts are the Maximum events from Table } 6.13 \text { and include undetected events } \\
\text { Hrep }=2.3 \mathrm{~km}^{2} \\
\text { Lrep }=4.6 \mathrm{~km}^{2} \\
\text { Srep }=51 \mathrm{~km}^{2} \\
\text { Estimations assume random location of repository areas in volcanic zones }\end{array}$} \\
\hline
\end{tabular}

Several important features are illustrated by the maximum probability bounds of Table 6.22 :

1. Regional background, or minimum probability bounds for the probability of magmatic disruption of a repository area are about $7 \times 10^{-10}$ to $3 \times 10^{-9}$ events $\mathrm{yr}^{-1}$. The probability of magmatic disruption of the Yucca Mountain site must be $>$ these background bounds. 
2. The YMR and the NESZ give the lowest maximum probability bounds because these bounds are for zones that include the Yucca Mountain site.

3. The highest maximum probability bounds from Table 6.22 are for the pull-apart models, an observation that is consistent with these zones having the highest CIV.

4. The assumption of maximum event rates and location of a repository in a volcanic zone result in an upper probability bound approaching $10^{-7}$ events year ${ }^{-1}$. The conservatism of the assumptions used for these probability estimations makes it physically implausible for any probability estimate to exceed these bounds.

The probability bounds of Tables 6.21 and 6.22 are consistent with almost all published probability estimates for the YMR (Crowe et al., 1995) and are consistent with the $95 \%$ confidence bound of $4.5 \times 10^{-8}$ events year ${ }^{-1}$ from the volcanism expert judgment study (Geomatrix, 1996).

Sensitivity Analysis of PVHA for the Aeromagnetic Anomalies of Amargosa Valley and Crater Flat. Only one aeromagnetic anomaly of the Amargosa Valley has been investigated using exploratory drilling, and this site has been dated at about 3.85 Ma (Crowe et al., 1995). The DOE made a recent decision to modify current site characterization plans and not undertake exploratory drilling of the remaining aeromagnetic anomalies. This section assesses the potential programmatic impact of this decision. This impact is defined by assuming that all the undrilled aeromagnetic anomalies are of Quaternary age $(=1.6 \mathrm{Ma})$. Revised recurrence rates are estimated using these higher Quaternary event counts, and mean values are assigned to other probability variables for PVHA. An assigned Quaternary age is judged to be conservative for several reasons. First, Quaternary basalt centers in Crater Flat show only partial burial by alluvium. By comparison, the buried aeromagnetic anomalies of the Amargosa Valley should be of pre-Quaternary age. Second, the drilled aeromagnetic anomaly is of Pliocene age (Crowe et al., 1995), consistent with a preQuaternary age of the undrilled anomalies. The assumptions for this section are conservative if the aeromagnetic anomalies of the Amargosa Valley are buried basalt centers. If the anomalies are produced by basalt intrusions, there is no limit on the youngest or upper age limit of the centers other than the constraints from the inferred polarity of the aeromagnetic anomalies (either < or > 700,000 years).

The mean disruption ratio for the Plio-Quaternary pull-apart zone is $2.1 \times 10^{-4}$ for the Hrep, $3.6 \times 10^{-4}$ for the Lrep and $8.7 \times 10^{-3}$ for the Srep (Table 6.11 ). The most likely event count (including undetected events) for the aeromagnetic anomalies of the Amargosa Valley is 5.4 events (Table 6.13). The aeromagnetic anomaly $\mathrm{A}$ is known to be of Pliocene age and must be subtracted from the most likely event count giving a total of 4.2 potential Quaternary events (1.2 events are subtracted from the Amargosa most likely event count to include undetected events). The most likely event count for the Quaternary pull-apart model is 3.8 events (Table 6.13), and this number is added to the event count for the aeromagnetic anomalies to give a total of 8 events for the Quaternary. This event count, divided by 1.6 Ma (Quaternary) assuming a homogeneous Poisson temporal model for event distribution, gives a recurrence rate of $5.0 \times 10^{-6}$ events year $^{-1}$, a number that is not significantly different from other alternative estimations of event rates. The disruption ratio of the Quaternary Amargosa Valley scenario must be smaller than the area of the PlioceneQuaternary pull-apart zone $\left(506 \mathrm{~km}^{2}\right.$; see Table 6.22) because anomaly A (Pliocene) is excluded from the volcanic zone. Therefore, the estimated disruption ratio is approximated as the area of the Lrep $\left(4.6 \mathrm{~km}^{2}\right)$ divided by $450 \mathrm{~km}^{2}\left(1.0 \times 10^{-2}\right)$. This estimate is compared with a mean disruption ratio for the Lrep for the Pliocene-Quaternary pull-apart model of $3.6 \times 10^{-4}$ (Table 6.11) and by 
extrapolation, a disruption ratio of about $5 \times 10^{-3}$ appears realistic for the sensitivity studies. The resulting probability of magmatic disruption of the Yucca Mountain site, assuming a Quaternary age for undrilled aeromagnetic anomalies, is about $2.5 \times 10^{-8}$ events year $^{-1}$. This estimate is not significantly different from alternative estimations of the probability of magmatic disruption of the Yucca Mountain site (Crowe et al., 1995; Geomatrix, 1996). Logically, this estimation is reasonable because the event rate doubles assuming a Quaternary age for the centers, but the disruption ratio decreases by almost a factor of two because of expansion of the volcanic zone. Further, the area added to the Quaternary volcanic zone does not strongly affect the disruption probability because it is distant from the Hrep, Lrep and Srep (not part of the CIV of the volcanic zone). Thus a fairly direct analyses shows that the assignment of a Quaternary age to the unexplored aeromagnetic anomalies of Amargosa Valley does not result in probability estimations that are significantly different than other estimations.

Two aeromagnetic anomalies in Crater Flat remain unexplored. The first is a broad magnetic high located in the central part of the flat, and the second is a small positive magnetic anomaly located about $1 \mathrm{~km}$ south of Little Cones ${ }^{3}$ (Kane and Bracken, 1983; Crowe et al., 1986). The former anomaly was investigated using exploratory drilling (USW VH-1), and the anomaly could not be related to Pliocene or Quaternary basaltic volcanic centers in the Crater Flat basin (Carr, 1982). An alternative and unresolved interpretation is that the anomaly may be produced by basaltic intrusions formed during stages of development of the Crater Flat basin (Chapter 3, this report; Brocher et al., 1996). The age of these intrusions is unknown, but the size of the magnetic high probably requires a moderate volume of basaltic magmatism which would be more consistent with the late Miocene phase of basaltic volcanic activity (Crowe, 1990). Accordingly, this aeromagnetic anomaly is judged to be unlikely to have a significant impact on PVHA.

The positive aeromagnetic anomaly associated with the Little Cones center is more problematic. If the anomaly represents either a Pliocene or Quaternary buried basaltic volcanic center, it is located within defined volcanic zones. Its primary effect on PVHA, therefore, would be to change the recurrence rate of volcanic events. Assuming the center represents 1 or at most 2 volcanic events, the increase in recurrence rates for the pull-apart volcanic zones (Table 6.13), the most sensitive models, are no more than 15 to 35\%, respectively, for the Plio-Quaternary and Quaternary intervals. This is not a significant increase, given the uncertainty of PVHA. A more sensitive issue is a subjective issue concerning the completeness of volcanism characterization studies for the Yucca Mountain site. All Pliocene and Quaternary volcanic centers of the Crater Flat basin, with the exception of the Lathrop Wells center, are reversely magnetized. The Little Cones aeromagnetic anomaly is a positive anomaly and may therefore be of normal polarity. If it is produced by a buried basaltic center, then it must represent an undocumented phase of volcanic activity in the Crater Flat basin. If it is a Miocene center, it would have no impact on PVHA. If it is a Pliocene or Quaternary volcanic center, then its impact on alternative models for PVHA cannot be judged without knowing the age and volume of the center. These data potentially could change interpretations of spatial patterns of volcanic events through time, event-slopes through time and repose intervals. The small size of the anomaly suggests it would not have a significant effect on interpretations of magma volumes through time. The likely impacts are minor if the center is of Pliocene age but could be more significant, particularly with respect to repose intervals for

\footnotetext{
${ }^{3}$ This original version of this report was completed before detailed ground magnetic studies of the Little Cones area were published by the Center for Nuclear Regulatory Waste Analysis.
} 
volcanic events, if the anomaly represents a buried Quaternary volcanic center. We suggest, given these considerations and the location of the anomaly site in the Crater Flat basin southwest of the Yucca Mountain site, that it would be advantageous to investigate the origin of the Little Cones aeromagnetic anomaly using exploratory drilling.

Northeast Boundaries of Volcanic Zones. Examination of the geometry of volcanic source zones used in this report (Golder Associates, 1995) allows a visual assessment of the sensitivity of PVHA to the location of the zone boundaries. In nearly all cases, the east or northeast boundary of volcanic zones is closest to the Yucca Mountain site. The results of the simulation modeling by Golder Associates (1995) show that the disruption probability is sensitive to the proximity of the source volcanic zones to areas of a repository or repository system. An obvious question is what is the sensitivity of PVHA to a change in the location of the northeast boundary of a volcanic zone? Several observations are important. The source zone boundaries in the simulation modeling for this report do not truncate volcanic events. The distribution of volcanic events is constrained to within a zone, but feeder dikes associated with the events are allowed in the simulations to extend beyond the source-zone boundaries. The expert judgment PVHA also treated zone boundaries as approximate. Experts allowed feeder dikes to extend beyond zone boundaries and/or allowed event locations to extend beyond zone boundaries by using a smoothing function that defined a decreased likelihood of events with distance from a zone boundary (Geomatrix, 1996). Thus, to a first approximation, the northeast boundaries of source zones in past PVHA were treated as imprecise boundaries.

We have used the results of simulation modeling of the disruption ratio from this report to evaluate the effect of changing the location of the northeast boundary. Generally, the effect of moving the northeast location of a zone boundary one-kilometer closer to the Yucca Mountain site is equivalent to increasing the length of a feeder dike by one kilometer. Both result in a higher disruption probability because of the increased number of dikes that can intersect a repository or repository system. The only differences in these comparisons are for specific combinations of zones and feeder dike parameters where the results show that that disruption ratio is nonlinear (Golder Associates, 1995).

The parameter matrix assigned to feeder dikes in the simulation modeling allows assessment of the effects of increased dike lengths (Golder Associates, 1995). Two sets of data from the simulation modeling are used to assess variability in the disruption ratio with increasing dike length. These are the simulation sets for simple dikes and simulation sets for complex dikes, where dike lengths were changed in 1 kilometer increments from, respectively, 3 to $7 \mathrm{~km}$ and 10.6 to 14.6 kilometers. Careful examination of the simulation results from the study by Golder Associates (1995) show that the most sensitive volcanic zones with respect to varying dike lengths are the Crater Flat and the pull-apart volcanic zones (Golder Associates, 1995). The data from the simple dike models for these volcanic zones are somewhat difficult to interpret because many of the simulations do not result in disruption of the Hrep, or Lrep, particularly for the CFVZ (see data appendix of Golder Associates) because the disruption probability was less than $10^{-4}$ or 1 in 10,000 , the number of iterations used in the simulations. To avoid this data limitation, we focused our analyses on the effects of dike lengths using the simulation data for the complex dike data set. Table 6.23 shows changes in the disruption ratio with increasing dike length for four volcanic zones and the three repository areas (Hrep, Lrep, and Srep). A set of 3-dimensional plots of the changes in the disruption ratio with increased dike length that corresponds to Table 6.23 are shown, respectively, on Figures 6.21 to 6.23 . 
Table 6.23. Variation in the Disruption Ratio with Increasing Dike Length (complex dikes, uniform distribution).

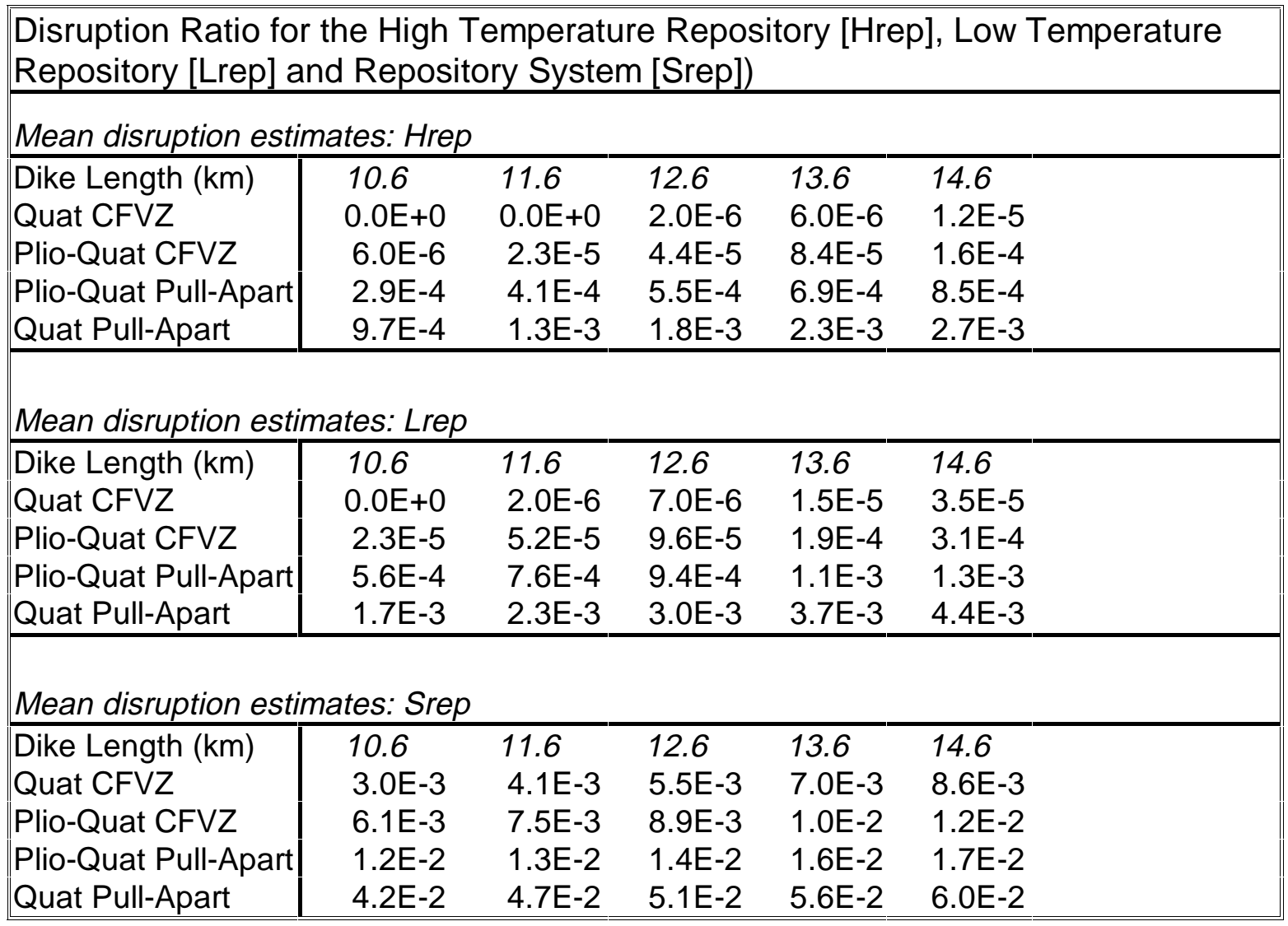




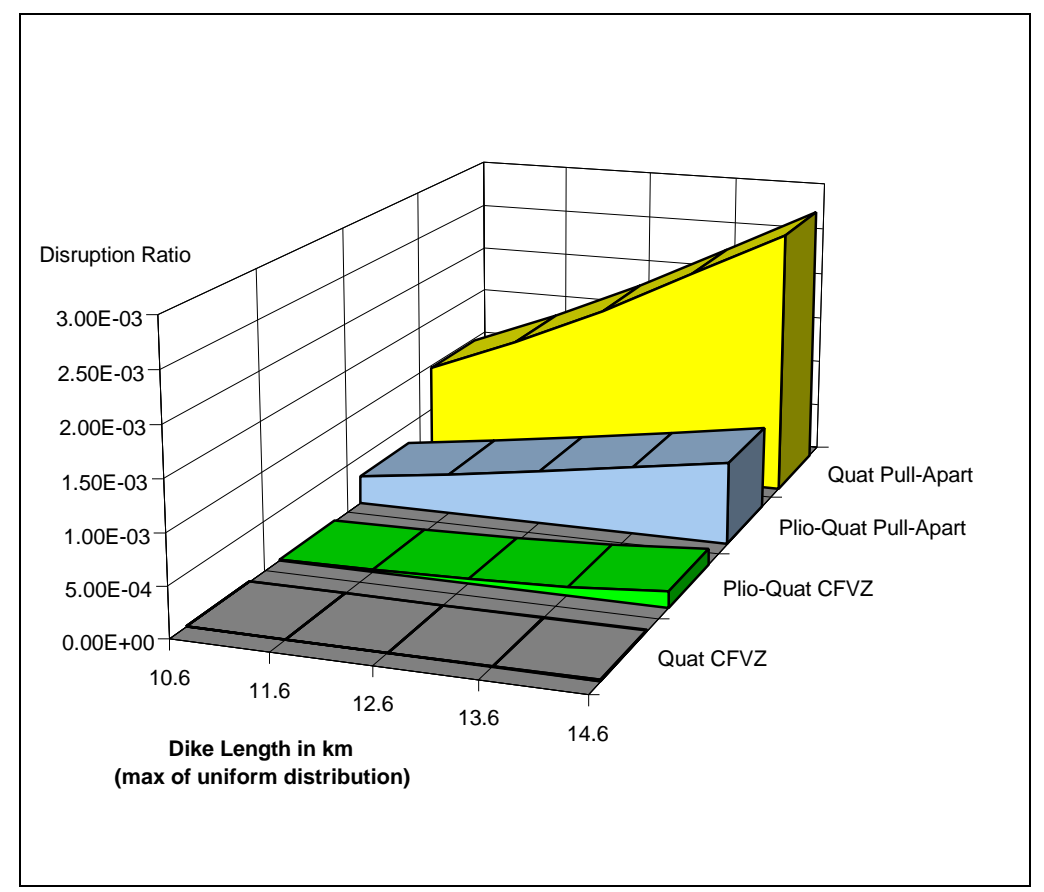

Figure 6.21. Disruption ratio versus dike length for high temperature repository.

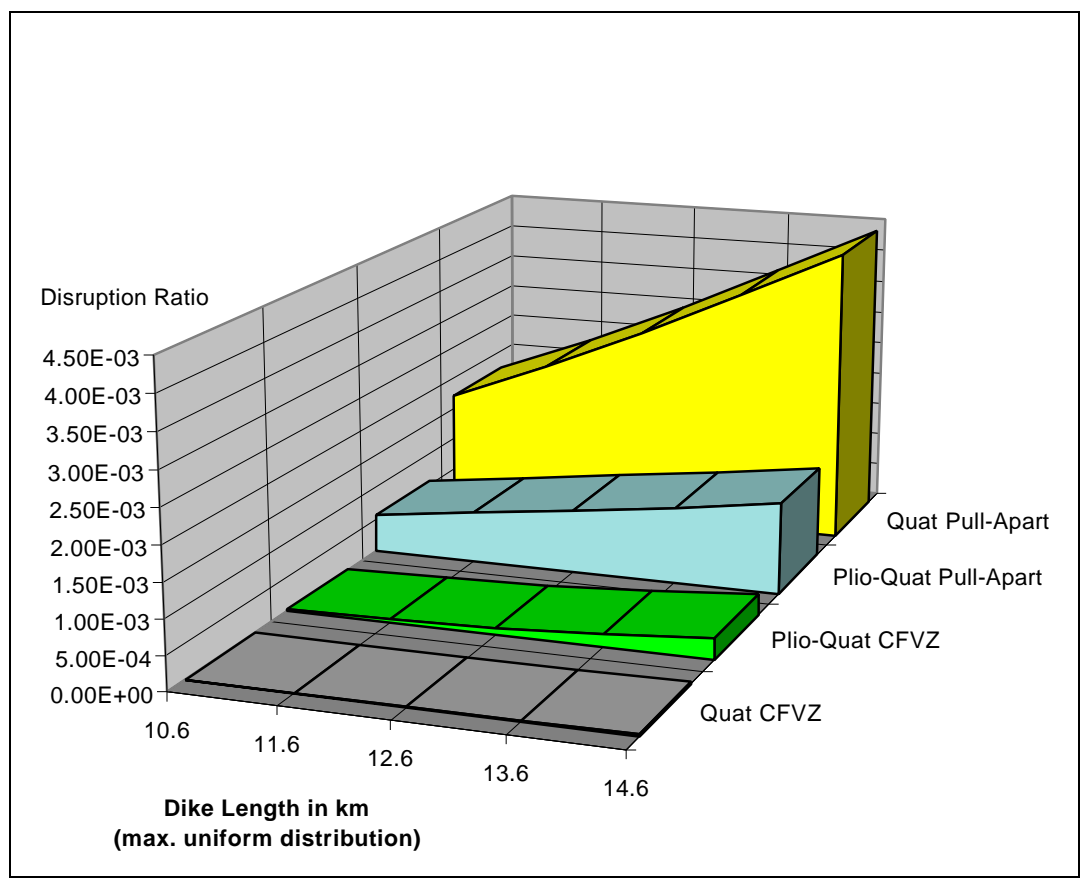

Figure 6.22 . Disruptive ratio versus dike length for low temperature repository. 


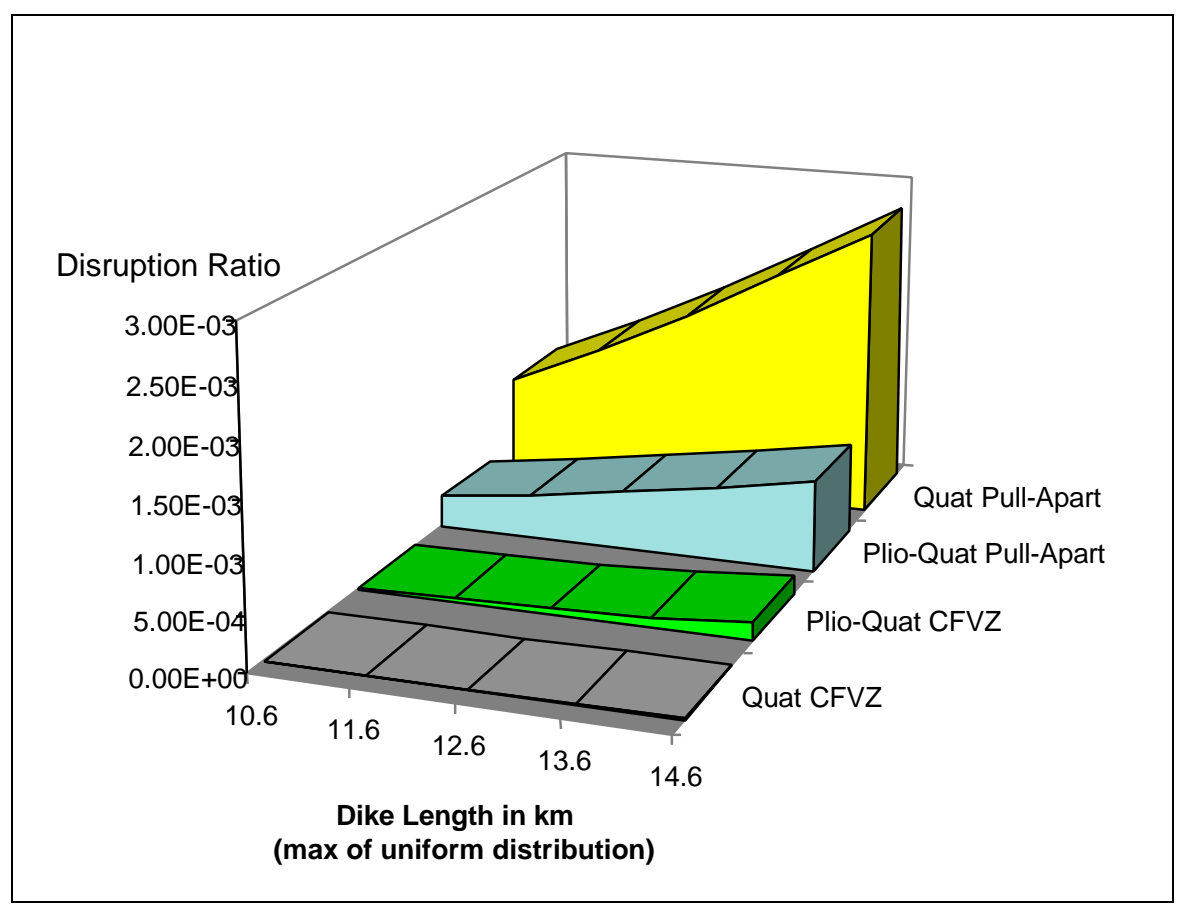

Figure 6.23. Disruptive ratio versus dike length for repository system.

There is limited sensitivity of the disruption ratio with respect to dike length for most zone models; the maximum sensitivity is show by the Quaternary pull-apart model, and it varies by about a factor of 3 for the Hrep, corresponding to an increase in dike length of 4 kilometers. However, these plots are somewhat misleading because the y-axis of each plot (disruption ratio) varies by over three orders of magnitude, and this large variation causes a scaling problem when displaying the changes in the disruption ratio for models with small initial disruption probabilities. This scaling problem is resolved by normalizing the disruption ratio for each volcanic zone to the previous value so that each segment of a plot shows the percentage change from a previous plot segment. Figures 6.24 to 6.26 show these normalized disruption ratios, and these plots reveal largely the reverse effects of Figures 6.21 to 6.23. That is, the maximum percentage change in the disruption ratio with increased dike lengths is for the CFVZ volcanic zones (Quaternary and Pliocene-Quaternary), the opposite of Figures 6.21 to 6.23. This reversed perspective for the percent-change plots is intuitive when considered with respect to the spatial geometry of volcanic zones relative to the location of the Hrep, Lrep, and Srep. The maximum percentage change in the disruption ratio is for volcanic zones that are near to but do not intersect repository zones. In these cases, increasing the dike length results in a pronounced stepped increase in the number of new cases of repository intersection, and, therefore a higher percentage increase in E2 compared to zones that are closer to a repository and repository system. This is especially applicable to some simulation sets for the CFVZ zones, where the disruption ratio is $<10^{-4}$ and limited, therefore, by the number of realizations used in the simulation modeling (Golder Associates, 1995). 
After evaluating the sensitivity of changing dike lengths on the disruption ratio, we came to three major conclusions:

1. The maximum increase in the probability of intersection of a repository and repository zone for a $4 \mathrm{~km}$ increase in dike length is approximately a factor of 3 . While this is an important increase, it is not a large increase given the uncertainty of PVHA.

2. The maximum increase in repository disruption with increased dike length is for models that are near to or partly overlap the Hrep, Lrep and the Srep. However, given the existing relatively high values of the disruption probability for these zones, the percentage increase is smaller than for zones that are not as close to the Hrep, Lrep and Srep.

3. The Crater Flat volcanic zones show maximum sensitivity to changing dike lengths. However, because these zones have relatively low initial disruption probabilities, these changes are not highly significant for PVHA.

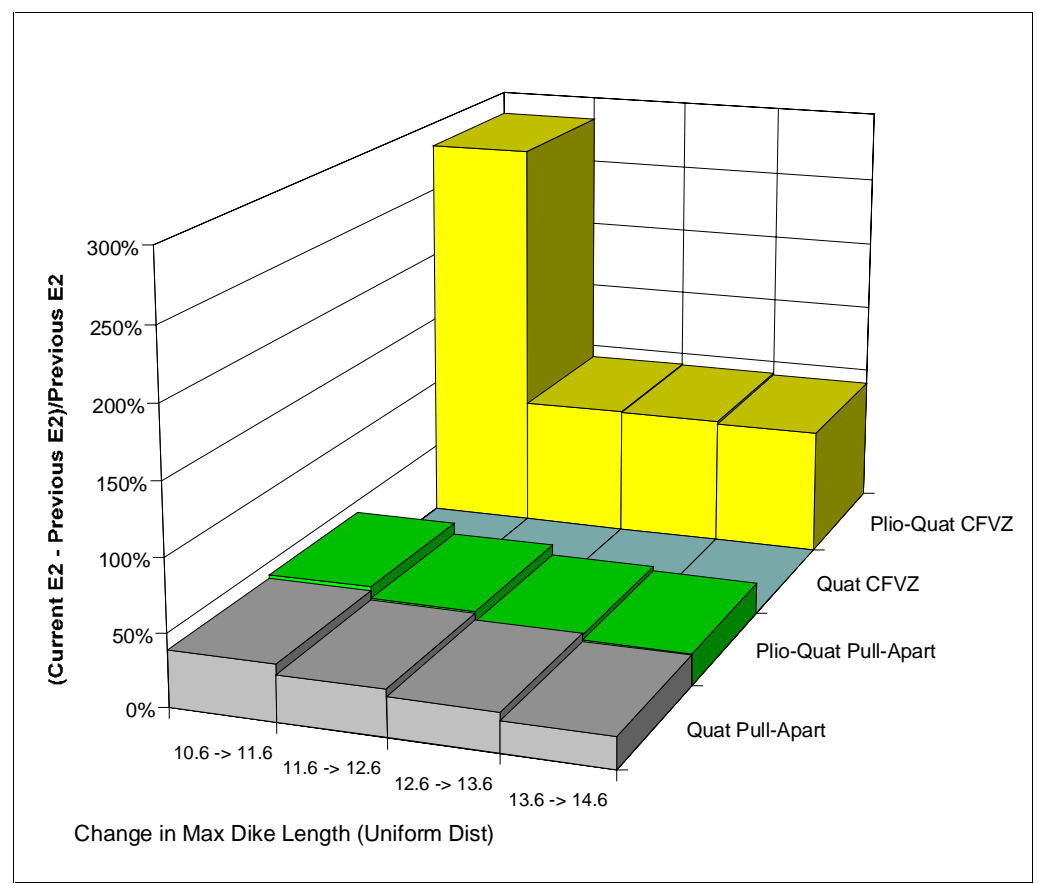

Figure 6.24 High Temperature repository - change in E2. 


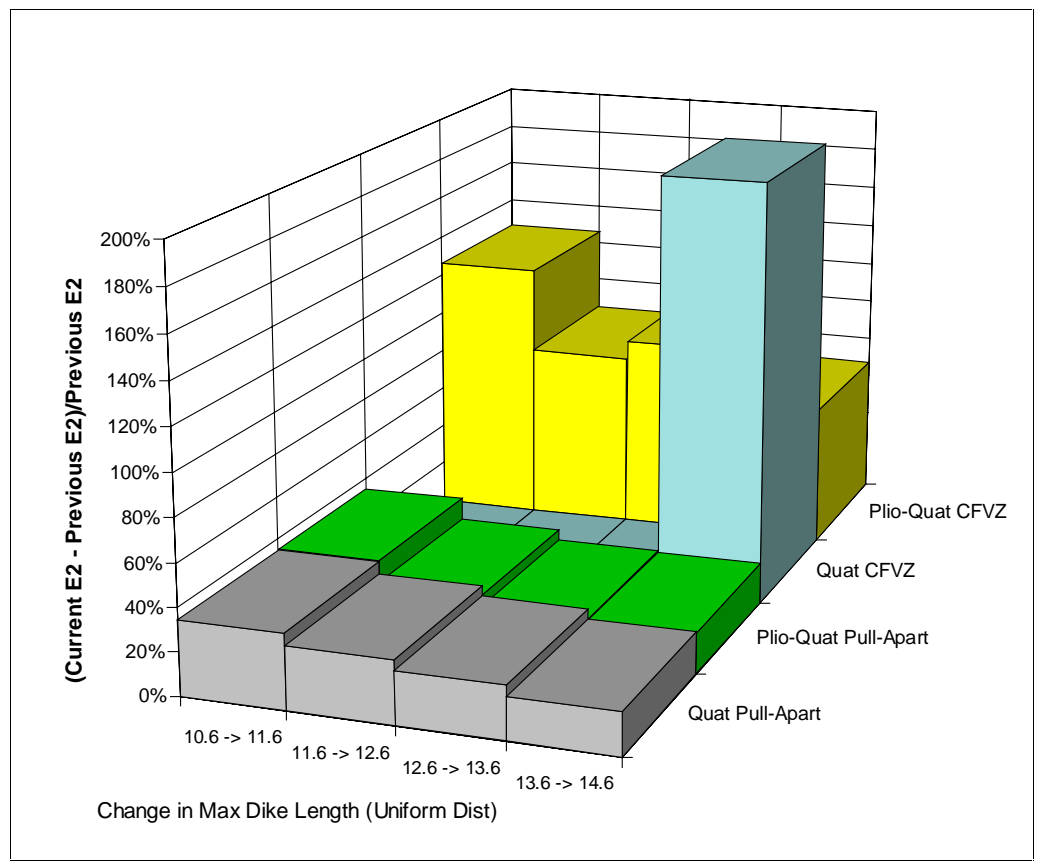

Figure 6.25. Low Temperature repository - change in E2.

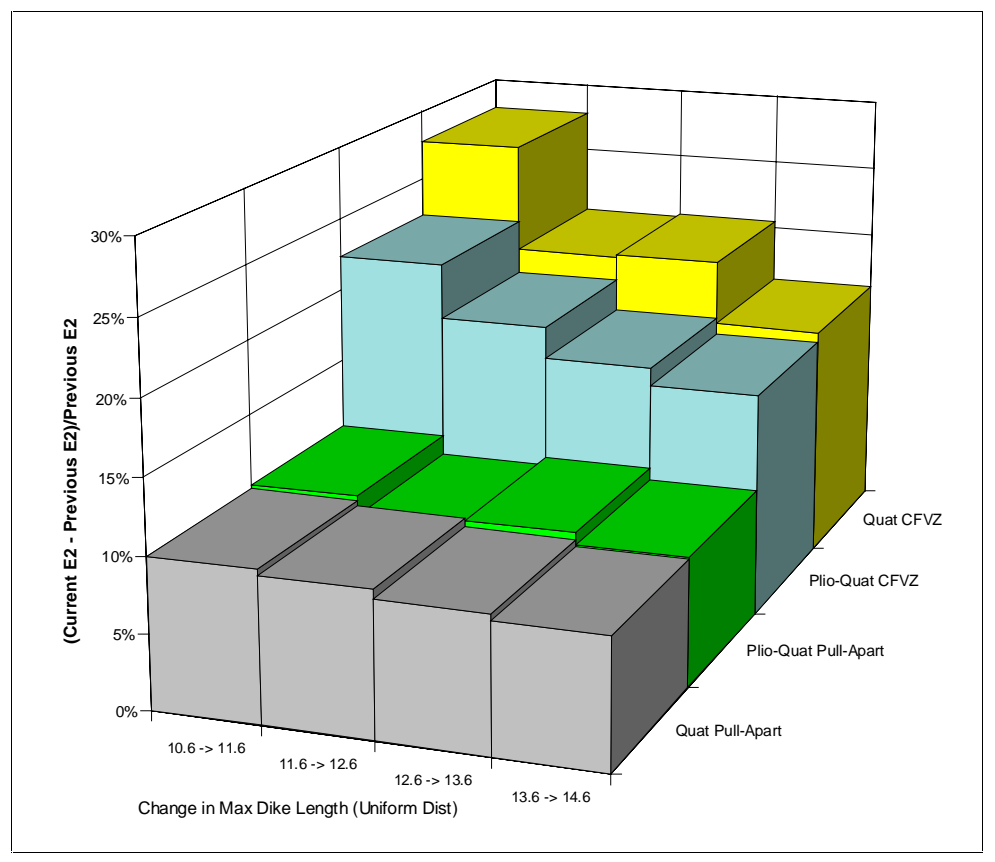

Figure 6.26. Repository system - change in E2. 


\section{Probabilistic Volcanic Risk Assessment}

The primary responsibility for assessing the effects of magmatic disruption of a potential repository is held by the group conducting TSPA; the effects of future magmatic events on a repository have been considered in past TSPA (Link et al., 1983; Banard et al., 1992; Barr et al., 1993; Crowe et al., 1993; Wallmann et al., 1993; Andrews et a., 1994; Wilson et al., 1994). An additional study of the effects of magmatic disruption of a repository was completed after the VSR was issued in mid-year 1995 (Crowe, 1995a; Golder Associates, 1995). This study used the results from simulation modeling of repository disruption (described in an earlier section of this report) to assign modeling parameters for assessing radiological releases associated with magmatic disruption of a repository and repository system. This section briefly describes the results of these assessments. The studies augment past investigations of the consequences of magmatic disruption of a repository, using the most current results from site characterization studies. They are intended to complement information used for TSPA, recognizing that the responsibility of assessing regulatory compliance for a repository remains with TSPA.

\section{A. Repository Integration Program.}

The computer code Repository Integration Program (RIP) was used as a simulation tool to assess the performance of a potential repository system at the Yucca Mountain site (Golder Associates, 1995). The significance or sensitivity of volcanic-driven radiological releases was assessed by comparing the base-case repository performance with an augmented-base case that includes radiological releases associated with a magmatic event. The base-case Yucca Mountain model (83YH5.RP) used in this study was provided by Intera and was developed for the YMP; the details of the base case model are described in TRW (1995) and are beyond the scope of this summary. However, the implementation of consequence studies of volcanic events is within the framework provided by the RIP code (saturated and unsaturated pathways, vertical columns within the unsaturated zone).

In the simulation modeling of volcanic effects, volcanic events are divided into two categories. A volcanic event for the effects study implicitly includes both the processes and products of surface volcanic eruptions and the subsurface processes associated with the ascent of magma through the crust; a volcanic event so defined can include intrusion of magma into the shallow crust without an accompanying surface eruption. The categories of volcanic events include: 1) those events that intersect a repository system $\left(51 \mathrm{~km}^{2}\right.$ area that encloses a repository and the area of volcanic effects) and 2) those events that intersect a repository. The second category can include volcanic events that terminate beneath a repository, that penetrate a repository but do not erupt, and that penetrate a repository and erupt (Golder Associates, 1995). Descriptions of the characteristics for individual volcanic events were determined using data from the site characterization studies and from the disruption simulation modeling described previously. Intrusion events that penetrate a repository must satisfy two criteria to erupt, and the data tested against the criteria are obtained from the simulation modeling of the disruption ratio. These criteria are: 1) the ratio of the length of the dike that intersects a repository to the total dike length must be $>0.25$ and 2) the total length of dike intersection of a repository must be greater than $500 \mathrm{~m}$. Both criteria are based on the observation that magma flow in a dike localizes to form one or more conduits and the conduit portions of a feeder dike are generally a small component of the total dike length. 
The consequences of magmatic events are described through parameter assignment in the RIP model, and these assignments are dependent on dike category. If a dike does not intersect the plan view of a repository, the consequences of the event are modeled using changes in the saturated zone. A dike effect area of $60 \mathrm{~m} \mathrm{(30} \mathrm{m} \mathrm{on} \mathrm{each} \mathrm{side} \mathrm{of} \mathrm{the} \mathrm{dike)} \mathrm{is} \mathrm{defined} \mathrm{as} \mathrm{an} \mathrm{area} \mathrm{of} \mathrm{decreased}$ radionuclide retardation, which results from the thermal effects of dike intrusion. However, this affected area is not significant in the RIP model because the dike width is very small compared to the total length of the saturated zone flow path $(5 \mathrm{~km})$. For dikes that penetrate a repository volume (plan view extended to depth), dike effects are described differently for each category of dike. Dikes that terminate beneath a repository are assumed to cause 1) waste package failure from enhanced corrosion associated with release of acidic gases from magma, and 2) reduction in radionuclide retardation in the immediately surrounding country rock. Waste package failure is modeled by moving the affected waste inventory of the intersected waste packages directly into transport column(s) in the unsaturated zone, a conservative assumption that assumes instantaneous failure of the package (Golder Associates, 1995). If a dike intersects a repository but does not meet the eruption criteria described above, it is assumed to terminate above a repository but below the surface. In this case, the intrusion consequences are assumed to be the same as intrusion of a dike below a repository, but the volume of the column of rock with reduced retardation is larger because the dike extends through a repository. For eruptive volcanic events, the events are assigned the same consequences as intrusions (waste canister failure, reduced retardation), and the volcanic event transports radioactive waste to the surface. The amount of transported waste is dependent on the dike length in a repository, and the volume of transported waste for the dike length is bounded by analogy to the volume of lithic (country-rock fragments) derived from repository depths (Valentine and Groves, 1996).

\section{B. Parameter Assignments: RIP Simulation Modeling.}

The event rates used for the RIP simulations were obtained from the event rate matrix for spatial and structural models and are documented in a spreadsheet that was included in a FY95 milestone report (Crowe, 1995). When using RIP, event rates were input as triangular distributions with estimated parameters values for the minimum, most likely value and maximum events. The disruption probabilities for the RIP modeling were described stochastically as conservative cumulative distributions by increasing the percentile values of cumulative distributions obtained from the FracMan simulation modeling by $10 \%$ of the value of the maximum bound. Graphical plots of the cumulative distributions used in the RIP simulations for the probability of disruption of the Hrep, Lrep and Srep are presented in the report by Golder Associates (1995). The dike length in a repository and the ratio of dike length in a repository to the total dike length were treated as cumulative distributions using the same approach, and individual cumulative distributions were obtained for each set of spatial and structural models; these cumulative distribution curves are also presented in the report by Golder Associates (1995).

An additional parameter was defined for the RIP simulations and is referred to as the effective dike area, or the area over which a dike modifies an intersected waste package or causes physical effects that decrease the retardation capability of the country rock. The effective dike area is a product of the dike length (from the cumulative distributions) multiplied by the dike width multiplied by a random factor used to account for the possibility of a dike branching into a sill. The width of the dike effect area is assumed to be $60 \mathrm{~m}$ and the sill factor is selected as a random variable from a uniform distribution ranging from 1 to 5 . The number of degraded waste packages for the simulations is defined as the ratio of the effective dike area to a repository area multiplied by the number of waste packages in a repository. The latter value was obtained from the base case 
model provided by Intera. If this ratio is less than 1/6 the repository area, the radiological releases are simulated by moving the affected waste inventory to the top of transport column 3 (chosen arbitrarily as a representative transport column). If the effective dike area is $>1 / 6$ the repository volume, the waste inventory of the degraded canisters is equally divided among the 6 transport columns.

Degradation of the retardation potential of the country rock affected by dike intrusion is a function of the termination site of the dike (above or below a repository) and the ratio of the effective dike area to a repository. No retardation effects are assigned to dikes that terminate above a repository because country rock above a repository does not contribute to transport retardation and the majority of magmatic degassing would occur above a repository. If the dike terminates below a repository, the retardation potential is reduced from the top of the Calico Hills (zeolitevitric facies) to the water table. The reduction of retardation potential is assigned to transport columns using the following assignment rules: 1) for an effective dike area of $<1 / 6$ repository area, the retardation reduction is assigned to transport column 3,2) for an effective dike area of $>1 / 6$ a repository area, the retardation reduction is assigned equally to the 6 transport columns.

Several assumptions are required to model magmatic events that result in an eruption. First, the waste inventory intersected by magma ascending in dike form is assumed to be uniformly distributed throughout a repository. Second, the incorporation of radioactive waste in ascending magma is bounded through analogy to the incorporation of lithic fragments (tuff country rock) in magma (Valentine et al., 1992; Valentine and Groves, 1996). The volume of lithic fragments derived from repository depth is dependent on the dike length in a repository and the extracted volume of lithic fragments per meter of dike length. The latter is treated as a truncated normal distribution with a mean of $8.5 \times 10^{-6}$, a standard deviation of $2.8 \times 10^{-5}$, and a lower bound of 1.0 $\times 10^{-7}$ (Golder Associates, 1995). Finally, because the RIP defines releases as a proportion of a waste package, the lithic fragment data is converted to a percentage of affected waste packages that could be transported to the accessible environment (Golder Associates, 1995).

Ten simulation sets were used for the RIP modeling with one thousand realizations per each set. The sets include a base case with no volcanic events and seven sets that describe the spatial and structural volcanic zones used in the simulation studies of magmatic disruption of a repository. Two addition sets that use two different time intervals (1.1 and 4.8 Ma) were run for some spatial and structural models. An event pruning parameter of 500 was used for simulations that do not include volcanic events, and this pruning parameter is weighted in the final results by the RIP code for calculation of a cumulative complementary distribution functions. The simulations were run for 100 time-steps and intervals of 10,000 and 100,000 years; the output results for the simulations are the cumulative releases from the waste package and the cumulative release to the accessible environment.

\section{Results of the RIP Simulation Modeling.}

The report by Golder Associates (1995) presents cumulative release curves for 10,000 and 100,000 years for all spatial and structural models. Figure 6.27 shows the estimated releases for 100,000 years from the model simulations for the NESZ, a model with a higher probability of disruption that generally gave the highest release curves. The figure shows that the cumulative releases for 100,000 years from a repository system, and including the effects of future magmatic events, does not show a significant deviation from the base-case results. Stated somewhat differently, the sensitivity of releases from future magmatic events is not a significant component of 


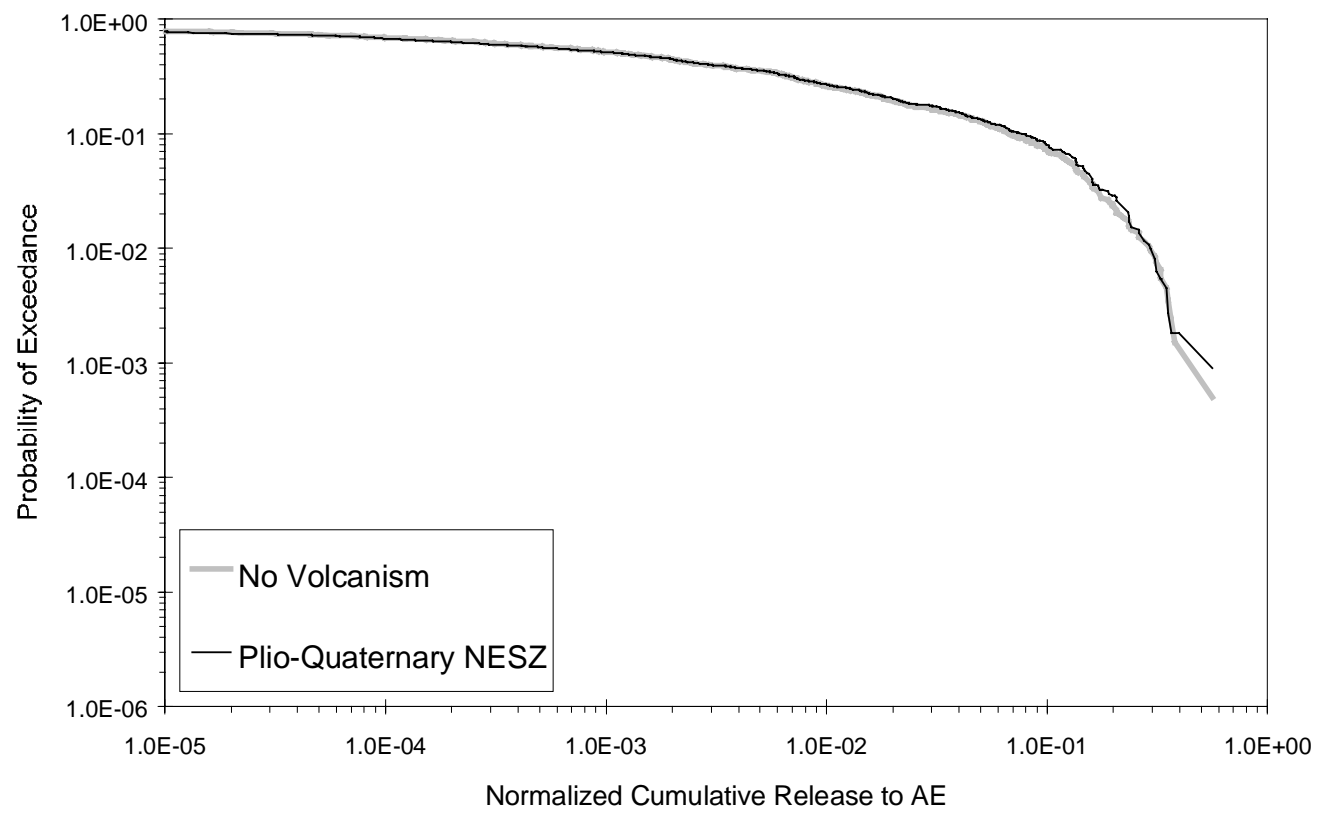

Figure 6.27. 100,000 year RIP simulation.

the performance of a repository and repository system over 10,000 to 100,000 years. This result is controlled by several factors. First, the annual occurrence probability of magmatic disruption is low (generally $\ll<10^{-7}$ year $^{-1}$ ) for both disruption of a repository and disruption of a repository system. Second, the volume of affected waste inventory (percent of waste package) moved directly to the accessible environment during magma ascent and eruption (using lithic fragments as analogs of waste behavior) is a small percentage of a repository inventory. Third, the highest probability event associated with magmatic disruption is intrusion of a dike into a repository system without directly affecting a repository itself. These events have limited affects on the performance of a repository system because of the small size of feeder dikes associated with these events and additionally because the system performance model implemented through TSPA assigns only limited importance to the saturated zone (Younker et al., 1992; Andrews et al., 1994; Wilson et al., 1994; TRW, 1995). Thus, it is difficult to significantly degrade the performance of a component of a repository or repository system from magmatic affects when the affected system is a minor component of TSPA.

To summarize, simulation modeling using the RIP code was conducted to assess radiological releases associated with magmatic disruption of a repository. The results are intended to compliment but not replace, the ongoing TSPA for the Yucca Mountain site. Data assignments in the release calculations were conservative, designed not to underestimate radiological releases. The modeling results are consistent with conclusions from TSPA that volcanism is not a significant issue for the Yucca Mountain site and the assignment of a priority 3 (lower priority) to further development of volcanic-process models both for eruptive and subsurface effects of magmatic events (TRW, 1995; pp. 10-27). 


\section{Final Conclusions of Volcanism Studies by Los Alamos National Laboratory}

The following four conclusions are based on (1) many years of probabilistic volcanic hazard studies and (2) less comprehensive, but generally definitive, probabilistic volcanic risk assessments in which volcanic risk is defined as a product of the probability and consequences of future volcanic/magmatic activity.

1. The conditional probability of a future magmatic event occurring and intersecting a potential repository and/or repository area at Yucca Mountain is very low (Crowe et al. 1995; see Section VII, this chapter).

2. There is striking agreement between probabilistic volcanic hazard studies conducted by Los Alamos National Laboratory on behalf of the DOE and the probabilistic volcanic hazard assessment conducted by an expert panel (Geomatrix, 1996) of nationally and internationally renowned scientists in the fields of volcanism and tectonism (Fig. 6.28).

3. Estimates of the consequences of penetration of the repository or repository area by a magmatic event show only limited changes from the expected behavior of a repository system (Fig. 6.27; TRW, 1995).

4. The combined low probability of repository disruption and the limited changes in repository performance associated with magmatic disruption support the inference that the risk of future volcanic activity for a potential repository at Yucca Mountain is extremely low.

The application of these conclusions with respect to the suitability of the Yucca Mountain site remains to be established by the DOE.

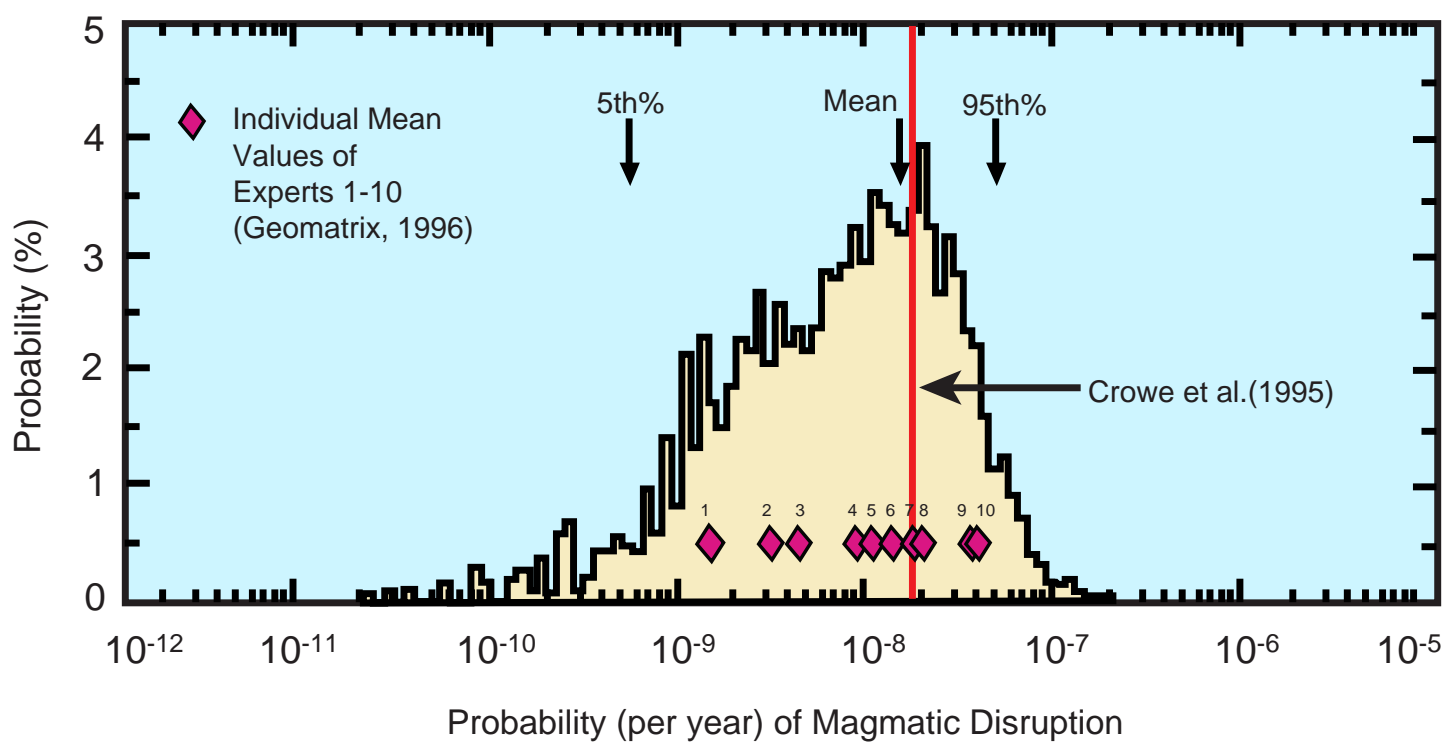

Figure 6.28. Aggregate frequency of the probability of magmatic disruption of the Yucca Mountain site established in an expert elicitation study that used a panel of experts on volcanism and tectonism. The diamonds are the mean of individual distributions established by panel experts; the vertical red line is the mean of the disruption distribution of Crowe et al. 1995 (modified from Figure 4-32 of Geomatrix, 1996). 


\section{Acknowledgments}

This work was supported by the Yucca Mountain Site Characterization Office as part of the Civilian Radioactive Waste Management Program. The US Department of Energy, Yucca Mountain Site Characterization Project, manages this project. This chapter is the final product of probabilistic volcanic hazard studies for the Yucca Mountain by the volcanism team assembled through the Los Alamos National Laboratory; the team members and support staff are listed and acknowledged in the preface to the VSR (Crowe et al., 1995). It has been an intriguing experience to conduct studies of the hazards of basaltic volcanism for the Yucca Mountain site since 1979. Perceptions of probabilistic volcanic hazard studies have evolved over this period from initial skepticism (late 70 s to early 80s), to slow acceptance with intensive quibbling over details (early 80 s to early 90s) and finally to more widespread acceptance typified by the interactions of the volcanism expert judgment panel (early 90s to 1996). It has been gratifying to be part of and to contribute to the evolutionary process of struggling to develop scientifically defendable approaches to assessing the hazards of rare events using limited and uncertain data sets. Clearly the quibbling has not stopped, but for now it appears to be focused on debates over who has the best probabilistic model. While this is progress, it does miss a key point of the probabilistic approach: differences between assumptions are not important if the resulting probability distributions for the hazard estimates are similar.

We want to express our appreciation for a constructive and insightful review of this chapter under severe time constraints by William Roberds of Golder Associates.

Far overshadowing recent events concerned with volcanism studies is the recent loss of my colleague, co-author and friend, Peter Wallmann. Peter bridged a unique knowledge gap between rock mechanics and volcanology and was a source of invaluable advice over the years on dike properties, simulation modeling, EXCEL spreadsheets and the soap-opera aspects of conducting volcanic hazard studies for the Yucca Mountain Project. He led a life that was uniquely balanced between family, friends, career, and science. Peter, you are missed.

\section{References}

Andrews, R.W. et al., 1994, “Total System Performance Assessment - 1993: An Evaluation Of The Potential Yucca Mountain Repository, Rept. B00000000-01717-220-00099-Rev. 01.

Barr, G. E., H. Dockery, R. Barnard, G. Valentine, B. Crowe, 1993, "Scenarios Constructed for Basaltic Igneous Activity at Yucca Mountain and Vicinity," Sandia National Laboratories, Report SAND91$1653,149 \mathrm{pp}$.

Barnard, R. W., M. L. Wilson, H. A. Dockery, J. H. Gauthier, P. G. Kaplan, R. R. Eaton, F. W. Bingham, T. H. Robey, 1992, “An Initial Total-System Performance Assessment for Yucca Mountain,” Sandia Report SAND91-2795, 11 Chapters.

Best, M. G., and W. H. Brimhall, "Late Cenozoic Alkalic Basaltic Magmas in the Western Colorado Plateau and the Basin and Range Transition Zone, USA, and their Bearing on Mantle Dynamics," Geological Society America 85, 1677-1690 (1974).

Bradshaw, T.K., and E.I. Smith, "Polygenetic Quaternary Volcanism at Crater Flat, Nevada," Journal of Volcanology and Geothermal Research 63, 165-182 (1994). 
Brocher, T.M., P.E. Hart, W.C. Hunter, and V.E. Langenheim, "Hybrid-Source Seismic Reflection Profiling Across Yucca Mountain, Nevada: Regional Lines 2 and 3," U. S. Geological Survey Open File report 96-28 pp. 1-110 (1996).

Brocher, T.M., W.C. Hunter, and V.E. Langenheim, "Structural Framework of Yucca Mountain, Nevada Based on Crustal-Scale Seismic Reflection Profiles and Potential Field Data," (submitted to Geological Society of America).

Bruce, P.M., and H.E. Huppert, "Solidification and Melting Along Dykes by the Laminar Flow of Basaltic Magma," in Magma Transport and Storage, M.P. Ryan Ed. 1(John Wiley \& Sons, New York, 1990), pp. 88-101.

Carr, W.J., "Volcanic-Tectonic History of Crater Flat, Southwestern Nevada, as Suggested by New Evidence from Drill Hole USW-VH-1 and Vicinity," US Geological Survey Open File report 82-457 (1982).

Carr, W.J., "Regional Structural Setting of Yucca Mountain, Southwestern Nevada, and Late Cenozoic Rates of Tectonic Activity in Part of the Southwestern Great Basin, Nevada and California," U.S. Geological Survey Open-File report 84-854, 109 pp. (1984).

Carr, W.J., "Styles Of Extension In The Nevada Test Site Region, Southern Walker Lane Belt; An Integration Of Volcano-Tectonic And Detachment Fault Models," in Geological Society America Memoir 176: Basin and Range Extensional Tectonics near the Latitude of Las Vegas, Nevada, B.P. Wernicke, Ed. (Geological Society America, Boulder, Colorado, 1990), pp. 283-303.

Champion, D.E., "Volcanic Episodes Near Yucca Mountain as Determined by Paleomagnetic Studies at Lathrop Wells, Crater Flat, and Sleeping Butte, Nevada," in Proceedings High Level Radioactive Waste Management: Proceedings of the Second Annual International Conference, Las Vegas, Nevada, April 28 - May 3, 1991 (American Nuclear Society, La Grange Park Illinois, 1991), pp. 61-67.

Champion, D.E., "Volcanic Episodes Near Yucca Mountain as Determined by paleomagnetic Studies at Lathrop Wells, Crater Flat, and Sleeping Butte, Nevada," U.S. Geological Survey Open File report 95-563 (1995).

Connor, C.B., and B.E. Hill, "Estimating the Probability of Volcanic Disruption of the Candidate Yucca Mountain Repository Using Spatially and Temporally Non Homogeneous Poisson Models," in Proceedings Site Characterization and Model Validation Focus'93 Symposium Volume (American Nuclear Society, La Grange Park, Illinois, 1993), pp. 174-181.

Connor, C.B. and B.E. Hill, "Three Nonhomogeneous Poisson Models for the Probability of Basaltic Volcanism: Application to the Yucca Mountain Region, Nevada," Journal of Geophysical Research 100, 10,107-10,125 (1995).

Cornell, C.A., "Probabilistic Analysis of Damage to Structures Under Seismic Loads," in Dynamic Waves in Civil Engineering D.A. Howells, I.P. Haigh, and C. Taylor, Eds. (John Wiley, London, 1971).

Cornell, C.A., "Engineering Seismic Risk Analysis," Bulletin of the Seismological Society of America 58, 1583-1606 (1968).

Crowe, B.M., "Volcanic Hazard Assessment for Disposal of High-level Radioactive Waste," in Recent Tectonics: Impact on Society (National Academy Press, Washington, D.C., 1986), Chap. 16, pp. 247-260. 
Crowe, B.M., "Basaltic Volcanic Episodes of the Yucca Mountain region," in High-Level Radioactive Waste Management: Proceedings of the First Annual International Conference, Las Vegas, Nevada, April 8-12, 1990 (American Nuclear Society, La Grange Park Illinois 1990), pp. 65-73.

Crowe, B.M., "Letter Report on the Evaluation of Structural Controls of Basaltic Volcanic Activity," Los Alamos National Laboratory Milestone report 3399, pp. 1-7, (1995a).

Crowe, B.M., "Los Alamos Letter Report: Revised Probability Estimates for the Yucca Mountain Region (Milestone T056),"Los Alamos National Laboratory Milestone report T056, pp. 1-8 (1995b).

Crowe, B.M., and W.J. Carr, "Preliminary Assessment of the Risk of Volcanism at a Proposed Nuclear Waste Repository in the Southern Great Basin," U.S. Geological Survey Open-File report 80-375, 15 pp. (1980).

Crowe, B.M., and F.V. Perry, "Volcanic Probability Calculations for the Yucca Mountain site: Estimation of Volcanic Rates," in Proceedings Nuclear Waste Isolation in the Unsaturated Zone, Focus '89 (American Nuclear Society, La Grange Park, Illinois, 1989), pp. 326-334.

Crowe, B.M., and F.V. Perry, "Preliminary Geologic Map of the Sleeping Butte Volcanic Centers," Los Alamos National Laboratory report LA-12101-MS, 11 pp. (1991).

Crowe, B. M., and F. V. Perry, "Los Alamos Letter Report: Completion of Field, Geochemistry and Geochronology Studies at the Sleeping Butte and Buckboard Mesa Basalt Centers," Los Alamos National Laboratory Milestone Report pp. 1-5, (1995).

Crowe, B.M., M.E. Johnson, and R.J. Beckman, "Calculation of the Probability of Volcanic Disruption of a High-Level Radioactive Waste Repository Within Southern Nevada, USA," Radioactive Waste Management 3, 167-190 (1982).

Crowe, B.M., F.V. Perry, G.A. Valentine, P.C. Wallmann and R. Kossik, "Simulation Modeling of the Probability of Magmatic Disruption of the Potential Repository Yucca Mountain Site," in Proceedings Site Characterization and Model Validation Focus'93 Symposium Volume (American Nuclear Society, La Grange Park, Illinois, 1993), pp. 182-191.

Crowe, B., F. Perry, J. Geissman, L. McFadden, S. Wells, M. Murrell, J. Poths, G.A. Valentine, L. Bower, and K. Finnegan, "Status of Volcanism Studies for the Yucca Mountain Site Characterization Project," Los Alamos National Laboratory report LA-12908-MS, pp. 1-363 (1995).

Crowe, B.M., R. Picard, G. Valentine, and F.V. Perry, "Recurrence Models of Volcanic Events: Applications to Volcanic Risk Assessment," in High-Level Radioactive Waste Management : Proceedings of the Third Annual International Conference, Las Vegas, Nevada, April 12-16, 1992 (American Nuclear Society, La Grange Park, Illinois, 1992), pp. 2344-2355.

Crowe, B.M., D.T. Vaniman, and W.J. Carr, "Status of Volcanic Hazard Studies for the Nevada Nuclear Waste Storage Investigations," Los Alamos National Laboratory report LA-9325-MS, 47 pp. (1983a).

Crowe, B.M., S. Self, D. Vaniman, R. Amos, and F. Perry, "Aspects of Potential Magmatic Disruption of a High-Level Radioactive Waste Repository in Southern Nevada," Journal of Geology 91, 259-276 (1983b).

Crowe, B.M., K.H. Wohletz, D.T. Vaniman, E. Gladney, and N. Bower, "Status of Volcanic Hazard Studies for the Nevada Nuclear Waste Storage Investigations," Los Alamos National Laboratory report LA-9325-MS, Vol. II, 101 pp. (1986). 
Crowe, B.M., B. Turrin, S. Wells, F. Perry, L. McFadden, C. Renault, D. Champion, and C. Harrington, "Volcanic Hazard Studies for the Yucca Mountain Project," Waste Management '89 1, 485-492 (1989).

Davis, J.C., Statistics and Data Analysis in Geology (John Wiley \& Sons, New York, 1986), 646 pp.

De la Cruz-Reyna, S., "Poisson Disttibuted Patterns of Explosive Eruptive Activity," Bulletin of Volcanology 54, 57-67 (1991).

Dershowitz, W., G. Lee, J. Geier, T. Foxford, P. LaPointe, and A. Thomas, FracMan Interactive Discrete Feature Data Analysis, Geometric Modeling, and Exploration Simulation: User Documentation Version 2.5 (Golder Associates Inc., Redmond, Washington, 1995).

Devore, J.L., Probability and Statistics for Engineering and the Sciences (Brooks/Cole Publishing Company, Monterey, California, 1987), 672 pp.

Dohrenwend, J.C., S.G. Wells, and B.D. Turrin, "Degradation of Quaternary Cinder Cones in the Cima Volcanic Field, Mojave, Desert, California," Geological Society of America Bulletin 97, 421-427 (1986).

Evans, M., N. Hastings, and B. Peacock, Statistical Distributions (John Wiley \& Sons, New York, 1993), $170 \mathrm{pp}$.

Fleck, R.J., M.A. Lanphere, B.D. Turrin, and D.A. Sawyer, "Chronology of late Miocene to Quaternary volcanism and tectonism in the southwest Nevada volcanic field," Geological Society of America Abstracts with Programs, 23, 25 (1991).

Fleck, R.J., B.D. Turrin, D.A. Sawyer, R.G. Warren, D.E. Champion, M.R. Hudson, and S.A. Minor, "Age and Character of Basaltic Rocks of the Yucca Mountain Region, Southern Nevada," Journal of Geolphysical Research 101, 8205-8227 (1996).

Fridrich, C.J., “Tectonic Evolution of Crater Flat Structural Basin, Yucca Mountain, Nevada,” (in press).

Geomatrix Consultants, Inc., "Probabilistic Volcanic Hazard Analysis for Yucca Mountain, Nevada." Civilian Radioactive Waste Management System, Management and Operating Contractor (TRW), Report BA0000000-01717-2200-00082, Rev. 0 (1996).

Golder Associates, "Effect of Structural Controls on Basaltic Volcanism and Eruptive Effects at Yucca Mountain, Nevada," Golder Associates, Redmond, Washington (1995).

Harris, A.G., J.E. Repetski, J.L. Clayton, J.A. Grow, M.D. Carr, and T.A. Davia, "Results from 1991 Wildcat Wells Near Yucca Mountain, Nevada," Geological Society America Abstracts with Programs, 24, p. 17 (1992).

Hasenaka, T., and I.S.E. Carmichael, "The Cinder Cones of Michoacan-Guanajuato, Central Mexico: Their Age, Volume, Distribution, and Magma Discharge Rate," Journal of Volcanology Geothermal Research 25, 105-124 (1985).

Ho, C.H., "Time Trend Analysis of Basaltic Volcanism for the Yucca Mountain site," Journal of Volcanology and Geothermal Research 46, 61-72 (1991).

Ho, C.H., "Risk Assessment for the Yucca Mountain High-Level Nuclear Repository Site: Estimation of Volcanic Disruption," Mathematical Geology 24, 347-364 (1992). 
Ho, C., "Sensitivity in Volcanic Hazard Assessment for the Yucca Mountain High-Level Nuclear Waste Repository Site: The Model and the Data," Mathematical Geology 27, 239-259 (1995).

Ho, C.H., E.I. Smith, D.L. Feurbach, and T.R. Naumann, "Eruptive Probability Calculation for the Yucca Mountain Site, USA: Statistical Estimation of Recurrence Rates," Bulletin of Volcanology 54, 50-56 (1991).

Kane, M.F., and R.E. Bracken, "Aeromagnetic Map of Yucca Mountain and Surrounding Regions, Southwest Nevada," U.S. Geological Survey Open-File report 83-616, 19 pp. (1983).

Klein, D.P., "Regionial Magnetotelluric Investigations," in Major Results of Geophysical Investigations at Yucca Mountain and Vicinity, Southern Nevada, H.W. Oliver, D.A. Ponce, and W.C. Hunter, Eds. U.S. Geological Survey Open-File report 95-74 (1995) pp. 89-124.

Langenheim, V.E., S.F. Carle, D.A. Ponce, and J.D. Philips, "Revision of an Aeromagnetic Survey of the Lathrop Wells Area, Nevada," U.S. Geological Survey Open-File report 91-46, 17 pp. (1991).

Langenheim, V.E., "Magnetic and Gravity Studies of Buried Volcanic Centers in the Amargosa Desert and Crater Flat, Southwest Nevada," U. S. Geological Survey Open File report (1995).

Langenheim, V.E., K.S. Kirchoff-Stein, and H.W. Oliver, "Geophysical Investigations of Buried Volcanic Centers Near Yucca Mountain, Southwest Nevada," in High Level Radioactive Waste Management:

Proceedings of the Fourth Annual International Conference, Las Vegas, Nevada, April 26-30, 1993

(American Nuclear Society, La Grange Park, Illinois, 1993), pp. 1840-1846.

Link, R., S. E Logan, H. S Ng, F. A. Rockenbach, and K. J. Hong, 1983, "Parametric Studies of Radiological Consequences of Basaltic Volcanism," Sandia National Laboratories Report. SAND 812375,219 pp.

Lister, J.R., and R.C. Kerr, "Fluid-Mechanical Models of Crack Propagation and Their Application to Magma Transport in Dykes," Journal of Geophysical Research 96, 10,049-10,077 (1991).

Los Alamos National Laboratory, "Probability of Magmatic Disruption of the Repository," Los Alamos Study Plan YMP-LANL-SP-8.3.1.8.1.1 R3, 48 pp. (1996).

Lutton, R.J., "Internal Structure of the Buckboard Mesa Basalt," Bulletin Volcanology 579-593 (1968).

Megill, R.E., An Introduction to Risk Analysis (PennWell Books, Tulsa, Oklahoma, 1984), 274 pp.

Menges, C.M., F.H. Swan, J.A. Oswald, J.R. Wesling, J.A. Coe, J.W. Whitney, and A.P. Thomas, "Preliminary Results of Paleoseismic Investigations of Quaternary Faults on Eastern Yucca Mountain, Nye County, Nevada," in High Level Radioactive Waste Management: Proceedings of the Fifth International Conference, Las Vegas, Nevada, May 22-26, 1994 (American Nuclear Society La Grange Park, Illinois, 1994), pp. 2373-2390.

National Research Council, Technical Bases for Yucca Mountain Standards (National Academy Press, Washington D.C., 1995).

Newendorp, P.D. Decision Analysis for Petroleum Exploration (PennWell Books, Tulsa, Oklahoma, 1974), 668 pp.

Olkin, I., L.J. Gleser, and C. Derman, Probability Models and Applications (McMillan College Publishing Company, New York, 1994), 715 pp. 
Oliver, H.W. and D.A. Ponce, "Introduction and Geologic Setting," in Major Results of Geophysical Investigations at Yucca Mountain and Vicinity, Southern Nevada, H.W. Oliver, D.A. Ponce, and W.C. Hunter, Eds., U. S. Geological Survey Open File-report 95-74 (1995), pp. 9-36.

Oliver, H.W., D.A. Ponce, and H.R. Blank, "Magnetic Investigations," in Major Results of Geophysical Investigations at Yucca Mountain and Vicinity, Southern Nevada, H.W. Oliver, D.A. Ponce, and W.C. Hunter, Eds., U. S. Geological Survey Open File-report 95-74 (1995), pp. 67-89.

Palisades Corporation @ RISK for Windows, Version 3.5, 1996.

Perry, F.V., and B.M. Crowe, "Geochemical Evidence for Waning Magmatism and Polygenetic Volcanism at Crater Flat, Nevada," in High-Level Radioactive Waste Management: Proceedings of the Third International Conference, Las Vegas, Nevada, April 12-16, 1992 (American Nuclear Society, La Grange Park Illinois, 1992), pp. 2344-2355.

Ratcliff, C.D., J.W. Geissman, F.V. Perry, B.M. Crowe and P.K. Zeitler, "Paleomagnetic Record of A Geomagnetic Field Reversal from Late Miocene Mafic Intrusions, southern Nevada," Science, 266, 412416 (1994).

Rosenberg, N.D., C.W. Gable, and L.H. Auer, "Spatial Scales of Effects on the Potential Yucca Mountain Repository Due to Convective Air Flow Induced by Igneous Intrusions," Los Alamos National Laboratory Milestone Report (1995).

Scandone, R., G. Arganese G., and F. Galdi, "The Evaluation of Volcanic Risk in the Vesuvian Area," Journal of Volcanology and Geothermal Research 58, 263-271 (1993).

Sheridan, M.F., "A Monte Carlo Technique to Estimate the Probability of Volcanic Dikes," in HighLevel Radioactive Waste Management: Proceedings of the Third Annual International Conference, Las Vegas, Nevada, April 12-16, 1992 (American Nuclear Society, La Grange Park, Illinois, 1992), pp. 20332038.

Smith, E.I., D.L. Feuerbach, T.R. Naumann, and J.E. Faulds, "The Area of Most Recent Volcanism Near Yucca Mountain, Nevada: Implications for Volcanic Risk Assessment," in High- Level Radioactive Waste Management: Proceedings of the Third Annual International Conference, Las Vegas, Nevada, April 8-12, 1990 (American Nuclear Society, La Grange Park, Illinois, 1990), pp. 81-90.

Smith, R.L., and R.G. Luedke, "Potentially Active Volcanic Lineaments and Loci in Western Conterminous United States," in Explosive Volcanism: Inception, Evolution and Hazards (National Academy Press, Washington DC, 1984), pp. 47-66.

TRW, Total System Performance Assessment - 1995: An Evaluation of the Potential Yucca Mountain Repository (TRW Environmental Safety Systems Inc., Las Vegas, 1995).

Tuckwell, H.C., Elementary Applications of Probability Theory (Champion and Hall, New York, 1988), $255 \mathrm{pp}$.

Turrin, B.D., D. Champion, and R.J. Fleck, ${ }^{40} \mathrm{Ar} /{ }^{39} \mathrm{Ar}$ Age of the Lathrop Wells Volcanic Center, Yucca Mountain, Nevada," Science 253, 654-657 (1991).

Turrin, B.D., D.E. Champion, and R.J. Fleck, "Measuring the Age of the Lathrop Wells Volcanic Center at Yucca Mountain," Science 257, 556-558 (1992). 
Valentine, G.A., B.M. Crowe, and F.V. Perry, "Physical Processes and Effects of Magmatism in the Yucca Mountain Region," in High- Level Radioactive Waste Management: Proceedings of the Third Annual International Conference, Las Vegas, Nevada, April 12-16, 1992 (American Nuclear Society, La Grange Park, Illinois, 1992), pp. 2344-2355.

Valentine G.A., and K.R. Groves, "Entrainment of Country Rock during Basaltic Eruptions of the Lucero Volcanic Field, New Mexico," Journal of Geology (1996).

Vaniman, D.T., and B.M. Crowe, "Geology and Petrology of the Basalts of Crater Flat: Applications to Volcanic Risk Assessment for the Nevada Nuclear Waste Storage Investigations," Los Alamos National Laboratory report LA-8845-MS, 67 pp. (1981).

Vaniman, D.T., B.M. Crowe, and E.S. Gladney, "Petrology and Geochemistry of Hawaiite Lavas from Crater Flat, Nevada," Contributions Mineralogy Petrology 80, 341-357 (1982).

Wallmann, P.C., "A Technique for Calculation of the Probability of Dikes Intersecting a Repository," in Proceedings Site Characterization and Model Validation Focus'93 Symposium Volume (American Nuclear Society, La Grange Park, Illinois, 1993), pp. 192-199.

Wallmann, P.C.I. Miller, and R. Kossik, "Assessment of Volcanic and Tectonic Hazards to High Level Radioactive Waste Repositories," in High-Level Radioactive Waste Management: Proceedings of the Fourth Annual International Conference, Las Vegas, Nevada, April 26-30, 1993 (American Nuclear Society, La Grange Park, Illinois, 1993), pp. 188-195.

Wells, S.G., L.D. McFadden, C.E. Renault, B.D. Turrin, and B.M. Crowe, "A Geomorphic Assessment of Quaternary Volcanism in the Yucca Mountain area, Nevada Test Site, Southern Nevada: Implications for the Proposed High-level Radioactive Waste Repository," Geology 18, 549-553 (1990).

Wells, S.G., B.M. Crowe, and L.D. McFadden, "Measuring the Age of the Lathrop Wells Volcanic Center at Yucca Mountain," Science 257, 555-558 (1992).

Whitney, J.W., and R.R. Shroba, "Comment and Reply on Geomorphic Assessment of late Quaternary Volcanism in the Yucca Mountain Area, Southern Nevada: Implications for the Proposed High-Level Radioactive Waste Repository," Geology 19, 661-662 (1991).

Wilson, L. and J.W. Head, "Ascent and Eruption of Basaltic Magma on the Earth and Moon," Journal of Geophysical Research 86, 2971-3001 (1981).

Wilson, M.L, .J.H. Gauthier, R.W. Banard, G.E. Barr, H.A. Dockery, E. Dunn, R.R. Eaton, D.C. Guerin, N.Lu, M.J. Martinez, R. Nilson, C.A.Rautman, T.H. Robey, B. Ross, E.E. Ryder, A.R. Schenker, S.A. Shannon, L.H. Skinner, W.G. Halsey, J.D. Halsey, J.D. Gansemer, L.C. Lewis, A.D. Loamont, I.R.Triay, A. Meijer, and D.E. Morris, Total-System Performance Assessment For Yucca Mountain -- SNL Second Iteration (TSPA-1993), Sandia report Sand 93-2675 (1994).

Wright, L.A. "Overview of the Role of Strike-Slip and Normal Faulting in the Neogene History of the Region Northeast of Death Valley, California-Nevada," Nevada Bureau of Mines and Geology Open-File 89-1, pp. 1-11 (1989).

Younker, J.L., W.B., Andrews, G.A. Fasano, C.C. Herrington, S.R. Mattson, R.C. Murray, L.B. Ballou, M.A. Revelli, L.E. Shephard, W.W. Dudley, D.T. Hoxie, R.J. Herbst, E.A. Patera, B.R. Judd, J.A. Docka, and L.D. Rickertsen, "Report of the Early Site Suitability Evaluation of the Potential Repository Site at Yucca Mountain, Nevada," Science Applications International Corporation report SAIC-91/8000 (1992). 